\title{
Publications of the \\ U.S. Geological Survey, \\ 1993
}

U.S. DEPARTMENT OF THE INTERIOR 


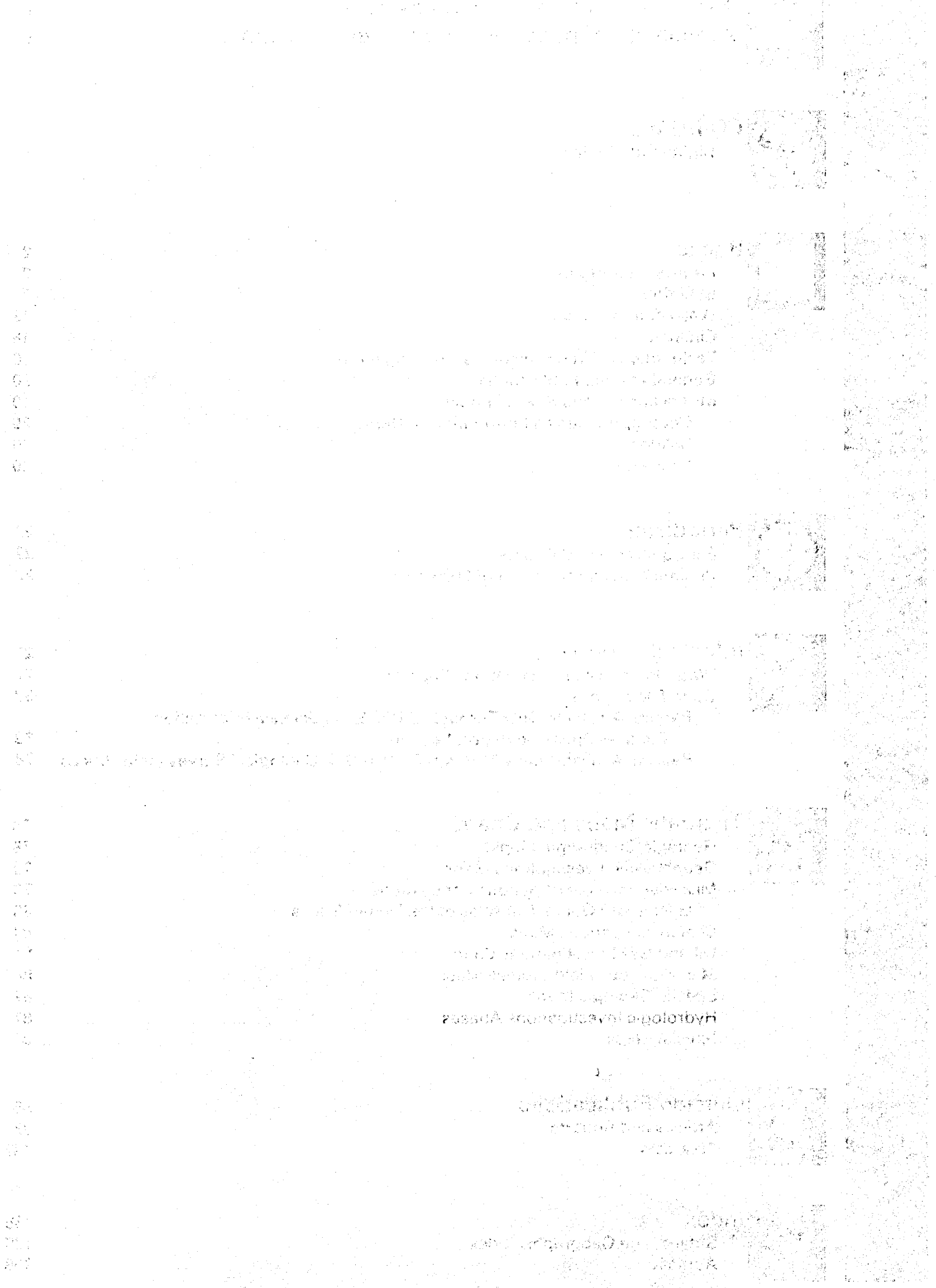



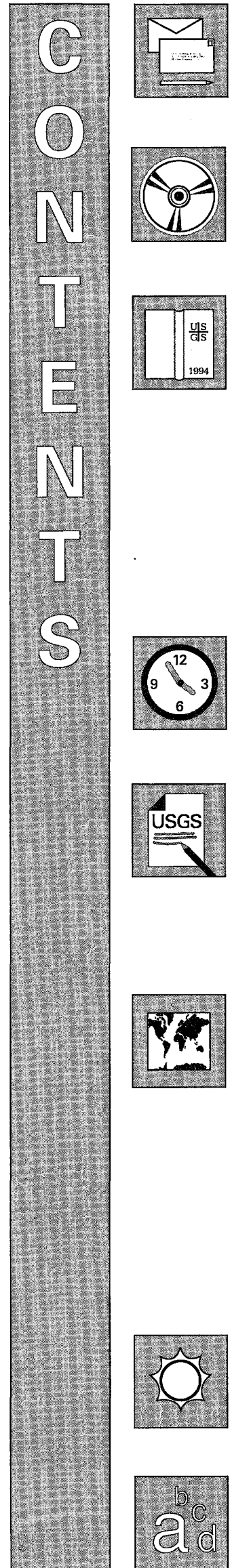

Availability of books and maps by mail Availability of books and maps over the counter .............................. v

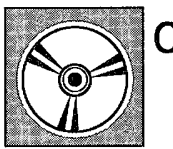

CD-ROM's

Digital Data Series

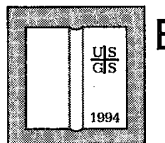

Books 2

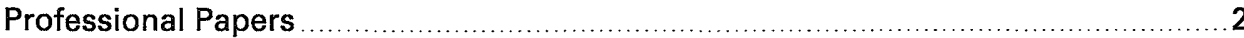

Bulletins ............................... 5

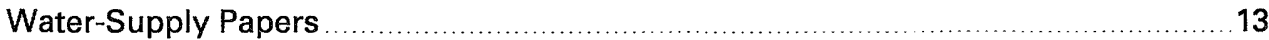

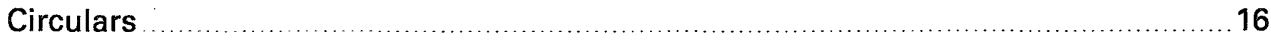

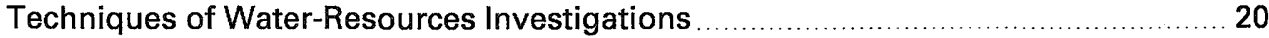

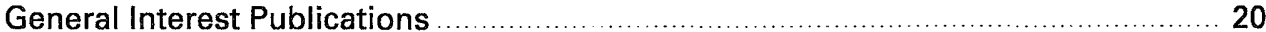

Miscellaneous and Special Books ............................................................ 20

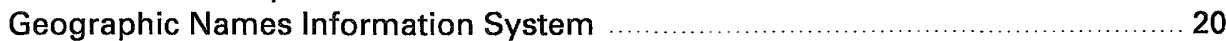

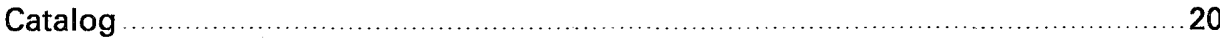

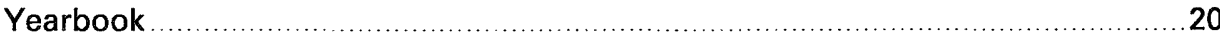

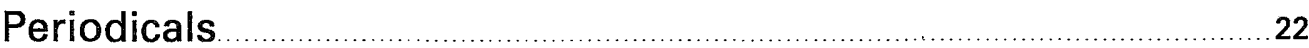

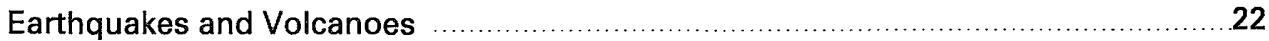

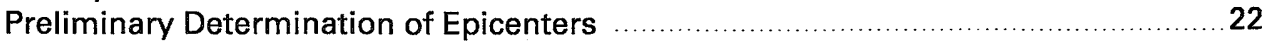

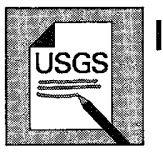

Informal Reports

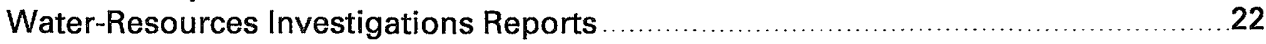

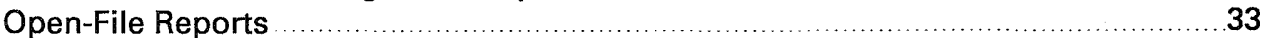

Reports Available Only Through USGS Earth Science Information Center-Open-File Report Section ................................................... 33 Reports Available Only Through Certain U.S. Geological Survey Field Offices .....78

Thematic Maps and Charts ………………………………………........78

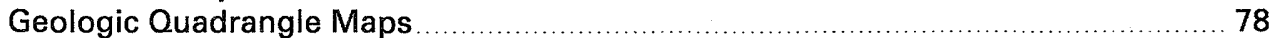

Geophysical Investigations Maps ............................................................. 79

Miscellaneous Investigations Series Maps ................................................ 79

Quaternary Geological Atlas of the United States .................................... 83

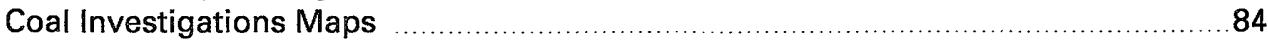

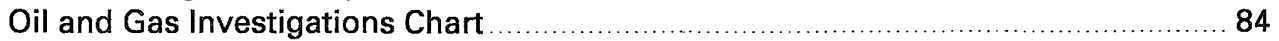

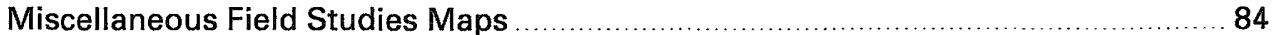

Special Geologic Maps ..................... 87

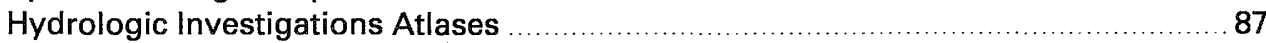

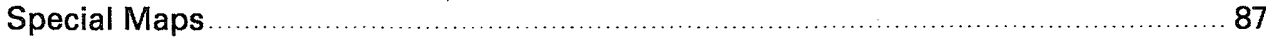

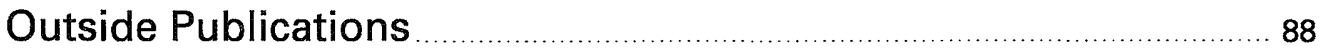

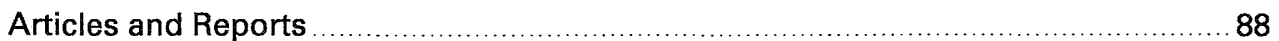

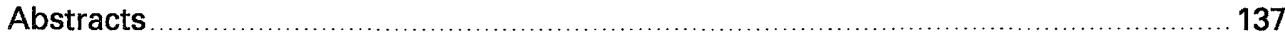

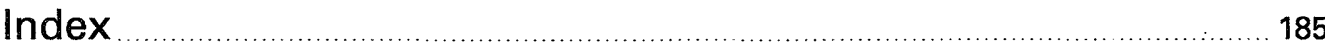

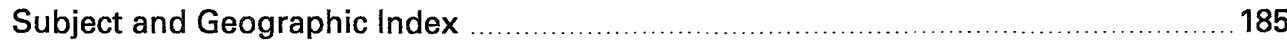

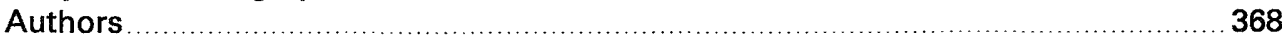




\section{Publications of the U.S. Geological Survey}

This catalog is a list of (1) books and maps ${ }^{1}$ that were published during 1993 , and (2) articles by U.S. Geological Survey personnel in non-U.S. Geological Survey journals and books that came to our attention in 1993; it supplements the permanent catalogs "Publications of the Geological Survey, 1879-1961", "Publications of the Geological Survey, 1962-1970", and "Publications of the U.S. Geological Survey, 1971 through 1981." These permanent catalogs, as well as some others, are available under the conditions indicated below from U.S. Geological Survey Map Distribution, Box 25286, MS 306, Federal Center, Denver, CO 80225. The catalogs are also available over the counter at any of the U.S. Geological Survey offices that sell books.

Permanent catalogs "Publications of the Geological Survey, 1879-1961" and "Publications of the Geological Survey, 1962-1970" may be purchased in paperback book form for $\$ 6.00$ and as microfiche for $\$ 4.00$.

Permanent catalog "Publications of the U.S. Geological Survey, 1971 through 1981" may be purchased in paperback book form (two volumes, publications listing and index) for $\$ 15$ and as a set of microfiche for $\$ 8.00$.

Supplements for $1982,1983,1984,1985,1986,1987,1988,1989,1990,1991$, and 1992, may be purchased in paperback book form and are priced as follows: $1982, \$ 3 ; 1983, \$ 3 ; 1984, \$ 3.25 ; 1985$, $\$ 3.75 ; 1986, \$ 4.25 ; 1987, \$ 4 ; 1988, \$ 3.75 ; 1989, \$ 4 ; 1990, \$ 4.50 ; 1991, \$ 4.25 ; 1992 ; \$ 5$.

State catalogs currently available may be purchased in paperback book form and are priced as follows: Alaska, \$3.50; Arkansas, \$1; California, \$4.75; Colorado, \$3.50; Florida, \$1; Massachusetts/Rhode Island/Connecticut, \$1; New York, \$1; Oregon, \$1; Pennsylvania/New Jersey, \$2.50; Utah, \$3.

Copies of the monthly catalog "New Publications of the U.S. Geological Survey" may be obtained free on request.

Those wishing to be placed on a free subscription list of the monthly catalog "New Publications of the U.S. Geological Survey" should apply in writing to the U.S. Geological Survey, 582 National Center, Reston, VA 22092.

Prices of available publications, except informal reports released to the open files and through the National Technical Information Service (NTIS), are given in (1) current issues of the monthly catalog "New Publications of the U.S. Geological Survey" and (2) "Price and Availability List of U.S. Geological Survey Publications (year)." Limited quantities of circulars and publications of general interest are free. Publications listed in this catalog but not found in the price and availability list are no longer available.

Prices of reports released to the open files (including reports prefixed OF and WRI) are given in a listing "U.S. Geological Survey Open-File Reports," updated bimonthly, available in microfiche for $\$ 3.50$ from USGS ESIC-Open-File Report Section, Box 25286, Denver, CO 80225.

Prices of reports released through the NTIS may be obtained by writing to the National Technical Information Service, U.S. Department of Commerce, Springfield, VA 22161; please include NTIS number preceding each item.

${ }^{1}$ Individual topographic quadrangle maps are not listed, they are shown on State indexes to topographic maps, which are free on application to U.S. Geological Survey, Map Distribution, Box 25286, Bldg. 810, Federal Center, Denver, $\mathrm{CO} 80225$, and to offices where books and maps are sold over the counter. These indexes also show commercial dealers in each State. 


\section{AVAILABILITY OF BOOKS AND MAPS BY MAIL}

In ordering books give the series designation and number, such as U.S. Geological Survey Bulletin 738, and the full title. In ordering maps give name or series designation and number, such as Fairfax, Va., 7.5-minute or GQ-851. Include your full address and zip code, plainly printed. Prepayment is required and should be made by check or money order payable to U.S. Department of the Interior - USGS, except for periodicals (see below). Postage stamps are not accepted. Do not send cash. Remittances must be in United States funds.

Prices listed include cost of domestic surface transportation. For transmittal outside the U.S.A. (except to Canada and Mexico), a surcharge of 25 percent of the net bill should be included to cover surface transportation.

\section{Books}

Professional papers, bulletins, water-supply papers, Techniques of Water-Resources Investigations, circulars, single copies of Earthquakes and Volcanoes, Preliminary Determination of Epicenters, the annual catalog Publications of the U.S. Geological Survey, and some miscellaneous reports, including some from the foregoing series that have gone out of print at the Superintendent of Documents, are obtainable by mail from

\section{U.S. Geological Survey, Map Distribution Box 25286, MS 306, Federal Center Denver, CO 80225}

On orders of 100 copies or more of the same report to the same address, a 25-percent discount is allowed (limited quantities of circulars and publications of general interest are usually free of charge). Open-file reports and reports available only through the NTIS should be ordered according to instructions under appropriate headings in this announcement. Discount does not apply to open-file reports and reports available through the NTIS.

Subscriptions to periodicals (Earthquakes and Volcanoes and Preliminary Determination of Epicenters) can be obtained ONLY from the

\section{Superintendent of Documents, Government Printing Office, Washington, DC 20402}

Domestic remittance should be made by check or money order (payable to Superintendent of Documents) or charged to VISA or MasterCard. Please add 25 percent for mailing to countries outside the U.S. and its possessions.

\section{Maps}

For maps of all areas of the United States, address mail orders to

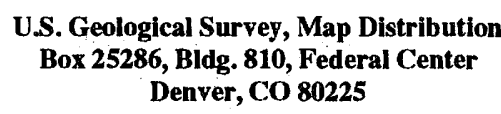

\author{
Residents of Alaska may order Alaska maps from
U.S. Geological Survey, Earth Science Information Center 101 12th Ave., Box 12 Fairbanks, AK 99701

On an order amounting to $\$ 500$ or more at the list price, a 50-percent discount is allowed; no other discount is applicable. The discount applies to all maps and charts distributed by the U.S. Geological Survey. A $\$ 1$ postage and handling charge is applicable on orders of less than $\$ 10$. Check or money order should be payable to Department of the Interior - USGS.

\section{AVAILABILITY OF BOOKS AND MAPS OVER THE COUNTER}

\section{Books and Maps}

Book reports and maps of the U.S. Geological Survey are available over the counter at the following U.S. Geological Survey offices, all of which are authorized agents of the Superintendent of Documents:

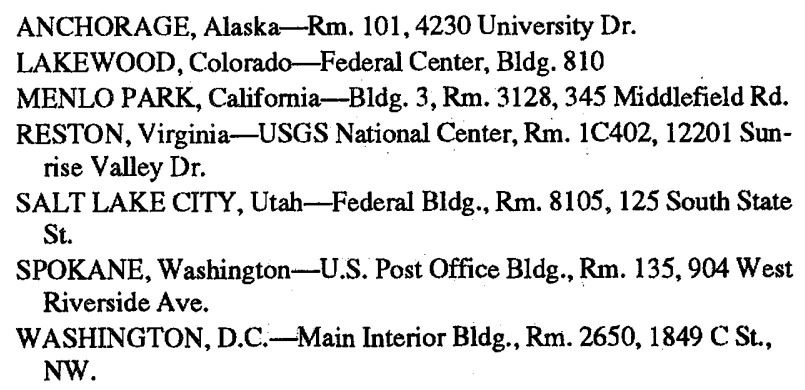

\section{Maps Only}

Maps may be purchased over the counter at the following U.S. Geological Survey offices:

FAIRBANKS, Alaska-New Federal Bldg., Rm. 126, 101 Twelfth Ave.

ROLLA, Missouri-1400 Independence Rd. STENNIS SPACE CENTER, Mississippi-Bldg. 3101

Survey maps are also sold by some 2,800 commercial dealers throughout the United States. Prices charged are generally higher than those shown on this list. Dealers are listed in each "State Catalog of Topographic and Other Published Maps," obtainable free of charge by mail or over the counter from U.S. Geological Survey offices listed on this page. 


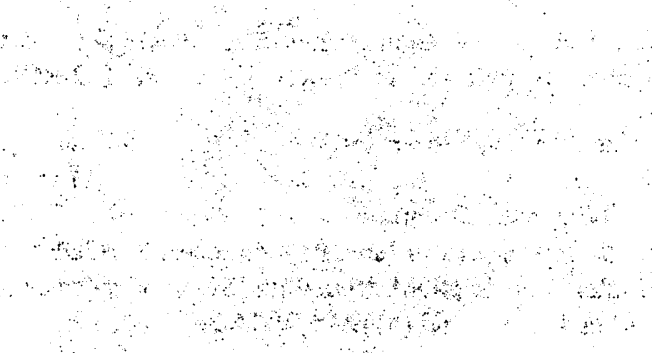

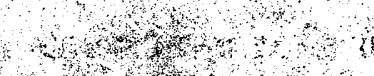
का ant?

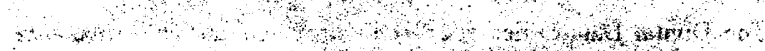

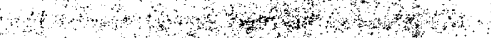
स.

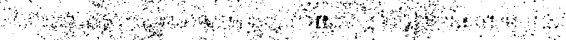

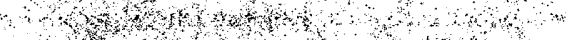

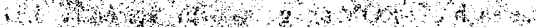

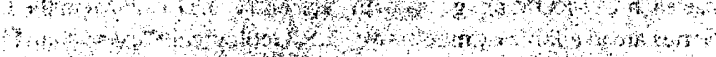

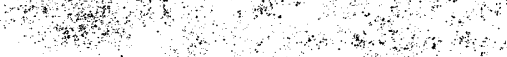

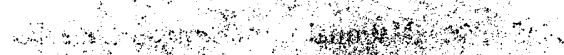

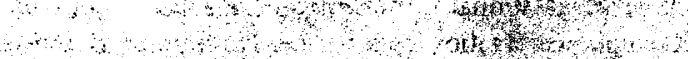

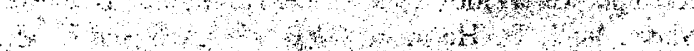
सै, $4+3$

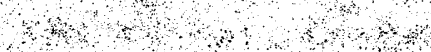
$+4$ $+1, y$ W.

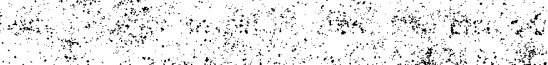

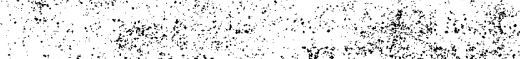
$\therefore$ a and and

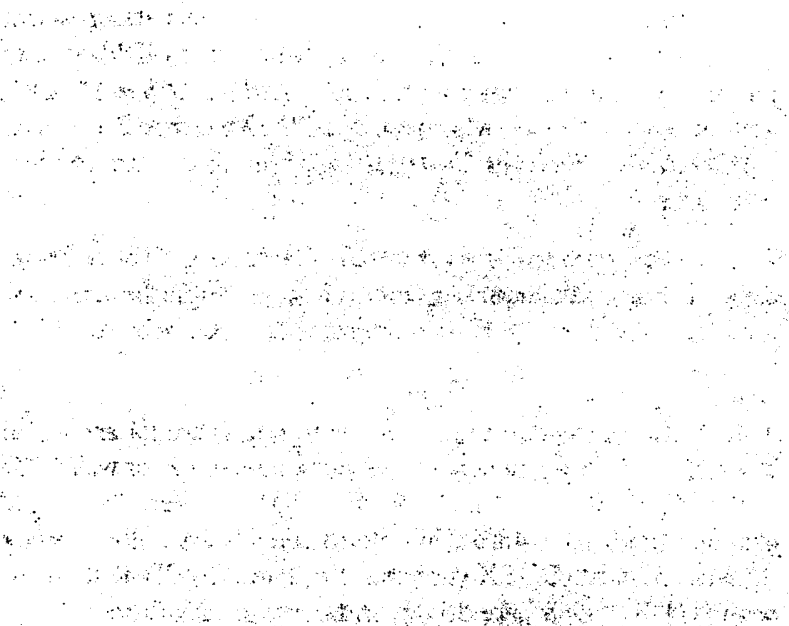

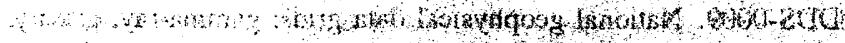

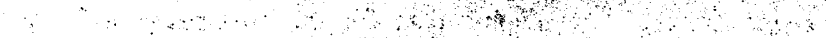

$$
x^{2}, \cdots
$$

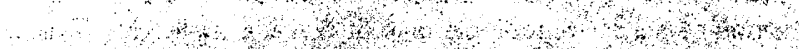

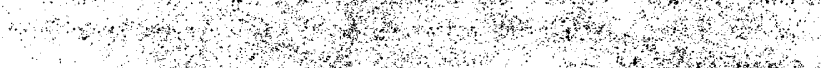
H.

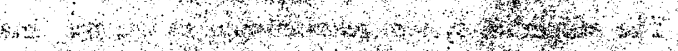

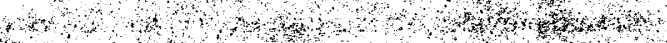

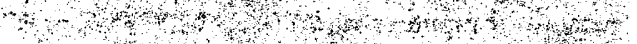

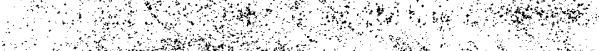

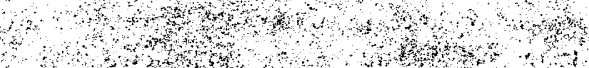

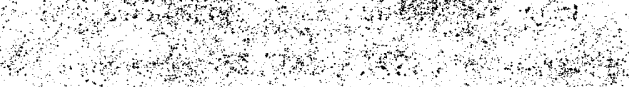
w

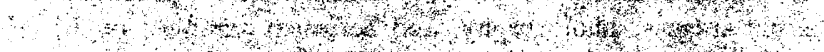

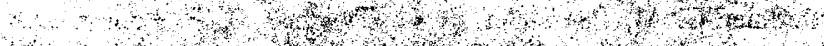

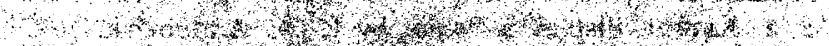

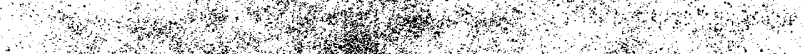

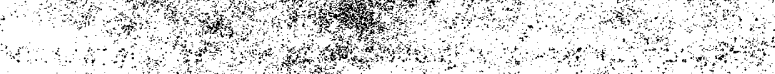

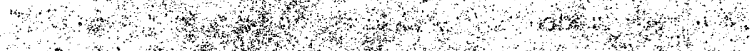

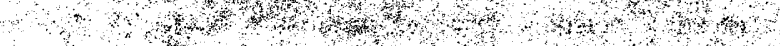

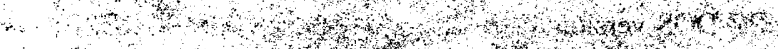

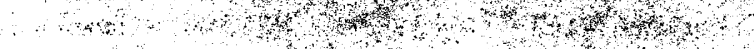

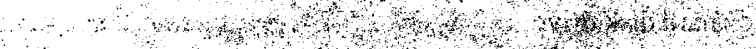

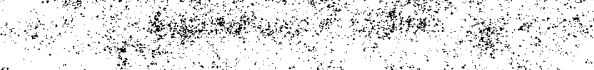

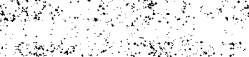

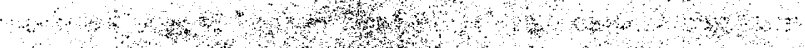

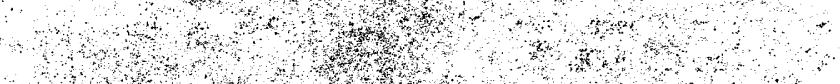

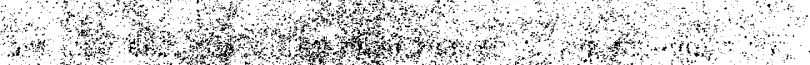

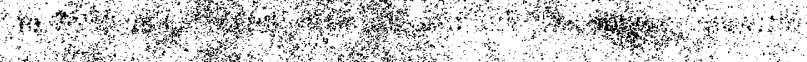

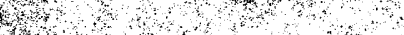




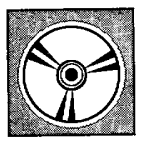

\section{CD-ROM's}

\section{DIGITAL DATA SERIES}

The Digital Data Series distributes large amounts of digital data (up to $680 \mathrm{MB}$ ) through the medium of Compact Disc-Read Only Memory technology. This medium takes advantage of the latest technological advances in digital mass-storage and in the internationally recognized standards (ISO9660) for CD-ROM's. Full instructions on computer technology required to use each CD-ROM are given with each entry. C.D-ROM's in the Digital Data Series are available by mail from: U.S. Geological Survey, Map Distribution, Box 25286, Bldg. 810, Federal Center, Denver, CO 80225. No discounts apply to CD-ROM's.

DDS-0001. National Geochemical Data Base; National Uranium Resource Evaluation data for the conterminous Western United States, by J. D. Hoffman, G. B. Gunnells and J. M. McNeal. 1991. One CD-ROM.

This CD-ROM was produced in accordance with the ISO 9660 standard; however, it is intended for use only on DOS-based computer systems. The minimum system requirements to use the data with the software provided on the disc are as follows: (1) an IBM or compatible personal computer with 640K RAM, (2) MS-or PC-DOS version 3.1 or later, (3) Microsoft MSCDEX version 2.1 or later, (4) CD-ROM drive with ISO 9660 software driver, and (5) hard disk drive.

DDS-0002. NEVADA. Geology of Nevada; a digital representation of the 1978 geologic map of Nevada, by R. M. Turner and W. J. Bawiec; display software by R. A. Ambroziak. 1991. One CD-ROM

The minimum system requirements to use the data with the software provided on this disc are: (1) an IBM or compatible personal computer with 640K RAM, (2) MS or PC-DOS version 3.1 or later and Microsoft MSCDEX version 2.1 or later, or $\mathrm{OS} / 2$ version or later, (3) CD-ROM drive with ISO 9660 software driver, (4) hard disk drive, and (5) EGA/VGA graphics system.

DDS-0003. MASSACHUSETTS. A geologic map of the sea floor in western Massachusetts Bay, constructed from digital sidescansonar images, photography, and sediment samples, by $\mathrm{M}$. H. Bothner, C. M. Parmenter, D. C. Twichell, C. F. Polloni, and H. J. Knebel; display software by R. A. Ambroziak. 1992. One CD-ROM.

The minimum system requirements to use the data with the software provided on this disc are as follows: (1) an IBM or compatible personal computer with 640K RAM, (2) MS- or PC-DOS version 3.1 or later, (3) Microsoft MSCDEX version 2.1 or later, (4) CD-ROM drive with ISO 9660 software driver, (5) hard disk drive, and (6)EGA/VGA graphics system. A math coprocessor is highly recommended.

DDS-0005. ALASKA. National Energy Research Seismic Library; processed seismic data for 29 lines in the National Petroleum Reserve in Alaska, by F. N. Zihlman and R. A. Ambroziak. 1992. One CD-ROM.

The minimum system requirements to use the data with the software provided on this disc are as follows: (1) an IBM or compatible personal computer (preferably having an 80386 or higher numbered processor) with 640K RAM, (2) MS- or PCDOS version 3.1 or later, (3) Microsoft MSCDEX version 2.1 or later, (4)CD-ROM drive with ISO 9660 software driver, (5) hard disk drive with a minimum of $7 \mathrm{MB}$ free space, and (6) EGA/VGA graphics system.

DDS-0006. Stratigraphic nomenclature databases for the United States, its possessions and territories. 1992. One CD-ROM.

The minimum system requirements to use the data with the software provided on this disc are as follows: (1) an IBM or compatible personal computer with 640K RAM, (2) MS- or PC-DOS version 4.01 or later, (3) Microsoft MSCDEX version 2.1 or later, (4) CD-ROM drive with ISO 9660 software driver, (5) hard disk drive, and (6) EGA/VGA color system.

Geologic Names Unit Lexicon (GNULEX), compiled by M. E. MacLachlan, W. A. Bryant, T. W. Judkins, E. D. Koozmin, R. C. Orndorff, M. L. Hubert, C. R. Murdock, S. W. Starrat and J. R. Le Compte.

Geologic Names of the United States (GEONAMES), compiled by C. R. Murdock and M. L. Hubert; data base designer and programmer, C. C. Abston.

DDS-0007. Digitized strong-motion accelerograms of North and Central American earthquakes 1933-1986, by L. C. Seekins, A. G. Brady, Catherine Carpenter and Nicholas Brown. 1992. One CD-ROM.

The minimum system requirements to use the catalog search software provided on this disc are as follows: (1) IBM or compatible personal computer with 512K RAM, (2) MS or PC-DOS version 3.1 or later, (3) Microsoft MSCDEX version 2.1 or later, (4) CD-ROM drive with ISO 9660 software driver, and (5) hard disk drive.

DDS-0008. Photographs from the U.S. Geological Survey Photographic Library (earthquakes, volcanoes, geologic hazards, and other phenomena), by J. K. McGregor and C. C. Abston. 1992. One CD-ROM.

The minimum system requirements to use this data are as follows: (1) DOS, IBM or compatible personal computer with $640 \mathrm{~K}$ RAM, (2) MS or PC-DOS version 5.0 or later, (3) SVGA graphics card $(640 \times 480 \times 256$ colors $)$ and SVGA color monitor, (4) Microsoft MSCDEX version 2.1 or later, (5) CD-ROM drive with ISO 9660 software driver, and (6) hard disk drive.

DDS-0009. National geophysical data grids; gamma-ray, gravity, magnetic, and topographic data for the conterminous United States, by J. D. Phillips, J. S. Duval and R. A. Ambroziak. 1993. One CD-ROM.

This CD-ROM was produced in accordance with the ISO 9660 standard and can be accessed by any computer system that has the appropriate software to read ISO 9660 discs. The menu system and other compiled programs included on the CD-ROM will work only on DOS-based computer systems. The data are available in ASCII format under the ASCII directory. The minimum system requirements to use the data with the software provided on this disc are as follows: (1) IBM or compatible personal computer with 640K RAM, (2) MS- or PC-DOS version 5.0 or later, (3) Microsoft MSCDEX version 2.1 or later, (4) CD-ROM drive with ISO 9660 software driver, (5) hard disk 
drive, (6) super VGA color graphics system, and (7) math coprocessor.

DDS-0010. Modern average global sea-surface temperature, by $P$. N. Schweitzer. 1993. One CD-ROM.

This CD-ROM was produced in conformance with both the ISO 9660 and Macintosh HFS standards. Software is provided on the disc to retrieve the yearly sea-surface temperature profile at any oceanic location and to display the data graphically. Software is included both in source and executable formats and runs on MS-DOS, Macintosh, and UNIX computer systems. Documentation for all data and software is included on the disc in both ASCII text and PostScript format. The minimum system requirements to use the data with the software provided on the disc follow. For MS-DOS systems, an IBM or compatible personal computer with MS- or PC-DOS version 3.3 or later, Microsoft MSCDEX version 2.1 or later, and a CD-ROM drive with an ISO 9660 driver are needed. For graphical output on MS-DOS systems, an 80386 or $80486 \mathrm{CPU}, 4 \mathrm{MB}$ of extended RAM, and a Super VGA graphics system are needed. For Macintosh systems, a Macintosh computer with a CD-ROM drive is needed. For graphical output on Macintosh systems, 4MB of RAM and a 256-color display are needed. For UNIX systems, an ANSIconformant C compiler and a CD-ROM drive with an ISO 9660 driver are needed. For graphical output on UNIX systems, 8MB of RAM and X Window System v. 11, r3 or later are needed.

DDS-0015. CD-ROM atlas of the deepwater parts of the U.S. Exclusive Economic Zone in the Atlantic Ocean, the Gulf of Mexico, and the eastern Caribbean Sea, by D. C. Twichell and C. F. Polloni; display software by R. A. Ambroziak; software documentation by C. A. Cook. 1993. One CD-ROM.

This CD-ROM was produced in accordance with the ISO 9660 standard and can be accessed by any computer system that has the appropriate software to read ISO 9660 discs; however, the disc is intended for use in a DOS environment. Users who do not have access to DOS will have to provide software to read and manipulate the data. The $\mathrm{C}$ source code for the DOS software and documentation are provided on this disc in the SSOURCE and DOCFILES subdirectories. The minimum system requirements to use the data with the software provided on the disc are as follows: (1) IBM or compatible personal computer, (2) $640 \mathrm{~K}$ RAM (at least $540 \mathrm{~K}$ free memory), (3) math coprocessor, (4) MS- or PC-DOS version 5.0 or later, (5) Microsoft MSCDEX version 2.1 or later, (6) CD-ROM drive with ISO 9660 software driver, (7) hard disk drive (5MB free), (8) Super VGA graphics card $(640 \times 480$ pixels with 256 colors), and (9) VGA color monitor.

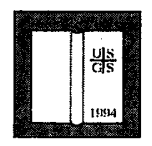

\section{BOOKS}

\section{PROFESSIONAL PAPERS}

Professional papers are mainly comprehensive scientific reports of wide and lasting interest and importance to professional scientists and engineers. Included are reports on the results of resource studies, and of topographic, hydrologic, and geologic investigations. They also include collections of related papers addressing different aspects of a single scientific topic.

P 0497-H. ARIZONA. Earth-fissure movements associated with fluctuations in ground-water levels near the Picacho Mountains, south-central Arizona, 1980-84, by M. C. Carpenter. 1993. p. H1-H49. (Mechanics of aquifer systems.) (Supersedes Open-file report 90-561.)

P 0870-A. IDAHO. The channel and waters of the upper Salmon River area, Idaho, by W. W. Emmett. 1975 (1992). p. A1A116. (Hydrologic evaluation of the upper Salmon River area. Idaho.) (Reprint.)

P 1177-B. NORTH CAROLINA. The Outer Banks of North Carolina, by Robert Dolan and H. F. Lins. Prepared in cooperation with the National Park Service. 1986 (1993). 47 p. (Reprint.)

P 1240-B. Facing geologic and hydrologic hazards; earth-science considerations, edited by W. W. Hays. 1981 (1992). p. B1B108. (Reprint.)

Introduction, by W. W. Hays and C. F. Shearer. p. B1-B3.

Ground shaking, by W. W. Hays. p. B6-B15.

Surface faulting, by M. G. Bonilla. p. B16-B22.

Earthquake-induced ground failures, by T. L. Youd and D. K. Keefer. p. B23-B31.

Tsunamis, by W. W. Hays. p. B32-B37.

Floods, by G. W. Edelen, Jr. p. B39-B53.

Landslides, by R. L. Schuster, D. J. Varnes and R. W. Fleming. p. B55-B65.

Expansive soils, by R. L. Schuster. p. B66-B72.

Subsidence, by Susan Lee and D. R. Nichols. p. B73-B85.

Volcanic eruptions, by D. R. Mullineaux. p. B87-B100.

Suggestions for improving decisionmaking to face geologic and hydrologic hazards, by W. W. Hays and C. F. Shearer. p. B103-B108.

P 1386-E. Glaciers of Europe, edited by R. S. Williams, Jr., and J. G. Ferrigno, U.S. Geological Survey. 1993. p. E1-E164. (Satellite image atlas of glaciers of the world, edited by R. S. Williams, Jr., and J. G. Ferrigno.)

Glaciers of the Alps; the Austrian Alps, by Helmut Rott, University of Innsbruck. p. E6-E13.

Glaciers of the Alps; the Swiss Alps, by K. E. Scherler, Swiss Federal Institute of Technology. p. E14-E22.

Glaciers of the Alps; the French Alps, by Louis Reynaud, Laboratoire de Glaciologie, St. Martin d'Hères. p. E23-E36.

Glaciers of the Alps; the Italian Alps, by R. S. Barbero, CNR; and Giorgio Zanon, University of Padua. p. E37-E48.

Glaciers of the Pyrenees, Spain and France, by David Serrat, University of Barcelona; and Josep Ventura, Cartographic Institute of Catalunya. p. E49-E61.

Glaciers of Norway, by Gunnar Ostrem and Nils Haakensen, Norwegian Water Resources and Energy Administration. p. E63-E107.

Glaciers of Sweden, by Valter Schytt (deceased), Stockholm University. p. E111-E125. 
Glaciers of Svalbard, Norway, by Olav Liestol, Norwegian Polar Research Institute. p. E127-E151.

Glaciers of Jan Mayen, Norway, by Olav Orheim, Norwegian Polar Research Institute. p. E153-E164.

P 1404-G. Hydrogeologic framework of the northern Atlantic Coastal Plain in parts of North Carolina, Virginia, Maryland, Delaware, New Jersey, and New York, by Henry Trapp, Jr. 1992. p. G1-G59. 13 plates in separate case, (Regional Aquifer-System Analysis; northern Atlantic Coastal Plain.)

P 1405-B. Hydrogeology of the Cambrian-Ordovician aquifer system in the northern Midwest, United States, by H. L. Young, with a section on Ground-water quality by D. I. Siegel. 1992. p. B1B99. 1 plate in pocket. (Regional Aquifer-System Analysis; northern Midwest.)

P 1405-C. Simulation of regional ground-water flow in the Cambrian-Ordovician aquifer system in the northern Midwest, United States, by R. J. Mandle and A. L. Knotis. 1992. p. C1-C97. (Regional Aquifer-System Analysis; northern Midwest.) (Supersedes Open-file report 87-689.)

P 1407-C. NEW MEXICO, TEXAS. Geohydrology and simulation of ground-water flow in the Mesilla Basin, Doña Ana County, New Mexico, and El Paso County, Texas, by P. F. Frenzel and C. A. Kaehler, with a section on Water quality and geochemistry by S. K. Anderholm. 1992. p. C1-C105. 5 plates in pocket. (Regional Aquifer-System Analysis, Southwest alluvial basins, New Mexico and adjacent states.) (Supersedes Open-file report 88-305.)

P 1408-F. IDAHO. Hydrology and digital simulation of the regional aquifer system, eastern Snake River plain, Idaho, by S. P. Garabedian. 1992. p. F1-F102. 10 plates in separate case. (Regional Aquifer-System Analysis; Snake River plain, Idaho.) (Supersedes Open-file report 87-237.)

P 1410-G. MISSISSIPPI, ALABAMA. Hydrogeology of the Southeastern Coastal Plain aquifer system in parts of eastern Mississippi and western Alabama, by M. J. Mallory. 1993. p. G1-G57. (Regional Aquifer-System Analysis; Southeastern Coastal Plain.)

P 1416-C. Geohydrologic units of the coastal lowlands aquifer system, south-central United States, by J. S. Weiss. 1992. p. C1-C32. 16 plates in separate case. (Regional Aquifer-System Analysis; Gulf Coastal Plain.) (Supersedes Open-file report 90173.)

P 1497-C. ALASKA. Distribution, facies, ages, and proposed tectonic associations of regionally metamorphosed rocks in east- and south-central Alaska, by Cynthia Dusel-Bacon, Bela Csejtey, Jr., H. L. Foster, E. O. Doyle, W. J. Nokleberg and George Plafker. Prepared in cooperation with the Alaska Department of $\mathrm{Na}$ tional Resources, Division of Geological and Geophysical Surveys. 1993. p. C1-C72. 2 plates in pocket. (Regionally metamorphosed rocks of Alaska.)

P 1506-D. WYOMING. Description and correlation of Eocene rocks in stratigraphic reference sections for the Green River and Washakie basins, Southwest Wyoming, by H. W. Roehler. 1992. p. D1-D83. 2 plates in pocket. (Geology of the Eocene Wasatch, Green River, and Bridger (Washakie) formations, greater Green River basin, Wyoming, Utah, and Colorado.)
P 1506-F. WYOMING, UTAH, COLORADO. Eocene climates, depositional environments, and geography, greater Green River basin, Wyoming, Utah, and Colorado, by H. W. Roehler. 1993. p. F1-F74. (Geology of the Eocene Wasatch, Green River, and Bridger (Washakie) formations, greater Green River basin, Wyoming, Utah, and Colorado.)

P 1519. UTAH. Applications of research from the U.S. Geological Survey program, assessment of regional earthquake hazards and risk along the Wasatch Front, Utah, edited by.P. L. Gori, U.S. Geological Survey. 1993: 167 p. (Supersedes Open-file report 90-225.)

Interactive workshops; essential elements of the earthquake hazards research and reduction program in the Wasatch Front, Utah, by P. L. Gori, U.S. Geological Survey. p. 1-15.

Reducing earthquake hazards in Utah; the crucial connection between researchers and practitioners, by W. J. Kockelman, U.S. Geological Survey. p. 16-74.

Public preceptions of the implementation of earthquake mitigation policies along the Wasatch Front in Utah, by G. E. Madsen, L. R. Anderson, Utah State University; J. H. Barnes, Salt Lake County Planning Division; and Genevieve Atwood, Utah Geological Survey. p. 75-81.

A data base designed for urban seismic hazards studies, by A. C. Tarr, U.S. Geological Survey. p. 82-90.

A mapping of ground-shaking intensities for Salt Lake County, Utah, by P. C. Emmi, University of Utah. p. 91-113.

Wasatch Front County Hazards Geologist Program, by G. E. Christenson, Utah Geological Survey. p. 114-120.

Surface-fault rupture; a guide for land-use planning, Utah and Juab counties, Utah, by R. M. Robison, Utah County Planning Department. p. 121-128.

Landslide hazards; a guide for land-use planning, Davis County Utah, by R. M. Robison, Utah County Planning Department; and Mike Lowe, Davis County Planning Department. p. 129137.

Rockfall hazards; a guide for land-use planning, Salt Lake County, Utah, by C. V. Nelson, Delta Geotechnical Consultants. p. $138-142$.

Debris-flow hazards; a guide for land-use planning, Davis County, Utah, by Mike Lowe, Davis County Planning Department. p. 143-150.

Liquefaction hazards, a guide for land-use planning, Davis County, Utah, by Mike Lowe, Davis County Planning Department. p. 151-157.

Tectonic subsidence hazard; a guide for land-use planning, Utah and Juab counties, Utah, by R. M. Robison, Utah County Planning Department. p. 158-162.

Hazards from earthquake-induced ground failure in sensitive clays, vibratory settlement, and flooding due to seiches, surfacedrainage disruptions, and increased ground-water discharge, Davis County, Utah, by Mike Lowe, Davis County Planning Department. p. 163-167.

P 1520. WYOMING. New stratigraphic subdivisions and redefinition of subdivisions of late Archean and early Proterozoic 
metasedimentary and metavolcanic rocks of the Sierra Madre and Medicine Bow Mountains, southern Wyoming, by R. S. Houston, K. E. Karlstrom, P. J. Graff and A. J. Flurkey. Prepared in cooperation with the U.S. Department of Energy, Wyoming Geological Survey, and Geology Department of the University of Wyoming. 1992. 50 p. 1 plate in pocket.

$P$ 1521. OREGON, CALIFORNIA. Stratigraphy of the Cretaceous Hornbrook Formation, southern Oregon and Northern California, by T. H. Nilsen. 1993.89 p. 1 plate in pocket.

P 1524. MONTANA. Geology of the Libby thrust belt of northwestern Montana and its implications to regional tectonics, by J. E. Harrison and E. R. Cressman. 1993. 42 p. 2 plates in pocket.

P 1527. Seismicity of the United States, $1568-1989$ (revised), by C. W. Stover and J. L. Coffman. 1993. 418 p.

P 1530-A. MINNESOTA. Field observations, preliminary model analysis, and aquifer thermal efficiency, by R. T. Miller and G. N. Delin. Prepared in cooperation with the University of Minnesota and the Minnesota Geological Survey. 1993. p. A1-A55. (Cyclic injection, storage, and withdrawal of heated water in a sandstone aquifer at St. Paul, Minnesota.)

P 1532. WYOMING. Stratigraphy of the Upper Cretaceous Fox Hills Sandstone and adjacent parts of the Lewis Shale and Lance Formation, east flank of the Rock Springs Uplift, Southwest Wyoming, by H. W. Roehler. 1993. 57 p. 5 plates in pocket.

P 1533. The Upper Cretaceous dimorphic pachydiscid ammonite Menuites in the Western Interior of the United States, by W. A. Cobban, U.S. Geological Survey; and W. J. Kennedy, Oxford University. 1993. $14 \mathrm{p}$.

P 1536. INDIANA, ILLINOIS. Liquefaction evidence for one or more strong Holocene earthquakes in the Wabash Valley of southern Indiana and Illinois, with a preliminary estimate of magnitude, by S. F. Obermeier, U.S. Geological Survey; J. R. Martin, Virginia Polytechnic Institute and State University; A. D. Frankel, U.S. Geological Survey; T. L. Youd, Brigham Young University; P. J. Munson, C. A. Munson, Indiana University; and E. C. Pond, Virginia Polytechnic Institute and State University. 1993. 27 p. (Supersedes Open-file report 92-406.)

$P$ 1537. COLORADO. Mineralogy, mineral chemistry, and paragenesis of gold, silver, and base-metal ores of the North Amethyst vein system, San Juan Mountains, Mineral County, Colorado, by N. K. Foley, S. W. Caddey, C. B. Byington and D. M. Vardiman. $1993.39 \mathrm{p}$.

P 1542. Allostratigraphy of the U.S. middle Atlantic continental margin; characteristics, distribution, and depositional history of principal unconformity-bounded upper Cretaceous and Cenozoic sedimentary units, by C. W. Poag, U.S. Geological Survey; and L. W. Ward, Virginia Museum of Natural History. 1993. 81 p.

P 1550-C. CALIFORNIA. The Loma Prieta, California, earthquake of October 17, 1989; preseismic observations, edited by $\mathbf{M}$. J. S. Johnston, U.S. Geological Survey. 1993. p. C1-C85. (Earthquake occurrence; coordinated by W. H. Bakun and W. H. Prescott.)

Seismicity in the southern Santa Cruz Mountains during the 20-year period before the earthquake, by J. A. Olson and D. P. Hill, U.S. Geological Survey. p. C3-C16.
Analysis of low-frequency-electromagnetic-field measurements near the epicenter, by A. C. Fraser-Smith, Arman Bernardi, R. A. Helliwell, P. R. McGill, and O. G. Villard, Jr., Stanford University. p. C17-C25.

Seismomagnetic effects, by R. J. Mueller and M. J. S. Johnston, U.S. Geological Survey. p. C27-C30.

Near-source short- to intermediate-period ground motions, by $R$. A. White and W. L. Ellsworth, U.S. Geological Survey. p. C31-C46.

A reported streamflow increase, by E. A. Roeloffs, U.S. Geological Survey. p. C47-C51.

Near-field high-resolution strain measurements, by M. J. S. Johnston, U.S. Geological Survey; and A. T. Linde, Carnegie Institution of Washington. p. C53-C58.

A shear-strain precursor, by M. T. Gladwin, R. L. Gwyther, and R. H. G. Hart, University of Queensland, Australia. p. C59-C65.

No convincing precursory geodetic anomaly observed, by $\mathrm{Mi}$ chael Lisowski, J. C. Savage, W. H. Prescott, J. L. Svarc, and M. H. Murray, U.S. Geological Survey. p. C67-C72.

Detection of hydrothermal precursors to large Northern California earthquakes, by P. G. Silver, N. J. Valette-Silver; Carnegie Institution of Washington; and Olga Kolbek, Calistoga, California. p. C73-C80.

Borehole strain measurements of solid-Earth-tidal amplitudes, by A. T. Linde, Carnegie Institution of Washington; M. T. Gladwin, University of Queensland, Australia; and M. J. S. Johnston, U.S. Geological Survey. p. C81-C85.

P 1553-B. CALIFORNIA. The Loma Prieta, California, earthquake of October 17, 1989; public response, edited by P. A. Bolton, Battelle Human Affairs Research Center, Seattle, WA; and coordinated by D. S. Mileti, Colorado State University. 1993. p. B1-B69.

Introduction, by P. A. Bolton, Battelle Human Affairs Research Center, Seattle, WA. p. B1-B2.

Human behavior during and immediately after the earthquake, by L. B. Bourque, University of California at Los Angeles; L. A. Russell, University of California at Los Angeles and Southern California Earthquake Preparedness Project; and J. D. Goltz, Southern California Earthquake Preparedness Project. p. B3-B22.

Citizen participation in emergency response, by P. W. O'Brien and D. S. Mileti, Colorado State University. p. B23-B30.

Public response to aftershock warnings, by D. S. Mileti and P. W. O'Brien, Colorado State University. p. B31-B41.

Emergency sheltering and housing of earthquake victims; the case of Santa Cruz County, by R. C. Bolin and L. M. Stanford, New Mexico State University. p. B43-B50.

Building content hazards and behavior of mobility-restricted residents, by M. M. Rahimi and Glenn Azevedo, University of Southern California. p. B51-B62. 
Earthquake preparedness behavior of students and nonstudents, by John-Paul Mulilis and T. S. Duval, University of Southern California. p. B63-B69.

\section{BULLETINS}

Bulletins contain significant data and interpretations that are of lasting scientific interest but are generally more limited in scope or geographic coverage than professional papers. They include the results of resource studies and of geologic and topographic investigations; as well as collections of short papers related to a specific topic.

B 1737-E. ARIZONA. Mineral resources of the Wabayuma Peak Wilderness Study Area, Mohave County, Arizona, by C. M. Conway, J. R. Hassemer, D. H. Knepper, Jr., J. A. Pitkin, R. C. Jachens, U.S. Geological Survey; and M. L. Chatman, U.S. Bureau of Mines. 1990. p. E1-E52. 1 plate in pocket. (Mineral resources of wilderness study areas; Black Mountains region, Arizona.)

B 1770. Methods for geochemical analysis, edited by P. A. Baedecker. 1987 (1992). 131 p. (Reprint.)

A. Analysis of geologic materials by direct-current arc emission spectrography and spectrometry, by D. W. Golightly, A. F. Dorrzapf, Jr., R. E. Mays, T. L. Fries and N. M. Conklin. p. A1-A13.

B. Inductively coupled plasma-atomic emission spectrometry, by F. E. Lichte, D. W. Golightly and P. J. Lamothe. p. B1B10.

C. Atomic absorption methods, by P. J. Aruscavage and J. G. Crock. p. C1-C6.

D. Chemical methods of separation for optical emission, atomic absorption spectrometry, and colorimetry, by S. A. Wilson, J. S. Kane, J. G. Crock and D. B. Hatfield. p. D1-D14.

E. Analysis of geologic materials by wavelength-dispersive $X$ ray fluorescence spectrometry, by J. E. Taggart, Jr., J. R. Lindsay, B. A. Scott, D. V. Vivit, A. J. Bartel and K. C. Stewart. p. E1-E19.

F. Energy-dispersive X-ray fluorescence spectrometry, by R. G. Johnson and B. S. King. p. F1-F5.

G. Major and minor elements requiring individual determination, classical whole rock analysis, and rapid rock analysis, by L. L. Jackson, F. W. Brown and S. T. Neil. p. G1-G23.

$H$. Instrumental neutron activation analysis of geochemical samples, by P. A. Baedecker and D. M. McKown. p. H1H14.

I. Determination of uranium and thorium by delayed neutron counting, by D. M. McKown and H. T. Millard, Jr. p. I1I12.

J. Radiochemical neutron activation analysis of geologic materials, by G. A. Wandless. p. J1-J8.

K. Isotope-dilution mass spectrometry, by J. A. Philpotts. p. K1-K5.

B 1787-BB. UTAH. Stratigraphy of the Eocene part of the Green River Formation in the south-central part of the Uinta Basin, Utah, by R. R. Remy, Institute for Energy Technology, Norway. 1992. p. BB1-BB79. 1 plate in pocket. (Evolution of sedimentary basins; Uinta and Piceance basins.)

B 1787-DD. UTAH, COLORADO. Surface vitrinite reflectance study of the Uinta and Piceance basins and adjacent areas, eastern Utah and western Colorado; implications for the development of Laramide basins and uplifts, by R. C. Johnson and V. F. Nuccio. 1993. p. DD1-DD38. 2 plates in pocket. (Evolution of sedimentary basins; Uinta and Piceance basins.)

B 1787-EE. COLORADO, NEW MEXICO. Stratigraphy of the Mississippian System, south-central Colorado and north-central New Mexico, by A. K. Armstrong, U.S. Geological Survey; B. L. Mamet, University of Montreal; and J. E. Repetski, U.S. Geological Survey. 1992. p. EE1-EE22. 1 plate in pocket. (Evolution of sedimentary basins; Uinta and Piceance basins.)

B 1787-GG. COLORADO. Stratigraphic correlations between the Eagle Valley Evaporite and Minturn Formation, Eagle Basin, Northwest Colorado, by C. J. Schenk. 1992. p. GG1-GG8. (Evolution of sedimentary basins; Uinta and Piceance basins.)

B 1787-HH. UTAH. Geometry and structural evolution of gilsonite dikes in the eastern Uinta Basin, Utah, by E. R. Verbeek and M. A. Grout. Prepared in cooperation with the U.S. Department of Energy. 1993. p. HH1-HH42. 1 plate in pocket. (Evolution of sedimentary basins; Uinta and Piceance basins.)

B 1787-Q. COLORADO, UTAH. Cretaceous and Tertiary paleogeographic reconstructions for the Uinta-Piceance Basin Study Area, Colorado and Utah, by K. J. Franczyk, T. D. Fouch, R. C. Johnson, C. M. Molenaar and W. A. Cobban. 1992. p. Q1Q37. (Evolution of sedimentary basins; Uinta and Piceance basins.)

B 1808-O. Stratigraphy, structure, and paleogeography of Pennsylvanian and Permian rocks, San Juan Basin and adjacent areas, Utah, Colorado, Arizona, and New Mexico, by A. C. Huffman, Jr. and S. M. Condon. 1993. p. O1-O44. 18 plates in pockets. (Evolution of sedimentary basins; San Juan Basin.)

B 1839-I,J. Principal oil and gas plays in the Appalachian Basin (Province 131). Middle Eocene intrusive igneous rocks of the central Appalachian Valley and Ridge Province; setting, chemistry, and implications for crustal structure, by Wallace de Witt, Jr., C. S. Southworth, K. J. Gray and J. F. Sutter. 1993. 61 p. (Evolution of sedimentary basins; Appalachian Basin.) (Chapters $I$ and $J$ are issued as a single volume and are not available separately.) (B 1839-I supersedes Open-file report 88-450-S.)

I. Principal oil and gas plays in the Appalachian Basin (Province 131), by Wallace de Witt, Jr. p. I1-I37.

J. Middle Eocene intrusive igneous rocks of the central Appalachian Valley and Ridge Province; setting, chemistry, and implications for crustal structure, by C. S. Southworth, K. J. Gray and J. F. Sutter. p. J1-J24.

B 1839-K. OHIO, PENNSYLVANIA, WEST VIRGINIA. Stratigraphic framework of Cambrian and Ordovician rocks in the central Appalachian Basin from Medina County, Ohio, through southwestern and south-central Pennsylvania to Hampshire County, West Virginia, by R. T. Ryder, A. G. Harris and J. E. Repetski. 1992. p. K1-K32. 1 plate in pocket. (Evolution of sedimentary basins; Appalachian Basin.) 
B 1839-L. NEW YORK. Stratigraphy of Silurian rocks in Shawangunk Mountain, southeastern New York, including a historical review of nomenclature, by J. B. Epstein. 1993. p. L1L40. 1 plate in pocket. (Evolution of sedimentary basins; Appalachian Basin.)

B 1842-D. Steady movement of landslides in fine-grained soils; a model for sliding over an irregular slip surface, by R. L. Baum, U.S. Geological Survey; and A. M. Johnson, Purdue University. 1993. p. D1-D28.

B 1904-L. MICHIGAN. Thick-skinned, south-verging backthrusting in the Felch and Calumet troughs area of the Penokean Orogen, northern Michigan, by J. S. Klasner, Western Illinois University; and P. K. Sims, U.S. Geological Survey. 1993. p. L1-L28. (Contributions to Precambrian geology of Lake Superior region; edited by P. K. Sims and L. M. H. Carter.)

B 1904-P. MICHIGAN. Geology of volcanic rocks in the south half of the Ishpeming greenstone belt, Michigan, by T. J. Bornhorst and R. C. Johnson, Michigan Technological University. 1993. p. P1-P13. (Contributions to Precambrian geology of Lake Superior region; edited by P. K. Sims and L. M. H. Carter

B 1904-Q. MICHIGAN. Structural geology of parautochthonous and allochthonous terranes of the Penokean Orogeny in upper Michigan; comparisons with northern Appalachian tectonics, by W. J. Gregg, Michigan Technological University. 1993. p. Q1Q28. (Contributions to Precambrian geology of Lake Superior region; edited by P. K. Sims and L. M. H. Carter.)

B 1904-S. The Great Lakes tectonic zone; revisited, by P. K. Sims and W. C. Day. 1993. p. S1-S11. (Contributions to Precambrian geology of Lake Superior region; edited by P. K. Sims and L. M. H. Carter.)

B 1909. Petroleum geology of the Devonian and Mississippian black shale of eastern North America, edited by J. B. Roen, U.S. Geological Survey; and R. C. Kepferle, Eastern Kentucky University. Studies undertaken for the Morgantown Technology Center of the U.S. Department of Energy. 1993. 358 p. 13 plates in separate case. (Chapters A-N are issued as a single volume and are not available separately.)

A. Introductory review; Devonian and Mississippian black shale, eastern North America, by J. B. Roen, U.S. Geological Survey. p. A1-A8.

B. Stratigraphy of Devonian black shales and associated rocks in the Appalachian Basin, by Wallace de Witt, Jr., J. B. Roen, and L. G. Wallace, U.S. Geological Survey. p. B1-B57.

C. New Albany Shale (Devonian and Mississippian) of the Illinois Basin, by N. R. Hasenmueller, Indiana Geological Survey. p. C1-C19.

D. Review and revision of the Devonian-Mississippian stratigraphy in the Michigan Basin, by R. D. Matthews, Chicago. p. D1-D85.

E. Stratigraphy of the Kettle Point Formation (Upper Devonian of southwestern Ontario, Canada); implications for depositional setting and resources potential, by D. J. Russell, BP Resources Canada p. E1-E11.
F. A depositional model and basin analysis for the gas-bearing black shale (Devonian and Mississippian) in the Appalachian Basin, by R. C. Kepferle, Eastern Kentucky University. p. F1F23.

G. Illite crystallinity as an indicator of the thermal maturity of Devonian black shales in the Appalachian Basin, by J. W. Hosterman, deceased. p. G1-G9.

H. Petrography and reservoir geology of Upper Devonian shales, northern Ohio, by R. F. Broadhead, New Mexico Bureau of Mines and Mineral Resources. p. H1-H15.

I. Source rocks and hydrocarbon generation in the New Albany Shale (Devonian-Mississippian) of the Illinois Basin; a review, by R. M. Cluff, The Discovery Group, Denyer. p. I1-I15.

J. Use of formation-density logs to determine organic-carbon content in Devonian shales of the western Appalachian Basin and an additional example based on the Bakken. Formation of the Williston Basin, by J. W. Schmoker, U.S. Geological Survey. p. J1-J14.

K. Structural parameters that affect Devonian shale gas production in West Virginia and eastern Kentucky, by R. C. Shumaker, West Virginia University. p. K1-K38.

L. Production and production controls in Devonian shales, West Virginia, by D. G. Patchen and M. E. Hohn, West Virginia Geological and Economic Survey. p. L1-L28.

M. Detailed study of Devonian black shales encountered in nine wells in western New York State, by A. M. Van Tyne, Van Tyne Consulting, Wellsville, NY. p. M1-M16.

N. Estimates of unconventional natural gas resources of the Devonian shales of the Appalachian Basin, by R. R. Charpentier, Wallace de Witt, Jr., G. E. Claypool, U.S. Geological Survey; L. D. Harris, deceased; R. F. Mast, J. D. Megeath, J. B. Roen, and J. W. Schmoker, U.S. Geological Survey. p. N1N20.

B 1917-L. WYOMING, MONTANA. Sedimentology and depositional history of the lower Paleocene Tullock Member of the Fort Union Formation, Powder River basin, Wyoming and Montana, by J. L. Brown. 1993. p. L1-L42. 3 plates in pocket. (Evolution of sedimentary basins; Powder River basin;)

B 1917-M. WYOMING, MONTANA. Cambrian through Mississippian rocks of the Powder River basin, Wyoming, Montana, and adjacent areas, by D. L. Macke. 1993. p. M1-M174.

B 1917-O. WYOMING. Miocene cooling in the southwestern Powder River basin, Wyoming; preliminary evidence from apatite fission-track analysis, by N. D. Naeser. 1992. p. O1-O17. (Evolution of sedimentary basins; Powder River basin.)

B 1917-P. WYOMING, MONTANA. Depositional history of Triassic rocks in the area of the Powder River basin, northeastern Wyoming and southeastern Montana, by E. A. Johnson. 1993. p. P1-P30. (Evolution of sedimentary basins; Powder River basin

B 1955. VERMONT. Geology, geochemistry, and mineral resource assessment of the Big Branch and Peru Peak wildernesses and the Wilder Mountain Roadless Area, Rutland and Bennington counties, Vermont, by J. D. Peper and E. A. Downie. 1992. 26 p. 4 plates in pocket. 
B 1966. Monitoring volcanoes; techniques and strategies used by the staff of the Cascades Volcano Observatory, 1980-90, edited by J. W. Ewert and D. A. Swanson, U.S. Geological Survey. 1992. $223 \mathrm{p}$

1. A real-time seismic-amplitude measurement system (RSAM), by T. L. Murray and E. T. Endo, U.S. Geological Survey. p. 5-10.

2. A low-data-rate digital telemetry system, by T. L. Murray, U.S. Geological Survey. p. 11-23.

3. Operating low-power telemetry networks in severe environments, by A. B. Lockhart, T. L. Murray, and B. T. Furukawa, U.S. Geological Survey. p. 25-36.

4. A system for acquiring, storing, and analyzing low-frequency time-series data in near-real time, by T. L. Murray, U.S. Geological Survey. p. 37-43.

5. Seismic data-acquisition systems at the Cascades Volcano Observatory, by E. T. Endo and G. M. Smith, U.S. Geological Survey. p. 45-52.

6. Methods used to monitor deformation of the crater floor and lava dome at Mount St. Helens, Washington, by E. Y. Iwatsubo and D. A. Swanson, U.S. Geological Survey. p. 5368.

7. Electronic tiltmeters for volcano monitoring; lessons from Mount St. Helens, by Daniel Dzurisin, U.S. Geological Survey. p. $69-83$.

8. Slope-distance measurements to the flanks of Mount St. Helens, late 1980 through 1989, by E. Y. Iwatsubo, L. J. Topinka, and D. A. Swanson, U.S. Geological Survey. p. 8594.

9. Monitoring radial crack deformation by displacement meters, by E. Y. Iwatsubo, J. W. Ewert, and T. L. Murray. p. 95101.

10. Trilateration and distance-measuring techniques used at Cascades and other volcanoes, by E. Y. Iwatsubo and D. A. Swanson, U.S. Geological Survey. p. 103-114.

11. Installation of bench marks and permanent reflectors for geodetic deformation networks, by $\mathrm{M}$. P. Doukas and J. W. Ewert, U.S. Geological Survey. p. 115-124.

12. Geodetic leveling as a tool for studying restless volcanoes, by Daniel Dzurisin, U.S. Geological Survey. p. 125-134.

13. Using first-order class II geodetic leveling procedures to monitor vertical displacement, by K. M. Yamashita and W. P. Kaiser, U.S. Geological Survey. p. 135-141.

14. Single-setup leveling used to monitor vertical displacement (tilt) on Cascades volcanoes, by K. M. Yamashita, U.S. Geological Survey. p. 143-149.

15. A single-setup trigonometric leveling method for monitoring ground-tilt changes, by J. W. Ewert, U.S. Geological Survey. p. $151-158$.

16. Lake-level monitoring as a tool for studies of crustal deformation, by J. W. Kleinman, U.S. Geological Survey; and P. M. Otway, New Zealand Geological Survey. p. 159-174.
17. Techniques for continuous monitoring of surface water at active volcanoes; examples from Loowit drainage, Mount St. Helens, and Kelut crater lake, Indonesia, by K. A. McGee, A. J. Sutton, D. E. Wieprecht, and M. E. Iven, U.S. Geological Survey. p. $175-179$

18. Fundamental volcanic-gas-study techniques; an integrated approach to monitoring, by A. J. Sutton, K. A, McGee, T. J. Casadevall, and J. B. Stokes, U.S. Geological Survey. p. 181-188.

19. Video surveillance of active volcanoes using slow-scan television, by B. T. Furukawa, T. L. Murray, and K. A. McGee, U.S. Geological Survey. p. 189-194.

20. Basic photography at Mount St. Helens and other Cascades volcanoes, by L. J. Topinka, U.S. Geological Survey. p. $195-$ 217.

21. The importance of field observations for monitoring volcanoes, and the approach of "keeping monitoring as simple as practical", by D. A. Swanson, U.S. Geological Survey. p. 219-223.

B 1968. ALASKA. Interpretation of reconnaissance geochemical data from the Port Moller, Stepovak Bay, and Simeonof Island quadrangles, Alaska Peninsula, Alaska, by J. G. Frisken. 1992. 47 p. 3 plates in pocket.

B 1976. Stratigraphy of the late Proterozoic Murdama Group, Saudi Arabia, by R. C. Greene. 1993. 59 p. 2 plates in pocket.

B 1979. TENNESSEE, NORTH CAROLINA, SOUTH CAROLINA. Bedrock geology and mineral resources of the Knoxville $1^{\circ} \times 2^{\circ}$ Quadrangle, Tennessee, North Carolina, and South Carolina, by G. R. Robinson, F. G. Lesure, J. I. Marlowe, I, N. K. Foley and S. H. Clark. 1992.73 p. 2 plates in pocket.

B 1981. WEST VIRGINIA, VIRGINIA. Geomorphic studies of the storm and flood of November 3-5, 1985, in the upper Potomac and Cheat River basins in West Virginia and Virginia, edited by R. B. Jacobson, U.S. Geological Survey. 1993. 187 p. 3 plates in pocket. (Chapters A-E are issued as a single volume and are not available separately.)

A. Introduction; Geomorphic studies of the storm and flood of November 3-5, 1985, in the upper Potomac and Cheat River basins, by R. B. Jacobson, U.S. Geological Survey. p. A1A3.

B. Meteorology of the storm of November 3-5, 1985, in West Virginia and Virginia, by S. J. Colucci, Cornell University; R. B. Jacobson, U.S. Geological Survey; and Steven Greco, University of Virginia. p. B1-B31.

C. Landslides triggered by the storm of November 3-5, 1985 , Wills Mountain Anticline, West Virginia and Virginia, by R. B. Jacobson, J. P. McGeehin, E. D. Cron, U.S. Geological Survey; C. E. Carr, Carleton College; J. M. Harper, and A. D. Howard, University of Virginia. p. C1-C33.

D. Depositional aspects of the November 1985 flood on Cheat River and Black Fork, West Virginia, by J. S. Kite and R. C. Linton, West Virginia University. p. D1-D24.

E. Flood hydrology and geomorphic effects on river channels and flood plains; the flood of November 4-5, 1985, in the South Branch Potomac River basin of West Virginia, by A. J. Miller, 
University of Maryland; and D. J. Parkinson, Johns Hopkins University. p. E1-E96.

B 1988-C. NEVADA. Mesozoic and Tertiary rocks near Elko, Nevada; evidence for Jurassic to Eocene folding and low-angle faulting, by K. B. Ketner and A. G. Alpha. 1992. p. C1-C13. (Evolution of sedimentary basins, eastern Great Basin; H. E. Cook and C. J. Potter, project coordinators.)

B 1988-D. NEVADA. Paleozoic and Mesozoic rocks of Mount Ichabod and Dorsey Canyon, Elko County, Nevada; evidence for post-Early Triassic emplacement of the Roberts Mountains and Golconda allochthons, by K. B. Ketner, B. L. Murchey, R. G. Stamm and B. R. Wardlaw. 1993. p. D1-D12. (Evolution of sedimentary basins, eastern Great Basin; H. E. Cook and C. J. Potter, project coordinators.)

B 1988-E. NEVADA. Isolated carbonate bodies composed of stacked debris-flow deposits on a fine-grained carbonate lower slope of Devonian age, Antelope. Peak, Elko County, Nevada, by P. M. Sheehan, Milwaukee Public Museum; J. M. Pandolfi, Australian Institute of Marine Science; and K. B. Ketner, U.S. Geological Survey. 1993. p. E1-E12. (Evolution of sedimentary basins, eastern Great Basin; H. E. Cook and C. J. Potter, project coordinators.)

B 1988-F. NEVADA. Coralliferous carbonate shelves of Mississippian age, west side of Antler Orogen, central Nevada, by W. J. Sando, U.S. Geological Survey; with an appendix on Foraminifera and algae, by B. L. Mamet, Université de Montréal. 1993. p. F1-F29. (Evolution of sedimentary basins, eastern Great Basin; H. E. Cook and C. J. Potter, project coordinators.)

B 1988-G. NEVADA. Upper Devonian to Upper Mississippian strata of the Antler foreland in the Leppy Hills, easternmost northern Nevada, by K. M. Nichols and N. J. Silberling. 1993. p. G1-G13. (Evolution of sedimentary basins, eastern Great Basin; H. E. Cook and C. J. Potter, project coordinators.)

B 1989-D. Paleohydrology of the central United States, by D. G. Jorgensen. 1992. p. D1-D32. (Strategic and critical minerals in the Midcontinent region, United States; edited by W. C. Day and D. E. Lane.)

B 1989-E. Petrography and correlation of Precambrian clastic sedimentary rocks associated with the Midcontinent Rift System, by Pieter Berendsen, Kansas Geological Survey; and Andrzej Barczuk, University of Warsaw, Poland. 1993. p. E1-E20. (Strategic and critical minerals in the Midcontinent region, United States; edited by W. C. Day and D. E. Lane.)

B 1993. MONTANA. Rocks and structure of the north-central part of the Anaconda Range, Deer Lodge and Granite counties, Montana, by D. J. Lidke and C. A. Wallace. 1992.31 p. 1 plate in pocket.

B 1994. PENNSYLVANIA. Geology of the New Tripoli Quadrangle, Lehigh, Berks, Schuylkill, and Carbon counties, Pennsylvania, by J. B. Epstein and.P. T. Lyttle. Prepared in cooperation with the Pennsylvania Department of Environmental Resources, Bureau of Topographic and Geologic Survey. 1993. 19 p. 1 plate in pocket.

B 1995-C. CALIFORNIA. Cooccurrence of Fe-, Fe-Ca-, and Caphosphate minerals in concretions within the Monterey Formation; a record of uplift of the Santa Maria Basin, California, by D. Z.
Piper, C. M. Isaacs, and M. D. Medrano. 1993. p. C1-C15. (Evolution of sedimentary basins/onshore oil and gas investigations, Santa Maria Province; edited by M. A. Keller.)

B 1996. ALASKA. Redoubt Volcano, Southern Alaska; a hazard assessment based on eruptive activity through 1968 , by A. B. Till, M. E. Yount and J. R. Riehle. 1993. 19 p. 1 plate in pocket.

B 1998. NEVADA. The Beowawe Geysers, Nevada, before geothermal development, by D. E. White. 1992.25 p.

B 2000-E. UTAH. Sedimentologic analysis of cores from the Upper Triassic Chinle Formation and the Lower Permian Cutler Formation, Lisbon Valley, Utah, by R. F. Dubiel and J. L. Brown. 1993. p. E1-E40. (Evolution of sedimentary basins, Paradox Basin; A. C. Huffman, Jr., project coordinator.)

B 2002. Submarine landslides; selected studies in the U.S. Exclusive Economic Zone, edited by W. C. Schwab, H. J. Lee, and D. C. Twichell, U.S. Geological Survey. 1993. 204 p. 1 plate in pocket.

Submarine landslides; an introduction, by H. J. Lee, W. C. Schwab, and J. S. Booth, U.S. Geological Survey. p. 1-13.

U.S. Atlantic continental slope landslides; their distribution, general attributes, and implications, by J. S. Booth, D. W. O'Leary, Peter Popenoe, and W. W. Danforth, U.S. Geological Survey. p. 14-22.

Submarine mass movement, a formative process of passive continental margins; the Munson-Nygren landslide complex and the Southeast New England landslide complex, by D. W. O'Leary, U.S. Geological Survey. p. 23-39.

The Cape Fear landslide; slope failure associated with salt diapirism and gas hydrate decomposition, by Peter Popenoe, E. A. Schmuck, and W. P. Dillon, U.S. Geological Survey. p. 4053.

Ancient crustal fractures control the location and size of collapsed blocks at the Blake Escarpment, east of Florida, by W. P. Dillon, J. S. Risch, K. M. Scanlon, P. C. Valentine, U.S. Geological Survey; and Q. J. Huggett, Institute of Oceanographic Sciences, England. p. 54-59.

Tectonic and stratigraphic control on a giant submarine slope failure; Puerto Rico insular slope, by W. C. Schwab, W. W. Danforth, and K. M. Scanlon, U.S. Geological Survey. p. 6068.

Slope failure of carbonate sediment on the West Florida Slope, by D. C. Twichell, P. C. Valentine, and L. M. Parson, Institute of Oceanographic Sciences, England. p. 69-78.

Slope failures in an area of high sedimentation rate; offshore Mississippi River delta, by J. M. Coleman, Louisiana State University; D. B. Prior, Geological Survey of Canada; L. E. Garrison, Texas A\&M University; and H. J. Lee, U.S. Geological Survey. p. 79-91.

Salt tectonics and slope failure in an area of salt domes in the northwestern Gulf of Mexico, by B. A. McGregor, U.S. Geological Survey; R. G. Rothwell, N. H. Kenyon, Institute of Oceanographic Sciences, England; and D. C. Twichell, U.S. Geological Survey. p. 92-96. 
Slope stability in regions of sea-floor gas hydrate; Beaufort Sea continental slope, by R. E. Kayen and H. J. Lee, U.S. Geological Survey. p. 97-103.

Mass movement related to large submarine canyons along the Beringian margin, Alaska, by P. R. Carlson, H. A. Karl, B. D. Edwards, J. V. Gardner, and R. Hall, U.S. Geological Survey. p. 104-116.

Comparison of tectonic and stratigraphic control of submarine landslides on the Kodiak upper continental slope, Alaska, by $\mathbf{M}$. A. Hampton, U.S. Geological Survey. p. 117-122.

Submarine landslides that had a significant impact on man and his activities; Seward and Valdez, Alaska, by M. A. Hampton, U.S. Geological Survey; R. W. Lemke, Lakewood, CO; and H. W. Coulter, Washington, DC. p. 123-134.

Processes controlling the style of mass movement in glaciomarine sediment; northeastern Gulf of Alaska, by W. C. Schwab and H. J. Lee, U.S. Geological Survey. p. 135-142.

Liquefaction of continental shelf sediment; the Northern California earthquake of 1980 , by M. E. Field, U.S. Geological Survey. p. 143-150.

A submarine landslide associated with shallow sea-floor gas and gas hydrates off Northern California, by M. E. Field and J. H. Barber, Jr., U.S. Geological Survey. p. 151-157.

Sur submarine landslide, a deep-water sediment slope failure, by C. E. Gutmacher and W. R. Normark, U.S. Geological Survey. p. 158-166.

Seismically induced mudflow in Santa Barbara Basin, California, by B. D. Edwards, H. J. Lee, and M. E. Field, U.S. Geological Survey. p. 167-175.

Submarine landslides in a basin and ridge setting, Southern California, by M. E. Field and B. D. Edwards, U.S. Geological Survey. p. 176-183.

Giant volcano-related landslides and the development of the Hawaiian Islands, by W. R. Normark, J. G. Moore, and M. E. Torresan, U.S. Geological Survey. p. 184-196.

Submarine slope failures initiated by Hurricane Iwa, Kahe Point, Oahu, Hawaii, by W. R. Normark, U.S. Geological Survey; Pat Wilde, University of California at Berkeley; J. F. Campbell, Seafloor Surveys International, Honolulu, HI; T. E. Chase, U.S. Geological Survey; and Bruce Tsutsui, University of Hawaii. p. 197-204.

B 2003. ALASKA. Geochemical survey of the Baird Mountains $1^{\circ} \times 3^{\circ}$ Quadrangle, Northwest Alaska, by P. F. Folger, R. J. Goldfarb and B. A. Cieutat. 1992.77 p. 1 plate in pocket.

B 2005. TENNESSEE, NORTH CAROLINA. Geology and mineral resource potential of the Chattanooga $1^{\circ} \times 2^{\circ}$ Quadrangle, Tennessee and North Carolina; a preliminary assessment, by S. H. Clark, G. T. Spanski, D. G. Hadley and A. H. Hofstra. 1993. 35 p. 2 plates in pocket.

B 2006. HAWAII. Isoseismal maps, macroseismic epicenters, and estimated magnitudes of historical earthquakes in the Hawaiian Islands, by Max Wyss, University of Colorado; and R. Y. Koyanagi, U.S. Geological Survey. 1992. 93 p.
B 2011. NEVADA, UTAH. Heterogeneous Neogene strain and its bearing on horizontal extension and horizontal and vertical contraction at the margin of the extensional orogen, Mormon Mountains area, Nevada and Utah, by R. E. Anderson and T. P. Barnhard. 1993. 43 p. 5 plates in pocket.

$B$ 2013. Industrial minerals in the Basin and Range region; workshop proceedings, compiled and edited by E. W. Tooker, U.S. Geological Survey. Prepared in cooperation with the U.S. Bureau of Mines, Nevada Bureau of Mines and Geology, Utah Geological Survey, and Idaho Geological Survey. 1992. $132 \mathrm{p}$.

Introduction, by E. W. Tooker, U.S. Geological Survey. p. $1-4$.

Welcome, by M. L. Allison, Utah Geological Survey. p. 4.

Status of industrial-mineral resources, moderated by E. H. Bennett, Idaho Geological Survey. p. 4-34.

Industrial-mineral-supply/demand perspectives for Idaho, Nevada, Utah, and the nation, with a focus on construction materials, by A. F. Barsotti, V. V. Tepordei, and G. T. Austin, U.S. Bureau of Mines. p. 5-11.

Industrial rock and mineral production in Utah, 1990, by B. T. Tripp, Utah Geological Survey. p. 11-22.

Industrial minerals in Nevada, by S. B. Castor, Nevada Bureau of Mines and Geology. p. 22-28.

Industrial minerals in Idaho, by E. H. Bennett, Idaho Geological Survey. p. 28-34.

Future needs and problems in the Basin and Range region, moderated by B. W. Buck, J.B.R. Consultants Group, Salt Lake City, UT. p. 34-48.

Growth of population and limitations on resource availability, by Robert Buchanan, Salt Lake City Corp. p. 35-39.

Environmental concerns for land, air, and water, by James Scherer, U.S. Environmental Protection Agency. p. 39-43.

Interstate activity in the formulation of regulations governing mine waste, by D. R. Nielson, Utah Department of Natural Resources. p. 44-47.

A perspective on regional industrial-mineral problems, moderated by J. E. Christensen, Utah Mining Association. p. 48-68.

Economic problems of industrial-mineral mining, convened by C. W. Berry, University of Utah. p. 48-57.

Industrial-mineral marketing, by L. I. Weiner, American Gilsonite Co., Salt Lake City, UT. p. 48-52.

The art of financing an industrial-mineral enterprise, by R. W. Bernick, Sr., First Interstate Bank of Utah. p. 52-53.

Problems of business deals, taxes, and economic analysis, by $\mathrm{C}$. W. Berry, University of Utah. p. 53-57.

Environmental and support-system problems for industrial-mineral mining, convened by B. W. Buck, J.B.R. Consultants Group, Salt Lake City, UT. p. 57-58.

Land-access issues from the Federal perspective, by S. J. Brooks, U.S. Bureau of Land Management. p. 58-59. 
Problems of mine permitting in the Great Basin, by G. M. Eurick, American Barrick Mining Co., Tooele, UT. p. 59-61.

Environmental problems in planning mining-support systems, by C. L. Smith, Dames and Moore. p. 61-68.

Industrial minerals from the perspective of government, moderated by M. L. Allison, Utah Geological Survey. p. 68-73.

Politics and industrial minerals, by S. M. Matheson, former governor of Utah. p. 69-73.

Expanding industrial-mineral opportunities in the Basin and Range region, moderated by $R$. C. Bradt, University of Nevada. p. 73-96.

Potential for the use of industrial minerals in advanced-material applications, by G. R. Hyde, U.S. Bureau of Mines. p. 73-76.

USBM research activities, by G. R. Hyde, U.S. Bureau of Mines. p. 76-77.

USGS industrial-mineral-research activities, by M. P. Foose, U.S. Geological Survey. p. 77-78.

Research potential of the state geological surveys and universities, by J. G. Price, Nevada Bureau of Mines and Geology. p. 79-81.

New-market development; how it has been done, moderated by R. C. Bradt, University of Nevada. p. 84-90.

Developing new markets for beryllium, a high-value specialty material, by T. B. Parsonage, Brush Wellman, Elmore, $\mathrm{OH}$. p. 84-87.

New-product development from low-value material by the Idaho Quartzite Corporation, by Don Seehusen, Idaho Quartzite Corp. p. 87-90.

Public education through public-relations expertise and communications technology, by John Marz, Dunn-Draper-Glen-Marz, Reno, NV. p. 90-96.

Future actions to meet industrial-mineral needs, moderated by $\mathrm{J}$. G. Price, Nevada Bureau of Mines and Geology. p. 96-120.

Industry perspective for high-volume, low-value materials, by Douglas Clark, Monroc, Salt Lake City, UT. p. 96-98.

Industry perspective for low-volume, high-value commodities, by J. R. Harmon, Standard Industrial Minerals, Reno, NV. p. 98-99.

The land planner's perspective; local-government regulation of mining activities, by Michael Harper, Washoe County Department of Comprehensive Planning. p. 99-103.

Proposal for organizing industrial-mineral coalitions in the Western States, by M. P. Foose, U.S. Geological Survey. p. 104105.

The Interstate Mining Compact Commission, an established regional organization, by G. E. Conrad, Interstate Mining Compact Commission. p. 105-110.

State geologists' views about the concept of state or regional industrial-minerals coalitions, by J. G. Price, Nevada Bureau of Mines and Geology. p. 110-111.
Some additional observations about coalitions, by E. H. Bennett, Idaho Geological Survey. p. 111-112.

A Utah perspective on the coalition proposal, by M. L. Allison, Utah Geological Survey. p. 112-113.

Summary of the discussion about the creation of an industrialminerals coalition in the Western States, by E. W. Tooker, U.S. Geological Survey. p. 118-120.

Closing comments, by M: W. Foose, U.S: Geological Survey, p. $120-121$.

B 2014. CALIFORNIA. Petrology, mineralogy, and geochemistry of the Lower Coon Mountain Pluton, Northern California, with respect to the distribution of platinum-group elements, by $\mathrm{N}$. J Page, Floyd Gray and Andrew Griscom. 1993. 75 p. 1 plate in pocket.

B 2015. CALIFORNIA. Stratigraphy and structure of Paleozoic outer continental-margin rocks in Pilot Knob Valley, north-central Mojave Desert, California, by M. D. Carr, A. G. Harris, F. G. Poole and R. J. Fleck. 1992. 33 p. 1 plate in pocket.

B 2017. SOUTH CAROLINA. Specification of source zones, recurrence rates, focal depths, and maximum magnitudes for earthquakes affecting the Savannah River Site in South Carolina, by G. A. Bollinger, U.S. Geological Survey and Seismological Observatory, Virginia Polytechnic Institute and State University. 1992. $57 \mathrm{p}$.

B 2019. NEVADA, CALIFORNIA: Geology and mineral resources of the Reno $1^{\circ}$ by $2^{\circ}$ Quadrangle, Nevada and California, by D. A. John, J. H. Stewart, J. E. Kilburn, N. J. Silberling and L. C. Rowan. 1993.65 p. 4 plates in pocket.

B 2021-C. ARIZONA. Chiricahua Peak Quadrangle, Cochise County, Arizona; analytic data and geologic sample catalog, by E. A. du Bray, D. B. Yager and J. S. Pallister. 1993. p. C1-C22. 1 plate in pocket. (Geologic sampling of the Chiracahua Mountains, Arizona.)

B 2024. Shorter contributions to paleontology and stratigraphy, 1992, edited by W. J. Sando, U.S. Geological Survey. 1993. 43 p. (Chapters A-B are issued as a single volume and are not available separately.)

A. Upper Cretaceous heteromorph ammonites from the Baculites compressus Zone of the Pierre Shale in north-central Colorado, by W. A. Cobban, U.S. Geological Survey; W. J. Kennedy, Oxford University Museum; and G. R. Scott, Lakewood, CO. p. A1-A11.

B. The Siphonophrentidae (rugose corals, Devonian) of eastern North America, by W. A. Oliver, Jr., U.S. Geological Survey, U.S. National Museum of Natural History. p. B1-B32.

B 2025. NEW MEXICO, COLORADO. Guide to the development and application of geographic information systems for sedimentary basin analysis; case study for the San Juan Basin, New Mexico and Colorado, by B. M. Miller. 1992. 37 p.

B 2029. VIRGINIA. The volcanogenic Mount Rogers Formation and the overlying glaciogenic Konnarock Formation; two late Proterozoic units in southwestern Virginia, by D. W. Rankin. 1993. $26 \mathrm{p}$. 
B 2030. SOUTH CAROLINA. Biostratigraphy of the Middendorf Formation (Upper Cretaceous) in a corehole at Myrtle Beach, South Carolina, by G. S. Gohn, H. J. Dowsett and N. F. Sohl. Prepared in cooperation with the South Carolina Water Resources Commission. 1992. $12 \mathrm{p}$.

B 2032-A. Geologic investigations of the 1988 Tennant Creek, Australia, earthquakes; implications for paleoseismicity in stable continental regions, by A. J. Crone, M. N. Machette, U.S. Geological Survey; and J. R. Bowman, Australian National University. Paleoseismological studies in Australia. 1992. p. A1-A51. 2 plates in pocket. (Paleoseismological studies in Australia.)

B 2032-B. Geologic investigations of the 1986 Marryat Creek, Australia, earthquake; implications for paleoseismicity in stable continental regions, by M. N. Machette, A. J. Crone, U.S. Geological Survey; and J. R. Bowman, Australian National University. 1993. p. B1-B28. 2 plates in pocket. (Paleoseismological studies in Australia.)

B 2034-A. Petroleum exploration plays and resource estimates, 1989, onshore United States; Region 1, Alaska; Region 2, Pacific Coast, edited by R. B. Powers. 1993. p. A1-A138.

Introduction, by R. B. Powers. p. A1-A5.

Region 1, Alaska; geologic framework, by R. B. Powers. p. A6-A7.

Arctic Coastal Plain province (058), by K. J. Bird. p. A8-A25.

Northern Foothills province (059), by K. J. Bird. p. A26-A31.

Southern Foothills-Brooks Range province (060), by K. J. Bird. p. A32-A37.

Kandik province (061), by L. B. Magoon. p. A38-A41.

Alaska interior (062), Kandik (part) (061), Interior Lowlands (063), and Copper River basin (066) provinces, by L. B. Magoon. p. A42-A45.

Bristol Basin province (064), by L. B. Magoon. p. A46-A49. Hope Basin province (065), by M. A. Fisher. p. A50-A51.

Cook Inlet province (067), by L. B. Magoon. p. A52-A57.

Alaska Peninsula province (068), by L. B. Magoon and Hugh McLean. p. A58-A59.

Gulf of Alaska province (069), by T. R. Bruns. p. A60-A63.

Kodiak Island province (070), by M. A. Fisher. p. A64-A65.

Southeastern Alaska province (071), by T. R. Bruns. p. A66.

Region 2, Pacific Coast; geologic framework, by R. B. Powers. p. A70-A71.

Western Oregon-Washington province (072), by R. G. Stanley. p. A72-A75.

Sacramento Basin province (073), by L. A. Beyer. p. A76A83.

San Joaquin Basin province (074), by L. A. Beyer. p. A84A99.

Los Angeles Basin province (075), by L. A. Beyer. p. A100A107.
Ventura Basin province (076), by M. A. Keller. p. A108A113.

Santa Maria Basin province (077), by C. M. Isaacs. p. A114A117.

Central Coastal basins province (078), by C. M. Isaacs. p. A118-A121.

Sonoma-Livermore basins province (079), by Hugh McLean. p. A122-A125.

Humboldt Basin province (080), by Hugh McLean. p. A126A129.

Eastern Oregon-Washington province (081), by M. E. Tennyson. p. A130-A133.

Eastern California province (081A), by H. E. Cook. p. A134. A135.

B 2035. COLORADO. Mineral resource potential and geology of the White River National Forest and the Dillon Ranger District of the Arapaho National Forest, Colorado, by M. I. Toth, A. B. Wilson, T. M. Cookro, Viki Bankey, G. K. Lee, and J. E. Case, U.S. Geological Survey; with a section on Salable commodities, by J. S. Dersch, U.S. Forest Service. 1993. 117 p. 4 plates in pocket.

B 2036. Late Pliocene-early Pleistocene ecologic changes in the Arctic Ocean borderland, by C. A. Repenning and E. M. Brouwers. 1992. $37 \mathrm{p}$.

B 2037. Allophaiomys and the age of the Olyor Suite, Krestovka sections, Yakutia, by C. A. Repenning. 1992.95 p.

B 2038. OREGON. Age and origin of the fluvial terraces in the central Coast Range, western Oregon, by S. F. Personius. 1993. 56 p. 4 plates in pocket.

B 2039. Advances related to United States and international mineral resources; developing frameworks and exploration technologies, edited by R. W. Scott, Jr., P. S. Detra, and B. R. Berger, U.S. Geological Survey. 1993. 277 p. 1 plate in pocket.

USGS; meeting our Nation's need for mineral resources through applied, basic, and technology research, by B. R. Berger and P. S. Detra, U.S. Geological Survey. p. 1-3.

A. Tertiary calderas and regional extension of the east-central part of the Tintic-Deep Creek mineral belt, eastern Great Basin, Utah, by D. B. Stoeser, U.S. Geological Survey. p. 5-23.

B. Basement structure in the Railroad Valley-Grant Range region, east-central Nevada, from interpretation of potential-field anomalies, by H. R. Blank, Jr., U.S. Geological Survey. p. 25-30.

C. Magnetic interpretation of a mineralized shear zone in the southern part of the Idaho Batholith, by M. D. Kleinkopf, U.S. Geological Survey. p. 31-33.

D. Role of lithospheric flexure and plate convergence in the genesis of some mississippi-valley-type zinc deposits in the Appalachians, by D. C. Bradley, U.S. Geological Survey. p. 35-43. 
E. $\mathrm{Rb}-\mathrm{Sr}$ isotopic redistribution and character of hydrothermal fluids in the Catheart Mountain Cu-Mo deposit, Maine, by R. A. Ayuso and N. K. Foley, U.S. Geological Survey. p. 45-57.

F. Structure and origin of the Ely copper deposit, east-central Vermont, by T. W. Offield, J. F. Slack, U.S. Geological Survey; and S. A. Wittinbrink, Northwestern University. p. 5968.

G. Gold, silver, and base metal epithermal mineral deposits around the Gulf of California, Mexico; relationship between mineralization and major structures, by J. G. Staude, U.S. Geological Survey. p. 69-78.

H. Cenozoic geology and mineral deposits of the Berenguela District, northwestern Bolivia, by A. R. Wallace, R. F. Hardyman, R. M. Tosdal, U.S. Geological Survey; Nestor Jimenez, J. L. Lizeca, and Fernando Murillo, Servicio Geológico de Bolivia. p. 79-86.

I. K-Ar ages of Bolivian Tertiary polymetallic vein deposits, by S. D. Ludington, E. H. McKee, and N. B. Shew, U.S. Geological Survey. p. 87-93.

J. Gold and silver in acid-sulfate alteration and quartz-sericitepyrite stockworks, La Española Prospect, northwestern Altiplano, Bolivia, by A. H. Hofstra, R. F. Hardyman, U.S. Geological Survey; Luis Barrera, and Orlando Sanjines, Servicio Geológico de Bolivia. p. 95-106.

K. Mineralogy and chemistry of gold-associated skarn from Nambija, Zamora Province, Ecuador; a reconnaissance study, by J. M. Hammarstrom, U.S. Geological Survey. p. 107-118.

L. Geochronology and geochemistry of the Ladolam gold deposit, Lihir Island, and gold deposits and volcanoes of Tabar and Tatau, Papua New Guinea, by J. J. Rytuba, E. H. McKee, and D. P. Cox, U.S. Geological Survey p. 119-126.

M. Volatiles in clay minerals from sedimentary and hydrothermal environments; a potential petrologic and minerals-assessment tool?, by C. G. Whitney and G. P. Landis, U.S. Geological Survey. p. 127-140.

N. Mapping minerals with imaging spectroscopy, by R. N. Clark, C. A. Swayze, and A. J. Gallagher, U.S. Geological Survey. p. 141-150.

O. Satellite image processing for enhanced spectral discrimination and interpretability, by D. H. Knepper, Jr., U.S. Geological Survey. p. 151-153.

P. ${ }^{40} \mathrm{Ar} /{ }^{39} \mathrm{Ar}$ studies of fluid inclusions in vein quartz from Battle Mountain, Nevada, by E. H. McKee, J. E. Conrad, B. D. Turrin, and T. G. Theodore, U.S. Geological Survey. p. 155-165.

Q. Heavy minerals at the Fall Zone; a theoretical model of grain size, density, and gradient, by C. E. Larsen, U.S. Geological Survey. p. $167-180$.

R. Use of geochemical surveys in Ti-Hf-REE-Th-U placer exploration; a Mid-Atlantic-states example, by A. E. Grosz, U.S. Geological Survey. p. 181-188.

S. The effects of hydrothermally altered bedrock on natural forest vegetation in the Snow Camp-Saxapahaw area, North Carolina, and the resulting expressions in Landsat TM imagery, by Alba Payás, Servei Geológic de Catalunya, Spain; R. G. Schmidt, U.S. Geological Survey; and Andreu Bonet, University of Barcelona, Spain. p. 189-200.

T. Aeromagnetic survey of north-central Minnesota, by R. J. Horton, W. C. Day, and R. E. Bracken, U.S. Geological Survey. p. 201-204.

U. Mineralogic and fluid-inclusion studies of the Pea Ridge iron-rare-earth-element deposit, Southeast Missouri, by G. B. Sidder, W. C. Day, U.S. Geological Survey; L. M. Nuelle, Doe Run Co., Viburnum, MO; C. M. Seeger, and E. B. Kisvarsanyi, Missouri Department of Natural Resources. p. 205-216.

V. Mineral resource potential of the White River National Forest and the Dillon Ranger District of the Arapaho National Forest, Colorado, by M. I. Toth, A. B. Wilson, T. M. Cookro, Viki Bankey, G. K. Lee, U.S. Geological Survey; and J. S. Dersch, U.S. Forest Service. p. 217-232.

W. Geophysical studies of the White River National Forest, northwestern and central Colorado, by Viki Bankey, U.S. Geological Survey. p. 233-236.

$X$. Locating buried conductive material along the Getchell Trend, Osgood Mountains, Nevada; implications for gold exploration and the carbon-gold association(?), by V. J. S. Grauch and D. B. Hoover, U.S. Geological Survey. p. 237-244.

Y. Gold in Devonian carbonate rocks at Cedar Peak, southern Snake Mountains, northeastern Nevada, by C. H. Thorman and W. E. Brooks, U.S. Geological Survey. p. 245-261.

Z. Occurrences of native gold containing silver, mercury, copper, and palladium in Lemhi County, east-central Idaho, by G. A. Desborough, W. H. Raymond, and J. M. Nishi, U.S. Geological Survey. p. 263-273.

AA. The importance of source rocks in formation of metallicsulfide ore deposits, by B. R. Doe, U.S. Geological Survey. p. 275-277.

B 2042-C. ARIZONA. Structural context of mid-Tertiary mineralization in the Mammoth and San Manuel districts, southeastern Arizona, by E. R. Force and L. J. Cox. 1992. p. C1-C28. 1 plate in pocket. (Mineral resource studies along the Sierrita-Mogollon transect, Arizona-New Mexico.)

B 2043. VERMONT. Landslide hazards in Vermont, by C. A. Baskerville, F. T. Lee, U.S. Geological Survey; and C. A. Ratté, Vermont State Geologist. Prepared in cooperation with the Vermont Geological Survey. 1993. 23 p.

B 2046. The USGS reference sample Devonian Ohio Shale SDO-1, edited by J. S. Kane, U.S. Geological Survey. 1993. 65 p.

A. Statistical treatment of contributed data in the derivation of recommended concentrations for Devonian Ohio Shale SDO-1, by J. S. Kane, U.S. Geological Survey. p. A1-A32.

B. Determination of major and 11 trace elements (XRF), gold (AAS), carbon and sulfur (COUL) in USGS Devonian Ohio Shale SDO-1, by Otmar Spies, Bernhard Stribrny, Josef Konopasek, and Hans Urban, Frankfurt University, Germany. p. B1-B7. 
C. Inductively coupled plasma determination of nine rare earth elements in the USGS Devonian Ohio Shale SDO-1, by Iwan Roelandts, University of Liege, Belgium. p. C1-C6.

D. Instrumental neutron activation analysis of Devonian Ohio Shale SDO-1. by G. A. Wandless, U.S. Geological Survey. p. D1-D5.

E. Relation between volatile components and loss on ignition as applied to the analysis of USGS reference Devonian Ohio Shale SDO-1 and rare earth element analyses, by Miroslav Huka and Ivan Rubeska, Geological Survey of Prague, Czechoslovakia. p. E1-E5.

F. A study to determine sources of interlaboratory variability in measured loss on ignition (LOI) for Devonian Ohio Shale SDO1, by J. S. Kane and C. J. Skeen, U.S. Geological Survey. p. F1-F9.

G. Analysis of SDO-1 pressed powder pellets by X-ray fluorescence; a note of caution, by O. C. Kopp and F. C. Furman, University of Tennessee. p. G1.

B 2048. Object-oriented expert systems and their applications to sedimentary basin analysis, by B. M. Miller. 1993. $31 \mathrm{p}$.

B 2050. Comparison of the Cretaceous-Tertiary boundary impact events and the 0.77-Ma Australasian tektite event; relevance to mass extinction, by E. C. Chao. 1993. 22 p.

B 2051. WYOMING. Coastal sedimentation along a segment of the interior seaway of North America, Upper Cretaceous Baxter Shale, and Blair and Rock Springs formations, Rock Springs Uplift, Southwest Wyoming, by H. W. Roehler. 1993. 31 p.

B 2052. NEVADA. The Seaman volcanic center; a rare middle Tertiary stratovolcano in southern Nevada, by E. A. du Bray. 1993. $19 \mathrm{p}$.

B 2054. OREGON. Hydrothermal alteration in the Mount Hood area, Oregon, by K. E. Bargar, T. E. Keith and M. H. Beeson. 1993. $70 \mathrm{p}$.

B 2061-A. COLORADO, NEW MEXICO. Distribution and properties of clinoptilolite-bearing tuffs in the Upper Jurassic Morrison Formation on the Ute Mountain Ute Reservation, southwestern Colorado and northwestern New Mexico, by P. L. Hansley and R. A. Sheppard. Prepared in cooperation with the Ute Mountain Ute Tribe and the U.S. Bureau of Indian Affairs. 1993. p. A1A11. (Geologic studies of the Ute Mountain Ute Indian Reservation.)

B 2065. ${ }^{40} \mathrm{Ar} /{ }^{39} \mathrm{Ar}$ age spectra and total-fusion ages of tektites from Cretaceous-Tertiary boundary sedimentary rocks in the Beloc Formation, Haiti, by G. B. Dalrymple, G. A. Izett, L. W. Snee and J. D. Obradovich. 1993. 20 p.

\section{WATER-SUPPLY PAPERS}

Water-supply papers include reports on the geology, hydrology, quality, recoverability, and utilization of water resources. They include also several series of statistical reports on streamflow, floods, ground-water levels, and water quality.

W 1536-C. A simple method for determining specific yield from pumping tests, by L. E. Ramsahoye and S. M. Lang. Prepared in cooperation with the New Jersey Department of Conservation and Economic Development. 1961 (1993). 46 p. (Ground-water hydraulics.) (Reprint.)

W 1536-G. Constant-head pumping test of a multiaquifer well to determine characteristics of individual aquifers, by G. D. Bennett and E. P. Patten, Jr. 1962 (1992). p. 181-203. (Ground-water hydraulics.) (Reprint.)

W 1619-U. Methods of measuring soil moisture in the field, by A. I. Johnson. 1962 (1992). p. U1-U25. (Contributions to the hydrology of the United States.) (Reprint.)

W 2220. Basic ground-water hydrology, by R. C. Heath. Prepared in cooperation with the North Carolina Department of Natural Resources and Community Development. 1983 (1993). 84 p. (Reprint.)

W 2339. Guide for selecting Manning's roughness coefficients for natural channels and flood plains, by G. J. Arcement, Jr. and V. R. Schneider. Prepared in cooperation with the U.S. Department of Transportation, Federal Highway Administration. 1989. 38 p. (Reprint.)

W 2340. Selected papers in the hydrologic sciences, 1988-92, edited by Seymour Subitzky, U.S. Geological Survey. 1992. 207 p. (Separate papers are not available.)

Comparisons of ground-water quality in selected land use areas, Central Florida, by A. T. Rutledge, U.S. Geological Survey. p. $1-7$.

Quantification of natural ground-water evapotranspiration in Smith Creek valley, Lander County, Nevada, by L. B. Hines, U.S. Geological Survey. p. 9-20.

Climatological and hydrological factors affecting the Lake Thompson chain of lakes in eastern South Dakota, by D. S. Hansen and W. A. Miller, U.S. Geological Survey. p. 21-38.

Automatic system for measuring and recording fluorometry data from multiple sources, South Cascade Glacier, Washington, by A. G. Fountain, U.S. Geological Survey. p. 39-49.

Model analysis of hydraulic properties of a leaky aquifer system, Sarasota County, Florida, by C. B. Hutchinson and J. T. Trommer, U.S. Geological Survey. p. 49-62.

Maximizing sustainable ground-water withdrawals; comparing accuracy and computational requirements for steady-state and transient digital modeling approaches, by R. C. Peralta, Utah State University; R. R. A. Cantiller, University of Arkansas; and G. L. Mahon, U.S. Geological Survey. p. 63-74.

Hydrology and water-level fluctuations of Devils Lake, North Dakota, by G. J. Wiche, U.S. Geological Survey. p. 75-87.

Geochemical indicators used to determine source of saline water in Mesozoic aquifers, Montezuma Canyon area, Utah, by B. A. Kimball, U.S. Geological Survey. p. 89-106.

Using the area of diversion for pumping centers to estimate potential freshwater production in coastal aquifers, east-central Florida, by Michael Planert, U.S. Geological Survey. p. 107118.

Identification of net-flux rates for ground-water models, by $\mathrm{P}$. M. Martin, U.S. Geological Survey; and T. J. Durbin, S. S. Papadopulos and Associates. p. 119-130. 
A method for estimating velocity and depth of streams at low flow in southeastern Louisiana, by F. N. Lee, U.S. Geological Survey. p. 131-136.

Issues in debris-flow research; personal views, by Cheng-lung Chen, U.S. Geological Survey. p. 137-143.

An examination of spatially representative water-quality sampling methods in the tidal Potomac River, by R. H. Coupe, U.S. Geological Survey. p. 145-150.

Modeling flood flows from a hypothetical failure of the glacial moraine impounding Carver Lake near Sisters, Oregon, by Antonius Laenen, K. M. Scott, J. E. Costa, and L. L. Orzol, U.S. Geological Survey. p. 151-164.

Ground-water-flow modeling and optimization techniques applied to high-ground-water problems in San Bernardino, California, by W. R. Danskin and J. R. Freckleton, U.S. Geological Survey. p. $165-177$.

Hydrogeochemical evidence for subsurface inflow to Stagecoach Valley, Lyon County, Nevada, by J. R. Harrill, A. H. Welch, and A. M. Preissler, U.S. Geological Survey. p. 179. 193.

A comparison of the Brune and Churchill methods for computing sediment yields applied to a reservoir system, by $\mathrm{S}$. W. Trimble and W. P. Carey, U.S. Geological Survey. p. 195-202.

Bubble-gage registration errors caused by gas column density, by Winchell Smith, U.S. Geological Survey. p. 203-207.

W 2364. Sediment characteristics of North Carolina streams, 197079 , by C. E. Simmons. Prepared in cooperation with the North Carolina Department of Environment, Health, and Natural Resources. 1993. 84 p. (Supersedes Open-file report 87-701.)

W 2384. WEST VIRGINIA. Effects of underground mining and mine collapse on the hydrology of selected basins in West Virginia, by W. A. Hobba, Jr. Prepared in cooperation with the West Virginia Geological and Economic Survey. 1993. 79 p.

W 2386. ILLINOIS. Water and tritium movement through the unsaturated zone at a low-level radioactive-waste disposal site near Sheffield, Illinois, 1981-85, by P. C. Mills and R. W. Healy. 1993. 72 p. (Supersedes Open-file report 89-271.)

W 2387. NEW YORK. Estimation of hydraulic conductivity of a riverbed and aquifer system on the Susquehanna River in Broome County, New York, by R. M. Yager. 1993. 49 p. 1 plate in pocket.

W 2388. VIRGINIA. Hydraulic characteristics of, and groundwater flow in, coal-bearing rocks of southwestern Virginia, by $G$. E. Harlow, Jr. and G. D. LeCain. Prepared in cooperation with the Virginia Department of Mines, Minerals, and Energy, Division of Mined Land Reclamation, and the Powell River Project. 1993. 36 p. 1 plate in pocket. (Supersedes Open-file report 91-250.)

W 2390. ILLINOIS. Effects of low-level radioactive-waste disposal on water chemistry in the unsaturated zone at a site near Sheffield, Illinois, $1982-84$, by C. A. Peters, R. G. Striegl, P. C. Mills and R. W. Healy. 1992. 74 p. (Supersedes Open-file report 90-373.)

W 2391. GEORGIA. Geohydrology and evaluation of waterresource potential of the upper Floridan Aquifer in the Albany area, southwestern Georgia, by L. J. Torak, G. S. Davis, G. A. Strain and J. G. Herndon. Prepared in cooperation with City of Albany Water, Gas, and Light Commission. 1993. 59 p. 2 plates in pocket. (Supersedes Open-file report 91-52.)

W 2392. SOUTH CAROLINA, GEORGIA. Ground-water chemical evolution and diagenetic processes in the upper Floridan Aquifer, southern South Carolina and northeastern Georgia, by R. A. Burt. Prepared in cooperation with the South Carolina Water Resources Commission. 1993. 76 p. (Supersedes Open-file report 89-27.)

W 2393. INDIANA. Effects of advanced treatment of municipal wastewater on the White River near Indianapolis, Indiana; trends in water quality, 1978-86, by C. G. Crawford and D. J. Wangsness. Prepared in cooperation with the City of Indianapolis, Department of Public Works. 1993. 23 p. (Supersedes Open-file report 88-335.)

W 2395. Discharge-measurement system using an acoustic Doppler current profiler with applications to large rivers and estuaries, by M. R. Simpson and R. N. Oltmann. 1993. 32 p. (Supersedes Open-file report 91-487.)

W 2396. CALIFORNIA. Numerical simulation of ground-water flow in the central part of the western San Joaquin Valley, California, by K. R. Belitz, S. P. Phillips and J. M. Gronberg. Prepared in cooperation with the San Joaquin Valley Drainage Program. 1993. 69 p. (Supersedes Open-file report 91-535.)

W 2400. National water summary 1990-91; hydrologic events and stream water quality, by U.S. Geological Survey (R. W. Paulson, E. B. Chase, J. S. Williams, and D. W. Moody, compilers). 1993. 590 p.

Overview, by R. W. Paulson, E. B. Chase, J. S. Williams, and D. W. Moody, U.S. Geological Survey. p. 3-10.

Introduction, by R. W. Paulson, E. B. Chase, J. S. Williams, and D. W. Moody, U.S. Geological Survey. p. 11-12.

Review of water year 1990 hydrologic conditions and water-related events, by G. J. McCabe, Jr., J. D. Fretwell, and E. B. Chase, U.S. Geological Survey. p. 14-31.

Seasonal summaries of hydrologic conditions, water year 1990, by G. J. McCabe; Jr., U.S. Geological Survey; W. O. Brown, and R. R. Heim, Jr., National Oceanic and Atmospheric Administration. p. 32-39.

Review of water year 1991 hydrologic conditions and water-related events, by G. J. McCabe, Jr., J. D. Fretwell, and E. B. Chase, U.S. Geological Survey. p. 40-55.

Seasonal summaries of hydrologic conditions, water year 1991, by R. R. Heim, Jr., National Oceanic and Atmospheric Administration; G. J. McCabe, Jr., U.S. Geological Survey; and W. O. Brown, National Oceanic and Atmospheric Administration. p. 56-63.

Factors affecting stream water quality, and water-quality trends in four drainage basins in the conterminous United States, 190590, by J. D. Hem, U.S. Geological Survey. p. 67-92.

Statistical analysis of water-quality data, by D. R. Helsel, U.S. Geological Survey. p. 93-100. 
Assuring the reliability of water-quality data, by L. C. Friedman, U.S. Geological Survey. p. 101-110.

Stream water quality in the conterminous United States; status and trends of selected indicators during the 1980's, by R. A. Smith, R. B. Alexander, and K. J. Lanfear, U.S. Geological Survey. p. 111-140.

Nationwide water-quality reporting to the Congress as required under Section 305(b) of the Clean Water Act, by A. E. Mayio and G. H. Grubbs, U.S. Environmental Protection Agency. p. 141-146.

Introduction to State summaries of stream water quality, by $R$. W. Paulson, E. B. Chase, J. S. Williams, and D. W. Moody, U.S. Geological Survey. p. 148-154.

Alabama stream water quality, prepared by W. S. Mooty, U.S. Geological Survey. p. 155-162.

Alaska stream water quality, prepared by R. L. Rickman, U.S. Geological Survey. p. 163-170.

Arizona stream water quality, prepared by H. H. Schumann, U.S. Geological Survey; and Edwin Swanson, Arizona Department of Environmental Quality. p. 171-178.

Arkansas stream water quality, prepared by J. C. Petersen, W. R. Green, U.S. Geological Survey; and W. E. Keith, Arkansas Department of Pollution Control and Ecology. p. 179-186.

California stream water quality, prepared by R. T. Iwatsubo, U.S. Geological Survey; and Richard Woodard, California Department of Water Resources. p. 187-196.

Colorado stream water quality, prepared by R. F. Middelburg, U.S. Geological Survey. p. 197-206.

Connecticut stream water quality, prepared by K. P. Kulp, J. R. Bohr, U.S. Geological Survey; and F. S. Banach, Connecticut Department of Environmental Protection. p. 207-214.

Delaware stream water quality, prepared by G. N. Paulachok, J. D. Blomquist, U.S. Geological Survey; and J. F. Davis, Delaware Department of Natural Resources and Environmental Control. p. 215-220.

Florida stream water quality, prepared by G. A. Irwin, U.S. Geological Survey; and T. M. Swihart, Florida Department of Environmental Regulation. p. 221-230.

Georgia stream water quality, prepared by J. B. McConnell, G. R. Buell, U.S. Geological Survey; and W. M. Winn, Georgia Department of Natural Resources, Environmental Protection Division. p. 231-238.

Hawaii stream water quality, prepared by J. J. S. Yee and M. G. Lum, U.S. Geological Survey. p. 239-246.

Idaho stream water quality, prepared by W. H. Low, U.S. Geological Survey. p. 247-254.

Illinois stream water quality, prepared by G. O. Balding and R. H. Coupe, U.S. Geological Survey. p. 255-262.

Indiana stream water quality, prepared by E. R. Bayless, J. D. Martin, U.S. Geological Survey; and D. E. Clark, Indiana Department of Environmental Management. p. 263-268.
Iowa stream water quality, prepared by M. L. Clark, U.S. Geological Survey; and J. R. Olson, Iowa Department of Natural Resources. p. 269-276.

Kansas stream water quality, prepared by J. F. Kenny, U.S. Geological Survey; and D. H. Snethen, Kansas Department of Health and Environment. p. 277-284.

Kentucky stream water quality, prepared by Rene Garcia and L. H. Woosley, Jr., U.S. Geological Survey. p. 285-292.

Louisiana stream water quality, prepared by J. J. Gilbert. U.S. Geological Survey. p. 293-300.

Maine stream water quality, prepared by S. A. Olson and D. J. Cowing, U.S. Geological Survey. p. 301-308.

Maryland and the District of Columbia stream water quality, prepared by J. D. Blomquist, U.S. Geological Survey; and J. S. Garrison, Maryland Department of the Environment. p. 309-316.

Massachusetts stream water quality, prepared by J. L. Strause, U.S. Geological Survey. p. 317-324.

Michigan stream water quality, prepared by S. P. Blumer, U.S. Geological Survey. p. 325-334.

Minnesota stream water quality, prepared by L. H. Tornes, U.S. Geological Survey. p. 335-342.

Mississippi stream water quality, prepared by L. J. Slack, U.S. Geological Survey; and Randy Reed, Mississippi Department of Environmental Quality, Office of Pollution Control. p. 343350.

Missouri stream water quality, prepared by J. V. Davis, U.S. Geological Survey; and J. R. Howland, Missouri Department of Natural Resources. p. 351-360.

Montana stream water quality, prepared by J. R. Knapton, U.S. Geological Survey; and L. L. Bahls, Montana Department of Health and Environmental Sciences. p. 361-370.

Nebraska stream water quality, prepared by A. H. Chen, C. G. Hoy, U.S. Geological Survey; and J. F. Bender, Nebraska Department of Environmental Control. p. 371-378.

Nevada stream water quality, prepared by R. L. Seiler, U.S. Geological Survey. p. 379-386.

New Hampshire stream water quality, prepared by K. W. Toppin, U.S. Geological Survey. p. 387-394.

New Jersey stream water quality, prepared by K. W. Robinson, Connie Pak, U.S. Geological Survey; Kevin Berry, and William Minervini, New Jersey Department of Environmental Protection and Energy. p. 395-402.

New Mexico stream water quality, prepared by Kim Ong, R. L. Lepp, U.S. Geological Survey; and Jim Piatt, New Mexico Environment Department. p. 403-412.

New York stream water quality, prepared by R. J. Rogers, U.S. Geological Survey and G. K. Hansen, New York State Department of Environmental Conservation. p. 413-420.

North Carolina stream water quality, prepared by C. R. Barnes and M. S. Davenport, U.S. Geological Survey. p. 421-428. 
North Dakota stream water quality, prepared by W. R. Berkas, U.S. Geological Survey; and M. J. Ell, North Dakota State Department of Health and Consolidated Laboratories. p. 429 436.

Ohio stream water quality, prepared by C. J. Oblinger Childress, G. F. Koltun, U.S. Geological Survey; and Dan Dudley, Ohio Environmental Protection Agency. p. 437-444.

Oklahoma stream water quality, prepared by J. K. Kurklin, U.S. Geological Survey; and David Jennings, Oklahoma Department of Pollution Control. p. 445-454.

Oregon stream water quality, prepared by J. M. Laenen, U.S. Geological Survey; and Elizabeth Thomson, Oregon Department of Environmental Quality. p. 455-462.

Pennsylvania stream water quality, prepared by D. R. Williams, U.S. Geological Survey. p. 463-470.

Puerto Rico stream water quality, prepared by R. J: Vachier, U.S. Geological Survey. p. $471-476$.

Rhode Island stream water quality, prepared by R. W. Bell, U.S. Geological Survey. p. $477-484$.

South Carolina stream water quality, prepared by W. F. Falls and S. C. Lambert, U.S. Geological Survey. p. 485-490.

South Dakota stream water quality, prepared by T. E. McKallip, U.S. Geological Survey. p. 491-498.

Tennessee stream water quality, prepared by A. B. Hoos, U.S. Geological Survey. p. 499-506.

Texas stream water quality, prepared by J. E. Veenhuis, U.S. Geological Survey; and David Buzan, Texas Water Commission. p. 507-516.

Utah stream water quality, prepared by C. B. Burden, D. W. Stephens, U.S. Geological Survey; and William Harned, Utah Department of Health. p. 517-524.

Vermont stream water quality, prepared by J. C. Denner, U.S. Geological Survey; and Jerome McArdle, Vermont Division of Water Quality. p. 525-530.

Virginia stream water quality, prepared by D. L. Belval, U.S. Geological Survey; and L. D. Seivard, Virginia Water Control Board. p. 531-538.

Washington stream water quality, prepared by S. S. Embrey, U.S. Geological Survey. p. 539-546.

West Virginia stream water quality, prepared by M. C. Waldron, U.S. Geological Survey. p. 547-554.

Western Pacific Islands stream water quality, prepared by J. J. S. Yee and M. G. Lum, U.S. Geological Survey. p. 555-560.

Wisconsin stream water quality, prepared by P. A. Kammerer, Jr. and W. R. Krug, U.S. Geological Survey. p. 561-568.

Wyoming stream water quality, prepared by D. A. Peterson, U.S. Geological Survey. p. 569-576.

W 2402. FLORIDA. Biogeochemical and hydrological processes controlling the transport and fate of 1,2-dibromoethane (EDB) in soil and ground water, Central Florida, by B. G. Katz. 1993. 35 p.
W 2403. NORTH CAROLINA. Low-flow characteristics of streams in North Carolina, by G. L. Giese and R. R. Mason, Jr. Prepared in cooperation with the North Carolina Department of Environment, Health, and Natural Resources 1993. 29 p. 2 plates in pocket. (Supersedes Open-file report 90-399.)

W 2412. Factors affecting areas contributing recharge to wells in shallow aquifers, by T. E. Reilly and D. W. Pollock. 1993. 21 p.

\section{CIRCULARS}

Circulars present technical or nontechnical information of wide popular interest in a format designed for distribution at no cost to the public. They are published to disseminate administrative information or important scientific information of an ephemeral nature.

C 0930-M. International Strategic Minerals Inventory summary report; niobium (columbium) and tantalum, by R. N. Crockett, British Geological Survey (Natural Environment Research Council); and D. M. Sutphin, U.S. Geological Survey. Prepared as a cooperative effort among earth-science and mineral-resource agencies of Australia, Canada, Federal Republic of Germany, Republic of South Africa, United Kingdom, and United States of America. 1993. $36 \mathrm{p}$.

C 0930-N. International Strategic Minerals Inventory summary report; rare-earth oxides, by W. D. Jackson and Grey Christiansen, U.S. Bureau of Mines. Prepared as a cooperative effort among earth-science and mineral-resource agencies of Australia, Canada, the Federal Republic of Germany, the Republic of South Africa, the United Kingdom, and the United States of America. 1993. 68 p.

C 1007. Manmade organic compounds in the surface waters of the United States; a review of current understanding, by J. A. Smith, P. J. Witkowski and T. V. Fusillo. 1988 (1993). 92 p. (Reprint.)

C 1031. National Seismic System science plan, by: T. H. Heaton, U.S. Geological Survey; D. L. Anderson, California Institute of Technology; W. J. Arabasz, University of Utah; R. P. Buland, W. L. Ellsworth, S. H. Hartzell, U.S. Geological Survey; Thorne Lay, University of Michigan; and Paul Spudich, U.S. Geological Survey. 1989 (1993). 42 p. (Reprint.)

C 1080. DELAWARE, MARYLAND, VIRGINIA: Are fertilizers and pesticides in the ground water? A case study of the Delmarva Peninsula, Delaware, Maryland, and Virginia, by P. A. Hamilton and R. J. Shedlock. 1992 (1993). 16 p. (Reprint.)

C 1081. Estimated use of water in the United States in 1990, by W. B. Solley, R. R. Pierce and H. A. Perlman. 1993. 76 p.

C 1083. MISSOURI. Responses to Iben Browning's prediction of a 1990 New Madrid, Missouri, earthquake, by W. J. Spence, U.S. Geological Survey; R. B. Herrmann, St. Louis University; A. C. Johnston, Memphis State University; and B. G. Reagor, U.S. Geólogical Survey. 1993. 248 p.

C 1086. Proceedings of the U.S. Geological Survey global change research forum, Herndon, Virginia, March 18-20, 1991, edited by J. A. Kelmelis and K. M. Snow, U.S. Geological Survey. 1993. $121 \mathrm{p}$.

Welcome and introductory remarks, by S. E. Ragone, U.S. Geological Survey. p. 1-2. 
The Committee on Earth and Environmental Sciences; its role in Federal research, by D. L. Peck, U.S. Geological Survey. p. $3-4$.

U.S. Global Change Research Program, by Robert Corell, National Science Foundation. p. 5-8.

U.S. Department of the Interior/U.S. Geological Survey Global Change Research Program, by J. A. Kelmelis, U.S. Geological Survey. p. 9-11.

Interagency working group on data management for global change, by Eliot Christian, U.S. Geological Survey. p. 12-14.

A fragile seam of dark blue light, by J. A. Eddy, University Corporation for Atmospheric Research. p. 15-22.

Earth system history and global change, by R. Z. Poore, U.S. Geological Survey. p. 23-26.

Climate, hydrology, and water resources, by H. F. Lins, U.S. Geological Survey. p. 27-32.

Terrestrial implications and uncertainties in the atmospheric carbon dioxide budget, by E. T. Sundquist, U.S. Geological Survey. p. 33-36.

Land data and information management, by D. T. Lauer, U.S. Geological Survey. p. 37-39.

Developing a sound basis for national policy, by Allan Bromley, Assistant to the President for Science and Technology. p. 40 42.

The receding threat from global warming, by P. J. Michaels, University of Virginia. p. 43-50.

Pliocene climates, by T. M. Cronin, R. Z. Poore, H. J. Dowsett, and R. S. Thompson, U.S. Geological Survey. p. 51-52.

Desert processes, by C. S. Breed, U.S. Geological Survey. p. 53-54.

Satellite image atlas of glaciers of the world, by R. S. Williams, Jr., and J. G. Ferrigno, U.S. Geological Survey. p. 55.

Sensitivity of water resources in the Delaware River basin to climate change, by G. J. McCabe, Jr., D. M. Wolock, G. D. Tasker, M. A. Ayers, and L. E. Hay, U.S. Geological Survey. p. 56-62.

A strategy for large-area land characterization; the conterminous United States example, by T. R. Loveland, U.S. Geological Survey. p. 63-67.

A distributed visualization modeling environment for methane flux, by William Acevedo, U.S. Geological Survey; L. A. Morrissey, and G. P. Livingston, TGS Technology. p. 68.

Long climatic records from sediment cores in western North America; results and prospects, by D. P. Adam, U.S. Geological Survey. p. 68-69.

Transects of long climatic records, by D. P. Adam, U.S. Geological Survey. p. 69.

Late Cenozoic climates of Alaska and Yukon; a joint U.S. Geological Survey-Geological Survey of Canada global change research project, by T. A. Ager, U.S. Geological Survey. p. 69-70.

Sustainable development; focus for Department of the Interior global change human interactions experiment, by R. H. Alexander, U.S. Geological Survey. p. 70.

Using spatial statistics to improve estimates of regional methane emissions from tundra ecosystems, by S. P. Benjamin, U.S. Geological Survey; G. P. Livingston, and R. E. Rossi, TGS Technology. p. 71.

Reconstructing climate of the Great Basin for the past 25,000 years; completed and ongoing research, by L. V. Benson, U.S. Geological Survey. p. 71.

From fire to flood; Pacific climate and southwestern watershed management, by J. L. Betancourt, U.S. Geological Survey. p. 72.

Soil interpretations for global change modeling and impact assessment, by N. B. Bliss, TGS Technology. p. 72-73.

A 3-million year terrestrial climate record and the variable character of the marine-terrestrial climate connection, by J. P. Bradbury, U.S. Geological Survey. p. 73.

Arctic Ocean winter polynya zones during 1978-87, by W. J. Campbell, U.S. Geological Survey; and Per Gloersen, NASA. p. 73-74.

Global change data management, by D. M. Carneggie, U.S. Geological Survey. p. 74.

Late Cenozoic Arctic climatic change, by L. D. Carter, U.S. Geological Survey. p. 75.

"Cool" vs. "warm" winter precipitation and its effect on surface hydrology in the Western United States, by D. R. Cayan, Scripps Institution of Oceanography. p. 76.

Data management planning, by Eliot Christian, U.S. Geological Survey. p. 76.

Climatic change inferred from borehole-temperature measurements, by G. D. Clow and A. H. Lachenbruch, U.S. Geological Survey. p. 77.

Interrelations between gas hydrates of Northern Alaska and atmospheric methane, by T. S. Collett and K. A. Kvenvolden, U.S. Geological Survey. p. 77-78.

Stratigraphy of climatic change in large lakes, by S. M. Colman, U.S. Geological Survey. p. 78.

Rates of Holocene climate change; evidence from varved lake sediments, by W. E. Dean and J. P. Bradbury, U.S. Geological Survey. p. 79.

Varve chronology or ${ }^{14} \mathrm{C}$ dating; which do you believe?, by $\mathrm{W}$. E. Dean, U.S. Geological Survey. p. 79.

Multiscale characterization of land cover complexity in Colorado, by Lee De Cola, U.S. Geological Survey. p. 80.

Description of interdecadal trends in surface temperatures of the Sierra Nevada and Gunnison River areas using singular-spectrum analysis, by M. D. Dettinger, U.S. Geological Survey. p. 80-81. 
Pliocene marine climate records, by H. J. Dowsett, L. B. Wiggs, and R. Z. Poore, U.S. Geological Survey. p. 81.

Climate, lakes, and ostracodes, by R. M. Forester, U.S. Geological Survey. p. 81-82.

The effect of climate change on the hydrology of glacier regions, by A. G. Fountain, U.S. Geological Survey. p. 82.

Report of a workshop on the Correlation of marine and terrestrial records of climate changes in the Western United States, by J. V. Gardner, A. M. Sarna-Wojcicki, D. P. Adam, W. E. Dean, J. P. Bradbury, and H. J. Rieck, U.S. Geological Survey. p. 83 .

Assessing the human impact of global change in Western United States and Alaska, by L. J. Gaydos, U.S. Geological Survey. p. 83.

Role of volcanic emissions in global change, by T. M. Gerlach, U.S. Geological Survey. p. 84.

Climatic and paleo-oceanographic history of the Canada Basin, Arctic Ocean, by Arthur Grantz, R. L. Phillips, S. D. May, M. W. Mullen, R. Z. Poore, and H. J. Rieck, U.S. Geological Survey. p. 84-85.

The effect of changes in data resolution on hydrologic response, by C. A. Hallam, U.S. Geological Survey. p. 85.

Coral fluorescence as an index of runoff in South Florida, by R. B. Halley, U.S. Geological Survey. p. 86.

Seawater temperature and coral bleaching in the Florida Keys; no relation to global warming....yet, by R. B. Halley, U.S. Geological Survey; and J. H. Hudson, Florida Keys National Marine Sanctuary. p. 86-87.

The Old Crow Tephra; a stratigraphic marker for the last interglaciation in Alaska?, by T. D. Hamilton, U.S. Geological Survey. p. 87 .

Nutrient and carbon dynamics in soil systems, by J. W. Harden, R. K. Mark, D. H. Showalter, E. T. Sundquist, and R. F. Stallard, U.S. Geological Survey. p. 88.

Estimation of precipitation patterns in the Delaware and Gunnison River basins, by L. E. Hay and W. A. Battaglin, U.S. Geological Survey. p. 88.

Lake Baikal, southeastern Siberia; prospects for paleoclimate research, by P. P. Hearn, S. M. Colman, U.S. Geological Survey; E. B. Karbanov, Russian Academy of Science; and D. F. Williams, University of South Carolina. p. 89.

Geomagnetism and climate, by D. C. Herzog, U.S. Geological Survey. p. 89-90.

Modeling the late-Pleistocene paleohydrology of the Great Basin, by S. W. Hostetler, U.S. Geological Survey. p. 90.

Large-area digital elevation data and their derivatives, by S. K. Jenson, U.S. Geological Survey. p. 90-91.

Satellite passive microwave observations of snow conditions in the upper Colorado River basin, by E. G. Josberger, W. J. Campbell, U.S. Geological Survey; Per Gloersen, and A. T. C. Chang, NASA. p. 91.
Planar pattern of delayed postglacial uplift in New England; a datum for measuring late glacial sea-level changes, by Carl Koteff and G. R. Robinson, U.S. Geological Survey. p. 92.

Permafrost and gas hydrates as possible sources of atmospheric methane at high latitudes, by K. A. Kvenvolden and T. S. Collett, U.S. Geological Survey. p. 92-93.

Paleoclimate reconstructions from Alaskan ice records; teleconnections between Pacific-North American (PNA), reverse PNA, and El Niño-Southern Oscillation (ENSO) states, by G. P. Landis, J. J. Fitzpatrick, T. K. Hinkley, and R. O. Rye, U.S. Geological Survey. p. 93.

HCDN (hydro-climatic data network); a U.S. Geological Survey streamflow data set for climatological analysis, by J. M. Landwehr and J. R. Slack, U.S. Geological Survey. p. 93-94.

Stochastic analysis of $\delta^{18} \mathrm{O}$ and $\delta^{13} \mathrm{C}$ time series found in a continuous 500,000-year climatic record from Great $B$ asin vein calcite, by J. M. Landwehr, I. J. Winograd, T. B. Coplen, A. C. Riggs, K. R. Ludwig, and B. J. Szabo, U.S. Geological Survey. p. 94.

Water, energy, and biogeochemical budgets in the Luquillo Mountains, Puerto Rico, by M. C. Larsen, P. D. Collar, and R. F. Stallard, U.S. Geological Survey. p. 94-95.

Investigation of climate-hydrology interactions using coupled atmospheric and hydrologic models, by G. H. Leavesley, U.S. Geological Survey. p. 95.

Land characterization using remotely sensed data and artificial neural networks, by G. P. Lemeshewsky, U.S. Geological Survey. p. 96.

Biogeochemical cycling of carbon and related elements in estuarine wetlands, by J. S. Leventhal, L. L. Jackson, K. S. Smith, L. S. Balistrieri, and Katherine Walton-Day, U.S. Geological Survey. p. 96-97.

Monitoring the dynamics of the Antarctic coastline with Landsat images, by B. K. Lucchitta, L. M. Bertolini, J. G. Ferrigno, and R. S. Williams, Jr., U.S. Geological Survey. p. 97.

Glacier growth and shrinkage related to climate variations and nonclimatic factors in Alaska, by L. R. Mayo, U.S. Geological Survey. p. 97-98.

Photogrammetry and global change, by R. B. McEwen, U.S. Geological Survey. p. 98.

Continental hydrology and global climate, by P. C. D. Milly, U.S. Geological Survey. p. 99.

Glacier monitoring for global change; three case studies, by B. F. Molnia, U.S. Geological Survey. p. 99-100.

Monitoring land surface responses to social and economic pressures in Sahelian Africa, by D. G. Moore, U.S. Geological Survey; G. G. Tappan, and M. E. Wehde, TGS Technology. p. 100 .

Quantification of information contained in outputs of general circulation models, by M. E. Moss, U.S. Geological Survey. p. 101.

Late Quaternary sea level history of the Pacific Coast of North America; a detailed record of the last glacial/interglacial cycle, 
by D. R. Muhs, J. F. Whelan, U.S. Geological Survey; G. L. Kennedy, Los Angeles County Museum of Natural History; and T. K. Rockwell, San Diego State University. p. 101-102.

History of desertification on the Great Plains; a Holocene history of eolian sand movement, by D. R. Muhs, H. T. Millard, Jr., R. F. Madole, and C. J. Schenk, U.S. Geological Survey. p. 102-103.

The global land information system, by L. R. Oleson, U.S. Geological Survey. p. 103.

Methane in Mono Lake, California, by R. S. Oremland, U.S. Geological Survey. p. 103-104.

Assessment of effects of potential climate change on the hydrology of the Gunnison River basin, by R. S. Parker and W. A. Battaglin, U.S. Geological Survey. p. 104.

The Panola Mountain research watershed; hydrologic and biogeochemical process research, a watershed approach, by N. E. Peters, R. P. Hooper, and T. G. Huntington, U.S. Geological Survey. p. 105.

Climatic variability in the San Francisco Bay estuarine system, by D. H. Peterson, U.S. Geological Survey; andD. R. Cayan, Scripps Institution of Oceanography. p. 105-106.

Phosphate and trace metals in Cenozoic phytoplankton; a signal of changing ocean chemistry, by D. Z. Piper, V. G. Mossotti, and D. J. Bukry, U.S. Geological Survey. p. 106.

Potential effects of climate change on the surface-water resources of the Carson, American, and Truckee River basins, by Alex Pupacko, U.S. Geological Survey. p. 107.

Development of land data sets for studies of global climate change, by F. G. Sadowski, and A. H. Watkins, U.S. Geological Survey. p. 107.

Use of ash layers in the reconstruction of Earth system history; correlation and age calibration of high resolution stratigraphicclimate records in the oceans and on land, by A. M. SarnaWojcicki, C. E. Meyer, and Elmira Wan, U.S. Geological Survey. p. 107-108.

Water, energy, and biogeochemical budgets at Sleepers River, Danville, Vermont, by J. B. Shanley and E. T. Sundquist, U.S. Geological Survey. p. 108-109.

Baseline studies for monitoring global climate change in the Arctic environment; a remote sensing-spatial data base approach, by M. B. Shasby, U.S. Geological Survey. p. 109.

Sulfur isotope geochemistry of paleoclimate change in Lake Baikal, Siberia, by E. C. Spiker and A. L. Bates, U.S. Geological Survey. p. 109-110.

Examination of biogeochemical processes in tropical watersheds of Puerto Rico and Panama, by R. F. Stallard, U.S. Geological Survey. p. 110.

Developing land surface characterization requirements for water and energy exchange models, by L. T. Steyaert, U.S. Geological Survey. p. 111.

Consumption of atmospheric methane in unsaturated soils, by $R$. G. Striegl, U.S. Geological Survey. p. 111-112.
A monthly water balance model to study possible impacts of climate change in the Delaware River basin, by G. D. Tasker, M. A. Ayers, D. M. Wolock, and G. J. McCabe, Jr., U.S. Geological Survey. p. 112.

Paleobotanical evidence of population dynamics and paleoclimatic fluctuations, by R. S. Thompson, U.S. Geological Survey; and P. J. Bartlein, University of Oregon. p. 112-113.

Some anticipated and measured responses of glaciers to global change in Alaska, by D. C. Trabant, U.S. Geological Survey. p. 113.

Banded corals as indicators of tropical Pacific paleoclimate, by G. W. Tribble and C. D. Hunt, Jr., U.S. Geological Survey. p. 114.

An investigation of the water, energy, and biogeochemical budgets of Loch Vale and other Rocky Mountain watersheds, by J. T. Turk, N. E. Spahr, and D. H. Campbell, U.S. Geological Survey. p. 114.

Some recent advances in statistical analysis of spatial random processes, by A. V. Vecchia, U.S. Geological Survey. p. 115.

Hydrologic and biogeochemical budgets in temperate lakes and their watersheds, northern Wisconsin, by J. F. Walker, D. P. Krabbenhoft, and J. F. Elder, U.S. Geological Survey. p. 115.

Assessment of the potential effects of climate change on salinity intrusion in Delaware Bay, by R. A. Walters, U.S. Geological Survey. p. 116.

Synoptic-scale climate and mass balance interactions in western North America, by R. A. Walters, U.S. Geological Survey. p. 116-117.

Modeling the spatial distribution of solar radiation incident on the land surface, by R. D. Watts, U.S. Geological Survey. p. 117.

Relations between upper-air flow patterns, climate, and hydrologic variability in the Red River of the North basin in North Dakota, South Dakota, Minnesota, Manitoba, and Saskatchewan, by G. J. Wiche, U.S. Geological Survey; J. L. Knox, Consulting Meteorologist, Toronto; and L. E. Welsh, National Hydrology Research Centre, Saskatoon. p. 118.

Arctic data interactive; demonstration of a hypermedia system, by D. A. Wiltshire, U.S. Geological Survey. p. 118-119.

Carbon dioxide contributions of the terrestrial biosphere to the global carbon cycle, by B. E. Wright, U.S. Geological Survey. p. 119.

C 1088. MONTANA. The Conterminous United States Mineral Assessment Program; background information to accompany folio of geologic, geochemical, remote sensing, and mineral resources maps of the Butte $1^{\circ} \times 2^{\circ}$ Quadrangle, Montana, by J. E. Elliott, C. M. Trautwein, C. A. Wallace, G. K. Lee, L. C. Rowan and W. F. Hanna. 1993. 17 p.

C 1090. WASHINGTON. Persistence of the DDT pesticide in the Yakima River basin, Washington, by J. F. Rinella, P. A. Hamilton, and S. W. McKenzie; graphic design and layout by J. M. Rubin. 1993. 24 p. 
C 1091. ALASKA. 1992 annual report on Alaska's mineral resources, edited by Diedra Bohn and J. L. Schneider. Prepared in cooperation with the U.S. Bureau of Land Management, Fish and Wildlife Service, Minerals Management Service, National Park Service, U.S. Bureau of Mines, U.S. Forest Service, and the Department of Energy. 1992. $65 \mathrm{p}$.

C 1094. ALASKA. The Alaska Mineral Resource Assessment Program; background information to accompany mineral-resource and geologic maps of the Anchorage Quadrangle, south-central Alaska, by D. J. Madden-McGuire and G. R. Winkler. 1993. $23 \mathrm{p}$.

C 1105. Understanding our fragile environment; lessons from geochemical studies, by L. P. Gough and others. $1993.34 \mathrm{p}$.

C 1110. Natural aggregate, building America's future, by W. H. Langer and V. M. Glanzman. 1993. 39 p. (Public issues in earth science.)

C 1111. Societal value of geologic maps, by R. L. Bernknopf, U.S. Geological Survey; D. S. Brookshire, University of New Mexico; D. R. Soller, U.S. Geological Survey; M. J. McKee, University of New Mexico; J. F. Sutter, J. C. Matti, and R. H. Campbell, U.S. Geological Survey. 1993. 53 p.

C 1120-A. Flood discharges in the upper Mississippi River basin, 1993, by Charles Parrett, N. B. Melcher and R. W. James, Jr. 1993. 14 p. (Floods in the upper Mississippi River basin, 1993.)

C 1120-B. Precipitation in the upper Mississippi River basin, January 1 through July 31, 1993, by K. L. Wahl, K. C. Vining and G. J. Wiche. 1993. 13 p. (Floods in the upper Mississippi River basin, 1993.)

C 1120-C. Occurrence and transport of agricultural chemicals in the Mississippi River basin, July through August 1993, by D. A. Goolsby, W. A. Battaglin and E. M. Thurman. 1993, 22 p. (Floods in the upper Mississippi River basin.)

\section{TECHNIQUES OF WATER-RESOURCES INVESTIGATIONS}

TWI 03-B4. Regression modeling of ground-water flow; Supplement 1 , Modifications to the computer code for nonlinear regression solution of steady-state ground-water flow problems, by R. L. Cooley. 1993. 8 p.

TWI 06-A3. AMODular Finite-Element model (MODFE) for areal and axisymmetric ground-water-flow problems; Part 1, Model description and user's manual, by L. J. Torak. 1993. 136 p. (Supersedes Open-file report 90-194.)

TWI 06-A5. AMODular Finite-Element model(MODFE) for areal and axisymmetric ground-water-flow problems; Part 3, Design philosophy and programming details, by L. J. Torak. 1993. 243 p. (Supersedes Open-file report 91-471.)

\section{GENERAL INTEREST PUBLICATION}

General Interest Publications briefly summarize, for nontechnical readers, the latest information on major topics in the earth sciences about which the Survey receives frequent inquiries from the general public. This series of booklets, brochures, leaflets, and essay reprints are written by Survey scientists and cover topics such as earthquakes, energy resources, ground water, landforms and land use, marine geology, rain, rocks and mineral resources.
Fossils, rocks, and time, by L. E. Edwards and John Pojeta, Jr. 1993. $26 \mathrm{p}$.

\section{Miscellaneous and Special Books} GEOGRAPHIC NAMES INFORMATION SYSTEM (GNIS)

The Geographic Names Information System currently consists of approximately two million name entries with information about the feature name and category and its geographic location by coordinates, county,and USGS topographic maps. The name file was developed from published 7.5-minute topographic maps. In areas where 7.5-minute maps have not been published, 15-minute maps or 1:250,000-scale maps provided basic name data.

Alphabetical listings are available for each State, territory and outlying area. These preliminary gazetteers list only those names found on the topographic maps of the U.S. Geological Survey. Two topical listings are available: a national listing of populated places and an abridged version of all States, territories and outlying areas, which contains about 40,000 populated places, other administrative places, and major physical features. Many of these files are also available in microfiche.

Other computer listings, specialized searches, and computer tapes may also be purchased.

GNIS, developed by Branch of Geographic Names, Office of Geographic and Cartographic Research, National Mapping Division, is the basis for Professional Paper 1200. The first chapter, P-1200-NJ (New Jersey) was published in 1982 (revised 1983). Each State, territory, and outlying area will be published as a separate chapter after further research and compilation. All other Federal sources, most State sources and other pertinent materials as well as historical documents are researched to complete the requirements for the National Names Depository. Additional published gazetteers include Arizona, Concise, Delaware, Florida, Indiana, Kansas, North Dakota, and South Dakota; and lowa and Oregon are complete and in various stages of printing and editing. State files in compilation include Alabama, Massachusetts, Mississippi, Pennsylvania, Rhode Island and Utah. The interim materials described may meet the needs of a wide variety of potential users until all chapters have been published.

Products may be ordered from Earth Science Information Center, U.S. Geological Survey, 507 National Center, Reston, Virginia 22092. Telephone (703) 648-6045.

Information may be requested from U.S. Geological Survey, Manager GNIS, 523 National Center, Reston, Virginia 22092. Telephone (703) 648-4544.

\section{CATAlog}

Publications of the U.S. Geological Survey, 1992. 1993. 501 p.

\section{YEARBOOK}

United States Geological Survey yearbook, fiscal year 1992. 1993. $123 \mathrm{p}$.

Hurricanes and coastal erosion; the lessons of Andrew in Louisiana, by A. H. Sallenger, Jr. and S. J. Williams. p. 1-3.

Hydrology and Hurricane Andrew in Florida, by W. B. Scott. p. 3-5.

Hurricane Iniki; effects on the coast of Kauai, by B. M. Richmond and M. A. Hampton. p. 5-6.

Meeting demand for maps in storm's wake, by H. L. Zohn. p. 7-8. 
Stewardship after the storm, by T. P. Harlow. p. 9.

Real-live lessons in earth science, by K. D. Gunderson and W. R. Hassibe. p. 18-20.

Adventures in earth science; public lecture series, by M. V. Bonito. p. 20-21.

Volunteers for science, by M. C. Jefferson. p. 26-27.

Volunteers help keep PACE, by Jill McCarthy. p. 27.

Volunteers at Bering Glacier, Alaska, by M. F. Orzech. p. 27-28.

Partnerships in education, by S. C. Wells. p. 28-29.

Learning about water, by S. J. Vandas. p. 29-31.

Outreach in geology education, by L. G. Wallace. p. 31 .

Enriching partnerships in the Southwest, by J. E. Crawforth and A. E. Joines, Jr. p. 31-32.

Education outreach at Hampton University, by E. L. Findley. p. 32 .

Career planning for the year 2000, by M. C. Jefferson. p. 3233.

Women's Advisory Committee, by Margo Kingston. p. 33.

Women's executive leadership program, by S. L. Roach. p. 33-34.

Ethnic Minority Advisory Committee, by J. M. Williams. p. 34.

Enjoy outdoors America, by J. H. Wittmann. p. 35.

The 1992 Chicago underground flood, by S. F. Blanchard and A. R. Schmidt. p. 37-39.

Hydrologic research at the five management systems evaluation areas, by D. W. Morganwalp. p. 39-40.

Using hydrologic data to forecast floods, by C. W. Boning and E. A. Stallings. p. 41-42.

National Water-Quality Assessment; public outreach and involvement, by P. A. Hamilton. p. 42-45.

CFC's; tools for age-dating and tracing shallow ground water, by L. N. Plummer and Eurybiades Busenberg. p. 45-47.

Glen Canyon environmental study, by J. D. Smith and R. H. Webb. p. $47-51$.

USGS continues coordination of water-resources information, by N. C. Lopez and P. V. Dresler. p. 51-53.

Southern Lake Michigan coastal erosion study, by D. W. Folger. p. 55-57.

Volcanic ash and aircraft, by T. P. Miller. p. 57-59.

Nearly a century of earth science cooperation in Puerto Rico, by W. J. Bawiec, R. E. Learned and J. N. Weaver. p. 59-60.

National oil and gas assessment, by D. L. Gautier. p. 61-62.

The Southern California Earthquake Center, by L. A. Wald. p. 62-66.
The National Geologic Mapping Act of 1992; background and challenges, by M. W. Reynolds. p. 66-68.

Robotics in the geochemical laboratory, by Stephen Wilson and R. M. O'Leary. p. 69.

Partnerships in the National Mapping Program, by R. L. Kleckner, p. $71-73$.

Spatial Data Transfer Standard; the key to data sharing, by Kathryn Wortman. p. 73-74.

Digital orthophotoquads, by G. L. Fairgrieve. p. 75-76.

Arctic region; sensitive indicator of global change, by $M$. B. Shasby and J. C. Eidenshink. p. 76-77.

Involvement in the Earth Observing System, by R. J. Thompson and L. R. Oleson. p. 78.

Availability of global digital topographic data, by S. K. Jenson and K. S. Larson. p. 78-79.

Global resources information data base, by R. E. Beck. p. 81 .

Gold exploration in Saudi Arabia, by K. A. Sargent. p. 81-82.

New Zealand Antarctic mapping program, by J. L. Mullins. p. 82.

Holes of opportunity; continental scientific drilling, by D. P. Russ and K. A. Dodd. p. 82-83.

Cooperation with Hungary, by P. G. Teleki. p. 83-84.

EXPOMIN '92, by A. T. Ovenshine. p. 84-85.

Major international mapping meetings held in Washington, D.C., by A. R. Stevens. p. 85.

Mexico and U.S. sign cooperative mapping agreement, by $A$. R. Stevens. p. 85 .

Mineral resource studies in Bolivia, by S. D. Ludington. p. 86-88.

29th international geological congress meets in Kyoto, Japan, by J. R. Keith and A. T. Ovenshine. p. 89.

Telecommunications and emergency response, by C. A. Lawson and C. E. Mortensen. p. 93-95.

Video aspects of scientific visualization, by R. A. MacDonald and C. F. Ferrigno. p. 95-96.

GeoMedia; teaching earth science through new technology, by D. A. Wiltshire and M. E. Powell. p. 96-98.

WAIS; improved access to information, by E. J. Christian and T. L. Gauslin. p. 98-99.

Systems partnerships, by K. K. Lee. p. 102-104.

Partnerships with other DOI bureaus, by J. L. Murphy, J. A. Walbert and D. L. Burton. p. 104-105.

Employment outreach, by R. C. Williams. p. 105-106. 


\section{PERIODICALS}

\section{EARTHQUAKES AND VOLCANOES}

For a complimentary copy write to Earthquakes and Volcanoes, U.S. Geological Survey, 904 National Center, Reston, VA 22092.

Earthquakes and Volcanoes, v. 23, no. 1. 1992. p. 1-48.

Earthquakes and Volcanoes, v. 23, no. 2. 1992. p. 49-88.

Earthquakes and Volcanoes, v. 23, no. 3. 1992. p. 89-148.

Earthquakes and Volcanoes, v. 23, no. 4. 1992. p. 149-192.

Earthquakes and Volcanoes, v. 23, no. 5. 1992. p. 193-240.

Earthquakes and Volcanoes, v. 23, no. 6. 1992. p. 241-288.

\section{PRELIMINARY DETERMINATION OF EPICENTERS}

For sale by the Superintendent of Documents, U.S. Govemment Printing Office, Washington, D.C. 20402.

Single copies of monthly issues may be purchased only from USGS ESICOpen-File Report Section, Box 25286, Mail Stop 517, Denver, CO 80225.

Preliminary determination of epicenters. Monthly listing for June 1992. $36 \mathrm{p}$.

Preliminary determination of epicenters. Monthly listing for July 1992. $44 \mathrm{p}$.

Preliminary determination of epicenters. Monthly listing for August 1992. $40 \mathrm{p}$.

Preliminary determination of epicenters. Monthly listing for September $1992.36 \mathrm{p}$.

Preliminary determination of epicenters. Monthly listing for October $1992.36 \mathrm{p}$.

Preliminary determination of epicenters. Monthly listing for November $1992.36 \mathrm{p}$.

Preliminary determination of epicenters. Monthly listing for December 1992 . $32 \mathrm{p}$.

Preliminary determination of epicenters. Monthly listing for January $1993.40 \mathrm{p}$.

Preliminary determination of epicenters. Monthly listing for February $1993.28 \mathrm{p}$.

Preliminary determination of epicenters. Monthly listing for March 1993. 36 p.

Preliminary determination of epicenters. Monthly listing for April 1993. $32 \mathrm{p}$.

Preliminary determination of epicenters. Monthly listing for May 1993. 44 p.
INFORMAL REPORTS

\section{WATER-RESOURCES INVESTIGATIONS REPORTS}

"Water-Resources Investigations Reports" (WRI) in this listing is applied to reports that are of an interpretative nature made available to the public outside the formal USGS publications series. WRI's are not reproduced and distributed in quantity as are formal USGS publications, but are available for public inspection at the indicated depositories.

The following WRI reports are available from: USGS ESIC-Open-File Report Section, Box 25286, Mail Stop 517, Denver, CO 80225 (telephone 303-236-7476). For specific ordering instructions, please refer to "Reports Available Only Through USGS ESIC-Open-File Report Section" under "Open-File Reports." When ordering, use the WRI number preceding each item, and do not mix orders for WRI reports and open-file reports with orders for other U.S. Geological Survey products.

In the water-resources investigations report and the open-file report listings that follow, offices where reports may be inspected are identified by the symbols listed below:

A Earth Science Information Center, Rm. 101, 4230 University Dr., Anchorage, AK 99508-4664.

Da Library, Rm. C2002, Bldg. 20, Denver Federal Center, Lakewood, CO 80225 .

F Library, 2255 North Gemini Dr., Flagstaff, AZ 86001.

M Library, 345 Middlefield Rd., Menlo Park, CA 94025.

NC Library, Rm. 4A100, National Center, 12201 Sunrise Valley Dr., Reston, VA 22092.

S Earth Science Information Center, Rm. 135, U.S. Courthouse, West 920 Riverside Ave., Spokane, WA 99201.

U Earth Science Information Center, Rm. 8105, Federal Bldg., 125 South State St., Salt Lake City, UT 84138.

Wa Earth Science Infromation Center, U.S. Department of the Interior, Rm. 2650, 1849 C St., NW, Washington, DC 20240.

$\mathrm{Wb}$ U.S. Department of the Interior, Natural Resources Library, Gifts and Exchange Section, 1849 C St., NW, Washington, DC 20240 .

WRI 85-4267. CONNECTICUT. Water quality of Lake Waramaug and surrounding watershed, Litchfield County, Connecticut, by K. P. Kulp and David Grason. Prepared in cooperation with the Northwest Connecticut Regional Planning Agency, Lake Waramaug Task Force. 1992. 97 p. (NC, Da, M, Wb.)

WRI 87-4144. CONNECTICUT. Hydrogeology, ground-water availability, and water quality in the Titicus River valley, Ridgefield, Connecticut, by S. J. Grady, M. F. Weaver and J. W. Bingham. Prepared in cooperation with the Town of Ridgefield. 1992. 50 p., 5 over-size sheets. (NC, Da, M, Wb; USGS, WRD, Abraham A. Ribicoff Federal Bldg., 450 Main St., Room 525, Hartford, CT 06103.)

WRI 88-4127. NEW YORK. Geohydrology and 1985 groundwater levels on Manhasset Neck, Long Island, New York, by R. N. Casson. Prepared in cooperation with the Nassau County Department of Public Works. 1992. 29 p., 2 over-size sheets. (NC, Da, M, Wb; USGS, WRD, P.O. Box 1669, Albany, NY 12201.)

WRI 88-4208. OKLAHOMA, TEXAS. Simulation of groundwater flow in the Antlers Aquifer in southeastern Oklahoma and northeastern Texas, by R. B. Morton. Prepared in cooperation with the U.S. Army Corps of Engineers. 1992. 22 p., 7 over-size sheets, scale 1:500,000 (1 inch = about 8 miles). (NC, Da, M, Wb; USGS, WRD, Broadway Executive Park, Bldg. 7, 202 NW 66th, Oklahoma City, OK 73116.) 
WRI 90-4011. PENNSYLVANIA. Water quality of the upper West Branch Susquehanna River and tributary streams between Curwensville and Renovo. Pennsylvania. May and July 1984, by R. A. Hainly and J. L. Barker. 1993. 61 p. (NC, Da, M, Wb; USGS, WRD, 840 Market St., Lemoyne, PA 17043-1586.)

WRI 90-4056. SOUTH CAROLINA. Simulation of the effects of proposed construction of Twelfth Street extension and of floodplain reforestation on flood elevations, Congaree River near Columbia, South Carolina, by R. E. Schuck-Kolben and S. T. Benedict. Prepared in cooperation with the South Carolina Department of Highways and Public Transportation. 1992. 37 p., 11 over-size sheets. (NC, Da, M, Wb.)

WRI 90-4085. WASHINGTON, OREGON. Ground-water pumpage from the Columbia Plateau, Washington and Oregon, by D. R. Cline and C. A. Collins. Prepared in cooperation with the State of Washington Department of Ecology. 1992. 31 p., 5 oversize sheets, scale 1:1,250,000 (1 inch = about 19 miles). (NC, Da, M, Wb, S; USGS, WRD, 1201 Pacific Ave., Suite 600, Tacoma, WA 98402.)

WRI 90-4105. UTAH, ARIZONA. Simulation of ground-water flow and water-level declines that could be caused by proposed withdrawals, Navajo Sandstone, southwestern Utah and northwestern Arizona, by V. M. Heilweil and G. W. Freethey. Prepared in cooperation with the National Park Service. 1992. 51 p., 3 over-size sheets, scale 1:250,000 ( 1 inch = about 4 miles). (NC, $\mathrm{Da}, \mathrm{M}, \mathrm{Wb}, \mathrm{U}$.

WRI 90-4124. WISCONSIN. Sediment transport, particle sizes, and loads in lower reaches of the Chippewa, Black, and Wisconsin rivers in western Wisconsin, by W. J. Rose. Prepared in cooperation with the U.S. Army Corps of Engineers. 1992.38 p. (NC, $\mathrm{Da}, \mathrm{M}, \mathrm{Wb}$; USGS, WRD, 6417 Normandy Lane, Madison, WI 53719-1133.)

WRI 90-4125. PUERTO RICO. Elevation of water table and hydrologic conditions in the Rio Lapa to Rio Majada area, Puerto Rico, for December 1988, and April, July, and October 1989, by Orlando Ramos-Gines. 1990. (NC, Da, M, Wb; USGS, WRD, P.O. Box 364424, San Juan, PR 00936.) Available only from USGS, WRD, P.O. Box 364424, San Juan, PR 00936.

WRI 90-4126. WISCONSIN. Hydrology and water quality of Powers Lake, southeastern Wisconsin, by S. J. Field. Prepared in cooperation with the Powers Lake Management District. 1993. 36 p. (NC, Da, M, Wb; USGS, WRD, 6417 Normandy Lane, Madison, WI 53719-1133.)

WRI 90-4131. PENNSYLVANIA. Evaluation of agricultural best-management practices in the Conestoga River headwaters, Pennsylvania; description and water quality of the Little Conestoga Creek headwaters prior to the implementation of nutrient management, by D. K. Fishel, M. J. Brown, K. M. Kostelnik and M. A. Howse. Prepared in cooperation with the Pennsylvania Department of Environmental Resources. 1992. 68 p. (NC, Da, M, Wb; USGS, WRD, 840 Market St., Lemoyne, PA 17043.)

WRI 90-4150. MINNESOTA. Simulation of ground-water flow in the St. Peter Aquifer in an area contaminated by coal-tar derivatives, St. Louis Park, Minnesota, by D. L. Lorenz and J. R. Stark. Prepared in cooperation with the U.S. Environmental Protection Agency. 1990. 37 p. (NC, Da, M, Wb; USGS, WRD, 2280 Woodall Dr., Mounds View, MN 55112.)
WRI 90-4151. NEW JERSEY. Geohydrology of, and simulation of ground-water flow in, the valley-fill deposits in the Ramapo River valley, New Jersey, by M. C. Hill, G. P. Lennon, G. A. Brown, C. S. Hebson and S. J. Rheaume. Prepared in cooperation with the New Jersey Department of Environmental Protection and Energy. 1992. 92 p., 4 over-size sheets, scale 1:24,000 (1 inch $=2000$ feet). (NC, Da, M, Wb; USGS, WRD, Mountain View Office Park, 810 Bear Tavern Rd., Suite 206, West Trenton, NJ 08628.)

WRI 90-4154. WYOMING. Assessment of the hydrologic system and hydrologic effects of uranium exploration and mining in the Southern Powder River Basin Uranium District and adjacent areas, Wyoming, 1983, by M. E. Lowry, P. B. Daddow and S. J. Rucker, IV. Prepared in cooperation with the Wyoming State Engineer and the Wyoming Department of Environmental Quality. 1993. 42 p., 2 over-size sheets, scale 1:100,000 (1 inch = about 1.6 miles). (NC, Da, M, Wb, U; USGS, WRD, 2617 East Lincolnway, Suite B, Cheyenne, WY 82001.)

WRI 90-4161. NEW HAMPSHIRE. Geohydrology and water quality of stratified-drift aquifers in the Bellamy, Cocheco, and Salmon Falls River basins, southeastern New Hampshire, by T. J. Mack and S. M. Lawlor. Prepared in cooperation with the New Hampshire Department of Environmental Services, Water Resources Division. 1992. 89 p., 3 over-size sheets, scale 1:24,000 ( 1 inch $=2,000$ feet). (NC, Da, M, Wb.)

WRI 90-4182. NEW YORK. Ground-water quality in the Bethpage-Hicksville-Levittown area, Long Island, New York, with emphasis on volatile organic compounds, by S. M. Feldman, D. A. Smolensky and J. P. Masterson. Prepared in cooperation with the Nassau County Department of Health. 1992. 51 p. (NC, Da, M, Wb; USGS, WRD, P.O. Box 1669, Albany, NY 12201.)

WRI 90-4205. NEW YORK. Base flow of 10 south-shore streams, Long Island, New York, 1976-85, and the effects of urbanization on base flow and flow duration, by A. G. Spinello and D. L. Simmons. Prepared in cooperation with the Nassau County Department of Public Works and the Suffolk County Department of Health Services. 1992. 34 p. (NC, Da, M, Wb; USGS, WRD, 5 Aerial Way, Syosset. NY 11791.)

WRI 91-4012. NEW YORK. Rates of water movement through the floors of selected stormwater basins in Nassau County, Long Island, New York, by H. F. Ku and D. B. Aaronson. Prepared in cooperation with the Nassau County Department of Public Works. 1992.121 p., 1 over-size sheet. (NC, Da, M, Wb; USGS, WRD, P.O. Box 1669, Albany, NY 12201.)

WRI 91-4024. OHIO. Geohydrology and quality of water in aquifers in Lucas, Sandusky, and Wood counties, northwestern Ohio, by K. J. Breen and D. H. Dumouchelle. Prepared in cooperation with Lucas County, Sandusky County Department of Public Health, Wood County, and the cities of Maumee, Oregon, Sylvania, and Toledo, Ohio. 1991. 234 p., 11 over-size sheets. (NC, Da, M, Wb.)

WRI 91-4025. NEW HAMPSHIRE. Geohydrology and water quality of stratified-drift aquifers in the lower Merrimack and coastal river basins, southeastern New Hampshire, by P. J. Stekl and S. M. Flanagan. Prepared in cooperation with the New Hampshire Department of Environmental Services, Water Resources Division. 1992. 93 p., 7 over-size sheets, scale 1:24,000 
( 1 inch $=2,000$ feet). (NC, Da, M, Wb; USGS, WRD, 525 Clinton St., Bow, NH 03304.)

WRI 91-4030. NEW YORK. Estimated thickness and potential well yield of stratified-drift in selected areas of northern Westchester County, New York; by R. F. Snow and S. W. Wolcott. Prepared in cooperation with the Westchester County Water Agency. 1992. 6 over-size sheets, scale $1: 24,000(1$ inch $=2,000$ feet $)$. (NC, Da, M, Wb; WRD, USGS, P.O. Box 1669, Albany, NY 12201.)

WRI 91-4033. NEW MEXICO. Hydrogeology and ground-water chemistry of the San Andres-Glorieta Aquifer in the Acoma Embayment and eastern Zuni Uplift, west-central New Mexico, by J. A. Baldwin and S. K. Anderholm. Prepared in cooperation with New Mexico State Engineer Office, Pueblo of Acoma, Pueblo of Laguna, and the U.S. Bureau of Indian Affairs. 1992. 304 p., 2 over-size sheets. (NC, Da, M, Wb, U; USGS, WRD, Pinetree Corporate Centre, Suite 200, 4501 Indian School Rd. NE, Albuquerque, NM 87110.)

WRI 91-4044. WYOMING. Water resources of Washakie County, Wyoming, by D. D. Susong, M. L. Smalley and E. R. Banta. Prepared in cooperation with the Wyoming State Engineer. 1993. 82 p., 2 over-size sheets, scale 1:500,000 (1 inch = about 8 miles). (NC, Da, M, Wb, U; USGS, WRD, 2617 East Lincolnway, Suite B, Cheyenne, WY 82001.)

WRI 91-4063. OREGON. Urban storm runoff in the Roseburg area, Oregon, as related to urban flood characteristics of the Willamette Valley, by L. E. Hubbard. Prepared in cooperation with the Water Resources Survey, Douglas County, Oregon. 1992. 28 p. (NC, Da, M, Wb, S; USGS, WRD, 1201 Pacific Ave., Suite 600, Tacoma, WA 98402; USGS, Library, 5400 MacArthur, Vancouver, WA 98661.)

WRI 91-4065. NEW MEXICO. Isostatic residual gravity anomalies of New Mexico, by C. E. Heywood. Prepared in cooperation with the New Mexico State Engineer Office. 1992. 27 p. (NC, Da, M, Wb, U; USGS, WRD, Pinetree Corporate Ctr., Suite 200, 4501 Indian School Rd. NE, Albuquerque, NM 87110.)

WRI 91-4073. WASHINGTON. Surface-water-quality assessment of the Yakima River basin, Washington; areal distribution of fecal-indicator bacteria, July 1988, by S. S. Embrey. 1992. 34 p., 2 over-size sheets, scale 1:250,000 (1 inch = about 4 miles). (NC, Da, M, Wb, S; USGS, WRD, 1201 Pacific Ave., Suite 600, Tacoma, WA 98402; USGS Library, Room 656, West 920 Riverside Ave., Spokane, WA 99201.)

WRI 91-4087. OREGON. Summary appraisal of water resources of the Umatilla Indian Reservation, Oregon, by J. B. Gonthier and E. L. Bolke. 1993. 54 p., 1 over-size sheet, scale 1:250,000 (1 inch = about 4 miles). (NC, Da, M, Wb, S; USGS, WRD, Library, 5400 McArthur, Vancouver, WA 98661.)

WRI 91-4095. COLORADO. Assessment of effects of military maneuvers on the streamflow, water quality, and sediment yields at the U.S. Army Pinon Canyon Maneuver Site, Las Animas County, Colorado, by Paul von Guerard, R. S. Parker and R. G. Dash. Prepared in cooperation with the U.S. Department of the Army, Fort Carson Military Reservation. 1993. 84 p., 1 over-size sheet, scale 1:100,000 (1 inch = about 1.6 miles). (NC, Da, M, Wb, U; USGS, WRD, Box 25046, Mail Stop 415, Denver Federal Ctr., Denver, CO 80225.)
WRI 91-4108. WYOMING. Surface- and ground-water quality in the Owl Creek basin, north-central Wyoming, by K. M. Ogle. Prepared in cooperation with the Northern Arapaho Tribe. 1992. 65 p., 1 over-size sheet, scale $1: 100,000$ ( 1 inch = about 1.6 miles $)$. (NC, Da, M, Wb., USGS, WRD, 2617 East Lincolnway, Suite B, Cheyenne, WY 82001.)

WRI 91-4109. LOUISIANA. Generalized potentiometric surfaces of the Red River alluvial aquifer, Pool 1, Red River waterway area, central Louisiana, by C. W. Smoot and Angel Martin, Jr. Prepared in cooperation with the U.S. Army Corps of Engineers and the U.S. Soil Conservation Service. 1991. 7 over-size sheets, scale 1:62,500 (1 inch = about 1 mile $).(\mathrm{NC}, \mathrm{Da}, \mathrm{M}, \mathrm{Wb}$.

WRI 91-4110. Feasibility of using portable, noninvasive pipe flowmeters and time totalizers for determining water use, by U.S. Geological Survey. Prepared in cooperation with the Indiana Department of Natural Resources, Division of Water. 1992. $65 \mathrm{p}$. (NC, Da, M, Wb; USGS, WRD, 5957 Lakeside Blvd., Indianapolis, IN 46278-1996.)

WRI 91-4115. FLORIDA. Hydrologic conditions in the Nassau River basin, northeastern Florida, 1982-89, by J. E. Coffin, P. S. Hampson and Joel Steward. Prepared in cooperation with the Saint Johns River Water Management District. 1992. 112 p. (NC, Da, M, Wb; USGS, WRD, Suite B-5, 4710 Eisenhower Blvd., Tampa, FL 33614.)

WRI 91-4116. ALABAMA. Geohydrology of the principal aquifers in Butler County, Alabama, by J. C. Scott and R. H. Cobb. Prepared in cooperation with the Butler County Water Authority and Greenville Waterworks Board. 1992. 34 p. (NC, Da, M, Wb; USGS, WRD, 520 19th Ave., Tuscaloosa, AL 37501; and P.O. Box 210337, Montgomery, AL 36121-0337.)

WRI 91-4117. UTAH. Salt budget for West Pond, Utah, April 1987 to April 1988, by K. M. Waddell, J. W. Gwynn, C. B. Burden and S. R. Wold. 1992. 29 p. (NC, Da, M, Wb, U.)

WRI 91-4119. CALIFORNIA. Spatial distribution of selenium and other inorganic constituents in ground water underlying a drained agricultural field, western San Joaquin Valley, California, by D. A. Leighton, S. J. Deverel and J. K. Macdonald. Prepared in cooperation with the San Joaquin Valley Drainage Program. 1992. 73 p. (NC, Da, M, Wb; USGS, WRD, Federal BIdg., Room W-2233, 2800 Cottage Way, Sacramento, CA 95825; and 5735 Kearny Villa Rd., Suite O, San Diego, CA 92123.)

WRI 91-4120. MICHIGAN. Hydrologic provinces of Michigan, by $S$. J. Rheaume. Prepared in cooperation with the Michigan Department of Natural Resources, Geological Survey Division. 1991. 73 p., 1 over-size sheet. (NC, Da, M, Wb; USGS, WRD, 6520 Mercantile Way, Suite 5, Lansing, MI 48911.)

WRI 91-4121. ALABAMA. Geohydrology and ground-water availability in western Marshall and eastern Morgan counties, Alabama, by C. R. Bossong. Prepared in cooperation with the City of Arab Waterworks Board. 1992. 30 p. (NC, Da, M, Wb; USGS, WRD, 520 19th Ave., Tuscaloosa, AL 35401; and P.O. Box 210337, Montgomery, AL 36121-0337.)

WRI 91-4123. FLORIDA. Factors that affect public-supply water use in Florida, with a section on projected water use to the year 2020, by R. L. Marella. Prepared in cooperation with the Florida Department of Environmental Regulation. 1992. 35 p. (NC, Da, M, Wb; USGS, WRD, Suite 107, 9100 NW 36 St., Miami, FL 
33178; Suite 222, 3728 Phillips Hwy., Jacksonville, FL 32207; Suite B-5, 4710 Eisenhower Blvd., Tampa. FL 33634-6381; and Suite 3015, 227 North Bronough St., Tallahassee, FL 32301.)

WRI 91-4126. NEW JERSEY. Water resources of the unconfined aquifer system of the Great Egg Harbor River basin, New Jersey, 1989-90, by M. K. Watt and M. L. Johnson. Prepared in cooperation with the New Jersey Department of Environmental Protection and Energy. 1991. 5 over-size sheets. (NC, Da, M, Wb; USGS, WRD, Mountain View Office Park, 810 Bear Tavern Rd., Suite 206, West Trenton, NJ 08628.)

WRI 91-4133. MICHIGAN. Hydrogeology of Huron County, Michigan, by M. J. Sweat. Prepared in cooperation with Huron County and the Michigan Department of Natural Resources. 1992. 76 p., 1 over-size sheet. (NC, Da, M, Wb; USGS, WRD, 6520 Mercantile Way, Suite 5, Lansing, MI 48911.)

WRI 91-4142. CALIFORNIA. Evaluation of a ground-water flow and transport model of the upper Coachella Valley, California, by E. G. Reichard and J. K. Meadows. Prepared in cooperation with the California Regional Water Quality Control Board, Colorado River Basin Region. 1992. 101 p. (NC, Da, M, Wb; USGS, WRD, Federal Bldg., Room W-2233, 2800 Cottage Way, Sacramento, CA 95825; and Suite O, 5735 Kearny Villa Rd., San Diego, CA 92123.)

WRI 91-4148. CALIFORNIA. Simulation of freshwater and saltwater flow in the coastal aquifer system of the Purisima Formation in the Soquel-Aptos Basin, Santa Cruz County, California, by $\mathrm{H}$. I. Essaid. 1992. 35 p. (NC, Da, M, Wb; USGS, WRD, Federal Bldg., Room W-2233, 2800 Cottage Way, Sacramento, CA 95825; and 5735 Kearny Villa Rd., Suite O, San Diego, CA 92123.)

WRI 91-4149. Properties and chemical constituents in ground water from the Mississippi River valley alluvial aquifer and permeable zone A (Holocene-upper Pleistocene deposits), south-central United States, by R. A. Pettijohn, J. F. Busby and J. D. Beckman. 1992. 5 over-size sheets, scale 1:3,500,000 (1 inch = about 55 miles). (NC, Da, M, Wb; USGS, WRD, GC RASA, 8011 Cameron Rd., Bldg. 1, Austin, TX 78753.)

WRI 91-4150. Properties and chemical constituents in ground water from the Upper Claiborne Aquifer, Gulf Coast regional aquifer systems, south-central United States, by R. A. Pettijohn, J. F. Busby and T. B. Layman. 1993. 5 over-size sheets, scale 1:3,500,000 (1 inch = about 55 miles). (NC, Da, M, Wb; USGS, WRD, RASA, 8011 Cameron Rd., Bldg. B, Austin, TX 787543898.)

WRI 91-4151. Properties and chemical constituents in ground water from permeable zone $\mathrm{C}$ (lower Pliocene-upper Miocene deposits), coastal lowlands aquifer system, south-central United States, by R. A. Pettijohn, J. F. Busby and M. A. Cervantes. 1993. 5 over-size sheets, scale 1:3,500,000 (1 inch = about 55 miles). (NC, Da, M, Wb; USGS, WRD, RASA, 8011 Cameron Rd., Bldg. B, Austin, TX 78754-3898.)

WRI 91-4152. Properties and chemical constituents in ground water from permeable zone B (lower Pleistocene-upper Pliocene deposits), coastal lowlands aquifer system, south-central United States, by R. A. Pettijohn, J. F. Busby and T. B. Layman. 1993. 5 over-size sheets, scale $1: 3,500,000$ ( 1 inch $=$ about 55 miles). (NC, Da, M, Wb; USGS, WRD, RASA, 8011 Cameron Rd., Bldg. B, Austin, TX 78754-3898.)
WRI 91-4155. NEW MEXICO, TEXAS. Simulation of groundwater flow in the Mesilla Basin, Dona Ana County, New Mexico, and El Paso County, Texas, by P. F. Frenzel. Prepared in cooperation with the U.S. Section, International Boundary and Water Commission, United States and Mexico. 1992. 157 p. (NC, Da, M, Wb, U; USGS, WRD, Pinetree Corporate Ctr., Suite 200, 4501 Indian School Rd. NE, Albuquerque, NM 87110.) (Supplement to Open-file report 88-305.)

WRI 91-4167. NEVADA. Lithologic properties of carbonaterock aquifers at five test wells in the Coyote Spring Valley area, southern Nevada, as determined from geophysical logs, by D. L. Berger. Prepared in cooperation with the State of Nevada, the Las Vegas Valley Water District, and the U.S. Bureau of Reclamation. 1992. 27 p. (NC, Da, M, Wb, U; USGS, WRD, 6770 South Paradise, Las Vegas, NV 89119; and 333 West Nye Lane, Carson City, NV 89706.)

WRI 91-4168. FLORIDA. A preliminary approach to the use of borehole data, including television surveys, for characterizing secondary porosity of carbonate rocks in the Floridan aquifer system, by P. S. Safko and J. J. Hickey. 1992 . 69 p. (NC, Da, M, Wb; USGS, WRD, Suite B-5, 4710 Eisenhower Blvd., Tampa, FL 33634.)

WRI 91-4169. NEW JERSEY. Hydrologic conditions in the upper Rockaway River basin, New Jersey, 1984-86, by F. L. Schaefer, P. T. Harte, J. A. Smith and B. A. Kurtz. Prepared in cooperation with the New Jersey Department of Environmental Protection and Energy. 1993. 103 p., 2 over-size sheets, scale 1:48,000 ( 1 inch $=4,000$ feet). (NC, Da, M, Wb; USGS, WRD, Mountain View Office Park, 810 Bear Tavern Rd., Suite 206, West Trenton, NJ 08628.)

WRI 91-4173. TENNESSEE. Hydrogeology, ground-water quality, and potential for water-supply contamination near the Shelby County landfill in Memphis, Tennessee, by W. S. Parks and J. E. Mirecki. Prepared in cooperation with the Shelby County Department of Public Works. 1992. 79 p. (NC, Da, M, Wb; USGS, WRD, Room A-413 Federal Bldg., Nashville, TN 37203; 1013 North Broadway, Knoxville, TN 37917; and AgriCenter International, 7777 Walnut Grove Rd., Suite LLB2, Memphis, TN38119.)

WRI 91-4176. COLORADO. Water-quality variations and trends in Monument and Fountain creeks, El Paso and Pueblo counties, Colorado, water years 1976-88, by B. C. Ruddy. Prepared in cooperation with the Colorado Springs Department of Utilities. 1993. 66 p. (NC, Da, M, Wb, U; USGS, WRD, Box 25046, Mail Stop 415, Denver Federal Ctr., Denver, CO 80225.)

WRI 91-4177. NEW HAMPSHIRE. Geohydrology of, and simulation of ground-water flow in, the Milford-Souhegan glacial-drift aquifer, Milford, New Hampshire, by P. T. Harte and T. J. Mack. Prepared in cooperation with the U.S. Environmental Protection Agency. 1992. 104 p. (NC, Da, M, Wb; USGS, WRD, 525 Clinton St., Bow, NH 03304.)

WRI 91-4178. GEORGIA. Evaluation of the hydrogeology and contamination in the vicinity of an abandoned manufactured gas plant in Albany, Georgia, by M. J. Chapman. Prepared in cooperation with the City of Albany, Water, Gas, and Light Commission. 1991. 36 p. (NC, Da, M, Wb; USGS, WRD, Peachtree Business Ctr., Suite 130, 3039 Antwiler Rd., Doraville, GA 30360 2824.) 
WRI 91-4179. MARYLAND. Water withdrawal and use in Maryland, 1988-89, by J. C. Wheeler. Prepared in cooperation with the Maryland Water Resources Administration and the Maryland Geological Survey. 1992. 40 p. (NC, Da. M, Wb; USGS, WRD. 208 Carroll Bldg., 8600 La Salle Rd., Towson, MD 21204.)

WRI $91-4180$. FLORIDA. Hydrogeologic setting and preliminary data analysis for the hydrologic-budget assessment of Lake Barco, an acidic seepage lake in Putnam County, Florida, by L. A. Sacks, T. M. Lee and A. B. Tihansky. Prepared in cooperation with the Florida Department of Environmental Regulation. 1992. 28 p. (NC, Da, M, Wb; USGS, WRD, Suite B-5, 4710 Eisenhower Blvd., Tampa, FL 33634.)

WRI 91-4181. FLORIDA. Effects of effluent spray irrigation and sludge disposal on ground water in a karst region, Northwest Pinellas County, Florida, by J. T. Trommer. Prepared in cooperation with Pinellas County, Florida. 1992. 32 p. (NC, Da, M, Wb; USGS, WRD, Suite B-5, 4710 Eisenhower Blvd., Tampa, FL 33614.)

WRI 91-4182. PENNSYLVANIA. Altitude and configuration of the potentiometric surface in the crystalline and metasedimentary rocks, northeastern Chester County, Pennsylvania, May through October 1990, by B. C. McManus. Prepared in cooperation with the Chester County Water Resources Authority. 1992. 1 oversize sheet, scale 1:24,000 (1 inch $=2,000$ feet). (NC, Da, M, Wb; USGS, WRD, Great Valley Corporate Ctr., 111 Great Valley Pkwy., Malvern, PA 19355.)

WRI 91-4185. NEVADA, ARIZONA. Geohydrologic reconnaissance of Lake Mead National Recreation Area; Virgin River, Nevada, to Grand Wash Cliffs, Arizona, by J. T. Bales and R. L. Laney. Prepared in cooperation with the U.S. National Park Service. 1992. 29 p., 1 over-size sheet. (NC, Da, M, Wb; USGS, WRD, 375 South Euclid Ave., Tucson, AZ 85719-6644; 1545 West University Dr., Tempe, AZ 85281; 2255 North Gemini Dr., Flagstaff, AZ 86001; and 1940 South 3rd Ave., Yuma, AZ 85364.)

WRI 91-4186. FLORIDA. Hydrochemistry of the surficial and intermediate aquifer systems in Florida, by M. P. Berndt and B. G. Katz. Prepared in cooperation with the Florida Department of Environmental Regulation. 1992. 24 p. (NC, Da, M, Wb; USGS, WRD, Suite 3015, 227 North Bronough St., Tallahassee, FL 32301.)

WRI 91-4190. TENNESSEE. Ground-water hydrology of the lower Wolftever Creek basin, with emphasis on the Carson Spring area, Hamilton County, Tennessee, by D. A. Webster and J. K. Carmichael. Prepared in cooperation with the Eastside Utility District. 1993. 47 p. (NC, Da, M, Wb; USGS, WRD, 810 Broadway, Suite 500, Nashville, TN 37203; 1013 North Broadway, Knoxville, TN 37917; and AgriCenter International, 7777 Walnut Grove Rd., Suite LLB2, Memphis, TN 38119.)

WRI 91-4191. NEW JERSEY. Ground-water hydrology and simulation of saltwater encroachment, shallow aquifer system of southern Cape May County, New Jersey, by F. J. Spitz and T. H. Barringer. 1992.87 p. (NC, Da, M, Wb; USGS, WRD, Mountain View Office Park, 810 Bear Tavern Rd., Suite 206, West Trenton, NJ 08628.)

WRI 91-4194. MICHIGAN. Statistical models for estimating daily streamflow in Michigan, by D. J. Holtschlag and Habib Salehi. Prepared in cooperation with the Michigan Department of
Natural Resources. 1992. 48 p. (NC, Da, M, Wb; USGS, WRD, 6520 Mercantile Way, Suite 5, Lansing, MI 48911.)

WRI 91-4195. TENNESSEE. Public water-supply system and water use in Tennessee, 1988, by S. S. Hutson and A. J. Morris. Prepared in cooperation with the Tennessee Department of Environment and Conservation, Division of Water Supply. 1992. 74 p. (NC, Da, M, Wb; USGS, WRD, Room A-413 Federal Bldg., Nashville, TN 37203; 1013 North Broadway, Knoxville, TN 37917; and AgriCenter International, 7777 Walnut Grove Rd., Suite LLB2, Memphis, TN 38119.)

WRI 91-4196. FLORIDA. Hydrochemistry of the upper Floridan Aquifer, Florida, by B. G. Katz. Prepared in cooperation with the Florida Department of Environmental Regulation. 1992. 37 p., 10 over-size sheets, scale 1:3,300,000 ( 1 inch = about 52 miles $)$. (NC, Da, M, Wb; USGS, WRD, Suite 3015, 227 North Bronough St., Tallahassee, FL 32301.)

WRI 91-4197. HAWAII. Geology and stream infiltration of North Halawa Valley, Oahu, Hawaii, by S. K. Izuka. Prepared in cooperation with the State of Hawaii Department of Transportation. 1992. 21 p., 2 over-size sheets, scale $1: 12,000$ (one inch $=1,000$ feet). (NC, Da, M, Wb.)

WRI 91-4199. WYOMING, MONTANA. Chemical quality of surface water and mathematical simulation of the surface-water system, Powder River drainage basin, northeastern Wyoming and southeastern Montana, by J. B. Lindner-Lunsford, Charles Parrett, J. F. Wilson, Jr. and C. A. Eddy-Miller. Prepared in cooperation with the Wyoming Water Development Commission, Montana Department of Natural Resources and Conservation, and the Wyoming State Engineer. 1992. 85 p. (NC, Da, M, Wb, U; USGS, WRD, 2617 East Lincolnway, Suite B, Cheyenne, WY 82001.)

WRI 92-4000. SOUTH CAROLINA. Potentiometric surfaces of November 1989 and declines in the potentiometric surfaces between November 1982 and November 1989 for the Black Creek and Middendorf aquifers in South Carolina, by W. J. Stringfield and B. G. Campbell. Prepared in cooperation with the South Carolina Water Resources Commission. 1993. 2 over-size sheets. (NC, Da, M, Wb.)

WRI 92-4004. NEW MEXICO. Geohydrology and potential hydrologic effects of surface coal mining of the San Augustine Coal Area and adjacent areas, Catron and Cibola counties, New Mexico, by R. G. Myers. Prepared in cooperation with the U.S. Bureau of Land Management. 1992. 52 p. (NC, Da, M, Wb, U; USGS, WRD, Pinetree Corporate Ctr., Suite 200, 4501 Indian School Rd. NE, Albuquerque, NM 87110.)

WRI 92-4012. NEW HAMPSHIRE. Integrated use of surfacegeophysical methods to indicate subsurface fractures at Tibbetts Road, Barrington, New Hampshire, by D. A. Lieblich, F. P. Haeni and R. E. Cromwell. Prepared in cooperation with the U.S. Environmental Protection Agency. 1992. 33 p. (NC, Da, M, Wb; USGS, WRD, 450 Main St., Room 525, Hartford, CT 06103.)

WRI 92-4014. IDAHO. Water levels in selected wells and directions of ground-water movement near Fort Hall, Fort Hall Indian Reservation, southeastern Idaho, by D. J. Parliman and H. W. Young. Prepared in cooperation with the Shoshone-Bannock Tribes, Fort Hall Indian Reservation. 1993. 13 p. (NC, Da, M, Wb; USGS, WRD, 230 Collins Rd., Boise, ID 83702.) 
WRI 92-4018. TENNESSEE. Hydrology of the Cave Springs area near Chattanooga, Hamilton County, Tennessee, by A. D. Bradfield. Prepared in cooperation with the Hixson Utility District. 1992 . 28 p. (NC, Da, M; USGS, WRD, 810 Broadway, Suite 500, Nashville, TN 37203; 1013 North Broadway, Knoxville. TN 37917; and AgriCenter International, 7777 Walnut Grove Rd., Suite LLB2, Memphis, TN 38119.)

WRI 92-4019. INDIANA. Suspended sediment in Trail Creek at Michigan City, Indiana, by C. G. Crawford and D. V. Jacques. 1992. 18 p. (NC, Da, M, Wb; USGS, WRD, 5957 Lakeside Blvd., Indianapolis, IN 46278-1996.)

WRI 92-4020. NORTH DAKOTA. Techniques for estimating peak-flow frequency relations for North Dakota, by T. J. Williams-Sether. Prepared in cooperation with the North Dakota Department of Transportation. 1992. 57 p. (NC, Da, M, Wb; USGS, WRD, 821 East Interstate Ave., Bismarck, ND 58501.)

WRI 92-4025. INDIANA. Hydrologic data and hydrologic budget for Summit Lake Reservoir, Henry County, east-central Indiana, water years 1989 and 1990, by R. F. Duwelius. Prepared in cooperation with the Indiana Department of Natural Resources. 1993. 47 p. (NC, Da, M, Wb; USGS, WRD, 5957 Lakeside BIvd., Indianapolis, IN 46278-1996.)

WRI 92-4027. IDAHO. Seasonal changes in ground-water quality and ground-water levels and directions of ground-water movement in southern Elmore County, southwestern Idaho, including Mountain Home Air Force Base, 1990-91, by H. W. Young, D. J. Parliman and M. L. Jones. Prepared in cooperation with the Department of the Air Force. 1992. 22 p., 2 over-size sheets. (NC, Da, M, Wb; USGS, WRD, 230 Collins Rd., Boise, ID 83702.)

WRI 92-4029. WISCONSIN. Simulation of the effects of hypothetical residential development on water levels in Graber Pond, Middleton, Wisconsin, by L. B. House. Prepared in cooperation with the City of Middleton, Wisconsin. 1993. 10 p. (NC, Da, M, Wb; USGS, WRD, 6417 Normandy Lane, Madison, WI 537191133.)

WRI 92-4030. COLORADO. Analysis of residential use of water in the Denver metropolitan area, Colorado, 1980-87, by D. W. Litke and L. F. Kauffman. Prepared in cooperation with the City and County of Denver, Board of Water Commissioners. 1993. 69 p. (NC, Da, M, Wb, U; USGS, WRD, Box 25046, Mail Stop 415, Denver Federal Ctr., Denver, CO 80225-0046.)

WRI 92-4032. NEVADA. Sediment properties and water movement through shallow unsaturated alluvium at an arid site for disposal of low-level radioactive waste near Beatty, Nye County, Nevada, by J. M. Fischer. 1992. 48 p. (NC, Da, M, Wb, U; USGS, WRD, 6770 South Paradise, Las Vegas, NV 89119; and 333 West Nye Lane, Carson City, NV 89706.)

WRI 92-4033. INDIANA. Sedimentation in Long Lake, Noble County, northeastern Indiana, 1959-88, by D. E. Renn. Prepared in cooperation with the Indiana Department of Natural Resources. 1993. 42 p. (NC, Da, M, Wb; USGS, WRD, 5957 Lakeside Blvd., Indianapolis, IN 46278-1996.)

WRI 92-4034. VIRGINIA. Water quality and evaluation of rawwater-routing scenarios, Chickahominy, Diascund Creek, and Little Creek reservoirs, southeastern Virginia, 1983-86, by D. D. Lynch. Prepared in cooperation with the City of Newport News Department of Public Utilities. 1992. 104 p. (NC, Da, M, Wb;
USGS, WRD, 3600 West Broad St., Room 606, Richmond, VA 23230.)

WRI 92-4035. CALIFORNIA. Land subsidence and problems affecting land use at Edwards Air Force Base and vicinity, California, 1990, by J. C. Blodgett and J. S. Williams. Prepared in cooperation with the U.S. Department of the Air Force. 1992. 25 p. (NC, Da, M, Wb; Nancy Ordazzo, USGS, WRD, 2800 Cottage Way, Federal Bldg., Room W-2233, Sacramento, CA 95825; and 5735 Kearny Villa Rd., Suite O, San Diego, CA 92123.)

WRI 92-4039. Immediate and long-term hazards from lahars and excess sedimentation in rivers draining Mount Pinatubo, Philippines, by T. C. Pierson, R. J. Janda, J. V. Umbal and A. S. Daag. Prepared in cooperation with the Philippine Institute of Volcanology and Seismology and the U.S. Agency for International Development. 1992. 35 p., 1 over-size sheet, scale 1:250,000 ( 1 inch $=4$ miles). (NC, Da, M, Wb.)

WRI 92-4040. SOUTH CAROLINA. Determination of flood hydrographs for streams in South Carolina; Volume 2, Estimation of peak-discharge frequency, runoff volumes and flood hydrographs for urban watersheds, by L. R. Bohman. Prepared in cooperation with the South Carolina Department of Highways and Public Transportation. 1992. 79 p. (NC, Da, M, Wb.)

WRI 92-4042. NEW YORK. Maximum known stages and discharges of New York streams, 1865-1989, with descriptions of five selected floods, 1913-85, by Richard Lumia and P. M. Murray. Prepared in cooperation with the New York State Department of Transportation. 1993. 123 p., 2 over-size sheets. (NC, Da, M, Wb; USGS, WRD, P.O. Box 1669, Albany, NY 12201.)

WRI 92-4044. ARKANSAS. Trends in stream water-quality data in Arkansas during several time periods between 1975 and 1989, by J. C. Peterson. 1992. 182 p. (NC, Da, M, Wb; USGS, WRD, 2301 Federal Office Bldg., 700 West Capitol Ave., Little Rock, AR 72201.)

WRI 92-4048. MONTANA. Analysis of the magnitude and frequency of floods and the peak-flow gaging network in Montana, by R. J. Omang. Prepared in cooperation with the Montana Department of Transportation, the U.S. Department of Transportation, and the U.S. Department of Agriculture. 1992. 70 p., 1 over-size sheet. (NC, Da, M, Wb, U, S; USGS, WRD, Room 428 Federal Bldg., 301 South Park Ave., Helena, MT 59626-0076; USGS Field Headquarters, Eastern Montana Coll., 1500 North 30th, Billings, MT 59101.)

WRI 92-4049. HAWAII. Statistical summary of hydrologic and water-quality data from the North Halawa, Haiku, and Kamooalii drainage basins, Oahu, Hawaii, water years $1983-89$, by M. F. Wong and B. R. Hill. Prepared in cooperation with the State of Hawaii, Department of Transportation. 1992. 52 p. (NC, Da, M, Wb.)

WRI 92-4050. COLORADO. Hydrology of the Hart Syncline area, northwestern Colorado, by W. P. Van Liew and S. G. Robson. Prepared in cooperation with the U.S. Bureau of Land Management and Moffat County. 1993. 97 p., 1 over-size sheet, scale $1: 24,000$ ( 1 inch $=2,000$ feet). (NC, Da, M, Wb, U; USGS, WRD, Box 25046, Mail Stop 415, Denver Federal Ctr., Denver, CO 80225.)

WRI 92-4051. NEVADA. Shallow ground water in the Whitney area, southeastern Las Vegas Valley, Clark County, Nevada; Part 
II, Assessment of a proposed strategy to reduce the contribution of salts to Las Vegas Wash, by T. J. Burbey. Prepared in cooperation with the U.S. Bureau of Reclamation. 1993. 58 p. (NC, Da, M, Wb, U; USGS, WRD, 333 West Nye Lane, Carson City, NV 89706; and 6770 South Paradise, Las Vegas, NV 89119.)

WRI 92-4053. COLORADO. Limnological characteristics, nutrient loading and limitation, and potential sources of taste and odor problems in Standley Lake, Colorado, by D. K. Mueller and B. C. Ruddy. Prepared in cooperation with the City of Arvada, City of Golden, City of Northglenn, City of Thornton, City of Westminster, and Jefferson County. 1993. 55 p. (NC, Da, M, Wb, U; USGS, WRD, Box 25046, Mail Stop 415, Denver Federal Ctr., Denver, CO 80225.)

WRI 92-4056. NEW HAMPSHIRE. Integrated use of surfacegeophysical methods to indicate subsurface fractures at Milford, New Hampshire, by D. A. Lieblich, F. P. Haeni and J. W. Lane, Jr. Prepared in cooperation with the U.S. Environmental Protection Agency. 1992. 38 p. (NC, Da, M, Wb; USGS, WRD, 450 Main St., Room 525, Hartford, CT 06103.)

WRI 92-4057. KENTUCKY. Trihalomethane formation potential of Kentucky River water, by R. E. Rathbun, K. D. White and R. D. Evaldi. 1992. 16 p. (NC, Da, M, Wb; USGS, WRD, Box 25046, Mail Stop 408, Denver Federal Ctr., Denver, CO 80225 0046.)

WRI 92-4058. FLORIDA. Reconnaissance study of water quality at nine dairy farms in North Florida, 1990-91, by W. J. Andrews. Prepared in cooperation with the Florida Department of Environmental Regulation. 1992. 39 p. (NC, Da, M, Wb; USGS, WRD, Suite 3015, 227 North Bronough St., Tallahassee, FL 32301; Suite 107, 9100 NW 36 St., Miami, FL 33178; Suite 1006, 224 West Central Pkwy., Altamonte Springs, FL 32714; and Suite B-5, 4710 Eisenhower Blvd., Tampa, FL 33634-6381.)

WRI 92-4060. Comparison of conventional onsite recorders and satellite telemetry for surface-water data collection by the U.S. Geological Survey, by Charles Parrett and E. F. Hubbard, Jr. 1992. 30 p. (NC, Da, M, Wb, U, S; USGS, Field Headquarters, Eastern Montana Coll., 1500 North 30th, Billings, MT 59101.)

WRI 92-4061. FLORIDA. Documentation of a digital spatial data base for hydrologic investigations, Broward County, Florida, by R. S. Sonenshein. Prepared in cooperation with the South Florida Water Management District and the Broward County Office of Natural Resource Protection. 1992. 55 p. (NC, Da, M, Wb; USGS, WRD, Suite 107, 9100 NW 36th St., Miami, FL 33178.)

WRI 92-4062. FLORIDA. Salinity distribution and variation with freshwater inflow and tide, and potential changes in salinity due to altered freshwater inflow in the Charlotte Harbor estuarine system, Florida, by Y. E. Stoker. 1992.30 p. (NC, Da, M, Wb; USGS, WRD, Suite B-5, 4710 Eisenhower Blvd., Tampa, FL 33634.)

WRI 92-4066. MONTANA. Irrigation-canal leakage in the Flathead Indian Reservation, northwestern Montana, by S. E. Slagle. Prepared in cooperation with the Confederated Salish and Kootenai Tribes and the U.S. Bureau of Indian Affairs. 1992. 77 p. (NC, Da, M, Wb, U, S; USGS, WRD, Room 428, Federal Bldg., 301 South Park, Helena, MT 59626-0076; USGS Field Headquarters, Eastern Montana Coll., 1500 North 30th, Billings, MT 59101.)

WRI 92-4067. COLORADO. Description of techniques used to drill, complete, and develop wells and to test and sample aquifers at a surface coal mine in northwestern Colorado, by R. S. Williams, Jr. and G. M. Clark. Prepared in cooperation with the U.S. Bureau of Land Management and the U.S. Office of Surface Mining Reclamation and Enforcement. 1993. 39 p. (NC, Da, M, Wb, U; USGS, WRD, Box 25046, Mail Stop 415, Denver Federal Ctr., Denver, CO 80225.)

WRI 92-4069. FLORIDA. Effects of tidal stage and ground-water levels on the discharge and water quality of springs in coastal Citrus and Hernando counties, Florida, by D. K. Yobbi. Prepared in cooperation with the Southwest Florida Water Management District. 1992.44 p. (NC, Da, M, Wb; USGS, WRD, Suite 3015, 227 North Bronough St., Tallahassee, FL 32301; and Suite B-5, 4710 Eisenhower Blvd., Tampa, FL 33614.)

WRI 92-4070. UTAH. Physical extent, recharge areas, relative potential for recharge and contamination, and quality of water in the principal aquifers, western Kane County, Utah, by L. E. Spangler, G. W. Freethey and G. A. Green. Prepared in cooperation with the Utah Department of Environmental Quality, Division of Water Quality, Kane County, and the City of Kanab. 1993. $50 \mathrm{p}$., 1 over-size sheet, scale 1:253,440 ( 1 inch $=4$ miles). (NC, $\mathrm{Da}, \mathrm{M}, \mathrm{Wb}, \mathrm{U}$.

WRI 92-4072. OHIO. Altitude of top of bedrock in the vicinity of Wright-Patterson Air Force Base, Ohio, by D. H. Dumouchelle. Prepared in cooperation with the U.S. Department of Defense. 1992. 1 over-size sheet, scale 1:53,300 (1 inch = about 4,500 feet $)$. (NC, Da, M, Wb.)

WRI 92-4073. WEST VIRGINIA. Hydrologic characteristics of abandoned coal mines used as sources of public water supply in McDowell County, West Virginia, by G. M. Ferrell. Prepared in cooperation with the West Virginia Governor's Office of Community and Economic Development, West Virginia Geological and Economic Survey, and the City of Welch. 1992. 37 p. (NC, Da, M, Wb; USGS, WRD, 603 Morris St., Charleston, WV 25301.)

WRI 92-4074. CONNECTICUT. Identification of hydraulically conductive fractures intersecting boreholes in fractured gneiss near Ashford, Connecticut; by F. L. Paillet, Aaron Green and Joseph Gurrieri. 1992. 28 p. (NC, Da, M, Wb.)

WRI 92-4075. Quality-assurance data for routine water analysis in the National Water-Quality Laboratory of the U.S. Geological Survey for water year 1989 , by T. J. Maloney, A. S. Ludtke and T. L. Krizman. 1992. 98 p. (NC, Da, M, Wb, U; USGS, WRD, Box 25046, Mail Stop 401, Denver Federal Ctr., Denver, CO 80225.)

WRI 92-4076. FLORIDA. Geohydrology of Osceola County, Florida, by G. R. Schiner. Prepared in cooperation with the South Florida Water Management District and the St. Johns River Water Management District. 1993. 68 p. (NC Da, M, Wb; USGS, WRD, Suite 1006, 9100 West Center St., Altamonte Springs, FL 32714.)

WRI 92-4077. WISCONSIN. Hydrogeology of glacial deposits in a preglacial bedrock valley, Waukesha County, Wisconsin, by W. G. Batten and T. D. Conlon. Prepared in cooperation with the Waukesha Water Utility. 1993. 15 p. (NC, Da, M, Wb; USGS, WRD, 6417 Normandy Lane, Madison, WI 53719-1133.)

WRI 92-4078. KENTUCKY. Quality of storm-water runoff in three watersheds in Elizabethtown, Kentucky, by Rene Garcia. 
Prepared in cooperation with the U.S. Environmental Protection Agency. 1992. 27 p. (NC, Da, M, Wb.)

WRI 92-4080. MISSISSIPPI. Potentiometric-surface maps of the Ripley and the Paleozoic aquifers in northeastern Mississippi, August through December 1987, by G. D. Goldsmith. Prepared in cooperation with the Mississippi Department of Environmental Quality, Office of Land and Water Resources. 1992. 1 over-size sheet. (NC, Da, M, Wb; USGS, WRD, 100 West Capitol St., Suite 710, Jackson, MS 39269.)

WRI 92-4081. COLORADO. Trace-dilution experiments and solute-transport simulations for a mountain stream, Saint Kevin Gulch, Colorado, by R. E. Broshears, K. E. Bencala, B. A. Kimball and D. M. McKnight. 1993. 18 p. (NC, Da, M, Wb, U; USGS, WRD, Box 25046, Mail Stop 415, Denver Federal Ctr., Denver, CO 80225-0046.)

WRI 92-4082. TENNESSEE. Recent sedimentation and surfacewater flow patterns on the flood plain of the North Fork Forked Deer River, Dyer County, Tennessee, by W. J. Wolfe and T. H. Diehl. Prepared in cooperation with the Tennessee Wildlife Resources Agency. 1993. 22 p. (NC, Da, M, Wb; USGS, WRD, 810 Broadway, Suite 500, Nashville, TN 37203; 1013 North Broadway, Knoxville TN 37917; and AgriCenter International, 7777 Walnut Grove Rd., Suite LLB2, Memphis, TN 38119.)

WRI 92-4084. UTAH. Detailed study of selenium and selected elements in water, bottom sediment, and biota associated with irrigation drainage in the middle Green River basin, Utah, 1988-90, by D. W. Stephens, Bruce Waddell, L. A. Peltz and J. B. Miller. Prepared in cooperation with the U.S. Fish and Wildlife Service, U.S. Bureau of Reclamation, and U.S. Bureau of Indian Affairs. 1992.164 p. (NC, Da, M, Wb, U.)

WRI 92-4086. FLORIDA. Ground-water contamination potential and quality in Polk County, Florida, by G. L. Barr. Prepared in cooperation with Polk County and the Southwest Florida Water Management District. 1992.92 p. (NC, Da, M, Wb; USGS, WRD, Suite B-5, 4710 Eisenhower Blvd., Tampa, FL 33634.)

WRI 92-4090. VIRGINIA. Hydrogeology and water quality of the shallow ground-water system in eastern York County, Virginia, by D. L. Richardson and A. R. Brockman. Prepared in cooperation with the York County Department of Environmental Sciences. 1992. 41 p. (NC, Da, M, Wb; USGS, WRD, 603 Morris St., Charleston, WV 25301; 208 Carroll Bldg., 8600 La Salle Rd., Towson, MD 21204; and 300 South New St., Federal Bldg., Room 1201, Dover, DE 19901.)

WRI 92-4091. WYOMING. Transport of sediment by streams in the Sierra Madre, southern Wyoming, by J. G. Rankl and M. L. Smalley. Prepared in cooperation with the Wyoming Water Development Commission. 1992. 29 p. (NC, Da, M, Wb, U; USGS, WRD, 2617 East Lincolnway, Suite B, Cheyenne, WY 82001.)

WRI 92-4092. TENNESSEE. Geochemistry of and radioactivity in ground water of the Highland Rim and Central Basin aquifer systems, Hickman and Maury counties, Tennessee, by G. E. Hileman and R. W. Lee. Prepared in cooperation with the Tennessee Department of Environment and Conservation. 1993. 26 p. (NC, $\mathrm{Da}, \mathrm{M}$, Wb; USGS, WRD, 810 Broadway, Suite 500, Nashville, TN 37203.)

WRI 92-4094. ARKANSAS. Overview of susceptibility of aquifers to contamination, Union County, Arkansas, by V. A. Leidy and R. E. Taylor. Prepared in cooperation with the Arkansas Department of Health. 1992. 35 p. (NC, Da, M, Wb; USGS, WRD, 2301 Federal Office Bldg., 700 West Capitol Ave., Little Rock, AR 72201.)

WRI 92-4095. Overview and bibliography of methods for evaluating the surface-water infiltration component of the rainfall-runoff process, by R. B. King. Prepared in cooperation with the Illinois Department of Transportation, Division of Water Resources. 1992. 169 p. (NC, Da, M, Wb, Wa; USGS, WRD, 102 East Main St., 4th Floor, Urbana, IL 61801.)

WRI 92-4097. NORTH CAROLINA. The storm and flood of September 15, 1989, in Fayetteville, North Carolina, by R. R. Mason, Jr. and W. S. Caldwell. Prepared in cooperation with the City of Fayetteville, North Carolina. 1992. 26 p., 1 over-size sheet, scale 1:24,000 (1 inch = 2,000 feet). (NC, Da, M, Wb.)

WRI 92-4099. HAWAII. Estimation of median streamflows at perennial stream sites in Hawaii, by R. A. Fontaine, M. F. Wong and Iwao Matsuoka. Prepared in cooperation with the State of Hawaii, Department of Land and Natural Resources. 1992. 37 p. (NC, Da, M, Wb.)

WRI 92-4100. NEW YORK. Evaluation of statistical models to predict chemical quality of shallow ground water in the Pine Barrens of Suffolk County, Long Island, New York, by P. E. Stackelberg and S. F. Siwiec. Prepared in cooperation with the Long Island Regional Planning Board. 1993. 26 p. (NC, Da, M, Wb; USGS, WRD, P.O. Box 1669, Albany, NY 12201.)

WRI 92-4102. Properties and chemical constituents in ground water from the Lower Claiborne-Upper Wilcox Aquifer, Gulf Coast regional aquifer systems, south-central United States, by R. A. Pettijohn, J. F. Busby and M. A. Cervantes. 1993. 5 oversize sheets, scale 1:3,500,000 ( 1 inch = about 55 miles $)$. (NC, Da, M, Wb; USGS, WRD, RASA, 8011 Cameron Rd., Bldg. B, Austin, TX 78754-3898.)

WRI 92-4103. Properties and chemical constituents in ground water from permeable zone $\mathrm{E}$ (lower Miocene-upper Oligocene deposits), coastal lowlands aquifer system, south-central United States, by R. A. Pettijohn, J. F. Busby and T. B. Layman. 1993. 5 over-size sheets, scale 1:3,500,000 (1 inch = about 55 miles). (NC, Da, M, Wb; USGS, WRD, RASA, 8011 Cameron Rd., Bldg. B, Austin, TX 78754-3898.)

WRI 92-4104. Properties and chemical constituents in ground water from the Middle Claiborne Aquifer, Gulf Coast regional aquifer systems, south-central United States, by R. A. Pettijohn, J. F. Busby and M. A. Cervantes. 1993. 5 over-size sheets, scale 1:3,500,000 ( 1 inch = about 55 miles). (NC, Da, M, Wb; USGS, WRD, RASA, 8011 Cameron Rd., Bldg. B, Austin, TX 78754-3898.)

WRI 92-4105. Properties and chemical constituents in ground water from permeable zone D (middle Miocene deposits), coastal lowlands aquifer system, south-central United States, by R. A. Pettijohn, J. F. Busby and J. D. Backman. 1993. 5 over-size sheets, scale 1:3,500,000 (1 inch = about 55 miles). (NC, Da, M, Wb; USGS, WRD, RASA, 8011 Cameron Rd., Bldg. B, Austin, TX 78754-3898.)

WRI 92-4108. OREGON. Preliminary results of the simulation of Oregon coastal basins using precipitation-runoff modeling system (PRMS), by R. L. Allen and Antonius Laenen. Prepared in co- 
operation with the U.S. Bureau of Land Management. 1993. 98 p. (NC, Da, M, Wb; USGS, WRD, 10615 SE Cherry Blossom Dr., Portland, OR 97216; and Library, 5400 MacArthur, Vancouver, WA 98661.)

WRI 92-4110. NORTHDAKOTA. Movement of water in seasonally frozen soil, southeastern North Dakota, $1985-87$, by D. G. Emerson. Prepared in cooperation with the North Dakota State Water Commission. 1992. 32 p. (NC, Da, M, Wb; USGS, WRD, 821 East Interstate Ave., Bismarck, ND 58501-1199.)

WRI 92-4111. VIRGINIA. Hydrogeologic framework of the shallow aquifer system of York County, Virginia, by A. R. Brockman and D. L. Richardson. Prepared in cooperation with the York County Department of Environmental Services. 1992. 36 p. (NC, Da, M, Wb; USGS, WRD, 3600 West Broad St., Room 606, Richmond, VA 23230.)

WRI 92-4113. INDIANA. Sedimentation in Whitewater Lake, Union County, east-central Indiana, 1959-88, by D. E. Renn. Prepared in cooperation with the Indiana Department of Natural Resources. 1993 . 60 p. (NC, Da, M, Wb; USGS, WRD, 5957 Lakeside Blvd., Indianapolis, IN 46278-1996.)

WRI 92-4114. GUAM. Storage capacity of Fena Valley Reservoir, Guam, Mariana Islands, 1990 , by L. Y. Nakama. Prepared in cooperation with the U.S. Department of the Navy. 1992. 17 p. (NC, Da, M, Wb.)

WRI $92-4116$. MONTANA, IDAHO. Plan of study for the Regional Aquifer-System Analysis of the Northern Rocky Mountains intermontane basins, Montana and Idaho, by D. W. Clark and Eloise Kendy. 1992. 16 p. (NC, Da, M, Wb, U, S; USGS, WRD, Room 428, Federal Bldg., 301 South Park Ave., Helena, MT 59626-0076; and 230 Collins Rd., Boise, ID 83702-4520; USGS Field Headquarters, Eastern Montana Coll., 1500 North 30th, Billings, MT 59101.)

WRI 92-4117. TEXAS. Evaluation of the use of remote-sensing data to identify crop types and estimate irrigated acreage, Uvalde and Medina counties, Texas, 1989 , by L. H. Raymond, G. M. Nalley and P. L. Rettman. Prepared in cooperation with the Edwards Underground Water District. 1992. 21 p. (NC, Da, M, Wb; USGS, WRD, 8011 Cameron Rd., Bldg. 1, Austin, TX 78753.)

WRI 92-4118. MISSOURI. Discharge ratings for tainter and roller gates at lock and dam No. 25 on the Mississippi River near Winfield, Missouri, by T. W. Alexander. Prepared in cooperation with the U.S. Army Corps of Engineers. 1992. 20 p. (NC, Da, M, Wb; USGS, WRD, 1400 Independence Rd., Mail Stop 200, Rolla, MO 65401.)

WRI 92-4120. ARKANSAS. Water-level maps of the Mississippi River valley alluvial aquifer in eastern Arkansas, 1989, by P. W. Westerfield and G. J. Gonthier. Prepared in cooperation with the Arkansas Geological Commission, Arkansas Soil and Water Conservation Commission, local conservation districts, and the U.S. Soil Conservation Service, 1992. 1 over-size sheet. (NC, Da, M, Wb; USGS, WRD, 2301 Federal Office Bldg., 700 West Capitol Ave., Little Rock, AR 72201.)

WRI 92-4123. Data encapsulation using Fortran-77 modules; a first step toward object-oriented programming in water resources, by D. B. Thompson, L. L. DeLong and J. M. Fulford 1992.
67 p. (NC, Da, M, Wb; USGS, WRD, Suite 3015, 227 North Bronough St., Tallahassee, FL 32301.)

WRI 92-4124. Finite-difference interblock transmissivity for unconfined aquifers and for aquifers having smoothly varying transmissivity, by D. J. Goode and C. A. Appel. 1992. 79 p. (NC, Da, M, Wb.)

WRI 92-4126. ARKANSAS. Scour around bridge piers on streams in Arkansas, by R. E. Southard. Prepared in cooperation with the Arkansas State Highway and Transportation Department. 1992. 29 p. (NC, Da, M, Wb; USGS, WRD, 2301 Federal Office Bldg., 700 West Capitol Ave., Little Rock, AR 72201.)

WRI 92-4129. NORTH CAROLINA. Selected water-quality and biological characteristics of streams in some forested basins of North Carolina, 1985-88, by W. S. Caldwell. Prepared in cooperation with the North Carolina Department of Environment. Health, and Natural Resources. 1992. 114 p. (NC, Da, M, Wb; USGS, WRD, P.O. Box 30728, Raleigh, NC 27622.)

WRI 92-4130. OHIO. Distribution and variability of fecal-indicator bacteria in Scioto and Olentangy rivers in the Columbus, Ohio, area, by D. N. Myers. Prepared in cooperation with the City of Columbus, Ohio, Division of Sewerage and Drainage. 1992. 61 p. (NC, Da, M, Wb.)

WRI 92-4131. TENNESSEE. Hydrology of Melton Valley at Oak Ridge National Laboratory, Tennessee, by Patrick Tucci. Prepared in cooperation with the U.S. Department of Energy. 1992. 76 p. (NC, Da, M, Wb; USGS, WRD, Room A-413 Federal Bldg., Nashville, TN 37203; 1013 North Broadway, Knoxville, TN 37917; and AgriCenter International, 7777 Walnut Grove Rd., Suite LLB2, Memphis, TN 38119.)

WRI 92-4132. ALASKA. Glacier runoff and sediment transport and deposition, Eklutna Lake basin, Alaska, by T. P. Brabets. Prepared in cooperation with the Municipality of Anchorage. 1992. 47 p., 1 over-size sheet, scale 1:63,360 (1 inch $=1$ mile). (NC, Da, M, Wb; USGS, WRD, 4230 University Dr., Suite 201, Anchorage, AK 99508-4664; 800 Yukon Dr., Fairbanks, AK 99775; and P.O. Box 21568, Juneau, AK 99802.)

WRI 92-4133. ARIZONA. Soil moisture and remotely sensed spectral data in a partial canopy cotton field at the Maricopa Agricultural Center, Pinal County, Arizona, 1988, by S. J. OwenJoyce. Prepared in cooperation with the Arizona Department of Water Resources. 1992. 26 p. (NC, Da, M, Wb; USGS, WRD, 375 South Euclid Ave., Tucson, AZ 85719-6644; 1545 West University Dr., Tempe, AZ 85281; 2255 North Gemini Dr., Flagstaff, AZ 86001; and 1940 South 3rd Ave., Yuma, AZ 85364.)

WRI 92-4136. OREGON. Preliminary evaluation of water-quality conditions of Johnson Creek, Oregon, by T. K. Edwards and D. A. Curtiss. Prepared in cooperation with the City of Portland, Bureau of Environmental Services. 1993. 15p. (NC, Da, M, Wb, S; USGS, Library, 5400 McArthur, Vancouver, WA 98661; and USGS, WRD, 1201 Pacific Ave., Suite 600, Tacoma, WA 98402.)

WRI 92-4137. KANSAS. Ground- and surface-water interaction between the Kansas River and associated alluvial aquifer, northeastern Kansas, by R. J. Wolf and J. O. Helgesen. Prepared in cooperation with the U.S. Bureau of Reclamation. 1993. $49 \mathrm{p}$. (NC, Da, M, Wb; USGS, WRD, 4821 Quail Crest Pl., Lawrence, KS 66049; and 206 Fulton Terrace, Garden City, KS 67846.) 
WRI 92-4138. KENTUCKY. Contamination of soil, soil gas, and ground water by hydrocarbon compounds near Greear, Morgan County, Kentucky, by A. G. Alexander, D. D. Zettwoch, M. D. Unthank and R. B. Burns. Prepared in cooperation with the Kentucky Natural Resources and Environmental Protection Cabinet, Division of Waste Management. 1992. 37 p. (NC, Da, M, Wb.)

WRI 92-4140. FLORIDA. Water withdrawals, use, and trends in Florida, 1990, by R. L. Marella. Prepared in cooperation with the Florida Department of Environmental Regulation, Northwest Florida Water Management District, St. Johns River Water Management District, South Florida Water Management District, Southwest Florida Water Management District, and the Suwannee River Water Management District. 1992. 38 p. (NC, Da, M, Wb; USGS, WRD, Suite 3015, 227 North Bronough St., Tallahassee, FL 32301.)

WRI 92-4147. Effectiveness of highway edgedrains, by $\mathrm{H}$. $\mathrm{H}$. Jeffcoat, F. A. Kilpatrick, J. B. Atkins and J. L. Pearman. Prepared for the U.S. Department of Transportation. 1992. 79 p. (NC, Da, M, Wb.)

WRI 92-4149. ILLINOIS. Floods of September 26-October 4, 1986, and August 14-17, 1987, in Illinois, by G. O. Balding and A. L. Ishii. Prepared in cooperation with the Illinois Department of Transportation, Division of Water Resources. 1993. 105 p., 1 over-size sheet. (NC, Da, M, Wb, Wa; USGS, WRD, 102 East Main St., 4th Floor, Urbana, IL 61801.)

WRI 92-4150. KENTUCKY. Water quality of selected streams in Jefferson County, Kentucky, 1988-91, by R. D. Evaldi, R. J. Burns and B. L. Moore. Prepared in cooperation with the Louisville and Jefferson County Metropolitan Sewer District. 1993. 177 p. (NC, Da, M, Wb.)

WRI 92-4153. CALIFORNIA. Summary of ground-water data and evaluation of ground-water monitoring networks for eastern Merced County, California, by S. N. Hamlin. Prepared in cooperation with the City of Merced. 1993. 14 p. (NC, Da, M, Wb; USGS, WRD, Federal Bldg., Room W-2233, 2800 Cottage Way, Sacramento, CA 95825.)

WRI 92-4155. Documentation of finite-element mesh generation programs using a geographic information system, by $R$. A. Lowther and E. L. Kuniansky. 1992. 188 p. (NC, Da, M, Wb; USGS, WRD, 8011 Cameron Rd., Bldg. 1, Austin, TX 78753.) (Software information available from E. L. Kuniansky, USGS, WRD, Austin, TX 78753.)

WRI 92-4160. UTAH. Maps showing recharge areas and quality of ground water for the Navajo Aquifer, western Washington County, Utah, by G. W. Freethey. 1993. 1 over-size sheet, scales $1: 240,000(1 \mathrm{inch}=$ about 3.8 miles $)$ and 1:375,000 ( 1 inch = about 6 miles). (NC, Da, M, Wb, U.)

WRI 92-4162. MONTANA. Hydrology of valley fill and potential for additional ground-water withdrawals along the north flank of the Little Rocky Mountains, Fort Belknap Indian Reservation, north-central Montana, by D. W. Briar, P. K. Christensen and D. J. Oellermann. Prepared in the cooperation with the U.S. Bureau of Indian Affairs and the Fort Belknap Community Council. 1993. 86 p., 2 over-size sheets. (NC, Da, M, Wb, U, S; USGS, WRD, 301 South Park Ave., Room 428, Federal Bldg., Helena, MT, 59626-0076; USGS, Field Headquarters, Eastern Montana Coll., 1500 North 30th, Billings, MT 59101.)
WRI 92-4163. MONTANA. Lithologic logs of observation wells and test holes drilled in 1987 in valley fill along the north flank of the Little Rocky Mountains, Fort Belknap Indian Reservation, north-central Montana, by D. W. Briar and P. K. Christensen. Prepared in cooperation with the U.S. Bureau of Indian Affairs and the Fort Belknap Community Council. 1993. 41 p. (NC, Da, M, Wb, U, S; USGS, WRD, Room 428 Federal Bldg., 301 South Park Ave., Helena, MT 59626-0076; USGS, Field Headquarters, Eastern Montana Coll., 1500 North 30th, Billings, MT 59101.)

WRI 92-4165. TENNESSEE. Flood frequency of streams in rural basins of Tennessee, by J. D. Weaver and C. R. Gamble. Prepared in cooperation with the Tennessee Department of Transportation. 1993. 38 p. (NC, Da, M, Wb; USGS, WRD, 810 Broadway, Suite 500, Nashville, TN 37203; 1013 North Broadway, Knoxville, TN 37917; and AgriCenter International, 7777 Walnut Grove Rd., Suite LLB2, Memphis, TN 38119.)

WRI 92-4167. MISSOURI. Effects of reclamation on water quality and geochemical processes in lakes in an abandoned surface coal mine in Henry County, Missouri; August 1988-May 1990, by D. W. Blevins and A. C. Ziegler. Prepared in cooperation with the Missouri Department of Natural Resources, Land Reclamation Commission. 1992. 65 p. (NC, Da, M, Wb; USGS, WRD, 1400 Independence Rd., Mail Stop 200, Rolla, MO 65401.)

WRI 92-4168. HAWAII. Geohydrology and possible transport routes of polychlorinated biphenyls in Haiku Valley, Oahu, Hawaii, by S. K. Izuka, B. R. Hill, P. J. Shade and G. W. Tribble. Prepared in cooperation with the U.S. Coast Guard, Civil Engineering Unit, Honolulu. 1993. 48 p. (NC, Da, M, Wb.)

WRI 92-4169. KANSAS. Hydrogeology and ground-water-quality conditions at the Reno County landfill, south-central Kansas, 1990-91, by B. A. Heck, N. C. Myers and D. A. Hargadine. Prepared in cooperation with Reno County, Kansas. 1992. 56 p. (NC, Da, M; USGS, WRD, 4821 Quail Crest Pl., Lawrence, KS 66049; 206 Fulton Terrace, Garden City, KS 67846.)

WRI 92-4172. CALIFORNIA. Changes in water-quality conditions in Lexington Reservoir, Santa Clara County, California, following a large fire in 1985 and flood in 1986 , by M. J. Taylor, J. M. Shay and S. N. Hamlin. Prepared in cooperation with the Santa Clara Valley Water District. 1993. 23 p. (NC, Da, M, Wb; USGS, WRD, Federal Bldg., Room W-2233, 2800 Cottage Way, Sacramento, CA 95825; and 5735 Kearny Villa Rd., Suite O, San Diego, CA 92123.)

WRI 92-4175. VIRGINIA. Quality of ground water in the Coastal Plain physiographic province of Virginia, by M. J. Focazio, G. K. Speiran and M. E. Rowan. Prepared in cooperation with the Hampton Roads Planning District Commission and Virginia Water Control Board. 1992. 20 p., 5 over-size sheets. (NC, Da, M, Wb; USGS, WRD, 603 Morris St., Charleston, WV 25301; 208 Carroll Bldg., 8600 La Salle Rd., Towson, MD 21204; and 300 South New St., Federal Bldg., Room 1201, Dover, DE 19901.)

WRI 92-4177. KANSAS. Hydrogeology and ground-water-quality conditions at the Sumner County landfill, south-central Kansas, $1989-90$, by N. C. Myers, B. A. Heck and D. A. Hargadine. Prepared in cooperation with Sumner County, Kansas. 1993. 52 p. (NC, Da, M, Wb; USGS, WRD, 4821 Quail Crest Pl., Lawrence, KS 66049; and 206 Fulton Terrace, Garden City, KS 67846.)

WRI 92-4183. PENNSYLVANIA. Altitude and configuration of the potentiometric surface in Springfield Township, Bucks 
County, Pennsylvania, April 1991 through October 1991, by C. L. Schreffler. Prepared in cooperation with New Hope Borough and Bridgeton, Buckingham, Nockamixon, Plumstead, Solebury, Springfield, Tinicum, and Wrightstown townships, Bucks County, Pennsylvania. 1993. 1 over-size sheet, scale 1:24,000 (1 inch = 2,000 feet). (NC, Da, M, Wb; USGS, WRD, 111 Great Valley Pkwy., Malvern, PA 19355.)

WRI 92-4184. IDAHO. Geophysical logging studies in the Snake River Plain Aquifer at the Idaho National Engineering Laboratory; wells 44,45 , and 46, by R. H. Morin, Warren Barrash, F. L. Paillet and T. A. Taylor. 1993. 44 p. (NC, Da, M, Wb.)

WRI 92-4185. MONTANA. Water-surface profile and flood boundaries for the computed 100-year flood, Porcupine Creek, Fort Peck Indian Reservation and adjacent area, Montana, by R. J. Omang. Prepared in cooperation with the Fort Peck Tribes. 1993. 1 over-size sheet, scale 1:24,000 (1 inch $=2,000$ feet). (NC, Da, M, Wb, U, S; USGS, WRD, Room 428 Federal Bldg., 301 South Park Ave., Helena, MT 59626-0076; and Eastern Montana Coll., 1500 North 30th, Billings, MT 59101.)

WRI 92-4190. TEXAS. Ground-water conditions in Pecos County, Texas, 1987, by T. A. Small and G. B. Ozuna. Prepared in cooperation with the City of Fort Stockton, Texas. 1993. 63 p., 9 over-size sheets. (NC, Da, M, Wb; USGS, WRD, 8011 Cameron Rd., Bldg. A., Austin, TX 78754-3898.)

WRI 92-4193. NEW MEXICO. Ground-water-level fluctuations in the Cochiti Dam-Peña Blanca area, Sandoval County, New Mexico, 1976-89, by P. J. Blanchard. Prepared in cooperation with the U.S. Army Corps of Engineers. 1993. 72 p. (NC, Da, M, Wb; USGS, WRD, 4501 Indian School Rd. NE, Suite 200, Albuquerque, NM 87110-3929.)

WRI 92-4194. PENNSYLVANIA. Altitude and configuration of the potentiometric surfaces of the upper and lower aquifer systems in Bridgeton, Nockamixon, and Tinicum townships, Bucks County, Pennsylvania, April 1991 through April 1992, by B. C. McManus and C. J. Rowland. Prepared in cooperation with New Hope Borough and Bridgeton, Buckingham, Nockamixon, Plumstead, Solebury, Springfield, Tinicum, and Wrightstown townships, Bucks County, Pennsylvania. 1993. 1 over-size sheet. (NC, Da, M, Wb; USGS, WRD, 111 Great Valley Pkwy., Malvern, PA 19355.)

WRI 92-4195. KENTUCKY. Use of dye tracing to define the direction of ground-water flow from a Superfund waste-disposal site in karst terrane, near Auburn, Kentucky, by D. S. Mull. Prepared in cooperation with the U.S. Environmental Protection Agency. 1993. 28 p., 1 over-size sheet; scale 1:24,000 ( 1 inch $=2,000$ feet $)$. (NC, Da, M, Wb.)

WRI 92-4196. IDAHO. Statistical summaries of streamflow data for selected gaging stations on and near the Idaho National Engineering Laboratory, Idaho, through September 1990 , by M. A. Stone, L. J. Mann and L. C. Kjelstrom. Prepared in cooperation with the U.S. Department of Energy. 1993. 35 p. (NC, Da, M, Wb; USGS, WRD, 230 Collins Rd., Boise, ID 83702.)

WRI 93-4001. IDAHO. Effects of well discharges on hydraulic heads in and spring discharges from the geothermal aquifer system in the Bruneau area, Owyhee County, southwestern Idaho, by C. E. Berenbrock. Prepared in cooperation with the U.S. Fish and Wildlife Service. 1993. 58 p. (NC, Da, M, Wb.)
WRI 93-4002. FLORIDA. Hydrology and water quality of unmined and reclaimed basins in phosphate-mining areas, west-central Florida, by B. R. Lewelling and R. W. Wylie. Prepared in cooperation with the Florida Institute of Phosphate Research. 1993. 93 p. (NC, Da, M, Wb; USGS, WRD, Suite B-5, 4710 Eisenhower Blvd., Tampa, FL 33634.)

WRI 93-4007. COLORADO, NEW MEXICO. Methane-concentration and methane-isotope data for ground water and soil gas in the Animas River valley, Colorado and New Mexico, 1990-91, by D. T. Chafin, D. M. Swanson and D. W. Grey. Prepared in cooperation with the Colorado Oil and Gas Conservation Commission, La Plata County, and the Southern Ute Tribal Council. 1993. 86 p., 1 over-size sheet, scale 1:24,000 (1 inch =2,000 feet). (NC, $\mathrm{Da}, \mathrm{M}$, Wb; USGS, WRD, Bldg. 53, Denver Federal Ctr., Mail Stop 415, Box 25046, Lakewood, CO 80225; Federal Bldg., Room 210, PO Box 3367, 701 Camino Del Rio, Durango, CO 81302.) (Interim report.)

WRI 93-4011. Documentation of a computer program (STREAMLINK) to represent direct-flow connections in a coupled ground-water and surface-water model, by E. D. Swain. Prepared in cooperation with the South Florida Water Management District. 1993. 62 p. (NC, Da, M, Wb; Suite 107, 9100 NW 36th St., Miami, FL 33178.)

WRI 93-4012. MISSOURI. Surface-water and sediment quality in the Old Lead Belt, southeastern Missouri; $1988-89$, by B. J. Smith and J. G. Schumacher. Prepared in cooperation with the Missouri Department of Natural Resources, Land Reclamation Commission. 1993. 92 p. (NC, Da, M, Wb; USGS, WRD, 1400 Independence Rd., Mail Stop 200, Rolla, MO 65401.)

WRI 93-4013. ARKANSAS. Regionalization of low-flow characteristics of Arkansas streams, by A. H. Ludwig and G. D. Tasker. Prepared in cooperation with the Arkansas Soil and Water Conservation Commission. 1993. 26 p., 1 over-size sheet, scale $1: 1,000,000$ ( 1 inch = 16 miles $)$; one $31 / 2$ inch DS/HD diskette. (NC, Da, M, Wb; USGS, WRD, 2301 Federal Office Bldg., 700 West Capitol Ave., Little Rock, AR 72201.)

A 3 1/2-inch floppy disk containing the Fortran program is included in the report. The program is compatible with the MS DOS operating system.

WRI 93-4015. VIRGINIA. Documentation of geographic-information-system coverages and data-input files used for analysis of the geohydrology of the Virginia coastal plain, by M. J. Focazio and T. B. Samsel, III. Prepared in cooperation with the Hampton Roads Planning District Commission and the Virginia Water Control Board. 1993. 53 p. (NC, Da, M, Wb; USGS, WRD, 603 Morris St., Charleston, WV 25301; 208 Carroll Bldg., 8600 La Salle Rd., Towson, MD 21204; and 300 South New St., Federal Bldg., Room 1201, Dover, DE 19901.)

WRI 93-4016. GEORGIA. Techniques for estimating magnitude and frequency of floods in rural basins of Georgia, by T. C. Stamey and G. W. Hess. Prepared in cooperation with the Georgia Department of Transportation. $1993.69 \mathrm{p}$. (NC, Da, M, Wb; USGS, WRD, Peachtree Business Ctr., Suite 130, 3039 Amwiler Rd., Doraville, GA 30360-2824.)

WRI 93-4030. CALIFORNIA. Application of a hydrochemical model and a multivariate soil-solution mixing model to alpine watersheds in the Sierra Nevada, California, by R. P. Hooper and N. E. Peters. Prepared in cooperation with the California Air 
Resources Board. 1993. 58 p. (NC, Da, M, Wb; USGS, WRD, 3039 Amwiler Rd., Peachtree Business Ctr., Suite 130, Atlanta, GA 30360-2824.)

WRI 93-4031. NORTH CAROLINA. Bathymetry of Lake Michie, Durham County, North Carolina, 1990-92, by J. C. Weaver. Prepared in cooperation with the City of Durham Department of Water Resources and the North Carolina Department of Environment, Health and Natural Resources. 1993. 1 over-size sheet, scale 1:4,800 (1 inch = 400 feet). (NC, Da, M, Wb; USGS, WRD, 3916 Sunset Ridge Rd., Raleigh, NC 27607; and Spalding Woods Office Park, 3850 Holcomb Bridge Rd., Suite 160, Norcross, GA 30092.)

WRI 93-4036. KANSAS. Hydrogeology and ground-water-quality conditions at the Harvey County landfill, south-central Kansas, 1990, by J. O. Helgesen, B. A. Heck and D. A. Hargadine. Prepared in cooperation with Harvey County, Kansas. 1993. 44 p. (NC, Da, M, Wb; USGS, WRD, 4821 Quail Crest Pl., Lawrence, KS 66049; and 206 Fulton Terrace, Garden City, KS 67846.)

WRI 93-4038. GEORGIA. Ground-water quality of the upper Floridan Aquifer near an abandoned manufactured gas plant in Albany, Georgia, by M. J. Chapman. Prepared in cooperation with the Albany Water, Gas, and Light Commission. 1993. 19 p. (NC, Da, M, Wb; USGS, WRD, 3039 Amwiler Rd., Peachtree Business Ctr., Suite 130, Atlanta, GA 30360-2824.)

WRI 93-4047. OHIO. Hydrogeology, simulated ground-water flow, and ground-water quality, Wright-Patterson Air Force Base, Ohio, by D. H. Dumouchelle, C. W. Schalk, G. L. Rowe and J. T. de Roche. Prepared in cooperation with Wright-Patterson Air Force Base. 1993. 152 p. (NC, Da, M, Wb.)

WRI 93-4054. IDAHO. Age dating ground water by use of chlorofluorocarbons $\left(\mathrm{CCl}_{3} \mathrm{~F}\right.$ and $\left.\mathrm{CCl}_{2} \mathrm{~F}_{2}\right)$, and distribution of chlorofluorocarbons in the unsaturated zone, Snake River Plain Aquifer, Idaho National Engineering Laboratory, Idaho, by Eurybiades Busenberg, E. P. Weeks, L. N. Plummer and R. C. Bartholomay. Prepared in cooperation with the U.S. Department of Energy. 1993. 47 p. (NC, Da, M, Wb; USGS, WRD, 230 Collins Rd., Boise, ID 83702.)

WRI 93-4060. WASHINGTON. Long-term effects of irrigation with imported water on water levels and water quality, by B. W. Drost, J. C. Ebbert and S. E. Cox. Prepared in cooperation with the State of Washington Department of Ecology. 1993. $19 \mathrm{p}$. (NC, Da, M, Wb.)

WRI 93-4076. Hydro-Climatic Data Network (HCDN) streamflow data set, 1874-1988, by J. R. Slack, A. M. Lumb and J. M. Landwehr. 1993. One CD-ROM. (NC, Da, M, Wb.)

All of the data are present in ASCII files readable on any system supporting ISO 9660 standard CD-ROMs. Minimum system requirements for using the software: IBM PC compatible; $540 \mathrm{~K}$ RAM free, MS-DOS 3.1 or higher; Microsoft MSCDEX 2.1 or higher; CD-ROM reader with ISO 9660 driver; and hard disk with at least $1 \mathrm{MB}$ free space.

\section{OPEN-FLE REPORTS}

Open-file reports include unpublished manuscript reports, maps, and other material and are made available for public consultation and use. They are a nonpermanent form of publication that may be cited in other publications as sources of information. They are not considered to be a part of the formal literature.

Most open-file reports are available from: USGS ESIC-Open-File Report Section, Box 25286, Mail Stop 517, Federal Center, Denver, CO 80225 (telephone: 303-236-7476). The following listing of open-file reports is subdivided to show which reports are available from the Denver facility and which ones are not. Specific instructions for ordering and availability of reports are given under each sublisting.

Open-file reports are also available for reference only, not for purchase, at additional locations indicated in each open-file listing. Symbols for these locations are defined above for Water-Resources Investigations Reports.

\section{Reports Available Only Through USGS Earth Science Infor- mation Center-Open-File Report Section}

Microfiche and (or) black and white paper copies of most reports may be obtained from: USGS ESIC-Open-File Report Section, Box 25286, Mail Stop 517, Federal Center, Denver, CO 80225 (telephone 303-236-7476). When ordering, please use the open-file number and full title. Do not mix orders for open-file reports with orders for other Geological Survey products. Prices for duplicate slides and color photographs can be obtained on request. Check or money order, in exact amount for open-file reports ordered, should be payable to Department of the Interior-USGS. Prepayment is required. No discount is applicable. For transmittal outside the U.S.A. (except Canada and Mexico), a surcharge of 25 percent of the bill should be included to cover surface transportation.

OF 85-0642. PUERTO RICO. Agua subterranea en Puerto Rico [Ground water in Puerto Rico], by Ferdinand Quiñones-Marquez and José Alicea-Ortiz. 1985. 6 p. (NC, Da, M, Wb; USGS, WRD, GPO Box 4424, San Juan, PR 00936.)

OF 89-0450-C. CALIFORNIA. Petroleum geology of the Santa Maria Basin assessment province, California for the 1987 national assessment of undiscovered oil and gas resources, by C. M. Isaacs. 1992. 43 p. (NC, Da, M; California Dep. of Conservation, Div. of Mines and Geol., Mail Stop 14-34, Library, $801 \mathrm{~K}$ St., Sacramento, CA 95814-3532; 1145 Market St., 3rd Floor, San Francisco, CA 94103; and State Office Bldg., 107 South Broadway, Los Angeles, CA 90012.)

OF 89-0450-D. CALIFORNIA. Petroleum geology of the Central Coastal Basins assessment province, California, for the 1987 national assessment of undiscovered oil and gas resources, by C. M. Isaacs. 1992. 49 p. (NC, Da, M; California Dep. of Conservation, Div. of Mines and Geol., Mail Stop 14-34, Library, $801 \mathrm{~K}$ St., Sacramento, CA 95814-3532; 1145 Market St., 3rd Floor, San Francisco, CA 94103; and State Office Bldg., 107 South Broadway, Los Angeles, CA 90012.)

OF 89-0583. NEW HAMPSHIRE. Geohydrologic, groundwater-quality, and streamflow data for the stratified-drift aquifers in the Bellamy, Cocheco, and Salmon Falls River basins, southeastern New Hampshire, by S. M. Lawlor and T. J. Mack. Prepared in cooperation with the New Hampshire Department of Environmental Services, Water Resources Division. 1992. 137 p., 3 over-size sheets, scale 1:48,000 ( 1 inch $=4,000$ feet $)$. (NC, $\mathrm{Da}, \mathrm{M}, \mathrm{Wb}$.)

OF 90-0110. MISSISSIPPI. Channel and bank stability of Wolf Creek, and a tributary at U.S. Highway 45 near Wheeler, Prentiss County, Mississippi, by K. V. Wilson, Jr. and D. P. Turnipseed. Prepared in cooperation with the Mississippi State Highway Department. 1992. 18 p. (NC, Da, M, Wb; USGS, WRD, 100 West Capitol St., Suite 710; Jackson, MS 39269.) 
OF 90-0130. County-level estimates of nitrogen and phosphorus fertilizer use in the United States, 1945 to 1985, by R. B. Alexander and R. A. Smith. 1990. 12 p. (NC, Da, M, Wb.)

OF 90-0153. NEVADA. Hydrologic data for east-central Nevada, water years $1982-88$, by C. S. Savard and E. J. Crompton. Prepared in cooperation with the Nevada Division of Water Resources. 1993. 128 p. (NC, Da, M, Wb, U; USGS, WRD, 333 West Nye Lane, Carson City, NV 89701; and 1500 East Tropicana, Suite 201, Las Vegas, NV 89119.)

OF 90-0194. A modular finite-element model (MODFE) for areal and axisymmetric ground-water-flow problems; Part 1, Model description and user's manual, by L. J. Torak. 1992. 153 p. (NC, Da, M, Wb; USGS, WRD, 6481-B Peachtree Industrial Blvd., Doraville, GA 30360.)

OF 90-0369. NEVADA. Geohydrologic data from test holes UE25 UZ \#4 and UE-25 UZ \#5, Yucca Mountain, Nye County, Nevada, by C. L. Loskot and D. P. Hammermeister. 1992. 56 p. (NC, Da, M, Wb; USGS, WRD, Box 25046, Mail Stop 421, Denver Federal Ctr., Denver, CO 80225.)

OF 90-0381. NEVADA. Water-resources data for the Devils Hole area, Nye County, Nevada, July $1978-S e p t e m b e r 1988$, by C. L. Westenberg. Prepared in cooperation with the National Park Service. 1993.13 p. (NC, Da, M, Wb, U; USGS, WRD, Room 224, Federal Bldg., 705 North Plaza St., Carson City, NV 89701; and 1500 East Tropicana, Suite 201, Las Vegas, NV 89119.)

OF 90-0506. OREGON. Analytical results and sample locality map of stream-sediment, heavy-mineral-concentrate, rock, vegetation, lake-sediment, and evaporite samples from the Diablo Mountain Wilderness Study Area(OR-001-058), Lake County, Oregon, by B. M. Adrian, D. L. Fey, H. D. King and P. L. Hageman. 1993. 42 p., 1 over-size sheet, scale 1:48,000 (1 inch $=4,000$ feet). (NC, Da, M, S; Oregon Dep. of Geol. and Mineral Industries, Suite 965, 800 NE Oregon St. \#28, Portland, OR 97232-2162.)

OF 90-0672. IDAHO. Analytical results and sample locality map of stream-sediment and heavy-mineral-concentrate samples from the Kelly-Cayuse Wilderness-proposed and Cook Mountain and East Weitas Special Management Areas, Clearwater National Forest, Clearwater and Idaho counties, Idaho, by B. M. Adrian, H. N. Barton, R. T. Hopkins, J. M. Motooka and B. H. Roushey. 1992. 28 p., 1 over-size sheet, scale $1: 100,000(1$ inch $=$ about 1.6 miles). (NC, Da, M, U, S; Idaho Geol. Surv., Univ. of Idaho Campus, Morrill Hall, Room 332, Moscow ID 83843.)

OF 90-0677. CALIFORNIA. Measurement of structural response characteristics of full-scale buildings; selection of structures, by $R$. D. Marshall, L. T. Phan and Mehmet Celebi. National Institute of Standards and Technology, Interagency Rep. 90-4511. 1990. 16 p. (NC, Da, M.)

OF 91-0014. Joint Education Initiative, JEdI, 1990 teacher activities book, edited by J. D. Sproull. 1991. 76 p. (NC, Da, M.)

The 1990 Joint Education Initiative (JEdI); an agent of change for education, by J. D. Sproull. p. 1-3.

CD-ROM, by E. J. McFaul: p. 4.

Digital image processing summary, by Jet Propulsion Laboratory. p. 5 .
JEdI disc descriptions, by D. K. Traudt. p. 6-7.

JEdI activities summary, by J. D. Sproull. p. 8.

Developing a physiographic map of North America, by M. C. Horn and Dana Van Burgh. p. 9-15.

Modeling coastal flooding, by J. D. Sproull. p. 16-19.

Biomes; detecting vegetation through remote sensing, by Barclay Anderson and Rebecca McDonnell. p. 20-22.

Changing ozone levels in the Earth's atmosphere, by Anthony Marcino, William Miller and JoAnn Mulvany. p. 23-27.

Earthquakes; interpreting first motion from seismograms, by Harold Banks, Adrienne Herriott and Dennis McFaden. p. 2837.

Temperature/salinity profiles of the Pacific Ocean, by Donald Hyatt and Richard Knight. p. 38-41.

Identifying atoms and molecules in comets, by A. M. Stowe. p. 42-51.

Antarctica; three views, by Jeanne Endrikat and Keith Franklin. p. 52-58.

Enhancing Voyager images, by Gary Purinton. p. 59-67.

Sea floor features; analyzing and mapping the ocean floor, by P. F. Corro. p. 68-72.

OF 91-0032. CALIFORNIA. Short-term earthquake hazard assessment for the San Andreas Fault in Southern California, chaired by L. M. Jones, K. E. Sieh, D. C. Agnew, C. R. Allen, Roger Bilham, Mark Ghilarducci, B. H. Hager, Egill Hauksson, K. W. Hudnut, D. D. Jackson and A. G. Sylvester. 1991. 42 p. (NC, $\mathrm{Da}, \mathrm{M}$; California Dep. of Conservation, Div. of Mines and Geol., Mail Stop 14-34, Library, 801 K St., Sacramento CA 95814-3532; State Office Bldg., 107 Broadway, Los Angeles, CA 90012.)

Prediction probabilities from foreshocks, by D. C. Agnew and L. M. Jones. $13 \mathrm{p}$.

OF 91-0098. IDAHO, OREGON. Summary of the Snake River plain Regional Aquifer-System Analysis in Idaho and eastern Oregon, by G. F. Lindholm. 1993. 62 p., 1 over-size sheet, scale 1:1,000,000 ( 1 inch = about 16 miles). (NC, Da, M, Wb; USGS, WRD, 230 Collins Rd., Boise, ID 83702.)

OF 91-0180. NEW YORK. Ground-water quality in five areas of differing land use in Nassau and Suffolk counties, Long Island, New York, 1987-88, by C. E. LeaMond, R. J. Haefner, S. J. Cauller and P. E. Stackelberg. 1992. 67 p. (NC, Da, M, Wb; USGS, WRD, 5 Aerial Way, Syosset, NY 11791.)

OF 91-0366-A. $\mathrm{MacH}_{2} \mathrm{O}$; a computer interface to calculate the thermodynamic and transport properties of pure water, by R. J. Rosenbauer. 1991. 65 p. (NC, Da, M.)

OF 91-0366-BC. $\mathrm{MacH}_{2} \mathrm{O}$; a computer interface to calculate the thermodynamic and transport properties of pure water, by R. J. Rosenbauer. 1991. Two 3 1/2 inch diskettes. (NC, Da, M.)

Requirements: Apple-Macintosh computer; minimum 512K RAM; math coprocessor.

OF 91-0435. CALIFORNIA. Preliminary geologic map of the East Mojave National Scenic Area, California, compiled by D. M. 
Miller, R. J. Miller, J. E. Nielson, H. G. Wilshire, K. A. Howard and Paul Stone. 1991. 8 p., 1 over-size sheet. (NC, Da, M; California Dep. of Conservation, Div. of Mines and Geol., Mail Stop 14-34, Library, 801 K St., Sacramento, CA 95814-3532; 1145 Market St., 3rd Floor, San Francisco, CA 94103; and State Office Bldg., 107 South Broadway, Los Angeles, CA 90012.)

OF 91-0441-T. WASHINGTON. Evaluation of liquefaction potential, Seattle, Washington, by W. P. Grant, W. J. Perkins and T. L. Youd. 1992. 44 p., 1 over-size sheet. (NC, Da, M, S; Geol. and Earth Resources Div., Dep. of Natural Resources, Olympia WA 98504; David A. Johnston Cascade Volcano Observatory, 5400 MacArthur Blvd., Vancouver, WA 98661; Dep. of Geol. and Mineral Industries, 910 State Office Bldg., Portland, OR 97201-5528.)

OF 91-0449-A. REMAPP-PC; remote sensing image processing software for MS-DOS personal computers, version 2.00, by K. E. Livo and A. J. Gallagher. 1991. 83 p. (Documentation.) (NC, Da, M.) (Supersedes OF 90-88-A.)

OF 91-0449-B. REMAPP-PC; remote sensing image processing software for MS-DOS personal computers, version 2.00, by K. E. Livo and A. J. Gallagher. 1991. One $51 / 4$ inch diskette. (Installation and executable programs.) (NC, Da, M.) (Supersedes $\mathrm{OF}$ 90-88 B-E.)

Requirements: IBM PC or compatible; minimum 640K RAM; VGA graphics board (SuperVGA not supported). Diskette is 5 . $1 / 4$ inch, high density, MS-DOS format.)

OF 91-0449-C. REMAPP-PC; remote sensing image processing software for MS-DOS personal computers, version 2.00 , by K. E. Livo and A. J. Gallagher. 1991. One 5 1/4 inch diskette. (Executable programs and source code.) (NC, Da, M.) (Supersedes OF 90-88 B-E.)

Requirements: IBM PC or compatible; minimum 640K RAM; VGA graphics board (SuperVGA not supported). Diskette is 5 $1 / 4$ inch, high density, MS-DOS format.

OF 91-0449-D. REMAPP-PC; remote sensing image processing software for MS-DOS personal computers, version 2.00 , by K. E. Livo and A. J. Gallagher. 1991. One 51/4 inch diskette. (Documentation and Landsat MSS test images; Canon City, Colorado.) (NC, Da, M.) (Supersedes OF 90-88 B-E.)

Requirements: IBM PC or compatible; minimum 640K RAM; VGA graphics board (SuperVGA not supported). Diskette is 5 $1 / 4$ inch, high density, MS-DOS format.

OF 91-0449-E. REMAPP-PC; remote sensing image processing software for MS-DOS personal computers, version 2.00 , by K. E. Livo and A. J. Gallagher. 1991. One 5 1/4 inch diskette. (Landsat 4 TM text images (TM Disk 1 of 2); Canon City and Central City, Colorado.) (NC, Da, M.) (Supersedes OF 90-88 B-E.)

Requirements: IBM PC or compatible; minimum 640K RAM; VGA graphics board (SuperVGA not supported). Diskette is 5 $1 / 4$ inch, high density, MS-DOS format.

OF 91-0449-F. REMAPP-PC; remote sensing image processing software for MS-DOS personal computers, version 2.00 , by K. E. Livo and A. J. Gallagher. 1991. One $51 / 4$ inch diskette. (Landsat 4 TM text images (TM Disk 2 of 2); Canon City and Central City, Colorado.)(NC, Da, M.) (Supersedes OF 90-88 B-E.)
Requirements: IBM PC or compatible; minimum 640K RAM; VGA graphics board (SuperVGA not supported). Diskette is 5 1/4 inch, high density, MS-DOS format.

OF 91-0449-G. REMAPP-PC; remote sensing image processing software for MS-DOS personal computers, version 2.00 , by K. E. Livo and A. J. Gallagher. 1991. One $51 / 4$ inch diskette. (AVIRIS (NASA) imaging spectrometry test data; Globe Hill-Cripple Creek, Colorado.) (NC, Da, M.) (Supersedes OF 90-88 B-E.)

Requirements: IBM PC or compatible; minimum 640K RAM; VGA graphics board (SuperVGA not supported). Diskette is 5 $1 / 4$ inch, high density, MS-DOS format.)

OF 91-0453. WASHINGTON. Surface-water-quality assessment of the Yakima River basin, Washington; analysis of available water-quality data through 1985 water year, by J. F. Rinella, S. W. McKenzie and G. J. Fuhrer. 1992. 244 p., 1 over-size sheet, scale 1:250,000 (1 inch = about 4 miles). (NC, Da, M, Wb.)

Water-resource development, by O. J. Perala. p. 30-38.

Bed sediment, by T. L. Fries and J. L. Ryder. p. 142-147.

Fish and other aquatic biological communities, by S. S. Embrey and B. D. Watson. p. 163-176.

OF 91-0454. WASHINGTON. Executive summary; surfacewater-quality assessment of the Yakima River basin, Washington; analysis of available water-quality data through 1985 water year, by J. F. Rinella, S. W. McKenzie and G. J. Fuhrer. 1992. 15 p. (NC, Da, M, Wb.)

OF 91-0455. NEW MEXICO, TEXAS. Listing of model input values for the simulation of ground-water flow in the Mesilla Basin, Dona Ana County, New Mexico, and El Paso County, Texas, by P. F. Frenzel. 1992. 7 p., two $51 / 4$ inch DS/DD IBM compatible diskettes. (NC, Da, M, Wb; USGS, WRD, 4501 Indian School Rd. NE, Suite 200, Albuquerque, NM 87110.) (Supplement to WRI 91-4155 and OF 88-305.)

OF 91-0458. ALASKA. Water-quality and soil assessment at 28 exploratory wellsites in the National Petroleum Reserve in Alaska, 1989-90, by J. O. Brunett, G. L. Solin, M. R. Carr, R. L. Glass, G. L. Nelson and R. C. Buchmiller. 1991. 127 p., thirteen $51 / 4$ inch diskettes. (NC, Da, M, Wb.)

The data for the report are on thirteen 51/4 inch, 1.2MB diskettes that can be used on an IBM PC or compatible. The data are in 132-column ASCII format.

OF 91-0471. A modular finite-element model (MODFE) for areal and axisymmetric ground-water-flow problems; Part 3, Design philosophy and programming details, by L. J. Torak. 1992. 261 p. (NC, Da, M, Wb; USGS, WRD, 6481-B Peachtree Industrial Blvd., Doraville, GA 30360.)

OF 91-0478. NEVADA. Simulated water-level declines caused by withdrawals from wells J-13 and J-12 near Yucca Mountain, Nevada, by J. B. Czarnecki. Prepared in cooperation with U.S. Department of Energy. 1992. 20 p. (NC, Da, M, Wb.)

OF 91-0483. SOUTH CAROLINA. Saltwater movement in the upper Floridan Aquifer beneath Port Royal Sound, South Carolina, by B. S. Smith. Prepared in cooperation with the South Carolina Water Resources Commission. 1993. 64 p. (NC, Da, M, Wb; USGS; WRD, Stephenson Ctr., Suite 129, 720 Gracern Rd., Columbia, SC 29210-7651.) 
OF 91-0485. Hydrologic and sedimentologic data collected during three cruises at low water on the Mississippi River and some of its tributaries, July 1987-June 1988, by J. A. Moody and R. H. Meade. 1992. 143 p. (NC, Da, M, Wb.)

OF 91-0493. NEVADA. Water levels in continuously monitored wells in the Yucca Mountain area, Nevada, 1985-88, by R. R. Luckey, D. H. Lobmeyer and D. J. Burkhardt. Prepared in cooperation with the U.S. Department of Energy. 1993. 252 p. (NC, Da, M, Wb; USGS, WRD, Bldg. 53, Denver Federal Ctr., Mail Stop 415, Box 25046, Lakewood, CO 80225.)

OF 91-0513. Membrane-micelle model for humus in soils and sediments and its relation to humification, by R. L. Wershaw. 1992. 64 p. (NC, Da, M, Wb.)

OF 91-0533. WYOMING. Physical, chemical, and biological data for detailed study of irrigation drainage in the Kendrick Reclamation Project area, Wyoming, 1988-90, by R. B. See, D. A. Peterson and Pedro Ramirez, Jr. Prepared in cooperation with the U.S. Fish and Wildlife Service, U.S. Bureau of Reclamation, and the Wyoming Department of Environmental Quality. 1992. 272 p. (NC, Da, M, Wb, U; USGS, WRD, 2617 East Lincolnway, Suite B, Cheyenne, WY 82001.)

OF 91-0535. CALIFORNIA. Numerical simulation of groundwater flow in the central part of the western San Joaquin Valley, California, by K. R. Belitz, S. P. Phillips and J. M. Gronberg. Prepared in cooperation with the San Joaquin Valley Drainage Program. 1992. 71 p. (NC, Da, M, Wb; USGS, WRD, Federal Bldg., Room W-2234, 2800 Cottage Way, Sacramento, CA 95825; and 5735 Kearny Villa Rd., Suite O, San Diego, CA 92123.)

OF 91-0573. MISSOURI. Total intensity magnetic anomaly map of Missouri, by T. G. Hildenbrand and R. P. Kucks. 1991. 1 over-size sheet, scale 1:500,000 (1 inch = about 8 miles). (NC, Da, M; Department of Natural Resources, Div. of Geol. and Land Surv., 111 Fairgrounds Rd., PO Box 250, Rolla, MO 65401.)

OF 91-0600-D. Preliminary determination of epicenters; monthly listing October-December 1991, by National Earthquake Information Center. 1991. 92 p. (NC, Da, M.)

OF 91-0623. NEVADA. Photogeologic and kinematic analysis of lineaments at Yucca Mountain, Nevada; implications for strikeslip faulting and oroclinal bending, by J. M. O'Neill, J. W. Whitney and M. R. Hudson. Prepared in cooperation with the U.S. Department of Energy. 1992. 24 p., 1 over-size sheet, scale 1:24,000 (1 inch = 2,000 feet). (NC, Da, M, U; Nevada Bur. of Mines and Geol., Univ. of Nevada-Reno, Reno, NV 89557-0088.)

OF 91-0640. ARIZONA. Complete Bouguer gravity map of the Bagdad $0.5^{\circ}$ by $1^{\circ}$ Quadrangle, Arizona, by J. D. Hendricks, J. B. Plescia and A. K. Matic. 1991. 1 over-size sheet, scale 1:100,000 ( 1 inch = about 1.6 miles). (NC, Da, M, U; Arizona Bur. of Geol. and Mineral Technol., 845 North Park Ave., Tucson, AZ 85719.)

OF 92-0008-A. ALASKA. Analytical results and sample locality maps of rock samples from the eastern Goodnews Bay Quadrangle, Southwest Alaska, by J. E. Gray, B. M. Adrian, P. L. Hageman and J. E. Kilburn. 1992. 21 p. (NC, Da, M, A, S; Alaska Div. of Geol. and Geophys. Surv., P.O. Box 7028, Anchorage, AK 99510; U.S. Dep. of Interior, Alaska Resource Library, 701 C St., Box 36, Anchorage, AK 99513.)
OF 92-0008-B. ALASKA. Analytical results and sample locality maps of rock samples from the eastern Goodnews Bay Quadrangle, Southwest Alaska, by J. E. Gray, B. M. Adrian, P. L. Hageman and J. E. Kilburn. 1992. One $51 / 4$ inch diskette. (NC, Da, M, A, S; Alaska Div. of Geol. and Geophys. Surv., P.O. Box 7028, Anchorage, AK 99510; U.S. Dep. of the Interior, Alaska Resource Library, 701 C St., Box 36, Anchorage, AK 99513.)

Requirements: IBM compatible computer using MS DOS with a $51 / 4$ inch, $360 \mathrm{~K}$ drive.

OF 92-0009. Methods for separation and total stable isotope analysis of alunite, by M. D. Wasserman, R. O. Rye, P. M. Bethke and Antonio Arribas, Jr. 1992. 20 p. (NC, Da, M.)

OF 92-0020-B. ALASKA. Ophiolitic and other mafic-ultramafic metallogenic provinces in Alaska; west of the 141st meridian, by J. Y. Foley. 1992. 55 p., 1 over-size sheet, scale 1:2,500,000 (1 inch = about 40 miles). (NC, Da, M, A, S; U.S. Dep. of the Interior, Alaska Resource Library, $701 \mathrm{C} \mathrm{St.,} \mathrm{Box} \mathrm{36,} \mathrm{Anchorage,}$ AK 99513; Alaska Div. of Geol. and Geophys. Surv., 794 University Ave., Suite 200, Fairbanks, AK 99709-3645.)

OF 92-0020-E. ALASKA. Ophiolitic complexes and associated rocks near the Border Ranges fault zone, south central Alaska, by L. E. Burns. 1992. 7 p., 1 over-size sheet. (NC, Da, M, A, S; U.S. Dep. of the Interior, Alaska Resource Library, 701 C St., Box 36, Anchorage, AK 99513; Alaska Div. of Geol. and Geophys. Surv., 794 University Ave,, Suite 200, Fairbanks, AK 99709-3645.)

OF 92-0020-G. ALASKA. Ophiolitic terranes of East-Central and Southwestern Alaska, by W. W. Patton, Jr. and S. E. Box. 1992. 13 p., 2 over-size sheets. (NC, Da, M, A, S; U.S. Dep. of the Interior, Alaska Resource Library, $701 \mathrm{C} \mathrm{St.,} \mathrm{Box} \mathrm{36,} \mathrm{Anchor-}$ age, AK 99513; Alaska Div. of Geol. and Geophys. Surv., 794 University Ave., Suite 200, Fairbanks, AK 99709-3645,)

OF 92-0026. WISCONSIN. Data on water quality, lake sediment, and lake-level fluctuation, St. Croix Indian Reservation, Wisconsin, 1981-87, by D. P. Krabbenhoft and J.. T. Krohelski. Prepared in cooperation with the St. Croix Indian Tribe of Wisconsin. 1992. 53 p. (NC, Da, M, Wb; USGS, WRD, 6417 Normandy Lane, Madison, WI 53719-1133.)

OF 92-0027. IOWA. The ground-water level monitoring network in Iowa, by $R$. B. Lambert. Prepared in cooperation with the Iowa Department of Natural Resources. $1992.31 \mathrm{p}$. (NC, Da, M, Wb; USGS, WRD, P.O. Box 1230, 400 South Clinton, Room 269, Iowa City, IA 52244.)

OF 92-0028. NEVADA. Borehole and geohydrologic data for test hole USW UZ-6, Yucca Mountain, Nye County, Nevada, by M. S. Whitfield, Jr., C. M. Cope and C. L. Loskot. Prepared in cooperation with the U.S. Department of Energy. 1993. 36 p. (NC, Da, M, Wb; USGS, WRD, Yucca Mountain Project Branch, Room H-2726, Bldg. 53, Mail Stop 421, Denver Federal Ctr., Denver, CQ 80225-0046.)

OF 92-0052. Sensitivity of water resources in the Delaware River basin to climate variability and change, by $M$. A. Ayers, D. M. Wolock, G. J. McCabe,Jr., L. E. Hay and G. D. Tasker. 1993. 68 p. (NC, Da, M, Wb; USGS, WRD, Suite 206, 810 Bear Tavern Rd., West Trenton, NJ 08628.)

Water supply and water use, by D. J. Phelan and M. A. Ayers. p. 28-29. 
Effects of climate, topography, and soils on hydrologic characteristics, by D. M. Wolock and C. V. Price. p. 29-30.

Effects on estuary salinity, by R. A. Walters and M. A. Ayers. p. 48-53.

Effects on coastal aquifers, by W. H. Werkheiser and M. A. Ayers. p. 53-54.

OF 92-0055. INDIANA. Ground-water levels and directions of flow in the vicinity of a pumping well field, Elkhart, Indiana, December 1989, by R. F. Duwelius and L. R. Watson. Prepared in cooperation with the U.S. Environmental Protection Agency. 1992. 24 p. (NC, Da, M, Wb; USGS, WRD, 5957 Lakeside Blvd., Indianapolis, IN 46278.)

OF 92-0065. WEST VIRGINIA. Flow and solute-transport models for the New River in the New River Gorge National River, West Virginia by J. B. Wiley. Prepared in cooperation with the National Park Service. 1992. 53 p. (NC, Da, M, Wb; USGS, WRD, 603 Morris St., Charleston, WV 25301.)

OF 92-0083. Accounting system for water use by vegetation in the lower Colorado River valley, by S. J. Owen-Joyce. 1992. 2 p. (NC, Da, M, Wb, A, S.) (Water fact sheet.)

OF 92-0085. IOWA, MINNESOTA. Agricultural chemical interchange between ground water and surface water, Cedar River basin, Iowa and Minnesota; a study description, by P. J. Squillace, M. J. Liszewski and E. M. Thurman. 1993. 26 p. (NC, Da, M, Wb; USGS, WRD, Room 269, Federal Bldg., 400 South Clinton St., Iowa City, IA 52244.)

OF 92-0094. IOWA. Floods of 1986 and 1990 in the Raccoon River basin, west-central Iowa, by R. W. Baebenroth and B. D. Schaap. Prepared in cooperation with the Iowa Department of Transportation, Highway Research Advisory Board. 1992. 144 p. (NC, Da, M, Wb; USGS, WRD, 400 South Clinton St., Iowa City, IA 52244; Federal Bldg., Room 250, 8 South 6th St., Council Bluffs, IA 51502; and Federal Bldg., Room 456, 205 South 8th St., Fort Dodge, IA 50501.)

OF 92-0095. NEW HAMPSHIRE. Geohydrologic and groundwater-quality data for stratified-drift aquifers in the Exeter, Lamprey, and Oyster River basins, southeastern New Hampshire, by R. B. Moore. Prepared in cooperation with the New Hampshire State Department of Environmental Services, Water Resources Division. 1992. 136 p., 4 over-size sheets, scale 1:24,000 (1 inch = 2,000 feet). (NC, Da, M, Wb; USGS, WRD, 525 Clinton St., Bow, NH 03304.)

OF 92-0105. Documentation of a computer program for data retrieval from U.S. Geological Survey National Water-Data Storage and Retrieval System, by J. E. Morris. 1992. 64 p., one 5 1/4 inch diskette. (NC, Da, M, Wb; USGS, WRD, 1400 Independence Rd., Rolla, MO 65401.)

Requirements: IBM PC or compatible computer using DOS 3.0 or higher; a minimum of $425 \mathrm{~K}$ of random access memory (RAM), a hard disk, a 5 1/4 inch floppy disk drive, and a Hayes compatible modem. The quantity of disk space needed on the hard disk for PC-WATSTORE is less than $400 \mathrm{~K}$. Additional space will be required when the results of the retrievals are stored on the personal computer. PC-WATSTORE was written to use KERMIT and the modem to dial the Amdahl computer. Remote job entry software and a synchronous modem also may be used.
PC-WATSTORE was developed using the $\mathrm{C}$ programming language.

OF 92-0108. ARKANSAS. A user's guide to the Arkansas Rural Water-Delivery Network Geographic Information System (GIS) software, by J. E. Monical. Prepared in cooperation with the Arkansas Soil and Water Conservation Commission. 1992. $22 \mathrm{p}$. (NC, Da, M, Wb; USGS, WRD, 700 West Capitol Ave., 2301 Federal Office Bldg., Little Rock, AR 72201.)

OF 92-0113. GEORGIA. Annual peak discharges and stages for gaging stations in Georgia through September 1990, by G. W. Hess and T. C. Stamey. Prepared in cooperation with the Georgia Department of Transportation, Highway Division. 1993. 277 p. (NC, Da, M, Wb.)

OF 92-0114. MICHIGAN. Ground-water data for Michigan, 1990, by G. C. Huffman and C. R. Whited. Prepared in cooperation with the Michigan Department of Natural Resources, Geological Survey Division. 1993. 51 p. (NC, Da, M, Wb; USGS, WRD, 6520 Mercantile Way, Suite 5, Lansing, MI 48911.)

OF 92-0120. OHIO. Streamflow, water-quality, and biological data on streams in an area of longwall coal mining, southern Ohio, water years $1987-89$, by A. W. Coen, III. Prepared in cooperation with the Ohio Department of Natural Resources, Division of Reclamation. 1992. 71 p. (NC, Da, M, Wb; USGS, WRD, 975 West Third Ave., Columbus, OH 43212.)

OF 92-0122. COLORADO. Climatologic, soil-water, groundwater, geologic, surface-water, and water-quality data for a surface coal mine in northwestern Colorado, by R. S. Williams, Jr., G. M. Clark and N. E. Spahr. Prepared in cooperation with the U.S. Bureau of Land Management and the Colorado Department of Natural Resources, Mined Land Reclamation Division. 1993. 218 p. (NC, Da, M, Wb.)

OF 92-0123. NORTH CAROLINA. An interim report on flows in the lower Roanoke River, and water quality and hydrodynamics of Albemarle Sound, North Carolina, October 1989-April 1991, by J. D. Bales, A. G. Strickland and R. G. Garrett. Prepared in cooperation with the Albemarle-Pamlico Estuarine Study, Division of Water Resources of the North Carolina Department of Environment, Health, and Natural Resources, U.S. Army Corps of Engineers. 1993. 133 p. (NC, Da, M, Wb; USGS, WRD, 3916 Sunset Ridge Rd., Raleigh, NC 27607.)

OF 92-0124. UTAH. Records of wells in sandstone and alluvial aquifers and chemical data for water from selected wells in the Navajo Aquifer in the vicinity of the Greater Aneth oil field, San Juan County, Utah, by L. E. Spangler. Prepared in cooperation with the Utah Division of Oil, Gas, and Mining, and the U.S. Environmental Protection Agency. 1992. 44p. (NC, Da, M, Wb, U.)

OF 92-0129. Hydro-Climatic Data Network (HCDN); a U.S. Geological Survey stream-discharge data set for the United States for the study of climate variation, 1874-1988, by R. J. Slack and J. M. Landwehr. 1992. 193 p. One $51 / 4$ inch DS/HD IBM compatible diskette. (NC, $\mathrm{Da}, \mathrm{M}, \mathrm{Wb}$.)

The files on the disk are written in ASCII character type mode.

OF 92-0134. New pressure-based water-level sensor used by the U.S. Geological Survey, by V. J. Latkovich. 1992. 6 p. (NC, Da, M, Wb.) 
OF 92-0135. TENNESSEE. Well-construction, water-level, geophysical, and water-quality data for ground-water monitoring wells for Arnold Air Force Base, Tennessee, by C. J. Hough, E. N. Mahoney and J. A. Robinson. Prepared in cooperation with the U.S. Air Force, Arnold Air Force Base. 1992. 88 p. (NC, Da, M, Wb; USGS, WRD, 810 Broadway, Suite 500, Nashville, TN 37203.)

OF 92-0138. A coupled surface-water and ground-water flow model for simulation of stream-aquifer interaction, by $E$. D. Swain and E. J. Wexler. Prepared in cooperation with the South Florida Water Management District. 1993. 162 p. (NC, Da, M, Wb; USGS, WRD, Suite 3015, 227 North Bronough St., Tallahassee, FL 32301; Suite 107, 9100 NW 36th St., Miami, FL 33178; Suite 1006, 224 West Central Pkwy., Altamonte Springs, FL 32714; and Suite B-5, 4710 Eisenhower Blvd., Tampa, FL 33634.)

OF 92-0143. MASSACHUSETTS. A study of ground-water flow beneath the Massachusetts Military Reservation, Cape Cod, Massachusetts, by P. M. Barlow and D. R. LeBlanc. Prepared in cooperation with the National Guard Bureau. 1992. 2 p. (NC, Da, M, Wb; USGS, WRD, 28 Lord Rd., Suite 280, Marlborough, MA 01752.)

OF 92-0144. Determination of error in individual discharge measurements, by V. B. Sauer and R. W. Meyer. 1992. 21 p. (NC, $\mathrm{Da}, \mathrm{M}, \mathrm{Wb}$.)

OF 92-0146. Methods of analysis by the U.S. Geological Survey National Water Quality Laboratory; determination of total phosphorus by a Kjeldahl digestion method and an automated colorimetric finish that includes dialysis, by C. J. Patton and E. P. Truitt. 1992. 39 p. (NC, Da, M, Wb.)

OF 92-0150. PUERTO RICO. Research plan for the investigation of water, energy, and biogeochemical budgets in the Luquillo Mountains, Puerto Rico, by M. C. Larsen, P. D. Collar and R. F. Stallard. 1993, 19 p. (NC, Da, M, Wb; USGS, WRD, Hwy. $28 \mathrm{~km} 7.2$, Bldg. 652, GSA Ctr., Guaynabo, PR 00657.)

OF 92-0153. NEW JERSEY. Water-quality reconnaissance of the perimeter of the Rolling Knoll Landfill near Green Village, New Jersey, and electromagnetic survey of the parts of the landfill within the Great Swamp National Wildlife Refuge, 1989, by K. S. Turner, M. A. Hardy and R. J. Tapper. Prepared on behalf of the U.S. Fish and Wildlife Service. 1993. 38 p. (NC, Da, M, Wb; USGS, WRD, Mountain View Office Park, 810 Bear Tavern Rd., Suite 206, West Trenton, NJ 08628.)

OF 92-0154. IOWA. Summary of water-resources activities of the U.S. Geological Survey in Iowa, fiscal year 1992, compiled by $R$. A. Karsten. 1992. 108 p. (NC, Da, M, Wb; USGS, WRD, 400 South Clinton St., lowa City, IA 52244; Federal Bldg., Room 250, 8 South 6th St., Council Bluffs, IA 51502; and Federal Bldg., Room 456, 205 South 8 th St., Fort Dodge, IA 50501.)

OF 92-0156. IDAHO. Chemical constituents in water from wells in the vicinity of the Naval Reactors Facility, Idaho National Engineering Laboratory, Idaho, 1989-90, by L. L. Knobel, R. C. Bartholomay, S. J. Wegner and D. D. Edwards. Prepared in cooperation with the U.S. Department of Energy. 1992. 38 p. (NC, Da, M, Wb; USGS, WRD, 230 Collins Rd., Boise, ID 83702; and Idaho National Engineering Laboratory, CF-690, Room 164, Idaho Falls, ID 83403.)
OF 92-0157. MICHIGAN. Water resources activities in Michigan, 1991, compiled by R. M. Corey. Prepared in cooperation with State and Federal agencies. 1992. 82 p. (NC, Da, M, Wb; USGS, WRD, 6520 Mercantile Way, Suite 5, Lansing, MI 48911.)

OF 92-0160. TEXAS. Summary of hydrologic data for the San Gabriel River basin and Edwards Aquifer, Georgetown area, Texas, water year 1990, by W. E. Reeves and L. F. Land. Prepared in cooperation with the City of Georgetown. 1992. 1 oversize sheet. (NC, Da, M, Wb; USGS, WRD, 8011 Cameron Rd., Austin, TX 78753.)

OF 92-0161. Water Resources Research Grant Program project descriptions, fiscal year 1991, compiled by Melvin Lew and P. D. Murray. 1992. 163 p. (NC, Da, M, Wb.)

OF 92-0163. Summary of the U.S. Geological Survey National Field Quality Assurance Program from 1979 through 1989, by D. L. Stanley, W. J. Shamine and L. J. Schroder. 1992. 14 p. (NC, Da, M, Wb; USGS, WRD, Suite 3015, 227 North Bronough St., Tallahassee, Fl 32301; Suite 107, 9100 NW 36 St., Miami, FL 33178; Suite 1006, 224 West Central Pkwy., Altamonte Springs, FL 32714; and Suite B-5, 4710 Eisenhower Blvd., Tampa, FL 33634.)

OF 92-0165. PENNSYLVANIA. Evaluation of nutrient qualityassurance data for Alexanders and Mount Rock Spring basins, Cumberland County, Pennsylvania, by E. C. Witt, III, D. J. Hippe and R. M. Giovannitti. Prepared in cooperation with the Pennsylvania Department of Environmental Resources, Bureau of Water-Quality Management. 1992. 31 p. (NC, Da, M, Wb; USGS, WRD, 840 Market St., Lemoyne, PA 17043.)

OF 92-0166. TENNESSEE. Construction, lithologic, and hydrologic data for test wells in the Cedar Grove area, Carroll County, Tennessee, by S. E. Johnson and J. K. Carmichael. Prepared in cooperation with the Cedar Grove Utility District. 1993. 14 p. (NC, Da, M, Wb; USGS, WRD, 810 Broadway, Suite 500, Nashville, TN 37203.)

OF 92-0167. IOWA. Management Systems Evaluation Area; Iowa, Walnut Creek watershed, by.P. J. Soenksen, J. L. Hatfield and J. L. Baker. 1992. 2 p. (NC, Da, M, Wb, A, S, U.) (Water fact sheet.)

OF 92-0168. MARYLAND. Acid rain and its effect on streamwater quality on Catoctin Mountain, Maryland, by K. C. Rice and O. P. Bricker. 1992. 2p. (NC, Da, M, Wb, A, S, U.) (Water fact sheet.)

OF 92-0173. UTAH, IDAHO. Selected hydrologic data for Cache Valley, Utah and Idaho, 1969-91, by D. M. Roark and K. M. Hanson. Prepared in cooperation with the Utah Department of Natural Resources. 1992. 65 p., 1 over-size sheet. (NC, Da, M, Wb, U.)

OF 92-0174. IDAHO. Purgeable organic compounds in ground water at the Idaho National Engineering Laboratory, Idaho; 1990 and 1991, by M. J. Liszewski and L. J. Mann. Prepared in cooperation with the U.S. Department of Energy. 1992 . 19 p. (NC, Da, M, Wb; USGS, WRD, 230 Collins Rd., Boise, ID 83702; and Idaho National Engineering Laboratory, CF-690, Room 164, Idaho Falls, ID 83403.)

OF 92-0175. IDAHO. Compilation of selected data for thermalwater wells and springs in Idaho, 1921 through 1991, by D. J. 
Parliman and H. W. Young. 1992. 201 p. (NC, Da, M, Wb; USGS, WRD, 230 Collins Rd., Boise, ID 83702.)

OF 92-0198. ARIZONA. Preliminary geologic map of the Mohon Mountains volcanic field, Mohave and Yavapai counties, Arizona, by A. M. Simmons and A. W. Ward. 1992. 2 over-size sheets, scale $1: 50,000$ ( 1 inch $=$ about 4,200 feet $)$. (NC, Da, M, U; Arizona Bur. of Geol. and Mineral Technol., 845 North Park Ave., Tucson, AZ 85719.)

OF 92-0206. HAWAII. Cruise report; GLORIA survey of the Hawaiian island chain, F2-90-HW, by S. V. Dadisman, M. S. Marlow, R. G. Rothwell and Malcolm Harris. 1992. 65 p. (NC, $\mathrm{Da}, \mathrm{M}$.

OF 92-0210-A. CALIFORNIA. Analytical results and sample locality map of rock samples from the Hayfork $30^{\prime} \times 1^{\circ}$ Quadrangle (northwest quarter of the Redding $1^{\circ} \times 2^{\circ}$ Quadrangle), Humboldt and Trinity counties, California, by J. R. Hassemer, M. L. Silberman and R. T. Hopkins. 1992.74 p., 1 over-size sheet, scale $1: 100,000$ ( 1 inch = about 1.6 miles). (NC, Da, M; California Dep. of Conservation, Div. of Mines and Geol., Mail Stop 14-34, Library, 801 K St., Sacramento, CA 95814-3532; 1145 Market St., 3rd Floor, San Francisco, CA 94103; and State Office Bldg., 107 South Broadway, Los Angeles, CA 90012.)

OF 92-0210-B. CALIFORNIA. Analytical results and sample locality map of rock samples from the Hayfork $30^{\circ} \times 1^{\circ}$ Quadrangle (northwest quarter of the Redding $1^{\circ} \times 2^{\circ}$ Quadrangle), Humboldt and Trinity counties, California, by J. R. Hassemer, M. L. Silberman and R. T. Hopkins. 1992. One $51 / 4$ inch diskette. (NC, Da, M; California Dep. of Conservation, Div. of Mines and Geol., Mail Stop 14-34, Library, 801 K St., Sacramento, CA 95814-3532; 1145 Market St., 3rd Floor, San Francisco, CA 94103; and State Office Bldg., 107 South Broadway, Los Angeles, CA 90012.)

This report contains digital geochemical data and text documentation on a $51 / 4$ inch, $360 \mathrm{~K}$ distribution diskette. The text and data files are in standard ASCII format. Requirements: an IBM PCor compatible computer using PC/MS DOS, and a floppy disk drive capable of reading a $51 / 4$ inch, $360 \mathrm{~K}$ diskette.

OF 92-0262. Palynomorph census data from Pliocene strata of the U.S. Atlantic Coastal Plain (Massachusetts to Central Florida), by R. J. Litwin and V. A. Andrle. 1992. 25 p. (NC, Da, Wa; South Carolina Geol. Surv, 5 Geology Rd., Columbia, SC 292109998; Div. of Land Resources, Dep. of Environment, Health, and Natural Resources, P.O. Box 27687, Raleigh, NC 27611; Virginia Div. of Mineral Resources, Natural Resources Bldg., Alderman and McCormick Rds., P.O. Box 3667, Charlottesville, VA 22903; Georgia Geol. Surv., 19 Martin Luther King Jr. Dr. SW, Room 400, Atlanta, GA 30334.)

OF 92-0263. Modern palynomorph and weather census data from the U.S. Atlantic coast (Continental Margin Program samples and selected NOAA weather stations), by R. J. Litwin and V. A. Andrle. 1992. 31 p. (NC, Da, Wa; Connecticut Geol. and Natural History Surv., 165 Capitol Ave., Room 553, Hartford, CT 06106; Georgia Geol. Surv., 19 Martin Luther King Jr. Dr. SW, Room 400, Atlanta, GA 30334; Div. of Land Resources, Dep. of Environment, Health, and National Resources, P.O. Box 27687, Raleigh, NC 27611; New York State Geol. Surv., 3136 Cultural Education Ctr., Empire State Plaza, Albany, NY 12230; South Carolina Geol. Surv., 5 Geology Rd., Columbia, SC 29210-9998;
Virginia Div. of Mineral Resources, Natural Resources Bldg., Alderman and McCormick Rds., P.O. Box 3667, Charlottesville, VA 22903.)

OF 92-0268. SOUTH CAROLINA. Geochemical data for 85 heavy-mineral concentrates from selected areas in Greenville and Laurens counties, South Carolina, by semi-quantitative emission spectrography, by J. C. Jackson, B. M. Adrian and R. T. Hopkins. 1992. 11 p. (NC, Da, M; South Carolina. Surv., 5 Geology Rd., Columbia, SC 29210-9998.)

OF 92-0281. Measured sections from the the Bara, Lakhra, and Laki formations in Sindh, Pakistan; a progress report, by Christopher Wnuk, J. R. SanFilipo, Mohammad Fariduddin, S. F. Fatmi, S. A. Khan and A. H. Chandio. 1992.89 p. (NC, Da, M.)

OF 92-0282-A. VERMONT. Preliminary bedrock geologic map of the Mount Holly Quadrangle and portions of the Ludlow Quadrangle, Rutland and Windsor counties, Vermont; by N. M. Ratcliffe. Prepared in cooperation with the State of Vermont. 1992. 16 p., 2 over-size sheets, scale $1: 24,000$ ( 1 inch $=2,000$ feet). (NC, Da.)

OF 92-0315. ALASKA. Analytical results, sample locality map, and descriptions of rock samples from the Bethel and southern part of the Russian Mission $1^{\circ} \times 3^{\circ}$ quadrangles, Southwest Alaska, by T. P. Frost, L. A. Bradley, R. M. O'Leary and J. M. Motooka. 1992. 229 p., 1 over-size sheet, scale 1:250,000 (1 inch = about 4 miles). (NC, Da, M, A, S; U.S. Dep. of the Interior, Alaska Resource Library, $701 \mathrm{C}$ St., Box 36, Anchorage, AK 99513; Alaska Div. of Geol. and Geophys. Surv., 794 University Ave., Suite 200, Fairbanks, AK 99709-3645.)

OF 92-0316-A. CALIFORNIA. Analytical results and sample locality map of rock samples from the Garberville $30^{\prime} \times 1^{\circ}$ Quadrangle (southwest quarter of the Redding $1^{\circ} \times 2^{\circ}$ Quadrangle), Humboldt, Trinity, Shasta, Tehama, and Mendocino counties, California, by J. R. Hassemer, M. L. Silberman and R. T. Hopkins. 1992. 67 p., 1 over-size sheet, scale 1:100,000 (1 inch = about 1.6 miles). (NC, Da, M; California Dep. of Conservation, Div. of Mines and Geol., Mail Stop 14-34, Library, 801 K St., Sacramento, CA 95814-3532; 1145 Market St., 3rd Floor, San Francisco, CA 94103; and State Office Bldg., 107 South Broadway, Los Angeles, CA 90012.)

OF 92-0316-B. CALIFORNIA. Analytical results and sample locality map of rock samples from the Garberville $30^{\prime} \times 1^{\circ}$ Quadrangle (southwest quarter of the Redding $1^{\circ} \times 2^{\circ}$ Quadrangle), Humboldt, Trinity, Shasta, Tehama, and Mendocino counties, California, by J. R. Hassemer, M. L. Silberman and R. T. Hopkins. 1992. One $51 / 4$ inch diskette. (NC, Da, M; California Dep. of Conservation, Div. of Mines and Geol., Mail Stop 14-34, Library, 801 K St., Sacramento, CA 95814-3532; 1145 Market St., 3rd Floor, San Francisco, CA 94103; and State Office Bldg., 107 South Broadway, Los Angeles, CA 90012.)

This report contains digital geochemical data and text documentation on a $51 / 4 \mathrm{inch}, 360 \mathrm{~K}$ distribution diskette. The text and data files are in standard ASCII format. Requirements: an IBM PC or compatible computer using PC/MS DOS, and a floppy disk drive capable of reading a $51 / 4$ inch, $360 \mathrm{~K}$ diskette.

OF 92-0340. NEVADA, CALIFORNIA. Seismicity and focal mechanisms for the southern Great Basin of Nevada and California in 1991, by S. C. Harmsen. 1992. 100 p. (NC, Da, M, U; Cali- 
fornia Dep. of Conservation, Div. of Mines and Geol., Mail Stop 14-34, Library, 801 K St., Sacramento, CA 95814-3532; 185 Berry St., Suite 3600, San Francisco, CA 94107-1728; and State Office Bldg., 107 South Broadway, Los Angeles, CA 90012; Nevada Bur. of Mines and Geol., Univ. of Nevada-Reno, Reno, NV 89557. 0088.)

OF 92-0343. NEVADA. Gravity and magnetic data of Fortymile Wash, Nevada Test Site, Nevada, by D. A. Ponce, S. B. Kohrn and Sandra Waddell. 1993. 33 p. (NC, Da, M, U; Nevada Bur. of Mines and Geol., Univ. of Nevada, Reno, NV 89557-0088.)

OF 92-0345. The preparation of plant material and determination of weight percent ash, by T. R. Peacock. 1992 . 9 p. (NC, Da, M.)

OF 92-0346. ALASKA. Geologic map of the lower BelugaChuitna area, Tyonek A-3 and A-4 quadrangles, south-central Alaska, by H. R. Schmoll and L. A. Yehle. 1992. 27 p. (NC, Da, M, A, S; Alaska Div. of Geol. and Geophys. Surv., 794 University Ave., Suite 200, Fairbanks, AK 99709-3645; U.S. Dep. of Interior, Alaska Resource Library, 701 C St., Box 36, Anchorage, AK 99513.)

OF 92-0369-A. NPBAS; a BASIC program for nonparametric comparisons of two or more independent groups of data, by M. L. Millgate. 1992. 40 p. (NC, Da, M.)

OF 92-0369-B. NPBAS; a BASIC program for nonparametric comparisons of two or more independent groups of data, by M. L. Millgate. 1992. One $51 / 4$ inch DS/DD diskette. (NC, Da, M.)

The program is designed to run on IBM and compatible personal computers (640K available memory). The report is contained on a $51 / 4$ inch, $360 \mathrm{~K}$ floppy diskette.

OF 92-0377-A. U.S. Geological Survey 1:2,000,000-scale map of shoreline erosion and accretion of the Mid-Atlantic coast, by Robert Dolan and Judith Peatross. 1992. 1 over-size sheet (30 inches $\times 30$ inches), scale $1: 2,000,000(1$ inch $=$ about 32 miles $)$. (M, Da, NC.)

OF 92-0377-B. U.S. Geological Survey 1:2,000,000-scale map of shoreline erosion and accretion of the Mid-Atlantic coast; data supplement, by Robert Dolan and Judith Peatross. 1992. 114 p. (M, Da, NC.)

OF 92-0379-A. ALASKA. Analytical results of stream-sediment samples from the Bethel and southern part of the Russian Mission $1^{\circ} \times 3^{\circ}$ quadrangles, Southwest Alaska, by T. P. Frost, E. A. Bailey, L. A. Bradley, R. M. O'Leary and J. M. Motooka. 1992. 119 p. (NC, Da, M, A, S; U.S. Dep. of the Interior, Alaska Resource Library, 701 C St., Box 36; Anchorage, AK 99513; Alaska Dep. of Natural Resources, Div. of Geol. and Geophys. Surv., 794 University Ave., Suite 200, Fairbanks, AK 99709. 3645.)

OF 92-0379-B. ALASKA. Analytical results of stream-sediment samples from the Bethel and southern part of the Russian Mission $1^{\circ} \times 3^{\circ}$ quadrangles, Southwest Alaska, by T. P. Frost, E. A. Bailey, L. A. Bradley and R. M. O'Leary. 1992. One $31 / 2$ inch diskette. (NC, Da, M, A, S; U.S. Dep. of the Interior, Alaska Resource Library, 701 C St., Box 36, Anchorage, AK 99513; Alaska Dep. of Natural Resources, Div. of Geol. and Geophys. Surv., 794 University Ave., Suite 200, Fairbanks, AK 99709 3645.)
Requirements: IBM 286, 386, or 486 PC or compatible; floppy disk drive able to read $31 / 2$ inch $1.44 \mathrm{MB}$ diskette; PC or MS DOS operating system or Macintosh $\Pi$ series computer equipped with a $20 \mathrm{MB}$ (minimum) hard drive, operating system 6.03 or greater, and a Macintosh Superdrive (1.44MB floppy disk drive). For use of data in.WK1 format, any data manipulation program that can read.WK1 files.

OF 92-0380-A. ALASKA. Analytical results of non-magnetic heavy-mineral-concentrate sample data from the Bethel and southern part of the Russian Mission $1^{\circ} \times 3^{\circ}$ quadrangles, Southwest Alaska, by T. P. Frost, E. A. Bailey, L. A. Bradley, R. M. O'Leary and J. M. Motooka. 1992. 98 p. (NC, Da, M, A, S; U.S. Dep. of the Interior, Alaska Resource Library, $701 \mathrm{C}$ St., Box 36, Anchorage, AK 99513; Alaska Dep. of Natural Resources, Div. of Geol. and Geophys. Surv., 794 University Ave., Suite 200, Fairbanks, AK 99709-3645.)

OF 92-0380-B. ALASKA. Analytical results of non-magnetic heavy-mineral-concentrate sample data from the Bethel and southern part of the Russian Mission $1^{\circ} \times 3^{\circ}$ quadrangles, Southwest Alaska, by T. P. Frost, E. A. Bailey, L. A. Bradley, R. M. O'Leary and J. M. Motooka. 1992. One $31 / 2$ inch diskette. (NC, Da, M, A, S; U.S. Dep. of the Interior, Alaska Resource Library, 701 C St., Box 36, Anchorage, AK 99513; Alaska, Dep. of Natural Resources, Div. of Geol. and Geophys. Surv., 794 University Ave., Suite 200, Fairbanks, AK 99709-3645.)

Requirements: IBM 286,386 , or 486 PC or compatible, floppy disk drive able to read $31 / 2$ inch $1.44 \mathrm{MB}$ diskette, $\mathrm{PC}$ or MS DOS operating system; or Macintosh II series computer equipped with a $20 \mathrm{MB}$ (minimum) hard drive, operating system 6.03 or greater, and a Macintosh Superdrive (1.44MB floppy disk drive). For use of data in .WK1 format, any data manipulation program that can read.WK1 files.

OF 92-0381. Well log evaluation of natural gas hydrates, by T. S. Collett. 1992. 28 p. (NC, Da, M.)

OF 92-0382. Current patterns over the shelf and slope adjacent to the Gulf of the Farallones; executive summary, by M. A. Noble, S. R. Ramp and K. L. Kinoshita. 1992. 26 p. (NC, Da, M.)

OF 92-0383. CALIFORNIA. Abundances of major elements and sedimentary components in cuttings from the Repetto, Sisquoc, and Monterey formations, OCS P-0188 H-1 and H-2 wells, Hondo oil field, offshore Santa Barbara-Ventura Basin, Southern California, by C. M. Isaacs, J. H. Tomson, K. C. Stewart and L. L. Jackson. 1992. 46 p. (NC, Da, M; California Dep. of Conservation, Div. of Mines and Geol., Mail Stop 14-34, Library, $801 \mathrm{~K}$ St., Sacramento, CA 95814-3532; 1145 Market St., 3rd Floor, San Francisco, CA 94103; and State Office Bldg., 107 South Broadway, Los Angeles, CA 90012.)

OF 92-0384. IDAHO. Analytical results and sample locality map of stream-sediment and heavy-mineral-concentrate samples from the Mallard-Larkins Wilderness-Proposed, Clearwater and St. Joe national forests, Clearwater and Shoshone counties, Idaho, by H. N. Barton, R. T. Hopkins, B. H. Roushey and P. H. Briggs. 1992. 30 p., one $51 / 4$ inch diskette, 1 over-size sheet, scale 1:125,000 ( 1 inch = about 2 miles). (NC, Da, M, U, S; Idaho Geol. Surv., Univ. of Idaho Campus, Morrill Hall, Room 332, Moscow, ID 83843.) 
One 5 1/4 inch DS/DD IBM compatible diskette. MS-DOS 2.0 or greater, coprocessor required for the conversion program (included on the diskette).

OF 92-0385. UTAH. Preliminary geologic map of the Stockton 7 1/2-minute Quadrangle, Tooele County, Utah, by E. W. Tooker and R. J. Roberts. 1992. 22 p., 1 over-size sheet, scale 1:24,000 (1 inch = 2,000 feet). (NC, Da, M, U; Utah Geol. Surv., 2363 Foothill Dr., Salt Lake City, UT 84109-1491.)

OF 92-0386. Improved density gradient separation techniques using sodium polytungstate and a comparison to the use of other heavy liquids, by G. L. Skipp and I. K. Brownfield. 1993. 16 p. (NC, Da, M.)

OF 92-0387. CALIFORNIA. Rock falls in Yosemite Valley, California; by G. F. Wieczorek, J. B. Snyder, C. S. Alger and K. A. Isaacson. 1992. 191 p., 4 over-size sheets, one 5 1/4 inch diskette. (NC, Da, M; California Dep. of Conservation, Div. of Mines and Geol., 660 Bercut Dr., Sacramento, CA 95814-0131; 1145 Market St., 3rd Floor, San Francisco, CA 94103; and State Office Bldg., 107 South Broadway, Los Angeles, CA 90012.)

Requirements: MS-DOS, high density, ASCII format.

OF 92-0388. WYOMING. Joint-history summary and orientation data for Upper Cretaceous sandstones, Rawlings and Rock Springs uplifts, Washakie Basin, southern Wyoming, by M. A. Grout and E. R. Verbeek. 1992. 30 p. (NC, Da, M, U; Geol. Surv. of Wyoming, P.O. Box 3008, University Station, Laramie, WY 82071.)

OF 92-0389. Composite geophysical model for continental volcanic-hosted epithermal mineralization; Cox and Singer mineral deposit models numbered $25 \mathrm{~b}, 25 \mathrm{c}, 25 \mathrm{~d}$, and $25 \mathrm{e}$, by D. P. Klein and Viki Bankey. 1992. 15 p. (NC, Da, M.)

OF 92-0390-A. Bibliography of well-log application; cumulative edition, to September 30, 1992, by S. E. Prensky. 1992. Three $31 / 2$ inch diskettes. (NC, Da, M.)

Macintosh version consisting of three text files on three $31 / 2$ inch 1.44MB disks. Formatted in Microsoft Word, version 5.0.

OF 92-0390-B. Bibliography of well-log application; cumulative edition, to September 30, 1992, by S. E. Prensky. 1992. Three $31 / 2$ inch diskettes. (NC, Da, M.)

IBM-PC, or compatible, version, consisting of three text files on three $31 / 2$ inch $1.44 \mathrm{MB}$ disks. Formatted in WordPerfect, version 5.1 .

OF 92-0391. Abstracts of the U.S. Geological Survey, central region, 1992 poster review, compiled by C. E. Barker and A. B. Coury. 1992. 35 p. (NC, Da, M.)

Geoscience imagery hazards; identification and application of preservation techniques by U.S. Geological Survey field records and photographic libraries, by C. G. MacDonald, J. K. McGregor, C. A. Edwards and I. L. Hopkins. p. 1.

The new geologic map of North America, by J. C. Reed, Jr. p. 2.

USGS Core Research Center; a million feet of geologic history, by D. L. Richards and T. C. Michalski. p. 3.
Leaching of Mesozoic marine shales of eastern Colorado; environmental hazard and (or) source for uranium in young deposits?, by Sigrid Asher-Bolinder and R. A. Zielinski. p. 4.

Quaternary carbonate paleodune deposits in central and western Abu Dhabi Emirate, United Arab Emirates, by E. M. Brouwers, D. G. Hadley and T. M. Bown. p. 5.

Holocene deformation in the Ganges-Brahmaputra Delta; a factor in flood distribution in Bangladesh, by D. A. Coates, J. W. Whitney, D. L. Sawatzky and A. K. Alam. p. 6.

Radon measurement uncertainty; why a black and white number shouldn't be pulled from a sea of gray, by G. M. Reimer, S. L. Szarzi and J. M. Been. p. 7.

Geochemical variation of Arctic margin low-sulfur Cretaceous and Tertiary coals, North Slope, Alaska, by R. H. Affolter, G. D. Stricker, S. B. Roberts and M. E. Brownfield. p. 8.

An estimate of the minimum number of measurements needed to constrain the mean random vitrinite reflectance of disseminated organic matter, by C. E. Barker and M. J. Pawlewicz. p. 9-10.

Petrography and reflectance of vitrinite-like particles in Precambrian rocks, U.S.A. and Russia, by M. J. Pawlewicz and J. G. Palacas. p. 11.

Effects of subsidence rates on Cretaceous coal accumulation, Western Interior U.S., by L. N. Roberts and M. A. Kirschbaum. p. 12.

Cretaceous coals in Alaska's Arctic margin (North Slope); geology and resources, by G. D. Stricker. p. 13.

Coal in northwestern Puerto Rico, by J. N. Weaver. p. 14.

Proterozoic oil in fluid inclusions in the Midcontinent Rift; implications for the origin of oil at White Pine, Michigan, by R. C. Burruss and J. L. Mauk. p. 15.

A microcomputer program to generate lognormal probability distribution graphs for petroleum resource assessment, by R. A. Crovelli and R. H. Balay. p. 16.

Thermal history of selected areas in the Paradox Basin, Utah and Colorado, by B. L. Crysdale, B. F. Nuccio and C. E. Barker. p. 17.

Tar sands and heavy oils; resources, recovery and realism, by B. L. Crysdale, C. J. Schenk and R. F. Meyer. p. 18.

Results from 1991 wildcat wells near Yucca Mountain, Nevada, by A. G. Harris, J. E. Repetski, J. L. Clayton, J. A. Grow, M. D. Carr and T. A. Daws. p. 19.

Multifaceted studies of a lacustrine source rock, the Paleogene Green River Formation, Colorado, Utah, and Wyoming, by $\mathrm{M}$. L. Tuttle, W. E. Dean, M. R. Stanton, James Collister, W. J. Harrison, T. D. Fouch, J. K. Pitman, Trond Hanesand and Nils Telnaes. p. 20.

Constraints on extensional fault geometries in eastern Railroad Valley, Nevada, based on seismic reflection and gravity data, by J. A. Grow, H. R. Blank, Jr., C. J. Potter and J. J. Miller. p. 21. 
An aeromagnetic and aeroradioactivity overview of the Colorado Front Range, by J. C. Reed, Jr., Isidore Zietz and J. S. Duval. p. 22.

Work sheets for seismotectonic map of the New Madrid $2^{\circ} \times 2^{\circ}$ area, by B. S. Rhea, R. L. Wheeler and A. C. Tarr. p. 23.

Palynostratigraphy of the Mid-Cretaceous Mancos Shale, western Colorado, by R. A. Cushman, Jr. p. 24.

Triprojectate pollen from the Campanian of the Mancos Shale, western Colorado, by R. A. Cushman, Jr. and D. J. Nichols. p. 25.

Measured sections and paleotectonic interpretation of upper Frontier Formation and lower Beaverhead Group, Lima Peaks area, Southwest Montana, by J. C. Haley, T. S. Dyman and W. J. Perry, Jr. p. 26.

Shocked zircons in the Onaping Formation; further proof of impact origin, by B. F. Bohor and W. J. Betterton. p. 27-28.

Evidence for petroleum-assisted speleogenesis, Lechuguilla Cave, Carlsbad Caverns National Park, New Mexico, by K. I. Cunningham and K. I. Takahashi. p. 29

Petrology and diagenesis of Pennsylvanian Tradewater Group sandstones in the.Illinois Basin, southwestern Indiana, by P. L. Hansley. p. 30 .

Anadarko Basin reservoir and non-reservoir sandstones; a comparison of porosity trends, by T. C. Hester and J. W. Schmoker. p. 31 .

Effects of sedimentologic and petrologic heterogeneity on reservoir properties of the Upper Cretaceous Sussex Sandstone in the House Creek Field, Powder River basin, Wyoming, by D. K. Higley. p. 32.

Isotopic dating of Lava Creek B tephra in terrace deposits along the Wind River, Wyoming; implication for post $0.6 \mathrm{Ma}$ uplift of the Yellowstone Hotspot, by G. A. Izett, K. L. Pierce, N. D. Naeser and Cheryl Jaworowski. p. 33.

Measuring stone decay with close-range photogrammetry, Merchants Exchange, Philadelphia, Pennsylvania, USA, by J. A. Messerich, J. A. Coe, C. L. Pillmore, S. I. Sherwood, Anett Andersen and V. G. Mossotti. p. 34.

Origin of breccia of the Isom Formation near Cedar Breaks National Monument, Markagunt Plateau, southwestern Utah, by D. W. Moore. p. 35.

OF 92-0392. Organization and design of an automated laboratory information management system for the Branch of Geochemistry research and operational laboratory, by A. L. Sutton and J. H. Christie. 1992. 20 p. (NC, Da, M.)

OF 92-0394. MISSISSIPPI. Preliminary lithologic logs for three stratigraphic test holes in Jackson County, Mississippi, by G. S. Gohn, Juergen Reinhardt and J. A. Garrison, Jr. 1992. 20 p. (NC, Da, M; Office of Geol., P.O. Box 20307, Jackson, MS 39289-1307; Geol. Surv. of Alabama, 420 Hackberry Lane, P.O. Box 0, Tuscaloosa, AL 35486-9780.)

OF 92-0395. WEST VIRGINIA, VIRGINIA. Preliminary results of coring surficial deposits in the Winchester $30 \times 60$ minute Quadrangle, West Virginia and Virginia, by A. J. Froelich, M. F. Hoffman, and S. S. Taunton; with a section on Geophysical log- ging and monitor well completion of the core holes, by D. J. Phelan. 1992. 46 p. (NC.)

OF 92-0396. NORTH CAROLINA. Heavy-mineral concentrations associated with some gamma-ray aeroradiometric anomalies over Cretaceous sediments in North Carolina; implications for locating placer mineral deposits near the fall zone, by A. E. Grosz, F. C. San Juan, Jr. and J. C. Reid. 1992. 27 p. (NC, Da, M.)

OF 92-0397. Sample handling and curation protocol for the Western Interior Seaway Scientific Drilling Project, by W. E. Dean and M. A. Arthur. 1992. 6 p. (NC, Da, M.)

OF 92-0399. NEW JERSEY. Distribution of selected Campanian and Maastrichtian Ostracoda in stratigraphic test holes of the New Jersey coastal plain, by G. S. Gohn. Prepared in cooperation with the New Jersey Geological Survey. 1992. 25 p. (NC, Da, M; New Jersey Geol. Surv., Div. of Water Resources-CNO29, Trenton, $\mathrm{NJ}$ 08625.)

OF 92-0408. WYOMING, IDAHO. Geochronology of the late Cenozoic volcanism of Yellowstone National Park and adjoining areas, Wyoming and Idaho, by J. D. Obradovich. 1992. 45 p. 1 over-size sheet. (NC, Da, M, U, S; Geol. Surv. of Wyoming, P.O. Box 3008, University Station, Laramie, WY 82071; Idaho Geol. Surv., Univ. of Idaho Campus, Morrill Hall, Room 332, Moscow, ID 83843.)

OF 92-0413. Pliocene planktic foraminifer census data from Deep Sea Drilling Project Hole 607 and Ocean Drilling Program Hole 661A, by H. J. Dowsett and S. M. West. 1992. 4 p. (NC, Da, M.)

OF 92-0414. Pliocene planktic foraminifer census data from Deep Sea Drilling Project Hole 396 and Ocean Drilling Program Hole 672, by L. B. Wiggs and H. J. Dowsett. 1992. 5 p. (NC, Da, M.)

OF 92-0418. Pliocene planktic foraminifer census data from Deep Sea Drilling Project holes 541 and 546, by H. J. Dowsett and E. F. Polanco. 1992. 4 p. (NC, Da, M.)

OF 92-0426. Summary of lithostratigraphy and stratigraphic correlations in piston cores from Northwind Ridge, Arctic Ocean, from USCGC Polar Star, 1988, by R. L. Phillips, Arthur Grantz, M. W. Mullen, H. J. Rieck, M. W. McLaughlin and T. L. Selkirk. 1992. 110 p., 4 over-size sheets. (NC, Da, M.)

OF 92-0439. ALASKA. Diatoms from ice-rafted sediment collected from the Beaufort Sea, Arctic Alaska, by J. A. Barron. 1992. 16 p. (NC, Da, M, A, S; U.S. Dep. of the Interior, Alaska Resource Library, 701 C St., Box 36, Anchorage, AK 99513; Alaska Div. of Geol. and Geophys. Surv., 794 University Ave., Suite 200, Fairbanks, AK 99709-3645.)

OF 92-0441: A course on PC-based seismic networks, edited by W. H. Lee and D. A. Dodge. 1992. 535 p. (NC, Da, M.)

Regional seismic networks in California, by J. P. Eaton. p. $1-52$.

PC-based seismic systems, by W. H. Lee. p. 53-78.

Seismometers theory and practice, by J. P. Eaton. p. 79-99.

Basic techniques for telemetry, by J. R. VanSchaack. p. 100 114. 
Realtime seismic data acquisition, by W. H. Lee. p. 115-137.

The XDETECT program, by W. H. Lee. p. 138-151.

The TDETECT program, by J. R. Evans. p. 152-164.

Routine seismic network data processing, by W. H. Lee. p. 165-189.

Plotting seismograms and maps, by Robert Banfill. p. 190-206.

Mathematics for earthquake location, by W. H. Lee. p. 207225.

Local earthquake location programs, by J. C. Lahr. p. 226250.

Computing travel time and derivatives, by W. H. Lee. p. 251280.

Development of earthquake magnitude scales, by J. P. Eaton. p. 281-315.

Coda waves for magnitude and Q, by W. H. Lee. p. 316-335.

PCEQ and QCODA, by C. M. Valdes. p. 336-358.

Mathematics for waveform analysis, by A. Lomax. p. 359382.

The SEISGRAM program, by A. Lomax. p. 383-404.

Focal mechanism; theory and history, by P. A. Reasenberg. p. 405-423.

The FPFIT program, by D. H. Oppenheimer. p. 424-460.

Mathematics for seismic tomography, by W. H. Lee. p. 461478.

Applications of seismic tomography, by H. M. Iyer. p. 479511.

Appendix; Implementing a PC-based seismic system; questions \& answers, by W. H. Lee. p. 512-521.

OF 92-0445. Modern mobile methane measurements in marshes, by J. S. Leventhal. 1992. 24 p. (NC, Da, M.)

OF 92-0446. CALIFORNIA. Geologic setting of the Yucaipa Quadrangle, San Bernardino and Riverside counties, California, by J. C. Matti, D. M. Morton, B. F. Cox, S. E. Carson and T. J. Yetter. 1992. 14 p., 1 over-size sheet, scale 1:24,000 (1 inch = 2,000 feet). (NC, Da, M; California Dep. of Conservation, Div. of Mines and Geol., Mail Stop 14-34, Library, $801 \mathrm{~K} \mathrm{St.,} \mathrm{Sacra-}$ mento, CA 95814-3532; 185 Berry St., Suite 3600, San Francisco, CA 94107-1728; and State Office Bldg., 107 South Broadway, Los Angeles, CA 90012.)

OF 92-0447. CALIFORNIA. Environmental impacts of pipeline corridors in the Mojave Desert, California, by H. G. Wilshire. 1992. 55 p. (NC, Da, M; California Dep. of Conservation, Div. of Mines and Geol., Library, Mail Stop 14-34, 801 K St., Sacramento, CA 95814-3532; 1145 Market St., 3rd Floor, San Francisco, CA 94103; and State Office Bldg., 107 South Broadway, Los Angeles, CA 90012.)

OF 92-0450. NEVADA. Geodetic leveling data used to define historical height changes between Tonopah Junction and Las Vegas, Nevada, by T. D. Gilmore. 1992. 133 p. (NC, Da, M, U;
Nevada Bur. of Mines and Geol., Univ. of Nevada, Reno, NV 89557.)

OF 92-0451. ILLINOIS. Water-resources activities of the U.S. Geological Survey in Illinois, 1990, compiled by G. O. Balding. 1992. 96 p. (NC, Da, M, Wb.)

OF 92-0452. ILLINOIS. Water-resources activities of the U.S. Geological Survey in Iilinois, 1991, compiled by G. O. Balding. 1992. 98 p. (NC, Da, M, Wb.)

OF 92-0456. CALIFORNIA. Trace metals in clams (Macoma balthica) and sediments at Palo Alto mudflat in South San Francisco Bay, California; May 1991-May 1992, by S. N. Luoma, D. J. Cain, C. L. Brown and Michelle Hornberger. Prepared in cooperation with the City of Palo Alto, California. 1992. 51 p. (NC, Da, M, Wb; USGS, WRD, Mail Stop 465, 345 Middlefield Rd., Menlo Park, CA 94025.)

OF 92-0457. Simulation of soluble waste transport and buildup in surface waters using tracers, by F. A. Kilpatrick. 1992.68 p. (NC, Da, M.)

OF 92-0459. MARYLAND. Potentiometric surface of the Aquia Aquifer in southern Maryland, September 1990, by F. K. Mack, S. E. Curtin, D. C. Andreasen and J. C. Wheeler. 1992. 1 p. (NC, Da, M, Wb; USGS, WRD, 208 Carroll Bldg., 8600 La Salle Rd., Towson, MD 21204; and Tawes State Office Bldg., E-2, 580 Taylor Ave., Annapolis, MD 21401.)

OF 92-0460. MARYLAND. Potentiometric surface of the Magothy Aquifer in southern Maryland, September 1990, by F. K. Mack, S. E. Curtin, D. C. Andreasen and J. C. Wheeler. 1992. 1 p. (NC, Da, M, Wb; USGS, WRD, 208 Carroll Bldg., 8600 La Salle Rd., Towson, MD 21204; and Tawes State Office Bldg., E-2, 580 Taylor Ave., Annapolis, MD 21401.)

OF 92-0461. MARYLAND. Potentiometric surface of the upper Patapsco Aquifer in southern Maryland, September 1990, by F. K. Mack, S. E. Curtin, D. C. Andreasen and J. C. Wheeler. 1992. 1 p. (NC, Da, M, Wb; USGS, WRD, 208 Carroll Bldg., 8600 La Salle Rd., Towson, MD 21204; and Tawes State Office Bldg., E-2, 580 Taylor Ave., Annapolis, MD 21401.)

OF 92-0462. MARYLAND. Potentiometric surface of the lower Patapsco Aquifer in southern Maryland, September 1990, by F. K. Mack, S. E. Curtin, D. C. Andreasen and J. C. Wheeler. 1992. 1 p. (NC, Da, M, Wb; USGS, WRD, 208 Carroll Bldg., 8600 La Salle Rd., Towson, MD 21204; and Tawes State Office Bldg., E-2, 580 Taylor Ave., Annapolis, MD 21401.)

OF 92-0463. MARYLAND. The difference between the potentiometric surfaces of the Aquia Aquifer of September 1982 and September 1990 in southern Maryland, by F. K. Mack, S. E. Curtin, D. C. Andreasen and J. C. Wheeler. 1992. 1 p. (NC, Da, M, Wb; USGS, WRD, 208 Carroll Bldg., 8600 La Salle Rd., Towson, MD 21204; and Tawes State Office Bldg., E-2, 580 Taylor Ave., Annapolis, MD 21401.)

OF 92-0464. MARYLAND. The difference between the potentiometric surfaces of the Magothy Aquifer of September 1975 and September 1990 in southern Maryland, by F. K. Mack, S. E. Curtin, D. C. Andreasen and J. C. Wheeler. 1992. 1 p. (NC, Da, M, Wb; USGS, WRD, 208 Carroll Bldg., 8600 La Salle Rd., Towson, MD 21204; and Tawes State Office Bldg., E-2, 580 Taylor Ave., Annapolis, MD 21401.) 
OF 92-0465. NEW MEXICO. Annual water-resources review, White Sands Missile Range, New Mexico, 1988, by R. G. Myers and S. C. Sharp. Prepared in cooperation with White Sands Missile Range. 1992. 23 p. (NC, Da, M, Wb, U; USGS, WRD, 4501 Indian School Rd. NE, Suite 200, Albuquerque, NM 87110.)

OF 92-0466. FLORIDA. Potentiometric surface of the upper Floridan Aquifer in the St. Johns River Water Management District and vicinity, Florida, May 1992, by L. A. Bradner, L. C. Murray, G. G. Phelps and R. M. Spechler. Prepared in cooperation with the St. Johns River Water Management District, South Florida Water Management District, and the Southwest Florida Water Management District. 1992. 1 over-size sheet. (NC, Da, $\mathrm{M}, \mathrm{Wb}$.)

OF 92-0468. ARIZONA. Hydrologic data from the study of acidic contamination in the Miami Wash-Pinal Creek area, Arizona, water years 1990-91, by S. A. Longsworth and A. M. Taylor. 1992. 59 p. (NC, Da, M, Wb; USGS, WRD, 375 South Euclid Ave., Tucson, AZ 85719; 1545 West University Dr., Tempe, AZ 85281; 1940 South 3rd Ave., Yuma, AZ 85364; and 2255 North Gemini Dr., Flagstaff, AZ 86001.)

OF 92-0469. MISSISSIPPI. Water-quality and bottom-materialchemistry data for the Yazoo River Basin Demonstration Erosion Control Project, north-central Mississippi, February 1988-September 1991, by L. J. Slack. Prepared in cooperation with the U.S. Army Corps of Engineers. 1992. 197 p. (NC, Da, M, Wb.)

OF 92-0471. FLORIDA. Potentiometric surfaces of the intermediate aquifer system, west-central Florida, May 1992, by R. A. Mularoni. Prepared in cooperation with the Southwest Florida Water Management District. 1992. 1 over-size sheet. (NC, Da, $\mathrm{M}, \mathrm{Wb}$.)

OF 92-0472. FLORIDA. Potentiometric surface of the upper Floridan Aquifer, west-central Florida, May 1992, by R. A. Mularoni. Prepared in cooperation with the Southwest Florida Water Management District. 1992. 1 over-size sheet. (NC, Da, M, Wb.)

OF 92-0473. NEW YORK. Water-resources programs in the New York District, fiscal years 1990-92, compiled by M. P. Marshall. 1992. 67 p. (NC, Da, M, Wb.)

OF 92-0475. MINNESOTA. Climatic data for Williams Lake, Hubbard County, Minnesota, 1987-1988, by R. S. Parkhurst, D. A. Merk, D. O. Rosenberry and T. C. Winter. 1992. 39 p. (NC, Da, M, Wb.)

OF 92-0476. NEW YORK. Selected data on water quality and bottom material of New York streams, 1987-88, by J. F. Weigel. Prepared in cooperation with the New York State Department of Environmental Conservation. 1993. 250 p. (NC, Da, M, Wb; USGS, WRD, James T. Foley Courthouse, P.O. Box 1669, Albany, NY 12201.)

OF 92-0477. Documentation of a computer program to simulate horizontal-flow barriers using the U.S. Geological Survey's modular three-dimensional finite-difference ground-water flow model, by P. A. Hsieh and J. R. Freckleton. Prepared in cooperation with the City of Santa Barbara. 1993. 32 p. (NC, Da, M, Wb; USGS, WRD, Federal Bldg., Room W-2233, 2800 Cottage Way, Sacramento, CA 95825; and 5735 Kearny Villa Rd., Suite O, San Diego, CA 92123.)
OF 92-0479. ALASKA. Activities of the Alaska District, Water Resources Division, U.S. Geological Survey, 1992, compiled by E. F. Snyder. Prepared in cooperation with the U.S. Bureau of Land Management, U.S. National Park Service, U.S. Department of Agriculture, U.S. Department of the Army, U.S. Air Force, U.S. Navy; Alaska state agencies; cities of Anchorage, Cordova, Juneau, Sitka; Kenai Peninsula Borough, Kenai Soil and Water Conservation District, and University of Alaska Fairbanks. 1992. 21 p. (NC, Da, M, Wb, A, S; USGS, WRD, 4230 University Dr., Suite 201, Anchorage, AK 99508-4664; 800 Yukon Dr., Fairbanks, AK 99775-5170; and 9101 Mendenhall Mall Rd. Federal Bldg. Annex., Juneau, AK 99801.)

OF 92-0480. Methods of analysis by the U.S. Geological Survey National Water Quality Laboratory; determination of dissolved organic carbon by UV-promoted persulfate oxidation and infrared spectrometry, by R. W. Brenton and T. L. Arnett. 1993. 12 p. (NC, Da, M, Wb.)

OF 92-0482. TENNESSEE. Rainfall, streamflow, and peak stage data collected at the Murfreesboro, Tennessee, gaging network, March 1989 through July 1992, by G. S. Outlaw, D. E. Butner, R. L. Kemp, A. T. Oaks and G. S. Adams. Prepared in cooperation with the City of Murfreesboro, Tennessee. 1992: $68 \mathrm{p}$. (NC, Da, M, Wb; USGS, WRD, 810 Broadway, Suite 500, Nashville, TN 37203.)

OF 92-0483. OREGON. Debris-flow research flume at H. J. Andrews Experimental Forest, Oregon, by R. M. Iverson, J. E. Costa and R. G. LaHusen. 1992. 2 p. (NC, Da, M, Wb.)(Water fact sheet.)

OF 92-0484. NEVADA. Selected meteorological data for an arid site near Beatty, Nye County, Nevada, calendar year 1989, by J. L. Wood and B. J. Andraski. 1992. 27 p. (NC, Da, M, Wb; USGS, WRD, 333 West Nye Lane, Carson City, NV 89706; and 6770 South Paradise Rd., Las Vegas, NV 89119.)

OF 92-0485. ILLINOIS. Rainfall in and near Du Page County, Illinois, February 1986-September 1991, by J. J. Duncker, T. J. Vail and J. D. Earle. Prepared in cooperation with Du Page County, Department of Environmental Concerns. 1993. 142 p. (NC, Da, M, Wb; USGS, WRD, 102 East Main St., 4th Floor, Urbana, IL 61801.)

OF 92-0486. HAWAII. Hourly rainfall and reported debris flows for selected storm periods, 1935-91, in and near the Honolulu District, Hawaii, by J. D. Torikai and R. C. Wilson. Prepared in cooperation with the City and County of Honolulu, Department of Public' Works. 1992.76 p. (NC, Da, M, Wb.)

OF 92-0489. Hydrogeology of the basal confining unit of the carbonate aquifer system in the Midwestern Basins and Arches region of Indiana, Ohio, Michigan, and Illinois, by G. D. Casey. 1992. 2 over-size sheets. (NC, Da, M, Wb; USGS, WRD, 975 West 3rd Ave., Columbus, $\mathrm{OH} 43212$.

OF 92-0490. Proposed algorithm for determining the delta intercept of a thermocouple psychrometer curve, by M. A. Kurzmack. Prepared in cooperation with the U.S. Department of Energy. 1993. 8 p. (NC, Da, M, Wb.)

OF 92-0492. LOUISIANA. Water-resources activities in Louisiana, fiscal years $1990-92$, compiled by D. M. Smothers and W. C. Martin. 1992. 58 p. (NC, Da, M, Wb.) 
Louisiana hydrologic atlas map No. 6; water-quality survey of the Barataria Basin, 1988, by D. K. Demcheck. p. 48.

Plan of study for selected toxic substances in the Calcasieu River, Louisiana, by D. K. Demcheck. C. R. Demas and P. B. Curwick. p. 49.

Chemical, tissue, and physical data from water and bottom material in the lower Calcasieu River, Louisiana, by D. K. Demcheck, C. R. Demas and C. R. Garrison. p. 50.

Water use in Louisiana, 1990, by J. K. Lovelace. p. 51.

Calibration and sensitivity analysis of a ground-water flow model of the coastal lowlands aquifer system in parts of Louisiana, Mississippi, Alabama, and Florida, by Angel Martin, Jr. and C. D. Whiteman, Jr. p. 52.

Hydrology of the coastal lowlands aquifer system in parts of Alabama, Florida, Louisiana, and Mississippi, by Angel Martin, Jr. and C. D. Whiteman, Jr. p. 53.

Simulated response to pumping stresses in the Sparta Aquifer, northern Louisiana and southern Arkansas, by H. C. McWreath, J. D. Nelson and D. J. Fitzpatrick. p. 54.

Geohydrology and simulation of flow in the Chicot aquifer system of southwestern Louisiana, by D. J. Nyman, K. J. Halford and Angel Martin, Jr. p. 55.

Generalized potentiometric surfaces of the Red River alluvial aquifer, Pool 1, Red River Waterway area, central Louisiana, by C. W. Smoot and Angel Martin, Jr. p. 56.

Louisiana ground-water map No. 3; potentiometric surface, 1989, and water-level changes, 1980-89, of the Sparta Aquifer in north-central Louisiana, by C. W. Smoot and R. C. Seanor. p. 57.

Organic chemical analyses of ground water in Louisiana, water years 1984-88, by C. G. Stuart and C. R. Demas. p. 58.

OF 92-0493. Characteristics of U.S. Geological Survey discharge measurements for water year 1990, by J. M. Fulford. 1992. 79 p. (NC, Da, M, Wb.)

OF 92-0494. Guidelines for studies of contaminants in biological tissues for the National Water-Quality Assessment Program, by J. K. Crawford and S. N. Luoma. 1993. 69 p. (NC, Da, M, Wb; USGS, WRD, 840 Market St., Lemoyne, PA 17043.)

OF 92-0495. Quality assurance/quality control manual; National Water Quality Laboratory, edited by J. W. Pritt and J. W. Raese. 1992. 33 p. (NC, Da, M, Wb, U.)

OF 92-0496. ARKANSAS. Summary of report water use for Arkansas counties, 1990, by T. W. Holland and C. A. Manning. Prepared in cooperation with the Arkansas Soil and Water Conservation Commission. 1992. 21 p. (NC, Da, M, Wb.)

OF 92-0497. UTAH. Water-resources activities in Utah by the U.S. Geological Survey, October 1, 1990, to September 30, 1991, by J. S. Gates and E. E. Hardy. 1992. 49 p. (NC, Da, M, Wb.)

OF 92-0498. NORTH CAROLINA. Hydrologic and water-quality data in selected agricultural drainages in Beaufort and Hyde counties, North Carolina, $1988-90$, by M. W. Treece and J. D. Bales. Prepared in cooperation with the North Carolina Department of Environment, Health, and Natural Resources. 1992. 89 p. (NC, Da, M, Wb; USGS, WRD, 3916 Sunset Ridge Rd., Raleigh, NC 27607.)

OF 92-0500. IOWA. Hydrologic data for a study of pre-lilinoian glacial till in Linn County, Iowa, water year 1991, by P. R. Bowman. Prepared in cooperation with the Iowa Department of Natural Resources, Geological Survey Bureau. 1992.66 p. (NC, $\mathrm{Da}, \mathrm{M}, \mathrm{Wb}$; USGS, WRD, 400 South Clinton St., Iowa City, IA 52244; Federal Bldg., Room 250, 8 South 6th St., Council Bluffs, IA 51502; and Federal Bldg., Room 456, 205 South 8th St., Fort Dodge, IA 50501.)

OF 92-0501. HAWAII. Geology, hydrology and mechanics of the Alani-Paty Landslide, Manoa Valley, Oahu, Hawaii, by R. L. Baum and M. E. Reid. Prepared in cooperation with the City and County of Honolulu, Department of Public Works. 1992. 87 p., 6 over-size sheets. (NC, Da, M; Div. of Water and Land Dev., P.O. Box 373, Honolulu, HI 96809. .)

OF 92-0502. Bibliography of publications prepared by U.S. Geological Survey personnel under cooperative programs with the U.S. Department of Energy and predecessor agencies, 1957-1991, with emphasis on nuclear testing programs, by V. M. Glanzman. Prepared in cooperation with the U.S. Department of Energy. 1992. 83 p. (NC, Da, M, U; Nevada Bur. of Mines and Geol., Univ. of Nevada-Reno, Reno, NV 89557-0088.)

OF 92-0503. NEW MEXICO. Gravity data at the western rim of the Bursum Caldera, New Mexico; including principal facts, profiles and gravity contour maps, by G. A. Abrams, R. M. Senterfit and D. P. Klein. 1992. 11 p. 1 over-size sheet, scale 1:100,000 ( 1 inch = about 1.6 miles). (NC, Da, M, U; New Mexico Bur. of Mines and Mineral Resources, Campus Station, Socorro, NM 87801.)

OF 92-0504. WYOMING. Field guide to the Quaternary geology of Jackson Hole, Wyoming, by K. L. Pierce and J. D. Good. 1992. 54 p. (NC, Da, M, U; Geol. Surv. of Wyoming, P.O. Box 3008, University Station, Laramie, WY 82071.)

Holocene vegetation and climate of Grand Teton National Park and vicinity, by Cathy Whitlock. p. 50-54.

OF 92-0508. Biostratigraphic dating of late Neogene sedimentation on the western shelf, Great Bahama Bank, by B. H. Lidz. 1992. 126 p. (NC, Da.)

OF 92-0509-A. ARIZONA. Analytical results for rock and stream-sediment samples, Kaibab National Forest, Coconino County, Arizona, by M. A. Chaffee, R. R. Carlson, D. L. Fey and P. M. Theodorakos. 1992. 143 p., 2 over-size sheets, scale 1:250,000 ( 1 inch = about 4 miles). (NC, Da, M, U; Bur. of Geol. and Mineral Technol., 845 North Park Ave., Tucson, AZ 85719.)

OF 92-0509-B. ARIZONA. Analytical results for rock and stream-sediment samples, Kaibab National Forest, Coconino County, Arizona, by M. A. Chaffee, R. R. Carlson, D. L. Fey and P. M. Theodorakos. 1992. One 5 1/4 inch diskette. (NC, Da, M, U; Bur. of Geol. and Mineral Technol., 845 North Park Ave., Tucson, AZ 85719.)

Requirements: IBM PC or compatible computer using MS-DOS; and 1.2MB $51 / 4$ inch floppy disk drive.

OF 92-0513. PUERTO RICO. High-resolution seismic-reflection and echo-sounder data from cruise Jena 91-11 on the south shelf 
of Puerto Rico; Isla Caja de Muertos and Salinas to Jobos areas, by J. L. Trias and K. M. Scanlon. 1992. 3 p. (NC, Da, M.)

OF 92-0514. Industrial minerals, today and tomorrow; the raw materials to build the upper Midwest, edited and compiled by $G$. B. Sidder, P. K. Sims, Sarah Chadima, and R. F. Biek. 1992. 144 p. (NC, Da, M; Geol. Surv., 2642 University Ave., St. Paul, MN 55114-1057; Illinois State Geol. Surv., Natural Resources Bldg., 615 East Peabody Dr., Room 121, Champaign, IL 61820; Indiana Geol. Surv., Dep. of Natural Resources, 611 North Walnut Grove, Bloomington, IN 47405; Geol. Surv. Div., Michigan Dep. of Natural Resources, P.O. Box 30028, Lansing, MI 48909; North Dakota Geol. Surv., University Station, Grand Forks, ND 58202-8156; Dep. of Natural Resources, Div. of Geol. Surv., Fountain Square, Bldg. B, Columbus, OH 43224; Dep. of Water and Natural Resources, South Dakota Geol. Surv., Sci. Ctr., Univ, of South Dakota, Vermillion, SD 57069; Wisconsin Geol. and Natural History Surv., Univ. of Wisconsin, 3817 Mineral Point Rd., Madison, WI 53705.)

Problems of U.S. infrastructure in the twenty-first century, by N. R. Connery. p. 1

New construction materials demands and resource availability, by G. C. Harris. p. 2-3.

Research required for improved quality control, by $\mathbf{M}$. R. Thompson. p. 4.

Environmental issues and solutions; the prisoners' dilemma; a look at environmental decision-making and the mineral industry, by E. K. Lehmann. p. 5 .

Economics of production, distribution, and marketing, by $\mathrm{H}$. $\mathrm{H}$. Murray. p. 6.

Land use, conflict and resolutions; integrating aggregate mining into the planning process, by A. M. Bauer. p. 7 .

Planning for mineral extraction; pits and pitfalls; by Randall Graves. p. 8.

Mineral extraction meets planning and zoning, by Mark Wyckoff. p. 9

County planning, preservation, regulation, and reclamation, by Ed Sieben and P. S. Bus. p. 10.

Land use classification and conflict, by T. A. Thompson, P. N. Irwin, C. H. Ault and S. J. Baedke. p. 11.

A regional approach to evaluating aggregate needs, by C. J. Schenk. p. 12-13.

Industrial minerals to the year 2000; how will we meet the demand?, by J. R. Dunn. p. 14-15.

Whatever happened to common sense?, by L. R. Guzzo. p. 16.

Nonmetallic mineral industry and resources of Wisconsin, by B. A. Brown and T. J. Evans. p. 17.

Gravel pit reclamation in Minnesota, by Cindy Buttleman. p. 18-19.

Industrial minerals in South Dakota, by Sarah Chadima and Barb Regynski. p. 20.
Investigation of kaolin in eastern Redwood County, Minnesota, using gravity, magnetic and electrical resistivity methods, by $\mathrm{V}$. W. Chandler, S. A. Hauck, M. Severson, J. J. Heine, J. Reichhoff and B. D. Schaap. p. 21.

Economic potential for industrial minerals in the Paducah $1^{\circ} \times$ $2^{\circ}$ Quadrangle in southern Illinois and adjacent Kentucky and Missouri; the results of CUSMAP assessment, by J. J. Eidel, J. W. Baxter, R. E. Hughes, J. M. Masters, R. R. Pool, L. R. Smith, B. J. Stiff, W. Anderson, G. R. Dever, Jr., W. W. Olive, M. C. McFarland, A. Reuff, T. S. Hayes and R. B. Berg. p. 22-23.

Regional and local geologic, mineralogic, and geochemical controls of the industrial clay grades in the Minnesota River valley, by J. J. Heine and T. A. Toth. p. 24-25.

Industrial minerals exploration and research in Michigan, by A. M. Johnson, M. A. Gere, Jr. and S. P. Sundeen. p. 26-27.

Natural aggregates; national and regional assessments, by W. $H$. Langer. p. $28-30$.

Minnesota's aggregate mapping program, by J. D. Lehr. p. 31-32.

Mineral frontiers on Indian lands, by Stephen Manydeeds. p. 33-34.

The impact of urban development on the stone industry of the Chicago-Milwaukee metropolitan area, by D. G. Mikulic and Joanne Kluessendorf. p. 35-36.

Industrial minerals information for local government; geologic resources plates of the Minnesota County Geologic Atlas Program, by J. H. Mossler. p. 37.

Evaluation of the carbonate resources of southern Minnesota, by H. B. Niles and J. H. Mossler. p. 38.

Dimension stone inventory of northern Minnesota, by $M$. W. Oberhelman and R. Riihiluoma. p. 39.

Kittson County, Minnesota, bloating clays, by J. A. Oreskovich. p. 40-41.

Kaolinitic saproliths of central and western Minnesota, by D. R. Setterholm and G. B. Morey. p. $42-43$.

Mineral assessment, inventory, and marketing study programs of the Oglala Sioux Pine Ridge Indian Reservation, by Donavan Shangreaux and Haiyu Shi. p. 44.

The minerals source, by U.S. Bureau of Mines. p. 45 .

Industrial minerals in Ohio, by S. L. Weisgerber and D. A. Stith. p. 46.

The mineral industry of Illinois, 1989 , by D. H. White, Jr. p. 47-54.

Illinois; industrial mineral information and regulation, compiled by J. J. Eidel. p. 55-58.

The mineral industry of Indiana, 1989, by W. J. West. p. 59 . 65.

Indiana; industrial mineral information and regulation, compiled by K. R. Shaffer. p. 66-74. 
The mineral industry of Michigan, 1989, by L. E. Esparza and M. A. Gere, Jr. p. 75-82.

Michigan; industrial mineral information and regulation, compiled by S. P. Sundeen. p. 83-87.

The mineral industry of Minnesota. 1989, by L. E. Esparza. p. 88-98.

The mineral industry of North Dakota, 1989, by L. E. Esparza. p. 99-101.

North Dakota; industrial mineral information and regulation, compiled by R. F. Biek. p. 102-104.

The mineral industry of Ohio, 1989 , by L. J. Prosser, Jr. p. 105-111.

Ohio; industrial mineral information and regulation, compiled by D. A. Stith and Pat Fagan. p. 112-119.

The mineral industry of South Dakota, 1989, by L. E. Esparza. p. 120-125.

South Dakota; industrial mineral information and regulation, compiled by Michael Cepak. p. 126-129.

The mineral industry of Wisconsin, 1989, by L. E. Esparza and T. J. Evans. p. 130-140.

Solid-mineral leases on Indian lands, by Richard Wilson. p. 141-144.

OF 92-0516. NEVADA. Safety of proposed Yucca Mountain nuclear repository as regards geological and geophysical factors; evaluation of minority report by Archambeau and Price, by J. F. Evernden. 1992. 97 p. (NC, Da, M, U; Nevada Bur. of Mines and Geol., Univ. of Nevada-Reno, Reno, NV 89557-0088.)

OF 92-0517. Biostratigraphic and paleoecologic analysis of ostracode assemblages from late Paleocene and early Eocene sedimentary rocks, Core UAK-5, Ganjo Takkar Inlier, Sindh Province, Pakistan, by E. M. Brouwers and F. S. Farah. 1992. 82 p. (NC, Da, M.)

OF 92-0520. WASHINGTON. Surface-water-quality assessment of the Yakima River basin in Washington; chemical analyses of major, minor, and trace elements in fine-grained streambed sediment, by J. L. Ryder, R. F. Sanzolone, G. J. Fuhrer and E. L. Mosier. 1992. 60 p., 1 over-size sheet, one $51 / 4$ inch DS/HD IBM compatible diskette. (NC, Da, M, S; Geol. and Earth Resources Div., Dep. of Natural Resources, Olympia, WA 98504; David A. Johnston Cascade Volcano Observatory, 5400 MacArthur Blvd., Vancouver, WA 98661.)

Diskette version requires an IBM PC or compatible computer using MS-DOS.

OF 92-0521. HAWAII. Development of rainfall warning thresholds for debris flows in the Honolulu District, Oahu, by R. C. Wilson, J. D. Torikai and S. D. Ellen. 1992. 45 p. (NC, Da, M.)

OF 92-0524. Geologic controls and resource potential of natural gas in deep sedimentary basins in the United States, edited by T. S. Dyman. 1992. 295 p., 9 over-size sheets, scale 1:5,000,000 (1 inch $=$ about 80 miles $)$. (NC, Da, M.)

Distribution of porosity in sedimentary rocks as a function of time-temperature exposure, by J. W. Schmoker. p. 29-62.
Trends in sandstone porosity in the Anadarko Basin with respect to thermal maturity, by T. C. Hester. p. 63-75.

Pore throats, capillary pressures, porosity, and permeability of clastic reservoirs in the Uinta, Wind River, and Anadarko basins, by C. W. Keighin. p. 76-85.

Geologic characteristics of deep natural gas resources, edited by T. S. Dyman. p. 86-147.

Geologic characteristics of deep natural gas resources based on data from significant fields and reservoirs, by T. S. Dyman, C. W. Spencer, J. K. Baird, R. C. Obuch and D. T. Nielsen. p. 87-113.

Maps illustrating the distribution of deep wells in the U.S. by geologic age, by C. J. Wandrey and D. K. Vaughan. p. 114116.

Deep gas reservoir pressure and initial potential test data, U.S., by C. W. Spencer and C. J. Wandrey. p. 117-147.

Deep gas-prone basins of the Rocky Mountain region, by W. J. Perry, Jr. p. 148-160.

Source-rock potential of Precambrian rocks in selected basins of the U.S., by J. G. Palacas. p. 161-172.

$\mathrm{C}_{15}$ hydrocarbon $(\mathrm{HC})$ thermal destruction as related to highrank, deep-basin gas resource bases, by L. C. Price. p. 173277.

Migration of 10's to 100's of TCF of hydrocarbon and nonhydrocarbon gases from the deep crust; composition, flux, and tectonic setting, by R. C. Burruss. p. 278-284.

Resource assessment methodologies and deep gas resources, by G. L. Dolton and R. A. Crovelli. p. 285-295.

OF 92-0525. Informal notes; workshop on the Application of isotope systems to geological problems, convened by R. A. Ayuso and K. J. Schultz. 1992. 366 p. One CD-ROM. (NC, Da.)

Innovative uses of $\mathrm{Pb}$ isotopic measurements; dating stromatolites and tracing sand dunes, by J. N. Aleinikoff. p. 7-14.

$\mathrm{Pb}-\mathrm{Nd}-\mathrm{O}$ isotopic compositions of igneous rocks; implications for petrogenesis and terrane correlation, Cape Breton Island, Nova Scotia, Canada, by R. A. Ayuso, S. M. Barr, F. J. Longstaffe and Ernst Hegner. p. 15-23.

The use of $\mathrm{K}-\mathrm{Ar}$ and ${ }^{40} \mathrm{Ar} /{ }^{39} \mathrm{Ar}$ techniques to date multiple thermal events; an example from the Bayan Obo Fe-Nb-REE ore deposit, China, by J. E. Conrad. p. 24-26.

Lead isotopic composition of galena from Malaysia, an S-type granite terrane, by B. R. Doe. p. 27-62.

Mass spectrometric measurements of ${ }^{234} \mathrm{U} /{ }^{238} \mathrm{U}$ and ${ }^{230} \mathrm{Th} /{ }^{238} \mathrm{U}$ and dating late Quaternary carbonates, by R. L. Edwards. p. 63-64.

$\mathrm{Nd}$ isotopes as tracers of the origin and evolution of the continental lithosphere, by G. L. Farmer. p. 65-73.

Paragenetic constraints on the $\mathrm{Pb}$ isotopic and trace element character of $\mathrm{Au}-\mathrm{Ag}$ mineralized rocks of the North Amethyst Vein, Mineral County, Colorado, by N. K. Foley and R. A. Ayuso. p. 74-82. 
Direct dating of ductile deformation fabrics; an integrated microstructural/geochronologic approach, by S. R. Getty. p. 83-91.

Recent developments in dating ancient crustal fluid flow, by A. N. Halliday, Matthias Ohr, Klaus Mezger, J. T. Chesley, Shun'ichi Nakai and C. P. DeWolf. p. 92-99.

$\mathrm{Re}$ and $\mathrm{Os}$ isotopic study of Ni-Mo-PGE-rich sulfide layers and black shales, Yukon Territory, Canada and South China, by M. F. Horan, J. W. Morgan and R. I. Grauch. p. 100-101.

Modern applications of precise U-Pb geochronology, by T. E. Krogh. p. 102-105.

Pbisotopic composition of Paleozoic sediments derived from the Appalachian Orogen, by E. J. Krogstad. p. 106.

Alleghanian cleavage and Acadian diagenesis in the Martinsburg Formation, eastern Pennsylvania; ${ }^{40} \mathrm{Ar} /{ }^{39} \mathrm{Ar}$ whole-rock data and geological constraints, by M. J. Kunk, R. P. Wintsch and J. B. Epstein. p. 107.

Radiogenic isotopes in seawater and sedimentary systems, by J. D. Macdougall. p. 108-115.

${ }^{40} \mathrm{Ar} /{ }^{39} \mathrm{Ar}$ studies of fluid inclusions in vein quartz from Battle Mountain, Nevada, by E. H. McKee. p. 116-120.

Isotopic provinciality in the shallow mantle, on-craton and offcraton volcanism, and implications for lithospheric growth in the Western USA, by M. A. Menzies. p. 121-128.

Geochronology in granulites, by Klaus Mezger. p. 129-148.

The nature of the crust in western Alaska as inferred from the chemical and isotopic composition of Late Cretaceous to early Tertiary magmatic rocks in western Alaska, by E. J. MollStalcup and T. P. Frost. p. 149-152.

Rhenium and osmium isotope systematics in meteorites, by J. W. Morgan. p. 153-154.

$\mathrm{Nd}$ and $\mathrm{Pb}$ isotopic evolution of basalts of the $1.1 \mathrm{Ga}$ Midcontinent Rift; evidence for a region-wide model for plume-lithosphere-asthenosphere interaction, by S. W. Nicholson and S. B. Shirey. p. 155-161.

The Rb-Sr, Sm-Nd and Re-Os isotopic systems and the cosmochronology and geochronology of igneous rocks, by S. B. Shirey. p. 162-192.

The hydrothermal stability of zircon; preliminary experimental and isotopic studies, by A. K. Sinha, D. M. Wayne and D. A. Hewitt. p. 193-195.

Crustal evolution of Grenville terranes in the Central and Southern Appalachians; the $\mathrm{Pb}$ isotope perspective for Grenville tectonics, by J. E. Parks, P. J. Jenks and A. K. Sinha. p. 196.

Argon thermochronology of mineral deposits, compiled by L. W. Snee. p. 197-210.

Rhenium-osmium data for sulfides and oxides from climax-type granite-molybdenum systems; Mt. Emmons, Colorado, by H. J. Stein, J. W. Morgan, R. J. Walker and M. F. Horan. p. 211.

${ }^{40} \mathrm{Ar} /{ }^{39} \mathrm{Ar}$ thermochronology; applications to stratigraphy, tectonics, and mineralization, compiled by J. F. Sutter. p. 212 224.
Isotopic reference materials; absolute or otherwise, compiled by R. D. Vocke, Jr. p. 225-326.

Applications of the rhenium-osmium isotope system to geologic problems, by R. J. Walker. p. 327-328.

The $\mathrm{Pb}-\mathrm{Sr}-\mathrm{Nd}$ isotopic troika; theory and applications, by R. E. Zartman. p. 329-366.

OF 92-0526-A. Geophysics advisor expert system version 2.0 , by G. R. Olhoeft. U.S. Environmental Protection Agency, Environmental Monitoring Systems Laboratory, Report EPA/600/R92/200. 1992. 21 p. (NC, Da, M.)

OF 92-0526-B. Geophysics advisor expert system version 2.0 , by G. R. Olhoeft. U.S. Environmental Protection Agency, Environmental Monitoring Systems Laboratory, Report EPA/600/R92/200. 1992. One 5 1/4 inch DS/DD diskette. (NC, Da, M.)

This report is written in True BASIC 2.01 to run under Microsoft MS-DOS 2.0 or later on IBM-PC or true compatible computers with $640 \mathrm{~K}$ or greater memory available to the program. No source code is available.

OF 92-0527. Properties and hazards of 108 selected substances; 1992 edition, by J. E. Lucius, G. R. Olhoeft, P. L. Hill and S. K. Duke. 1992. 554 p. (NC, Da, M.)

OF 92-0528. NEW MEXICO. A geologic overview and one-day field guide of the Taos Plateau volcanic field, Taos County, New Mexico, by R. A. Thompson and N. J. McMillan. 1992. 23 p. (NC, Da, M, U; New Mexico Bur. of Mines and Mineral Resources, Campus Station, Socorro, NM 87801.)

OF 92-0530. LOUISIANA. Representative publications from the Louisiana Barrier Island Erosion Study, compiled by S. J. Williams, H. A. Cichon, K. A. Westphal and K. E. Ramsey. Prepared in cooperation with the Louisiana Geological Survey. 1992. 557 p. (NC, Da, M.)

Coastal erosion and wetlands loss in Louisiana; status of U.S. Geological Survey coastal research activities, by S. J. Williams. p. 1-4.

Louisiana Barrier Island Erosion Study, by A. H. Sallenger, Jr., Shea Penland, S. J. Williams and J. R. Suter. p. 5-18.

Delta plain development and sea level history in the Terrebonne coastal region, Louisiana, by Shea Penland, J. R. Suter and R. A. McBride. p. 19-35.

The people, boats, homes, and economics of "the bayou country", by D. W. Davis. p. 37-54.

Evolution of Cat Island Pass, Louisiana, by J. R. Suter and Shea Penland. p. 55-70.

Transgressive evolution of the Chandeleur Islands, Louisiana, by J. R. Suter, Shea Penland, S. J. Williams and J. L. Kindinger. p. 71-78.

A geomorphologic model for Mississippi Delta evolution, by Ron Boyd and Shea Penland. p. 79-88.

Transgressive depositional systems of the Mississippi delta plain; a model for barrier shoreline and shelf sand development, by Shea Penland, Ron Boyd and J. R. Suter. p. 89-106. 
Barrier island erosion and protection in Louisiana; a coastal geomorphological perspective, by Shea Penland and J. R. Suter. p. 107-118.

Louisiana Barrier Island Erosion Study; further results, by A. H. Sallenger, Jr., Shea Penland, S. J. Williams, B. E. Jaffe and J. R. Suter. p. 119-127.

Sea-level rise and subsidence in Louisiana and the Gulf of Mexico, by K. E. Ramsey and Shea Penland. p. 129-138.

Erosion and washover in coastal Louisiana, by William Ritchie and Shea Penland. p. 139-150.

The 1985 hurricane impacts on the Isles Dernieres, Louisiana; a temporal and spatial analysis of the coastal geomorphic changes, by Shea Penland, Karolien Debusschere, K. A. Westphal, J. R. Suter, R. A. McBride and P. D. Reimer. p. 151.

Sequence stratigraphy of the Mississippi Delta, by Ron Boyd, J. R. Suter and Shea Penland. p. 167-176.

Massive sediment bypassing of a wide tidal inlet; Cat Island Pass, Louisiana, by B. E. Jaffe, A. H. Sallenger, Jr. and J. H. List. p. 177-185.

Distribution and textural character of surficial sediments, Isles Dernieres to Ship Shoal region, Louisiana, by S. J. Williams, Shea Penland and R. C. Circé p. 187-192.

Inner shelf deposits of the Louisiana-Mississippi-Alabama region, Gulf of Mexico, by J. L. Kindinger, Shea Penland, S. J. Williams and J. R. Suter. p. 193-200.

Offshore and onshore sediment resource delineation and usage for coastal erosion control in Louisiana; the Isles Dernieres and Plaquemines barrier systems, by Shea Penland, Joann Mossa, R. A. McBride, K. E. Ramsey, J. R. Suter, C. G. Groat and S. J. Williams. p. 201-213.

Coastal land loss in Louisiana, by Shea Penland, H. H. Roberts, S. J. Williams, A. H. Sallenger, Jr., D. R. Cahoon, D. W. Davis and C. G. Groat. p. 215-229.

Coastal land loss; using barrier island techniques in Louisiana to protect estuarine environments, by Shea Penland, S. J. Williams and K. E. Ramsey. p. 231-232.

Relative sea-level rise in Louisiana and the Gulf of Mexico; 1908-1988, by Shea Penland and K. E. Ramsey. p. 233-252.

Preliminary assessments of the occurrence and effects of utilization of sand and aggregate resources of the Louisiana inner shelf, by J. R. Suter, Joann Mossa and Shea Penland. p. 253-259.

Offshore sand resources for coastal erosion control in Louisiana, by Shea Penland, J. R. Suter, K. E. Ramsey, R. A. McBride, S. J. Williams and C. G. Groat. p. 261-272.

Aeolian sand bodies of the South Louisiana coast, by William Ritchie. p. 273-295.

Facies architecture of the Bayou Grand Caillou area; an abandoned shallow water delta of the Mississippi River delta plain, by R. A. McBride, Shea Penland and J. T. Mestayer. p. 297 305.
Results of geologic processes studies of barrier island erosion and wetlands loss in coastal Louisiana, by S. J. Williams, Shea Penland and A. H. Sallenger, Jr. p. 307-317.

Effects of sea level rise on the Mississippi River delta plain, by Shea Penland, R. A. McBride, S. J. Williams, Ron Boyd and J. R. Suter. p. 319-334.

Geologic controls on the formation and evolution of Quaternary coastal deposits of the northern Gulf of Mexico, by S. J. Williams, Shea Penland, A. H. Sallenger, Jr., R. A. McBride and J. L. Kindinger. p. 335-348.

Late Quaternary geologic framework, north-central Gulf of Mexico, by J. L. Kindinger, Shea Penland, S. J. Williams, G. R. Brooks, J. R. Suter and R. A. McBride. p. 349-363.

Mapping barrier island changes in Louisiana; techniques, accuracy, and results, by R. A. McBride, M. W. Hiland, Shea Penland, S. J. Williams, M. R. Byrnes, K. A. Westphal, B. E. Jaffe and A. H. Sallenger, Jr. p. 365-380.

Accuracy of shoreline change rates as determined from maps and aerial photographs, by F. J. Anders and M. R. Byrnes. p. 381-390.

Large-scale coastal evolution of Louisiana's barrier islands, by J. H. List, B. E. Jaffe and A. H. Sallenger, Jr. p. 391-405.

Recent geologic development of the eastern Louisiana continental shelf, by G. R. Brooks, J. L. Kindinger, Shea Penland, S. J. Williams, J. R. Suter and R. A. McBride. p. 407-409.

The Mississippi delta plain's levees, crevasses, and sediments, by D. W. Davis. p. 411-419.

Morphodynamics of the Isles Dernieres barrier shoreline, Louisiana; 1984-1989, by Karolien Debusschere, Shea Penland, K. A. Westphal, R. A. McBride and P. D. Reimer. p. 421-435.

Morphodynamic signature of storm impact processes at the Isles Dernieres barrier island arc; 1984-1989, by Karolien Debusschere, Shea Penland, K. A. Westphal and R. A. McBride. p. 437.

Morphodynamic signature of the 1985 hurricane impacts on the northern Gulf of Mexico, by Shea Penland, J. R. Suter, A. H. Sallenger, Jr., S. J. Williams, R. A. McBride, K. A. Westphal, P. D. Reimer and B. E. Jaffe. p. 439-453.

Environmental issues in the Gulf of Mexico; stimulus for research, by C. G. Groat and S. J. Williams. p. 455.

Nearshore Holocene stratigraphy, northern Gulf of Mexico; integration of regional geologic studies, by J. L. Kindinger, Shea Penland, S. J. Williams, J. R. Suter, R. A. McBride, G. R. Brooks and S. D. Locker. p. 457-463.

Holocene development of shelf-phase Mississippi River delta plains, by Shea Penland, R. A. McBride, J. R. Suter, Ron Boyd and S. J. Williams. p. 465-468.

Holocene geologic framework of the Trinity Shoal region, Louisiana continental shelf, by D. L. Pope, Shea Penland, J. R. Suter and R. A. McBride. p. 469-479.

Rates of relative sea level change in the northern Gulf of Mexico, by K. E. Ramsey. p. 481-487. 
Implications of accelerated sea-level rise on Louisiana coastal environments, by K. E. Ramsey, Shea Penland and H. H. Roberts. p. 489-504.

Late Quaternary chronostratigraphic framework, northern Gulf of Mexico, by J. R. Suter, Ron Boyd and Shea Penland. p. 505-506.

Aerial videotape mapping of coastal geomorphic changes, by Karolien Debusschere, Shea Penland, K. A. Westphal, P. D. Reimer and R. A. McBride. p. 507-527.

Accuracy standards and development of a national shoreline change data base, by M. R. Byrnes, R. A. McBride and M. W. Hiland. p. 529-544.

Regional coastal erosion research and beach preservation, by $\mathrm{A}$. H. Sallenger, Jr., J. H. List, B. E. Jaffe, Shea Penland and S. J. Williams. p. 545-557.

OF 92-0531. CALIFORNIA. Aeromagnetic map of the Livermore area, Central California. 1992. 1 over-size sheet, scale 1:250,000 ( 1 inch = about 4 miles). (NC, Da, M.; California Dep. of Conservation, Mail Stop 14-34, Library, 801 K St., Sacramento, CA 95814-3532; 1145 Market St., 3rd Floor, San Francisco, CA 94103; and State Office Bldg., 107 South Broadway, Los Angeles, CA 90012.)

OF 92-0534. Epoch 2002 user's guide for ultrasonic velocity measurements in glacier ice, by J. J. Fitzpatrick. 1992.17 p. (NC, $\mathrm{Da}, \mathrm{M}$.)

OF 92-0536. Digital mapping of the side-scan sonar data with the Woods Hole image processing system software, by V. F. Paskevich. 1992. 87 p. (NC.)

OF 92-0537. A novel application of high-resolution camcorders for the marine environment, by Henry Chezar and J. C. Erickson. 1992. 13 p. (NC, Da, M.)

OF 92-0539-A. CALIFORNIA. Preface to preliminary geology reports for the Cooperative Monterey Organic Geochemistry Study, Santa Maria and Santa Barbara-Ventura basins, California, by C. M. Isaacs. 1992 . 6 p. (NC, Da, M; California Dep. of Conservation, Div. of Mines and Geol., Mail Stop 14-34, Library, 801 K St., Sacramento, CA 95814-3532; 1145 Market St., 3rd Floor, San Francisco, CA 94103; and State Office Bldg., 107 South Broadway, Los Angeles, CA 90012.)

OF 92-0539-B. CALIFORNIA. Preliminary geologic background for rock samples from Naples Beach and Lions Head in the Cooperative Monterey Organic Geochemistry Study, Santa Maria and Santa Barbara-Ventura basins, California, by C. M. Isaacs. 1992. 37 p. (NC, Da, M; California Dep. of Conservation, Div. of Mines and Geol., Mail Stop 14-34, Library, 801 K St., Sacramento, CA 95814-3532; 1145 Market St., 3rd Floor, San Francisco, CA 94103; and State Office Bldg., 107 South Broadway, Los Angeles, CA 90012.)

OF 92-0539-C. CALIFORNIA. Preliminary data on rock samples (KG-1 to KG-24) in the Cooperative Monterey Organic Geochemistry Study, Santa Maria and Santa Barbara-Ventura basins, California, by C. M. Isaacs, R. M. Pollastro, R. G. Arends, J. A. Barron, M. L. Cotton, M. V. Filewicz, B. P. Flower and D. Z. Piper. 1992. 29 p. (NC, Da, M; California Dep. of Conservation, Div. of Mines and Geol., Mail Stop 14-34, Library, 801 K St., Sacramento, CA 95814-3532; 1145 Market St., 3rd Floor, San
Francisco, CA 94103; and State Office Bldg., 107 South Broadway, Los Angeles, CA 90012.)

OF 92-0539-D. CALIFORNIA. Preliminary correlation and age of rock samples (KG-1 to KG-24) in the Cooperative Monterey Organic Geochemistry Study, Santa Maria and Santa BarbaraVentura basins, California, by C. M. Isaacs, J. H. Tomson, M. D. Lewan, R. G. Arends, M. L. Cotton and M. V. Filewicz. 1992. 12 p. (NC, Da, M; California Dep. of Conservation, Div. of Mines and Geol., Mail Stop 14-34, Library, 801 K St., Sacramento, CA 95814-3532; 1145 Market St., 3rd Floor, San Francisco, CA 94103; and State Office Bldg., 107 South Broadway, Los Angeles, CA 90012.)

OF 92-0539-E. CALIFORNIA. Geology handbook for the Cooperative Monterey Organic Geochemistry Study, Santa Maria and Santa Barbara-Ventura basins, California, by C. M. Isaacs. 1992. 35 p. (NC, Da, M; California Dep. of Conservation, Div. of Mines and Geol., Mail Stop 14-34, Library, 801 K St., Sacramento, CA 95814-3532; 1145 Market St., 3rd Floor, San Francisco, CA 94103; and State Office Bldg., 107 South Broadway, Los Angeles, CA 90012.)

OF 92-0539-F. CALIFORNIA. Preliminary petroleum geology background and well data for oil samples in the Cooperative Monterey Organic Geochemistry Study, Santa Maria and Santa Barbara-Ventura basins, California, by C. M. Isaacs. 1992. 40 p. (NC, Da, M; California Dep. of Conservation, Div. of Mines and Geol., Mail Stop 14-34, Library, 801 K St., Sacramento, CA 95814-3532; 1145 Market St., 3rd Floor, San Francisco, CA 94103; and State Office Bldg., 107 South Broadway, Los Angeles, CA 90012.)

OF 92-0541. MARYLAND. Characteristics and weathering features of sandstone quoins at Fort McHenry, Baltimore, Maryland, by E. S. McGee and M. E. Woodruff. 1992. 10 p. (NC.)

OF 92-0542. IDAHO. Paleomagnetic polarity of some vertebrate fossil localities of the Glenns Ferry Formation in the Chalk Hills, near Froman Ferry, western Snake River plain, Southwest Idaho, by D. J. Van Domelen and H. J. Rieck. 1992. 17 p. (NC, Da, M, U, S; Idaho Geol. Surv., Univ. of Idaho Campus, Morrill Hall, Room 332, Moscow ID 83843.)

OF 92-0543. User's manual for ANALYST version 2.00; an IBMPC computer program for control of a thermal-ionization, singlecollector mass-spectrometer, by K. R. Ludwig. 1992. 89 p. (NC, Da, M.)

OF 92-0544. CALIFORNIA. Geophysical logging of cored section in the Long Valley exploration well, Long Valley, California, by P. H. Nelson, J. L. Mikesell and J. E. Kibler. 1992. 13 p. (NC, Da, M; California Dep. of Conservation, Div. of Mines and Geol., 660 Bercut Dr., Sacramento, CA 95814-0131; 1145 Market St., 3rd Floor, San Francisco, CA 94103; and State Office Bldg., 107 South Broadway, Los Angeles, CA 90012.)

OF 92-0547. Preliminary bibliography of the geology and mineral deposits of Nicaragua, by H. A. Pierce. 1992. 34 p. (NC, Da, M.)

OF 92-0548. CALIFORNIA. Aeromagnetic map of the El Cajon 1:100,000 scale Quadrangle, California, by R. C. Jachens. 1992. 1 over-size sheet, scale $1: 100,000$ ( 1 inch = about 1.6 miles). (NC, Da, M; California Dep. of Conservation, Div. of Mines and Geol., Mail Stop 14-34, Library, 801 K St., Sacramento, CA 95814-3532; 
1145 Market St., 3rd Floor, San Francisco, CA 94103; and State Office Bldg., 107 South Broadway, Los Angeles, CA 90012.)

OF 92-0549. CALIFORNIA. Aeromagnetic map of the Palm Springs 1:100,000 scale Quadrangle, California, by R. C. Jachens. 1992. 1 over-size sheet, scale 1:100,000 (1 inch = about 1.6 miles). (NC, Da, M; California Dep. of Conservation, Div. of Mines and Geol., Mail Stop 14-34, Library, 801 K St., Sacramento, CA 95814-3532; 1145 Market St., 3rd Floor, San Francisco, CA 94103; and State Office Bldg., 107 South Broadway, Los Angeles, CA 90012.)

OF 92-0550. The texture of surficial sediments in northeastern Long Island Sound, by L. J. Poppe, R. S. Lewis and A. M. Moffett. 1992. 13 p. (NC, Da, M.)

OF 92-0551. MASSACHUSETTS. A geologic overview of Cape Cod; a guide for the Sigma Xi field trip, by R. N. Oldale. 1992. 13 p. (NC.)

OF 92-0552. ALASKA. Supplemental analytical results and sample locality map of stream-sediment and heavy-mineral-concentrate samples from the Craig Study Area; Craig, Dixon Entrance, Ketchikan, and Prince Rupert quadrangles, Alaska, by D. E. Detra, J. M. Motooka and J. B. Cathrall. 1992. 17 p., one $51 / 4$ inch diskette, 1 over-size sheet, scale 1:250,000 (1 inch = about 4 miles). (NC, Da, M, A, S; Alaska Div. of Geol. and Geophys. Surv., P.O. Box 7028, Anchorage, AK 99510; U.S. Dep. of Interior, Alaska Resource Library, 701 C St., Box 36, Anchorage, AK 99513.)

This report contains digital geochemical data on a DS/DD IBM compatible diskette. It requires MS-DOS 2.0 or greater for operation.

OF 92-0553-A. Interactive inversion of dipole loop-loop electromagnetic data for layered earth models using numerical integration and complex image theory (version 1.0 ), by W. L. Anderson. 1992. 42 p. (NC, Da, M.)

OF 92-0553-B. Interactive inversion of dipole loop-loop electromagnetic data for layered earth models using numerical integration and complex image theory (version 1.0), by W. L. Anderson. 1992. Two 3 1/2 inch DS/HD diskettes. (NC, Da, M.)

Minimum hardware requirements: 386 IBM compatible PC; 3MB RAM; math coprocessor; EGA or VGA video adapter and monitor; hard disk with more than $3 \mathrm{MB}$ free space; and a 1.44MB (HD) floppy disk drive. Minimum software requirements: MS-DOS 3.0 or higher; and RSoft RPlot Scientific Graphics (version 2.05).

OF 92-0554. NEVADA. Preliminary geologic map of the Riverside Quadrangle, Clark County, Nevada, by D. L. Hoover, R. G. Bohannon and F. W. Simonds. 1992. 20 p., 1 over-size sheet, scale 1:24,000 (1 inch =2,000 feet). (NC, Da, M, U; Nevada Bur. of Mines and Geol., Univ. of Nevada-Reno, Reno, NV 89557 0088.)

OF 92-0555. CALIFORNIA. Currents over the slope off San Francisco, California, by M. A. Noble and K. L. Kinoshita. Prepared in cooperation with the U.S. Navy. 1992. 38 p. (NC, $\mathrm{Da}, \mathrm{M}$; California Dep. of Conservation, Div. of Mines and Geol., Mail Stop 14-34, Library, 801 K St., Sacramento, CA 95814-3532; 1145 Market St., 3rd Floor, San Francisco, CA 94103; and State Office Bldg., 107 South Broadway, Los Angeles, CA 90012.)
OF 92-0556. USGS seismic refraction surveys in the Ross Sea, 1984-1990, by G. R. Cochrane, A. K. Cooper, J. R. Childs and P. E. Hart. 1992. 17 p. (NC, Da, M.)

OF 92-0557. The geophysical expression of selected mineral deposit models, edited by D. B. Hoover; W. D. Heran and P. L. Hill. 1992. 129 p. (NC, Da, M.)

Geophysical model of carbonatites, compiled by D. B. Hoover. p. 80-83.

Geophysical model of diamond pipes, compiled by D. B. Hoover and D. L. Campbell. p. 85-88.

Geophysical model of tin skarn and related deposits, compiled by D. B. Hoover and D. H. Knepper, Jr. p. 89-94.

Geophysical model of hot springs Au-Ag, compiled by W. D. Heran. p. 95-97.

Geophysical model of Creede, Comstock, Sado, Goldfield and related epithermal precious metal deposits, compiled by D. P. Klein and Viki Bankey. p. 98-106.

Geophysical model of carbonate-hosted $\mathrm{Au}-\mathrm{Ag}$, compiled by W. D. Heran and D. B. Hoover. p. 107-111.

Geophysical model of Olympic Dam Cu-U-Au, compiled by D. B. Hoover and L. E. Cordell. p. 112-115.

Geophysical model of low sulfide Au-quartz veins, compiled by W. D. Heran. p. 116-118.

Geophysical model of Homestake Au, compiled by W. D. Heran. p. 119-125.

Geophysical model of placer Au-PGE and PGE-Au, compiled by W. D. Heran and W. S. Wojniak. p. 126-129.

OF 92-0558. OHIO, KENTUCKY. Regional aspects of Pottsville and Allegheny stratigraphy and depositional environments; Ohio and Kentucky, by C. L. Rice, R. L. Martino and E. R. Slucher. 1992. 67 p. (NC, Da, M; Pirtle Geol. Library, 100 Bowman Hall, Univ. of Kentucky, Lexington, KY 40506.)

Introduction, by C. L. Rice. p. 1-5.

Stop 1; basal Pennsylvanian sandstones and conglomerates, north of Jackson, Ohio, by C. L. Ketering, Jr. p. 6-12.

Stop 2; basal Pennsylvanian strata, near Jackson, Ohio, by R. L. Martino, C. L. Rice and E. R. Slucher. p. 13-16.

Facies architecture of sandstones below the No. 2 coal bed between stops 2 and 3, Jackson County, Ohio, by D. F. Dominic. p. 17-20.

Stop 3; section above No. 2 coal bed near Jackson, Ohio, in measured sections M3, M4, M5, and M6, by R. L. Martino, C. L. Rice and E. R. Slucher. p. 21-23.

Stop 4; lower part of the Allegheny Group, southeastern Ohio, by C. L. Rice. p. 24-27.

Stop 5; basal Pennsylvanian strata, Kentucky AA Highway, 0.5 km west of Kentucky Route 7, by R. L. Martino and C. L. Rice. p. 28-30.

Stop 6; basal Pennsylvanian strata, Kentucky AA Highway, 3.5 km west of Kentucky Route 7, by R. L. Martino and C. L. Rice. p. 31-33. 
Preliminary analysis of a marine interval near the Howland Lookout Tower on Kentucky AA Highway, by J. B. Bennington. p. 34-40.

Stop 7; basal Allegheny Group, southern Ohio, by C. L. Rice. p. $40-42$.

Stop 8; basal "Allegheny" strata, northeastern Kentucky, by C. L. Rice. p. $43-46$.

Stop 9; Gregoryville exposure on I-64, Kentucky; an examination of two Middle Carboniferous depositional models, by D. R. Chesnut, Jr., S. F. Greb, C. F. Eble and C. L. Rice. p. 4755.

Stop 10; estuarine tidal rhythmites, lower Breathitt Formation (Pennsylvanian), eastern Kentucky, by R. L. Martino and D. D. Sanderson. p. 56-67.

OF 92-0559. Composite and disaggregated maps as preliminary aids to analysis of manganese nodule geochemistry, by J. M. Botbol. 1992, 49 p. (NC, Da, M.)

OF 92-0560-A. ALASKA. VOLPLOT; a PC-based program for viewing Cook Inlet volcano-seismic data, by G. D. March and T. L. Murray. 1992. 6 p. (NC, Da, M.)

OF 92-0560-B. ALASKA. VOLPLOT; a PC-based program for viewing Cook Inlet volcano-seismic data, by G. D. March and T. L. Murray. 1992. One $51 / 4$ inch diskette. (NC, Da, M.)

Requirements: IBM PC compatible; 640K RAM; math coprocessor, hard disk; modem; Procomm + communications software; Geograf graphics drivers.

OF 92-0561. Zayante seismic experiment; data report, by W. H. Lee. 1993 . 269 p., four $31 / 2$ inch diskettes. (NC, Da, M.)

Requirements: IBM 386 or 486 PC or compatible; minimum 1MB RAM; math coprocessor; VGA graphics board and monitor; minimum 40MB hard disk; $31 / 2$ inch floppy disk drive; $P C$ or MS DOS 4.01 or later, and IASPEI Software Library Volumes 1,2 , and 3 .

OF 92-0562. ALASKA. Geologic map of the Livengood Quadrangle, Alaska, by F. R. Weber, K. L. Wheeler, C. D. Rinehart, R. M. Chapman and R. B. Blodgett. 1992. 20 p., 1 over-size sheet, scale 1:250,000 (1 inch = about 4 miles). (NC, Da, M, A, S; U.S. Dep. of the Interior, Alaska Resource Library, 701 C St., Box 36, Anchorage, AK 99513; Alaska Dep. of Natural Resources, Div. of Geol. and Geophys. Surv., 794 University Ave., Suite 200, Fairbanks, AK 99709-3645.)

OF 92-0564. Modifications of two palynological processing techniques; ultrasonic processing and early-stage sieving; by T. P. Sheehan. 1992. 7 p. (NC, Da, M.)

OF 92-0565. YoNav; your own integrated navigation system for DOS platforms, by J. T. Gann. 1992. 62 p., two $31 / 2$ inch DS/HD IBM compatible diskettes. (NC, Da, M.)

Requirements: IBM AT or compatible microcomputer, VGA graphics board capable of $640 \times 480$ graphics resolution, at least one serial port and at least $2 \mathrm{MB}$ extended or expanded memory.

OF 92-0566. Maps showing the distribution of juvenile cod in relation to the sedimentary environment of eastern Georges Bank, by R. G. Lough, P. C. Valentine, C. L. Brown and W. L. Michaels. 1992. 1 over-size sheet. (NC, Da, M; USGS, Gosnold
Laboratory, Quissett Campus, Woods Hole Rd., Woods Hole, MA 02543, telephone 508-457-2239.)

OF 92-0567. PUERTO RICO. Mineral resource assessment of Puerto Rico; field trip, June 25, 1992, edited by J. N. Weaver; and led by R. A. Harris, J. H. Schellekens, G. E. McKelvey and D. P. Cox. 1992. 43 p. (NC, Da, M; Serv. Geol. de Puerto Rico, Dep. de Recursos Naturales, Apartado 5887, Puerta de Tierra, San Juan, PR 00906.)

OF 92-0568. PENNSYLVANIA. Field trip guidebook; the anthracite basins of eastern Pennsylvania, by J. R. Levine and J. R. Eggleston. 1992. 72 p. (NC, Da, M.)

Regional physiography and geology, by J. R. Levine. p. 1-3. Stratigraphy and depositional environments, by J. R. Eggleston. p. 4-8.

Structural geology and tectonics, by J. R. Eggleston, J. R. Levine and E. J. Daniels. p. 9-12.

Mineralogy of coal and shale in the anthracite region, by E. J. Daniels. p. 13-18.

Coalification, diagenesis, and burial/thermal history of the anthracite region, by J. R. Levine. p. 19-27.

Reflectance anisotropy of coals from the anthracite region, by J. R. Levine. p. 28-32.

Paleobotany, by Christopher Wnuk. p. 33-34.

Economic geology, by J. R. Eggleston. p. 34-38.

Mining and labor history, by D. C. Glick. p. 39-41.

Cultural and physical geography of the field trip route, by D. C. Glick and J. R. Levine. p. 42-47.

OF 92-0569. Data acquisition system for magnetotellurics, by $\mathrm{T}$. P. Grover. 1992. 29 p. (NC, Da, M.)

OF 92-0570. CALIFORNIA. Data report for 1991 active-source seismic profiles in the San Francisco Bay area, California, by J. M. Murphy, R. D. Catchings, W. M. Kohler, G. S. Fuis and Donna Eberhart-Phillips. 1992. 45 p. (NC, Da, M; California Dep. of Conservation, Div. of Mines and Geol., Mail Stop 14-34, Library, 801 K St., Sacramento, CA 95814-3532; 1145 Market St., 3rd Floor, San Francisco, CA 94103; and State Office Bldg., 107 South Broadway, Los Angeles, CA 90012.)

OF 92-0571. CALIFORNIA. Rock-Eval pyrolysis and vitrinite reflectance results from outcrop samples of the Rincon Shale (lower Miocene) collected at the Tajiguas Landfill, Santa Barbara County, California, by R. G. Stanley,Z. C. Valin and M. J. Pawlewicz. 1992. 27 p. (NC, Da, M; California Dep. of Conservation, Div. of Mines and Geol., Mail Stop 14-34, Library, 801 K St., Sacramento, CA 95814-3532; 1145 Market St., 3rd Floor, San Francisco, CA 94103; and State Office Bldg., 107 South Broadway, Los Angeles, CA 90012.)

OF 92-0572. NEVADA. Assessment of geophysical logs from borehole USW G-2, Yucca Mountain, Nevada, by P. H. Nelson and Ulrich Schimschal. Prepared in cooperation with the U.S. Department of Energy. 1993. 34 p. (NC, Da, M, U; Nevada Bur. of Mines and Geol., Univ. of Nevada-Reno, Reno, NV 89557 0088.) 
OF 92-0573-A. ALASKA. Magnetic media file of analytical results and geochemical signatures of lode gold, placer gold, and heavy-mineral concentrates from mining districts in central, western, and northern Alaska, by J. B. Cathrall, George VanTrump, J. C. Antweiler and E. L. Mosier. 1992. 17 p. (NC, Da, M, A, S; Alaska Div. of Geol. and Geophys. Surv., P.O. Box 7028, Anchorage, AK 99510; U.S. Dep. of Interior, Alaska Resource Library, 701 C St., Box 36, Anchorage, AK 99513.)

OF 92-0573-B. ALASKA. Magnetic media file of analytical results and geochemical signatures of lode gold, placer gold, and heavy-mineral concentrates from mining districts in central, western, and northern Alaska, by J. B. Cathrall, George VanTrump, J. C. Antweiler and E. L. Mosier. 1992. One $51 / 4$ inch diskette. (NC, Da, M, A, S; Alaska Div. of Geol. and Geophys. Surv., P.O. Box 7028, Anchorage, AK 99510; U.S. Dep. of Interior, Alaska Resource Library, 701 C St., Box 36, Anchorage, AK 99513.)

The magnetic media is a double density $(360 \mathrm{~K}), 51 / 4$ inch floppy disk with the data written in an ASCII format for use with an IBM PC or compatible personal computer.

OF 92-0575. CALIFORNIA. The Cape Mendocino earthquakes of April 25 and 26, 1992, by B. G. Reagor and L. R. Brewer. 1992. 27 p. (NC, Da, M; California Dep. of Conservation, Div. of Mines and Geol., Mail Stop 14-34, Library, $801 \mathrm{~K} \mathrm{St.,} \mathrm{Sacra-}$ mento, CA 95814-3532; 1145 Market St., 3rd Floor, San Francisco, CA 94103; and State Office Bldg., 107 South Broadway, Los Angeles, CA 90012.)

OF 92-0576. Potential for the occurrence of thick lignite deposits in the Thar Desert and adjacent lower Indus Plain, Sindh Province, Pakistan, by J. R. SanFilipo, Christopher Wnuk, Mohammad Fariduddin, Mujeeb Ahmad, S. A. Khan, Mehtab-ur-Rahman, A. H. Chandio and R. A. Khan. Prepared jointly by the Geological Survey of Pakistan and the U.S. Geological Survey under the auspices of the U.S. Agency for International Development. 1992. 131 p. (NC.)

OF 92-0577. CALIFORNIA. LEAP; local earthquake analysis program on VAX-VMS for Southern California Seismic Network data, by L. A. Wald and L. M. Jones. 1992. 49 p. (NC, Da, M; California Dep. of Conservation, Div. of Mines and Geol., Mail Stop 14-34, Library, 801 K St., Sacramento, CA 95814-3532; 1145 Market St., 3rd Floor, San Francisco, CA 94103; and State Office Bldg., 107 South Broadway, Los Angeles, CA 90012.)

OF 92-0578. PUERTO RICO. Copper resources in secondary enrichment blankets at Tanamá, Puerto Rico, by D. P. Cox. 1992. 5 p., 2 over-size sheets. (NC, Da, M.)

OF 92-0579-A. Bibliography of well-log applications annual update; October 1, 1991 to September 30, 1992, by S. E. Prensky. 1992. 122 p. (NC, Da, M.)

OF 92-0579-B. Bibliography of well-log applications annual update; October 1, 1991 to September 30, 1992, by S. E. Prensky. 1992. One $31 / 2$ inch diskette. (NC, Da, M.)

Macintosh version consisting of one text file on one $31 / 2$ inch $800 \mathrm{~K}$ disk. Formatted in Microsoft Word, version 5.0.

OF 92-0579-C. Bibliography of well-log applications annual update; October 1, 1991 to September 30, 1992, by S. E. Prensky. 1992. One $31 / 2$ inch diskette. (NC, Da, M.)
IBM-PC, or compatible, version, consisting of one $31 / 2$ inch 1.44MB disk. Formatted in WordPerfect, version 5.1.

OF 92-0580. NEVADA. Preliminary geologic map of the Mount Ichabod area, Elko County, Nevada, by K. B. Ketner, B. L. Murchey, R. G. Stamm and B. R. Wardlaw. 1992. 1 over-size sheet, scale 1:24,000 (1 inch =2,000 feet). (NC, Da, M, U; Nevada Bur. of Mines and Geol., Univ. of Nevada-Reno, Reno, NV 89557-0088.)

OF 92-0581. WASHINGTON. Stratigraphy and sedimentology of the Raging River Formation (early? and middle Eocene), King County, Washington, by S. Y. Johnson. 1992. 38 p. (NC, Da, M, S; Geol. and Earth Resources Div., Dep. of Natural Resources, Olympia, WA 98504; David A. Johnston Cascade Volcano Observatory, 5400 MacArthur Blvd., Vancouver, WA 98661.)

OF 92-0582. ALASKA. Analytical results in digital format of rock samples from the Bethel and part of the Russian Mission $1^{\circ}$ by $3^{\circ}$ quadrangles, Alaska, by T. P. Frost. 1992. 6 p. One $31 / 2$ inch DS/HD IBM compatible diskette. (NC, Da, M, A, S; U.S. Dep. of the Interior, Alaska Resource Library, $701 \mathrm{C}$ St., Box 36, Anchorage, AK 99513; Alaska Div. Geol. and Geophys. Surv., 794 University Ave., Suite 200, Fairbanks, AK 99709-3645.)

Requirements: IBM 286,386 , or 486 PC or compatible; minimum $20 \mathrm{MB}$ hard disk; floppy disk drive able to read $31 / 2$ inch 1.44MB diskette; PC or MS DOS operating system. For use of data in STATPAC format, USGS STATPAC programs (Van Trump and Miesch, 1977, Computers and Geosciences, v. 3, p. 475-488); for use in .WK1 format, any data manipulation program that can read. WK1 files.

OF 92-0583. Significant earthquakes of the world, 1990, compiled by W. J. Person and J. M. Jacobs. $1992 .{ }^{9}$ p. (NC, Da, M.)

OF 92-0584. Significant earthquakes of the world, 1991, compiled by W. J. Person and J. M. Jacobs. 1992. 9 p. (NC, Da, M.)

OF 92-0585. Publications of the U.S. Geological Survey Branch of Atlantic Marine Geology; calendar year 1991, by M. C. MonsWengler and R. N. Oldale. 1992. 19 p. (NC, Da, M.)

OF 92-0586. HAWAII. Core lithology, State of Hawaii Scientific Observation Hole 4, Kilauea Volcano, Hawaii, by F. A. Trusdell, Elizabeth Novak and S. R. Evans. 1992. 72 p. (NC, Da, M.)

OF 92-0588. CALIFORNIA. Contact relations of the Ione and Valley Springs formations in the east-central Great Valley, California, by A. J. Bartow. 1992. 13 p., 1 over-size sheet. (NC, Da, M; California Dep. of Conservation, Div. of Mines and Geol., Mail Stop 14-34, Library, 801 K St., Sacramento, CA 95814-3532; 1145 Market St., 3rd Floor, San Francisco, CA 94103; and State Office Bldg., 107 South Broadway, Los Angeles, CA 90012.)

OF 92-0589. UTAH. Preliminary report and map of the geology of Smithsonian Butte Quadrangle, Washington County, Utah, by D. W. Moore and E. G. Sable. 1992. 17 p., 1 over-size sheet, scale 1:24,000 (1 inch = 2,000 feet). (NC, Da, M, U; Utah Geol. Surv., 2363 Foothill Dr., Salt Lake City, UT 84109-1403.)

OF 92-0590. DUMPSEGY v1.0; a program to examine the contents of SEG-Y disk-image seismic data, by F. N. Zihlman. 1992. 30 p. 30 pgs., two $51 / 4$ inch diskettes. (NC, Da, M.)

DUMPSEGY is an interactive, character-based program allowing the user to "dump" a SEG-Y format seismic data file to the 
screen or an ASCII disk file. The user may use DUMPSEGY to display the EBCDIC header, binary header, individual trace headers, the SEG-Y format samples of individual traces, or those sample values converted to floating point values. DUMPSEGY will also allow the user to create SEG-Y format data files which are subsets of the original SEG-Y data file. Examples of creating SEG-Y data files are given in the documentation. DUMPSEGY is written in ANSI C and capable of being compiled on either DOS or UNIX systems supporting ANSI C. DOS environment system requirements: Intel 80286 or higher processor, DOS 3.0 or later, a hard disk drive or CD-ROM containing the input file(s), and a math coprocessor is NOT required, but will be used if available and is strongly recommended.

OF 92-0591-A. ARIZONA. Stream-sediment and panned-concentrate geochemical surveys for gold in Precambrian rock, westem Grand Canyon, Arizona, by K. J. Wenrich, B. S. Van Gosen, G. H. Billingsley and J. C. Antweiler. Prepared in cooperation with the Hualapai Tribe and the U.S. Bureau of Indian Affairs. 1992. 50 p. (NC, Da, M, U; Arizona Bur. of Geol. and Mineral Technol., 845 North Park Ave., Tucson, AZ 85719.)

OF 92-0591-B. ARIZONA. Stream-sediment and panned-concentrate geochemical surveys for gold in Precambrian rock, westem Grand Canyon, Arizona, by K. J. Wenrich, B. S. Van Gosen, G. H. Billingsley and J. C. Antweiler. Prepared in cooperation with the Hualapai Tribe and the U.S. Bureau of Indian Affairs. 1992. 50 p. One $51 / 4$ inch diskette. (NC, Da, M, U; Arizona Bur. of Geol. and Mineral Technol., 845 North Park Ave., Tucson, AZ 85719.)

Requirements: IBM PC or compatible, WordPerfect 5.0 or higher, dBase III plus or program to read ASCII files.

OF 92-0592. SOUTH DAKOTA, NEBRASKA. A reconnaissance study of radon levels in soils developed on the Upper Cretaceous Pierre Shale just above the Sharon Springs Member in the Missouri River valley in southeastern South Dakota and northeastern Nebraska, by K. A. Dickinson. 1992. 11 p. (NC, Da, M; Dep. of Water and Natural Resources, South Dakota Geol. Surv., Sci. Ctr., Univ. of South Dakota, Vermillion, SD 57069; Conservation and Surv. Div., Inst. of Agriculture and Natural Resources, 113 Nebraska Hall, Univ. of Nebraska, Lincoln, NE 68588-0517.)

OF 92-0593. Industrial mineral deposit models; descriptive models for three lacustrine deposit types, by G. J. Orris. 1992. 14 p. (NC, Da, M.)

OF 92-0594. ALASKA. Preliminary geologic map of the Mount Hayes Quadrangle, eastern Alaska Range, Alaska, by W. J. Nokleberg, J. N. Aleinikoff, I. M. Lange, S. R. Silva, R. T. Miyaoka, C. E. Schwab, and R. E. Zehner; with contributions for selected areas from G. C. Bond, D. H. Richter, T. E. Smith, and J. H. Stout. 1992. 39 p., 1 over-size sheet, scale 1:250,000 ( 1 inch = about 4 miles). (NC, Da, M, A, S; U.S. Dep. of the Interior, Alaska Resource Library, $701 \mathrm{C} \mathrm{St}$., Box 36, Anchorage, AK 99513; Alaska Dep. of Natural Resources, Div. of Geol. and Geophys. Surv., 794 University Ave., Suite 200, Fairbanks, AK 99709-3645.)

OF 92-0595. CALIFORNIA. Evaluation of selected metallic and nonmetallic mineral resources, West Mojave Management Area, Southern California. $1992.89 \mathrm{p}$. (NC, Da, M; California Dep. of Conservation, Div. of Mines and Geol., Mail Stop 14-34, Library, 801 K St., Sacramento, CA 95814-3532; 1145 Market St., 3rd
Floor, San Francisco, CA 94103; and State Office Bldg., 107 South Broadway, Los Angeles, CA 90012.)

OF 92-0596. ALASKA. Bibliography of research and exploration in the Glacier Bay region, Southeastern Alaska, 1798-1992, compiled by D. L. Howe, G. P. Streveler and D. A. Brew. 1992. 70 p. (NC, Da, M, A, S, U.S. Dep, of the Interior, Alaska Resource Library, 701 C St., Box 36, Anchorage, AK 99513; Alaska Dep. of Natural Resources, Div. of Geol. and Geophys. Surv., 794 University Ave. Suite 200, Fairbanks, AK 99709 3645.)

OF 92-0597. Descriptions of seismic array components; Part 2, Software modules for data acquisition/processing, by W. H. Lee. 1993. 316 p., one $31 / 2$ inch diskette. (NC, Da, M.)

Requirements: IBM 386 or 486 PC or compatible; minimum 1 MB RAM; math coprocessor; VGA graphics board and monitor; minimum 40MB hard disk; $31 / 2$ inch floppy disk drive; PC or MS DOS 4.01 or later; Microsoft C, Macro Assembler, and Fortran Compilers; and plotting library modules by Small Systems Support and Symmetric Research.

OF 92-0598. Descriptions of seismic array components; Part 3, Software modules for data conversion, by W. H. Lee. 1992. 111 p., one $31 / 2$ inch diskette. (NC, Da, M.)

Requirements IBM 386 or 486 PC or compatible; minimum $1 \mathrm{MB}$ RAM; math coprocessor, VGA graphics board and monitor; minimum 40MB hard disk; $31 / 2$ inch floppy disk drive; PC or MS DOS 4.01 or later; and Microsoft C Compiler.

OF 92-0599. ARIZONA. Tabulation of $\mathrm{N}_{2}, \mathrm{O}_{2}, \mathrm{CO}_{2}$, and $\mathrm{He}$ concentrations in soil gases collected on a regular basis for 11 months from a site at Tucson, Arizona, by M. E. Hinkle and T. F. Harms. 1992. 16 p. (NC, Da, M, U; Bur. of Geol. and Mineral Technol., 845 North Park Ave., Tucson, AZ 85719.)

OF 92-0600-A. Preliminary determination of epicenters; monthly listing January-March 1992, by National Earthquake Information Center. 1992. 96 p. (NC, Da, M.)

OF 92-0600-B. Preliminary determination of epicenters; monthly listing April-June 1992, by National Earthquake Information Center. 1992 . 143 p. (NC, Da, M.)

OF 92-0600-C. Preliminary determination of epicenters; monthly listing July-September 1992, by National Earthquake Information Center. 1992. 116 p. (NC, Da, M.)

OF 92-0600-D. Preliminary determination of epicenters; monthly listing October-December 1992, by National Earthquake Information Center. 1992. 104 p. (NC, Da, M.)

OF 92-0601-A. Earthquake data report, January 1992, by National Earthquake Information Center. 1992. 340 p. (NC, Da, M.)

OF 92-0601-B. Earthquake data report, January 1992, by National Earthquake Information Center. 1992. Three $51 / 4$ inch diskettes. (NC, Da, M.)

The EDR data are written on 1.2MB, high density, $51 / 4$ inch diskettes and are readable by IBM PC or compatible computers running DOS version 2.0 or higher.

OF 92-0602-A. Earthquake data report, February 1992, by National Earthquake Information Center. 1992. 296 p. (NC, Da, M.) 
OF 92-0602-B. Earthquake data report, February 1992, by National Earthquake Information Center. 1992. Three $51 / 4$ inch diskettes. (NC, Da, M.)

The EDR data are written on 1.2MB, high density, 5 1/4 inch diskettes and are readable by IBM PC or compatible computers running DOS version 2.0 or higher.

OF 92-0603-A. Earthquake data report, March 1992, by National Earthquake Information Center. 1992. 408 p. (NC, Da, M.)

OF 92-0603-B. Earthquake data report, March 1992, by National Earthquake Information Center. 1992. Four $51 / 4$ inch diskettes. (NC, Da, M.)

The EDR data are written on 1.2MB, high density, $51 / 4$ inch diskettes and are readable by IBM PC or compatible computers running DOS version 2.0 or higher.

OF 92-0604-A. Earthquake data report, April 1992, by National Earthquake Information Center. 1992. 403 p. (NC, Da, M.)

OF 92-0604-B. Earthquake data report, April 1992, by National Earthquake Information Center. 1992. Four $51 / 4$ inch diskettes. (NC, Da, M.)

The EDR data are written on 1.2MB, high density, $51 / 4$ inch diskettes and are readable by IBM PC or compatible computers running DOS version 2.0 or higher.

OF 92-0605-A. Earthquake data report, May 1992, by National Earthquake Information Center. 1992. 437 p. (NC, Da, M.)

OF 92-0605-B. Earthquake data report, May 1992, by National Earthquake Information Center. 1992. Five 5 1/4 inch diskettes. (NC, Da, M.)

The EDR data are written on 1.2MB, high density, $51 / 4$ inch diskettes and are readable by IBM PC or compatible computers running DOS version 2.0 or higher.

OF 92-0606-A. Earthquake data report, June 1992, by National Earthquake Information Center. 1992. 425 p. (NC, Da, M.)

OF 92-0606-B. Earthquake data report, June 1992, by National Earthquake Information Center. 1992. Five $51 / 4$ inch diskettes. (NC, Da, M.)

The EDR data are written on 1.2MB, high density, $51 / 4$ inch diskettes and are readable by IBM PC or compatible computers running DOS version 2.0 or higher.

OF 92-0607-A. Earthquake data report, July 1992, by National Earthquake Information Center. 1992. 250 p. (NC, Da, M.)

OF 92-0607-B. Earthquake data report, July 1992, by National Earthquake Information Center. 1992. Five $51 / 4$ inch diskettes. (NC, Da, M.)

The EDR data are written on 1.2MB, high density, $51 / 4$ inch diskettes and are readable by IBM PC or compatible computers running DOS version 2.0 or higher. All files are ASCII and the documentation is given in file AAREADME.DAT on the first disk.

OF 92-0608-A. Earthquake data report, August 1992, by National Earthquake Information Center. 1992. 458 p. (NC, Da, M.)
OF 92-0608-B. Earthquake data report, August 1992, by National Earthquake Information Center. 1992. Five $51 / 4$ inch diskettes. (NC, Da, M.)

The EDR data are written on 1.2MB, high density, $51 / 4$ inch diskettes and are readable by IBM PC or compatible computers running DOS version 2.0 or higher. All files are ASCII and the documentation is given in file AAREADME.DAT on the first disk.

OF 92-0609-A. Earthquake data report, September 1992, by National Earthquake Information Center. 1992. 437 p. (NC, Da, M.)

OF 92-0609-B. Earthquake data report, September 1992, by National Earthquake Information Center. 1992. Five $51 / 4$ inch diskettes. (NC, Da, M.)

The EDR data are written on 1.2MB, high density, $51 / 4$ inch diskettes and are readable by IBM PC or compatible computers running DOS version 2.0 or higher. All files are ASCII and the documentation is given in file AAREADME.DAT on the first disk.

OF 92-0610-A. Earthquake data report, October 1992, by National Earthquake Information Center. 1992. 455 p. (NC, Da, M.)

OF 92-0610-B. Earthquake data report, October 1992, by National Earthquake Information Center. 1992. Five $51 / 4$ inch diskettes (NC, Da, M.)

The EDR data are written on $1.2 \mathrm{MB}$, high density, $51 / 4$ inch diskettes and are readable by IBM PC or compatible computers running DOS version 2.0 or higher. All files are ASCII and the documentation is given in file AAREADME.DAT on the first disk.

OF 92-0611-A. Earthquake data report, November 1992, by National Earthquake Information Center. 1992. 420 p. (NC, Da, M.)

OF 92-0611-B. Earthquake data report, November 1992, by National Earthquake Information Center. 1992. Four $51 / 4$ inch diskettes. (NC, Da, M.)

The EDR data are written on 1.2MB, high density, $51 / 4$ inch diskettes and are readable by IBM PC or compatible computers running DOS version 2.0 or higher. All files are ASCII and the documentation is given in file AAREADME.DAT on the first disk.

OF 92-0612-A. Earthquake data report, December 1992, by National Earthquake Information Center. 1992. 425 p. (NC, Da, M.)

OF 92-0612-B. Earthquake data report, December 1992, by National Earthquake Information Center. 1992. Five $51 / 4$ inch diskettes. (NC, $\mathrm{Da}, \mathrm{M}$.)

The EDR data are written on 1.2MB high density, $51 / 4$ inch diskettes and are readable by IBM PC or compatible computers running DOS version 2.0 or higher. All files are ASCII and the documentation is given in file AAREADME.DAT on the first disk.

OF 92-0613. NEVADA. Preliminary geologic map of the Pahroc Summit Pass Quadrangle and part of the Hiko SE Quadrangle, Lincoln County, Nevada, by R. B. Scott and W C Swadley. 1992. 13 p., 1 over-size sheet, scale $1: 24,000$ ( 1 inch $=2,000$ feet $)$. 
(NC, Da, M, U; Nevada Bur. of Mines and Geol., Univ. of Nevada-Reno, Reno, NV 89557-0088.)

OF 92-0614. COLORADO. Ion exchange capture of copper, lead, and zinc in acid-rock drainages of Colorado using natural clinoptilolite; preliminary field studies, by G. A. Desborough. 1992. 16 p. (NC, Da, M, U; John W. Rold, Colorado Geol. Surv., 1313 Sherman St., Room 715, Denver, CO 80203; Donald Fawcett, Office of the State Engineer, Ground Water Section, 1313 Sherman St., Room 818, Denver, CO 80203.)

OF 92-0615. MINNESOTA. Gold and spectrographic analyses of 110 outcrop and 238 B-horizon soil samples from the western Vermilion District, northeastern Minnesota, by J. B. McHugh, R. T. Hopkins, H. V. Alminas and G. T. Hill. 1992. 38 p. 38 pgs., one $51 / 4$ inch diskette. (NC, Da, M; Minnesota Geol. Surv., 2642 University Ave., St. Paul, MN 55114-1057.)

This report contains digital geochemical data and text documentation on a $51 / 4 \mathrm{inch}, 1.2 \mathrm{MB}$ distribution diskette. The data files on diskette are in USGS STATPAC (.STP) format. A data format conversion program, STP2DAT.EXE has been included on the diskette to provide eight additional formats into which the $>$ STP files can be changed. The text files are in standard ASCII format.

OF 92-0626. MISSOURI. Water-resources activities of the U.S. Geological Survey in Missouri, 1991-92, compiled by K. L. Jenkins-Bartle. 1992.78 p. (NC, Da, M, Wb.)

OF 92-0627. CALIFORNIA, NEVADA, COLORADO. Hydrologic and climatic data bases used to assess potential effects of climate change on water resources of American River, Carson River, and Truckee River basins, California-Nevada, and of Gunnison River basin, Colorado, by M. H. August, J. M. Jacoboni, A. E. Jeton, R. S. Parker, Alex Pupacko, B. C. Ruddy, J. L. Smith and K. T. Redmond. 1992. 72 p. (NC, Da, M, Wb, U; USGS, WRD, 333 West Nye Lane, Carson City, NV 89706; and 6770 South Paradise Rd., Las Vegas, NV 89119.)

OF 92-0628. COLORADO. Planning document of water, energy, and biogeochemical-budget (WEBB) research project, Loch Vale watershed, Rocky Mountain National Park, Colorado, by J. T. Turk, N. E. Spahr and D. H. Campbell. 1993. 18 p. (NC, Da, M, Wb; USGS, WRD, Room H-2101, Bldg. 53, Denver Federal Ctr., Lakewood, CO 80225.)

OF 92-0629. GEORGIA. Water-supply potential of major streams and the upper Floridan Aquifer in the vicinity of Savannah, Georgia, by Reggina Garza and R. E. Krause. Prepared in cooperation with the Chatham County-Savannah Metropolitan Planning Commission. 1992.49 p., 19 over-size sheets. (NC, Da, M, Wb; USGS, WRD, 3039 Amwiler Rd., Suite 130, Peachtree Business Ctr., Atlanta, GA 30360-2824.)

OF 92-0632. Hydro-climatic data network (HCDN); a U.S. Geological Survey streamflow data set for the United States for the study of climate fluctuations, $1874-1988$, by J. M. Landwehr and J. R. Slack. 1992. 2 p. (NC, Da, M, Wb, A, S, U.) (Water fact sheet.)

OF 92-0633. NEBRASKA. Water-resources activities of the U.S. Geological Survey in Nebraska, fiscal years 1990-91, compiled by D. J. Fitzpatrick and J. E. McKinney. 1992. 48 p. (NC, Da, M, Wb; USGS, WRD, 100 Centennial Mall North, 406 Federal Bldg., Lincoln, NE 68510; Hwy. 11 North, Ord, NE 68862; P.O.
Box 787, 729 Main St., Bridgeport, NE 69336; and P.O. Box 426, 315 Nelson St., Cambridge, NE 69022.)

OF 92-0634. Methods of analysis by the U.S. Geological Survey National Water Quality Laboratory; determination of metals in water by inductively coupled plasma-mass spectrometry, by L. M. Faires. 1993. 28 p. (NC, Da, M, Wb.)

OF 92-0637. Study guide for a beginning course in ground-water hydrology; Part II, Instructor's guide, by O. L. Franke, T. E. Reilly, H. T. Buxton and D. L. Simmons. 1993. 128 p. (NC, Da, M, Wb.) (Part I, Course participants, issued as OF 90-183.)

OF 92-0638. KENTUCKY. Stormwater data for Jefferson County, Kentucky, 1991-92, by R. D. Evaldi and B. L. Moore. Prepared in cooperation with the Louisville and Jefferson County Metropolitan Sewer District. 1992. 82 p. (NC, Da, M, Wb; USGS, WRD, 2301 Bradley Ave., Louisville, KY 40217.)

OF 92-0639. NORTH CAROLINA. Simulation of unsteady flow in the Roanoke River from near Oak City to Williamston, North Carolina, by A. G. Strickland and J. D. Bales. Prepared in cooperation with the North Carolina Department of Environment, Health, and Natural Resources, and the U.S. Army Corps of Engineers. 1993. 49 p. (NC, Da, M, Wb; USGS, WRD, 3916 Sunset Ridge Rd., Raleigh, NC 27607.)

OF 92-0640. UTAH. Selected hydrologic data for Salt Lake Valley, Utah, 1990-92, with emphasis on data from the shallow unconfined aquifer and confining layers, by S. A. Thiros. Prepared in cooperation with the Utah Department of Natural Resources and the Utah Department of Environmental Quality. 1992. 60 p., 1 over-size sheet. (NC, Da, M, Wb, U.)

OF 92-0641. OKLAHOMA. Ground-water-quality assessment of the Central Oklahoma Aquifer, Oklahoma; hydrologic, waterquality, and quality assurance data $1987-90$, by D. M. Ferree, S. C. Christenson, A. H. Rea and B. A. Mesander. 1992. 193 p. (NC, Da, M, Wb.)

OF 92-0643. IDAHO. Water-level data for selected wells on or near the Idaho National Engineering Laboratory, Idaho, 1983 through 1990 , by D. S. Ott, D. D. Edwards and R. C. Bartholomay. Prepared in cooperation with the U.S. Department of Energy. 1992. 307 p. (NC, Da, M, Wb; USGS, WRD, 230 Collins Rd., Boise, ID 83702; and Idaho National Engineering Laboratory, CF-690, Room 164, Idaho Falls, ID 83403.)

OF 92-0644. WASHINGTON. Surface-water-quality assessment of the Yakima River basin, Washington; pesticide and other traceorganic-compound data for water, sediment, soil, and aquatic biota, 1987-91, by J. F. Rinella, S. W. McKenzie, J. K. Crawford, W. T. Foreman, P. M. Gates, G. J. Fuhrer and M. L. Janet. 1992. 154 p. (NC, Da, M, Wb.)

OF 92-0645. COLORADO. Initial findings of synoptic snowpack sampling in the Colorado Rocky Mountains, by J. T. Turk, D. H. Campbell, G. P. Ingersoll and D. A. Clow. Prepared in cooperation with the Colorado Department of Health, U.S. Forest Service, and U.S. Environmental Protection Agency. 1992. 6 p. (NC, Da, M, Wb.)

OF 92-0646. MASSACHUSETTS. Results of geophysical surveys at Hocomonco Pond, Westborough, Massachusetts, by B. P. Hansen. Prepared in cooperation with the U.S. Environmental Protection Agency, Water Management Division. 1993, 19 p. 
(NC, Da, M, Wb; USGS, WRD, 28 Lord Rd., Suite 280, Marlborough, MA 01752.)

OF 92-0647. NEW HAMPSHIRE. Locations of fracture intervals inferred from borehole logs of eight wells at the Holton Circle Superfund site, Londonderry, New Hampshire, by B. P. Hansen. Prepared in cooperation with the U.S. Environmental Protection Agency, Waste Management Division. 1993. 22 p. (NC, Da, M, Wb; USGS, WRD, 28 Lord Rd., Suite 280, Marlborough, MA 01752; and 525 Clinton St., Bow, NH 03304.)

OF 92-0648. TENNESSEE. Hydrologic and hydraulic analyses at Akin Branch and Cayce Valley Branch, Columbia, Tennessee, by G. S. Outlaw. Prepared in cooperation with the City of Columbia. 1993.56 p. (NC, Da, M, Wb; USGS, WRD, 810 Broadway, Suite 500, Nashville, TN 37203.)

OF 92-0649. MARYLAND. Acid rain induced changes in streamwater quality during storms on Catoctin Mountain, Maryland, by K. C. Rice and O. P. Bricker. 1992. 2 p. (NC, Da, M, Wb, A, S, U.) (Water fact sheet.)

OF 92-0651. Hydrologic and sedimentologic data collected during four cruises at high water on the Mississippi River and some of its tributaries, March 1989 through June 1990, by J. A. Moody and R. H. Meade. 1993. 227 p. (NC, Da, M, Wb, U.)

OF 92-0652. A data base of nitrate in ground-water samples from the conterminous United States, by K. J. Lanfear. 1992. 7 p. (NC, Da, M, Wb.)

OF 92-0653. NEW MEXICO. Rainfall and runoff data for the Albuquerque, New Mexico, metropolitan area, 1984-88, by K. D. Metzker, R. L. Gold and R. P. Thomas. Prepared in cooperation with the Albuquerque Metropolitan Arroyo Flood Control Authority and the City of Albuquerque. 1993. 388 p. (NC, Da, M, Wb, U; USGS, WRD, 4501 Indian School Rd. NE, Suite 200, Albuquerque, NM 87110.)

OF 92-0655. CALIFORNIA. Water-quality data for shallow wells in the western and southern Tulare Basin, San Joaquin Valley, California, May to August 1989, by W. C. Swain and L. F. Duell, Jr. Prepared in cooperation with the California Department of Water Resources and the San Joaquin Valley Drainage Program. 1993. 30 p. (NC, Da, M, Wb; USGS, WRD, Federal Bldg., Room W-2233, 2800 Cottage Way, Sacramento, CA 95825; and 5735 Kearny Villa Rd., Suite O, San Diego, CA 92123.)

OF 92-0659. Source code for the computer program and sample data set for the simulation of cylindrical flow to a well using the U.S. Geological Survey modular finite-difference ground-water flow model, by T. E. Reilly and A. W. Harbaugh. 1992. 12 p., one 5 1/4 inch diskette. (NC, Da, M, Wb.)

An MS-DOS compatible, 1.2MB diskette is included with this report.

OF 92-0661. Archiving data from Gulf Coast Regional Aquifer System Analysis study, by K. A. Kirkpatrick. 1993.18 p. (NC, Da, M, Wb, S; USGS, WRD, 10615 SE Cherry Blossom Dr., Portland, OR 97216.)

OF 92-0679. LOGRAF; lognormal graph for resource assessment forecast, by R. A. Crovelli and R. H. Balay. 1992. 30 p. 30 pgs., one $51 / 4$ inch diskette. (NC, Da, M.)
Requirements: IBM-PC or compatible; minimum $400 \mathrm{~K}$ free memory; MS-DOS 3.3 or higher; VGA graphics adapter; PostScript laser printer. A numeric coprocessor is not required.

OF 92-0680. Reprocessing of reflection seismic lines R111 and R102, Risha gas field, Hashemite Kingdom of Jordan, by J. J. Miller, W. F. Agena and M. W. Lee. 1992. 29 p. (NC, Da, M.)

OF 92-0681. NEVADA. Preliminary geologic map of the Paleozoic rocks in the Arrow Canyon Quadrangle, Clark County, Nevada, by W. R. Page. 1992. 13 p., 1 over-size sheet, scale 1:24,000 (1 inch = 2,000 feet). (NC, Da, M, U; Nevada Bur. of Mines and Geol., Univ. of Nevada-Reno, Reno, NV 89557-0088.)

OF 92-0682. INDIANA. Indiana coal and associated rock samples collected from 1975 to 1977 , by C. L. Oman, W. A. Hassenmueller and L. J. Bragg. 1992. 129 p. (NC, Da, M.)

OF 92-0685. Catalog of pre-Cretaceous geologic drill-hole data from the upper Mississippi Embayment; a revision and update of Open-file report 90-260, compiled by R. L. Dart. 1992. 253 p. (NC, Da, M; Geol. Surv. of Alabama, P.O. Box 0, University Station, Tuscaloosa, AL 35486; Arkansas Geol. Commission, 3815 West Roosevelt Rd., Little Rock, AR 72204; Illinois State Geol. Surv., Natural Resources Bldg., 615 East Peabody Dr., Room 121, Champaign, IL 61820; Kentucky Geol. Surv., Univ. of Kentucky, 311 Breckinridge Hall, Lexington, KY 40506; Pirth Geol. Library, 100 Bowman Hall, Univ. of Kentucky, Lexington, KY 40506; Dep. of Natural Resources, Div. of Geol. and Land Surv., 111 Fairgrounds Rd., P.O. Box 250, Rolla, MO 65401; Bur. of Geol., Mississippi Dep. of Natural Resources, P.O. Box 5348, Jackson, MS 39216; Dep. of Conservation, Div. of Geol., Customs House, 701 Broadway, Nashville, TN 37219-5237.) (Openfile report 90-260 never released. For additional information write to R. L. Dart, USGS, Mail Stop 966, Denver, CO 80225; telephone 303-273-8637.)

OF 92-0686. HAWAII. Hawaiian Volcano Observatory; Summary 90 Part II, Deformation data, January to December 1990, by M. K. Sako, P. T. Delaney, A. J. Largo, Asta Miklius and A. T. Okamura. 1992. 64 p. (NC, Da, M.)

OF 92-0687. ARIZONA. Map of industrial mineral occurrences in the national forests of Arizona, compiled by B. B. Houser. 1992. 30 p., 1 over-size sheet. (NC, Da, M, U; Arizona Bur. of Geol. and Mineral Technol., 845 North Park Ave., Tucson, AZ 85719.)

OF 92-0689. COLORADO. Measured section of the Pennsylvanian Hermosa Group near Hermosa, Colorado, by K. J. Franczyk. 1992. 32 p. (NC, Da, M, U; John W. Rold, Colorado Geol. Surv., 1313 Sherman St., Room 715, Denver, CO 80203; Donald Fawcett, Office of the State Engineer, Ground Water Section, 1313 Sherman St., Room 818, Denver, CO 80203.)

OF 92-0690. ALASKA. Map and table of mineral deposits on Annette Island, Alaska, by S. M. Karl. 1992. 57 p., 1 over-size sheet, scale 1:63,360 (1 inch = 1 mile). (NC, Da, M, A, S; U.S. Dep. of the Interior, Alaska Resource Library, 701 C St., Box 36, Anchorage, AK 99513; Alaska Dep. of Natural Resources, Div. of Geol. and Geophys. Surv., 794 University Ave., Suite 200, Fairbanks, AK 99703-3645.)

OF 92-0691. Demonstration disk for USGS-OEMG mapping software, by C. A. Cook and R. A. Ambroziak. 1992. 3 p. 3 pgs., one 5 1/4 inch DS/HD IBM compatible diskette. (NC, Da, M.) 
OF 92-0693. Seismic survey of Lake Baikal, Siberia; operational technical summary for the RV Balkash and RV Titov, 15 August to 30 September 1992, by D. R. Nichols, G. K. Miller and Lyosha Akentiev. 1992. 20 p. (NC, Da, M.)

OF 92-0694. Using regional geologic information to assess relative aquifer contamination potential; an example from the central United States, by D. R. Soller and R. C. Berg. 1992. 1 oversize sheet, scale 1:1,000,000 ( 1 inch = about 16 miles $)$. (NC, Da, M.)

OF 92-0695. OREGON, CALIFORNIA. Preliminary geologic map of the Carberry Creek Quadrangle, Oregon and California, by M. M. Donato. 1992. 1 over-size sheet, scale 1:24,000 (1 inch $=2,000$ feet). (NC, Da, M, S; California Dep. of Conservation, Div. of Mines and Geol., Mail Stop 14-34, Library, $801 \mathrm{~K}$ St., Sacramento, CA 95814-3532; 1145 Market St., 3rd Floor, San Francisco, CA 94103; and State Office Bldg., 107 South Broadway, Los Angeles, CA 90012; Oregon Dep. of Geol. and Mineral Industries, Suite 965, 800 Northeast Oregon St. \#28, Portland, OR 97232.)

OF 92-0696. Oil and gas resource assessment areas; 1992; lower 48 states, compiled by G. L. Dolton, K. L. Varnes, D. L. Gautier and J. K. Baird. 1992. 1 over-size sheet, scale 1:5,000,000 ( 1 inch $=$ about 80 miles $)$. (NC, Da, M.)

OF 92-0697. KANSAS. Preliminary geologic map of the Bloom SE Quadrangle and part of the Simmons Creek Quadrangle, Clark County, Kansas, by M. W. Green and G. M. Fairer. Prepared in cooperation with the Kansas Geological Survey. 1993. 5 p., 1 over-size sheet, scale 1:24,000 (1 inch $=2,000$ feet). (NC, Da, M; Kansas Geol. Surv. 1930 Constant Ave., Campus West, Univ. of Kansas, Lawrence, KS 66046.)

OF 92-0698. KANSAS. Preliminary geologic map of the Bloom SW Quadrangle and parts of the Bloom, Minneola, and Fowler SE quadrangles, Clark County, Kansas, by G. M. Fairer and M. W. Green. Prepared in cooperation with the Kansas Geological Survey. 1993. 5 p., 1 over-size sheet, scale 1:24,000 (1 inch $=2,000$ feet). (NC, Da, M; Kansas Geol., Surv., 1930 Constant Ave., Campus West, Univ. of Kansas, Lawrence, KS 66046.)

OF 92-0699. ${ }^{40} \mathrm{Ar}-{ }^{39} \mathrm{Ar}$ dating of the Jaramillo normal subchron and the Matuyama and Brunhes geomagnetic boundary, by G. A. Izett and J. D. Obradovich. 1992. 22 p. (NC, Da, M.)

OF 92-0700-A. NEW JERSEY. Aeromagnetic gridded data for New Jersey, by S. L. Snyder. 1992. 11 p. 11 pgs., three $51 / 4$ inch DS/HD IBM compatible diskettes. (NC, Da, M.)

OF 92-0701. ALASKA. ${ }^{40} \mathrm{Ar} /{ }^{39} \mathrm{Ar}$ age-spectrum data for whole rock basalts, and plagioclase and biotite from tephra; a trayerse down the Porcupine Riyer, East-Central Alaska, by M. J. Kunk and Henry Cortesini, Jr. 1992. 81 p. (NC, Da, M, A, S; Alaska Dep. of Natural Resources, Div. of Geol. and Geophys. Surv., 794 University Ave., Suite 200, Fairbanks, AK 99709-3645; U.S. Dep. of the Interior, Alaska Resource Library, 701 C St., Anchorage, AK 99513.)

OF 92-0703. PUERTO RICO. Sand-sized heavy mineral distributions in the Rio Cibuco system and adjacent rivers of north-central Puerto Rico, by Gretchen Luepke and L. J. Poppe. 1993. 28 p. (NC, Da, M.)
OF 92-0704. Comparison of the Cracow-Silesian mississippi valley-type district, southern Poland, with mississippi valley-type districts in North America, by D. L. Leach and J. G. Viets. 1992. 72 p. (NC, Da, M.)

OF 92-0705. Descriptive model of stratabound sulfur and contained-sulfur model of stratabound sulfur, by K. R. Long. 1992. 8 p. (NC, Da, M.)

OF 92-0706. ALASKA. Marine geologic investigations of Disenchantment Bay, Alaska, after breakup of 1986 Hubbard Glacier ice dam; RV Karluk Cruise K1-91-YB, 21-28 June 1991, by P. R. Carlson, R. D. Powell, E. A. Cowan and D. E. Lawson. 1992. 41 p. (NC, Da, M, A, S; U.S. Dep. of the Interior, Alaska Resource Library, 701 C St., Box 36, Anchorage, AK 99513; Alaska Dep. of Natural Resources, Div. of Geol. and Geophys. Surv., 794 University Ave., Suite 200, Fairbanks, AK 997093645.)

OF 92-0707. CALIFORNIA. Ca-Mg carbonate deposits, Warnick Canyon, Colusa County, California, by R. L. Oscarson, T. S. Presser and W. W. Carothers. 1992. 32 p. (NC, Da, M; California Dep. of Conservation, Div. of Mines and Geol., Mail Stop 14-34, Library, 801 K St., Sacramento, CA 95814-3532; 1145 Market St., 3rd Floor, San Francisco, CA 94103; and State Office Bldg., 107 South Broadway, Los Angeles, CA 90012.)

OF 92-0708-A. ALASKA. Analytical data and sample locality map of stream-sediment and heavy-mineral-concentrate samples collected from the Horn Mountains area, Sleetmute Quadrangle, Southwest Alaska, by P. M. Theodorakos, J. C. Borden, J. H. Bullock, Jr., J. E. Gray and P. L. Hageman. 1992. 35 p. (NC, Da, M, S, A; Alaska Div. of Geol. and Geophys. Surv., 794 University Ave., Suite 200, Fairbanks, AK 99709-3645; U.S. Dep. of Interior, Alaska Resource Library, 701 C St., Box 36, Anchorage, AK 99513.)

OF 92-0708-B. ALASKA. Analytical data and sample locality map of stream-sediment and heavy-mineral-concentrate samples collected from the Horn Mountains area, Sleetmute Quadrangle, Southwest Alaska, by P. M. Theodorakos, J. C. Borden, J. H. Bullock, Jr., J. E. Gray and P. L. Hageman. 1992. One 5 1/4 inch diskette. (NC, Da, M, S, A; Alaska Div. of Geol. and Geophys. Surv., 794 University Ave., Suite 200, Fairbanks, AK 99709-3645; U.S. Dep. of Interior, Alaska Resource Library, 701 C St., Box 36, Anchorage, AK 99513.)

Requirements: IBM compatible computer using MS DOS with a $51 / 4$ inch, $360 \mathrm{~K}$ drive.

OF 92-0709. COLORADO. Analytical results and sample locality maps of stream-sediment and heavy-mineral-concentrate samples from the San Juan National Forest, Archuleta, Dolores, Hinsdale, La Plata, Mineral, Montezuma, Rio Grande, San Juan, and San Miguel counties, Colorado, by H. N. Barton, D. L. Fey, J. M. Motooka and R. T. Hopkins. 1992. 46 p., 1 over-size sheet, scale 1:250,000 (1 inch = about 4 miles $)$, one $51 / 4$ inch diskette. (NC, Da, M, U; John W. Rold, Colorado Geol. Surv., 1313 Sherman St., Room 715, Denver, CO 80203; Donald Fawcett, Office of the State Engineer, Ground Water Section, 1313 Sherman St., Room 818, Denver, CO 80203.)

Requirements: one 5 1/4 inch DS/DD IBM compatible diskette. MS-DOS 2.0 or greater, coprocessor required for the conversion program (included on the diskette). 
OF 92-0710. NEW MEXICO. A digital geologic map and explanation of San Antonio Mountain Quadrangle, Rio Arriba and Taos counties, New Mexico, by R. A. Thompson and P. W. Lipman. 1992. 7 p., one $51 / 4$ inch diskette. (NC, Da, M, U; New Mexico Bur. of Mines and Mineral Resources, Campus Station, Socorro, NM 87801.)

The dataset is distributed on an IBM compatible, $51 / 4$ inch, 1.2MB format diskette.

OF 92-0711. NEW MEXICO, COLORADO. A digital geologic map and explanation of the Los Pinos Quadrangle, Rio Arriba and Taos counties, New Mexico and Conejos County, Colorado, by R. A. Thompson and P. W. Lipman. 1992. 7 p., one $51 / 4$ inch diskette. (NC, Da, M, U; New Mexico Bur. of Mines and Mineral Resources, Campus Station, Socorro, NM 87801; John W. Rold, Colorado Geol. Surv., 1313 Sherman St., Room 715, Denver, CO 80203; Donald Fawcett, Office of the State Engineer, Ground Water Section, 1313 Sherman St., Room 818, Denver, CO 80203.)

The dataset is distributed on an IBM compatible, $51 / 4$ inch, 1.2MB format diskette.

OF 92-0712. Palynological data from Pliocene sediments, DSDP Leg 5 Site 32, northeastern Pacific Ocean, by R. F. Fleming. 1992. 24 p. (NC, Da, M.)

OF 92-0713. IDAHO. Palynological data from a 989-ft (301-m) core of Pliocene and early Pleistocene sediments from Bruneau, Idaho, by R. S. Thompson. 1992. 28p. (NC, Da, M, U, S; Idaho Geol. Surv., Univ. of Idaho Campus, Morrill Hall, Room 332, Moscow, ID 83843.)

OF 92-0714. Deep seismic reflection studies in the Pacific Northwest U.S., by F. N. Zihlman. Prepared in cooperation with the U.S. Department of Energy. 1992. One CD-ROM. (NC, Da, M.)

DOS environment system requirements: Intel 80286 or higher processor; DOS 3.0 or later; a math coprocessor is NOT required, but will be used if available and is strongly recommended; Microsoft MSCDEX version 2.1 or later; CD-ROM drive with ISO 9660 software driver; EGA/VGA/Hercules graphics system. Macintosh system requirements: CD-ROM drive with ISO 9660 or Macintosh HFS software driver.

OF 92-0715. WASHINGTON. Wellbore breakout analysis for determining tectonic stress orientations in Washington State, by $M$. E. Magee and M. L. Zoback. 1992. 56 p. (NC, Da, M, S; Washington DNR/Div. of Geol. and Earth Resources Library, 1111 Washington St. SE, Olympia, WA 98501 (mail address: PO Box 47007, Olympia, WA 98504-7007).

OF 92-0716. VIRGINIA. Geologic map of Loudoun County, Virginia, compiled by W. C. Burton, A. J. Froelich, J. S. Schindler and C. S. Southworth. Prepared in cooperation with the Department of Natural Resources, Loudoun County, Virginia. 1993. 17 p., 1 over-size sheet, scale $1: 100,000$ (1 inch = about 1.6 miles). (NC, Da, M, Wa; Virginia Div. of Mineral Resources, Natural Resources Bldg., Alderman and McCormick Rds., P.O. Box 3667, Charlottesville, VA 22903.)

OF 92-0717. PUERTO RICO. Progress of studies on the impact of Hurricane Hugo on the coastal resources of Puerto Rico, edited by W. C. Schwab and R. W. Rodriguez. 1992. 95 p. (NC, Da, M.)
Hurricane Hugo; a description of the storm, by R. W. Rodriguez, R. M. Webb and D. M. Bush. p. 8-14.

Historical shoreline analysis, by B. R. Richmond, E. R. Thieler and W. W. Danforth. p. 15-19.

Coastal monitoring, by B. R. Richmond, Milton Carlo, J. L. Trias and R. W. Rodriguez. p. 20-28.

Coastal hazards mapping, by D. M. Bush and B. R. Richmond. p. 29-35.

Historical shoreline analysis using digital techniques, by W. W. Danforth and E. R. Thieler. p. 36-42.

Effects of Hurricane Hugo on offshore sand deposits, by C. M. DeLorey, L. J. Poppe and R. W. Rodriguez. p. 43-59.

Insular shelf sedimentologic processes; Playa de Luquillo, by W. C. Schwab, W. W. Danforth, R. W. Rodriguez, M. H. Gowen and T. F. O'Brien. p. 60-72.

Quantitative analysis of sidescan sonar imagery, by $\mathrm{M}$. H. Gowen, W. C. Schwab and W. W. Danforth. p. 73-79.

Assessment of damage to coral reefs by Hurricane Hugo, by E. A. Shinn and R. B. Halley. p. 80-91.

OF 92-0719. SEAPCONE; a seafloor piezometric cone penetrometer system, by W. J. Winters, G. K. Miller and J. S. Booth. 1992. 36 p. (NC, Da, M.)

OF 92-0720. Four AVS modules; READ.NETCDF, TOPO2IRREG, Z-SLICER, WIDE-ARROW, by E. L. Wright. 1992. 9 p. (NC, Da, M.)

OF 92-0721. Analytical results for B-horizon soil samples, from the International Falls and Roseau $1^{\circ} \times 2^{\circ}$ quadrangles, Minnesota/Ontario, by G. O. Riddle, A. L. Meier, J. M. Motooka, O. Erlich, J. R. Clark, J. A. Saunders, D. L. Fey and T. Sparks. 1992. 13 p. 10 p., one $31 / 2$ inch diskette. (NC, Da, M; Minnesota Geol. Surv., 2642 University Ave., St. Paul, MN 55114-1057; Minnesota Dep. of Natural Resources, Div. of Minerals, P.O. Box 567, 1525 3rd Ave. East, Hibbing, MN 55746.)

A 3 1/2 inch high-density (1.44MB) IBM-compatible diskette is included with the report, and requires $6.3 \mathrm{MB}$ of free disk space.

OF 92-0722. The value of barrier islands; 1 , Mitigation of locallygenerated wind-wave attack on the mainland, by J. H. List and M. E. Hansen. 1992. 18 p. (NC, Da, M.)

OF 92-0723. SOUTH CAROLINA. Data report for a seismic refraction/wide-angle reflection investigation of the Atlantic Coastal Plain in South Carolina, by J. H. Luetgert, H. M. Benz, E. E. Criley and Song-Lin Li. 1993. 35 p. (NC, Da, M; Norman K. Olson, State Geologist, South Carolina Geol. Surv., 5 Geology Rd., Columbia, SC 29210-9998.)

OF 92-0724. ALASKA. Magnetic susceptibility measurements and sample locations of granitic rocks from along a transect of the Coast Mountains near Juneau, Alaska, by J. L. Drinkwater, A. B. Ford and D. A. Brew. 1992. 22 p. (NC, Da, M, A, S; U.S. Dep. of the Interior, Alaska Resource Library, 701 C St., Box 36, Anchorage, AK 99513; Alaska Dep. of Natural Resources, Div. of Geol. and Geophys. Surv., 794 University Ave., Suite 200, Fairbanks, AK 99709-3645.) 
OF 92-0725. VIRGINIA. Preliminary geologic map of the Aspen and nearby areas, Virginia, by A. E. Nelson. 1993. 1 over-size sheet, scale 1:48,000 (1 inch = 4,000 feet). (NC, Da, M, Wa; Virginia Div, of Mineral Resources, Natural Resources Bldg., Alderman and McCormick Rds., P.O. Box 3667, Charlottesville, VA 22903.)

OF 93-0001-A. REPORT; a program for generating method descriptions and bibliographies of routine work performed in analytical laboratories, by J. N. Grossman and M. W. Doughten. 1993. 8 p. (NC, Da, M.)

OF 93-0001-B. Method descriptions and bibliography of routine work performed by the Branch of Geochemistry analytical laboratories, U.S. Geological Survey, by M. W. Doughten and J. N. Grossman. 1993. 16 p. (NC, Da, M.)

OF 93-0001-C. A program for generating method descriptions and bibliographies of routine work performed in analytical chemistry laboratories, by J. N. Grossman and M. W. Doughten. 1993. One $31 / 2$ inch diskette. (NC, Da, M.)

Requirements: IBM PC or compatible 80486-based system, or 80386-based system with math coprocessor; minimum $570 \mathrm{~K}$ available RAM; HP LaserJet series II or higher, or compatible printer.

OF 93-0002. WYOMING. Principal facts for 284 gravity stations in the Newcastle $1^{\circ} \times 2^{\circ}$ Quadrangle, northeastern Wyoming, by Courteney Williamson and S. L. Robbins. 1992. 23 p. (NC, Da, M, U; Geol. Surv. of Wyoming, P.O. Box 3008, University Station, Laramie, WY 82071.)

OF 93-0003. UTAH. Preliminary geologic map of the Parowan Quadrangle, Iron County, Utah, by Florian Maldonado and R. C. Moore. 1993. 11 p., 1 over-size sheet, scale $1: 24,000(1 \mathrm{inch}=$ 2,000 feet). (NC, Da, M, U; Utah Geol. Surv., 2363 Foothill Dr., Salt Lake City, UT 84109-1403.)

OF 93-0004. Geology and hydrocarbon resources of onshore basins in eastern China, by G. F. Ulmishek. 1992.150 p. (NC, $\mathrm{Da}, \mathrm{M}$.)

OF 93-0005. Program TracePlot, version 1.1; seismic trace plotting program for the Macintosh, by J. J. Miller. 1992 . $10 \mathrm{p}$., one 3 $1 / 2$ inch diskette. (NC, Da, M.)

TracePlot, version 1.1 is a Macintosh application designed to display the seismic traces contained in a SEG-Y format disk file on the CRT screen of a Macintosh micro-computer running operating system 6.0 or higher. User-controlled options are available to specify display parameters like scale, gain, plotting style, timing line annotation, plot direction, etc. Color and Monochrome monitors are supported. TraceCopy, version 1.1 is designed to copy a subset of the traces and/or a subset of the samples from the input SEG-Y format disk file to another, smaller file. Input files must be in standard SEG-Y exchange format as specified by the Society of Exploration Geophysicists (Barry, et al., 1975). Data samples must be type \#1:IBM floating point ( 4 bytes ( 32 bits) per sample).

OF 93-0007. Ocean bottom seismometers operation during the seismic survey of Lake Baikal, Siberia, autumn 1992, by U. S. ten Brink, Alik Badardinov, G. K. Miller and D. F. Coleman. 1992. 24 p. (NC, Da, M.)
OF 93-0010. NEW JERSEY. Geochemical data for Jurassic basalts in the early Mesozoic Newark Basin, New Jersey; the data of G. T. Faust, by H. E. Belkin and D. F. Fiorito. 1993. 51 p. (NC, Da, M.)

OF 93-0011. The Farallones moored array data report, by K. L. Kinoshita, M. A. Noble and S. R. Ramp. 1993. 108 p. (NC, Da, M.)

OF 93-0012. A suggested rationale and selected bibliography for using rule-based expert computer systems (artificial intelligence) in recurrent petroleum resource assessments, by W. C. Butler. 1993. 126 p. (NC, Da, M.)

OF 93-0013. Program Kolor-map and section Amiga version 1.0, by A. A. Zohdy. 1993.85 p. 85 pgs., one $31 / 2$ inch diskette. (NC, Da, M.)

Requirements are an Amiga computer with a minimum of $5 \mathrm{MB}$ RAM (4MB Fast RAM and 1MB Chip RAM), running under AmigaDOS 1.3 or higher. A math coprocessor is recommended but not required: A program that reads files from MS-DOS diskettes into the Amiga is required (for example, CrossDOS, which is part of AmigaDOS 2.1 and higher).

OF 93-0014. ALASKA. Element concentrations and baselines for moss, lichen, spruce, and surface soils, in and near Wrangell-Saint Elias National Park and Preserve, Alaska, by J. G. Crock, K. A. Beck, D. L. Fey, P. L. Hageman, C. S. Papp and T. R. Peacock. Prepared in cooperation with the U.S. National Park Service. 1993. 98 p. (NC, Da, M, A, S; Alaska Dep. of Natural Resources, Div. of Geol. and Geophys. Surv., 794 University Ave., Suite 200, Fairbanks, AK 99709-3645; U.S. Dep. of Interior, Alaska Resource Library, 701 C St., Box 36, Anchorage, AK 99513.)

OF 93-0015. HAWAII. Drilling report and core logs for the 1988 drilling of Kilauea Iki lava lake, Kilauea Volcano, Hawaii, with summary descriptions of the occurrence of foundered crust and fractures in the drill core, by R. T. Helz. 1993. 57 p. (NC, Da, M.)

OF 93-0016. Analyses of Landsat thematic mapper images of the Berenguela-Charaña area, Bolivia, by B. A. Eiswerth. 1993. 18 p., 5 over-size sheets. (NC, Da, M.)

OF 93-0017-A. COLORADO. Analytical results, basic statistics, and locality map of rabbitbrush (genus Chrysothamnus) samples from the Mineral Hot Springs and Valley View Hot Springs Known Geothermal Resource Areas, northern San Luis Valley, Colorado, by J. A. Erdman and George VanTrump. 1993, 18 p., 1 oversize sheet, scale 1:24,000 ( 1 inch $=2,000$ feet). (NC, Da, M, U; John W. Rold, Colorado Geol. Surv., 1313 Sherman St., Room 715, Denver, CO 80203; Donald Fawcett, Office of the State Engineer, Ground Water Section, 1313 Sherman St., Room 818, Denver, CO 80203.)

OF 93-0017-B. COLORADO. Analytical results, basic statistics, and locality map of rabbitbrush (genus Chrysothamnus) samples from the Mineral Hot Springs and Valley View Hot Springs Known Geothermal Resources Areas, northern San Luis Valley, Colorado, by'J. A. Erdman and George VanTrump. 1993. One 5 1/4 inch diskette.' (NC, Da; M, U; John W. Rold, Colorado Geol. Surv., 1313 Sherman St., Room 715, Denver, CO 80203; Donald Fawcett, Office of the State Engineer, Ground Water Section, 1313 Sherman St., Room 818, Denver, CO 80203.) 
The data referenced in this report are written on a $1.2 \mathrm{MB}$, high density, $51 / 4$ inch diskette, readable by an IBM PC or compatible computer running DOS, version 2.0 or higher. An executable program is provided to allow this binary file to be converted to any of $\mathbf{8}$ different formats.

OF 93-0018. COLORADO. Principal facts for gravity stations in the Sangre de Cristo Mountains, Rio Grande and Isabel national forests, south-central Colorado, by G. A. Abrams. 1993. 4 p. (NC, Da, M, U; John W. Rold, Colorado Geol. Surv., 1313 Sherman St., Room 715, Denver, CO 80203; Donald Fawcett, Office of the State Engineer, Ground Water Section, 1313 Sherman St., Room 818, Denver, CO 80203.)

OF 93-0019. Studies of sediment transport by Beaufort Gyre pack ice, 1992; sediment, ice \& water data, by Michael McCormick, P. W. Barnes and Erk Reimnitz. 1993. 38 p. (NC, Da, M.)

OF 93-0020. OREGON, CALIFORNIA. Field core processing techniques used by USGS 1991 drilling operations in the upper Klamath Basin, Oregon and California, by D. P. Adam. 1993. 13 p. (NC, Da, M, S; California Dep. of Conservation, Div. of Mines and Geol., Mail Stop 14-34, Library, $801 \mathrm{~K}$ St., Sacramento, CA 95814-3532; 1145 Market St., 3rd Floor, San Francisco, CA 94103; and State Office Bldg., 107 South Broadway, Los Angeles, CA 90012; Oregon Dep. of Geol. and Mineral Industries, Suite 965, 800 NE Oregon St. \#28, Portland, OR 97232.)

OF 93-0021. NEVADA. Megabreccia of the Big Ten Peak Caldera, Nye County, Nevada, by W. J. Keith. 1993. 17 p. (NC, $\mathrm{Da}, \mathrm{M}, \mathrm{U}$; Nevada Bur. of Mines and Geol., Univ. of Nevada, Reno, NV 89557.)

OF 93-0022. PC-PLOT, an IBM-PC compatible version of the earthquake plotting program QPLOT, by T. L. Murray, J. A. Power and F. W. Klein. 1993. 17 p., one 5 1/4 inch diskette. (NC, Da, M.)

Requirements: IBM PC compatible; 64OK RAM; math coprocessor; hard drive; Geograf graphics drivers.

OF 93-0023. Comments on the "three-step" method for quantification of undiscovered mineral resources, by M. W. Bultman, E. R. Force, M. E. Gettings and F. S. Fisher. 1993. 59 p. (NC, Da, M.)

OF 93-0024. VIRGINIA. Preliminary geologic map of the Middletown Quadrangle, Frederick and Shenandoah counties, Virginia, by R. C. Orndorff, J. B. Epstein and R. C. McDowell. 1993. 1 over-size sheet, scale $1: 24,000$ ( 1 inch $=2,000$ feet). (NC, Wa; Virginia Div. of Mineral Resources, P.O. Box 3667, Charlottesville, VA 22903.)

OF 93-0025. VIRGINIA. Structural analysis of divergent folds in the Martinsburg and Oranda formations; Middletown 7.5-minute Quadrangle, VA, by J. B. Epstein. 1993. 13 p. (NC, Da, M, Wa; Virginia Div. of Mineral Resources, P.O. Box 3667, Charlottesville, VA 22903.) (Report to accompany the geologic map of the Middletown Quadrangle, Orndorff and others, 1993.)

OF 93-0027. PENNSYLVANIA. Altitude and configuration of the potentiometric surface in Plumstead Township, Bucks County, Pennsylvania, June 1991 through November 1991, by C. L. Schreffler. Prepared in cooperation with Buckingham, Nockamixon, Plumstead, Solebury, Springfield, Tinicum, and Wrightstown townships, Bucks County, Pennsylvania. 1993. 1 over-size sheet, scale 1:24,000 (1 inch $=2,000$ feet). (NC, Da, M,
Wb; USGS, WRD, Great Valley Corporate Ctr., 111 Great Valley Pkwy., Malvern, PA 19355.)

OF 93-0028. PENNSYLVANIA. Altitude and configuration of the potentiometric surface in New Hope Borough and Solebury Township, Bucks County, Pennsylvania, October 1991 through April 1992, by C. L. Schreffler. Prepared in cooperation with New Hope Borough and Bridgeton, Buckinghain, Nockamixon, Plumstead, Solebury, Springfield, Tinicum, and Wrightstown townships, Bucks County, Pennsylvania. 1993. 1 over-size sheet, scale 1:24,000 (1 inch = 2,000 feet). (NC, Da, M, Wb; USGS, WRD, Great Valley Corporate Ctr., 111 Great Valley Pkwy., Malvern, PA 19355.)

OF 93-0029. Hydrologic data-collection stations whose stream water quality data were available to prepare the 1990-91 National Water Summary on Stream Water Quality, by K. J. Lanfear. 1993. 48 p. (NC, Da, M, Wb.)

OF 93-0032. Report on the U.S. Geological Survey's evaluation program for standard reference samples distributed in October 1992; T-121 (trace constituents), M-124 (major constituents), N36 (nutrients), N-37 (nutrients), P-19 (low ionic strength), and Hg-15 (mercury), by H. K. Long and J. W. Farrar. 1993. 114 p. (NC, Da, M, Wb.)

OF 93-0034. IDAHO. Chemical constituents in water from wells in the vicinity of the Naval Reactors Facility, Idaho National Engineering Laboratory, Idaho, 1990-91, by R. C. Bartholomay, L. L. Knobel and B. J. Tucker. Prepared in cooperation with the U.S. Department of Energy. 1993. 70 p. (NC, Da, M, Wb; USGS, WRD, 230 Collins Rd., Boise, ID 83702; and Idaho National Engineering Laboratory, CF-690, Room 164, Idaho Falls, ID 83403.)

OF 93-0035. SOUTH CAROLINA. Water-resources activities, South Carolina, 1989-91, by S. C. Lambert, M. S. Davenport and G. G. Patterson. 1993. 82 p. (NC, Da, M, Wb.)

OF 93-0036. Global Change Hydrology Program, by H. F. Lins. 1993. 2 p. (NC, Da, M, Wb, A, S, U.) (Water fact sheet.)

OF 93-0039. Procedures for adjusting regional regression models of urban-runoff quality using local monitoring data, by A. B. Hoos and J. K. Sisolak. 1993. 39 p. (NC, Da, M, Wb; USGS, WRD, 810 Broadway, Suite 500, Nashville, TN 37203.)

OF 93-0040. DELAWARE, MARYLAND, VIRGINIA. Waterquality assessment of the Delmarva Peninsula, Delaware, Maryland, and Virginia; effects of agricultural activities on, and distribution of, nitrate and other inorganic constituents in the surficial aquifer, by P. A. Hamilton, J. M. Denver, P. J. Phillips and R. J. Shedlock. 1993. 95 p., one $31 / 2$ inch DS/HD IBM compatible diskette. (NC, Da, M, Wb; USGS, WRD, 208 Carroll Bldg., 8600 La Salle Rd., Towson, MD 21204.)

OF 93-0042. MINNESOTA. Effects of focused recharge on the transport of agricultural chemicals at the Princeton, Minnesota, Management Systems Evaluation Area (MSEA), 1991-92, by G. N. Delin and M. K. Landon. 1993. 8 p. (NC, Da, M, Wb.)

OF 93-0043. MINNESOTA. Ground-water quality at the Management Systems Evaluation Area (MSEA) near Princeton, Minnesota, 1991, by M. K. Landon, G. N. Delin, J. A. Lamb and L. Guo. Prepared in cooperation with the University of Minne- 
sota Department of Soil Science and the U.S. Department of Agriculture. 1993.8 p. (NC, Da, M, Wb.)

OF 93-0048. ARKANSAS. Use of water in Arkansas, 1990, by T. W. Holland. Prepared in cooperation with the Arkansas Soil and Water Conservation Commission. 1993. 9 p. (NC, Da, M, Wb.)

OF 93-0049. FLORIDA. Potentiometric surface of the upper Floridan Aquifer, west-central Florida, September 1992, by R. A. Mularoni. Prepared in cooperation with the Southwest Florida Water Management District. 1993. 1 over-size sheet. (NC, Da, $\mathrm{M}, \mathrm{Wb}$.)

OF 93-0050. FLORIDA. Potentiometric surface of the upper Floridan Aquifer in the St. Johns River Water Management District and vicinity, September 1992, by L. C. Murray, R. M. Spechler, G. G. Phelps and L. A. Bradner. Prepared in cooperation with the St. Johns River Water Management District, South Florida Water Management District, and Southwest Florida Water Management District. 1993. 1 over-size sheet. (NC, Da, M, Wb.)

OF 93-0052. NORTH DAKOTA. Water-resources activities, North Dakota District, fiscal year 1992, compiled by C. R. Martin. 1993.55 p. (NC, Da, M, Wb; USGS, WRD, 821 East Interstate Ave., Bismarck, ND 58501-1199.)

OF 93-0053. FLORIDA. Potentiometric surfaces of the intermediate aquifer system, west-central Florida, September 1992, by R. A. Mularoni. Prepared in cooperation with the Southwest Florida Water Management District. 1993. 1 over-size sheet. (NC, Da, $\mathrm{M}, \mathrm{Wb}$.)

OF 93-0054. ARIZONA. Floods in Arizona, January 1993, by $R$. D. MacNish, C. F. Smith and K. E. Goddard. 1993. 2p. (NC, $\mathrm{Da}, \mathrm{M}, \mathrm{Wb}$; USGS, WRD, 375 South Euclid Ave., Tucson, AZ $85719 ; 1545$ West University Dr., Tempe, AZ 85281; 1940 South 3rd Ave., Yuma, AZ 85364; and 2255 North Gemini Dr., Flagstaff, AZ 86001.) (Water fact sheet.)

OF 93-0055. GEORGIA. Water, energy, and biogeochemical budgets investigation at Panola Mountain research watershed, Stockbridge, Georgia; a research plan, by T. G. Huntington, R. P. Hooper, N. E. Peters, T. D. Bullen and Carol Kendall. 1993. 39 p. (NC, Da, M, Wb; USGS, WRD, Peachtree Business Ctr., Suite 130, 3039 Amwiler Rd., Atlanta, GA 30360-2824.)

OF 93-0056. Trend analysis of sulfate, nitrate, and $\mathrm{pH}$ data collected at National Atmospheric Deposition Program/National Trends Network stations between 1980 and 1991, by W. G. Baier and T. A. Cohn. 1993. 13 p. (NC, Da, M, Wb.)

OF 93-0057. CALIFORNIA. Dissolved nutrient and suspended particulate matter data for the San Francisco Bay estuary, October 1988 through September 1991, by S. W. Hager. 1993. 52 p. (NC, Da, M, Wb.)

OF 93-0058. Hydrologic Instrumentation Facility of the U.S. Geological Survey annual report for fiscal year 1992, by V. J. Latkovich and D. C. Tracey. 1993. 51 p. (NC, Da, M, Wb.)

OF 93-0059. CALIFORNIA. Executive summary; application of a hydrochemical model and soil-solution mixing model to alpine watersheds in the Sierra Nevada, California, by R. P. Hooper and N. E. Peters. Prepared in cooperation with the California Air Resources Board. 1993. 2 p. (NC, Da, M, Wb; USGS, WRD, 3039 Amwiler Rd., Suite 130, Atlanta, GA 30360.) (Companion report to WRI 93-4030.)
OF 93-0062. TEXAS. Approximate altitude of water levels in wells completed in the Chicot and Evangeline aquifers in Fort Bend County and adjacent areas, Texas, January-February 1991, by G. L. Locke. Prepared in cooperation with the Fort Bend Subsidence District. 1993. 2 over-size sheets. (NC, Da, M, Wb; USGS, WRD, 8011 Cameron Rd., Bldg. 1, Austin, TX 78753.)

OF 93-0064. MONTANA. Radon in ground water of western Montana, by D. W. Clark and D. W. Briar. 1993. 2 p. (NC, $\mathrm{Da}, \mathrm{M}, \mathrm{Wb}, \mathrm{A}, \mathrm{S}, \mathrm{U}$.) (Water fact sheet.)

OF 93-0065. MINNESOTA. Water-resources activities of the U.S. Geological Survey in Minnesota, 1991, compiled by G. L. Amos and T. A. Winterstein. 1993. 73 p. (NC, Da, M, Wb.)

OF 93-0066. NORTH DAKOTA. Physical-property, water-quality, plankton, and bottom-material data for Devils Lake and East Devils Lake, North Dakota, September 1988 through October 1990, by S. K. Sando and B. A. Sether. Prepared in cooperation with the North Dakota Game and Fish Department. 1993. 178 p. (NC, Da, M, Wb; USGS, WRD, 821 East Interstate Ave., Bismarck, ND 58501-1199.)

OF 93-0067. FLORIDA. Water-resources activities in Florida, 1992-93, compiled by M. E. Glenn. Prepared in cooperation with Federal, state, and local agencies. 1993.99 p. (NC, Da, M, Wb.)

OF 93-0069. NORTH CAROLINA. Water-quality data from continuously monitored sites in the Albemarle Sound estuarine system, North Carolina, 1989-91, by R. G. Garrett. Prepared in cooperation with the North Carolina Department of Environment, Health and Natural Resources, Albemarle-Pamlico Estuarine Study. 1993. 257 p. (NC, Da, M, Wb.)

OF 93-0070. ARKANSAS. Bacterial survey of Nimrod Lake, Arkansas, spring and summer 1992, by R. L. Joseph and E. E. Morris. Prepared in cooperation with the U.S. Army Corps of Engineers. 1993. 1 over-size sheet. (NC, Da, M, Wb.)

OF 93-0071. Proceedings of a pressure transducer-packer workshop, June 25-28, 1991, compiled by V. J. Latkovich. 1993. 48 p. (NC, Da, M, Wb.)

Some experience gained from using packers and transducers in ground-water investigations of crystalline-rock aquifers, by $P$. A. Hsieh. p. 5-7.

Wire line logs and conventional packers; issues and research opportunities, by F. L. Paillet and A. E. Hess. p. 9-13.

Basic data recorder system test results, by D. H. Rapp. p. 15.

Evaluation of two submersible pressure transducer systems, by G. V. Steele. p. 17-18.

Regional Aquifer-System Analysis double-packer aquifer tests, by D. B. Westjohn. p. 19-20.

Use of pressure transducers to gather time drawdown data in single-hole pump tests, Wellston area, Oklahoma, by R. A. Funkhouser. p. 21.

Use of pressure transducers in the Arkansas District, by T. E. Lamb. p. 23.

Use of packers and transducers in aquifer tests in Castle Pines, Colorado, by S. G. Robson. p. 25. 
Packer-transducer use in the Arizona District, by M. C. Carpenter. p. 27-30.

Monitoring static water levels in the Yucca Mountain area, by G. M. O'Brien. p. 31-32.

Pressure transducer applications; site saturated zone, Yucca Mountain Project, by J. M. Gemmell. p. 33.

Upgrade of packer and transducer equipment used in fracture testing in Colorado oil shale project, by L. L. Matson. p. 35.

Research into the processes of flow and solute transport in fractured rock; experiences in equipment development by staff from Environment Canada, by K. S. Novakowski. p. 37-38.

Hydraulic fracture stimulation of crystalline-bedrock aquifers using a self-contained packer and sensor system, by James Waltz and R. E. Boyle. p. 39-42.

OF 93-0073. NEVADA. Earthquake-induced water-level fluctuations at Yucca Mountain, Nevada, June 1992, by G. M. O'Brien. Prepared in cooperation with the U.S. Department of Energy. 1993. 12 p. (NC, Da, M, Wb.)

OF 93-0076. Directory of assistance centers of the National Water Data Exchange (NAWDEX), by C. D. Blackwell. 1993. 40 p. (NC, Da, M, Wb.) (Supersedes OF 91-507.)

OF 93-0079. MINNESOTA. Effects of focused recharge on transport of agricultural chemicals at the Princeton, Minn., Management Systems Evaluation Area (MSEA), 1991-92, by G. N. Delin and M. K. Landon. 1993. 2 p. (NC, Da, M, Wb, A, S, U.) (Water fact sheet.)

OF 93-0081. TEXAS. Approximate changes in water levels in wells completed in the Chicot and Evangeline aquifers 1990-93 and 1992-93, Fort Bend County and adjacent areas, Texas, by $\mathrm{H}$. X. Santos and D. L. Barbie. Prepared in cooperation with the Fort Bend Subsidence District. 1993. 4 over-size sheets. (NC, Da, M, Wb; USGS, WRD, 8011 Cameron Rd., Bldg. A, Austin, TX 78754-3898.)

OF 93-0083. CALIFORNIA. Physical, chemical, and biological data for detailed study of irrigation drainage in the Salton Sea area, California, 1988-90, by R. A. Schroeder, Mick Rivera, and others. Prepared by the U.S. Geological Survey and U.S. Fish and Wildlife Service, in cooperation with the U.S. Bureau of Reclamation, U.S. Bureau of Indian Affairs, and the California Regional Water Quality Control Board. 1993. 179 p. (NC, Da, M, Wb; USGS, WRD, Federal Bldg., Room W-2233, 2800 Cottage Way, Sacramento, CA 95825; and 5735 Kearny Villa Rd., Suite O, San Diego, CA 92123.)

OF 93-0084. NEW MEXICO. Water-quality data from the San Juan and Chaco rivers and selected alluvial aquifers, San Juan County, New Mexico, by C. R. Thorn. Prepared in cooperation with the U.S. Bureau of Reclamation. 1993. 37 p. (NC, Da, M, Wb, U; USGS, WRD, 4501 Indian School Rd. NE, Suite 200, Albuquerque, NM 87110.)

OF 93-0086. TEXAS. Approximate changes in water levels in wells completed in the Chicot and Evangeline aquifers, 1977-93 and 1992-93, and measured compaction, 1973-92, in the HoustonGalveston region, Texas, by M. C. Kasmarek, L. S. Coplin and Al Campodonico. Prepared in cooperation with the Harris-Gal- veston Coastal Subsidence District and the City of Houston. 1993. 3 p., 4 over-size sheets. ( $N C, D a, M, W b$.)

OF 93-0087. KANSAS, NEBRASKA. The occurrence and transport of agricultural pesticides in the Tuttle Creek lake-stream system, Kansas and Nebraska, by H. E. Bevans, C. H. Fromm and S. A. Watkins. Prepared in cooperation with the Kansas Department of Health and Environment. 1993. 44 p., 1 over-size sheet. (NC, Da, M, Wb; USGS, WRD, 4821 Quail Crest Pl., Lawrence, KS 66049; and 206 Fulton Terrace, Garden City, KS 67846.)

OF 93-0092. KANSAS. Description of geographic-informationsystem files containing water-resource-related data compiled and collected for Wyandotte County, northeastern Kansas, by C. V. Hansen. Prepared in cooperation with the Wyandotte County Health Department. 1993. 46 p. (NC, Da, M, Wb; USGS, WRD, 4821 Quail Crest P1., Lawrence, KS 66049-3839; and 206 Fulton Terrace, Garden City, KS 67846.)

OF 93-0094. ALASKA. Channel geometry data of streams in the lower Drift River basin affected by the 1989-90 eruptions of Redoubt Volcano, Alaska, by J. M. Dorava, B. A. May, D. F. Meyer and L. V. Myers. 1993. 66 p. (NC, Da, M, Wb, A, S; USGS, WRD, 4230 University Dr., Suite 201, Anchorage, AK 99508-4664; 800 Yukon Dr., Fairbanks, AK 99775-5170; and 9101 Mendenhall Mall Rd., Federal Bldg. Annex, Suite 8, Juneau, AK 99802.)

OF 93-0095. ALASKA. Hydrologic conditions and low-flow investigations of the lower Bradley River near Homer, Alaska, October 1991 to February 1992, by R. L. Rickman. Prepared in cooperation with the Alaska Energy Authority. 1993. 17 p. (NC, Da, M, Wb, A; USGS, WRD, 4230 University Dr., Suite 201, Anchorage, AK 99508-4664; 800 Yukon Dr., Fairbanks, AK 99775-5170; and 9109 Mendenhall Mall Rd., Federal Bldg. Annex, Suite 8, Juneau, AK 99802.)

OF 93-0096. ARKANSAS. Ground-water levels in the alluvial aquifer in eastern Arkansas, 1992, by P. W. Westerfield and S. T. Touschner. Prepared in cooperation with the Arkansas Soil and Water Conservation Commission, U.S. Soil Conservation Service, and local conservation districts. 1993. 25 p. (NC, Da, $\mathrm{M}, \mathrm{Wb}$.)

OF 93-0097. NEVADA. Water-related scientific activities of the U.S. Geological Survey in Nevada, fiscal years 1991-92, compiled by M. T. Foglesong. 1993. 77 p. (NC, Da, M, Wb, U; USGS, WRD, 333 West Nye Lane, Carson City, NV 89706; and 6770 South Paradise Rd., Las Vegas, NV 89119.)

OF 93-0101. MISSOURI. Occurrence of pesticides, nitrite plus nitrate, arsenic, and iron in water from two reaches of the Missouri River alluvium, northwestern Missouri; July 1988 and June-July 1989, by A. C. Ziegler, W. C. Wallace, D. W. Blevins and R. D. Maley. Prepared in cooperation with the Missouri Department of Health. 1993. $30 \mathrm{p}$. (NC, Da, M, Wb.)

OF 93-0102. IDAHO. Radionuclides, inorganic constituents, organic compounds, and bacteria in water from selected wells and springs from the southern boundary of the Idaho National Engineering Laboratory to the Hagerman area, Idaho, 1991, by R. C. Bartholomay, D. D. Edwards and L. J. Campbell. Prepared in cooperation with the U.S. Department of Energy and Idaho Department of Water Resources. 1993. 42 p. (NC, Da, M, Wb; USGS, WRD, 230 Collins Rd., Boise, ID 83702; and Idaho Na- 
tional Engineering Laboratory, CF-690, Room 164, Idaho Falls, ID 83403.)

OF 93-0104. Methods for sampling fish communities as part of the National Water-Quality Assessment Program, by M. R. Meador, T. F. Cuffney and M. E. Gurtz. 1993. 40 p. (NC, Da, M, Wb; USGS, WRD, 3916 Sunset Ridge Rd., Raleigh, NC 27607.)

OF 93-0106. COLORADO, NEBRASKA, WYOMING. Bibliography of water-related studies, South Platte River basin; Colorado, Nebraska, and Wyoming, by K. F. Dennehy and J. R. OrtizZayas. 1993. 278 p. (NC, Da, M, Wb, U; USGS, WRD, Room H-2101, Bldg. 53, Denver Federal Ctr., Mail Stop 415, Box 25046, Denver, CO 80225-0046.)

OF 93-0109. MISSOURI. Water-quality data for the Missouri River and Missouri River alluvium near Weldon Spring, St. Charles County, Missouri; 1991-92, by M. J. Kleeschulte. Prepared in cooperation with the U.S. Department of Energy. 1993. 44 p. (NC, Da, M, Wb.)

OF 93-0112. TEXAS. Summary of water-resources activities of the U.S. Geological Survey in Texas; fiscal years 1989-92, compiled by K. E. Uzcategui. 1993.83 p., 1 over-size sheet. (NC, $\mathrm{Da}, \mathrm{M}, \mathrm{Wb}$.)

OF 93-0114. Hydrogeologic, water-quality, and land-use data for the reconnaissance of herbicides and nitrate in near-surface aquifers of the Midcontinental United States, 1991, by D. W. Kolpin, M. R. Burkart and E. M. Thurman. 1993. 61 p. (NC, Da, M, Wb, Wa; USGS, WRD, 400 South Clinton St., Iowa City, IA 52244; 102 East Main St., 4th Floor, Urbana, IL 61801; 5957 Lakeside Blvd., Indianapolis, IN 46278-1996; 4821 Quail Crest P1., Lawrence, KS 66049; 6520 Mercantile Way, Suite 5, Lansing, MI 48911; 2280 Woodale Dr., Mounds View, MN 55112; 1400 Independence Rd., Mail Stop 200, Rolla, MO; Room 406, Federal Bldg., Lincoln, NE 68508; 821 East Interstate Ave., Bismarck, ND 58501-1199; 975 West Third Ave., Columbus, OH 43212; 6417 Normandy Lane, Madison, WI 53719-1133; and Room 408, Federal Bldg., Huron, SD 57350.)

OF 93-0115. PENNSYLVANIA. Water-quality data for two surface coal mines reclaimed with alkaline waste or urban sewage sludge, Clarion County, Pennsylvania, May 1983 through November 1989 , by D. L. Dugas, C. A. Cravotta, III and D. A. Saad. Prepared in cooperation with the Pennsylvania Department of Environmental Resources, Bureau of Mining and Reclamation. 1993. 153 p. (NC, Da, M, Wb; USGS, WRD, 840 Market St., Lemoyne, PA 17043-1586.)

OF 93-0117. NORTH DAKOTA. User documentation for North Dakota geochemical data-base software system; input, update, and retrieval procedures, by J. W. Atwood. Prepared in cooperation with the North Dakota State Public Service Commission. 1993. 28 p. (NC, Da, M, Wb; USGS, WRD, 821 East Interstate Ave., Bismarck, ND 58501-1199.)

OF 93-0119. Ground-water withdrawal in 1990; Midwest Basins and Arches Regional Aquifer Systems Study Area, by E. A. Beary. 1993. 2 p. (NC, Da, M, Wb, A, S; USGS, WRD, 975 West 3rd Ave., Columbus, OH 43212.) (Water fact sheet.)

OF 93-0120. The U.S. Geological Survey Federal-State Cooperative Water-Resources Program, fiscal year 1992, by B. K. Gilbert and W. B. Mann, IV. 1993. 33 p. (NC, Da, M, Wb.)
OF 93-0122. ARKANSAS. Hydrologic data collected in Maumelle and Winona reservoir systems, central Arkansas, May 1989 through October 1992, by W. R. Green and B. L. Louthian. Prepared in cooperation with the Little Rock Municipal Water Works. 1993. 253 p. (NC, Da, M, Wb.)

OF 93-0123. An optimization model for selecting training course locations, U.S. Geological Survey, by T. A. Cohn and W. G. Baier. 1993. 15 p. (NC, Da, M, Wb.)

OF 93-0125. Methods of analysis by the U.S. Geological Survey National Water Quality Laboratory; determination of inorganic and organic constituents in water and fluvial sediments, edited by M. J. Fishman. 1993. 217 p. (NC, Da, M, Wb, U.)

OF 93-0127. MINNESOTA. Climatic data for Shingobee Lake and Williams Lake, Hubbard County, Minnesota, 1989-91, by R. S. Parkhurst, D. A. Merk, D. O. Rosenberry and T. C. Winter. 1993. 34 p. (NC, Da, M, Wb.)

OF 93-0129. WISCONSIN. Water-resources investigations in Wisconsin, 1993, by D. E. Maertz. 1993. 101 p. (NC, Da, M, Wb.)

OF 93-0136. ARKANSAS. Summary of reported agriculture and irrigation water use in Arkansas County, Arkansas, 1991, by T. W. Holland and C. A. Manning. Prepared in cooperation with the Arkansas Soil and Water Conservation Commission. 1993. 8 p. (NC, Da, M, Wb.)

OF 93-0138. Directory of member organizations of the National Water Data Exchange (NAWDEX), by C. D. Blackwell. 1993. 107 p. (NC, Da, M, Wb.)

OF 93-0140. MISSOURI. U.S. Geological Survey ground-water studies in Missouri, by B. J. Smith. 1993. 2p. (NC, Da, M, Wb, A, S, U.) (Water fact sheet.)

OF 93-0142. WYOMING. Seepage, soil, and sediment data for selected canals, Wind River Federal Irrigation Project, Wyoming, $1990-91$, by K. A. Miller. Prepared in cooperation with the Shoshone Tribe, Northern Arapahoe Tribe, and U.S. Bureau of Indian Affairs. 1993. 24 p. (NC, Da, M, Wb, U; USGS, WRD, 2617 East Lincolnway, Suite B, Cheyenne, WY 82001; and 1225 Market St., Riverton, WY 82501.)

OF 93-0144. NEW MEXICO. Sources of information and data pertaining to geohydrology in the vicinity of the Roswell Basin, in parts of Chaves, Eddy, De Baca, Guadalupe, Lincoln, and Otero counties, New Mexico, by D. P. McAda and T. D. Morrison. 1993. 78 p. (NC, Da, M, Wb, U; USGS, WRD; 4501 Indian School Rd. NE, Suite 200, Albuquerque, NM 87110.)

OF 93-0146. CALIFORNIA. Particulate organic matter in the San Francisco Bay estuary, California; chemical indicators of its origin and assimilation into the benthic food web, by J. E. Cloern, E. A. Canuel and S. M. Wienke. 1993. 46 p. (NC, Da, M, Wb; USGS, WRD, Federal Bldg., Room W-2233, 2800 Cottage Way, Sacramento, CA 95825.)

OF 93-0148. CALIFORNIA. Drilling, construction, and subsurface data for piezometers on Edwards Air Force Base, Antelope Valley, California, 1991-92, by D. L. Rewis. Prepared in cooperation with the U.S. Department of the Air Force. 1993. 35 p. (NC, Da, M, Wb; USGS, WRD, Federal Bldg., Room W-2233, 2800 Cottage Way, Sacramento, CA 95825; and 5735 Kearny Villa Rd., Suite O, San Diego, CA 92123.) 
OF 93-0149. IDAHO. Water-resources activities of the U.S. Geological Survey in Idaho, fiscal years 1989-90, compiled by B. N. Kemp. 1993. 52 p. (NC, Da, M, Wb; USGS, WRD, 230 Collins Rd., Boise, ID 83702; and Idaho National Engineering Laboratory, CF-690, Room 164, Idaho Falls, ID 83403.)

OF 93-0150. ARKANSAS. Hydrogeologic data for Carroll County, Arkansas, by J. V. Brahana, V. A. Leidy, John Lindt and S. A. Hodge. Prepared in cooperation with the Arkansas Soil and Water Conservation Commission. 1993. 32 p. (NC, Da, M, Wb.)

OF 93-0153. MISSOURI. Geochemical data for the Weldon Spring training area and vicinity property, St. Charles County, Missouri; 1990-92, by J. G. Schumacher, S. J. Sutley and J. D. Cathcart. Prepared in cooperation with the U.S. Army Corps of Engineers, Kansas City District. 1993. 80 p. (NC, Da, M, Wb; USGS, WRD, 1400 Independence Rd., Mail Stop 200, Rolla, MO 65401.)

OF 93-0154. Water Resources Research Grant Program projects descriptions, fiscal year 1992, compiled by Melvin Lew and P. D. Murray. 1993. 113 p. (NC, Da, M, Wb.)

OF 93-0162. ALASKA. Hydrologic data for the lower Copper River, Alaska, May to September 1992, by T. P. Brabets. Prepared in cooperation with the Alaska Department of Transportation and Public Facilities. 1993. 26 p. (NC, Da, M, Wb, A, S; USGS, WRD, 4230 University Dr., Suite 201, Anchorage, AK 995084664; 800 Yukon Dr., Fairbanks, AK 99775-5170; and 9101 Mendenhall Mall Rd., Federal Bldg. Annex, Suite 8, Juneau, AK 99802.)

OF 93-0163. NORTH CAROLINA. Water-quality and biological data for selected streams, lakes, and wells in the High Point.Lake watershed, Guilford County, North Carolina, 1988-89, by M. S. Davenport. Prepared in cooperation with the City of High Point, North Carolina. 1993. 144 p. (NC, Da, M, Wb.)

OF 93-0166. ARKANSAS. Summary of reported agriculture and irrigation water use in Ashley County, Arkansas, 1991, by T. W. Holland and C. A. Manning. Prepared in cooperation with the Arkansas Soil and Water Conservation Commission. 1993. 8 p. (NC, Da, M, Wb.)

OF 93-0167. ARKANSAS. Summary of reported agriculture and irrigation water use in Chicot County, Arkansas, 1991, by T. W. Holland and C. A. Manning. Prepared in cooperation with the Arkansas Soil and Water Conservation Commission. 1993. 8 p. (NC, Da, M, Wb.)

OF 93-0171. ARKANSAS, OKLAHOMA. Annual yield and selected hydrologic data for the Arkansas River Basin Compact Arkansas-Oklahoma 1992 water year, by C. S. Barks, R. L. Blazs and S. T. Touschner. Prepared in cooperation with the Arkansas River Compact Commission Arkansas-Oklahoma. 1993. 42 p. (NC, Da, M, Wb.)

OF 93-0177. CALIFORNIA. Preliminary data and age-correlation for extra rock samples (KG-25 to KG 47) in the Cooperative Monterey Organic Geochemistry Study, Santa Maria and Santa Barbara-Ventura basins, California, by C. M. Isaacs, J. H. Tomson, J. A. Barron, David Bukry and M. D. Lewan. 1993. 23 p. (NC, Da, M; California Dep. of Conservation, Div. of Mines and Geol., Mail Stop 14-34, Library, 801 K St., Sacramento, CA 95814-3532; 1145 Market St., 3rd Floor, San Francisco, CA
94103; and State Office Bldg., 107 South Broadway, Los Angeles, CA 90012.)

OF 93-0178. PUERTO RICO. Analytical results and sample locality map of soil samples from the Río Viví porphyry copper district, municipios of Utuado and Adjuntas, Puerto Rico, by R. E. Learned, H. A. Pierce and lleana Perez. 1992. 38 p., 1 over-size sheet. (NC, Da, M.)

OF 93-0179. PUERTO RICO. Analytical results and sample locality map of soil samples from the Tanama-Helecho porphyry copper district, municipios of Utuado and Adjuntas, Puerto Rico, by R. E. Learned, H. A. Pierce and Ileana Perez. 1992. 34 p., 1 over-size sheet. (NC, Da, M.)

OF 93-0180. CALIFORNIA. Eocene benthic foraminiferal assemblages of the Palo Alto 7-1/2' Quadrangle, California, by Kristin McDougall. 1993. 93 p. (NC, Da, M; California Dep. of Conservation, Div. of Mines and Geol., Mail Stop 14-34, Library, 801 K St., Sacramento, CA 95814-3532; 1145 Market St., 3rd Floor, San Francisco, CA 94103; and State Office Bldg., 107 South Broadway, Los Angeles, CA 90012.)

OF 93-0181. Reconnaissance report on the 12 October 1992 Dahshur, Egypt, earthquake, by P. C. Thenhaus, R. V. Sharp, Mehmet Celebi, A. B. Ibrahim and Hendrik Van de Pol. 1993. 63 p. (NC, Da, M.)

OF 93-0182. CALIFORNIA. Supplementary data on diatoms and calcareous nannofossils and preliminary revised ages for rock samples (KG-1 to KG-24) in the Cooperative Monterey Organic Geochemistry Study, Santa Maria and Santa Barbara-Ventura basins, California, by C. M. Isaacs, J. A. Barron and David Bukry. 1993. 13 p. (NC, Da, M; California Dep. of Conservation, Div. of Mines and Geol., Mail Stop 14-34, Library, $801 \mathrm{~K}$ St., Sacramento, CA 95814-3532; 1145 Market St., 3rd Floor, San Francisco, CA 94103; and State Office Bldg., 107 South Broadway, Los Angeles, CA 90012.)

OF 93-0183. COLORADO. Skarn-hosted mineralization in Paleozoic rocks beneath the Idarado Mine, northwest San Juan Mountains, Colorado, by J. N. Mayor and F. S. Fisher. 1993. 16 p., 1 over-size sheet. (NC, Da, M; USGS, Room 8105 Federal Bldg., 125 South State St., Salt Lake City, UT 84138-1177; Colorado Geol. Surv., 1313 Sherman St., Room 715, Denver, CO 80203.)

OF 93-0184. MONTANA. Conodont biofacies in a ramp to basin setting (latest Devonian and earliest Carboniferous) in the Rocky Mountains of southernmost Canada and northern Montana, by L. E. Savoy and A. G. Harris. 1993. 38 p. (NC, Da, M, U, S; Montana Bur. of Mines and Geol., Montana Coll. of Mineral Sci. and Technol., Butte, MT 59701.)

OF 93-0185. MASSACHUSETTS. Erosion of Nantucket Island's eastern shore, December 1922, by D. W. Folger, D. S. Blackwood, R. N. Oldale, D. S. Foster, C. L. Brown and W. N. Tiffney, Jr. 1993. One VHS video tape. (NC, Da, M.)

OF 93-0186. NEVADA. Rock-Eval pyrolysis data from well cuttings samples, eastern Nevada, collected during 1991, by C. E. Barker, R. J. Szmajter, T. A. Daws and C. N. Threlkeld. 1993. 4 p. (NC, Da, M, U; Nevada Bur. of Mines and Geol., Univ. of Nevada-Reno, Reno, NV 89557-0088.)

OF 93-0187. A portable vacuum hammer seismic source for use in tunnel environments, by R. D. Carroll and J. E. Magner. Pre- 
pared in cooperation with the U.S. Defense Nuclear Agency and the U.S. Department of Energy. 1993. 35 p. (NC, Da, M.)

OF 93-0188-A. Cartographic technical standards on the Apple Macintosh, by J. F. Vigil. 1993. 74 p. (NC, Da, M.)

OF 93-0188-B. Cartographic technical standards on the Apple Macintosh, by J. F. Vigil. 1993. Five $31 / 2$ inch diskettes. (NC, Da, M.)

Requirements: The program will run on any Macintosh with at least $4 \mathrm{MB}$ of RAM (8MB preferred), a $20-\mathrm{MB}$ hard disk, and Macintosh Operating System 6.0.5 or higher.

OF 93-0189. OREGON, WASHINGTON. The Cenozoic geology of the Oregon and Washington Coast Range; and road log for the Northwest Petroleum Association 9th annual field trip; Cenozoic geology of coastal Northwest Oregon, by P. D. Snavely, Jr., R. E. Wells and D. L. Minasian. 1993. 40 p. (NC, Da, M, S; Oregon Dep. of Geol. and Mineral Industries, Suite 956, 800 Northeast Oregon St. \#28, Portland, OR 97232.)

OF 93-0190. UTAH. Preliminary geologic map of Navajo Lake Quadrangle, Kane and Iron counties, Utah, by D. W. Moore and N. L. David. 1993. 20 p., 1 over-size sheet, scale 1:24,000 (1 inch $=2,000$ feet). (NC, Da, M, U.)

OF 93-0191. CALIFORNIA. The preliminary damage and intensity survey for the Landers, California, earthquake of June 28, 1992, by L. R. Brewer. 1993. 32 p. (NC, Da, M; California Dep. of Conservation, Div. of Mines and Geol., Mail Stop 14-34, Library, 801 K St., Sacramento, CA 95814-3532; 1145 Market St., 3rd Floor, San Francisco, CA 94103; and State Office Bldg., 107 South Broadway, Los Angeles, CA 90012.)

OF 93-0192. WYOMING. Assessed oil and gas plays in Wyoming; generalized location maps and mean estimates of undiscovered recoverable conventional oil, gas, and natural gas liquids of plays appraised in the 1989 National assessment for oil and gas, by R. B. Powers and K. L. Varnes. 1993. 43 p. (NC, $\mathrm{Da}, \mathrm{Da}, \mathrm{M}, \mathrm{U}$; Geol. Surv. of Wyoming, P.O. Box 3008, University Station, Laramie, WY 82071.)

OF 93-0194. Descriptive, and grade and tonnage model for goldantimony deposits, by V. I. Berger. 1993. 24 p. (NC, Da, M.)

OF 93-0195. National Earthquake Hazards Reduction Program, summaries of technical reports; Volume XXXIV, compiled by $\mathbf{M}$. L. Jacobson. Prepared by participants in the National Earthquake Hazards Reduction Program. 1993. 983 p. (In two volumes.) (NC, Da, M.)

OF 93-0196. A look at the benefits of post-processed differential GPS, by J. T. Gann. 1993. 7 p. (NC, Da, M.)

OF 93-0197-A. Movie footage of the activity of Paricutín Volcano, Michoacán, Mexico, 1945-1952, by Carl Fries, Jr., Kenneth Segerstrom, R. I. Tilling, D. E. White and R. E. Wilcox. 1993. 16 p. (NC, Da, M.)

OF 93-0197-B. Movie footage of the activity of Paricutín Volcano, Michoacán, Mexico, 1945-1952, by Carl Fries, Jr., Kenneth Segerstrom, R. I. Tilling, D. E. White and R. E. Wilcox. 1993. One 45 -minute $1 / 2$ inch VHS videotape. (NC, Da, M.)

OF 93-0198. CALIFORNIA, NEVADA. Geologic map of the New York Mountains area, California and Nevada, by D. M. Miller and J. L. Wooden. 1993.10 p., 1 over-size sheet, scale
1:50,000 (1 inch = about 4,200 feet). (NC, Da, M, U; California Dep. of Conservation, Div. of Mines and Geol., Mail Stop 14-34, Library, 801 K St., Sacramento, CA 95814-3532; 1145 Market St., 3rd Floor, San Francisco, CA 94103; and State Office Bldg., 107 South Broadway, Los Angeles, CA 90012; Nevada Bur. of Mines and Geol., University of Nevada, Reno, NV 89557.)

OF 93-0199. OKLAHOMA, ARKANSAS. Annotated bibliography of graptolite references from Oklahoma, Arkansas, and adjacent areas, with a list of cited species, by Claire Carter. 1993. 22 p. (NC, Da, M.)

OF 93-0200. Modeling sand and gravel deposits; initial strategy and preliminary examples, by J. D. Bliss. 1993. 31 p. (NC, Da, M.)

OF 93-0203. UTAH. Preliminary geologic map of the Enterprise Quadrangle, Washington and Iron counties, Utah, by H. R. Blank, Jr. 1993. 33 p., 1 over-size sheet, scale 1:24,000 (1 inch = 2,000 feet). (NC, Da, M, U; Utah Geol. Surv., 2363 Foothill Dr., Salt Lake City, UT 84109-1403.)

OF 93-0204. Significant earthquakes of the world, 1980-1984, compiled by W. J. Person and edited by J. M. Jacobs. 1993. 27 p. (NC, Da, M.)

OF 93-0205. CALIFORNIA. Preliminary geologic map of the Calabasas 7.5' Quadrangle, Southern California, by R. F. Yerkes and P. K. Showalter. 1993. 11 p., 1 over-size sheet, scale 1:24,000 (1 inch = 2,000 feet). (NC, Da, M; California Dep. of Conservation, Div. of Mines and Geol., Mail Stop 14-34, Library, 801 K St., Sacramento, CA 95814-3532; 1145 Market St., 3rd Floor, San Francisco, CA 94103; and State Office Bldg., 107 South Broadway, Los Angeles, CA 90012.)

OF 93-0206. CALIFORNIA. Preliminary geologic map of the Canoga Park 7.5' Quadrangle, Southern California, compiled by R. F. Yerkes and R. H. Campbell. 1992. 10 p., 1 over-size sheet, scale 1:24,000 (1 inch $=2,000$ feet). (NC, Da, M; California Dep. of Conservation, Div. of Mines and Geol., Mail Stop 14-34, Library, 801 K St., Sacramento, CA 95814-3532; 1145 Market St., 3rd Floor, San Francisco, CA 94103; and State Office Bldg., 107 South Broadway, Los Angeles, CA 90012.)

OF 93-0207. MONTANA. Mineral resource assessment of the Absaroka-Beartooth study area, Custer and Gallatin national forests, Montana, edited by J. M. Hammarstrom, M. L. Zientek and J. E. Elliott. 1993. 295 p., 19 over-size sheets, scale 1:126,720 ( 1 inch $=2$ miles). (NC, Da, M, U, S; Montana Bur. of Mines and Geol., Montana Coll. of Mineral Sci. and Technol., Butte, MT 59701.)

A. The Absaroka-Beartooth study area, by J. M. Hammarstrom, J. E. Elliott, B. S. Van Gosen and M. L. Zientek. p. A1-A22.

B. Geology of the Absaroka-Beartooth study area, by J. E. Elliott, B. S. Van Gosen, E. A. du Bray, E. J. LaRock and M. L. Zientek. p. B1-B23.

C. Geophysics of the Absaroka-Beartooth area, by D. M. Kulik. p. C1-C6.

D. Geochemistry of the Absaroka-Beartooth area, by G. K. Lee and R. R. Carlson. p. D1-D11. 
E. Mineral occurrences and level of exploration, by J. M. Hammarstrom and M. L. Zientek. p. E1-E38.

F. Mineral resource appraisal for locatable minerals; the Stillwater Complex, by M. L. Zientek. p. F1-F83.

G. Mineral resource assessment for locatable minerals (exclusive of the Stillwater Complex), by J. M. Hammarstrom, M. L. Zientek, J. E. Elliott, B. S. Van Gosen, R. R. Carlson, G. K. Lee and D. M. Kulik. p. G1-G78.

H. Hydrocarbon potential of the Absaroka-Beartooth study area; a preliminary summary, by W. J. Perry, Jr. and E. J. LaRock. p. H1-H5.

I. Coal and coal bed methane resources of the AbsarokaBeartooth study area, by J. N. Weaver and J. R. Gruber, Jr. p. I1-I7.

J. Summary of estimates of undiscovered resources, by J. M. Hammarstrom and M. L. Zientek. p. J1-J6.

OF 93-0208-A. Annotated bibliography of metallogenic maps (material mostly published between 1960 and 1987), compiled by M. P. Foose and Karen Bryant. 1993. 91 p. (NC, Da, M.)

OF 93-0208-B. Annotated bibliography of metallogenic maps (material mostly published between 1960 and 1987 ), compiled by $\mathbf{M}$. P. Foose and Karen Bryant. 1993. (NC, Da, M.)

The computer diskette presents this information in three different forms. The first is as ASCII text which can be imported by most IBM PC-compatible word processors. The second is a similar text file in Word for Windows format. The third is in Lotus 123 version 1.x format. Most IBM-PC-compatible spreadsheet programs can translate this file. This spreadsheet file enables the user to import these references into most databases and to manipulate (sort and extract) records. The requirements to access these computer files are an IBM PC or compatible computer capable of running standard word processing and spreadsheet software, and reading 51/4 inch $1.2 \mathrm{MB}$ high-density diskettes.

OF 93-0210. LOUISIANA. Louisiana Coastal Geographic Information System Network; alpha version 0.1, year three final report, by R. A. McBride, M. W. Hiland, F. W. Jones, DeWitt Braud, Jr., L. D. Wayne, H. R. Streiffer, M. C. Carpenter, A. J. Lewis, Sudish Mogli, Jay Arnold, Srinivasa Lingineni and S. J. Williams. 1993. 96 p. (NC, Da, M.)

Louisiana Coastal GIS Network; relational database design for a spatially indexed cataloging system, by M. W. Hiland, L. D. Wayne and H. R. Streiffer. p. 30-46. (NC, Da, M.)

OF 93-0211. OREGON, WASHINGTON. Aeromagnetic map of the Portland-Vancouver metropolitan area, Oregon and Washington, by S. L. Snyder, T. J. Felger, R. J. Blakely and R. E. Wells. 1993. 1 over-size sheet, scale 1:100,000 (1 inch = about 1.6 miles). (NC, Da, M, S; Washington DNR/Div. of Geol. and Earth Resources Library, 1111 Washington St. SE, Olympia, WA 98501 (mail address: PO Box 47007, Olympia, WA 98504-7007; Oregon Dep. of Geol. and Industries, Suite 965, 800 NE Oregon St. No. 28, Portland, OR 97232.)

OF 93-0212. OREGON, WASHINGTON. Characteristics of sediments from selected lakes of Oregon and Washington and their potential for obtaining high-resolution paleoclimate records, by $\mathrm{W}$. E. Dean and J. P. Bradbury. 1993. 21 p. (NC, Da, M, S; Dep. of Geol. and Mineral Industries, 910 State Office Bldg., Portland, OR 97201-5528; and Earth Resources Div., Dep. of Natural Resources, Olympia, WA 98504; David A. Johnston Cascade Volcano Observatory, 5400 MacArthur Blvd., Vancouver, WA 98661.)

OF 93-0213. HAWAII. Map of debris-flow hazard in Honolulu District of Oahu, Hawaii, by S. D. Ellen, R. K. Mark, S. H. Cannon and D. L. Knifong. 1993. 28 p., 1 over-size sheet. (NC, Da, M.)

OF 93-0214. Texture of the surficial sediments in Fishers Island Sound, by L. J. Poppe, R. S. Lewis and A. M. Moffett. 1993. 28 p. (NC, Da, M.)

OF 93-0215. ALASKA. Barite deposits in the Howard Pass Quadrangle and possible relations to barite elsewhere in the northwestern Brooks Range, Alaska, by J. S. Kelley, I. L. Tailleur, R. L. Morin, K. M. Reed, A. G. Harris, J. M. Schmidt, F. M. Brown and J. M. Kurtak. 1993. 13 p., 9 over-size sheets; sheet 2, scale 1:63,360 (1 inch = 1 mile). (NC, Da, M, A, S; U.S. Dep. of Interior, Alaska Resource Library, $701 \mathrm{C}$ St., Box 36. Anchorage, AK 99513; Alaska Div. of Geol. and Geophys. Surv., 794 University Ave., Suite 200, Fairbanks, AK 99709-3645.)

OF 93-0216. Dense three-dimensional array near Garni, Armenia as part of the Joint Eurasian Seismic Studies Program (objectives, array design, archived data, and preliminary wave-slowness analysis), edited by G. N. Glassmoyer and R. D. Borcherdt. 1993. 450 p. (NC, Da, M.)

1. Summary and objectives for a dense three-dimensional array near Garni, Armenia, by J. R. Filson, R. D. Borcherdt, W. H. Lee, Edward Cranswick, C. M. Dietel, E. D. Sembera, J. J. Mori, Joe Sena, L. Hakhverdian, R. Amirbekian, V. Aharonian, K. Safarian, H. Galagian, G. Apoian and Robert Banfill. p. 1-3.

2. Site selection, array design, and recording instrumentation for the dense three-dimensional array near Garni, Armenia, by R. D. Borcherdt, J. R. Filson, W. H. Lee, Edward Cranswick, C. M. Dietel, G. N. Glassmoyer, E. D. Sembera, J. J. Mori, L. Hakhverdian, R. Amirbekian, V. Aharonian, K. Safarian, H. Galagian, G. Apoian and Robert Banfill. p. 4-16.

3. Digital GEOS data from Garni, Armenia as archived on optical disk, by G. N. Glassmoyer. p. 17-333.

4. A PC-based seismic system for Armenia, by W. H. Lee, Edward Cranswick and Robert Banfill. p. 334-415.

5. Near-surface measurements of $P$ - and $S$-wave velocities from the dense three-dimensional array near Garni, Armenia, by J. J. Mori, J. R. Filson, Edward Cranswick, R. D. Borcherdt, G. N. Glassmoyer, W. H. Lee, R. Amirbekian, V. Aharonian and L. Hakhverdian. p. 416-449.

OF 93-0217-A. CALIFORNIA. Principal facts and base station descriptions for gravity data compiled for the Santa Ana $1^{\circ}$ by $2^{\circ}$ Quadrangle, California, by R. F. Sikora, V. E. Langenheim, Shawn Biehler, L. A. Beyer and R. H. Chapman. 1993. 63 p. (NC, Da, M; California Dep. of Conservation, Div. of Mines and Geol., Mail Stop 14-34, Library, 801 K St., Sacramento, CA 95814-3532; 1145 Market St., 3rd Floor, San Francisco, CA 94103; and State Office Bldg., 107 South Broadway, Los Angeles, CA 90012.) 
OF 93-0217-B. CALIFORNIA. Principal facts and base station descriptions for gravity data compiled for the Santa Ana $1^{\circ}$ by $2^{\circ}$ Quadrangle, California, by R. F. Sikora, V. E. Langenheim, Shawn Biehler, L. A. Beyer and R. H. Chapman. 1993. One 3 $1 / 2$ inch diskette. (NC, Da, M; California Dep. of Conservation, Div. of Mines and Geol., Mail Stop 14-34, Library, $801 \mathrm{~K}$ St., Sacramento, CA 95814-3532; 1145 Market St., 3rd Floor, San Francisco, CA 94103; and State Office Bldg., 107 South Broadway, Los Angeles, CA 90012.)

Requirements: IBM PC or compatible, DOS v. 2.0 or higher, with a $31 / 2$ inch high density disk drive or a Macintosh with a Super Drive and Apple File Exchange software to convert from PC to MAC. On a PC, the file should be read into and out of text editor to align columns. On a Macintosh some editing will be needed to align columns after converting from $\mathrm{PC}$ to $\mathrm{MAC}$.

OF 93-0218. Planktic foraminifer census data from Northwind Ridge cores PI-88-AR P3, PI-88-AR P7 and PI-88-AR P9, Arctic Ocean, by K. M. Foley and R. Z. Poore. 1993. 11 p. (NC, Da, M.)

OF 93-0219. CALIFORNIA. Digital recordings of aftershocks of the April 25 and 26, 1992, Cape Mendocino, California, earthquakes, by D. L. Carver. 1993. 64 p. (NC, Da, M; California Dep. 'of Conservation, Div. of Mines and Geol., Mail Stop 14-34, Library, 801 K St., Sacramento, CA 95814-3532; 1145 Market St., 3rd Floor, San Francisco, CA 94103; and State Office Bldg., 107 South Broadway, Los Angeles, CA 90012.)

OF 93-0220. NEVADA. Preliminary geologic map of the Rowland-Bearpaw Mountain area, Elko County, Nevada, by K. B. Ketner, J. E. Repetski, B. R. Wardlaw and R. G. Stamm. 1993. 1 over-size sheet, scale $1: 24,000$ ( 1 inch $=2,000$ feet $)$. (NC, Da, M, U; Nevada Bur. of Mines and Geol., Univ. of NevadaReno, Reno, NV 89557-0088.)

OF 93-0221. Location of acoustic sources using seismological techniques and software, by J. C. Lahr and F. G. Fischer. 1993. 9 p. (NC, Da, M.)

OF 93-0222. VIRGINIA. Stratigraphic distribution and bibliography of fossil fish, amphibians, and reptiles from Virginia, by R. E. Weems. 1993. 49 p. (NC, Da, M, Wa; Virginia Div. of Mineral Resources, P.O. Box 3667, Charlottesville, VA 22903.)

OF 93-0223. CALIFORNIA. Preliminary maps showing Quaternary geology of the Patterson and Crows Landing 7.5-minute quadrangles, California, by J. M. Sowers, J. S. Noller and W. R. Lettis. 1993. 3 over-size sheets, scale 1:24,000 (1 inch $=2,000$ feet). (NC, Da, M; California Dep. of Conservation, Div. of Mines and Geol., Mail Stop 14-34, Library, 801 K St., Sacramento, CA 95814-3532; 1145 Market St., 3rd Floor, San Francisco, CA 94103; and State Office Bldg., 107 South Broadway, Los Angeles, CA 90012.)

OF 93-0224. CALIFORNIA. Preliminary maps showing Quaternary geology of the Solyo and Lone Tree Creek 7.5-minute quadrangles, California, by J. S. Noller, J. M. Sowers and W. R. Lettis. 1993. 3 over-size sheets, scale 1:24,000 (1 inch $=2,000$ feet). (NC, Da, M; California Dep. of Conservation, Div. of Mines and Geol., Mail Stop 14-34, Library, 801 K St., Sacramento, CA 95814-3532; 1145 Market St., 3rd Floor, San Francisco, CA 94103; and State Office Bldg., 107 South Broadway, Los Angeles, CA 90012.)
OF 93-0225. CALIFORNIA. Preliminary maps showing Quaternary geology of the Tracy and Midway 7.5-minute quadrangles, California, by J. M. Sowers, J. S. Noller and W. R. Lettis. 1993. 3 over-size sheets, scale 1:24,000 (1 inch $=2,000$ feet). (NC, Da, M; California Dep. of Conservation, Div. of Mines and Geol., Mail Stop 14-34, Library, 801 K St., Sacramento, CA 95814-3532; 1145 Market St., 3rd Floor, San Francisco, CA 94103; and State Office Bldg., 107 South Broadway, Los Angeles, CA 90012.)

OF 93-0226. Program TracePlot, version 2.0; seismic trace plotting program for the Macintosh, by J. J. Miller. 1993. 17 p., one 3 $1 / 2$ inch diskette. (NC, Da, M.) (Supersedes OF 93-5.)

Diskette is $31 / 2$ inch, $800 \mathrm{~K}$ Macintosh format.

OF 93-0227. CALIFORNIA. The Southern California Network Bulletin, January-December 1992, by L. A. Wald, Kathy Watts, J. J. Mori and Katrin Douglass. 1993. 54 p. (NC, Da, M; California Dep. of Conservation, Div.. of Mines and Geol., Mail Stop 14-34, Library, 801 K St., Sacramento, CA 95814-3532; 1145 Market St., 3rd Floor, San Francisco, CA 94103; and State Office Bldg., 107 South Broadway, Los Angeles, CA 90012.)

OF 93-0228. Grade-tonnage data for detachment-fault related polymetallic deposits, by K. R. Long. 1993.18 p. (NC, Da, M.)

OF 93-0230. OKLAHOMA. Porosity, depth, and thermal-maturity data for sandstones of the Anadarko Basin, Oklahoma, and other selected locations in the Northern Hemisphere, by T. C. Hester and J. W. Schmoker. 1993. 46 p. (NC, Da, M.)

OF 93-0231. VIRGINIA. Data, software, and applications for education and research in geology; Virginia, by R. A. Ambroziak, G. R. Woodwell, C. A. Cook and R. E. Wicks. 1993. One CD-ROM. (NC, Da, M, Wa; Virginia Div. of Mineral Resources, Natural Resources Bldg., Alderman and McCormick Rds., P.O. Box 3667, Charlottesville, VA 22903.)

IBM or compatible personal computer, preferably having an 80386 or higher numbered processor; 640K RAM; MS- or PC-DOS version 3.1 or later; Microsoft MSCDEX version 2.1 or later; CD-ROM drive with ISO 9660 software driver; mouse; super VGA, 156 colors, necessary for imaging, EGA/VGA minimum for mapping; and math coprocessor desirable.

OF 93-0232. CALIFORNIA. Uranium-series dates on sediments of the high shoreline of Panamint Valley, California, by J. A. Fitzpatrick and J. L. Bischoff. 1993. 15 p. (NC, Da, M; California Dep. of Conservation, Div. of Mines and Geol., Mail Stop 14-34, Library, 801 K St., Sacramento, CA 95814-3532; 1145 Market St., 3rd Floor, San Francisco, CA 94103; and State Office Bldg., 107 South Broadway, Los Angeles, CA 90012,)

OF 93-0233. WASHINGTON. Geologic map of surficial deposits in the Seattle $30^{\prime} \times 60^{\prime}$ Quadrangle, by J. C. Yount, J. P. Minard and G. R. Dembroff. 1993. 2 over-size sheets; sheet 1 , scale $1: 100,000$ (1 inch = about 1.6 miles). (NC, Da, M, S; Washington DNR, Div. of Geol. and Earth Resources Library, 1111 Washington St. SE, Olympia, WA 98501.)

OF 93-0234-A. Interactive inversion of transient electromagnetic data for a central-induction loopover layered earth models (version 1.0.), by W. L. Anderson. 1993. 33 p. (NC, Da, M.)

OF 93-0234-B. Interactive inversion of transient electromagnetic data for a central-induction loop over layered earth models (version 
1.0), by W. L. Anderson. 1993. One $31 / 2$ inch diskette. (NC, $\mathrm{Da}, \mathrm{M}$.

Minimum hardware requirements: 386 IBM compatible PC; 2MB RAM; math coprocessor; EGA or VGA video adapter and monitor; hard disk with more than $3 \mathrm{MB}$ free space; and a 1.44MB (HD) floppy disk drive. Minimum software requirements: MS-DOS 3.0 or higher; and RSoft (TM) Inc. RPlot Scientific Graphics (version 2.05).

OF 93-0235. IDAHO. Structural analysis and ore controls in the Coeur d'Alene mining district, Idaho, by R. R. Reid, T. J. Hayden, C. S. Wavra and W. D. Bond. 1993. 66 p. (NC, Da, M, U, S; Idaho Geol. Surv., Morrill Hall, Room 332, Univ. of Idaho Campus, Moscow, ID 83843.)

OF 93-0236. MICHIGAN. Preliminary data on the lithology, bromine distribution, and insoluble minerals from the A-1 Evaporite Formation, Salina Group, in the JEM Petroleum Corporation, Bruggers 3-7 Core, Missaukee County, Michigan, by O. B. Raup and R. J. Hite. 1993. 15 p. (NC, Da, M; Geol. Surv. Div., Michigan Dep. of Natural Resources, P.O. Box 30028, Lansing, MI 48909.)

OF 93-0237. Drift ice as a geologic agent, by S. M. Wessells, Erk Reimnitz, P. W. Barnes and E. W. Kempema. 1993. One 20minute VHS video tape. (NC, D绐 M.)

OF 93-0238. ALASKA. Onshore-offshore wide-angle seismic recordings of the 1989 Alaskan EDGE profile; five-day recorder data, by T. M. Brocher and M. J. Moses. 1993. 25 p. (NC, Da, M.)

OF 93-0240-A. NURE stream sediment geochemical data indicative of prospective terranes for Ti-Zr-REE placer exploration in selected regions of the United States, by A. E. Grosz. 1993. 157 p. (NC, Da, M.)

OF 93-0240-B. NURE stream sediment geochemical data indicative of prospective terranes for Ti-Zr-REE placer exploration in selected regions of the United States, by A. E. Grosz. 1993. One $51 / 4$ inch diskette. (NC, Da, M.)

Requirements: IBM PC or compatible; minimum 640K RAM. Diskette containing text and data in ASCII (DOS) format; $51 / 4$ inch, $1.2 \mathrm{MB}$ capacity.

OF 93-0241-A. GKS-PC; a kernel graphics programming system for IBM-PC and compatible microcomputers, by R. H. Balay. 1993. 52 p. (NC, Da, M.)

OF 93-0241-B. GKS-PC; a kernel graphics programming system for IBM-PC and compatible microcomputers, by R. H. Balay. 1993. One $51 / 4$ inch diskette. (NC, Da, M.)

Requirements; IBM-PC or compatible; minimum $400 \mathrm{~K}$ free memory; MS-DOS 3.3 or higher; CGA, EGA, VGA, AT\&T or Hercules graphics adapter and compatible monitor; Epson compatible dot matrix printer; (optional) Summagraphics compatible graphics tablet. A numeric coprocessor is optional, but recommended.

OF 93-0242. MudScan; PC based sidescan sonar real-time data acquisition, logging and display system, by J. T. Gann, L. D. Kooker and M. E. Boyle. 1993. 23 p. (NC, Da, M.)

OF 93-0243. NEW JERSEY. Analytical results for As species and related elements in interstitial porewater and sediment from the
Maurice River and Union Lake in Vineland, New Jersey, by W. H. Ficklin, L. S. Balistrieri, P. L. Hageman, C. S. Papp, D. L. Fey and Matthew Westgate. 1993. 24 p. (NC, Da, M.)

OF 93-0244. VIRGINIA, NORTH CAROLINA. Preliminary geologic map of the South Boston $30 \times 60$ minute Quadrangle, Virginia and North Carolina, by J. W. Horton, Jr., J. D. Peper, J. D. Marr, Jr., W. C. Burton and P. E. Sacks. Prepared in cooperation with the Virginia Division of Mineral Resources. 1993. 20 p., 1 over-size sheet. scale 1:100,000 (1 inch = about 1.6 miles $)$. (NC, Da, M, Wa; Virginia Div. of Mineral Resources, Natural Resources Bldg., Alderman and McCormick Rd., P.O. Box 3667, Charlottesville, VA 22903; Div. of Land Resources, Dep. of Natural Resources and Community Dev., 512 North Salisbury St., P.O. Box 27687, Raleigh, NC 27611.)

OF 93-0245. Microcrack populations associated with a propagating shear fracture in granite, by D. E. Moore. 1993.88 p. (NC, Da, M.)

OF 93-0248. Petroleum exploration plays and resource estimates, 1989, onshore United States; Region 3, Colorado Plateau and Basin and Range, edited by R. B. Powers. 1993. 112 p. (NC, Da, M, S, U; Idaho Geol. Surv., Univ. of Idaho Campus, Morrill Hall, Room 332, Moscow, ID 83843; Nevada Bur. of Mines and Geol., Univ. of Nevada-Reno, Reno, NV 89557-0088; Bur. of Geol. and Mineral Technol., 845 North Park Ave., Tucson, AZ 85719; Utah Geol. Surv., 2363 Foothill Dr., Salt Lake City, UT 84109-1403; New Mexico Bur. of Mines and Mineral Resources, Campus Station, Socorro, NM 87801; Geol. Surv. of Wyoming, P.O. Box 3008, University Station, Laramie, WY 82071; John W. Rold, Colorado Geol. Surv., 1313 Sherman St., Room 715, Denver, CO 80203; Donald Fawcett, Office of the State Engineer, Ground Water Section, 1313 Sherman St., Room 818, Denver, CO 80203.)

Introduction, by R. B. Powers. p. 1-8.

Geologic framework, by R. B. Powers. p. 9-10.

Eastern Basin and Range Province (082), by J. A. Peterson. p. 11-16.

Western Basin and Range Province (083), by H. E. Cook. p. 17-20.

Idaho-Snake River downwarp province (084), by J. A. Peterson. p. 21-24.

Paradox Basin province (085), by J. A. Peterson. p. 25-34.

Uinta-Piceance-Eagle basins province (086), by C. W. Spencer. p. 35-44.

Park basins province (087), by E. K. Maughan. p. 45-48.

San Juan Basin province (088), by A. C. Huffman, Jr. p. $49-$ 65.

Albuquerque-Santa Fe-San Luis Rift basins province (089), by C. M. Molenaar. p. 66-73.

Wyoming-Utah-Idaho thrust belt province (090), by R. B. Powers. p. 74-92.

North Arizona province (091), by W. C. Butler. p. 93-98.

South-central New Mexico province (092), by W. C. Butler. p. 99-102. 
Southern Arizona-southwestern New Mexico province, by W. C. Butler. p. 103-106.

OF 93-0249. NEVADA. Quantitative geochemistry of rocks from the Adelaide mining district, Humboldt County, Nevada, by T. M. Cookro. 1993. 169 p. (NC, Da, M, U; Nevada Bur. of Mines and Geol., Univ. of Nevada-Reno, Reno, NV 89557-0088.)

OF 93-0250. COLORADO. Colorado's ancient bristlecone pines, by F. C. Brunstein. 1993. 5 p. (NC, Da, M, U; John W. Rold, Colorado Geol. Surv., 1313 Sherman St., Room 715, Denver, CO 80203; Donald Fawcett, Office of the State Engineer, Ground Water Section, 1313 Sherman St., Room 818, Denver, CO 80203.)

OF 93-0251. Introduction to wide area information servers, by $E$. J. Christian. 1993. One 35-minute VHS videotape. (NC, Da, M.)

OF 93-0255. Lithological and geophysical characteristics of the Pakistan Mineral Development Corporation's THL core hole; implications for the coal resource potential of the lower and middle part of the Bara Formation in the Lakhra area of Sindh, Pakistan, by Christopher Wnuk, J. R. SanFilipo, S. F. Fatmi, S. A. Khan and Mohammad Fariduddin. Prepared in cooperation with the Geological Survey of Pakistan. 1993. 137 p. (NC, Da, M.)

OF 93-0256. The stratigraphy and coal resource potential of the Bara Formation in the Fort Ranikot area, Sindh Province, Pakistan; a progress report, by Christopher Wnuk, J. R. SanFilipo, A. H. Chandio and S. F. Fatmi. Prepared in cooperation with the Geological Survey of Pakistan. 1993. 63 p. (NC, Da, M.)

OF 93-0257. An all-weather time-lapse video recording station, by Henry Chezar and J. E. Thomas. 1993. 9 p. (NC, Da, M.)

OF 93-0258-A. Evaluation of the United States Geological Survey's three-step assessment methodology, by D. P. Harris and Michael Rieber. 1993. 675 p. (NC, Da, M.)

OF 93-0258-B. Evaluation of the United States Geological Survey's three-step assessment methodology, by D. P. Harris and Michael Rieber. 1993. Two 3 1/2 inch diskettes. (NC, Da, M.)

Minimum hardware requirements: IBM compatible PC; $1.2 \mathrm{MB}$ floppy disk drive. Minimum software requirements: MS-DOS 3.0 or higher; and WordPerfect 5.0 or higher.

OF 93-0259-A. OREGON. Analytical results and sample locality map of stream-sediment, heavy-mineral-concentrate, and rock samples from the Upper Leslie Gulch (OR-003-074) and Slocum Creek (OR-003-075) Wilderness Study Areas, Malheur County, Oregon, by P. L. Hageman, H. D. King, J. L. Jones and M. S. Erickson. 1993. 23 p. (NC, Da, M, S; Dep. of Geol. and Mineral Industries, 910 State Office Bldg., Portland, OR 97201-5528.)

OF 93-0259-B. OREGON. Analytical results and sample locality map of stream-sediment, heavy-mineral-concentrate, and rock samples from the Upper Leslie Gulch (OR-003-074) and Slocum Creek (OR-003-075) Wilderness Study Areas, Malheur County, Oregon, by P. L. Hageman, H. D. King, J. L. Jones and M. S. Erickson. 1993. One 5 1/4 inch diskette. (NC, Da, M. S; Dep. of Geol. and Mineral Industries, 910 State Office Bldg., Portland, OR 97201-5528.)

Data files on diskette are in STATPAC (NST) format. An executable data conversion program, STP2DAT.EXE has been included to provide various format options into which the NST file may be changed. Text file is in ASCII format. Requirements: IBM compatible computer using MS DOS with a $51 / 4$ inch, $360 \mathrm{~K}$ drive.

OF 93-0260. UTAH. Analytical results for soil samples collected at the Roosevelt Hot Springs Known Geothermal Resource Area, Utah 1976-1987, by M. E. Hinkle. 1993. 14 p., one $51 / 4$ inch diskette. (NC, Da, M, U; Utah Geol. Surv., 2363 Foothill Dr., Salt Lake City, UT 84109-1403.)

Requirements: IBM or compatible PC using MS DOS, with a 5 $1 / 4$ inch, $360 \mathrm{~K}$ drive.

OF 93-0262-A. A bibliography of geomorphometry with a topical key to the literature and an introduction to the numerical characterization of topographic form, by R. J. Pike. 1993 . $132 \mathrm{p}$. (NC, Da, M.)

OF 93-0262-B. A bibliography of geomorphometry with a topical key to the literature and an introduction to the numerical characterization of topographic form, by R. J. Pike. 1993. (NC, Da, M.)

Macintosh version consisting of one text file on one $31 / 2$ inch 1.44MB diskette. Formatted in Microsoft Word, version 5.0

OF 93-0262-C. A bibliography of geomorphometry with a topical key to the literature and an introduction to the numerical characterization of topographic form, by R. J. Pike. 1993. (NC, Da, M.)

IBM-PC or compatible version, consisting of one text file on one $31 / 2$ inch $1.44 \mathrm{MB}$ diskette. Formatted in WordPerfect, version 5.0

OF 93-0263. CALIFORNIA. Geologic setting of the East Antelope Basin, with emphasis on fissuring on Rogers Lake; Edwards AFB, Mojave Desert, California, by A. W. Ward, G. L. Dixon and R. C. Jachens. 1993. 9 p. (NC, Da, M; California Dep. of Conservation, Div. of Mines and Geol., Mail Stop 14-34, Library, 801 K St., Sacramento, CA 95814-3532; 1145 Market St., 3rd Floor, San Francisco, CA 94103; and State Office Bldg., 107 South Broadway, Los Angeles, CA 90012.)

OF 93-0264. Cape Hatteras to the Mid Atlantic Ridge; demultiplexing and archiving a unique multichannel seismic reflection data set, by W. F. Agena, D. R. Hutchinson, M. W. Lee and H. L. Oliver. 1993.19 p. (NC, Da, M.)

OF 93-0266. ALASKA. Acoustic profiles of sediment in a meltwater lake adjacent to the Bering Glacier, Alaska, RV Karluk Cruise K2-91-YB, July 1-7, 1991, by P. R. Carlson, R. A. Tagg and B. F. Molnia. 1993. 26 p. (NC, Da, M, A, S; U.S. Dep. of the Interior, Alaska Resource Library, 701 C St., Box 36, Anchorage, AK 99513; Alaska Dep. of Natural Resources, Div. of Geol. and Geophys. Surv., 794 University Ave., Suite 200, Fairbanks, AK 99709-3645.)

OF 93-0267. Abundances of $\mathrm{Li}, \mathrm{Rb}$, and $\mathrm{Sr}$ in $\mathrm{W}-2, \mathrm{BCR}-1$, and AC-E determined by isotope dilution mass spectroscopy, by Norma Rait, F. G. Walthall and J. A. Philpotts. 1993. 6 p. (NC, Da, M.)

OF 93-0268-A. INDIANA. Preliminary digital Quaternary geologic map data for Indiana, by D. R. Soller and Wai-See Moy. 1993. 5 p. (NC, Da, M.) 
OF 93-0268-B. INDIANA. Preliminary digital Quaternary geologic map data for Indiana, by D. R. Soller and Wai-See Moy. 1993. Four $31 / 2$ inch DS/HD diskettes. (NC, Da, M.)

Requirements; a computer with DOS (version 2.01 or higher) operating system, $31 / 2$ inch high-density disk drive, and a hard disk drive with at least $5 \mathrm{MB}$ of unused storage space; a computer with ARC/INFO GIS software; and a method of file transfer between these computers, unless the DOS computer also supports ARC/INFO.

OF 93-0270. UTAH. Sedimentological descriptions and geophysical logs of two 300-m cores collected from the Straight Cliffs Formation of the Kaiparowits Plateau, Kane County, Utah, by R. D. Hettinger. 1993. 50 p. (NC, Da, M, U; Utah Geol. Surv., 2363 Foothill Dr., Salt Lake City, UT 84109-1403.)

OF 93-0271. CALIFORNIA. Preliminary geologic map of the onshore part of the Palo Alto 1:100,000 Quadrangle, California, compiled by E. E. Brabb. 1993. 21 p., 1 over-size sheet, scale 1:62,500 (1 inch = about 1 mile). (NC, Da, M; California Dep. of Conservation, Div. of Mines and Geol., Mail Stop 14-34, Library, 801 K St., Sacramento, CA 95814-3532; 1145 Market St., 3rd Floor, San Francisco, CA 94103; and State Office Bldg., 107 South Broadway, Los Angeles, CA 90012.)

OF 93-0272. CALIFORNIA. Death Valley, California; surface micro-relief statistics and radar scatterometer data, by G. G. Schaber and G. L. Berlin. Prepared for the National Aeronautics and Space Administration. 1993. 232 p. (NC, Da, M; California Dep. of Conservation, Div. of Mines and Geol., Mail Stop 14-34, Library, 801 K St., Sacramento, CA 95814-3532; 1145 Market St., 3rd Floor, San Francisco, CA 94103; and State Office Bldg., 107 South Broadway, Los Angeles, CA 90012.)

OF 93-0273. ARKANSAS, TENNESSEE. Progress report on chronostratigraphic and paleoclimatic studies, middle Mississippi River valley, eastern Arkansas and western Tennessee, edited by H. W. Markewich. 1993. 61 p. (NC, Da, M.)

Regional geology and stratigraphic framework, by $\mathrm{H}$. W. Markewich. p. 4-6.

Carbon-14, by Meyer Rubin, J. P. McGeehin and H. W. Markewich. p. 6-7.

Beryllium-10, by M. J. Pavich. p. 7-8.

TL, OSL, and IRSL dating techniques, by H. T. Millard, Jr. and P. B. Maat. p. 8-9.

Detailed loess and Paleosol stratigraphy, by L. B. Ward, E. M. Rutledge and D. A. Wysocki. p. 9-23.

Composition of MMV loess, by S. G. Van Valkenburg and H. W. Markewich. p. 23.

Mineral magnetic studies of MMV loess, by D. T. Rodbell, J. G. Rosenbaum and R. L. Reynolds. p. 23-25.

Palynology of latest Pleistocene Loosahatchie River sediments, by F. J. Rich. p. 25-27.

OF 93-0274. X-ray mineralogy of sediments from the southern Black Sea and selected rivers, by L. J. Poppe and B. J. Hay. 1993. 13 p. (NC, Da, M.)

OF 93-0276. CALIFORNIA. Onshore-offshore wide-angle seismic recordings of the San Francisco Bay area seismic imaging experiment (BASIX); the five-day recorder data, by T. M. Brocher and M. J. Moses. 1993. 89 p. (NC, Da, M; California Dep. of Conservation, Div. of Mines and Geol., Mail Stop 14-34, Library, 801 K St., Sacramento, CA 95814-3532; 185 Berry St., Suite 3600, San Francisco, CA 94107-1728; and State Office Bldg., 107 South Broadway, Los Angeles, CA 90012.)

OF 93-0277. CALIFORNIA. Aeromagnetic map of the San Jose 1:100,000 scale Quadrangle, California, by C. W. Roberts and R. C. Jachens. 1993. 1 over-size sheet, scale 1:100,000 (1 inch $=$ about 1.6 miles). (NC, Da, M; California Dep. of Conservation, Div. of Mines and Geol., Mail Stop 14-34; Library, $801 \mathrm{~K}$ St., Sacramento, CA 95814-3532; 185 Berry St., Suite 3600, San Francisco, CA 94107-1728; and State Office Bldg., 107 South Broadway, Los Angeles, CA 90012.)

OF 93-0278-A. Landslide effects, by T. R. Alpha. 1993. 43 p. (NC, Da, M.)

OF 93-0278-B. Landslide effects, by T. R. Alpha. 1993. One 3 $1 / 2$ inch diskette. (NC, Da, M.)

Requirements: Apple Computer, HyperCard 2.0 software, and an Apple Macintosh computer with high-density drive. If using System 7, recommend usage of at least $3 \mathrm{MB}$ of RAM with 1.5MB of system memory available for HyperCard.

OF 93-0279. CALIFORNIA. Schlumberger soundings near Twentynine Palms, California, by R. J. Bisdorf. 1993. 72 p. (NC, Da, M; California Dep. of Conservation, Div. of Mines and Geol., Mail Stop 14-34, Library, 801 K St., Sacramento, CA 95814-3532; 185 Berry St., Suite 3600, San Francisco, CA $94107-$ 1728; and State Office Bldg., 107 South Broadway, Los Angeles, CA 90012.)

OF 93-0280. Digital grade and tonnage data for 50 types of mineral deposits; Macintosh version, by D. A. Singer, D. L. Mosier and W. D. Menzie. 1993. One $31 / 2$ inch diskette. (NC, Da, M.)

Requirements for the program are: any word processor or spreadsheet program that can read text formatted data that is tab delineated, and an Apple Macintosh computer.

OF 93-0281. Analysis of soil reference materials PL-1 and BPGM1 for the Polish Committee on Standardization Measures and Quality Control, by S. A. Wilson, P. H. Briggs, J. S. Mee and D. F. Siems. 1993. 18 p. (NC, Da, M.)

OF 93-0282. COLORADO. A direct-current resistivity survey near Mineral Hot Springs, San Luis Valley, Colorado, by A. A. Zohdy and R. J. Bisdorf. 1993. 61 p. (NC, Da, M, U; John W. Rold, Colorado Geol. Surv., 1313 Sherman St., Room 715, Denver, CO 80203; Donald Fawcett, Office of the State Engineer, Ground Water Section, 1313 Sherman St., Room 818, Denver, CO 80203.)

OF 93-0284. WASHINGTON. Occurrences of Recent and Holocene intertidal diatoms (Bacillariophyta) in northern Willapa Bay, Washington, by Eileen Hemphill-Haley. 1993. 94 p. (NC, Da, M, S; Washington DNR/Div. of Geol. and Earth Resources Library, 1111 Washington St. SE, Olympia, WA 98501.)

OF 93-0285-A. MONTANA. Bibliography of geologic references (1872-1992) to the Absaroka-Beartooth Study Area in the Custer and Gallatin national forests, south-central Montana, compiled by B. S. Van Gosen. 1993. 71 p. (NC, Da, M, U, S; Montana Bur. 
of Mines and Geol., Montana Coll. of Mineral Sci. and Technol., Butte, MT 59701.)

OF 93-0285-B. MONTANA. Bibliography of geologic references (1872-1992) to the Absaroka-Beartooth Study Area in the Custer and Gallatin national forests, south-central Montana, compiled by B. S. Van Gosen. 1993. One $51 / 4$ inch diskette. (NC, Da, M, U, S; Montana Bur. of Mines and Geol., Montana Coll. of Mineral Sci. and Technol., Butte, MT 59701.)

The bibliography is provided on $51 / 4$ inch, high-density (1.2MB) diskette in two IBM-compatible formats: (1) a WordPerfect (version 5.1) file, and (2) an ASCII data file. The ASCII data file should be amenable to transport into most IBM-compatible word-processing programs.

OF 93-0286. CALIFORNIA. Uranium-series dates on oyster shells from marine terraces of San Pablo Bay, California, by E. J. Helley, J. A. Fitzpatrick and J. L. Bischoff. 1993. 4 p. (NC, $\mathrm{Da}, \mathrm{M} ;$ California Dep. of Conservation, Div. of Mines and Geol., Mail Stop 14-34, Library, 801 K St., Sacramento, CA 95814-3532; 1145 Market St., 3rd Floor, San Francisco, CA 94103; and State Office Bldg., 107 South Broadway, Los Angeles, CA 90012.)

OF 93-0287. HYPERMAG; an interactive, 2- and 2 1/2-dimensional gravity and magnetic modeling program; version 3.5 , by $R$. W. Saltus and R. J. Blakely. 1993. 39.p. (NC, Da, M.)

Requirements: a computer with an ANSI77 Fortran compiler, a $\mathrm{C}$ compiler, and the $\mathrm{X}$-windows library (MIT X11 version 5 or later). To edit the plot files produced by HYPERMAG, a graphics program that understands Adobe Illustrator input format is required. To make hardcopy of the HYPERMAG plots, you need a PostScript printer, or conversion software that accepts PostScript.

OF 93-0289. WASHINGTON. Taxonomy of Recent and fossil (Holocene) diatoms (Bacillariophyta) from northern Willapa Bay, Washington, by Eileen Hemphill-Haley. 1993. 151 p. (NC, Da, M, S; Washington DNR, Div. of Geol. and Earth Resources Library, 1111 Washington St. SE, Olympia, WA 98501.)

OF 93-0290. CALIFORNIA. USGS National Earthquake Hazard Reduction Program (NEHRP) in Northern California in FY93, by W. H. Bakun. 1993. 20 p. (NC, Da, M; California Dep. of Conservation, Div. of Mines and Geol., Mail Stop 14-34, Library, 801 K St., Sacramento, CA 95814-3532; 1145 Market St., 3rd Floor, San Francisco, CA 94103; and State Office Bldg., 107 South Broadway, Los Angeles, CA 90012.)

OF 93-0291. MISSOURI. Description of insoluble residues from the T. P. Russell No. 1 drill hole and other drill holes in southeastern Missouri, by D. S. Collins and R. A. Bohm. 1993. (NC, Da, M; Dep. of Natural Resources, Div. of Geol. and Land Surv., 111 Fairgrounds Rd., P.O. Box 250, Rolla, MO 65401.)

OF 93-0292-G. Geologic radon potential of EPA Region 7; Iowa, Kansas, Missouri, and Nebraska, edited by R. R. Schumann. Prepared in cooperation with the U.S. Environmental Protection Agency. 1993. 147 p. (NC, Da, M; Iowa Geol. Surv., 123 North Capitol St., Iowa City, IA 52242; Kansas Geol. Surv., 1930 Constant Ave., Campus West, Univ. of Kansas, Lawrence, KS 66046; Dep. of Natural Resources, Div. of Geol. and Land Surv., 111 Fairgrounds Rd., P.O. Box 250, Rolla, MO 65401; Conservation and Surv. Div., Institute of Agriculture and Natural Resources, 113 Nebraska Hall, Univ. of Nebraska, Lincoln, NE 68588-0517.)
1. The USGS/EPA state radon potential assessments; an introduction, by L. C. Gundersen, R. R. Schumann and S. W. White. p. 1-35.

2. EPA Region 7 geologic radon potential summary, by R. R. Schumann, J. K. Otton and S. L. Szarzi. p. 36-45.

3. Preliminary geologic radon potential assessment of Iowa, by R. R. Schumann. p. 46-70.

4. Preliminary geological radon potential assessment of Kansas, by R. R. Schumann. p. 71-95.

5. Preliminary geologic radon potential assessment of Missouri, by J. K. Otton. p. 96-124.

6. Preliminary geologic radon potential assessment of Nebraska, by R. R. Schumann. p. 125-147.

OF 93-0292-H. Geologic radon potential of EPA Region 8; Colorado, Montana, North Dakota, South Dakota, Utah, and Wyoming, edited by R. R. Schumann. Prepared in cooperation with the U.S. Environmental Protection Agency. 1993. 184 p. (NC, Da, M, U, S; Vicki J. Cowart, Colorado Geol. Surv., 1313 Sherman St., Room 715, Denver, CO 80203; Donald Fawcett, Office of the State Engineer, Ground Water Section, 1313 Sherman St., Room 818, Denver, CO 80203; Montana Bur. of Mines and Geol., Montana Coll. of Mineral Sci. and Technol., Butte, MT 59701; North Dakota Geol. Surv., University Station, Grand Forks, ND 58202 8156; Dep. of Water and Natural Resources; South Dakota Geol. Surv., Sci. Ctr., Univ. of South Dakota, Vermillion, SD 57069; Utah Geol. Surv., 2363 Foothill Dr., Salt Lake City, UT 841091403; Geol. Surv. of Wyoming, P.O. Box 3008, University Station, Laramie, WY 82071.)

1. The USGS/EPA state radon potential assessments; an introduction, by L. C. Gundersen, R. R. Schumann and S. W. White. p. 1-35.

2. EPA Region 8 geologic radon potential summary, by R. R. Schumann, D. E. Owen, R. F. Dubiel and S. L. Szarzi. p. $36-41$.

3. Preliminary geologic radon potential assessment of Colorado, by R. F. Dubiel. p. 42-68.

4. Preliminary geologic radon potential assessment of Montana, by D. E. Owen. p. 69-90.

5. Preliminary geologic radon potential assessment of North Dakota, by R. R. Schumann. p. 91-115.

6. Preliminary geologic radon potential assessment of South Dakota, by R. R. Schumann. p. 116-137.

7. Preliminary geologic radon potential assessment of Utah, by R. F. Dubiel. p. $138-161$.

8. Preliminary geologic radon potential assessment of Wyoming, by R. F. Dubiel. p. 162-184.

OF 93-0292-I. Geologic radon potential of EPA Region 9; Arizona, California, Hawaii, and Nevada, edited by R. R. Schumann. Prepared in cooperation with the U.S. Environmental Protection Agency. 1993. 142 p. (NC, Da, M, U; Bur. of Geol. and Mineral Technol., 845 North Park Ave., Tucson, Az 85719; Div. of Water and Land Dev., P.O. Box 373, Honolulu, HI 96809; Nevada Bur. of Mines and Geol., Univ. of Nevada-Reno, Reno, NV 89557-0088; California Dep. of Conservation, Div. of Mines and 
Geol., Mail Stop 14-34, Library, 801 K St., Sacramento, CA 95814-3532; 185 Berry St., Suite 3600, San Francisco, CA 94107 1728; and State Office Bldg., 107 South Broadway, Los Angeles, CA 90012.)

1. The USGS/EPA state radon potential assessments; an introduction, by L. C. Gundersen, R. R. Schumann and S. W. White. p. 1-35.

2. EPA Region 9 geologic radon potential summary, by J. K. Otton, D. E. Owen, R. F. Dubiel, G. M. Reimer and S. L. Szarzi. p. $36-43$.

3. Preliminary geologic radon potential assessment of Arizona, by R. F. Dubiel and D. E. Owen. p. 44-69.

4. Preliminary geologic radon potential assessment of California, by J. K. Otton. p. 70-93.

5. Preliminary geologic radon potential assessment of Hawaii, by G. M. Reimer. p. 94-122.

6. Preliminary geologic radon potential assessment of Nevada, by D. E. Owen. p. 123-142.

OF 93-0292-J. Geologic radon potential of EPA Region 10; Alaska, Idaho, Oregon, and Washington, edited by R. R. Schumann. Prepared in cooperation with the U.S. Environmental Protection Agency. 1993. 146 p. (NC, Da, M, A, S, U; Alaska Dep. of Natural Resources, Div. of Geol. and Geophys. Surv., 794 University Ave., Suite 200, Fairbanks, AK 99709-3645; U.S. Dep. of Interior, Alaska Resource Library, $701 \mathrm{C}$ St., Box 36, Anchorage, AK 99513; Idaho Geol. Surv., Univ. of Idaho Campus, Morrill Hall, Room 332, Moscow, ID 83843; Oregon Dep. of Geol. and Mineral Industries, Suite 965, 800 NE Oregon St. \#28, Portland, OR 97232-2162; Geol. and Earth Resources Div., Dep. of Natural Resources, Olympia, WA 98504; David A. Johnston Cascade Volcano Observatory, 5400 MacArthur Blvd., Vancouver, WA 98661.)

1. The USGS/EPA state radon potential assessments; an introduction, by L. C. Gundersen, R. R. Schumann and S. W. White. p. 1-35.

2. EPA Region 10 geologic radon potential summary, by J. K. Otton, K. A. Dickinson, D. E. Owen and S. L. Szarzi. p. 36-46.

3. Preliminary geologic radon potential assessment of Alaska, by K. A. Dickinson. p. 47-77.

4. Preliminary geologic radon potential assessment of Idaho, by D. E. Owen. p. 78-102.

5. Preliminary geologic radon potential assessment of Oregon, by J. K. Otton. p. 103-124.

6. Preliminary geologic radon potential assessment of Washington, by J. K. Otton. p. 125-146.

OF 93-0293. WYOMING. Evaluation of near-infrared spectra for detecting ammonium minerals at Shoshone geyser basin, Yellowstone National Park, Wyoming, by M. D. Krohn. 1993. 11 p. (NC, Da, M, U; Geol. Surv. of Wyoming, P.O. Box 3008, University Station, Laramie, WY 82071.)

OF 93-0294. CALIFORNIA. A landowner's guide to U.S.G.S. investigations in Merced and Stanislaus counties, edited by Katherine O'Neill and Thomas Black. 1993. 8 p. (NC, Da, M; Cali- fornia Dep. of Conservation, Div. of Mines and Geol., Mail Stop 14-34, Library, 801 K St., Sacramento, CA 95814-3532; 1145 Market St., 3rd Floor, San Francisco, CA 94103; and State Office Bldg., 107 South Broadway, Los Angeles, CA 90012.)

OF 93-0295. Review of procedures for calculating USGS short-period seismograph system response, by J. P. Eaton. 1993. 26 p. (NC, Da, M.)

OF 93-0297. WASHINGTON. Geologic map of the Blue Lake Quadrangle, southern Cascade Range, Washington, by D. A. Swanson. 1993. 34 p., 2 over-size sheets, scale 1:24,000 (1 inch $=2,000$ feet). (NC, Da, M, S; Washington DNR/Div. of Geol. and Earth Resources Library, 1111 Washington St. SE, Olympia, WA 98501.)

OF 93-0298. CALIFORNIA. Map of seafloor declivity and fall lines on the continental slope, Gulf of the Farallones, Central California, by M. A. Hampton, F. L. Wong, R. V. Lugo and C. W. Steele. 1993. 1 over-size sheet, scale 1:250,000 (1 inch $=$ about 4 miles). (NC, Da, M; California Dep. of Conservation. Div. of Mines and Geol., Mail Stop 14-34, Library, $801 \mathrm{~K} \mathrm{St}$, Sacramento, CA 95814-3532; 185 Berry St., Suite 3600, San Francisco, CA 94107-1728; and State Office Bldg., 107 South Broadway, Low Angeles, CA 90012.)

OF 93-0299. NEVADA. Preliminary geologic map of the Pahute Mesa $30^{\prime} \times 60^{\prime}$ Quadrangle, Nevada, by S. A. Minor, D. A Sawyer, R. R. Wahl, V. A. Frizzell, Jr., S. P. Schilling, R. G. Warren, P. P. Orkild, J. A. Coe, M. R. Hudson, R. J. Fleck, M. A. Lanphere, W C Swadley and J. C. Cole. 1993. 39 p., 1 over-size sheet, scale 1:100,000 ( 1 inch = about 1.6 miles). (NC, Da, M, U; Nevada Bur. of Mines and Geol., Univ. of NevadaReno, Reno, NV 89557-0088.)

OF 93-0301. CALIFORNIA. Data report for the 1991 Bay area seismic imaging experiment (BASIX), by Jill McCarthy and P. E. Hart. 1993. 26 p. (NC, Da, M; California Dep. of Conservation, Div. of Mines and Geol., Mail Stop 14-34, Library, $801 \mathrm{~K}$ St., Sacramento, CA 95814-3532; 185 Berry St., Suite 3600, San Francisco, CA 94107-1728; and State Office Bldg., 107 South Broadway, Los Angeles, CA 90012.)

OF 93-0302. OREGON. Preliminary geologic map of the Hebo Quadrangle, Tillamook and Yamhill counties, Oregon, by P. D. Snavely, Jr., N. S. NacLeod and D. L. Minasian. 1993. 1 oversize sheet, scale 1:24,000 (1 inch $=2,000$ feet). (NC, Da, M, S; Oregon Dep. of Geol. and Mineral Industries, Suite 965, $800 \mathrm{NE}$ Oregon St. \#28, Portland, OR 97232.)

OF 93-0303. SOUTH CAROLINA. Biogeochemical studies of the salt marsh and a barrier island at Cape Romain National Wildlife Refuge, South Carolina, edited by L. L. Jackson. 1993. 128 p. (NC, Da, M; South Carolina Geol. and Geodetic Surv., Harbison Forest Rd., Columbia, SC 28210.)

A. Baseline element concentrations in Spartina alterniflora and salt-marsh sediments at Cape Romain National Wildlife Refuge, South Carolina, by L. L. Jackson, L. P. Gough and R. C. Severson. p. A1-A49.

B. Baseline element concentrations in soils and plants, Bull Island, Cape Romain National Wildlife Refuge, South Carolina, by L. P. Gough, R. C. Severson and L. L. Jackson. p. B1B19. 
C. Assessment of possible anthropogenic influences on the biogeochemistry of the salt marsh and a barrier island at Cape Romain National Wildlife Refuge, South Carolina, by L. L. Jackson, L. P. Gough and R. C. Severson. p. C1-C23.

D. Chemical analysis results for biogeochemical studies at Cape Romain National Wildlife Refuge, South Carolina, by L. L. Jackson, L. P. Gough, R. C. Severson, P. H. Briggs, J. D. Cathcart, J. G. Crock, D. L. Fey, C. S. Papp, T. R. Peacock and S. A. Wilson. p. D1-D37.

OF 93-0305. DLGSCOD, DLGOCOD, DLGSGSM, DLGOGSM, programs for IBM-PC compatible microcomputers, by G. I. Selner and J. D. Hoffman. 1993. 22 p., one 5 1/4 inch diskette. (NC, Da, M.)

This report contains one $51 / 4$ inch IBM compatible diskette with programs to convert 1:100,000-scale DLG data to GSMAP data bases.

OF 93-0306. COLORADO. Porosity and permeability data for the Point Lookout Sandstone from core holes 1HCMS and 2HCMS, northern San Juan Basin, La Plata County, Colorado, by R. S. Zech and C. W. Keighin. Prepared in cooperation with the Southern Ute Tribe and the U.S. Bureau of Indian Affairs. 1993. 180 p. (NC, Da, M, U; John W. Rold, Colorado Geol. Surv., 1313 Sherman St., Room 715, Denver, CO80203; Donald Fawcett, Office of the State Engineer, Ground water Section, 1313 Sherman, St., Room 818, Denver, CO 80203.)

OF 93-0309. ALASKA. Earthquake locations determined by the Southern Alaska seismograph network for October 1971 through May 1989, by K. A. Fogleman, J. C. Lahr, C. D. Stephens and R. A. Page. 1993. 54 p. (NC, Da, M, A, S; U.S. Dep. of the Interior, Alaska Resource Library, $701 \mathrm{C} \mathrm{St.,} \mathrm{Box} \mathrm{36,} \mathrm{Anchorage,}$ AK 99513; Alaska Dep. of Natural Resources, Div. of Geol. and Geophys. Surv., 794 University Ave., Suite 200, Fairbanks, AK 99709-3645).

OF 93-0310. COLORADO. Preliminary geologic map of the New Castle Quadrangle, Garfield County, Colorado, by M. W. Green, G. M. Fairer and R. R. Shroba. 1993. 33 p., 1 over-size sheet, scale 1:24,000 (1 inch = 2,000 feet). (NC, Da, M, U; Vicki J. Cowart, Colorado Geol. Surv., 1313 Sherman St., Room 715, Denver, CO 80203; Donald Fawcett, Office of the State Engineer, Ground Water Section, 1313 Sherman St., Room 818, Denver, CO 80203.)

OF 93-0311. CALIFORNIA. Uranium-series and radiocarbon dates on tufas from Searles Lake, California, by J. F. Garcia, J. L. Bischoff, G. I. Smith and D. A. Trimble. 1993. 8 p. (NC, $\mathrm{Da}, \mathrm{M}$; California Dep. of Conservation, Div. of Mines and Geol., Mail Stop 14-34, Library, 801 K St., Sacramento, CA 95814-3532; 185 Berry St., Suite 3600, San Francisco, CA 94107-1728; and State Office Bldg., 107 South Broadway, Los Angeles, CA 90012.)

OF 93-0312. OHIO, KENTUCKY. Preliminary analysis of conodont occurrences in Pennsylvanian strata of Ohio and Kentucky, by B. R. Wardlaw, C. L. Rice and R. G. Stamm. 1993. 9 p. (NC, Da, M; Pirtle Geol. Library, 100 Bowman Hall, Univ. of Kentucky, Lexington, KY 40506.)

OF 93-0314. OREGON. Chemical analyses of pre-Mazama silicic volcanic rocks, inclusions, and glass separates, Crater Lake, Oregon, by P. E. Bruggman, C. R. Bacon, J. S. Mee, S. T. Pribble and D. F. Siems. 1993. 20 p. (NC, Da, M, S; Oregon Dep. of Geol. and Mineral Industries, Suite 965, 800 NE Oregon St. , Portland, OR 97232.)

OF 93-0318. OREGON. Onshore-offshore wide-angle seismic recordings from central Oregon; the five-day recorder data, by T. $M$. Brocher, M. J. Moses and A. M. Tréhu. 1993. 24 p. (NC, Da, M, S; Oregon Dep. of Geol. and Mineral Industries, Suite 965, 800 NE Oregon St. \#28, Portland, OR 97232.)

OF 93-0319. OREGON. Seismic refraction data across the Coast Range and Willamette Basin in central Oregon; the 1991 Pacific Northwest experiment, by A. M. Tréhu, Steve Azevedo, J. N. Nabelek, J. H. Luetgert, W. D. Mooney, Isa Asudeh and Brad Isbell. 1993. 31 p. (NC, Da, M, S; Oregon Dep. of Geol. and Mineral Industries, Suite 965, 800 NE Oregon St \#28, Portland, OR 97232.)

OF 93-0320. COLORADO. Preliminary geologic map of the Storm King Mountain Quadrangle, Garfield County, Colorado, by G. M. Fairer, M. W. Green and R. R. Shroba. 1993. 33 p., 1 over-size sheet, scale 1:24,000 (1 inch =2,000 feet). (NC, Da, M, U; Vicki J. Cowart, Colorado Geol. Surv., 1313 Sherman St., Room 715, Denver, CO 80203; Donald Fawcett, Office of the State Engineer, Ground Water Section, 1313 Sherman St., Room 818 , Denver, CO 80203.)

OF 93-0321. COLORADO. Ion-exchange of clinoptilolite-rich rocks in Argo drain water at Idaho Springs, Colorado, and related experimental aspects, by G. A. Desborough. 1993. 23 p. (NC, Da, M, U; John W. Rold, Colorado Geol. Surv., 1313 Sherman St., Room 715, Denver, CO 80203; Donald Fawcett, Office of the State Engineer, Ground Water Section, 1313 Sherman St., Room 818, Denver, CO 80203:)

OF 93-0323. Recent developments and emerging technology in well logging and formation evaluation; with a selected bibliography, by S. E. Prensky. 1993. 34 p. (NC, Da, M.)

OF 93-0324. A dual drawworks controller for borehole tomography, by T. P. Grover, R. P. Kipfinger and D. L. Wright. 1993. 37 p. (NC, Da, M.)

OF 93-0325. ALASKA. Map and compilation of structural data from lode-gold mineral occurrences in the Chugach-Prince William Terrane of Southern Alaska, by P. J. Haeussler and D. C. Bradley. 1993. 53 p., 1 over-size sheet, scale 1:506,880 (1 inch $=$ 8 miles). (NC, Da, M, A, S; U.S. Dep. of the Interior, Alaska Resource Library, 701 C St., Box 36, Anchorage, AK 99513; Alaska Dep. of Natural Resources, Div. of Geol. and Geophys. Surv., 794 University Ave., Suite 200, Fairbanks, AK 99709. 3645.)

OF 93-0327. IDAHO. Petrography, age, and paleomagnetism of basalt lava flows in coreholes Well 80, NRF 89-04, NRF 89-05, and ICPP 123, Idaho National Engineering Laboratory, by M. A. Lanphere, D. E. Champion and M. A. Kuntz. 1993. 40 p. (NC, Da, M, U, S; Idaho Geol. Surv., Morrill Hall, Room 332, Univ. of Idaho Campus, Moscow, ID 83843.)

OF 93-0328. Digital metallogenic data set for North America and South America, by M. P. Foose. 1993. One $31 / 2$ inch diskette. (NC, Da, M.)

The dBASE III file format requires 2,281,543 bytes of computer space. The Lotus version 1.x spreadsheet file format requires $1,897,680$ bytes of computer space. These two file formats are 
accessible by many of the widely used spreadsheet and database programs. The requirements to access these computer files are an IBM PC or compatible computer capable of running standard spreadsheet or data base software and reading $51 / 4$ inch $1.4 \mathrm{MB}$ high-density diskettes.

OF 93-0329. ARIZONA. Mineral resource assessment of undiscovered mineral deposits for selected mineral deposit types in the Kaibab National Forest, Arizona, by J. D. Bliss; with a section on Mineral resource assessment of solution-collapse breccia pipe uranium deposits, by J. D. Bliss and C. T. Pierson. 1993. 68p. (NC, Da, M, U; Arizona Bur. of Geol. and Mineral Technol.., 845 North Park Ave., Tucson, AZ 85719.)

OF 93-0330. Branch of Petroleum Geology bibliography, 1992, compiled by Helen Colburn. 1992. 28 p. (NC, Da, M.)

OF 93-0332. WASHINGTON. Analysis of Cenozoic subsidence at three sites in vicinity of the Seattle Basin, Washington, by S. Y. Johnson. 1993. 17 p. (NC, Da, M, S; Geol. and Earth Resources Div., Dep. of Natural Resources, Olympia, WA 98504; David A. Johnston Cascade Volcano Observatory, 5400 MacArthur Blvd., Vancouver, WA 98661.)

OF 93-0335. NORTH DAKOTA, SOUTH DAKOTA. Subsurface stratigraphic analysis of Upper Cretaceous rocks, southeastern flank of the Williston Basin, North and South Dakota, by J. K. Baird and T. S. Dyman. 1993. 20 p. (NC, Da, M; North Dakota Geol. Surv., University Station, Grand Forks, ND 58202-8156; Dep. of Water and Natural Resources, South Dakota Geol. Surv., Sci. Ctr., Univ. of South Dakota, Vermillion, SD 57069.)

OF 93-0336. Conversion of the Radiometric Age Data Bank (RADB) to the National Geochronological Data Base (NGDB), by B. D. Marshall. 1993. 76 p. (NC, Da, M.)

OF 93-0337. Petroleum exploration plays and resource estimates, 1989, onshore United States; Region 4, Rocky Mountains and Northern Great Plains, edited by R. B. Powers. 1993. 194 p. (NC, Da, M, U, S; Montana Bur. of Mines and Geol., Montana Coll. of Mineral Sci. and Technol., Butte, MT 59701; North Dakota Geol. Surv., University Station, Grand Forks, ND 582028156; Dep. of Water and Natural Resources, South Dakota Geol. Surv., Sci. Ctr., Univ. of South Dakota, Vermillion, SD 57069; Geol. Surv. of Wyoming, P.O. Box 3008, University Station, Laramie, WY 82071; Conservation and Surv. Div., Inst. of Agriculture and Natural Resources, 113 Nebraska Hall, Univ. of Nebraska, Lincoln, NE 68588-0517; New Mexico Bur. of Mines and Mineral Resources, Campus Station, Socorro, NM 87801; John W. Rold, Colorado Geol. Surv., 1313 Sherman St., Room 715, Denver, CO 80203; Donald Fawcett, Office of the State Engineer, Ground Water Section, 1313 Sherman St., Room 818, Denver, CO 80203.)

Introduction, by R. B. Powers. p. 1-8.

Geologic framework, by R. B. Powers. p. 9-10.

Williston Basin province (094), by J. A. Peterson. p. 11-24.

Sioux Arch province (095), by J. A. Peterson. p. 25-26.

Sweetgrass Arch province (096), by T. S. Dyman. p. 27-39.

Central Montana province (097), by E. K. Maughan. p. 4045 .
Montana thrust belt province (098), by W. J. Perry, Jr. p. 4656.

Southwest Montana province (099), by W. J. Perry, Jr. p. 5770 .

Wind River basin province (100), by J. E. Fox and G. L. Dolton. p. 71-84.

Powder River basin province (101), by G. L. Dolton and J. E. Fox. p. 85-116.

Southwestern Wyoming basins province (102), by B. E. Law. p. 117-143.

Bighorn Basin province (103), by J. E. Fox and G. L. Dolton. p. 144-161.

Denver Basin province (104), by D. L. Gautier. p. 162-176.

Las Animas Arch province (105), by E. A. Merewether. p. 177-185.

Raton Basin-Sierra Grande uplift province (106), by E. A. Merewether. p. 186-190.

OF 93-0338. Maps of major active faults, Western Hemisphere, International Lithosphere Program (ILP), Project II-2; guidelines for U.S. database and map, June 1993, by K. M. Haller, M. N. Machette and R. L. Dart. 1993. 45 p. (NC, Da, M.)

OF 93-0339. ALASKA. Metallogenesis of mainland Alaska and the Russian Northeast, by W. J. Nokleberg, T. K. Bundtzen, D. J. Grybeck, R. D. Koch, R. A. Eremin, I. S. Rozenblum, A. A. Sidorov, S. G. Byalobzhesky, G. M. Sosunov, V. I. Shpikerman and M. E. Gorodinsky. Prepared in cooperation with the Alaska Division of Geological and Geophysical Surveys, Russian Academy of Sciences, and Geological Committee of Northeastern Russia. 1993. 230 p., 3 over-size sheets, scale 1:4,000,000 (1 inch = about 65 miles). (NC, Da, M, A, S; U.S. Dep. of the Interior, Alaska Resource Library, 701 C St., Box 36, Anchorage, AK 99513; Alaska Dep. of Natural Resources, Div. of Geol. and Geophys. Surv., 794 University Ave., Suite 200. Fairbanks, AK 99709-3645.)

OF 93-0340. CALIFORNIA. Distribution and taxonomy of late Quaternary diatoms from gravity cores L13-81-G117, L13-81G138, L13-81-G145, and TT197-G330, Northern California continental slope, by Eileen Hemphill-Haley. 1993. 108 p. (NC, Da, M; California Dep. of Conservation, Div. of Mines and Geol., Mail Stop 14-34, Library, 801 K St., Sacramento, CA 95814-3532; 185 Berry St., Suite 3600, San Francisco, CA 94107-1728; and State Office Bldg., 107 South Broadway, Los Angeles, CA 90012.)

OF 93-0341. PUERTORICO. Sand-sized heavy-mineral distributions in offshore insular shelf sediments of north-central Puerto Rico, by Gretchen Luepke and L. J. Poppe. 1993. 17 p. (NC, Da, M.)

OF 93-0342-A. HAWAII. Inflation and cooling data from pahoehoe sheet flows on Kilauea Volcano, by Ken Hon, J. P. Kauahikaua and Kevin Mackay. 1993. 29 p. (NC, Da, M; Div. of Water and Land Dev., P.O. Box 373, Honolulu, HI 96809.)

OF 93-0342-B. HAWAII. Inflation and cooling data from pahoehoe sheet flows on Kilauea Volcano, by Ken Hon, J. P. Kauahikaua and Kevin Mackay. 1993. One $31 / 2$ inch diskette. 
(NC, Da, M; Div. of Water and Land Dev., P.O. Box 373, Honolulu, HI 96809.)

$31 / 2$ inch IBM-compatible diskette that includes a variety of ASCII and spreadsheet data formats.

OF 93-0343. COLORADO. Geological setting of the Leadville mining district, Lake County, Colorado, by A. R. Wallace. 1993. 20 p. (NC, Da, M, U; Vicki J. Cowart, Colorado Geol. Surv., 1313 Sherman St., Room 715, Denver, CO 80203; Donald Fawcett, Office of the State Engineer, Ground Water Section, 1313 Sherman St., Room 818, Denver, CO 80203.)

OF 93-0345. MINNESOTA. Economic heavy minerals in glaciofluvial sediments of Minnesota, by Gretchen Luepke. 1993. 11 p. (NC, Da, M.)

OF 93-0347. WASHINGTON, OREGON: Data report for a seismic refraction/wide-angle reflection investigation of the Puget Basin and Willamette Valley in western Washington and Oregon, by J. H. Luetgert, W. D. Mooney, A. M. Tréhu, J. N. Nabelek, G. R. Keller, K. C. Miller, Isa Asudeh and Brad Isbell. 1993. 73 p. (NC, Da, M, S; Washington DNR/Div. of Geol. and Earth Resources Library, 1111 Washington St. SE, Olympia, WA 98501; Oregon Dep. of Geol. and Mineral Industries, Suite 965, 800 NE Oregon St. \#28, Portland, OR 97232.)

OF 93-0348. CALIFORNIA. Broad belts of shear zones as the common form of surface rupture produced by the 28 June 1992 Landers, California, earthquake, by A. M. Johnson, R. W. Fleming and K. M. Cruikshank. 1993. 61 p., 1 over-size sheet. (NC, Da, M; California Dep. of Conservation, Div. of Mines and Geol., Mail Stop 14-34, Library, 801 K St., Sacramento, CA 95814-3532; 185 Berry St., Suite 3600, San Francisco, CA $94107-$ 1728; and State Office Bldg., 107 South Broadway, Los Angeles, CA 90012.)

OF 93-0349. Geologic Hazards Data-Base catalog; central United States, by A. C. Tarr. 1993. 145 p. (NC, Da, M; Geol. Surv. of Alabama, P.O. Box 0, University Station, Tuscaloosa, AL 35486; Kentucky Geol. Surv., Univ. of Kentucky, 311 Breckinridge Hall, Lexington, KY 40506; Pirth Geol. Library, 100 Bowman Hall, Univ. of Kentucky, Lexington, KY 40506; Bur. of Geol., Mississippi Dep. of Natural Resources, P.O. Box 5348, Jackson, MS 39216; Dep. of Natural Resources, Div. of Geol. and Land Surv., 111 Fairgrounds Rd., P.O. Box 250, Rolla, MO 65401.)

OF 93-0352. Base sheet generation for 1:24,000-scale maps, by J. E. Findley. 1993. 31 p., one $31 / 2$ inch IBM/UNIX compatible diskette. (M, Da, NC.)

Hardware requirements: Data General workstations operating under AViion-DG/UX 5.4.1. Software requirements: ARC/INFO version 6.1.

OF 93-0405. Determining the source of water pumped from wells along the lower Colorado River, by R. R. Wilson and S. J. Owen-Joyce. 1993. 2 p. (NC, Da, M, Wb, A, S, U.) (Water fact sheet.)

OF 93-0418. Selected papers on agricultural chemicals in water resources of the Midcontinental United States, compiled by D. A. Goolsby, L. L. Boyer and G. E. Mallard. 1993. 89 p. (NC,Da, $\mathrm{M}, \mathrm{Wb}$.)
Occurrence, distribution, and transport of agricultural chemicals in surface waters of the Midwestern United States, by D. A. Goolsby and W. A. Battaglin. p. 1-25.

Annual use and transport of agricultural chemicals in the Mississippi River, 1991-92, by W. A. Battaglin, D. A. Goolsby and R. H. Coupe. p. 26-40.

Relation of nitrate concentrations in surface water to land use in the upper-Midwestern United States, by D. K. Mueller, B. C. Ruddy and W. A. Battaglin. p. 41-50.

Persistence of herbicides in selected reservoirs in the Midwestern United States; some preliminary results, by D. A. Goolsby, W. A. Battaglin, J. D. Fallon, D. S. Aga, D. W. Kolpin and E. M. Thurman. p. 51-63.

Pesticides in near-surface aquifers; results of the Midcontinental United States ground-water reconnaissance, 1991-92, by D. W. Kolpin, D. A. Goolsby, D. S. Aga, J. L. Iverson and E. M. Thurman. p. 64-74.

Occurrence, deposition, and long range transport of herbicides in precipitation in the Midwestern and northeastern United States, by D. A. Goolsby, E. M. Thurman, M. L. Pomes, M. T. Meyers and W. A. Battaglin. p. 75-89.

OF 93-0424. ARKANSAS. Summary of reported agriculture and irrigation water use in Clay County, Arkansas, 1991, by T. W. Holland and C. A. Manning. Prepared in cooperation with the Arkansas Soil and Water Conservation Commission. 1993. 8 p. (NC, Da, M, Wb.)

OF 93-0425. ARKANSAS. Summary of reported agriculture and irrigation water use in Craighead County, Arkansas, 1991, by T. W. Holland and C. A. Manning. Prepared in cooperation with the Arkansas Soil and Water Conservation Commission. 1993. 8 p. (NC, Da, M, Wb.)

OF 93-0427. ARKANSAS. Summary of reported agriculture and irrigation water use in Cross County, Arkansas, 1991, by T. W. Holland and C. A. Manning. Prepared in cooperation with the Arkansas Soil and Water Conservation Commission. 1993. 9 p. (NC, Da, M, Wb.)

OF 93-0428. ARKANSAS. Summary of reported agriculture and irrigation water use in Desha County, Arkansas, 1991, by T. W. Holland and C. A. Manning. Prepared in cooperation with the Arkansas Soil and Water Conservation Commission. 1993. 8 p. (NC, Da, M, Wb.)

OF 93-0429. ARKANSAS. Summary of reported agriculture and irrigation water use in Drew County, Arkansas, 1991, by T. W. Holland and C. A. Manning. Prepared in cooperation with the Arkansas Soil and Water Conservation Commission. 1993. 8 p. (NC, Da, M, Wb.)

OF 93-0430. ARKANSAS. Summary of reported agriculture and irrigation water use in Greene County, Arkansas, 1991, by T. W. Holland, C. A. Manning and K. L. Stafford. Prepared in cooperation with Arkansas Soil and Water Conservation Commission. 1993. 8 p. (NC, Da, M, Wb.)

OF 93-0431. ARKANSAS. Summary of reported agriculture and irrigation water use in Independence County, Arkansas, 1991, by T. W. Holland, C. A. Manning and K. L. Stafford. Prepared 
in cooperation with the Arkansas Soil and Water Conservation Commission. 1993. 8 p. (NC, Da, M, Wb.)

OF 93-0432. ARKANSAS. Summary of reported agriculture and irrigation water use in Jackson County, Arkansas, 1991, by T. W. Holland, C. A. Manning and K. L. Stafford. Prepared in cooperation with the Arkansas Soil and Water Conservation Commission. 1993. 8 p. (NC, Da, M, Wb.)

OF 93-0501. Physical environment of the underground nuclear test site on Novaya Zemlya, Russia, by J. R. Matzko. 1993. 28 p. (NC, Da, M.)

OF 93-0504. Geologic constraints on metallogeny of magmatically underplated lower crust in the Ivrea-Verbano Zone, northern Italy, by C. R. Thornber, J. E. Quick, Adriano Mayer and Silvano Sinigoi. 1993. 22 p. (NC, Da, M.)

OF 93-0505. MONTANA. Geochemical data for selected rock samples from the Absaroka-Beartooth Study Area, Custer and Gallatin national forests, Montana, by J. M. Hammarstrom and K. J. Gray. 1993. 33 p. (NC, Da, M, U, S; Montana Bur. of Mines and Geol., Montana Coll. of Mineral Sci. and Technol., Butte, MT 59701.)

OF 93-0506. CALIFORNIA, NEVADA. Geologic mapping index to the Death Valley National Monument area, California and Nevada, by S. P. Schilling and R. A. Thompson. 1993. 51 p. (NC, Da, M, U; California Dep. of Conservation, Div. of Mines and Geol., Mail Stop 14-34, Library, 801 K St., Sacramento, CA 95814-3532; 185 Berry St., Suite 3600, San Francisco, CA 941071728; and State Office Bldg., 107 South Broadway, Los Angeles, CA 90012.)

OF 93-0508-A. ALASKA. Principal facts for gravity stations on Annette Island, Southeast Alaska, by K. R. Bond. 1993. 12 p. (NC, Da, M, A, S; Alaska Dep. of Natural Resources, Div. of Geol. and Geophys. Surv., 794 University Ave., Suite 200, Fairbanks, AK 99709-3645; U.S. Dep. of the Interior, Alaska Resource Library, 701 C St., Box 36, Anchorage, AK 99513.)

OF 93-0508-B. ALASKA. Principal facts for gravity stations on Annette Island, Southeast Alaska, by K. R. Bond. 1993. One 5 $1 / 4$ inch DS/HD IBM compatible diskette. (NC, Da, M, A, S; Alaska Dep. of Natural Resources, Div. of Geol. and Geophys. Surv., 794 University Ave., Suite 200, Fairbanks, AK 99709-3645; U.S. Dep. of the Interior, Alaska Resource Library, 701 C St., Box 36, Anchorage, AK 99513.)

OF 93-0509. Estimation of response spectra and peak accelerations from western North America earthquakes; an interim report, by D. M. Boore, W. B. Joyner and T. E. Fumal. 1993. 72 p. (NC, $\mathrm{Da}, \mathrm{M}$.)

OF 93-0511. System 9, GSMAP, and other programs for the IBM $\mathrm{PC}$ and compatible microcomputers, to assist workers in the earth sciences, by G. I. Selner and R. B. Taylor. 1993. 372 p., 2 over-size sheets, two $31 / 2$ inch diskettes. (NC, Da, M.) (Supersedes OF 92-217-A,B.)

OF 93-0512-A. HAWAII. Annotated bibliography; volcanology and volcanic activity with a primary focus on potential hazard impacts for the Hawaii Geothermal Project, by R. B. Moore, P. T. Delaney and J. P. Kauahikaua. 1993. 10 p. (NC, Da, M; Div. of Water and Land Dev., P.O. Box 373, Honolulu, HI 96809.)
OF 93-0513. USGS Permo-Carboniferous fossil locality register; Part 1, Introduction to PC-FILES, by T. W. Henry, O. B. Williams and P. A. Holroyd. 1993. 38 p. (NC, Da, M.)

OF 93-0515. Modern benthic foraminifer census data from boxcores collected on Northwind Ridge, Arctic Ocean during the PI-92-AR cruise of the U.S.C.G.C. Polar Star, by K. M. Foley and S. E. Ishman. 1993. 9 p. (NC, Da, M.)

OF 93-0516. The Venus geologic mappers' handbook, by K. L. Tanaka, G. G. Schaber, M. G. Chapman, E. R. Stofan, D. B. Campbell, P. A. Davis, J. E. Guest, G. E. McGill, P. G. Rogers, R. S. Saunders and J. R. Zimbelman. 1993. 54 p. (NC, $\mathrm{Da}, \mathrm{M}$.)

OF 93-0519. NEVADA. Geologic map of the northern part of the Simpson Park Mountains (Rocky Hills and western part of the Pete Hanson Creek quadrangles), Eureka County, Nevada, by E. H. McKee and J. E. Conrad. 1993. 7 p., 1 over-size sheet, scale $1: 24,000$ ( 1 inch = 2,000 feet). (NC, Da, M, U; Nevada Bur. of Mines and Geol., Univ. of Nevada, Reno, NV 89557.)

OF 93-0522. TEXAS, NEW MEXICO. Petroleum exploration plays and resource estimates, 1989 , onshore United States; Region 5, West Texas and eastern New Mexico, edited by R. B. Powers. 1993. 84 p. (NC, Da, M, U; Bur. of Econ. Geol., Univ. of Texas at Austin, University Station, Box X, Austin, TX 78713-75; New Mexico Bur. of Mines and Mineral Resources, Campus Station, Socorro, NM 87801.)

Introduction, by R. B. Powers. p. 1-8.

Geologic framework, by R. B. Powers. p. 9-10.

Permian Basin (107), by Keith Robinson. p. 11-42.

Palo Duro Basin (108), by M. E. Henry. p. 43-56.

Pedernal Uplift (109), by M. E. Henry. p. 57-58.

Bend Arch-Fort Worth Basin (110), by M. M. Ball. p. 59-76.

Marathon fold belt (111), by M. E. Henry. p. 77-81.

OF 93-0524. CALIFORNIA. A study of seawater intrusion using direct-current soundings in the southeastern part of the Oxnard Plain, California, by A. A. Zohdy, P. M. Martin and R. J. Bisdorf. 1993. 139 p. (NC, Da, M; California Dep. of Conservation, Div. of Mines and Geol., Mail Stop 14-34, Library, $801 \mathrm{~K}$ St., Sacramento, CA 95814-3532; 185 Berry St., Suite 3600, San Francisco, CA 94107-1728; and State Office Bldg., 107 South Broadway, Los Angeles, CA 90012.)

OF 93-0525. CALIFORNIA. Preliminary geologic map of the Oat Mountain 7.5' Quadrangle, Southern California, by R. F. Yerkes and R. H. Campbell. 1993. 13 p., 1 over-size sheet, scale 1:24,000 (1 inch = 2,000 feet). (NC, Da, M; California Dep. of Conservation, Div. of Mines and Geol., Mail Stop 14-34, Library, 801 K St., Sacramento, CA 95814-3532; 185 Berry St., Suite 3600, San Francisco, CA 94107-1728; and State Office Bldg., 107 South Broadway, Los Angeles, CA 90012.)

OF 93-0526. The generation of raster-format geologic maps using digital image-processing on the Macintosh computer; a tutorial guide, by C. D. Condit and A. V. Acosta. 1993. 63 p., two 3 $1 / 2$ inch $\mathrm{DS} / \mathrm{HD}$ diskettes. (NC, $\mathrm{Da}, \mathrm{M}$.)

Requirements to use the tutorial: any Macintosh with an 8-bit (256) color monitor and 8MB of RAM, a 20-MB hard disk, and 
Macintosh System 7.0.0 or higher. A high density disk drive is needed to read the diskettes; the tutorial guide (in MS Word 5.1 format) is included as one of the SEA text files.

OF 93-0527. IDAHO. Gold analyses of 881 stream sediment samples from the western Payette National Forest and contiguous areas, Idaho, by J. B. McHugh, K. C. Watts, Jr., H. N. Barton and H. D. King. 1993. 21 p., one 5 1/4 inch DS/HD diskette. (NC, Da, M, U, S; Idaho Geol. Surv., Univ. of Idaho Campus, Morrill Hall, Room 332, Moscow, ID 83843.)

Requirements: IBM AT, PS/2, or fully compatible computer (80286 and higher); DOS 2.0 or later; at least $512 \mathrm{~K}$ of RAM (640K recommended); hard disc with at least $6 \mathrm{MB}$ of space available; CGA or VGA graphics board.

OF 93-0533. USGS Branch of Geochemistry, sample submittal manual, fourth edition, by C. M. Murphy, R. V. Mendes and S. T. Smith. 1993.38 p. (NC, Da, M.)

OF 93-0536. GSMDATUM and GSPDATUM, programs for DOS microcomputers to convert data in GSMAP or GSPOST format between the NAD 27 and NAD 83 coordinate systems, by G. I. Selner and R. B. Taylor. 1993. 3 p., three $31 / 2$ inch IBM compatible DS/HD computer diskettes. (NC, Da, M.)

OF 93-0538. NEVADA. New radiometric ages related to alteration and mineralization in the vicinity of Yucca Mountain, Nye County, Nevada, by E. H. McKee and J. R. Bergquist. 1993. 28 p., 1 over-size sheet. (NC, Da, M, U; Nevada Bur. of Mines and Geol., Univ. of Nevada, Reno, NV 89557.)

OF 93-0543. Preliminary map showing the thickness and character of Quaternary sediments in the United States east of the Rocky Mountains, by D. R. Soller. 1993. 1 over-size sheet, scale 1:3,500,000 (1 inch = about 55 miles). (NC, Da, M.)

OF 93-0546. SLOPE; A BASIC program to compute the gravitational stress within a finite slope using a DOS-based PC computer, by P. S. Powers and W. Z. Savage. 1993. 28 p., one $31 / 2$ inch DS/DD IBM compatible diskette. (NC, Da, M.)

Requirements to run the executable: IBM PC or compatible; DOS 3.X or above; 640K RAM; math coprocessor, and a text editor. One $31 / 2$ inch diskette, $720 \mathrm{~K}$.

OF 93-0549. KANSAS. USGS Permo-Carboniferous fossil locality register; Part 2, Kansas PC-FILES, by T. W. Henry and P. A. Holroyd. 1993. 124 p., one $51 / 4$ inch DS/HD diskette. (NC, Da, M; Kansas Geol. Surv., Univ. of Kansas, 1930 Constant Ave., Campus West, Lawrence, KS 66047-2598; Univ. of Kansas, Dep. of Geol., Lawrence, KS 66045; Kansas State Univ., Dep. of Geol., Manhattan, KS 66506.)

The software for accessing the records for KSPCFILE.dbf is dBASE IV.

OF 93-0573-B. MAINE. Total-field aeromagnetic map of part of northern Maine, by K. R. Bond. 1993. One 5 1/4 inch diskette. (NC, Da, M.)

The digital data are in ASCII format on a 5 1/4 inch IBM-compatible floppy disk.

OF 93-0575. Computer programs released as U.S. Geological Survey publications through June 1993, by J. M. McGuirk, R. C. Orndorff, K. A. Dodd, G. B. Gunnells and Yula Sakss. 1993. One 3 1/2 inch diskette. (NC, Da, M.)
Requirements to search this data base are IBM PC or compatible computer, $31 / 2$ inch disk drive, and a minimum of 512K RAM.

\section{Reports Available Only Through Certain USGS Field Offices}

For information on availability and price of these reports, write to the address indicated by a dagger ( $\dagger$ ) in the listing for the report.

OF 92-0533. CALIFORNIA. Southern California earthquakes, by S. K. Goter. 1992. 1 p., 1 over-size sheet, scale 1:375,000 (1 inch = about 6 miles). (NC, Da, M; California Dep. of Conservation, Div. of Mines and Geol., Mail Stop 14-34, Library, $801 \mathrm{~K}$ St., Sacramento, CA 95814-3532; 1145 Market St., 3rd Floor, San Francisco, CA 94103; and State Office Building, 107 South Broadway, Los Angeles, CA 90012.) †Susan Goter, USGS, Box 25046, Denver Federal Ctr., Mail Stop 967, Denver, CO 80225; telephone 303-273-8477.

OF 93-0113. NORTH CAROLINA. U.S. Geological Survey; North Carolina's water resources; a partnership with State, Federal, and local agencies, by M. D. Winner, Jr. 1993, 8 p. (NC, Da, M, Wb.) +USGS, WRD, 3916 Sunset Ridge Rd., Raleigh, NC 27607; telephone 919-571-4000.

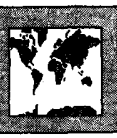

\section{THEMATIC MAPS AND CHARTS}

\section{GEOLOGIC QUADRANGLE MAPS}

Multicolor geologic maps on topographic bases in $71 / 2$ - or 15 -minute quadrangle units; scales mainly $1: 24,000$ or $1: 62,500$; show bedrock, surficial, or engineering geology. Maps are accompanied by brief texts and some maps by structure and columnar sections also.

GQ-1679. WASHINGTON. Geologic map of the Spirit Lake East Quadrangle, Skamania County, Washington, by R. C. Evarts and R. P. Ashley. Prepared in cooperation with the Washington Department of Natural Resources Geology and Earth Resources Division. 1993. Lat $46^{\circ} 15^{\prime}$ to $46^{\circ} 22^{\prime} 30^{\prime \prime}$, long $117^{\circ} 15^{\prime}$ to $122^{\circ} 07^{\prime} 30^{\prime \prime}$. Scale $1: 24,000(1$ inch $=2,000$ feet $)$. Sheet 41 by 32 inches (in color). (Accompanied by 12-page text.)

GQ-1688. ALASKA. Geologic map of the Nabesna B-6 Quadrangle, south-central Alaska, by D. H. Richter, J. G. Smith, H. R. Schmoll and R. L. Smith. 1993. Lat $62^{\circ} 15^{\prime}$ to $62^{\circ} 30^{\prime}$, long $143^{\circ} 30^{\prime}$ to $144^{\circ}$. Scale $1: 63,360(1 \mathrm{inch}=1 \mathrm{mile})$. Sheet 43 by 29 $1 / 2$ inches (in color).

GQ-1705. GEORGIA. Geologic map of the Dahlonega Quadrangle, Lumpkin and White counties, Georgia, by A. E. Nelson. 1992. Lat $34^{\circ} 30^{\prime}$ to $34^{\circ} 37^{\prime} 30^{\prime \prime}$, long $83^{\circ} 52^{\prime} 30^{\prime \prime}$ to $84^{\circ}$. Scale $1: 24,000$ ( 1 inch $=2,000$ feet). Sheet 45 by 38 inches (in color).

GQ-1707. NEW JERSEY. Bedrock geologic map of the Newton East Quadrangle, Sussex County, New Jersey, by A. A. Drake, Jr., U.S. Geological Survey; and R. A. Volkert, New Jersey Geological Survey. Prepared in cooperation with the New Jersey Geological Survey. 1993. Lat $41^{\circ}$ to $41^{\circ} 07^{\prime} 30^{\prime \prime}$, long $74^{\circ} 37^{\prime} 30^{\prime \prime}$ to $74^{\circ} 45^{\prime}$. Scale $1: 24,000$ ( 1 inch $=2,000$ feet $)$. Sheet 42 by 41 inches (in color).

GQ-1712. UTAH. Geologic map of the Parowan Gap Quadrangle, Iron County, Utah, by Florian Maldonado and V. S. Williams. 1993. Lat $37^{\circ} 52^{\prime} 30^{\prime \prime}$ to $38^{\circ}$, long $112^{\circ} 52^{\prime} 30^{\prime \prime}$ to $113^{\circ}$. Scale $1: 24,000$ ( 1 inch $=2,000$ feet). Sheet 42 by 31 inches (in color). 
GQ-1713. UTAH. Geologic map of the Paragonah Quadrangle, Iron County, Utah, by Florian Maldonado and V. S. Williams. 1993. Lat $37^{\circ} 52^{\prime} 30^{\prime \prime}$ to $38^{\circ}$, long $112^{\circ} 45^{\prime}$ to $112^{\circ} 52^{\prime} 30^{\prime \prime}$. Scale $1: 24,000$ ( 1 inch $=2,000$ feet). Sheet 37 by 28 inches (in color).

GQ-1714. NEVADA. Geologic map of the Weiser Ridge Quadrangle, Clark County, Nevada, by R. G. Bohannon. 1992. Lat $36^{\circ} 30^{\prime}$ to $36^{\circ} 37^{\prime} 30^{\prime \prime}$, long $114^{\circ} 30^{\prime}$ to $114^{\circ} 37^{\prime} 30^{\prime \prime}$. Scale $1: 24,000$ ( 1 inch $=2,000$ feet). Sheet $421 / 2$ by 32 inches (in color.)

GQ-1716. NEW MEXICO. Geologic map of the Casamero Lake Quadrangle, McKinley County, New Mexico, by J. F. Robertson. 1993. Lat $35^{\circ} 30^{\prime}$ to $35^{\circ} 37^{\prime} 30^{\prime \prime}$, long $108^{\circ}$ to $108^{\circ} 07^{\prime} 30^{\prime \prime}$. Scale $1: 24,000$ ( 1 inch $=2,000$ feet). Sheet 44 by 34 inches (in color). (Supersedes Open-file report 76-681.)

GQ-1721. UTAH, NEVADA. Geologic map of the Dodge Spring Quadrangle, Washington County, Utah, and Lincoln County, Nevada, by R. E. Anderson and L. F. Hintze. 1993. Lat $37^{\circ} 15^{\prime}$ to $37^{\circ} 22^{\prime} 30^{\prime \prime}$, long $114^{\circ}$ to $114^{\circ} 07^{\prime} 30^{\prime \prime}$. Scale $1: 24,000$ ( 1 inch $=$ 2,000 feet). Sheet 45 by 34 inches (in color).

GQ-1724. MONTANA. Geologic map of the Medicine Lodge Peak Quadrangle, Beaverhead County, Southwest Montana, by J. W. M'Gonigle. 1993 . Lat $44^{\circ} 45^{\prime}$ to $44^{\circ} 52^{\prime} 30^{\prime \prime}$, long $113^{\circ}$ to $113^{\circ} 07^{\prime} 30^{\prime \prime}$. Scale 1:24,000 ( 1 inch $=2,000$ feet $)$. Sheet 50 by 34 inches (in color.)

GQ-1729. MONTANA. Geologic map of the Ennis Lake Quadrangle, Madison County, Montana, by K. S. Kellogg. 1993. Lat $45^{\circ} 22^{\prime} 30^{\prime \prime}$ to $45^{\circ} 30^{\prime}$, long $111^{\circ} 37^{\prime} 30^{\prime \prime}$ to $111^{\circ} 45^{\prime}$. Scale $1: 24,000$ ( 1 inch $=2,000$ feet). Sheet 40 by 31 inches (in color).

GQ-1730. NEVADA. Geologic map of the Delamar Lake Quadrangle, Lincoln County, Nevada, by R. B. Scott, W C Swadley, U.S. Geological Survey; and S. W. Novak, Charles Evan \& Associates. 1993. Lat $37^{\circ} 15^{\prime}$ to $37^{\circ} 22^{\prime} 30^{\prime \prime}$, long $114^{\circ} 52^{\prime} 30^{\prime \prime}$ to $115^{\circ}$. Scale 1:24,000 (1 inch $=2,000$ feet). Sheet 42 by 40 inches (in color)

\section{GEOPHYSICAL INVESTIGATIONS MAPS}

Maps on topographic or planimetric bases; various scales; show results of surveys using geophysical techniques, such as gravity, magnetic, seismic, or radioactivity, which reflect subsurface structures that are of economic or geologic significance. Many maps are correlated with the geology.

GP-1003-A. NEVADA. Electromagnetic survey maps showing apparent resistivity of the Getchell gold trend, Osgood Mountains, north-central Nevada, by W. S. Wojniak, D. B. Hoover and V. J. Grauch. 1993. Three sheets. Lat $40^{\circ} 45^{\prime}$ to $41^{\circ} 15^{\prime}$, long $117^{\circ} 15^{\prime}$ to $117^{\circ} 30^{\prime}$. Each sheet, Scale $1: 100,000(1$ inch $=$ about 1.6 miles). Sheet 1,57 by 40 inches; sheets $2-3,57$ by 36 inches (all in color).

GP-1004-D. The magnetic field of the Earth, 1990; declination chart, by N. W. Peddie. 1993. Scale 1:40,053,700 (along equator only). Sheet 48 by 34 inches (in color). (Van der Grinten projection.) (Available flat only.) (Supersedes GP-987-D.)

GP-1004-F. The magnetic field of the Earth, 1990; total intensity chart, by N. W. Peddie. 1993. Scale 1:40,053,700 (along equator only). Sheet 48 by 34 inches (in color). (Van der Grinten projection.) (Available flat only.) (Supersedes GP-987-F.)

GP-1004-H. The magnetic field of the Earth, 1990; horizontal intensity chart, by N. W. Peddie. 1993. Scale 1:40,053,700 (along equator only). Sheet 48 by 34 inches (in color). (Van der Grinten projection.) (Available flat only.) (Supersedes GP-987-H.)

GP-1004-I. The magnetic field of the Earth, 1990; inclination chart, by N. W. Peddie. 1993. Scale 1:40,053,700 (along equator only). Sheet 48 by 34 inches (in color). (Van der Grinten projection.) (Available flat only.) (Supersedes GP-987-I.)

GP-1004-Z. The magnetic field of the Earth, 1990; vertical intensity chart, by N. W. Peddie. 1993. Scale 1:40,053,700 (along equator only). Sheet 48 by 34 inches (in color). (Van der Grinten projection.) (Available flat only.) (Supersedes GP-987-Z.)

\section{MISCELLANEOUS INVESTIGATIONS SERIES MAPS}

Maps on planimetric or topographic bases; regular and irregular areas; various scales; a wide variety of format and subject matter. The series also includes 7 1/2-minute quadrangle photogeologic maps on planimetric bases which show geology as interpreted from aerial photographs. Series also includes maps of Mars and the Moon.

I-1257-M. CALIFORNIA. Map of debris-flow probability, San Mateo County, California, by R. K. Mark. 1992. Two sheets. Sheet 1 , Lat $37^{\circ} 06^{\prime}$ to $37^{\circ} 43^{\prime}$, long $122^{\circ} 04^{\prime} 30^{\prime \prime}$ to $122^{\circ} 33^{\prime} 15^{\prime \prime}$. Sheet 1, Scale 1:62,500 (1 inch = about 1 mile $)$. Each sheet $401 / 2$ by 48 inches (all in color).

I-1797-D. UTAH, COLORADO. Stratigraphic cross section of Cretaceous rocks along the north flank of the Uinta Basin, northeastern Utah, to Rangely, northwestern Colorado, by C. M. Molenaar and B. W. Wilson. 1993. Sheet 40 by 30 inches (in color).

I-1803-H. IDAHO, MONTANA. Geologic map of the Dillon $1^{\circ} \times$ $2^{\circ}$ Quadrangle, Idaho and Montana, by E. T. Ruppel, J. M. O'Neill and D. A. Lopez. 1993. Lat $45^{\circ}$ to $46^{\circ}$, long $112^{\circ}$ to $114^{\circ}$. Scale $1: 250,000$ ( 1 inch $=$ about 4 miles $)$. Sheet 50 by 41 inches (in color).

I-1935. SOUTH CAROLINA. Geology of the Cainhoy, Charleston, Fort Moultrie, and North Charleston quadrangles, Charleston and Berkeley counties, South Carolina, by R. E. Weems and E. M. Lemon, Jr. Prepared in cooperation with the U.S. Nuclear Regulatory Commission. 1993. Two sheets. Lat $32^{\circ} 45^{\prime}$ to $33^{\circ}$; long $79^{\circ} 45^{\prime}$ to $80^{\circ}$. Sheet 1 , Scale $1: 24,000(1$ inch $=2,000$ feet $)$; sheet 2 , scale $1: 62,500$ ( 1 inch = about 1 mile). Sheet 1,41 by 56 inches; sheet 2,41 by 50 inches (all in color).

I-1943. CALIFORNIA. Geologic maps of upper Cenozoic deposits in Central California, by J. L. Chin, J. R. Morrow, C. R. Ross and H. E. Clifton. 1993. Three sheets. Sheet 1 , lat $38^{\circ}$ to $39^{\circ}$, long $122^{\circ} 15^{\prime}$ to $124^{\circ}$; sheet 2 , lat $37^{\circ}$ to $38^{\circ}$, long $120^{\circ} 30^{\prime}$ to $122^{\circ} 45^{\prime}$; sheet 3 , lat $36^{\circ}$ to $37^{\circ}$, long $120^{\circ}$ to $122^{\circ} 12^{\prime}$. Each sheet, scale $1: 250,000$ ( 1 inch = about 4 miles $)$. Sheet 1,51 by 27 inches; sheets $2-3,47$ by 27 inches (all in color).

I-1946. WASHINGTON. Geologic map of the Cape Flattery, Clallam Bay, Ozette Lake, and Lake Pleasant quadrangles, northwestern Olympic Peninsula, Washington, by P. D. Snavely, Jr., N. S. MacLeod, and A. R. Niem; with major contributions by D. L. Minasian, J. E. Pearl, and W. W. Rau. 1993. Lat $48^{\circ}$ to $48^{\circ} 25^{\prime}$, long $124^{\circ} 15^{\prime}$ to $124^{\circ} 45^{\prime}$. Scale $1: 48,000$ ( 1 inch $=4,000$ feet). Sheet 42 by 56 inches (in color). (Supersedes Open-file report 86-344-B.)

I-1963. WASHINGTON. Geologic map of the Skykomish River 30- by 60-minute Quadrangle, Washington, by R. W. Tabor, V. 
A. Frizzell, Jr., D. B. Booth, R. B. Waitt, J. T. Whetten and R. E. Zartman. 1993. Lat $47^{\circ} 30^{\circ}$ to $48^{\circ}$, long $121^{\circ}$ to $122^{\circ}$. Scale $1: 100,000$ ( 1 inch = about 1.6 miles). Sheet 54 by 41 inches (in color). (Accompanied by 42-page text.) (Supersedes Open-file report 82-747.)

I-1984. ALASKA. Geologic map of the Cordova and Middleton Island quadrangles, Southern Alaska, by G. R. Winkler and George Plafker. 1993. Lat $59^{\circ} 45^{\prime}$ to $61^{\circ}$, long $144^{\circ}$ to $147^{\circ}$. Scale $1: 250,000$ ( 1 inch $=$ about 4 miles). Sheet 51 by 39 inches (in color). (Supersedes Open-file report 81-1164.)

1-1995. CALIFORNIA. Geologic map of Glass Mountain, Mono County, California, by J. M. Metz and R. A. Bailey. 1993. Lat $37^{\circ} 43^{\prime}$ to $37^{\circ} 50^{\prime}$, long $118^{\circ} 40^{\prime}$ to $118^{\circ} 49^{\prime}$. Scale $1: 24,000$ ( 1 inch $=2,000$ feet). Sheet 58 by 41 inches (in color).

I-2003. NEW YORK. Bedrock and engineering geologic maps of Bronx County and parts of New York and Queens counties, New York, by C. A. Baskerville. 1992. Two sheets. Each sheet, lat $40^{\circ} 45^{\prime}$ to $40^{\circ} 55^{\prime}$, long $73^{\circ} 45^{\prime}$ to $73^{\circ} 57^{\prime} 30^{\prime \prime}$. Each sheet, scale $1: 24,000$ ( 1 inch $=2,000$ feet). Sheet 1,54 by 41 inches; sheet 2 , 54 by 37 inches (all in color).

I-2005. WASHINGTON. Geologic map of upper Eocene to Holocene volcanic and related rocks in the Cascade Range, Washington, by J. G. Smith. 1993. Two sheets. Sheet 1, lat $45^{\circ} 30^{\prime}$ to $49^{\circ}$, long $120^{\circ}$ to $123^{\circ}$; sheet 2 , lat $45^{\circ}$ to $49^{\circ}$, long $120^{\circ}$ to $123^{\circ}$. Sheet 1 , scale $1: 500,000$ ( 1 inch $=$ about 8 miles $)$. Sheet 1,44 by 37 inches; sheet 2,28 by 40 inches (all in color). (Accompanied by 19-page text.)

I-2032. ALASKA. Quaternary geologic map of the Mount Katmai Quadrangle and adjacent parts of the Naknek and Afognak quadrangles, Alaska, by J. R. Riehle and R. L. Detterman. 1993. Lat $58^{\circ}$ to $59^{\circ}$, long $153^{\circ}$ to $158^{\circ}$. Scale $1: 250,000(1$ inch $=$ about 4 miles). Sheet 48 by 36 inches (in color).

I-2050-F. MONTANA. Maps showing mineral resource assessment for porphyry and stockwork deposits of copper, molybdenum, and tungsten and for stockwork and disseminated deposits of gold and silver in the Butte $1^{\circ} \times 2^{\circ}$ Quadrangle, Montana, by J. E. Elliott, C. A. Wallace, G. K. Lee, J. C. Antweiler, D. J. Lidke, L. C. Rowan, W. F. Hanna, C. M. Trautwein, J. L. Dwyer and S. H. Moll. 1993. Three sheets. Lat $46^{\circ}$ to $47^{\circ}$, long $112^{\circ}$ to $114^{\circ}$. Sheet 1 , scale $1: 250,000$ ( 1 inch = about 4 miles $)$; sheets 2-3, scale 1:500,000 ( 1 inch = about 8 miles). Sheet 1, 30 by 50 inches; sheets $2-3,48$ by 36 inches (all in color). (Accompanied by 30 -page text.)

I-2089-C. Map showing bottom topography of the Pacific continental margin, Point Conception to Point Loma, by T. E. Chase, U.S. Geological Survey; Pat Wilde, University of California at Berkeley; W. R. Normark, G. I. Evenden, C. P. Miller, B. A. Seekins, J. D. Young, M. S. Grim and C. J. Lief, U.S. Geological Survey. Prepared in cooperation with the U.S. Geological Survey and National Oceanic and Atmospheric Administration Joint Office for Mapping and Research. 1992 . Lat $30^{\circ} \mathrm{N}$ to $35^{\circ} \mathrm{N}$, long $117^{\circ} \mathrm{W}$ to $126^{\circ} \mathrm{W}$. Scale $1: 1,000,000$ ( 1 inch = about 4 miles). Sheet 42 by 29 inches (in color). (Supersedes Open-file report 81-443.)

I-2090-A. Map showing sediment isopachs in the deep-sea basins of the Pacific continental margin, Cape Mendocino to Point Conception, by J. V. Gardner, D. A. Cacchione, D. E. Drake, B. D. Edwards, M. E. Field, M. A. Hampton, H. A. Karl, U.S.
Geological Survey; N. H. Kenyon, D. G. Masson, Institute of Oceanographic Sciences, England; D. S. McCulloch, and M. S. Grim, U.S. Geological Survey. Prepared in cooperation with the U.S. Geological Survey-National Oceanic and Atmospheric Administration Joint Office for Mapping and Research. 1993. Lat $34^{\circ} \mathrm{N}$ to $41^{\circ} \mathrm{N}$, long $117^{\circ} \mathrm{W}$ to $129^{\circ} \mathrm{W}$. Scale $1: 1,000,000(1$ inch $=$ about 16 miles). Sheet 56 by 38 inches (in color).

I-2090-B. Map showing depth to basement in the deep-sea basins of the Pacific continental margin, Cape Mendocino to Point Conception, by J. V. Gardner, D. A. Cacchione, D. E. Drake, B. D. Edwards, M. E. Field, M. A. Hampton, H. A. Karl, U.S. Geological Survey; N. H. Kenyon, D. G. Masson, Institute of Oceanographic Sciences, England; D. S. McCulloch, and M. S. Grim, U.S. Geological Survey. Prepared in cooperation with the U.S. Geological Survey-National Oceanic and Atmospheric Administration Joint Office for Mapping and Research. 1993. Lat $34^{\circ} \mathrm{N}$ to $41^{\circ} \mathrm{N}$, long $117^{\circ} \mathrm{W}$ to $129^{\circ} \mathrm{W}$. Scale $1: 1,000,000(1$ inch $=$ about 16 miles). Sheet 56 by 38 inches (in color).

I-2090-C. Map showing bottom topography of the Pacific continental margin, Cape Mendocino to Point Conception, by T, E. Chase, U.S. Geological Survey; Pat Wilde, University of California at Berkeley; W. R. Normark, G. I. Evenden, C. P. Miller, B. A. Seekins, J. D. Young, M. S. Grim, and C. J. Lief, U.S. Geological Survey. 1992 . Lat $34^{\circ} \mathrm{N}$ to $41^{\circ} \mathrm{N}$, long $117^{\circ} \mathrm{W}$ to $129^{\circ} \mathrm{W}$. Scale $1: 1,000,000(1$ inch $=$ about 16 miles $)$. Sheet 52 by 36 inches (in color).

I-2091-C. Map showing bottom topography of the Pacific continental margin, Strait of Juan de Fuca to Cape Mendocino, by M. S. Grim, T. E. Chase, G. I. Evenden, M. L. Holmes, W. R. Normark, U.S. Geological Survey; Pat Wilde, University of California at Berkeley; C. J. Fox, NOAA, Pacific Marine Environmental Laboratory; C. J. Lief and B. A. Seekins, U.S. Geological Survey. Prepared in cooperation with the U.S. Geological Survey-National Oceanic and Atmospheric Administration Joint Office for Mapping and Research. 1992 . Lat $40^{\circ} \mathrm{N}$ to $49^{\circ} \mathrm{N}$, long $122^{\circ} \mathrm{W}$ to $132^{\circ} \mathrm{W}$. Scale $1: 1,000,000(1$ inch = about 16 miles). Sheet 41 by 46 inches (in color).

I-2150-A. LOUISIANA. Louisiana barrier island erosion study; atlas of shoreline changes in Louisiana from 1853-1989, edited by S. J. Williams, U.S. Geological Survey; Shea Penland, Louisiana Geological Survey; and A. H. Sallenger, Jr., U.S. Geological Survey. 1992.103 p. spiral bound, 24 inches by 19 inches (in color).

I-2164. ALASKA. Geologic map of the Valdez A-4, B-3, B-4, C-3, $\mathrm{C}-4$, and D-4 quadrangles, northern Chugach Mountains and southern Copper River basin, Alaska, by George Plafker, J. S. Lull, W. J. Nokleberg, G. H. Pessel, W. K. Wallace and G. R. Winkler. 1992 . Lat $61^{\circ}$ to $62^{\circ}$, long $144^{\circ} 45^{\prime}$ to $145^{\circ} 30^{\circ}$. Scale $1: 125,000$ ( 1 inch = about 2 miles). Sheet 49 by 40 inches (in color).

I-2168. WYOMING. Geologic map of the Evanston $30^{\prime} \times 60^{\prime}$ Quadrangle, Uinta and Sweetwater counties, Wyoming, by J. $\mathrm{H}$. Dover and J. W. McGonigle. 1993. Lat $41^{\circ}$ to $41^{\circ} 30^{\prime}$, long $110^{\circ}$ to $111^{\circ}$. Scale $1: 100,000(1$ inch = about 1.6 miles $)$. Sheet 56 by $311 / 2$ inches (in color).

I-2173. NEVADA. Geologic map of the Meadow Valley Mountains, Lincoln and Clark counties, Nevada, by E. H. Pampeyan. 1993. Two sheets. Sheet 1 , lat $37^{\circ}$ to $37^{\circ} 15^{\prime}$, long $114^{\circ} 30^{\prime}$ to 
$114^{\circ} 45^{\prime}$; sheet 2 , lat $36^{\circ} 45^{\prime}$ to $37^{\circ}$, long $114^{\circ} 37^{\prime} 30^{\prime \prime}$ to $114^{\circ} 56^{\prime \prime \prime}$. Each sheet, scale $1: 50,000$ ( 1 inch $=$ about 4,200 feet $)$. Sheet 1,57 by 36 inches (in color); sheet 2, 30 by 36 inches. (Accompanied by 19-page text.) (Supersedes Open-file report 89-182.)

I-2198. ARIZONA. Geological map of the Poachie Range, Mohave and Yavapai counties, Arizona, by B. H. Bryant. 1992. Lat $34^{\circ} 22^{\prime} 30^{\prime \prime}$ to $34^{\circ} 30^{\prime}$, long $113^{\circ} 15^{\prime}$ to $113^{\circ} 37^{\prime} 30^{\prime \prime}$. Scale $1: 25,000$ ( 1 inch $=$ about 2,083 feet). Sheet 56 by 41 inches (in color). (Supersedes Open-file report 88-390.)

I-2199. UTAH. Surficial geologic map of the Weber Segment, Wasatch fault zone, Weber and Davis counties, Utah, by A. R. Nelson and S. F. Personius. 1993. Lat $40^{\circ} 50^{\prime}$ to $41^{\circ} 21^{\prime} 02^{\prime \prime}$, long $111^{\circ} 50^{\prime}$ to $111^{\circ} 58^{\prime} 05^{\prime \prime}$. Scale $1: 50,000$ ( 1 inch $=$ about 4,200 feet $)$. Sheet $371 / 2$ by 51 inches (in color). (Accompanied by 22-page text.)

I-2206. Landforms of the conterminous United States; a digital shaded-relief portrayal, by G. P. Thelin and R. J. Pike. 1991 (1992). Scale $1: 3,500,000$ ( 1 inch $=$ about 55 miles $)$. Sheet 55 by $351 / 2$ inches. (Accompanied by 16-page text.) (Reprint.)

I-2208. Geologic map of the MTM 25057 and 25052 quadrangles, Kasei Valles region of Mars, by D. H. Scott. Prepared for the National Aeronautics and Space Administration. 1993. Lat 22.5 to $27.5^{\circ}$, long $50^{\circ}$ to $60^{\circ}$. Scale $1: 502,000(1 \mathrm{~mm}=502 \mathrm{~m})$ at $50^{\circ}$ long. Sheet 56 by 41 inches (in color). (Transverse Mercator projection.)

I-2209. Geologic map of Io, by D. A. Crown, Ronald Greeley, R. A. Craddock and G. G. Schaber. Prepared for the National Aeronautics and Space Administration. 1992. The whole satellite. Scale $1: 15,000,000(1 \mathrm{~mm}=15 \mathrm{~km})$ at $0^{\circ}$ lat. Sheet 49 by 35 inches (in color). (Mercator projection.)

I-2232. WYOMING. Geologic map of the Esterbrook-Braae area, Albany, Converse, and Platte counties, Wyoming, by G. L. Snyder, U.S. Geological Survey; with a section on Economic geology of base and precious metals, by C. S. Bow, Lakewood, CO. 1993. Lat $42^{\circ} 22^{\prime} 30^{\prime \prime}$ to $42^{\circ} 32^{\prime} 30^{\prime \prime}$, long $105^{\circ} 15^{\prime}$ to $105^{\circ} 30^{\prime}$. Scale 1:24,000 ( 1 inch $=2,000$ feet). Sheet 58 by 41 inches (in color).

I-2266. NEW MEXICO, COLORADO. Geologic and structurecontour map of the Raton $30^{\prime} \times 60^{\prime}$ Quadrangle, Colfax and Union counties, New Mexico, and Las Animas County, Colorado, by G. R. Scott and C. L. Pillmore. 1993. Lat $36^{\circ} 30^{\prime}$ to $37^{\circ}$, long $104^{\circ}$ to $105^{\circ}$. Scale $1: 100,000$ ( 1 inch $=$ about 1.6 miles $)$. Sheet 54 by 39 inches (in color).

I-2267. MONTANA. Geologic and structure maps of the Kalispell $1^{\circ} \times 2^{\circ}$ Quadrangle, Montana, and Alberta and British Columbia, by J. E. Harrison, E. R. Cressman and J. W. Whipple. 1992. Two sheets. Lat $48^{\circ}$ to $49^{\circ}$, long $114^{\circ}$ to $116^{\circ}$. Each sheet, scale $1: 250,000$ ( 1 inch = about 4 miles $)$. Sheet 1,58 by 41 inches; sheet 2,40 by 28 inches (all in color). (Supercedes Open-file report 83-502)

I-2274. HAWAII. Geologic map of Hilo 7 1/2' Quadrangle, Island of Hawaii, by J. M. Buchanan-Banks. 1993. Lat $19^{\circ} 37^{\prime} 30^{\prime \prime}$ to $19^{\circ} 45^{\prime}$, long $115^{\circ}$ to $115^{\circ} 07^{\prime} 30^{\prime \prime}$. Scale $1: 24,000(1$ inch $=2,000$ feet). Sheet 46 by 40 inches (in color). (Accompanied by 17 -page text.)

I-2276. Shaded relief and surface markings map and shaded relief map of the lunar near side. Prepared for the National Aeronautics and Space Administration. 1992. Two sheets. Lat $50^{\circ} \mathrm{S}$ to $50^{\circ} \mathrm{N}$, long $100^{\circ} \mathrm{E}$ to $100^{\circ} \mathrm{W}$. Each sheet, scale $1: 5,000,000(1 \mathrm{~mm}=5$ $\mathrm{km}$ at $34^{\circ}$ lat. Each sheet 42 by $301 / 2$ inches (in color). (Mercator projection.)

I-2279-A. Maps showing the sea-floor topography of eastern Georges Bank, by P. C. Valentine, E. W. Strom and C. L. Brown. Prepared in cooperation with the National Marine Fisheries Service. 1992 . Lat $41^{\circ} 15^{\prime} \mathrm{N}$ to $42^{\circ} \mathrm{N}$, long $65^{\circ} 45^{\prime} \mathrm{W}$ to $67^{\circ} 30^{\prime} \mathrm{W}$. Scale $1: 250,000(1 \mathrm{inch}=$ about 4 miles $)$. Sheet 44 by 32 inches (in color).

I-2279-B. Maps showing the sedimentary environment of eastern Georges Bank, by P. C. Valentine, E. W. Strom, U.S. Geological Survey; R. G. Lough, National Marine Fisheries Service; and C. L. Brown, U.S. Geological Survey. Prepared in cooperation with the National Marine Fisheries Service. 1993. Lat $41^{\circ} 15^{\prime} \mathrm{N}$ to $42^{\circ} \mathrm{N}$, long $65^{\circ} 45^{\prime} \mathrm{W}$ to $67^{\circ} 30^{\prime} \mathrm{W}$. Scale $1: 250,000(1$ inch $=$ about 4 miles). Sheet 45 by 37 inches (in color).

I-2287. Geologic map and structure sections of the Sierra Juárez, Chihuahua, Mexico, by H. D. Drewes and Russ Dyer. 1993. Two sheets. Sheet 1 , Lat $31^{\circ} 40^{\prime}$ to $31^{\circ} 37^{\prime} 30^{\prime \prime}$, long $106^{\circ} 27^{\prime} 30^{\prime \prime}$ to $106^{\circ} 37^{\prime} 30^{\prime \prime}$. Sheet 1 , scale approximately $1: 12,500(1 \mathrm{inch}=1,042$ feet). Sheet 1,40 by 56 inches; sheet 2,52 by 39 inches (all in color).

I-2290. ARIZONA. Geologic map of the Jumpup Canyon and Big Springs quadrangles, Mohave and Coconino counties, Arizona, by G. H. Billingsley. 1992 . Lat $36^{\circ} 30^{\prime}$ to $36^{\circ} 45^{\prime}$, long $112^{\circ} 15^{\prime}$ to $112^{\circ} 45^{\prime}$. Scale 1:62,500 (1 inch = about 1 mile $)$. Sheet 53 by 31 inches (in color).

I-2291-A. ARIZONA, NEW MEXICO, TEXAS. Maps showing distribution, composition, and age of early and middle Cenozoic volcanic centers in Arizona, New Mexico, and West Texas, by R. G. Luedke. 1993. Two sheets. Lat $30^{\circ}$ to $37^{\circ}$, long $102^{\circ}$ to $114^{\circ}$. Each sheet, scale 1:1,000,000 ( 1 inch $=$ about 16 miles $)$. Sheet 1 , 50 by 39 inches; sheet 2,50 by 40 inches (all in color). (Accompanied by 16-page text.)

I-2299. IDAHO. Geologic map of the Slate Creek-John Day Creek area, Idaho County, Idaho, by Karen Lund, U.S. Geological Survey; W. F. McCollough, Polytech, Inc.; and E. H. Price, CER Corp. 1993. Lat $45^{\circ} 30^{\prime}$ to $45^{\circ} 45^{\prime}$, long $116^{\circ}$ to $116^{\circ} 22^{\prime} 30^{\prime \prime}$. Scale $1: 50,000$ ( 1 inch = about 4,200 feet). Sheet 50 by 32 inches (in color).

I-2311. Controlled photomosaic of the MTM 20032 Quadrangle, Ares-Maja Valles region of Mars. Prepared for the National Aeronautics and Space Administration. 1993. Lat $17.5^{\circ}$ to $22.5^{\circ}$, long $30^{\circ}$ to $35^{\circ}$. Scale $1: 502,000(1 \mathrm{~mm}=502 \mathrm{~m})$ at $30^{\circ}$ long. Sheet 26 by 37 inches. (Transverse Mercator projection.)

I-2312. Controlled photomosaic of the MTM 25032 Quadrangle, Ares-Maja Valles region of Mars. Prepared for the National Aeronautics and Space Administration. 1993. Lat $22.5^{\circ}$ to $27.5^{\circ}$, long $30^{\circ}$ to $35^{\circ}$. Scale $1: 502,000(1 \mathrm{~mm}=502 \mathrm{~m})$ at $30^{\circ}$ long. Sheet 25 by 37 inches. (Transverse Mercator projection.)

I-2313. Controlled photomosaic of the MTM 25037 Quadrangle, Ares-Maja Valles region of Maps. Prepared for the National Aeronautics and Space Administration. 1993. Lat $22.5^{\circ}$ to $27.5^{\circ}$, long $35^{\circ}$ to $40^{\circ}$. Scale $1: 502,000(1 \mathrm{~mm}=502 \mathrm{~m})$ at $30^{\circ}$ long. Sheet 25 by 37 inches. (Transverse Mercator projection.) 
I-2314. Controlled photomosaic of the MTM 20037 Quadrangle, Ares-Maja Valles region of Mars. Prepared for the National Aeronautics and Space Administration. 1993 . Lat $17.5^{\circ}$ to $22.5^{\circ}$, long $35^{\circ}$ to $40^{\circ}$. Scale $1: 502,000(1 \mathrm{~mm}=502 \mathrm{~m})$ at $30^{\circ}$ long. Sheet 26 by 37 inches. (Transverse Mercator projection.)

I-2315. Controlled photomosaic of the MTM 25042 Quadrangle, Ares-Maja Valles region of Mars. Prepared for the National Aeronautics and Space Administration. 1993. Lat $22.5^{\circ}$ to $27.5^{\circ}$, long $40^{\circ}$ to $45^{\circ}$. Scale $1: 502,000(1 \mathrm{~mm}=502 \mathrm{~m})$ at $50^{\circ}$ long. Sheet 25 by 37 inches. (Transverse Mercator projection.)

I-2316. Controlled photomosaic of the MTM 45162 Quadrangle, Arcadia Planitia region of Mars. Prepared for the National Aeronautics and Space Administration. 1993. Lat $42.5^{\circ}$ to $47.5^{\circ}$, long $160^{\circ}$ to $165^{\circ}$. Scale $1: 502,000(1 \mathrm{~mm}=502 \mathrm{~m})$ at $170^{\circ}$ long. Sheet 21 by 37 inches. (Transverse Mercator projection.)

I-2317. Controlled photomosaic of the MTM 45167 Quadrangle, Arcadia Planitia region of Mars. 1993 . Lat $42.5^{\circ}$ to $47.5^{\circ}$, long $165^{\circ}$ to $170^{\circ}$. Scale $1: 502,000(1 \mathrm{~mm}=502 \mathrm{~m})$ at $170^{\circ}$ long. Sheet 21 by 37 inches. (Transverse Mercator projection.)

I-2318. Controlled photomosaic of the MTM 45172 Quadrangle, Arcadia Planitia region of Mars. Prepared for the National Aeronautics and Space Adiministration. 1993. Lat $42.5^{\circ}$ to $47.5^{\circ}$, long $170^{\circ}$ to $175^{\circ}$. Scale $1: 502,000(1 \mathrm{~mm}=502 \mathrm{~m})$ at $170^{\circ}$ long. Sheet 21 by 37 inches. (Transverse Mercator projection.)

I-2319. Controlled photomosaic of the MTM 45177 Quadrangle, Arcadia Planitia region of Mars. Prepared for the National Aeronautics and Space Administration. 1993. Lat $42.5^{\circ}$ to $47.5^{\circ}$, long $175^{\circ}$ to $180^{\circ}$. Scale $1: 502,000(1 \mathrm{~mm}=502 \mathrm{~m})$ at $170^{\circ}$ long. Sheet 21 by 37 inches. (Transverse Mercator projection.)

I-2320. Controlled photomosaic of the MTM 40137 Quadrangle, Acheron Fossae region of Mars. Prepared for the National Aeronautics and Space Administration. 1993. Lat $37.5^{\circ}$ to $42.5^{\circ}$, long $135^{\circ}$ to $140^{\circ}$. Scale $1: 502,000(1 \mathrm{~mm}=502 \mathrm{~m})$ at $130^{\circ}$ long. Sheet 22 by 37 inches. (Transverse Mercator projection.)

I-2321. Controlled photomosaic of the MTM 40142 Quadrangle, Acheron Fossae region of Mars. Prepared for the National Aeronautics and Space Administration. 1993. Lat $37.5^{\circ}$ to $42.5^{\circ}$, long $140^{\circ}$ to $145^{\circ}$. Scale $1: 502,000(1 \mathrm{~mm}=502 \mathrm{~m})$ at $150^{\circ}$ long. Sheet 22 by 37 inches. (Transverse Mercator projection.)

I-2322. Controlled photomosaic of the MTM 35142 Quadrangle, Acheron Fossae region of Mars. Prepared for the National Aeronautics and Space Administration. 1993. Lat $32.5^{\circ}$ to $37.5^{\circ}$, long $140^{\circ}$ to $145^{\circ}$. Scale $1: 502,000(1 \mathrm{~mm}=502 \mathrm{~m})$ at $150^{\circ}$ long. Sheet $231 / 2$ by 37 inches. (Transverse Mercator projection.)

I-2323. Controlled photomosaic of the MTM 35137 Quadrangle, Acheron Fossae region of Mars. Prepared for the National Aeronautics and Space Administration. 1993. Lat $32.5^{\circ}$ to $37.5^{\circ}$, long $135^{\circ}$ to $140^{\circ}$. Scale $1: 502,000(1 \mathrm{~mm}=502 \mathrm{~m})$ at $130^{\circ}$ long. Sheet $231 / 2$ by 37 inches. (Transverse Mercator projection.)

I-2324. Controlled photomosaic of the MTM 35132 Quadrangle, Acheron Fossae region of Mars. Prepared for the National Aeronautics and Space Administration. 1993. Lat $32.5^{\circ}$ to $37.5^{\circ}$, long $130^{\circ}$ to $135^{\circ}$. Scale $1: 502,000(1 \mathrm{~mm}=502 \mathrm{~m})$ at $130^{\circ}$ long. Sheet $231 / 2$ by 37 inches. (Transverse Mercator projection.)

I-2325. Controlled photomosaic of the MTM 40132 Quadrangle, Acheron Fossae region of Mars. Prepared for the National Aero- nautics and Space Administration. 1993. Lat $37.5^{\circ}$ to $42.5^{\circ}$, long $130^{\circ}$ to $135^{\circ}$. Scale $1: 502,000(1 \mathrm{~mm}=502 \mathrm{~m})$ at $130^{\circ}$ long. Sheet 22 by 37 inches. (Transverse Mercator projection.)

I-2332. Controlled photomosaic of the MTM -35307 Quadrangle, western Hellas Planitia region of Mars. Prepared for the National Aeronautics and Space Administration. 1993. Lat -37.5 to $-32.5^{\circ}$, long $305^{\circ}$ to $310^{\circ}$. Scale $1: 502,000(1 \mathrm{~mm}=502 \mathrm{~m})$ at $310^{\circ}$ long. Sheet 23 by 38 inches. (Transverse Mercator projection.)

I-2333. Controlled photomosaic of the MTM -35312 Quadrangle, western Hellas Planitia region of Mars. Prepared for the National Aeronautics and Space Administration. 1993. Lat $-37.5^{\circ}$ to $32.5^{\circ}$, long $310^{\circ}$ to $315^{\circ}$. Scale $1: 502,000(1 \mathrm{~mm}=502 \mathrm{~m})$ at $310^{\circ}$ long. Sheet 23 by 38 inches. (Transverse Mercator projection.)

I-2334. Controlled photomosaic of the MTM -40302 Quadrangle, western Hellas Planitia region of Mars. Prepared for the National Aeronautics and Space Administration. 1993. Lat $-42.5^{\circ}$ to $37.5^{\circ}$, long $300^{\circ}$ to $305^{\circ}$. Scale $1: 502,000(1 \mathrm{~mm}=502 \mathrm{~m})$ at $310^{\circ}$ long. Sheet 22 by 38 inches. (Transverse Mercator projection.)

I-2335. Controlled photomosaic of the MTM -40307 Quadrangle, western Hellas Planitia region of Mars. Prepared for the National Aeronautics and Space Administration. 1993. Lat $-42.5^{\circ}$ to $37.5^{\circ}$, long $305^{\circ}$ to $310^{\circ}$. Scale $1: 502,000(1 \mathrm{~mm}=502 \mathrm{~m})$ at $310^{\circ}$ long. Sheet 22 by 37 inches. (Transverse Mercator projection.)

I-2336. Controlled photomosaic of the MTM -40312 Quadrangle, western Hellas Planitia region of Mars. Prepared for the National Aeronautics and Space Administration. 1993. Lat $-42.5^{\circ}$ to $37.5^{\circ}$, long $310^{\circ}$ to $315^{\circ}$. Scale $1: 502,000(1 \mathrm{~mm}=502 \mathrm{~m})$ at $310^{\circ}$ long. Sheet 22 by 38 inches. (Transverse Mercator projection.)

I-2337. Controlled photomosaic of the MTM 40312 Quadrangle, northern Arabia region of Mars. Prepared for the National Aeronautics and Space Administration. 1993. Lat $37.5^{\circ}$ to $42.5^{\circ}$, long $310^{\circ}$ to $315^{\circ}$. Scale $1: 502,000(1 \mathrm{~mm}=502 \mathrm{~m})$ at $310^{\circ}$ long. Sheet 22 by 38 inches. (Transverse Mercator projection.)

I-2338. Controlled photomosaic of the MTM 40317 Quadrangle, northern Arabia region of Mars. Prepared for the National Aeronautics and Space Administration. 1993. Lat $37.5^{\circ}$ to $42.5^{\circ}$, long $315^{\circ}$ to $320^{\circ}$. Scale $1: 502,000(1 \mathrm{~mm}=502 \mathrm{~m})$ at $310^{\circ}$ long. Sheet 22 by 38 inches. (Transverse Mercator projection.)

I-2339. Controlled photomosaic of the MTM 45312 Quadrangle, northern Arabia region of Mars. Prepared for the National Aeronautics and Space Administration. 1993. Lat $42.5^{\circ}$ to $47.5^{\circ}$, long $310^{\circ}$ to $315^{\circ}$. Scale $1: 502,000(1 \mathrm{~mm}=502 \mathrm{~m})$ at $310^{\circ}$ long. Sheet 20 by 38 inches. (Transverse Mercator projection.)

I-2340. Controlled photomosaic of the MTM 45317 Quadrangle, northern Arabia region of Mars. Prepared for the National Aeronautics and Space Administration. 1993. Lat $42.5^{\circ}$ to $47.5^{\circ}$, long $315^{\circ}$ to $320^{\circ}$. Scale $1: 502,000(1 \mathrm{~mm}=502 \mathrm{~m})$ at $310^{\circ}$ long. Sheet 20 by 38 inches. (Transverse Mercator projection.)

I-2342. NEVADA. Geologic map of late Cenozoic deposits and faults in the southern part of the Davis Mountain 15' Quadrangle, Esmeralda County, Nevada, by M. C. Reheis, T. L. Sawyer, J. L. Slate and A. R. Gillespie. 1993. Lat $37^{\circ} 45^{\prime}$ to $37^{\circ} 55^{\prime}$, long $118^{\circ}$ to $118^{\circ} 15^{\prime}$. Scale $1: 24,000(1$ inch $=2,000$ feet). Sheet 56 by 41 inches (in color).

I-2343-A. MONTANA, WYOMING. Geologic and structure map, with contours on top of the Pierre Shale, for the north half of the 
Powder River basin, southeastern Montana and northeastern Wyoming, by N. M. Denson, M. L. Gibson and G. L. Sims. 1993. Lat $44^{\circ}$ to $45^{\circ} 30^{\prime}$, long $104^{\circ} 30^{\prime}$ to $107^{\circ} 30^{\prime}$. Scale $1: 200,000$ ( 1 inch = about 3.2 miles). Sheet 58 by 41 inches (in color).

I-2343-B. WYOMING. Geologic and structure map, with contours on top of the Pierre Shale, for the south half of the Powder River basin, northeastern Wyoming, by N. M. Denson, M. L. Gibson and G. L. Sims. 1993. Lat $42^{\circ} 30^{\prime}$ to $44^{\circ}$, long $104^{\circ}$ to $107^{\circ}$. Scale $1: 200,000$ ( 1 inch $=$ about 3.2 miles $)$. Sheet 58 by 41 inches (in color).

I-2355. MICHIGAN. Structure map of Archean rocks, Palmer and Sands 7 1/2-minute quadrangles, Michigan, showing Great Lakes tectonic zone, by P. K. Sims. 1993 . Lat $46^{\circ} 22^{\prime} 30^{\prime \prime}$ to $46^{\circ} 30^{\prime}$, long $87^{\circ} 22^{\prime} 30^{\prime \prime}$ to $87^{\circ} 37^{\prime} 30^{\prime \prime}$. Scale $1: 24,000$ (1 inch $=2,000$ feet). Sheet 44 by 29 inches (in color).

I-2356. WISCONSIN, MICHIGAN. Geologic map of Precambrian rocks of parts of Iron Mountain and Escanaba $30^{\prime} \times 60^{\prime}$ quadrangles, northeastern Wisconsin and adjacent Michigan, by $P$. K. Sims and K. J. Schulz. 1993. Lat $45^{\circ} 30^{\prime}$ to $46^{\circ}$, long $87^{\circ} 45^{\prime}$ to $88^{\circ} 30^{\prime}$. Scale $1: 100,000$ ( 1 inch $=$ about 1.6 miles $)$. Sheet 53 by 31 inches (in color).

I-2364-B. WEST VIRGINIA. Peat resources in West Virginia, by C. C. Cameron. Prepared in cooperation with the West Virginia Geological and Economic Survey. 1993. Lat $39^{\circ} 02^{\prime} 30^{\prime \prime}$ to $39^{\circ} 10^{\prime}$, long $79^{\circ} 22^{\prime} 30^{\prime \prime}$ to $79^{\circ} 27^{\prime} 30^{\prime \prime}$. Scale $1: 24,000$ (1 inch $=2,000$ feet $)$. Sheet 28 by 34 inches (in color).

I-2369. MASSACHUSETTS, VERMONT. Bedrock geologic map of the Williamstown and North Adams quadrangles, Massachusetts and Vermont, and part of the Cheshire Quadrangle, Massachusetts, by N. M. Ratcliffe, U.S. Geological Survey; D. B. Potter, Hamilton College; and R. S. Stanley, University of Vermont. Prepared in cooperation with the Commonwealth of Massachusetts, Department of Public Works; and the State of Vermont, Geological Survey. 1993. Two sheets. Lat $42^{\circ} 30^{\prime}$ to $42^{\circ} 45^{\prime}$, long $73^{\circ}$ to $73^{\circ} 15^{\prime}$. Each sheet, scale 1:24,000 (1 inch $=2,000$ feet $)$. Sheet 1,41 by 52 inches; sheet 2,37 by 48 inches (all in color). (Accompanied by 13-page text.)

I-2377. KANSAS. Geologic map of the Bush City Quadrangle and parts of the Kincaid, Centerville, and Blue Mound quadrangles, Anderson County, Kansas, by W. D. Johnson, Jr. Prepared in cooperation with the Kansas Geological Survey. 1993. Lat $38^{\circ} 02^{\prime} 30^{\prime \prime}$ to $38^{\circ} 15^{\prime}$, long $95^{\circ} 05^{\prime}$ to $95^{\circ} 15^{\prime}$. Scale $1: 24,000$ (1 inch $=2,000$ feet). Sheet 36 by 44 inches (in color).

I-2378. KANSAS. Geologic map of the Westphalia Quadrangle and parts of the Geneva, Aliceville, and Neosho Falls quadrangles, Anderson County, Kansas, by W. D. Johnson, Jr. Prepared in cooperation with the Kansas Geological Survey. 1993. Lat $38^{\circ} 02^{\prime} 30^{\prime \prime}$ to $38^{\circ} 15^{\prime}$, long $95^{\circ} 22^{\prime} 30^{\prime \prime}$ to $95^{\circ} 30^{\prime}$. Scale $1: 24,000$ (1 inch $=2,000$ feet). Sheet 30 by 44 inches (in color).

I-2379. KANSAS. Geologic map of the Welda Quadrangle and part of the Colony Quadrangle, Anderson County, Kansas, by W. D. Johnson, Jr. Prepared in cooperation with the Kansas Geological Survey. 1993. Lat $38^{\circ} 02^{\prime} 30^{\prime \prime}$ to $38^{\circ} 15^{\prime}$, long $95^{\circ} 15^{\prime}$ to $95^{\circ} 22^{\prime} 30^{\prime \prime}$. Scale $1: 24,000$ ( 1 inch $=2,000$ feet). Sheet 30 by 44 inches (in color.)

I-2380-A. MONTANA, WYOMING. Geologic map showing thickness of the Upper Cretaceous Pierre Shale in the north half of the Powder River basin, southeastern Montana and northeastern Wyoming, by N. M. Denson, M. L. Gibson and G. L. Sims. 1993. Lat $44^{\circ}$ to $45^{\circ} 30^{\prime}$, long $104^{\circ} 30^{\prime}$ to $107^{\circ} 30^{\prime}$. Scale $1: 200,000$ ( 1 inch $=$ about 3.2 miles). Sheet 57 by 41 inches (in color).

I-2380-B. WYOMING. Geologic map showing thickness of the Upper Cretaceous Pierre Shale in the south half of the Powder River basin, northeastern Wyoming and adjacent areas, by N. M. Denson, M. L. Gibson and G. L. Sims. 1993. Lat $42^{\circ} 30^{\prime}$ to $44^{\circ}$, long $104^{\circ}$ to $107^{\circ}$. Scale $1: 200,000$ ( 1 inch = about 3.2 miles $)$. Sheet 58 by 40 inches (in color).

I-2392. Indexes of Mars topographic maps published by the U.S. Geological Survey January 1, 1993. Prepared for the National Aeronautics and Space Administration. 1993. Sheet $261 / 2$ by 37 inches.

I-2394. NEVADA. Geologic map of the Snowstorm Mountains and vicinity, Elko and Humboldt counties, Nevada, by A. R. Wallace. 1993. Lat $41^{\circ} 07^{\prime} 30^{\prime \prime}$ to $41^{\circ} 30^{\prime}$, long $116^{\circ} 45^{\prime}$ to $117^{\circ} 07^{\prime} 30^{\prime \prime}$. Scale $1: 50,000(1$ inch $=$ about 4,200 feet $)$. Sheet 42 by 41 inches (in color).

I-2408. MARIANA ISLANDS. Geologic map of Alamagan Volcano, northern Mariana Islands, by R. B. Moore and F. A. Trusdell. 1993. Lat $17^{\circ} 34 \mathrm{~N}$ to $17^{\circ} 37^{\prime} 30^{\prime} \mathrm{N}$, long $145^{\circ} 50^{\prime} \mathrm{E}$ to $145^{\circ} 47^{\prime} 30^{\prime \prime}$ E. Scale $1: 12,500$ ( 1 inch = about 1,030 feet $)$. Sheet 42 by 26 inches (in color).

I-2420. ARIZONA. Geologic map of the Tombstone volcanic center, Cochise County, Arizona, by R. B. Moore. 1993. Lat $31^{\circ} 35^{\prime}$ to $31^{\circ} 50^{\prime}$, long $110^{\circ}$ to $110^{\circ} 15^{\prime}$. Scale $1: 50,000$ (1 inch = about 4,200 feet). Sheet 31 by 29 inches (in color).

\section{MISCELLANEOUS INVESTIGATIONS SERIES MAPS- QUATERNARY GEOLOGICAL ATLAS OF THE UNITED STATES}

I-1420 (NG-14). Quaternary map of the Monterey $4^{\circ} \times 6^{\circ}$ Quadrangle, United States. State compilations by D. W. Moore and E. G. Wermund, Jr. Edited and integrated by the D. W. Moore and G. M. Richmond. Prepared in cooperation with the Texas Bureau of Economic Geology. 1993. Lat $24^{\circ}$ to $28^{\circ}$, long $96^{\circ}$ to $102^{\circ}$. Scale $1: 1,000,000$ ( 1 inch = about 16 miles). Sheet 47 by 31 inches (in color).

I-1420 (NH-14). Quaternary geologic map of the Austin $4^{\circ} \times 6^{\circ}$ Quadrangle, United States. State compilations by D. W. Moore and E. G. Wermund, Jr. Edited and integrated by D. W. Moore, G. M. Richmond, and A. C. Christiansen. Prepared in cooperation with the Texas Bureau of Economic Geology. 1993. Lat $28^{\circ}$ to $32^{\circ}$, long $96^{\circ}$ to $102^{\circ}$. Scale $1: 000,000$ ( 1 inch = about 16 miles $)$. Sheet $521 / 2$ by 33 inches (in color).

I-1420 (NJ-10). CALIFORNIA. Quaternary geologic map of the San Francisco Bay $4^{\circ} \times 6^{\circ}$ Quadrangle, United States, compiled by Clyde Wahrhaftig, S. W. Stine, and N. K. Huber. Edited and integrated by N. K. Huber. Prepared in cooperation with the Department of Geology and Geophysics, University of California, Berkeley. 1993. Lat $36^{\circ}$ to $40^{\circ}$, long $120^{\circ}$ to $126^{\circ}$. Scale $1: 1,000,000$ ( 1 inch = about 16 miles). Sheet 50 by 36 inches (in color).

I-1420 (NJ-14). Quaternary geologic map of the Wichita $4^{\circ} \times 6^{\circ}$ Quadrangle, United States. State compilations by J. E. Denne, K. V. Luza, G. M. Richmond, K. M. Jensen, W. D. Fishman, 
and E. G. Wermund, Jr. Edited and integrated by G. M. Richmond and A. C. Christiansen. Prepared in cooperation with the Kansas Geological Survey, Oklahoma Geological Survey, and Texas Bureau of Economic Geology. 1993. Lat $36^{\circ}$ to $40^{\circ}$, long $96^{\circ}$ to $102^{\circ}$. Scale $1: 1,000,000(1$ inch $=$ about 16 miles $)$. Sheet 52 by 41 inches (in color).

I-1420 (NJ-15). Quaternary geologic map of the Ozark Plateau $4^{\circ} \mathrm{X}$ $6^{\circ}$ Quadrangle, United States. State compilations by J. W. Whitfield, R. A. Ward, J. E. Denne, D. F. Holbrook, W. V. Bush, J. A. Lineback, K. V. Luza, K. M. Jensen, and W. D. Fishman. Edited and integrated by G. M. Richmond and D. L. Weide. Prepared in cooperation with the Missouri Department of Natural Resources, Kansas Geological Survey, Arkansas Geological Commission, Illinois State Geological Survey, and Oklahoma Geological Survey. 1993. Lat $36^{\circ}$ to $40^{\circ}$, long $90^{\circ}$ to $96^{\circ}$. Scale $1: 1,000,000$ ( 1 inch = about 16 miles). Sheet 50 by 35 inches (in color):

I-1420 (NK-18). Quaternary map of the Hudson River $4^{\circ} \times 6^{\circ}$ Quadrangle, United States and Canada. State and Provincial compilations by D. S. Fullerton, W. D. Sevon, E. H. Muller, Sheldon Judson, R. F. Black, P. W. Wagner, J. H. Hartshorn, W. F. Chapman, and W. D. Cowan. Edited and integrated by D. S. Fullerton. Prepared in cooperation with the Pennsylvania Topographic and Geologic Survey, Syracuse University, New York State Geological Survey, Princeton University, University of Connecticut, University of Vermont, University of Massachusetts, Slippery Rock State College, and Ontario Geological Survey. 1992. Lat $40^{\circ}$ to $44^{\circ}$, long $72^{\circ}$ to $78^{\circ}$. Scale $1: 1,000,000(1 \mathrm{inch}=$ about 16 miles). Sheet 54 by 41 inches (in color). (Accompanied by 19 -page text.)

I-1420 (NL-17). Quaternary geologic map of the Sudbury $4^{\circ} \times 6^{\circ}$ Quadrangle, United States and Canada. State and Province compilations by E. V. Sado, D. S. Fullerton, C. L. Baker, and W. R. Farrand. Edited and integrated by D. S. Fullerton. Prepared in cooperation with the Ontario Geological Survey and the University of Michigan, Department of Geological Sciences. 1993. Lat $44^{\circ}$ to $48^{\circ}$, long $78^{\circ}$ to $84^{\circ}$. Scale $1: 1,000,000(1$ inch $=$ about 16 miles). Sheet $511 / 2$ by 31 inches (in color).

I-1420 (NL-18). Quaternary geologic map of the Ottawa $4^{\circ} \times 6^{\circ}$ Quadrangle, United States and Canada. State and provincial compilations by N. R. Gadd, J. J. Veillette, D. S. Fullerton, P. W. Wagner, and W. F. Chapman. Edited and integrated by D. S. Fullerton. Prepared in cooperation with the Geological Survey of Canada; Ontario Geological Survey; University of Vermont, Department of Geology; and Slippery Rock State College, Department of Geology, Pennsylvania. 1993. Lat $44^{\circ}$ to $48^{\circ}$, long $72^{\circ}$ to $78^{\circ}$. Scale $1: 1,000,000$ ( 1 inch $=$ about 16 miles $)$. Sheet 56 by 32 inches (in color).

\section{COAL INVESTIGATIONS MAPS}

Geologic maps on topographic or planimetric bases; various scales; show bedrock geology, stratigraphy, and structural relations in certain coalresource areas.

C-0142. MONTANA. Geologic map showing distribution of clinker in the Tertiary Fort Union and Wasatch formations, northern Powder River basin, Montana, by E. L. Heffern, D. A. Coates, Jason Whiteman and M. S. Ellis. 1993. Lat $45^{\circ}$ to $46^{\circ} 30^{\prime}$, long $105^{\circ} 115^{\prime}$ to $107^{\circ}$. Scale $1: 175,000$ ( 1 inch $=$ about 2.8 miles $)$. Sheet 41 by 56 inches (in color).
C-0144. UTAH. Geologic map of the Horse Flat Quadrangle, Kane County, Utah, by W. E. Bowers. 1993. Lat $37^{\circ} 15^{\prime}$ to $37^{\circ} 22^{\prime} 30^{\prime \prime}$, long $111^{\circ} 45^{\prime}$ to $111^{\circ} 52^{\prime} 30^{\prime \prime}$. Scale $1: 24,000$ ( 1 inch $=2,000$ feet $)$. Sheet 34 by 34 inches (in color).

\section{OIL AND GAS INVESTIGATIONS CHARTS}

Charts show stratigraphic information for certain oil and gas fields and other areas having hydrocarbon potential.

OC-0135. MONTANA, WYOMING. Stratigraphic cross sections A-A' through F-F', showing electric logs of Upper Cretaceous and older rocks, Powder River basin, Montana and Wyoming, by J. E. Fox. 1993. Three sheets. Lat $43^{\circ}$ to $45^{\circ}$, long $104^{\circ}$ to $107^{\circ}$. Sheet 1,27 by 58 inches; sheet 2,32 by 58 inches; sheet 3,27 by 58 inches. (Supersedes Open-file reports 86-465-A,B,C,D,E,F.)

OC-0136. WYOMING. Stratigraphic cross sections G-G' through L-L', showing electric logs of Upper Cretaceous and older rocks, Powder River basin, Wyoming, by J. E. Fox. 1993. Three sheets. Lat $43^{\circ}$ to $45^{\circ}$, long $104^{\circ}$ to $107^{\circ}$. Sheet 1,32 by 56 inches; sheet 2,32 by 55 inches; sheet 3,32 by 58 inches. (Supersedes Open-file reports 86-465-G,H,I,J,K,L.)

OC-0137. WYOMING. Stratigraphic cross sections M-M' through R-R', showing electric logs of Upper Cretaceous and older rocks, Powder River basin, Wyoming, by J. E. Fox. 1993. Three sheets. Lat $43^{\circ}$ to $45^{\circ}$, long $104^{\circ}$ to $107^{\circ}$. Sheet 1,24 by 58 inches; sheet 2,27 by 58 inches; sheet 3,31 by 58 inches. (Supersedes Open-file reports $86-465 \mathrm{M}-\mathrm{R}$.)

OC-0138. MONTANA, WYOMING. Stratigraphic cross sections $S-S^{\prime}$ through V-V', showing electric logs of Upper Cretaceous and older rocks, Powder River basin, Montana and Wyoming, by J. E. Fox. 1993. Two sheets. Lat $43^{\circ}$ to $45^{\circ}$, long $104^{\circ}$ to 107 . Each sheet 31 by 58 inches. (Supersedes Open-file reports 86-465S,T,U,V:)

OC-0140. WYOMING, MONTANA. Geological log signatures of lower Tertiary and Upper Cretaceous rocks in the Powder River basin, Wyoming and Montana, by D. A. Seeland, J. K. Hardie, A. B. Gibbons, E. A. Johnson, L. R. Biewick, M. W. McLellan, C. L. Molnia and F. W. Pierce. 1993. Lat $42^{\circ}$ to $48^{\circ}$, long $102^{\circ}$ to $108^{\circ}$. Sheet 31 by 27 inches.

\section{MISCELLANEOUS FIELD STUDIES MAPS}

Multicolor or black and white maps on topographic or planimetric bases; quadrangle or irregular areas; various scales. Pre-1971 maps show bedrock geology in relation to specific mining or mineral-deposit problems; the majority of post-1971 maps are preliminary black and white maps on various subjects such as environmental studies or Wilderness mineral investigations.

MF-1835-H. Maps showing areal extent of selected Paleozoic shales in the northern Midcontinent, U.S.A., compiled by W. P. Pratt. Prepared in cooperation with the geological surveys of Arkansas, Illinois, Iowa, Kansas, Minnesota, Missouri, Nebraska, Oklahoma, and Wisconsin. 1992. Seven sheets. Lat $36^{\circ}$ to $46^{\circ}$, long $88^{\circ}$ to $100^{\circ}$. Each sheet, scale $1: 1,000,000$ ( 1 inch =about 16 miles). Each sheet $421 / 2$ by 52 inches. (Folio of the northern Midcontinent area.)

MF-1838-D. ALASKA. Maps showing metallic mineral resources of the Bendeleben and Solomon quadrangles, western Alaska, by B. M. Gamble and A. B. Till. 1993. Three sheets. Lat $64^{\circ} 15^{\prime}$ to $66^{\circ}$, long $162^{\circ}$ to $165^{\circ}$. Each sheet, scale $1: 250,000(1 \mathrm{inch}=$ 
about 4 miles). Sheet 1,38 by 38 inches; sheet 2,26 by 38 inches; sheet 3,29 by 38 inches. (Accompanied by 22-page text.)

MF-1877-A. NEVADA. Geologic map of the Tonopah $1^{\circ}$ by $2^{\circ}$ Quadrangle, central Nevada, by D. H. Whitebread and D. A. John. 1992 . Lat $38^{\circ}$ to $39^{\circ}$, long $116^{\circ}$ to $118^{\circ}$. Scale $1: 250,000(1$ inch $=$ about 4 miles). Sheet 42 by 28 inches. (Accompanied by 13-page text.) (Folio of the Tonopah $1^{\circ}$ by $2^{\circ}$ Quadrangle, central Nevada.)

MF-1994-D. MISSOURI, ARKANSAS. Mineral-resource assessment maps of the Harrison $1^{\circ} \times 2^{\circ}$ Quadrangle, Missouri and Arkansas, by W. P. Pratt, T. S. Hayes, R. L. Erickson, U.S. Geological Survey; E. B. Kisvarsanyi, M. C. McFarland, A. W. Rueff, Missouri Geological Survey; W. V. Bush, G. W. Colton, and J. D. McFarland III, Arkansas Geological Commission. Prepared in cooperation with the Missouri Department of Natural Resources, Division of Geology and Land Survey, and the Arkansas Geological Commission. 1993 . Lat $36^{\circ}$ to $37^{\circ}$, long $92^{\circ}$ to $94^{\circ}$. Scale $1: 500,000(1$ inch $=$ about 8 miles $)$. Sheet 40 by 58 inches (in color). (Accompanied by 22-page text.)

MF-1996-E. ALASKA. Mineralogical maps showing distribution of selected ore-related minerals in the nonmagnetic, heavy-mineral-concentrate fraction of stream sediment from the Mount Hayes $1^{\circ} \times 3^{\circ}$ Quadrangle, eastern Alaska Range, Alaska, by R. B. Tripp, G. C. Curtin, W. J. Nokleberg, D. L. Huston and J. R. Hampton. 1993. Three sheets. Lat $63^{\circ}$ to $64^{\circ}$, long $144^{\circ}$ to $147^{\circ}$. Each sheet, scale 1:250,000 ( 1 inch $=$ about 4 miles $)$. Each sheet 34 by 42 inches (all in color). (Accompanied by 13-page text.) (Folio of the Mount Hayes Quadrangle.)

MF-2081-C. UTAH. Maps showing the distribution of barium, beryllium, copper, lead, molybdenum, silver, and tin in stream-sediment samples, Delta $1^{\circ} \times 2^{\circ}$ Quadrangle, Utah, by D. R. Zimbelman. 1993. Three sheets. Lat $39^{\circ}$ to $40^{\circ}$, long $112^{\circ}$ to $114^{\circ}$. Each sheet, scale $1: 250,000$ ( 1 inch = about 4 miles $)$. Sheets $1-2,41$ by 57 inches; sheet 3,36 by 24 inches (all in color).

MF-2081-D. UTAH. Maps showing distribution of gold, antimony, arsenic, bismuth, cadmium, and zinc in stream-sediment samples, Delta $1^{\circ} \times 2^{\circ}$ Quadrangle, Utah, by D. R. Zimbelman. 1993. Two sheets. Lat $39^{\circ}$ to $40^{\circ}$, long $112^{\circ}$ to $114^{\circ}$. Each sheet, scale $1: 250,000$ ( 1 inch = about 4 miles). Each sheet, 41 by 57 inches (all in color).

MF-2081-E. UTAH. Maps showing distribution of antimony, arsenic, barium, beryllium, bismuth, cadmium, copper, lead, molybdenum, silver, tin, tungsten, and zinc in heavy-mineral-concentrate samples, Delta $1^{\circ} \times 2^{\circ}$ Quadrangle, Utah, by D. R. Zimbelman. 1993. Five sheets. Lat $39^{\circ}$ to $40^{\circ}$, long $112^{\circ}$ to $114^{\circ}$. Each sheet, scale $1: 250,000$ ( 1 inch $=$ about 4 miles). Sheets $1-4,41$ by 57 inches; sheet 5,36 by 24 inches (all in color).

MF-2083-B. Magnetic anomaly map of the central Cayman Trough, northwestern Caribbean Sea, by W. P. Dillon, N. T. Edgar, U.S. Geological Survey; L. M. Parson, Institute of Oceanographic Sciences, England; K. M. Scanlon, G. R. Driscoll, U.S. Geological Survey; and C. L. Jacobs, Institute of Oceanographic Sciences. Prepared in cooperation with the Institute of Oceanographic Sciences. 1993 . Lat $18^{\circ}$ to $19^{\circ}$, long $80^{\circ}$ to $83^{\circ}$. Scale $1: 402,000$ at lat $18^{\circ} 30^{\prime}$ N. Sheet 39 by 34 inches (in color). (Mercator projection.)

MF-2125-E. KANSAS, MISSOURI. Assessment of the Joplin $1^{\circ}$ $\times 2^{\circ}$ Quadrangle, Kansas and Missouri, for mississippi valley-type deposits and other minerals, by W. P. Pratt, T. S. Hayes, R. L. Erickson, U.S. Geological Survey; Pieter Berendsen, Kansas Geological Survey; and E. B. Kisvarsanyi, Missouri Department of Natural Resources. Prepared in cooperation with the Kansas Geological Survey and the Missouri Department of Natural Resources, Division of Geology and Land Survey. 1993. Two sheets. Sheet 2 , lat $37^{\circ}$ to $38^{\circ}$, long $94^{\circ}$ to $96^{\circ}$. Sheet 2 , scale $1: 250,000$ (1 inch = about 4 miles). Sheet 1,46 by 34 inches; sheet 2,37 by 50 inches (in color). (Folio of the Joplin $1^{\circ} \times 2^{\circ}$ Quadrangle, Kansas and Missouri.)

MF-2144-B. ALASKA. Maps showing geochemistry and mineralogy of nonmagnetic heavy-mineral-concentrate samples from the southern part of the Chandler Lake Quadrangle, Alaska, by K. D. Kelley, S. J. Sutley and J. G. Frisken. 1993. Two sheets. Sheet 1 , lat $68^{\circ}$ to $69^{\circ}$, long $150^{\circ}$ to $153^{\circ}$; sheet 2, lat $68^{\circ}$ to $68^{\circ} 30^{\prime}$, long $150^{\circ}$ to $153^{\circ}$. Each sheet, scale $1: 250,000$ (1 inch = about 4 miles). Sheet 1,48 by 34 inches; sheet 2,47 by 35 inches.

MF-2144-C. ALASKA. Maps showing geochemistry of sediment samples from the southern part of the Chandler Lake Quadrangle, Alaska, by K. D. Kelley, H. N. Barton, S. J. Sutley and R. M. O'Leary. 1993 . Two sheets. Sheet 1 , lat $68^{\circ}$ to $69^{\circ}$, long $150^{\circ}$ to $153^{\circ}$; sheet 2 , lat $68^{\circ}$ to $68^{\circ} 30^{\prime}$, long $150^{\circ}$ to $153^{\circ}$. Each sheet, scale $1: 250,000$ ( 1 inch = about 4 miles $)$. Sheet 1,52 by 34 inches; sheet 2,32 by 39 inches.

MF-2144-D. ALASKA. Maps showing geochemistry of sediment samples from the northern part of the Chandler Lake Quadrangle, Alaska, by K. D. Kelley and S. J. Sutley. 1993. Two sheets. Sheet 1 , lat $68^{\circ}$ to $69^{\circ}$, long $150^{\circ}$ to $153^{\circ}$; sheet 2 , lat $68^{\circ} 30^{\prime}$ to $69^{\circ}$, long $150^{\circ}$ to $153^{\circ}$. Each sheet, scale $1: 250,000$ ( 1 inch $=$ about 4 miles). Sheet 1,48 by 30 inches; sheet 2,54 by 37 inches.

MF-2203. NORTH CAROLINA, VIRGINIA. Reconnaissance geochemistry in the southern part of the Virgilina District, North Carolina and Virginia, by F. G. Lesure. 1993. Lat $36^{\circ} 17^{\prime} 30^{\prime \prime}$ to $36^{\circ} 37^{\prime} 30^{\prime \prime}$, long $78^{\circ} 42^{\prime} 30^{\prime \prime}$ to $79^{\circ} 05^{\prime}$. Scale $1: 48,000$ (1 inch $=$ 4,000 feet). Sheet 56 by 40 inches.

MF-2207. ALASKA. Maps showing distribution of selected minerals in the nonmagnetic heavy-mineral fraction of stream-sediment samples, Medfra Quadrangle, Alaska, by R. B. Tripp and H. D. King. 1993 . Lat $63^{\circ}$ to $64^{\circ}$, long $153^{\circ}$ to $156^{\circ}$. Scale 1:250,000 ( 1 inch = about 4 miles $)$. Sheet 53 by 41 inches.

MF-2208. NEW JERSEY, NEW YORK. Stratigraphic relations of the sedimentary rocks below the Lower Jurassic Orange Mountain Basalt, northern Newark Basin, New Jersey and New York, by R. A. Parker. Prepared in cooperation with the New Jersey Geological Survey. 1993. Lat $40^{\circ} 22^{\prime} 30^{\prime \prime}$ to $41^{\circ}$, long $74^{\circ}$ to $74^{\circ} 45^{\prime}$. Scale $1: 100,000(1$ inch $=$ about 1.6 miles $)$. Sheet 52 by 40 inches (in color).

MF-2209. NORTH CAROLINA. Bathymetry at the head of the Cape Fear Slide, offshore North Carolina, by E. A. Schmuck, Peter Popenoe, U. S. Geological Survey; C. K. Paull, University of North Carolina; and C. L. Brown, U. S. Geological Survey. 1992 . Lat $32^{\circ} 50^{\prime} \mathrm{N}$ to $33^{\circ} 20^{\prime} \mathrm{N}$, long $75^{\circ} 40^{\prime} \mathrm{W}$ to $76^{\circ} 20^{\prime} \mathrm{W}$. Scale $1: 150,000$ ( 1 inch $=$ about 2.4 miles $)$. Sheet 37 by 26 inches.

MF-2211. GLORIA mosaic of the deep sea floor off the Atlantic coast of the United States, by J. S. Schlee, W. P. Dillon, Peter Popenoe, J. M. Robb and D. W. O'Leary. 1992. Lat $28^{\circ} \mathrm{N}$ to $40^{\circ} \mathrm{N}$, long $66^{\circ} \mathrm{W}$ to $80^{\circ} \mathrm{W}$. Scale $1: 2,000,000(1$ inch $=$ about 32 miles). Sheet 54 by 40 inches. 
MF-2212. CALIFORNIA. Isopach map showing Quaternary deposits in the Gulf of Santa Catalina area, California, by P. A. McCrory. 1993. Two sheets. Sheet 1 , lat $32^{\circ} 30^{\prime}$ to $34^{\circ}$, long $117^{\circ}$ to $118^{\circ} 30^{\prime}$. Sheet 1 , scale $1: 250,000$ ( 1 inch = about 4 miles $)$. Sheet 1,45 by 31 inches; sheet 2,50 by 32 inches.

MF-2213. GEORGIA. Geochemical reconnaissance of the Carroll County gold belt and southwestern part of the Dahlonega gold belt, western Georgia, by F. G. Lesure. 1993. Two sheets. Sheet 1 , lat $34^{\circ}$ to $34^{\circ} 20^{\prime}$, long $84^{\circ} 15^{\prime}$ to $84^{\circ} 55^{\prime}$; sheet 2 , lat $33^{\circ} 22^{\prime} 30^{\prime \prime}$ to $34^{\circ}$, long $84^{\circ} 37^{\prime} 30^{\prime \prime}$ to $85^{\circ} 22^{\prime} 30^{\prime \prime}$. Sheet 1 , scale $1: 48,000$ ( 1 inch $=4,000$ feet); sheet 2 , scale $1: 100,000$ ( 1 inch = about 1.6 miles $)$. Sheet 1,50 by 32 inches; sheet 2,53 by 42 inches (all in color). (Accompanied by 21-page text.)

MF-2214. ALABAMA. Geochemical reconnaissance of the Blue Hill and Gregory Hill gold mines and vicinity, Tallapoosa County, Alabama, by F. G. Lesure. 1993 . Lat $32^{\circ} 45^{\prime}$ to $33^{\circ}$, long $85^{\circ} 45^{\prime}$ to $86^{\circ}$. Scale $1: 1,500$ ( 1 inch $=133$ feet $)$. Sheet 45 by 37 inches.

MF-2215-A. SOUTH CAROLINA, GEORGIA, NORTH CAROLINA. Suitability of bedrock for construction stone in the Greenville $1^{\circ} \times 2^{\circ}$ Quadrangle, South Carolina, Georgia, and North Carolina, by J. P. D'Agostino, J. W. Horton, Jr., A. E. Nelson and J. W. Clarke. 1993 . Lat $34^{\circ}$ to $35^{\circ}$, long $82^{\circ}$ to $84^{\circ}$. Scale 1:250,000 ( 1 inch = about 4 miles $)$. Sheet 32 by 42 inches.

MF-2216. COLORADO. Geologic map of the Philadelphia Creek Quadrangle, Rio Blanco County, Colorado, by R. C. Johnson and M. C. Smith. 1993. Lat $39^{\circ} 52^{\prime} 30^{\prime \prime}$ to $40^{\circ}$, long $108^{\circ} 37^{\prime} 30^{\prime \prime}$ to $108^{\circ} 45^{\prime}$. Scale $1: 24,000$ ( 1 inch $=2,000$ feet $)$. Sheet 41 by 51 inches.

MF-2217-A. ALASKA. Geochemical maps showing the distribution of selected elements in stream-sediment samples from the Craig, Dixon Entrance, and western edges of the Ketchikan and Prince Rupert quadrangles, Southeast Alaska, by J. B. Cathrall, B. F. Arbogast, George VanTrump and S. K. McDanal. 1993. Two sheets. Lat $54^{\circ} 45^{\prime}$ to $56^{\circ}$, long $131^{\circ} 30^{\prime}$ to $134^{\circ} 40^{\prime}$. Each sheet, scale $1: 250,000$ ( 1 inch = about 4 miles). Sheet 1,40 by 57 inches; sheet 2,34 by 31 inches.

MF-2217-B. ALASKA. Geochemical maps showing the distribution and concentration of selected elements in nonmagnetic heavymineral-concentrate samples from stream sediment from the Craig, Dixon Entrance, and western edges of the Ketchikan and Prince Rupert quadrangles, Southeast Alaska, by J. B. Cathrall, S. K. McDanal, George VanTrump, B. F. Arbogast and D. J. Grybeck. 1993. Two sheets. Lat $54^{\circ} 45^{\prime}$ to $56^{\circ}$, long $131^{\circ} 30^{\prime}$ to $134^{\circ} 40^{\prime}$. Each sheet, scale $1: 250,000$ ( 1 inch = about 4 miles $)$. Sheet 1,41 by 56 inches; sheet 2,35 by 30 inches.

MF-2218. TENNESSEE. Logs of exploratory trenches through liquefaction features on late Quaternary terraces in the Obion River valley, northwestern Tennessee, by D. T. Rodbell and Lee-Ann Bradley. 1993. Two sheets. Sheet 1,54 by 39 inches; sheet 2,48 by 37 inches.

MF-2220. COLORADO. Preliminary geologic map of the East Evacuation Creek Quadrangle, Garfield and Rio Blanco counties, Colorado, by M. P. Pantea. 1993 . Lat $39^{\circ} 37^{\prime} 30^{\prime \prime}$ to $39^{\circ} 45^{\circ}$, long $108^{\circ} 52^{\prime} 30^{\prime \prime}$ to $109^{\circ}$. Scale $1: 24,000(1 \mathrm{inch}=2,000$ feet $)$. Sheet 38 by 36 inches.

MF-2221. NEW JERSEY. Bathymetry, sidescan sonar image, and surficial geological interpretation of the inner shelf off Little Egg
Inlet, New Jersey, by D. C. Twichell, U.S. Geological Survey; and K. W. Able, Rutgers University. Prepared in cooperation with Rutgers University. 1993 . Two sheets. Lat $39^{\circ} 27^{\prime} \mathrm{N}$ to $39^{\circ} 30^{\prime} \mathrm{N}$, long $74^{\circ} 13^{\prime} \mathrm{W}$ to $74^{\circ} 17^{\prime} \mathrm{W}$. Each sheet, scale $1: 15,000(1$ inch $=$ about 1,300 feet). Sheet 1,33 by 50 inches; sheet 2,44 by 26 inches. (Mercator projection.)

MF-2223. NORTH CAROLINA. Preliminary geology and geochemistry of rocks and saprolite in part of the Franklin Quadrangle, Macon County, North Carolina, by F. G. Lesure and E. R. Force. 1993. Lat $35^{\circ} 07^{\prime} 30^{\prime \prime}$ to $35^{\circ} 15^{\prime}$, long $83^{\circ} 22^{\prime} 30^{\prime \prime}$ to $83^{\circ} 30^{\prime}$. Scale $1: 24,000$ ( 1 inch $=2,000$ feet $)$. Sheet 40 by 40 inches.

MF-2224. VERMONT. Bedrock geologic map of the Sunderland Quadrangle, Bennington and Windham counties, Vermont, by W. C. Burton. 1993. Lat $43^{\circ}$ to $43^{\circ} 07^{\prime} 30^{\prime \prime}$, long $73^{\circ}$ to $73^{\circ} 07^{\prime} 30^{\prime \prime}$. Scale $1: 24,000(1$ inch $=2,000$ feet $)$. Sheet $481 / 2$ by $381 / 2$ inches.

MF-2226-A. ALASKA. Preliminary geologic map of the Bethel and southern Russian Mission quadrangles, Southwestern Alaska, by S. E. Box, E. J. Moll-Stalcup, T. P. Frost and J. M. Murphy. 1993. Lat $60^{\circ}$ to $61^{\circ} 15^{\prime}$, long $159^{\circ}$ to $162^{\circ}$. Scale $1: 250,000$ ( 1 inch = about 4 miles). Sheet 42 by $431 / 2$ inches. (Accompanied by 20-page text.) (Folio of the Bethel area.)

MF-2227. ALASKA. Geochemical map showing the distribution of gold in the Anchorage $1^{\circ} \times 3^{\circ}$ Quadrangle, Alaska, by D. J. Madden-McGuire and R. B. Tripp. 1993. Lat $61^{\circ}$ to $62^{\circ}$, long $147^{\circ}$ to $150^{\circ}$. Scale $1: 250,000(1$ inch $=$ about 4 miles $)$. Sheet 45 by 34 inches (in color).

MF-2228. ALASKA. Map showing metallic mineral resource potential in the Goodnews Bay, Hagemeister Island, and Nushagak Bay $1^{\circ} \times 3^{\circ}$ quadrangles, Southwest Alaska, by J. E. Kilburn, R. J. Goldfarb, Andrew Griscom and S. E. Box. 1993. Four sheets. Sheets $2-4$, lat $58^{\circ} 30^{\prime}$ to $60^{\circ}$, long $158^{\circ}$ to $162^{\circ} 30^{\prime}$. Sheets $2-4$, scale $1: 250,000$ ( 1 inch = about 4 miles). Sheet 1,52 by 40 inches; sheets $2-4,45$ by 36 inches (in color).

MF-2230. ARIZONA. Geologic map of the Turkey Mountain Quadrangle, Coconino County, Arizona, by G. W. Weir and L. D. Nealey. 1993. Lat $34^{\circ} 37^{\prime} 30^{\prime \prime}$ to $34^{\circ} 45^{\prime}$, long $111^{\circ} 15^{\prime}$ to $111^{\circ} 22^{\prime} 30^{\prime \prime}$. Scale $1: 24,000(1 \mathrm{inch}=2,000$ feet $)$. Sheet 28 by 32 inches.

MF-2231. HAWAII. Bathymetry of south flank of Kilauea Volcano, Hawaii, by W. W. Chadwick, Jr., Oregon State University; J. R. Smith, Jr., University of Hawaii; J. G. Moore, D. A. Clague, U.S. Geological Survey; M. O. Garcia, University of Hawaii; and C. G. Fox, National Oceanic and Atmospheric Administration. Prepared in cooperation with the National Oceanic and Atmospheric Administration Joint Office for Mapping and Research. 1993. Lat $18^{\circ} 30^{\prime}$ to $19^{\circ} 30^{\prime}$, long $154^{\circ} 42^{\prime}$ to $155^{\circ} 30^{\prime}$. Scale $1: 150,000(1$ inch $=$ about 2.4 miles $)$. Sheet 26 by 38 inches (in color).

MF-2232. COLORADO. Geologic map of the Divide Creek Quadrangle, Rio Blanco and Moffat counties, Colorado, by W. J. Hail, Jr. and B. E. Barnum. 1993. Lat $40^{\circ} 07^{\prime} 30^{\prime \prime}$ to $40^{\circ} 15^{\prime}$, long $108^{\circ} 30^{\prime}$ to $108^{\circ} 37^{\prime} 30^{\prime \prime}$. Scale $1: 24,000$ ( 1 inch $=2,000$ feet $)$. Sheet 33 by 29 inches.

MF-2233. HAWAII. Bathymetry of southern Mauna Loa Volcano, Hawaii, by W. W. Chadwick, Jr., Oregon State University; J. G. Moore, U.S. Geological Survey; M. O. Garcia, University of Hawaii; and C. G. Fox, National Oceanic and Atmospheric Ad- 
ministration. Prepared in cooperation with the National Oceanic and Atmospheric Administration Joint Office for Mapping and Research. 1993. Lat $18^{\circ} 30^{\prime}$ to $19^{\circ} 30^{\prime}$, long $155^{\circ} 24^{\prime}$ to $156^{\circ} 12^{\prime}$. Scale $1: 150,000(1$ inch $=$ about 2.4 miles $)$. Sheet $251 / 2$ by 44 inches (in color).

MF-2234. IDAHO. Geologic map of the Blackbird Mountain 15minute Quadrangle, Lemhi County, Idaho, by K. V. Evans and J. J. Connor. 1993 . Lat $45^{\circ}$ to $45^{\circ} 15^{\prime}$, long $114^{\circ} 15^{\prime}$ to $114^{\circ} 30^{\prime}$. Scale 1:62,500 ( 1 inch = about 1 mile $)$. Sheet 34 by 27 inches.

MF-2236. COLORADO. Complete Bouguer gravity anomaly map of the State of Colorado, by G. A. Abrams. 1993. Lat $37^{\circ}$ to $41^{\circ}$, long $102^{\circ}$ to $109^{\circ}$. Scale $1: 500,000(1$ inch $=$ about 8 miles $)$. Sheet 56 by 40 inches. (Supersedes GP-895.)

MF-2238. Map showing late Cenozoic extensional tilt patterns and associated structures in Sonora and adjacent areas, Mexico, by J. H. Stewart and Jaime Roldán-Quintana. 1994. Lat $26^{\circ}$ to $32^{\circ}$, long $108^{\circ}$ to $115^{\circ}$. Scale $1: 1,000,000$ ( 1 inch $=$ about 16 miles $)$. Sheet 51 by 38 inches.

MF-2242. Geologic map of the Guri and southern part of the Tucupita $2^{\circ} \times 3^{\circ}$ quadrangles, Bolivar State, Venezuela, by D. P. Cox, Floyd Gray, U.S. Geological Survey; Juan Acosta, Corporación Venezolana de Guayana; J. H. Stewart, U.S. Geological Survey; Jesús Arespón, Corporación Venezolana de Guayana; W. E. Brooks, U.S. Geological Survey; Luis Franco, Edixon Salazar, and Yolanda Lopez, Corporación Venezolana de Guayana. Prepared in cooperation with the Corporación Venezolana de Guayana, Técnica Minera. 1993. Lat $6^{\circ} \mathrm{N}$ to $8^{\circ} 45^{\prime} \mathrm{N}$, long $60^{\circ} \mathrm{W}$ to $63^{\circ} \mathrm{W}$. Scale 1:500,000 (1 inch $=$ about 8 miles $)$. Sheet 50 by 41 inches.

MF-2250. UTAH. Geologic map of the Nutters Hole Quadrangle, Uintah and Carbon counties, Utah, by W. B. Cashion. 1994. Lat $39^{\circ} 45^{\prime}$ to $39^{\circ} 52^{\prime} 30^{\prime \prime}$, long $109^{\circ} 45^{\prime}$ to $109^{\circ} 52^{\prime} 30^{\prime \prime}$. Scale $1: 24,000$ ( 1 inch $=2,000$ feet). Sheet 28 by 32 inches.

MF-2252. WISCONSIN. Shoreline and coastal wetland variability along the west shore of Green Bay, Marinette and Oconto counties, Wisconsin, by G. L. Shideler. 1994. Lat $44^{\circ} 30^{\prime}$ to $45^{\circ}$, long $87^{\circ} 37^{\prime} 30^{\prime \prime}$ to $88^{\circ} 57^{\prime} 30^{\prime \prime}$. Scale $1: 24,000$ ( 1 inch $=2,000$ feet). Sheet 45 by 41 inches.

MF-2253. MONTANA. Geologic map of the Big Timber Stock and vicinity, southern Crazy Mountains, Sweet Grass and Park counties, south-central Montana, by E. A. du Bray, J. E. Elliott, A. B. Wilson, B. S. Van Gosen and L. A. Rosenberg. 1993. Lat $46^{\circ}$ to $46^{\circ} 07^{\prime} 30^{\prime \prime}$, long $110^{\circ} 15^{\prime}$ to $110^{\circ} 25^{\prime}$. Scale $1: 24,000$ (1 inch $=2,000$ feet). Sheet $451 / 2$ by 33 inches.

\section{SPECIAL GEOLOGIC MAPS}

KENTUCKY. Geologic map of Kentucky. Prepared in cooperation with the Kentucky Geological Survey. 1992 . Lat $37^{\circ}$ to $39^{\circ}$, long $82^{\circ}$ to $89^{\circ}$. Scale $1: 500,000$ ( 1 inch = about 8 miles $)$. Sheet 58 by 41 1/4 inches (in color). Recompiled and revised from the Geologic map of Kentucky, scale 1:250,000 (1 inch = about 4 miles), 1981.)

ARKANSAS. Geological map of Arkansas, by B. R. Haley, U.S. Geological Survey; assisted by E. E. Glick, U.S. Geological Survey, and W. V. Bush, B. F. Clardy, C. G. Stone, M. B. Woodward and D. L. Zachry, Arkansas Geological Commission. Prepared in cooperation with the Arkansas Geological Commis- sion. 1993. Lat $33^{\circ}$ to $36^{\circ}$, long $90^{\circ}$ to $94^{\circ}$. Scale $1: 500,000$ (1 inch $=$ about 8 miles). Sheet 52 by 34 inches (in color). (Available flat only.) (Revision.)

\section{HYDROLOGIC INVESTIGATIONS ATLASES}

Multicolored or black and white maps on topographic or planimetric bases presenting a wide range of geohydrologic data; both regular and irregular areas.

HA-0551. MINNESOTA. Water resources of the Little Fork River watershed, northeastern Minnesota, by J. O. Helgesen, G. F. Lindholm and D. W. Ericson. Prepared in cooperation with the Minnesota Department of Natural Resources Division of Waters, Soils, and Minerals. 1976 (1993). Lat $47^{\circ} 30^{\prime}$ to $48^{\circ} 30^{\prime}$, long $92^{\circ} 30^{\prime}$ to $93^{\circ} 30^{\prime}$. Sheet 54 by 40 inches (in color.) (Two-sided map.) (Reprint.)

HA-0722-G. KANSAS. Geohydrologic systems in Kansas; geohydrology of the Great Plains aquifer system, by H. E. McGovern and R. J. Wolf. 1993. Two sheets. Lat $37^{\circ}$ to $40^{\circ}$, long $95^{\circ}$ to $102^{\circ}$. Sheet 1 , scales $1: 1,000,000(1$ inch $=$ about 16 miles $)$ and 1:3,000,000 (1 inch $=$ about 48 miles $)$; sheet 2 , scales $1: 1,000,000(1 \mathrm{inch}=$ about 16 miles $), 1: 2,000,000(1 \mathrm{inch}=$ about 32 miles), and 1:3,000,000 ( 1 inch = about 48 miles $)$. Sheet 1,53 by 38 inches; sheet 2,49 by 40 inches (all in color).

HA-0722-H. KANSAS. Geohydrologic systems in Kansas; geohydrology of the upper aquifer unit in the Western Interior Plains aquifer system, by J. F. Kenny, C. V. Hansen and R. J. Wolf. 1993. Two sheets. Lat $37^{\circ}$ to $40^{\circ}$, long $95^{\circ}$ to $102^{\circ}$. Each sheet, scale $1: 500,000$ ( 1 inch = about 8 miles $)$. Sheet 1,45 by 37 inches; sheet 2,46 by 40 inches (all in color).

HA-0722-I. KANSAS. Geohydrologic systems in Kansas; geohydrology of the lower aquifer unit in the Western Interior Plains aquifer system, by L. J. Combs, C. V. Hansen and R. J. Wolf. 1993. Three sheets. Lat $37^{\circ}$ to $40^{\circ}$, long $95^{\circ}$ to $102^{\circ}$. Each sheet, scale $1: 1,500,000$ ( 1 inch = about 24 miles $)$. Sheet 1,51 by 33 inches; sheet 2,37 by 40 inches; sheet 3,34 by 33 inches (all in color).

HA-0730-J. Ground water atlas of the United States; Segment 9, Iowa, Michigan, Minnesota, and Wisconsin, by P. G. Olcott. 1992. p. J1-J31. (Atlas $18 \times 23$ inches.)

\section{SPECIAL MAPS}

Central United States earthquakes, 1974-1991. 1992. Scale $1: 1,000,000$ ( 1 inch = about 16 miles $)$. Poster 26 by $321 / 2$ inches (base satellite image is in color).

The North American vegetation index map, developed and produced jointly by: U.S. Geological Survey and Canada Centre for Remote Sensing. 1993. Lat $10^{\circ}$ to $50^{\circ}$, long $70^{\circ}$ to $130^{\circ}$. Scale $1: 12,500,000$ ( 1 inch = about 198 miles $)$. Sheet 31 by 31 inches (in color). (Accompanied by 3-page text.) 


\section{OUTSIDE PUBLICATIONS}

\section{ARTICLES AND REPORTS}

Articles by U.S. Geological Survey personnel in non-U.S. Geological Survey publications that came to our attention in 1993. Non-U.S. Geological Survey personnel who share authorship in articles with U.S. Geological Survey personnel are indicated by an asterisk $\left(^{*}\right)$ immediately following the name. These publications are not available from the U.S. Geological Survey.

OP-1. G. A. Abers*, Goran Ekstrom*, M. S. Marlow and E. L. Geist. Bering Sea earthquake of February 21,1991; active faulting along the Bering shelf edge. Journal of Geophysical Research, B, Solid Earth and Planets. v. 98, no. 2, February 10, 1993. p. 2155-2165.

OP-2. Ulrich Achauer*, P. K. Maguire*, James Mechie*, W. V. Green*, Claus Prodehl*, Karl Fuchs*, M. A. Khan*, G. R. Keller*, W. D. Mooney, B. Jacob*, Hans Thybo*, I. O. Nyambok*, J. P. Patel*, L. W. Braile*, G. A. Thompson*, D. J. Gajewski*, R. P. Meyer*, P. M. Davis* and D. Riaroh*. Some remarks on the structure and geodynamics of the Kenya Rift. Tectonophysics, in Geodynamics of rifting; Volume II, Case history studies on rifts; North and South America and Africa. v. 213, no. 1-2, October 30,1992 . p. 257-268.

OP-3. J. G. Acker* and O. P. Bricker. The "simplest" watershed; an in-situ study of bedrock-atmospheric deposition reactions. Proceedings - International Symposium on Water-Rock Interaction. 7, 1992. p. 533-536.

OP-4. C. D. Adams*, S. J. Randtke*, E. M. Thurman and R. A. Hulsey*. Atrazine and its degradation products in soil and ground water, and the effectiveness of water-treatment processes for their removal. Proceedings from the Annual University of Kansas Environmental Engineering Conference, in Proceedings from the 40th annual University of Kansas environmental engineering conference. 40,1990 . p. 1-24.

OP-5. C. D. Adams* and E. M. Thurman. Formation and transport of deethylatrazine in the soil and vadose zone. Journal of Environmental Quality. v. 20, no. 3, September 1991. p. 540547.

OP-6. T. S. Ahlbrandt, K. K. Krohn and G. C. Curtin. Energy and mineral resources in and near NP lands. Park Science. v. 13, no. 1, 1993. p. 10-11.

OP-7. J. C. Aitchison*, P. M. Ashley*, M. C. Blake, Jr. and P. G. Flood*. Tectonics and metallogenesis, southern part of the New England Orogen; field excursion; in New England Orogen; tectonics and metallogenesis. (J. D. Kleeman, editor). Armidale, N.S.W.: Univ. N. Engl., Dep. Geol. and Geophys. November 1988. p. 308-313.

OP-8. J. Aitchison* and B. L. Murchey (editors). Significance and application of Radiolaria to terrane analysis. Palaeogeography, Palaeoclimatology, Palaeoecology: v. 96, no. 1-2, October 6, 1992. $174 \mathrm{p}$.

OP-9. G. V. Albino. Application of metal zoning to gold exploration in porphyry copper systems; discussion. Journal of Geochemical Exploration. v. 48, no. 3, August 1, 1993. p. 359-365.

OP-10. J. N. Aleinikoff, J. C. Reed, Jr. and Ed DeWitt. COLORADO. The Mount Evans Batholith in the Colorado Front Range; revision of its age and reinterpretation of its structure. Geological
Society of America Bulletin. v. 105, no. 6, June 1993. p. 791806.

OP-11. J. N. Aleinikoff, J. C. Reed, Jr. and J. L. Wooden. COLORADO. Lead isotopic evidence for the origin of Paleo- and Mesoproterozoic rocks of the Colorado Province, U.S.A. Precambrian Research. v. 63, no. 1-2, September 1993. p. 97-122.

OP-12. J. N. Aleinikoff, Marianne Walter, M. J. Kunk and P. P. Hearn. Do ages of authigenic K-feldspar date the formation of mississippi valley-type $\mathrm{Pb}-\mathrm{Zn}$ deposits, central and southeastern United States?; $\mathrm{Pb}$ isotopic evidence. Geology (Boulder). v. 21, no. 1, January 1993. p. 73-76.

OP-13. D. J. Allen*, W. J. Hinze* and W. F. Cannon. Drainage, topographic, and gravity anomalies in the Lake Superior region; evidence for a $1100 \mathrm{Ma}$ mantle plume. Geophysical Research Letters. v. 19, no. 21, November 3, 1992. p. 2119-2122.

OP-14. J. C. Alt*, W. C. Shanks, III and M. C. Jackson*. MARIANA ISLANDS. Cycling of sulfur in subduction zones; the geochemistry of sulfur in the Mariana island arc and back-arc trough. Earth and Planetary Science Letters. v. 119 , no. 4, October 1993. p. $477-494$.

OP-15. C. J. Ammon* and J. E. Vidale. Tomography without rays. Bulletin of the Seismological Society of America. v. 83, no. 2, April 1993. p. 509-528.

OP-16. L. D. Anderson, D. B. Kent and J. A. Davis. Reduction of $\mathrm{Cr}(\mathrm{VI})$ under mildly reducing conditions in a sand and gravel aquifer. Proceedings - International Symposium on Water-Rock Interaction. 7, 1992. p. 495-498.

OP-17. O. J. Anderson* and W. J. Mapel. NEW MEXICO. Geology and coal resources, Shoemaker Canyon SE Quadrangle, Cibola County, New Mexico. Open File Report (New Mexico, Bureau of Mines and Mineral Resources). Report no. 172, May 1983. $32 \mathrm{p}$.

OP-18. R. E. Anderson. WASHINGTON, IDAHO. The Newport Fault; Eocene listric normal faulting, mylonitization, and crustal extension in northeastern Washington and northwestern Idaho: Discussion. Geological Society of America Bulletin. v. 105 , no. 11 , November 1993. p. 1511-1512.

OP-19. R. E. Anderson and T. P. Barnhard. NEVADA, UTAH, ARIZONA. Aspects of three-dimensional strain at the margin of the extensional orogen, Virgin River depression area, Nevada, Utah, and Arizona. Geological Society of America Bulletin. v. 105, no. 8, August 1993. p. 1019-1052.

OP-20. R. Y. Anderson*, J. P. Bradbury, W. E. Dean and Minze Stuiver*. MINNESOTA. Chronology of Elk Lake sediments; coring, sampling, and time-series construction. Special Paper - Geological Society of America, in Elk Lake, Minnesota; evidence for rapid climate change in the north-central United States. (J. P. Bradbury, editor and others). 276, 1993. p. 37 43.

OP-21. R. Y. Anderson*, W. E. Dean and J. P. Bradbury. MINNESOTA. Elk Lake in perspective. Special Paper - Geological Society of America, in Elk Lake, Minnesota; evidence for rapid climate change in the north-central United States. (J. P. Bradbury, editor and others). 276, 1993. p. 1-6. 
OP-22. B. J. Andraski and Birl Lowery*. Erosion effects on soil water storage, plant water uptake, and corn growth. Soil Science Society of America Journal. v. 56, no. 6, December 1992. p. 1911-1919.

OP-23. D. J. Andrews, D. H. Oppenheimer and J. J. Lienkaemper. CALIFORNIA. The Mission link between the Hayward and Calaveras faults. Journal of Geophysical Research, B, Solid Earth and Planets. v. 98, no. 7, July 10, 1993. p. 12,083-12,095.

OP-24. E. D. Andrews and J. D. Smith. A theoretical model for calculating marginal bedload transport rates of gravel, in Dynamics of gravel-bed rivers. (P. Billi, editor and others). New York, NY: John Wiley \& Sons, 1992. p. 41-52.

OP-25. L. M. Anovitz*, E. J. Essene*, G. W. Metz*, S. R. Bohlen, E. F. Westrum, Jr.* and B. S. Hemingway. Heat capacity and phase equilibria of almandine, $\mathrm{Fe}_{3} \mathrm{Al}_{2} \mathrm{Si}_{3} \mathrm{O}_{12}$. Geochimica et Cosmochimica Acta. v. 57, no. 17, September 1993. p. 4191-4204.

OP-26. S. S. Anthony. MARSHALL ISLANDS. Majoro Atoll, in Hydrology and water resources of small islands; a practical guide. (A. Falkland, editor). Paris: UNESCO, 1991. p. 368374.

OP-27. G. B. Arehart*, K. A. Foland*, C. W. Naeser and S. E. Kesler*. NEVADA. ${ }^{40} \mathrm{Ar} /{ }^{39} \mathrm{Ar}, \mathrm{K} / \mathrm{Ar}$, and fission track geochronology of sediment-hosted disseminated gold deposits at PostBetze, Carlin Trend, northeastern Nevada. Economic Geology and the Bulletin of the Society of Economic Geologists. v. 88, no. 3, May 1993. p. 622-646.

OP-28. Jafar Arkani-Hamed*, G. G. Schaber and R. G. Strom*. Constraints on the thermal evolution of Venus inferred from Magellan data. Journal of Geophysical Research, E, Planets. v. 98, no. 3, March 25, 1993. p. 5309-5315.

OP-29. Jafar Arkani-Hamed*, G. G. Schaber and R. G. Strom*. Constraints on the thermal evolution of Venus inferred from Magellan data. LPI Contribution, in Papers presented to the international colloquium on Venus. (Lunar and Planetary Institute). 789, 1992. p. 5-6.

OP-30. N. T. Arndt*, G. K. Czamanske, J. L. Wooden and V. A. Fedorenko*. Mantle and crustal contributions to continental flood volcanism. Tectonophysics, in Relationships between mantle processes and geologic processes at or near the Earth's surface. (M. J. Wortel, editor and others). v. 223, no. 1-2, July 30, 1993. p. $39-52$.

OP-31. Antonio Arribas, Jr.*, R. M. Tosdal and J. L. Wooden. Lead isotope constraints on the origin of base- and precious-metal deposits from southeastern Spain, in Source, transport and deposition of metals. (Maurice Pagel, editor and others). Rotterdam: A. A. Balkema, 1991. p. 241-244.

OP-32. J. K. Arthur. MISSISSIPPI. Overview of the Cockfield and Strata aquifers in the Jackson metropolitan area, Mississippi. Proceedings - Mississippi Water Resources Conference, in Twenty-second Mississippi water resources conference. (B. J. Daniel, editor). 22, 1992. p. 128-138.

OP-33. G. M. Ashley* and T. D. Hamilton. ALASKA. Fluvial response to late Quaternary climatic fluctuations, central Kobuk
Valley, northwestern Alaska. Journal of Sedimentary Petrology. v. 63 , no. 5 , September 1993. p. 814-827.

OP-34. E. D. Attanasi, K. J. Bird and R. F. Mast. ALASKA. Economics and the national oil and gas assessment; the case of onshore Northern Alaska. AAPG Bulletin. v. 77, no. 3, March 1993. p. 491-504.

OP-35. B. F. Atwater, Héctor Jiménez Núñez* and Claudio VitaFinzi*. New late Holocene emergence despite earthquake-induced submergence, south-central Chile. Quaternary International, in Impacts of tectonics on Quaternary coastal evolution. (Yoko Ota, editor and others). 15-16, 1992. p. 77-85.

OP-36. B. F. Atwater and A. L. Moore*. WASHINGTON. A tsunami about 1000 years ago in Puget Sound, Washington. Science. v. 258, no. 5088, December 4. 1992. p. 1614-1617.

OP-37. R. A. Ayuso and J. G. Arth. VERMONT. The Northeast Kingdom Batholith, Vermont; magmatic evolution and geochemical constraints on the origin of Acadian granite rocks. Contributions to Mineralogy and Petrology. v. 111, no. 1, 1992. p. 1-23.

OP-38. William Back. Coastal karst formed by ground-water discharge, Yucatan, Mexico. International Contributions to Hydrogeology, in Hydrogeology of selected karst regions. (William Back, editor and others). 13, 1992. p. 461-466.

OP-39. William Back and Gultekin Gunay*. Tectonic influences on groundwater flow systems in karst of the Southwest Taurus Mountains, Turkey. International Contributions to Hydrogeology, in Hydrogeology of selected karst regions. (William Back, editor and others). 13, 1992. p. 263-272.

OP-40. William Back, J. S. Herman* and Henri Paloc* (editors). Hydrogeology of selected karst regions. International Contributions to Hydrogeology. 13,1992. $493 \mathrm{p}$.

OP-41. William Back and E. R. Landa. Ingesting the consequences of water-rock interaction; historical notes on bottled water and spas. Proceedings - International Symposium on Water-Rock Interaction. 7, 1992. p. 767-770.

OP-42. C. R. Bacon. OREGON. Partially melted granodiorite and related rocks ejected from Crater Lake caldera, Oregon. Special Paper - Geological Society of America, in The second Hutton symposium on the origin of granites and related rocks; proceedings. (P. E. Brown, editor and others). 272, 1992. p. 27-47.

OP-43. C. R. Bacon, Sally Newman* and E. M. Stolper*. OREGON. Water, $\mathrm{CO}_{2}, \mathrm{Cl}$, and $\mathrm{F}$ in melt inclusions in phenocrysts from three Holocene explosive eruptions, Crater Lake, Oregon. American Mineralogist. v. 77, no. 9-10, October 1992. p. 1021-1030.

OP-44. M. J. Baedecker, I. M. Cozzarelli, J. R. Evans and P. P. Hearn. Authigenic mineral formation in aquifers rich in organic material. Proceedings - International Symposium on Water-Rock Interaction. 7, 1992. p. 257-261.

OP-45. W. C. Bagby and J. S. Cline*. NEVADA. Constraints on the pressure of formation of the Getchell gold deposit, Humboldt County, Nevada, as interpreted from secondary-fluid-inclusion data, in Geology and ore deposits of the Great Basin; symposium proceedings. (G. L. Raines, editor and others). Reno, NV: Geological Society of Nevada, 1991. p. 793-804. 
OP-46. R. M. Baker* and W. S. Mooty. ALABAMA. Use of water in Alabama, 1990. Geological Survey of Alabama Informatiọn Series. Report no. 59E, 1993. 49 p.

OP-47. A. Barbanti* and M. H. Bothner. A procedure for partitioning bulk sediments into distinct grain-size fractions for geochemical analysis. Environmental Geology. v. 21, no. 1-2, April 1993. p. 3-13.

OP-48. E. Barg*, D. Lal*, J. R. Southon*, M. W. Caffee*, R. C. Finkel*, A. J. Jull* and M. J. Pavich. Applications of cosmogenic nuclear methods for studying soil erosion and formation rates. Proceedings - International Symposium on Water-Rock Interaction. 7, 1992. p. 541-543.

OP-49. K. E. Bargar. WYOMING. Particles in Yellowstone fluid inclusions resemble bacteria. Proceedings - International Symposium on Water-Rock Interaction. 7, 1992. p. 263-266.

OP-50. C. E. Barker and M. J. Pawlewicz. An empirical determination of the minimum number of measurements needed to estimate the mean random vitrinite reflectance of disseminated organic matter. Organic Geochemistry, in Collected papers from the ninth annual meeting of the Society for Organic Petrology. (S. A. Stout, editor and others). v. 20, no. 6, August 1993 . p. 643651.

OP-51. H. L. Barnes*, R. W. Charles*, D. G. Coles*, D. H. Dahlem*, J. M. Ferry*, Grant Garven*, A. K. Kronenberg, M. J. Lippman*, Meijer Arend*, J. B. Moody*, G. A. Parks*, Edward Patera*, E. W. Roedder and W. E. Seyfried*. Rock-fluid interactions, in Workshop on Fundamental geochemistry needs for nuclear waste isolation. (B. R. Erdal, chairperson). September 1985. p. 15-22. Available from: NTIS, Springfield, VA, United States.

OP-52. T. P. Barnhard. UTAH. Fault-scarp studies of the Oquirrh Mountains, Utah. Miscellaneous Publication (Utah Geological and Mineral Survey), in In the footsteps of G. K. Gilbert; Lake Bonneville and neotectonics of the eastern Basin and Range Province; guidebook for field trip twelve. (M. N. Machette, editor). Report no. 88-1, 1988. p. 52-54.

OP-53. S. E. Barrientos*, George Plafker and Emilio Lorca*. Postseismic coastal uplift in southern Chíle. Geophysical Research Letters. v. 19, no. 7, April 3, 1992. p. 701-704.

OP-54. J. A. Barron. Pliocene paleoclimatic interpretation of DSDP Site 580 (NW Pacific) using diatoms. Marine Micropaleontology. v. 20, no. 1, October 1992. p. 23-44.

OP-55. P. J. Bartlein*, Thompson Webb, III* and S. W. Hostetler. Climatology. Studies in Mathematical Geology, in Techniques for determining probabilities of geologic events and processes. (R. L. Hunter, editor and others). 4, 1992. p. 99. 122.

OP-56. Claudio Bartolini*, J. H. Stewart, Claire Carter, B. L. Murchey and J. E. Repetski. Stratigraphy of Paleozoic eugeoclinal strata in Sierra El Aliso, central Sonora, México. Boletín del Departamento de Geología Uni-Son. v. 6, no. 1-2, December 1989. p. 11-21.

OP-57. P. B. Barton and I-Ming Chou. Refinement of the evaluation of the role of $\mathrm{CO}_{2}$ in modifying estimates of the pressure of epithermal mineralization. Economic Geology and the Bulletin of the Society of Economic Geologists. v. 88, no. 4. July 1993. p. 873-884.

OP-58. P. B. Barton and I-Ming Chou. Calculation of the vaporsaturated liquidus for the $\mathrm{NaCl}-\mathrm{CO}_{2}-\mathrm{H}_{2} \mathrm{O}$ system. Geochimica et Cosmochimica Acta. v. 57, no. 12, June 1993. p. 2715-2723.

OP-59. A. L. Bates, E. C. Spiker, W. H. Orem and W. C. Burnett*. PALAU. Speciation and isotopic composition of sulfur in sediments from Jellyfish Lake, Palau. Chemical Geology. v. 106, no. 1-2, May 5 , 1993. p. 63-76.

OP-60. L. G. Batten. National Capital Urban Planning Project; development of a three-dimensional GIS. GIS/LIS - Proceedings, Annual Conference and Exposition, in GIS/LIS ' 89 proceedings. 1989, 1989. p. 781-786.

OP-61. D. M. Batty and L. R. Herbert. UTAH. Ground-water conditions in Utah, spring of 1992. Cooperative Investigations Report - Utah, Department of Natural Resources. Report no. 32, 1992. $91 \mathrm{p}$.

OP-62. H. H. Bauer. WASHINGTON, OREGON. Estimates of ground-water recharge in parts of eastern Washington and northeastern Oregon. AWRA Monograph Series, in Regional aquifer systems of the United States; aquifers of the Far West. (K. R. Prince, editor and others). 16, June 1991. p. 109-126.

OP-63. W. J. Bawiec and W. D. Grundy. Computer-generated surfaces and grids of the geometry, rock type, and chemistry of a bedded mineral deposit. AAPG Computer Applications in Geology, in Computer modeling of geologic surfaces and volumes. (D. E. Hamilton, editor and others). 1, 1992. p. 37-46.

OP-64. Peter Bayliss*, Chen Keqiao*, A. J. Criddle* and G. A. Desborough. Mineral nomenclature; sulrhodite. Mineralogical Magazine. v. 56, no. 382, March 1992. p. 125-126.

OP-65. J. C. Behrendt, W. E. LeMasurier*, A. K. Cooper, FranzTessensohn*, A. M. Tréhu* and D. Damaske*. Geophysical studies of the West Antarctic Rift System. Tectonics. v. 10, no. 6, December 1991. p. 1257-1273.

OP-66. H. E. Belkin and H. M. Sparck*. ALASKA. Mercury, arsenic, antimony, and selenium contents of sediment from the Kuskokwim River, Bethel, Alaska, USA. Environmental Geology. v. 22, no. 2, October 1993. p. 106-110.

OP-67. B. K. Bender* and D. M. Perkins. Treatment of parameter uncertainty and variability for a single seismic hazard map. Earthquake Spectra. v. 9, no. 2, May 1993. p. 165-195.

OP-68. L. V. Benson. Factors affecting ${ }^{14} \mathrm{C}$ ages of lacustrine carbonates; timing and duration of the last highstand lake in the Lahontan Basin. Quaternary Research (New York). v. 39, no. 2, March 1993. p. 164-174.

OP-69. L. V. Benson. Timing of the last highstand of Lake Lahontan. Journal of Paleolimnology. v. 5, no. 2, 1990. p. $115-126$.

OP-70. H. M. Benz and J. E. Vidale. Probing Earth's interior using seismic arrays. Geotimes. v. 38 , no. 7 , July 1993 . p. 20 22.

OP-71. H. M. Benz and J. E. Vidale. Sharpness of upper-mantle discontinuities determined from high-frequency reflections. $\mathrm{Na}$ - 
ture (London). v. 365, no. 6442, September 9, 1993. p. 147150.

OP-72. G. L. Bertoldi. CALIFORNIA. Overview of Phase 1 Regional Aquifer-System Analysis, Central Valley, California. AWRA Monograph Series, in Regional aquifer systems of the United States; aquifers of the Far West. (K. R. Prince, editor and others). 16, June 1991. p. 15-28.

OP-73. G. L. Bertoldi. Subsidence and consolidation in alluvial aquifer systems. Report - California Water Resources Center. 77, September 1992. p. 63-74.

OP-74. K. J. Bird and C. M. Molenaar. The North Slope foreland basin, Alaska. AAPG Memoir, in Foreland basins and fold belts. (R. W. Macqueen, editor and others). 55, 1992. p. 363 393.

OP-75. P. W. Birkeland, M. N. Machette and K. M. Haller. Soils as a tool for applied Quaternary geology. Miscellaneous Publication (Utah Geological and Mineral Survey). Report no. 91-3, April 1991. 63 p.

OP-76. J. L. Bischoff, J. A. Fitzpatrick and R. J. Rosenbauer. The solubility and stabilization of ikaite $\left(\mathrm{CaCO}_{3} \cdot 6 \mathrm{H}_{2} \mathrm{O}\right)$ from $0^{\circ}$ to $25^{\circ} \mathrm{C}$; environmental and paleoclimatic implications for thinolite tufa. Journal of Geology. v. 101, no. 1, January 1993. p. 2133.

OP-77. J. L. Bischoff, Scott Stine*, R. J. Rosenbauer*, J. A. Fitzpatrick* and T. W. Stafford, Jr.*. CALIFORNIA. Ikaite precipitation by mixing of shoreline springs and lake water, Mono Lake, California, USA. Geochimica et Cosmochimica Acta. v. 57, no. 16, August 1993. p. 3855-3865.

OP-78. M. C. Blake, Jr. and B. L. Murchey. CALIFORNIA. A California model for the New England fold belt, in New England Orogen; tectonics and metallogenesis. (J. D. Kleeman, editor). Armidale, N.S.W.: Univ. N. Engl., Dep. Geol. and Geophys. November 1988. p. 20-31.

OP-79. R. J. Blakely and R. C. Jachens. NEVADA. Concealed mineral deposits in Nevada; insights from three-dimensional analysis of gravity and magnetic anomalies, in Geology and ore deposits of the Great Basin; symposium proceedings. (G. L. Raines, editor and others). Reno, NV: Geological Society of Nevada, 1991. p. $185-192$.

OP-80. J. H. Blanford* and D. I. Stannard. ARIZONA. Spatial variability of energy fluxes at Walnut Gulch. Conference on Biometeorology and Aerobiology, in Tenth conference on Biometeorology and aerobiology; special session on Hydrometeorology; proceedings. 10, 1991. p. 158-160.

OP-81. D. D. Blankenship*, R. E. Bell*, S. M. Hodge, J. M. Brozena*, J. C. Behrendt and C. A. Finn. Active volcanism beneath the West Antarctic ice sheet and implications for ice-sheet stability. Nature(London). v. 361, no. 6412, February 11, 1993. p. $526-529$.

OP-82. J. D. Bliss and S. S. Olson*. Current gold rush in Madre de Dios Department, Peru. Mining Engineering. v. 44, no. 7 , July 1992. p. 693-695.

OP-83. R. B. Bloch*, Roland von Huene, P. E. Hart and C. M. Wentworth. CALIFORNIA. Style and magnitude of tectonic shortening normal to the San Andreas Fault across Pyramid Hills and Kettleman Hills South Dome, California. Geological Society of America Bulletin. v. 105, no. 4, April 1993. p. 464-478.

OP-84. R. B. Blodgett. ALASKA. Dutrochus, a new microdomatid (Gastropoda) genus from the Middle Devonian (Eifelian) of west-central Alaska. Journal of Paleontology. v. 67, no. 2, March 1993. p. 194-197.

OP-85. R. B. Blodgett. ALASKA. Taxonomy and paleobiogeographic affinities of an early Middle Devonian (Eifelian) gastropod faunule from the Livengood Quadrangle, east-central Alaska. Palaeontographica. Abteilung A: PaläozoologieStratigraphie. v. 221, no. 4-6, March 1992. p. 125-168.

OP-86. R. B. Blodgett and J. G. Johnson. NEVADA. Early Middle Devonian (Eifelian) gastropods of central Nevada. Palaeontographica. Abteilung A: Paläozoologie-Stratigraphie. v. 222, no. 4-6, May 1992. p. 83-139.

OP-87. C. D. Blome and M. K. Nestell*. OREGON. Field guide to the geology and paleontology of pre-Tertiary volcanic arc and melange rocks, Grindstone, Izee, and Baker terranes, east-central Oregon. Oregon Geology. v. 54, no. 6, November 1992. p. 123-144.

OP-88. C. D. Blome and K. M. Reed*. Acid processing of preTertiary radiolarian cherts and its impact on faunal content and biozonal correlation. Geology (Boulder). v. 21, no. 2, February 1993. p. $177-180$.

OP-89. A. E. Blum and D. D. Eberl. Determination of clay particle thicknesses and morphology using scanning force microscopy. Proceedings - International Symposium on Water-Rock Interaction. 7, 1992. p. 133-136.

OP-90. Yehuda Bock*, D. C. Agnew*, Peng Fang*, J. F. Genrich*, B. H. Hager*, T. A. Herring*, K. W. Hudnut, R. W. King*, S. C. Larsen*, J. B. Minster*, Keith Stark*, Shimon Wdowinski* and F. K. Wyatt*. Detection of crustal deformation from the Landers earthquake sequence using continuous geodetic measurements. Nature (London). v. 361, no. 6410, January 28 , 1993. p. 337-340.

OP-91. O. A. Bogatikov*, A. G. Gurbanov*, V. I. Kovalenko*, N. I. Koronovskiy*, P. W. Lipman and A. A. Tsvetkov*: The upper Chegem Caldera complex in the North Caucasus. International Geology Review. v. 34, no. 2, February 1992. p. 131-147.

OP-92. R. G. Bohannon, J. A. Grow, J. J. Miller and H. R. Blank, Jr. NEVADA, ARIZONA. Seismic stratigraphy and tectonic development of Virgin River depression and associated basins, southeastern Nevada and northwestern Arizona. Geological Society of America Bulletin. v. 105, no. 4, April 1993. p. 501-520.

OP-93. B. F. Bohor and D. M. Triplehorn*. Tonsteins; altered volcanic-ash layers in coal-bearing sequences. Special Paper Geological Society of America. 285, 1993. 44 p.

OP-94. A. J. Bol*, R. S. Coe*, C. S. Grommé and J. W. Hillhouse. ALASKA. Paleomagnetism of the Resurrection Peninsula, Alaska; implications for the tectonics of southern Alaska and the Kula-Farallon Ridge. Journal of Geophysical Research, B, Solid Earth and Planets. v. 97, no. 12, November 10, 1992. p. $17,213-17,232$. 
OP-95. A. A. Bookstrom. COLORADO. The Silver PlumeGeorgetown District. Colorado School of Mines Quarterly. v. 93 , no. 1,1993 . p. $25-30$.

OP-96. J. S. Booth and D. W. O'Leary. A statistical overview of mass movement characteristics on the North American Atlantic outer continental margin. Marine Geotechnology. v. 10, no. 12, June 1991. p. 1-18.

OP-97. T. M. Bown and J. G. Fleagle*. Systematics, biostratigraphy, and dental evolution of the Palaeothentidae, later Oligocene to early-middle Miocene (Deseadan-Santacrucian) caenolestoid marsupials of South America. Memoir - Paleontological Society. 29, March 1993. 76 p.

OP-98. T. M. Bown and M. J. Kraus*. WYOMING. Timestratigraphic reconstruction and integration of paleopedologic, sedimentologic, and biotic events (Willwood Formation, lower Eocene, Northwest Wyoming, U.S.A.). Palaios. v. 8, no. 1, February 1993 . p. 68-80.

OP-99. J. P. Bradbury and W. E. Dean (editors). MINNESOTA. Elk Lake, Minnesota; evidence for rapid climate change in the north-central United States. Special Paper - Geological Society of America. 276, 1993. $336 \mathrm{p}$

OP-100. J. P. Bradbury, W. E. Dean and R. Y. Anderson*. MINNESOTA. Holocene climatic and limnologic history of the north-central United States as recorded in the varved sediments of Elk Lake, Minnesota; a synthesis. Special Paper - Geological Society of America, in Elk Lake, Minnesota; evidence for rapid climate change in the north-central United States. (J. P. Bradbury, editor and others). 276, 1993. p. 309-328.

OP-101. J. P. Bradbury and K. V. Dieterich-Rurup. MINNESOTA. Holocene diatom paleolimnology of Elk Lake, Minnesota. Special Paper - Geological Society of America, in Elk Lake, Minnesota; evidence for rapid climate change in the north-central United States. (J. P. Bradbury, editor and others). 276, 1993. p. 215-237.

OP-102. A. G. Brady. The United States Geological Survey accelerograph network in the U.S.; operations, record processing and research. NBSIR, in Wind and seismic effects. (N. J. Raufaste, editor). Report no. NBSIR 88-3703, 1987. p. 33-36.

OP-103. J. D. Bredehoeft and L. F. Konikow. Ground-water models; validate or invalidate. Ground Water. v. 31, no. 2, April 1993. p. 178-179.

OP-104. G. N. Breit, M. E. Cast and M. R. Stanton. Chromium redistribution within continental red beds; $a$ function of pore-water chemistry. Proceedings - International Symposium on WaterRock Interaction. 7, 1992. p. 499-502.

OP-105. D. A. Brew. Mesozoic and Cenozoic intrusions and batholiths of the Circum-Pacific region as analogues of pre-Phanerozoic batholiths; a summary. Proceedings of the International Conference on Basement Tectonics, in Basement tectonics 8; Characterization and comparison of ancient and Mesozoic continental margins. (M. J. Bartholomew, editor and others). 8, 1988. p. $169-177$.

OP-106. D. A. Brew, L. J. Drew and S. D. Ludington. ALASKA. The study of the undiscovered mineral resources of the Tongass National Forest and adjacent lands, Southeastern Alaska. Nonrenewable Resources. v. 1, no. 4, 1992. p. 303-322.
OP-107. N. T. Bridges. Martian particle size based on thermal inertia corrected for elevation-dependent atmospheric properties. Proceedings of the Lunar and Planetary Science Conference, in Abstracts of papers submitted to the Twenty-fourth lunar and planetary science conference. (Douglas Blanchard, chairperson and others). 24, 1993. p. 189-190.

OP-108. T. M. Brocher, M. D. Carr, K. F. Fox, Jr. and P. E. Hart. NEVADA. Seismic reflection profiling across Tertiary extensional structures in the eastern Amargosa Desert, southern Nevada, Basin and Range Province. Geological Society of America Bulletin. v. 105, no. 1, January 1993. p. 30-46.

OP-109. E. M. Brouwers and R. M. Forester. Synonymies of Leptocythere klutinensis Forester and Brouwers, 1985, and Cytheromorpha knikensis Forester and Brouwers, 1985. Journal of Paleontology. v. 67, no: 1, January 1993. p. 158.

OP-110. E. M. Brouwers, N. O. Jorgensen* and T. M. Cronin. Climatic significance of the ostracode fauna from the Pliocene Kap Kobenhavn Formation, North Greenland. Micropaleontology. v. 37, no. 3, 1991. p. 245-267.

OP-111. C. E. Brown. Use of principal-component, correlation, and stepwise multiple-regression analyses to investigate selected physical and hydraulic properties of carbonate-rock aquifers. Journal of Hydrology. v. 147, no. 1-4, June 15, 1993. p. 169195.

OP-112. N. E. Brown*, Alexandra Navrotsky*, G. L. Nord, Jr. and S. K. Banerjee*. Hematite-ilmenite $\left(\mathrm{Fe}_{2} \mathrm{O}_{3}-\mathrm{FeTiO}_{3}\right)$ solid solutions; determinations of $\mathrm{Fe}$-Ti order from magnetic properties. American Mineralogist. v. 78, no. 9-10, October 1993. p. 941951.

OP-113. R. D. Brown, R. E. Wallace and D. P. Hill. CALIFORNIA. The San Andreas fault system, California, U.S.A. Annales Tectonicae, in Major active faults of the world; results of IGCP Project 206. (R. C. Bucknam and others). 6, Suppl. 1992. p. 261-284.

OP-114. W. M. Brown. Information for disaster reduction; the National Landslide Information Center, US Geological Survey. Proceedings of the International Symposium on Landslides = Comptes Rendus du Symposium International sur les Glissements de Terrain, in Landslides; proceedings of the sixth international symposium. (D. H. Bell, editor). 6, 1992. p. 891-892.

OP-115. M. E. Brownfield, E. E. Foord, S. J. Sutley and Theodore Botinelly. MAINE. Kosnarite, $\mathrm{KZ}_{2}\left(\mathrm{PO}_{4}\right)_{3}$, a new mineral from Mount Mica and Black Mountain, Oxford County, Maine. American Mineralogist. v. 78, no. 5-6, June 1993. p. 653-656.

OP-116. C. J. Bryan. HAWAII. A possible triggering mechanism for large Hawaiian earthquakes derived from analysis of the 26 June 1989 Kilauea south flank sequence. Bulletin of the Seismological Society of America. v. 82, no. 6, December 1992. p. 2368-2390.

OP-117. B. H. Bryant. Memorial to Wallace M. Cady, 19121991. Memorials - Geological Society of America. 22, 1992. p. 89-91.

OP-118. B. H. Bryant. The onset of the Laramide Orogeny. Colorado School of Mines Quarterly. v. 93, no. 1, 1993. p. 17-19. 
OP-119. R. C. Bucknam and P. L. Hancock. Major active faults of the world; results of IGCP Project 206. Annales Tectonicae. 6, Suppl. 1992. 284 p.

OP-120. R. C. Bucknam, Eileen Hemphill-Haley and E. B. Leopold*. WASHINGTON. Abrupt uplift within the past 1700 years at southern Puget Sound, Washington. Science. v. 258, no. 5088, December 4, 1992. p. 1611-1614.

OP-121. C. G. Bufe and D. J. Varnes. CALIFORNIA. Predictive modeling of the seismic cycle of the greater San Francisco Bay region. Journal of Geophysical Research, B, Solid Earth and Planets. v. 98, no. 6, June 10, 1993. p. 9871-9883.

OP-122. T. D. Bullen and Y. K. Kharaka. WYOMING. Isotopic composition of $\mathrm{Sr}, \mathrm{Nd}$ and $\mathrm{Li}$ in thermal waters from the Norris-Mammoth corridor, Yellowstone National Park and surrounding region. Proceedings - International Symposium on Water-Rock Interaction, in Proceedings of the 7th international symposium on Water-rock interaction; Volume 2, Moderate and high temperature environments. (Y. K. Kharaka, editor and others). 7, 1992. p. 897-901.

OP-123. T. K. Bundtzen*, M. L. Miller, G. M. Laird* and K. F. Bull*. ALASKA. Geology and mineral resources of Iditarod mining district, Iditarod B-4 and eastern B-5 quadrangles, Southwestern Alaska. Professional Report - Alaska. Division of Geological \& Geophysical Surveys. Report no. 97, 1992. 46 p. Available from: Alaska Div. of Geol. and Geophys. Surv., Fairbanks, AK, United States.

OP-124. B. C. Burchfiel*, P. W. Lipman and M. L. Zoback (editors). The Cordilleran Orogen; conterminous U.S., in the collection The geology of North America. Geol. Soc. Am. G-3, 1992. $724 \mathrm{p}$.

OP-125. J. D. Byerlee. The change in orientation of subsidiary shears near faults containing pore fluid under high pressure. Tectonophysics, in Earthquake source physics and earthquake precursors. (Takeshi Mikumo, editor and others). v. 211, no. 1-4, September 30, 1992. p. 295-303.

OP-126. J. D. Byerlee. Model for episodic flow of high-pressure water in fault zones before earthquakes. Geology (Boulder). v. 21, no. 4, April 1993. p. 303-306.

OP-127. J. D. Byerlee and J. C. Savage. Coulomb plasticity within the fault zone. Geophysical Research Letters. v. 19, no. 23, December 2, 1992 . p. 2341-2344.

OP-128. D. A. Cacchione and D. E. Drake. CALIFORNIA. Shelf sediments transport; an overview with applications to the Northern California continental shelf. The Sea. 9, Part B, 1990. p. 729-773.

OP-129. D. A. Cacchione and D. E. Drake. ALASKA. Bottom and near-bottom sediment dynamics in Norton Sound, Alaska. Outer Continental Shelf Environmental Assessment Program Final Reports of Principal Investigators (OCSEAP Final Reports). 74, October 1991. p. 77-143.

OP-130. E. C. Callender and Liba Granina*. Transition metal geochemistry of sedimentary pore fluids associated with hydrothermal activity in Lake Baikal, Russia. Proceedings - International Symposium on Water-Rock Interaction. 7, 1992. p. 621-626.
OP-131. C. C. Cameron and D. A. Emery. Classifying and mapping wetlands and peat resources using digital cartography. ASTM Special Technical Publication = American Society for Testing and Materials Special Technical Publication, in Geographic information systems (GIS) and mapping; practices and standards. (A. I. Johnson, editor and others). 1126, 1992. p. 195-206.

OP-132. K. L. Cameron*, J. V. Robinson*, Sidney Niemeyer*, G. J. Nimz*, D. C. Kuentz*, R. S. Harmon*, S. R. Bohlen and K. D. Collerson*. Contrasting styles of pre-Cenozoic and mid-Tertiary crustal evolution in northern Mexico; evidence from deep crustal xenoliths from La Olivina. Journal of Geophysical Research, B, Solid Earth and Planets. v. 97, no. 12, November 10,1992 . p. $17,353-17,376$.

OP-133. D. H. Campbell, J. T. Turk and N. E. Spahr. COLORADO. Response of Ned Wilson Lake Watershed, Colorado, to changes in atmospheric deposition of sulfate. Water Resources Research. v. 27, no. 8, August 1991. p. 2047-2060.

OP-134. I. H. Campbell*, G. K. Czamanske, V. A. Fedorenko*, R. I. Hill* and V. Stepanov*. Synchronism of the Siberian Traps and the Permian-Triassic boundary. Science. v. 258 , no. 5089, December 11, 1992. p. 1760-1763.

OP-135. W. H. Campbell. Electrical properties of the Earth's mantle. Pure and Applied Geophysics. v. 125, no. 2-3, 1987. $497 \mathrm{p}$.

OP-136. W. H. Campbell, B. R. Arora* and R. Schiffmacher*. External Sq currents in the India-Siberia region. Journal of Geophysical Research, A, Space Physics. v. 98, no. 3, March 1, 1993. p. $3741-3752$.

OP-137. W. F. Cannon. The Midcontinent Rift in the Lake Superior region with emphasis on its geodynamic evolution. Tectonophysics, in Geodynamics of rifting; Volume II, Case history studies on rifts; North and South America and Africa. (P. A. Ziegler, editor). v. 213, no. 1-2, October 30, 1992. p. $41-48$.

OP-138. W. F. Cannon and W. J. Hinze*. Speculations on the origin of the North American Midcontinent Rift. Tectonophysics, in Geodynamics of rifting; Volume II, Case history studies on rifts; North and South America and Africa. (P. A. Ziegler, editor). v. 213, no. 1-2, October 30, 1992. p. 49-55.

OP-139. W. F. Cannon, S. W. Nicholson, C. A. Hedgman, L. G. Woodruff and K. J. Schulz. MICHIGAN. Geology of Keweenawan Supergroup rocks near the Porcupine Mountains, Ontonagon and Gogebic counties, Michigan. Guidebook Series, in Keweenawan copper deposits of western upper Michigan. (T. J. Bornhorst, editor). 13, October 1992. p. 163-197.

OP-140. P. R. Carlson, H. A. Karl and B. D. Edwards. ALASKA. Mass sediment failure and transport features revealed by acoustic techniques, Beringian margin, Bering Sea, Alaska. Marine Geotechnology. v. 10, no. 1-2, June 1991. p. 33-51.

OP-141. M. H. Carr. Water inventories on Earth and Mars; clues to atmosphere formation. LPI Contribution, in Papers presented to the workshop on the Evolution of the Martian atmosphere. (B. M. Jakosky, convener and others). 787, 1992. p. 6.

OP-142. M. H. Carr, R. O. Kuzmin* and P. L. Masson*. Geology of Mars. Episodes. v. 16, no. 1-2, June 1993. p. 307-315. 
OP-143. P. E. Carrara and D. A. Trimble. WASHINGTON. A Glacier Peak and Mount Saint Helens J volcanic ash couplet and the timing of deglaciation in the Colville Valley area, Washington. Canadian Journal of Earth Sciences = Journal Canadien des Sciences de la Terre. v. 29, no. 11 , November 1992. p. 2397-2405.

OP-144. G. A. Carver*, D. W. Valentine*; A. S. Jayko and W. H. Li*. CALIFORNIA. Cape Mendocino earthquake, April 25, 1992; coseismic coastal uplift caused by earthquake. Newsletter Earthquake Engineering Research Institute, v. 26, no. 7, July 1992. p. $1-2$.

OP-145. D. A. Castillo and W. L. Ellsworth. CALIFORNIA. Seismotectonics of the San Andreas fault system between Point Arena and Cape Mendocino in Northern California; implications for the development and evolution of a young transform. Journal of Geophysical Research, B, Solid Earth and Planets. v. 98, no. 4, April 10, 1993. p. 6543-6560.

OP-146. D. A. Castillo* and Brennan O'Neill. Constraints on the state of stress in old oceanic crust of the Indo-Australian Plate, Northwest of Australia. Proceedings of the Ocean Drilling Program, Scientific Results, in Proceedings of the Ocean Drilling Program, Argo abyssal plain/Exmouth Plateau; covering Leg 123 of the cruises of the drilling vessel JOIDES Resolution, Singapore, Republic of Sing., to Singapore, Republic of Sing., sites 765-766, 28 August 1988-1 November 1988. (F. M. Gradstein and others). 123,1992 . p. 503-513.

OP-147. L. D. Cecil, T. M. Beasley, J. R. Pittman*, R. L. Michel, P. W. Kubik*, Pankaj Sharma*, Udo Fehn* and H. E. Gove*. IDAHO. Water infiltration rates in the unsaturated zone at the Idaho National Engineering Laboratory estimated from chlorine- 36 and tritium profiles, and neutron logging. Proceedings - International Symposium on Water-Rock Interaction. 7, 1992. p. $709-714$.

OP-148. D. J. Chadwick, G. G. Schaber, R. G. Strom* and D. M. Duval*. Bright crater outflows; possible emplacement mechanisms. LPI Contribution, in Papers presented to the international colloquium on Venus. (Lunar and Planetary Institute). 789, 1992. p. 20-21.

OP-149. K. R. Chamberlain*, S. C. Patel*, B. R. Frost* and G. L. Snyder. WYOMING. Thick-skinned deformation of the Archean Wyoming Province during Proterozoic arc-continent collision; with Suppl. Data 9339. Geology (Boulder). v. 21, no. 11, November 1993. p. $995-998$.

OP-150. H. H. Chang*, M. E. Jennings and Steve Olona*. Computer simulation of river channel changes at a bridge crossing on a point bar, in Hydraulic engineering; saving a theoretical resource, in search of solutions. (M. E. Jennings, editor and others). New York, NY: Am. Soc. Civ. Eng. 1992. p. 76-81.

OP-151. J. P. Chanton*, C. S. Martens*, C. K. Paull and J. A. Coston*. Sulfur isotope and porewater geochemistry of Florida Escarpment seep sediments. Geochimica et Cosmochimica Acta. v. 57, no. 6, March 1993. p. 1253-1266.

OP-152. E. C. Chao. Problems and methodology of the petrologic analysis of coal facies, in 1983 international conference on Coal science; proceedings. (S. W. Chun, president). Int. Energy Agency, 1983. p. 385-388.
OP-153. E. C. Chao, J. M. Back, J. A. Minkin and Ren Yinchen*. Host-rock controlled epigenetic, hydrothermal metasomatic origin of the Bayan Obo REE-Fe-Nb ore deposit, Inner Mongolia, P.R.C. Applied Geochemistry, in Minerals for future materials. (Yuan Zhongxin, convener and others). v. 7, no. 5. September 1992. p. 443-458.

OP-154. F. H. Chapelle. Ground-water microbiology and geochemistry. New York, NY: John Wiley and Sons, 1993. 424 p.

OP-155. M. J. Chapman and E. S. Bair*. Mapping a brine plume using surface geophysical methods in conjunction with ground water quality. Ground Water Monitoring Review. v. 12, no. 3, 1992. p. 203-209.

OP-156. G. B. Chappell, T. C. Jaeger and Lesley Ogrosky. Toward a feature-based world; making the transition from DLG to DLG-E. GIS/LIS - Proceedings, Annual Conference and Exposition, in GIS/LIS 92 annual conference and exposition; proceedings. 1992, 1992. p. 105-115.

OP-157. Cheng-lung Chen. Unique laminar-flow stability limit based on shallow-water theory. Journal of Hydraulic Engineering. v. 119 , no. 7 , July 1993 , p. $816-829$.

OP-158. J. T. Chesley*, A. N. Halliday, L. W. Snee*, Klaus Mezger*, T. J. Shepherd* and R. C. Scrivener*. Thermochronology of the Cornubian Batholith in Southwest England; implications for pluton emplacement and protracted hydrothermal mineralization. Geochimica et Cosmochimica Acta. v. 57, no. 8, April 1993. p. 1817-1835.

OP-159, R. L. Christiansen, R. S. Yeats*, S. A. Graham*, W. A. Niem*, A. R. Niem and P. D. Snavely, Jr.*. Post-Laramide geology of the U.S. Cordilleran region, in The Cordilleran Orogen; conterminous U.S. (B. C. Burchfiel, editor and others), in the collection The geology of North America. Geol. Soc. Am. G-3, 1992. p. 261-406.

OP-160. Nils Christophersen* and R. P. Hooper. Multivariate analysis of stream water chemical data; the use of principal components analysis for the end-member mixing problem. Water Resources Research. v. 28, no. 1, January 1992, p. 99-107.

OP-161. Nils Christophersen*, Colin Neal* and R. P. Hooper. Modelling the hydrochemistry of catchments; a challenge for the scientific method. Journal of Hydrology. v. 152, no. 1-4, 1993. p. 1-12.

OP-162. C. F. Chung*, D. A. Singer and W. D. Menzie. CALIFORNIA. Predicting sizes of undiscovered mineral deposits; an example using mercury deposits in California; reply. Economic Geology and the Bulletin of the Society of Economic Geologists. v. 88, no. 1, February 1993. p. 209.

OP-163. C. S. Churcher*, A. V. Morgan* and L. D. Carter. ALASKA. Arctodus simus from the Alaskan Arctic Slope. Canadian Journal of Earth Sciences $=$ Journal Canadien des Sciences de la Terre. v. 30, no. 5, May 1993. p. 1007-1013.

OP-164. D. A. Clague and W. A. Bohrson*. HAWAII. Origin of xenoliths in the trachyte at Puu Waawaa, Hualalai Volcano, Hawaii. Contributions to Mineralogy and Petrology. v. 108, no. 4, 1991. p. 439-452.

OP-165. A. E. Clark*, J. S. Herman* and B. F. Jones. The chemical influence of clay minerals on groundwater composition 
in a lithologically heterogeneous carbonate aquifer. Proceedings - International Symposium on Water-Rock Interaction. 7, 1992. p. 779-782.

OP-166. D. W. Clark and Eloise Kendy. MONTANA, IDAHO. Regional analysis of the northern Rocky Mountains intermontane basins, Montana and Idaho. AWRA Monograph Series, in Regional aquifer systems of the United States; aquifers of the Far West. (K. R. Prince, editor and others). 16, June 1991. p. 55 64.

OP-167. G. M. Clark and R. S. Williams, Jr. COLORADO. Hydrologic and geochemical characterization of recharge and groundwater flow in a reclaimed-coal-mined land, northwestern Colorado. Reclamation Research Unit Publication, in Proceedings of the Fifth Billings symposium on Disturbed land rehabilitation: Volume II, Hazardous waste management, wildlife, hydrology, drainages, erosion and wetlands; soils, minesoils and overburden; linear disturbances; oil and gas. (F. F. Munshower, chairperson and others). 9003, 1990. p. 173-185.

OP-168. J. R. Clark. Enzyme-induced leaching of B-horizon soils for mineral exploration in areas of glacial overburden. Institution of Mining and Metallurgy, Transactions, Section B: Applied Earth Sciences. 102, April 1993. p. B19-B29.

OP-169. J. R. Clark. Detection of bedrock-related geochemical anomalies at the surface of transported overburden. Explore. 76, July 1992. p. 1, 5-6, 8-11.

OP-170. S. H. Clark, M. J. Gallagher* and F. G. Poole. World barite resources; a review of recent production patterns and a genetic classification. Proceedings. Congress of the Council of Mining and Metallurgical Institutions, in Council of Mining and Metallurgical Institutions, fourteenth congress; Minerals, materials and industry. (W. G. Yuill, chairperson). 14, July 1990, p. 175-184.

OP-171. J. S. Clarke. GEORGIA. Geohydrologic evaluation of two springs in the Georgia Piedmont, in Proceedings of a conference on Ground water in the Piedmont of the Eastern United States. (C. C. Daniel, III, editor and others). Clemson, SC: Clemson University, 1989. p. 614-627.

OP-172. J. S. Clarke and M. F. Peck. GEORGIA. Groundwater availability in south metropolitan Atlanta region, Georgia, in Proceedings of the 1991 Georgia water resources conference. (K. J. Hatcher, editor). Athens, GA: Univ, Ga. 1991. p. 1316.

OP-173. J. S. Clarke, J. W. Sorenson*, H. G. Strickland* and George Collins*. Development of ground-water vulnerability database for the U.S. Environmental Protection Agency's hazard ranking system using a geographic information system. ASTM Special Technical Publication = American Society for Testing and Materials Special Technical Publication, in Geographic information systems (GIS) and mapping; practices and standards. (A. I. Johnson, editor and others). 1126, 1992. p. 226-246.

OP-174. R. T. Clarke*, C. M. Isaacs, W. C. Belfield* and P. C. Ramirez* (prefacers). CALIFORNIA. The Miocene Monterey Formation; depositional and diagenetic facies along the Santa Barbara, California coastal area. Tulsa, OK: Am. Assoc. Pet. Geol. 1987. variously paginated.
OP-175. J. M. Cleveland. The chemistry of plutonium. La Grange Park, IL: Am. Nucl. Soc. 1979. 653 p.

OP-176. G. D. Clow. The extent of temporal smearing in surfacetemperature histories derived from borehole temperature measurements. Global and Planetary Change, in Climatic change inferred from underground temperatures. (T. J. Lewis, editor). v. 6, no. 2-4, December 1992. p. 81-86.

OP-177. W. A. Cobban and W. J. Kennedy*. TEXAS. Middle Campanian ammonites and inoceramids from the Wolfe City Sand in northeastern Texas. Journal of Paleontology, v. 67, no. 1 , January 1993. p. 71-82.

OP-178. W. A. Cobban and W. J. Kennedy*. TEXAS. Campanian Trachyscaphites spiniger ammonite fauna in Northeast Texas. Palaeontology. v. 35, no. 1, February 1992. p. 63-93.

OP-179. Massimo Cocco* and John Boatwright. The envelopes of acceleration time histories. Bulletin of the Seismological Society of America. v. 83, no. 4, August 1993. p. 1095-1114.

OP-180. Philip Cohen. Toxic substances hydrology programs of the U.S. Geological Survey, in First USA/USSR joint conference on Environmental hydrology and hydrogeology. (J. E. Moore and others). Dubuque, IA: Kendall/Hunt Publ. Co. 1991. p. 2130.

OP-181. Philip Cohen. Toxic substances hydrology programs of the U.S. Geological Survey. Hydrological Science and Technology, in Proceedings of the USA/USSR joint conference on Environmental hydrology and hydrogeology. (J. E. Moore, editor and others). v. 7 , no. $1-4,1991$. p. 45-54.

OP-182. D. S. Coleman*, T. P. Frost and A. F. Glazner*. CALIFORNIA. Evidence from the Lamarck Granodiorite for rapid Late Cretaceous crust formation in California. Science. v. 258, no. 5090, December 18, 1992. p. 1924-1926.

OP-183. M. L. Coleman*, D. B. Hedrick*, D. R. Lovley, D. C. White* and Kenneth Pye*. Reduction of $\mathrm{Fe}(\mathrm{III})$ in sediments by sulphate-reducing bacteria. Nature (London). v. 361, no. 6411, February 4, 1993. p. 436-438.

OP-184. C. A. Collins and D. R. Cline. WASHINGTON, OREGON. Ground-water pumpage in the Columbia Plateau, Washington and Oregon. AWRA Monograph Series, in Regional aquifer systems of the United States; aquifers of the Far West. (K. R. Prince, editor and others). 16, June 1991. p. 99-107.

OP-185. Jean-Yves Collot* and M. A. Fisher. The d'Entrecasteaux zone-New Hebrides island arc collision zone; an overview. Proceedings of the Ocean Drilling Program, Part A: Initial Reports, in Proceedings of the Ocean Drilling Program, Vanuatu (New Hebrides), covering Leg 134 of the cruises of the drilling vessel JOIDES Resolution, Port of Townsville, Queensland, Australia, to Suva, Republic of Fiji, sites 827-833,11 October 1990-17 December 1990. (Jean-Yves Collot and others). 134, March 1992. p. 19-31.

OP-186. Jean-Yves Collot*, H. G. Greene, L. B. Stokking*, Kazumi Akimoto*, M. V. Ask*, P. E. Baker*, Louis Briqueu*, Thierry Chabernaud*, M. G. Collins*, Massimo Coltorti*, M. A. Fisher, Toshiaki Hasenaka*, M. A. Hobart*, Anton Kram. mer*, J. N. Leonard*, J. B. Martin*, J. I. MartinezRodriguez*, Stefan Menger*, Martin Meschede*, Bernard Pelletier*, R. C. Perembo*, T. M. Quinn*, R. P. Reid*, W. R. 
Riedel*, Pierrick Roperch*, T. S. Staerker*, F. W. Taylor* and Xixi Zhao*. Summary and conclusions. Proceedings of the Ocean Drilling Program, Part A: Initial Reports, in Proceedings of the Ocean Drilling Program, Vanuatu (New Hebrides), covering Leg 134 of the cruises of the drilling vessel JOIDES Resolution, Port of Townsville, Queensland, Australia, to Suva, Republic of Fiji, sites 827-833, 11 October 1990-17 December 1990. (JeanYves Collot and others). 134, March 1992. p. 561-577.

OP-187. Jean-Yves Collot*, H. G. Greene, L. B. Stokking*, Kazumi Akimoto*, M. V. Ask*, P. E. Baker*, Louis Briqueu*, Thierry Chabernaud*, M. G. Collins*, Massimo Coltorti*, M. A. Fisher, Toshiaki Hasenaka*, M. A. Hobart*, Anton Krammer*, J. N. Leonard*, J. B. Martin*, J. I. MartinezRodriguez*, Stefan Menger*, Martin Meschede*, Bernard Pelletier*, R. C. Perembo*, T. M. Quinn*, R. P. Reid*, W. R. Riedel*, Pierrick Roperch*, T. S. Staerker*, F. W. Taylor* and Xixi Zhao*. Site 830. Proceedings of the Ocean Drilling Program, Part A: Initial Reports, in Proceedings of the Ocean Drilling Program, Vanuatu (New Hebrides), covering Leg 134 of the cruises of the drilling vessel JOIDES Resolution, Port of Townsville, Queensland, Australia, to Suva, Republic of Fiji, sites 827833, 11 October 1990-17 December 1990. (Jean-Yves Collot and others). 134, March 1992. p. 261-315.

OP-188. Jean-Yves Collot*, H. G. Greene, L. B. Stokking*, Kazumi Akimoto*, M. V. Ask*, P. E. Baker*, Louis Briqueu*, Thierry Chabernaud*, M. G. Collins*, Massimo Coltorti*, M. A. Fisher, Toshiaki Hasenaka*, M. A. Hobart*, Anton Krammer*, J. N. Leonard*, J. B. Martin*, J. I. MartinezRodriguez*, Stefan Menger*, Martin Meschede*, Bernard Pelletier*, R. C. Perembo*, T. M. Quinn*, R. P. Reid*, W. R. Riedel*, Pierrick Roperch*, T. S. Staerker*, F. W. Taylor* and Xixi Zhao*. Site 832. Proceedings of the Ocean Drilling Program, Part A: Initial Reports, in Proceedings of the Ocean Drilling Program, Vanuatu (New Hebrides), covering Leg 134 of the cruises of the drilling vessel JOIDES Resolution, Port of Townsville, Queensland, Australia, to Suva, Republic of Fiji, sites 827833, 11 October 1990-17 December 1990. (Jean-Yves Collot and others). 134, March 1992. p. 487-477.

OP-189. Jean-Yves Collot*, H. G. Greene, L. B. Stokking*, Kazumi Akimoto*, M. V. Ask*, P. E. Baker*, Louis Briqueu*, Thierry Chabernaud*, M. G. Collins*, Massimo Coltorti*, M. A. Fisher, Toshiaki Hasenaka*, M. A. Hobart*, Anton Krammer*, J. N. Leonard*, J. B. Martin*, J. I. MartinezRodriguez*, Stefan Menger*, Martin Meschede*, Bernard Pelletier*, R. C. Perembo*, T. M. Quinn*, R. P. Reid*, W. R. Riedel*, Pierrick Roperch*, T. S. Staerker*, F. W. Taylor* and Xixi Zhao*. Site 827. Proceedings of the Ocean Drilling Program, Part A: Initial Reports, in Proceedings of the Ocean Drilling Program, Vanuatu (New Hebrides), covering Leg 134 of the cruises of the drilling vessel JOIDES Resolution, Port of Townsville, Queensland, Australia, to Suva, Republic of Fiji, sites 827 833, 11 October 1990-17 December 1990. (Jean-Yves Collot and others). 134, March 1992. p. 95-137.

OP-190. Jean-Yves Collot*, H. G. Greene, L. B. Stokking*, Kazumi Akimoto*, M. V. Ask*, P. E. Baker*, Louis Briqueu*, Thierry Chabernaud*, M. G. Collins*, Massimo Coltorti*, M. A. Fisher, Toshiaki Hasenaka*, M. A. Hobart*, Anton Krammer*, J. N. Leonard*, J. B. Martin*, J. I. MartinezRodriguez*, Stefan Menger*, Martin Meschede*, Bernard Pelletier*, R. C. Perembo*, T. M. Quinn*, R. P. Reid*, W. R.
Riedel*, Pierrick Roperch*, T. S. Staerker*, F. W. Taylor* and Xixi Zhao*. Site 829. Proceedings of the Ocean Drilling Program, Part A: Initial Reports, in Proceedings of the Ocean Drilling Program, Vanuatu (New Hebrides), covering Leg 134 of the cruises of the drilling vessel JOIDES Resolution, Port of Townsville, Queensland, Australia, to Suva, Republic of Fiji, sites 827 833, 11 October 1990-17 December 1990. (Jean-Yves Collot and others). 134, March 1992. p. 179-260.

OP-191. Jean-Yves Collot*, H. G. Greene, L. B. Stokking*, Kazumi Akimoto*, M. V. Ask*, P. E. Baker*, Louis Briqueu*, Thierry Chabernaud*, M. G. Collins*, Massimo Coltorti*, M. A. Fisher, Toshiaki Hasenaka*, M. A. Hobart*, Anton Krammer*, J. N. Leonard*, J. B. Martin*, J. I. MartinezRodriguez*, Stefan Menger*, Martin Meschede*, Bernard Pelletier*, R. C. Perembo*, T. M. Quinn*, R. P. Reid*, W. R. Riedel*, Pierrick Roperch*, T. S. Staerker*, F. W. Taylor* and Xixi Zhao*. Proceedings of the Ocean Drilling Program, Vanuatu (New Hebrides), covering Leg 134 of the cruises of the drilling vessel JOIDES Resolution, Port of Townsville, Queensland, Australia, to Suva, Republic of Fiji, sites 827-833, 11 October 1990-17 December 1990; Introduction. Proceedings of the Ocean Drilling Program, Part A: Initial Reports, in Proceedings of the Ocean Drilling Program, Vanuatu (New Hebrides), covering Leg 134 of the cruises of the drilling vessel JOIDES Resolution, Port of Townsville, Queensland, Australia, to Suva, Republic of Fiji, sites 827-833, 11 October 1990-17 December 1990. (Jean-Yves Collot and others). 134, March 1992. p. 5-18.

OP-192. Jean-Yves Collot*, H. G. Greene, L. B. Stokking*, Kazumi Akimoto*, M. V. Ask*, P. E. Baker*, Louis Briqueu*, Thierry Chabernaud*, M. G. Collins*, Massimo Coltorti*, M. A. Fisher, Toshiaki Hasenaka*, M. A. Hobart*, Anton Krammer*, J. N. Leonard*, J. B. Martin*, J. I. MartinezRodriguez*, Stefan Menger*, Martin Meschede*, Bernard Pelletier*, R. C. Perembo*, T. M. Quinn*, R. P. Reid*, W. R. Riedel*, Pierrick Roperch*, T. S. Staerker*, F. W. Taylor* and Xixi Zhao*. Site 831. Proceedings of the Ocean Drilling Program, Part A: Initial Reports, in Proceedings of the Ocean Drilling Program, Vanuatu (New Hebrides), covering Leg 134 of the cruises of the drilling vessel JOIDES Resolution, Port of Townsville, Queensland, Australia, to Suva, Republic of Fiji, sites 827 833, 11 October 1990-17 December 1990. (Jean-Yves Collot and others). 134, March 1992. p. 317-386.

OP-193. Jean-Yves Collot*, H. G. Greene, L. B. Stokking*, Kazumi Akimoto*, M. V. Ask*, P. E. Baker*, Louis Briqueu*, Thierry Chabernaud*, M. G. Collins*, Massimo Coltorti*, M. A. Fisher, Toshiaki Hasenaka*, M. A. Hobart*, Anton Krammer*, J. N. Leonard*, J. B. Martin*, J. I. MartinezRodriguez*, Stefan Menger*, Martin Meschede*, Bernard Pelletier*, R. C. Perembo*, T. M. Quinn*, R. P. Reid*, W. R. Riedel*, Pierrick Roperch*, T. S. Staerker*, F. W. Taylor* and Xixi Zhao*. Site 833. Proceedings of the Ocean Drilling Program, Part A: Initial Reports, in Proceedings of the Ocean Drilling Program, Vanuatu (New Hebrides), covering Leg 134 of the cruises of the drilling vessel JOIDES Resolution, Port of Townsville, Queensland, Australia, to Suva, Republic of Fiji, sites 827 833, 11 October 1990-17 December 1990. (Jean-Yves Collot and others). 134, March 1992. p. 479-557.

OP-194. Jean-Yves Collot*, H. G. Greene, L. B. Stokking*, Kazumi Akimoto*, M. V. Ask*, P. E. Baker*, Louis Briqueu*, Thierry Chabernaud*, M. G. Collins*, Massimo Coltorti*, M. 
A. Fisher, Toshiaki Hasenaka*, M. A. Hobart*, Anton Krammer*, J. N. Leonard*, J. B. Martin*, J. I. MartinezRodriguez*, Stefan Menger*, Martin Meschede*, Bernard Pelletier*, R. C. Perembo*, T. M. Quinn*, R. P. Reid*, W. R. Riedel*, Pierrick Roperch*, T. S. Staerker*, F. W. Taylor* and Xixi Zhao*. Explanatory notes. Proceedings of the Ocean Drilling Program, Part A: Initial Reports, in Proceedings of the Ocean Drilling Program, Vanuatu (New Hebrides), covering Leg 134 of the cruises of the drilling vessel JOIDES Resolution, Port of Townsville, Queensland, Australia, to Suva, Republic of Fiji, sites 827-833, 11 October 1990-17 December 1990. (Jean-Yves Collot and others). 134, March 1992. p. 65-91.

OP-195. Jean-Yves Collot*, H. G. Greene, L. B. Stokking*, Kazumi Akimoto*, M. V. Ask*, P. E. Baker*, Louis Briqueu*, Thierry Chabernaud*, M. G. Collins*, Massimo Coltorti*, M. A. Fisher, Toshiaki Hasenaka*, M. A. Hobart*, Anton Krammer*, J. N. Leonard*, J. B. Martin*, J. I. MartinezRodriguez*, Stefan Menger*, Martin Meschede*, Bernard Pelletier*, R. C. Perembo*, T. M. Quinn*, R. P. Reid*, W. R. Riedel*, Pierrick Roperch*, T. S. Staerker*, F. W. Taylor* and Xixi Zhao*. Site 828. Proceedings of the Ocean Drilling Program, Part A: Initial Reports, in Proceedings of the Ocean Drilling Program, Vanuatu (New Hebrides), covering Leg 134 of the cruises of the drilling vessel JOIDES Resolution, Port of Townsville, Queensland, Australia, to Suva, Republic of Fiji, sites 827 833, 11 October 1990-17 December 1990. (Jean-Yves Collot and others). 134, March 1992. p. 139-177.

OP-196. Jean-Yves Collot*, H. G. Greene, L. B. Stokking*, Kazumi Akimoto*, M. V. Ask*, P. E. Baker*, Louis Briqueu*, Thierry Chabernaud*, M. G. Collins*, Massimo Coltorti*, M. A. Fisher, Toshiaki Hasenaka*, M. A. Hobart*, Anton Krammer*, J. N. Leonard*, J. B. Martin*, J. I. MartinezRodriguez*, Stefan Menger*, Martin Meschede*, Bernard Pelletier*, R. C. Perembo*, T. M. Quinn*, R. P. Reid*, W. R. Riedel*, Pierrick Roperch*, T. S. Staerker*, F. W. Taylor*, Xixi Zhao* and L. H. Dearmont*. Proceedings of the Ocean Drilling Program, Vanuatu (New Hebrides), covering Leg 134 of the cruises of the drilling vessel JOIDES Resolution, Port of Townsville, Queensland, Australia, to Suva, Republic of Fiji, sites 827-833, 11 October 1990-17 December 1990. Proceedings of the Ocean Drilling Program, Part A: Initial Reports. 134, March 1992. $1136 \mathrm{p}$.

OP-197. Jean-Yves Collot*, S. E. Lallemand*, Bernard Pelletier*, J. P. Eissen*, Georgette Glaçon*, M. A. Fisher, H. G. Greene, Jean Boulin*, J. Danie1* and Michel Monzier*. Geology of the d'Entrecasteaux-New Hebrides Arc collision zone; results from a deep submersible survey. Tectonophysics. v. 212 , no. $3-4$, October 15,1992 . p. $213-241$.

OP-198. S. M. Colman (compiler). Initial results of U.S.-Soviet paleoclimate study of Lake Baikal. Eos, Transactions, American Geophysical Union. v. 73, no. 43, October 27, 1992. p. 457, 460-462.

OP-199. S. M. Colman, D. S. Foster and D. W. Harrison. Depression and other lake-floor morphologic features in deep water, southern Lake Michigan. Journal of Great Lakes Research. v. 18 , no. 2,1992 . p. $267-279$.

OP-200. S. M. Colman, G. A. Jones*, R. M. Forester and D. S. Foster*. Holocene paleoclimatic evidence and sedimentation rates from a core in southwestern Lake Michigan. Journal of Paleolimnology. v. 4, no. 3, 1990. p. 269-284.

OP-201. S. M. Colman and K. L. Pierce. Varied records of early Wisconsinan alpine glaciation in the Western United States derived from weathering-rind thickness. Special Paper - Geological Society of America, in The last interglacial-glacial transition in North America. (P. U. Clark, editor and others). 270, 1992. p. 269-278.

OP-202. Marwin Columba C.* and C. G. Cunningham. Geologic model for the mineral deposits of the La Joya District, Oruro, Bolivia. Economic Geology and the Bulletin of the Society of Economic Geologists. v. 88, no. 3, May 1993. p. 701-708.

OP-203. K. C. Condie*, P. D. Noll, Jr. and C. M. Conway. ARIZONA. Geochemical and detrital mode evidence for two sources of early Proterozoic sedimentary rocks from the Tonto Basin Supergroup, central Arizona. Sedimentary Geology. v. 77, no. 2, April 1992. p. 51-76.

OP-204. J. E. Conrad and E. H. McKee. CALIFORNIA. Geology and mineral resources of the southwestern Inyo Mountains. Annual Field Trip Guidebook. South Coast Geological Society, in Geology and mineral wealth of the Owens Valley region, California. (E. M. Gath, editor and others). Report no. 15, 1987. p. 80-93.

OP-205. J. E. Conrad, E. H. McKee, J. J. Rytuba, J. T. Nash and W. C. Utterback*. NEVADA. Geochronology of the Sleeper Deposit, Humboldt County, Nevada; epithermal gold-silver mineralization following emplacement of a silicic flow-dome complex. Economic Geology and the Bulletin of the Society of Economic Geologists. v. 88, no. 2, April 1993. p. 317-327.

OP-206. Rodolfo Console*, R. di Giovambattista*, P. Favali*, B. W. Presgrave and G. Smriglio*. Seismicity of the Adriatic Microplate. Tectonophysics. v. 218, no. 4, 1993. p. 343-354.

OP-207. J. E. Constantz. Comparison of isothermal and isobaric water retention paths in nonswelling porous materials. Water Resources Research. v. 27, no. 12, December 1991. p. 31653170.

OP-208. H. E. Cook and M. E. Taylor. Paleozoic carbonate passive-margin evolution and resulting petroleum reservoirs; Great Basin, Western United States, in Geology and ore deposits of the Great Basin; symposium proceedings. (G. L. Raines, editor and others). Reno, NV: Geological Society of Nevada, 1991. p. 1-4.

OP-209. R. L. Cooley. Exact Scheffé-type confidence intervals for output from groundwater flow models; 1 , Use of hydrogeologic information. Water Resources Research. v. 29, no. 1, January 1993. p. 17-33.

OP-210. R. L. Cooley. Exact Scheffé-type confidence intervals for output from groundwater flow models; 2, Combined use of hydrogeologic information and calibration data. Water Resources Research. v. 29 , no. 1, January 1993. p. 35-50.

OP-211. A. K. Cooper, M. S. Marlow, D. W. Scholl and A. J. Stevenson. Evidence for Cenozoic crustal extension in the Bering Sea region. Tectonics. v. 11, no. 4, August 1992. p. 719-731.

OP-212. L. E. Cordell, J. D. Phillips and R. H. Godson. USGS potential-field geophysical software for $\mathrm{PC}$ and compatible micro- 
computers. Geophysics: The Leading Edge of Exploration. v. 12, no. 4, April 1993. p. 290.

OP-213. Massimo Cortini and C. C. Barton. Nonlinear forecasting analysis of inflation-deflation patterns of an active caldera (Campi Flegrei, Italy). Geology (Boulder). v. 21, no. 3, March 1993. p. 239-242.

OP-214. M. A. Cosca*, E. J. Essene*, M. J. Kunk and J. F. Sutter. Differential unroofing within the Central Metasedimentary Belt of the Grenville Orogen; constraints from ${ }^{40} \mathrm{Ar} /{ }^{39} \mathrm{Ar}$ thermochronology. Contributions to Mineralogy and Petrology. v. 110, no. 2-3, April 1992. p. 211-225.

OP-215. J. A. Coston, C. C. Fuller and J. A. Davis. MASSACHUSETTS. The search for a geochemical indicator of lead and zinc sorption in a sand and gravel aquifer, Falmouth, Massachusetts, USA. Proceedings - International Symposium on WaterRock Interaction. 7, 1992. p. 41-44.

OP-216. K. J. Covay, A. M. Sturrock, Jr. and D. C. Sasser. LOUISIANA. Water requirements for growing rice in southwestern Louisiana, 1985-86. Water Resources Technical Report (Baton Rouge, La.). Report no. 52,1992. 14 p.

OP-217. D. P. Cox. PUERTO RICO. Estimation of undiscovered deposits in quantitative mineral resource assessments; examples from Venezuela and Puerto Rico. Nonrenewable Resources. v. 2, no. 2,1993 . p. 82-91.

OP-218. D. P. Cox, S. D. Ludington, M. G. Sherlock*, D. A. Singer*, B. R. Berger* and J. V. Tingley*. NEVADA. Mineralization patterns in time and space in the Great Basin of Nevada, in Geology and ore deposits of the Great Basin; symposium proceedings. (G. L. Raines, editor and others). Reno, NV: Geological Society of Nevada, 1991. p. 193-198.

OP-219. I. M. Cozzarelli and M. J. Baedecker. Oxidation of hydrocarbons coupled to reduction of inorganic species in groundwater. Proceedings - International Symposium on Water-Rock Interaction. 7, 1992. p. 275-278.

OP-220. Edward Cranswick. The information content of high-frequency seismograms and the near-surface geologic structure of "hard rock" recording sites. Pure and Applied Geophysics, in Scattering and attenuation of seismic waves; I. (Rushan Wu, editor and others). v. 128, no. 1-2, 1988. p. 333-363.

OP-221. Edward Cranswick, B. Gardner, S. Hammond* and Robert Banfill*. Recording ground motions where people live. Eos, Transactions, American Geophysical Union. v. 74, no. 21, May 25, 1993. p. 243-244.

OP-222. T. M. Cronin and H. J. Dowsett. PRISM; warm climates of the Pliocene. Geotimes. v. 38, no. 11, November 1993. p. 17-19.

OP-223. T. M. Cronin, R. C. Whatley*, A. M. Wood*, Akira Tsukagoshi*, Noriyuki Ikeya*, E. M. Brouwers and W. M. Briggs, Jr.*. Microfaunal evidence for elevated Pliocene temperatures in the Arctic Ocean. Paleoceanography. v. 8, no. 2, April 1993. p. 161-173.

OP-224. D. E. Crowe*, S. W. Nelson, P. E. Brown*, W. C. Shanks, III and J. W. Valley*. ALASKA. Geology and geochemistry of volcanogenic massive sulfide deposits and related igneous rocks, Prince William Sound, south-central Alaska; reply.
Economic Geology and the Bulletin of the Society of Economic Geologists. v. 88, no. 5, August 1993. p. 1285-1288.

OP-225. J. K. Crowley. A spectral reflectance study (0.4-2.5 pm) of selected playa evaporite mineral deposits and related geochemical processes. International Geoscience and Remote Sensing Symposium, in 10th annual international geoscience and remote sensing symposium. (V. V. Salomonson, chairperson). 10, 1990. p. 965.

OP-226. J. K. Crowley. Spectral reflectance analysis of playa evaporite minerals; potential for use in playa geochemical studies and mineral resource exploration, in Geology and ore deposits of the Great Basin; symposium proceedings. (G. L. Raines, editor and others). Reno, NV: Geological Society of Nevada, 1991. p. 255-262.

OP-227. J. K. Crowley. CALIFORNIA. Mapping playa evaporite minerals with AVIRIS data; a first report from Death Valley, California. Remote Sensing of Environment. v. 44, no. 2-3, June 1993. p. 337-356.

OP-228. S. S. Crowley, L. F. Ruppert, H. E. Belkin, R. W. Stanton and T. A. Moore*. Factors affecting the geochemistry of a thick, subbituminous coal bed in the Powder River basin; volcanic, detrital, and peat-forming processes. Organic Geochemistry, in Collected papers from the ninth annual meeting of the Society for Organic Petrology. (S. A. Stout, editor and others). v. 20, no. 6, August 1993. p. 843-853.

OP-229. M. J. Cruickshank. Marine sand and gravel mining and processing technologies. Marine Mining. v. 7, no. 2, 1988. p. 149-163.

OP-230. R. R. Cruz. NEW MEXICO. Groundwater levels, Mimbres Basin South, New Mexico, 1982-1987. Report no. GWL-MBS-82187, 1991. 1 sheet. Available from: N.M. State Eng. Off., United States.

OP-231. C. G. Cunningham, Antonio Arribas, Jr.* and J. J. Rytuba. Mineralized and unmineralized calderas in Spain; Part I, Evolution of the Los Frailes Caldera. Mineralium Deposita, in Gold '89 in Europe. (Francis Saupé, prefacer and others). 25, Suppl. 1990. p. 21-28.

OP-232. V. D. Cvetkovic*, A. M. Shapiro and Gedeon Dagan*. A solute flux approach to transport in heterogeneous formations; 2, Uncertainty analysis. Water Resources Research. v. 28, no. 5, May 1992. p. 1377-1388.

OP-233. G. K. Czamanske, T. W. Sisson, J. L. Campbell* and W. J. Teesdale*. Micro-PIXE analysis of silicate reference standards. American Mineralogist. v. 78, no. 9-10, October 1993. p. 893-903.

OP-234. J. B. Czarnecki, Daniel Ronen*, Mordeckai Magaritz* and Levy Kroitoru*. CALIFORNIA. A hint of recharge at Franklin Lake playa, Inyo County, California, USA. Proceedings International Symposium on Water-Rock Interaction. 7, 1992. p. $631-634$

OP-235. J. B. Czarnecki and W. E. Wilson. NEVADA. Conceptual models of regional ground-water flow and planned studies at Yucca Mountain, Nevada. Hydrological Science and Technology. v. 7 , no. $1-4,1991$. p. $15-25$. 
OP-236. Gedeon Dagan*, V. D. Cvetkovic* and A. M. Shapiro. A solute flux approach to transport in heterogeneous formations; 1 , The general framework. Water Resources Research. v. 28, no. 5, May 1992. p. 1369-1376.

OP-237. G. B. Dalrymple and Graham Ryder*. ${ }^{40} \mathrm{Ar} /{ }^{39} \mathrm{Ar}$ age spectra of Apollo 15 impact melt rocks by laser step-heating and their bearing on the history of lunar basin formation. Journal of Geophysical Research, E, Planets. v. 98, no. 7, July 25, 1993. p. $13,085-13,095$.

OP-238. J. E. Damuth* and W. R. Normark. Seismic facies and sedimentary processes of modern submarine fans and turbidite systems; introduction, in Seismic facies and sedimentary processes of submarine fans and turbidite systems. (Paul Weimer, editor and others), in the collection Frontiers in sedimentary geology. (A. H. Bouma, editor). New York, NY: Springer-Verlag, 1991. p. 319322.

OP-239. C. C. Daniel, III. NORTH CAROLINA. Correlation of well yield to well depth and diameter in fractured crystalline rocks, North Carolina, in Proceedings of a conference on Ground water in the Piedmont of the Eastern United States. (C. C. Daniel, III, editor and others). Clemson, SC: Clemson University, 1989. p. 638-653.

OP-240. C. C. Daniel, III, R. K. White* and P. A. Stone* (editors). Proceedings of a conference on Ground water in the Piedmont of the Eastern United States. Clemson, SC: Clemson University, $1989.688 \mathrm{p}$.

OP-241. Peter Dartnell and J. V. Gardner. Digital imaging of sediment cores for archives and research. Journal of Sedimentary Petrology. v. 63, no. 4, July 1993. p. 750-751.

OP-242. A. S. Davis, S. H. Gunn, LedaBeth Gray, M. S. Marlow and F. L. Wong. Petrology and isotopic composition of Quaternary basanites dredged from the Bering Sea continental margin near Navarin Basin. Canadian Journal of Earth Sciences = Journal Canadien des Sciences de la Terre. v. 30, no. 5, May 1993. p. $975-984$.

OP-243. E. E. Davis*, M. J. Mottl*, A. T. Fisher*, P. A. Baker*, Keir Becker*, Maria Boni*, J. J. Boulègue*, C. A. Brunner*, R. C. Duckworth*, J. M. Franklin*, W. D. Goodfellow*, H. M. Gröschel-Becker*, Masataka Kinoshita*, B. A. Konyukhov*, Ulrike Körner*, S. G. Krasnov*, M. G. Langseth*, Shaozhi Mao*, Vesna Marchig*, Katsumi Marumo*, Hirokuni Oda*, C. A. Rigsby*, B. R. Simoneit*, D. S. Stakes*, H. W. Villinger*, C. G. Wheat*, J. K. Whelan* and R. A. Zierenberg. Hot rocks and massive sulfide; northern Juan de Fuca Ridge. Eos, Transactions, American Geophysical Union. v. 73, no. 17, April 28, 1992. p. 193, 196-198.

OP-244. J. A. Davis and K. F. Hayes. Geochemical processes at mineral surfaces; an overview. ACS Symposium Series, in Geochemical processes at mineral surfaces. (J. A. Davis, editor and others). 323,1986 . p. 1-18.

OP-245. J. A. Davis and K. F. Hayes (editors). Geochemical processes at mineral surfaces. ACS Symposium Series. 323, 1986. $683 \mathrm{p}$.

OP-246. D. D. Dawson*, R. G. Strom* and G. G. Schaber. Monte Carlo computer simulations of Venus equilibrium and global resurfacing models. LPI Contribution, in Papers presented to the international colloquium on Venus. (Lunar and Planetary Institute). 789, 1992. p. 27-29.

OP-247. W. C. Day. MINNESOTA. Petrology of the Rainy Lake area, Minnesota, USA; implications for petrotectonic setting of the Archean southern Wabigoon Subprovince of the Canadian Shield. Contributions to Mineralogy and Petrology. v. 105, no. 3, 1990. p. 303-321.

OP-248. W. E. Dean. MINNESOTA. Physical properties, mineralogy, and geochemistry of Holocene varved sediments from Elk Lake, Minnesota. Special Paper - Geological Society of America, in Elk Lake, Minnesota; evidence for rapid climate change in the north-central United States. (J. P. Bradbury, editor and others). 276, 1993. p. $135-157$.

OP-249. W. E. Dean, Eville Gorham* and D. J. Swaine*. MINNESOTA. Geochemistry of surface sediments of Minnesota lakes. Special Paper - Geological Society of America, in Elk Lake, Minnesota; evidence for rapid climate change in the north-central United States. (J. P. Bradbury, editor and others). 276, 1993. p. 115-133.

OP-250. W. E. Dean and R. O. Megard*. MINNESOTA. Environment of deposition of $\mathrm{CaCO}_{3}$ in Elk Lake, Minnesota. Special Paper-Geological Society of America, in Elk Lake, Minnesota; evidence for rapid climate change in the north-central United States. (J. P. Bradbury, editor and others). 276, 1993. p. $97-$ 113.

OP-251. W. E. Dean and Minze Stuiver*. MINNESOTA. Stable carbon and oxygen isotope studies of the sediments of Elk Lake, Minnesota. Special Paper - Geological Society of America, in Elk Lake, Minnesota; evidence for rapid climate change in the northcentral United States. (J. P. Bradbury, editor and others). 276, 1993. p. 163-180.

OP-252, P. T. Delaney, Asta Miklius, Thora Arnadottir*, A. T. Okamura and M. K. Sako. HAWAII. Motion of Kilauea Volcano during sustained eruption from the Puu Oo and Kupaianaha vents, 1983-1991. Journal of Geophysical Research, B, Solid Earth and Planets. v. 98, no. 10, October 10, 1993. p. 17,80117,820 .

OP-253. David Deming. ALASKA. Regional permeability estimates from investigations of coupled heat and groundwater flow, North Slope of Alaska. Journal of Geophysical Research, B, Solid Earth and Planets. v. 98, no. 9, September 10,1993. p. 16,27116,286 .

OP-254. R. P. Denlinger and R. M. Iverson. Limiting equilibrium and liquefaction potential in infinite submarine slopes. Marine Geotechnology. v. 9, no. 4, December 1990. p. 299-312.

OP-255. J. N. Densmore, G. K. Middleton* and J. A. Izbicki. CALIFORNIA. Surface-water releases for ground-water recharge, Santa Clara River, Ventura County, California. American Water Resources Association Technical Publication Series TPS, in American Water Resources Association 28th annual conference and symposium on Managing water resources during global change. (Raymond Herrmann, editor). 92-4, 1992. p. 407-416.

OP-256. M. D. Dettinger and D. R. Cayan*. CALIFORNIA. Climate-change scenarios for the Sierra Nevada, California, based on winter atmospheric-circulation patterns. American Water Re- 
sources Association Technical Publication Series TPS, in American Water Resources Association 28th annual conference and symposium on Managing water resources during global change. (Raymond Herrmann, editor). 92-4, 1992. p. 681-690.

OP-257. T. W. Dibblee, Jr. CALIFORNIA. Geology of the Imperial Valley region, California. Annual Field Trip Guidebook. South Coast Geological Society, in Geology of the Imperial Valley, California. (P. D. Guptil, editor and others). 14, November 9 , 1986. p. 1-14.

OP-258. J. H. Dieterich. Earthquake nucleation on faults with rate- and state-dependent strength. Tectonophysics, in Earthquake source physics and earthquake precursors. (Takeshi Mikumo, editor and others). v. 211 , no. $1-4$, September 30,1992 . p. 115 134.

OP-259. J. H. Dieterich and M. F. Linker. Fault stability under conditions of variable normal stress. Geophysical Research Letters. v. 19 , no. 16 , August 21, 1992. p. 1691-1694.

OP-260. M. F. Diggles. CALIFORNIA, NEVADA. Geology and mineral resource potential of the White Mountains, Inyo and Mono counties, California and Nevada. Annual Field Trip Guidebook. South Coast Geological Society, in Geology and mineral wealth of the Owens Valley region, California. (E. M. Gath, editor and others). Report no. 15,1987. p. 120-132.

OP-261. J. R. Dine, J. C. Adamski and M. D. Tompkins* (compilers). MARYLAND. Hydrologic data for Howard County, Maryland. Water Resources Basic Data Report (1972). Report no. $19,1992.240 \mathrm{p}$.

OP-262. J. R. Dingler, S. A. Hsu* and T. E. Riess. LOUISIANA. Theoretical and measured aeolian sand transport on a barrier island, Louisiana, USA. Sedimentology. v. 39 , no. 6 , December 1992. p. 1031-1043.

OP-263. E. W. Domack* and S. E. Ishman. Oceanographic and physiographic controls on modern sedimentation within Antarctic fjords. Geological Society of America Bulletin. v. 105, no. 9, September 1993. p. 1175-1189.

OP-264. J. L. Domagalski* and N. M. Dubrovsky. CALIFORNIA. Pesticide residues in the regional aquifer of the San Joaquin Valley, California. AWRA Monograph Series, in Regional aquifer systems of the United States; aquifers of the Far West. (K. R. Prince, editor and others). 16, June 1991. p. 29-42.

OP-265. J. M. Donnelly-Nolan. CALIFORNIA. Thermal waters and mineralization in The Geysers-Clear Lake area, California, USA. Proceedings - International Symposium on Water-Rock Interaction, in Proceedings of the 7th international symposium on Water-rock interaction; Volume 2, Moderate and high temperature environments. (Y. K. Kharaka, editor and others). 7, 1992. p. 1279-1281.

OP-266. J. M. Donnelly-Nolan. CALIFORNIA. Medicine Lake Volcano and Lava Beds National Monument, Siskiyou and Modoc counties. California Geology. v. 45, no. 5, October 1992. p. 145-153.

OP-267. J. M. Donnelly-Nolan, M. G. Burns, F. E. Goff*, E. K. Peters* and J. M. Thompson. CALIFORNIA. The GeysersClear Lake area, California; thermal waters, mineralization, volcanism, and geothermal potential. Economic Geology and the
Bulletin of the Society of Economic Geologists. v. 88, no. 2, April 1993. p. 301-316.

OP-268. T. J. Donovan*, D. P. O'Brien*, J. G. Bryan* and K. I. Cunningham. Near-surface magnetic indicators of buried hydrocarbons; aeromagnetic detection and separation of spurious signals. Bulletin (Association of Petroleum Geochemical Explorationists). v. 2, no. 1, December 1986. p. 1-20.

OP-269. J. S. Downey, K. E. Kolm* and E. D. Gutentag. NEVADA. Selection of geohydrologic boundaries for ground-water flow models, Yucca Mountain, Nevada, in Waste management '90; working towards a cleaner environment; waste processing, transportation, storage and disposal, technical programs and public education; proceedings of the symposium on Waste management; Volume II, HLW \& LLW technology. (R. G. Post, editor). Am. Nucl. Soc. 1990. p. 725-734.

OP-270. H. J. Dowsett, T. M. Cronin, R. Z. Poore, R. S. Thompson, R. C. Whatley* and A. M. Wood*. Micropaleontological evidence for increased meridional heat transport in the North Atlantic Ocean during the Pliocene. Science. v. 258, no. 5085, November 13, 1992. p. 1133-1135.

OP-271. H. J. Dowsett and Paul Loubere*. High resolution late Pliocene sea-surface temperature record from the Northeast Atlantic Ocean. Marine Micropaleontology. v. 20, no. 2, December 1992. p. 91-105.

OP-272. L. J. Drew. The crisis over the 1988 national oil and gas assessment for the United States. Nonrenewable Resources. v. 2, no. 1,1993 . p. $3-13$.

OP-273. L. J. Drew and W. D. Menzie. Is there a metric for mineral deposit occurrence probabilities?. Nonrenewable Resources. v. 2 , no. 2 , 1993. p. $92-105$.

OP-274. L. J. Drew and J. H. Schuenemeyer*. The evolution and use of discovery process models at the U.S. Geological Survey. AAPG Bulletin. v. 77, no. 3, March 1993. p. 467-478.

OP-275. J. L. Drinkwater, G, K. Czamanske and A. B. Ford. Apatite of the Dufek Intrusion; distribution, paragenesis, and chemistry. The Canadian Mineralogist. 28, Part 4, December 1990. p. $835-854$.

OP-276. L. F. Duell, Jr. CALIFORNIA, NEVADA. Use of regression models to estimate effects of climate change on seasonal streamflow in the American and Carson River basins, CaliforniaNevada. American Water Resources Association Technical Publication Series TPS, in American Water Resources Association 28th annual conference and symposium on Managing water resources during global change. (Raymond Herrmann, editor). 924, 1992. p. 731-740.

OP-277. W. A. Duffield, G. H. Heiken*, Duncan Foley* and A. S. McEwen. Oblique synoptic images, produced from digital data, display strong evidence of a "new" caldera in southwestern Guatemala. Journal of Volcanology and Geothermal Research. v. 55, no. 3-4, March 1993. p. 217-224.

OP-278. W. A. Duffield and Joaquin Ruiz*. NEW MEXICO. Compositional gradients in large reservoirs of silicic magma as evidenced by ignimbrites versus Taylor Creek Rhyolite lava domes. Contributions to Mineralogy and Petrology. v. 110, no. 2-3, April 1992. p. 192-210. 
OP-279. M. A. Dungan*, B. S. Singer*, Laurie Brown*, J. M. Rhodes*, Andrew Wulff*, Jim Pickens*, Lynn Gualtieri*, C. P. Ervin*, J. P. Davidson*, Steve Nelson*, F. A. Frey*, R. A. Thompson, Wes Hildreth, R. E. Drake*, Jorge Lobato* and Leopoldo Lopez-Escobar*. The life history of an Andean volcano. Eos, Transactions, American Geophysical Union. v. 73, no. 38, September 22, 1992.

OP-280. D. D. Dunn and H. R. Hejl, Jr. TEXAS. United States Geological Survey bridge scour evaluation program in Texas, in Hydraulic engineering; saving a theoretical resource, in search of solutions. (M. E. Jennings, editor and others). New York, NY: Am. Soc. Civ. Eng. 1992. p. 82-84.

OP-281. W. B. Durham*, S. H. Kirby and L. A. Stern. Effects of dispersed particulates on the rheology of water ice at planetary conditions. Journal of Geophysical Research, E, Planets. v. 97, no. 12 , December 25, 1992. p. 20,883-20,897.

OP-282. W. B. Durham*, S. H. Kirby and L. A. Stern. Flow of ices in the ammonia-water system. Journal of Geophysical Research, B, Solid Earth and Planets. v. 98, no. 10, October 10, 1993. p. $17,667-17,682$.

OP-283. J. T. Dutro, Jr. Memorial to Mackenzie Gordon, Jr., 1913-1992. Memorials - Geological Society of America. 23, 1993. p. $115-119$.

OP-284. J. J. Dvorak. HAWAII. Mechanism of explosive eruptions of Kilauea Volcano, Hawaii. Bulletin of Volcanology. v. 54, no. 8, December 1992. p. 638-645.

OP-285. R. M. Easton*, L. E. Edwards, R. R. Jordan* and D. E. Owen*. Stratigraphic regulation and guidance; a critique of current tendencies in stratigraphic codes and guides: Discussion. Geological Society of America Bulletin. v. 105, no. 8, August 1993. p. 1135-1136.

OP-286. Donna Eberhart-Phillips and A. J. Michael. CALIFORNIA. Three-dimensional velocity structure, seismicity, and fault structure in the Parkfield region, Central California. Journal of Geophysical Research, B, Solid Earth and Planets. v. 98, no. 9, September 10, 1993. p. 15,737-15,758.

OP-287. D. D. Eberl. Three zones for burial metamorphism. Proceedings - International Symposium on Water-Rock Interaction, in Proceedings of the 7th international symposium on Water-rock interaction; Volume 2, Moderate and high temperature environments. (Y. K. Kharaka, editor and others). 7, 1992. p. 1165 1167.

OP-288. D. D. Eberl. Three zones for illite formation during burial diagenesis and metamorphism. Clays and Clay Minerals. v. 41 , no. 1 , February 1993 . p. $26-37$.

OP-289. D. D. Eberl, Jan Srodon* and H. R. Northrop. Potassium fixation in smectite by wetting and drying. ACS Symposium Series, in Geochemical processes at mineral surfaces. (J. A. Davis, editor and others). 323, 1986. p. 296-326.

OP-290. G. M. Edson. ARIZONA. Mineralien aus der Roten Wolke; die Grube "Red Cloud" im Bezirk La Paz, Arizona, USA [Minerals from the Red Cloud Mine, La Paz County, Arizona]. Mineralien-Welt. v. 2, no. 3, 1991. p. 16-25.

OP-291. L. E. Edwards. SOUTH CAROLINA, GEORGIA. Dinocysts from the lower Tertiary units in the Savannah River area,
South Carolina and Georgia. Proceedings of the Bald Head Island Conference on Coastal Plains Geology, in Proceedings of the Second Bald Head Island conference on coastal plains geology; Savannah River region; transition between the Gulf and Atlantic coastal plains. (V. A. Zullo, editor and others). 2, May 1992. p. 97-99.

OP-292. L. E. Edwards. New semiquantitative (paleo)temperature estimates using dinoflagellate cysts, an example from the North Atlantic Ocean, in Neogene and Quaternary dinoflagellate cysts and acritarchs. (M. J. Head, editor and others). Salt Lake City, UT: Publishers Press, September 1992. p. 69-87.

OP-293. L. E. Edwards and V. A. Andrle. Distribution of selected dinoflagellate cysts in modern marine sediments, in Neogene and Quaternary dinoflagellate cysts and acritarchs. (M. J. Head, editor and others). Salt Lake City, UT: Publishers Press, September 1992. p. 259-288.

OP-294. R. L. Edwards*, C. D. Gallup*, K. R. Ludwig, K. R. Simmons, I. J. Winograd, B. J. Szabo and A. C. Riggs. NEVADA. Dating of the Devils Hole calcite vein; discussion and reply. Science.'v. 259, no. 5101, March 12, 1993. p. 16261627.

OP-295. S. L. Eittreim, Nikita Ragozin*, H. S. Gnibidenko* and C. E. Helsley*. Crustal age between the Clipperton and Clarion fracture zones. Geophysical Research Letters. v. 19, no. 24, December 24, 1992. p. 2365-2368.

OP-296. A. K. El-Shazly* and M. A. Lanphere. Two high-pressure metamorphic events in NE Oman; evidence from ${ }^{40} \mathrm{Ar} /{ }^{39} \mathrm{Ar}$ dating and petrological data. Journal of Geology. v. 100, no. 6 , November 1992. p. 731-751.

OP-297. J. F. Elder* and J. J. Collins. Freshwater molluscs as indicators of bioavailability and toxicity of metals in surface-water systems. Reviews of Environmental Contamination and Toxicology. 122,1991 . p. $37-79$.

OP-298. W. A. Elders* and J. H. Sass. CALIFORNIA. The technical challenges and scientific results of the Salton Sea Scientific Drilling Project, USA; the relevance of geothermal experience to ultradeep drilling, in Super-deep continental drilling and deep geophysical sounding. (Karl Fuchs, editor and others), in the collection Exploration of the deep continental crust. (H. J. Behr, editor and others). Berlin: Springer Verlag, 1990. p. 170-179.

OP-299. S. A. Elias*, S. K. Short* and R. L. Phillips. ALASKA. Paleoecology of late-glacial peats from the Bering land bridge, Chukchi Sea shelf region, northwestern Alaska. Quaternary Research (New York). v. 38, no. 3, November 1992. p. 371-378.

OP-300. J. G. Elliott and R. S. Parker. COLORADO. Potential climate-change effects on bed-material entrainment, the Gunnison Gorge, Colorado. American Water Resources Association Technical Publication Series TPS, in American Water Resources Association 28th annual conference and symposium on Managing water resources during global change. (Raymond Herrmann, editor). 92-4, 1992. p. 751-759.

OP-301. W. L. Ellis. OKLAHOMA. Stress distribution in southcentral Oklahoma and its relationship to crustal structure and contemporary seismicity. Proceedings - Symposium on Rock Mechanics, in Rock mechanics as a multidisciplinary science; pro- 
ceedings of the 32nd U.S. symposium. (Jean-Claude Roegiers, editor). 32, 1991. p. 73-81.

OP-302. W. L. Ellsworth. CALIFORNIA. Earthquake prediction; getting beyond numerology. Nature (London). v. 363, no. 6426, May 20, 1993. p. 206-207.

OP-303. H. I. Essaid. Long-term issues in ground water management; seawater intrusion. Report - California Water Resources Center. 77, September 1992. p. 75-92.

OP-304. H. I. Essaid* and K. M. Hess. Monte Carlo simulations of multiphase flow incorporating spatial variability of hydraulic properties. Ground Water. v. 31, no. 1, February 1993. p. 123134.

OP-305. E. J. Essene*, P. Z. Rogers*, C. J. Duffy*, B. S. Hemingway, D. E. Hobart*, R. E. Mesmer*, T. W. Newton*, D. L. Perry*, Dhanpat Rai* and R. J. Silva*. Thermodynamics of solutions and minerals, in Workshop on Fundamental geochemistry needs for nuclear. waste isolation. (B. R. Erdal, chairperson). September 1985. p. 39-45. Available from: NTIS, Springfield, VA, United States.

OP-306. W. C. Evans, G. W. Kling*, M. L. Tuttle, Greg Tanyileke* and L. D. White. Gas buildup in Lake Nyos, Cameroon; the recharge process and its consequences. Applied Geochemistry. v. 8 , no. 3 , May 1993 . p. 207-221.

OP-307. N. F. Exon* and M. S. Marlow. The New Ireland Basin; a frontier basin in Papua New Guinea, in Petroleum exploration in Papua New Guinea. (G. J. Carman, editor and others). Brown Prior Anderson Pty. February 1992. p. 513-532.

OP-308. G. M. Fairer (compiler). Geologic map of the Wadi Baysh Quadrangle, Sheet 17F, Kingdom of Saudi Arabia. Map Kingdom of Saudi Arabia, Ministry of Petroleum and Mineral Resources. Report no. GM-77C, 1985. 23 p., 1 sheet.

OP-309. G. M. Fairer (compiler). Geologic map of the Wadi Baysh Quadrangle, Sheet 17F, Kingdom of Saudi Arabia. Map Kingdom of Saudi Arabia, Ministry of Petroleum and Mineral Resources. Report no. GM-77A, 1985. 23 p., 1 sheet.

OP-310. Christophe Falguères*, Henry de Lumley* and J. L. Bischoff. U-series dates for stalagmitic flowstone $\mathrm{E}$ (Riss/Würm interglaciation) at Grotte du Lazaret, Nice, France. Quaternary Research (New York). v. 38, no. 2, September 1992. p. 227. 233.

OP-311. J. L. Fanning, G. A. Doonan and L. T. Montgomery. GEORGIA. Water use in Georgia by county for 1990: Information Circular-Georgia Geologic Survey. Report no. 90,1992. 98 p.

OP-312. J. L. Fanning*, G. A. Doonan*, V. P. Trent and R. D. McFarlane*. GEORGIA. Power generation and related water use in Georgia. Information Circular - Georgia Geologic Survey. Report no. $87,1991.37 \mathrm{p}$.

OP-313. G. L. Farmer*, D. E. Broxton*, R. G. Warren* and W. J. Pickthorn. NEVADA. Nd, $S r$, and $O$ isotopic variations in metaluminous ash-flow tuffs and related volcanic rocks at the Timber Mountain/Oasis Valley Caldera Complex, SW Nevada; implications for the origin and evolution of large-volume silicic magma bodies. Contributions to Mineralogy and Petrology. v. 109 , no. 1,1991 . p. 53-68.
OP-314. H. Faure*, C. S. Breed and J. F. McCauley. Paleodrainages of the eastern Sahara; the Nile problem and itsrelevance to the Chad Basin. Journal of African Earth Sciences, and the Middle East. v. 14, no. 1, January 1992. p. 153-154.

OP-315. W. H. Ficklin, G. S. Plumlee, K. S. Smith and J. B. $\mathrm{McHugh}$. Geochemical classification of mine drainages and natural drainages in mineralized areas. Proceedings - International Symposium on Water-Rock Interaction. 7, 1992. p. 381-384.

OP-316. J. E. Fierstein and Wes Hildreth. ALASKA. The plinian eruptions of 1912 at Novarupta, Katmai National Park, Alaska. Bulletin of Volcanology. v. 54, no. 8, December 1992. p. 646684.

OP-317. W. I. Finch, Shen Feng *, Chen Zuyi * and R. B. McCammon (reporters). Descriptive models of major uranium deposits in China. Nonrenewable Resources. v. 2, no. 1, 1993. p. $39-48$.

OP-318. M. A. Fisher. Underway geophysics. Proceedings of the Ocean Drilling Program, Part A: Initial Reports, in Proceedings of the Ocean Drilling Program, Vanuatu (New Hebrides), covering Leg 134 of the cruises of the drilling vessel JOIDES Resolution, Port of Townsville, Queensland, Australia, to Suva, Republic of Fiji, sites 827-833, 11 October 1990-17 December 1990. (JeanYves Collot and others). 134, March 1992. p. 55-63.

OP-319. M. J. Flohr and J. S. Huebner. CALIFORNIA. Mineralogy and geochemistry of two metamorphosed sedimentary manganese deposits, Sierra Nevada, California, USA. Lithos. v. 29, no. 1-2, 1992. p. 57-85.

OP-320. M. G. Foreman*, R. F. Henry*, R. A. Walters and V. A. Ballantyne*. A finite element model for tides and resonance along the north coast of British Columbia. Journal of Geophysical Research, C, Oceans. v. 98, no. 2, February 15, 1993. p. 2509. 2531.

OP-321. G. D. Foster*, W. T. Foreman and P. M. Gates. Performance of the Goulden large-sample extractor in multiclass pesticide isolation and preconcentration from stream water. Journal of Agricultural and Food Chemistry. v. 39, no. 9, 1991. p. 1618-1622.

OP-322. G. R. Foulger* and B. R. Julian. Non-double-couple earthquakes at the Hengill-Grensdalur volcanic complex, Iceland; are they artifacts of crustal heterogeneity?. Bulletin of the Seismological Society of America. v. 83, no. 1, February 1993. p. 3852.

OP-323. A. G. Fountain. WASHINGTON. Geometry and flow conditions of subglacial water at South Cascade Glacier, Washington State, U.S.A.; an analysis of tracer injections. Journal of Glaciology. v. 39 , no. 131,1993 . p. 143-156.

OP-324. R. O. Fournier. CALIFORNIA. Double-diffusive convection in geothermal systems; the Salton Sea, California, geothermal system as a likely candidate. Geothermics. v. 19 , no. 6 , 1990. p. $481-496$.

OP-325. R. O. Fournier. Scientific drilling to investigate the physical and chemical nature of fluids in the Earth's crust at $400-500^{\circ} \mathrm{C}$, in Super-deep continental drilling and deep geophysical sounding. (Karl Fuchs, editor and others), in the collection Exploration of the deep continental crust. (H. J. Behr, editor and others). Berlin: Springer Verlag, 1990. p. 342-351. 
OP-326. R. O. Fournier and J. M. Thompson. Composition of steam in the system $\mathrm{NaCl}-\mathrm{KCl}-\mathrm{H}_{2} \mathrm{O}$-quartz at $600^{\circ} \mathrm{C}$. Geochimica et Cosmochimica Acta. v. 57, no. 18, September 1993. p. $4365-4375$.

OP-327. R. O. Fournier, J. M. Thompson and R. A. Hutchinson*. WYOMING. The geochemistry of hot spring waters at Norris Geyser basin, Yellowstone National Park, USA. Proceedings - International Symposium on Water-Rock Interaction, in Proceedings of the 7th international symposium on Water-rock interaction; Volume 2, Moderate and high temperature environments. (Y. K. Kharaka, editor and others). 7, 1992. p. 12891292.

OP-328. Arthur Frankel. CALIFORNIA. Rupture process of the 1987 Superstition hills earthquake from the inversion of strongmotion data; discussion. Bulletin of the Seismological Society of America. v. 82, no. 3, June 1992. p. 1511-1518.

OP-329. Arthur Frankel. CALIFORNIA. Three-dimensional simulations of ground motions in the San Bernardino Valley, California, for hypothetical earthquakes on the San Andreas Fault. Bulletin of the Seismological Society of America. v. 83, no. 4, August 1993. p. 1020-1041.

OP-330. Irving Friedman, Carl Benson* and Jim Gleason. Isotopic changes during snow metamorphism. Special Publication-Geochemical Society, in Stable isotope geochemistry; a tribute to Samuel Epstein. (H. P. Taylor, editor and others). 3, 1991. p. 211-221.

OP-331. L. C. Friedman, L. J. Schroder and M. G. Brooks. Recovery of several volatile organic compounds from simulated water samples; effect of transport and storage. Environmental Science \& Technology, ES \& T. v. 20, no. 6, August 1986. p. 826-829.

OP-332. V. A. Frizzell, Jr, and P. W. Weigand*. CALIFORNIA. Whole-rock K-Ar ages and geochemical data from middle Cenozoic volcanic rocks, Southern California; a test of correlations across the San Andreas Fault. Memoir - Geological Society of America, in The San Andreas fault system; displacement, palinspastic reconstruction, and geologic evolution. (R. E. Powell, editor and others). 178, 1993. p. 273-287.

OP-333. T. P. Frost and J. M. Mattinson*. CALIFORNIA. Age and tectonic implications of mid-Mesozoic calc-alkalic hornblende-rich mafic plutonic rocks of the eastern Sierra Nevada, California. Isochron/West. 59, May 1993. p. 11-16.

OP-334. J. M. Fulford. Characteristics of U.S. Geological Survey discharge measurements for water year 1990, in Hydraulic engineering; saving a theoretical resource, in search of solutions. (M. E. Jennings, editor and others). New York, NY: Am. Soc. Civ. Eng. 1992. p. 452-457.

OP-335. C. C. Fuller, J. A. Davis, D. J. Cain, P. J. Lamothe, T. L. Fries, G. Fernandez*, J. A. Vargas* and M. M. Murillo*. Distribution and transport of sediment-bound metal contaminants in the Rio Grande de Tarcoles, Costa Rica (Central America). Water Research (Oxford). v. 24, no. 7, July 1990. p. 805-812.

OP-336. C. C. Fuller, J. A. Davis and G. A. Waychunas*. Surface chemistry of ferrihydrite; Part 2, Kinetics of arsenate adsorp- tion and coprecipitation. Geochimica et Cosmochimica Acta. v. 57, no. 10, May 1993. p. 2271-2282.

OP-337. J. L. Fulton. Development of spatial data guidelines and standards; spatial data set documentation to support hydrologic analysis in the U.S. Geological Survey. ASTM Special Technical Publication = American Society for Testing and Materials Special Technical Publication, in Geographic information systems (GIS) and mapping; practices and standards. (A. I. Johnson, editor and others). 1126, 1992. p. 30-37.

OP-338. T. E. Fumal, S. K. Pezzopane*, R. J. Weldon, II* and D. P. Schwartz. CALIFORNIA. A 100-year average recurrence-interval for the San Andreas Fault at Wrightwood, California. Science. v. 259, no. 5092, January 8, 1993. p. 199-203.

OP-339. Gabor Gaal* and K. J. Schulz (editors). Precambrian metallogeny related to plate tectonics. Precambrian Research. v. 58 , no. $1-4$, October $1992.446 \mathrm{p}$.

OP-340. J. M. Gardner-Taggart*, H. G. Greene and M. T. Ledbetter*. CALIFORNIA. Neogene folding and faulting in southern Monterey Bay, Central California, USA. Marine Geology. v. 113, no. 3-4, August 1993. p. 163-177.

OP-341. George Garklavs (editor). Minnesota Academy of Science; 61 st annual meeting. Journal of the Minnesota Academy of Science. v. 57, no. 2, 1993. 46 p.

OP-342. L. J. Garside*, H. F. Bonham, Jro*, J. V. Tingley* and E. H. McKee. NEVADA, CALIFORNIA. Potassium-argon ages of igneous rocks and alteration minerals associated with mineral deposits, western and southern Nevada and eastern California. Isochron/West: 59, May 1993. p. 17-23.

OP-343. A. E. Gates* and L. C. Gundersen (editors). Geologic controls on radon. Special Paper - Geological Society of America. 271, 1992. $88 \mathrm{p}$.

OP-344. A. E. Gates* and L. C. Gundersen. VIRGINIA. Sensitivity of soil radon to geology and the distribution of radon and uranium in the Hylas Zone area, Virginia. Special Paper - Geological Society of America, in Geologic controls on radon. (A. E. Gates, editor and others). 271, 1992. p. 17-27.

OP-345. E. L. Geist, M. A. Fisher and D. W. Scholl. Largescale deformation associated with ridge subduction. Geophysical Journal International. v. 115, no. 2, November 1993. p. 344366.

OP-346. G. R. Gelfenbaum and M. A. Noble. SOUTH CAROLINA. Significant bed elevation changes related to Gulf Stream dynamics on the South Carolina continental shelf. Continental Shelf Research. v. 13, no. 4, April 1993. p. 385-405.

OP-347. A. C. Gellis. Decreasing trends of suspended sediment loads in selected streamflow stations in New Mexico. Proceedings of the Annual New Mexico Water Conference, in 36th annual New Mexico water conference; agencies and science working for the future. (C. T. Ortega Klett, editor). Report no. 265, April 1992. p. 77-93.

OP-348. T. M. Gerlach. HAWAII. Oxygen buffering of Kilauea volcanic gases and the oxygen fugacity of Kilaurea basalt. Geochimica et Cosmochimica Acta. v. 57, no. 4, April 1993. p. 795-814. 
OP-349. Aberra Getahun*, M. H. Reed* and R. B. Symonds. ALASKA. Augustine Volcano fumarole wall rock alteration; mineralogy, zoning and numerical models of its formation process. Proceedings - International Symposium on Water-Rock Interaction, in Proceedings of the 7 th international symposium on Waterrock interaction; Volume 2, Moderate and high temperature environments. (Y. K. Kharaka, editor and others). 7, 1992. p. 1411-1414.

OP-350. Jacob Gibs, G. A. Brown, K. S. Turner, C. L. MacLeod*, J. C. Jelinski and S. A. Koehnlein. Effects of smallscale vertical variations in well-screen inflow rates and concentrations of organic compounds on the collection of representative ground-water-quality samples. Ground Water. v. 31, no. 2, April 1993. p. 201-208.

OP-351. T. G. Gibson. Paleogene foraminiferal approaches to coastal plain problems. Proceedings of the Bald Head Island Conference on Coastal Plains Geology, in Proceedings of the Second Bald Head Island conference on coastal plains geology; Savannah River region; transition between the Gulf and Atlantic coastal plains. (V. A. Zullo, editor and others). 2, May 1992. p. 100103.

OP-352. S. R. Gillespie. The value of GIS to the federal government. GIS/LIS - Proceedings, Annual Conference and Exposition, in GIS/LIS '92 annual conference and exposition; proceedings. 1992, 1992. p. 256-264.

OP-353. E. T. Gjessing* and R. C. Petersen, Jr. (editors). Experimental acidification of a catchment and its humic lake. Environment International. v. 18, no. 6, 1992. p. 533-666.

OP-354. B. F. Glenister*, D. W. Boyd*, W. M. Furnish*, R. E. Grant*, M. T. Harris*, H. Kozur*, L. L. Lambert*, W. W. Nassickhuk*, N. D. Newell*, L. C. Pray*, Claude Spinosa*, B. R. Wardlaw, G. L. Wilde* and T. E. Yancey*. The Guadalupian; proposed international standard for a Middle Permian series. International Geology Review. v. 34, no. 9, September 1992. p. 857-888.

OP-355. P. D. Glynn and D. L. Parkhurst. Modeling non-ideal solid-solution aqueous-solution reactions in mass-transfer computer codes. Proceedings - International Symposium on WaterRock Interaction. 7, 1992. p. 175-179.

OP-356. G. S. Gohn. NORTH CAROLINA, SOUTH CAROLINA. Evolution of lithostratigraphy concepts in the study of Cretaceous sediments of the Carolinas. Proceedings of the Bald Head Island Conference on Coastal Plains Geology, in Proceedings of the Second Bald Head Island conference on coastal plains geology; Savannah River region; transition between the Gulf and Atlantic coastal plains. (V. A. Zullo, editor and others). 2, May 1992. p. 43-49.

OP-357. J. S. Gomberg. NEVADA, CALIFORNIA. Correction to Seismicity and shear strain in the southern Great Basin of Nevada and California. Journal of Geophysical Research, B, Solid Earth and Planets. v. 98, no. 3, March 10, 1993. p. 4473-4476.

OP-358. J. S. Gomberg. Tectonic deformation in the New Madrid seismic zone; inferences from map view and cross-sectional boundary element models. Journal of Geophysical Research, B, Solid Earth and Planets. v. 98, no. 4, April 10, 1993. p. 66396664.
OP-359. B. K. Goodwin*, R. E. Weems, G. P. Wilkes*, A. J. Froelich and J. P. Smoot. VIRGINIA. Guidebook to the geology of the Richmond and Taylorsville basins, east-central Virginia. AAPG, East. Sect. November 1985. 60 p.

OP-360. Mackenzie Gordon, Jr., T. W. Henry and J. D. Treworgy*. OKLAHOMA, ARKANSAS. Late Mississippian productoid brachiopods Inflatia, Keokukia, and Adairia, Ozark region of Oklahoma and Arkansas. Memoir - Paleontological Society. 30, May 1993. 29 p.

OP-361. F. M. Gradstein*, J. N. Ludden*, A. C. Adamson*, P. O. Baumgartner*, Roland Beausillon*, S. T. Bolmer*, P. R. Bown*, N. R. Brereton*, R. T. Buffler*, D. A. Castillo*, J. S. Compton*, J. A. Dumoulin*, C. M. Griffiths*, David Haig*, D. T. Heggie*, Akira Ishiwatari*, M. A. Kaminski*, Kazuto Kodama*, David Kopaska-Merkel*, J. P. Marcoux*, Andrew McMinn*, M. J. Moran*, Jörg Mutterlose*, J. G. Ogg*, Brennan O'Neill, Terry Plank*, Michael Riggins*, Michael Schott*; G. R. Simmons*, Jürgen Thurow*, S. K. Stewart*, D. M. Kennett* and E. K. Mazzullo*. Proceedings of the Ocean Drilling Program, Argo abyssal plain/Exmouth Plateau; covering Leg 123 of the cruises of the drilling vessel JOIDES Resolution, Singapore, Republic of Sing., to Singapore, Republic of Sing., sites 765-766, 28 August 1988-1 November 1988. Proceedings of the Ocean Drilling Program, Scientific Results. 123, 1992. 846 p.

OP-362. R. I. Grauch and R. M. Kettler* (conveners). Abstracts from the 1991 annual meeting of the U.S. Working Group of the International Geological Correlation Program Project 254, Metalliferous black shales and related ore deposits. Journal of Geochemical Exploration. v. 46, no. 2, 1992. p. 229-242.

OP-363. R. I. Grauch, J. B. Murowchick*, R. M. Coveney, Jr.* and Chen Nansheng*. Extreme concentration of Mo, Ni, PGE and Au in anoxic marine basins, China and Canada, in Source, transport and deposition of metals. (Maurice Pagel, editor and others). Rotterdam: A. A. Balkema, 1991. p. 531-534.

OP-364. V. J. Grauch. Limitations on digital filtering of the DNAG magnetic data set for the conterminous U.S. Geophysics. v. 58 , no. 9, September 1993. p. 1281-1296.

OP-365. V. J. Grauch and Viki Bankey. NEVADA. Preliminary results of aeromagnetic studies of the Getchell disseminated gold deposit trend, Osgood Mountains, north-central Nevada, in Geology and ore deposits of the Great Basin; symposium proceedings. (G. L. Raines, editor and others). Reno, NV: Geological Society of Nevada, 1991. p. 781-791.

OP-366. Ronald Greeley*, S. D. Kadel*, D. A. Williams*, L. R. Gaddis, J. W. Head*, A. S. McEwen, S. L. Murchie*, Engelbert Nagel*, Gerhard Neukum*, C. M. Pieters*, J. M. Sunshine*, Roland Wagner* and M. J. Belton*. Galileo imaging observations of lunar maria and related deposits. Journal of Geophysical Research, E, Planets, in Special section on Galileo Earth/Moon encounter. v. 98, no. 9, September 25, 1993. p. 17,183-17,205.

OP-367. A. W. Green, E. W. Worthington, L. N. Baransky*, E. N. Fedorov*, N. A. Kurneva*, V. A. Pilipenko*, D. N. Shvetzov*; A. A. Bektemirov* and G. V. Philipov*. Alfven field line resonances at low latitudes $(L=1.5)$. Journal of Geophysical Research, A, Space Physics. v. 98, no. 9, September 1, 1993. p. $16,693-15,699$. 
OP-368. H. G. Greene, Jean-Yves Collot*, Bernard Pelletier* and S. E. Lallemand*. Observation of forearc seafloor deformation along the North d'Entrecasteaux Ridge-New Hebrides island arc collision zone from Nautile submersible. Proceedings of the Ocean Drilling Program, Part A: Initial Reports, in Proceedings of the Ocean Drilling Program, Vanuatu (New Hebrides), covering Leg 134 of the cruises of the drilling vessel JOIDES Resolution, Port of Townsville, Queensland, Australia, to Suva, Republic of Fiji, sites 827-833, 11 October 1990-17 December 1990. (JeanYves Collot and others). 134, March 1992. p. 43-53.

OP-369. J. P. Greenhouse*, Michael Brewster*, George Schneider, J. D. Redman*, A. P. Annan*, G. R. Olhoeft*, J. E. Lucius*, K. A. Sander* and A. T. Mazzella*. Geophysics and solvents; the Borden experiment. Geophysics: The Leading Edge of Exploration. v. 12, no. 4, April 1993. p. 261-267.

OP-370. W. R. Greenwood. Geologic map of the Jibal Al Qahr Quadrangle, Sheet 19G, Kingdom of Saudi Arabia. Map - Kingdom of Saudi Arabia, Ministry of Petroleum and Mineral Resources. Report no. GM-76C, 1985. 17 p., 1 sheet.

OP-371. W. R. Greenwood (compiler). Geologic map of the Bi'r Idamah Quadrangle, Sheet 18G, Kingdom of Saudi Arabia. Map - Kingdom of Saudi Arabia, Ministry of Petroleum and Mineral Resources. Report no. GM-79A, 1985. 30 p., 1 sheet.

OP-372. W. R. Greenwood (compiler). Geologic map of the Bi'r Idamah Quadrangle, Sheet 18G, Kingdom of Saudi Arabia. Map - Kingdom of Saudi Arabia, Ministry of Petroleum and Mineral Resources. Report no. GM-79C, 1985. 1 sheet.

OP-373. E. S. Grew*, D. I. Belakovskiy*, M. E. Fleet*, M. G. Yates*, J. J. McGee and Nicholas Marquez*. Reedmergnerite and associated minerals from peralkaline pegmatite, Dara-i-Pioz, southern Tien Shan, Tajikistan. European Journal of Mineralogy. v. 5, no. 5, October 1993. p. 971-984.

OP-374. George Gryc. Memorial to George O. Gates, 1905-1990. Memorials - Geological Society of America. 23, 1993. p. 151154.

OP-375. B. L. Gulson*, S. E. Church, K. J. Mizon* and A. L. Meier. Lead isotopes in iron and manganese oxide coatings and their use as an exploration guide for concealed mineralization. Applied Geochemistry. v. 7, no. 6, November 1992. p. 495511.

OP-376. Gultekin Gunay*, A. I. Johnson* and William Back (editors). Hydrogeological processes in karst terranes. IAHS-AISH Publication. 207, 1991. 412 p.

OP-377. L. C. Gundersen. The effect of rock type, grain size, sorting, permeability, and moisture on measurements of radon in soil gas; a comparison of two measurement techniques. Journal of Radioanalytical and Nuclear Chemistry, in Proceedings of the Second international conference on Methods and applications of radioanalytical chemistry; Part 4. v. 161, no. 2, August 1992. p. 325-337.

OP-378. L. C. Gundersen and R. T. Peake*. TEXAS, ALABAMA, NEW JERSEY. Radon in the coastal plain of Texas, Alabama, and New Jersey. Special Paper - Geological Society of America, in Geologic controls on radon. (A. E. Gates, editor and others). 271,1992 . p. 53-64.
OP-379. L. C. Gundersen, R. R. Schumann, J. K. Otton, R. F. Dubiel, D. E. Owen and K. A. Dickinson. Geology of radon in the United States. Special Paper - Geological Society of America, in Geologic controls on radon. (A. E. Gates, editor and others). 271, 1992. p. 1-16.

OP-380. S. C. Guptill. Geographical information science; the search for an organizing principle. GIS/LIS - Proceedings, Annual Conference and Exposition, in GIS/LIS '90 proceedings. 1990, vol. 2, 1990. p. 843-845.

OP-381. S. C. Guptill. Multiple representations of geographic entitles through space and time. Proceedings of the International Symposium on Spatial Data Handling, in Proceedings of the 4th international symposium on Spatial data handling. 4, Vol. 2, 1990. p. 859-868.

OP-382. S. C. Guptill. A national geographic data system; a concept. GIS/LIS - Proceedings, Annual Conference and Exposition, in GIS/LIS ' 92 annual conference and exposition; proceedings. 1992, 1992. p. 300-302.

OP-383. S. C. Guptill and Michael Stonebraker*. The Sequoia 2000 approach to managing large spatial object databases. Proceedings of the International Symposium on Spatial Data Handling, in Proceedings; 5th international symposium on Spatial data handling. ( $P$. Bresnahan, editor and others). 5, 1992. p. 642651.

OP-384. F. P. Haeni, Gary Placzek and R. E. Trent. Use of ground penetrating radar to investigate refilled scour holes at bridge foundations. Special Paper - Geological Survey of Finland, in Fourth international conference on Ground penetrating radar. (Pauli Hanninen, editor and others). 16, 1992. p. 285-292.

OP-385. J. T. Hagstrum and B. L. Murchey. CALIFORNIA. Deposition of Franciscan Complex cherts along the paleoequator and accretion to the American margin at tropical paleolatitudes. Geological Society of America Bulletin. v. 105, no. 6, June 1993. p. 766-778.

OP-386. D. K. Hall*, R. S. Williams, Jr. and K. J. Bayr*. Glacier recession in Iceland and Austria. Eos, Transactions, American Geophysical Union. v. 73 , no. 12, March 24, 1992. p. 129,135, 141.

OP-387. D. W. Hall. PENNSYLVANIA. Effects of pipe-outlet terracing on ground-water quantity near Churchtown, Pennsylvania. Ground Water. v. 31, no. 1, February 1993. p. 41-49.

OP-388. D. W. Hall. PENNSYLVANIA. Effects of nutrient management on nitrate levels in ground water near Ephrata, Pennsylvania. Ground Water. v. 30, no. 5, October 1992. p. 720730.

OP-389. Bernard Hallet*, J. S. Walder and C. W. Stubbs*. Weathering by segregation ice growth in microcracks at sustained sub-zero temperatures; verification from an experimental study using acoustic emissions. Permafrost and Periglacial Processes, in Cryogenic weathering; proceedings of a workshop on Mechanical weathering. (Kevin Hall, chairperson and others). v. 2, no. 4, December 1991. p. 283-300.

OP-390. T. D. Hamilton and G. M. Ashley*. ALASKA. Epiguruk; a late Quaternary environmental record from northwestern Alaska; with Suppl. Data 9314. Geological Society of America Bulletin. v. 105, no. 5, May 1993. p. 583-602. 
OP-391. T. D. Hamilton, G. M. Ashley*, K. M. Reed* and C. E. Schweger*. ALASKA. Late Pleistocene vertebrates and other fossils from Epiguruk, northwestern Alaska. Quaternary Research (New York). v. 39, no. 3, May 1993. p. 381-389.

OP-392. W. B. Hamilton. Evolution of convergent plates. Proceedings of the International Conference on Basement Tectonics, in Basement tectonics 8; Characterization and comparison of ancient and Mesozoic continental margins. (M. J. Bartholomew, editor and others). 8, 1988. p. 3-4.

OP-393. J. M. Hammarstrom and E-an Zen*. Calcic amphibole equilibria and a new amphibole-plagioclase geothermometer; discussion. Contributions to Mineralogy and Petrology. v. 111, no. 2, 1992. p. 264-266.

OP-394. J. L. Hannah*, Alec Macbeth and H. J. Stein*. UTAH. Field relations between Tertiary magmatism and tintic-type ore deposits, East Tintic Mountains, Utah, in Geology and ore deposits of the Great Basin; symposium proceedings. (G. L. Raines, editor and others). Reno, NV: Geological Society of Nevada, 1991. p. 485-489.

OP-395. P. L. Hansley and J. L. Brown. WYOMING, MONTANA. Provenance of the Tullock Member of the Fort Union Formation, Powder River basin, Wyoming and Montana; evidence for early Paleocene Laramide uplift. The Mountain Geologist. v. 30, no. 1, January 1993. p. 25-34.

OP-396. J. W. Harden, E. T. Sundquist, R. F. Stallard and R. K. Mark. Dynamics of soil carbon during deglaciation of the Laurentide ice sheet. Science. v. 258 , no. 5090 , December 18 , 1992. p. 1921-1924.

OP-397. R. F. Hardyman and J. S. Oldow*. NEVADA. Tertiary tectonic framework and Cenozoic history of the central Walker Lane, Nevada, in Geology and ore deposits of the Great Basin; symposium proceedings. (G. L. Raines, editor and others). Reno, NV: Geological Society of Nevada, 1991. p. 279-301.

OP-398. S. S. Harlan. ARIZONA. Paleomagnetism of middle Proterozoic diabase sheets from central Arizona. Canadian Journal of Earth Sciences = Journal Canadien des Sciences de la Terre. v. 30 , no. 7 , July 1993 . p. $1415-1426$.

OP-399. D. H. Harlow, R. A. White, M. J. Rymer and Salvador Alvarez G.*. The San Salvador earthquake of 10 October 1986 and its historical context. Bulletin of the Seismological Society of America. v. 83, no. 4, August 1993. p. 1143-1154.

OP-400. G. E. Harlow, Jr. and D. L. Nelms. VIRGINIA, NEW JERSEY. Use of geographic information system to identify hydrogeologic units in the Piedmont and Blue Ridge physiographic provinces, Virginia to New Jersey, in Proceedings of a conference on Ground water in the Piedmont of the Eastern United States. (C. C. Daniel, III, editor and others). Clemson, SC: Clemson University, 1989. p. 312-316.

OP-401. T. A. Harms*, A. S. Jayko and M. C. Blake, Jr. CALIFORNIA. Kinematic evidence for extensional unroofing of the Franciscan Complex along the Coast Range Fault, northern Diablo Range, California. Tectonics. v. 11, no. 2, April 1992. p. 228241.

OP-402. T. A. Harms* and B. L. Murchey. Setting and occurrence of late Paleozoic radiolarians in the Sylvester Allochthon, part of a proto-Pacific ocean floor terrane in the Canadian Cordil- lera. Palaeogeography, Palaeoclimatology, Palaeoecology, in Significance and application of Radiolaria to terrane analysis. (J. Aitchison, editor and others). v. 96, no. 1-2, October 6, 1992. p. 127-139.

OP-403. D. A. Harned and C. C. Daniel, III. The transition zone between bedrock and regolith; conduit for contamination?, in Proceedings of a conference on Ground water in the Piedmont of the Eastern United States. (C. C. Daniel, III, editor and others). Clemson, SC: Clemson University, 1989. p. 336-348.

OP-404. E. L. Harp and M. A. Noble. UTAH. An engineering rock classification to evaluate seismic rock-fall susceptibility and its application to the Wasatch Front. Bulletin of the Association of Engineering Geologists. v. 30, no. 3, September 1993. p. 293-319.

OP-405. R. A. Harris and S. M. Day*. Dynamics of fault interaction; parallel strike-slip faults. Journal of Geophysical Research, B, Solid Earth and Planets. v. 98, no. 3, March 10, 1993. p. 4461-4472.

OP-406. R. A. Harris and R. W. Simpson. CALIFORNIA. Stress caused by the 1992 Landers earthquake. Quarterly of San Bernardino County Museum Association, in Landers; earthquakes and aftershocks. (R. E. Reynolds, compiler). v. 40, no. 1, 1993. p. 61-64.

OP-407. S. H. Hartzell. Site response estimation from earthquake data. Bulletin of the Seismological Society of America. v. 82, no. 6, December 1992. p. 2308-2327.

OP-408. J. W. Harvey and K. E. Bencala. The effect of streambed topography on surface-subsurface water exchange in mountain catchments. Water Resources Research. v. 29, no. 1, January 1993. p. 89-98.

OP-409. R. W. Harvey. Evaluation of particulate and solute tracers for investigations of bacterial transport behavior in groundwater, in Proceedings of the First international symposium on Microbiology of the deep subsurface. (C. B. Fliermans, editor and others). USA: WSRC Inf. Serv. Sect. Publ. Group, 1990. p. 7.159-7.165.

OP-410. P. G. Hatcher*, I. A. Breger, G. E. Maciel* and N. M. Szeverenyi*. Chemical structures in coal; geochemical evidence for the presence of mixed structural components, in 1983 international conference on Coal science; proceedings. (S. W. Chun, president). Int. Energy Agency, 1983. p. 310-313.

OP-411. Egill Hauksson*, L. K. Hutton* and L. M. Jones. CALIFORNIA. Preliminary report on the 1992 Landers earthquake sequence in Southern California, in Landers earthquake of June 28, 1992, San Bernardino County, California; field trip guidebook. (G. S. Rasmussen, leader and others): October 10, 1992. p. 23-31.

OP-412. R. S. Haupt* and D. W. Folger. VERMONT, NEW YORK. Paper plant effluent revisited, southern Lake Champlain, Vermont and New York. Environmental Geology. v. 21, no. 12, April 1993. p. 77-83.

OP-413. J. W. Hawkins*, L. M. Parson*, James Allen*, Niels Abrahamsen*, Ulrich Bednarz*, Gerard Blanc*, S. H. Bloomer*, Reidulv Boe*, T. R. Bruns, W. B. Bryan*, G. C. Chaproniere*, Peter Clift*, Anthony Ewart*, M. G. Fowler*, J. M. Hergt*, R. A. Hodkinson*, Dawn LaVoie*, Jacquelyn Ledbet- 
ter*, Chris McLeod*, Kristen Nilsson*, Hiroshi Nishi*, Cristelle Pratt*, P. J. Quinterno, Robin Reynolds*, Guy Rothwell*, W. W. Sager*, Dietmar Schops*, Sione Soakai* and Michael Styzen*. Evolution of backarc basins; ODP Leg 135, Lau Basin. Eos, Transactions, American Geophysical Union. v. 73, no. 22, June 2, 1992. p. 241, 243, 246-247.

OP-414. F. C. Hawthorne*, Luciano Ungaretti*, Roberta Oberti*, Piero Bottazzi* and G. K. Czamanske. Li; an important component in igneous alkali amphiboles. American Mineralogist. v. 78, no. 7-8, August 1993. p. 733-745.

OP-415. W. W. Hays, William Anderson*, C. G. Bufe, R. M. Chung*, Brian Cowan*, Barry Heyman*, H. J. Lagorio*, Eric Noji*, James Whitcomb* and Richard Wright*. The National Earthquake Hazards Reduction Program (NEHRP); postearthquake investigations. Earthquake Spectra. v. 9, no. 2, May 1993. p. 197-208.

OP-416. J. W. Head*, S. L. Murchie*, J. F. Mustard*, C. M. Pieters*, Gerhard Neukum*, A. S. McEwen, Ronald Greeley*, Engelbert Nagel* and M. J. Belton*. Lunar impact basins; new data for the western limb and far side (Orientale and South PoleAitken basins) from the first Galileo flyby. Journal of Geophysical Research, E, Planets, in Special section on Galileo Earth/Moon encounter. v. 98, no. 9, September 25,1993 . p. 17,149-17,181.

OP-417. R. C. Heath. The Piedmont ground-water system, in Proceedings of a conference on Ground water in the Piedmont of the Eastern United States. (C. C. Daniel, III, editor and others). Clemson, SC: Clemson University, 1989. p. 1-13.

OP-418. J. R. Hein, M. S. Morrison and L. M. Gein. Central Pacific Basin cobalt-rich ferromanganese crusts; historical perspective and regional variability. Circum-Pacific Council for Energy and Mineral Resources, Earth Science Series, in Geology and offshore mineral resources of the Central Pacific Basin. (B. H. Keating, editor and others). 14, 1991. p. 261-283.

OP-419. J. R. Hein, Hsueh-Wen Yeh*, S. H. Gunn, W. V. Sliter, L. M. Benninger* and Chung-Ho Wang*. Two major Cenozoic episodes of phosphogenesis recorded in Equatorial Pacific seamount deposits. Paleoceanography. v. 8, no. 2, April 1993. p. 293-311.

OP-420. Kosuke Heki*, G. R. Foulger*, B. R. Julian and C. H. Jahn*. Plate dynamics near divergent boundaries; geophysical implications of postrifting crustal deformation in NE Iceland. Journal of Geophysical Research, B, Solid Earth and Planets. v. 98, no. 8, August 10,1993. p. 14,279-14,297.

OP-421. D. R. Helsel and R. M. Hirsch. Statistical methods in water resources. Studies in Environmental Science (Amsterdam). 49, 1992. 522 p.

OP-422. T. W. Henry and J. T. Dutro, Jr. Mackenzie Gordon, Jr. (1913-1992). Journal of Paleontology. v. 67, no. 3, May 1993. p. 494-496.

OP-423. W. J. Herb. MINNESOTA. Minnesota District Water Resources Division; information and technical assistance, in Agrichemicals and groundwater protection; resources and strategies for state and local management. Navarre, MN: Freshwater Found. 1989. p. 93-97.

OP-424. L. R. Herbert, C. B. Burden and B. K. Thomas. UTAH. Seepage study of the Timpanogos, Wasatch, Sagebrush and Spring Creek, UpperCharleston, and Lower Charleston canals, Wasatch County, Utah, 1989. Technical Publication-State of Utah, Department of Natural Resources. Report no. 104, 1992. $44 \mathrm{p}$.

OP-425. L. R. Herbert and B. K. Thomas. UTAH, IDAHO. Seepage study of the Bear River including Cutler Reservoir in Cache Valley, Utah and Idaho. Technical Publication - State of Utah, Department of Natural Resources. Report no. 105, 1992. $18 \mathrm{p}$.

OP-426. Richard Hereford. ARIZONA. Entrenchment and widening of the upper San Pedro River, Arizona. Special Paper - Geological Society of America. 282, 1993. 46 p.

OP-427. P. A. Herrera, M. L. Silberman and L. G. Closs. CALIFORNIA. Alteration mineral assemblage and trace element zoning at Bodie Bluff, northern part of the Bodie mining district, Mono County, California, in Geology and ore deposits of the Great Basin; symposium proceedings. (G. L. Raines, editor and others). Reno, NV: Geological Society of Nevada, 1991. p. 11891193.

OP-428. P. T. Herrera*, L. G. Closs* and M. L. Silberman. CALIFORNIA. Alteration and geochemical zoning in Bodie Bluff, Bodie mining district, eastern California. Journal of Geochemical Exploration, in Deep exploration using lithogeochemistry. (E. L. Hoffman, editor and others). v. 48, no. 2, July 1, 1993. p. 259-275.

OP-429. J. R. Herring and R. J. Fantel*. Phosphate rock demand into the next century; impact on world food supply. Nonrenewable Resources. v. 2, no. 3, 1993. p. 226-246.

OP-430. K. M. Hess, W. N. Herkelrath and H. I. Essaid. MINNESOTA. Determination of subsurface fluid contents at a crudeoil spill site. Journal of Contaminant Hydrology. v. 10, no. 1, June 1992. p. 75-96.

OP-431. K. M. Hess, S. H. Wolf* and M. A. Celia*. MASSACHUSETTS. Large-scale natural gradient tracer test in sand and gravel, Cape Cod, Massachusetts; 3, Hydraulic conductivity variability and calculated macrodispersivities. Water Resources Research. v. 28, no. 8, August 1992. p. 2011-2027.

OP-432. R. N. Hey*, J. M. Sinton*, M. C. Kleinrock*, R. N. Yonover*, K. C. Macdonald*, S. P. Miller*, R. C. Searle*, D. M. Christie*, T. M. Atwater*, N. H. Sleep*, H. P. Johnson* and C. A. Neal. Alvin investigation of an active propagating rift system, Galapagos $95.5^{\circ} \mathrm{W}$. Marine Geophysical Researches. v. 14, no. 3, August 1992. p. 207-226.

OP-433. S. H. Hickman and B. J. Evans*. Growth of grain contacts in halite by solution-transfer; implications for diagenesis, lithification, and strength recovery, in Fault mechanics and transport properties of rocks; a festschrift in honor of W. F. Brace. (B. J. Evans, editor and others). San Diego, CA: Acad. Press, 1992. p. $253-280$.

OP-434. A. Hietanen. IDAHO. Role of replacement in the genesis of anorthosite in the Boehls Butte area, Idaho. Bulletin of the Geological Society of Finland. v. 58, no. 1, 1986. p. 71-79.

OP-435. D. K. Higley, K. I. Takahashi and R. F. Mast. Computer-animated display of oil and gas exploration across the continental United States. Geobyte. v. 7, no. 6, December 1992. p. 53-56. 
OP-436. T. G. Hildenbrand, J. G. Rosenbaum and J. P. Kauahikaua. HAWAII. Aeromagnetic study of the Island of Hawaii. Journal of Geophysical Research, B, Solid Earth and Planets. v. 98 , no. 3 , March 10,1993 . p. 4099-4119.

OP-437. D. P. Hill. A note on ambient pore pressure, fault-confined pore pressure, and apparent friction. Bulletin of the Seismological Society of America. v. 83, no. 2, April 1993. p. 583-586.

OP-438. D. P. Hill, P. A. Reasenberg, A. J. Michael, W. J. Arabasz*, G. C. Beroza*, D. S. Brumbaugh*, J. N. Brune*, R. Castro*, S. D. Davis*, D. M. dePolo*, W. L. Ellsworth, J. S. Gomberg, S. C. Harmsen, L. House*, S. M. Jackson*, M. J. Johnston, L. M. Jones, R. Keller*, S. D. Malone*, L. Munguia*, S. Nava*, J. C. Pechmann*, A. R. Sanford*, R. W. Simpson, R. B. Smith*, M. A. Stark*, M. C. Stickney*, A. Vidal*, S. R. Walter, V. Wong* and J. E. Zollweg*. CALIFORNIA. Seismicity remotely triggered by the magnitude 7.3 Landers, California, earthquake. Science. v. 260, no. 5114, June 11, 1993. p. 1617-1623.

OP-439. J. M. Hill*, J. P. Halka*, R. Conkwright*, K. Koczot* and S. M. Colman. Distribution and effects of shallow gas on bulk estuarine sediment properties. Continental Shelf Research, in Methane in marine sediments conference. (A. M. Davis, convener). v. 12 , no. 10 , October 1992 . p. 1219-1229.

OP-440. S. W. Hobbs. Memorial to Paul Averitt, 1908-1991. Memorials - Geological Society of America. 23, 1993. p. 23-26.

OP-441. A. H. Hofstra, G. P. Landis, J. S. Leventhal, H. R. Northrop, R. O. Rye, T. C. Doe* and A. R. Dahl*. NEVADA. Genesis of sediment-hosted, disseminated gold deposits by fluid mixing and sulfidation of iron in the host rocks; chemical reaction path modelling of ore depositional processes at Jerritt Canyon, Nevada, in Geology and ore deposits of the Great Basin; symposium proceedings. (G. L. Raines, editor and others). Reno, NV: Geological Society of Nevada, 1991. p. 235-237.

OP-442. T. D. Hoisch and Carol Simpson*. CALIFORNIA. Rise and tilt of metamorphic rocks in the lower plate of a detachment fault in the Funeral Mountains, Death Valley, California. Journal of Geophysical Research, B, Solid Earth and Planets. v. 98, no. 4, April 10, 1993. p. 6805-6827.

OP-443. R. T. Holcomb and R. C. Searle*. Large landslides from oceanic volcanoes. Marine Geotechnology. v. 10, no. 1-2, June 1991. p. 19-32.

OP-444. F. D. Holland, Jr.* and John Pojeta, Jr. Kenneth Edward Caster (1908-1992). Journal of Paleontology. v. 67, no. 6, November 1993. p. 1095-1096.

OP-445. T. L. Holzer and M. M. Clark. CALIFORNIA. Sand boils without earthquakes. Geology (Boulder). v. 21, no. 10, October 1993. p. 873-876.

OP-446. Masahiko Honda*, Ian McDougall*, D. B. Patterson*, Anthony Doulgeris* and D. A. Clague. HAWAII. Noble gases in submarine pillow basalt glasses from Loihi and Kilauea, Hawaii; a solar component in the Earth. Geochimica et Cosmochimica Acta. v. 57, no. 4, April 1993. p. 859-874.

OP-447. D. B. Hoover, V. J. Grauch, J. A. Pitkin, M. D. Krohn and H. A. Pierce. NEVADA. Getchell trend airborne geophysics; an integrated airborne geophysical study along the
Getchell trend of gold deposits, north-central Nevada, in Geology and ore deposits of the Great Basin; symposium proceedings. (G. L. Raines, editor and others). Reno, NV: Geological Society of Nevada, 1991. p. 739-758.

OP-448. S. W. Hostetler, G. T. Bates* and F. Giorgi*. Interactive coupling of a lake thermal model with a regional climate model. Journal of Geophysical Research, D, Atmospheres. v. 98, no. 3, March 20, 1993. p. 5045-5057.

OP-449. J. C. Houghton*, G. L. Dolton, R. F. Mast, C. D. Masters and D. H. Root. U.S. Geological Survey estimation procedure for accumulation size distributions by play. AAPG Bulletin. v. 77, no. 3, March 1993. p. 454-466.

OP-450. D. W. Houseknecht. USGS researches energy. Geotimes. v. 38, no. 3, March 1993. p. 21-22.

OP-451. D. W. Houseknecht, D. F. Bensley*, L. A. Hathon* and P. H. Kastens*. Rotational reflectance properties of Arkoma Basin dispersed vitrinite; insights for understanding reflectance populations in high thermal maturity regions. Organic Geochemistry, in Collected papers from the Eighth annual meeting of the Society for Organic Petrology. (J. C. Hower, editor and others). v. 20 , no. 2, February 1993 . p. $187-196$.

OP-452. B. B. Houser. DAHO. Quaternary stratigraphy of an area northeast of American Falls Reservoir, eastern Snake River plain, Idaho. Memoir - Geological Society of America, in Regional geology of eastern Idaho and western Wyoming. (P. K. Link, editor and others). 179, 1992. p. 269-288.

OP-453. D. G. Howell, K. J. Bird and D. L. Gautier. Oil; when will we run out?. Earth. v. 2, no. 2, March 1993. p. 26-33.

OP-454. T. V. Hromadka, II, C. E. Berenbrock, J. R. Freckleton and G. L. Guymon*. A two-dimensional dam-break flood plain model. Advances in Water Resources. v. 8, no. 1, 1985. p. $7-14$.

OP-455. T. V. Hromadka, II* and Chintu Lai. The complex variable boundary element method in engineering analysis. New York, NY: Springer-Verlag, 1987. $386 \mathrm{p}$.

OP-456. Hua Renmin*, Ruan Huichu*, Ni Pei* and D. P. Cox. Water-rock interaction in the forming process of Dongchuan copper deposit, China. Proceedings - International Symposium on Water-Rock Interaction, in Proceedings of the 7th international symposium on Water-rock interaction; Volume 2, Moderate and high temperature environments. (Y. K. Kharaka, editor and others). 7,1992 . p. 1589-1591.

OP-457. Huang Wankang*, Wang Junwen*, A. R. Basu* and Mitsunobu Tatsumoto. A study of $\mathrm{REE}$ and $\mathrm{Pb}, \mathrm{Sr}, \mathrm{Nd}$ isotopes in garnet-lherzolite xenoliths from Mingxi, Fujian Province. Diqiu Huaxue $=$ Geochimica. v. 1992, no. 2, 1992. p. 101-113.

OP-458. J. S. Huebner, M. J. Flohr and J. N. Grossman. Chemical fluxes and origin of a manganese carbonate-oxide-silicate deposit in bedded chert. Chemical Geology. v. 100, no. 1-2, October 15, 1992. p. 93-118.

OP-459. R. E. Hughes* and R. L. Smith. Archaeology, geology, and geochemistry in obsidian provenance studies. Special Paper Geological Society of America, in Effects of scale of archaeological and geoscientific perspectives. (J. K. Stein, editor and others). 283,1993 . p. $79-91$. 
OP-460. Stephen Hughes and J. H. Luetgert. NEW YORK. Crustal structure of the southeastern Grenville Province, northern New York State and eastern Ontario. Journal of Geophysical Research, B, Solid Earth and Planets. v. 97, no. 12, November 10, 1992. p. $17,455-17,479$.

OP-461. Stephen Hughes, J. H. Luetgert and N. I. Christensen*. Reconciling deep seismic refraction and reflection data from the Grenvillian-Appalachian boundary in western New England. Tectonophysics. v. 225 , no. 4 , October 30,1993 . p. $255-269$.

OP-462. C. R. Hupp and D. E. Bazemore*. TENNESSEE. Temporal and spatial patterns of wetland sedimentation, West Tennessee. Journal of Hydrology, in Hydrogeology of wetlands. (T. C. Winter, editor and others). v. 141, no. 1-4, January 1993. p. $179-196$.

OP-463. D. R. Hutchinson. Continental margins; windows into Earth's history. Oceanus (Woods Hole). v. 35, no. 4, 1993. p. 34-44.

OP-464. R. A. Hutchinson* and J. M. Thompson. WYOMING. The travertine totem forest of Yellowstone National Park, USA; geological controls and geochemistry. Proceedings - International Symposium on Water-Rock Interaction, in Proceedings of the 7th international symposium on Water-rock interaction; Volume 2, Moderate and high temperature environments. (Y. K. Kharaka, editor and others). 7, 1992. p. 1419-1421.

OP-465. R. W. Hutchinson* and J. P. Albers. Metallogenic evolution of the Cordilleran region of the Western United States, in The Cordilleran Orogen; conterminous U.S. (B. C. Burchfiel, editor and others), in the collection The geology of North America. Geol. Soc. Am. G-3, 1992. p. 629-652.

OP-466. L. K. Hutton* and L. M. Jones. CALIFORNIA. Local magnitudes and apparent variations in seismicity rates in Southern California. Bulletin of the Seismological Society of America. v. 83, no. 2, April 1993. p. 313-329.

OP-467. S. E. Ingebritsen and S. A. Rojstaczer*. Controls on geyser periodicity. Science. v. 262, no. 5135, November 5 , 1993. p. 889-892.

OP-468. S. E. Ingebritsen, M. A. Scholl and D. R. Sherrod. OREGON. Heat flow from four new research drill holes in the Western Cascades, Oregon, U.S.A. Geothermics. v. 22, no. 3, June 1993. p. 151-163.

OP-469. C. M. Isaacs. CALIFORNIA. Field notes on the Monterey Formation, Santa Barbara area, California, in The Miocene Monterey Formation; depositional and diagenetic facies along the Santa Barbara, California coastal area. (R. T. Clarke, prefacer and others). Tulsa, OK: Am. Assoc. Pet. Geol. 1987. p. 1-30.

OP-470. S. E. Ishman. Circumantarctic benthic foraminifers. Sedimentology Research Laboratory Contribution, in Workshop on Antarctic glacial marine and biogenic sedimentation notes for a shortcourse; Part 2, Biogenic sedimentation. (J. R. Bryan, editor). 57, Part 2, March 1993. p. 105-133.

OP-471. J. D. Istok*, J. D. Smyth* and A. L. Flint. Multivariate geostatistical analysis of ground-water contamination; a case history. Ground Water. v. 31, no. 1, February 1993. p. 63-74.

OP-472. R. M. Iverson. Sensivity of stability analyses to groundwater data. Proceedings of the International Symposium on Land- slides = Comptes Rendus du Symposium International sur les Glissements de Terrain, in Landslides; proceedings of the sixth international symposium. (D. H. Bell, editor). 6,1992. p. 451457.

OP-473. J. A. Izbicki. CALIFORNIA. Sources of chloride in ground water of the Oxnard Plain, Califomia. AWRA Monograph Series, in Regional aquifer systems of the United States; aquifers of the Far West. (K. R. Prince, editor and others). 16, June 1991. p. 5-14.

OP-474. J. A. Izbicki, R. L. Michel and P. M. Martin. ${ }^{3} \mathrm{H}$ and ${ }^{14} \mathrm{C}$ as tracers of ground-water recharge, in Irrigation and drainage; saving a threatened resource; in search of solutions. (Ted Engman, editor). New York, NY: American Society of Civil Engineers, 1992. p. 122-127.

OP-475. G, A. Izett; W. A. Cobban, J. D. Obradovich and M. J. Kunk. SOUTH DAKOTA. The Manson impact structure; ${ }^{40} \mathrm{Ar} /{ }^{39} \mathrm{Ar}$ age and its distal impact ejecta in the Pierre Shale in southeastern South Dakota. Science. v. 262, no. 5134, October 29, 1993. p. 729-732.

OP-476. L. L. Jackson. NPS/USGS cooperative biochemistry studies. Park Science. v. 13, no. 1,1993. p. 14.

OP-477. L. L. Jackson and S. R. Roof. Determination of the forms of carbon in geologic materials. Geostandards Newsletter. v. 16 , no. 2,1992 . p. 317-323.

OP-478. O. B. James. The ancient lunar crust, Apollo 17 region. LPI Technical Report, in Workshop on Geology of the Apollo 17 landing site. (Graham Ryder, editor and others). 92-09, Part 1, 1992. p. $17-20$.

OP-479. S. U. Janecke* and L. W. Snee. IDAHO. Timing and episodicity of middle Eocene volcanism and onset of conglomerate deposition, Idaho. Journal of Geology. v. 101, no. 5, September 1993. p. 603-621.

OP-480. Raymond Jeanloz*, Bridget O'Neill*, M. P. Pasternak*, R. D. Taylor* and S. R. Bohlen. Mössbauer spectroscopy of $\mathrm{Mg}_{0.9} \mathrm{Fe}_{0.1} \mathrm{SiO}_{3}$ perovskite. Geophysical Research Letters. v. 19, no. 21, November 3, 1992. p. 2135-2138.

OP-481. M. E. Jennings (editor). Symposium on Urban hydrology; proceedings. Bethesda, MD: Am. Water Resour. Assoc. November 1990.

OP-482. M. E. Jennings and N. G. Bhowmik* (editors). Hydraulic engineering; saving a theoretical resource, in search of solutions. New York, NY: Am. Soc. Civ. Eng. 1992. 1244 p.

OP-483. P. W. Jewell*, R. F. Stallard and G. L. Mellor*. Numerical studies of bottom shear stress and sediment distribution on the Amazon continental shelf. Journal of Sedimentary Petrology. v. 63, no. 4, July 1993 . p. 734-745.

OP-484. Wei-Teh Jiang*, D. R. Peacor* and J. F. Slack. Microstructures, mixed layering, and polymorphism of chlorite and retrograde berthierine in the Kidd Creek massive sulfide deposit, Ontario. Clays and Clay Minerals. v. 40, no. 5, October 1992. p. 501-514.

OP-485. R. W. Jibson. PUERTO RICO. The Mameyes, Puerto Rico, landslide disaster of October 7, 1985. Reviews in Engineering Geology, in Landslides/landslide mitigation. (J. E. Slosson, editor and others). 9, 1992. p. 37-54. 
OP-486. R. W. Jibson and D. K. Keefer. Analysis of the seismic origin of landslides; examples from the New Madrid seismic zone. Geological Society of America Bulletin. v. 105, no. 4, April 1993. p. 521-536.

OP-487. R. W. Jibson and J. G. Staude. ILLINOIS. Bluff recession rates along the Lake.Michigan shoreline in Illinois. Bulletin of the Association of Engineering Geologists. v. 29, no. 2, June 1992. p. 103-117.

OP-488. H. E. Jobson and E. D. Andrews. Major sedimentation issues for the USGS. Hydraulic Engineering: Proceedings of the National Conference on Hydraulic Engineering, in Hydraulic engineering; Proceedings of the 1990 national convention. (H. H. Chang, editor and others). 1990,1990 . p. 1009-1014.

OP-489. D. A. John, J. T. Nash, C. W. Clark* and W. H. Wulftange*. NEVADA. Geology, hydrothermal alteration, and mineralization at the Paradise Peak gold-silver-mercury deposit, Nye County, Nevada, in Geology and ore deposits of the Great Basin; symposium proceedings. (G. L. Raines, editor and others). Reno, NV: Geological Society of Nevada, 1991. p. 10201050.

OP-490. C. M. Johnson*, P. W. Lipman and G. K. Czamanske. NEW MEXICO. H, O, Sr, Nd, and Pb isotope geochemistry of the Latir volcanic field and cogenetic intrusions, New Mexico, and relations between evolution of a continental magmatic center and modifications of the lithosphere. Contributions to Mineralogy and Petrology. v. 104, no. 1, January 1990. p. 99-124.

OP-491. J. G. Johnson* and R. B. Blodgett. Russian Devonian brachiopod genera Cyrtinoides and Komiella in North America. Journal of Paleontology. v. 67, no. 6, November 1993. p. 952 958.

OP-492. M. J. Johnsson, D. G. Howell and K. J. Bird. ALASKA. Thermal maturity patterns in Alaska; implications for tectonic evolution and hydrocarbon potential. AAPG Bulletin. $v$. 77 , no. 11, November 1993. p. 1874-1903.

OP-493. P. A. Johnsson*, A. E. Blum*, M. F. Hochella, Jr.*, G. A. Parks and Garrison Sposito*. Direct observation of muscovite basal-plane dissolution and secondary phase formation; an XPS, LEED, and SFM study. Proceedings - International Symposium on Water-Rock Interaction. 7, 1992. p. 159-162.

OP-494. R. H. Johnston. Historical development of concepts of regional groundwater flow in the Floridan Aquifer system, Southeastern United States. IAHS-AISH Publication, in Hydrogeological processes in karst terranes. (Gultekin Gunay, editor and others). 207,1991 . p. 351-357.

OP-495. M. E. Jones* and Antonius Laenen (editors). Interdisciplinary approaches in hydrology and hydrogeology. Minneapolis, MN: Am. Inst. Hydrol. 1992. 618 p.

OP-496. W. B. Joyner and D. M. Boore. Methods for regression analysis of strong-motion data. Bulletin of the Seismological Society of America. v. 83, no. 2, April 1993. p. 469-487.

OP-497. W. B. Joyner and D. M. Boore. Strong earthquake ground motion and engineering design. Geotechnical News. v. 9, no. 1, March 1991. p. 21-26.

OP-498. Hiroki Kamata, Keiko Suzuki-Kamata and C. R. Bacon. OREGON. Deformation of the Wineglass Welded Tuff and the timing of caldera collapse at Crater Lake, Oregon. Journal of Volcanology and Geothermal Research. v. 56, no. 3, June 1993. p. 253-265.

OP-499. R. J. Kamilli and C. J. Zablocki. Electric-field-ratio profiling at the Silsilah tin-bearing greisen deposit, Kingdom of Saudi Arabia. Exploration and Mining Geology. v. 2, no. 2, April 1993. p. 155-163.

OP-500. A. R. Kampf*, L. L. Jackson, G. B. Sidder, E. E. Foord and P. M. Adams*. CALIFORNIA. Ferrisurite, the $\mathrm{Fe}^{3+}$ analogue of surite, from Inyo County, California. American Mineralogist. v. 77 , no. 9-10, October 1992. p. 1107-1111.

OP-501. Hiroo Kanamori*, Goran Ekstrom*, A. M. Dziewonski*, J. S. Barker* and S. A. Sipkin. Seismic radiation by magma injection; an anomalous seismic event near Tori Shima, Japan. Journal of Geophysical Research, B, Solid Earth and Planets. v. 98, no. 4, April 10,1993. p. 6511-6522.

OP-502. Hiroo Kanamori* and J. J. Mori. Harmonic excitation of mantle Rayleigh waves by the 1991 eruption of Mount Pinatubo, Philippines. Geophysical Research Letters. v. 19, no. 7, April 3, 1992. p. 721-724.

OP-503. Hiroo Kanamori*, J. J. Mori, Egill Hauksson*, T. H. Heaton, L. K. Hutton* and L. M. Jones. Determination of earthquake energy release and $\mathrm{ML}_{\mathrm{L}}$ using TERRAscope. Bulletin of the Seismological Society of America. v. 83, no. 2, April 1993. p. $330-346$.

OP-504. Hiroo Kanamori*, Hong-Kie Thio*, D. S. Dreger*, Egill Hauksson* and T. H. Heaton. CALIFORNIA. Initial investigation of the Landers, Califormia, earthquake of 28 June 1992 using TERRAscope. Geophysical Research Letters. v. 19, no. 22, November 20 , 1992. p. $2267-2270$.

OP-505. J. S. Kane, D. F. Siems and B. F, Arbogast. Geochemical exploration reference samples GXR-1 to GXR-4 and GXR-6; evaluation of homogeneity based on high precision analyses. Geostandards Newsletter. v. 16, no. 1, 1992. p. 45-54.

OP-506. W. F. Kane*, R. C. Milici and T. M. Gathright, II*. Geologic factors affecting coal mine roof stability in the Eastern United States. Bulletin of the Association of Engineering Geologists. v. 30 , no. 2 , June 1993. p. 165-179.

OP-507. E. T. Kanemasu*, S. B. Verma*, E. A. Smith*, L. J. Fritschen*, M. L. Wesely*, R. T. Field*, W. P. Kustas*, H. L. Weaver, J. B. Stewart*, R. J. Gurney*, G. Panin* and J. B. Moncrieff*. KANSAS. Surface flux measurements in FIFE; an overview. Journal of Geophysical Research, D, Atmospheres, in First ISLSCP field experiment (FIFE). (R. E. Murphy, prefacer). v. 97 , no. 17 , November 30,1992 . p. $18,547-18,555$.

OP-508. J. S. Kargel. Possible Recent and ancient glacial ice flow in the South Polar region of Mars. LPI Technical Report, in Workshop on the Polar regions of Mars; geology, glaciology, and climate history. (S. M. Clifford, editor and others). 92-08, Part 1, 1992. p. 13-16.

OP-509. J. S. Kargel, Jeffrey Moore* and T. J. Parker* (editors). Workshop on the Martian northern plains; sedimentological, periglacial, and paleoclimatic evolution. LPI Technical Report. 9304, Part 1, 1993. 23 p. 
OP-510. S. M. Karl, G. A. Wandless and Anne-Marie Karpoff*. Sedimentological and geochemical characteristics of Leg 129 siliceous deposits. Proceedings of the Ocean Drilling Program, Scientific Results, in Proceedings of the Ocean Drilling Program; scientific results; old Pacific crust; covering Leg 129 of the cruises of the drilling vessel JOIDES Resolution, Apra Harbor, Guam, to Apra Harbor, Guam, sites 800-802, 20 November 1989-18 January 1990. (R. L. Larson and others). 129, 1990. p. 31-76.

OP-511. H. R. Karlsson*, S. J. Jakobsson* and J. G. Moore. Oxygen isotope studies of hydrothermally altered basalts from Surtsey, Iceland. Proceedings - International Symposium on Water-Rock Interaction, in Proceedings of the 7th international symposium on Water-rock interaction; Volume 2, Moderate and high temperature environments. $(Y . K$. Kharaka, editor and others). 7, 1992. p. 939-942.

OP-512. K. E. Karlstrom*, C. F. Miller*, J. A. Kingsbury* and J. L. Wooden. CALIFORNIA. Pluton emplacement along an active ductile thrust zone, Piute Mountains, southeastern California; interaction between deformational and solidification processes. Geological Society of America Bulletin. v. 105, no. 2, February 1993. p. 213-230.

OP-513. B. G. Katz. FLORIDA. Persistence of a soil fumigant (1,2-dibromoethane) in ground water, Florida, USA, in First USA/USSR joint conference on Environmental hydrology and hydrogeology. (J. E. Moore and others). Dubuque, IA: Kendall/Hunt Publ. Co. 1991. p. 208-217.

OP-514. B. G. Katz and A. F. Choquette. FLORIDA. Aqueous geochemistry of the sand-and-gravel aquifer, Northwest Florida. Ground Water. v. 29, no. 1, 1991. p. 47-55.

OP-515. D. S. Kaufman*, L. D. Carter, G. H. Miller*, G. L. Farmer* and D. A. Budd*. Strontium isotopic composition of Pliocene and Pleistocene molluscs from emerged marine deposits, North American Arctic. Canadian Journal of Earth Sciences = Journal Canadien des Sciences de la Terre. v. 30, no. 3, March 1993. p. 519-534.

OP-516. R. E. Kayen and H. J. Lee. Pleistocene slope instability of gas hydrate-laden sediment on the Beaufort Sea margin. Marine Geotechnology. v. 10, no. 1-2, June 1991. p. 125-141.

OP-517. D. K. Keefer. The susceptibility of rock slopes to earthquake-induced failure. Bulletin of the Association of Engineering Geologists. v. 30, no. 3, September 1993. p. 353-361.

OP-518. C. W. Keighin, R. S. Zech and R. W. Dunbar*. COLORADO. The Point Lookout Sandstone; a tale of two cores, or petrology, diagenesis, and reservoir properties of Point Lookout Sandstone, southern Ute Indian Reservation, San Juan Basin, Colorado. The Mountain Geologist. v. 30, no. 1, January 1993. p. 4-16.

OP-519. R. S. Keir* and R. L. Michel. Interface dissolution control of the ${ }^{14} \mathrm{C}$ profile in marine sediment. Geochimica et Cosmochimica Acta. v. 57, no. 15, August 1993. p. 3563 3573.

OP-520. T. E. Keith. A look at silica phases in evolving hydrothermal systems. Proceedings - International Symposium on Water-Rock Interaction, in Proceedings of the 7th international symposium on Water-rock interaction; Volume 2, Moderate and high temperature environments. (Y. K. Kharaka, editor and others). 7, 1992. p. 1423-1426.

OP-521. G. R. Keller*, L. W. Braile*, P. M. Davis*, R. P. Meyer*, W. D. Mooney, Claus Prodeh1*, James Mechie*, Ulrich Achauer*, W. Kaminski*, Karl Fuchs*, A. Glahn*, C. Grosse*, Harald Hoffmann*, R. Stangl*, R. Stellrecht*, A. Githui*, M. Baker*, M. A. Khan*, P. K. Maguire*, W. Kirk*, E. E. Criley, J. H. Luetgert, B. Jacob*, P. Slack*, W. V. Green*, S. Harder*, Hans Thybo*, M. Demartin*, S. Scarascia*, Alfred Hirn*, J. R. Bowman*, I. O. Nyambok*, S. J. Gaciri*, J. P. Patel*, E. Dindi*, D. H. Griffiths*, R. F. King*, A. E. Mussett*, G. A. Thompson*, K. H. Olsen*, R. Vees*, D. J. Gajewski*, A. Schulte*, J. Obel*, F. Mwango*, J. Mukinya* and D. Riaroh*. Kenya Rift International Seismic Project, 19891990 experiment. Eos, Transactions, American Geophysical Union. v. 73, no. 33, August 18, 1992. p. 345, 349-351.

OP-522. W. D. Keller*, R. B. Hall, E. E. Foord and D. J. Keller*. MISSOURI. Phosphate minerals in some fireclays of Missouri. CMS News. August, August 1992. p. 28-29.

OP-523. K. S. Kellogg. IDAHO. Cretaceous thrusting and Neogene block rotation in the northern Portneuf Range region, southeastern Idaho. Memoir - Geological Society of America, in Regional geology of eastern Idaho and western Wyoming. (P. K. Link, editor and others). 179, 1992. p. 95-113.

OP-524. Carol Kendall, M. A. Mast and K. C. Rice. Tracing watershed weathering reactions with $8^{13} \mathrm{C}$. Proceedings - International Symposium on Water-Rock Interaction. 7, 1992. p. 569-572.

OP-525. W. J. Kennedy* and W. A. Cobban. ARKANSAS. Campanian ammonites from the Annona Chalk near Yancy, Arkansas. Journal of Paleontology. v. 67, no. 1, January 1993. p. 83-97.

OP-526. W. J. Kennedy* and W. A. Cobban. TEXAS. Maastrichtian ammonites from the Corsicana Formation in Northeast Texas. Geological Magazine. v. 130, no. 1, January 1993. p. 57-67.

OP-527. W. J. Kennedy* and W. A. Cobban. ARKANSAS. Ammonites from the Saratoga Chalk (Upper Cretaceous), Arkansas. Journal of Paleontology. v. 67, no. 3, May 1993. p. 404434.

OP-528. W. J. Kennedy* and W. A. Cobban. NEW JERSEY, MARYLAND, DELAWARE. Lower Campanian (Upper Cretaceous) ammonites from the Merchantville Formation of New Jersey, Maryland, and Delaware. Journal of Paleontology. v. 67 , no. 5, September 1993. p. 828-849.

OP-529. W. J. Kennedy* and W. A. Cobban. NEW JERSEY. Ammonite fauna from the Wenonah Formation (Upper Cretaceous) of New Jersey. Journal of Paleontology. v. 68, no. 1, January 1994. p. 95-110.

OP-530. D. B. Kent, J. A. Davis, L. D. Anderson and B. A. Rea. Ligand-enhanced transport of strongly adsorbing metal ions in the ground-water environment. Proceedings - International Symposium on Water-Rock Interaction. 7,1992. p. 805-808.

OP-531. K. B. Ketner. NEVADA. Stratigraphy and strata-bound lead-zinc-barium mineralization of lower Paleozoic western-facies rocks in northeastern Nevada, in Geology and ore deposits of the 
Great Basin; symposium proceedings. (G. L. Raines, editor and others). Reno, NV: Geological Society of Nevada, 1991. p. 539. 551.

OP-532. R. M. Kettler, R. O. Rye, S. E. Kesler, P. A. Meyers, José Polanco and Norman Russell. Gold deposition by sulfidation of ferrous $\mathrm{Fe}$ in the lacustrine sediments of the Pueblo Viejo District (Dominican Republic); the effect of $\mathrm{Fe}-\mathrm{C}-\mathrm{S}$ diagenesis on later hydrothermal mineralization in a maar-diatreme complex. Chemical Geology, in Geochemistry of metalliferous black shales. (P. A. Meyers, editor and others). v. 99, no. 1-3, September 10, 1992. p. 29-50.

OP-533. Y. K. Kharaka, P. D. Lundegard*, Gil Ambats, W. C. Evans and J. L. Bischoff. Generation of aliphatic acid anions and carbon dioxide by hydrous pyrolysis of crude oils. Applied Geochemistry. v. 8, no. 4, July 1993. p. 317-324.

OP-534. Y. K. Kharaka and A. S. Maest (editors). Proceedings of the 7th international symposium on Water-rock interaction; Volume 2, Moderate and high temperature environments. Proceedings - International Symposium on Water-Rock Interaction. 7, 1992. p. $861-1686$.

OP-535. Y. K. Kharaka and A. S. Maest (editors). Proceedings of the 7th international symposium on water-rock interaction; Volume 1, Low temperature environments. Proceedings - International Symposium on Water-Rock Interaction. 7, 1992. 858 p.

OP-536. Y. K. Kharaka, R. H. Mariner, W. C. Evans and B. M. Kennedy*. WYOMMNG. Composition of gases from the Norris-Mammoth corridor, Yellowstone National Park, USA; evidence for a magmatic source near Mammoth Hot Springs. Proceedings - International Symposium on Water-Rock Interaction, in Proceedings of the 7th international symposium on Water-rock interaction; Volume 2, Moderate and high temperature environments. (Y. K. Kharaka, editor and others). 7, 1992. p. 13031307.

OP-537. I. V. Kholodkevich*, J. L. Bischoff and R. J. Rosenbauer. Alkali basalt/seawater hydrothermal alteration. Proceedings - International Symposium on Water-Rock Interaction, in Proceedings of the 7th international symposium on Water-rock interaction; Volume 2, Moderate and high temperature environments. (Y. K. Kharaka, editor and others). 7, 1992. p. 16471650.

OP-538. B. A. Kimball, R. E. Broshears, D. M. McKnight and K. E. Bencala. Effect of instream $\mathrm{pH}$ modification on aluminum. Proceedings - International Symposium on Water-Rock Interaction. 7, 1992. p. 393-396.

OP-539. Chi-Yu King. Comment on ${ }^{222} \mathrm{Rn}$ premonitory signals for earthquakes?. Eos, Transactions, American Geophysical Union. v. 73 , no. 48 , December 1,1992 . p. $517-518$.

OP-540. Chi-Yu King and Guangwei Luo*. Variations of electric resistance and $\mathrm{H}_{2}$ and $\mathrm{Rn}$ emissions of concrete blocks under increasing uniaxial compression. Pure and Applied Geophysics. v. 134 , no. 1,1990 . p. $45-56$.

OP-541. Chi-Yu King and Zongjin Ma. CALIFORNIA. Migration of historical earthquakes in California. Pure and Applied Geophysics. v. 127 , no. 4,1988. p. 627-639.

OP-542. G. C. King*, Derek Sturdy* and J. W. Whitney. The landscape geometry and active tectonics of Northwest Greece; with
Suppl. Data 9238. Geological Society of America Bulletin. v. 105 , no. 2, February 1993. p. 137-161.

OP-543. M. J. Kingston. CALIFORNIA. Geologic mapping from airborne visible and near-infrared relative band depth images, Mountain Pass, California. International Geoscience and Remote Sensing Symposium, in 10th annual international geoscience and remote sensing symposium. (V. V. Salomonson, chairperson). 10, 1990. p. $1703-1706$.

OP-544. S. H. Kirby and A. K. Kronenberg. Will nonhydrostatic stresses and inelastic rock deformation significantly influence the geochemical interactions between fluids and rocks in nuclear waste repository applications?, in Workshop on Fundamental geochemistry needs for nuclear waste isolation. (B. R. Erdal, chairperson). September 1985. p. 71-22. Available from: NTIS, Springfield, VA, United States.

OP-545. R. W. Kistler. Chemical and isotopic characteristics of plutons in the Great Basin, in Geology and ore deposits of the Great Basin; symposium proceedings. (G. L. Raines, editor and others). Reno, NV: Geological Society of Nevada, 1991. p. $107-$ 109.

OP-546. H. J. Knebel. MASSACHUSETTS. Sedimentary environments within a glaciated estuarine-inner shelf system; Boston Harbor and Massachusetts Bay. Marine Geology. v. 110, no. 1-2, February 1993. p. 7-30.

OP-547. D. S. Knopman and E. F. Hollyday. PENNSYLVANIA. Variation in specific capacity in fractured rocks, Pennsylvania. Ground Water. v. 31, no. 1, February 1993. p. 135-145.

OP-548. E. Knox* and D. W. Moody. Influence of hydrology, soil properties, and agricultural land use on nitrogen in groundwater, in Managing nitrogen for groundwater quality and farm profitability. (R. F. Follett, editor and others). Madison, WI: Soil Sci. Soc. Am. 1991. p. 19-57.

OP-549. L. G. Kodosky* and T. E. Keith. ALASKA. Factors controlling the geochemical evolution of fumarolic encrustations, Valley of Ten Thousand Smokes, Alaska. Journal of Volcanology and Geothermal Research. v. 55, no. 3-4, March 1993. p. 185200.

OP-550. Christian Koeberl*, J. B. Hartung*, M. J. Kunk, Jeffrey Klein*, Jun-ichi Matsuda*, Keisuke Nagao*, W. U. Reimold* and Dieter Storzer*. The age of the Roter Kamm impact crater, Namibia; constraints from ${ }^{40} \mathrm{Ar}-{ }^{39} \mathrm{Ar}, \mathrm{K}-\mathrm{Ar}, \mathrm{Rb}-\mathrm{Sr}$, fission track, and ${ }^{10} \mathrm{Be}-{ }^{26} \mathrm{Al}$ studies. Meteoritics. v. 28, no. 2, June 1993. p. 204-212.

OP-551. S. C. Komor and H. W. Anderson, Jr.*. MINNESOTA. Nitrogen isotopes as indicators of nitrate sources in Minnesota sand-plain aquifers. Ground Water. v. 31, no. 2, April 1993. p. 260-270.

OP-552. S. C. Komor and J. W. Valley*. Deep drilling at the Siljan Ring impact structure; oxygen-isotope geochemistry of granite. Contributions to Mineralogy and Petrology. v. 105, no. 5, 1990. p. 516-532.

OP-553. L. F. Konikow and J. D. Bredehoeft. Ground-water models cannot be validated. Advances in Water Resources, in Validation of geo-hydrological models; Part 1. (S. M Hassanizadeh, editor and others). v. 15, no. 1, 1992. p. 75-83. 
OP-554. R. A. Koski, R. C. Lamons*, J. A. Dumoulin and R. M. Bouse. CALIFORNIA. Massive sulfide metallogenesis at a late Mesozoic sediment-covered spreading axis; evidence from the Franciscan Complex and contemporary analogues. Geology (Boulder). v. 21, no. 2, February 1993. p. 137-140.

OP-555. Carl Koteff, G. R. Robinson*, Richard Goldsmith* and W. B. Thompson*. Delayed postglacial uplift and synglacial sea levels in coastal central New England. Quaternary Research (New York). v. 40, no. 1, July 1993. p. 46-54.

OP-556. M. J. Kraus and T. M. Bown. WYOMING. Shortterm sediment accumulation rates determined from Eocene alluvial Paleosols. Geology (Boulder). v. 21, no. 8, August 1993. p. 743-746.

OP-557. M. D. Krohn, Carol Kendall, J. R. Evans and T. L. Fries. Relations of ammonium minerals at several hydrothermal systems in the Western U.S. Journal of Volcanology and Geothermal Research. v. 56, no. 4, August 1, 1993. p. 401-413.

OP-558. R. D. Krushensky. Treasure trove in Central and Eastern Europe. Geotimes. v. 38, no. 4, April 1993. p. 19-21.

OP-559. Gerhard Kuhn and R. S. Parker. COLORADO. Transfer of watershed-model-parameter values to noncalibrated basins in the Gunnison River basin, Colorado. American Water Resources Association Technical Publication Series TPS, in American Water Resources Association 28th annual conference and symposium on Managing water resources during global change. (Raymond Herrmann, editor). 92-4, 1992. p. 741-750.

OP-560. M. A. Kuntz. IDAHO. A model-based perspective of basaltic volcanism, eastern Snake River plain, Idaho. Memoir Geological Society of America, in Regional geology of eastern Idaho and western Wyoming. (P. K. Link, editor and others). 179, 1992. p. 289-304.

OP-561. M. A. Kuntz, H. R. Covington and L. J. Schorr*. IDAHO. An overview of basaltic volcanism of the eastern Snake River plain, Idaho. Memoir - Geological Society of America, in Regional geology of eastern Idaho and western Wyoming. (P. K. Link, editor and others). 179, 1992. p. 227-267.

OP-562. W. P. Kustas*, M. S. Moran*, P. J. Pinter, Jr.*, L. E. Hipps*, E. Swiatek*, D. I. Stannard and J. H. Blanford*. Issues in mapping evapotranspiration over large areas with remote sensing data from MONSOON 90. Conference on Biometeorology and Aerobiology, in Tenth conference on Biometeorology and aerobiology; special session on Hydrometeorology; proceedings. 10,1991 . p. 151-154.

OP-563. K. A. Kvenvolden. Gas hydrates, geological perspective and global change. Reviews of Geophysics. v. 31, no. 2, May 1993. p. $173-187$.

OP-564. K. A. Kvenvolden, P. R. Carlson, C. N. Threlkeld and Augusta Warden. ALASKA. Possible connection between two Alaskan catastrophes occurring $25 \mathrm{yr}$ apart (1964 and 1989). Geology (Boulder). v. 21, no. 9, September 1993. p. 813-816.

OP-565. Yue-Kuen Kwok* and L. A. Beyer. Gravity due to a body with rotational symmetry about a vertical axis. Geophysics. v. 58 , no. 2, February 1993 . p. $298-306$.

OP-566. Chintu Lai. Computational open channel hydraulics for movable-bed problems. Hydraulic Engineering: Proceedings of the National Conference on Hydraulic Engineering, in Hydraulic engineering; Proceedings of the 1990 national convention. ( $H$. $H$. Chang, editor and others). 1990,1990 . p. 493-499.

OP-567. Chintu Lai and R. W. Shaffranek. Frictional resistance treatment in unsteady open-channel flow simulation, in Channel flow resistance; centennial of Manning's formula. (B. C. Yen, editor). Littleton, CO: Water Resour. Publ. 1992. p. 409-420.

OP-568. E. R. Landa. Buried treasure to buried waste; the rise and fall of the radium industry. Colorado School of Mines Quarterly. v. 82, no. $2,1987.77 \mathrm{p}$.

OP-569. J. O. Langbein, D. P. Hill, T. N. Parker and S. K. Wilkinson. CALIFORNIA. An episode of reinflation of the Long Valley Caldera, eastern California; 1989-1991. Journal of Geophysical Research, B, Solid Earth and Planets. v. 98, no. 9, September 10,1993. p. $15,851-15,870$.

OP-570. I. M. Lange, W. J. Nokleberg, S. R. Newkirk*, J. N. Aleinikoff, S. E. Church and H. R. Krouse*. ALASKA. Devonian volcanogenic massive sulfide deposits and occurrences, southern Yukon-Tanana Terrane, eastern Alaska Range, Alaska. Economic Geology and the Bulletin of the Society of Economic Geologists. v. 88, no. 2, April 1993. p. 344-376.

OP-571. P. A. Lapcevic*, K. S. Novakowski* and F. L. Paillet. Analysis of flow in an observation well intersecting a single fracture. Journal of Hydrology. v. 151, no. 2-4, 1993. p. 229239.

OP-572. A. C. Lasaga*, D. L. Bish*, D. T. Vaniman*, Eurybiades Busenberg, F. W. Dickson*, B. J. Giletti*, G. R. Holdren*, Radomir Petrovich*, J. V. Walter*, A. M. White* and M. I. Wood*. Kinetics of geochemical processes, in Workshop on Fundamental geochemistry needs for nuclear waste isolation. (B. R. Erdal, chairperson). September 1985. p. 23-38. Available from: NTIS, Springfield, VA, United States.

OP-573. T. F. Lawton*, G. T. Basabilvazo, S. A. Hodgson*, D. A. Wilson*, G. H. Mack*, W. C. McIntosh*, S. G. Lucas* and K. K. Kietzke*. NEW MEXICO. Laramide stratigraphy of the Little Hatchet Mountains, southwestern New Mexico. New Mexico Geology. v. 15, no. 1, February 1993. p. 9-15.

OP-574. D. L. Leach. Application of fluid inclusions to minerals exploration. Explore. 72, July 1991. p. 12, 14-15.

OP-575. D. L. Leach and E. L. Rowan. MISSOURI. Fluid-inclusion studies of regionally extensive epigenetic dolomites, Bonneterre Dolomite(Cambrian), Southeast Missouri; evidence of multiple fluids during dolomitization and lead-zinc mineralization: Alternative interpretation. Geological Society of America Bulletin. v. 105 , no. 7 , July 1993 . p. 968-971.

OP-576. P. P. Leahy. Consistent data on water quality; it's long overdue. Geotimes. v. 37, no. 12, December 1992. p. 5.

OP-577. G. H. Leavesley, M. D. Branson* and L. E. Hay. Using coupled atmospheric and hydrologic models to investigate the effects of climate change in mountainous regions. American Water Resources Association Technical Publication Series TPS, in American Water Resources Association 28th annual conference and symposium on Managing water resources during global change. (Raymond Herrmann, editor). 92-4, 1992. p. 691-700. 
OP-578: H. J. Lee. Marine slope stability; preface. Marine Geotechnology. v. 10, no. 1-2, June 1991. p. iii-iv.

OP-579. H. J. Lee, W. C. Schwab, B. D. Edwards and R. E. Kayen. Quantitative controls on submarine slope failure morphology. Marine Geotechnology. v. 10, no. 1-2, June 1991. p. 143 157.

OP-580. T. J. Leiker, C. E. Rostad and C. R. Barnes. A reconnaissance study of halogenated organic compounds in catfish from the lower Mississippi River and its major tributaries. American Water Resources Association Technical Publication Series TPS, in Resource development of the Lower Mississippi River; symposium papers. (Dhamo Dhamotharau, editor). 27, 1991. p. 185194.

OP-581. R. W. Leinz. The need for quality control in analytical geochemistry. Explore. 70, January 1991. p. 1, 4-5.

OP-582. R. W. Leinz and D. B. Hoover. The Russian CHIM method; electrically or diffusion-driven collection of ions? Explore. 79, April 1993. p. 1,5-9.

OP-583. S. V. Letunova*, V. V. Kovalsky* and J. R. Watterson. Geochemical ecology of microorganisms. Colorado School of Mines Quarterly. v. 82, no. 3, 1987. 98 p.

OP-584. J. S. Leventhal. Comparison of organic geochemistry and metal enrichment in two black shales; Cambrian Alum Shale of Sweden and Devonian Chattanooga Shale of the United States. Mineralium Deposita. v. 26, no. 2, 1991. p. 104-112.

OP-585. S. D. Lewis. Geophysical setting of the Sulu and Celebes seas. Proceedings of the Ocean Drilling Program, Scientific Results, in Proceedings of the Ocean Drilling Program, Celebes and Sulu seas; covering Leg 124 of the cruises of the drilling vessel JOIDES Resolution, Singapore, Republic of Sing., to Manila, Philippines, Sites 767-771, 1 November 1988-4 January 1989. (E. A. Silver and others). 124,1991 . p. 65-73.

OP-586. S. D. Lewis, J. H. Behrmann*, R. J. Musgrave*, N. L. Bangs*, Per Boden*, K. M. Brown*, Hélène Collombat*, A. N. Didenko*, B. M. Didyk*, R. D. Forsythe*, P. N. Froelich*, Xenia Golovchenko*, Victor Kurnosov*, Nancy Lindsley-Griffin*, K. M. Marsaglia*, Soichi Osozawa*, D. J. Prior*, D. S. Sawyer*, D. W. Scholl, Dorothee Spiegler*, Kari Strand*, Kozo Takahashi*, Marta Torres*, Marta Vega-Faundez*, Hernán Vergara* and Amane Waseda*. Geology and tectonics of the Chile triple junction. Eos, Transactions, American Geophysical Union. v. 73, no. 38, September 22, 1992. p. 404-405, 410 .

OP-587. S. D. Lewis, D. L. Merrill*, Xiaotao Du*, Claude Rangin*, E. A. Silver*, M. T. von Breymann*, Ulrich Bèrner*, Philippe Bertrand*, C. G. Betzler*, G. W. Brass*, Vindell Hsü*, Zehui Huang*, R. D. Jarrard*, B. K. Linsley*, Carla Müller*, Alexandra Nederbragt*, G. J. Nichols*, Manuel Pubellier*, F. G. Sajona*, R. P. Scherer*, D. D. Sheu*, Hidetoshi Shibuya*, Jih-Ping Shyu*, R. B. Smith*, Terence Smith*, R. U. Solidum*, Piera Spadea* and D. D. Tannant*. Underway geophysics. Proceedings of the Ocean Drilling Program, Part A: Initial Reports, in Proceedings of the Ocean Drilling Program, Celebes and Sulu Seas, covering Leg 124 of the cruises of the drilling vessel JOIDES Resolution, Singapore, Republic of Sing., to Manila, Philippines, Sites 767-771, 1 November 1988-4 January 1989. (Claude Rangin and others). 124, May 1990. p. 43-86.
OP-588: R. D. Libra*, G. R. Hallberg, R. D. Rowden* and E. A. Bettis, III*. IOWA. Environmental geology of the Big Spring groundwater basin, Northeast lowa. Guidebook Series (Iowa. Department of Natural Resources. Geological Survey Bureau). Report no. 15, May 1992. $51 \mathrm{p}$.

OP-589. T. D. Light, S. H. Moll, S. W. Bie and G. K. Lee. ALASKA. Reconnaissance guidelines for gold exploration in central Alaska. Journal of Geochemical Exploration, in Geochemical exploration 1991. (F. W. Dickson, editor and others). v. 47, no. 1-3, April 1993. p. 89-108

OP-590. C. J. Lind and L. D. Anderson. Trace metal scavenging by precipitating $\mathrm{Mn}$ and $\mathrm{Fe}$ oxides. Proceedings - International Symposium on Water-Rock Interaction. 7, 1992. p. 397-402.

OP-591. C. J. Lind and J. D. Hem. ARIZONA. Manganese minerals and associated fine particulates in the streambed of Pinal Creek, Arizona, U.S.A.; a mining-related acid drainage problem. Applied Geochemistry. v. 8, no. 2, January 1993. p. 67-80.

OP-592. C. J. Lind and J. D. Hem. ARIZONA. Manganese minerals and associated fine particulates in the streambed of Pinal Creek, Arizona, U.S.A.; a mining-related acid drainage problem. Applied Geochemistry. v. 8, no. 1, January 1993. p. 67-80.

OP-593. S. C. Lindvall* and K. W. Hudnut. CALIFORNIA. Field guide to the area of maximum displacements along the 1992 Landers earthquake rupture, in Landers earthquake of June 28 , 1992, San Bernardino County, California; field trip guidebook. (G. S. Rasmussen, leader and others). October 10, 1992. p. 3338.

OP-594. P. K. Link*, M. A. Kuntz and L. B. Platt* (editors). IDAHO, WYOMING. Regional geology of eastern Idaho and western Wyoming. Memoir - Geological Society of America. 179, 1992. $312 \mathrm{p}$.

OP-595. B. R. Lipin, B. O. Mysen* and G. C. Ulmer* (editors). Collection of papers on phase equilibria. Journal of the American Ceramic Society. v. 75, no. 6, June 1992. p. 1316-1711.

OP-596. P. W. Lipman. Magmatism in the Cordilleran United States; progress and problems, in The Cordilleran Orogen; conterminous U.S. (B. C. Burchfiel, editor and others), in the collection The geology of North America. Geol. Soc. Am. G-3, 1992. p. 481-514.

OP-597. R. J. Litwin and S. R. Ash*. NORTH CAROLINA. Revision of the biostratigraphy of the Chatham Group (Upper Triassic), Deep River basin, North Carolina, USA. Review of Palaeobotany and Palynology. v. 77, no. 1-2, April 20,1993. p. 75-95.

OP-598. R. K. Livingston. USGS national water quality assessment program. WRRI Report, in Toward a common goal; forging water-quality partnerships. (Tom Bahr). 257, May 1991. p. 47 55.

OP-599. M. R. Llamas*, William Back and Jean Margat*. Groundwater use; equilibrium between social benefits and potential environmental costs. Applied Hydrogeology. v. 1, no. 2, 1992. p. 3-14.

OP-600. D. A. Lockner. Room temperature creep in saturated granite. Journal of Geophysical Research, B, Solid Earth and Planets. v. 98, no. 1, January 10, 1993. p. 475-487. 
OP-601. D. A. Lockner and J. D. Byerlee. How geometrical constraints contribute to the weakness of mature faults. Nature (London). v. 363, no. 6426, May 20, 1993. p. 250-252.

OP-602. D. A. Lockner, J. D. Byerlee, V. Kuksenko*, A. Pon-

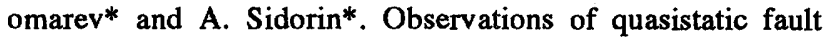
growth from acoustic emissions, in Fault mechanics and transport properties of rocks; a festschrift in honor of W. F. Brace. (B. J. Evans, editor and others). San Diego, CA: Acad. Press, 1992. p. 3-31.

OP-603. D. A. Lockner, Ze'ev Reches and D. E. Moore*. Microcrack interaction leading to shear fracture. Proceedings Symposium on Rock Mechanics, in Rock mechanics; Proceedings of the 33rd U.S. symposium. (J. R. Tillerson, editor and others). 33, 1992. p. 807-816.

OP-604. P. J. Loferski and R. J. Arculus*. MONTANA. Multiphase inclusions in plagioclase from anorthosites in the Stillwater Complex, Montana; implications for the origin of the anorthosites. Contributions to Mineralogy and Petrology. v. 114, no. 1, May 1993. p. 63-78.

OP-605. Austin Long*, C. J. Eastoe*, R. S. Kaufmann*, J. G. Martin, Laurie Wirt* and J. B. Finley*. High-precision measurement of chlorine stable isotope ratios. Geochimica et Cosmochimica Acta. v. 57, no. 12, June 1993. p. 2907-2912.

OP-606. N. C. Lopez. Overview of U.S. Geological Survey water resources information programs, in Agrichemicals and groundwater protection; resources and strategies for state and local management. Navarre, MN: Freshwater Found. 1989. p. 87-91.

OP-607. J. K. Lovelace. LOUISIANA. Water use and trends for withdrawals from the lower Mississippi River in southeastern Louisiana, 1990. American Water Resources Association Technical Publication Series TPS, in Resource development of the Lower Mississippi River; symposium papers. (Dhamo Dhamotharau, editor). 27, 1991. p. 205-213.

OP-608. D. R. Lovley, E. E. Roden, E. J. Phillips and J. C. Woodward. Enzymatic iron and uranium reduction by sulfate-reducing bacteria. Marine Geology. v. 113, no. 1-2, July 1993. p. $41-53$.

OP-609. B. K. Lucchitta. The Taurus-Littrow dark mantle, light mantle, crater cluster, and scarp. LPI Technical Report, in Workshop on Geology of the Apollo 17 landing site. (Graham Ryder, editor and others). 92-09, Part 1, 1992. p. 31.

OP-610. B. K. Lucchitta, J. A. Bowell and Franz Tessensohn*. Landsat images for Antarctic research. Memorie della Società Geologica Italiana, in Geosciences in Victoria Land, Antarctica; proceedings of the meeting. (C. A. Ricci, editor). 33, 1987. p. $35-40$.

OP-611. Ivo Lucchitta and N. H. Suneson*. Dips and extension. Geological Society of America Bulletin. v. 105, no. 10, October 1993. p. 1346-1356.

OP-612. K. J. Lucey. IOWA. Analysis of the ground-water flow system, geochemistry, and underseepage in the vicinity of the Red Rock Dam near Pella, Iowa, in Interdisciplinary approaches in hydrology and hydrogeology. (M. E. Jones, editor and others). Minneapolis, MN: Am. Inst. Hydrol. 1992. p. 119-130.
OP-613. K. R. Ludwig and K. R. Simmons. ARIZONA. U/Pb dating of uranium ores in collapse-breccia pipes, Grand Canyon region, in Source, transport and deposition of metals. (Maurice Pagel, editor and others). Rotterdam: A. A. Balkema, 1991. p. 405-408.

OP-614. Karen Lund, L. S. Beard and W. J. Perry, Jr. NEVADA. Relation between extensional geometry of the northern Grant Range and oil occurrences in Railroad Valley, east-central Nevada. AAPG Bulletin. v. 77, no. 6, June 1993. p. 945-962.

OP-615. P. D. Lundegard*, Y. K. Kharaka and R. J. Rosenbauer*. Petroleum as a potential diagenetic agent; experimental evidence. Proceedings - International Symposium on Water-Rock Interaction. 7, 1992. p. 329-335.

OP-616. P. C. Lyons, E. C. Robertson and Leanne Milton*. C. Wroe Wolfe's geology course on radio-station WGBH (Boston) in 1954. Journal of Geological Education. v. 41, no. 2, March 1993. p. $170-171$.

OP-617. J. W. M'Gonigle and G. B. Dalrymple. MONTANA. ${ }^{40} \mathrm{Ar} /{ }^{39} \mathrm{Ar}$ ages of Challis volcanic rocks and the initiation of Tertiary sedimentary basins in southwestern Montana. The Mountain Geologist. v. 30, no. 4, October 1993. p. 112-118.

OP-618. M. N. Machette. Slope-morphometric dating. Miscellaneous Publication (Utah Geological and Mineral Survey), in Dating methods applicable to Quaternary geologic studies in the Western United States. (S. L. Forman, editor). Report no. 89-7, 1989. p. $30-42$.

OP-619. M. N. Machette. UTAH. American Fork Canyon, Utah; Holocene faulting, the Bonneville fan-delta complex, and evidence for the Keg Mountain oscillation. Miscellaneous Publication (Utah Geological and Mineral Survey), in In the footsteps of G. K. Gilbert; Lake Bonneville and neotectonics of the eastern Basin and Range Province; guidebook for field trip twelve. (M. N. Machette, editor). Report no. 88-1, 1988. p. 89-95.

OP-620. M. N. Machette. UTAH. Exposures of transgressive and regressive sediments of the Bonneville Lake cycle along Dry Creek near Lehi, Utah. Miscellaneous Publication (Utah Geological and Mineral Survey), in In the footsteps of G. K. Gilbert; Lake Bonneville and neotectonics of the eastern Basin and Range Province; guidebook for field trip twelve. (M. N. Machette, editor). Report no. 88-1, 1988. p. 96-99.

OP-621. M. N. Machette, S. F. Personius and A. R. Nelson. UTAH. The Wasatch fault zone, U.S.A. Annales Tectonicae, in Major active faults of the world; results of IGCP Project 206. (R. C. Bucknam and others). 6, Suppl. 1992. p. 5-39.

OP-622. M. N. Machette and W. E. Scott. UTAH. Field trip introduction; a brief review of research on lake cycles and neotectonics of the eastern Basin and Range Province. Miscellaneous Publication (Utah Geological and Mineral Survey), in In the footsteps of G. K. Gilbert; Lake Bonneville and neotectonics of the eastern Basin and Range Province; guidebook for field trip twelve. (M. N. Machette, editor). Report no. 88-1, 1988. p. 6-14.

OP-623. D. J. Madden-McGuire. NEVADA. Stratigraphy of the limestone-bearing part of the Lower Cambrian to Lower Ordovician Preble Formation near its type locality, Humboldt County, north-central Nevada, in Geology and ore deposits of the Great Basin; symposium proceedings. (G. L. Raines, editor and oth- 
ers). Reno, NV: Geological Society of Nevada, 1991. p. 875893.

OP-624. D. J. Madden-McGuire, S. M. Smith, Theodore Botinelly, M. L. Silberman and D. E. Detra. NEVADA. Nature and origin of alluvium above the Rabbit Creek gold deposit, Getchell gold belt, Humboldt County, Nevada, in Geology and ore deposits of the Great Basin; symposium proceedings. (G. L. Raines, editor and others). Reno, NV: Geological Society of Nevada, 1991. p. 895-911.

OP-625. A. S. Maest, S. P. Pasilis, L. G. Miller and D. K. Nordstrom. CALIFORNIA. Redox geochemistry of arsenic and iron in Mono Lake, California, USA. Proceedings - International Symposium on Water-Rock Interaction. 7, 1992. p. 507-511.

OP-626. L. B. Magoon and D. E. Anders. ALASKA. Oil-tosource-rock correlation using carbon-isotopic data and biological marker compounds, Cook Inlet-Alaska Peninsula, Alaska, in Biological markers in sediments and petroleum; a tribute to Wolfgang K. Seifert. (J. M. Moldowan, editor and others). Englewood Cliffs, NJ: Prentice Hall, 1992. p. 241-274.

OP-627. B. J. Maher*, Q. J. Browne* and E. H. McKee. NEVADA. Constraints on the age of gold mineralization and metallogenesis in the Battle Mountain-Eureka mineral belt, Nevada. Economic Geology and the Bulletin of the Society of Economic Geologists. v. 88, no. 2, April 1993. p. 469-478.

OP-628. R. L. Malcolm. The uniqueness of humic substances in each of soil, stream and marine environments. Analytica Chimica Acta. v. 232, no. 1, 1990. p. 19-30.

OP-629. G. E. Mallard, M. J. Baedecker, H. I. Essaid and R. P. Eganhouse. Hydrocarbon transport and degradation in ground water. Geotimes. v. 38 , no. 12, December 1993. p. 18-20.

OP-630. C. A. Manduca*, M. A. Kuntz and L. T. Silver*. IDAHO. Emplacement and deformation history of the western margin of the Idaho Batholith near McCall, Idaho; influence of a major terrane boundary. Geological Society of America Bulletin. v. 105, no. 6, June 1993. p. 749-765.

OP-631. M. T. Mangan, K. V. Cashman* and Sally Newman*. HAWAII. Vesiculation of basaltic magma during eruption. Geology (Boulder). v. 21, no. 2, February 1993. p. 157-160.

OP-632. E. A. Mankinen and D. E. Champion. HAWAII. Broad trends in geomagnetic paleointensity on Hawaii during Holocene time. Journal of Geophysical Research, B, Solid Earth and Planets. v. 98, no. 5, May 10, 1993. p. 7959-7976.

OP-633. E. A. Mankinen and D. E. Champion. HAWAII. Latest Pleistocene and Holocene geomagnetic paleointensity on $\mathrm{Ha}$ waii. Science. v. 262 , no. 5132 , October 15 , 1993. p. $412-416$.

OP-634. G. M. Mann and C. E. Meyer. Late Cenozoic structure and correlations to seismicity along the Olympic-Wallowa Lineament, Northwest United States. Geological Society of America Bulletin. v. 105, no. 7, July 1993. p. 853-871.

OP-635. C. E. Manning and S. R. Bohlen*. The reaction titanite + kyanite $=$ anorthite + rutile and titanite-rutile barometry in eclogites. Contributions to Mineralogy and Petrology. v. 109, no. 1, 1991. p. 1-9.

OP-636. C. E. Manning*, S. E. Ingebritsen and D. K. Bird*. Missing mineral zones in contact metamorphosed basalts. Amer- ican Journal of Science. v. 293, no. 9, November 1993. p. 894938.

OP-637. R. H. Mariner, Y. K. Kharaka, Gil Ambats and L. D. White. WYOMING. Chemical composition and stable isotopes of thermal waters, Norris-Mammoth corridor, Yellowstone National Park, USA. Proceedings - International Symposium on Water-Rock Interaction, in Proceedings of the 7th international symposium on Water-rock interaction; Volume 2, Moderate and high temperature environments. (Y. K. Kharaka, editor and others). 7, 1992, p. $963-966$.

OP-638. R. H. Mariner, T. S. Presser and W. C. Evans. Geothermometry and water-rock interaction in selected thermal systems in the Cascade Range and Modoc Plateau, Western United States. Geothermics. v. 22, no. 1, February 1993. p. 1-15.

OP-639. M. S. Marlow, N. F. Exon* and S. V. Dadisman. Hydrocarbon potential and gold mineralization in the New Ireland Basin, Papua New Guinea. AAPG Memoir, in Geology and geophysics of continental margins. (J. S. Watkins, editor and others). 53, 1992. p. 119-137.

OP-640. C. J. Marone* and B. D. Kilgore. Scaling of the critical slip distance for seismic faulting with shear strain in fault zones. Nature (London). v. 362, no. 6421, April 15, 1993. p. 618-621.

OP-641. D. C. Marron. SOUTH DAKOTA. Floodplain storage of mine tailings in the Belle Fourche River system; a sediment budget approach. Earth Surface Processes and Landforms. v. 17, no. 7, November 1992. p. 675-685.

OP-642. S. P. Marsh. 1992; the geosciences in review; Economic geology; tools and technology; exploration geochemistry. Geotimes. v. 38, no. 2, February 1993. p. 17-18.

OP-643. B. D. Marshall, J. F. Whelan, Z. E. Peterman, Kiyoto Futa, S. A. Mahan and J. S. Stuckless. NEVADA. Isotopic studies of fracture coatings at Yucca Mountain, Nevada, USA. Proceedings - International Symposium on Water-Rock Interaction. 7, 1992. p. 737-740.

OP-644. J. A. Martin and W. P. Pratt (editors). MISSOURI. Geology and mineral-resource potential of the Springfield $1^{\circ} \times 2^{\circ}$ quadrangle, Missouri, as appraised in September 1985. Open File Report Series - Geology and Land Survey Division. Report no. OFR-85-42-MR, 1985. $82 \mathrm{p}$.

OP-645. G. R. Marzolf and C. W. Wood*. ARIZONA. Longterm monitoring and research in Lake Powell. Park Science. v. 13, no. 1,1993 . p. $7-9$.

OP-646. C. D. Masters. U.S. Geological Survey petroleum resource assessment procedures. AAPG Bulletin. v. 77, no. 3, March 1993. p. 452-453.

OP-647. L. G. Mastin and B. M. Myers. WASHINGTON. Shallow explosion-like seismicity and steam-and-ash emissions at Mount St. Helens, August 1989-June 1991. Washington Geology. v. 20, no. 2, June 1992. p. 12-18.

OP-648. M. V. Matthews* and Paul Segall. CALIFORNIA. Estimation of depth-dependent fault slip from measured surface deformation with application to the 1906 San Francisco earthquake. Journal of Geophysical Research, B, Solid Earth and Planets. v. 98 , no. 7 , July 10,1993 . p. $12,153-12,163$. 
OP-649. J. C. Matti and D. M. Morton. CALIFORNIA. Paleogeographic evolution of the San Andreas Fault in Southern California; a reconstruction based on a new cross-fault correlation. Memoir - Geological Society of America, in The San Andreas fault system; displacement, palinspastic reconstruction, and geologic evolution. (R. E. Powell, editor and others). 178, 1993. p. 107-159.

OP-650. H. M. May. The hydrolysis of aluminum; conflicting models and the interpretation of aluminum geochemistry. Proceedings - International Symposium on Water-Rock Interaction. 7, 1992. p. 13-21.

OP-651. L. R. Mayo. ALASKA. Overview of Alaskan program; special considerations regarding cold glaciers. NHRI Science Report, in Glacier mass-balance measurements; a manual for field and office work. (Gunnar Ostrem and others). Report no. 4, 1991. p. 175-183.

OP-652. S. D. McAuley, R. S. Nicholson, J. L. Barringer and G. J. Blyskun*. NEW JERSEY. Plan to evaluate the hydrogeology of the valley-fill and carbonate-rock aquifers near Long Valley in the New Jersey Highlands. Open File Report - New Jersey Geological Survey. Report no. 92-3, 1992. 24 p.

OP-653. P. J. McCabe, J. A. Breyer*, E. C. Kosters*, G. L. Chmura* and A. Bailey*. LOUISIANA. Sedimentary and botanical factors influencing peat accumulation in the Mississippi Delta; discussion and reply. Journal of the Geological Society of London. v. 146, no. 5, September 1989. p. 877-880.

OP-654. R. B. McCammon and J. A. Briskey, Jr. A proposed national mineral-resource assessment. Nonrenewable Resources. v. 1 , no. 4,1992 . p. $259-266$.

OP-655. R. B. McCammon and W. I. Finch. The deposit size frequency method for estimating undiscovered uranium deposits. Nonrenewable Resources. v. 2, no. 2, 1993. p. 106-112.

OP-656. Ian McDougall*, F. H. Brown*, T. E. Cerling* and J. W. Hillhouse. A reappraisal of the geomagnetic polarity time scale to $4 \mathrm{Ma}$ using data from the Turkana Basin, East Africa. Geophysical Research Letters. v. 19, no. 23, December 2, 1992. p. 2349-2352.

OP-657. A. S. McEwen, L. R. Gaddis, Gerhard Neukum*, Harald Hoffmann*, C. M. Pieters* and J. W. Head*. Galileo observations of post-Imbrium lunar craters during the first EarthMoon flyby. Journal of Geophysical Research, E, Planets, in Special section on Galileo Earth/Moon encounter. v. 98, no. 9, September 25, 1993. p. 17,207-17,231.

OP-658. E. R. McFarland. MARYLAND. Ground-water hydrology, geochemistry, and nitrogen transport in a saprolite-fractured schist aquifer under agricultural land in the Piedmont physiographic province of Maryland, in Proceedings of a conference on Ground water in the Piedmont of the Eastern United States. (C. C. Daniel, III, editor and others). Clemson, SC: Clemson University, 1989. p. 442-454.

OP-659. W. D. McFarland. OREGON, NEVADA, CALIFORNIA. Regional aquifer study of the alluvial basins of Oregon, Nevada, and California. AWRA Monograph Series, in Regional aquifer systems of the United States; aquifers of the Far West. (K. R. Prince, editor and others). 16, June 1991. p. 43-53.
OP-660. A. F. McGarr, J. D. Bicknell, E. D. Sembera and R. W. Green*. Analysis of exceptionally large tremors in two gold mining districts of South Africa. Pure and Applied Geophysics. v. 129 , no. $3-4,1989$. p. $295-307$.

OP-661. J. J. McGee. Lunar ferroan anorthosites; mineralogy, compositional variations, and petrogenesis. Journal of Geophysical Research, E, Planets. v. 98, no. 5, May 25, 1993. p. 90899105.

OP-662. E. H. McKee and J. E. Conrad. CALIFORNIA. Geology and mineral resource potential of the southeastern part of the Inyo Mountains, California. Annual Field Trip Guidebook. South Coast Geological Society, in Geology and mineral wealth of the Owens Valley region, California. (E. M. Gath, editor and others). Report no. 15,1987 . p. 94-111.

OP-663. P. W. McKinley. PUERTO RICO. Baseline waterquality evaluation of three basins in the upper Rio Grande de Arecibo Basin, Puerto Rico. American Water Resources Association Technical Publication Series TPS, in Proceedings of the International symposium on Tropical hydrology and Fourth Caribbean Islands water resources congress. (J. H. Krishna, editor and others). 90-2, 1990. p. 433-441.

OP-664. D. M. McKnight*, G. R. Aiken* and R. L. Smith. Aquatic fulvic acids in microbially based ecosystems; results from two desert lakes in Antarctica. Limnology and Oceanography. v. 36, no. 5, 1991. p. 998-1006.

OP-665. H. C. McWreath (editor). Water management of river systems; 27th annual AWRA conference. American Water Resources Association Technical Publication Series TPS. 27, 1991. p. $269-462$.

OP-666. R. H. Meade, J. M. Rayol*, S. C. Da Conceicao* and J. R. Natividade*. Backwater effects in the Amazon River basin of Brazil. Environmental Geology and Water Sciences. v. 18, no. 2, September 1991. p. 105-114.

OP-667. G. P. Meeker and T. K. Hinkley. HAWAII. The structure and composition of microspheres from the Kilauea Volcano, Hawaii. American Mineralogist. v. 78, no. 7-8, August 1993. p. 873-876.

OP-668. R. O. Megard*, J. P. Bradbury and W. E. Dean. MINNESOTA. Climatic and limnologic setting of Elk Lake. Special Paper - Geological Society of America, in Elk Lake, Minnesota; evidence for rapid climate change in the north-central United States. (J. P. Bradbury, editor and others). 276, 1993. p. 19-36.

OP-669. N. B. Melcher and Charles Parrett. 1993 Upper Mississippi River floods. Geotimes. v. 38, no. 12, December 1993. p. 15-17.

OP-670. Carlos Mendoza. Coseismic slip of two large Mexican earthquakes from teleseismic body waveforms; implications for asperity interaction in the Michoacan plate boundary segment. Journal of Geophysical Research, B, Solid Earth and Planets. v. 98, no. 5, May 10, 1993. p. 8197-8210.

OP-671. M. L. Merritt. Representing canals and seasonal inundated wetlands in a ground-water flow model of a surficial aquifer, in Interdisciplinary approaches in hydrology and hydrogeology. (M. E. Jones, editor and others). Minneapolis, MN: Am. Inst. Hydrol. 1992. p. 31-45. 
OP-672. M. L. Merritt. Aspects of numerical and representational methods related to the finite-difference simulation of advective and dispersive transport of freshwater in a thin brackish aquifer. Journal of Hydrology. v. 148, no. 1-4, July 1993. p. 61-92.

OP-673. A. J. Michael, D. H. Oppenheimer and Paul Rosenberg. Seismological results. Newsletter - Earthquake Engineering Research Institute. v. 26, no. 7, July 1992 . p. 3-4.

OP-674. G. E. Michael*, D. E. Anders and B. E. Law. NEW MEXICO, COLORADO. Geochemical evaluation of Upper Cretaceous Fruitland Formation coals, San Juan Basin, New Mexico and Colorado. Organic Geochemistry, v. 20, no. 4, May 1993. p. $475-498$.

OP-675. M. R. Midgett and M. J. Fishman. Determination of total chromium in fresh waters by atomic absorption. Atomic Spectroscopy. v. 6, no. 6, December 1967. p. 128-131.

OP-676. Takeshi Mikumo*, Keiiti Aki*, Mitiyasu Ohnaka*, L. J. Ruff* and Paul Spudich (editors). Earthquake source physics and earthquake precursors. Tectonophysics, v. 211, no. 1-4, September 30, 1992. p. 1-344.

OP-677. D. S. Mileti*, P. A. Bolton*, Gabriel Fernandez* and R. G. Updike. The eruption of Nevado del Ruiz Volcano, Colombia, South America, November 13, 1985. Natural Disaster Studies. 4, 1991. $109 \mathrm{p}$.

OP-678. C. F, Miller*, J. M. Hanchar*, J. L. Wooden, V. C. Bennett*, T. M. Harrison*, D. A. Wark* and D. A. Foster*. Source region of a granite batholith; evidence from lower crustal xenoliths and inherited accessory minerals. Special Paper - Geological Society of America, in The second Hutton symposium on the origin of granites and related rocks; proceedings. (P. E. Brown, editor and others). 272, 1992. p. 49-62.

OP-679. D. M. Miller, T. H. Nilsen* and W. L. Bilodeau*. Late Cretaceous to early Eocene geologic evolution of the U.S. Cordillera, in The Cordilleran Orogen; conterminous U.S. (B. C. Burchfiel, editor and others), in the collection The geology of North America. Geol. Soc. Am. G-3, 1992. p. 205-260.

OP-680. D. M. Miller, R. M. Tosdal and R. G. Anderson*. Continental tectonics and magmatism of the Jurassic North American Cordillera. GSA Today. v. 3, no. 8, August 1993, p. 206207.

OP-681. Charles Milton, J. J. McGee and H. T. Evans, Jr. ARKANSAS. Mahlmoodite, $\mathrm{FeZr}\left(\mathrm{PO}_{4}\right)_{2} \cdot 4 \mathrm{H}_{2} \mathrm{O}$, a new iron zirconium phosphate mineral from Wilson Springs, Arkansas. American Mineralogist. v. 78, no. 3-4, April 1993. p. 437-440.

OP-682. P. J. Modreski. Garnet; featured mineral group at the 1993 Tucson show. Rocks and Minerals. v. 68, no. 1, February 1993. p. 20-33.

OP-683. A. F. Moench. Convergent radial dispersion; a note on evaluation of the Laplace transform solution. Water Resources Research. v. 27, no. 12, December 1991. p. 3261-3264.

OP-684. A. F. Moench. Computation of type curves for flow to partially penetrating wells in water-table aquifers. Ground Water. v. 31, no. 6, December 1993. p. 966-971.

OP-685. D. W. Mogk*, P. A. Mueller*, J. L. Wooden and D. R. Bowes*. The northern Wyoming Province; contrasts in Archean crustal evolution. Proceedings of the International Con- ference on Basement Tectonics, in Basement tectonics 8; Characterization and comparison of ancient and Mesozoic continental margins. (M. J. Bartholomew, editor and others). 8, 1988. p. 283-297.

OP-686. B. F. Molnia. 1992; the geosciences in review; Research; highlights and trends in major fields; surficial studies; polar research. Geotimes. v. 38, no. 2, February 1993, p. 30-31.

OP-687. B. F. Molnia. Responsible science. GSA Today, v. 3, no. 1, January 1993. p. 7

OP.688. D, E. Moore and J. D. Byerlee. CALIFORNIA. Relationships between sliding behavior and internal geometry of laboratory fault zones and some creeping and locked strike-slip faults of California. Tectonophysics, in Earthquake source physics and earthquake precursors. (Takeshi Mikumo, editor and others). $v$, 211 , no. $1-4$, September 30,1992 . p. 305-316.

OP-689. D. E. Moore, R. Summers and J. D. Byerlee. Deformation of granite during triaxial friction tests, in Mechanics of jointed and faulted rock; proceedings of the international conference. (H. P. Rossmanith, editor). Rotterdam: A. A. Balkema, 1990. p. $345-352$.

OP-690. H. J. Moore, R. S. Saunders*, J. J. Plaut* and T. J. Parker*. Magellan stereo images and Venusian geology. LPI Contribution, in Papers presented to the international colloquium on Venus. (Lunar and Planetary Institute). 789, 1992. p. 71-72.

OP-691. J. E. Moore*, H. M. Haitjema* and ChesterZenone (editors). Proceedings of the USA/USSR joint conference on Environmental hydrology and hydrogeology. Hydrological Science and Technology. v, 7, no. 1-4, 1991. p. 35-270.

OP-692. J. E. Moore, R. A. Kanivetsky*, J. S. Rosenshein, Chester Zenone and S. C. Csallany*. First USA/USSR joint conference on Environmental hydrology and hydrogeology. Dubuque, IA: Kendall/Hunt Publ. Co. 1991. 440 p.

OP-693. J. G. Moore and R. K. Mark. HAWAII. Morphology of the Island of Hawaii. GSA Today. v. 2, no. 12, December 1992. p. 257-259, 262.

OP-694. J. G. Moore, W. R. Normark and C. E, Gutmacher. HAWAII. Major landslides on the submarine flanks of Mauna Loa Volcano, Hawaii. Landslide News. 6, August 1992. p. 13-16.

OP-695. T. A. Moore and R. E. Hilbert. Petrographic and anatomical characteristics of plant material from two peat deposits of Holocene and Miocene age, Kalimantan, Indonesia. Review of Palaeobotany and Palynology. v. 72, no. 3-4, July 7, 1992. p. 199-227.

OP-696. G. B. Morgan, VI*, I-Ming Chou, J. D. Pasteris" and S. N. Olsen*. Re-equilibration of $\mathrm{CO}_{2}$ fluid inclusions at controlled hydrogen fugacities. Journal of Metamorphic Geology. v. 11, no. 1, January 1993 . p. 155-164.

OP-697. L. A. Morgan. IDAHO, WYOMDNG. Stratigraphic relations and paleomagnetic and geochemical correlations of ignimbrites of the Heise volcanic field, eastern Snake River plain, eastern Idaho and western Wyoming. Memoir - Geological Society of America, in Regional geology of eastern Idaho and western Wyoming. (P. K. Link, editor and others), 179, 1992. p. 215226. 
OP-698. J. J. Mori. CALIFORNIA. Fault plane determinations for three small earthquakes along the San Jacinto Fault, California; search for cross faults. Journal of Geophysical Research, B, Solid Earth and Planets. v. 98, no. 10, October 10, 1993. p. 17,71117,722 .

OP-699. J. J. Mori, K. W. Hudnut*, L. M. Jones and Donna Eberhart-Phillips. CALIFORNIA. Rapid scientific response to the Landers earthquake, in Landers earthquake of June 28, 1992 , San Bernardino County, California; field trip guidebook. (G. S. Rasmussen, leader and others). October 10,1992. p. 15-18.

OP-700. J. J. Mori, K. W. Hudnut, L. M. Jones, Egill Hauksson* and L. K. Hutton*. CALIFORNIA. Rapid scientific response to Landers quake. Eos, Transactions, American Geophysical Union. v. 73 , no. 39, September 29, 1992. p. 417, 418.

OP-701. J. L. Morrison* and B. S. Ramey. Issues and trends of concern to the URISA membership; a thirty year survey of URISA's literature. Annual Conference Proceedings of the Urban and Regional Information Systems Association, in IS/GIS/LIS and public policies, plans, and programs; thirty years in perspective. (Barry Wellar and others). 1992, Vol. 5, 1992. p. 42-58.

OP-702. C. A. Morrow, B. Radney and J. D. Byerlee. Frictional strength and the effective pressure law of montmorillonite and illite clays, in Fault mechanics and transport properties of rocks; a festschrift in honor of W. F. Brace. (B. J. Evans, editor and others). San Diego, CA: Acad. Press, 1992. p. 69-88.

OP-703. D. M. Morton and J. C. Matti. CALIFORNIA. Extension and contraction within an evolving divergent strike-slip fault complex; the San Andreas and San Jacinto fault zones at their convergence in Southern California. Memoir - Geological Society of America, in The San Andreas fault system; displacement, palinspastic reconstruction, and geologic evolution. (R. E. Powell, editor and others). 178,1993 . p. 217-230.

OP-704. M. E. Moss. Hydrologic implications of climate uncertainty in the Western United States, in Managing water resources in the West under conditions of climate uncertainty. (U.S., Commission on Geosciences, Environment, and Resources, Committee on Climate Uncertainty and Water Resources Management, Water Science and Technology Board). Washington, DC: Natl. Acad. Press, 1991. p. 148-156.

OP-705. P. A. Mueller*, R. D. Shuster*, J. L. Wooden, E. A. Erslev* and D. R. Bowes*. MONTANÄ. Age and composition of Archean crystalline rocks from southern Madison Range, Montana; implications for crustal evolution in the Wyoming Craton; with Suppl. Data 9308. Geological Society of America Bulletin. v. 105, no. 4, April 1993. p. 437-446.

OP-706. D. R. Muhs. The last interglacial-glacial transition in North America; evidence from uranium-series dating of coastal deposits. Special Paper - Geological Society of America, in The last interglacial-glacial transition in North America. (P. U. Clark, editor and others). 270, 1992. p. 31-51.

OP-707. D. R. Muhs; T. K. Rockwell* and G. L. Kennedy*. OREGON, CALIFORNIA. Late Quaternary uplift rates of marine terraces on the Pacific coast of North America, southern Oregon to Baja California Sur. Quaternary International, in Impacts of tectonics on Quaternary coastal evolution. (Yoko Ota, editor and others). $15-16,1992$. p. 121-133.
OP-708. B. L. Murchey and D. L. Jones*. A mid-Permian chert event; widespread deposition of biogenic siliceous sediments in coastal, island arc and oceanic basins. Palaeogeography, Palaeoclimatology, Palaeoecology, in Significance and application of Radiolaria to terrane analysis. (J. Aitchison, editor and others). v. 96 , no. 1-2, October 6,1992. p. 161-174.

OP-709. Emiliano Mutti* and W. R. Normark. An integrated approach to the study of turbidite systems, in Seismic facies and sedimentary processes of submarine fans and turbidite systems. (Paul Weimer, editor and others), in the collection Frontiers in sedimentary geology. (A. H. Bouma, editor). New York, NY: Springer-Verlag, 1991. p. 75-106.

OP-710. Emiliano Mutti* and W. R. Normark. Comparing examples of modern and ancient turbidite systems; problems and concepts. Short Course Volume, in Deep-marine sedimentation; depositional models and case histories in hydrocarbon exploration \& development. (G. C. Brown, editor and others). 66, 1990. p. 153-198.

OP-711. D. L. Naftz, K. A. Miller and R. B. See. WYOMING. Using glacial ice cores from Wyoming as long-term records of atmospheric deposition quality and climate change; a progress report. Hydata News and Views. v. 10, no. 4, July 1991. p. 23-24.

OP-712. D. L. Naftz, J. A. Rice* and J. R. Ranville. WYOMING. Glacial ice composition; a potential long-term record of the chemistry of atmospheric deposition, Wind River Range, Wyoming. Water Resources Research. v. 27, no. 6, June 1991. p. 1231-1238.

OP-713. B. S. Nagy*, François Gauthier-Lafaye*, Philippe Holliger*, D. J. Mossman*, J. S. Leventhal and M. J. Rigali*. Role of organic matter in the Proterozoic Oklo natural fission reactors, Gabon, Africa. Geology (Boulder). v. 21, no. 7, July 1993. p. 655-658.

OP-714. B. S. Nagy*, J. S. Leventhal and R. I. Grauch (editors). Metalliferous black shales and related ore deposits. Precambrian Research. v. 61 , no. 3-4, March 1, 1993. p. 169-322.

OP-715. J. T. Nash and J. J. Connor. IDAHO. Iron and chlorine as guides to stratiform $\mathrm{Cu}-\mathrm{Co}$-Au deposits, Idaho cobalt belt, USA. Mineralium Deposita. v. 28, no. 2, April 1993. p. 99-106.

OP-716. J, T. Nash, W. C. Utterback* and J. A. Saunders*. NEVADA. Geology and geochemistry of the Sleeper gold deposits, Humboldt County, Nevada; an interim report, in Geology and ore deposits of the Great Basin; symposium proceedings. (G. L. Raines, editor and others). Reno, NV: Geological Society of Nevada, 1991. p. 1063-1084.

OP-717. K. C. Neff. The spatial data transfer standard (Fips 173); a management overview. GIS/LIS - Proceedings, Annual Conference and Exposition, in GIS/LIS '92 annual conference and exposition; proceedings. 1992, 1992. p. 614-617.

OP-718. A. R. Nelson. UTAH. The northern part of the Weber segment of the Wasatch fault zone near Ogden, Utah. Miscellaneous Publication (Utah Geological and Mineral Survey), in In the footsteps of G. K. Gilbert; Lake Bonneville and neotectonics of the eastern Basin and Range Province; guidebook for field trip twelve. (M. N. Machette, editor). Report no. 88-1, 1988. p. 33-37. 
OP-719. A. R. Nelson and W. F. Manley*. Holocene coseismic and aseismic uplift of Isla Mocha, south-central Chile. Quaternary International, in Impacts of tectonics on Quaternary coastal evolution. (Yoko Ota, editor and others). 15-16, 1992. p. 61-76.

OP-720. A. R. Nelson, Yoko Ota*, T. W. Stafford, Jr.*, Masatomo Umitsu*, Kaoru Kashima* and Yoshiaki Matsushima*. OREGON, WASHINGTON. High-precision accelerator-massspectrometer radiocarbon dating of buried tidal-marsh soils; an approach to estimating the frequency and coastal extent of subduction zone earthquakes in Oregon and Washington. NUREG/CP (United States, Nuclear Regulatory Commission), in Proceedings of the U.S. Nuclear Regulatory Commission Nineteenth water reactor safety information meeting. (A. J. Weiss, compiler). Report no. NUREG/CP-0119, April 1992. p. 463-478.

OP-721. B. K. Nelson*, S. W. Nelson and A. B. Till. ALASKA. Nd- and Sr-isotope evidence for Proterozoic and Paleozoic crustal evolution in the Brooks Range, northern Alaska. Journal of Geology. v. 101, no. 4, July 1993. p. 435-450.

OP-722. C. H. Nelson, Jesús Baraza* and Andrés Maldonado*. Mediterranean undercurrent sandy contourites, Gulf of Cadiz, Spain. Sedimentary Geology, in Contourites and bottom currents. (D. A. Stow, editor and others). v. 82, no. 1-4, January 1993. p. 103-131.

OP-723. C. H. Nelson, Andrés Maldonado*, J. H. Barber, Jr. and Belén Alonso*. Modern sand-rich and mud-rich siliciclastic aprons; alternative base-of-slope turbidite systems to submarine fans, in Seismic facies and sedimentary processes of submarine fans and turbidite systems. (Paul Weimer, editor and others), in the collection Frontiers in sedimentary geology. (A. H. Bouma, editor). New York, NY: Springer-Verlag, 1991. p. 171-190.

OP-724. P. H. Nelson. NEVADA. Geological and mineralogical controls on physical properties of tuffs at Yucca Mountain. The Log Analyst. v. 34, no. 1, February 1993. p. 58-68.

OP-725. K. D. Newell*, R. C. Burruss and J. G. Palacas. KANSAS. Thermal maturation and organic richness of potential petroleum source rocks in Proterozoic Rice Formation, North American Mid-Continent Rift System, northeastern Kansas. AAPG Bulletin. v. 77 , no. 11, November 1993. p. 1922-1941.

OP-726. C. G. Newhall and R. S. Punongbayan*. Help wanted. Nature (London). v. 364, no. 6438, August 12, 1993. p. 568.

OP-727. W. D. Nichols. The uncertainty of water budget estimates in the Great Basin. American Water Resources Association Technical Publication Series TPS, in American Water Resources Association 28th annual conference and symposium on Managing water resources during global change. (Raymond Herrmann, editor). 92-4, 1992. p. 309-317.

OP-728. S. W. Nicholson, W. F. Cannon and K. J. Schulz. Metallogeny of the Midcontinent Rift System of North America. Precambrian Research, in Precambrian metallogeny related to plate tectonics. (Gabor Gaal, editor and others). v. 58, no. 1-4, October 1992. p. 355-386.

OP-729. D. Nie*, E. T. Kanemasu*, L. J. Fritschen*, H. L. Weaver, E. A. Smith*, S. B. Verma*, R. T. Field*, W. P. Kustas* and J. B. Stewart*. KANSAS. An intercomparison of surface energy flux measurement systems used during FIFE 1987. Journal of Geophysical Research, D, Atmospheres, in First
ISLSCP field experiment (FIFE). (R. E. Murphy, prefacer). v. 97 , no. 17 , November 30, 1992. p. 18,715-18,724.

OP-730. J. E. Nielson, J. R. Budahn, D. M. Unruh and H. G. Wilshire. CALIFORNIA. Actualistic models of mantle metasomatism documented in a composite xenolith from Dish Hill, California. Geochimica et Cosmochimica Acta. v. 57, no. 1 , January 1993. p. 105-121.

OP-731. A. R. Niem, N. S. MacLéod, P. D. Snavely, Jr., David Huggins, J. D. Fortier, H. J. Meyer, Alan Seeling and W. A. Niem (compilers). OREGON. Onshore and offshore geologic cross section, northern Oregon coast range to continental slope. Special Paper - Oregon, Department of Geology and Mineral Industries. 26, 1992. $73 \mathrm{p}$.

OP-732. J. R. Nimmo. Semiempirical model of soil water hysteresis. Soil Science Society of America Journal. v. 56, no. 6, December 1992. p. 1723-1730.

OP-733. J. R. Nimmo, K. C. Akstin and K. A. Mello. Improved apparatus for measuring hydraulic conductivity at low water content. Soil Science Society of America Journal. v. 56, no. 6, December 1992. p. 1758-1761.

OP-734. S. P. Nishenko. Circum-Pacific seismic potential; 1989 1999. Pure and Applied Geophysics, in Aspects of Pacific seismicity. (E. A. Okal, editor). v. 135, no. 2, 1991. p. 169-259.

OP-735. S. P. Nishenko, L. R. Sykes*, D. D. Jackson* and Y. Y. Kagan*. Seismic gap hypothesis; ten years after; discussion and reply. Journal of Geophysical Research, B, Solid Earth and Planets. v. 98, no. 6, June 10, 1993. p. 9909-9920.

OP-736. D. C. Noble*, S. I. Weiss* and E. H. McKee. NEVADA. Magmatic and hydrothermal activity, caldera geology, and regional extension in the western part of the southwestern Nevada volcanic field, in Geology and ore deposits of the Great Basin; symposium proceedings. (G. L. Raines, editor and others). Reno, NV: Geological Society of Nevada, 1991. p. $913-$ 934.

OP-737. D. K. Nordstrom, R. H. McNutt*, Ignasi Puigdomenech*, J. A. Smellie* and M. Wolf*. Ground water chemistry and geochemical modeling of water-rock interactions at the Osamu Utsumi Mine and the Morro do Ferro analogue study sites, Pocos de Caldas, Minas Gerais, Brazil. Journal of Geochemical Exploration, in The Pocos de Caldas Project; natural analogues of processes in a radioactive waste repository, Part I. (N. A. Chapman, editor and others). v. 45, no. 1-3, November 1992. p. 249-287.

OP-738. W. R. Normark, H. W. Posamentier* and Emiliano Mutti*. Turbidite systems; state of the art and future directions. Reviews of Geophysics. v. 31, no. 2, May 1993. p. 91-116.

OP-739. E. B. Nuhfer*, R. Y. Anderson*, J. P. Bradbury and W. E. Dean. MINNESOTA. Modern sedimentation in Elk Lake, Clearwater County, Minnesota. Special Paper - Geological Society of America, in Elk Lake, Minnesota; evidence for rapid climate change in the north-central United States. (J. P. Bradbury, editor and others). 276, 1993. p. 75-96.

OP-740. A. M. Nur* and J. S. Walder. Hydraulic pulses in the Earth's crust, in Fault mechanics and transport properties of rocks; a festschrift in honor of W. F. Brace. (B. J. Evans, editor and others). San Diego, CA: Acad. Press, 1992. p, 461-474. 
OP-741. C. J. Nutt, C. H. Thorman*, D. R. Zimbelman* and R. W. Gloyn*. UTAH. Geologic setting and trace-element geochemistry of the Detroit mining district and Drum gold mine, Drum Mountains, west-central Utah, in Geology and ore deposits of the Great Basin; symposium proceedings. (G. L. Raines, editor and others). Reno, NV: Geological Society of Nevada, 1991. p. 491509.

OP-742. D. J. Nyman, J. N. Beck*, G. N. Rao* and H. E. Murray*. LOUISIANA. The Sabine River diversion canal and groundwater conservation in Calcasieu Parish, Louisiana. American Water Resources Association Technical Publication Series TPS, in Resource development of the Lower Mississippi River; symposium papers. (Dhamo Dhamotharau, editor). 27, 1991. p. 253-259.

OP-743. S. B. O'Connell*, W. B. Ryan* and W. R. Normark. Evolution of a fan channel on the surface of the outer Mississippi Fan; evidence from side-looking sonar, in Seismic facies and sedimentary processes of submarine fans and turbidite systems. (Paul Weimer, editor and others), in the collection Frontiers in sedimentary geology. (A. H. Bouma, editor). New York, NY: Springer-Verlag, 1991. p. 365-381.

OP-744. D. W. O'Leary. Structure and morphology of submarine slab slides; clues to origin and behavior. Marine Geotechnology. v. 10, no. 1-2, June 1991. p. 53-69.

OP-745. W. T. Oakley. MISSISSIPPI. Ground-water information data base for Mississippi maintained by the U.S. Geological Survey. Proceedings - Mississippi Water Resources Conference, in Twenty-second Mississippi water resources conference. (B. J. Daniel, editor). 22, 1992. p. 122-127.

OP-746. J. D. Obradovich, D. T. Dockery, III* and C. C. Swisher, III*. MISSISSIPPI. ${ }^{40} \mathrm{Ar}-{ }^{39} \mathrm{Ar}$ ages of bentonite beds in the upper part of the Yazoo Formation (upper Eocene) west-central Mississippi. Mississippi Geology. v. 14, no. 1, March 1993. p. $1-9$.

OP-747. J. G. Ogg*, S. M. Karl and R. J. Behl*. Jurassic through Early Cretaceous sedimentation history of the Central Equatorial Pacific and of sites 800 and 801 . Proceedings of the Ocean Drilling Program, Scientific Results, in Proceedings of the Ocean Drilling Program; scientific results; old Pacific crust; covering Leg 129 of the cruises of the drilling vessel JOIDES Resolution, Apra Harbor, Guam, to Apra Harbor, Guam, sites 800-802, 20 November 1989-18 January 1990. (R. L. Larson and others). 129, 1990. p. 571-613.

OP-748. R. N. Oldale and S. M. Colman. On the age of the penultimate full glaciation of New England. Special Paper - Geological Society of America, in The last interglacial-glacial transition in North America. (P. U. Clark, editor and others). 270, 1992. p. $163-170$.

OP-749. R. N. Oldale, S. M. Colman* and G. A. Jones*. MASSACHUSETTS. Radiocarbon ages from two submerged strandline features in the western Gulf of Maine and a sea-level curve for the northeastern Massachusetts coastal region. Quaternary Research (New York). v. 40, no. 1, July 1993. p. 38-45.

OP-750. N. H. Oliver*, T. C. Hoering*, T. W. Johnson, Douglas Rumble, III* and W. C. Shanks, III. MAINE. Sulfur isotopic disequilibrium and fluid-rock interaction during metamorphism of sulfidic black shales from the Waterville-Augusta area, Maine,
USA. Geochimica et Cosmochimica Acta. v. 56, no. 12, December 1992. p. 4257-4265.

OP-751. Joan Oltman-Shay* and P. A. Howd. Edge waves on nonplanar bathymetry and alongshore currents; a model and data comparison. Journal of Geophysical Research, C, Oceans. v. 98, no. 2, February 15,1993 . p. $2495-2507$.

OP-752. D. H. Oppenheimer, G. C. Beroza*, G. A. Carver*, L. A. Dengler*, J. P. Eaton, L. Gee*, F. I. Gonzalez*, A. S. Jayko, W. H. Li*, Michael Lisowski, M. E. Magee*, G. A. Marshall, M. H. Murray, R. McPherson*, Barbara Romanowicz*, K. Satake*, R. W. Simpson, P. G. Somerville*, R. S. Stein and D. W. Valentine*. CALIFORNIA. The Cape Mendocino, California, earthquakes of April 1992; subduction at the triple junction. Science. v. 261 , no. 5120 , July 23 , 1993. p. $433-438$.

OP-753. S.S. Oriel. IDAHO, WYOMING. The Idaho-Wyoming salient of the North-American Cordilleran foreland thrust belt. Bulletin de la Société Géologique de France, Huitième Série, in Géologie des cordillères Nord-Américaines; Première partie; Artique et Canada, Etats-Unis; overthrust belt et avant pays; Séance spécialisée de la Société Géologique de France (Geology of the North American Cordilleras; First part; Arctic and Canada, United States; overthrust belt and foreland; special session of the Geological Society of France). (François Roure, chairperson). v. 2, no. 5, October 1986. p. 755-765.

OP-754. L. A. Orlowski*, W. D. Grundy, P. W. Mielke, Jr.* and S. A. Schumm*. Geological applications of multi-response permutation procedures. Mathematical Geology. v. 25, no. 4, May 1993. p. 483-500.

OP-755. C. J. Orth*, Moses Attrep, Jr.*, L. R. Quintana*, W. P. Elder, E. G. Kauffman*, Richard Diner* and Tomas Villamil*. Elemental abundance anomalies in the late Cenomanian extinction interval; a search for the source(s). Earth and Planetary Science Letters. v. 117, no. 1-2, May 1993. p. 189-204.

OP-756. Yoko Ota*, A. R. Nelson and K. R. Berryman* (editors). Impacts of tectonics on Quaternary coastal evolution. Quaternary International. $15-16,1992.184 \mathrm{p}$.

OP-757. J. P. Owens. Problems in regional stratigraphic correlation of the Paleogene deposits of the Atlantic Coastal Plain. Proceedings of the Bald Head Island Conference on Coastal Plains Geology, in Proceedings of the Second Bald Head Island conference on coastal plains geology; Savannah River region; transition between the Gulf and Atlantic coastal plains. (V. A. Zullo, editor and others). 2, May 1992. p. 25-28.

OP-758. J. B. Paces and J. D. Miller, Jr.*. MINNESOTA. Precise $\mathrm{U}-\mathrm{Pb}$ ages of Duluth Complex and related mafic intrusions, northeastern Minnesota; geochronological insights to physical, petrogenetic, paleomagnetic, and tectonomagnetic processes associated with the $1.1 \mathrm{Ga}$ Midcontinent Rift System. Journal of Geophysical Research, B, Solid Earth and Planets. v. 98, no. 8, August 10, 1993. p. 13,997-14,013.

OP-759. B. M. Page* and T. M. Brocher. CALIFORNIA. Thrusting of the Central California margin over the edge of the Pacific Plate during the transform regime. Geology (Boulder). v. 21, no. 7, July 1993. p. 635-638. 
OP-760. F. L. Paillet. Graphical overlay applications in geotechnical log analysis. International Symposium on Borehole Geophysics for Minerals, Geotechnical, and Groundwater Applications, in Borehole geophysics for minerals, geotechnical and groundwater applications. (P. G. Killeen, prefacer). 4, August 1991. p. 249-264.

OP-761. F. L. Paillet, R. T. Kay*, D. Yeskis* and W. H. Pedler*. Integrating well logs into a multiple-scale investigation of a fractured sedimentary aquifer. The Log Analyst. v. 34, no. 1, February 1993. p. 24-40.

OP-762. C. A. Palmer and R. H. Filby*. Determination of mode of occurrence of trace elements in the upper Freeport coal bed using size and density separation procedures, in 1983 international conference on Coal science; proceedings. (S. W. Chun, president). Int. Energy Agency, 1983. p. 365-368.

OP-763. M. R. Palmer* and J. F. Slack. Boron isotopic composition of tourmaline from massive sulfide deposits and tourmalinites. Contributions to Mineralogy and Petrology. v. 103, no. 4, 1989. p. 434-451.

OP-764. Daniela Pantosti*, D. P. Schwartz and Gianluca Valensise*. Paleoseismology along the 1980 surface rupture of the Irpinia Fault; implications for earthquake recurrence in the Southern Apennines, Italy. Journal of Geophysical Research, B, Solid Earth and Planets. v. 98 , no. 4, April 10, 1993. p. 6561-6577.

OP-765. K. G. Papke. NEVADA. Industrial mineral deposits of Nevada. Map-Nevada Bureau of Mines and Geology. Report no. 46, 1973. 1 sheet.

OP-766. S. K. Park*, M. J. Johnston, T. R. Madden*, F. D. Morgan* and H. F. Morrison*. Electromagnetic precursors to earthquakes in the ULF band; a review of observations and mechanisms. Reviews of Geophysics. v. 31, no. 2, May 1993. p. 117-132.

OP-767. W. S. Parks. TENNESSEE. Four levels of terrace deposits and remnants of high-level fluvial deposits in the Hatchie River valley, Hebron area, Hardeman County, Tennessee. Mississippi Geology. v. 13, no. 4, December 1992. p. 63-70.

OP-768. M. Parrot* and M. J. Johnston (editors). Seismo-electromagnetic effects. Physics of the Earth and Planetary Interiors. v. 77, no. 1-2, April 1993. p. 1-141.

OP-769. Tom Parsons and G. A. Thompson*. Does magmatism influence low-angle normal faulting?: Reply. Geology (Boulder). v. 21, no. 10, October 1993. p. 957-958.

OP-770. M. P. Pasternak*, R. D. Taylor*, Raymond Jeanloz* and S. R. Bohlen. Magnetic ordering transition in $\mathrm{Mg}_{0.9} \mathrm{Fe}_{0.1} \mathrm{SiO}_{3}$ orthopyroxene. American Mineralogist. v. 77, no. 9-10, October 1992. p. 901-903.

OP-771. D. L. Peck. USGS and NPS; science partners in the parks. Park Science. v. 13, no. 1, 1993. p. 1.

OP-772. C. A. Perry. A correlation between precipitation in the Western United States and solar-irradiance variations. American Water Resources Association Technical Publication Series TPS, in American Water Resources Association 28th annual conference and symposium on Managing water resources during global change. (Raymond Herrmann; editor). 92-4, 1992. p. 721-729.
OP-773. S. F. Personius. UTAH. A brief summary of the surficial geology along the Brigham City segment of the Wasatch fault zone, Utah. Miscellaneous Publication (Utah Geological and Mineral Survey), in In the footsteps of G. K. Gilbert; Lake Bonneville and neotectonics of the eastern Basin and Range Province; guidebook for field trip twelve. (M. N. Machette, editor). Report no. 88-1, 1988. p. 27-32.

OP-774. Z. E. Peterman, J. S. Stuckless, S. A. Mahan, B. D. Marshall, E. D. Gutentag and J. S. Downey. NEVADA. Strontium isotope characterization of the Ash Meadows groundwater system, southern Nevada, USA. Proceedings - International Symposium on Water-Rock Interaction. 7, 1992. p. 825-829.

OP-775. C. A. Peters, J. D. Higgin, P. A. Burger* and I. C. Yang*. A preliminary study of the chemistry of pore water extracted from tuff by one-dimensional compression. Proceedings International Symposium on Water-Rock Interaction. 7, 1992. p. 741-745.

OP-776. N. E. Peters. NEW YORK. Chloride cycling in two forested lake watersheds in the west-central Adirondack Mountains, New York, U.S.A. Water, Air and Soil Pollution. v. 59, no. 1-2, 1991. p. 201-215.

OP-777. P. J. Phillips and R. J. Shedlock. DELAWARE. Hydrology and chemistry of groundwater and seasonal ponds in the Atlantic Coastal Plain in Delaware, USA. Journal of Hydrology, in Hydrogeology of wetlands. (T. C. Winter, editor and others). v. 141 , no. $1-4$, January 1993 . p. 157-178.

OP-778. B. S. Pierce, R. W. Stanton and C. F. Eble*. WEST VIRGINIA. Comparison of the petrography, palynology and paleobotany of the Stockton coal bed, West Virginia and implications for paleoenvironmental interpretations. Organic Geochemistry, in Collected papers from the Eighth annual meeting of the Society for Organic Petrology. (J. C. Hower, editor and others). v. 20, no. 2, February 1993. p. 149-166.

OP-779. H. A. Pierce and D. B. Hoover. NEVADA. Airborne electromagnetic applications; mapping structure and electrical boundaries beneath cover along the Getchell Trend, Nevada, in Geology and ore deposits of the Great Basin; symposium proceedings. (G. L. Raines, editor and others). Reno, NV: Geological Society of Nevada, 1991. p. 771-780.

OP-780. K. L. Pierce and L. A. Morgan. The track of the Yellowstone hot spot; volcanism, faulting, and uplift. Memoir - Geological Society of America, in Regional geology of eastern Idaho and western Wyoming. (P. K. Link, editor and others). 179, 1992. p. $1-53$.

OP-781. T. C. Pierson. Rainfall-triggered lahars at Mt. Pinatubo, Philippines, following the June 1991 eruption. Landslide News. 6, August 1992. p. 6-9.

OP-782. T. C. Pierson, R. M. Iverson and S. D. Ellen. HAWAII. Spatial and temporal distribution of shallow landsliding during intense rainfall, southeastern Oahu, Hawaii. Proceedings of the International Symposium on Landslides $=$ Comptes Rendus dụ Symposium International sur les Glissements de Terrain, in Landslides; proceedings of the sixth international symposium. (D. H. Bell, editor). 6, 1992. p. 1393-1398.

OP-783. C. M. Pieters*, J. W. Head*, J. M. Sunshine*, E. M. Fischer*, S. L. Murchie*, M. J. Belton*, A. S. McEwen, L. 
R. Gaddis, Ronald Greeley*, Gerhard Neukum*, R. Jaumann* and Harald Hoffmann*. Crustal diversity of the Moon; compositional analyses of Galileo solid state imaging data. Journal of Geophysical Research, E, Planets, in Special section on Galileo Earth/Moon encounter. v. 98, no. 9, September 25, 1993. p. $17,127-17,148$.

OP-784. J. A. Pitkin. NEVADA. Radioelement data of the Getchell Trend, Humboldt County, Nevada; geologic discussion and possible significance for gold exploration, in Geology and ore deposits of the Great Basin; symposium proceedings. (G. L. Raines, editor and others). Reno, NV: Geological Society of Nevada, 1991. p. 759-770.

OP-785. George Plafker and S. N. Ward*. Backarc thrust faulting and tectonic uplift along the Caribbean Sea coast during the April 22, 1991 Costa Rica earthquake. Tectonics. v. 11, no. 4, August 1992. p. 709-718.

OP-786. J. J. Plaut*, R. S. Saunders*, E. R. Stofan*, R. L. Kirk, G. G. Schaber, L. A. Soderblom, P. G. Ford*, G. H. Pettengill*, D. B. Campbell*, N. J. Stacy*, R. E. Arvidson* and Ronald Greeley*. Anomalous scattering behavior of selected impact "parabola" features; Magellan cycle-to-cycle comparisons. LPI Contribution, in Papers presented to the international colloquium on Venus. (Lunar and Planetary Institute). 789, 1992. p. 92-93.

OP-787. I. R. Plimer*, J. F. Slack, W. W. Gardiner*, D. V. Venugopal* and D. E. Large*. Metallogenesis around the world. Institution of Mining and Metallurgy, Transactions, Section B: Applied Earth Sciences, in Mineral deposit modelling in relation to crustal reservoirs of the ore-forming elements. (M. J. Gallagher, chairperson). 101, December 1992. p. 165-166.

OP-788. G. S. Plumlee, K. S. Smith, W. H. Ficklin and P. H. Briggs. Geological and geochemical controls on the composition of mine drainages and natural drainages in mineralized areas. Proceedings - International Symposium on Water-Rock Interaction. 7, 1992. p. 419-422.

OP-789. L. N. Plummer. Approach to equilibrium in solid solution-aqueous solution systems; the $\mathrm{KCl}-\mathrm{KBr}-\mathrm{H}_{2} \mathrm{O}$ system at $25^{\circ} \mathrm{C}$. ACS Symposium Series, in Geochemical processes at mineral surfaces. (J. A. Davis, editor and others). 323, 1986. p. 561573.

OP-790. L. N. Plummer, E. C. Prestemon and D. L. Parkhurst. NETPATH; an interactive code for interpreting NET geochemical reactions from chemical and isotopic data along a flow PATH. Proceedings - International Symposium on Water-Rock Interaction. 7, 1992. p. 239-242.

OP-791. C. W. Poag, L. J. Poppe, D. W. Folger, D. S. Powars, R. B. Mixon, L. E. Edwards and Scott Bruce*. Deep Sea Drilling Project Site 612 bolide event; new evidence of a late Eocene impact-wave deposit and a possible impact site, U.S. east coast: Reply. Geology (Boulder). v. 21, no. 5, May 1993. p. 478-479.

OP-792. John Pojeta, Jr. Fossils, U.S. Geological Survey and the public lands. Park Science. v. 13, no. 1, 1993. p. 15.

OP-793. R. M. Pollastro. Considerations and applications of the illite/smectite geothermometer in hydrocarbon-bearing rocks of
Miocene to Mississippian age. Clays and Clay Minerals. v. 41, no. 2, April 1993. p. 119-133.

OP-794. R. M. Pollastro and B. F. Bohor. Origin and clay-mineral genesis of the Cretaceous-Tertiary boundary unit, Western Interior of North America. Clays and Clay Minerals. v. 41, no. 1, February 1993. p. 7-25.

OP-795. D. A. Ponce. NEVADA. Gravity and magnetic anomalies in the Ely Quadrangle, Nevada, and anomalies related to granitic plutons, in Geology and ore deposits of the Great Basin; symposium proceedings. (G. L. Raines, editor and others). Reno, NV: Geological Society of Nevada, 1991. p. 103-106.

OP-796. F. G. Poole, R. J. Madrid* and J. F. Oliva-Becerril*. Geological setting and origin of stratiform barite in central Sonora, Mexico, in Geology and ore deposits of the Great Basin; symposium proceedings. (G. L. Raines, editor and others). Reno, NV: Geological Society of Nevada, 1991. p. 517-522.

OP-797. F. G. Poole, J. H. Stewart, A. R. Palmer*, C. A. Sandberg, R. J. Madrid*, R. J. Ross, Jr.*, L. F. Hintze*, M. M. Miller* and C. T. Wrucke. Latest Precambrian to latest Devonian time; development of a continental margin, in The Cordilleran Orogen; conterminous U.S. (B. C. Burchfiel, editor and others), in the collection The geology of North America. Geol. Soc. Am. G-3, 1992. p. 9-56.

OP-798. R. Z. Poore. Editorial. Paleoceanography. v. 8, no. 2, April 1993. p. 135-136.

OP-799. R. Z. Poore, R. L. Phillips and H. J. Rieck. Paleoclimate record for Northwind Ridge, western Arctic Ocean. Paleoceanography. v. 8, no. 2, April 1993. p. 149-159.

OP-800. L. J. Poppe and A. M. Moffett*. MASSACHUSETTS. Ground water discharge and the related nutrient and trace metal fluxes into Quincy Bay, Massachusetts. Environmental Monitoring and Assessment. v. 25, no. 1,1993. p. 15-27.

OP-801. L. J. Poppe and C. W. Poag. Mesozoic stratigraphy and paleoenvironments of the Georges Bank basin; a correlation of exploratory and COST wells. Marine Geology. v. 113, no. 3-4, August 1993. p. 147-162.

OP-802. R. E. Powell. Foreword. Memoir - Geological Society of America, in The San Andreas fault system; displacement, palinspastic reconstruction, and geologic evolution. (R. E. Powell, editor and others). 178, 1993. p. vii-xix.

OP-803. R. E. Powell. CALIFORNIA. Balanced palinspastic reconstruction of pre-late Cenozoic paleogeology, Southern California; geologic and kinematic constraints on evolution of the San Andreas fault system. Memoir - Geological Society of America, in The San Andreas fault system; displacement, palinspastic reconstruction, and geologic evolution. (R. E. Powell, editor and others). 178,1993 . p. 1-106.

OP-804. R. E. Powell, R. J. Weldon, II* and J. C. Matti (editors). CALIFORNIA. The San Andreas fault system; displacement, palinspastic reconstruction, and geologic evolution. Memoir - Geological Society of America. 178, 1993. 332 p.

OP-805. W. R. Premo and Mitsunobu Tatsumoto. Isotopic ages and characteristics of ancient (pre-Serenitatis) crustal rocks at Apollo 17. LPI Technical Report, in Workshop on Geology of the 
Apollo 17 landing site. (Graham Ryder, editor and others). 92-09, Part 1, 1992. p. 45-48.

OP-806. W. R. Premo and Mitsunobu Tatsumoto. U-Th-Pb, Rb$\mathrm{Sr}$, and $\mathrm{Sm}-\mathrm{Nd}$ isotopic systematics of lunar troctolitic cumulate 76535; implications on the age and origin of this early lunar, deep-seated cumulate. Proceedings of the Lunar and Planetary Science Conference, in Proceedings of Lunar and planetary science. (Graham Ryder, editor and others). 22, 1992. p. 381-397.

OP-807. S. E. Prensky (compiler). Bibliography of well-log applications. The Log Analyst. v. 33, no. 6, December 1992. p. 520-558.

OP-808. C. S. Prentice, Paul Mann*, F. W. Taylor*, G. Burr* and S. Valastro*. Paleoseismicity of the North American-Caribbean plate boundary (Septentrional Fault), Dominican Republic. Geology (Boulder). v. 21, no. 1, January 1993. p. 49-52.

OP-809. J. G. Price*, S. B. Castor* and D. M. Miller. NEVADA. Highly radioactive topaz rhyolites of the Toano Range, northeastern Nevada. American Mineralogist. v. 77, no. 9-10, October 1992. p. 1067-1073.

OP-810. L. C. Price. Thermal stability of hydrocarbons in nature; limits, evidence, characteristics, and possible controls. Geochimica et Cosmochimica Acta, in Survivability of organic matter at high temperatures; implications for life. (S. A. Macko, editor and others). v. 57, no. 14, July 1993. p. 3261-3280.

OP-811. K. R. Prince and A. I. Johnson* (editors). Regional aquifer systems of the United States; aquifers of the Far West. AWRA Monograph Series. 16, June 1991. 127 p.

OP-812. C. M. Pringle*, G. L. Rowe*, F. J. Triska, J. F. Fernandez* and John West*. Landscape linkages between geothermal activity and solute composition and ecological response in surface water draining the Atlantic slope of Costa Rica. Limnology and Oceanography. v. 38, no. 4, June 1993. p. 753-774.

OP-813. M. S. Pringle. Radiometric ages of basaltic basement recovered at Sites 800, 801, and 802, Leg 129, western Pacific Ocean. Proceedings of the Ocean Drilling Program, Scientific Results, in Proceedings of the Ocean Drilling Program; scientific results; old Pacific crust; covering Leg 129 of the cruises of the drilling vessel JOIDES Resolution, Apra Harbor, Guam, to Apra Harbor, Guam, sites 800-802, 20 November 1989-18 January 1990. (R. L. Larson and others). 129,1990 . p. $389-401$.

OP-814. J. E. Quick and R. P. Denlinger. The possible role of ductile deformation in the formation of layered gabbros in ophiolites. Ofioliti. v. 17 , no. 2,1992 . p. 249-253.

OP-815. J. E. Quick and R. P. Denlinger. Ductile deformation and the origin of layered gabbro in ophiolites. Journal of Geophysical Research, B, Solid Earth and Planets. v. 98, no. 8, August 10,1993 . p. $14,015-14,027$.

OP-816. S. E. Ragone, M. R. Burkart, E. M. Thurman and C. A. Perry. Planned studies of agrichemicals in ground and surface water in the Mid-continental United States, in Agrichemicals and groundwater protection; resources and strategies for state and local management. Navarre, MN: Freshwater Found. 1989. p. 99111.

OP-817. G. L. Raines, R. E. Lisle*, R. W. Schafer* and W. H. Wilkinson* (editors). Geology and ore deposits of the Great
Basin; symposium proceedings. Reno, NV: Geological Society of Nevada, 1991. $1251 \mathrm{p}$.

OP-818. B. S. Ramey. U.S. Geological Survey National Mapping Program; digital mapmaking procedures for the 1990s. Photogrammetric Engineering and Remote Sensing, in U.S. National Report. (Stan Morain, editor). v. 58, no. 8, August 1992. p. 1113-1116.

OP-819. Claude Rangin*, E. A. Silver*, M. T. von Breymann*, Ulrich Berner*, Philippe Bertrand*, C. G. Betzler*, G. W. Brass*, Vindell Hsü*, Zehui Huang*, R. D. Jarrard*, S. D. Lewis, B. K. Linsley*, D. L. Merrill*, Carla Müller*, Alexandra Nederbragt*, G. J. Nichols*, Manuel Pubellier*, F. G. Sajona*, R. P. Scherer*, D. D. Sheu*, Hidetoshi Shibuya*, JihPing Shyu*, R. B. Smith*, Terence Smith*, R. U. Solidum*, Piera Spadea* and D. D. Tannant*. Site 771. Proceedings of the Ocean Drilling Program, Part A: Initial Reports, in Proceedings of the Ocean Drilling Program, Celebes and Sulu Seas, covering Leg 124 of the cruises of the drilling vessel JOIDES Resolution, Singapore, Republic of Sing., to Manila, Philippines, Sites 767771, 1 November 1988-4 January 1989. (Claude Rangin and others). 124, May 1990. p. 399-413.

OP-820. Claude Rangin*, E. A. Silver*, M. T. von Breymann*, Ulrich Berner*, Philippe Bertrand*, C. G. Betzler*, G. W. Brass*, Vindell Hsü*, Zehui Huang*, R. D. Jarrard*, S. D. Lewis, B. K. Linsley*, D. L. Merrill*, Carla Müller*, Alexandra Nederbragt*, G. J. Nichols*, Manuel Pubellier*, F. G. Sajona*, R. P. Scherer*, D. D. Sheu*, Hidetoshi Shibuya*, JihPing Shyu*, R. B. Smith*, Terence Smith*, R. U. Solidum*, Piera Spadea* and D. D. Tannant*. Site 769. Proceedings of the Ocean Drilling Program, Part A: Initial Reports, in Proceedings of the Ocean Drilling Program, Celebes and Sulu Seas, covering Leg 124 of the cruises of the drilling vessel JOIDES Resolution, Singapore, Republic of Sing., to Manila, Philippines, Sites 767 771, 1 November 1988-4 January 1989. (Claude Rangin and others). 124, May 1990. p. 299-342.

OP-821. Claude Rangin*, E. A. Silver*, M. T. von Breymann*, Ulrich Berner*, Philippe Bertrand*, C. G. Betzler*, G. W. Brass*, Vindell Hsï*, Zehui Huang*, R. D. Jarrard*, S. D. Lewis, B. K. Linsley*, D. L. Merrill*, Carla Müller*, Alexandra Nederbragt*, G. J. Nichols*, Manuel Pubellier*, F. G. Sajona*, R. P. Scherer*, D. D. Sheu*, Hidetoshi Shibuya*, JihPing Shyu*, R. B. Smith*, Terence Smith*, R. U. Solidum*, Piera Spadea* and D. D. Tannant*. Site 770. Proceedings of the Ocean Drilling Program, Part A: Initial Reports, in Proceedings of the Ocean Drilling Program, Celebes and Sulu Seas, covering Leg 124 of the cruises of the drilling vessel JOIDES Resolution, Singapore, Republic of Sing., to Manila, Philippines, Sites 767771, 1 November 1988-4 January 1989. (Claude Rangin and others). 124, May 1990. p. 343-397.

OP-822. Claude Rangin*, E. A. Silver*, M. T. von Breymann*, Ulrich Berner*, Philippe Bertrand*, C. G. Betzler*, G. W. Brass*, Vindell Hsü*, Zehui Huang*, R. D. Jarrard*, S. D. Lewis, B. K. Linsley*, D. L. Merrill*, Carla Müller*, Alexandra Nederbragt*, G. J. Nichols*, Manuel Pubellier*, F. G. Sajona*, R. P. Scherer*, D. D. Sheu*, Hidetoshi Shibuya*, JihPing Shyu*, R. B. Smith*, Terence Smith*, R. U. Solidum*, Piera Spadea* and D. D. Tannant*. Site 768. Proceedings of the Ocean Drilling Program, Part A: Initial Reports, in Proceedings of the Ocean Drilling Program, Celebes and Sulu Seas, covering Leg 
124 of the cruises of the drilling vessel JOIDES Resolution, Singapore, Republic of Sing., to Manila, Philippines, Sites $767-$ 771, 1 November 1988-4 January 1989. (Claude Rangin and others). 124, May 1990. p. 195-297.

OP-823. Claude Rangin*, E. A. Silver*, M. T. von Breymann*, Ulrich Berner*, Philippe Bertrand*, C. G. Betzler*, G. W. Brass*, Vindell Hsü*, Zehui Huang*, R. D. Jarrard*, S. D. Lewis, B. K. Linsley*, D. L. Merrill*, Carla Müller*, Alexandra Nederbragt*, G. J. Nichols*, Manuel Pubellier*, F. G. Sajona*, R. P. Scherer*, D. D. Sheu*, Hidetoshi Shibuya*, JihPing Shyu*, R. B. Smith*, Terence Smith*, R. U. Solidum*, Piera Spadea* and D. D. Tannant*. Summary of shipboard results. Proceedings of the Ocean Drilling Program, Part A: Initial Reports, in Proceedings of the Ocean Drilling Program, Celebes and Sulu Seas, covering Leg 124 of the cruises of the drilling vessel JOIDES Resolution, Singapore, Republic of Sing., to Manila, Philippines, Sites 767-771, 1 November 1988-4 January 1989. (Claude Rangin and others). 124, May 1990. p. 415-419.

OP-824. Claude Rangin*, E. A. Silver*, M. T. von Breymann*, Ulrich Berner*, Philippe Bertrand*, C. G. Betzler*, G. W. Brass*, Vindell Hsü*, Zehui Huang*, R. D. Jarrard*, S. D. Lewis, B. K. Linsley*, D. L. Merrill*, Carla Müller*, Alexandra Nederbragt*, G. J. Nichols*, Manuel Pubellier*, F. G. Sajona*, R. P. Scherer*, D. D. Sheu*, Hidetoshi Shibuya*, JihPing Shyu*, R. B. Smith*, Terence Smith*, R. U. Solidum*, Piera Spadea* and D. D. Tannant*. Explanatory notes. Proceedings of the Ocean Drilling Program, Part A: Initial Reports, in Proceedings of the Ocean Drilling Program, Celebes and Sulu Seas, covering Leg 124 of the cruises of the drilling vessel JOIDES Resolution, Singapore, Republic of Sing., to Manila, Philippines, Sites 767-771, 1 November 1988-4 January 1989. (Claude Rangin and others). 124, May 1990. p. 7-37.

OP-825. Claude Rangin*, E. A. Silver*, M. T. von Breymann*, Ulrich Berner*, Philippe Bertrand*, C. G. Betzler*, G. W. Brass*, Vindell Hsü*, Zehui Huang*, R. D. Jarrard*, S. D. Lewis, B. K. Linsley*, D. L. Merrill*, Carla Müller*, Alexandra Nederbragt*, G. J. Nichols*, Manuel Pubellier*, F. G. Sajona*, R. P. Scherer*, D. D. Sheu*, Hidetoshi Shibuya*, JihPing Shyu*, R. B. Smith*, Terence Smith*, R. U. Solidum*, Piera Spadea* and D. D. Tannant*. General introduction. Proceedings of the Ocean Drilling Program, Part A: Initial Reports, in Proceedings of the Ocean Drilling Program, Celebes and Sulu Seas, covering Leg 124 of the cruises of the drilling vessel JOIDES Resolution, Singapore, Republic of Sing., to Manila, Philippines, Sites 767-771, 1 November 1988-4 January 1989. (Claude Rangin and others). 124, May 1990. p. 5-6.

OP-826. B. L. Reed, M. A. Lanphere and T. P. Miller. ALASKA. Double Glacier Volcano, a "new" Quaternary volcano in the eastern Aleutian volcanic arc. Bulletin of Volcanology. $v$. 54, no. 8, December 1992. p. 631-637.

OP-827. J. C. Reed, Jr. COLORADO. Precambrian rocks in Tenmile Canyon. Colorado School of Mines Quarterly. v. 93, no. 1, 1993. p. 31-33.

OP-828. J. C. Reed, Jr., B. H. Bryant and P. K. Sims. COLORADO. Geology and mineral resources of central Colorado. Colorado School of Mines Quarterly. v. 93, no. 1, 1993. p. 7-15.

OP-829. M. H. Reed* and G. S. Plumlee. Collapse of acid waters into boiling hydrothermal system and the origin of late stage pyrite and related kaolinite. Proceedings - International Symposium on Water-Rock Interaction, in Proceedings of the 7th international symposium on Water-rock interaction; Volume 2, Moderate and high temperature environments. (Y. K. Kharaka, editor and others). 7, 1992. p. 1083-1086.

OP-830. C. L. Regan. International exchanges of publications; the U.S. Geological Survey Library system's perspective. Proceedings - Geoscience Information Society, in International initiatives in geoscience information; a global perspective; proceedings of the twenty-sixth meeting of the Geoscience Information Society. (Dena Fracolli, editor). 22, 1992. p. 63-73.

OP-831. M. C. Reheis, J. L. Slate*, A. M. Sarna-Wojcicki and C. E. Meyer. NEVADA, CALIFORNIA. A late Pliocene to middle Pleistocene pluvial lake in Fish Lake valley, Nevada and California; with Suppl. Data 9318. Geological Society of America Bulletin. v. 105, no. 7, July 1993. p. 953-967.

OP-832. T. E. Reilly and Jacob Gibs. Effects of physical and chemical heterogeneity on water-quality samples obtained from wells. Ground Water. v. 31, no. 5, October 1993. p. 805-813.

OP-833. G. M. Reimer. Methodology for rapid assessment of the radon potential of soils. Journal of Radioanalytical and Nuclear Chemistry, in Proceedings of the Second international conference on Methods and applications of radioanalytical chemistry; Part 4. v. 161, no. 2, August 1992. p. 377-387.

OP-834. G. M. Reimer and A. A. Roberts*. Correcting soil-gas helium concentrations for diurnal variations. Bulletin (Association of Petroleum Geochemical Explorationists). v. 1, no. 1, December 1985. p. 1-17.

OP-835. Erk Reimnitz, P. W. Barnes and W. S. Weber. Particulate matter in pack ice of the Beaufort Gyre. Journal of Glaciology. v. 39 , no. 131,1993 . p. $186-198$.

OP-836. Erk Reimnitz, E. C. Hayden, Michael McCormick and P. W. Barnes. Preliminary observations on coastal sediment loss through ice rafting in Lake Michigan. Journal of Coastal Research. v. 7 , no. 3,1991. p. 653-664.

OP-837. Erk Reimnitz, Michael McCormick, Kristin McDougall and E. M. Brouwers. ALASKA. Sediment export of ice rafting from a coastal polynya, Arctic Alaska, U.S.A. Arctic and Alpine Research. v. 25, no. 2, May 1993. p. 83-98.

OP-838. Juergen Reinhardt. Overview of the Cretaceous in the Gulf Coastal Plain. Proceedings of the Bald Head Island Conference on Coastal Plains Geology, in Proceedings of the Second Bald Head Island conference on coastal plains geology; Savannah River region; transition between the Gulf and Atlantic coastal plains. (V. A. Zullo, editor and others). 2, May 1992. p. 7-18.

OP-839. M. W. Reynolds and J. F. Sutter. Geologic mapping; implementing the National Geologic Mapping Act of 1992; Perspective 2, U.S. Geological Survey's National Geologic Mapping Program. GSA Today. v. 2, no. 11, November 1992. p. 244.

OP-840. B. S. Rhea. OREGON. Geomorphic observations of rivers in the Oregon coast range from a regional reconnaissance perspective. Geomorphology. v. 6, no. 2, January 1993. p. $135-150$.

OP-841. C. A. Rice, M. L. Tuttle and R. L. Reynolds. The analysis of forms of sulfur in ancient sediments and sedimentary 
rocks: comments and cautions. Chemical Geology. v. 107, no. 1-2, July 20, 1993. p. 83-95.

OP-842. J. W. Rice, Jr. Antarctic lakes (above and beneath the ice sheet); analogues for Mars. LPI Technical Report, in Workshop on the Polar regions of Mars; geology, glaciology, and climate history. (S. M. Clifford, editor and others). 92-08, Part 1, 1992. p. 23-24.

OP-843. Pascal Richet*, R. A. Robie and B. S. Hemingway. Entropy and structure of silicate glasses and melts. Geochimica et Cosmochimica Acta. v. 57, no. 12, June 1993. p. 2751-2766.

OP-844. B. M. Richmond. Coastal geology of Upolu, western Samoa. Circum-Pacific Council for Energy and Mineral Resources, Earth Science Series, in Geology and offshore mineral resources of the Central Pacific Basin. (B. H. Keating, editor and others). 14,1991 . p. 101-125.

OP-845. J. R. Riehle, D. E. Champion, D. A. Brew* and M. A. Lanphere*. ALASKA. Pyroclastic deposits of the Mount Edgecumbe volcanic field, Southeast Alaska; eruptions of a stratified magma chamber. Journal of Volcanology and Geothermal Research. v. 53, no. 1-4, November 1992. p. 117-143.

OP-846. J. R. Riehle, Raymond Herrmann*, C. R. Bacon, B. A. Samora* and C. C. Heliker. Volcano studies in national parks; USGS helps NPS to keep a watchful eye on restless volcanoes while improving our understanding of how volcanoes work. Park Science. v. 13, no. 1,1993 . p. 6-7.

OP-847. J. N. Rinker*, C. S. Breed, J. F. McCauley and P. A. Corl*. Remote sensing field guide; desert. ETL / Prepared for U.S. Army Engineer Topographic Laboratories. Report no. ETL-0588, September 1991. Variously paginated.

OP-848. E. I. Robbins and A. S. Iberall*. Mineral remains of early life? On Mars?. Geomicrobiology Journal. v. 9, no. 1, March 1991. p. 51-66.

OP-849. A. C. Roberts*, T. S. Ercit*, R. C. Erd and R. L. Oscarson*. CALIFORNIA. Szymanskiite, $\mathrm{Hg}^{1+}$ ${ }_{16}(\mathrm{Ni}, \mathrm{Mg})_{6}\left(\mathrm{CO}_{3}\right)_{12}(\mathrm{OH})_{12}\left(\mathrm{H}_{3} \mathrm{O}\right)^{1+}{ }_{8 \cdot \mathrm{v} 2} \mathrm{O}$, a new mineral species from the Clear Creek Claim, San Benito County, California. The Canadian Mineralogist. 28, Part 4, December 1990. p. 703-707.

OP-850. L. N. Roberts and P. J. McCabe. COLORADO. Peat accumulation in coastal-plain mires; a model for coals of the Fruitland Formation (Upper Cretaceous) of southern Colorado, USA. International Journal of Coal Geology. v. 21, no. 3, August 1992. p. 115-138.

OP-851. R. A. Robie, B. S. Hemingway, Philippe Gillet* and B. Reynard*. On the entropy of glaucophane $\mathrm{Na}_{2} \mathrm{Mg}_{3} \mathrm{Al}_{2} \mathrm{Si}_{8} \mathrm{O}_{22}(\mathrm{OH})_{2}$. Contributions to Mineralogy and Petrology. v. 107, no. 4, June 1991. p. 484-486.

OP-852. G. R. Robinson. Metal transport and deposition in hydrothermal systems buffered by mineral assemblages. Proceedings - International Symposium on Water-Rock Interaction, in Proceedings of the 7th international symposium on Water-rock interaction; Volume 2, Moderate and high temperature environments. (Y. K. Kharaka, editor and others). 7, 1992. p. 1613 1616.

OP-853. G. R. Robinson. Tectonic development of base-metal and barite-vein deposits associated with the early Mesozoic basins of eastern North America. Proceedings of the International Conference on Basement Tectonics, in Basement tectonics 8; Characterization and comparison of ancient and Mesozoic continental margins. (M. J. Bartholomew, editor and others). 8, 1988. p. 711-725.

OP-854. S. G. Robson* and E. R. Banta. Comparison of specific-storage and storage-coefficient values measured by aquifertest, barometric-efficiency and aquifer-compression techniques in deep, closely spaced wells, in Conference proceedings on Groundwater engineering and management conference. Colorado Water Resources Research Institute, 1990. p. 223-233.

OP-855. D. T. Rodbell. Late Pleistocene equilibrium-line reconstructions in the northern Peruvian Andes. Boreas. v. 21, no. 1, 1992. p. $43-52$.

OP-856. D. T. Rodbell and E. S. Schweig, III. TENNESSEE. The record of seismically induced liquefaction on late Quaternary terraces in northwestern Tennessee. Bulletin of the Seismological Society of America. v. 83, no. 1, February 1993. p. 269-278.

OP-857. D. J. Roddy, D. Hatfield*, P. Hassig*, M. Rosenblatt*, L. A. Soderblom and E. De Jong*. Computer simulations of comet- and asteroidlike bodies passing through the Venusian atmosphere; preliminary results on atmospheric and ground shock effects. LPI Contribution, in Papers presented to the international colloquium on Venus. (Lunar and Planetary Institute). 789, 1992. p. $94-96$.

OP-858. P. W. Rodgers. Maximizing the signal-to-noise ratio of the electromagnetic seismometer; the optimum coil resistance, amplifier characteristics, and circuit. Bulletin of the Seismological Society of America. v. 83, no. 2, April 1993. p. 561-582.

OP-859. W. P. Rogers*, D. English, R. L. Schuster and R. M. Kirkham. COLORADO, Large rock slide/debris avalanche in the San Juan Mountains, southwestern Colorado, USA, July 1991. Landslide News. 6, August 1992. p. 22-24.

OP-860. D. M. Rohr*, R. B. Blodgett and W. M. Furnish*. Maclurina manitobensis (Whiteaves) (Ordovician Gastropoda); the largest known Paleozoic gastropod. Journal of Paleontology. v. 66, no. 6,1992 . p. $880-884$.

OP-861. D. H. Root and E. D. Attanasi. Small fields in the national oil and gas assessments. AAPG Bulletin. v. 77 , no. 3, March 1993. p. 485-490.

OP-862. D. H. Root and R. F. Mast. Future growth of known oil and gas fields. AAPG Bulletin. v. 77, no. 3, March 1993. p. 479-484.

OP-863. J. G. Rosenbaum. NEVADA. Magnetic grain-size variations through an ash flow sheet; influence on magnetic properties and implications for cooling history. Journal of Geophysical Research, B, Solid Earth and Planets. v. 98, no. 7, July 10,1993. p. 11,715-11,727.

OP-864. Malcolm Ross. Suspect minerals and human health; a commentary. The Lattice. v. 7, no. 1, February 1991. p. 10-11.

OP-865. H. J. Rossmeissl. The spatial data transfer standard; a progress report. GIS/LIS - Proceedings, Annual Conference and Exposition, in GIS/LIS ' 89 proceedings. 1989, 1989. p. 699 706. 
OP-866. H. J. Rossmeissl and R. D. Rugg. An approach to data exchange; the spatial data transfer standard. ASTM Special Technical Publication $=$ American Society for Testing and Materials Special Technical Publication, in Geographic information systems (GIS) and mapping; practices and standards. (A. I. Johnson, editor and others). 1126,1992 . p. 38-44.

OP-867. Shahrokh Rouhani* and L. J. Torak. Geostatistical coestimation of ground water flow parameters. ERC. Report no. ERC 05-91, June 1991. 44 p.

OP-868. J. W. Rudnicki*, J. Yin* and E. A. Roeloffs. CALIFORNIA. Analysis of water level changes induced by fault creep at Parkfield, California. Journal of Geophysical Research, B, Solid Earth and Planets. v. 98, no. 5, May 10, 1993. p. 81438152.

OP-869. D. D. Runnels*, J. F. Kerrisk*, Lawrence Wangen*, T. S. Bowers*, R. M. Capuano*, D. J. Isherwood*, E. A. Jenne*, Abraham Lerman*, F. J. Pearson, Jr.*, L. N. Plummer, B. J. Travis*, A. J. Valocchi* and. T. J. Wolery*. Modeling, in Workshop on Fundamental geochemistry needs for nuclear waste isolation. (B. R. Erdal, chairperson). September 1985. p. 59-67. Available from: NTIS, Springfield, VA, United States.

OP-870. L. F. Ruppert and T. A. Moore*. Differentiation of volcanic ash-fall and water-borne detrital layers in the Eocene Senakin coal bed, Tanjung Formation, Indonesia. Organic Geochemistry, in Collected papers from the Eighth annual meeting of the Society for Organic Petrology. (J. C. Hower, editor and others). v. 20, no. 2, February 1993. p. 233-247.

OP-871. A. T. Rutledge. A new method for calculating a mathematical expression for streamflow recession, in Irrigation and drainage; proceedings of the 1991 national conference. (W. F. Ritter, editor). New York, NY: Am. Soc. Civ. Eng. 1991. p. 337-343.

OP-872. R. O. Rye. The evolution of magmatic fluids in the epithermal environment; the stable isotope perspective. Economic Geology and the Bulletin of the Society of Economic Geologists. v. 88 , no. 3, May 1993 . p. $733-752$.

OP-873. R. O. Rye and P. M. Bethke. Acid-sulfate alteration and vein alunite formation in volcanic terrains; stable isotope systematics. Chishitsu Chosajo Hokoku = Report - Geological Survey of Japan, in High-temperature acid fluids and associated alteration and mineralization. (Yukihiro Matsuhisa, editor and others). Report no. 277, 1991. p. 5-8.

OP-874. R. O. Rye and A. H. Truesdell. WYOMING. The question of recharge to the geysers and hot springs of Yellowstone National Park, Wyoming, USA. Proceedings - International Symposium on Water-Rock Interaction, in Proceedings of the 7th international symposium on Water-rock interaction; Volume 2, Moderate and high temperature environments. (Y. K. Kharaka, editor and others). 7, 1992. p. 1345-1348.

OP-875. J. J. Rytuba, Antonio Arribas, Jr.*, C. G. Cunningham, E. H. McKee, M. H. Podwysocki, J. G. Smith and W. C. Kelly*. Mineralized and unmineralized calderas in Spain; Part II, evolution of the Rodalquilar caldera complex and associated goldalunite deposits. Mineralium Deposita, in Gold '89 in Europe. (Francis Saupé, prefacer and others). 25, Suppl. 1990. p. 29-35.
OP-876. J. J. Rytuba and D. B. Vander Meulen. OREGON, IDAHO. Hot-spring precious-metal systems in the Lake Owyhee volcanic field, Oregon-Idaho, in Geology and ore deposits of the Great Basin; symposium proceedings. (G. L. Raines, editor and others). Reno, NV: Geological Society of Nevada, 1991. p. 1085-1096.

OP-877. R. W. Saltus. WASHINGTON. Upper-crustal structure beneath the Columbia River Basalt Group, Washington; gravity interpretation controlled by borehole and seismic studies. Geological Society of America Bulletin. v. 105, no. 9, September 1993. p. $1247-1259$.

OP-878. Constance Sancetta*, Mitchell Lyle*, L. E. Heusser*, Rainer Zahn* and J. P. Bradbury. CALIFORNIA. Late-glacial to Holocene changes in winds, upwelling, and seasonal production of the Northern California current system. Quaternary Research (New York). v. 38, no. 3, November 1992. p. 359-370.

OP-879. W. E. Sanford, W. W. Wood and T. B. Councell. Calcium chloride-dominated brines; an ion-exchange model. Proceedings - International Symposium on Water-Rock Interaction. 7, 1992. p. 669-672.

OP-880. J. C. Savage. The uncertainty in earthquake conditional probabilities. Geophysical Research Letters. v. 19, no. 7, April 3, 1992. p. 709-712.

OP-881. J. C. Savage. CALIFORNIA. The Parkfield prediction fallacy. Bulletin of the Seismological Society of America. v. 83, no. 1, February 1993 . p. 1-6.

OP-882. J. C. Savage and Michael Lisowski. CALIFORNIA. Inferred depth of creep on the Hayward Fault, Central California. Journal of Geophysical Research, B, Solid Earth and Planets. v. 98, no. 1, January 10,1993 . p. 787-793.

OP-883. J. C. Savage, Michael Lisowski, W. H. Prescott and A. M. Pitt. MONTANA. Deformation from 1973 to 1987 in the epicentral area of the 1959 Hebgen Lake, Montana, earthquake $\left(M_{S}\right.$ = 7.5). Journal of Geophysical Research, B, Solid Earth and Planets. v. 98, no. 2, February 10, 1993. p. 2145-2153.

OP-884. W. Z. Savage, H. S. Swolfs* and Bernard Amadei*. On the state of the Vancouver Island region; 3D numerical, analogue model and field site results. Pure and Applied Geophysics. v. 138 , no. 2,1992 . p. $207-228$.

OP-885. W. Z. Savage, D. J. Varnes, R. L. Schuster and R. W. Fleming. COLORADO. The Slumgullion earthflow, southwestern Colorado, USA. Landslide News. 6, August 1992. p. 19-22.

OP-886. K. M. Scanlon and D. G. Masson*. Fe-Mn nodule field indicated by GLORIA, north of the Puerto Rico Trench. Geo-Marine Letters. v. 12, no. 4, 1992. p. 208-213.

OP-887. G. G. Schaber, R. G. Strom*, H. J. Moore, L. A. Soderblom, R. L. Kirk, D. J. Chadwick, D. D. Dawson*, L. R. Gaddis, J. M. Boyce* and J. F. Russell. Impact craters on Venus; an overview from Magellan observations. LPI Contribution, in Papers presented to the international colloquium on Venus. (Lunar and Planetary Institute). 789, 1992. p. 100-101.

OP-888. R. W. Schaffranek and R. A. Baltzer. Horizontal density-gradient effects on simulation of flow and transport in the Potomac Estuary. Hydraulic Engineering: Proceedings of the National Conference on Hydraulic Engineering, in Hydraulic engi- 
neering; Proceedings of the 1990 national convention. (H. $\mathrm{H}$. Chang, editor and others). 1990, 1990. p. 1251-1256.

OP-889. C. J. Schenk, J. W. Schmoker and J. E. Fox*. WYOMING. Sedimentology of Permian upper part of the Minnelusa Formation, eastern Powder River basin, Wyoming, and a comparison of the subsurface. The Mountain Geologist. v. 30 , no. 2, April 1993. p. 71-80.

OP-890. Peter Schiffmann*, Peter Evarts*, R. C. Williams* and W. J. Pickthorn. CALIFORNIA. Hydrothermal metamorphism in oceanic crust from the Coast Range ophiolite of California; fluid-rock interaction in a rifted island arc. Petrology and Structural Geology, in Ophiolite genesis and evolution of the oceanic lithosphere. (Tjerk Peters, editor and others). 5, 1991. p. 399425 .

OP-891. J. L. Schlottmann and G. N. Breit. OKLAHOMA. Mobilization of As and $U$ in the Central Oklahoma Aquifer, USA. Proceedings - International Symposium on Water-Rock Interaction. 7, 1992. p. 835-838.

OP-892. D. H. Schoellhamer. FLORIDA. Observation of sediment resuspension in old Tampa Bay, Florida. Hydraulic Engineering: Proceedings of the National Conference on Hydraulic Engineering, in Hydraulic engineering; Proceedings of the 1990 national convention. (H. H. Chang, editor and others). 1990, 1990. p. 51-56.

OP-893. D. H. Schoellhamer. FLORIDA. Biological interference of optical backscatterance sensors in Tampa Bay, Florida. Marine Geology. v. 110, no. 3-4, March 1993. p. 303-313.

OP-894. D. H. Schoellhamer. Summary of non-cohesive sediment transport processes at the bed/water column interface, in Hydraulic engineering; saving a theoretical resource, in search of solutions. (M. E. Jennings, editor and others). New York, NY: Am. Soc. Civ. Eng. 1992. p. 375-380.

OP-895. D. H. Schoellhamer and V. A. Levesque. FLORIDA. Wind generated wave resuspension of sediment in Old Tampa Bay, Florida. Hydraulic Engineering: Proceedings of the National Conference on Hydraulic Engineering, in Proceedings of the 1991 national conference on Hydraulic engineering. (R. M. Shane, editor). 1991,1991 . p. 85-90.

OP-896. D. W. Scholl and R. H. Herzer*. Geology and resource potential of the southern Tonga platform. AAPG Memoir, in Geology and geophysics of continental margins. (J. S. Watkins, editor and others). 53, 1992. p. 139-156.

OP-897. M. A. Scholl, S. E. Ingebritsen, H. I. Essaid and C. G. Fox*. Consequences of phase separation on the distribution of hydrothermal fluids at ASHES vent field, Axial Volcano, Juan de Fuca Ridge; discussion and reply. Journal of Geophysical Research, B, Solid Earth and Planets. v. 98, no. 2, February 10, 1993. p. $1813-1818$.

OP-898. C. A. Scholz*, K. D. Klitgord, D. R. Hutchinson, U. S. ten Brink, L. P. Zonenshain*, A. Y. Gol'mshtok* and T. C. Moore*. Results of 1992 seismic reflection experiment in Lake Baikal. Eos, Transactions, American Geophysical Union. v. 74, no. 41 , October 12,1993 . p. $465,469-470$.

OP-899. R. D. Schopp and R. J. Burns. NEW JERSEY. Local flood warning systems in New Jersey. Special Publication - Natural Hazards Research and Applications Information Center, in
Inspiration; come to the headwaters; proceedings of the Fifteenth annual conference of the Association of State Floodplain Managers. (Jerry Louthain, chairperson). 24, 1992. p. 172-175.

OP-900. Hans Schouten*, K. D. Klitgord and D. G. Gallo*. Edge-driven microplate kinematics. Journal of Geophysical Research, B, Solid Earth and Planets. v. 98, no. 4, April 10, 1993. p. 6689-6701.

OP-901. A. P. Schultz, C. R. Wiggs* and S. D. Brower*. WEST VIRGINIA. Geologic and environmental implications of high soil-gas radon concentrations in the Great Valley, Jefferson and Berkeley counties, West Virginia. Special Paper - Geological Society of America, in Geologic controls on radon. (A. E. Gates, editor and others). 271, 1992. p. 29-44.

OP-902. R. R. Schumann, D. E. Owen and Sigrid Asher-Bolinder. Effects of weather and soil characteristics on temporal variations in soil-gas radon concentrations. Special Paper - Geological Society of America, in Geologic controls on radon. (A. E. Gates, editor and others). 271, 1992. p. 65-72.

OP-903. R. L. Schuster and J. P. Lockwood. Geologic hazards at Lake Nyos, Cameroon, West Africa. AEG News. v. 34, no. 2, April 1991. p. 28-29.

OP-904. R. L. Schuster, R. L. Logan* and P. T. Pringle*. WASHINGTON. Prehistoric rock avalanches in the Olympic Mountains, Washington. Science. v. 258, no. 5088, December 4, 1992. p. $1620-1621$.

OP-905. D. P. Schwartz and W. R. Lund. UTAH. Paleoseismicity and earthquake recurrence at Little Cottonwood Canyon, Wasatch fault zone, Utah. Miscellaneous Publication (Utah Geological and Mineral Survey), in In the footsteps of G. K. Gilbert; Lake Bonneville and neotectonics of the eastern Basin and Range Province; guidebook for field trip twelve. (M. N. Machette, editor). Report no. 88-1, 1988. p. 82-85.

OP-906. D. H. Scott, M. G. Chapman, J. W. Rice, Jr. and J. M. Dohm. New evidence of lacustrine basins on Mars; Amazonis and Utopia planitiae. Proceedings of the Lunar and Planetary Science Conference, in Proceedings of Lunar and planetary science. (Graham Ryder, editor and others). 22, 1992. p. 53-62.

OP-907. K. M. Scott. Risk analysis of sediment gravity flows at Cascade Range volcanoes; approaches and analogies with alluvial fans, in Interdisciplinary approaches in hydrology and hydrogeology. (M. E. Jones, editor and others). Minneapolis, MN: Am. Inst. Hydrol. 1992. p. 222-230.

OP-908. W. E. Scott. UTAH. Transgressive and high-shore deposits of the Bonneville Lake cycle near North Salt Lake, Utah. Miscellaneous Publication (Utah Geological and Mineral Survey), in In the footsteps of G. K. Gilbert; Lake Bonneville and neotectonics of the eastern Basin and Range Province; guidebook for field trip twelve. (M. N. Machette, editor). Report no. 88-1, 1988. p. $38-42$.

OP-909. W. E. Scott. UTAH. G. K. Gilbert's observations of post-Bonneville movement along the Warm Springs Fault, Salt Lake County, Utah. Miscellaneous Publication (Utah Geological and Mineral Survey), in In the footsteps of G. K. Gilbert; Lake Bonneville and neotectonics of the eastern Basin and Range Province; guidebook for field trip twelve. (M. N. Machette, editor). Report no. 88-1, 1988. p. 44-46. 
OP-910. W. E. Scott. UTAH. Temporal relations of lacustrine and glacial events at Little Cottonwood and Bells canyons, Utah. Miscellaneous Publication (Utah Geological and Mineral Survey), in In the footsteps of G. K. Gilbert; Lake Bonneville and neotectonics of the eastern Basin and Range Province; guidebook for field trip twelve. (M. N. Machette, editor). Report no. 88-1, 1988. p. 78-81.

OP-911. W. E. Scott. UTAH. Deposits of the last two deep-lake cycles at Point of the Mountain, Utah. Miscellaneous Publication (Utah Geological and Mineral Survey), in In the footsteps of G. K. Gilbert; Lake Bonneville and neotectonics of the eastern Basin and Range Province; guidebook for field trip twelve. (M. N. Machette, editor). Report no. 88-1, 1988. p. 86-88.

OP-912. R. R. Seal, II and R. O. Rye. IDAHO. Stable isotope study of fluid inclusions in fluorite from Idaho; implications for continental climates during the Eocene. Geology (Boulder). v. 21, no. 3, March 1993. p. 219-222.

OP-913. Paul Segall and Yijun Du*. CALIFORNIA. How similar were the 1934 and 1966 Parkfield earthquakes?. Journal of Geophysical Research, B, Solid Earth and Planets. v. 98, no. 3, March 10, 1993. p. 4527-4538.

OP-914. J. C. Seitz*, J. D. Pasteris* and I-Ming Chou. Raman spectroscopic characterization of gas mixtures; I, Quantitative composition and pressure determination of $\mathrm{CH}_{4}, \mathrm{~N}_{2}$ and their mixtures. American Journal of Science. v. 293, no. 4, April 1993. p. 297-321.

OP-915. L. A. Senior and K. L. Vogel. PENNSYLVANIA. Geochemistry of radium-226 and radium-228, and radon-222 in ground water in the Chickies Quartzite, southeastern Pennsylvania, in Proceedings of a conference on Ground water in the Piedmont of the Eastern United States. (C. C. Daniel, III, editor and others). Clemson, SC: Clemson University, 1989. p. 547-565.

OP-916. N. J. Shackleton*, K. R. Ludwig, K. R. Simmons, I. J. Winograd, B. J. Szabo, J. M. Landwehr and A. C. Riggs. NEVADA. Last interglacial in Devils Hole; discussion and reply. Nature (London). v. 362, no. 6421, April 15, 1993. p. 596.

OP-917. J. B. Shanley. GEORGIA. Sulfate retention and release in soils at Panola Mountain, Georgia. Soil Science. v. 153, no. 6, June 1992. p. 499-508.

OP-918. J. B. Shanley and N. E. Peters. GEORGIA. Variations in aqueous sulfate concentrations at Panola Mountain, Georgia. Journal of Hydrology. v. 146, no. 1-4, June 1, 1993. p. 361382.

OP-919. K. W. Shanley* and P. J. McCabe. UTAH. Alluvial architecture in a sequence stratigraphic framework; a case history from the Upper Cretaceous of southern Utah, USA. Special Publication of the International Association of Sedimentologists, in The geological modelling of hydrocarbon reservoirs and outcrop analogues. (S. S. Flint, editor and others). 15, 1993. p. 21-55.

OP-920. V. L. Sharpton*, G. B. Dalrymple, L. E. Marin*, Graham Ryder*, B. C. Schuraytz* and Jaime Urrutia-Fucugauchi*. New links between the Chicxulub impact structure and the Cretaceous/Tertiary boundary. Nature (London). v. 359, no. 6398, October 29, 1992. p. 819-821.

OP-921. D. R. Shawe. NEVADA. Structurally controlled gold trends imply large gold resources in Nevada, in Geology and ore deposits of the Great Basin; symposium proceedings. (G. L. Raines, editor and others). Reno, NV: Geological Society of Nevada, 1991. p. 199-212.

OP-922. R. J. Shedlock. DELAWARE, MARYLAND, VIRGINIA. The Delmarva study. Geotimes. v. 38, no. 12, December 1993. p. 12-14.

OP-923. R. J. Shedlock, D. A. Wilcox*, T. A. Thompson* and D. A. Cohen. INDIANA. Interactions between ground water and wetlands, southern shore of Lake Michigan, USA. Journal of Hydrology, in Hydrogeology of wetlands. (T. C. Winter, editor and others). v. 141, no. 1-4, January 1993. p. 127-155.

OP-924. A. H. Shen*, W. A. Bassett* and I-Ming Chou. The $\alpha-$ $\beta$ quartz transition at high temperatures and pressures in a diamond-anvil cell by laser interferometry. American Mineralogist. v. 78, no. 7-8, August 1993. p. 694-698.

OP-925. G. T. Shen*, J. E. Cole*, D. W. Lea*, L. J. Linn*, E. A. McConnaughey and R. G. Fairbanks*. Surface ocean variability at Galapagos from 1936-1982; calibration of geochemical tracers in corals. Paleoceanography. v. 7, no. 5, October 1992. p. 563-588.

OP-926. D. S. Sheppard*, C. J. Janik and T. E. Keith*. ALASKA. A comparison of gas geochemistry of fumaroles in the 1912 ashflow sheet and on active stratovolcanoes, Katmai National Park, Alaska. Journal of Volcanology and Geothermal Research. v. 53, no. 1-4, November 1992. p. 185-197.

OP-927. E. A. Shinn and B. H. Lidz. Impact of offshore drilling in the eastern Gulf of Mexico. Proceedings - Offshore Technology Conference, in 24th annual Offshore technology conference; 1992 proceedings; Geology, earth sciences and environment. (S. J. Leverette, chairperson). v. 24, no. 1, 1992. p. 517-524.

OP-928. E. A. Shinn, R. P. Steinen*, R. F. Dill* and R. P. Major*. Lime-mud layers in high-energy tidal channels; a record of hurricane deposition. Geology (Boulder). v. 21, no. 7, July 1993. p. 603-606.

OP-929. W. G. Shope, Jr. Use of electronic microprocessorbased instrumentation by the U.S. Geological Survey for hydrologic data collection. Hydraulic Engineering: Proceedings of the National Conference on Hydraulic Engineering, in Proceedings of the 1991 national conference on Hydraulic engineering. (R. M. Shane, editor). 1991, 1991. p. 774-779.

OP-930. M. A. Siders*, D. D. Runnells* and D. R. Norton. WYOMING. Impact of the 1988 forest fires on the chemistry of non-thermal ground water in Yellowstone National Park, USA. Proceedings - International Symposium on Water-Rock Interaction. 7,1992 . p. $433-436$.

OP-931. K. E. Sieh*, L. M. Jones, Egill Hauksson*, K. W. Hudnut, Donna Eberhart-Phillips, T. H. Heaton, S. E. Hough, L. K. Hutton*, Hiroo Kanamori*, Anne Lilje*, S. C. Lindvall*, S. F. McGill*, J. J. Mori, C. M. Rubin*, J. A. Spotila*, J. M. Stock*, H. K. Thio*, J. A. Treiman*, B. P. Wernicke* and Judith Zachariasen*. CALIFORNIA. Near-field investigations of the Landers earthquake sequence, April to July 1992. Science. v. 260, no. 5105, April 9, 1993. p. 171-176.

OP-932. R. P. Signell and Bradford Butman. MASSACHUSETTS. Modeling tidal exchange and dispersion in Boston Har- 
bor. Journal of Geophysical Research, C, Oceans. v. 97, no. 10, October 15, 1992. p. 15,591-15,606.

OP-933. N. J. Silberling. NEVADA. Allochthonous terranes of western Nevada, in Geology and ore deposits of the Great Basin; symposium proceedings. (G. L. Raines, editor and others). Reno, NV: Geological Society of Nevada, 1991. p. 101-102.

OP-934. M. L. Silberman and Joanne Danielson*. CALIFORNIA. Gold-bearing quartz veins in the Klamath Mountains in the Redding $1 \times 2$ degree quadrangle, Northern California. California Geology. v. 46, no. 2, April 1993. p. 35-44.

OP-935. N. S. Simon, S. A. Hatcher and C. R. Demas. LOUISIANA. Comparison of methods for the removal of organic carbon and extraction of chromium, iron and manganese from an estuarine sediment standard and sediment from the Calcasieu River estuary, Louisiana, U.S.A. Chemical Geology. v. 100, no. 3-4, November 10,1992. p. 175-189.

OP-936. J. D. Sims. CALIFORNIA. Chronology of displacement on the San Andreas Fault in Central California; evidence from reversed positions of exotic rock bodies near Parkfield, California. Memoir - Geological Society of America, in The San Andreas fault system; displacement, palinspastic reconstruction, and geologic evolution. (R. E. Powell, editor and others). 178, 1993. p. 231256.

OP-937. P. K. Sims. COLORADO. Ore deposits of the Central City-Idaho Springs area. Colorado School of Mines Quarterly. v. 93, no. 1, 1993. p. 21-23.

OP-938. D. A. Singer. Basic concepts in three-part quantitative assessments of undiscovered mineral resources. Nonrenewable Resources. v. 2, no. 2, 1993. p. 69-81.

OP-939. S. A. Sipkin. Display and assessment of earthquake focal mechanisms by vector representation. Bulletin of the Seismological Society of America. v. 83, no. 6, December 1993. p. 1871-1880.

OP-940. S. A. Sipkin and R. E. Needham. Moment-tensor solutions estimated using optimal filter theory; global seismicity, 1991. Physics of the Earth and Planetary Interiors. v. 75, no. 4, January 1993. p. 199-204.

OP-941. B. A. Skipp and P. K. Link*. IDAHO, MONTANA. Middle and late Proterozoic rocks and late Proterozoic tectonics in the southern Beaverhead Mountains, Idaho and Montana; a preliminary report. Memoir - Geological Society of America, in Regional geology of eastern Idaho and western Wyoming. (P. K. Link, editor and others). 179, 1992. p. 141-154.

OP-942. J. F. Slack, M. R. Palmer*, B. P. Stevens* and R. G. Barnes*. Origin and significance of tourmaline-rich rocks in the Broken Hill District, Australia. Economic Geology and the Bulletin of the Society of Economic Geologists. v. 88, no. 3, May 1993. p. 505-541.

OP-943. A. J. Smith*, L. D. Delorme* and R. M. Forester. A lake's solute history from ostracodes; comparison of methods. Proceedings - International Symposium on Water-Rock Interaction. 7, 1992. p. 677-680.

OP-944. D. B. Smith, D. B. Hoover and R. F. Sanzolone. COLORADO. Preliminary studies of the CHIM electrogeochemical method at the Kokomo Mine, Russell Gulch, Colorado. Jour- nal of Geochemical Exploration. v. 46, no. 3, February 1, 1993. p. $257-278$.

OP-945. D. B. Smith, P. K. Theobald, Shen Shiquan*, Ren Tianxiang* and Hou Zhizhui*. The Hatu gold anomaly, XinjiangUygur Autonomous Region, China; testing the hypothesis of aeolian transport of gold. Journal of Geochemical Exploration, in Geochemical exploration 1991. (F. W. Dickson, editor and others). v. 47, no. 1-3, April 1993. p. 201-216.

OP-946. E. A. Smith*, A. Y. Hsu*, W. L. Crosson*, R. T. Field*, L. J. Fritschen*, R. J. Gurney*, E. T. Kanemasu*, W. P. Kustas*, D. Nie*, W. J. Shuttleworth*, J. B. Stewart*, S. B. Verma*, H. L. Weaver and M. L. Wesely*. KANSAS. Area-averaged surface fluxes and their time-space variability over the FIFE experimental domain. Journal of Geophysical Research, D, Atmospheres, in First ISLSCP field experiment (FIFE). (R. E. Murphy, prefacer). v. 97, no. 17, November 30, 1992. p. $18,599-18,622$

OP-947. J. D. Smith and E. D. Andrews. ARIZONA. Channel margin and eddy bar deposition along the Colorado River in Grand Canyon NP. Park Science. v. 13, no. 1, 1993. p. 3-4.

OP-948. K. S. Smith, W. H. Ficklin, G. S. Plumlee and A. L. Meier. Metal and arsenic partitioning between water and suspended sediment at mine-drainage sites in diverse geologic settings. Proceedings - International Symposium on Water-Rock Interaction. 7, 1992. p. 443-447.

OP-949. R. L. Smith, L. G. Miller and B. L. Howes. The geochemistry of methane in Lake Fryxell, an amictic, permanently ice-covered, Antarctic lake. Biogeochemistry. v. 21, no. 2, 1993. p. 95-115.

OP-950. N. F. Sohl. Overview of the Cretaceous of the Atlantic Coastal Plain. Proceedings of the Bald Head Island Conference on Coastal Plains Geology, in Proceedings of the Second Bald Head Island conference on coastal plains geology; Savannah River region; transition between the Gulf and Atlantic coastal plains. (V. A. Zullo, editor and others). 2, May 1992. p. 19-22.

OP-951. Tomás Soler*, W. E. Strange* and L. D. Hothem. Accurate determination of Cartesian coordinates at geodetic stations using the Global Positioning System measurements. Geophysical Research Letters. v. 19, no. 6, March 20,1992. p. 533-536.

OP-952. D. R. Soller. A regional three-dimensional map of Laurentide glacial sediments in the United States; overview and applications for hydrogeology and land use, in Memoirs of the International symposium on Hydrogeological maps as tools for economic and social development. Hanover: International Association of Hydrogeologists, 1989. p. 107-114.

OP-953. R. A. Sommerfeld*, Clark Judy* and Irving Friedman. Isotopic changes during the formation of depth hoar in experimental snowpacks. Special Publication - Geochemical Society, in Stable isotope geochemistry; a tribute to Samuel Epstein. (H. P. Taylor, editor and others). 3, 1991. p. 205-209.

OP-954. M. L. Sorey and C. D. Farrar. CALIFORNIA. A conceptual model of the hydrothermal system in Long Valley Caldera, California, USA. Proceedings - International Symposium on Water-Rock Interaction, in Proceedings of the 7th international symposium on Water-rock interaction; Volume 2, Moderate and 
high temperature environments. (Y. K. Kharaka, editor and others). 7, 1992. p. 1357-1362.

OP-955. M. L. Sorey, B. M. Kennedy*, W. C. Evans, C. D. Farrar and G. A. Suemnicht*. CALIFORNIA. Helium isotope and gas discharge variations associated with crustal unrest in Long Valley Caldera, California, 1989-1992. Journal of Geophysical Research, B, Solid Earth and Planets. v. 98, no. 9, September 10, 1993. p. $15,871-15,889$.

OP-956. G. F. Sowers* and R. L. Schuster. General report/Discussion session 6; Invited lecture; Volcanic debris avalanche and lahar deposits. Proceedings of the International Conference on Soil Mechanics and Foundation Engineering = Comptes Rendus du Congres International de Mecanique des Sols et des Travaux de Fondations, in Proceedings of the Twelfth international conference on Soil mechanics and foundation engineering - Comptes rendus du douzieme congres international de mecanique des sols et des travaux de fondations. 12 , Vol. 4, 1992. p. 2453-2461.

OP-957. R. S. Sparks*, M. V. Stasiuk*, M. Gardeweg and D. A. Swanson*. Welded breccias in andesite lavas. Journal of the Geological Society of London. 150, Part 5, September 1993. p. 897-902.

OP-958. Paul Spudich. On the inference of absolute stress levels from seismic radiation. Tectonophysics, in Earthquake source physics and earthquake precursors. (Takeshi Mikumo, editor and others). v. 211 , no. $1-4$, September 30,1992. p. 99-106.

OP-959. Paul Spudich and Masahiro Iida*. CALIFORNIA. The seismic coda, site effects, and scattering in alluvial basins studied using aftershocks of the 1986 North Palm Springs, California, earthquake as source arrays. Bulletin of the Seismological Society of America. v. 83, no. 6, December 1993. p. 1721-1743.

OP-960. M. G. Stamatakis* and J. R. Hein. Origin of barite in Tertiary marine sedimentary rocks from Lefkas Island, Greece. Economic Geology and the Bulletin of the Society of Economic Geologists. v. 88, no. 1, February 1993. p. 91-103.

OP-961. C. L. Stamos, S. K. Predmore and A. A. Zohdy. Use of D-C resistivity to map saline ground water, in Irrigation and drainage; saving a threatened resource; in search of solutions. (Ted Engman, editor). New York, NY: American Society of Civil Engineers, 1992. p. 80-85.

OP-962. D. I. Stannard. Comparison of Penman-Monteith, Shuttleworth-Wallace, and modified Priestley-Taylor evapotranspiration models for wildland vegetation in semiarid rangeland. Water Resources Research. v. 29, no. 5, May 1993. p. 13791392.

OP-963. L. E. Starr. USGS National Mapping Division; preparing for the twenty-first century. GIS/LIS - Proceedings, Annual Conference and Exposition, in GIS/LIS '90 proceedings. 1990, vol. 2,1990 . p. $872-881$.

OP-964. L. K. Steck and W. A. Prothero, Jr.*. CALIFORNIA. Observations of direct $P$-wave slowness and azimuth anomalies for teleseisms recorded in Long Valley Caldera, California. Bulletin of the Seismological Society of America. v. 83, no. 5, October 1993. p. 1391-1419.

OP-965. H. J. Stein and J. L. Hannah*. UTAH. Comprehensive model for the formation of the Tintic ore deposits, western Utah, eastern Basin and Range Province, USA, in Source, transport and deposition of metals. (Maurice Pagel, editor and others). Rotterdam: A. A. Balkema, 1991. p. 349-354.

OP-966. R. S. Stein, G. C. King* and Jian Lin*. CALIFORNIA. Change in failure stress on the southern San Andreas fault system caused by the 1992 magnitude $=7.4$ Landers earthquake. Science. v. 258 , no. 5086 , November 20,1992 . p. $1328-1332$.

OP-967. M. G. Steltenpoh1*, Zbignew Cymerman*, E. J. Krogh* and M. J. Kunk. Exhumation of eclogitized continental basement during Variscan lithospheric delamination and gravitational collapse, Sudety Mountains, Poland; with Suppl. Data 9341. Geology (Boulder). v. 21, no. 12, December 1993. p. 1111-1114.

OP-968. M. G. Steltenpohl* and M. J. Kunk. ALABAMA, GEORGIA. ${ }^{40} \mathrm{Ar} /{ }^{39} \mathrm{Ar}$ thermochronology and Alleghanian development of the southernmost Appalachian Piedmont, Alabama and Southwest Georgia; with Suppl. Data 9315. Geological Society of America Bulletin. v. 105, no. 6, June 1993. p. 819-833.

OP-969. W. J. Stephenson, J. K. Odum, K. M. Shedlock, T. L. Pratt and R. A. Williams. Mini-Sosie high-resolution seismic method aids hazards studies. Eos, Transactions, American Geophysical Union. v. 73 , no. 44, November 3, 1992. p. 473, 475476.

OP-970. W. J. Stephenson, R. B. Smith* and J. R. Pelton*. UTAH. A high-resolution seismic reflection and gravity survey of Quaternary deformation across the Wasatch Fault, Utah. Journal of Geophysical Research, B, Solid Earth and Planets. v. 98, no. 5, May 10, 1993. p. 8211-8223.

OP-971. C. R. Stern*, Wes Hildreth and Stephen Moorbath*. Commenton "Crustal contributions to arc magmatism in the Andes of central Chile" by W. Hildreth and S. Moorbath; discussion and reply. Contributions to Mineralogy and Petrology. v. 108, no. 1-2,1991. p. 241-252.

OP-972. C. H. Stevens*, Paul Stone and R. W. Kistler. A speculative reconstruction of the middle Paleozoic continental margin of southwestern North America. Tectonics. v. 11, no. 2, April 1992. p. 405-419.

OP-973. J. H. Stewart and J. E. Carlson. NEVADA. Cenozoic rocks of Nevada; four maps and brief description of distribution, lithology, age, and centers of volcanism. Map - Nevada Bureau of Mines and Geology. Report no. 52, 1976. 5 p., 4 sheets.

OP-974. S. L. Stipp*, G. A. Parks*, D. K. Nordstrom and J. O. Leckie*. Solubility-product constant and thermodynamic properties for synthetic otavite, $\mathrm{CdCO}_{3}(\mathrm{~s})$, and aqueous association constants for the $\mathrm{Cd}(\mathrm{II})-\mathrm{CO}_{2}-\mathrm{H}_{2} \mathrm{O}$ system. Geochimica et Cosmochimica Acta. v. 57, no. 12, June 1993. p. 2699-2713.

OP-975. J. L. Stoddard* and P. S. Murdoch. NEW YORK. Catskill Mountains, in Acidic deposition and aquatic ecosystems; regional case studies. (D. F. Charles, editor). New York, NY: Springer-Verlag New York, 1991. p. 237-271.

OP-976. Stephen Stokes* and C. S. Breed. ARIZONA. A chronostratigraphic re-evaluation of the Tusayan Dunes, Moenkopi Plateau and southern Ward Terrace, northeastern Arizona. Geological Society Special Publications, in The dynamics and environmental context of aeolian sedimentary systems. (Kenneth Pye, editor). 72, 1993. p. 75-90. 
OP-977. Paul Stone and C. H. Stevens*. Large-magnitude Permian shortening and continental-margin tectonics in the southern Cordillera: Discussion. Geological Society of America Bulletin. v. 105 , no. 2, February 1993. p. 279-280.

OP-978. N. C. Sturchio*, M. T. Murrell*, K. L. Pierce and M. L. Sorey. WYOMING. Yellowstone travertines; U-series ages and isotope ratios $(\mathrm{C}, \mathrm{O}, \mathrm{Sr}, \mathrm{U})$. Proceedings - International Symposium on Water-Rock Interaction, in Proceedings of the 7th international symposium on Water-rock interaction; Volume 2, Moderate and high temperature environments. (Y. K. Kharaka, editor and others). 7,1992 . p. 1427-1430.

OP-979. P. J. Sugarman*, K. G. Miller*, J. P. Owens and M. D. Feigenson*. NEW JERSEY. Strontium-isotope and sequence stratigraphy of the Miocene Kirkwood Formation, southern New Jersey. Geological Society of America Bulletin. v. 105, no. 4, April 1993. p. 423-436.

OP-980. E. T. Sundquist. The global carbon dioxide budget. Science, in Special section; evolution of atmospheres. v. 259, no. 5097, February 12, 1993. p. $934-941$.

OP-981. J. F. Sutter and Paul Stone. Geologic maps and digital data sets; their role in management and preservation of NPS lands. Park Science. v. 13, no. 1, 1993. p. 11-12.

OP-982. Keiko Suzuki-Kamata, Hiroki Kamata and C. R. Bacon. OREGON. Evolution of the caldera-forming eruption at Crater Lake, Oregon, indicated by component analysis of lithic fragments. Journal of Geophysical Research, B, Solid Earth and Planets. v. 98 , no. 8 , August 10,1993 . p. $14,059-14,074$.

OP-983. L. A. Swain. Regional aquifer-system analysis of the Appalachian Valley and Ridge, Piedmont, and Blue Ridge physiographic provinces, in Proceedings of a conference on Ground water in the Piedmont of the Eastern United States. (C. C. Daniel, III, editor and others). Clemson, SC; Clemson University, 1989. p. 285-292.

OP-984. J. J. Sweeney*, A. K. Burnham*, C. E. Barker and N. H. Bostick*. Implications for organic maturation studies of evidence for a geologically rapid increase and stabilization of vitrinite reflectance at peak temperature; Cerro Prieto geothermal system, Mexico; discussion and reply. AAPG Bulletin. v. 77 , no. 4, April 1993. p. 665-678.

OP-985. D. S. Sweetkind, R. L. Reynolds, D. A. Sawyer and J. G. Rosenbaum. COLORADO. Effects of hydrothermal alteration on the magnetization of the Oligocene Carpenter Ridge Tuff, Bachelor Caldera, San Juan Mountains, Colorado, Journal of Geophysical Research, B, Solid Earth and Planets. v. 98, no. 4, April 10,1993 . p. $6255-6266$.

OP-986. Z. G. Szabo, O. S. Zapecza and J. P. Nawyn. NEW JERSEY. Effects of ground-water geochemistry on the distribution of dissolved uranium and radium-226 in the Newark Basin, New Jersey, in Proceedings of a conference on Ground water in the Piedmont of the Eastern United States. (C. C. Daniel, III, editor and others). Clemson, SC: Clemson University, 1989. p. 566-586.

OP-987. K. L. Tanaka and M. G. Chapman. Kasei Valles, Mars; interpretation of canyon materials and flood sources. Proceedings of the Lunar and Planetary Science Conference, in Proceedings of
Lunar and planetary science. (Graham Ryder, editor and others). 22, 1992. p. 73-83.

OP-988. K. L. Tanaka and G. G. Schaber. Can a time-stratigraphic classification system be developed for Venus?. LPI Contribution, in Papers presented to the international colloquium on Venus. (Lunar and Planetary Institute). 789, 1992. p. 124-125.

OP-989. David Tappin* and A. H. Sallenger, Jr. Coastal morphology and sediment study of Tongatapu, Kingdom of Tonga. SOPAC Technical Bulletin, in Workshop on Coastal processes in the South Pacific island nations. (Jioji Kotobalavu, prefacer and others). 7, 1991. p. 131-143.

OP-990. H. E. Taylor, R. C. Averett and L. Mazzu*. ARIZONA. Measuring Colorado water quality in the Grand Canyon NP. Park Science. v. 13, no. 1, 1993. p. 12-14.

OP-991: H. E. Taylor, J. R. Garbarino and S. R. Koirtyohann. Flame ionization mass spectrometry: isotope ratio determinations for potassium. Applied Spectroscopy. v. 45, no. 5, 1991. p. 886-889.

OP-992. P. C. Thenhaus. Intensity distribution. Newsletter Earthquake Engineering Research Institute. v. 26, no, 12, December 1992. p. 7 .

OP-993. P. C. Thenhaus, S. L. Hanson, Ismet Effendi*, E. K. Kertapati* and S. T. Algermissen. Pilot studies of seismic hazard and risk in North Sulawesi Province, Indonesia. Earthquake Spectra. v. 9, no. 1, February 1993. p. 97-120.

OP-994. T. G. Theodore and J. M. Hammarstrom. NEVADA. Petrochemistry and fluid-inclusion study of skarns from the northern Battle Mountain mining district, Nevada, in Geology and ore deposits of the Great Basin; symposium proceedings. (G. L. Raines, editor and others). Reno, NV: Geological Society of Nevada, 1991. p. $405-406$.

OP-995. J. M. Thomas, A. H. Welch, M. S. Lico, J. L. Hughes and Rita Whitney. NEVADA, CALIFORNIA. Radionuclides in ground water of the Carson River basin, western Nevada and eastern California, U.S.A. Applied Geochemistry. v. 8, no. 5, September 1993. p. 447-471.

OP-996. R. E. Thomas, M. R. Khan* and S. A. Khan*. Coal resources of the Sonda coal field, Sindh Province, Pakistan. International Journal of Coal Geology, in World class coal deposits; proceedings of the 28th international geological congress. (A. T. Cross, editor). v. 23 , no. $1-4$, September 1, 1993. p. 159-191.

OP-997. J. M. Thompson, R. H. Mariner, L. D. White, T. S. Presser and W. C. Evans. CALIFORNIA. Thermal waters along the Konocti Bay fault zone, Lake County, California; a re-evaluation. Journal of Volcanology and Geothermal Research. v. 53 , no. $1-4$, November 1992 . p. 167-183.

OP-998. J. J. Thordsen, Y. K. Kharaka, R. H. Mariner and L. D. White. WYOMING. Controls on the distribution of stable isotopes of meteoric water and snow in the greater Yellowstone National Park region, USA. Proceedings - International Symposium on Water-Rock Interaction. 7,1992. p. 591-595.

OP-999. C. H. Thorman, K. B. Ketner, W. E. Brooks, L. W. Snee and R. A. Zimmermann. NEVADA. Late Mesozoic-Cenozoic tectonics in northeastern Nevada, in Geology and ore deposits of the Great Basin; symposium proceedings. (G. L. 
Raines, editor and others). Reno, NV: Geological Society of Nevada, 1991. p. 25-45.

OP-1000. E. M. Thurman*, D. A. Goolsby*,M. T. Meyer* and D. W. Kolpin. Herbicides in surface waters of the Midwestern United States; the effect of spring flush. Environmental Science \& Technology, ES \& T. v. 25, no. 10, October 1991. p. 1794 1796.

OP-1001. R. I. Tilling and J. J. Dvorak. HAWAII. Anatomy of a basaltic volcano. Nature (London). v. 363, no. 6425, May 13, 1993. p. 125-133.

OP-1002. R. P. Tollo* and Sara Arav. VIRGINIA. The Robertson River igneous suite (Blue Ridge Province, Virginia); late Proterozoic anorogenic (A-type) granitoids of unique petrochemical affinity. Proceedings of the International Conference on Basement Tectonics, in Basement tectonics 8; Characterization and comparison of ancient and Mesozoic continental margins. (M. J. Bartholomew, editor and others). 8, 1988. p. 425-441.

OP-1003. R. P. Tollo* and David Gottfried. NEW JERSEY. Petrochemistry of Jurassic basalt from eight cores, Newark Basin, New Jersey; implications for the volcanic petrogenesis of the Newark Supergroup. Special Paper - Geological Society of America, in Eastern North American Mesozoic magmatism. (J. H. Puffer, editor and others). 268, 1992. p. 233-259.

OP-1004. T. J. Toy*, W. R. Osterkamp and K. G. Renard*. Prediction by regression and intrarange data scatter in surface-process studies. Environmental Geology. v. 22, no. 2, October 1993. p. 121-128.

OP-1005. G. W. Tribble. Organic matter oxidation and aragonite diagenesis in a coral reef. Journal of Sedimentary Petrology. v. 63, no. 3, May 1993. p. 523-527.

OP-1006. R. B. Tripp and J. B. Cathrall. ALASKA. Hidden gems in the NURE data; placer exploration potential for Au, PGM, REE, and other metals in the Arctic Coastal Plain and Foothills provinces, Alaska. Explore. 79, April 1993. p. 11-12.

OP-1007. J. W. Troester. PUERTO RICO. The northern karst belt of Puerto Rico; a humid tropical karst. International Contributions to Hydrogeology, in Hydrogeology of selected karst regions. (William Back, editor and others). 13, 1992. p. 475-486.

OP-1008. J. T. Turk and N. E. Spahr. Rocky Mountains, in Acidic deposition and aquatic ecosystems; regional case studies. (D. F. Charles, editor). New York, NY: Springer-Verlag New York, 1991. p. 471-501.

OP-1009. A. K. Turner*, J. S. Downey and K. E. Kolm*. NEVADA. Potential applications of three-dimensional geoscientific mapping and modeling systems to hydrogeological assessments at Yucca Mountain, Nevada, in Conference proceedings; NCGA GIS ' 90 ; bring the user community together. Natl. Comp. Graph. Assoc. 1990. p. 294-302.

OP-1010. D. P. Turnipseed and J. A. Smith. MISSISSIPPI. Monitoring lateal movement and stability of channel banks on the Pearl River in Mississippi. Proceedings - Mississippi Water Resources Conference, in Twenty-second Mississippi water resources conference. (B. J. Daniel, editor). 22, 1992. p. $101-114$.
OP-1011. M. L. Tuttle, P. H. Briggs, W. C. Evans, G. W. Kling and J. P. Lockwood*. Influence of mafic minerals on water chemistry and water-column stability of Lake Nyos, Cameroon. Proceedings - International Symposium on Water-Rock Interaction. 7, 1992. p. 449-452.

OP-1012. D. C. Twichell, N. H. Kenyon*, L. M. Parson* and B. A. McGregor. Depositional patterns of the Mississippi Fan surface; evidence from GLORIA II and high-resolution seismic profiles, in Seismic facies and sedimentary processes of submarine fans and turbidite systems. (Paul Weimer, editor and others), in the collection Frontiers in sedimentary geology. (A. H. Bouma, editor). New York, NY: Springer-Verlag, 1991. p. 349-363.

OP-1013. G. C. Ulmer*, B. O. Mysen* and B. R. Lipin. Editorial comment on paper by Arnulf Muan. Journal of the American Ceramic Society, in Collection of papers on phase equilibria. (B. R. Lipin, editor and others). v. 75, no. 6, June 1992. p. 13311332.

OP-1014. G. F. Ulmishek, R. R. Charpentier, C. C. Barton and R. G. Miller*. The global oil system; the relationship between oil generation, loss, half-life, and the world crude oil resource; discussion and reply. AAPG Bulletin. v. 77, no. 5, May 1993. p. 896-902.

OP-1015. G. E. Ulrich, M. W. Reynolds and R. B. Taylor. Toward digital geologic map standards; a progress report. ASTM Special Technical Publication = American Society for Testing and Materials Special Technical Publication, in Geographic information systems (GIS) and mapping; practices and standards. (A. I. Johnson, editor and others). 1126, 1992. p. 18-29.

OP-1016. J. J. Vaccaro. WASHINGTON, OREGON, IDAHO. Summary of the Columbia Plateau Regional Aquifer-System Analysis, Washington, Oregon, and Idaho. AWRA Monograph Series, in Regional aquifer systems of the United States; aquifers of the Far West. (K. R. Prince, editor and others). 16, June 1991. p. 65-97.

OP-1017. J. J. Vaccaro, R. S. Dinicola and H. H. Bauer. Recognition of the interdependence of surface water and ground-water resource investigation, in Interdisciplinary approaches in hydrology and hydrogeology. (M. E. Jones, editor and others). Minneapolis, MN: Am. Inst. Hydrol. 1992. p. 1-8.

OP-1018. N. J. Valette-Silver*, Fouad Tera* and M. J. Pavich. CALIFORNIA. ${ }^{10} \mathrm{Be}$ and ${ }^{9} \mathrm{Be}$ in the Salton Sea (USA) and other geothermal systems. Proceedings - International Symposium on Water-Rock Interaction, in Proceedings of the 7 th international symposium on Water-rock interaction; Volume 2, Moderate and high temperature environments. (Y. K. Kharaka, editor and others). 7, 1992. p. 983-986.

OP-1019. R. D. van der Hilst* and E. R. Engdahl. Step-wise relocation of ISC earthquake hypocenters for linearized tomographic imaging of slab structure. Physics of the Earth and Planetary Interiors, in Lateral heterogeneity and earthquake location. (Domenico Giardini, editor). v. 75, no. 1-3, December 31, 1992. p. 39-53.

OP-1020. R. D. van der Hilst*, E. R. Engdahl and Wim Spakman*. Tomographic inversion of $\mathrm{P}$ and $\mathrm{pP}$ data for aspherical mantle structure below the Northwest $P$ acific region. Geophysical Journal International. v. 115, no. 1, October 1993. p. 264-302. 
OP-1021. Richard Van Horn. UTAH. An alternative interpretation of deposits at the North Salt Lake City gravel pit, Utah. Miscellaneous Publication (Utah Geological and Mineral Survey), in In the footsteps of G. K. Gilbert; Lake Bonneville and neotectonics of the eastern Basin and Range Province; guidebook for field trip twelve. (M. N. Machette, editor). Report no. 88-1, 1988. p. 43.

OP-1022. Richard Van Horn and D: J. Varnes. UTAH. The Draper Formation (Lake Bonneville Group) in southern Utah. Miscellaneous Publication (Utah Geological and Mineral Survey), in In the footsteps of G. K. Gilbert; Lake Bonneville and neotectonics of the eastern Basin and Range Province; guidebook for field trip twelve. (M. N. Machette, editor). Report no. 88-1, 1988. p. 101-103.

OP-1023. P. C. Van Metre and J. R. Gray. ARIZONA, NEW MEXICO. Effects of uranium mining discharges on water quality in the Puerco River basin, Arizona and New Mexico. Hydrological Sciences Journal = Journal des Sciences Hydrologiques. v. 37 , no. 5 , October 1992. p. $463-480$.

OP-1024. D. J. Varnes. Predicting earthquakes by analyzing accelerating precursory seismic activity. Pure and Applied Geophysics. v. 130 , no. 4,1989 . p. 661-686.

OP-1025. G. S. Vartanyan*, J. D. Bredehoeft and E. A. Roeloffs. Gidrogeologicheskiye metody issledovaniy tektonicheskikh naprazheniy [Hydrogeological methods of investigating tectonic stress]. Sovetskaya Geologiya. v. 1991, no. 9, September 1991: p. 3-12.

OP-1026. Bruce Velde*, D. Moore, A. Badri* and B. Ledesert*. Fractal and length analysis of fractures during brittle to ductile changes. Journal of Geophysical Research, B, Solid Earth and Planets. v. 98 , no. 7, July 10, 1993. p. 11,935-11,940.

OP-1027. W. R. Vennum*, P. D. Rowley and T. S. Laudon*. Plutonic rocks of the English Coast and northern Behrendt Mountains, eastern Ellsworth Land, Antarctica. Antarctic Journal of the United States, in 1991 review. v. 26, no. 5, 1991. p. 41-44.

OP-1028. V. R. Vermeul*, J. D. Istok*, A. L. Flint and J. L. Pikul, Jr.*. An improved method for quantifying soil macroporosity. Soil Science Society of America Journal. v. 57, no. 3, June 1993. p. 809-816.

OP-1029. Lev Vernik*, D. A. Lockner and M. D. Zoback*. Anisotropic strength of some typical metamorphic rocks from the KTB pilot hole, Germany. Scientific Drilling. v. 3, no. 4, 1992. p. 153-160.

OP-1030. J. H. Vernon*, F. L. Paillet, W. H. Pedler* and W. J. Griswold*. Application of borehole geophysics in defining the wellhead protection area for a fractured crystalline bedrock aquifer. The Log Analyst. v. 34, no. 1, February 1993. p. 41-57.

OP-1031. J. E. Vidale and H. M. Benz. Seismological mapping of fine structure near the base of the Earth's mantle. Nature (London). v. 361, no. 6412, February 11, 1993. p. 529-532.

OP-1032. J. E. Vidale and H. M. Benz. A sharp and flat section of the core-mantle boundary. Nature (London). v. 359, no. 6396, October 15, 1992. p. 627-629.

OP-1033. J. E. Vidale and Heidi Houston*. The depth dependence of earthquake duration and implications for rupture mecha- nisms. Nature (London). v. 365, no. 6441, September 2, 1993. p. $45-47$.

OP-1034. J. E. Vidale and Thorne Lay*. Phase boundaries and mantle convection. Science. v. 261, no. 5127, September 10 , 1993. p. $1401-1402$.

OP-1035. J. G. Viets, R. T. Hopkins and B. M. Miller. Variations in minor and trace metals in sphalerite from mississippi valley-type deposits of the Ozark region; genetic implications; reply. Economic Geology and the Bulletin of the Society of Economic Geologists. v. 88, no. 5, August 1993. p. 1281-1284.

OP-1036. R. M. Vogel*, W. O. Thomas, Jr. and T. A. McMahon*. Flood-flow frequency model selection in southwestern United States. Journal of Water Resources Planning and Management. v. 119 , no. 3, June 1993. p. 353-366.

OP-1037. Roland von Huene* and D. W. Scholl. The return of sialic material to the mantle indicated by terrigeneous material subducted at convergent margins. Tectonophysics, in New horizons in strong motion; seismic studies and engineering practice. (A. G. Green, editor and others). v. 219, no. 1-3, 1993. p. 163-175.

OP-1038. J. H. Voncken*, H. L. Van Roermund*, A. M. van der Eerden*, J. B. Jansen* and R. C. Erd. Holotype buddingtonite; an ammonium feldspar without zeolitic $\mathrm{H}_{2} \mathrm{O}$. American Mineralogist. v. 78, no. 1-2, February 1993. p. 204209.

OP-1039. C. I. Voss and Johan Andersson*. Regional flow in the Baltic Shield during Holocene coastal regression. Ground Water. v. 31, no. 6, December 1993. p. 989-1006.

OP-1040. D. A. Vroblesky, J. F. Robertson, Mario Fernandez and C. M. Aelion*. The permeable-membrane method of passive soil-gas collection. Ground Water Management, in Proceedings of the Sixth national outdoor conference on Aquifer restoration, ground water monitoring, geophysical methods; a conference and exposition. (Anita Stanley, editor). 11, 1992. p. 316.

OP-1041. Uzi Vulkan and J. S. Duval. NEVADA. Multivariate statistical analysis of geophysical data in Nevada. Geophysics. v. 58, no. 5, May 1993. p. 749-755.

OP-1042. N. Waber and D. K. Nordstrom. Geochemical modeling of granitic ground waters at the Stripa site (Sweden) using a mass balance approach. Proceedings - International Symposium on Water-Rock Interaction. 7, 1992. p. 243-246.

OP-1043. K. L. Wahl. Extrapolation of regional flood frequency relations based on flow variability. Special Publication - Natural Hazards Research and Applications Information Center, in Inspiration; come to the headwaters; proceedings of the Fifteenth annual conference of the Association of State Floodplain Managers. (Jerry Louthain, chairperson). 24, 1992. p. 138-142.

OP-1044. K. L. Wahl. Is April to July runoff really decreasing in the Western United States?. Proceedings of the Western Snow Conference, in 59th annual meeting; Western snow conference. 59, 1991. p. $67-78$.

OP-1045. K. L. Wahl. Evaluation of trends in runoff in the Western United States. American Water Resources Association Technical Publication Series TPS, in American Water Resources 
Association 28th annual conference and symposium on Managing water resources during global change. (Raymond Herrmann, editor). $92-4,1992$. p. 701-710.

OP-1046. D. J. Wald, S. H. Hartzell and D. V. Helmberger. CALIFORNIA. Rupture processes of the 1987 Superstition Hills earthquake from the inversion of strong-motion data; reply. Bulletin of the Seismological Society of America. v. 82, no. 3, June 1992. p. 1519-1533.

OP-1047. D. J. Wald*, Hiroo Kanamori*, D. V. Helmberger* and T. H. Heaton. CALIFORNIA. Source study of the 1906 San Francisco earthquake. Bulletin of the Seismological Society of America. v. 83, no. 4, August 1993. p. 981-1019.

OP-1048. A. R. Wallace. NEVADA. Effect of late Miocene extension on the exposure of gold deposits in north-central Nevada, in Geology and ore deposits of the Great Basin; symposium proceedings. (G. L. Raines, editor and others). Reno, NV: Geological Society of Nevada, 1991. p. 179-183.

OP-1049. L. G. Wallace. USGS supports K-12 education. Geotimes. v. 38, no. 1, January 1993. p. 12-15.

OP-1050. S. R. Wallace* and A. A. Bookstrom. COLORADO. The Climax porphyry molybdenum system. Colorado School of Mines Quarterly. v. 93, no. 1, 1993. p. 35-41.

OP-1051. R. B. Wanty, P. F. Folger, David Frishman, P. H. Briggs, W. C. Day and E. P. Poeter*. COLORADO. Weathering of Pikes Peak Granite; field, experimental, and modelling observations. Proceedings - International Symposium on WaterRock Interaction. 7, 1992. p. 599-602.

OP-1052. R. B. Wanty, E. P. Lawrence and L. C. Gundersen. A theoretical model for the flux of radon from rock to ground water. Special Paper - Geological Society of America, in Geologic controls on radon. (A. E. Gates, editor and others). 271, 1992. p. 73-78.

OP-1053. P. L. Ward. SUDS; the Seismic Unified Data System. Eos, Transactions, American Geophysical Union. v. 73, no. 35, September 1, 1992. p. 380.

OP-1054. Kenneth Watson. Processing remote sensing images using the 2-D FFT; noise reduction and other applications. Geophysics. v. 58, no. 6, June 1993. p. 835-852.

OP-1055. Kenneth Watson. Two-temperature method for measuring emissivity. Remote Sensing of Environment. v. 42, no. 2, November 1992. p. 117-121.

OP-1056. Kenneth Watson. Spectral ratio method for measuring emissivity. Remote Sensing of Environment. v. 42, no. 2, November 1992. p. 113-116.

OP-1057. J. R. Watterson. ALASKA. Preliminary evidence for the involvement of budding bacteria in the origin of Alaskan placer gold: Reply. Geology (Boulder). v. 21, no. 3, March 1993. p. 280 .

OP-1058. G. A. Waychunas*, B. A. Rea, C. C. Fuller and J. A. Davis. Surface chemistry of ferrihydrite; Part 1, EXAFS studies of the geometry of coprecipitated and adsorbed arsenate. Geochimica et Cosmochimica Acta. v. 57, no. 10, May 1993. p. 2251-2269.
OP-1059. C. F. Waythomas, P. D. Lea* and R. C. Walter*. ALASKA. Stratigraphic context of Old Crow Tephra, Holitna Lowland, interior Southwest Alaska. Quaternary Research (New York). v. 40, no. 1, July 1993. p. 20-29.

OP-1060. R. H. Webb, S. S. Smith* and V. A. McCord*. UTAH, ARIZONA. Historic channel change of Kanab Creek, southern Utah and northern Arizona, 1991. Monograph - Grand Canyon Natural History Association. 9, 1991. 91 p.

OP-1061. J. D. Webster. Partitioning of F between $\mathrm{H}_{2} \mathrm{O}$ and $\mathrm{CO}_{2}$ fluids and topaz rhyolite melt; implications for mineralizing magmatic-hydrothermal fluids in F-rich granitic systems. Contributions to Mineralogy and Petrology. v. 104, no. 4, 1990. p. 424-438.

OP-1062. C. M. Weitz*, Charles Elachi*, H. J. Moore, A. T. Basilevsky*, B. A. Ivanov* and G. G. Schaber. Low-emissivity impact craters on Venus. LPI Contribution, in Papers presented to the international colloquium on Venus. (Lunar and Planetary Institute). 789, 1992. p. 129-131.

OP-1063. R. J. Weldon, II*, K. E. Meisling* and J. Alexander. CALIFORNIA. A speculative history of the San Andreas Fault in the central Transverse Ranges, California. Memoir - Geological Society of America, in The San Andreas fault system; displacement, palinspastic reconstruction, and geologic evolution. (R. E. Powell, editor and others). 178, 1993. p. 161-198.

OP-1064. L. G. Wennerberg. Multiple-scattering interpretations of coda-Q measurements. Bulletin of the Seismological Society of America. v. 83, no. 1, February 1993. p. 279-290.

OP-1065. A. F. White, A. E. Blum, T. D. Bullen, M. L. Peterson, M. S. Schulz and J. W. Harden. CALIFORNIA. A three million year weathering record for a soil chronosequence developed in granitic alluvium, Merced, California, USA. Proceedings - International Symposium on Water-Rock Interaction. 7, 1992. p. 607-610.

OP-1066. R. A. White and D. H. Harlow. Destructive uppercrustal earthquakes of Central America since 1900. Bulletin of the Seismological Society of America. v. 83, no. 4, August 1993. p. 1115-1142.

OP-1067. M. J. Whitehouse, J. S. Stacey and F. K. Miller. WASHINGTON, IDAHO. Age and nature of the basement in northeastern Washington and northern Idaho; isotopic evidence from Mesozoic and Cenozoic granitoids. Journal of Geology. v. 100, no. 6, November 1992. p. 691-701.

OP-1068. C. G. Whitney. Dioctahedral smectite reactions at elevated temperatures; effects of $\mathrm{K}$-availability, $\mathrm{Na} / \mathrm{K}$ ratio and ionic strength. Applied Clay Science, in Clays and hydrosilicate gels in nuclear fields. (Alain Meunier, editor). v. 7, no. 1-3, July 1992. p. 97-112.

OP-1069. C. G. Whitney and Bruce Velde. Changes in particle morphology during illitization; an experimental study. Clays and Clay Minerals. v. 41, no. 2, April 1993. p. 209-218.

OP-1070. J. W. Whitney and C. D. Harrington*. NEVADA. Relict colluvial boulder deposits as paleoclimatic indicators in the Yucca Mountain region, southern Nevada. Geological Society of America Bulletin. v. 105, no. 8, August 1993. p. 1008-1018. 
OP-1071. G. J. Wiche. NORTH DAKOTA. Evaporation computed by energy-budget and mass-transfer methods and water-balance estimates for Devils Lake, North Dakota, 1986-88. Water-Resources Investigation (Bismarck, ND). Report no. 11, 1992. 52 p.

OP-1072. W. D. Wiggins*, P. M. Harris* and R. C. Burruss. TEXAS, NEW MEXICO. Geochemistry of post-uplift calcite in the Permian Basin of Texas and New Mexico. Geological Society of America Bulletin. v. 105, no. 6, June 1993. p. 779-790.

OP-1073. R. J. Wilber*, J. A. Whitehead*, R. B. Halley and J. D. Milliman*. Carbonate-periplatform sedimentation by density flows; a mechanism for rapid off-bank and vertical transport of shallow-water fines: Comment. Geology (Boulder). v. 21, no. 7, July 1993. p. 667-668.

OP-1074. D. E. Wilhelms. Last chance at Taurus-Littrow. LPI Technical Report, in Workshop on Geology of the Apollo 17 landing site. (Graham Ryder, editor and others). 92-09, Part 1, 1992. p. 61-63.

OP-1075. D. A. Willard, T. M. Cronin, S. E. Ishman and R. J. Litwin. FLORIDA. Terrestrial and marine records of climatic and environmental changes during the Pliocene in subtropical Florida. Geology (Boulder). v. 21, no. 8, August 1993. p. 679-682.

OP-1076. R. A. Williams, K. W. King and J. C. Tinsley. UTAH. Site response estimates in Salt Lake Valley, Utah, from borehole seismic velocities. Bulletin of the Seismological Society of America. v. 83, no. 3, June 1993. p. 862-889.

OP-1077. T. C. Winter and M. R. Llamas* (editors). Hydrogeology of wetlands. Journal of Hydrology. v. 141, no. 1-4, January 1993. p. 1-269.

OP-1078. T. C. Winter and M. R. Llamas*. Introduction to the 28th international geological congress symposium on the Hydrogeology of wetlands. Journal of Hydrology, in Hydrogeology of wetlands. (T. C. Winter, editor and others). v. 141, no. 1-4, January 1993 . p. 1-3.

OP-1079. R. P. Wintsch*, J. F. Sutter, M. J. Kunk, J. N. Aleinikoff and M. J. Dorais*. Contrasting P-T-t paths; thermochronologic evidence for a late Paleozoic final assembly of the Avalon composite terrane in the New England Appalachians. Tectonics. v. 11, no. 3, June 1992. p. 672-689.

OP-1080. C. J. Wolfe*, E. A. Bergman and S. C. Solomon*. Oceanic transform earthquakes with unusual mechanisms or locations; relation to fault geometry and state of stress in the adjacent lithosphere. Journal of Geophysical Research, B, Solid Earth and Planets. v. 98, no. 9, September 10, 1993. p. 16,187-16,211.

OP-1081. J. A. Wolfe and R. O. Rye. IDAHO. Stable isotope study of fluid inclusions in fluorite from Idaho; implications for continental climates during the Eocene: Reply. Geology (Boulder). v. 21, no. 11, November 1993. p. 1051-1052.

OP-1082. J. A. Wolfe and W. C. Wehr*. Rosaceous Chamaebatiaria-like foliage from the Paleogene of western North America. Aliso. v. 12 , no. 1,1988 . p. 177-200.

OP-1083. J. A. Wolfe and W. C. Wehr*. WASHINGTON. Significance of the Republic Eocene fossil plants. Republic, WA: Stonerose Interp. Cent. 199?. 17 p.
OP-1084. W. J. Wolfe and B. A. Bryan. TENNESSEE. Drought-related West Tennessee channel bank failures. Hydraulic Engineering: Proceedings of the National Conference on Hydraulic Engineering, in Proceedings of the 1991 national conference on Hydraulic engineering. (R. M. Shane, editor). 1991, 1991. p. 1156-1161.

OP-1085. Ming-Ko Woo* and T. C. Winter. The role of permafrost and seasonal frost in the hydrology of northern wetlands in North America. Journal of Hydrology, in Hydrogeology of wetlands. (T. C. Winter, editor and others). v. 141, no. 1-4, January 1993. p. 5-31.

OP-1086. J. L. Wooden, G. K. Czamanske, V. A. Fedorenko*, N. T. Arndt*, Catherine Chauvel*, R. M. Bouse, B. W. King, R. J. Knight* and D. F. Siems*. Isotopic and trace-element constraints on mantle and crustal contributions to Siberian continental flood basalts, Noril'sk area, Siberia. Geochimica et Cosmochimica Acta. v. 57, no. 15, August 1993. p. 3677-3704.

OP-1087. J. L. Wooden, G. K. Czamanske and M. L. Zientek. MONTANA. A lead isotopic study of the Stillwater Complex, Montana; constraints on crustal contamination and source regions. Contributions to Mineralogy and Petrology. v. 107, no. 1, 1991. p. 80-93.

OP-1088. Max Wyss* and R. Y. Koyanagi. HAWAII. Seismic gaps in Hawaii. Bulletin of the Seismological Society of America. v. 82, no. 3, June 1992. p. 1373-1387.

OP-1089. T. M. Yanosky and D. A. Vroblesky. Relation of nickel concentrations in tree rings to groundwater contamination. Water Resources Research. v. 28, no. 8, August 1992. p. 2077 2083.

OP-1090. H. L. Young. WISCONSIN. Digital computer model of the sandstone aquifer in southeastern Wisconsin. Technical Report - Southeastern Wisconsin Regional Planning Commission. Report no. 16, April 1976. 42 p.

OP-1091. J. B. Young*, H. Aichele* and B. W. Presgrave. Region name conventions in the Flinn-Engdahl regionalization scheme. Geophysical Journal International. v. 114, no. 2, August 1993. p. 411-413.

OP-1092. Nabih Yousef, Samy Adham, Mehmet Celebi and Josephine Malilay*. Cairo, Egypt earthquake of October 12, 1992. Newsletter - Earthquake Engineering Research Institute. v. 26, no. 12 , December 1992. p. 1-6.

OP-1093. P. J. Zarriello. NEW YORK. Effects of increased retention time on storm-runoff quality in a normally dry flow-detention basin, Monroe County, New York, in Symposium on Urban hydrology; proceedings. (M. E. Jennings, editor). Bethesda, MD: Am. Water Resour. Assoc. November 1990. p. 111-123.

OP-1094. R. E. Zartman. MONTANA. Archean crustal lead in the Helena Embayment of the Belt Basin, Montana. Proceedings of the International Conference on Basement Tectonics, in Basement tectonics 8; Characterization and comparison of ancient and Mesozoic continental margins. (M. J. Bartholomew, editor and others). 8, 1988. p. 699-710.

OP-1095. F. N. Zihlman and M. P. Pantea. USGS explores CDROM technology. Geotimes. v. 38, no. 7, July 1993 . p. 17-19. 
OP-1096. D. R. Zimbelman. UTAH. Geology and geochemistry of gold deposits within and close to the Delta $1^{\circ} \times 2^{\circ}$ Quadrangle, west-central Utah, in Geology and ore deposits of the Great Basin; symposium proceedings. (G. L. Raines, editor and others). Reno, NV: Geological Society of Nevada, 1991. p. 263-277.

OP-1097. P. L. Zweng*, J. K. Mortensen* and G. B. Dalrymple. Thermochronology of the Camflo gold deposit, Malartic, Quebec; implications for magmatic underplating and the formation of gold-bearing quartz veins. Economic Geology and the Bulletin of the Society of Economic Geologists, in A special issue devoted to Abitibi ore deposits in a modern context. (E. T. Spooner, prefacer and others). v. 88, no. 6, October 1993. p. 1700-1721.

\section{ABSTRACTS}

\begin{abstract}
s are condensed but informative summaries of presentations made at meetings of scientific and professional organizations. Typically they summarize the principal conclusions of an author's current work but contain little supporting data. Non-U.S. Geological Survey personnel who share authorship in abstracts with U.S. Geological Survey personnel are indicated by an asterisk $\left(^{*}\right)$ immediately following the name. These publications are not available from the U.S. Geological Survey.
\end{abstract}

OP-1098. D. P. Adam. OREGON, CALIFORNIA. Paleoenvironmental records from the upper Klamath Basin, Oregon and California [abstr.] Abstracts with Programs - Geological Society of America, in Geological Society of America, Cordilleran Section, 88th annual meeting. v. 24, no. 5, May 1992. p. 2.

OP-1099. D. D. Adams*, C. J. Freeman*, R. J. Goldfarb, C. A. Gent and L. W. Snee. ALASKA. Age and geochemical constraints on mesothermal gold mineralization, Valdez Creek District, Alaska [abstr.] Abstracts with Programs - Geological Society of America, in Geological Society of America, Cordilleran Section, 88th annual meeting. v. 24, no. 5, May 1992. p. 2.

OP-1100. J. C. Adamski. MARYLAND. Geochemistry and hydrogeology of a fractured crystalline-rock aquifer in the Piedmont physiographic province, Howard County, Maryland [abstr.] Abstracts with Programs - Geological Society of America, in Geological Society of America, Southeastern Section, 27th annual meeting. v. 24, no. 3, March 1992. p. 1.

OP-1101. T. A. Ager and J. M. White*. ALASKA. Palynological evidence for climate and vegetation changes during middle to late Miocene time in northeastern Alaska [abstr.] Abstracts with Programs - Geological Society of America, in Geological Society of America, Cordilleran Section, 88th annual meeting. v. 24, no. 5, May 1992. p. 2.

OP-1102. D. C. Agnew and L. M. Jones. Prediction probabilities from foreshocks [abstr.] Seismological Research Letters, in 85th annual meeting of the Seismological Society of America. v. 61 , no. 1, March 1990. p. 15-16.

OP-1103. T. S. Ahlbrandt, J. L. Clayton and C. J. Schenk. Climatic fluctuations; possible controlling factor in source-rock and reservoir quality of Pennsylvanian cycles in Rocky Mountain basins [abstr.] Abstracts with Programs - Geological Society of America, in Geological Society of America, 1992 annual meeting. v. 24 , no. 7,1992 . p. 31 .

OP-1104. J. R. Albanese*, W. M. Kelly* and A. E. Grosz. NEW YORK. Aggregate and heavy-mineral resources of the continental shelf in the eastern New York Bight [abstr.] Abstracts with
Programs - Geological Society of America, in Geological Society of America, Northeastern Section, 28th annual meeting. v. 25, no. 2, March 1993. p. 1.

OP-1105. J. N. Aleinikoff and R. H. Moench. NEW HAMPSHIRE. U-Pb zircon ages of the Ordovician Ammonoosuc Volcanics and related plutons near Littleton and Milan, New Hampshire [abstr.] Abstracts with Programs - Geological Society of America, in Geological Society of America, Southeastern Section, 27th annual meeting. v. 24, no. 3, March 1992. p. 2.

OP-1106. J. N. Aleinikoff, Marianne Walter, P. T. Lyttle, W. C. Burton, G. W. Leo, A. E. Nelson, J. S. Schindler and C. S. Southworth. VIRGINIA. U-Pb zircon and monazite ages of middle Proterozoic rocks, northern Blue Ridge, Virginia [abstr.] Abstracts with Programs - Geological Society of America, in Geological Society of America, Northeastern Section, 28th annual meeting. v. 25, no. 2, March 1993. p. 2.

OP-1107. Guillermo Alfaro*, M. E. Cisternas*, Leonardo Diáz*, Sonia Helle* and N. J Page. Geoquimica de las rocas ultramaficas del complejo ofiolitico de la Cordillera de la Costa del Sur de Chile con enfasis en los elementos del Grupo del Platino; PGE [Geochemistry of the ultramafic rocks of the ophiolite complex in Cordillera de la Costa of southern Chile with emphasis on the platinum group elements; PGE] [abstr.] Serie Comunicaciones Departamento de Geología, Facultad de Ciencias Físicas y Matemáticas, Universidad de Chile, in Resumenes; $5^{\circ}$ congreso geologico chileno (Abstracts of the 5th Chilean geological congress). (José Corvalán D., editor and others). 39, 1988. p. 46.

OP-1108. S. T. Algermissen and E. V. Leyendecker. The estimation of earthquake spectra in the United States for building code purposes [abstr.] Eos, Transactions, American Geophysical Union, in AGU 1992 spring meeting. v. 73, no. 14, supplement, April 7, 1992. p. 206.

OP-1109. S. T. Algermissen and P. C. Thenhaus. The Worldwide Earthquake Risk Management Program; a progress report [abstr.] Eos, Transactions, American Geophysical Union, in AGU 1992 spring meeting. v. 73, no. 14, supplement, April 7, 1992. p. 205.

OP-1110. C. N. Alpers, D. K. Nordstrom and J. W. Ball. An evaluation of the solubility product constant of jarosite from oxidized mine waters aged 12 years [abstr.] Terra Cognita, in First international symposium on Thermodynamics of natural processes. v. 8 , no. 2,1988 . p. 178.

OP-1111. R. A. Ambroziak, R. E. Wicks* and G. R. Woodwell*. CD-ROM based courseware utilizing geologic information visualization [abstr.] Abstracts with Programs - Geological Society of America, in Geological Society of America, 1992 annual meeting. v. 24, no. 7, 1992. p. 132.

OP-1112. J. L. Anderson*, A. P. Barth*, E. E. Bender*, M. J. Davis*, D. F. Farber*, E. M. Hayes*, K. A. Johnson*, E. D. Young*, J. L. Wooden and R. M. Tosdal. CALIFORNIA. San Gabriel (Tujunga) Terrane; coming home to Mojave [abstr.] Abstracts with Programs - Geological Society of America, in Geological Society of America, 1990 annual meeting. v. 22, no. 7, 1990. p. 303.

OP-1113. R. R. Anderson*, J. B. Hartung*, D. J. Roddy and E. M. Shoemaker. IOWA. Research core drilling in the Manson impact structure, Iowa [abstr.] LPI Contribution, in Papers pre- 
sented to the International conference on Large meteorite impacts and planetary evolution. (B. O. Dressler, chairperson and others). 790,1992 . p. $2-3$.

OP-1114. R. R. Anderson*, B. J. Witzke*, J. B. Hartung*, E. M. Shoemaker and D. J. Roddy. IOWA. Descriptions and preliminary interpretations of cores recovered from the Manson impact structure (Iowa) [abstr.] Proceedings of the Lunar and Planetary Science Conference, in Abstracts of papers submitted to the Twenty-fourth lunar and planetary science conference. (Douglas Blanchard, chairperson and others). 24, 1993. p. 35-36.

OP-1115. M. A. Arthur*, L. R. Kump*, W. E. Dean and R. L. Larson*. Superplume, supergreenhouse? [abstr.] Eos, Transactions, American Geophysical Union, in AGU-MSA 1991 spring meeting. v. 72 , no. 17, April 23, 1991. p. 301.

OP-1116. Sigrid Asher-Bolinder. Cookeite in filled sinks of the Ozark Uplift; an indication of hydrothermal alteration [abstr.] Abstracts with Programs - Geological Society of America, in Geological Society of America, North-Central Section, 26th annual meeting. v. 24, no. 4, April 1992. p. 3.

OP-1117. Sigrid Asher-Bolinder, M. B. Goldhaber and M. R. Hudson. MVT fluids altered filled-sink deposits of the Ozark Uplift [abstr.] Abstracts with Programs - Geological Society of America, in Geological Society of America, North-Central Section, 27th annual meeting. v. 25, no. 3, March 1993. p. 3.

OP-1118. B. F. Atwater. WASHINGTON. A Seattle tsunami 1100 years ago [abstr.] Abstracts with Programs - Geological Society of America, in Geological Society of America, Cordilleran Section, 88th annual meeting. v. 24, no. 5, May 1992. p. 4.

OP-1119. B. F. Atwater. WASHINGTON. Prehistoric earthquakes in western Washington [abstr.] Abstracts with Programs Geological Society of America, in Geological Society of America, Cordilleran Section, 88th annual meeting. v. 24, no. 5, May 1992. p. 4.

OP-1120. B. F. Atwater. Great earthquakes of the last 2000 years in the Pacific Northwest [abstr.] NUREG/CP (United States, Nuclear Regulatory Commission), in Proceedings of the U.S. Nuclear Regulatory Commission; Eighteenth water reactor safety information meeting. (A. J. Weiss, compiler). Report no. NUREG/CP-0114, April 1991. p. 337.

OP-1121. E. V. Axtmann, R. F. Stallard and B. H. Vaughn*. WASHINGTON. Controls on subglacial weathering in a small glacierized basin in the northern Cascade Mountains, Washington [abstr.] Eos, Transactions, American Geophysical Union, in AGU 1993 spring meeting. v. 74, no. 16, Suppl. May 1993. p. 329.

OP-1122. R. A. Ayuso and S. M. Barr*. Lead isotopic compositions of plutonic rocks in Cape Breton Island, Nova Scotia; implications for petrogenesis and terrane correlation [abstr.] Abstracts with Programs - Geological Society of America, in Geological Society of America, Northeastern Section, 28th annual meeting. v. 25, no. 2, March 1993. p. 3.

OP-1123. L. E. Babcock* and R. B. Blodgett. ALASKA. Biogeographic and paleogeographic significance of Middle Cambrian trilobites of Siberian aspect from southwestern Alaska [abstr.] Abstracts with Programs - Geological Society of America, in Geological Society of America, Cordilleran Section, 88th annual meeting. v. 24, no. 5, May 1992. p. 4.
OP-1124. C. R. Bacon. OREGON. Partially melted granodiorite and related rocks in the ejecta of Crater Lake Caldera, Oregon [abstr.] Abstracts with Programs - Geological Society of America, in Geological Society of America, Cordilleran Section, 88th annual meeting. v. 24, no. 5, May 1992. p. 4.

OP-1125. M. S. Baig*, L. W. Snee and R. D. Lawrence*. Early Proterozoic to late Paleozoic tectonic history of the Northwest Himalaya, Pakistan; ${ }^{40} \mathrm{Ar} /{ }^{39} \mathrm{Ar}$ constraints [abstr.] Abstracts with Programs - Geological Society of America, in Geological Society of America, 1992 annual meeting. v. 24, no. 7, 1992. p. 281.

OP-1126. A. K. Baird*, W. B. Wadsworth* and D. M. Morton. CALIFORNIA. An application of X-ray diffraction modes to variability throughout the Lakeview Mountains Pluton, Southern California [abstr.] Abstracts with Programs - Geological Society of America, in Geological Society of America, Cordilleran Section, 88th annual meeting. v. 24, no. 5, May 1992. p. 5.

OP-1127. P. A. Baker*, S. L. Cross*, S. J. Burns* and R. A. Zierenberg. Geochemistry of carbon and sulfur in hydrothermal sediments of the middle valley of the Juan de Fuca Ridge [abstr.] AAPG Bulletin, in AAPG Pacific Section abstracts. v. 77, no. 4, April 1993. p. 689.

OP-1128. R. J. Baker and A. L. Baehr. Use of column studies in conjunction with a gas-transport model to determine gasoline-hydrocarbon degradation rates in unsaturated sandy porous media [abstr.] Eos, Transactions, American Geophysical Union, in AGU 1992 spring meeting. v. 73, no. 14, Suppl. April 7, 1992. p. 115.

OP-1129. P. E. Baldauf*, G. C. Stephens*, M. J. Kunk and F. E. Nullo*. Argon-argon age spectra results of homblende from the Huincan Intrusive Suite; implications for the structural development of the Andean foreland; southern Mendoza Province, Argentina [abstr.] Abstracts with Programs - Geological Society of America, in Geological Society of America, 1992 annual meeting. v. 24 , no. 7,1992 . p. 188.

OP-1130. B. P. Baldigo and P. S. Murdoch. NEW YORK. Effect of acidic episodes on Brook Trout (Salveinus fontinalis) survival and populations in streams of the Catskill Mountains, New York [abstr.] Eos, Transactions, American Geophysical Union, in AGU 1992 spring meeting. v. 73, no. 14, Suppl. April 7, 1992. p. 114.

OP-1131. J. D. Bales. NORTH CAROLINA. Hydrodynamics and circulation of the Pamlico and Neuse River estuaries [abstr.], in Albemarle-Pamlico estuarine study; project abstracts, FY 1989 \& FY 1990. Report no. 90-18, October 1990. p. 26. Available from: N.C. Dep. Nat. Resour. and Comm. Div., United States.

OP-1132. M. M. Ball. The Bahamian megabank hypothesis [abstr.] Abstracts with Programs - Geological Society of America, in Geological Society of America, 1990 annual meeting. v. 22, no. 7,1990 . p. 233.

OP-1133. M. M. Ball. Caribbean Plate interactions [abstr.] AAPG Bulletin, in AAPG/SVG international congress/exhibition; abstracts. v. 77, no. 2, February 1993. p. 305.

OP-1134. J. F. Banfield*, B. F. Jones and D. R. Veblen*. OREGON. An AEM-TEM study of sequential weathering and diagenetic reactions, Abert Lake, south-central Oregon [abstr.] Abstracts 
with Programs - Geological Society of America, in Geological Society of America, 1990 annual meeting. v. 22, no. 7, 1990. p. 292.

OP-1135. C. E. Barker. Calibration of the vitrinite reflectance geothermometer using an improved resolution of the peak temperature from reequilibrated fluid inclusions in burial, geothermal and contact metamorphic environments [abstr.] Annual Meeting of the Society for Organic Petrology. Abstracts and Program, in Ninth annual meeting of the Society for Organic Petrology. (S. A. Stout, editor). 9, July 23, 1992. p. 8.

OP-1136. C. E. Barker, Yvonne Bone*, I. R. Duddy*, S. J. Marshallsea* and P. F. Green*. Peak temperature estimated from fluid inclusions and vitrinite reflectance next to a thin dike near San Remo, Victoria, Australia [abstr.] Annual Meeting of the Society for Organic Petrology. Abstracts and Program, in Ninth annual meeting of the Society for Organic Petrology. (S. A. Stout, editor). 9, July 23, 1992. p. 102-104.

OP-1137. C. E. Barker and M. J. Pawlewicz. An estimate of the minimum number of measurements needed to constrain the mean random vitrinite reflectance of disseminated organic matter [abstr.] Annual Meeting of the Society for Organic Petrology. Abstracts and Program, in Ninth annual meeting of the Society for Organic Petrology. (S. A. Stout, editor). 9, July 23, 1992. p. 10-11.

OP-1138. Fred Barker and G. L. Farmer*. Granites as crustal probes; process vs. source [abstr.] Eos, Transactions, American Geophysical Union, in AGU-MSA 1991 spring meeting. v. 72, no. 17, April 23, 1991. p. 301.

OP-1139. C. G. Barnes*, Kenneth Johnson*, M. A. Barnes*, Tore Prestvik* and R. W. Kistler. OREGON. The Grayback Pluton; magmatism in a Jurassic back-arc environment, Klamath Mountains, Oregon [abstr.] Special Paper - Geological Society of America, in The second Hutton symposium on the origin of granites and related rocks; proceedings. (P. E. Brown, editor and others). 272, 1992. p. 485.

OP-1140. C. G. Barnes*, H. R. Karlsson*, K. Johnson* and R. W. Kistler. OREGON. Isotopic variation of pre- and post-Nevadan plutons, (Middle Jurassic-Early Cretaceous) Klamath Mountains [abstr.] Abstracts with Programs - Geological Society of America, in Geological Society of America, Cordilleran Section, 88th annual meeting, 1992. (A. D. Johnston, chairperson). v. 24, no. 5, May 1992. p. 6.

OP-1141. C. G. Barnes*, S. W. Petersen*, Tore Prestvik*, R. W. Kistler and B. Sundvoll*. CALIFORNIA, OREGON. Isotopic variation of Jurassic plutons, Klamath Mountains [abstr.] Abstracts with Programs - Geological Society of America, in Geological Society of America, 1990 annual meeting. v. 22, no. 7, 1990. p. 345.

OP-1142. D. F. Barnes. ALASKA. Small gravity changes indicate that different processes are involved in post-1964-Alaskanearthquake elevation changes [abstr.] Eos, Transactions, American Geophysical Union, in AGU 1993 fall meeting. v. 74, no. 43, Suppl. October 26, 1993. p. 95.

OP-1143. P. W. Barnes*, E. C. Hayden*, Michael McCormick* and Erk Reimnitz. The effect of ice on coastal erosion in southern Lake Michigan; a video [abstr.] Abstracts with Programs - Geological Society of America, in Geological Society of America, North- eastern Section, 28th annual meeting. v. 25, no. 2, March 1993. p. 4.

OP-1144. J. A. Barron. The unique contribution of biostratigraphy; getting it across [abstr.] Annual Meeting Abstracts - American Association of Petroleum Geologists and Society of Economic Paleontologists and Mineralogists, in American Association of Petroleum Geologists 1993 annual convention. 1993, April 1993. p. 72-73.

OP-1145. J. A. Barron, Birger Larsen* and J. G. Baldauf*. Extensive late Eocene and early Oligocene Antarctic glaciation and climatic fluctuations during the late Neogene; a synthesis of ODP Leg 119 [abstr.] Abstracts with Programs - Geological Society of America, in Geological Society of America, 1990 annual meeting. v. 22 , no. 7, 1990. p. 171.

OP-1146. A. P. Barth*, R. M. Tosdal* and J. L. Wooden*. CALIFORNIA. Initiation of the Mesozoic Cordilleran arc in Southern California [abstr.] Abstracts with Programs - Geological Society of America, in Geological Society of America, Cordilleran Section, 88th annual meeting, 1992. (A. D. Johnston, chairperson). v. 24, no. 5, May 1992. p. 6.

OP-1147. M. J. Bartholomew*, S. E. Lewis*, A. P. Schultz and R. C. McDowell. A preliminary Alleghanian tectonothermal sequence for the Appalachian fold and thrust belt [abstr.] Abstracts with Programs - Geological Society of America, in Geological Society of America, 1992 annual meeting. v. 24, no. 7, 1992. p. 158.

OP-1148. M. D. Barton*, H. E. Trim* and J. N. Grossman. CALIFORNIA. The time-space development of a two-mica granite and its aureole; the Birch Creek Pluton, White Mountains, California [abstr.] Abstracts with Programs - Geological Society of America, in Geological Society of America, 1990 annual meeting. v. 22 , no. 7,1990 . p. $179-180$.

OP-1149. A. T. Basilevsky*, R. M. Batson and G. A. Burba*. Pre-Magellan mapping of northern Venus; completion of a joint U.S./U.S.S.R. project [abstr.] Abstracts of Papers Submitted to the Lunar and Planetary Science Conference, in Abstracts of papers submitted to the Twenty-first lunar and planetary science conference. (Lunar and Planetary Institute). 21, 1990. p. 50-51.

OP-1150. A. L. Bates, E. C. Spiker and W. H. Orem. PALAU. Sediments from Jellyfish Lake, Palau; sulfur species and their isotopic composition [abstr.] Abstracts of Papers - American Chemical Society, National Meeting, in 203rd ACS national meeting. 203, 1992. p. GEOC 47.

OP-1151. D. W. Beaty*, G. P. Landis and T. B. Thompson*, COLORADO. Comparative geology and genetic relationships among the $\mathrm{Pb}-\mathrm{Zn}-\mathrm{Ag}$-Au ores hosted in the Leadville Dolomite in central Colorado [abstr.] Abstracts with Programs - Geological Society of America, in Geological Society of America, 1990 annual meeting. v. 22 , no. 7,1990 . p. 181.

OP-1152. J. L. Becker*, M. J. Kunk, R. P. Wintsch* and A. A. Drake, Jr. MARYLAND, VIRGINIA. Evidence for pre-Taconic metamorphism in the Potomac Terrane, Maryland and Virginia; hornblende and muscovite ${ }^{40} \mathrm{Ar} /{ }^{39} \mathrm{Ar}$ results [abstr.] Abstracts with Programs - Geological Society of America, in Geological Society of America, Northeastern Section, 28th annual meeting. v. 25, no. 2, March 1993. p. 5. 
OP-1153. J. F. Bell, III*, W. M. Calvin, J. B. Pollack* and David Crisp*. An observational search for $\mathrm{CO}_{2}$ ice clouds on Mars [abstr.] Proceedings of the Lunar and Planetary Science Conference, in Abstracts of papers submitted to the Twenty-fourth lunar and planetary science conference. (Douglas Blanchard, chairperson and others). 24, 1993. p. 83-84.

OP-1154. M. J. Bennett, M. G. Bonilla and T. L. Holzer. CALIFORNIA. Liquefaction in the Marina District, San Francisco, California, during the Loma Prieta earthquake [abstr.] Abstracts with Programs - Geological Society of America, in Geological Society of America, 1990 annual meeting. v. 22, no. 7, 1990. p. 188.

OP-1155. P. C. Bennett*, F. K. Hiebert* and M. J. Baedecker. Microbial influences on inorganic solute mobilization and transport in an oil contaminated aquifer [abstr.] Abstracts with Programs - Geological Society of America, in Geological Society of America, 1992 annual meeting. v. 24 , no. 7,1992 . p. 128.

OP-1156. L. V. Benson, S. W. Hostetler and F. Giorgi. Climate induced variation in the hydrologic balances of Lake Lahontan and Lake Bonneville during the past 25,000 years [abstr.] Abstracts with Programs - Geological Society of America, in Geological Society of America, 1990 annual meeting. v. 22, no. 7, 1990. p. 253.

OP-1157. H. M. Benz, George Zandt* and D. H. Oppenheimer. CALIFORNIA. Seismic imaging of the subducting plate and the slabless window beneath Northern California [abstr.] Seismological Research Letters, in 85th annual meeting of the Seismological Society of America. v. 61, no. 1, March 1990. p. 32.

OP-1158. B. R. Berger. Tectonic setting of Tertiary hydrothermal systems in the Great Basin region [abstr.] Proceedings of the International Conference on Basement Tectonics, in Basement tectonics 8; Characterization and comparison of ancient and Mesozoic continental margins. (M. J. Bartholomew, editor and others). 8,1988 . p. 729 .

OP-1159. B. R. Berger and L. W. Snee. WASHINGTON. Thermochronologic constraints on mylonite and detachment fault development, Kettle Highlands, northeastern Washington and southern British Columbia [abstr.] Abstracts with Programs Geological Society of America, in Geological Society of America, 1992 annual meeting. v. 24 , no. 7,1992 . p. 65

OP-1160. E. A. Bergman. The International Seismological Observing Period (ISOP) in Asia and the western Pacific [abstr.] Eos, Transactions, American Geophysical Union, in AGU 1992 western Pacific geophysical meeting. v. 73, no. 25, Suppl. June 23, 1992. p. 56.

OP-1161. E. A. Bergman. The International Seismological Observing Period (ISOP); simulations and data flow [abstr.] Eos, Transactions, American Geophysical Union, in AGU 1992 western Pacific geophysical meeting. v. 73, no. 25, Suppl. June 23, 1992. p. 56.

OP-1162. L. M. Bertolini and A. S. McEwen. Digital mosaic and elevation model of central Valles Marineris, Mars [abstr.] Abstracts of Papers Submitted to the Lunar and Planetary Science Conference, in Abstracts of papers submitted to the Twenty-first lunar and planetary science conference. (Lunar and Planetary Institute). 21, 1990. p. 75-76.
OP-1163. J. P. Bibring*, Y. Langevin*, S. Erard*, O. Forni*, P. L. Masson*, C. J. Sotin*, M. Combes*, V. I. Moroz*, A. Coradini*, V. Formisano*, J. W. Head*, L. A. Soderblom, F. P. Fanale*, T. B. McCord* and D. P. Cruikshank*. The observation of the surface of Mars by the ISM instrument on board the Phobos 2 spacecraft [abstr.] Abstracts of Papers Submitted to the Lunar and Planetary Science Conference, in Abstracts of papers submitted to the Twenty-first lunar and planetary science conference. (Lunar and Planetary Institute). 21, 1990. p. 79-80.

OP-1164. N. L. Blair. Use of a citation index to quantify the influence of Earth science researchers on work of others [abstr.] Abstracts with Programs - Geological Society of America, in Geological Society of America, 1992 annual meeting. v. 24, no. 7, 1992. p. 248.

OP-1165. M. C. Blake, Jr. and M. A. Lanphere. CALIFORNIA. Upper Cretaceous blueschist-facies metamorphism in the Diablo Range, Northern California [abstr.] Abstracts with Programs - Geological Society of America, in Geological Society of America, Cordilleran Section, 88th annual meeting, 1992. (A. D. Johnston, chairperson). v. 24, no. 5, May 1992 . p. 8.

OP-1166. M. C. Blake, Jr. and C. M. Wentworth. CALIFORNIA, OREGON. Preliminary metamorphic facies map of western California and southwestern Oregon [abstr.] Abstracts with Programs - Geological Society of America, in Geological Society of America, 1992 annual meeting. v. 24, no. 7, 1992. p. 292.

OP-1167. R. J. Blakely and W. D. Stanley. CALIFORNIA. The Geysers magma chamber revisited; constraints from idealbody theory and new density measurements [abstr.] Eos, Transactions, American Geophysical Union, in AGU 1992 fall meeting. v. 73 , no. 43 , suppl. October 27,1992 . p. $348-349$.

OP-1168. R. B. Blodgett and W. G. Gilbert*. Paleogeographic relations of lower and middle Paleozoic strata of Southwest and west-central Alaska [abstr.] Abstracts with Programs - Geological Society of America, in Geological Society of America, Cordilleran Section, 88th annual meeting, 1992. (A. D. Johnston, chairperson). v. 24, no. 5, May 1992. p. 8.

OP-1169. C. D. Blome, S. W. Nelson and S. M. Karl. ALASKA. Accretionary history of the chert-rich McHugh Complex, southern Alaska [abstr.] Abstracts with Programs - Geological Society of America, in Geological Society of America, 1990 annual meeting. v. 22 , no. 7,1990 . p. 321-322.

OP-1170. A. E. Blum, M. F. Hochella, Jr.* and A. F. White. CALIFORNIA. The surface chemistry of feldspars during weathering; XPS measured surface compositions from a soil in the San Joaquin Valley, CA [abstr.] Abstracts with Programs - Geological Society of America, in Geological Society of America, 1990 annual meeting. v. 22 , no. 7,1990 . p. 291-292.

OP-1171. Paul Bodin*, W. Z. Savage, J. S. Gomberg and M. E. Jackson*. COLORADO. The Slumgullion earthflow; an analog to crustal-scale tectonics? [abstr.] Eos, Transactions, American Geophysical Union, in AGU 1993 fall meeting. v. 74, no. 43, Suppl. October 26, 1993. p. 67.

OP-1172. R. G. Bohannon, E. L. Geist and Christopher Sorlien*. CALIFORNIA. Miocene extensional tectonism on California continental borderland between San Clemente and Patton Escarpment [abstr.] AAPG Bulletin, in AAPG Pacific Section abstracts. v. 77, no. 4, April 1993. p. 691. 
OP-1173. S. R. Bohlen, B. R. Hacker*, W. B. Hankins, J. O. Eckert, Jr., S. H. Kirby, Jun Liu and J. L. Mosenfelder*. Reac- tion kinetics, P-T-t paths and rates of tectonic processes [abstr.] Abstracts with Programs - Geological Society of America, in Geological Society of America, 1992 annual meeting. v. 24, no. 7, 1992. p. 256.

OP-1174. J. K. Bohlke, J. M. Denver, C. J. Gwinn, L. N. Plummer, Eurybiades Busenberg and S. A. Dunkle. MARYLAND. Combined use of nitrogen isotopes and ground-water dating to document nitrate fluxes and transformations in small agricultural watersheds; Delmarva Peninsula, Maryland [abstr.] Eos, Transactions, American Geophysical Union, in AGU 1992 spring meeting. v. 73, no. 14, Suppl. April 7, 1992. p. 140

OP-1175. J. K. Bohlke and J. J. Irwin*. Noble gases and halides in gold quartz veins as indicators of fluid sources, salinity sources, mixing, and unmixing [abstr.], in Greenstone gold and crustal evolution; NUNA conference volume. (François Robert, editor and others). St. John's, NF: Geol. Assoc. Canada, 1990. p. 134.

OP-1176. J. S. Böhlke and E. L. Shock*. Carbonic acid dissociation in aqueous metamorphic fluids [abstr.] Abstracts with Programs - Geological Society of America, in Geological Society of America, 1990 annual meeting. v. 22, no. 7, 1990. p. 348.

OP-1177. B. F. Bohor. Large meteorite impacts; the K/T model [abstr.] LPI Contribution, in Papers presented to the International conference on Large meteorite impacts and planetary evolution. (B. O. Dressler, chairperson and others). 790, 1992. p. 8-9.

OP-1178. B. F. Bohor and W. J. Betterton. Shocked zircons in the Onaping Formation; further proof of impact origin [abstr.] LPI Contribution, in Papers presented to the International conference on Large meteorite impacts and planetary evolution. (B. O. Dressler, chairperson and others). 790, 1992. p. 9-10.

OP-1179. B. F. Bohor and W. J. Betterton. Arroyo el Mimbral, Mexico, K/T unit; origin as debris flow/turbidite, not a tsunami deposit [abstr.] Proceedings of the Lunar and Planetary Science Conference, in Abstracts of papers submitted to the Twenty-fourth lunar and planetary science conference. (Douglas Blanchard, chairperson and others). 24, 1993. p. 143-144.

OP-1180. B. F. Bohor and W. J. Betterton. K-T spherules; clarifying the concept [abstr.] Abstracts of Papers Submitted to the Lunar and Planetary Science Conference, in Abstracts of papers submitted to the Twenty-first lunar and planetary science conference. (Lunar and Planetary Institute). 21, 1990. p. 107-108.

OP-1181. B. F. Bohor, B. P. Glass* and W. J. Betterton. WYOMING. K/T spherules from Haiti and Wyoming; origin, diagenesis, and similarity to some microtektites [abstr.] Proceedings of the Lunar and Planetary Science Conference, in Abstracts of papers submitted to the Twenty-fourth lunar and planetary science conference. (Douglas Blanchard, chairperson and others). 24, 1993. p. $145-146$.

OP-1182. B. F. Bohor and A. L. Meier. REE abundances of tonsteins and K-T boundary claystones by ICP-MS [abstr.] Abstracts of Papers Submitted to the Lunar and Planetary Science Conference, in Abstracts of papers submitted to the Twenty-first lunar and planetary science conference. (Lunar and Planetary Institute). 21, 1990. p. 109-110.
OP-1183. Ornella Bonamassa*, J. E. Vidale, W. H. Lee and H. Liu. The relation between ground motions and near-surface geology [abstr.] Eos, Transactions, American Geophysical Union, in AGU 1992 fall meeting. v. 73, no. 43, suppl. October 27, 1992. p. 338 .

OP-1184. R. D. Borcherdt and K. W. Campbell*. Predictive mapping of strong ground shaking for seismic hazard zonation [abstr.] Eos, Transactions, American Geophysical Union, in AGU 1992 spring meeting. v. 73, no. 14, supplement, April 7, 1992. p. 206 .

OP-1185. M. H. Bothner and J. F. Grassle*. NEW YORK. Indicators and biological effects of contamination in sediments beneath the 106-mile sewage sludge dumpsite off New York; an overview [abstr.] Eos, Transactions, American Geophysical Union, in AGU 1992 spring meeting. v. 73, no. 14, Suppl. April 7, 1992. p. 164.

OP-1186. S. E. Box. ALASKA. Evidence for basin-margin right-slip faulting during Kuskokwim Group deposition, southwestern Alaska [abstr.] Abstracts with Programs - Geological Society of America, in Geological Society of America, Cordilleran Section, 88th annual meeting, 1992. (A. D. Johnston, chairperson). v. 24, no. 5, May 1992. p. 8-9.

OP-1187. S. E. Box. WASHINGTON. Detachment origin for Republic Graben, NE Washington [abstr.] Abstracts with Programs - Geological Society of America, in Geological Society of America, Cordilleran Section, 88th annual meeting, 1992. (A. D. Johnston, chairperson). v. 24, no. 5, May 1992. p. 9.

OP-1188. J. Boyd*, R. P. Wintsch* and M. J. Kunk. Possible polymetamorphism in the Bronson Hill terranes; a 100 m.y. age gradient in ${ }^{40} \mathrm{Ar} /{ }^{39} \mathrm{Ar}$ hornblende ages [abstr.] Abstracts with Programs - Geological Society of America, in Geological Society of America, Northeastern Section, 28th annual meeting. v. 25, no. 2, March 1993. p. 6.

OP-1189. T. M. Boyd*, E. R. Engdahl and W. J. Spence. ALASKA. Comparison of Aleutian aftershock locations; inferences on the nature of seismic moment release [abstr.] Eos, Transactions, American Geophysical Union, in AGU 1993 fall meeting. v. 74, no. 43, Suppl. October 26, 1993. p. 95.

OP-1190. E. E. Brabb. Reducing landslide damage [abstr.] Eos, Transactions, American Geophysical Union, in AGU 1989 fall meeting. v. 70, no. 43, October 24, 1989. p. 1003.

OP-1191. J. V. Brahana. MISSOURI, ARKANSAS. Tectonic control of regional ground-water flow in deeply buried aquifers of the northern Mississippi Embayment, Missouri and Arkansas [abstr.] Abstracts with Programs - Geological Society of America, in Geological Society of America, North-Central Section, 27th annual meeting. v. 25, no. 3, March 1993. p. 9.

OP-1192. J. V. Brahana. Conceptual model of hydrogeology in the Ozark plateaus region during Pennsylvanian time [abstr.] Abstracts with Programs - Geological Society of America, in Geological Society of America, North-Central Section, 27th annual meeting. v. 25, no. 3, March 1993. p. 9.

OP-1193. T. J. Bralower* and W. V. Sliter. An integrated Cretaceous calcareous nannofossil and planktonic foraminifer biostratigraphy [abstr.] Annual Meeting Abstracts - American Association of Petroleum Geologists and Society of Economic 
Paleontologists and Mineralogists, in American Association of Petroleum Geologists 1993 annual convention. 1993, April 1993. p. 79.

OP-1194. D. A. Brew. ALASKA. Origin and distribution of granitic and related rocks in the Coast plutonic-metamorphic complex, N. American Cordillera, Southeastern Alaska, U.S.A. [abstr.] Special Paper - Geological Society of America, in The second Hutton symposium on the origin of granites and related rocks; proceedings. (P. E. Brown, editor and others). 272, 1992. p. 486.

OP-1195. D. A. Brew, S. M. Karl, R. A. Loney, A. B. Ford, G. R. Himmelberg and J. M. Hammarstrom. ALASKA. Jurassic and Cretaceous batholiths of southeastern Alaska; how many arcs? [abstr.] Abstracts with Programs - Geological Society of America, in Geological Society of America, Cordilleran Section, 88th annual meeting, 1992. (A. D. Johnston, chairperson). v. 24, no. 5, May 1992. p. 9.

OP-1196. A. R. Brockman and G. E. Harlow, Jr. VIRGINIA. The shallow aquifer system at the Naval Surface Warfare Center, Dahlgren Laboratory, Dahlgren, Virginia [abstr.] AAPG Bulletin, in AAPG Eastern Section meeting. v. 77, no. 8, August 1993. p. 1466.

OP-1197. H. C. Brooks*, M. Cummings*, J. G. Evans and M. L. Ferns*. IDAHO. Geology of the northwest $1 / 4$ of the Boise $2^{\circ}$ Sheet [abstr.] Abstracts with Programs - Geological Society of America, in Geological Society of America, Cordilleran Section, 88th annual meeting, 1992. (A. D. Johnston, chairperson). v. 24, no. 5, May 1992. p. 10 .

OP-1198. E. M. Brouwers, D. G. Hadley and T. M. Bown. Quaternary carbonate paleodune deposits in central and western Abu Dhabi Emirate, United Arab Emirates [abstr.] Abstracts with Programs - Geological Society of America, in Geological Society of America, 1992 annual meeting. v. 24, no. 7, 1992. p. 314.

OP-1199. Marc Brouxel and Mitsunobu Tatsumoto. The Estherville mesosiderite; a polymict breccia formed 4.42 to $4.55 \mathrm{Ga}$ ago; $\mathrm{U}-\mathrm{Pb}, \mathrm{Rb}-\mathrm{Sr}$, and $\mathrm{Sm}-\mathrm{Nd}$ isotopic evidence [abstr.] Abstracts of Papers Submitted to the Lunar and Planetary Science Conference, in Abstracts of papers submitted to the Twenty-first lunar and planetary science conference. (Lunar and Planetary Institute). 21, 1990. p. 133-134.

OP-1200. C. E. Brown, W. W. Wood and W. E. Sanford. TEXAS. Use of direct-current electrical-resistivity and electromagnetic techniques to investigate subsurface conditions around a saline lake on the Southern High Plains, Texas [abstr.] Abstracts with Programs - Geological Society of America, in Geological Society of America, 1992 annual meeting. v. 24, no. 7, 1992. p. 302.

OP-1201. S. R. Brown* and D. J. Andrews. Scale-independent description of the closure of a single fracture under varying normal stress [abștr.] Eos, Transactions, American Geophysical Union, in AGU-MSA 1991 spring meeting. v. 72, no. 17, April 23, 1991. p. 286.

OP-1202. T. D. Bullen and P. B. McMahon. SOUTH CAROLINA. Evolution of ${ }^{87} \mathrm{Sr} /{ }^{86} \mathrm{Sr}$ and $\delta^{7} \mathrm{Li}$ in groundwater from the Black Creek Aquifer; confirmation of a model for the origin of $\mathrm{Na}-\mathrm{HCO}_{3}$ waters in clastic aquifers [abstr.] Eos, Transactions,
American Geophysical Union, in AGU 1992 spring meeting. v. 73, no. 14, Suppl. April 7, 1992. p. 139.

OP-1203. T. K. Bundtzen* and M. L. Miller. ALASKA. Petrology and metallogeny of Late Cretaceous-early Tertiary igneous rocks, Kuskokwim Mountains, Southwest Alaska [abstr.] Abstracts with Programs - Geological Society of America, in Geological Society of America, Cordilleran Section, 88th annual meeting, 1992. (A. D. Johnston, chairperson). v. 24, no. 5, May 1992. p. 11.

OP-1204. R. C. Burruss and J. L. Mauk*. MICHIGAN. Proterozoic oil in fluid inclusions in the Midcontinent Rift; implications for the origin of oil at White Pine, Michigan [abstr.] Abstracts with Programs - Geological Society of America, in Geological Society of America, 1992 annual meeting. v. 24, no. 7, 1992. p. 213.

OP-1205. L. M. Bybell and J. M. Self-Trail. Evolutionary trends in Paleocene and Eocene calcareous nannofossil species from the Gulf and Atlantic coastal plains [abstr.] Annual Meeting Abstracts - American Association of Petroleum Geologists and Society of Economic Paleontologists and Mineralogists, in American Association of Petroleum Geologists 1993 annual convention. 1993, April 1993. p. 81-82.

OP-1206. A. P. Byrnes* and C. W. Keighin. Effects of confining stress on pore throats and capillary pressure measurements, selected sandstone reservoir rocks [abstr.] Annual Meeting Abstracts - American Association of Petroleum Geologists and Society of Economic Paleontologists and Mineralogists, in American Association of Petroleum Geologists 1993 annual convention. 1993, April 1993. p. 82.

OP-1207. F. Caccavo, Jr.*, R. P. Blakemore* and D. R. Lovley. NEW HAMPSHIRE. Isolation and characterization of a Fe(III)and $\mathrm{Mn}(\mathrm{IV})$-reducing microorganism from Great Bay, New Hampshire [abstr.] Abstracts of Papers - American Chemical Society, National Meeting, in 203rd ACS national meeting. 203, 1992. p. GEOC 123

OP-1208. E. C. Callender, R. G. Deike, D. M. Webster, B. J. Libby and R. Rossmann*. Geochemical and mineralogic indicators of sedimentation in Lake Baikal, southeastern Siberia, USSR [abstr.] Eos, Transactions, American Geophysical Union, in AGUMSA 1991 spring meeting. v. 72, no. 17, April 23, 1991. p. 307.

OP-1209. W. M. Calvin and T. V. King. Analysis of Mariner 6 and 7 spectra for weak absorption features from 2 to $6 \mu \mathrm{m}$ [abstr.] Abstracts of Papers Submitted to the Lunar and Planetary Science Conference, in Abstracts of papers submitted to the Twenty-first lunar and planetary science conference. (Lunar and Planetary Institute). 21, 1990 . p. 153-154.

OP-1210. W. M. Calvin, T. Z. Martin* and G. B. Hansen*. Spatial variation in the seasonal south polar cap of Mars as observed by Mariner 7 [abstr.] Proceedings of the Lunar and Planetary Science Conference, in Abstracts of papers submitted to the Twenty-fourth lunar and planetary science conference. (Douglas Blanchard, chairperson and others). 24,1993 . p. 243-244.

OP-1211. C. C. Cameron, C. A. Palmer and J. S. Esterle*. The geology of selected peat-forming environments in temperate and tropical latitudes [abstr.] International Geological Congress, Abstracts - Congres Geologique Internationale, Resumes, in Twenty- 
eighth International Geological Congress; abstracts. 28, Vol. 1 , 1989. p. $1.229-1.230$.

OP-1212. H. Candiotti de Los Rios*, D. C. Noble* and E. H. McKee. Geological setting, paragenesis, and zoning of epithermal silver veins of Arcata District, southern Peru [abstr.] International Geological Congress, Abstracts-Congres Geologique Internationale, Resumes, in Twenty-eighth International Geological Congress; abstracts. 28, Vol. 1, 1989. p. 1.233-1.234.

OP-1213. W. F. Cannon and A. G. Green*. From the Pacific to the Atlantic; a transect of the North American continent near the Canada-U.S. border; the Great Lakes portion [abstr.] International Geological Congress, Abstracts-Congres Geologique Internationale, Resumes, in Twenty-eighth International Geological Congress; abstracts. 28, Vol. 1, 1989. p. 1.235 .

OP-1214. W. F. Cannon, Z. E. Peterman and P. K. Sims. The use of $\mathrm{Rb}-\mathrm{Sr}$ biotite ages to date thrust faulting and estimate the paleogeothermal gradient related to the Midcontinent Rift [abstr.] Abstracts with Programs - Geological Society of America, in Geological Society of America, 1990 annual meeting. v. 22, no. 7, 1990. p. 369.

OP-1215. W. F. Cannon, J. D. Phillips, A. G. Green* and Patrick Morel-á-l'Hussier*. Great Lakes segment of the Canada-U.S. border transect [abstr.] Abstracts with Programs - Geological Society of America, in Geological Society of America, 1990 annual meeting. v. 22 , no. 7,1990 . p. 191.

OP-1216. W. F. Cannon, L. G. Woodruff and M. J. Daines*. A thermal lag model for native copper mineralization in the Midcontinent Rift System of Lake Superior [abstr.] Abstracts with Programs - Geological Society of America, in Geological Society of America, 1992 annual meeting. v. 24, no. 7, 1992. p. 61.

OP-1217. R. W. Carlson*, H. H. Kieffer, K. H. Baines*, K. J. Becker, G. E. Danielson*, Kathleen Edwards, F. P. Fanale*, J. Forsythe*, L. R. Gaddis, J. C. Granahan*, J. Hui*, T. V. Johnson*, R. Lopes-Gautier*, L. W. Kamp*, D. L. Matson*, T. B. McCord*, R. Mehlman*, A. C. Ocampo*, L. A. Soderblom, W. D. Smythe*, J. M. Torson and P. R. Weissman*. Preliminary report of lunar observations by the near-infrared mapping spectrometer (NIMS) during the second Galileo Earth-Moon encounter [abstr.] Proceedings of the Lunar and Planetary Science Conference, in Abstracts of papers submitted to the Twenty-fourth lunar and planetary science conference. (Douglas Blanchard, chairperson and others). 24, 1993. p. 255-256.

OP-1218. V. L. Carlson-Foscz*, Naomi Oreskes* and D. K. Nordstrom. COLORADO. Mobility of rare earth elements in the Ophir region, San Juan Mountains, Colorado [abstr.] Eos, Transactions, American Geophysical Union, in AGU-MSA 1991 spring meeting. v. 72, no. 17, April 23, 1991. p. 308.

OP-1219. J. R. Carpenter* and L. G. Wallace. Classroom earth science activities for use with USGS teacher packets [abstr.] Abstracts with Programs - Geological Society of America, in Geological Society of America, 1992 annual meeting. v. 24, no. 7, 1992. p. 133.

OP-1220. M. C. Carpenter. ARIZONA. Earth-fissure movements associated with fluctuations in groundwater level, south central Arizona, 1980-1984 [abstr.] International Geological Congress, Abstracts-Congres Geologique Internationale, Resumes, in Twenty-eighth International Geological Congress; abstracts. 28, Vol. 1, 1989. p. 1.243 .

OP-1221. M. H. Carr. The effects of floods, volcanism and polar processes on the $\mathrm{D} / \mathrm{H}$ ratio in the Martian atmosphere [abstr.] Abstracts of Papers Submitted to the Lunar and Planetary Science Conference, in Abstracts of papers submitted to the Twenty-first lunar and planetary science conference. (Lunar and Planetary Institute). 21, 1990. p. 168-169.

OP-1222. M. H. Carr. Martian volcanism [abstr.] International Geological Congress, Abstracts-Congres Geologique Internationale, Resumes, in Twenty-eighth International Geological Congress; abstracts. 28, Vol. 1, 1989. p. 1.243.

OP-1223. M. H. Carr. Future Mars exploration [abstr.] International Geological Congress, Abstracts-Congres Geologique Internationale, Resumes, in Twenty-eighth International Geological Congress; abstracts. 28, Vol. 1, 1989. p. 1.243-1.244.

OP-1224. M. H. Carr. The fate of water deposited in the low-lying northern plains [abstr.] LPI Technical Report, in Workshop on the Martian northern plains; sedimentological, periglacial, and paleoclimatic evolution. (J. S. Kargel, editor and others). 93-04, Part 1, 1993. p. 3-4.

OP-1225. L. D. Carter and J. F. Whelan. ALASKA. Restricted Arctic sea ice during deposition of the late Pleistocene Flaxman Member of the Gubik Formation, Alaska [abstr.] Eos, Transactions, American Geophysical Union, in AGU 1992 spring meeting. v. 73, no. 14, suppl. April 7, 1992. p. 287-288.

OP-1226. M. D. Carter, N. K. Gardner, J. C. Cobb*, R. S. Sites* and Nick Fedorko, III*. Coal availability studies; how much of our nation's coal is actually minable? [abstr.] Abstracts with Programs - Geological Society of America, in Geological Society of America, Southeastern Section, 27th annual meeting. v. 24, no. 3, March 1992. p. 11.

OP-1227. K. D. Cartier, L. A. Peltz and K. F. Long. CALIFORNIA, NEVADA. Tahoe Environmental Geographic Information System, Lake Tahoe basin, California and Nevada [abstr.], in American Institute of Professional Geologists, 1992 annual meeting and symposium; Geologic reason, a basis for decisions affecting society. (Steve Friberg, chairperson). American Institute of Professional Geologists, September 1992. p. 11.

OP-1228. G. D. Casey. Preliminary hydrogeologic framework of the Silurian and Devonian carbonate aquifer system in the Midwestern basins and arches region of Indiana, Ohio, Michigan, and Illinois [abstr.] Abstracts with Programs - Geological Society of America, in Geological Society of America, 1992 annual meeting. v. 24 , no. 7,1992 . p. 281-282.

OP-1229. M. E. Cast and J. L. Carter*. TEXAS. Stratabound chromium concentrations in the Tecovas Formation, Palo Duro Canyon, Texas [abstr.] Abstracts with Programs - Geological Society of America, in Geological Society of America, 1990 annual meeting. v. 22 , no. 7,1990 . p. 363 .

OP-1230. P. R. Castillo* and M. S. Pringle. Cretaceous volcanism in the western Pacific sampled at sites 800 and 802, ODP Leg 129 [abstr.] Eos, Transactions, American Geophysical Union, in AGU-MSA 1991 spring meeting. v. 72, no. 17, April 23, 1991. p. 300 . 
OP-1231: C. B. Cecil. Carboniferous climate history of the Ozark Dome and the Eastern and Western Interior basins [abstr.] Abstracts with Programs - Geological Society of America, in Geological Society of America, North-Central Section, 27th annual meeting. v. 25, no. 3, March 1993. p. 11.

OP-1232. C. B. Cecil, F. T. Dulong and N. T. Edgar. Allogenic processes, sediment flux, and Carboniferous stratigraphy in the Appalachian Basin [abstr.] Abstracts with Programs - Geological Society of America, in Geological Society of America, 1992 annual meeting. v. 24 , no. 7,1992 . p. 32 .

OP-1233. C. B. Cecil, N. T. Edgar, T. S. Ahlbrandt and J. L. Clayton. Paleoclimates and the origin of carbonaceous strata in the Pennsylvanian System of the U.S.A. [abstr.] Annual Meeting Abstracts - American Association of Petroleum Geologists and Society of Economic Paleontologists and Mineralogists, in American Association of Petroleum Geologists 1993 annual convention. 1993, April 1993. p. 83.

OP-1234. C. B. Cecil, R. W. Stanton, F. T. Dulong and L. F. Ruppert. Recent developments on the origin of mineral matter in coal [abstr.], in 1983 international conference on Coal science; proceedings. (S. W. Chun, president). Int. Energy Agency, 1983. p. 381.

OP-1235. D. J. Chadwick and B. K. Lucchitta. Fault geometries and extension in the Valles Marineris, Mars [abstr.] Proceedings of the Lunar and Planetary Science Conference, in Abstracts of papers submitted to the Twenty-fourth lunar and planetary science conference. (Douglas Blanchard, chairperson and others). 24, 1993. p. 263-264.

OP-1236. D. J. Chadwick and G. G. Schaber. A two-stage (turbulent-drainage) mechanism for the emplacement of impact crater outflows on Venus [abstr.] Proceedings of the Lunar and Planetary Science Conference, in Abstracts of papers submitted to the Twenty-fourth lunar and planetary science conference. (Douglas Blanchard, chairperson and others). 24, 1993. p. 265-266.

OP-1237. C. I. Chalokwu* and M. R. Colberg. ALABAMA. Thermobarometry and calculated fluid composition of migmatitic schists in the contact zone of the Farmville Granite, Alabama Piedmont [abstr.] Abstracts with Programs - Geological Society of America, in Geological Society of America, 1990 annual meeting. v. 22 , no. 7,1990 . p. 258 .

OP-1238. E. C. Chao, J. A. Minkin, J, M. Back, R. L. Erickson, L. J. Drew, P. M. Okita, E. H. McKee, J. E. Conrad, B. D. Turrin, Mitsunobu Tatsumoto, Wang Junwen*, C. A. Edwards, R. V. Buden, Hou Zonglin*, Ren Yingzhen*, Meng Qingren* and Sun Weijun*. Epigenetic, hydrothermal-metasomatic origin of the Bayan Obo Fe-Nb-REE ore deposit of Inner Mongolia, China [abstr.] International Geological Congress, Abstracts-Congres Geologique Internationale, Resumes, in 28th international geological congress; abstracts. 28, Vol. 1, 1989. p. 1.262 .

OP-1239. F. H. Chapelle and P. B. McMahon. Hydrological control of bacterial populations and organic material diagenesis in deep subsurface coastal plain sediments [abstr.] International Geological Congress, Abstracts - Congres Geologique Internationale, Resumes, in 28th international geological congress; abstracts. 28 , Vol. 1, 1989. p. 1.262 .
OP-1240. M. G. Chapman. Basal scarp, paleoglacier, and fissure flows of Elysium Mons, Mars [abstr.] Proceedings of the Lunar and Planetary Science Conference, in Abstracts of papers submitted to the Twenty-fourth lunar and planetary science conference. (Douglas Blanchard, chairperson and others). 24, 1993. p. 271272.

OP-1241. M. G. Chapman. Evidence for an ice sheet/frozen lake in Utopia Planitia, Mars [abstr.] LPI Technical Report, in Workshop on the Martian northern plains; sedimentological, periglacial, and paleoclimatic evolution. (J. S. Kargel, editor and others). 93-04, Part 1, 1993. p. 4-5.

OP-1242. M. G. Chapman and K. L. Tanaka. Geologicmapping of lower Mangala Valles, Mars; evidence of flooding, sapping, debris flow, and volcanism [abstr.] Abstracts of Papers Submitted to the Lunar and Planetary Science Conference, in Abstracts of papers submitted to the Twenty-first lunar and planetary science conference. (Lunar and Planetary Institute). 21, 1990. p. 179.

OP-1243. R. W. Charles*, W. F. Goff*, D. Janecky*, C. J. Janik and J. B. Hulen*. NEW MEXICO. State of equilibrium and ore mineralization in core hole VC-2a, Sulfur Springs, Valles Caldera, New Mexico [abstr.] International Geological Congress, Abstracts - Congres Geologique Internationale, Resumes, in 28th international geological congress; abstracts. 28 , Vol. 1, 1989. p. 1.263-1.264.

OP-1244. R. R. Charpentier and B. E. Law. Estimation of coalbed methane contents from geologic data [abstr.] Annual Meeting Abstracts - American Association of Petroleum Geologists and Society of Economic Paleontologists and Mineralogists, in American Association of Petroleum Geologists 1993 annual convention. 1993, April 1993. p. 83-84.

OP-1245. R. R. Charpentier and C. A. Sandberg. Statistical support for conodont biofacies model for anchoralis-latus zone (Osagean) [abstr.] Abstracts with Programs - Geological Society of America, in Geological Society of America, North-Central Section, 27th annual meeting. v. 25, no. 3, March 1993. p. 11.

OP-1246. J. T. Chesley*, A. N. Halliday*, Klaus Mezger*, L. W. Snee, T. J. Shepherd* and R. C. Scrivener*. Emplacement and cooling history of the Cornubian Batholith; implications for the effects of multiple pluton emplacment on hydrothermal circulation [abstr.] Eos, Transactions, American Geophysical Union, in AGU 1992 spring meeting. v. 73, no. 14, suppl. April 7, 1992. p. 283.

OP-1247. I-Ming Chou. Measurement of $\mathrm{H}_{2} \mathrm{O}$ activities in the $\mathrm{N}_{2}$ $\mathrm{H}_{2} \mathrm{O}$ fluids at $2 \mathrm{kbar}$ and $600^{\circ} \mathrm{C}$ [abstr.] Abstracts with Programs Geological Society of America, in Geological Society of America, 1990 annual meeting. v. 22, no. 7, 1990. p. 342.

OP-1248. I-Ming Chou and G. L. Cygan. Equilibrium and steadystate redox control in hydrothermal experiments [abstr.] International Geological Congress, Abstracts-Congres Geologique Internationale, Resumes, in 28th international geological congress. 28, Vol. 1, 1989. p. 1.287 .

OP-1249. B. A. Chouet. Transient response of fluid-driven crack and its implication for excitation mechanism of harmonic tremor [abstr.] International Geological Congress, Abstracts-Congres Geologique Internationale, Resumes, in 28th international geological congress. 28 , Vol. 1, 1989. p. 1.289-1.290. 
OP-1250. B. A. Chouet, R. A. Page, C. D. Stephens, J. C. Lahr and J. A. Power. ALASKA. Source parameters of the LP swarm preceding the December 14, 1989 eruption of Redoubt Volcano, Alaska [abstr.] Eos, Transactions, American Geophysical Union, in AGU 1992 fall meeting. v. 73, no. 43, suppl. October 27, 1992. p. 342-343.

OP-1251. S. C. Christenson and A. H. Rea. OKLAHOMA. Factors related to pesticide occurrence in ground water in the Oklahoma City urban area [abstr.] American Water Resources Association Technical Publication Series TPS, in Water management of river systems; 27th annual AWRA conference. (H. C. McWreath, editor). 27, 1991. p. 343-344.

OP-1252. D. J. Chure*, C. E. Turner and Fred Peterson. UTAH. An embryo of the ornithopod dinosaur Camptosaurus from the Morrison Formation (Upper Jurassic) of Dinosaur National Monument, Utah [abstr.] Journal of Vertebrate Paleontology, in Society of Vertebrate Paleontology, fifty-second annual meeting. (R. J. Emry, editor and others). v. 12, no. 3, Suppl. September 1992. p. $23 \mathrm{~A}-24 \mathrm{~A}$.

OP-1253. D. H. Clark*, A. R. Gillespie* and M. M. Clark. CALIFORNIA. Effects of debris cover on ELA estimates of cirque glaciers, Sierra Nevada, California [abstr.] Abstracts with Programs - Geological Society of America, in Geological Society of America, Cordilleran Section, 88th annual meeting, 1992. (A. D. Johnston, chairperson). v. 24, no. 5, May 1992. p. 15.

OP-1254. M. M. Clark, D. H. Clark* and A. R. Gillespie*. CALIFORNIA. Little Ice Age rock glaciers and moraines of the Sierra Nevada; thinly covered glacial ice [abstr.] Abstracts with Programs - Geological Society of America, in Geological Society of America, Cordilleran Section, 88th annual meeting, 1992. (A. D. Johnston, chairperson). v. 24, no. 5, May 1992. p. 15.

OP-1255. M. S. Clark*, P. G. Lillis and Glenn Gregory*. The Sespe oil fields; a possible kinetic trap with a subthrust source [abstr.] AAPG Bulletin, in AAPG Pacific Section abstracts. v. 77, no. 4, April 1993. p. 693.

OP-1256. P. U. Clark* and J. S. Walder. Distribution of eskers deposited by the Laurentide and Eurasian ice sheets as an indicator of subglacial bed conditions [abstr.] Program with Abstracts Geological Association of Canada; Mineralogical Association of Canada; Canadian Geophysical Union, Joint Annual Meeting. 16, May 1991. p. 24.

OP-1257. S. H. Clark. A genetic classification for barite deposits of North America [abstr.] International Geological Congress, Abstracts-Congres Geologique Internationale, Resumes, in 28th international geological congress. 28, Vol. 1, 1989. p. 1.300 .

OP-1258. J. W. Clarke and J. A. Peterson. Romashkino oil field, USSR [abstr.] International Geological Congress, AbstractsCongres Geologique Internationale, Resumes, in 28th international geological congress. 28, Vol. 1, 1989. p. 1.300-1.301.

OP-1259. S. H. Clarke, Jr. and G. A. Carver*. Breadth of interplate coupling in the southern Cascadia subduction zone; implications for earthquake magnitudes [abstr.] Abstracts with Programs - Geological Society of America, in Geological Society of America, Cordilleran Section, 88th annual meeting, 1992. (A. D. Johnston, chairperson). v. 24, no. 5, May 1992. p. 15.
OP-1260. J. L. Clayton. A new approach to oil-source rock correlation; extraction of the oil phase from source rocks [abstr.] Annual Meeting Abstracts - American Association of Petroleum Geologists and Society of Economic Paleontologists and Mineralogists, in American Association of Petroleum Geologists, 1992 annual convention. (George Eynon, chairperson). 1992, 1992. p. 20.

OP-1261. J. L. Clayton. Oil and gas basins in the former Soviet Union [abstr.] AAPG Bulletin, in AAPG international conference and exhibition; abstracts. v. 77, no. 9, September 1993. p. 1613.

OP-1262. J. L. Clayton and Chen Jianyu*. UTAH, COLORADO. Organic geochemistry of black shale and associated oils of the Pennsylvanian Hermosa Group, Paradox Basin, Utah and Colorado [abstr.] AAPG Bulletin, in AAPG Rocky Mountain Section meeting. v. 77, no. 8, August 1993. p. 1445.

OP-1263. J. L. Clayton and Istvan Koncz*. Petroleum geochemistry of the Zala Basin, Hungary [abstr.] Annual Meeting Abstracts - American Association of Petroleum Geologists and Society of Economic Paleontologists and Mineralogists, in American Association of Petroleum Geologists 1993 annual convention. 1993, April 1993. p. 86.

OP-1264. J. L. Clayton, D. D. Rice and R. W. Stanton. Geochemical and geological controls on generation and accumulation of oil and gas from coalbeds, Western United States [abstr.] Annual Meeting Abstracts - American Association of Petroleum Geologists and Society of Economic Paleontologists and Mineralogists, in American Association of Petroleum Geologists, 1992 annual convention; late abstracts. (George Eynon, chairperson). 1992, 1992. p. 83.

OP-1265. J. L. Clayton, G. F. Ulmishek, P. G. Lillis, M. M. Ball, G. L. Dolton, T. A. Daws, R. F. Mast, Augusta Warden, M. Keller*, V. Bogino*, Zinovy Poznaikovitch* and Yang Jianqiang*. Petroleum geochemistry and exploration potential of the Pripyat Basin (USSR) [abstr.] Annual Meeting Abstracts American Association of Petroleum Geologists and Society of Economic Paleontologists and Mineralogists, in American Asssociation of Petroleum Geologists 1993 annual convention. 1993, April 1993. p. 86.

OP-1266. S. M. Clifford* and M. H. Carr. The subsurface hydrologic response of Mars to the thermal evolution of its early crust [abstr.] LPI Technical Report, in Workshop on the Martian surface and atmosphere through time. (R. M. Haberle, convener and others). $92-02,1992$. p. 37-38.

OP-1267. L. G. Closs*, M. L. Silberman and P. T. Herrera*. CALIFORNIA. Geochemical zoning in the northern part of the Bodie mining district, Mono County, California; a comparison to the "hot-spring" model [abstr.] Program with Abstracts - Geological Association of Canada; Mineralogical Association of Canada; Canadian Geophysical Union, Joint Annual Meeting. 16, May 1991. p. 24.

OP-1268. J. G. Clough* and R. B. Blodgett. ALASKA. A Southwest Alaska Late Silurian-Early Devonian algal reef-rimmed carbonate ramp; depositional cycles and regional significance [abstr.] Abstracts with Programs - Geological Society of America, in Geological Society of America, Cordilleran Section, 88th annual meeting, 1992. (A. D. Johnston, chairperson). v. 24, no. 5, May 1992. p. 16. 
OP-1269. G. D. Clow and R. M. Haberle*. Free convention in the Martian atmosphere [abstr.] Abstracts of Papers Submitted to the Lunar and Planetary Science Conference, in Abstracts of papers submitted to the Twenty-first lunar and planetary science conference. (Lunar and Planetary Institute). 21, 1990. p. 210-211.

OP-1270. G. D. Clow and R. M. Haberle*. Characteristics of the Martian atmospheric surface layer [abstr.] Abstracts of Papers Submitted to the Lunar and Planetary Science Conference, in Abstracts of papers submitted to the Twenty-first lunar and planetary science conference. (Lunar and Planetary Institute). 21, 1990. p. 209.

OP-1271. M. A. Clynne. CALIFORNIA. Character of volcanism and magmatic processes in the Lassen area of the Cascade Arc, Northern California [abstr.] Abstracts with Programs - Geological Society of America, in Geological Society of America, Cordilleran Section, 88th annual meeting, 1992. (A. D. Johnston, chairperson). v. 24, no. 5, May 1992. p. 16.

OP-1272. A. G. Coates*, J. B. Jackson*, L. C. Collins*, T. M. Cronin, H. J. Dowsett, L. M. Bybell and J. A. Obando*. Closure of the Isthmus of Panama; the near-shore marine record in Costa Rica and Panama [abstr.] Abstracts with Programs - Geological Society of America, in Geological Society of America, 1990 annual meeting. v. 22 , no. 7,1990 . p. 365 .

OP-1273. D. A. Coates and A. K. Alam*. The Mymensingh Terrace; evidence of Holocene deformation in the delta of the Brahmaputra River, central Bangladesh [abstr.] Abstracts with Programs - Geological Society of America, in Geological Society of America, 1990 annual meeting. v. 22, no. 7, 1990. p. 310.

OP-1274. Massimo Cocco* and Paul Spudich. Iterative frequencydomain inversion of ground motions to determine earthquake rupture behavior [abstr.] Seismological Research Letters, in 85th annual meeting of the Seismological Society of America. v. 61, no. 1, March 1990. p. 21.

OP-1275. Massimo Cocco* and Paul Spudich. Space-time dependence of source parameters on an extended fault resulting from the inversion of ground motion amplitudes [abstr.] Terra Abstracts, in Sixth meeting of the European Union of Geosciences. v. 3, no. 1, 1991. p. 152 .

OP-1276. J. A. Coe, J. W. Whitney and P. A. Glancy. NEVADA. Photogrammetric analysis of modern hillslope erosion at Yucca Mountain, Nevada [abstr.] Abstracts with Programs - Geological Society of America, in Geological Society of America, 1992 annual meeting. v. 24, no. 7, 1992. p. 296.

OP-1277. Philip Cohen. National assessment of ground-water quality in the United States; new directions of the U.S. Geological Survey [abstr.] International Geological Congress, AbstractsCongres Geologique Internationale, Resumes, in 28th international geological congress. 28, Vol. 1, 1989. p. 1.309 .

OP-1278. T. A. Cohn. Describing lake levels on the Great Lakes; what kind of model is appropriate? [abstr.] Eos, Transactions, American Geophysical Union, in AGU 1992 spring meeting. v. 73, no. 14, Suppl. April 7, 1992. p. 117.

OP-1279. J. E. Coker*, M. G. Steltenpoh1*, A. Andresen*, L. P. Gromet* and M. J. Kunk. U-Pb and $40 \mathrm{Ar} / 39 \mathrm{Ar}$ thermochronology and tectonic evolution of the Ofoten-Troms region, North Norwegian Caledonides [abstr.] Abstracts with Programs -
Geological Society of America, in Geological Society of America, 1992 annual meeting. v. 24, no. 7, 1992, p. 235-236.

OP-1280. A. T. Cole, W. L. Ellsworth and G. C. Beroza*. Determining earthquake kinship from waveform catalogs [abstr.] Eos, Transactions, American Geophysical Union, in AGU 1992 fall meeting. v. 73 , no. 43 , suppl. October 27, 1992. p. 344.

OP-1281. R. B. Cole* and R. G. Stanley. CALIFORNIA. Alluvial-fan and lacustrine fan-delta sedimentation in west-central California during the middle Tertiary transition from subduction to transform tectonics [abstr.] Abstracts with Programs - Geological Society of America, in Geological Society of America, 1992 annual meeting. v. 24, no. 7, 1992. p. 51-52.

OP-1282. D. S. Coleman*, A. F. Glazner* and T. P. Frost. CALIFORNIA. Isotopic homogeneity within the compositionally heterogeneous Lamarck Granodiorite, Sierra Nevada, California [abstr.] Abstracts with Programs - Geological Society of America, in Geological Society of America, Cordilleran Section, 88th annual meeting, 1992. (A. D. Johnston, chairperson). v. 24, no. 5, May 1992. p. 16.

OP-1283. P. D. Collar and A. E. Ogden*. TENNESSEE. Hydrochemical survey of carbonate ground waters in Putman and Jackson counties, Tennessee [abstr.] The NSS Bulletin, in National Speleological Society, 1990 annual meeting. (N. D. Peacock, editor). v. 53, no. 1, June 1991. p. 60.

OP-1284. T. S. Collett. Natural gas production from Arctic gas hydrates [abstr.] AAPG Bulletin, in AAPG international conference and exhibition; abstracts. v. 77, no. 9, September 1993. p. 1614.

OP-1285. T. S. Collett and K. J. Bird. ALASKA. Gas hydrate surface simulating seismic reflector in the Prudhoe Bay-Kuparuk River region of northern Alaska [abstr.] Annual Meeting Abstracts - American Association of Petroleum Geologists and Society of Economic Paleontologists and Mineralogists, in American Association of Petroleum Geologists 1993 annual convention. 1993 , April 1993. p. 87.

OP-1286. Jean-Yves Collot* and M. A. Fisher. Stages of structural evolution of accretionary complex; effects of collision between seamounts, ridges, and the New Hebrides island arc [abstr.] International Geological Congress, Abstracts-Congres Geologique Internationale, Resumes, in 28th international geological congress. 28, Vol. 1, 1989. p. 1.315 .

OP-1287. Jean-Yves Collot*, H. G. Greene and L. B. Stokking*. Tectonique collisionnelle le long de la zone de subduction des Nouvelles-Hébrides; résultats des forages du Leg ODP 134 [Collision tectonics along the New Hebrides subduction zone; results of ODP Leg 134] [abstr.] Réunion Annuelle des Sciences de la Terre, in 14e réunion des sciences de la terre; macro et micro regards sur la terre (14th symposium on earth science; the Earth in macro and micro). 14, 1992. p. 41.

OP-1288. S. M. Colman and D. S. Foster. High-resolution seismic and core data from southern Lake Michigan; glacial and post-glacial history of the lake basin [abstr.] Eos, Transactions, American Geophysical Union, in AGU 1992 spring meeting. v. 73, no. 14, Suppl. April 7, 1992. p. 147-148.

OP-1289. S. M. Colman, D. S. Foster, L. D. Keigwin*, G. A. Jones*, R. M. Forester and D. S. Sweetkind. History of late 
glacial discharge and Lake Agassiz influx in the Lake Michigan basin [abstr.] Abstracts with Programs - Geological Society of America, in Geological Society of America, 1992 annual meeting. v. 24 , no. 7,1992 . p. $273-274$.

OP-1290. S. M. Colman and G. A. Jones*. Variations in Holocene rates of sedimentation in southern Lake Michigan [abstr.] Abstracts with Programs - Geological Society of America, in Geological Society of America, 1990 annual meeting. v. 22, no. 7,1990 . p. 311-312.

OP-1291. S. M. Colman, E. B. Karabanov* and A. Bardardinov*. Preliminary results of high-resolution seismic-reflection surveys of Lake Baikal, Siberia [abstr.] Eos, Transactions, American Geophysical Union, in AGU-MSA 1991 spring meeting. v. 72 , no. 17 , April 23, 1991. p. 306.

OP-1292. V. J. Comer, E. C. Spiker and P. G. Hatcher*. Chemical and carbon isotopic composition of refractory components in leaves [abstr.] Abstracts of Papers - American Chemical Society, National Meeting, in 203rd ACS national meeting. 203, 1992. p. GEOC 48.

OP-1293. R. D. Congdon, P. C. Lyons and W. F. Outerbridge. Use of silicate-melt (glass) inclusions in determining magmatic source of kaolinized volcanic ash beds (tonsteins) in coal beds in the Appalachian Basin [abstr.] Abstracts with Programs - Geological Society of America, in Geological Society of America, Southeastern Section, 27th annual meeting. v. 24, no. 3, March 1992. p. 13.

OP-1294. R. D. Congdon, R. G. Resmini* and B. D. Marsh*. MONTANA. Differentiation style in the Box Elder and Shonkin Sag laccoliths; dependence on initial conditions [abstr.] Eos, Transactions, American Geophysical Union, in AGU 1993 spring meeting. v. 74, no. 16, Suppl. May 1993. p. 336.

OP-1295. H. E. Cook and M. E. Taylor. Evolution of early Paleozoic carbonate seamount, Maly Karatau Range, southern Kazakhstan, USSR; new evidence for early history of Kazakhstania [abstr.] International Geological Congress, Abstracts - Congres Geologique Internationale, Resumes, in 28th international geological congress. 28, Vol. 1, 1989. p. 1.3221.323 .

OP-1296. T. M. Cookro and P. L. Hansley. IDAHO. The Tungsten Jim Mine and Beaver Creek occurrence, Bayhorse mining district, Custer County, central Idaho; genesis of skarn [abstr.] Abstracts with Programs - Geological Society of America, in Geological Society of America, 1992 annual meeting. v. 24, no. 7, 1992. p. 354 .

OP-1297. L. E. Cordell, G. B. Sidder and W. C. Day. MISSOURI. Aeromagnetic constraints on shape of parent magma source at Pea Ridge, Missouri, magnetite mine [abstr.] Abstracts with Programs - Geological Society of America, in Geological Society of America, North-Central Section, 27th annual meeting. v. 25, no. 3, March 1993. p. 14

OP-1298. E. A. Cowan*, R. D. Powell*, D. E. Lawson* and P. R. Carlson. ALASKA. Direct measurements by submersible of surge-type turbidity currents in a fjord channel, Southeast Alaska [abstr.] Abstracts with Programs - Geological Society of America, in Geological Society of America, 1992 annual meeting. v. 24, no. 7,1992 . p. 84 .
OP-1299. S. D. Craigg. NEW MEXICO. Hydrogeology of saline springs along the southeastern margin of the San Juan Basin, northwestern New Mexico [abstr.] AAPG Bulletin, in AAPG Rocky Mountain Section meeting. v. 77, no. 8, August 1993. p. 1445.

OP-1300. Edward Cranswick, M. E. Meremonte, D. M. Worley, J. S. Gomberg, D. L. Carver, J. Brooks, S. C. Harmsen, J. B. Duggar, T. W. Van Dreser, Robert Banfill* and C. Early*. NEVADA. Phased micro-array recordings of aftershocks of the 28 June 1992 Little Skull Mountain (NTS) earthquake [abstr.] Eos, Transactions, American Geophysical Union, in AGU 1992 fall meeting. v. 73 , no. 43 , suppl. October 27,1992 . p. 338.

OP-1301. C. A. Cravotta, III. PENNSYLVANIA. Effect of sewage sludge on formation of acidic water at reclaimed coal mines in western Pennsylvania [abstr.] Abstracts with Programs - Geological Society of America, in Geological Society of America, Southeastern Section, 27th annual meeting. v. 24, no. 3, March 1992. p. 14.

OP-1302. R. E. Criss* and D. E. Champion. NEVADA. Oxygen isotope imaging of unicellular and convective flow of hydrothermal fluid around an epizonal intrusion, Comstock Lode mining district, Nevada [abstr.] Abstracts with Programs - Geological Society of America, in Geological Society of America, 1992 annual meeting. v. 24 , no. 7,1992 . p. 171 .

OP-1303. T. M. Cronin and Thorleifur Einarsson*. PlioPleistocene marine Ostracoda from Tjornes, Iceland; paleoclimatic and paleobiogeographical implications [abstr.] Abstracts with Programs - Geological Society of America, in Geological Society of America, 1990 annual meeting. v. 22, no. 7, 1990. p. 175.

OP-1304. D. E. Crowe and W. C. Shanks, III. Laser microprobe $\delta^{34} S$ study of coexisting sulfide pairs; seeing through metamorphism [abstr.] Eos, Transactions, American Geophysical Union, in AGU-MSA 1991 spring meeting. v. 72, no. 17, April 23, 1991. p. 292.

OP-1305. S. S. Crowley, L. F. Ruppert*, H. E. Belkin* and T. A. Moore*. MONTANA. The geochemistry of the AndersonDietz coal bed of the Powder River basin, Montana, in relation to detrital and volcanic-ash components [abstr.] Annual Meeting of the Society for Organic Petrology. Abstracts and Program, in Ninth annual meeting of the Society for Organic Petrology. (S. A. Stout, editor). 9, July 23, 1992. p. 109-111.

OP-1306. C. G. Cunningham*, James McNamee*, José PintoVasquez* and G. E. Ericksen. A model for volcanic-dome hosted precious-metal deposits in Bolivia [abstr.] Abstracts with Programs - Geological Society of America, in Geological Society of America, 1990 annual meeting. v. 22, no. 7, 1990. p. 181.

OP-1307. M. G. Curren* and S. E. Ishman. Stable isotopic signatures of Antarctic bottom water masses, Pacific margin of the Antarctic Peninsula; a tool for interpreting ice margin fluctuations [abstr.] Abstracts with Programs - Geological Society of America, in Geological Society of America, 1992 annual meeting. v. 24, no. 7, 1992. p. 90.

OP-1308. B. B. Curry*, R. M. Forester and N. K. Bleuer*. Paleohydrology of lakes as a means for climatic reconstruction; examples of full-glacial records from a Midwestern upland pond and slackwater basin [abstr.] Abstracts with Programs - Geological Society of America, in Geological Society of America, North-Cen- 
tral Section, 26th annual meeting. v. 24, no. 4, April 1992. p. 11.

OP-1309. B. B. Curry*, R. M. Forester, Hong Zhu* and R. G. Baker*. ILLINOIS. Wisconsinan and Sangamonian climate interpreted from fossil ostracodes and vegetation in south-central Illinois [abstr.] Abstracts with Programs - Geological Society of America, in Geological Society of America, 1992 annual meeting. v. 24 , no. 7,1992 . p. $180-181$.

OP-1310. Emilio Custodio*, M. Manzano* and B. F. Jones. Saline water in Llobregat Delta aquifers, Barcelona, Spain [abstr.] International Geological Congress, Abstracts-Congres Geologique Internationale, Resumes, in 28th international geological congress; abstracts. 28, Vol. 1, 1989. p. 1.355 .

OP-1311. G. L. Cygan, I-Ming Chou and D. M. Sherman. Reassessment of the annite breakdown reaction using new hydrothermal experimental techniques [abstr.] Eos, Transactions, American Geophysical Union, in AGU-MSA 1991 spring meeting. v. 72, no: 17, April 23, 1991. p. 313.

OP-1312. G. L. Cygan, J. J. Hemley and W. L. d'Angelo. Experimental determination of zinc-chloride speciation in buffered solutions at $300-600^{\circ} \mathrm{C}$ and $0.5-2.0 \mathrm{kbar}$ [abstr.] Abstracts with Programs - Geological Society of America, in Geological Society of America, 1990 annual meeting. v. 22, no. 7, 1990. p. 167.

OP-1313. G. K. Czamanske, L. J. Cabri*, M. L. Zientek, A. P. Likhachev*, L. C. Calk and R. L. Oscarson. Proton microprobe analyses of dominant phases in the $\mathrm{Cu}-\mathrm{Fe}-\mathrm{Ni}-\mathrm{S}$ system, Oktyabr'sky Mine, Noril'sk-Talnakh District, USSR [abstr.] Program with Abstracts - Geological Association of Canada; Mineralogical Association of Canada; Canadian Geophysical Union, Joint Annual Meeting. 16, May 1991. p. 27.

OP-1314. G. B. Dalrymple and Graham Ryder*. ${ }^{40} \mathrm{Ar} /{ }^{39} \mathrm{Ar}$ age spectra of Apollo 15 impact melt rocks using a continuous laser system [abstr.] Eos, Transactions, American Geophysical Union, in AGU 1992 spring meeting. v. 73, no. 14, supplement, April 7, 1992. p. 362.

OP-1315. G. B. Dalrymple and Graham Ryder*. ${ }^{40} \mathrm{Ar} /{ }^{39} \mathrm{Ar}$ laser step heating ages of some Apollo 15 impact melt rocks [abstr.] Proceedings of the Lunar and Planetary Science Conference, in Twenty-second Lunar and Planetary Science Conference. 22, 1991. p. 273-274.

OP-1316. J. S. Daly*, J. N. Aleinikoff, C. F. Gower*, J. M. McLelland* and N. M. Ratcliffe. Contrasting styles of Proterozoic crustal evolution in the Grenville Province [abstr.] Eos, Transactions, American Geophysical Union, in AGU 1992 spring meeting. v. 73, no. 14, suppl. April 7, 1992. p. 340 .

OP-1317. W. D. Dalziel*, B. C. Storey*, D. I. MacDonald*, M. P. Maslanyj*, I. C. Millar*, R. J. Pankhurst*, S. W. Garrett*, A. M. Grunow*, D. V. Kent*, J. L. Isbell* and W. R. Vennum. Antarctica and global tectonic processes; a preliminary view based on results of joint UK-US West Antarctic Tectonics Project 1983-1988 [abstr.] International Geological Congress, Abstracts-Congres Geologique Internationale, Resumes, in 28th international geological congress; abstracts. 28, Vol. 1, 1989. p. 1.364-1.365.

OP-1318. R. L. Dart and H. S. Swolfs. Seismotectonics of Reelfoot Rift basement structures [abstr.] Abstracts with Programs -
Geological Society of America, in Geological Society of America, North-Central Section, 27th annual meeting. v. 25, no. 3, March 1993. p. 16.

OP-1319. J. A. Davis and C. C. Fuller. Thermodynamics and kinetics of trace metal sorption processes on metal surfaces [abstr.] TerraCognita, in First international symposium on Thermodynamics of natural processes. v. 8, no. 2,1988 . p. 179.

OP-1320. L. E. Davis*, G. D. Webster* and T. S. Dyman. IDAHO. Bannock Peak Limestone (Upper Mississippian to Middle Pennsylvanian) designated as a new basal formation of the Oquirrh GP in SE Idaho [abstr.] Abstracts with Programs - Geological Society of America, in Geological Society of America, 1992 annual meeting. v. 24 , no. 7,1992 . p. 359.

OP-1321. P. A. Davis and K. L. Tanaka. Small volcanoes in Tempe Terra, Mars; their detailed morphometry and inferred geologic significance [abstr.] Proceedings of the Lunar and Planetary Science Conference, in Abstracts of papers submitted to the Twenty-fourth lunar and planetary science conference. (Douglas Blanchard, chairperson and others). 24, 1993. p. 379-380.

OP-1322. P. A. Davis, K. L. Tanaka and M. P. Golombek*. Shallow crustal discontinuities and graben and scarp formation in the Tharsis region of Mars [abstr.] Proceedings of the Lunar and Planetary Science Conference, in Abstracts of papers submitted to the Twenty-fourth lunar and planetary science conference. (Douglas Blanchard, chairperson and others). 24, 1993. p. 381-382.

OP-1323. P. A. Davis, K. L. Tanaka, M. P. Golombek* and J. B. Plescia*. Interactions of tectonic, igneous, and hydraulic processes in the North Tharsis region of Mars [abstr.] Proceedings of the Lunar and Planetary Science Conference, in Twenty-second Lunar and Planetary Science Conference. 22, 1991. p. 285-286.

OP-1324, P. T. Davis*, P. W. Birkeland*, Nel Caine* and D. T. Rodbell. COLORADO. New radiocarbon ages from cirques in Colorado Front Range [abstr.] Abstracts with Programs - Geological Society of America, in Geological Society of America, 1992 annual meeting. v. 24 , no. 7,1992 . p. 347.

OP-1325. P. B. Dawson, B. A. Chouet, J. C. Lahr and R. A. Page. ALASKA. Spatial relationship between LP earthquakes and a shallow three-dimensional velocity anomaly beneath $\mathrm{Re}$ doubt Volcano, Alaska [abstr.] Eos, Transactions, American Geophysical Union, in AGU 1992 fall meeting. v. 73, no. 43, suppl. October 27, 1992. p. 343.

OP-1326. W. C. Day, G. B. Sidder and E. B. Kisvarsanyi*. MISSOURI. Petrogenetic controls on the formation of middle Proterozoic irontcoppertrare earth element deposits of Missouri [abstr.] Abstracts with Programs - Geological Society of America, in Geological Society of America, North-Central Section, 27th annual meeting. v. 25, no. 3, March 1993. p. 16.

OP-1327. W. C. Day, G. B. Sidder, R. O. Rye, L. M. Nuelle* and E. B. Kisvarsanyi*. The middle Proterozoic rhyolite-hosted Pea Ridge iron and rare-earth-element deposit; a magmatic source for olympic dam-type deposits in the Midcontinent region of the U.S.A. [abstr.] Special Paper - Geological Society of America, in The second Hutton symposium on the origin of granites and related rocks; proceedings. (P. E. Brown, editor and others). 272, 1992. p. 489 . 
OP-1328. Lee De Cola. COLORADO. Global vegetation change in complex topography; a Colorado prototype study [abstr.] GIS/LIS - Proceedings, Annual Conference and Exposition, in GIS/LIS '90 proceedings. 1990, vol. 2, 1990. p. 772.

OP-1329. Fernando de Moraes*, C. A. Goncalves*, D. P. O'Brien*, H. B. Evans* and F. G. Clutson. Borehole gravity measurements in Sergipe State, Brazil [abstr.] SEG Abstracts, in Society of Exploration Geophysicists, Sixty-first annual international meeting and exposition; expanded abstracts with biographies, 1991 technical program. 61, 1991. p. 142-144.

OP-1330. Patrick De Wever*, Hervé Chamley*, F. Michaud*, J. A. Barron, J. P. Caulet*, P. Dumitrica*, Elisabeth Fourtanier and Jacques Bourgois*. Diatoms, radiolarians and silicoflagellates biostratigraphy and clay mineralogy of Cenozoic sediments from NAUTIPERC cruise (off northern Peru, $5-11^{\circ} S$ ) [abstr.] Eos, Transactions, American Geophysical Union, in AGU 1992 spring meeting. v. 73, no. 14, Suppl. April 7, 1992. p. 152.

OP-1331. W. E. Dean and M. A. Arthur*. Sediments from the Black Sea and Peru margin as analogues for non-metalliferous black shales [abstr.] Journal of Geochemical Exploration, in Abstracts from the 1991 annual meeting of the U.S. Working Group of the International Geological Correlation Program Project 254, Metalliferous black shales and related ore deposits. (R. I. Grauch, convener and others). v. 46, no. 2, 1992. p. 235-236.

OP-1332. W. E. Dean and M. A. Arthur*. Cretaceous Western Interior Seaway Continental Scientific Drilling Project [abstr.] Eos, Transactions, American Geophysical Union, in AGU 1993 fall meeting. v. 74, no. 43, Suppl. October 26, 1993. p. 102

OP-1333. R. H. DeAngelis. Digital data manipulations and integration for regional federal planning [abstr.] URISA Proceedings, in URISA 91; information and technology; gateway to solutions; Volume V; Abstracts; all papers accepted for the 1991 annual conference. 1991, 1991. p. 65.

OP-1334. R. G. Deike, D. M. Webster and E. C. Callender. Mineralization within surficial sediments, Academician Ridge, Lake Baikal [abstr.] Eos, Transactions, American Geophysical Union, in AGU-MSA 1991 spring meeting. v. 72, no. 17, April 23, 1991. p. 307.

OP-1335. M. P. deVries and W. O. Freeman. NEW YORK. Use of acoustic Doppler current profiles and other time-series data for modeling flow and salt transport in the Hudson River, New York [abstr.] American Water Resources Association Technical Publication Series TPS, in Water management of river systems; 27th annual AWRA conference. (H. C. McWreath, editor). 27, 1991. p. 419-420.

OP-1336. S. F. Dieh1, C. K. Throckmorton and C. W. Clendenin*. MISSOURI. Significance of recurrent fault movement at Grays Point Quarry, Southeast Missouri [abstr.] Abstracts with Programs - Geological Society of America, in Geological Society of America, North-Central Section, 27th annual meeting. v. 25, no. 3, March 1993. p. 17.

OP-1337. W. P. Dillon, K. L. Fehlhaber and M. W. Lee. Gas hydrates; their distribution and significance in sea-floor sediments of the U.S. Atlantic margin [abstr.] Annual Meeting Abstracts American Association of Petroleum Geologists and Society of Economic Paleontologists and Mineralogists, in American Asso- ciation of Petroleum Geologists 1993 annual convention. 1993, April 1993. p. 92.

OP-1338. J. M. Dohm and D. H. Scott. Relation between ages and elevations of Martian channels [abstr.] Proceedings of the Lunar and Planetary Science Conference, in Abstracts of papers submitted to the Twenty-fourth lunar and planetary science conference. (Douglas Blanchard, chairperson and others). 24, 1993. p. 407-408.

OP-1339. J. C. Dohrenwend. CALIFORNIA, NEVADA. Rates and patterns of piedmont evolution in the Southwest Basin and Range [abstr.] Quarterly of San Bernardino County Museum Association, in Quaternary history of the Mojave Desert; proceedings of the First annual symposium of the Mojave Desert Quaternary Research Center. (J. S. Reynolds, compiler). v. 34, no. 3-4, 1987. p. 57-58.

OP-1340. M. M. Donato and M. A. Lanphere. CALIFORNIA. Geochronologic studies of selected amphibolites in the northern Klamath Mountains [abstr.] Abstracts with Programs - Geological Society of America, in Geological Society of America, Cordilleran Section, 88th annual meeting, 1992. (A. D. Johnston, chairperson). v. 24, no. 5, May 1992. p. 20.

OP-1341. P. F. Donovan-Ealy* and J. D. Hendricks. ARIZONA. Gravity and magnetic anomalies associated with Tertiary volcanism and Proterozoic crustal boundary, Hopi Buttes volcanic field, Navajo Nation (Arizona) [abstr.] Abstracts with Programs Geological Society of America, in Geological Society of America, 1992 annual meeting. v. 24, no. 7, 1992. p. 82.

OP-1342. M. P. Doukas and C. I. Bauer*. ALASKA. Observations of the 18 August, 1992 eruption of Mount Spurr Volcano, Alaska, using satellite, seismic and ground observation data [abstr.] Eos, Transactions, American Geophysical Union, in AGU 1992 fall meeting. v. 73, no. 43, suppl. October 27, 1992. p. 346.

OP-1343. L. J. Drew, Meng Qingren* and Sun Weijun*. Observations on regional geology and alkali metasomatism associated with iron-niobium-rare earths ore bodies at Bayan Obo, Inner Mongolia, China [abstr.] International Geological Congress, Abstracts - Congres Geologique Internationale, Resumes, in 28th international geological congress; abstracts. 28, Vol. 1,1989. p. 1.416-1.417.

OP-1344. Yue Du*, G. D. Stanley, Jr** and Michael McCormick. CALIFORNIA. Reinterpretation of the Hosselkus Limestone of eastern Klamath Terrane; Late Triassic olistotromes in a volcanic arc basin [abstr.] Abstracts with Programs - Geological Society of America, in Geological Society of America, Cordilleran Section, 88th annual meeting. v. 24, no. 5, May 1992. p. 21.

OP-1345. F. T. Dulong and C. B. Cecil. Paleoclimate implications from Middle and Upper Carboniferous paleotectonic and paleoenvironmental reconstructions [abstr.] Abstracts with Programs - Geological Society of America, in Geological Society of America, 1992 annual meeting. v. 24, no. 7, 1992. p. 202.

OP-1346. R. A. Duncan* and M. S. Pringle. K/T boundary events were synchronous with rapid eruption of the Deccan flood basalts [abstr.] Eos, Transactions, American Geophysical Union, in AGU-MSA 1991 spring meeting. v. 72, no. 17, April 23, 1991. p. 301. 
OP-1347. W. R. Dupre* and J. C. Tinsley. CALIFORNIA. Geologic controls on liquefaction-induced ground failure in the Monterey Bay area, California, during the Loma Prieta earthquake, October 19, 1989 [abstr.] Abstracts with Programs - Geological Society of America, in Geological Society of America, 1990 annual meeting. v. 22 , no. 7, 1990. p. 188.

OP-1348. W. B. Durham* and S. H. Kirby. Planetary ices; a comparison of rheologies at $\mathrm{T}<200 \mathrm{~K}$ [abstr.] Abstracts of Papers Submitted to the Lunar and Planetary Science Conference, in Abstracts of papers submitted to the Twenty-first lunar and planetary science conference. (Lunar and Planetary Institute). 21, 1990. p. 305-306.

OP-1349. Cynthia Dusel-Bacon and V. L. Hansen*. ALASKA. High-P, moderate-T metamorphism and ductile deformation during early Mesozoic subduction and accretion, east-central Alaska [abstr.] Abstracts with Programs - Geological Society of America, in Geological Society of America, Cordilleran Section, 88th annual meeting. v. 24 , no. 5 , May 1992 . p. 21.

OP-1350. T. S. Dyman, J. W. Schmoker, C. W. Spencer, W. J. Perry, Jr., L. C. Price, J. G. Palacas, G. L. Dolton, R. C. Burruss, C. W. Keighin, T. C. Hester, C. J. Wandrey, D. K. Vaughan, D. T. Nielsen, R. C. Obuch, J. K. Baird and P. A. Westcott*. Geologic controls and resource potential of natural gas in deep sedimentary basins, United States [abstr.] Annual Meeting Abstracts - American Association of Petroleum Geologists and Society of Economic Paleontologists and Mineralogists, in American Association of Petroleum Geologists 1993 annual convention. 1993, April 1993. p. 95.

OP-1351. T. S. Dyman, R. G. Tysdal, C. A. Wallace and S. E. Lewis*. MONTANA. Correlation chart of Lower and LowerUpper Cretaceous Blackleaf Formation, eastern Pioneer Mountains, southwestern Montana, to Drummond, central-western Montana [abstr.] AAPG Bulletin, in AAPG Rocky Mountain Section meeting. v. 77, no. 8, August 1993. p. 1446.

OP-1352. D. D. Eberl and A. E. Blum. Clay particle sizes from atomic force microscopy [abstr.] Program and Abstracts - Annual Clay Minerals Conference, in Clay Minerals Society, 28th annual meeting. (D. R. Pevear, chairperson). 28, October 1991. p. 40.

OP-1353. D. D. Eberl and Jan Srodon*. Use of illite particle thickness, rather than expandability, as a measure of diagenetic grade [abstr.] Program and Abstracts - Annual Clay Minerals Conference, in Clay Minerals Society, 28th annual meeting. (D. R. Pevear, chairperson). 28, October 1991. p. 41.

OP-1354. S. M. Eberts. Preliminary hydrologic observations of regional aquifer system in glacial deposits and carbonate bedrock, Midwestern basin and arches region [abstr.] Abstracts with Programs - Geological Society of America, in Geological Society of America, 1992 annual meeting. v. 24, no. 7, 1992. p. 282.

OP-1355. J. O. Eckert, Jr., S. R. Bohlen and W. B. Hankins. Melting of granitic (Ab-An-Or-Qz) compositions in the presence of an $\mathrm{H}_{2} \mathrm{O}-\mathrm{CO}_{2}$ fluid [abstr.] Abstracts with Programs - Geological Society of America, in Geological Society of America, 1992 annual meeting. v. 24 , no. 7,1992 . p. 256.

OP-1356. N. T. Edgar, C. B. Cecil, M. S. Grim, M. R. Jones* and D. E. Searle*. Gulf of Carpentaria, a modern analog for ancient tropical epicontinental sea sedimentation [abstr.] Abstracts with Programs - Geological Society of America, in Geological
Society of America, 1992 annual meeting. v. 24, no. 7, 1992. p. 143.

OP-1357. J. R. Eggleston. Lacustrine sedimentation and origin of the Upper Pennsylvanian Redstone Limestone, Northern Appalachian Basin [abstr.] Abstracts with Programs - Geological Society of America, in Geological Society of America, Northeastern Section, 28th annual meeting. v. 25, no. 2, March 1993. p. 13.

OP-1358. S. L. Eittreim, A. K. Cooper and Jacques Wannesson*. Seismic stratigraphic clues regarding the history of ice sheet advances on the Wilkes Land margin [abstr.] Annual Meeting Abstracts - American Association of Petroleum Geologists and Society of Economic Paleontologists and Mineralogists, in American Association of Petroleum Geologists, 1992 annual convention. $1992,1992$. p. 36.

OP-1359. W. C. Elliott*, J. L. Aronson* and H. T. Millard, Jr. Iridium content of the basaltic tuffs of the Paleocene Balder Formation, North Sea [abstr.] Abstracts with Programs - Geological Society of America, in Geological Society of America, 1992 annual meeting. v. 24 , no. 7,1992 . p. 333.

OP-1360. W. L. Ellsworth. Forecasting earthquakes in the 1990's [abstr.] Eos, Transactions, American Geophysical Union, in AGU 1989 fall meeting. v. 70, no. 43 , October 24,1989 . p. 1003.

OP-1361. D. P. Elston, Zhang Huimin* and Zhang Wenzhi*. Paleomagnetic poles from middle and late Proterozoic Changcheng, Jixian, and Qingbaikou groups, Jixian County, North China [abstr.] International Geological Congress, Abstracts-Congres Geologique Internationale, Resumes, in 28th international geological congress; abstracts. 28, Vol. 1,1989. p. 1.448-1.449.

OP-1362. E. T. Endo, Daniel Dzurisin and D. A. Swanson. WASHINGTON. Geophysical and observational constraints for shallow ascent rates of dacitic magma at Mount St. Helens [abstr.] International Geological Congress, Abstracts-Congres Geologique Internationale, Resumes, in 28th international geological congress; abstracts. 28, Vol. 1, 1989. p. 1.453-1.454.

OP-1363. E. R. Engdahl. Global upper mantle structure from well-constrained hypocenters of explosions and earthquakes [abstr.] Seismological Research Letters, in 85th annual meeting of the Seismological Society of America. v. 61, no. 1, March 1990. p. 32.

OP-1364. E. R. Engdahl. Travel times for global earthquake location and phase identification; the iasp91 model [abstr.] Eos, Transactions, American Geophysical Union, in AGU 1992 western Pacific geophysical meeting. v. 73 , no. 25, Suppl. June 23 , 1992. p. 56-57.

OP-1365. E. R. Engdahl. The International Seismological Observing Period (ISOP); scientific rationale and opportunities [abstr.] Eos, Transactions, American Geophysical Union, in AGU 1992 western Pacific geophysical meeting. v. 73, no. 25, Suppl. June 23, 1992. p. 55-56.

OP-1366. D. C. Engebretson* and M. C. Blake, Jr. Temporal correlations between global plate reorganizations and blueschist occurrences [abstr.] Abstracts with Programs - Geological Society of America, in Geological Society of America, Cordilleran Section, 88th annual meeting. v. 24, no. 5, May 1992. p. 22.

OP-1367. K. J. Englund. VIRGINIA, WEST VIRGINIA. Depositional model for the Lower Mississippian (Tournaisian) rocks of 
Virginia and West Virginia, USA [abstr.] International Geological Congress, Abstracts-Congres Geologique Internationale, Resumes, in 28 th international geological congress; abstracts. 28 , Vol. 1, 1989. p. 1.454-1.455.

OP-1368. K. J. Englund, R. E. Thomas and J. B. Roen. KENTUCKY, TENNESSEE, VIRGINIA. Geology of the Cumberland Gap area, Kentucky, Tennessee, and Virginia [abstr.] AAPG Bulletin, in AAPG Eastern Section meeting. v. 77, no. 8, August 1993. p. 1468.

OP-1369. G. E. Ericksen, C. F. Ramirez*, J. F. Concha* and F. Urquida*. Landslide hazards in Southern Andes [abstr.] International Geological Congress, Abstracts-Congres Geologique Internationale, Resumes, in 28th international geological congress; abstracts. 28, Vol. 1, 1989. p. 1.456 .

OP-1370. A. F. Espinosa and M. Herraiz*. Technique for seismic moment determination [abstr.] International Geological Congress, Abstracts-Congres Geologique Internationale, Resumes, in 28th international geological congress; abstracts. 28, Vol. 1, 1989. p. 1.462 .

OP-1371. A. F. Espinosa and M. Herraiz*. Technique for seismic moment determination from strong ground-motion recordings [abstr.] International Geological Congress, Abstracts-Congres Geologique Internationale, Resumes, in 28th international geological congress; abstracts. 28, Vol. 1, 1989. p. 1.463.

OP-1372. A. F. Espinosa, Agustin Udias* and J. Mezcua*. Earthquake-hazard evaluation and mitigation in Spain; a United States-Spain bilateral science and technology program [abstr.] International Geological Congress, Abstracts-Congres Geologique Internationale, Resumes, in 28th international geological congress; abstracts. 28, Vol. 1, 1989. p. 1.462-1.463.

OP-1373. J. R. Evans, J. A. Philpotts and C. D. Taylor. ALASKA. Rare earth minerals in a "thunder egg" from Zarembo Island, Southeast Alaska; a scanning electron microscopy study [abstr.] Eos, Transactions, American Geophysical Union, in AGU 1992 spring meeting. v. 73, no. 14, suppl. April 7, 1992. p. 352.

OP-1374. J. R. Evans, J. J. Zucca* and C. Chiarabba*. Imaging magma chambers, intrusion pathways, and geothermal reservoirs of two Cascadian shield volcanoes by high-resolution NeHT seismic tomography [abstr.] Eos, Transactions, American Geophysical Union, in AGU 1992 western Pacific geophysics meeting. v. 73, no. 25, Suppl. June 23, 1992. p. 60.

OP-1375. H. C. Fairley*, Richard Hereford and J. R. Balsom*. ARIZONA. Current geoarcheological research in eastern Grand Canyon [abstr.], in First biennial conference on Research in Colorado Plateau national parks; program and abstracts of presented posters and papers. (Charles van Riper, III, chairperson). Flagstaff, AZ: North. Ariz. Univ. 1991. p. 29.

OP-1376. D. L. Farber*, M. J. Davis*, K. A. Johnson*, E. D. Young*, J. L. Wooden and R. M. Tosdal. CALIFORNIA. Late Jurassic bimodal alkalic plutonism and magma mixing in the Mojave Desert region, southeastern CA [abstr.] Abstracts with Programs - Geological Society of America, in Geological Society of America, 1989 annual meeting. (K. L. Shelton, chairperson). v. 21 , no. 6,1989 . p. $325-326$.
OP-1377. G. L. Farmer* and Fred Barker. Granites as probes to deep crust in western North America; an isotopic approach [abstr.] Eos, Transactions, American Geophysical Union, in AGU-MSA 1991 spring meeting. v. 72, no. 17, April 23, 1991. p. 302.

OP-1378. D. J. Faulkender*, J. W. Whitney and J. R. Underwood*. Origin and characteristics of An Nafud sand, north-central Saudi Arabia [abstr.] Abstracts with Programs - Geological Society of America, in Geological Society of America, 1992 annual meeting. v. 24 , no. 7,1992 . p. 298.

OP-1379. M. S. Fedosh*, J. P. Smoot and R. K. Kotra. NEW JERSEY. Sedimentology and organic geochemistry of the Jurassic Newark Basin, northern New Jersey [abstr.] Proceedings of the International Conference on Basement Tectonics, in Basement tectonics 8; Characterization and comparison of ancient and Mesozoic continental margins. (M. J. Bartholomew, editor and others). 8, 1988. p. 731-732.

OP-1380. S. B. Feldman*, L. W. Zelazny* and M. J. Pavich. Paleopedological reconstruction and quantitative analysis of weathering processes in the southern Piedmont Province [abstr.] Abstracts with Programs - Geological Society of America, in Geological Society of America, 1992 annual meeting. v. 24, no. 7, 1992. p. 230.

OP-1381. M. L. Ferns*, H. C. Brooks* and J. G. Evans. IDAHO. Volcanism in the Boise 2 degree sheet [abstr.] Abstracts with Programs - Geological Society of America, in Geological Society of America, Cordilleran Section, 88th annual meeting. v. 24, no. 5, May 1992. p. 23.

OP-1382. R. B. Finkelman, N. H. Bostick and F. T. Dulong. COLORADO. Influence of an igneous intrusion on the element distribution of a bituminous coal from Pitkin County, Colorado [abstr.] Annual Meeting of the Society for Organic Petrology. Abstracts and Program, in Ninth annual meeting of the Society for Organic Petrology. (S. A. Stout, editor). 9, July 23, 1992. p. 112-114.

OP-1383. J. M. Fischer, A. L. Baehr and N. P. Smith, Field determination of hydrocarbon degradation rates in shallow ground water by simulating transport of oxygen and carbon dioxide in the unsaturated zone [abstr.] Eos, Transactions, American Geophysical Union, in AGU 1992 spring meeting. v. 73, no. 14, Suppl. April 7, 1992. p. 115.

OP-1384. M. A. Fisher, T. M. Brocher, George Plafker, T. R. Bruns, E. L. Geist, R. A. Page and C. D. Stephens. ALASKA. Deep seismic reflections from a young suture zone and the asperity of the great, 1964 Alaskan earthquake [abstr.] Eos, Transactions, American Geophysical Union, in AGU 1993 fall meeting. v. 74, no. 43, Suppl. October 26, 1993. p. 95.

OP-1385. N. S. Fishman. ILLINOIS, INDIANA. Large-scale fluid movement in a Cambrian paleoaquifer; evidence from the Mt. Simon Sandstone, Illinois and Indiana [abstr.] Annual Meeting Abstracts - American Association of Petroleum Geologists and Society of Economic Paleontologists and Mineralogists, in American Association of Petroleum Geologists 1993 annual convention. 1993, April 1993. p. 102.

OP-1386. N. S. Fishman, C. E. Turner and R. A. Sheppard. CALIFORNIA. Authigenic illite in silicic tuffs of Pleistocene Lake Tecopa, California; a cautionary note for clay-mineral geothermometry [abstr.] Program and Abstracts - Annual Clay 
Minerals Conference, in Clay Minerals Society, 28th annual meeting. (D. R. Pevear, chairperson). 28, October 1991. p. 51.

OP-1387. W. M. Fitchen*, M. H. Gardner*, C. H. Kerans*, L. Little*, M. D. Sonnenfeld*, S. W. Tinker* and B. R. Wardlaw. ALASKA. Evolution of platform and basin architecture in mixed carbonate-siliciclastic sequences; latest Leonardian through Guadalupian Delaware Basin [abstr.] Annual Meeting Abstracts - American Association of Petroleum Geologists and Society of Economic Paleontologists and Mineralogists, in American Association of Petroleum Geologists, 1992 annual convention. 1992, 1992. p. 41.

OP-1388. R. F. Fleming* and D. J. Nichols. Nonmarine Cretaceous-Tertiary boundary, Southwestern United States [abstr.] Abstracts with Programs - Geological Society of America, in Geological Society of America, 1990 annual meeting. v. 22, no. 7, 1990. p. 278.

OP-1389. R. H. Fleming*, G. P. Meeker*, F. Radicati di Brozolo*, D. F. Blake* and L. D. White. Isotope ratio imaging of interplanetary dust particles [abstr.] Abstracts of Papers Submitted to the Lunar and Planetary Science Conference, in Abstracts of papers submitted to the Twenty-first lunar and planetary science conference. (Lunar and Planetary Institute). 21, 1990. p. 369370 .

OP-1390. I. B. Fletcher and L. M. Baker. Non-linear inversion of spectral ratios for a 1-D seismic velocity structure by simulated annealing [abstr.] Eos, Transactions, American Geophysical Union, in AGU 1992 fall meeting. v. 73, no. 43, suppl. October 27, 1992. p. 339.

OP-1391. R. M. Flores, J. M. Beggs* and P. R. King*. Sedimentology of tide-dominated reservoir sandstones in the Eocene Kapuni Group, Taranaki Basin, New Zealand [abstr.] Annual Meeting Abstracts - American Association of Petroleum Geologists and Society of Economic Paleontologists and Mineralogists, in American Association of Petroleum Geologists 1993 annual convention. 1993, April 1993. p. 102.

OP-1392. Christine Floss*, O. B. James, J. J. McGee and Ghislaine Crozaz*. Lunar ferroan anorthosites; rare earth element measurements of individual plagioclase and pyroxene grains [abstr.] Proceedings of the Lunar and Planetary Science Conference, in Twenty-second Lunar and Planetary Science Conference. 22, 1991. p. 391-392.

OP-1393. D. W. Folger. The southern Lake Michigan coastal erosion study [abstr.] Abstracts with Programs - Geological Society of America, in Geological Society of America, Northeastern Section, 28th annual meeting. v. 25, no. 2, March 1993. p. 15.

OP-1394. P. F. Folger, R. B. Wanty, W. C. Day, David Frishman, T. A. Taylor and E. P. Poeter*. Radon in a fractured bedrock aquifer; relationships with rock type and distribution of parent radionuclides [abstr.] Abstracts with Programs - Geological Society of America, in Geological Society of America, 1992 annual meeting. v. 24 , no. 7,1992 . p. 78 .

OP-1395. A. B. Ford. Repeated pre-Jurassic reactivation of pericratonic Transantarctic Mountains fold belts near Weddell Sea, followed by Jurassic rifting and voluminous mafic magmatism [abstr.] Eos, Transactions, American Geophysical Union, in AGUMSA 1991 spring meeting. v. 72, no. 17, April 23, 1991. p. 298.
OP-1396. A. B. Ford and D. A. Brew. ALASKA. Sitkoh Bay long-duration alkalic plutonism, Chichagof Island, SE Alaska [abstr.] Abstracts with Programs - Geological Society of America, in Geological Society of America, Cordilleran Section, 88th annual meeting. v. 24, no. 5, May 1992. p. 24.

OP-1397. K. F. Fox, Jr. ALASKA. Metamorphic core complexes within an Eocene extensional province in north-central Washington [abstr.] Abstracts with Programs - Geological Society of America, in Geological Society of America, Cordilleran Section, 88th annual meeting. v. 24, no. 5, May 1992. p. 25.

OP-1398. R. B. Fox. Production of U.S. Geological Survey 1:24,000-scale topographic maps from revised digital line graphs [abstr.] Abstracts with Programs - Geological Society of America, in Geological Society of America, North-Central Section, 27th annual meeting. v. 25, no. 3, March 1993. p. 19.

OP-1399. K. J. Franczyk, J. K. Pitman and D. C. Brew*. COLORADO. Proximal and distal facies of clastic-dominated Pennsylvanian strata along the eastern margin of the Paradox Basin, Colorado [abstr.] AAPG Bulletin, in AAPG Rocky Mountain Section meeting. v. 77, no. 8, August 1993. p. 1447-1448.

OP-1400. C. J. Fridrich and Jason Price*. NEVADA. Tectonic framework of Crater Flat Basin, adjacent to Yucca Mountain, Nevada; a preliminary report [abstr.] Abstracts with Programs Geological Society of America, in Geological Society of America, 1992 annual meeting. v. 24, no. 7,1992. p. 189-190.

OP-1401. T. P. Frost and E. J. Moll-Stalcup. OREGON. Early Cretaceous and Late Cretaceous-Paleocene plutonism in the Bethel region, southwestern Alaska; products of two magmatic arcs [abstr.] Abstracts with Programs - Geological Society of America, in Geological Society of America, Cordilleran Section, 88th annual meeting. v. 24, no. 5, May 1992. p. 25.

OP-1402. L. R. Gaddis*, L. A. Soderblom*,H. H. Kieffer* and K. F. Mullins. Separation of AVIRIS data into atmospheric, instrumental, and surface reflectance components through forced internal consistency [abstr.] Eos, Transactions, American Geophysical Union, in AGU 1992 spring meeting. v. 73, no. 14, Suppl. April 7, 1992. p. 184-185.

OP-1403. M. W. Gannett. OREGON. Thickness, distribution and nature of basin-fill sediments in the Willamette Valley, Oregon [abstr.] Abstracts with Programs - Geological Society of America, in Geological Society of America, Cordilleran Section, 88th annual meeting. v. 24, no. 5, May 1992. p. 25.

OP-1404. C. A. Gardner, B. E. Hill*, R. M. Negrini* and A. M. Sarna-Wojcicki. PUERTO RICO. Paleomagnetic correlation of middle Pleistocene ignimbrites from the Bend, Oregon area with distal tephra beds [abstr.] Abstracts with Programs - Geological Society of America, in Geological Society of America, Cordilleran Section, 88th annual meeting. v. 24, no. 5, May 1992. p. 26.

OP-1405. J. B. Garvin* and R. S. Williams, Jr. Morphometric comparison of Icelandic lava shield volcanoes versus selected Venusian edifices [abstr.] Proceedings of the Lunar and Planetary Science Conference, in Abstracts of papers submitted to the Twenty-fourth lunar and planetary science conference. (Douglas Blanchard, chairperson and others). 24, 1993. p. 523-524. 
OP-1406. J. B. Garvin* and R. S. Williams, Jr. Morphometry of shield volcanoes on Earth and Mars and implications for Venus [abstr.] Proceedings of the Lunar and Planetary Science Conference, in Twenty-second Lunar and Planetary Science Conference. 22, 1991. p. $431-432$.

OP-1407. Carey Gazis* and M. A. Lanphere. Laser ${ }^{40} \mathrm{Ar} /{ }^{39} \mathrm{Ar}$ studies of the Chegem Caldera and related intrusive rocks, northcentral Caucasus Mountains, Russia [abstr.] Eos, Transactions, American Geophysical Union, in AGU 1993 spring meeting. v. 74, no. 16, Suppl. May 1993. p. 334.

OP-1408. P. E. Geissler*, R. B. Singer* and B. K. Lucchitta. Dark materials in Valles Marineris; indications of the style of volcanism and magnetism in Mars [abstr.] Abstracts of Papers Submitted to the Lunar and Planetary Science Conference, in Abstracts of papers submitted to the Twenty-first lunar and planetary science conference. (Lunar and Planetary Institute). 21, 1990. p. $413-414$.

OP-1409. A. C. Gellis. Sediment loads in selected streams in Puerto Rico during the passage of Hurricane Hugo [abstr.] Abstracts with Programs - Geological Society of America, in Geological Society of America, 1990 annual meeting. v. 22, no. 7, 1990. p. 331.

OP-1410. S. A. Gilbert*, J. F. Casey*, D. C. Bradley and T. M. Kusky*. ALASKA. Geochemistry of siliciclastic rocks in the Peninsular, Chugach, and Prince William terranes; implications for the tectonic evolution of south central Alaska [abstr.] Abstracts with Programs - Geological Society of America, in Geological Society of America, 1992 annual meeting. v. 24, no. 7,1992. p. 305.

OP-1411. R. J. Gilliom and W. G. Wilber. Concepts for a national synthesis of pesticides in streams and aquifer systems; a component of the National Water-Quality Assessment Program [abstr.] American Water Resources Association Technical Publication Series TPS, in Water management of river systems; 27th annual AWRA conference. (H. C. McWreath, editor). 27, 1991. p. 367-368.

OP-1412. G. D. Ginsburg*, V. A. Soloviev*, R. E. Cranston*, T. D. Lorenson and K. A. Kvenvolden. Gas hydrate recovery from the continental slope near Sakhalin Island, Okhotsk Sea [abstr.] Eos, Transactions, American Geophysical Union, in AGU 1992 spring meeting. v. 73, no. 14, Suppl. April 7, 1992. p. 167.

OP-1413. G. H. Girty*, A. S. Yoshinobu*, M. S. Girty*, M. D. Wracher*, K. A. Bryan*, J. E. Skinner*, B. A. McNulty*, K. A. Bracchi*, D. S. Harwood and R. E. Hanson*. CALIFORNIA. U-Pb zircon geochronology of the Emigrant Gap composite pluton, northern Sierra Nevada, California; implications for the Nevadan Orogeny [abstr.] AAPG Bulletin, in AAPG Pacific Section abstracts. v. 77, no. 4, April 1993. p. 698-699.

OP-1414. B. P. Glass*, B. F. Bohor and W. J. Betterton. Cretaceous-Tertiary boundary spherules and Cenozoic microtektites; similarities and differences [abstr.] Proceedings of the Lunar and Planetary Science Conference, in Abstracts of papers submitted to the Twenty-fourth lunar and planetary science conference. (Douglas Blanchard, chairperson and others). 24, 1993. p. 539-540.

OP-1415. P. D. Glynn, L. N. Plummer and Eurybiades Busenberg. Thermodynamics of $(\mathrm{Ba}, \mathrm{Sr}) \mathrm{CO}_{3}$ and $(\mathrm{Sr}, \mathrm{Ca}) \mathrm{CO}_{3}$ solid-solutions; results from low-temperature aqueous coprecipitation and dissolution experiments [abstr.] Terra Cognita, in First international. symposium on Thermodynamics of natural processes. v. 8, no. 2, 1988. p. 178 .

OP-1416. R. J. Goldfarb, D. L. Leach and W. J. Pickthorn. ALASKA. Source of synorogenic fluids of the northern Cordillera; evidence from the Juneau gold belt, Alaska [abstr.], in Greenstone gold and crustal evolution; NUNA conference volume. (François Robert, editor and others). St. John's, NF: Geol. Assoc. Canada, 1990. p. 160-161.

OP-1417. M. B. Goldhaber, S. F. Diehl, M. J. Flohr and S. J. Sutley. Evidence for alkaline igneous activity and associated metasomatism in the Reelfoot Rift, south-central Midcontinent, U.S.A. [abstr.] Abstracts with Programs - Geological Society of America, in Geological Society of America, North-Central Section, 27th annual meeting. v. 25, no. 3, March 1993. p. 21-22.

OP-1418. M. B. Goldhaber, E. L. Mosier, S. E. Church and S. F. Diehl. MISSOURI. The critical role of hematite cement in the Lamotte Sandstone for the genesis of the Southeast Missouri mississippi valley-type lead districts [abstr.] Abstracts with Programs - Geological Society of America, in Geological Society of America, North-Central Section, 27th annual meeting. v. 25, no. 3, March 1993. p. 21.

OP-1419. M. B. Goldhaber, G. S. Plumlee, T. S. Hayes, C. J. Potter, E. L. Rowan and C. D. Taylor. ILLINOIS, KENTUCKY. The Illinois Kentucky fluorspar district; rift-related fluorite mineralization superimposed on a basinal brine flow system [abstr.] Abstracts with Programs - Geological Society of America, in Geological Society of America, 1992 annual meeting. v. 24, no. 7,1992 . p. $21-22$.

OP-1420. Peter Goldstein* and B. A. Chouet. HAWAII. Measurements of the depth, spatial extent, and spectra of harmonic tremor and gas-piston activity recorded with dense arrays on Kilauea Volcano, Hawaii, and the relative importance of source, path, and site effects [abstr.] Eos, Transactions, American Geophysical Union, in AGU 1992 fall meeting. v. 73, no. 43, suppl. October 27, 1992. p. 347.

OP-1421. M. P. Golombek*, K. L. Tanaka and W. B. Banerdt*. Strain accommodation beneath structures on Mars [abstr.] Proceedings of the Lunar and Planetary Science Conference, in Twenty-second Lunar and Planetary Science Conference. 22, 1991. p. 455-456.

OP-1422. M. P. Golombek*, K. L. Tanaka, W. B. Banerdt* and D. M. Tralli*. Mars seismicity through time from surface faulting [abstr.] [abstr.] Proceedings of the Lunar and Planetary Science Conference, in Twenty-second Lunar and Planetary Science Conference. 22, 1991. p. 451-452.

OP-1423. J. S. Gomberg, W. Z. Savage, Paul Bodin*, M. E. Meremonte, Edward Cranswick, B. Kindel*, T. L. Pratt, R. Williams, T. Bice, D. Overturf, P. S. Powers and J. C. Savage. COLORADO. The Slumgullion earthflow; slidequakes and creep [abstr.] Eos, Transactions, American Geophysical Union, in AGU 1993 fall meeting. v. 74, no. 43, Suppl. October 26, 1993. p. 67.

OP-1424. E. Gonzalez*, K. M. Fischer*, S. E. Hough, C. Nelsen* and X. Yang*. RHODE ISLAND. Site response in sediment-filled glacial valleys; a case study from Providence, RI 
[abstr.] Eos, Transactions, American Geophysical Union, in AGU 1992 fall meeting. v. 73 , no. 43, suppl. October 27, 1992. p. 338.

OP-1425. D. A. Goolsby. Agricultural chemicals in surfacewater resources of the midcontinental United States [abstr.] American Water Resources Association Technical Publication Series TPS, in Water management of river systems; 27th annual AWRA conference. (H. C. McWreath, editor). 27, 1991. p. 373-374.

OP-1426. Y. A. Gorby*, Harvey Bolton, Jr.* and D. R. Lovley. Microbial chromium reduction and immobilization [abstr.] Abstracts of Papers - American Chemical Society, National Meeting, in 203rd ACS national meeting. 203, 1992. p. GEOC 130.

OP-1427. R. R. Gottschalk*, H. G. Avé Lallemant*, J. S. Oldow* and L. W. Snee. ALASKA. ${ }^{40} \mathrm{Ar} /{ }^{39} \mathrm{Ar}$ thermochronology of metamorphic rocks in the south-central Brooks Range fold and thrust belt, Alaska [abstr.] Abstracts with Programs - Geological Society of America, in Geological Society of America, 1990 annual meeting. v. 22 , no. 7,1990 . p. 326.

OP-1428. Arthur Grantz. Geology and tectonic significance of southern Northwind Ridge, Arctic Ocean [abstr.] International Geological Congress, Abstracts - Congres Geologique Internationale, Resumes, in 28th international geological congress; abstracts. 28, Vol. 1, 1989. p. 1.580 .

OP-1429. Arthur Grantz and S. D. May. ALASKA. The Alaska Aulacogen of the Arctic mid-ocean ridge system [abstr.] Eos, Transactions, American Geophysical Union, in AGU 1992 spring meeting. v. 73, no. 14, suppl. April 7, 1992. p. 287.

OP-1430. Arthur Grantz, T. E. Moore and S. M. Roeske. ALASKA. Transect of Alaska from the Gulf of Alaska to the Arctic Ocean [ábstr.] International Geological Congress, Abstracts-Congres Geologique Internationale, Resumes, in 28th international geological congress; abstracts. $28, \mathrm{Vol} .1,1989$. p. $1.579-1-580$.

OP-1431. R. I. Grauch. Unconventional sources for platinum group elements and precious metals; early-middle Proterozoic unconformities [abstr.] International Geological Congress, Abstracts-Congres Geologique Internationale, Resumes, in 28th international geological congress; abstracts. 28, Vol. 1,1989. p. 1.582 .

OP-1432. R. I. Grauch, R. M. Coveney, Jr.* and J. B. Murowchick*. Black shales, continental rifts, and Ni-Mo-(PGEAu) deposits [abstr.] Abstracts with Programs - Geological Society of America, in Geological Society of America, 1992 annual meeting. v. 24, no. 7, 1992. p. 107.

OP-1433. J. E. Gray, R. J. Goldfarb, L. W. Snee and C. A. Gent. ALASKA. Geochemical and temporal conditions for the formation of mercury-antimony deposits, southwestern Alaska [abstr.] Abstracts with Programs - Geological Society of America, in Geological Society of America, Cordilleran Section, 88th annual meeting. v. 24, no. 5, May 1992. p. 28.

OP-1434. J. R. Gray, J. D. Smith and J. B. Graf. ARIZONA. Sediment-transport research, Grand Canyon, Arizona [abstr.], in First biennial conference on Research in Colorado Plateau national parks; program and abstracts of presented posters and papers. (Charles van Riper, III, chairperson). Flagstaff, AZ: North. Ariz. Univ. 1991. p. 29.
OP-1435. J. R. Gray, P. C. Van Metre and Laurie Wirt. ARIZONA. Radionuclide transport in the Little Colorado River basin [abstr.], in First biennial conference on Research in Colorado Plateau national parks; program and abstracts of presented posters and papers. (Charles van Riper, III, chairperson). Flagstaff, AZ: North. Ariz. Univ. 1991. p. 30.

OP-1436. S. C. Gray, R. Hausmann*, Ulrich Radtke* and J. R. Hein. Late Quaternary sealevel highstands based on uranium-series and ESR ages of drill-core corals from the Cook Islands, South Pacific [abstr.] Eos, Transactions, American Geophysical Union, in AGU 1989 fall meeting. v. 70, no. 43, October 24, 1989. p. 1051.

OP-1437. Ronald Greeley*, M. J. Belton*, L. Bolef*, M. H. Carr, C. R. Chapman*, M. E. Davies*, L. Doose*, F. P. Fanale*, L. R. Gaddis*, Richard Greenberg*, J. W. Head*, Harald Hoffmann*, R. Jaumann*, T. V. Johnson*, K. P. Klaasen*, R. Koloord*, A. S. McEwen, S. L. Murchie*, Gerhard Neukum*, Jürgen Oberst*, C. M. Pieters*, C. B. Pilcher*, J. Plutchak*, M. S. Robinson*, Robert Sullivan*, J. M. Sunshine* and Joseph Veverka*. Lunar maria and related deposits; preliminary Galileo imaging results [abstr.] Abstracts of Papers Submitted to the Lunar and Planetary Science Conference, in Twenty-second lunar and planetary science conference; press abstracts. 22,1991 . p. $17-18$.

OP-1438. Ronald Greeley*, M. J. Belton*, L. Bolef*, M. H. Carr, C. R. Chapman*, M. E. Davies*, L. Doose*, F. P. Fanale*, L. R. Gaddis*, Richard Greenberg*, J. W. Head*, Harald Hoffmann*, R. Jaumann*, T. V. Johnson*, K. P. Klaasen*, R. Koloord*, A. S. McEwen, S. L. Murchie*, Gerhard Neukum*, Jürgen Oberst*, C. M. Pieters*, C. B. Pilcher*, J. Plutchak*, M. S. Robinson*, Robert Sullivan*, J. M. Sunshine* and Joseph Veverka*. Lunar maria and related deposits; preliminary Galileo imaging results [abstr.] Proceedings of the Lunar and Planetary Science Conference, in Twenty-second Lunar and Planetary Science Conference. 22, 1991. p. 491-492.

OP-1439. Ronald Greeley*, M. J. Belton*, J. W. Head*, A. S. McEwen, C. M. Pieters*, Gerhard Neukum*, T. L. Becker, E. M. Fischer*, S. D. Kadel*, M. S. Robinson*, R. J. Sullivan*, J. M. Sunshine* and D. A. Williams*. Galileo imaging results from the second Earth-Moon flyby; lunar maria and related units [abstr.] Proceedings of the Lunar and Planetary Science Conference, in Abstracts of papers submitted to the Twenty-fourth lunar and planetary science conference. (Douglas Blanchard, chairperson and others). 24,1993 . p. 565-566.

OP-1440. A. G. Green* and W. F. Cannon. From the Pacific to the Atlantic; a transect of the North American continent near the Canada-U.S. border; status and future plans [abstr.] International Geological Congress, Abstracts-Congres Geòlogique Internationale, Resumes, in 28 th international geological congress; abstracts. 28, Vol. 1, 1989. p. 1.585 .

OP-1441. A. W. Green and W. F. Stuart*. Geomagnetic imaging of the core-mantle boundary [abstr.] Terra Cognita, in Abstracts of the 17 th international conference on mathematical geophysics. (A. M. Correig, editor). v. 8, no. 2, 1988. p. 145.

OP-1442. H. G. Greene, M. P. Kennedy* and S. H. Clarke, Jr. CALIFORNIA. Structural geology of the inner Southern California borderland; styles and patterns of deformation [abstr.] AAPG 
Bulletin, in AAPG Pacific Section abstracts. v. 77, no. 4, April 1993. p. 699.

OP-1443. H. G. Greene, W. L. Stubblefield*, A. E. Therberge, Jr.* and B. A. McGregor. Seafloor geology of Monterey submarine canyon system and adjacent areas [abstr.] International Geological Congress, Abstracts-Congres Geologique Internationale, Resumes, in 28th international geological congress; abstracts. 28 , Vol. 1, 1989. p. 1.587.

OP-1444. H. G. Greene, W. L. Stubblefield*, A. E. Therberge, Jr.* and B. A. McGregor. Geologic processes within Monterey submarine canyon [abstr.] International Geological Congress, Abstracts-Congres Geologique Internationale, Resumes, in 28th international geological congress; abstracts. 28, Vol. 1, 1989. p. 1.587-1.588.

OP-1445. E. S. Grew*, M. G. Yates*, D. I. Belakovskiy*, M. E. Fleet*, J. J. McGee and Nicholas Marquez*. Reedmergnerite and hyalotektite from alkaline pegmatite, Dara-I-Pioz, Tajikistan, and comparison with Langban, Sweden, Mn skarn [abstr.] Abstracts with Programs - Geological Society of America, in Geological Society of America, 1992 annual meeting. v. 24, no. 7, 1992. p. 259.

OP-1446. A. M. Grunow*, D. V. Kent*, W. D. Dalziel*, B. C. Storey*, D. I. MacDonald*, M. P. Maslanyj*, I. C. Millar*, P. J. Parkhurst*, S. W. Garrett*, J. L. Isbell* and W. R. Vennum. Reconstructions of West Antarctica within Gondwanaland; problems and possible solutions, results from joint UK-US West Antarctic Tectonics Project [abstr.] International Geological Congress, Abstracts-Congres Geologique Internationale, Resumes, in 28th international geological congress; abstracts. 28 , Vol. 1, 1989. p. 1.592 .

OP-1447. M. C. Guffanti, M. A. Clynne and L. J. Muffler. CALIFORNIA. Estimates of basalt fluxes into the Lassen volcanic region of the southern Cascade Range [abstr.] Abstracts with Programs - Geological Society of America, in Geological Society of America, Cordilleran Section, 88th annual meeting. v. 24, no. 5, May 1992. p. 29.

OP-1448. L. C. Gundersen. Assessing the geologic radon potential of the United States; problems and possibilities [abstr.], in American Institute of Professional Geologists, 1992 annual meeting and symposium; Geologic reason, a basis for decisions affecting society. (Steve Friberg, chairperson). American Institute of Professional Geologists, September 1992. p. 35.

OP-1449. A. Gurgui*, Emilio Custodio*, L. Candela* and L. F. Konikow. Fulfillment of model objective; generalized use by end users of Llobregat Delta model (Barcelona, Spain) [abstr.] International Geological Congress, Abstracts-Congres Geologique Internationale, Resumes, in 28th international geological congress; abstracts. 28, Vol. 1, 1989. p. 1.599.

OP-1450. B. R. Hacker*, S. R. Bohlen and S. H. Kirby. Albite $\rightarrow$ jadeite + quartz transformation in rock; mechanism and kinetics [abstr.] Abstracts with Programs - Geological Society of America, in Geological Society of America, 1992 annual meeting. v. 24, no. 7,1992 . p. 256.

OP-1451. B. R. Hacker*, M. M. Donato and W. G. Ernst*. Jurassic synmagmatic normal fault in the central Klamath Mountains [abstr.] Abstracts with Programs - Geological Society of
America, in Geological Society of America, Cordilleran Section, 88th annual meeting. v. 24, no. 5, May 1992. p. 29.

OP-1452. B. R. Hacker* and S. H. Kirby. Deformation experiments on calcite $\rightarrow$ aragonite [abstr.] Abstracts with Programs Geological Society of America, in Geological Society of America, 1990 annual meeting. v. 22, no. 7, 1990. p. 343.

OP-1453. D. G. Hadley, T. M. Bown and E. M. Brouwers. Late Miocene fluvial and shallow marine paleoenvironments, central and western Abu Dhabi Emirate, United Arab Emirates [abstr.] Abstracts with Programs - Geological Society of America, in Geological Society of America, 1992 annual meeting. v. 24, no. 7, 1992. p. 360 .

OP-1454. R. J. Haefner and G. L. Rowe, Jr. OHIO. Geochemical and geophysical analysis of shallow aquifer materials in Pennsylvanian coal-bearing strata in east-central Ohio [abstr.] Abstracts with Programs - Geological Society of America, in Geological Society of America, 1992 annual meeting. v. 24, no. 7, 1992. p. 283.

OP-1455. R. D. Hall* and R. R. Shroba. WYOMING. Evidence for glaciation during the early Wisconsin at Fremont Lake, Wind River Range, Wyoming [abstr.] Abstracts with Programs Geological Society of America, in Geological Society of America, 1990 annual meeting. v. 22, no. 7, 1990. p. 175.

OP-1456. R. P. Hall*, D. J. Hughes*, L. Joyner* and G. L. Snyder. WYOMING. Complex pyroxenes in Wyoming diabase dikes; lunar analogues [abstr.] Abstracts of Papers Submitted to the Lunar and Planetary Science Conference, in Abstracts of papers submitted to the Twenty-first lunar and planetary science conference. (Lunar and Planetary Institute). 21, 1990. p. 451-452.

OP-1457. R. B. Halley and K. R. Ludwig. ENEWETAK. Disconformities and $\mathrm{Sr}$-isotope stratigraphy reveal Neogene sea-level history at Enewetak Atoll [abstr.] International Geological Congress, Abstracts-Congres Geologique Internationale, Resumes, in Twenty-eighth international geological congress. 28 , Vol. 2, 1989. p. 2.14 .

OP-1458. P. A. Hamilton and J. M. Denver. DELAWARE, MARYLAND, VIRGINIA. Effects of agriculture chemicals on natural geochemistry of shallow groundwater, Delmarva Peninsula, Delaware, Maryland, and Virginia [abstr.] AAPG Bulletin, in AAPG Eastern Section meeting. v. 77, no. 8, August 1993. p. 1468-1469.

OP-1459. W. B. Hamilton. Venusian impact basins and cratered terrains [abstr.] LPI Contribution, in Papers presented to the International conference on Large meteorite impacts and planetary evolution. (B. O. Dressler, chairperson and others). 790, 1992. p. 33-35.

OP-1460. W. B. Hamilton. Evolution of convergent plates [abstr.] International Geological Congress, Abstracts-Congres Geologique Internationale, Resumes, in Twenty-eighth international geological congress. 28, Vol. 2, 1989. p. 2.20 .

OP-1461. J. M. Hammarstrom. CALIFORNIA, ALASKA. Mineral chemistry of Cretaceous plutons; hornblende geobarometry in Southern California and southeastern Alaska [abstr.] Abstracts with Programs - Geological Society of America, in Geological Society of America, Cordilleran Section, 88th annual meeting. v. 24, no. 5, May 1992. p. 30. 
OP-1462. J. M. Hammarstrom, P. B. Tomascak* and E. J. Krogstad*: MONTANA. Old crustal Nd signature for the Pioneer Batholith, MT [abstr.] Eos, Transactions, American Geophysical Union, in AGU 1993 spring meeting. v. 74, no. 16, Suppl. May 1993. p. 335.

OP-1463. J. M. Hammarstrom and E-an Zen*. Petrological characteristics of magmatic epidote-bearing granites of the Western Cordillera of America [abstr.] Special Paper - Geological Society of America, in The second Hutton symposium on the origin of granites and related rocks; proceedings. (P. E. Brown, editor and others). 272, 1992. p. 490-491.

OP-1464. J. L. Hannah*, H. J. Stein, L. W. Snee and M. A. Gutscher*. UTAH. A faulted caldera setting for the Tintic ore deposits; untangling structurally dismembered terranes in the eastern Basin and Range [abstr.] Abstracts with Programs - Geological Society of America, in Geological Society of America, 1992 annual meeting. v. 24, no. 7, 1992. p. 143-144.

OP-1465. P. L. Hansley. UTAH. Diagenetic history of the Permian White Rim Sandstone Member, Cutler Formation, Tar Sand Triangle, Paradox Basin, Utah [abstr.] Annual Meeting Abstracts - American Association of Petroleum Geologists and Society of Economic Paleontologists and Mineralogists, in American Association of Petroleum Geologists, 1992 annual convention. 1992, 1992. p. 51.

OP-1466. P. L. Hansley. INDIANA. Petrology and diagenesis of Pennsylvanian Tradewater Group sandstones in the Illinois Basin, southwestern Indiana [abstr.] Abstracts with Programs - Geological Society of America, in Geological Society of America, 1992 annual meeting. v. 24 , no. 7,1992 . p. 58 .

OP-1467. R. T. Hanson. ARIZONA. Postaudit analyses of groundwater models of an alluvial-aquifer system, Avra Valley, Arizona [abstr.] International Geological Congress, AbstractsCongres Geologique Internationale, Resumes, in 28th international geological congress; abstracts. 28, Vol. 2, 1989. p. 2.27.

OP-1468. R. T. Hanson. ARIZONA. Simulation of aquifer-system compaction in south-central Arizona [abstr.] International Geological Congress, Abstracts - Congres Geologique Internationale, Resumes, in 28 th international geological congress; abstracts. 28, Vol. 2, 1989. p. 2.27-2.28.

OP-1469. M. L. Harbin*, S. E. Swanson*, C. J. Nye* and T. P. Miller. ALASKA. Glass and mineral chemistry of the June 27, 1992 eruption of Mount Spurr, Alaska [abstr.] Eos, Transactions, American Geophysical Union, in AGU 1992 fall meeting. v. 73, no. 43, suppl. October 27, 1992. p. 346.

OP-1470. J. W. Harden. Quantification of soil development and mathematical-statistical treatment of data in soil chronosequence studies [abstr.] International Geological Congress, AbstractsCongres Geologique Internationale, Resumes, in 28th international geological congress; abstracts. 28, Vol. 2, 1989. p. 2.30-2.31.

OP-1471. R. W. Harrison and A. P. Schultz. MISSOURI, ILLINOIS. Faulting at Thebes Gap, Mo.-Ill:; implications for New Madrid tectonism [abstr.] Abstracts with Programs - Geological Society of America, in Geological Society of America, 1992 annual meeting. v. 24, no. 7, 1992. p. 191.

OP-1472. P. T. Harte and T. C. Winter. Considerations in the study of ground-water-flow systems in fractured crystalline rock of the New England Uplands [abstr.] Abstracts with Programs Geological Society of America, in Geological Society of America, Northeastern Section, 28th annual meeting. v. 25, no. 2, March 1993. p. 22.

OP-1473. R. W. Harvey. Factors affecting transport of bacteria through contaminated aquifer [abstr.] International Geological Congress, Abstracts-Congres Geologique Internationale, Resumes, in 28th international geological congress; abstracts. 28, Vol. 2, 1989. p. $2.35-2.36$.

OP-1474. D. S. Harwood. CALIFORNIA. Mesozoic geology of Mt. Jura, northern Sierra Nevada; a progress report [abstr.] AAPG Bulletin, in AAPG Pacific Section abstracts. v. 77, no. 4, April 1993. p. 700.

OP-1475. H. T. Haselton. K, Na exchange between high structural state ternary feldspars and molten chloride salts at $900^{\circ} \mathrm{C}$ and 1 bar [abstr.] Abstracts with Programs - Geological Society of America, in Geological Society of America, 1990 annual meeting. v. 22 , no. 7,1990 . p. $342-343$.

OP-1476. J. R. Hatch. Hydrocarbon source-rock evaluation of Desmoinesian (Middle Pennsylvanian) coals from part of the western region of the Interior coal province, U.S.A. [abstr.] Annual Meeting Abstracts - American Association of Petroleum Geologists and Society of Economic Paleontologists and Mineralogists, in American Association of Petroleum Geologists, 1992 annual convention. 1992, 1992. p. 53.

OP-1477. P. G. Hatcher, H. E. Lerch, and T. V. Verheyen*. Organic geochemical studies of the transformation of gymnospermous xylem during peatification and coalification to subbituminous coal [abstr.] International Geological Congress, Abstracts - Congres Geologique Internationale, Resumes, in 28th international geological congress; abstracts. 28 , Vol. 2,1989. p. 2.36-2.37.

OP-1478. P. G. Hatcher, M. A. Wilson*, A. M. Vassallo* and H. E. Lerch. Studies of angiospermous woods in Australian brown coal by nuclear magnetic resonance and analytical pyrolysis; new insights into early coalification [abstr.] International Geological Congress, Abstracts-Congres Geologique Internationale, Resumes, in 28th international geological congress; abstracts. 28, Vol. 2, 1989. p. 2.37.

OP-1479. R. D. Hatcher, Jr.*, W. A. Thomas*, P. H. Osberg, A. A. Drake, Jr.* and P. Robinson*. Exposed and subsurface U.S. Appalachian Orogen [abstr.] International Geological Congress, Abstracts-Congres Geologique Internationale, Resumes, in 28th international geological congress; abstracts. 28, Vol. 2 , 1989. p. 2.37 .

OP-1480. R. A. Haugerud, R. W. Tabor and C. D. Blome. WASHINGTON. Pre-Tertiary stratigraphy and multiple orogeny in the western North Cascades, Washington [abstr.] Abstracts with Programs - Geological Society of America, in Geological Society of America, Cordilleran Section, 88th annual meeting. v. 24, no. 5, May 1992. p. 32.

OP-1481. R. S. Haupt* and D. W. Folger. VERMONT, NEW YORK. Paper plant effluent in sediments of southern Lake Champlain [abstr.] Abstracts with Programs - Geological Society of America, in Geological Society of America, Northeastern Section, 28th annual meeting. v. 25, no. 2, March 1993. p. 22. 
OP-1482. B. R. Hawke*, P. D. Spudis*, P. G. Lucey* and J. F. Bell. The composition of the crust in the Orientale region of the Moon; a pre-Galileo view [abstr.] Abstracts of Papers Submitted to the Lunar and Planetary Science Conference, in Abstracts of papers submitted to the Twenty-first lunar and planetary science conference. (Lunar and Planetary Institute). 21, 1990. p. 473474.

OP-1483. W. W. Hays. Hazard assessments, contingency, planning, and public education [abstr.] International Geological Congress, Abstracts-Congres Geologique Internationale, Resumes, in 28th international geological congress; abstracts. 28, Vol. 2, 1989. p. 2.43-2.44.

OP-1484. W. W. Hays, M. A. Leslie*, R. De Conto* and C. A. Shaw. Atlantic margin sediments and paleodrainage of eastern and central North America [abstr.] International Geological Congress, Abstracts-Congres Geologique Internationale, Resumes, in 28th international geological congress; abstracts. 28, Vol. 2, 1989. p. $2.42-2.43$.

OP-1485. J. W. Head*, M. J. Belton*, Ronald Greeley*, C. M. Pieters*, E. M. Fischer*, J. M. Sunshine*, K. P. Klaasen*, A. S. McEwen, T. L. Becker, Gerhard Neukum*, Jürgen Oberst*, C. B. Pilcher*, J. Plutchak*, M. S. Robinson*, T. V. Johnson*, D. A. Williams*, S. D. Kadel*, R. J. Sullivan*, I. Antonenko* and N. T. Bridges. Lunar impact basins; new data for the nearside northern high latitudes and eastern limb from the second Galileo flyby [abstr.] Proceedings of the Lunar and Planetary Science Conference, in Abstracts of papers submitted to the Twenty-fourth lunar and planetary science conference. (Douglas Blanchard, chairperson and others). 24, 1993. p. 623-624.

OP-1486. J. W. Head*, M. J. Belton*, Ronald Greeley*, C. M. Pieters*, A. S. McEwen, Gerhard Neukum* and T. B. McCord*. Lunar Scout missions; Galileo encounter results and application to scientific problems and exploration requirements [abstr.] Proceedings of the Lunar and Planetary Science Conference, in Abstracts of papers submitted to the Twenty-fourth lunar and planetary science conference. (Douglas Blanchard, chairperson and others). 24, 1993. p. 625-626.

OP-1487. J. W. Head*, E. M. Fischer*, S. L. Murchie*, C. M. Pieters*, J. Plutchak*, J. M. Sunshine*, M. J. Belton*, M. H. Carr, C. R. Chapman*, M. E. Davies*, F. P. Fanale*, M. S. Robinson*, Ronald Greeley*, Robert Sullivan*, Richard Greenberg*, Paul Helfenstein*, Joseph Veverka*, Harald Hoffmann*, R. Jaumann*, Gerhard Neukum*, T. V. Johnson*, K. P. Klaasen*, A. S. McEwen, T. L. Becker and C. B. Pilcher*. Orientale and south pole-Aitken basins on the Moon; preliminary Galileo imaging results [abstr.] Abstracts of Papers Submitted to the Lunar and Planetary Science Conference, in Twenty-second lunar and planetary science conference; press abstracts. 22, 1991. p. 23-26.

OP-1488. J. H. Healy. Evaluation of an earthquake prediction algorithm [abstr.] Terra Abstracts, in Sixth meeting of the European Union of Geosciences. v. 3, no. 1, 1991. p. 162.

OP-1489. P. J. Heaney*, J. E. Post* and H. T. Evans, Jr. NEW JERSEY. Structure refinement of compositionally distinct bannisterite crystals from Broken Hill, Australia and Franklin, New Jersey [abstr.] Abstracts with Programs - Geological Society of America, in Geological Society of America, 1990 annual meeting. v. 22 , no. 7,1990 . p. 260.
OP-1490. P. J. Heaney*, R. A. Sheppard and J. E. Post*. Association of length-slow silica with evaporites [abstr.] Abstracts with Programs - Geological Society of America, in Geological Society of America, 1992 annual meeting. v. 24, no. 7, 1992. p. 231.

OP-1491. B. C. Hearn, Jr. MONTANA. Composite megacrysts and megacryst aggregates from the Williams kimberlites, Montana, USA; multiple products of mantle melts [abstr.] Proceedings of the International Kimberlite Conference, in Fifth international kimberlite conference; extended abstracts. 5, February 1991. p. 170-172.

OP-1492. P. P. Hearn, S. M. Colman, E. B. Karabanov* and D. F. Williams*. Lake Baikal, southeastern Siberia; prospects for paleoclimate research [abstr.] Eos, Transactions, American Geophysical Union, in AGU-MSA 1991 spring meeting. v. 72, no. 17, April 23, 1991. p. 306.

OP-1493. P. P. Hearn, J. F. Sutter and H. E. Belkin. Authigenic K-feldspar; an indicator of the geochronology and chemical evolution of mineralizing fluids in sediment-hosted lead and zinc deposits [abstr.] International Geological Congress, AbstractsCongres Geologique Internationale, Resumes, in 28th international geological congress; abstracts. 28, Vol. 2, 1989. p. 2.46-2.47.

OP-1494. P. P. Hearn, J. F. Sutter, A. Melnikov* and V. M. Zhelinsky*. High-resolution ${ }^{40} \mathrm{Ar} /{ }^{39} \mathrm{Ar}$ age-spectrum analysis of epigenetic K-feldspar from Culman Basin, southeastern Siberia; geochronometer for crustal fluids mobilized by regional tectonism [abstr.] International Geological Congress, Abstracts-Congres Geologique Internationale, Resumes, in 28th international geological congress; abstracts. 28, Vol. 2, 1989. p. 2.46 .

OP-1495. C. A. Hedgman. MICHIGAN. Petrology and provenance of a conglomerate facies of the Jacobsville Sandstone; Ironwood to Bergland, Michigan [abstr.] Abstracts with Programs Geological Society of America, in Geological Society of America, 1992 annual meeting. v. 24, no. 7, 1992. p. 329.

OP-1496. G. H. Heiken*, S. J. Goff* and C. J. Janik. The U.S. Agency for International Development-Los Alamos National Laboratory-U.S. Geological Survey Central American Geothermal Resources Program [abstr.] Abstracts with Programs - Geological Society of America, in Geological Society of America, 1992 annual meeting. v. 24 , no. 7,1992 . p. 165 .

OP-1497. Paul Helfenstein*, Joseph Veverka*, J. W. Head*, C. M. Pieters*, S. F. Pratt*, J. F. Mustard*, K. P. Klaasen*, Gerhard Neukum*, Harald Hoffmann*, R. Jaumann*, H. Rebhan*, A. S. McEwen and M. J. Belton*. Galileo photometry of Apollo landing sites [abstr.] Proceedings of the Lunar and Planetary Science Conference, in Abstracts of papers submitted to the Twenty-fourth lunar and planetary science conference. (Douglas Blanchard, chairperson and others). 24, 1993. p. 635-636.

OP-1498. M. A. Hellweg, Paul Spudich and J. B. Fletcher. CALIFORNIA. Coda $Q$ in the region of Parkfield, California; a temporal and spatial investigation [abstr.] Eos, Transactions, American Geophysical Union, in AGU 1992 spring meeting. v. 73, no. 14, supplement, April 7, 1992. p. 200.

OP-1499. R. T. Helz. HAWAII. Kilauea Iki; a model magma chamber [abstr.] Eos, Transactions, American Geophysical Union, 
in AGU-MSA 1991 spring meeting. v. 72, no. 17, April 23, 1991. p. 315.

OP-1500. R. T. Helz. MONTANA. Experimental constraints on the origin of the ultramafic series of the Stillwater Complex, Montana [abstr.] Abstracts with Programs - Geological Society of America, in Geological Society of America, 1992 annual meeting. v. 24 , no. 7,1992 . p. $85-86$.

OP-1501. J. R. Herring. GEORGIA. Concentrations of $\mathrm{Cd}$ and As in sediments of the Georgia shelf-anthropogenic or natural? [abstr.] Eos, Transactions, American Geophysical Union, in AGU 1989 fall meeting. v. 70, no. 43, October 24, 1989. p. 1045.

OP-1502. J. R. Herring and F. T. Manheim. GEORGIA. Geochemistry of the Neogene phosphatic sediments on the Georgia shelf [abstr.] Abstracts with Programs - Geological Society of America, in Geological Society of America, 1989 annual meeting. v. 21 , no. 6,1989 . p. 331 .

OP-1503. D. P. Hill and A. M. Pitt. CALIFORNIA. Long period earthquakes at mid-crustal depths beneath the western margin of Long Valley Caldera, California [abstr.] Eos, Transactions, American Geophysical Union, in AGU 1992 fall meeting. v. 73, no. 43, suppl. October 27, 1992. p. 343.

$\mathrm{OP}_{\mathrm{T}}$ 1504. J. W. Hillhouse. Using paleomagnetism and aeromagnetism to delineate ancient continental margins [abstr.] Proceedings of the International Conference on Basement Tectonics, in Basement tectonics 8; Characterization and comparison of ancient and Mesozoic continental margins. (M. J. Bartholomew, editor and others). 8, 1988. p. 733 .

OP-1505. M. E. Hinkle. Factors affecting concentrations of volatile species in soil gases [abstr.] International Geological Congress, Abstracts - Congres Geologique Internationale, Resumes, in 28th international geological congress; abstracts. 28 , vol. 2,1989 . p. 2.59 .

OP-1506. T. K. Hinkley. Metal scavenging and transport in early stages of volcanic exhalation [abstr.] International Geological Congress, Abstracts-Congres Geologique Internationale, Resumes, in 28th international geological congress; abstracts. 28 , vol. 2, 1989. p. $2.59-2.60$.

OP-1507. T, K. Hinkley. On the compositions and sources of dusts found in ice from modern and glacial times [abstr.] Eos, Transactions, American Geophysical Union, in AGU 1993 fall meeting. v. 74, no. 43, Suppl. October 26, 1993. p. 79.

OP-1508. M. F. Hochella, Jr.*, C. M. Eggleston*, P. A. Johnsson*, S. L. Stipp*, T. N. Tingle*, A. E. Blum and A. F. White. Examples of mineral surface structure, composition, and reactivity observed at the molecular and atomic levels [abstr.] Program with Abstracts - Geological Association of Canada; Mineralogical Association of Canada; Canadian Geophysical Union, Joint Annual Meeting. 16, May 1991. p. 56.

OP-1509. A. H. Hofstra and Poul Emsbo. A new method to analyze anions and cations in fluid inclusions using ion chromatography; applications to ore genesis [abstr.] Abstracts with Programs Geological Society of America, in Geological Society of America, 1992 annual meeting. v. 24, no. 7, 1992. p. 144.

OP-1510. C. W. Holmes and G. R. Brooks*. FLORIDA. Two orders of cyclic sedimentation on the Southwest Florida slope [abstr.] Abstracts with Programs - Geological Society of America, in Geological Society of America, 1990 annual meeting. v. 22, no. 7,1990 . p. 299 .

OP-1511. T. R. Holtz, Jr. Cursoriality in the Theropoda; morphometrics and biomechanics [abstr.] Journal of Vertebrate Paleontology, in Society of Vertebrate Paleontology, fifty-second annual meeting. (R. J. Emry, editor and others). v. 12, no. 3, Suppl. September 1992. p. 33A.

OP-1512. T. L. Holzer. Catastrophic collapse along fissures caused by withdrawal of groundwater from unconsolidated aquifer systems [abstr.] International Geological Congress, AbstractsCongres Geologique Internationale, Resumes, in 28th international geological congress; abstracts. 28, vol. 2, 1989. p. 2.67 .

OP-1513. R. W. Hook*, T. R. Miller*, D. Baird*, J. C. Ferm* and T. A. Moore. OHIO. A vertebrate-bearing cannel coal in the Allegheny Group (late Westphalian, Upper Carboniferous) of Mahoning County, Ohio [abstr.] Abstracts with Programs - Geological Society of America, in Geological Society of America, 1990 annual meeting. v. 22 , no. 7,1990 . p. 357.

OP-1514. R. P. Hooper. The use of mass balances in watershed modeling [abstr.] Eos, Transactions, American Geophysical Union, in AGU 1992 spring meeting. v. 73, no. 14, Suppl. April 7, 1992. p. 137.

OP-1515: R. P. Hooper and Nils Christophersen*. Predicting future episodic stream acidification in the Southeastern United States [abstr.] Eos, Transactions, American Geophysical Union, in AGU 1992 spring meeting. v. 73, no. 14, Suppl. April 7, 1992. p. 122.

OP-1516. I. L. Hopkins, C. A. Edwards, C. G. MacDonald and J. K. McGregor. Preservation and usage of geoscience imagery in the U.S. Geological Survey field records and photographic libraries 1879 to date [abstr.] Abstracts with Programs - Geological Society of America, in Geological Society of America, 1992 annual meeting. v. 24, no. 7, 1992. p. 167.

OP-1517. J. W. Horton, Jr., A. A. Drake, Jr. and D. W. Rankin. Interpretation of tectonostratigraphic terranes in central and southern Appalachian Orogen, USA [abstr.] International Geological Congress, Abstracts-Congres Geologique Internationale, Resumes, in 28th international geological congress; abstracts. 28, vol. 2,1989 . p. $2.73-2-74$.

OP-1518. D. W. Houseknecht, Gary Wood*, R. Jaques* and A. Gresham*. Influence of Ozark Uplift on Pennsylvanian sediment dispersal patterns [abstr.] Abstracts with Programs - Geological Society of America, in Geological Society of America, North-Central Section, 27th annual meeting. v. 25, no. 3, March 1993. p. 26-27.

OP-1519. D. G. Howell. Plate tectonics and petroleum habitats [abstr.] Warta Geologi $=$ Newsletter of the Geological Society of Malaysia, in Symposium on the Tectonic framework and energy resources of the western margin of the Pacific Basin. (Ahmad Said, president). v. 18, no. 6, December 1992. p. 257.

OP-1520. D. G. Howell and François Roure*. Accretion tectonics and crustal thickening; examples from Cordilleran and Tethyan orogens [abstr.] International Geological Congress, AbstractsCongres Geologique Internationale, Resumes, in 28th international geological congress; abstracts. 28, vol. 2, 1989. p. 2.76 . 
OP-1521. Russell Howorth* and H. G. Greene. Effects of cyclones Ursula, Carlotta and Uma in the Port Vila-Mele Bay area, Vanuatu [abstr.] SOPAC Technical Bulletin, in Workshop on Coastal processes in the South Pacific island nations. (Jioji Kotobalavu, prefacer and others). 7, 1991. p. 123-124.

OP-1522. D. T. Hoxie. Development of numerical hydrogeologic models related to siting of a high-lvel nuclear waste repository [abstr.] TIMS/ORSA Bulletin, in Tomorrow's algorithms today; program of the 29th TIMS/ORSA joint national meeting. 29, 1990. p. 108.

OP-1523. A. C. Huffman, Jr. COLORADO, UTAH. Late Paleozoic depositional controls in the Paradox Basin, Colorado and Utah [abstr.] Abstracts with Programs - Geological Society of America, in Geological Society of America, 1992 annual meeting. v. 24, no. 7,1992 . p. 31 .

OP-1524. R. E. Hughes* and R. L. Smith. Archaeology, geology and geochemistry in obsidian provenance studies [abstr.] Abstracts with Programs - Geological Society of America, in Geological Society of America, 1990 annual meeting. v. 22, no. 7, 1990. p. 152 .

OP-1525. Stephen Hughes, J. H. Luetgert, J. Hall*, J. Wright*, B. Roberts* and T. Coté*. Characterizing the Gander and Dunnage terranes in Newfoundland with wide-angle seismic reflection data [abstr.] Eos, Transactions, American Geophysical Union, in AGU 1992 spring meeting. v. 73, no. 14, supplement, April 7, 1992. p. 203.

OP-1526. M. F. Hult. Mobilization, transport and fate of hydrocarbon vapors in the unsaturated zone [abstr.] International Geological Congress, Abstracts-Congres Geologique Internationale, Resumes, in 28th international geological congress; abstracts. 28, vol. 2,1989 . p. 2.83 .

OP-1527. C. D. Hunt, Jr. HAWAII. Regional aquifers of Oahu, Hawaii; geohydrologic controls in high volcanic island setting [abstr.] International Geological Congress, Abstracts-Congres Geologique Internationale, Resumes, in 28th international geological congress; abstracts. 28 , vol. 2,1989 . p. 2.-83-2.84.

OP-1528. R. E. Hunter and D. M. Rubin. Longitudinal and reversing transverse dunes; how do they differ? [abstr.] International Geological Congress, Abstracts-Congres Geologique Internationale, Resumes, in 28th international geological congress; abstracts. 28 , vol. 2,1989 . p. 2.84

OP-1529. C. R. Hupp. ARKANSAS, TENNESSEE. Dendrogeomorphic approach to sedimentation in forested wetlands, Arkansas and West Tennessee [abstr.] International Geological Congress, Abstracts-Congres Geologique Internationale, Resumes, in 28th international geological congress; abstracts. 28 , vol. 2,1989 . p. $2.85-2.86$.

OP-1530. A. M. Hussey, II*, J. N. Aleinikoff and R. G. Marvinney*. MAINE. Reinterpretation of age and correlation between tectonostratigraphic units, southwestern Maine [abstr.] Abstracts with Programs - Geological Society of America, in Geological Society of America, Northeastem Section, 28th annual meeting. v. 25, no. 2, March 1993. p. 25.

OP-1531. C. B. Hutchinson, G. L. Sanders and A. D. Duerr. FLORIDA. Simulation of subsurface injection in Southwest Flor- ida [abstr.] Ground Water Management, in Solving ground water problems with models. 9, February 1992. p. 639-640.

OP-1532. D. R. Hutchinson, A. Y. Gol'mshtok*, C. A. Scholz*, T. C. Moore*, M. W. Lee and M. Kuzmin*. Bottom simulating reflector in Lake Baikal [abstr.] Eos, Transactions, American Geophysical Union, in AGU-MSA 1991 spring meeting. v. 72, no. 17, April 23, 1991. p. 307.

OP-1533. D. R. Hutchinson, M. W. Lee, J. C. Behrendt, W. F, Cannon, A. M. Tréhu*, A. G. Green* and Bernd Milkereit*. Structure and evolution of North American Midcontinent rift system from GLIMPCE deep seismic data [abstr.] International Geólogical Congress, Abstracts-Congres Geologique Internationale, Resumes, in 28th international geological congress; abstracts. 28 , vol. 2,1989 . p. 2.88 .

OP-1534. D. R. Hutchinson, R. S. White*, W. F. Cannon and K. J. Schulz. Keweenaw hot spot; an inferred middle Proterozoic mantle plume beneath North America [abstr.] Program with Abstracts - Geological Association of Canada; Mineralogical Association of Canada; Canadian Geophysical Union, Joint Annual Meeting. 16, May 1991. p. 58.

OP-1535. S. E. Ishman and H. J. Dowsett. Pliocene pre-glacial North Atlantic; a coupled sea surface-deep ocean circulation climate response [abstr.] Abstracts with Programs - Geological Society of America, in Geological Society of America, 1992 annual meeting. v. 24, no. 7, 1992. p. 222.

OP-1536. H. M. Iyer and P. B. Dawson. CALIFORNIA. Interpreting magma chamber models derived using teleseismic tomography; application to Long Valley, California [abstr.] Eos, Transactions, American Geophysical Union, in AGU 1992 western Pacific geophysics meeting. v. 73, no. 25, Suppl. June 23, 1992. p. 60 .

OP-1537. G. A. Izett. IOWA. Mineralogic data indicate the K-T boundary impact occurred on continental crust probably near Manson, Iowa [abstr.] Abstracts with Programs - Geological Society of America, in Geological Society of America, 1990 annual meeting. v. 22, no. 7, 1990. p. 280.

OP-1538. G. A. Izett and J. D. Obradovich. Laser total-fusion ${ }^{40} \mathrm{Ar}-{ }^{39} \mathrm{Ar}$ ages constrain timing of the Jaramillo normal polarity subchron and the Matuyama-Brunhes (M-B) boundary [abstr.] Abstracts with Programs - Geological Society of America, in Geological Society of America, 1992 annual meeting. v. 24, no. 7, 1992. p. 205-206.

OP-1539. G. A. Izett, K. L. Pierce, N. D. Naeser and Cheryl Jaworowski*. WYOMING. Isotopic dating of Lava Creek B Tephra in terrace deposits along the Wind River, Wyoming; implications for post $0.6 \mathrm{ma}$ uplift of the Yellowstone hotspot [abstr.] Abstracts with Programs - Geological Society of America, in Geological Society of America, 1992 annual meeting. v. 24, no. 7, 1992. p. 102.

OP-1540. G. A. Izett, R. L. Reynolds, J. G. Rosenbaum and J. M. Nishi. IOWA. A discontinuous melt sheet in the Manson impact structure [abstr.] Proceedings of the Lunar and Planetary Science Conference, in Abstracts of papers submitted to the Twenty-fourth lunar and planetary science conference. (Douglas Blanchard, chairperson and others). 24, 1993. p. 705-706. 
OP-1541. N. J. Jackson*, A. J. Boyce*, M. J. Whitehouse, A. E. Fallick* and A. J. Hall*. Isotopic constraints on the sources of sulphur and lead in the polygenetic ores in the Cornubian orefield, Southwest England [abstr.] Terra Abstracts, in Frontiers in isotope geosciences; abstracts. 3, Suppl. 1, 1991. p. 6-7.

OP-1542. R. B. Jacobson. WEST VIRGINIA. Geographic information system analysis of landslides on shale slopes, Pendleton County, West Virginia [abstr.] Abstracts with Programs - Geological Society of America, in Geological Society of America, 1992 annual meeting. v. 24 , no. 7,1992 . p. 203-204.

OP-1543. R. B. Jacobson. Application of a digital geographic information system in compilation and analysis of surficial geologic maps [abstr.] Abstracts with Programs - Geological Society of America, in Geological Society of America, North-Central Section, 27th annual meeting. v. 25, no. 3, March 1993. p. 28.

OP-1544. R. B. Jacobson, A. L. Pugh and R. A. McKenney. MISSOURI. Stratigraphic evidence of human-induced disturbance of Missouri Ozarks streams [abstr.] Abstracts with Programs - Geological Society of America, in Geological Society of America, North-Central Section, 27th annual meeting. v. 25, no. 3, March 1993. p. 28.

OP-1545. R. D. Jarrett. Use of paleohydrologic investigations in developing a flood warning system [abstr.], in Multi-objective river corridor planning; proceedings of the Urban stream corridor and stormwater management workshop and the Multi-objective management of river corridors and their restoration workshop. (Eve Gruntfest, editor). Madison, WI: Assoc. State Floodplain Manage. May 1991. p. 43-44.

OP-1546. A. S. Jayko. CALIFORNIA. Some comments on structural sequences in Franciscan blueschists [abstr.] Abstracts with Programs - Geological Society of America, in Geological Society of America, Cordilleran Section, 88th annual meeting. v. 24, no. 5, May 1992. p. 35.

OP-1547. A. S. Jayko and M. C. Blake, Jr. CALIFORNIA, OREGON. Northward displacements of forearc slivers in the Coast Ranges of California and Southwest Oregon during the late Mesozoic and early Cenozoic [abstr.] AAPG Bulletin, in AAPG Pacific Section abstracts. v. 77, no. 4, April 1993. p. 701-702.

OP-1548. E. A. Johnson, P. D. Warwick, S. B. Roberts and I. H. Khan*. Limestone-pebble conglomerate facies of the Eocene Ghazij Formation, Balochistan, Pakistan; evidence for collisionrelated tectonism on the northwestern margin of the Indian Plate [abstr.] Annual Meeting Abstracts - American Association of Petroleum Geologists and Society of Economic Paleontologists and Mineralogists, in American Association of Petroleum Geologists 1993 annual convention. 1993, April 1993. p. 124-125.

OP-1549. J. A. Johnson* and D. R. Sherrod. OREGON. Phreatic pits in the southeast margin of the Rattlesnake ash-flow tuff, Harney Basin, southeastern Oregon [abstr.] Abstracts with Programs - Geological Society of America, in Geological Society of America, Cordilleran Section, 88th annual meeting. v. 24, no. 5, May 1992. p. 36.

OP-1550. K. R. Johnson*, D. J. Nichols, Lisa Tauxe* and David Clark*. NORTH DAKOTA. Floral zonation and magnetostratigraphy of the Hell Creek (late Maastrichtian) and lower Fort Union (early Paleocene) formations, North Dakota [abstr.] Abstracts with Programs - Geological Society of America, in
Geological Society of America, 1990 annual meeting. v. 22, no. 7, 1990. p. 323.

OP-1551. M. J. Johnson. Quantifying evapotranspiration in desert environments [abstr.], in American Institute of Professional Geologists, 1992 annual meeting and symposium; Geologic reason, a basis for decisions affecting society. (Steve Friberg, chairperson). American Institute of Professional Geologists, September 1992. p. 13.

OP-1552. S. Y. Johnson and J. C. Yount. WASHINGTON. Toward a better understanding of the Paleogene paleogeography of the Puget Lowland, western Washington [abstr.] Abstracts with Programs - Geological Society of America, in Geological Society of America, Cordilleran Section, 88th annual meeting. v. 24, no. 5, May 1992. p. 36.

OP-1553. M. J. Johnsson, D. G. Howell and K. J. Bird. ALASKA. Petrography of Early Cretaceous sandstones of the Kandik Basin; implications for paleogeography of the northern Alaska [abstr.] Abstracts with Programs - Geological Society of America, in Geological Society of America, 1990 annual meeting. v. 22 , no. 7,1990 . p. $325-326$.

OP-1554. P. A. Johnsson*, A. E. Blum and M. F. Hochella, Jr.*. AFM study of the surface morphology of muscovite dissolved in water [abstr.] Program and Abstracts - Annual Clay Minerals Conference, in Clay Minerals Society, 28th annual meeting. (D. R. Pevear, chairperson). 28, October 1991. p. 83.

OP-1555. M. J. Johnston, R. J. Mueller and J. O. Langbein. CALIFORNIA. Ongoing volcanomagnetic, geodetic and seismicity anomalies observed from mid-1989 in Long Valley Caldera, California [abstr.] Eos, Transactions, American Geophysical Union, in AGU 1992 western Pacific geophysics meeting. v. 73, no. 25, Suppl. June 23, 1992. p. 60.

OP-1556. A. D. Jolly, J. A. Power, R. A. Page*, J. C. Lahr* and C. D. Stephens*. ALASKA. A comparison of baseline and pre-eruption depths of seismicity at Mt. Spurr Volcano, southcentral Alaska [abstr.] Eos, Transactions, American Geophysical Union, in AGU 1992 fall meeting. v. 73, no. 43, suppl. October 27, 1992. p. 342.

OP-1557. B. R. Julian. Limit cycles and chaos in a model of volcanic tremor [abstr.] Terra Cognita, in Abstracts of the 17th international conference on mathematical geophysics. (A. M. Correig, editor). v. 8 , no. 2,1988 . p. 117.

OP-1558. R. J. Kamilli. Genesis of the Proterozoic Silsilah tin deposit, Kingdom of Saudi Arabia [abstr.] Abstracts with Programs - Geological Society of America, in Geological Society of America, 1990 annual meeting. v. 22, no. 7, 1990. p. 180 .

OP-1559. R. J. Kamilli and R. E. Criss*. Genesis of the Proterozoic Baid al Jimalah tungsten deposit, Saudi Arabia; oxygenisotope evidence for participation of magmatic and metamorphic fluids [abstr.] Abstracts with Programs - Geological Society of America, in Geological Society of America, 1992 annual meeting. v. 24 , no. 7,1992 . p. 144.

OP-1560. D. C. Kamineni*, Anton Brown*, Z. E. Peterman and Denver Stone*. Radiometric ages, cooling rates and deformation of two granitic plutons in the Superior Province, Canadian Shield [abstr.] Abstracts with Programs - Geological Society of America, 
in Geological Society of America, 1990 annual meeting. v. 22, no. 7,1990 . p. 244.

OP-1561. J. S. Kargel. Crustal structure and igneous processes in a chondritic Io [abstr.] Proceedings of the Lunar and Planetary Science Conference, in Abstracts of papers submitted to the Twenty-fourth lunar and planetary science conference. (Douglas Blanchard, chairperson and others). 24, 1993. p. 751-752.

OP-1562. J. S. Kargel. The rheology and composition of cryovolcanic flows on icy satellites [abstr.] Proceedings of the Lunar and Planetary Science Conference, in Abstracts of papers submitted to the Twenty-fourth lunar and planetary science conference. (Douglas Blanchard, chairperson and others). 24, 1993. p. $755-756$.

OP-1563. J. S. Kargel. Geomorphic processes in the ArgyreDorsa Argentea region of Mars [abstr.] Proceedings of the Lunar and Planetary Science Conference, in Abstracts of papers submitted to the Twenty-fourth lunar and planetary science conference. (Douglas Blanchard, chairperson and others). 24, 1993. p. 753754.

OP-1564. J. S. Kargel. A wet-geology and cold-climate Mars model; punctuation of a slow dynamic approach to equilibrium [abstr.] LPI Technical Report, in Workshop on the Martian northern plains; sedimentological, periglacial, and paleoclimatic evolution. (J. S. Kargel, editor and others). 93-04, Part 1, 1993. p. 5-7.

OP-1565. J. S. Kargel and F. M. Costard*. Possible occurrence and origin of massive ice in Utopia Planitia [abstr.] LPI Technical Report, in Workshop on the Martian northern plains; sedimentological, periglacial, and paleoclimatic evolution. (J. S. Kargel, editor and others). 93-04, Part 1, 1993. p. 7-8.

OP-1566. K. E. Karlstrom*, C. F. Miller*, J. A. Kingsbury* and J. L. Wooden. CALIFORNIA. Synchronous magmatism and compressional deformation, Piute Mountains, SE California [abstr.] Eos, Transactions, American Geophysical Union, in AGU 1992 spring meeting. v. 73, no. 14, supplement, April 7, 1992. p. 276.

OP-1567. Danny Katzman*, Robyn Wright-Dunbar* and R. S. Zech. COLORADO. Preservation of transgressive deposits in the Upper Cretaceous Point Lookout Sandstone, Colorado; a reassessment of parasequence models [abstr.] Abstracts with Programs Geological Society of America, in Geological Society of America, 1990 annual meeting. v. 22, no. 7, 1990. p. 284.

OP-1568. S. J. Kauffman*, J. S. Herman*, L. A. Sacks, David . Dewitt* and J. L. Decker*. FLORIDA. Geochemical and hydrogeological controls on distributions of high sulfate concentrations in groundwater of the upper Floridan Aquifer [abstr.] Abstracts with Programs - Geological Society of America, in Geological Society of America, 1992 annual meeting. v. 24, no. 7, 1992. p. 302 .

OP-1569. C. W. Keighin and R. M. Flores. WYOMING. Petrographic heterogeneity, pore throats, and reservoir quality of Tertiary sandstones, Wind River basin, Wyoming [abstr.] Annual Meeting Abstracts - American Association of Petroleum Geologists and Society of Economic Paleontologists and Mineralogists, in American Association of Petroleum Geologists 1993 annual convention. 1993, April 1993. p. 127.
OP-1570. M. A. Keller and J. A. Barron. CALIFORNIA. Reevaluation of the Miguelito Member of the Pismo Formation of Montaña de Oro State Park, California, including new diatom age data [abstr.] AAPG Bulletin, in AAPG Pacific Section abstracts. v. 77, no. 4, April 1993. p. 703-704.

OP-1571. B. P. Kelley and D. W. Blevins. MISSOURI. Hydrology and nitrogen distribution in claypan soil and glacial till near Centralia, Missouri [abstr.] Abstracts with Programs - Geological Society of America, in Geological Society of America, NorthCentral Section, 27th annual meeting. v. 25, no. 3, March 1993. p. 30 .

OP-1572. Carol Kendall, T. D. Bullen and A. J. Jakeman*. New perspectives on how catchments "work" by use of carbon and strontium isotopes [abstr.] Eos, Transactions, American Geophysical Union, in AGU 1992 spring meeting. v. 73, no. 14, Suppl. April 7, 1992. p. 139.

OP-1573. Carol Kendall, K. C. Rice and M. A. Mast. Tracing seasonal changes in carbon sources in small catchments using $\delta^{13} \mathrm{C}$ [abstr.] Eos, Transactions, American Geophysical Union, in AGU 1992 spring meeting. v. 73, no. 14, Suppl. April 7, 1992. p. 112.

OP-1574. D. B. Kent, J. A. Davis, B. A. Rea, A. S. Maest, L. C. Anderson, A. J. Roman-Mas and T. D. Waite*. Geochemical processes affecting the transport of reactive ionic solutes in groundwater [abstr.], in V. M. Goldschmidt conference; program and abstracts. Geochem. Soc. 1990. p. 58.

OP-1575. C. H. Kerans*, W. M. Fitchen*, M. H. Gardner*, M. D. Sonnenfeld*, S. W. Tinker* and B. R. Wardlaw. TEXAS. Styles of sequence development within latest Leonardian through Guadalupian strata of the Guadalupe Mountains [abstr.] Annual Meeting Abstracts - American Association of Petroleum Geologists and Society of Economic Paleontologists and Mineralogists, in American Association of Petroleum Geologists, 1992 annual convention. 1992, 1992. p. 65.

OP-1576. R. M. Kettler*, S. E. Kessler*, P. A. Meyers* and R. O. Rye. Pyrite textures and morphologies in the Moore Orebody, Pueblo Viejo, Dominican Republic [abstr.] Journal of Geochemical Exploration, in Abstracts from the 1991 annual meeting of the U.S. Working Group of the International Geological Correlation Program Project 254, Metalliferous black shales and related ore deposits. (R. I. Grauch, convener and others). v. 46, no. 2, 1992. p. $241-242$.

OP-1577. Y. K. Kharaka. MISSISSIPPI. Geochemical modelling of interactions between metal-rich brines and sediments from central Mississippi salt dome basin, USA [abstr.] Terra Cognita, in First international symposium on Thermodynamics of natural processes. v. 8, no. 2,1988. p. 190.

OP-1578. Y. K. Kharaka, Gil Ambats and J. J. Thordsen. Distribution and significance of dicarboxylic acid anions in oil field waters [abstr.] Chemical Geology, in Geochemistry of the Earth surface; abstracts for the third international symposium on the Geochemistry of the Earth surface. (L. R. Kump, editor). v. 107 , no. 3-4, July 25,1993 . p. 499-501.

OP-1579. B. A. Kimball, R. E. Broshears, K. E. Bencala and D. M. McKnight. Calculation of rate constants for net instream chemical reactions in an acidic, metal-rich mountain stream [abstr.] Abstracts with Programs - Geological Society of America, in 
Geological Society of America, 1992 annual meeting. v. 24, no. 7, 1992. p. 326.

OP-1580. Chi-Yu King and L. Guangwei*. Variations of Rn and $\mathrm{H}_{2}$ emissions and electric resistivity in cement blocks under pressure [abstr.] International Geological Congress, Abstracts-Congres Geologique Internationale, Resumes, in Twenty-eighth international geological congress; abstracts. 28, Vol. 2, 1989. p. 2.249 .

OP-1581. G. C. King*, A. G. Lindh and D. H. Oppenheimer. CALIFORNIA. Seismic slip, segmentation, and the Loma Prieta earthquake; precursory slip? [abstr.] Terra Abstracts, in Sixth meeting of the European Union of Geosciences. v. 3, no. 1,1991. p. 166.

OP-1582. K. W. King, R. A. Williams, D. L. Carver, Edward Cranswick and D. M. Worley. CALIFORNIA. Site response and building damage in Santa Cruz, California [abstr.] Seismological Research Letters, in 85th annual meeting of the Seismological Society of America. v. 61, no. 1, March 1990. p. 13.

OP-1583. T. V. King, R. N. Clark, W. M. Calvin, D. M. Sherman, G. A. Swayze and R. H. Brown*. Evidence for ammonium-bearing minerals on Ceres [abstr.] Abstracts of Papers Submitted to the Lunar and Planetary Science Conference, in Twenty-second lunar and planetary science conference; press abstracts. 22,1991 . p. 31-33.

OP-1584. M. J. Kingston. CALIFORNIA, COLORADO. Developments in remote sensing of carbonatites; airborne imaging spectrometry at Mountain Pass, California and Iron Hill, Colorado [abstr.] Proceedings of the International Kimberlite Conference, in Fifth international kimberlite conference; extended abstracts. 5, February 1991. p. 219-221.

OP-1585. S. H. Kirby. Earthquakes in subducted slabs; a direct response to plate-scale forces or an indirect response to slab descent? [abstr.] Eos, Transactions, American Geophysical Union, in AGU 1992 spring meeting. v. 73, no. 14, supplement, April 7, 1992. p. 311-312.

OP-1586. S. H. Kirby, L. A. Stern and W. B. Durham*. Mechanisms and kinetics of the ice $\mathrm{I} \rightarrow \mathrm{II}$ transformation [abstr.] Eos, Transactions, American Geophysical Union, in AGU 1992 spring meeting. v. 73, no. 14, suppl. April 7, 1992. p. 295.

OP-1587. A. S. Kiremidjian*, H. Thrainsson*, Kimberly Ahrenis*, J. F. Schneider* and D. P. Schwartz. CALIFORNIA. Probabilities of occurrences of events on the northern San Andreas [abstr.] Seismological Research Letters, in 85th annual meeting of the Seismological Society of America. v. 61, no. 1, March 1990. p. 20.

OP-1588. R. L. Kirk. High-resolution topographic measurements from Magellan data [abstr.] Annual Meeting Abstracts - American Association of Petroleum Geologists and Society of Economic Paleontologists and Mineralogists, in American Association of Petroleum Geologists, 1992 annual convention. 1992, 1992. p. 65-66.

OP-1589. R. L. Kirk. Separation of topographic and intrinsic backscatter variations in biscopic radar images; a "magic airbrush" [abstr.] Proceedings of the Lunar and Planetary Science Conference, in Abstracts of papers submitted to the Twenty-fourth lunar and planetary science conference. (Douglas Blanchard, chairperson and others). 24, 1993. p. 803-804.

OP-1590. R. L. Kirk. Thermal models of insolation-driven nitrogen geysers on Triton [abstr.] Abstracts of Papers Submitted to the Lunar and Planetary Science Conference, in Abstracts of papers submitted to the Twenty-first lunar and planetary science conference. 21, 1990. p. 633-634.

OP-1591. R. L. Kirk. Diffusion kinetics of solid methane and nitrogen; implications for Triton [abstr.] Abstracts of Papers Submitted to the Lunar and Planetary Science Conference, in Abstracts of papers submitted to the Twenty-first lunar and planetary science conference. 21,1990 . p. 631-632.

OP-1592. R. L. Kirk. Models of solar-powered geysers on Triton [abstr.] Abstracts of Papers Submitted to the Lunar and Planetary Science Conference, in Abstracts of papers submitted to the Twenty-first lunar and planetary science conference; press abstracts. (Lunar and Planetary Institute). 21, 1990. p. 22-25.

OP-1593. R. L. Kirk and R. H. Brown*. Triton; a hot potato? [abstr.] Abstracts of Papers Submitted to the Lunar and Planetary Science Conference, in Twenty-second lunar and planetary science conference; press abstracts. 22, 1991. p. 35-38.

OP-1594. R. L. Kirk, K. B. Edwards, H. F. Morgan, L. A. Soderblom and T. L. Stoewe. Global Magellan-image map of Venus at full resolution [abstr.] Proceedings of the Lunar and Planetary Science Conference, in Abstracts of papers submitted to the Twenty-fourth lunar and planetary science conference. (Douglas Blanchard, chairperson and others). 24, 1993. p. 805-806.

OP-1595. R. L. Kirk, H. F. Morgan and J. F. Russell. The cartography of Venus with Magellan data [abstr.] Proceedings of the Lunar and Planetary Science Conference, in Abstracts of papers submitted to the Twenty-fourth lunar and planetary science conference. (Douglas Blanchard, chairperson and others). 24, 1993. p. 807.

OP-1596. R. L. Kirk, H. F. Morgan and J. F. Russell. The cartography of Venus with Magellan data [abstr.] Proceedings of the Lunar and Planetary Science Conference, in Abstracts of papers submitted to the Twenty-fourth lunar and planetary science conference. (Douglas Blanchard, chairperson and others). 24, 1993. p. 807.

OP-1597. K. D. Klitgord, A. Y. Gol'mshtok*, T. C. Moore*, C. A. Scholz*, D. R. Hutchinson and L. P. Zonenshain*. Structural style of Lake Baikal; a preliminary interpretation of multichannel seismic reflection profiles [abstr.] Eos, Transactions, American Geophysical Union, in AGU-MSA 1991 spring meeting. v. 72 , no. 17 , April 23, 1991. p. 306.

OP-1598. H. J. Knebel, R. R. Rendigs and M. H. Bothner. MASSACHUSETTS. Modern sedimentary environments in Boston Harbor [abstr.] Abstracts with Programs - Geological Society of America, in Geological Society of America, 1989 annual meeting. v. 21 , no. $6,1989$. p. 330.

OP-1599. C. F. Knutson*, J. R. Dyni, J. L. Qian*, F. D. Ball*, Vello Kattay*, V. A. Puura*, K. Urov*, A. Kogerman*, A. C. Hutton*, G. Solti* and E. M. Piper*. Oil shale in the 80s and 90s [abstr.] Annual Meeting Abstracts - American Association of Petroleum Geologists and Society of Economic Paleontologists 
and Mineralogists, in American Association of Petroleum Geologists 1993 annual convention. 1993, April 1993. p. 130.

OP-1600. D. W. Kolpin and M. R. Burkart*. Agricultural chemicals in near-surface aquifers in the Mid-continental United States, 1991 [abstr.] Abstracts with Programs - Geological Society of America, in Geological Society of America, North-Central Section, 27th annual meeting. v. 25, no. 3, March 1993. p. 31.

OP-1601. D. J. Kontak*, A. H. Clark*, Edward Farrar* and R. M. Tosdal. Geochronology and petrology of the San Gaban igneous complex of southern Peru; implications for Triassic-Jurassic felsic magmatism and Sn-W metallogeny in the Central Andes [abstr.] Program with Abstracts - Geological Association of Canada; Mineralogical Association of Canada; Canadian Geophysical Union, Joint Annual Meeting. 16, May 1991. p. 67.

OP-1602. David Kopaska-Merkel* and J. W. Schmoker. ALABAMA. Controls on porosity evolution in carbonate reservoirs of the Smackover Formation (Upper Jurassic), Alabama [abstr.] Annual Meeting Abstracts - American Association of Petroleum Geologists and Society of Economic Paleontologists and Mineralogists, in American Association of Petroleum Geologists 1993 annual convention. 1993, April 1993. p. 131.

OP-1603. R. M. Kosanke and C. B. Cecil. Pennsylvanian climatic changes as evidenced by palynomorph extinctions [abstr.] Abstracts with Programs - Geological Society of America, in Geological Society of America, 1992 annual meeting. v. 24, no. 7, 1992. p. 163 .

OP-1604. R. K. Kotra. Molecular geochemistry of Lake Baikal sediment cores; potential for deriving paleoclimatic and paleolimnologic information [abstr.] Eos, Transactions, American Geophysical Union, in AGU-MSA 1991 spring meeting. v. 72, no. 17, April 23, 1991. p. 307.

OP-1605. R. K. Kotra. Geochemistry of extractable organic matter in sediment cores from Lake Baikal, USSR [abstr.] Abstracts of Papers - American Chemical Society, National Meeting, in 203rd ACS national meeting. 203, 1992. p. GEOC 84.

OP-1606. R. L. Kovach* and G. E. Andreasen. The gravity field of the Dead Sea zone and neighboring areas [abstr.] Eos, Transactions, American Geophysical Union, in AGU 1992 spring meeting. v. 73 , no. 14, Suppl. April 7, 1992. p. 320-321.

OP-1607. M. J. Kozuch*, A. L. Heatherington*, P. A. Mueller*, T. W. Offield*, R. P. Koeppen and T. L. Klein. NORTH CAROLINA. Magmatism in the Carolina Terrane; isotopic evidence for a Grenville-age source for late Proterozoic volcanics and a mantle source for Silurian Concord Syenite [abstr.] Abstracts with Programs - Geological Society of America, in Geological Society of America, 1992 annual meeting. v. 24, no. 7, 1992. p. 217.

OP-1608. M. D. Krohn and R. G. Clark. WEST VIRGINIA. Regional environmental effects in West Virginia; linking biological and geological processes through temporal satellite analysis [abstr.] AAPG Bulletin, in AAPG Eastern Section meeting. v. 77, no. 8, August 1993. p. 1470.

OP-1609. M. D. Krohn and T. L. Purdy. NEVADA. Discovery of a 10-km zone of mineral-bound ammonium in the Cedar Mountains, Esmeralda County, Nevada [abstr.], in V. M. Goldschmidt conference; program and abstracts. Geochem. Soc. 1990. p. 59.

OP-1610. Anne Kuebler, K. C. Rice, O. P. Bricker and M. M. Kennedy. Comparison of solute mass balances and geology of four small Mid-Atlantic watersheds [abstr.] Eos, Transactions, American Geophysical Union, in AGU 1992 spring meeting. v. 73, no. 14, Suppl. April 7, 1992. p. 138.

OP-1611. M. J. Kunk and C. D. Henry*. TEXAS. A detailed chronology of silicic volcanism in the Davis Mountains, TransPecos, Texas [abstr.] Abstracts with Programs - Geological Society of America, in Geological Society of America, 1990 annual meeting. v. 22 , no. 7,1990 . p. 351 .

OP-1612. M. J. Kunk, P. T. Lyttle, J. S. Schindler and W. C. Burton. VIRGINIA. Constraints on the thermal history of the Blue Ridge in northernmost Virginia; ${ }^{40} \mathrm{Ar} /{ }^{39} \mathrm{Ar}$ age dating results [abstr.] Abstracts with Programs - Geological Society of America, in Geological Society of America, Northeastern Section, 28th annual meeting. v. 25, no. 2, March 1993. p. 31.

OP-1613. M. J. Kunk, L. W. Snee, B. M. French*, S. S. Harlan and J. J. McGee. IOWA. Preliminary ${ }^{40} \mathrm{Ar} /{ }^{39} \mathrm{Ar}$ age spectrum and laser probe dating of the M1 core of the Manson impact structure, Iowa; a K-T boundary crater candidate [abstr.] Proceedings of the Lunar and Planetary Science Conference, in Abstracts of papers submitted to the Twenty-fourth lunar and planetary science conference. (Douglas Blanchard, chairperson and others). 24, 1993. p. 835-836.

OP-1614. K. A. Kvenvolden. Methane and methane hydrate offshore at circum-Pacific margin [abstr.] International Geological Congress, Abstracts-Congres Geologique Internationale, Resumes, in Twenty-eighth international geological congress; abstracts. 28, Vol. 2, 1989. p. 2.247 .

OP-1615. K. A. Kvenvolden. Gas hydrates (clathrates) in the geosciences; resource, hazard, and global change [abstr.] AAPG Bulletin, in AAPG distinguished lecture tours, 1993-1994. v. 77, no. 11, November 1993. p. 2020.

OP-1616. K. A. Kvenvolden, T. D. Lorenson and W. S. Reeburgh*. ALASKA. Methane in permafrost; preliminary studies at the CRREL permafrost tunnel near Fox, Alaska [abstr.] Eos, Transactions, American Geophysical Union, in AGU 1992 spring meeting. v. 73, no. 14, Suppl. April 7, 1992. p. 119.

OP-1617. A. Y. Kwarteng* and P. S. Chavez, Jr. ARIZONA. Digital image processing of airborne geophysical data for uraniummineralized breccia pipes exploration in northwestern Arizona [abstr.] International Geological Congress, Abstracts-Congres Geologique Internationale, Resumes, in Twenty-eighth international geological congress; abstracts. 28, Vol. 2,1989. p. 2.248 .

OP-1618. J. C. Lahr, K. A. Fogleman, C. D. Stephens and R. A. Page. ALASKA. Stresses within the Pacific Plate of southern Alaska [abstr.] Eos, Transactions, American Geophysical Union, in AGU 1993 fall meeting. v. 74, no. 43, Suppl. October 26, 1993. p. 95.

OP-1619. K. R. Lajoie, L. M. Conlan, T. T. Furutani, D. J. Ponti and J. L. Saxton. CALIFORNIA. Intra- and inter-shell variability of amino-acid ratios in fossil Saxidomus shells from Goleta, California [abstr.] Abstracts with Programs - Geological 
Society of America, in Geological Society of America, 1990 annual meeting. v. 22 , no. 7,1990 . p. 145 .

OP-1620. S. E. Lallemand and Roland von Huene. Convergent margin erosion along Japan Trench [abstr.] International Geological Congress, Abstracts-Congres Geologique Internationale, Resumes, in Twenty-eighth international geological congress; abstracts. 28, Vol. 2, 1989. p. 2.254 .

OP-1621. D. D. Lambert*, S. B. Shirey*, R. W. Carlson*, R. J. Walker and J. W. Morgan. MONTANA. Os and Nd isotope geochemistry of the Stillwater Complex, Montana; evidence for Archean crustal recycling [abstr.], in V. M. Goldschmidt conference; program and abstracts. Geochem. Soc. 1990. p. 59.

OP-1622. L. L. Lambert* and B. R. Wardlaw. Preliminary morphometric analysis of the Permian conodont Mesogondolella idahoensis to M. serrata evolutionary transition [abstr.] Abstracts with Programs - Geological Society of America, in Geological Society of America, North-Central Section, 26th annual meeting. v. 24, no. 4, April 1992. p. 27.

OP-1623. Angie Lammers. Wise intermittent stream recognition and detection (WISRD) [abstr.] Abstracts with Programs - Geological Society of America, in Geological Society of America, NorthCentral Section, 27th annual meeting. v. 25, no. 3, March 1993. p. 33.

OP-1624. E. R. Landis. Coal in the western Pacific Basin, an overview [abstr.] Warta Geologi $=$ Newsletter of the Geological Society of Malaysia, in Symposium on the Tectonic framework and energy resources of the western margin of the Pacific Basin. (Ahmad Said, president). v. 18, no. 6, December 1992. p. 279.

OP-1625. G. P. Landis and L. W. Snee. ${ }^{40} \mathrm{Ar} /{ }^{39} \mathrm{Ar}$ systematics in amber and preservation of Earth paleoatmospheres in primary gas bubbles in amber [abstr.] Abstracts with Programs - Geological Society of America, in Geological Society of America, 1990 annual meeting. v. 22, no. 7, 1990. p. 173.

OP-1626. M. G. Langseth* and A. H. Lachenbruch. Review of thermal constraints on the age and evolution of the Amerasian Basin [abstr.] Eos, Transactions, American Geophysical Union, in AGU 1992 spring meeting. v. 73, no. 14, suppl. April 7, 1992. p. 286.

OP-1627. Bruno Lanson. Decomposition of X-ray diffraction patterns; a convenient way to describe complex I/S diagenetic evolution [abstr.] Program and Abstracts - Annual Clay Minerals Conference, in Clay Minerals Society, 28th annual meeting. (D. R. Pevear, chairperson). 28, October 1991. p. 97.

OP-1628. Henriette LaPierre*, Jacques Charvet*, Olivier Rouer*, C. Lecuyer*, Christian Coulon*, D. G. Howell and C. Campos*. CALIFORNIA, OREGON, NEVADA. Plate tectonic models proposed for the Cordillera geodynamic evolution $(\mathbf{N}$. California, Oregon, and Nevada) during Paleozoic and Mesozoic times [abstr.] International Geological Congress, Abstracts-Congres Geologique.Internationale, Resumes, in Twenty-eighth international geological congress; abstracts. 28, Vol. 2, 1989. p. 2.258-2.259

OP-1629. E. J. LaRock and K. I. Cunningham. NEW MEXICO. Recognition of microclimate zones through radon mapping, Lechuguilla Cave, Carlsbad Caverns National Park, New Mexico [abstr.] The NSS Bulletin, in Proceedings of the National Speleo- logical Society annual meeting. (N. D. Peacock, editor). v. 53, no. 2, December 1991. p. 118-119.

OP-1630. Birger Larsen* and A. K. Cooper. Early Antarctic glaciation; evidence from ODP Leg 119 drilling in Prydz Bay, Antarctica [abstr.] International Geological Congress, Abstracts-Congres Geologique Internationale, Resumes, in Twenty-eighth international geological congress; abstracts. 28, Vol. 2, 1989. p. 2.261 .

OP-1631. M. C. Larsen. PUERTO RICO. Landslides and pore pressure responses associated with Hurricane Hugo, September 1989, eastern Puerto Rico [abstr.] Abstracts with Programs - Geological Society of America, in Geological Society of America; 1990 annual meeting. v. 22 , no. 7, 1990. p. 331.

OP-1632. M. C. Larsen and Andrew Simon. PUERTO RICO. A rainfall intensity-duration threshold relation for landslide occurrence in the humid-tropical environment of Puerto Rico [abstr.] Abstracts with Programs - Geological Society of America, in Geological Society of America, 1992 annual meeting. v. 24, no. 7, 1992. p. 166.

OP-1633. P. B. Larson*, B. S. Zimmerman* and C. G. Cunningham. COLORADO. Mass flux and hydrothermal reactions in the hornblende latite porphyry, Rico paleothermal anomaly, Colorado [abstr.] Abstracts with Programs - Geological Society of America, in Geological Society of America, 1990 annual meeting. v. 22 , no. 7,1990 . p. 181 .

OP-1634. B. E. Law. Abnormally high formation pressure, Potwar Plateau, Pakistan [abstr.] Annual Meeting Abstracts American Association of Petroleum Geologists and Society of Economic Paleontologists and Mineralogists, in American Association of Petroleum Geologists, 1992 annual convention. 1992, 1992. p. 73 .

OP-1635. B. E. Law. WYOMING, UTAH. Paleofluid flow paths; evidence from thermal maturity mapping, greater Green River basin, Wyoming and Utah [abstr.] Annual Meeting Abstracts - American Association of Petroleum Geologists and Society of Economic Paleontologists and Mineralogists, in American Association of Petroleum Geologists, 1992 annual convention. 1992, 1992. p. 73.

OP-1636. B. E. Law. Nonlinear vitrinite reflectance profiles, eastern U.S. Gulf Coast [abstr.] Annual Meeting Abstracts American Association of Petroleum Geologists and Society of Economic Paleontologists and Mineralogists, in American Association of Petroleum Geologists 1993 annual convention. 1993, April 1993. p. 135.

OP-1637. R. D. Lawrence*, M. S. Baig*, J. H. Dilles*, J. R. LaFortune*, J. A. Dipietro*, S. S. Hughes*, P. S. Palmer-Rosenberg*, K. Pogue*, L. W. Snee, R. A. Tahirkheli*, A. A. Ghauri*, M. Q. Jan*, I. Ahmad*, M. Rafig*, A. H. Kazmi* and A. Hussain*. Tectonics south of the suture, northern Pakistan [abstr.]. International Geological Congress, Abstracts-Congres Geologique Internationale, Resumes, in Twenty-eighth international geological congress; abstracts. 28 , Vo1. 2,1989 . p. 2.265 .

OP-1638. P. P. Leahy. National water-quality assessment; an integrated and comprehensive multiscale approach [abstr.] American Water Resources Association Technical Publication Series TPS, in Water management of river systems; 27th annual AWRA conference. (H. C. McWreath, editor). 27, 1991. p. 341-342. 
OP-1639. S. A. Leake. ARIZONA. Simulation of delay in release of water from compaction in an aquifer system [abstr.] Eos, Transactions, American Geophysical Union, in AGU 1992 western Pacific geophysics meeting. v. 73, no. 25, suppl. June 23, 1992. p. 31.

OP-1640. S. A. Leake. New approaches to simulating aquifersystem compaction in models of regional groundwater flow [abstr.] International Geological Congress, Abstracts-Congres Geologique Internationale, Resumes, in Twenty-eighth international geological congress; abstracts. 28 , Vol. 2,1989. p. 2.271 2.272 .

OP-1641. H. J. Lee. Undersea landslides; extent and significance in the Pacific Ocean [abstr.] International Geological Congress, Abstracts-Congres Geologique Internationale, Resumes, in Twenty-eighth international geological congress; abstracts. 28, Vol. 2, 1989. p. 2.276.

OP-1642. K. Y. Lee. Stratigraphy, sedimentology, and economic potential of the Chilhowee Group in Central and Southern Appalachians, U.S.A. [abstr.] International Geological Congress, Abstracts-Congres Geologique Internationale, Resumes, in Twenty-eighth international geological congress; abstracts. 28 , Vol. 2, 1989. p. 2.276 .

OP-1643. J. A. Leenheer. Conservative transport of colloidal organic matter in the lower Mississippi River [abstr.] Abstracts of Papers - American Chemical Society, National Meeting, in 203rd ACS national meeting. 203, 1992. p. GEOC 58.

OP-1644. J. A. Leenheer, D. M. McKnight, E. M. Thurman and Patrick MacCarthy. Structural components and proposed structural models of fulvic acid from the Suwannee River [abstr.] Abstracts of Papers - American Chemical Society, National Meeting, in 200th ACS national meeting. 200, 1990 GEOC 48.

OP-1645. J. A. Leenheer, R. L. Wershaw, P. A. Brown and T. I. Noyes. Polyethylene-glycol residues from nonionic surfactants in the lower Mississippi River [abstr.] American Water Resources Association Technical Publication Series TPS, in Resource development of the lower Mississippi River; symposium papers. (Dhamo Dhamotharau, editor). 27, 1991. p. 183.

OP-1646. W. S. Leith, J. D. Unger and H. M. Benz. Crustal and upper mantle velocity variability in the former Soviet Union; a review of data from the Deep Seismic Sounding Program [abstr.] Eos, Transactions, American Geophysical Union, in AGU 1992 spring meeting. v. 73, no. 14, supplement, April 7, 1992. p. 208.

OP-1647. G. J. Leonard and K. L. Tanaka. Hellas Basin, Mars; formation by oblique impact [abstr.] Proceedings of the Lunar and Planetary Science Conference, in Abstracts of papers submitted to the Twenty-fourth lunar and planetary science conference. (Douglas Blanchard, chairperson and others). 24, 1993. p. 867-868.

OP-1648. L. L. Lesney. Chemical and isotopic evolution of ground water in the Midwestern Basins and Arches region [abstr.] Abstracts with Programs - Geological Society of America, in Geological Society of America, 1992 annual meeting. v. 24, no. 7, 1992. p. 241.

OP-1649. J. S. Leventhal. Controls and limitations of organic geochemistry in explaining metal enrichment in black shales; Cambrian Alum Shale of Sweden and Devonian Chattanooga
Shale of United States [abstr.] International Geological Congress, Abstracts-Congres Geologique Internationale, Resumes, in Twenty-eighth international geological congress; abstracts. 28, Vol. 2, 1989. p. 2.287.

OP-1650. R. S. Lewis*, J. R. Stone and Mary DigiacomoCohen*. Interpretation of glaciolacustrine and postglacial marine facies in Long Island Sound [abstr.] Abstracts with Programs Geological Society of America, in Geological Society of America, Northeastern Section, 28th annual meeting. v. 25, no. 2, March 1993. p. 33.

OP-1651. S. D. Lewis, J. H. Behrmann* and R. J. Musgrave*. Spatial temporal distributions of subduction accretion and erosion, ODP Leg 141, Chile margin triple junction [abstr.] Eos, Transactions, American Geophysical Union, in AGU 1992 spring meeting. v. 73, no. 14, suppl. April 7, 1992. p. 293.

OP-1652. Yong Li* and R. L. Dart. Mississippi Embayment syncline; a reactivation of the Reelfoot rift zone? [abstr.] Abstracts with Programs - Geological Society of America, in Geological Society of America, North-Central Section, 27th annual meeting. v. 25, no. 3, March 1993. p. 63.

OP-1653. F. E. Lichte and W. I. Ridley. The utility to geochemistry of inductively coupled plasma mass spectrometry (ICP-MS) with laser ablation; a progress report [abstr.] Abstracts of Papers Submitted to the Lunar and Planetary Science Conference, in Abstracts of papers submitted to the Twenty-first lunar and planetary science conference. 21, 1990. p. 694-695.

OP-1654. G. F. Lindholm. IDAHO. Basalt aquifer system underlying eastern Snake River plain in Idaho and hydrologic changes due to 100 years of irrigation [abstr.] International Geological Congress, Abstracts-Congres Geologique Internationale, Resumes, in Twenty-eighth international geological congress; abstracts. 28, Vol. 2, 1989. p. 2.302.

OP-1655. Chi-Hai Ling, Cheng-lung Chen and Chyan-Deng Jan*. Stress-strain relation in debris flow analysis [abstr.], in Hydraulic engineering; saving a theoretical resource, in search of solutions. (M. E. Jennings, editor and others). New York, NY: Am. Soc. Civ. Eng. 1992. p. 852.

OP-1656. B. R. Lipin, J. H. Schellekens*, A. L. Meier and M. W. Doughten. PUERTO RICO. Platinum-group metals in nickel-laterites in Puerto Rico [abstr.] Abstracts with Programs Geological Society of America, in Geological Society of America, 1992 annual meeting. v. 24 , no. 7,1992 . p. 62-63.

OP-1657. M. J. Lippmann*, A. H. Truesdell and A. Mañón M.*. The Cerro Prieto Field of northern Mexico; a multidisciplinary study of a geothermal system [abstr.] International Geological Congress, Abstracts-Congres Geologique Internationale, Resumes, in Twenty-eighth international geological congress; abstracts. 28, Vol. 2, 1989. p. 2.304.

OP-1658. Michael Lisowski, W. H. Prescott and J. C. Savage. CALIFORNIA. Little postseismic deformation detected after the Loma Prieta earthquake [abstr.] Seismological Research Letters, in 85th annual meeting of the Seismological Society of America. v. 61 , no. 1, March 1990. p. 17.

OP-1659. R. J. Litwin, Alfred Traverse* and S. R. Ash*. Regional correlation of lower Mesozoic continental strata in eastern Mesozoic basins (Atlantic Coast), Gulf Coast, and Colorado Pla- 
teau, USA [abstr.] International Geological Congress, AbstractsCongres Geologique Internationale, Resumes, in Twenty-eighth international geological congress; abstracts. 28 , Vol. 2, 1989. p. 2.309-2.310.

OP-1660. R. J. Litwin and R. E. Weems. VIRGINIA. Re-evaluation of the age of Triassic strata (Doswell Formation) of the Taylorsville Basin, Va. [abstr.] Virginia Journal of Science, in Virginia Academy of Science, 70th annual meeting. (J. H. Martin). v. 43, no. 2, 1992. p. 265.

OP-1661. Lanbo Liu*, M. D. Zoback* and Paul Segall. Viscosity estimate for the lower crust of the New Madrid seismic zone and its relation to intraplate seismicity [abstr.] Eos, Transactions, American Geophysical Union, in AGU 1992 western Pacific geophysics meeting. v. 73, no. 25, Suppl. June 23, 1992. p. 67.

OP-1662. S. D. Locker*, A. C. Hine* and E. A. Shinn. FLORIDA. High-resolution sequence stratigraphic framework of carbonate deposition controlled by sea level and geostrophic bottom currents, South Florida platform margin [abstr.] Abstracts with Programs - Geological Society of America, in Geological Society of America, 1992 annual meeting. v. 24, no. 7, 1992. p. 83.

OP-1663. P. J. Loferski and R. J. Arculus*. MONTANA. Rare-earth element geochemistry of the banded series of the Stillwater Complex, Montana, and its anorthosites [abstr.] Eos, Transactions, American Geophysical Union, in AGU-MSA 1991 spring meeting. v. 72 , no. 17 , April 23, 1991. p. 305.

OP-1664. D. L. Lorenz. Describing stream drainage systems using a geographic information system [abstr.] American Water Resources Association Technical Publication Series TPS, in Water management of river systems; 27th annual AWRA conference. (H. C. McWreath, editor). 27, 1991. p. 285-286.

OP-1665. D. R. Lovley, E. R. Landa, E. J. Phillips and J. C. Woodward. Remediation of uranium-contaminated soils using uranium extractants and microbial uranium reduction [abstr.] Abstracts of Papers - American Chemical Society, National Meeting, in Abstracts of papers; 203rd ACS national meeting. 203, 1992. p. GEOC 173.

OP-1666. J. Lu*, D. W. Sears*, B. D. Keck*, Martin Prinz*, J. N. Grossman and R. N. Clayton*. Semarkona type 1 chondrules compared with similar chondrules in other classes [abstr.] Abstracts of Papers Submitted to the Lunar and Planetary Science Conference, in Abstracts of papers submitted to the Twenty-first lunar and planetary science conference. 21,1990 . p. 720-721.

OP-1667. B. K. Lucchitta. Ice in the northern plains; relic of a frozen ocean? [abstr.] LPI Technical Report, in Workshop on the Martian northern plains; sedimentological, periglacial, and paleoclimatic evolution. (J. S. Kargel, editor and others). 93-04, Part 1, 1993. p. 9-10.

OP-1668. B. K. Lucchitta, R. A. Blaser and L. M. Bertolini. Valles Marineris, Mars; are pit chains formed by erosion and troughs by tectonism? [abstr.] Abstracts of Papers Submitted to the Lunar and Planetary Science Conference, in Abstracts of papers submitted to the Twenty-first lunar and planetary science conference. 21,1990 . p. $722-723$.

OP-1669. B. K. Lucchitta, N. K. Isbell and A. E. HowingtonKraus. Sedimentation, volcanism, and ancestral lakes in the Valles Marineris; clues from topography [abstr.] Proceedings of the Lunar and Planetary Science Conference, in Abstracts of papers submitted to the Twenty-fourth lunar and planetary science conference. (Douglas Blanchard, chairperson and others). 24, 1993. p. $905-$ 906.

OP-1670. K. R. Ludwig, K. R. Simmons, B. J. Szabo, A. C. Riggs and I. J. Winograd. NEVADA. Mass-spectrometric ${ }^{230} \mathrm{Th}-{ }^{234} \mathrm{U}-{ }^{238} \mathrm{U}$ dating of the Devils Hole calcite vein; a precise record of continuous growth from $\sim 566 \mathrm{ka}$ to $60 \mathrm{ka}$ [abstr.] Abstracts with Programs - Geological Society of America, in Geological Society of America, 1990 annual meeting. v. 22, no. 7, 1990. p. 310.

OP-1671. Karen Lund and L. W. Snee. IDAHO. Thermochronology of overlapping dynamothermal and plutonic events along the Salmon River suture, western Idaho [abstr.] Abstracts with Programs - Geological Society of America, in Geological Society of America, 1989 annual meeting. v. 21, no. 6, 1989. p. 307.

OP-1672. P. C. Lyons, A. T. Cross*,Z. Gao*, K. M. Gillis*, J. H. Calder*, E. L. Zodrow* and R. D. Congdon. Discovery of in-situ carbonate petrifications (coal balls) in the Foord Seam (Westphalian C, Upper Carboniferous), Stellarton, Nova Scotia, Canada; implications for origin of sulfur in the Foord Seam [abstr.] AAPG Bulletin, in AAPG Eastern Section meeting. v. 77, no. 8, August 1993. p. 1471.

OP-1673. P. C. Lyons, E. L. Zodrow* and W. H. Orem. Coalification of cuticle and compressed leaf tissue of the Carboniferous seed fern, Macroneuropteris (Neuropteris) scheuchzeri; implications for coalification to the bituminous coal stage [abstr.] Abstracts with Programs - Geological Society of America, in Geological Society of America, 1992 annual meeting. v. 24, no. 7, 1992. p. 163.

OP-1674. D. J. MacKinnon and K. L. Tanaka. A physical model of the impacted Martian crust; hydrologic and mechanical properties and geologic implications [abstr.] Abstracts of Papers Submitted to the Lunar and Planetary Science Conference, in Abstracts of papers submitted to the Twenty-first lunar and planetary science conference. 21,1990 . p. $728-729$.

OP-1675. R. W. MacLay and G. E. Groschen. TEXAS. Barrier faults control flowpaths within the Edwards Aquifer in the Balcones fault zone, San Antonio area, Texas [abstr.] Abstracts with Programs - Geological Society of America, in Geological Society of America, South-Central Section, 26th annual meeting. v. 24, no. 1, February 1992. p. 17.

OP-1676. R. F. Madole. COLORADO. Recurring deposition of eolian sand during the late Quaternary in northeastern Colorado [abstr.] Abstracts with Programs - Geological Society of America, in Geological Society of America, 1992 annual meeting. v. 24, no. 7,1992 . p. 314 .

OP-1677. F. T. Manheim, Peter Popenoe, P. F. Huddlestun* and J. R. Herring. GEORGIA. Phosphorites in Miocene strata off Georgia; implications of the TACTS corehole data [abstr.] Abstracts with Programs - Geological Society of America, in Geological Society of America, 1989 annual meeting. v. 21, no. 6, 1989. p. $330-331$.

OP-1678. G. D. March* and T. L. Murray. A method to provide recent earthquake hypocenter data to geographically-dispersed groups [abstr.] Eos, Transactions, American Geophysical Union, 
in AGU 1992 fall meeting. v. 73, no. 43, suppl. October 27, 1992. p. 348.

OP-1679. S. M. Marcus, S. B. Bartsch-Winkler and J. A. Briskey, Jr. Mineral-resource assessment of public lands [abstr.], in American Institute of Professional Geologists, 1992 annual meeting and symposium; Geologic reason, a basis for decisions affecting society. (Steve Friberg, chairperson). American Institute of Professional Geologists, September 1992. p. 43.

OP-1680. Louie Marincovich, Jr. ALASKA. Paleogeographic implications of coeval "Mesozoic" and Paleocene mollusks, Arctic Alaska [abstr.] AAPG Bulletin, in AAPG Pacific Section abstracts. v. 77, no. 4, April 1993. p. 707.

OP-1681. Louie Marincovich, Jr. Late Cenozoic evolution and development of the North Pacific molluscan fauna [abstr.] Annual Report - Western Society of Malacologists, in Western Society of Malacologists and American Malacological Union, combined annual meetings; abstracts and proceedings. (Hans Bertsch, editor and others). 24, June 8, 1992. p. 20.

OP-1682. R. K. Mark, R. J. Pike, Giovanni Bortoluzzi* and Paola Reichenbach*. Image from combined land and seafloor DEMs illuminates Tyrrhenian tectonics [abstr.] Eos, Transactions, American Geophysical Union, in AGU 1992 spring meeting. v. 73, no. 14, supplement, April 7, 1992. p. 280.

OP-1683. H. W. Markewich, H. T. Millard, Jr., M. J. Pavich, D. T. Rodbell, F. J. Rich*, E. M. Rutledge*, L. Ward*, S. G. Van Valkenburg and D. A. Wysocki*. ARKANSAS, TENNESSEE. Chronostratigraphic and paleoclimatic data for Quaternary loessial and fluvial deposits in the Mississippi River valley of Arkansas and Tennessee [abstr.] Abstracts with Programs - Geological Society of America, in Geological Society of America, 1992 annual meeting. v. 24 , no. 7,1992 . p. 50.

OP-1684. C. S. Martens* and E. A. Canuel. Organic matter accumulation, diagenesis and burial in a rapidly depositing coastal sediment [abstr.] Abstracts with Programs - Geological Society of America, in Geological Society of America, 1992 annual meeting. v. 24 , no. 7,1992 . p. 20 .

OP-1685. J. D. Martin, B. F. Connor and S. D. Zaugg. INDIANA. Reconnaissance sampling for synthetic organic compounds in the bottom sediments of two urban streams in Indianapolis [abstr.] American Water Resources Association Technical Publication Series TPS, in Water management of river systems; 27 th annual AWRA conference. (H. C. McWreath, editor). 27, 1991. p. 335-336.

OP-1686. C. D. Masters. World petroleum resources; where, why, and how much? [abstr.] Warta Geologi $=$ Newsletter of the Geological Society of Malaysia, in Symposium on the Tectonic framework and energy resources of the western margin of the Pacific Basin. (Ahmad Said, president). v. 18, no. 6, December 1992. p. 257-258.

OP-1687. R. E. Mattick, Istvan Koncz*, Bela Bardocz*, Arpad Szalay*, Karoly Szent-Gyorgyi*, Geza Csaszar* and Erika Juhasz*. Prospects for hydrocarbon exploration in the Mesozoic and Paleozoic sections of the Pannonian Basin in Hungary. [abstr.] AAPG Bulletin, in AAPG international conference and exhibition; abstracts. v. 77, no. 9, September 1993. p. 1645-1646.
OP-1688. J. L. Mauk*, C. S. Eldridge*, G. B. Hieshima*, L. G. Woodruff and R. W. Seasor*. MICHIGAN. An igneous contribution to sediment-hosted stratiform copper mineralization at White Pine Mine, Michigan; a working hypothesis [abstr.] Abstracts with Programs - Geological Society of America, in Geological Society of America, 1992 annual meeting. v. 24, no. 7, 1992. p. 23.

OP-1689. H. M. May. Clay mineral formation processes, solubilities and thermodynamic properties [abstr.] Terra Cognita, in First international symposium on Thermodynamics of natural processes. v. 8 , no. 2,1988 . p. 167-168.

OP-1690. F. K. Mazdab*, L. M. Anovitz*, B. S. Hemingway, R. A. Robie and Alexandra Navrotsky*. Thermodynamic properties of some boron-bearing minerals [abstr.] Abstracts with Programs - Geological Society of America, in Geological Society of America, 1992 annual meeting. v. 24, no. 7, 1992. p. 258.

OP-1691. K. J. McCaffrey*, C. F. Miller*, K. A. Howard, K. E. Karlstrom* and Carol Simpson*. CALIFORNIA. Granite emplacement and deformation in the Old Woman Mountains, southeastern California [abstr.] Special Paper - Geological Society of America, in The second Hutton symposium on the origin of granites and related rocks; proceedings. (P. E. Brown, editor and others). 272, 1992. p. 494.

OP-1692. M. H. McDermott. The spatial data transfer standard [abstr.] URISA Proceedings, in URISA 91; information and technology; gateway to solutions; Volume V; Abstracts; all papers accepted for the 1991 annual conference. 1991, 1991. p. 92-93.

OP-1693. A. S. McEwen. Clementine; anticipated scientific datasets from the Moon and Geographos [abstr.] Proceedings of the Lunar and Planetary Science Conference, in Abstracts of papers submitted to the Twenty-fourth lunar and planetary science conference. (Douglas Blanchard, chairperson and others). 24, 1993. p. 951-952.

OP-1694. A. S. McEwen. Temporal variability of the surface and atmosphere of Mars; Viking Orbiter color observations [abstr.] LPI Technical Report, in Workshop on the Martian surface and atmosphere through time. (R. M. Haberle, convener and others). 9202, 1992. p. 103-104.

OP-1695. A. S. McEwen. Global color and albedo variations on Triton [abstr.] Abstracts of Papers Submitted to the Lunar and Planetary Science Conference, in Abstracts of papers submitted to the Twenty-first lunar and planetary science conference. 21, 1990. p. $755-756$.

OP-1696. A. S. McEwen, T. L. Becker, M. S. Robinson*, K. P. Klaasen*, C. Heffernan* and J. M. Sunshine*. Lunar multispectral mosaics from Galileo's second Earth-Moon flyby [abstr.] Proceedings of the Lunar and Planetary Science Conference, in Abstracts of papers submitted to the Twenty-fourth lunar and planetary science conference. (Douglas Blanchard, chairperson and others). 24, 1993. p. 955.

OP-1697. A. S. McEwen, Ronald Greeley*, J. W. Head*, C. M. Pieters*, E. M. Fischer*, T. V. Johnson* and Gerhard Neukum*. Galileo SSI lunar observations; Copernican craters and soils [abstr.] Proceedings of the Lunar and Planetary Science Conference, in Abstracts of papers submitted to the Twenty-fourth lunar and planetary science conference. (Douglas Blanchard, chairperson and others). 24, 1993. p. 957-958. 
OP-1698. J. J. McGee. Mineralogy and compositional variations in lunar ferroan anorthosites [abstr.] Abstracts of Papers Submitted to the Lunar and Planetary Science Conference, in Abstracts of papers submitted to the Twenty-first lunar and planetary science conference. 21,1990 . p. 761-762.

OP-1699. R. G. McGimsey and J. M. Dorava. ALASKA. Eruption of Mount Spurr Volcano, Alaska, August 18, 1992; video footage [abstr.] Eos, Transactions, American Geophysical Union, in AGU 1992 fall meeting. v. 73, no. 43, suppl. October 27, 1992. p. $345-346$.

OP-1700. R. A. McKenney and R. B. Jacobson. ARKANSAS, MISSOURI. Stability of riffle-pool morphology in Ozarks streams [abstr.] Abstracts with Programs - Geological Society of America, in Geological Society of America, North-Central Section, 27th annual meeting. v. 25, no. 3, March 1993. p. 67.

OP-1701. Hugh McLean. CALIFORNIA. Miocene lavas constrain right slip movement on the West Huasna Fault in San Luis Obispo County to less than $8 \mathrm{~km}$ [abstr.] AAPG Bulletin, in AAPG Pacific Section abstracts. v. 77, no. 4, April 1993. p. 708-709.

OP-1702. M. O. McWilliams*, A. K. Baksi*, B. F. Bohor, G. A. Izett and A. V. Murali*. High-precision relative ages of $K / T$ boundary events in North America and Deccan Trap volcanism in India [abstr.] Eos, Transactions, American Geophysical Union, in AGU 1992 spring meeting. v. 73, no. 14, supplement, April 7, 1992. p. 363 .

OP-1703. E. A. Measures* and B. R. Wardlaw. TEXAS. Recognition of paleokarst in the Road Canyon Formation, Permian regional stratotype, West Texas [abstr.] Abstracts with Programs Geological Society of America, in Geological Society of America, 1990 annual meeting. v. 22, no. 7, 1990. p. 309.

OP-1704. G. P. Meeker. Evidence for low temperature equilibration in Allende CAI [abstr.] Abstracts of Papers Submitted to the Lunar and Planetary Science Conference, in Abstracts of papers submitted to the Twenty-first lunar and planetary science conference. 21,1990 . p. 781-782.

OP-1705. G. P. Meeker, J. E. Quick* and J. M. Paque*. Limited subsolidus diffusion in type B1 CAI; evidence from Ti distribution in spinel [abstr.] Proceedings of the Lunar and Planetary Science Conference, in Abstracts of papers submitted to the Twenty-fourth lunar and planetary science conference. (Douglas Blanchard, chairperson and others). 24, 1993. p. 969-970.

OP-1706. B. D. Meissner*, D. T. Long*, M. A. Wahrer*, P. N. Bauer, R. W. Lee and T. P. Wilson*. MICHIGAN. Geochemistry and source of solutes in ground water from the Marshall Sandstone regional aquifer, Michigan Basin [abstr.] Abstracts with Programs - Geological Society of America, in Geological Society of America, 1992 annual meeting. v. 24, no. 7, 1992. p. 240.

OP-1707. T. O. Mesko. Delineation of hydrogeologic terranes in the Piedmont and Blue Ridge physiographic provinces; southeastern and Mid-Atlantic United States [abstr.] AAPG Bulletin, in AAPG Eastern Section meeting. v. 77, no. 8, August 1993. p. 1471.

OP-1708. D. F. Meyer and D. C. Trabant. ALASKA. Laharproducing events and non-lahar-producing events at glacial-clad Cook Inlet volcanoes, Alaska [abstr.] Eos, Transactions, American
Geophysical Union, in AGU 1992 fall meeting. v. 73, no. 43, suppl. October 27, 1992. p. 346.

OP-1709. Klaus Mezger*, S. R. Bohlen, E. J. Essene* and A. N. Halliday*. Geochronology in granulites [abstr.], in V. M. Goldschmidt conference; program and abstracts. Geochem. Soc. 1990. p. 66.

OP-1710. B. M. Miller. Diagnostic expert systems; encoding geological knowledge for an exploration play analysis [abstr.] AAPG Bulletin, in AAPG Rocky Mountain Section meeting. v. 77, no. 8, August 1993. p. 1456.

OP-1711. C. F. Miller*, J. M. Hanchar*, T. M. Harrison*, D. A. Wark*, J. L. Wooden and V. C. Bennett*. The granitesource connection; narrowing the gap through study of lower crustal xenoliths and accessory minerals [abstr.] Eos, Transactions, American Geophysical Union, in AGU-MSA 1991 spring meeting. v. 72 , no. 17 , April 23,1991 . p. 303.

OP-1712. J. F. Miller* and J. E. Repetski. OKLAHOMA. Taxonomy, morphology, and biostratigraphic position of topotype material of Cordylodus proavus from the upper Signal Mountain Limestone, Arbuckle Mountains, Oklahoma [abstr.] Abstracts with Programs - Geological Society of America, in Geological Society of America, North-Central Section, 27th annual meeting. v. 25, no. 3, March 1993. p. 68.

OP-1713. L. G. Miller, R. S. Oremland and C. W. Culbertson. CALIFORNIA. The methane cycle in decomposing agricultural peat soils of the Sacramento-San Joaquin Delta, California [abstr.] Abstracts of Papers - American Chemical Society, National Meeting, in 203rd ACS national meeting. 203, 1992. p. GEOC 80.

OP-1714. T. P. Miller, S. R. McNutt, J. C. Eichelberger and C. A. Neal. ALASKA. The 1992 eruptions of Mt. Spurr Volcano, Alaska; an overview [abstr.] Eos, Transactions, American Geophysical Union, in AGU 1992 fall meeting. v. 73, no. 43, suppl. October 27, 1992. p. 342.

OP-1715. P. J. Modreski and R. A. Schreiner*. NEW MEXICO. Silver and copper mineralization at the Buckhorn Mine, Gallinas Mountains, New Mexico [abstr.] New Mexico Geology, in New Mexico mineral symposium. v. 15, no. 1, February 1993. p. 20 .

OP-1716. D. W. Mogk*, P. A. Mueller*, A. L. Heatherington*, E. Weyand* and J. L. Wooden. Archean trondhjemites; crustal growth or crustal evolution? [abstr.] Abstracts with Programs - Geological Society of America, in Geological Society of America, 1992 annual meeting. v. 24, no. 7, 1992. p. $92-93$.

OP-1717. D. C. Mohrig* and J. D. Smith. Predicting the migration rates of subaqueous dunes [abstr.] Abstracts with Programs Geological Society of America, in Geological Society of America, 1992 annual meeting. v. 24, no. 7, 1992. p. 277.

OP-1718. B. F. Molnia. ALASKA. Neoglacial history of the Malaspina Glacier, Alaska; inferences from two types of radar analyses [abstr.] Abstracts with Programs - Geological Society of America, in Geological Society of America, 1990 annual meeting. v. 22 , no. 7,1990 . p. $177-178$.

OP-1719. B. F. Molnia and D. G. Frank-Molnia*. ALASKA. Analysis of Alaskan glacial features using side-looking airborne radar data from CD-ROM [abstr.] Eos, Transactions, American 
Geophysical Union, in AGU 1992 spring meeting. v. 73, no. 14, Suppl. April 7, 1992. p. 105.

OP-1720. J. A. Moody. Mixing processes below the confluence of the Mississippi and Ohio rivers [abstr.] Eos, Transactions, American Geophysical Union, in AGU 1992 spring meeting. v. 73, no. 14, Suppl. April 7, 1992. p. 136.

OP-1721. D. E. Moore and D. A. Lockner. Role of stress-induced cracking in the generation of a segmented fault [abstr.] Abstracts with Programs - Geological Society of America, in Geological Society of America, 1992 annual meeting. v. 24, no. 7, 1992. p. 157.

OP-1722. H. J. Moore and P. A. Davis. Analyses and morphology of a lava flow, Ascraeus Mons, Mars [abstr.] Abstracts of Papers Submitted to the Lunar and Planetary Science Conference, in Abstracts of papers submitted to the Twenty-first lunar and planetary science conference. 21,1990 . p. 805-806.

OP-1723. H. J. Moore and J. M. Keller*. Surface-material maps of Viking landing sites on Mars [abstr.] Abstracts of Papers Submitted to the Lunar and Planetary Science Conference, in Abstracts of papers submitted to the Twenty-first lunar and planetary science conference. 21,1990 . p. 807-808.

OP-1724. H. J. Moore, J. J. Plaut* and T. J. Parker*. Relief of some small landforms on Venus [abstr.] Proceedings of the Lunar and Planetary Science Conference, in Abstracts of papers submitted to the Twenty-fourth lunar and planetary science conference. (Douglas Blanchard, chairperson and others). 24, 1993. p. 10031004.

OP-1725. H. J. Moore and P. M. Schenk*. Thick lava flows on Venus; distribution, morphology and terrestrial comparisons [abstr.] Eos, Transactions, American Geophysical Union, in AGU 1992 spring meeting. v. 73, no. 14, Suppl. April 7, 1992. p. 179.

OP-1726. G. B. Morgan, VI*, J. D. Pasteris* and I-Ming Chou. Reaction pathways and metastability in experimental $\mathrm{C}-\mathrm{O}-\mathrm{H}$ fluids [abstr.] Program with Abstracts - Geological Association of Canada; Mineralogical Association of Canada; Canadian Geophysical Union, Joint Annual Meeting. 16, 1991. p. 85.

OP-1727: J. W. Morgan, R. J. Walker and J. N. Grossman. Rhenium-osmium isotope systematics in enstatite chondrites [abstr.] Abstracts of Papers Submitted to the Lunar and Planetary Science Conference, in Abstracts of papers submitted to the Twenty-first lunar and planetary science conference. 21,1990 . p. 809-810.

OP-1728. J. J. Mori. CALIFORNIA. Rupture directivity observed for two magnitude 4 earthquakes near the San Jacinto Fault [abstr.] Seismological Research Letters, in 85th annual meeting of the Seismological Society of America. v. 61, no. 1, March 1990. p. 26.

OP-1729. J. J. Mori and Donna Eberhart-Phillips. Magma bodies inferred from 3-D velocity inversions at two large volcanoes; $\mathrm{Mt}$. Pinatubo, Philippines and Rabaul Caldera, Papua New Guinea [abstr.] Eos, Transactions, American Geophysical Union, in AGU 1992 fall meeting. v. 73 , no. 43 , suppl. October 27,1992 . p. 348

OP-1730. L. A. Moyer, D. F. Huber, P. G. Schruben and R. E. Arndt. Mineral sites and associated thematic data; how USGS uses these tools to address Federal land management issues [abstr.], in American Institute of Professional Geologists, 1992 annual meeting and symposium; Geologic reason, a basis for decisions affecting society. (Steve Friberg, chairperson). American Institute of Professional Geologists, September 1992. p. 44.

OP-1731. P. A. Mueller*, J. Hofle*, A. L. Heatherington*, J. L. Wooden, D. W. Mogk* and P. Thruston*. WYOMING. Origin of Archean low-grade metasedimentary rocks from the Jardine area, northern Wyoming Province [abstr.] Abstracts with Programs - Geological Society of America, in Geological Society of America, 1990 annual meeting. v. 22, no. 7, 1990. p. 175.

OP-1732. L. J. Muffler, J. W. Hedenquist*, S. E. Kesler* and E. Izawa*. Japan-U.S. seminar on Magmatic contributions to hydrothermal systems [abstr.] Eos, Transactions, American Geophysical Union, in AGU 1992 spring meeting. v. 73, no. 14, supplement, April 7, 1992. p. 353.

OP-1733. B. L. Murchey and M. C. Blake, Jr. CALIFORNIA. Evidence for subduction of a major ocean plate along the California margin during the Middle to early Late Jurassic [abstr.] AAPG Bulletin, in AAPG Pacific Section abstracts. v. 77, no. 4, April 1993. p. 710.

OP-1734. P. S. Murdoch. NEW YORK. Relation of stream chemistry to discharge in a headwater stream in the Catskill Mountains, N.Y. [abstr.], in Proceedings of the Chapman conference on hydrogeochemical responses of forested catchments. (M. R. Church, convener and others). 1989.

OP-1735. P. S. Murdoch and B. P. Baldigo. NEW YORK. Seasonal changes in the relation of stream $\mathrm{pH}$ to nitrate and dissolved organic carbon concentrations and their effect on trout mortality in the Catskill Mountains, New York [abstr.] Eos, Transactions, American Geophysical Union, in AGU 1992 spring meeting. v. 73, no. 14, Suppl. April 7, 1992. p. 121.

OP-1736. D. L. Naftz and L. E. Spangler. UTAH. Using geochemical techniques to identify salinity sources in the freshwater Navajo Aquifer, Aneth oil field, Utah [abstr.] AAPG Bulletin, in AAPG Rocky Mountain Section meeting. v. 77, no. 8, August 1993. p. $1456-1457$.

OP-1737. K. L. Nagy*, M. F. Hochella, Jr.*, A. E. Blum and A. C. Lasaga*. Evidence of dissolution and precipitation on gibbsite using atomic force microscopy [abstr.] Program and Abstracts Annual Clay Minerals Conference, in Clay Minerals Society, 28th annual meeting. (D. R. Pevear, chairperson). 28, October 1991. p. 120.

OP-1738. K. L. Nagy*, A. C. Lasaga* and A. E. Blum. Kinetics of dissolution and precipitation of the clay minerals kaolinite and gibbsite [abstr.], in V. M. Goldschmidt conference; program and abstracts. Geochem. Soc. 1990. p. 68.

OP-1739. C. A. Neal, R. G. McGimsey, M. P. Doukas, T. P. Miller, D. H. Richter, J. F. Paskievitch and Inyo Ellersieck. ALASKA. The August 18, 1992 eruption of Mount Spurr Volcano, Alaska; tephra-fall stratigraphy, distribution and impact [abstr.] Eos, Transactions, American Geophysical Union, in AGU 1992 fall meeting. v. 73, no. 43, suppl. October 27, 1992. p. 342.

OP-1740. C. H. Nelson, D. C. Twichell and W. C. Schwab. MISSISSIPPI. Influence of sediment supply and slope stability on 
depositional style of present-day Mississippi margin turbidite systems [abstr.] Annual Meeting Abstracts - American Association of Petroleum Geologists and Society of Economic Paleontologists and Mineralogists, in American Association of Petroleum Geologists 1993 annual convention. 1993, April 1993. p. 156.

OP-1741. P. H. Nelson and J. L. Mikesell. Magnetic susceptibility logs from sedimentary environments [abstr.] The Log Analyst, in The SPWLA 34th annual logging symposium and CWLS 14th evaluation symposium. v. 34, no. 2, April 1993. p. 45.

OP-1742. W. J. Nelson* and R. W. Harrison. Post-Cretaceous faulting at head of Mississippi Embayment [abstr.] Abstracts with Programs - Geological Society of America, in Geological Society of America, North-Central Section, 27th annual meeting. v. 25, no. 3, March 1993. p. 69-70.

OP-1743. S. G. Neuzil and C. B. Cecil. Evidence in peat of late Quaternary climate and sea level change, western Indonesia [abstr.] Abstracts with Programs - Geological Society of America, in Geological Society of America, 1992 annual meeting. v. 24, no. 7, 1992. p. 50 .

OP-1744. D. J. Nichols and J. L. Brown. MONTANA, WYOMING. The Cretaceous-Tertiary boundary in the Powder River basin, Montana and Wyoming, and its application to basin analysis [abstr.] Abstracts with Programs - Geological Society of America, in Geological Society of America, 1990 annual meeting. v. 22, no. 7,1990 . p. 364 .

OP-1745. D. J. Nichols and J. L. Brown. WYOMING, MONTANA. Cretaceous-Tertiary boundary in the Powder River basin, Wyoming and Montana [abstr.] Program and Abstracts - American Association of Stratigraphic Palynologists. Meeting, in American Association of Stratigraphic Palynologists 22nd annual meeting; program and abstracts. (K. M. Piel, convener). 22, 1989. p. 39.

OP-1746. Craig Nicholson* and R. L. Wesson. CALIFORNIA. An updated ten-year seismicity forecast for California (19871996); how are we doing? [abstr.] Seismological Research Letters, in 85th annual meeting of the Seismological Society of America. v. 61, no. 1 , March 1990 . p. 15.

OP-1747. S. W. Nicholson, W. F. Cannon and L. G. Woodruff. MICHIGAN. Alteration in the Porcupine Mountains, N. Michigan; $\mathrm{O}$ - and $\mathrm{Sr}$-isotopic ratios of basalts of the $1.1 \mathrm{Ga}$ Midcontinent Rift [abstr.] Abstracts with Programs - Geological Society of America, in Geological Society of America, 1992 annual meeting. v. 24 , no. 7,1992 . p. $60-61$.

OP-1748. J. E. Nielson and J. K. Nakata. ARIZONA. Flow origin of matrix structural zones \& size-sorting of inclusions in dikes, Black Canyon, Arizona [abstr.] Abstracts with Programs - Geological Society of America, in Geological Society of America, 1992 annual meeting. v. 24 , no. 7,1992 . p. 41.

OP-1749. T. H. Nilsen* and S. H. Clarke, Jr. CALIFORNIA. The Neogene forearc basin of Northern and Central California [abstr.] Abstracts with Programs - Geological Society of America, in Geological Society of America, 1990 annual meeting. v. 22, no. 7,1990 . p. 324 .

OP-1750. Kunihiko Nishiizumi*, C. P. Kohl*, J. R. Arnold*, M. W. Caffee*, R. C. Finkel*, J. R. Southon*, E. M. Shoemaker* and C. S. Shoemaker. Exposure histories of desert sands using in situ produced cosmogenic nuclides [abstr.] Eos, Transactions, American Geophysical Union, in AGU 1992 spring meeting. v. 73, no. 14, Suppl. April 7, 1992. p. 185.

OP-1751. J. E. Nolde* and R. C. Milici. VIRGINIA. Stratigraphic and structural controls of natural gas production from the Berea Sandstone (Mississippian), southwestern Virginia [abstr.] AAPG Bulletin, in AAPG Eastern Section meeting. v. 77, no. 8, August 1993. p. 1471-1472.

OP-1752. D. K. Nordstrom and J. W. Ball. Mineral saturation states in natural waters and their sensitivity to thermodynamic and analytical errors [abstr.] Terra Cognita, in First international symposium on Thermodynamics of natural processes. v. 8 , no. 2 , 1988. p. 167.

OP-1753. V. F. Nuccio and J. W. Schmoker. Measured and modeled vitrinite reflectance; comparisons in diverse basins [abstr.] Annual Meeting Abstracts - American Association of Petroleum Geologists and Society of Economic Paleontologists and Mineralogists, in American Association of Petroleum Geologists 1993 annual convention. 1993, April 1993. p. 159.

OP-1754. C. J. Nye*, T. P. Miller*, S. E. Swanson and M. L. Harbin. ALASKA. Major- and trace-element geochemistry of ejecta from the 1992 eruptions of Crater Peak, Mt. Spurr, Alaska [abstr.] Eos, Transactions, American Geophysical Union, in AGU 1992 fall meeting. v. 73, no. 43, suppl. October 27, 1992. p. 346.

OP-1755. J. T. O'Connor. VIRGINIA. Boron-, alkali-, and fluorine-deficient diagenetic tourmaline from Ordovician arenites in central Virginia [abstr.] Abstracts with Programs - Geological Society of America, in Geological Society of America, 1990 annual meeting. v. 22, no. 7, 1990. p. 259.

OP-1756. J. D. Obradovich. Advances and problems in time scale calibration [abstr.] Annual Meeting Abstracts - American Association of Petroleum Geologists and Society of Economic Paleontologists and Mineralogists, in American Association of Petroleum Geologists 1993 annual convention. 1993, April 1993. p. 160161.

OP-1757. J. D. Obradovich, W. A. Bryant, W. A. Cobban and W. J. Kennedy*. ARKANSAS. An isotopic age for the late Campanian Globotruncanita calcarata planktonic foraminifer from the Annona Chalk of S.W. Arkansas and its relation to the Western Interior ammonite zones [abstr.] Abstracts with Programs - Geological Society of America, in Geological Society of America, 1990 annual meeting. v. 22, no. 7, 1990. p. 234.

OP-1758. E. A. Okal* and S. H. Kirby. Deep earthquakes beneath the North Fiji Basin; faulting in a detached and recumbent slab transforming from metastable peridotite to the slab transitionzone mineral assemblage? [abstr.] Eos, Transactions, American Geophysical Union, in AGU 1993 fall meeting. v. 74, no. 43, Suppl. October 26, 1993. p. 97.

OP-1759. A. T. Okamura, Asta Miklius, P. G. Okubo and M. K. Sako. HAWAII. Forecasting eruptive activity in Mauna Loa Volcano, Hawaii [abstr.] Eos, Transactions, American Geophysical Union, in AGU 1992 fall meeting. v. 73, no. 43, suppl. October 27, 1992. p. 343.

OP-1760. S. D. Olmore. Cenozoic tectonic evolution of the northern margin of the Guiana Shield, Bolivar State, Venezuela [abstr.] 
Abstracts with Programs - Geological Society of America, in Geological Society of America, 1990 annual meeting. v. 22, no. 7, 1990. p. 337.

OP-1761. H. W. Olsen, K. R. Nelson*, J. D. Gill* and E. N. Yearsley*. Measuring non-Darcian flow in fine-grained soils [abstr.] Abstracts with Programs - Geological Society of America, in Geological Society of America, 1989 annual meeting. v. 21, no. 6,1989 . p. 323 .

OP-1762. D. H. Oppenheimer and M. E. Magee*. CALIFORNIA. The 1991 M6.0 Honeydew, California earthquake [abstr.] Eos, Transactions, American Geophysical Union, in AGU 1992 spring meeting. v. 73 , no. 14, supplement, April 7, 1992. p. 398.

OP-1763. W. H. Orem and H. E. Lerch. Lignin oxidation products in sediments of Lake Baikal; indicators of climate-induced changes in allochthonous organic matter [abstr.] Eos, Transactions, American Geophysical Union, in AGU-MSA 1991 spring meeting. v. 72 , no. 17 , April 23, 1991. p. 306.

OP-1764. W. H. Orem, H. E. Lerch and R. K. Kotra. Lignin oxidation products in sediments of Lake Baikal, USSR; indicators of climate history of Northeast Asia [abstr.] Abstracts of Papers American Chemical Society, National Meeting, in 203rd ACS national meeting. 203, 1992. p. GEOC 83.

OP-1765. R. S. Oremland, J. S. Blum and N. A. Steinberg. Selenate respiration by a freshwater bacterial culture [abstr.] Abstracts of Papers - American Chemical Society, National Meeting, in Abstracts of papers; 203rd ACS national meeting. 203, 1992. p. GEOC 164.

OP-1766. R. S. Oremland and C. W. Culbertson. Two novel inhibitors of methane monooxygenase and their application to investigations of methane flux [abstr.] Abstracts of Papers - American Chemical Society, National Meeting, in 203rd ACS national meeting. 203, 1992. p. GEOC 81.

OP-1767. J. G. Palacas, R. M. Flores, C. W. Keighin and D. E. Anders. WYOMING. Organic geochemical typing of oils in the Wind River basin, Wyoming [abstr.] Annual Meeting Abstracts American Association of Petroleum Geologists and Society of Economic Paleontologists and Mineralogists, in American Association of Petroleum Geologists 1993 annual convention. 1993, April 1993. p. 162.

OP-1768. J. S. Pallister, R. P. Hoblitt, C. G. Newhall and W. E. Scott. A basalt trigger for the 1991 eruptions of Pinatubo volcano? Yes [abstr.] Eos, Transactions, American Geophysical Union, in AGU 1992 fall meeting. v. 73, no. 43, suppl. October 27, 1992. p. 347.

OP-1769. C. A. Palmer, P. C. Lyons and C. J. Skeen. Chemohistology of a modern tree fern; implications for minor and trace elements in the Pittsburgh Coal [abstr.] Abstracts of Papers American Chemical Society, National Meeting, in 203rd ACS national meeting. 203, 1992. p. GEOC 86.

OP-1770. J. J. Papike*, M. N. Spilde*, K. C. Galbreath*, C. K. Shearer*, T. E. Keith and J. C. Laul*. ALASKA. Geochemistry and mineralogy of fumarole deposits, Valley of Ten Thousand Smokes, Alaska; alteration of rhyolite ash-flow tuff protolith [abstr.], in V. M. Goldschmidt conference; program and abstracts. Geochem. Soc. 1990. p. 72.
OP-1771. J. J. Papike*, M. N. Spilde*, C. K. Shearer*, K. C. Galbreath*, T. E. Keith and J. C. Laul*. ALASKA. Geochemistry and mineralogy of fumarole deposits, VTTS, Alaska; bulk chemical and mineralogical evolution of a dacitic fissure fumarole [abstr.] Abstracts with Programs - Geological Society of America, in Geological Society of America, 1990 annual meeting. v. 22, no. 7,1990 . p. 351-352.

OP-1772. J. F. Paskievitch, T. L. Murray, R. P. Hoblitt and C. A. Neal. ALASKA. Lightning associated with the 18 August, 1992 eruption of Mount Spurr [abstr.] Eos, Transactions, American Geophysical Union, in AGU 1992 fall meeting. v. 73, no. 43, suppl. October 27, 1992. p. 346.

OP-1773. J. D. Pasteris*, G. B. Morgan, VI* and I-Ming Chou. Geological implications of speciation in experimental C-O-H fluids [abstr.] Program with Abstracts - Geological Association of Canada; Mineralogical Association of Canada; Canadian Geophysical Union, Joint Annual Meeting. 16, 1991. p. 95.

OP-1774. M. J. Pavich. Zonation of chemical reactions in saprolite [abstr.], in V. M. Goldschmidt conference; program and abstracts. Geochem. Soc. 1990. p. 73.

OP-1775. Z. E. Peterman, J. S. Stuckless, J. S. Downey and E. D. Gutentag. NEVADA. Strontium-isotope geochemistry of the Ash Meadows ground-water system in southern Nevada [abstr.] Abstracts with Programs - Geological Society of America, in Geological Society of America, 1990 annual meeting. v. 22, no. 7, 1990. p. $295-296$.

OP-1776. M. T. Peters*, S. M. Wickham* and D. M. Miller. High $\delta^{13} \mathrm{C}$ late Proterozoic carbonates of the North American Cordillera [abstr.] Abstracts with Programs - Geological Society of America, in Geological Society of America, 1992 annual meeting. v. 24 , no. 7,1992 . p. 114.

OP-1777. J. A. Philpotts, M. J. Kunk, J. R. Evans, V. S. Lanev*, M. S. Rusanov* and V. V. Vakhrusheva*. ${ }^{40} \mathrm{Ar} /{ }^{39} \mathrm{Ar}$ thermochronology of mineral samples from rocks cored near the bottom of the 12-km-deep Kola Well, Russia [abstr.] Eos, Transactions, American Geophysical Union, in AGU 1992 spring meeting. v. 73 , no. 14, supplement, April 7, 1992. p. 370-371.

OP-1778. D. A. Pickett*, M. T. Murrell* and R. I. Tilling. $\mathrm{U} / \mathrm{Th}$ and Th isotopes in minerals from El Chichón trachyandesite; implications for crystal/liquid partitioning in andesitic systems [abstr.] Eos, Transactions, American Geophysical Union, in AGU 1993 spring meeting. v. 74, no. 16, Suppl. May 1993. p. 341.

OP-1779. B. S. Pierce, R. W. Stanton and R. D. Hettinger. UTAH. Sampling and characteristics of Cretaceous coals from the Kaiparowits Plateau, southern Utah [abstr.] Annual Meeting of the Society for Organic Petrology. Abstracts and Program, in Ninth annual meeting of the Society for Organic Petrology. (S. A. Stout, editor). 9, July 23, 1992. p. 49-50.

OP-1780. K. L. Pierce, D. G. Milbert* and R. W. Saltus. WYOMING. Geoid dome culminates on Yellowstone; Yellowstone Hotspot fed by a thermal mantle plume? [abstr.] Eos, Transactions, American Geophysical Union, in AGU 1992 spring meeting. v. 73, no. 14, suppl. April 7, 1992. p. 284.

OP-1781. C. M. Pieters*, M. J. Belton*, J. W. Head*, Ronald Greeley*, A. S. McEwen, E. M. Fischer*, J. M. Sunshine*, K. P. Klaasen*, J. Plutchak*, Gerhard Neukum* and T. V. John- 
son*. Compositional diversity of the lunar north pole; preliminary analyses of Galileo SSI data [abstr.] Proceedings of the Lunar and Planetary Science Conference, in Abstracts of papers submitted to the Twenty-fourth lunar and planetary science conference. (Douglas Blanchard, chairperson and others). 24, 1993. p. 1141-1142.

OP-1782. J. K. Pitman, M. B. Goldhaber, T. H. Shaw* and R. C. Burruss. ILLINOIS, KENTUCKY. Basin-scale brine movement in the Midcontinent during the late Paleozoic; evidence from the St. Peter Sandstone in the Illinois Basin [abstr.] Annual Meeting Abstracts - American Association of Petroleum Geologists and Society of Economic Paleontologists and Mineralogists, in American Association of Petroleum Geologists 1993 annual convention. 1993, April 1993. p. 166.

OP-1783. A. Plesinger*, E. A. Bergman and E. R. Engdahl. Measurement protocols for digitally-recorded seismograms [abstr.] Eos, Transactions, American Geophysical Union, in AGU 1992 western Pacific geophysical meeting. v. 73, no. 25, Suppl. June 23, 1992. p. 58.

OP-1784. A. Plesinger*, E. A. Bergman and E. R. Engdahl. PC-based software for seismological analysis at the observatory [abstr.] Eos, Transactions, American Geophysical Union, in AGU 1992 western Pacific geophysical meeting. v. 73, no. 25, Suppl. June 23, 1992. p. 58.

OP-1785. G. S. Plumlee and W. I. Ridley. Chemical reaction path modeling of hydrothermal processes on Mars; preliminary results [abstr.] LPI Technical Report, in Workshop on the Martian surface and atmosphere through time. (R. M. Haberle, convener and others). 92-02, 1992. p. 118-119.

OP-1786. L. N. Plummer. Geochemical modeling of water-rock interaction; past, present, future [abstr.]Proceedings - International Symposium on Water-Rock Interaction. 7, 1992. p. 23-33.

OP-1787. L. N. Plummer, Eurybiades Busenberg, P. D. Glynn and A. E. Blum. Dissolution of $\mathrm{SrCO}_{3}-\mathrm{CaCO}_{3}$ solid solutions in non-stoichiometric aqueous solutions [abstr.] Abstracts of Papers - American Chemical Society, National Meeting, in Abstracts of papers; 203rd ACS national meeting. 203, 1992. p. GEOC 179.

OP-1788. C. W. Poag, L. J. Poppe, D. S. Powars and R. B. Mixon. Distribution, volume, and depositional origin of upper Eocene bolide-generated sediments along the U.S. East Coast [abstr.] Abstracts with Programs - Geological Society of America, in Geological Society of America, 1992 annual meeting. v. 24, no. 7,1992 . p. $172-173$.

OP-1789. H. A. Pohn and B. F. Molnia. ALASKA. Structural analysis of side-looking airborne radar data for the western Brooks Range, AK [abstr.] Eos, Transactions, American Geophysical Union, in AGU 1992 spring meeting. v. 73, no. 14, suppl. April 7, 1992. p. 288.

OP-1790. H. A. Pohn and G. G. Schaber. Crater destruction on the Venusian highlands by tectonic processes [abstr.] Proceedings of the Lunar and Planetary Science Conference, in Abstracts of papers submitted to the Twenty-fourth lunar and planetary science conference. (Douglas Blanchard, chairperson and others). 24, 1993. p. 1161-1162.

OP-1791. R. M. Pollastro. The illite/smectite geothermometer; considerations and case-history studies in hydrocarbon-bearing rocks of Miocene to Mississippian in age [abstr.] Program and
Abstracts - Annual Clay Minerals Conference, in Clay Minerals Society, 28th annual meeting. (D. R. Pevear, chairperson). 28, October 1991. p. 128.

OP-1792. R. M. Pollastro and B. F. Bohor. Origin and genesis of clay minerals at the Cretaceous-Tertiary boundary interval, U.S. Western Interior [abstr.] Program and Abstracts - Annual Clay Minerals Conference, in Clay Minerals Society, 28th annual meeting. (D. R. Pevear, chairperson). 28, October 1991. p. 129.

OP-1793. D. J. Ponti. CALIFORNIA. Off-fault surface fractures produced by the 1989 Loma Prieta, California earthquake; a significant hazard for the Santa Cruz Mountains [abstr.] Abstracts with Programs - Geological Society of America, in Geological Society of America, 1990 annual meeting. v. 22, no. 7, 1990. p. 187.

OP-1794. D. J. Ponti and R. E. Wells. CALIFORNIA. Origin of surface ruptures that formed in the Santa Cruz Mountains, California, during the Loma Prieta earthquake [abstr.] Seismological Research Letters, in 85th annual meeting of the Seismological Society of America. v. 61, no. 1, March 1990. p. 17.

OP-1795. F. G. Poole and C. A. Sandberg. NEVADA. Relation of transitional-facies Woodruff Formation to Late Devonian continental margin in Nevada [abstr.] AAPG Bulletin, in AAPG Rocky Mountain Section meeting. v. 77, no. 8, August 1993. p. 1458.

OP-1796. R. Z. Poore, R. L. Phillips, H. J. Rieck and D. H. McNeil*. Quaternary paleoclimate record of the Northwind Ridge, western Arctic Ocean [abstr.] Eos, Transactions, American Geophysical Union, in AGU 1992 spring meeting. v. 73, no. 14, suppl. April 7, 1992. p. 287.

OP-1797. L. J. Poppe and C. W. Poag. Mesozoic stratigraphy and paleoenvironments of the Exxon 975-1 well, Georges Bank basin, U.S. North Atlantic outer continental shelf [abstr.] Abstracts with Programs - Geological Society of America, in Geological Society of America, Northeastern Section, 28th annual meeting. v. 25, no. 2, March 1993. p. 70-71.

OP-1798. K. W. Porter*, T. S. Dyman and R. G. Tysdal. MONTANA. Sequence boundaries and other surfaces in Lower and Lower-Upper Cretaceous rocks of central and southwestern Montana [abstr.] AAPG Bulletin, in AAPG Rocky Mountain Section meeting. v. 77, no. 8, August 1993. p. 1458.

OP-1799. C. J. Potter, M. B. Goldhaber, P. C. Heigold* and C. D. Taylor. Regional seismic reflection line, southern Illinois Basin, provides new data on Cambrian rift geometry, Hicks Dome genesis, and the Fluorspar area fault complex [abstr.] Abstracts with Programs - Geological Society of America, in Geological Society of America, 1992 annual meeting. v. 24, no. 7, 1992. p. 279.

OP-1800. C. L. Powell, II. Preliminary review of Holocene and Pleistocene northeastern Pacific Glycymeris [abstr.] Annual Report - Western Society of Malacologists, in Western Society of Malacologists and American Malacological Union, combined annual meetings; abstracts and proceedings. (Hans Bertsch, editor and others). 24, June 8, 1992. p. 8-9.

OP-1801. R. D. Powell*, D. E. Lawson*; E. A. Cowan*, L. E. Hunter*, Jinkui Cai* and P. R. Carlson. Submersible observations of grounding-lines and morainal banks of tidewater termini 
of temperate glaciers [abstr.] Program with Abstracts - Geological Association of Canada; Mineralogical Association of Canada; Canadian Geophysical Union, Joint Annual Meeting. 16, May 1991. p. 101.

OP-1802. J. A. Power, A. D. Jolly, S. D. Stihler, R. A. Page*, J. C. Lahr*, C. D. Stephens*, B. A. Chouet*, S. R. McNutt*, J. N. Davies* and G. D. March*. ALASKA. Precursory seismicity and forecasting of the 1992 eruptions of Mount Spurr, Alaska [abstr.] Eos, Transactions, American Geophysical Union, in AGU 1992 fall meeting. v. 73, no. 43, suppl. October 27, 1992. p. 342.

OP-1803. W. R. Premo. U-Pb isotopic ages and characteristics of ancient $(>4.0 \mathrm{Ga}$ ) lunar highland rocks [abstr.] Proceedings of the Lunar and Planetary Science Conference, in Abstracts of papers submitted to the Twenty-fourth lunar and planetary science conference. (Douglas Blanchard, chairperson and others). 24, 1993. p. $1169-1170$.

OP-1804. W. R. Premo and G. A. Izett. COLORADO. U-Pb provenance ages of shocked zircons from the K-T boundary, Raton Basin, Colorado [abstr.] Proceedings of the Lunar and Planetary Science Conference, in Abstracts of papers submitted to the Twenty-fourth lunar and planetary science conference. (Douglas Blanchard, chairperson and others). 24, 1993. p. 1171-1172.

OP-1805. W. R. Premo and Mitsunobu Tatsumoto. U-Pb isotopic systematics of ferroan anorthosite 60025 [abstr.] Proceedings of the Lunar and Planetary Science Conference, in Abstracts of papers submitted to the Twenty-fourth lunar and planetary science conference. (Douglas Blanchard, chairperson and others). 24, 1993. p. $1173-1174$.

OP-1806. M. S. Pringle. Rolling thunder of the Early Cretaceous; plateau basalts, EMI from the lower mantle, and the origin of the Dupal anomaly [abstr.] Eos, Transactions, American Geophysical Union, in AGU-MSA 1991 spring meeting. v. 72, no. 17, April 23, 1991. p. 300

OP-1807. L. C. Pusey* and J. E. Vidale. Accurate finite-difference calculation of WKBJ traveltimes and amplitudes [abstr.] SEG Abstracts, in Expanded abstracts with biographies, 1991 technical program, 61st annual international SEG meeting. 61, 1991. p. 1513-1516.

OP-1808. J. E. Quick, Luisa Negrini* and Silvano Sinigoi*. Deformation during magmatic underplating in the Ivrea-Verbano Zone, northwestern Italy [abstr.] Eos, Transactions, American Geophysical Union, in AGU-MSA 1991 spring meeting. v. 72, no. 17, April 23, 1991. p. 288.

OP-1809. D. H. Rapp. New serial-digital interface for pressure sensors acquired by the U.S. Geological Survey [abstr.] American Water Resources Association Technical Publication Series TPS, in Water management of river systems; 27th annual AWRA conference. (H. C. McWreath, editor). 27, 1991. p. 423.

OP-1810. B. A. Rea, J. A. Davis, G. A. Waychunas* and C. C. Fuller. Iron EXAFS study of two-line ferrihydrite with coprecipitated orthosilicate [abstr.] Abstracts of Papers - American Chemical Society, National Meeting, in 203rd ACS national meeting. 203, 1992. p. GEOC 55.

OP-1811. B. A. Rea, G. A. Waychunas*, J. A. Davis, C. C Fuller* and Garrison Sposito*. The use of Mossbauer and ex- tended X-ray absorption fine structure (EXAFS) spectroscopy to characterize the surface of two-line ferrihydrite [abstr.] Abstracts with Programs - Geological Society of America, in Geological Society of America, 1990 annual meeting. v. 22, no. 7,1990. p. 293.

OP-1812. P. A. Reasenberg, M. V. Matthews and Max Wyss*. HAWAII. Re-examination of seismicity rate fluctuations before the 1983 Kaoiki, Hawaii, (M 6.6) earthquake [abstr.] Seismological Research Letters, in 83rd annual meeting of the Seismological Society of America. v. 59, no. 1, March 1988. p. 19.

OP-1813. J. C. Reed, Jr., Isidore Zietz* and J. S. Duval. COLORADO. An aeromagnetic and aeroradioactivity overview of the Colorado Front Range [abstr.] Abstracts with Programs - Geological Society of America, in Geological Society of America, 1992 annual meeting. v. 24, no. 7, 1992. p. 205.

OP-1814. M. E. Reid and R. L. Baum. Mechanism of rainfallinduced pore-pressure increase in a clayey landslide [abstr.] Abstracts with Programs - Geological Society of America, in Geological Society of America, 1992 annual meeting. v. 24, no. 7, 1992. p. 203.

OP-1815. T. E. Reilly. Analysis of saltwater upconing [abstr.] AAAS Publication, in AAAS annual meeting, 156th national meeting; abstracts of papers. (M. D. Games, compiler). 89-43S, 1990. p. 29.

OP-1816. G. M. Reimer. Radon measurement uncertainty; why a black and white number shouldn't be pulled from a sea of gray [abstr.], in American Institute of Professional Geologists, 1992 annual meeting and symposium; Geologic reason, a basis for decisions affecting society. (Steve Friberg, chairperson). American Institute of Professional Geologists, September 1992. p. 36.

OP-1817. Juergen Reinhardt. Upper Cretaceous stratigraphy, facies, and sedimentary cyles in the eastern Gulf Coastal Plain [abstr.] Abstracts with Programs - Geological Society of America, in Geological Society of America, 1990 annual meeting. v. 22, no. 7,1990 . p. 234.

OP-1818. J. E. Repetski. Lower Ordovician conodonts from the Reelfoot Basin, southern Midcontinent, U.S.A. [abstr.] Abstracts with Programs - Geological Society of America, in Geological Society of America, North-Central Section, 26th annual meeting. v. 24, no. 4, April 1992. p. 61.

OP-1819. J. E. Repetski, R. L. Ethington*, W. M. Furnish* and D. J. Kennedy*. Conodonts from the Oneota and Gasconade dolomites (Lower Ordovician) of the central Midcontinent, U.S.A. [abstr.] Abstracts with Programs - Geological Society of America, in Geological Society of America, North-Central Section, 27th annual meeting. v. 25, no. 3, March 1993. p. 74-75.

OP-1820. P. J. Restrepo*, G. H. Leavesley, M. Dixon* and G. Stannard. The modular hydrologic modelling system; MHMS [abstr.] Eos, Transactions, American Geophysical Union, in AGU 1992 spring meeting. v. 73, no. 14, Suppl. April 7, 1992. p. 113.

OP-1821. C. L. Rice, H. E. Belkin, M. J. Kunk and T. W. Henry. Distribution, stratigraphy, mineralogy, and ${ }^{40} \mathrm{Ar} /{ }^{39} \mathrm{Ar}$ age spectra of the Middle Pennsylvanian fire clay tonstein of the central Appalachian Basin [abstr.] Abstracts with Programs - Geological 
Society of America, in Geological Society of America, 1990 annual meeting. v. 22, no. 7, 1990. p. 320-321.

OP-1822. D. D. Rice. Composition and origins of coalbed gas [abstr.] Annual Meeting Abstracts - American Association of Petroleum Geologists and Society of Economic Paleontologists and Mineralogists, in American Association of Petroleum Geologists 1993 annual convention. 1993, April 1993. p. 170-171.

OP-1823. D. D. Rice. Controls on coal-bed gas composition [abstr.] AAPG Bulletin, in AAPG international conference and exhibition; abstracts. v. 77, no. 9, September 1993. p. 1658.

OP-1824. K. C. Rice and O. P. Bricker. MARYLAND. Hydrologic, chemical, and isotopic characterization of two small watersheds on Catoctin Mountain, north-central Maryland, U.S.A. [abstr.] Chemical Geology, in Geochemistry of the Earth surface; abstracts for the third international symposium on the Geochemistry of the Earth surface. (L. R. Kump, editor). v. 107, no. 3-4, July 25, 1993. p. 319-321.

OP-1825. L. R. Riciputi*, C. M. Johnson*, D. A. Sawyer and P. W. Lipman. COLORADO. $\mathrm{Nd}, \mathrm{Sr}$, and $\mathrm{Pb}$ isotope evidence for crust/mantle interaction during silicic magmatism in the central San Juan caldera cluster, CO [abstr.] Abstracts with Programs Geological Society of America, in Geological Society of America, 1990 annual meeting. v. 22, no. 7, 1990. p. 256.

OP-1826. K. G. Ries, III and P. A. Steeves. MASSACHUSETTS. A geographic information system program for estimating low-streamflow statistics in Massachusetts [abstr.] American Water Resources Association Technical Publication Series TPS, in Water management of river systems; 27th annual AWRA conference. (H. C. McWreath, editor). 27, 1991. p. 287-289.

OP-1827. J. F. Rinella, J. K. Crawford, S. W. McKenzie and G. J. Fuhrer. WASHINGTON. Occurrence and distribution of DDT compounds in surface water, sediment, and fish from the Yakima River Basin, Washington, 1970-90 [abstr.] American Water Resources Association Technical Publication Series TPS, in Water management of river systems; 27th annual AWRA conference. (H. C. McWreath, editor). 27, 1991. p. 347-348.

OP-1828. J. C. Risley. MASSACHUSETTS. Application of generalized-least squares regression to estimate flow-duration statistics in Massachusetts [abstr.] American Water Resources Association Technical Publication Series TPS, in Water management of river systems; 27th annual AWRA conference. (H. C. McWreath, editor). 27, 1991. p. 435-437.

OP-1829. Keith Robinson. Estimates of offshore hydrocarbon resource potential in Tertiary sedimentary basins and areas along the western rim of the Pacific Basin [abstr.] Warta Geologi = Newsletter of the Geological Society of Malaysia, in Symposium on the Tectonic framework and energy resources of the western margin of the Pacific Basin. (Ahmad Said, president). v. 18, no. 6, December 1992. p. 260.

OP-1830. M. S. Robinson*, B. R. Hawke*, Kathleen Edwards, P. G. Lucey* and B. E. Clark*. Preliminary results from Mariner 10; high resolution images of the Moon [abstr.] Proceedings of the Lunar and Planetary Science Conference, in Abstracts of papers submitted to the Twenty-fourth lunar and planetary science conference. (Douglas Blanchard, chairperson and others). 24, 1993. p. 1207-1208.
OP-1831. M. S. Robinson*, P. J. Mouginis-Mark*, J. R. Zimbelman* and S. S. Wu. Comparative hypsometric analysis of both Earth and Venus topographic distributions [abstr.] Proceedings of the Lunar and Planetary Science Conference, in Abstracts of papers submitted to the Twenty-fourth lunar and planetary science conference. (Douglas Blanchard, chairperson and others). 24, 1993. p. 1209-1210.

OP-1832. M. S. Robinson*, P. J. Mouginis-Mark*, J. R. Zimbelman*, S. S. Wu, K. K. Ablin and A. E. HowingtonKraus. Apollinaris Patera, Mars; complex volcanic evolution through time [abstr.] Eos, Transactions, American Geophysical Union, in AGU 1992 spring meeting. v. 73, no. 14, Suppl. April 7, 1992. p. 184 .

OP-1833. T. K. Rockwell*, D. P. Schwartz, K. E. Sieh*, C. Rubin*, S. C. Lindvall*, M. Herzberg*, Deems Padgett* and T. E. Fumal. CALIFORNIA. Initial paleoseismic studies following the Landers earthquake; implications for fault segmentation and earthquake clustering [abstr.] Eos, Transactions, American Geophysical Union, in AGU 1993 fall meeting. v. 74, no. 43, Suppl. October 26, 1993. p. 67.

OP-1834. D. J. Roddy, E. M. Shoemaker and R. R. Anderson*. IOWA. The Manson impact crater; estimation of the energy of formation, possible size of the impacting asteroid or comet, and ejecta volume and mass [abstr.] Proceedings of the Lunar and Planetary Science Conference, in Abstracts of papers submitted to the Twenty-fourth lunar and planetary science conference. (Douglas Blanchard, chairperson and others). 24, 1993. p. 1211-1212.

OP-1835. R. W. Rodriguez, R. M. Webb and D. M. Bush*. PUERTO RICO. Hurricane Hugo's impact on Puerto Rico coastal settings; sandy shores, rocky coasts and an offshore sand deposit [abstr.] Abstracts with Programs - Geological Society of America, in Geological Society of America, 1990 annual meeting. v. 22, no. 7,1990 . p. 331 .

OP-1836. S. O. Rohmann* and C. G. Crawford. Estimating and evaluating amounts of metals transported to coastal areas by rivers [abstr.] American Water Resources Association Technical Publication Series TPS, in Water management of river systems; 27th annual AWRA conference. (H. C. McWreath, editor). 27,1991. p. 333-334.

OP-1837. Malcolm Ross, M. J. Flohr and D. R. Ross*. ARKANSAS. Compositional relations between natrolite, gonnardite, and thomsonite; products of nepheline alteration in alkaline rocks of the Magnet Cove igneous complex, Hot Springs, Arkansas [abstr.] Abstracts with Programs - Geological Society of America, in Geological Society of America, 1989 annual meeting. v. 21, no. 6,1989 . p. 326 .

OP-1838. S. L. Rotto and K. L. Tanaka. Chryse Planitia region, Mars; channeling history, flood-volume estimates, and scenarios for bodies of water in the northern plains [abstr.] LPI Technical Report, in Workshop on the Martian surface and atmosphere through time. (R. M. Haberle, convener and others). 92-02, 1992. p. 124-125.

OP-1839. B. N. Runnegar* and John Pojeta, Jr. The earliest bivalves and their Ordovician descendants [abstr.] Annual Report Western Society of Malacologists, in Western Society of Malacologists and Aimerican Malacological Union, combined annual meetings; abstracts and proceedings. (Hans Bertsch, editor and others). 24 , June 8,1992 . p. 1 . 
OP-1840. J. F. Russell and G. G. Schaber. Named Venusian craters [abstr.] Proceedings of the Lunar and Planetary Science Conference, in Abstracts of papers submitted to the Twenty-fourth lunar and planetary science conference. (Douglas Blanchard, chairperson and others). 24, 1993. p. 1219-1220.

OP-1841. Graham Ryder* and G. B. Dalrymple. Apollo 15 impact melts, the age of Imbrium, and the Earth-Moon impact cataclysm [abstr.] LPI Contribution, in Papers presented to the International conference on Large meteorite impacts and planetary evolution. (B. O. Dressler, chairperson and others). 790, 1992. p. $62-63$.

OP-1842. R. T. Ryder, J. J. Miller, J. A. Grow and N. M. Ratcliffe. PENNSYLVANIA. Interpreted reflection seismic events near the North Central Oil Corporation well, Newark Basin, Bucks County, Pennsylvania [abstr.] AAPG Bulletin, in AAPG Eastern Section meeting. v. 77, no. 8, August 1993. p. 1474.

OP-1843. M. J. Rymer. CALIFORNIA. The Bishop Ash in the Coachella Valley; stratigraphic and tectonic implications [abstr.] Quarterly of San Bernardino County Museum Association, in Abstracts of papers presented at the Mojave Desert Quaternary Research Center fourth annual symposium. (J. S. Reynolds, compiler). v. 37 , no. 2,1990 . p. 38 .

OP-1844. M. J. Rymer. CALIFORNIA. New Quaternary age control for strata within the Indio Hills, Southern California [abstr.] Quarterly of San Bernardino County Museum Association, in Abstracts of papers presented at the Mojave Desert Quaternary Research Center third annual symposium. (J. S. Reynolds, compiler). v. 36 , no. 2,1989 . p. 64 .

OP-1845. C. A. Sandberg, N. R. Hasenmueller* and C. B. Rexroad*. INDIANA. Conodont zonation, biofacies, and correlations of lower part of New Albany Shale (Devonian), central and southern Indiana [abstr.] Abstracts with Programs - Geological Society of America, in Geological Society of America, North-Central Section, 27th annual meeting. v. 25, no. 3, March 1993. p. 77.

OP-1846. C. A. Sandberg and F. G. Poole. NEVADA. Relation of Early Mississippian outer Joana Bank to Antler flysch trough, eastern Nevada [abstr.] AAPG Bulletin, in AAPG Rocky Mountain Section meeting. v. 77, no. 8, August 1993. p. 14591460.

OP-1847. C. A. Sandberg and J. E. Warme*. NEVADA. Conodont dating, biofacies, and catastrophic origin of Late Devonian (early Frasnian) Alamo Breccia, southern Nevada [abstr.] Abstracts with Programs - Geological Society of America, in Geological Society of America, North-Central Section, 27th annual meeting. v. 25, no. 3, March 1993. p. 77.

OP-1848. R. F. Sanford. Groundwater mixing beneath paleowetlands and the formation of tabular-type uranium deposits [abstr.] Abstracts with Programs - Geological Society of America, in Geological Society of America, 1990 annual meeting. v. 22, no. 7, 1990. p. 295.

OP-1849. W. E. Sanford and W. W. Wood. TEXAS. Modeling transport and reactions of brine; an example from Double Lakes of West Texas [abstr.] Abstracts with Programs - Geological Society of America, in Geological Society of America, 1992 annual meeting. v. 24 , no. 7,1992 . p. $326-327$.
OP-1850. J. T. Sankey. IDAHO. Late Blancan vertebrates and magnetostratigraphy from the upper Glenns Ferry Formation, southwestern Idaho [abstr.] Quarterly of San Bernardino County Museum Association, in Abstracts of papers presented at the Mojave Desert Quaternary Research Center fourth annual symposium. (J. S. Reynolds, compiler). v. 37, no. 2, 1990. p. 39.

OP-1851. R. S. Saunders*, R. E. Arvidson*, J. W. Head*, G. G. Schaber, S. C. Solomon*, E. R. Stofan*;A. T. Basilevsky*, J. E. Guest*, G. E. McGill* and H. J. Moore. Magellan; preliminary description of Venus surface geologic units [abstr.] Abstracts of Papers Submitted to the Lunar and Planetary Science Conference, in Twenty-second lunar and planetary science conference; press abstracts. 22, 1991. p. 57-58.

OP-1852. J. C. Savage. Interseismic crustal deformation at subduction zones [abstr.] Eos, Transactions, American Geophysical Union, in AGU 1989 fall meeting. v. 70, no. 43, October 24, 1989. p. 1050.

OP-1853. D. L. Sawatzky. Great Basin mineral assessment with geographic information systems [abstr.], in American Institute of Professional Geologists, 1992 annual meeting and symposium; Geologic reason, a basis for decisions affecting society. (Steve Friberg, chairperson). American Institute of Professional Geologists, September 1992. p. 45.

OP-1854. G. G. Schaber and D. J. Chadwick. Venus' impactcrater database; update to $\sim 98 \%$ of the planet's surface [abstr.] Proceedings of the Lunar and Planetary Science Conference, in Abstracts of papers submitted to the Twenty-fourth lunar and planetary science conference. (Douglas Blanchard, chairperson and others). 24, 1993. p. 1241-1242.

OP-1855. C. J. Schenk and R. M. Pollastro. UTAH. Reservoir characterization of heavy oil and tar sand reservoirs; an example from the Tertiary of the Uinta Basin, Utah [abstr.] AAPG Bulletin, in AAPG/SVG international congress/exhibition; abstracts. v. 77, no. 2, February 1993. p. 347.

OP-1856. C. J. Schenk and J. W. Schmoker. MISSISSIPPI. Role of halite in the evolution of sandstone porosity, Upper Jurassic Norphlet Formation, Mississippi salt basin [abstr.] AAPG Bulletin, in Gulf Coast Association of Geological Societies and Gulf Coast Section of SEPM meeting (AAPG Gulf Coast Section). v. 77, no. 9, September 1993. p. 1599.

OP-1857. J. W. Schmoker. Empirical porosity prediction to reduce exploration risk; examples from the J Sandstone, Denver Basin, and Mesaverde Group, Uinta and Piceance basins [abstr.] The Outcrop. v. 41, no. 7, July 1992. p. 4-5.

OP-1858. J. W. Schmoker and C. J. Schenk. ALABAMA. Porosity of the Norphlet Formation (Upper Jurassic), southwestern Alabama and vicinity [abstr.] Annual Meeting Abstracts - American Association of Petroleum Geologists and Society of Economic Paleontologists and Mineralogists, in American Association of Petroleum Geologists 1993 annual convention. 1993, April 1993. p. 178 .

OP-1859. D. W. Scholl and A. J. Stevenson. ALASKA. Tectonic evolution of the Pacific's Alaska-Bering Sea rim in terms of large-scale plate-boundary driven transpressive deformation [abstr.] Program with Abstracts - Geological Association of Canada; Mineralogical Association of Canada; Canadian Geophysical Union, Joint Annual Meeting. 16, May 1991. p. 112. 
OP-1860. J. W. Schoonmaker, Jr., A. N. Kover and B. C. Hanson*. The U.S. Geological Survey Side-Looking Airborne Radar Acquisition Program; an update and a look at petroleum exploration [abstr.] Annual Meeting Abstracts - American Association of Petroleum Geologists and Society of Economic Paleontologists and Mineralogists, in American Association of Petroleum Geologists 1993 annual convention. 1993, April 1993. p. 65.

OP-1861. A. P. Schultz, G. S. Baker and R. W. Harrison. Deformation associated with the Ste. Genevieve fault zone and MidContinent tectonics [abstr.] Abstracts with Programs - Geological Society of America, in Geological Society of America, 1992 annual meeting. v. 24 , no. 7,1992 . p. 181 .

OP-1862. R. L. Schuster and L. D. Alfaro*. Landslide hazards in the Gaillard Cut, Panama Canal Zone [abstr.] Abstracts with Programs - Geological Society of America, in Geological Society of America, 1992 annual meeting. v. 24, no. 7, 1992. p. 166.

OP-1863. W. C. Schwab, W. W. Danforth, C. M. DeLorey, L. J. Poppe, R. W. Rodriguez, J. L. Trias, Milton Carlo, B. R. Richmond, E. A. Shinn, R. B. Halley, E. R. Thieler*, M. H. Gowen* and D. M. Bush*. PUERTO RICO. Impact of Hurricane Hugo on the coastal resources of Puerto Rico [abstr.] Annual Meeting Abstracts - American Association of Petroleum Geologists and Society of Economic Paleontologists and Mineralogists, in American Association of Petroleum Geologists 1993 annual convention. 1993, April 1993. p. 179-180.

OP-1864. W. C. Schwab, D. C. Twichell, H. J. Lee, C. H. Nelson and N. H. Kenyon*. Upper Pleistocene mass flow deposits on the distal Mississippi Fan; mass transport mechanisms [abstr.] Annual Meeting Abstracts - American Association of Petroleum Geologists and Society of Economic Paleontologists and Mineralogists, in American Association of Petroleum Geologists 1993 annual convention. 1993, April 1993. p. 180.

OP-1865. D. P. Schwartz and C. S. Prentice. CALIFORNIA. Surface fractures in the Loma Prieta area, CA; 1906 \& 1989 [abstr.] Seismological Research Letters, in 85th annual meeting of the Seismological Society of America. v. 61, no. 1, March 1990. p. 16.

OP-1866. E. S. Schweig, III and M. A. Ellis*. The Bootheel Lineament, the 1811-1812 New Madrid earthquake sequence, and modern seismicity [abstr.] Abstracts with Programs - Geological Society of America, in Geological Society of America, 1992 annual meeting. v. 24 , no. 7,1992 . p. 153.

OP-1867. E. S. Schweig, III and M. A. Ellis*. New Madrid seismic zone recurrence intervals [abstr.] Abstracts with Programs Geological Society of America, in Geological Society of America, North-Central Section, 27th annual meeting. v. 25, no. 3, March 1993. p. 79.

OP-1868. D. H. Scott. Mars; new evidence for origin of some Valles Marineris layered deposits [abstr.] Proceedings of the Lunar and Planetary Science Conference, in Abstracts of papers submitted to the Twenty-fourth lunar and planetary science conference. (Douglas Blanchard, chairperson and others). 24, 1993. p. $1265-$ 1266.

OP-1869. R. R. Seal, II, J. M. Hammarstrom, L. W. Snee and A. H. Kazmi*. Geochemistry of the emerald deposits of Pakistan and Afghanistan [abstr.] Program with Abstracts - Geological Association of Canada; Mineralogical Association of Canada;
Canadian Geophysical Union, Joint Annual Meeting. 16, May 1991. p. 113.

OP-1870. R. R. Seal, II, R. O. Rye and W. C. Kelly*. Investigations of postentrapment retrograde ${ }^{18} \mathrm{O}$ exchange between inclusion fluids and quartz [abstr.] Abstracts with Programs - Geological Society of America, in Geological Society of America, 1990 annual meeting. v. 22 , no. 7,1990 . p. 250.

OP-1871. R. B. See, D. L. Naftz and C. L. Qualls. Using ageographic information system to determine potential sources of selenium contamination [abstr.] American Water Resources Association Technical Publication Series TPS, in Water management of river systems; 27 th annual AWRA conference. (H. C. McWreath, editor). 27, 1991. p. 291-291.

OP-1872. Paul Segall, Yijun Du* and Wayne Thatcher. CALIFORNIA. Were the 1934 \& 1966 Parkfield earthquakes similar? [abstr.] Seismological Research Letters, in 85th annual meeting of the Seismological Society of America. v. 61, no. 1, March 1990. p. 22.

OP-1873. F. E. Senftle*, A. N. Thorpe*, L. May*, A. Barkatt*, M. A. Adel-Hadadi*, G. S. Marbury*, G. A. Izett, Haraldur Sigurdsson* and F. J. Maurasse*. Magnetic properties and Mössbauer analyses of glass from the K-T boundary, Beloc, Haiti [abstr.] Proceedings of the Lunar and Planetary Science Conference, in Abstracts of papers submitted to the Twenty-fourth lunar and planetary science conference. (Douglas Blanchard, chairperson and others). 24, 1993. p. 1275-1276.

OP-1874. W. C. Shanks, III, R. R. Seal, II and P. P. Hearn. Stable isotope studies of pore waters and diatoms; paleolimnology of Lake Baikal [abstr.] Eos, Transactions, American Geophysical Union, in AGU-MSA 1991 spring meeting. v. 72, no. 17, April 23, 1991. p. 306.

OP-1875. J. B. Shanley, R. P. Hooper and N. E. Peters. Controls on sulfate mobility in a forested watershed as inferred from annual and event mass balance [abstr.] Eos, Transactions, American Geophysical Union, in AGU 1992 spring meeting. v. 73, no. 14, Suppl. April 7, 1992. p. 137.

OP-1876. R. J. Shedlock, M. T. Koterba, J. M. Denver and W. S. Banks. DELAWARE, MARYLAND, VIRGINIA. Occurrence and distribution of pesticides in the ground-water system of the Delmarva Peninsula, Delaware, Maryland, and Virginia, 198890 [abstr.] American Water Resources Association Technical Publication Series TPS, in Water management of river systems; 27th annual AWRA conference. (H. C. McWreath, editor). 27,1991. p. 345-346.

OP-1877. A. H. Shen*, W. A. Bassett* and I-Ming Chou. A new determination of the alpha-beta quartz boundary based on the equation of state of $\mathrm{H}_{2} \mathrm{O}$ and laser interferometry in a diamondanvil cell [abstr.] Abstracts with Programs - Geological Society of America, in Geological Society of America, 1992 annual meeting. v. 24 , no. 7,1992 . p. 254 .

OP-1878. D. M. Sherman. Electronic structure and chemical reactivity of the brucite $\left(\mathrm{Mg}(\mathrm{OH})_{2}\right)$ surface [abstr.] Abstracts of Papers - American Chemical Society, National Meeting, in 203rd ACS national meeting. 203, 1992. p. GEOC 68.

OP-1879. E. M. Shoemaker. Large-body impact is a geologic process [abstr.] Abstracts with Programs - Geological Society of 
America, in Geological Society of America, 1992 annual meeting. v. 24 , no. 7,1992 . p. 134.

OP-1880. E. M. Shoemaker and G. A. Izett. K/T boundary stratigraphy; evidence for multiple impacts and a possible comet stream [abstr.] LPI Contribution, in Papers presented to the International conference on Large meteorite impacts and planetary evolution. (B. O. Dressler, chairperson and others). 790, 1992. p. 66-68.

OP-1881. E. M. Shoemaker and Stewart Nozette*. Clementine; an inexpensive mission to the Moon and Geographos [abstr.] Proceedings of the Lunar and Planetary Science Conference, in Abstracts of papers submitted to the Twenty-fourth lunar and planetary science conference. (Douglas Blanchard, chairperson and others). 24, 1993. p. 1299-1300.

OP-1882. E. M. Shoemaker, D. J. Roddy and R. R. Anderson*. IOWA. Research program on the Manson impact crater, Iowa [abstr.] Proceedings of the Lunar and Planetary Science Conference, in Abstracts of papers submitted to the Twenty-fourth lunar and planetary science conference. (Douglas Blanchard, chairperson and others). 24, 1993. p. 1301-1302.

OP-1883. E. M. Shoemaker, C. S. Shoemaker, R. F. Wolfe and H. E. Holt. Earth-crossing asteroids, 1989 [abstr.] Abstracts of Papers Submitted to the Lunar and Planetary Science Conference, in Abstracts of papers submitted to the Twenty-first lunar and planetary science conference; press abstracts. (Lunar and Planetary Institute). 21, 1990. p. 51-52.

OP-1884. R. R. Shroba and R. D. Hall*. WYOMING. Major factors affecting soil development in the type Bull Lake and Pinedale glacial deposits, Wind River Range, Wyoming [abstr.] Abstracts with Programs - Geological Society of America, in Geological Society of America, 1990 annual meeting. v. 22, no. 7, 1990. p. 270.

OP-1885. G. B. Sidder, W. C. Day and R. O. Rye. MISSOURI. Fluid inclusion and stable isotope data for the Pea Ridge Fe-REE orebody, Missouri [abstr.] Abstracts with Programs Geological Society of America, in Geological Society of America, North-Central Section, 27th annual meeting. v. 25, no. 3, March 1993. p. 81.

OP-1886. A. M. Simmons*, J. E. Wright* and G. B. Haxel. ARIZONA. Tectonic significance of mantle sources for mafic synextensional dikes in metamorphic core complexes, southern Arizona and northern Sonora [abstr.] Abstracts with Programs Geological Society of America, in Geological Society of America, 1992 annual meeting. v. 24, no. 7, 1992. p. 41.

OP-1887. N. S. Simon and K. O. Dennen. Flux of metals between sediment and the water column [abstr.], in Hydraulic engineering; saving a theoretical resource, in search of solutions. (M. E. Jennings, editor and others). New York, NY: Am. Soc. Civ. Eng. 1992. p. $390-391$.

OP-1888. M. R. Simpson. A discharge measurement system using an acoustic Doppler current profiler [abstr.] American Water Resources Association Technical Publication Series TPS, in W ater management of river systems; 27th annual AWRA conference. (H. C. McWreath, editor). 27, 1991. p. 403-404.

OP-1889. P. K. Sims. The Great Lakes tectonic zone revisited [abstr.] Abstracts with Programs - Geological Society of America, in Geological Society of America, North-Central Section, 26th annual meeting. v. 24, no. 4, April 1992. p. 64-65.

OP-1890. J. R. Skilbrei, O. Eiken* and Y. Ohta*. Interpretation of aeromagnetic and reflection seismic data from the Billefjorden fault zone, Svalbard [abstr.] Abstracts with Programs - Geological Society of America, in Geological Society of America, 1992 annual meeting. v. 24 , no. 7,1992 . p. 83 .

OP-1891. J. R. Skilbrei, Odleiv Olesen* and J. I. Faleide*. Image analysis of geophysical data from the Barents Sea and Svalbard margins $\left(71^{\circ}-81^{\circ} \mathrm{N}\right)$ [abstr.] Eos, Transactions, American Geophysical Union, in AGU 1992 spring meeting. v. 73, no. 14, suppl. April 7, 1992. p. 288.

OP-1892. J. F. Slack, P. M. Okita, Wei-Teh Jiang* and D. R. Peacor*. Occurrence and significance of berthierine (Fe-Al serpentine) in the Kidd Creek volcanogenic massive sulphide deposit, Timmins, Ontario [abstr.] Program with Abstracts - Geological Association of Canada; Mineralogical Association of Canada; Canadian Geophysical Union, Joint Annual Meeting. 16, May 1991. p. 116.

OP-1893. N. H. Sleep* and M. L. Blanpied. Creep, compaction, and the weak rheology of major faults [abstr.] Eos, Transactions, American Geophysical Union, in AGU 1992 spring meeting. v. 73, no. 14, supplement, April 7, 1992. p. 272.

OP-1894. W. V. Sliter. Paleontologic correlation and characterization of Cretaceous organic-rich sequences [abstr.] Abstracts with Programs - Geological Society of America, in Geological Society of America, 1990 annual meeting. v. 22, no. 7, 1990. p. 171.

OP-1895. R. A. Sloto. PENNSYLVANIA. Drought management based on water-level data, Chester County, Pennsylvania [abstr.] American Water Resources Association Technical Publication Series TPS, in Water management of river systems; 27 th annual AWRA conference. (H. C. McWreath, editor). 27, 1991. p. $439-440$.

OP-1896. A. J. Smith* and R. M. Forester. A regional relationship between effective moisture, lake chemistry, and ostracodes [abstr.] Abstracts with Programs - Geological Society of America, in Geological Society of America, 1992 annual meeting. v. 24, no. 7,1992 . p. 180 .

OP-1897. G. I. Smith. CALIFORNIA. Runoff changes in the southwestern Basin-and-Range Province and the Mojave Desert; 150,000 years ago to the present [abstr.] Quarterly of San Bernardino County Museum Association, in Abstracts of papers presented at the Mojave Desert Quaternary Research Center fourth annual symposium. (J. S. Reynolds, compiler). v. 37, no. 2 , 1990. p. 40.

OP-1898. J. A. Smith and P. R. Jaffé*. WYOMING. Benzene transport through compacted porous media containing Wyoming bentonite and two types of organophilic bentonite [abstr.] Eos, Transactions, American Geophysical Union, in AGU 1992 spring meeting. v. 73, no. 14, Suppl. April 7, 1992. p. 115.

OP-1899. D. J. Soeder and J. E. Dishart. NEVADA. Porosity and permeability of tuffs from the unsaturated zone at Yucca Mountain, Nevada [abstr.] Abstracts with Programs - Geological Society of America, in Geological Society of America, 1992 annual meeting. v. 24 , no. 7,1992 . p. 200. 
OP-1900. S. S. Sorensen*, J. N. Grossman and M. D. Barton*. Styles of subduction zone metasomatism [abstr.] Abstracts with Programs - Geological Society of America, in Geological Society of America, 1992 annual meeting. v. 24, no. 7, 1992. p. 303.

OP-1901. M. Sosson*, Bernard Mercier de Lepinay*, Jacques Bourgois*, Patrick De Wever*, F. Michaud*, J. A. Barron and Elisabeth Fourtanier. Deep sea dives in the Chiclayo Canyon, northern Peru; tectonic regime of the Andean convergent margin [abstr.] Eos, Transactions, American Geophysical Union, in AGU 1992 spring meeting. v. 73, no. 14, Suppl. April 7, 1992. p. 152.

OP-1902. G. K. Speiran. VIRGINIA. Flow and quality of groundwater in coastal discharge areas of the eastern shore, Virginia [abstr.] AAPG Bulletin, in AAPG Eastern Section meeting. v. 77, no. 8, August 1993. p. 1475.

OP-1903. W. J. Spence. A model linking post-Laramide tectonics to the thermal evolution of the subducted (and sub-horizontal) Farallon Plate [abstr.] Abstracts with Programs - Geological Society of America, in Geological Society of America, 1990 annual meeting. v. 22, no. 7, 1990. p. 328.

OP-1904. E. C. Spiker and A. L. Bates. Sulfur isotope geochemistry of sediments from Lake Baikal, southeastern Siberia [abstr.] Eos, Transactions, American Geophysical Union, in AGU-MSA 1991 spring meeting. v. 72, no. 17, April 23, 1991. p. 307.

OP-1905. E. C. Spiker and A. L. Bates. Sulfur isotopic evidence for controls on sulfur incorporation in peat and coal [abstr.] AAPG Bulletin, in AAPG Eastern Section meeting. v. 77, no. 8, August 1993. p. 1475-1476.

OP-1906. E. C. Spiker, A. L. Bates, V. C. Weintraub, P. G. Hatcher* and S. A. Stout*. FLORIDA. Early diagenesis of sapropel and peat from Mud Lake, Florida; carbon and sulfur isotope geochemistry [abstr.] Annual Meeting Abstracts - American Association of Petroleum Geologists and Society of Economic Paleontologists and Mineralogists, in American Association of Petroleum Geologists 1993 annual convention. 1993, April 1993. p. 184.

OP-1907. J. D. Spooner and J. D. Woram. Monoscopic revision of digital cartographic data [abstr.] Abstracts with Programs Geological Society of America, in Geological Society of America, North-Central Section, 27th annual meeting. v. 25, no. 3, March 1993. p. 82.

OP-1908. T. S. Staerker*, S. W. Wise*, N. S. Lundberg*, R. P. Reid*, Jean-Yves Collot* and H. G. Greene. Nannofossil evidence from thrust faulting and sediment mixing in an accretionary complex (New Hebrides island arc) [abstr.] Annual Meeting Abstracts - American Association of Petroleum Geologists and Society of Economic Paleontologists and Mineralogists, in American Association of Petroleum Geologists 1993 annual convention. 1993, April 1993. p. 184-185.

OP-1909. J. K. Stamer and R. B. Zelt. KANSAS, NEBRASKA. Areal and temporal distribution of nitrogen-containing herbicides in surface water in the lower Kansas River basin, Kansas and Nebraska [abstr.] American Water Resources Association Technical Publication Series TPS, in Water management of river systems; 27th annual AWRA conference. (H. C. McWreath, editor). 27, 1991. p. $349-350$.
OP-1910. R. G. Stanley, Z. C. Valin and M. J. Pawlewicz. CALIFORNIA. Rock-Eval pyrolysis and vitrinite reflectance results from lower Miocene strata in the onshore Santa Maria Basin and Santa Barbara coastal area, California [abstr.] AAPG Bulletin, in AAPG Pacific Section abstracts. v. 77, no. 4, April 1993. p. 716-7.17.

OP-1911. R. W. Stanton, D. D. Rice, J. L. Clayton and R. M. Flores. Matrix-gel vitrinite types and Rock-Eval analysis of coal samples, Cretaceous age, from the San Juan and Piceance basins, USA [abstr.] Annual Meeting of the Society for Organic Petrology. Abstracts and Program, in Ninth annual meeting of the Society for Organic Petrology. (S. A. Stout, editor). 9, July 23, 1992. p. 57-58.

OP-1912. M: J. Starbuck. U.S. Geological Survey winter-over at the Amundsen-Scott South Pole Station [abstr.] Abstracts with Programs - Geological Society of America, in Geological Society of America, North-Central Section, 27th annual meeting. v. 25, no. 3, March 1993. p. 83.

OP-1913. H. J. Stein, J. W. Morgan, R. J. Walker* and M. F. Horan. COLORADO. Rhenium-osmium data for sulfides and oxides from climax-type granite-molybdenum systems; Mt. Emmons, Colorado [abstr.] Abstracts with Programs - Geological Society of America, in Geological Society of America, 1992 annual meeting. v. 24 , no. 7,1992 . p. 144.

OP-1914. R. S. Stein and Goran Ekstrom*. CALIFORNIA. Anatomy of a 110-Km-long blind thrust fault in Central California, from short \& long period seismology, geodesy, and seismic reflection profiles [abstr.] Seismological Research Letters, in 85th annual meeting of the Seismological Society of America. v. 61, no. 1, March 1990. p. 23.

OP-1915. M. B. Steiner* and E. M. Shoemaker. IOWA. Twopolarity magnetization in the Manson impact breccia [abstr.] Proceedings of the Lunar and Planetary Science Conference, in Abstracts of papers submitted to the Twenty-fourth lunar and planetary science conference. (Douglas Blanchard, chairperson and others). 24, 1993. p. 1347-1348.

OP-1916. M. G. Steltenpohl*, Zbignew Cymerman*, E. J. Krogh* and M. J. Kunk. Lithospheric delamination and gravitational collapse of the easternmost Alleghanian-Variscan Orogen, Sudetey Mountains, Poland [abstr.] Abstracts with Programs Geological Society of America, in Geological Society of America, 1992 annual meeting. v. 24, no. 7,1992. p. 185.

OP-1917. M. G. Steltenpohl*, Zbignew Cymerman* and M. J. Kunk. ${ }^{40} \mathrm{Ar} /{ }^{39} \mathrm{Ar}$ thermochronology and tectonic evolution of the easternmost Alleghanian-Variscan Orogen, Sudety Mountains, Poland [abstr.] The Journal of the Alabama Academy of Science, in Alabama Academy of Science abstracts. v. 63, no. 2, April 1992. p. 96.

OP-1918. M. G. Steltenpoh1*, S. A. Goldberg*, M. J. Kunk and Mac McRae*. ALABAMA, GEORGIA. Structural and age relations from the Goat Rock fault zone, Alabama and Georgia; evidence for Alleghanian development [abstr.] Abstracts with Programs - Geological Society of America, in Geological Society of America, 1990 annual meeting. v. 22, no. 7, 1990. p. 233.

OP-1919. S. M. Sterner*, K. S. Pitzer* and I-Ming Chou. Thermodynamic-PTX analysis of solid-liquid equilibria in the NaCl$\mathrm{KCl}-\mathrm{H}_{2} \mathrm{O}$ ternary system [abstr.] Abstracts with Programs - 
Geological Society of America, in Geological Society of America, 1990 annual meeting. v. 22 , no. 7,1990 . p. 342.

OP-1920. D. B. Stewart and J. H. Luetgert. MAINE. The formation of the lower crust beneath the Quebec-Maine-Gulf of Maine Global Geoscience Transect [abstr.] Abstracts with Programs - Geological Society of America, in Geological Society of America, 1990 annual meeting. v. 22, no. 7,1990. p. 192.

OP-1921. D. B. Stoesser, M. J. Whitehouse*, R. A. Agar* and J. S. Stacey. Pan-African accretion and continental terranes of the Arabian Shield, Saudi Arabia and Yemen [abstr.] Eos, Transactions, American Geophysical Union, in AGU-MSA 1991 spring meeting. v. 72, no. 17, April 23, 1991. p. 299.

OP-1922. R. E. Stoffregen*, R. O. Rye and M. D. Wasserman. Rates of alunite-water alkali and isotope exchange [abstr.] Abstracts with Programs - Geological Society of America, in Geological Society of America, 1990 annual meeting. v. 22, no. 7, 1990. p. 162.

OP-1923. S. A. Stout. Chemical fingerprinting of individual macerals in situ using laser micropyrolysis-GCMS [abstr.] Annual Meeting of the Society for Organic Petrology. Abstracts and Program, in Ninth annual meeting of the Society for Organic Petrology. (S. A. Stout, editor). 9, July 23, 1992. p. 59-61.

OP-1924. M. L. Strobel. NORTH DAKOTA. Hydrogeological restrictions to saline ground-water discharge in the Red River of the North drainage basin, North Dakota [abstr.] Abstracts with Programs - Geological Society of America, in Geological Society of America, 1992 annual meeting. v. 24, no. 7, 1992. p. 337.

OP-1925. M. L. Strobel. OHIO. Vertical flow of water in three types of glacial deposits in Ohio [abstr.] Abstracts with Programs - Geological Society of America, in Geological Society of America, North-Central Section, 26th annual meeting. v. 24, no. 4, April 1992. p. 66-67.

OP-1926. W. D. Stuart. CALIFORNIA. Plate-induced Miocene extension in Southern California [abstr.] Abstracts with Programs - Geological Society of America, in Geological Society of America, 1992 annual meeting. v. 24, no. 7, 1992. p. 279.

OP-1927. D. A. Sverjensky*, P. A. Molling and C. Zhu*. Chemical mass transfer calculations for magmatic hydrothermal systems [abstr.], in V. M. Goldschmidt conference; program and abstracts. Geochem. Soc. 1990. p. 85.

OP-1928. L. A. Swain. Hydrogeological characteristics of the bedrock aquifers in the Appalachian Valley and Ridge, Piedmont, Blue Ridge physiographic provinces of the Eastern and Southeastern United States [abstr.] AAPG Bulletin, in AAPG Eastern Section meeting. v. 77, no. 8, August 1993. p. 1476.

OP-1929. S. E. Swanson*, M. L. Harbin*, T. P. Miller and C. J. Nye*. ALASKA. Use of tephra as a petrologic tool; an example from the 1992 eruptions of Mt. Spurr, Alaska [abstr.] Eos, Transactions, American Geophysical Union, in AGU 1992 fall meeting. v. 73 , no. 43 , suppl. October 27,1992 . p. 346.

OP-1930. P. K. Swart*, J. J. Leder*, P. Kramer*, B. C. Fredrick*, R. E. Dodge and R. B. Halley*. FLORIDA. Climate records in corals from the Florida Keys [abstr.] Eos, Transactions, American Geophysical Union, in AGU 1992 spring meeting. v. 73, no. 14, Suppl. April 7, 1992. p. 150.
OP-1931. B. A. Swift, W. P. Dillon and M. W. Lee. FLORIDA. The Florida Cretaceous carbonate platform [abstr.] Annual Meeting Abstracts - American Association of Petroleum Geologists and Society of Economic Paleontologists and Mineralogists, in American Association of Petroleum Geologists 1993 annual convention. 1993, April 1993. p. 188.

OP-1932. B. A. Swift, W. P. Dillon, C. W. Poag and M. W. Lee. Structural and stratigraphic transect across the Florida Platform, eastern Gulf of Mexico to western Atlantic Ocean [abstr.] Eos, Transactions, American Geophysical Union, in AGU 1992 spring meeting. v. 73, no. 14, suppl. April 7, 1992. p. 289.

OP-1933. K. L. Tanaka. What were the effects of the formation of the Borealis Basin, Mars? [abstr.] Abstracts of Papers Submitted to the Lunar and Planetary Science Conference, in Twenty-second lunar and planetary science conference; press abstracts. 22, 1991. p. 67-69.

OP-1934. K. L. Tanaka. Hydrologic activity during late Noachian and early Hesperian downwarping of Borealis Basin, Mars [abstr.] Abstracts of Papers Submitted to the Lunar and Planetary Science Conference, in Twenty-second lunar and planetary science conference. (Graham Ryder, editor and others). 22, 1991. p. 1377 1378.

OP-1935. K. L. Tanaka. Stratigraphy of the Martian northern plains [abstr.] LPI Technical Report, in Workshop on the Martian northern plains; sedimentological, periglacial, and paleoclimatic evolution. (J. S. Kargel, editor and others). 93-04, Part 1, 1993. p. 15-17.

OP-1936. K. L. Tanaka and D. J. Chadwick. Extensional history of Mars' Tharsis region [abstr.] Proceedings of the Lunar and Planetary Science Conference, in Abstracts of papers submitted to the Twenty-fourth lunar and planetary science conference. (Douglas Blanchard, chairperson and others). 24, 1993. p. 1397-1398.

OP-1937. K. L. Tanaka and S. M. Clifford*. Seismic-triggering history of the catastrophic outflows in the Chryse region of Mars [abstr.] LPI Technical Report, in Workshop on the Martian northern plains; sedimentological, periglacial, and paleoclimatic evolution. (J. S. Kargel, editor and others). 93-04, Part 1, 1993. p. 17-18.

OP-1938. K. L. Tanaka and J. M. Dohm. Complex structure of the Thaumasia region of Mars [abstr.] Proceedings of the Lunar and Planetary Science Conference, in Abstracts of papers submitted to the Twenty-fourth lunar and planetary science conference. (Douglas Blanchard, chairperson and others). 24, 1993. p. 13991400 .

OP-1939. K. L. Tanaka and R. A. Schultz* Large, ancient, compressional structures on Mars [abstr.] Proceedings of the Lunar and Planetary Science Conference, in Abstracts of papers submitted to the Twenty-fourth lunar and planetary science conference. (Douglas Blanchard, chairperson and others). 24,1993. p. 14011402.

OP-1940. K. L. Tanaka and R. A. Schultz*. Late Noachian development of the Coprates Rise, Mars [abstr.] Abstracts of Papers Submitted to the Lunar and Planetary Science Conference, in Twenty-second lunar and planetary science conference. (Graham Ryder, editor and others). 22, 1991. p. 1379-1380. 
OP-1941. Toshiro Tanimoto*, L. A. Wald and T. H. Heaton. Surface wave phase plane reconstruction [abstr.] Eos, Transactions, American Geophysical Union, in AGU 1992 spring meeting. v. 73, no. 14, supplement, April 7, 1992. p. 201.

OP-1942. B. E. Taylor*, M. R. Palmer* and J. F. Slack. Kidd Creek tourmaline; an oxygen, hydrogen, and boron isotopic tracer of hydrothermal fluids [abstr.] Program with Abstracts - Geological Association of Canada; Mineralogical Association of Canada; Canadian Geophysical Union, Joint Annual Meeting. 16, May 1991. p. 122.

OP-1943. G. J. Taylor* and P. D. Spudis. Field work on the Moon; why we need it and how to do it [abstr.] Abstracts with Programs - Geological Society of America, in Geological Society of America, 1989 annual meeting. v. 21, no. 6,1989. p. 302.

OP-1944. S. C. Teerman. Source rock organic matter characterization; initial and supplemental TSOP research subcommittee report [abstr.] Annual Meeting of the Society for Organic Petrology. Abstracts and Program, in Ninth annual meeting of the Society for Organic Petrology. (S. A. Stout, editor). 9, July 23, 1992. p. 63.

OP-1945. M. E. Tennyson and W. R. Beeman. CALIFORNIA. California; a digital compilation in progress [abstr.] AAPG Bulletin, in AAPG Pacific Section abstracts. v. 77, no. 4, April 1993. p. 718 .

OP-1946. M. E. Tennyson and C. M. Isaacs. U.S. Geological Survey national assessment of oil and gas resources; Pacific region onshore and State offshore [abstr.] AAPG Bulletin, in AAPG Pacific Section abstracts. v. 77, no. 4, April 1993. p. 718.

OP-1947. J. N. Thamke, S. D. Craigg and T. M. Mendes*. MONTANA. Use of electromagnetic geophysical techniques and auger drilling to delineate saline-water plumes in the East Poplar oil field, Fort Peck Indian Reservation, northeastern Montana [abstr.] AAPG Bulletin, in AAPG Rocky Mountain Section meeting. v. 77, no. 8, August 1993. p. 1461.

OP-1948. P. C. Thenhaus, S. T. Algermissen and S. L. Hanson. CALIFORNIA. Ground-motion hazard implications of alternative earthquake recurrence models in Northern California [abstr.] Eos, Transactions, American Geophysical Union, in AGU 1992 spring meeting. v. 73 , no. 14, supplement, April 7, 1992. p. 206.

OP-1949. R. S. Thompson, H. J. Dowsett, R. Z. Poore and T. $M$. Cronin. Pliocene climates on land and sea; PRISM project results [abstr.] Eos, Transactions, American Geophysical Union, in AGU 1992 spring meeting. v. 73, no. 14, Suppl. April 7, 1992. p. 168.

OP-1950. J. Thorez*, D. Bossiroy*, R. M. Flores and C. W. Keighin. WYOMING. Non-facies selective clay paragenesis of sandstone reservoirs, Fuller Reservoir Field, Wind River basin, Wyoming [abstr.] Program and Abstracts - Annual Clay Minerals Conference, in Clay Minerals Society, 28th annual meeting. (D. R. Pevear, chairperson). 28, October 1991. p. 149.

OP-1951. K. A. Thorn and M. A. Mikita*. N-15 NMR investigation of ammonia and nitrite fixation by humic substances [abstr.] Abstracts of Papers - American Chemical Society, National Meeting, in 203rd ACS national meeting. 203, 1992. p. GEOC 77.
OP-1952. C. R. Thornber. Hot, cold, wet, and dry Hutaymah ultramafic inclusions; a record of mantle magmatism beneath the Arabian Shield and flanking the Red Sea Rift [abstr.] Proceedings of the International Kimberlite Conference, in Fifth international kimberlite conference; extended abstracts. 5, February 1991. p. 423-425.

OP-1953. R. I. Tilling and C. G. Newhall. Major challenges in mitigation of volcanic hazards in the 1990's [abstr.] Eos, Transactions, American Geophysical Union, in AGU 1989 fall meeting. v. 70 , no. 43 , October 24,1989 . p. 1003.

OP-1954. G. R. Timson and M. J. Speak. Enhanced digital line graph; the future of NMD digital data [abstr.] Abstracts with Programs - Geological Society of America, in Geological Society of America, North-Central Section, 27th annual meeting. v. 25, no. 3, March 1993. p. 85.

OP-1955. R. P. Tollo* and J. N. Aleinikoff. VIRGINIA. Age and compositional relations of the Robertson River igneous suite, Blue Ridge Province, Virginia; implications for the nature of Laurentian rifting [abstr.] Abstracts with Programs - Geological Society of America, in Geological Society of America, 1992 annual meeting. v. 24 , no. 7,1992 . p. 365 .

OP-1956. Noriko Torigoye, Keiji Misawa, G. B. Dalrymple and Mitsunobu Tatsumoto. U-Th- $\mathrm{Pb}, \mathrm{Sm}-\mathrm{Nd}$, and Ar-Ar isotopic systematics of lunar meteorite Yamato-793169 [abstr.] Proceedings of the Lunar and Planetary Science Conference, in Abstracts of papers submitted to the Twenty-fourth lunar and planetary science conference. (Douglas Blanchard, chairperson and others). 24, 1993. p. $1437-1438$.

OP-1957. R. M. Tosdal. CALIFORNIA, ARIZONA. Late Cretaceous tectonics of the Blythe-Quartzite region, SE California and SW Arizona; deformation within an oblique-slip orogen [abstr.] Proceedings of the International Conference on Basement Tectonics, in Basement tectonics 8; Characterization and comparison of ancient and Mesozoic continental margins. (M. J. Bartholomew, editor and others). 8, 1988. p. 740-741.

OP-1958. M. W. Treece and J. D. Bales. NORTH CAROLINA. Hydrologic and water-quality effects of artificial-drainage control [abstr.], in Albemarle-Pamlico estuarine study; project abstracts, FY 1989 \& FY 1990. Report no. 90-18, October 1990. p. 27. Available from: N.C. Dep. Nat. Resour. and Comm. Div., United States.

OP-1959. J. W. Troester and William Back. Wind as a hydrogeologic agent and cultural factor in the Lesser Antilles [abstr.] Abstracts with Programs - Geological Society of America, in Geological Society of America, 1992 annual meeting. v. 24, no. 7,1992 . p. 68 .

OP-1960. J. W. Troester, R. G. Deike, P. D. Robinson* and P. D. Collar. PUERTO RICO. Petrographic analyses and geochemical modeling of aqueous/solid phase reactions in the Valle de Yabucoa alluvial aquifer, Puerto Rico [abstr.] Abstracts with Programs - Geological Society of America, in Geological Society of America, 1990 annual meeting. v. 22, no. 7, 1990. p. 295.

OP-1961. D. E. Tromp* and C. G. Whitney. UTAH, COLORADO. Clay-mineral transformation as an indicator of depositional and diagenetic conditions in Pennsylvanian black shales, Paradox Member of the Hermosa Formation, Utah and Colorado 
[abstr.] AAPG Bulletin, in AAPG Rocky Mountain Section meeting. v. 77, no. 8, August 1993. p. 1462.

OP-1962. F. A. Trusdell, R. B. Moore, R. Y. Koyanagi, M. K. Sako and R. L. Ellorda. MARIANA ISLANDS. Volcanic hazards and hazards mitigation in the Commonwealth of the Northern Marianas Islands (CNMI) [abstr.] Eos, Transactions, American Geophysical Union, in AGU 1992 fall meeting. v. 73, no. 43, suppl. October 27, 1992. p. 349.

OP-1963. C. E. Turner and Fred Peterson. Stratigraphic framework for the Jurassic Morrison Formation, Southern Rocky Mountain region, and implications for Late Jurassic dinosaur chronology [abstr.] Abstracts with Programs - Geological Society of America, in Geological Society of America, 1992 annual meeting. v. 24, no. 7,1992 . p. 359.

OP-1964. Gary Tusker, G. J. McCabe, Jr. and D. M. Wolock. Hydrological impacts of climate change for the Delaware River basin [abstr.] American Water Resources Association Technical Publication Series TPS, in Water management of river systems; 27th annual AWRA conference. (H. C. McWreath, editor). 27, 1991. p. $449-450$.

OP-1965. M. L. Tuttle, T. R. Klett and Mark Richardson*. UTAH, COLORADO. Geochemical processes controlling sulfur, carbon, and metals in Pennsylvanian source rocks of the Paradox Basin, Utah and Colorado [abstr.] AAPG Bulletin, in AAPG Rocky Mountain Section meeting. v. 77, no. 8, August 1993. p. 1462.

OP-1966. D. C. Twichell, W. C. Schwab, N. H. Kenyon*, C. H. Nelson and H. J. Lee. Upper Pleistocene stratigraphy and sedimentation on the distal Mississippi Fan [abstr.] Annual Meeting Abstracts - American Association of Petroleum Geologists and Society of Economic Paleontologists and Mineralogists, in American Association of Petroleum Geologists 1993 annual convention. 1993, April 1993. p. 192-193.

OP-1967. G. F. Ulmishek. Geology and exploration potential of major petroleum basins in the former USSR [abstr.] AAPG Bulletin, in AAPG distinguished lecture tours, 1993-1994. v. 77, no. 11, November 1993. p. 2022.

OP-1968. D. M. Updegraff*, J. S. Reynolds*, R. L. Smith and T. R. Wildeman*. Bioremediation of acid mine drainage by a consortium of anaerobic bacteria in a constructed wetland [abstr.] Abstracts of Papers - American Chemical Society, National Meeting, in Abstracts of papers; 203rd ACS national meeting. 203, 1992. p. GEOC 174.

OP-1969. R. D. van der Hilst*, David Gubbins*, E. R. Engdahl and Roel Snieder*. Morphology of Tonga-Kermadec slab and P-wave propagation through subducted lithosphere [abstr.] Eos, Transactions, American Geophysical Union, in AGU 1992 western Pacific geophysics meeting. v. 73, no. 25, Suppl. June 23, 1992. p. 52 .

OP-1970. R. B. VanArsdale*, R. A. Williams, E. S. Schweig, III*, L. R. Kanter*, K. M. Shedlock, K. W. King and J. K. Odum. ARKANSAS. Tectonic origin of Crowley's Ridge, northeastern Arkansas [abstr.] Abstracts with Programs - Geological Society of America, in Geological Society of America, 1992 annual meeting. v. 24 , no. 7,1992 . p. 153.

OP-1971. J. G. Vedder, R. G. Bohannon and Hugh McLean. CALIFORNIA. Geology of Santa Catalina Island, California con- tinental borderland [abstr.] AAPG Bulletin, in AAPG Pacific Section abstracts. v. 77 , no. 4, April 1993. p. 720.

OP-1972. E. R. Verbeek and M. A. Grout. General properties of joints and joint networks in subhorizontally layered reservoir rocks [abstr.] AAPG Bulletin, in AAPG international conference and exhibition; abstracts. v. 77, no. 9, September 1993. p. 1674.

OP-1973. R. D. Vocke, Jr.*, E. S. Beary* and R. J. Walker. High precision lithium isotope ratio measurements of samples from a variety of natural sources [abstr.], in V. M. Goldschmidt conference; program and abstracts. Geochem. Soc. 1990. p. 89.

OP-1974. R. W. Vorder Bruegge*, M. E. Davies*, D. M. Horan*, P. G. Lucey*, C. M. Pieters*, A. S. McEwen, Stewart Nozette*, E. M. Shoemaker, S. W. Squyres* and P. C. Thomas*. The Clementine Mission science return at the Moon and Geographos [abstr.] Proceedings of the Lunar and Planetary Science Conference, in Abstracts of papers submitted to the Twenty-fourth lunar and planetary science conference. (Douglas Blanchard, chairperson and others). 24, 1993. p. 1469-1470.

OP-1975. B. J. Wagner. Optimal monitoring network design for groundwater flow and contaminant transport modelling under uncertainty [abstr.] Eos, Transactions, American Geophysical Union, in AGU 1992 spring meeting. v. 73, no. 14, Suppl. April 7, 1992. p. 134.

OP-1976. K. L. Wahl. Regional flood-frequency studies by the U.S. Geological Survey [abstr.] Proceedings from the ASDSO Annual Conference, in Proceedings from the 7th ASDSO annual conference. 7, 1990. p. 455-456.

OP-1977. R. J. Walker*, J. W. Morgan, M. F. Horan and R. N. Grossman. Rhenium-osmium isotope systematics of ordinary chondrites and iron meteorites [abstr.] Proceedings of the Lunar and Planetary Science Conference, in Abstracts of papers submitted to the Twenty-fourth lunar and planetary science conference. (Douglas Blanchard, chairperson and others). 24, 1993. p. 1477 1478.

OP-1978. R. J. Walker*, J. W. Morgan, A. J. Naldrett* and C. $\mathrm{Li}^{*}$. Re-Os isotope evidence for a major crustal component in $\mathrm{Ni}-\mathrm{Cu}$ sulfide ores, Sudbury igneous complex, Ontario [abstr.] Eos, Transactions, American Geophysical Union, in AGU-MSA 1991 spring meeting. v. 72, no. 17, April 23, 1991. p. 305.

OP-1979. R. J. Walker*, J. W. Morgan, A. J. Naldrett* and C. $\mathrm{Li}^{*}$. $\mathrm{Re}-\mathrm{Os}$ isotopic systematics of Ni-Cu sulfide ores, Sudbury igneous complex, Ontario; evidence for a major crustal component [abstr.] Program with Abstracts - Geological Association of Canada; Mineralogical Association of Canada; Canadian Geophysical Union, Joint Annual Meeting. 16, May 1991. p. 130.

OP-1980. R. J. Walker, P. J. Paulsen* and J. D. Fassett*. Resonance ionization and inductively coupled plasma source mass spectrometric techniques used for Re-Os isotopic measurements [abstr.], in V. M. Goldschmidt conference; program and abstracts. Geochem. Soc. 1990. p. 89.

OP-1981. Wuncheng Wang. IOWA. Active and inactive herbicide ingredients detected in ground water at selected locations in Iowa [abstr.] Abstracts with Programs - Geological Society of America, in Geological Society of America, North-Central Section, 27th annual meeting. v. 25, no. 3, March 1993. p. 88. 
OP-1982. B. R. Wardlaw. Permian conodont biogeography [abstr.] Abstracts with Programs - Geological Society of America, in Geological Society of America, 1990 annual meeting. v. 22, no. $7,1990$. p. 304.

OP-1983. B. R. Wardlaw and R. G. Stamm. Hindeodus [abstr.] Abstracts with Programs - Geological Society of America, in Geological Society of America, North-Central Section, 26th annual meeting. v. 24, no. 4, April 1992. p. 70.

OP-1984. T. R. Watters*, J. R. Zimbelman* and D. H. Scott. Arcuate and circular structures in the Tharsis region, evidence of coronae on Mars [abstr.] Proceedings of the Lunar and Planetary Science Conference, in Abstracts of papers submitted to the Twenty-fourth lunar and planetary science conference. (Douglas Blanchard, chairperson and others). 24, 1993. p. 1495-1496.

OP-1985. G. A. Waychunas*, J. A. Davis, C. C. Fuller and B. A. Rea. Effect of arsenate adsorption and coprecipitation on twoline ferrihydrite structure [abstr.] Abstracts with Programs - Geological Society of America, in Geological Society of America, 1990 annual meeting. v. 22, no. 7, 1990. p. 294.

OP-1986. G. A. Waychunas*, C. C. Fuller, B. A. Rea and J. A. Davis. Characterization of arsenate complexes on ferrihydrite and FeOOH surfaces via EXAFS spectroscopy [abstr.], in V. M. Goldschmidt conference; program and abstracts. Geochem. Soc. 1990. p. 90.

OP-1987. G. A. Waychunas*, B. A. Rea, C. C. Fuller and J. A. Davis. Wide angle X-ray scattering (WAXS) study of "two-line" ferrihydrite; effect of bidentate arsenate sorption on $\mathrm{Fe}$ oxyhydroxyl polymer structure [abstr.] Abstracts of Papers - American Chemical Society, National Meeting, in 203rd ACS national meeting. 203, 1992. p. GEOC 54.

OP-1988. D. J. Weary and A. G. Harris. PENNSYLVANIA, MARYLAND, WEST VIRGINIA. Earliest Frasnian (Late Devonian) conodonts from the Harrell Shale, western Valley and Ridge Province, Pennsylvania, Maryland, and West Virginia [abstr.] Abstracts with Programs - Geological Society of America, in Geological Society of America, North-Central Section, 26th annual meeting. v. 24 , no. 4 , April 1992. p. 70.

OP-1989. R. H. Webb. Climatic and spatial controls on flood frequency in the Southwestern United States [abstr.] Abstracts with Programs - Geological Society of America, in Geological Society of America, 1990 annual meeting. v. 22, no. 7, 1990. p. 253.

OP-1990. E. J. Weber*, K. A. Thorn and D. L. Spidle*. Kinetic and N-15 NMR spectroscopic studies of the covalent binding of aniline to humic substances [abstr.] Abstracts of Papers - American Chemical Society, National Meeting, in 203rd ACS national meeting. 203, 1992. p. GEOC 78 .

OP-1991. D. M. Webster and B. F. Jones. TEXAS. Paleoenvironmental implications of lacustrine clay minerals from the Double Lakes area, southern High Plains, Texas [abstr.] Program and Abstracts - Annual Clay Minerals Conference, in Clay Minerals Society, 28th annual meeting. (D. R. Pevear, chairperson). 28, October 1991. p. 172.

OP-1992. L. G. Wennerberg. CALIFORNIA. Observing source complexity in locally recorded accelerograms from Coalinga, California [abstr.] Seismological Research Letters, in 85th annual meeting of the Seismological Society of America. v. 61, no. 1, March 1990. p. 26.

OP-1993. K. J. Wenrich. ARIZONA. Azurite and other copper carbonates in northern Arizona solution-collapse breccia pipes [abstr.] The Mineralogical Record, in Tucson mineralogical symposium, 12th annual meeting; Azurite and other copper carbonates. (K. J. Wenrich, chairperson). v. 22, no. 1, February 1991. p. 67-68.

OP-1994. H. R. Westrich* and T. M. Gerlach. Mt. Pinatubo gas release estimated from glass inclusions? [abstr.] Eos, Transactions, American Geophysical Union, in AGU 1992 spring meeting. v. 73 , no. 14 , supplement, April 7, 1992. p. 367.

OP-1995. H. E. Wever*, B. C. Storey*, A. B. Ford and P. D. Rowley. Magmatic evolution of a Jurassic back-arc basin system in Northeast Palmer Land, Antarctic Peninsula [abstr.] International Symposium on Antarctic Earth Sciences, in Sixth international symposium on Antarctic earth science. 6, 1991. p. 647-648.

OP-1996. R. L. Wheeler and B. S. Rhea. MISSOURI. Preliminary seismotectonic maps of the New Madrid, Missouri, area [abstr.] Abstracts with Programs - Geological Society of America, in Geological Society of America, North-Central Section, 27th annual meeting. v. 25, no. 3, March 1993. p. 89.

OP-1997. A. F. White and M. F. Hochella, Jr.*. HAWAII. An XPS study of the surface chemistry and weathering characteristics of Recent basalt flows from Hawaii and Iceland [abstr.], in V. M. Goldschmidt conference; program and abstracts. Geochem. Soc. 1990. p. 92.

OP-1998, R. A. White, D. H. Harlow and B. A. Chouet. Longperiod earthquakes preceding and accompanying the June 1991 Mount Pinatubo eruptions [abstr.] Eos, Transactions, American Geophysical Union, in AGU 1992 fall meeting. v. 73, no. 43, suppl. October 27, 1992. p. 347.

OP-1999. Cathy Whitlock*, R. S. Thompson and P. J. Bartlein*. Climatic assessment of the last deglaciation in the Pacific Northwest as inferred from paleobotanical data [abstr.] Abstracts with Programs - Geological Society of America, in Geological Society of America, 1990 annual meeting. v. 22, no. 7, 1990. p. 354.

OP-2000. C. G. Whitney and Bruce Velde*. Textural changes and nucleation during the early stages of illitization; an experimental study [abstr.] Program and Abstracts - Annual Clay Minerals Conference, in Clay Minerals Society, 28th annual meeting. (D. R. Pevear, chairperson). 28, October 1991. p. 174.

OP-2001. C. M. Wicks and J. S. Herman*. Effects of physical heterogeneity on the configuration of the saltwater-freshwater mixing zone in carbonate aquifers [abstr.] Abstracts with Programs - Geological Society of America, in Geological Society of America, 1992 annual meeting. v. 24 , no. 7,1992 . p. 251-252.

OP-2002. D. A. Willard, T. M. Cronin and R. J. Litwin. FLORIDA. Correspondence of terrestrial and marine paleoclimates, SW Florida, during mid-Pliocene periods of global warmth [abstr.] Abstracts with Programs - Geological Society of America, in Geological Society of America, 1992 annual meeting. v. 24, no. 7,1992 . p. 268.

OP-2003. D. F. Williams*, S. M. Colman, P. P. Hearn, B. N. Khakhaev*, M. Kuzmin*, M. A. Grachev* and E. B. 
Karabanov*. The Baikal drilling project; American-Russian paleoclimate research at Lake Baikal, the world's deepest lake [abstr.] Eos, Transactions, American Geophysical Union, in AGU 1992 spring meeting. v. 73, no. 14, Suppl. April 7, 1992. p. 149.

OP-2004. D. F. Williams*, P. Jenkins*, E. B. Karabanov*, M. C. Shimaraeva*, S. M. Colman, P. P. Hearn and Y. Bogdanov*. Paleolimnological response of Lake Baikal during the late Quaternary to orbital forcing on Milankovitch time scales [abstr.] Eos, Transactions, American Geophysical Union, in AGUMSA 1991 spring meeting. v. 72, no. 17, April 23, 1991. p. 306.

OP-2005. W. C. Williams* and R. M. Bouse. Crustal lead signatures from Paleocene rocks in northern Chile [abstr.] Abstracts with Programs - Geological Society of America, in Geological Society of America, 1992 annual meeting. v. 24, no. 7, 1992. p. 298-299.

OP-2006. H. G. Wilshire. CALIFORNIA. Environmental impacts of pipeline corridors in the Mojave Desert, California [abstr.] Abstracts with Programs - Geological Society of America, in Geological Society of America, 1992 annual meeting. v. 24, no. 7, 1992. p. 243.

OP-2007. R. P. Wilson. The regulatory surface; a proposed method of identifying wells that yield Colorado River water [abstr.] American Water Resources Association Technical Publication Series TPS, in Water management of river systems; 27 th annual AWRA conference. (H. C. McWreath, editor). 27, 1991. p. 359-360.

OP-2008. D. A. Wiltshire and B. F. Molnia. Arctic Data InterActive; an electronic science journal [abstr.] Proceedings - Geoscience Information Society, in International initiatives in geoscience information; a global perspective; proceedings of the twenty-sixth meeting of the Geoscience Information Society. (Dena Fracolli, editor). 22, 1992. p. 151.

OP-2009. G. L. Wingard. The published record vs. the fossils; an example of the nature of extinction at the Cretaceous-Tertiary boundary [abstr.] Abstracts with Programs - Geological Society of America, in Geological Society of America, 1990 annual meeting. v. 22 , no. 7,1990 . p. 278.

OP-2010. Rich Wolf* and K. W. Hudnut. CALIFORNIA. A review of recent crustal deformation studies in the Southern California borderland region [abstr.] AAPG Bulletin, in AAPG Pacific Section abstracts. v. 77, no. 4, April 1993. p. 722.

OP-2011. D. M. Wolock, M. A. Ayers, G. J. McCabe, Jr. and L. E. Hay. Transient responses to climatic change of runoff in the Delaware River basin [abstr.] Abstracts with Programs - Geological Society of America, in Geological Society of America, 1990 annual meeting. v. 22, no. 7, 1990. p. 252.

OP-2012. W. W. Wood and W. E. Sanford. A hydrologic model to predict evaporite thickness and mineral suites [abstr.] Abstracts with Programs - Geological Society of America, in Geological Society of America, 1990 annual meeting. v. 22, no. 7, 1990. p. 362.

OP-2013. W. W. Wood and W. E. Sanford. TEXAS. Groundwater solutes and eolian processes; an example from the High Plains of Texas [abstr.] Abstracts with Programs - Geological
Society of America, in Geological Society of America, 1992 annual meeting. v. 24 , no. 7,1992 . p. 337.

OP-2014. J. L. Wooden, G. K. Czamanske, R. M. Bouse, A. P. Likhachev* and T. E. Zen'ko*. Pb isotopic data for flood basalts, mafic intrusive rocks, and Cu-Niores of the Noril'sk-Talnakh District, USSR [abstr.] Program with Abstracts - Geological Association of Canada; Mineralogical Association of Canada; Canadian Geophysical Union, Joint Annual Meeting. 16, May 1991. p. 135 .

OP-2015. J. L. Wooden, R. W. Kistler, A. C. Robinson, R. M. Tosdal and J. E. Wright*. A comparison of isotopic signatures of Mesozoic and Tertiary plutonism in the Western US; northern Great Basin vs. southern Basin and Range [abstr.] Eos, Transactions, American Geophysical Union, in AGU-MSA 1991 spring meeting. v. 72, no. 17, April 23, 1991. p. 302.

OP-2016. J. L. Wooden and P. A. Mueller*. WYOMING. Crustal growth in an early Archean enriched crust-mantle system; the Wyoming Province of the Western United States [abstr.] Eos, Transactions, American Geophysical Union, in AGU-MSA 1991 spring meeting. v. 72, no. 17, April 23, 1991. p. 296.

OP-2017. J. L. Wooden, P. A. Mueller*, K. d'Arcy* and Fred Barker. WYOMING. Rapid growth of late Archean crust in the Beartooth-Big Horn magmatic terrane, Wyoming Province [abstr.] Abstracts with Programs - Geological Society of America, in Geological Society of America, 1990 annual meeting. v. 22, no. 7, 1990. p. 174.

OP-2018. J. L. Wooden, J. S. Stacey, A. C. Robinson, R. W. Kistler, R. M. Tosdal and M. J. Whitehouse. Pb isotopic characteristics of Mesozoic intrusive magmatism along the craton margin in the western USA [abstr.] Proceedings of the International Conference on Basement Tectonics, in Basement tectonics 8; Characterization and comparison of ancient and Mesozoic continental margins. (M. J. Bartholomew, editor and others). 8, 1988. p. 741-742.

OP-2019. L. G. Woodruff, W. F. Cannon and J. M. Back. MICHIGAN. Chalcocite mineralization in the Portage Lake Volcanics of the Midcontinent Rift, Keweenaw Peninsula, Michigan [abstr.] Abstracts with Programs - Geological Society of America, in Geological Society of America, 1992 annual meeting. v. 24, no. 7,1992 . p. 61 .

OP-2020. B. M. Wrege. Students writing for their futures [abstr.] Abstracts with Programs - Geological Society of America, in Geological Society of America, 1990 annual meeting. v. 22, no. 7, 1990. p. 242.

OP-2021. J. E. Wright* and J. L. Wooden. Late Cretaceous crustal melting in the hinterland of the Sevier thrust belt; new inferences from $\mathrm{Sr}, \mathrm{Nd}$, and $\mathrm{Pb}$ isotopic data [abstr.] Abstracts with Programs - Geological Society of America, in Geological Society of America, 1990 annual meeting. v. 22, no. 7, 1990. p. 276.

OP-2022. S. S. Wu, A. E. Howington-Kraus and K. K. Ablin. Elevation distribution of Mars topography [abstr.] Abstracts of Papers Submitted to the Lunar and Planetary Science Conference, in Twenty-second lunar and planetary science conference. (Graham Ryder, editor and others). 22, 1991. p. 1525-1526.

OP-2023. R. M. Yager, D. H. Tepper and W. M. Kappel. NEW YORK. Hydrogeology of the Niagara Falls area; a summary 
of the U.S. Geological Survey study [abstr.], in International symposium on Groundwater issues of the lower Great Lakes. Buffalo, NY: Buffalo Assoc. Prof. Geol. 1991.

OP-2024. K. M. Yamashita, J. W. Kleinman, E. Y. Iwatsubo, J. W. Ewert, Daniel Dzurisin, J. B. Rundle* and R. S. Stein. CALIFORNIA. Results of 1992 leveling survey at Long Valley Caldera, California [abstr.] Eos, Transactions, American Geophysical Union, in AGU 1992 fall meeting. v. 73, no. 43, suppl. October 27, 1992. p. 347.

OP-2025. Keizo Yanai*, Hiroshi Takeda*, M. M. Lindstrom*, Mitsunobu Tatsumoto, Noriko Torigoye, Keiji Misawa*, P. H. Warren*, G. W. Kallemeyn*, Christian Koeberl*, Hideyasu Kojima*, K. Takahashi*, A. Masuda* and Kunihiko Nishiizumi*. Consortium reports on lunar meteorites Yamato 793169 and Asuka 881757, a new type of mare basalt [abstr.] Proceedings of the Lunar and Planetary Science Conference, in Abstracts of papers submitted to the Twenty-fourth lunar and planetary science conference. (Douglas Blanchard, chairperson and others). 24, 1993. p. 1555-1556.

OP-2026. George Zandt*, S. P. Jarpe* and H. M. Benz. NTS seismic yield experiment; rubble zone imaging [abstr.] Seismological Research Letters, in 85th annual meeting of the Seismological Society of America. v. 61, no. 1, March 1990. p. 11-12.

OP-2027. Marcos Zentilli*, B. R. Doe, C. E. Hedge, Orlando Alvarez C.*, Enrique Tidy F.* and J. A. Daroca*. Isotopos de plomo en yacimientos de tipo porfido cuprifero comparados con otros depositos metaliferos en los Andes del Norte de Chile y Argentina [Lead isotopes in porphyry copper deposits compared to other metallic deposits in the Andes of northern Chile and Argentina] [abstr.] Serie Comunicaciones - Departamento de Geología, Facultad de Ciencias Físicas y Matemáticas, Universidad de Chile, in Resumenes; $5^{\circ}$ congreso geologico chileno (Abstracts of the 5th Chilean geological congress). (José Corvalán D., editor and others). 39,1988 . p. 81 .
OP-2028. A. C. Ziegler, D. H. Wilkinson, R. D. Maley* and D. W. Blevins. Occurrence of herbicides and nitrate in rural domestic wells, west-central Missouri [abstr.] Abstracts with Programs Geological Society of America, in Geological Society of America, North-Central Section, 27th annual meeting. v. 25, no. 3, March 1993. p. 92.

OP-2029. R. A. Zierenberg. Formation of the Atantis II Deep massive sulfide deposit at the transition from continental rifting to seafloor spreading in the Red Sea [abstr.] Abstracts with Programs - Geological Society of America, in Geological Society of America, 1992 annual meeting. v. 24, no. 7, 1992. p. 24.

OP-2030. M. L. Zoback. State of stress in the Earth's crust [abstr.] Abstracts with Programs - Geological Society of America, in Geological Society of America, 1992 annual meeting. v. 24, no. 7, 1992. p. 40.

OP-2031. M. L. Zoback. Using stress orientations to constrain tectonic stress magnitudes at depth [abstr.] Eos, Transactions, American Geophysical Union, in AGU 1992 spring meeting. v. 73, no. 14, supplement, April 7, 1992. p. 298.

OP-2032. M. L. Zoback and M. D. Zoback*. Rapid short-term rates of intraplate seismicity related to episodic release of high pore pressure? [abstr.] Abstracts with Programs - Geological Society of America, in Geological Society of America, 1992 annual meeting. v. 24, no. 7, 1992. p. 153 .

OP-2033. M. L. Zoback and M. D. Zoback*. Episodic release of high pore pressure, an explanation of rapid short-term rates of intraplate seismicity [abstr.] Eos, Transactions, American Geophysical Union, in AGU 1992 spring meeting. v. 73, no. 14, supplement, April 7, 1992. p. 307.

OP-2034. E. L. Zodrow* and P. C. Lyons. The first discovery of in situ coal balls in Nova Scotia [abstr.] Report - Department of Mines and Energy (Halifax), in Program and summaries; Sixteenth annual open house and review of activities. (D. R. MacDonald, editor and others). Report no. 92-4, 1992. p. 37. 


\section{INDEX}

This is an index of U.S. Geological Survey publications issued in 1993 and articles by U.S. Geological Survey personnel in non-U.S. Geological Survey publications that came to our attention in 1993 divided into a general index, including subjects and areas, and an author index. The index was produced from the American Geological Institute's GeoRef database, under USGS contract 14-08-0001-23521.

\section{ABBREVIATIONS USED}

$\begin{array}{ll}\text { A- } & \text { Antarctic Geologic Map } \\ \text { B } & \text { Bulletin } \\ \text { C } & \text { Circular } \\ \text { C- } & \text { Coal Investigations Map } \\ \text { CAT } & \text { Catalog } \\ \text { CF } & \text { Coal Map } \\ \text { CP- } & \text { Circum-Pacific Map Series } \\ \text { DDS- } & \text { Digital Data Series } \\ \text { EV } & \text { Earthquakes and Volcanoes } \\ \text { GN } & \text { General Interest Publication } \\ \text { GP- } & \text { Geophysical Investigations Map } \\ \text { GQ- } & \text { Geologic Quadrangle Map } \\ \text { HA- } & \text { Hydrologic Investigations Atlas } \\ \text { HUM } & \text { Hydrologic Unit Map } \\ \text { I- } & \text { Miscellaneous Investigations Series Map } \\ \text { L- } & \text { Land Use and Land Cover Map } \\ \text { MF- } & \text { Miscellaneous Field Studies Map } \\ \text { MR- } & \text { Mineral Investigations Resources Map }\end{array}$

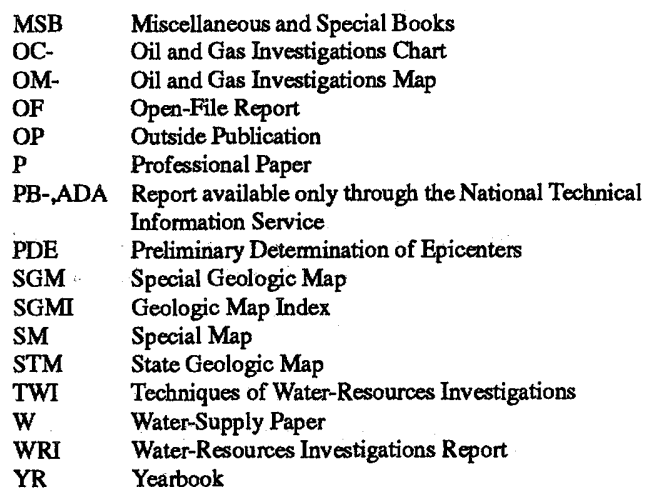

Outside journals and books are not available from the U.S. Geological Survey.

\section{SUBJECT AND GEOGRAPHIC INDEX}

\section{$\mathbf{A}$}

\section{A-1 Evaporite}

sedimentary petrology OF 93-0236

A-type granites Virginia OP-1002

AABW see Antarctic bottom water

Abean Orogeny see Hercynian Orogeny

Abenaki Formation Mesozoic OP-801

Aberdeen Proving Ground environmental geology OP-1089

Abert Lake

sedimentary petrology OP-1134

Abitibi Belt gold ores OP-1097

ablation OP-1653

Absaroka Range see Beartooth Mountains

Absaroka Supergroup natural gas OF 93-0337

Absaroka-Beartooth Study Area bibliography OF 93-0285-A; OF 93-0285-B mineral resources OF 93-0505

absolute age see also Ar/Ar, C-14; charcoal; $\mathrm{K} / \mathrm{Ar} ; \mathrm{Pb} / \mathrm{Pb} ; \mathrm{Rb} / \mathrm{Sr} ; \mathrm{Re} / \mathrm{Os} ; \mathrm{Sm} / \mathrm{Nd} ; \mathrm{Sr} / \mathrm{Sr}$; $\mathrm{Th} / \mathrm{Th} ; \mathrm{Th} / \mathrm{U}$; U/Pb; U/Th/Pb; uranium disequilibrium.

OF 93-0336

Alaska, metamorphism OP-1349

Appalachians, stratigraphy OP-1380

California

OP-333

Miocene OF 93-0182

Quaternary OP-707

Chile, Quatemary OP-279

\author{
China, metal ores OP-1238 \\ Colorado I-2266 \\ geochemistry OF 92-0525 \\ ground water YR \\ Manitoba, petrology OP-1560 \\ Mesozoic OP-1494 \\ Mexico, Quaternary OP-707 \\ Mississippi Valley, Quaternary OF 93-0273 \\ Montana, geochemistry OP-1094 \\ Nevada \\ OF 93-0538 \\ Quaternary C 1086 \\ volcanism $\mathrm{OF}$ 93-0021 \\ New Mexico I-2266 \\ Ontario, petrology OP-214; OP-1560 \\ Oregon, Quatemary OP-707 \\ Russian Federation, Phanerozoic OP-1493 \\ Saudi Arabia, orogeny OP-1921 \\ United States, Phanerozoic OP-1493 \\ Yemen, orogeny OP-1921 \\ Abu Dhabi \\ Quaternary OF 92-0391; OP-1198 \\ stratigraphy OP-1453 \\ abyssal fans see submarine fans \\ abyssal plains \\ Atlantic Coastal Plain, stratigraphy P 1542 \\ abyssolith see batholiths \\ academic institutions \\ YR \\ industrial minerals B 2013 \\ Academician Ridge \\ geophysical surveys OP-898 \\ Quaternary OP-1334 \\ Acadian Phase \\ Pennsylvania OF 92-0525 \\ Vermont, maps OF 92-0282-A
}

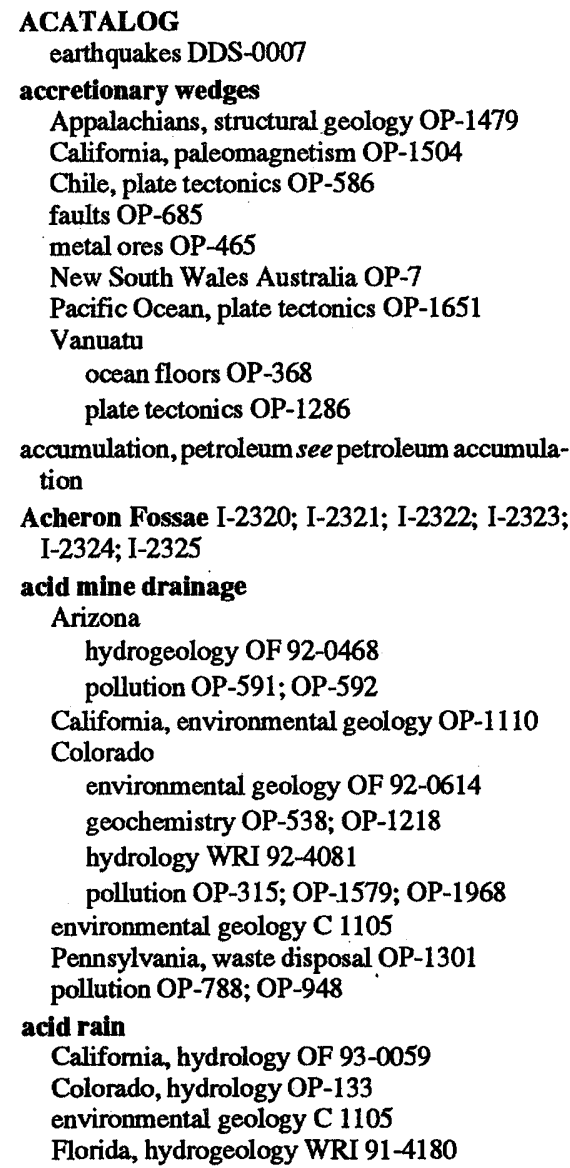


Georgia, hydrology C 1086; OF 93-0055; OP1515

hydrogeology OP-161

Maryland environmental geology OF 92-0168 hydrogeology OF 92-0649

New York

environmental geology OP-1130 pollution OP-975

Acoma Embayment ground water WRI 91-4033

acoustic methods see acoustical methods acoustic surveys see acoustical surveys acoustic waves see acoustical waves acoustical logging

engineering geology OP-760

Nevada, ground water WRI 91-4167

Tennessee, ground water OF 92-0135

acoustical methods see also GLORIA.

OF 93-0242

hydrology W 2395; OP-1335; OP-1888

marine geology OF 92-0536

sedimentary petrology OP-738

structural geology OP-602

acoustical surveys see also GLORIA.

Alaska

folds OP-1789

marine geology OF 92-0706

Quaternary OF 93-0266; OP-1719

California, structural geology OP-340

Gulf of Mexico

ocean floors OP-743

oceanography OP-1864

Quaternary OP-1966

Hawaii, geomorphology OP-694

Massachusetts

continental shelf OP-546

oceanography DDS-0003

sedimentation OP-1598

New Jersey, continental shelf MF-2221

Puerto Rico, oceanography OF 92-0513; OF $92-0717$

acoustical waves

seismic sources OF 93-0221

actinides see plutonium; thorium; uranium actinolite

Greenland, phase equilibria OP-636

action, frost see frost action

active faults

OP-119

Alaska

engineering geology OF 93-0338

seismology OP-1

California

P 1550-C; OP-23; OP-648

earthquakes YR; OF 91-0032; OP-90; OP126; OP-698; OP-931; OP-958

engineering geology OF 91-0032; OF 930348; OP-125; OP-688; OP-882

geochemistry OP-512

geophysical surveys OF 93-0276

plate tectonics OP-145

Quaternary OP-338; OP-1833

seismicity P $1550-C$; OP-286

seismology P 1550-C; OP-302; OP-357; OP-593; OP-868; OP-966; OP-1581 tectonophysics P 1550-C

Colorado

earthquakes OP-1423

geomorphology OP-1171

Dominican Republic, plate tectonics OP-808 earthquakes OP-539

Greece, plate tectonics OP-542

Hawaii, geophysical surveys OP-252

Italy, Quaternary OP-764

Mississippi Valley

OP-358

engineering geology OF 92-0391

Nevada, seismology OP-357

Northern Territory Australia, Quaternary B 2032-A

seismicity OP-1866

South Australia, Quatemary B 2032-B

Utah

OP-621

geologic hazards P 1519

Quatemary OP-970

Washington, Quaternary OP-120

Wyoming, tectonophysics OP-1780

active margins

Europe, plate tectonics OP-206

tectonophysics OP-463

active tectonics see neotectonics

actual age (absolute age) see absolute age

Adelaide mining district

metal ores OF 93-0249

Adirondack Mountains

geochemistry OP-776

geochronology OP-1709

structural geology OP-461

Admiralty-Revillagigedo Belt

metamorphic rocks OP-1194

petrology OP-1463

Adriatic Coast see Adriatic region

Adriatic Plate

plate tectonics OP-206

Adriatic region

plate tectonics OP-206

Adriatic Sea

pollution $\mathrm{OP}-47$

adularia

California, metal ores OP-428

aeolianite see eolianite

aeromagnetic maps

California, geophysical surveys OF 92-0531; OF 92-0548; OF 92-0549; OF 93-0277

Maine, geophysical surveys OF 93-0573-B

Missouri, geophysical surveys OF 91-0573

Oregon, geophysical surveys OF 93-0211

Washington, geophysical surveys OF 93-0211

Afghanistan

gems OP-1869

Afif Terrane

Proterozoic B 1976

tin ores OP-499

Afognak Quadrangle maps I-2032

Africa see also Central Africa; East Africa; North Africa; Sahara; Southern Africa; West Africa. conservation, Sahel C 1086

earthquakes, Nile Valley OP-992

fluvial features

Chad Basin OP-314

Nile River OP-314

geochemistry OP-1774

sedimentary petrology, Lake Magadi OP-1490

stratigraphy, Turkana Basin OP-656

tectonophysics, East African Rift OP-521

aftershocks

Alaska

earthquakes OP-1189

seismology OP-1
California

earthquakes OF 93-0219; OP-698; OP-700;

OP-931; OP-1183; OP-1762

geologic hazards P 1553-B; OP-221

plate tectonics OP-752

seismicity OP-286

seismology OP-407; OP-673

earthquakes OP-1024

Egypt, earthquakes OP-1092

engineering geology $\mathrm{OP}-67 ; \mathrm{OP}-415$

Hawaii

seismicity OP-1812

seismology OP-116

Nevada, earthquakes OP-1300

seismology OP-959

Ag see silver

aggradation

Alaska, geologic hazards OF 93-0094

Oregon, Quaternary B 2038

Texas, stratigraphy OP-1387; OP-1575

Utah, Cretaceous OP-919

aggregate see also sands.

OF 92-0514

Alaska C 1110

Atlantic Coastal Plain OP-1104

Basin and Range Province B 2013

clay mineralogy OP-1069

environmental geology OF 92-0514

Illinois OF 92-0514

Minnesota OF 92-0514

Wisconsin OF 92-0514

Agha Jari Formation

stratigraphy OP-1453

Agnes

Pennsylvania, geologic hazards YR

Agnotozoic see Proterozoic

agrichemicals ${ }^{\circ}$

Gulf Coastal Plain, environmental geology C 1120-C

Gulf of Mexico, environmental geology C 1120-C

Iowa, ground water OF 92-0085

Kansas, pollution OF 93-0087

Midwest

environmental geology OF 93-0418

pollution OF 93-0418

Minnesota

ground water OF 92-0085

pollution OF 93-0042; OF 93-0043; OF 930079

Nebraska, pollution OF-93-0087

New England, pollution OF 93-0418

pollution YR; OF 93-0418

agricultural waste

environmental geology OP-180

Florida, environmental geology WRI 92-4058

pollution OP-181

Ailsa Craig Granite

geochemistry OF 93-0267

air quality

Wyoming, Quaternary OP-711

Aitken Basin OP-1486; OP-1487

Akin Branch

hydrology OF 92-0648

Al see aluminum

Al-26

geomorphology OP-1750 
Alabama see also Appalachian Basin; Eutaw Formation; Mississippi Embayment; Piedmont; Selma Group; Smackover Formation; Tennessee River; Tuscaloosa Formation.

energy sources OF 92-0524

engineering geology OF 93-0349; OP-384

environmental geology OP-377; OP-378

geochronology

Chambers County Alabama OP-968

Lee County Alabama OP-968

Macon County Alabama OP-968

Tallapoosa County Alabama OP-968

gold ores, Tallapoosa County Alabama MF2214

ground water

P 1410-G; P 1416-C; WRI 91-4150; WRI 91-4151; WRI 91-4152; WRI 924102; WRI 92-4103; WRI 92-4104; WRI 92-4105; OF 92-0492; OP-46

Butler County Alabama WRI 91-4116

Marshall County Alabama WRI 91-4121

Morgan County Alabama WRI 91-4121

highways WRI 92-4147

hydrology W 2400

oceanography OF 92-0530

paleontology OP-1205

Quaternary OF 92-0530

sedimentary petrology

OP-1636

Mobile Bay OP-1858

seismology SM

structural geology OP-1918

ALACARTE

maps OP-1945

metamorphic rocks OP-1166

alachlor

Midwest, pollution OF 93-0418

Minnesota, pollution OF 93-0042; OF 930043; OF 93-0079

Alamagan Volcano

geologic hazards OP-1962 maps I-2408

Alamo Breccia stratigraphy OP-1847

Alamo-Hueco Basin natural gas OF 93-0248

Alani-Paty landslide

engineering geology OF 92-0501

soil mechanics OP-1814

Alaska see also Arctic Coastal Plain; Cook Inlet;

Endicott Group; Gubik Formation; Hemlock Conglomerate; Kuskokwim Group; Lisbume Group; Old Crow Tephra.

OF 92-0391

barite deposits, Brooks Range OF 93-0215

bibliography, Glacier Bay National Park OF $92-0596$

Cenozoic C 1086

continental shelf OP-837

continental slope

B 2002

Kodiak Island B 2002

core OP-1032

earthquakes

OF 93-0309; OP-1325; OP-1618

Aleutian Islands OP-1189

ecology YR; C 1086

economic geology

C 1091; OF 92-0525; MF-2217-A

Chugach Mountains C 1094

Matanuska Valley C 1094.

Prince William Sound C 1094
Talkeetna Mountains C 1094

energy sources

B 2034-A; OF 92-0391; OF 92-0524

Alaska Peninsula OP-626

Arctic National Wildlife Refuge OP-268

Brooks Range B 2034-A

Prudhoe Bay OP-1284

engineering geology B 2002; OF 93-0338; OP-

140

environmental geology

C 1086; OF 93-0292-J; SM

Aleutian Islands OP-564

Prince William Sound OP-564

Valdez Alaska OP-564

folds

Brooks Range OP-1427; OP-1789

Yukon-Koyukuk Basin OP-1427

geochemistry

OF 92-0391; OF 93-0014; OP-242; OP-

1373; OP-1754

Brooks Range OP-721

Katmai National Monument OP-926

Prince William Sound OP-1304

Prince William Terrane OP-1410

Valley of Ten Thousand Smokes OP-926; OP-1770; OP-1771

geochronology OF 92-0701

geologic hazards

YR; OF 93-0094

Anchorage Alaska YR

Valdez Alaska B 2002

geomorphology C 1086

geophysical surveys

B 1966; OF 93-0508-A; OF 93-0508-B

Kenai Peninsula OF 93-0238

gold ores

MF-2227; OP-589; OP-1057; OP-1099;

OP-1416

Chugach Mountains OF 93-0325

Prince William Terrane OF 93-0325

ground water HA-0730-J

heat flow, Brooks Range OP-253

hydrogeology

C 1081; OF 92-0479

National Petroleum Reserve Alaska OF 91 0458

hydrology

W 2400; C 1086; OF 92-0493; OF 93-

0029; OF 93-0076; OF 93-0095; OF 93-

0162

Anchorage Alaska WRI 92-4132

Fairbanks Alaska OP-330

intrusions OP-1401

Invertebrata OP-1681; OP-1800

magmas OP-845; OP-1469

maps

OF 92-0346; MF-2226-A; I-1984; I-2032

Alaska Range OF 92-0594

Chugach Mountains I-2164

Wrangell Mountains GQ-1688

marine geology, Yakutat Bay OF 92-0706

Mesozoic OP-1680

metal ores

OF 93-0339; MF-2228; OP-1203; OP-1433

Alaska Peninsula B 1968

Alaska Range MF-1996-E; OP-570

Prince William Sound OP-224

metamorphic rocks

Alexander Terrane P 1497-C; OP-1194

Chugach Mountains P 1497-C

metamorphism OP-1349

mineral resources OF 92-0008-A; OF 92-0008-

B; OF 92-0315; OF 92-0379-A; OF 92-
0379-B; OF 92-0690; OF 92-0708-A; OF 92-0708-B; MF-2144-B; MF-2144-C; MF-2144-D; OP-106

natural gas

YR; B 2034-A; OF 93-0230

Arctic National Wildlife Refuge OP-74

Brooks Range OP-74

National Petroleum Reserve Alaska OP-74

Trans-Alaska Pipeline OP-74

neotectonics, Shumagin Islands OP-1852

non-metal deposits C 1110

oceanography B 2002; OF 93-0019; OP-1298

paleobotany, Alaska Range OP-1082

Paleozoic, Nixon Fork Terrane OP-1168

palynomorphs OP-1101

petroleum

B 2034-A; OF 93-0330

Alaska Peninsula B 2034-A; OP-492

Aleutian Islands OP-492

Brooks Range OP-492

Kodiak Island B 2034-A

National Petroleum Reserve Alaska DDS0005 ; OP-1285

Prudhoe Bay OP-1285

Prudhoe Bay Field OP-1285

Seward Peninsula B 2034-A

petrology

OP-1195; OP-1461; OP-1463; OP-1929

Alexander Terrane OP-1396

Chichagof Island OP-1396

Chugach Mountains OF 92-0020-E

Juneau Alaska OF 92-0724

Katmai OP-316

pollution C 1007; OP-66

Quatemary

C 1086; OF 93-0266; OP-33; OP-299; OP-

390; OP-391; OP-651; OP-1250; OP-1342;

OP-1507; OP-1616; OP-1699; OP-1714;

OP-1718; OP-1739; OP-1772; OP-1801

Aleutian Islands OP-826

Chugach Mountains OP-1719

Valley of Ten Thousand Smokes OP-549

sea ice OF 93-0237

sedimentary petrology

OF 92-0391; OP-1268

Brooks Range OP-1553

seismicity OP-1802

seismology

P 1527; C 1031; OP-1556

Aleutian Islands OP-1

Anchorage Alaska OP-1142

Prince William Sound OP-1384

stratigraphy

OP-85; OP-708

Chugach Mountains OP-1169

Kenai Peninsula OP-1169

Turnagain Arm OP-1169

Valdez Alaska OP-1169

structural geology

Chugach Mountains OP-94

Prince William Terrane OP-94

tectonophysics OP-1430

Trilobita OP-1123

Vertebrata OP-163

volcanology OP-349.

waste disposal OF 92-0502

Alaska Aulacogen

plate tectonics OP-1429

Alaska earthquake 1964

Alaska

OP-1142; OP-1384

environmental geology OP-564 
neotectonics OP-1852

Japan, neotectonics OP-1852

Alaska Mineral Resource Assessment Program economic geology C 1094

mineral resources OF 92-0315; OF 92-0379-A; OF 92-0379-B; OF 92-0380-A; OF 920380-B

Alaska National Interest Lands Conservation Act

economic geology C 1091

Alaska Peninsula

energy sources OP-626

metal ores B 1968

petroleum B 2034-A; OP-492

Alaska Range

maps OF 92-0594

metal ores MF-1996-E; OP-570

paleobotany OP-1082

Alba Fossa OP-1984

Alba Patera

OP-1984

Syria OP-1322

Albany Georgia

ground water WRI 93-4038

hydrogeology W 2391

pollution WRI $91-4178$

albedo OP-107; OP-657; OP-1163; OP-1269; OP-

1439; OP-1695

Albemarle Group

geochemistry OP-1607

Albemarle Sound

hydrogeology OF 93-0069

hydrology OF 92-0123

Alberta

Devonian OF 93-0184

Albian

Arctic Ocean C 1086

albite

petrology OP-1450

albitization

Saudi Arabia, tin ores OP-1558

Albuquerque see Albuquerque New Mexico

Albuquerque Basin

natural gas OF 93-0248

Albuquerque New Mexico hydrology OF 92-0653

Aldan Shield

Phanerozoic OP-1493

Aldrich Mountains Group guidebook OP-87

Aleutian Islands see also Shumagin Islands. earthquakes OP-1189

environmental geology OP-564

petroleum OP-492

Quatemary OP-826

seismology OP-1

Aleutian Ridge

deformation OP-211

Aleutian Trench geophysical surveys OF 93-0238

Aleutians see Aleutian Islands

Alexander Archipelago see Chichagof Island

Alexander Terrane

metamorphic rocks P 1497-C; OP-1194

petrology OP-1396

Alfven waves

geophysics OP-367

algae

Alaska, sedimentary petrology OP-1268

Botryococcus, geochemistry OP-1923 calcareous algae

California OF 93-0177; OF 93-0182

South Carolina B 2030

Chrysophyta, Washington OF 93-0289

Costa Rica, geochemistry OP-812

diatoms

Atlantic Ocean OP-822

Califomia OF 93-0340

Celebes Sea OP-821

Minnesota OP-101

Pacific Ocean OP-819; OP-820; OP-822

Pliocene OP-222

Washington OF 93-0289

Emiliania huxleyi, Minnesota C 1086

nannofossils

Antarctic Ocean OP-1145

Atlantic Coastal Plain OP-1205

Atlantic Ocean OP-822

California OF 92-0539-D; OF 92-0539-E: OF 93-0177; OF 93-0182

Celebes Sea OP-821

Costa Rica OP-1272

Europe OP-1193

Gulf Coastal Plain OP-1205

Pacific Ocean OP-747; OP-819; OP-820 OP-822

Panama OP-1272

South Carolina B 2030

Vanuatu OP-197; OP-1908

algal flora see also stromatolites.

Canada, B 1909 coccoliths, Minnesota C 1086

diatom flora

Antarctic Ocean OP-1145

Arctic Ocean OF 92-0426; OF 92-0439

Arctic region OF 92-0439

California C 1086; OF 92-0539-D; OF 92 0539-E; OF 93-0177; OF 93-0182 OF 93-0340; OP-1570

Minnesota C 1086; OP-251; OP-668

New Jersey OP-979

Oregon OF 93-0212

Pacific Ocean OP-54

Russian Federation OP-1874

Washington OF 93-0212; OF 93-0284; OF 93-0289

nannofossils

Antarctic Ocean OP-1145

Atlantic Coastal Plain OP-1205

Atlantic Ocean OP-822

California OF 92-0539-D; OF 92-0539-E; OF 93-0177; OF 93-0182

Celebes Sea OP-821

Costa Rica OP-1272

Europe OP-1193

Gulf Coastal Plain OP-1205

Pacific Ocean OP-747; OP-819; OP-820; OP-822

Panama OP-1272

South Carolina B 2030

Vanuatu OP-197; OP-1908

natural gas B 1909

Nevada, stratigraphy B 1988-F

Ontario, Devonian B 1909

Peru, stratigraphy OP-1330

United States, B 1909

Washington, ecology OF 91-0453

Algeria

pollution OP-599

Algerita Escarpment geochemistry OP-1072

alginite

geochemistry OP-1923
Aliceville Quadrangle maps I-2378

aliphatic hydrocarbons see also alkanes. geochemistry OP-1923

alkali basalts see also basanite. Arizona OP-1748

geochemistry OP-537

alkali feldspar see also adularia; K-feldspar, microcline; sanidine.

California, soils OP-1170

alkali gabbros see ijolite

alkali metals see lithium; potassium; rubidium; sodium

alkaline basalt see alkali basalts

alkaline earth metals see barium; beryllium; calcium; magnesium; radium; strontium

alkanes see also methane; phytane; pristane.

Michigan, geochemistry OP-1204

Alleghanian see Allegheny Group

Alleghany Orogeny

Alabama

geochronology OP-968

structural geology OP-1918

Appalachians, structural geology OP-1079

Georgia

geochronology OP-968

structural geology OP-1918

Pennsylvania

areal geology B 1994

diagenesis OF 92-0568

geochronology OF 92-0525

structural geology OF 92-0568

Poland

Carboniferous OP-1917

structural geology OP-1916

Virginia, orogeny OP-1612

Allegheny Group see also Kittanning Formation. OF 92-0558; OF 93-0312; OP-1513

structural geology OP-1147

Allegheny Orogeny see Alleghany Orogeny

Allegheny River

hydrology W 2400

Allende Meteorite

petrology OP-1704

Allophaiomys

Vertebrata B 2037

allostratigraphy

Atlantic Coastal Plain P 1542

alluvial deposits see alluvium

alluvial fans see also fan deltas.

California

ground water OF 91-0535

stratigraphy OP-1281

Oregon, sediments OP-1403

Washington, engineering geology OP-907

alluvium

Alaska, Quaternary OP-33

Arizona

geologic hazards $\mathrm{P}$ 0497-H

geomorphology OP-426

Arkansas, Quaternary OF 93-0273

Califomia, soils OP-1065

Colorado

geophysical surveys OP-1813

Quatemary OP-1676

Dominican Republic, plate tectonics OP-808

Georgia, heavy mineral deposits B 2039

hydrogeology OP-659

Illinois, Quatemary P 1536

Indiana, Quatemary P 1536 
Kentucky, pollution WRI 92-4138

Missouri

geomorphology OP-1544

ground water OF 93-0109; OF 93-0140

pollution OF 93-0101

Montana, ground water WRI 92-4163

Nevada

gold ores OP-624

waste disposal WRI 92-4032

Puerto Rico, ground water OP-1960

Quatemary OP-459

seismology OP-959

South Carolina, heavy mineral deposits B 2039

Tennessee, Quaternary OF 93-0273

Washington, engineering geology OF 91-0441-

West Virginia, engineering geology OP-1542

alluvium aquifers

Arizona

geologic hazards $\mathrm{P}$ 0497- $\mathrm{H}$

ground water OP-1467; OP-1468

Arkansas, ground water WRI 92-4120; OF 930096

California, ground water OF 91-0535; OP-73

ground water W 2412

Gulf Coastal Plain, ground water WRI 91-4149

Hawaii, hydrogeology WRI 91-4197

hydrogeology OF 93-0405

Idaho, ground water WRI 92-4116

Iowa, ground water OF 92-0085

Kansas, hydrogeology WRI 92-4137

Louisiana, hydrogeology WRI 91-4109; OF 92-0492

Mexico, ground water WRI 91-4155

Minnesota, ground water OF 92-0085

Mississippi Valley, ground water WRI 91-4149

Montana, ground water WRI 92-41 16; WRI 92 4162; WRI 92-4163

New Jersey

ground water WRI 90-4151

hydrogeology WRI 91-4169; OP-652

New Mexico

ground water WRI 91-4155

hydrogeology OF 93-0084

New York, ground water WRI 90-4151

Oregon

hydrogeology WRI 91-4087

sediments OP-1403

Tennessee, ground water WRI 91-4173

Texas, ground water WRI 91-4155

Utah, ground water WRI 92-4070; OF 92-0124

almandine OP-25

Almeria Spain

gold ores OP-231

metal ores OP-875

Almond Formation

petroleum OP-1635

sedimentary petrology OF 92-0391

Alpes-Maritimes France see Nice France

Alpha Cordillera

tectonophysics OP-1626

Alpine Formation

Quaternary OP-1021

Alps see also Italy.

metal ores OF 93-0504

Quaternary

French Alps P 1386-E

Swiss Alps P 1386-E

Alsea River basin

hydrology WRI 92-4108
Altiplano

economic geology YR

metal ores B 2039; OF 93-0016; OP-202

Alum Mountain

petroleum B 2039

alum rock see alunite

Alum Rock earthquake 1988 seismology P 1550-C

Alum Shale geochemistry OP-584; OP-1649

aluminosilicates

Georgia, oceanography OP-1502

aluminum

Al-26, geomorphology OP-1750

Colorado, geochemistry OP-538

geochemistry OP-650

New York

hydrology OP-1734

pollution OP-412

pollution OP-1155

Vermont, pollution $\mathrm{OP}-412$

alunite

OP-1922

Bolivia, metal ores B 2039

California OP-557

Colorado, economic geology OP-872

economic geology OP-873

geochemistry OF 92-0009

Mexico, economic geology OP-872

Nevada OP-557

Peru, economic geology OP-872

Spain, metal ores OP-875

Utah, economic geology OP-872

Wyoming, thermal waters OF 93-0293

Alunite Ridge

economic geology OP-872

alunitization

economic geology OP-873

Amalia Tuff

geochemistry OP-490

Amargosa Desert

geochemistry OP-1775

Pleistocene OP-1670

structural geology OP-108

amargosite see bentonite

Amazon Basin

hydrology OP-666

Amazon River

continental shelf $\mathrm{OP}-483$

hydrology OP-666

Amazonian OP-906; OP-1240; OP-1242; OP1338; OP-1935; OP-1936

Amazonis Planitia OP-906

amber

Dominican Republic, stratigraphy OP-1625

amber mica see phlogopite

Amerasian Basin

structural geology OP-1428

tectonophysics OP-1626

American Falls Reservoir

Quaternary OP-452

American Fork Canyon structural geology OP-619

American River hydrogeology OP-276 hydrology C 1086

American River basin hydrology OF 92-0627

American Samoa see Samoa
American Water Resources Association hydrogeology OP-665

Amethyst Fault

metal ores P 1537

Amiga

maps OF 93-0013

amino acids see also isoleucine.

Antarctica, geochemistry OP-664

Pacific Ocean, geochemistry OP-628

ammonia compound

geophysics OP-282

Indiana, environmental geology W 2393

Ammonites

Arkansas

OP-1757

stratigraphy OP-527

ammonium minerals

California, sulfides OP-557

Nevada, sulfides OP-557

Ammonoidea see also Ammonites; Baculites; Desmoceratida.

New Jersey, stratigraphy OP-529

stratigraphy OP-528

Western Interior P 1533

ammonoids

Colombia, geochemistry OP-755

Colorado, stratigraphy B 2024

England, geochemistry OP-755

Iowa, geochronology OP-475

New Jersey, stratigraphy OP-529

Poland, geochemistry OP-755

South Dakota, geochronology OP-475

stratigraphy OP-354; OP-528

Texas, geochemistry OP-755

Ammonoosuc Volcanics OP-1105

amosite

pollution OP-864

amphibians

Idaho, paleomagnetism OP-1850

Ohio, stratigraphy OP-1513

Virginia, Phanerozoic OF 93-0222

amphibole group see also clinoamphibole. OP-414

Alaska, folds OP-1427

Appalachians, structural geology OP-1079

Missouri, metal ores B 2039

Russian Federation, Precambrian OP-1777

amphibolite see amphibolites

amphibolite facies

Alaska

metal ores OP-570

metamorphic rocks $P$ 1497-C

California, structural geology OP-1971

Canada, metamorphic rocks P 1497-C

geochronology OF 92-0525

Idaho, petrology OP-1671

Maryland, metamorphism OP-1152

Montana, petrology OP-1731

Virginia, metamorphism OP-1152

amphibolites

California, Phanerozoic OP-1340

Colorado OP-827

faults OP-685

Germany, rock mechanics OP-1029

New England, geochronology OF 92-0525

Saudi Arabia OP-1952

Amphitrites Patera OP-1647

AMRAP

economic geology C 1094 
mineral resources OF 92-0315; OF 92-0379-A; OF 92-0379-B; OF 92-0380-A; OF 920380-B

Amundsen-Scott Station OP-1912

An Nafud sand sea

sedimentary petrology OP-1378

Anaconda Range

structural geology B 1993

Anadarko Basin

energy sources OP-1753

ground water B 1989-D

natural gas OF 92-0524; OF 93-0230

petroleum OF 92-0391; OP-793

sedimentary petrology OP-1791

ANALYST

geochemistry OF 92-0543

anatase

Indonesia, sedimentary petrology OP-870

anatexis

California

geochemistry OP-678

magmas OP-1711

Anchorage Alaska

geologic hazards YR

hydrology WRI 92-4132

seismology OP-1142

Anchorage Quadrangle

economic geology C 1094

gold ores MF-2227

Anchorage region see Anchorage Alaska

ancient ice ages

Virginia, Proterozoic B 2029

Ancyloceratina

Invertebrata OP-525

Andalusia Spain see Almeria Spain

andalusite

geochemistry OP-1312

Anderson coal seam

geochemistry OP-1305

sedimentary petrology OP-228

Andes see also Altiplano; Argentina; Bolivia;

Chile; Peru.

Quatemary, Eastern Cordillera OP-855

structural geology OP-1129

andesites

Alaska

OP-316

Quaternary OP-826

Argentina, structural geology OP-1129

California

geochronology OP-342

metal ores OP-427

structural geology OP-1474; OP-17.01

Chile OP-957

Colorado, geochemistry OP-490

geochemistry OF 92-0525

Idaho OP-434

Mexico, geochemistry OP-1778

Nevada

geochemistry OP-1302

geochronology OP-342

New Mexico

geochemistry OP-490

stratigraphy OP-573

Oregon

OP-982

sedimentary petrology OP-1134

Russian Federation, geochronology OP-1407

Spain, metal ores OP-875

Washington OP-957
Andreanof Islands earthquake 1992

core OP-1032

Aneth Field

hydrogeology OP-1736

Angayucham/Tozitna Terrane

sedimentary petrology OP-1553

angiosperm flora

South Carolina, ecology OF 93-0303

angiosperms see also fossil wood.

Rosidae

Canada OP-1082

United States OP-1082

Spartina alterniflora, South Carolina OF 930303

anhydrite

Florida, sedimentary petrology OP-1931

anhydrite deposits

Ohio OF 92-0514

ANILCA

economic geology C 1091

aniline

geochemistry OP-1990

animal waste

Florida, environmental geology WRI 92-4058

Animas River valley

pollution WRI 93-4007

Annette Island

geophysical surveys OF 93-0508-A; OF 930508-B

mineral resources OF 92-0690

annite

phase equilibria OP-1311

Annona Chalk

foraminifera OP-1757

Invertebrata OP-525

annual growth rings see tree rings

annual report

YR

Alaska, economic geology C 1091

California, earthquakes OF 93-0290

hydrology OF 93-0058

anorthite

petrology OP-635

anorthosite

OP-661; OP-1392; OP-1482; OP-1698; OP

1803; OP-1805

Idaho OP-434

Minnesota, geochronology OP-758

Montana

OP-604

geochemistry OP-1663

Nova Scotia, geochemistry OP-1122

Antarctic bottom water

Pliocene OP-1535

Quatemary OP-1307

Antarctic Continent see Antarctica

Antarctic Ocean

geophysical surveys, Ross Sea OF 92-0556

oceanography OP-263

orogeny, Weddell Sea OP-1395

plate tectonics, Ross Sea OP-65

Pliocene, Antarctic bottom water OP-1535

Quatemary

Antarctic bottom water OP-1307

Bransfield Strait OP-1307

Prydz Bay OP-1358; OP-1630

Weddell Sea OP-1307

stratigraphy

Ross Sea OP-470

Weddell Sea OP-470 tectonophysics, Weddell Sea OP-1446

Tertiary, Prydz Bay OP-1145

Antarctic Peninsula

igneous rocks OP-1995

oceanography OP-263

plate tectonics OP-65

Quatemary OP-1307

stratigraphy $\mathrm{OP}-470$

tectonophysics OP-1446

Antarctic Plate

Chile, plate tectonics OP-586

Pacific Ocean, plate tectonics OP-1651

Antaretica

OP-842; OP-1912

environmental geology OF 91-0014

geochemistry OP-664

geophysical surveys

C 1086; OF 91-0014

Victoria Land OP-610

hydrology OP-949

igneous rocks, Antarctic Peninsula OP-1995 maps YR

mineralogy

Dufek Intrusion OP-275

Pensacola Mountains OP-275

oceanography

Antarctic Peninsula OP-263

South Shetland Islands OP-263 orogeny OP-1395

petrology, Ellsworth Land OP-1027

plate tectonics, Antarctic Peninsula OP-65

Quatemary

C 1086; OP-1630

Antarctic Peninsula OP-1307

Wilkes Land OP-1358

stratigraphy, Antarctic Peninsula OP-470

tectonophysics

OP-1317

Antarctic Peninsula OP-1446

Ellsworth Mountains OP-1446

Marie Byrd Land OP-1446

Tertiary OP-1145

Antelope Peak

sedimentary petrology B 1988-E

Antelope Range

Brachiopoda OP-491

stratigraphy OP-1846

Antelope Valley

geologic hazards WRI 92-4035

ground water OF 93-0148

Quatemary OF 93-0263

Anthozoa see Zoantharia

anthracite

Pennsylvania

OF 92-0568

stratigraphy OF 92-0568

structural geology OF 92-0568

anticlines see also arches.

Alaska

energy sources B 2034-A

petroleum B 2034-A

Califomia

OP-83; OP-1945

energy sources B 2034-A

natural gas B 2034-A

Idaho, Eocene OP-617

Montana

B 1993

energy sources OF 93-0337

Eocene OP-617

natural gas OF 93-0337

Pakistan, coal OF 93-0255; OF 93-0256 
Pennsylvania, energy sources OP-1842

Wyoming

energy sources $\mathrm{OF} 93-0337$

natural gas OF 93-0337

\section{anticlinoria}

New York OP-461

Vermont OP-461

Virginia OP-1612

Antilles see Greater Antilles; Lesser Antilles

antimony

Alaska, pollution OP-66

Utah, mineral resources MF-2081-D; MF2081-E

antimony ores

OF 93-0194

Alaska OP-1433

Antler Deposit

metal ores B 1737-E

Antler Orogeny

B 1917-M

Nevada

B 1988-F; B 1988-G; OP-1846

structural geology OP-999

Antlers Aquifer

ground water WRI 88-4208

Antrim Shale

B 1909

hydrogeology OP-1228

ANWR see Arctic National Wildlife Refuge

Anyloceratina

stratigraphy OP-526

apatite

Antarctica OP-275

Colorado, energy sources OP-518

Missouri, metal ores OP-1327

Montana, petrology OP-604

Nevada, gold ores OP-27

New Mexico, energy sources OP-518

Wyoming, Miocene B 1917-O

apatite ores see phosphate deposits

Apennine Front OP-237; OP-1841

Apennines

Quaternary OP-764

aplite

Oregon, geochemistry OP-42

Apollinaris Patera OP-1831; OP-1832

Appalachian Basin

Carboniferous OP-1232

diagenesis OF 92-0568

energy sources B 1909

hydrogeology OP-1228

natural gas B 1839-I,J; B 1909

Pennsylvanian OP-1357

petroleum B 1909

sedimentary petrology B 1839-I,J; OP-1234; OP-1293

stratigraphy B 1839-K; B 1839-L; B 1909; OF 92-0558; OP-1345; OP-1821

Appalachian Mountains see Appalachians

Appalachian Phase

Appalachians, structural geology OP-1479

geochemistry OF $92-0525$

Gulf Coastal Plain OP-1817

Maine, crust OP-1920

New York, structural geology OP-461

Quebec, crust OP-1920

tectonics OP-1517

Vermont, structural geology OP-461

Appalachians see also Avalon Terrane. areal geology
Great Appalachian Valley B 1994

Valley and Ridge Province B 1994

building stone MF-2215-A

economic geology

Blue Ridge Province B 1979; B 2005

Carolina slate belt B 2039

Piedmont B 1979

Valley and Ridge Province B 1979; B 2005

engineering geology, Valley and Ridge Prov-

ince OP-1542

environmental geology

Catskill Mountains OP-1130; OP-1735

Great Appalachian Valley OP-901

Piedmont OP-658

Valley and Ridge Province OF 92-0568

fluvial features B 1981

geochemistry

Carolina slate belt OP-1607

Piedmont OP-344; OP-917; OP-1774

Valley and Ridge Province B 1839-I,J

geochronology, Piedmont OP-968

geomorphology

B 1981

Piedmont WRI 93-4031

Valley and Ridge Province OF 92-0568 ground water

Blue Ridge Province OP-239; OP-400; OP983; OP-1707; OP-1928

Great Appalachian Valley OP-170

Piedmont OP-239; OP-240; OP-400; OP417; OP-915; OP-983; OP-1100; OP1707; OP-1928

Valley and Ridge Province W 2388; OP983; OP-1707; OP-1928

guidebook, Piedmont OP-359

heavy mineral deposits, Piedmont B 2039

hydrogeology

OF $92-0649$

Piedmont OP-171; OP-918

hydrology

B 1981

Blue Ridge Province OP-1610

Catskill Mountains OP-1734

Piedmont W 2403; C 1086; OP-1875

Valley and Ridge Province OP-1610

intrusions, Blue Ridge Province OP-1106 magmas OP-37

maps OF 93-0024; MF-2223

metal ores B 2039

orogeny, Blue Ridge Province OP-1612

peat I-2364-B

petrology

Blue Ridge Province OP-1002

Piedmont OP-1237

Phanerozoic OP-1493

pollution

Catskill Mountains OP-975

Piedmont OP-403

Proterozoic, Blue Ridge Province B 2029

sedimentary petrology

B 1839-I,J

Valley and Ridge Province OF 92-0568

stratigraphy

OP-1484; OP-1642

Piedmont OP-1380

Shawangunk Mountains B 1839-L

Valley and Ridge Province OP-1988

structural geology

B 1904-Q; OF 93-0025; OP-1147; OP1918

Blue Ridge Province OP-1955

Piedmont OP-1479; OP-1916

zinc ores B 2039
Application Visual System OF 92-0720

Aquia Aquifer

ground water OF 92-0459; OF 92-0463

hydrogeology OP-1196

Aquifer Thermal-Energy Storage

ground water $P$ 1530-A

aquifers see also alluvium aquifers; artesian waters; confined aquifers; leaky aquifers; perched aquifers; recharge; shallow aquifers; surficial aquifers; water resources.

OP-409

Alabama, ground water WRI 91-4121

Appalachians, ground water OP-400; OP-1928

Arizona

ground water OP-1639

structural geology OP-1220

Arkansas

ground water WRI 92-4094; OF 92-0492; OP-1191

hydrogeology OF 93-0150

Atlantic Coastal Plain

ground water $P$ 1404-G

hydrogeology OF 92-0629

California

geochemistry OP-1018

ground water WRI 91-4148; OF 93-0524; OP-72; OP-961

pollution OP-264; OP-473

Colorado

environmental geology OP-1394

ground water WRI 92-4067; OF 92-0122; OF 93-0071

hydrogeology W 2340

Connecticut, ground water WRI 87-4144

Delaware

ground water OF 92-0052

hydrogeology C 1086

engineering geology OP-760; OP-1512

environmental geology OP-548; OP-1411

Florida

geologic hazards YR

ground water W 2340; WRI 91-4168;

OF 92-0471; OF 92-0472; OF 93-0049; OF 93-0050; OF 93-0053; OP-494; OP514

hydrogeology OF 91-0483; OP-2001

waste disposal OP-1531

geochemistry OP-16; OP-44; OP-165; OP-530; OP-605

geologic hazards OP-1052

Georgia

ground water W 2392; WRI 93-4038; OP867

pollution WRI 91-4178

Great Lakes, ground water OP-1354

Great Lakes region, ground water OF 92-0694

ground water B 1989-D; W 1536-C; W 1536-

G; W 2340; WRI 92-4124; OF 92-0477; OF93-0071; OP-209; OP-210; OP-236; OP304; OP-683; OP-684; OP-761; OP-811; OP-1473; OP-1640; OP-1706

Gulf Coastal Plain, ground water WRI 91-4150; WRI 91-4151; WRI 91-4152; WRI 924102; WRI 92-4103; WRI 92-4104; WRI 92-4105; OF 92-0492; OF 92-0661

hydrogeology WRI 91-4196; OF 92-0466

Idaho

environmental geology OF 92-0156 ground water WRI 92-4184; OF 92-0643; OF 93-0034

hydrogeology WRI 93-4001; OF 91-0098; OF 92-0174; OF 93-0102; OP-166 
Illinois

hydrogeology OP-1782

sedimentary petrology OP-1385

Indiana

ground water OF 93-0119; OP-923

sedimentary petrology OP-1385

Iowa

ground water OF 92-0027

pollution OP-588; OP-1981

Kansas, ground water HA-0722-G; HA-0722H; HA-0722-I

Kentucky, hydrogeology OP-1782

Louisiana, ground water OF 92-0492

Maryland, ground water OF 92-0459; OF 920460; OF 92-0461; OF 92-0462; OF 920463; OF 92-0464; OP-1100; OP-1174

Massachusetts

geochemistry OP-215

ground water OF 92-0143; OP-431

pollution OP-1574

Mexico, hydrogeology OP-2001

Michigan, ground water OF 92-0114; OF 930071

Midwest

ground water $P$ 1405-B hydrogeology OP-1228

Minnesota ground water P 1530-A; OP-551 pollution WRI 90-4150

Mississippi, ground water WRI 92-4080

Mississippi Valley, ground water WRI 914150; WRI 92-4102; WRI 92-4104

Missouri, ground water OP-1191

Montana geochemistry OP-637 hydrogeology OP-166

Nevada, ground water WRI 91-4167; OF 910478; OP-269

New Hampshire ground water WRI 90-4161; WRI 91-4025; OF 92-0095 hydrogeology OF 89-0583

New Jersey geochemistry OP-219 ground water OF 92-0052; OP-350 hydrogeology C 1086

New Mexico, hydrogeology OF 93-0144

New York ground water WRI 88-4127; WRI 90-4182 hydrogeology W 2387

North Dakota, ground water OP-1924

Ohio ground water WRI 91-4024; WRI 93-4047; OF 93-0119; OP-1454 hydrogeology WRI 92-4072

Oklahoma, ground water OF 92-0641; OF 930071

Oregon

ground water WRI 90-4085

hydrogeology OF 91-0098

pollution $\mathrm{OP}-471$

Pennsylvania

ground water WRI 92-4194; OP-111; OP547

pollution OP-388

pollution OP-1030; OP-1155; OP-1600; OP1975

Puerto Rico, ground water OF 85-0642

South Carolina

ground water W 2392; WRI 92-4000 hydrogeology OF 91-0483

South Dakota, hydrology W 2340

Spain, ground water OP-1310
Sweden, geochemistry OP-1042

Tennessee ground water WRI 92-4092; OF 92-0135 hydrogeology OP-1283

Texas

environmental geology WRI 92-4117

ground water WRI 92-4155; OF 93-0081; OF 93-0086

hydrogeology OF 92-0160

Utah, hydrogeology W 2340

Virginia

ground water W 2388; WRI 92-4175; WRI 93-4015

Quaternary OF 92-0395

Washington, ground water WRI 90-4085

West Virginia, Quaternary OF 92-0395

Wisconsin, ground water WRI 92-4077; OP1090

Wyoming

geochemistry OP-637

hydrogeology WRI 91-4108

impact statements WRI 90-4154

Ar-40/Ar-39

California, Phanerozoic OP-1340

England, geochemistry OP-158

Far East, economic geology OF 92-0525

geochronology OF 92-0525

Great Britain, economic geology OF 92-0525

Idaho, Eocene OP-617

Mesozoic OP-1494

Mississippi, Oligocene OP-746

Montana, Eocene OP-617

Namibia, meteor craters OP-550

Nevada, geochemistry OF 92-0525

Ontario, petrology OP-214

Pacific Ocean, geochronology OP-813

Peru, geochronology OP-1601

Poland, Carboniferous OP-1917

Russian Federation, Phanerozoic OP-1493

stratigraphy OP-1756

United States, Phanerozoic OP-1493

\section{Ar/Ar}

OP-237; OP-805; OP-1314; OP-1315

Alabama, geochronology OP-968

Alaska

folds OP-1427

geochronology OF 92-0701

Appalachians, structural geology OP-1079

Argentina, structural geology OP-1129

Arkansas, foraminifera OP-1757

California

petrology OP-1691

Phanerozoic OP-1340

structural geology OP-442

China, metal ores OF 92-0525

Colorado, geochemistry OP -490

Connecticut, metamorphic rocks OP-1188

Dominican Republic, stratigraphy OP-1625

Far East, economic geology OF 92-0525

geochronology OF 92-0525

Georgia, geochronology OP-968

Great Britain, economic geology OF 92-0525

Haiti, geochronology B 2065

Idaho

Eocene OP-617

geochronology OP-479

petrology OP-1671

Quatemary OF 92-0408

India, geochronology OP-1346

Indonesia, geochronology OP-1538

Iowa

geochronology OP-475; OP-1613 paleomagnetism OP-1915

Ivory Coast, Quaternary OF 92-0699

lead-zinc deposits OP-12

Maryland, metamorphism OP-1152

Massachusetts, metamorphic rocks OP-1188

Mexico, geochronology OP-920

Mississippi, Oligocene OP-746

Montana

Eocene OP-617

geochronology B 2065

Nevada

geochemistry OF 92-0525

gold ores OP-27

metal ores OP-205

molybdenum ores B 2039

New Mexico

geochemistry OP -490

geochronology OP-1538

Quaternary OF 92-0699

Norway, structural geology OP-1279

Oman, Cretaceous OP-296

Pacific Ocean, Cretaceous OP-1230

Pakistan, structural geology OP-1125

Pennsylvania, geochronology OF 92-0525

petrology OP-1246; OP-1956

Poland

Carboniferous OP-1917

structural geology OP-967; OP-1916

Quebec, gold ores OP-1097

Russian Federation geochronology OP-1407

Precambrian OP-1777

South Dakota, geochronology OP-475

stratigraphy OP-1702; OP-1821

Texas, petrology OP-1611

Utah

metal ores OP-1464

stratigraphy B 1787-BB

Virginia

geochemistry B 1839-I,J

metamorphism OP-1152

orogeny OP-1612

West Virginia, geochemistry B 1839-I,J

Wyoming

Quatemary OF 92-0391; OF 92-0408

structural geology OP-1539

Arabia Regio I-2337; I-2338; I-2339; I-2340

Arabian Gulf see Persian Gulf

Arabian Peninsula see also Oman; Saudi Arabia;

United Arab Emirates; Yemen.

orogeny, Arabian Shield OP-1921

petrology, Arabian Shield OP-1952

tin ores, Arabian Shield OP-499; OP-1558

Arabian Sea see Persian Gulf

Arabian Shield

orogeny OP-1921

petrology OP-1952

tin ores OP-499; OP-1558

aragonite

OP-1452

California, sedimentary petrology OF 92-0707

Florida, Quatemary C 1086

geochemistry OP-1005; OP-1787

Minnesota, sedimentary petrology OP-250

Arapaho National Forest

economic geology B 2035

mineral resources B 2039

Arbuckle Mountains

Ordovician OP-1712

ARC/INFO

maps OP-1945

metamorphic rocks OP-1166 
Arcadia Planitia I-2316; I-2317; I-2318; I-2319

\section{Arcata District}

silver ores OP-1212

Archaean see Archean

Archaeogastropoda

OP-84

Alaska, stratigraphy OP-85

Nevada OP-86

archaeological sites

Quaternary OP-459

archaeology see also artifacts.

Arizona, Quatemary OP-1375

Colorado, Quaternary OP-1676

Archean

OP-168; OP-465; OP-685; OP-1199; OP-1621;

OP-1956; OP-1977; OP-2025

Alaska OP-1416

China OP-1238

Greenland OP-848

J-M Reef, metal ores OF 93-0207

Manitoba OP-1709

Michigan B 1904-P; B 1904-S; I-2355; OP1214; OP-1889

Minnesota B 1904-S; OP-247

Montana OP-604; OP-705; OP-1094; OP-1731

Namibia OP-550

New York OP-1709

Ontario OP-1892

Pacific Ocean OP-105

Quebec OP-1097

Rocky Mountains OP-1716

Wisconsin OP-1214

Wyoming P 1520; OP-149

archeology see archaeology

arches

Alaska, energy sources B 2034-A

Colorado, petroleum OF 93-0337

Midwest, ground water OF 92-0489

Nevada, petroleum OP-614

New Mexico, energy sources OF 93-0522

South Dakota, natural gas OF 93-0337

stratigraphy B 1839-K

Texas

energy sources OF 93-0522

petroleum OF 93-0522

Archosauria see Ornithischia; Saurischia

Archuleta National Forest

mineral resources OF 92-0709

arcs, island see island arcs

Arctic Archipelago

geochemistry OP-721

Mesozoic OP-1680

Quatemary B 2036

Arctic Coastal Plain

energy sources B 2034-A

heat flow OP-253

metal ores OP-1006

Quaternary OP-515

Arctic Data InterActive OP-2008

Arctic Islands see Arctic Archipelago

Arctic National Wildlife Refuge

energy sources OP-268

natural gas OP-74

Arctic Ocean

continental slope, Beaufort Sea B 2002

engineering geology, Beaufort Sea OP-516

Mesozoic OP-1680

oceanography

OP-835

Beaufort Sea OF 93-0019 plate tectonics, Mid-Arctic Ocean Ridge OP1429

Pliocene OP-223

Quaternary

B 2036; OF 92-0426; OF 93-0218; OF 930515; OP-799; OP-1796

Beaufort Sea C 1086; OF 92-0439; OP-515; OP-1225

Canada Basin C 1086

Chukchi Sea OP-299

sea ice C 1086; OF 93-0237

structural geology

OP-1428

Barents Sea OP-1890

tectonophysics

Alpha Cordillera OP-1626

Barents Sea OP-1891

Makarov Basin OP-1626

Mendeleyev Ridge OP-1626

Arctic region see also Canada; Greenland; Jan

Mayen; Svalbard.

continental shelf OP-837

ecology C 1086

energy sources

OP-1284

Arctic Coastal Plain B 2034-A

environmental geology $C 1086$

heat flow, Arctic Coastal Plain OP-253

metal ores, Arctic Coastal Plain OP-1006

Quaternary

C 1086; OF 92-0439

Arctic Coastal Plain OP-515

Svalbard P 1386-E

sedimentary petrology OF 92-0391

tectonophysics, Svalbard OP-1891

Vertebrata OP-163

Arctic Sea see Arctic Ocean

Arctodus simus yukonensis Vertebrata OP-163

areal geology see bibliography; guidebook; maps

Arecibo Puerto Rico

copper ores OF 93-0178; OF 93-0179

arendalite see epidote

arenite

Michigan OP-1495

Saudi Arabia, Proterozoic B 1976

Virginia, mineralogy OP-1755

Ares-Maja Valles I-2311; I-2312; I-2313; I-2314; I-2315

Argentina see also Patagonia.

copper ores OP-2027

geologic hazards OP-1369

structural geology

Mendoza Argentina OP-1129

Neuquen Basin OP-1129

argillization

Nevada, gold ores OP-27

Argo abyssal plain

deformation OP-146

marine geology OP-361

Argo Salt

Mesozoic OP-801

argon

Ar-40/Ar-39

California OP-1340

England OP-158

Far East OF 92-0525

geochronology OF 92-0525

Great Britain OF 92-0525

Idaho OP-617

Mesozoic OP-1494
Mississippi OP-746

Montana OP-617

Namibia OP-550

Nevada OF 92-0525

Ontario OP-214

Pacific Ocean OP-813

Peru OP-1601

Poland OP-1917

Russian Federation OP-1493

stratigraphy OP-1756

United States OP-1493

argon-argon see $\mathrm{Ar} / \mathrm{Ar}$

Argyre Planitia OP-1563

Ariel Satellite OP-1562

Aristarchus OP-1437

Arizona see also Chuar Group; Colorado River, Grand Canyon.

economic geology, Coconino County Arizona OF 93-0329

energy sources OF 93-0248

environmental geology OF 93-0292-I

geochemistry

OP-203; OP-590

Cochise County Arizona B 2021-C

Tucson Arizona OF 92-0599; OP-1505

geologic hazards

C 1086

Pinal County Arizona P 0497-H

geomorphology

OP-426

Coconino County Arizona OP-1060

geophysical surveys

YR

Mohave County Arizona OF 91-0640

Yavapai County Arizona OF 91-0640

geophysics, Cochise County Arizona OP-80 gold ores

Coconino County Arizona OF 92-0591-A; OF 92-0591-B

Mohave County Arizona OF 92-0591-A; OF 92-0591-B

ground water

YR

Coconino County Arizona WRI 90-4105

Mohave County Arizona WRI 90-4105; WRI 91-4185

Pima County Arizona OP-1467; OP-1468

Pinal County Arizona OP-1467; OP-1468; OP-1639

Tucson Basin OP-1468

hydrogeology

Coconino County Arizona OP-645

Gila County Arizona OF 92-0468

La Paz County Arizona OF 92-0083; OF 93 0405

Mohave County Arizona OF 92-0083; OF 93-0405

Yuma County Arizona OF 92-0083; OF 930405

hydrology

W 2400; WRI 92-4060; OF 93-0054; OP-

1044

Pinal County Arizona WRI 92-4133

igneous rocks OP-1112

impact statements

Coconino County Arizona YR

Mohave County Arizona YR

industrial minerals OF 92-0687

maps

Coconino County Arizona MF-2230; I-2290

Mohave County Arizona OF 92-0198; I2198; I-2290 
Tombstone Arizona I-2420

Yavapai County Arizona OF 92-0198; I2198

metal ores

Graham County Arizona OP-9

La Paz County Arizona OF 93-0228; OP290

Maricopa County Arizona OF 93-0228

Mohave County Arizona B 1737-E; OF 930228

Pinal County Arizona B 2042-C; OF 930228

mineral resources, Coconino County Arizona OF 92-0509-A; OF 92-0509-B

natural gas OF 93-0248

Neogene, Mohave County Arizona OP-92

neotectonics, Mohave County Arizona OP-611

petroleum

Apache County Arizona OF 93-0248

Navajo County Arizona OF 93-0248

petrology, Hopi Buttes Field OP-1341

pollution

Apache County Arizona OP-1023

Gila County Arizona OP-591; OP-592

Quaternary OP-976

sedimentary petrology, Coconino County Arizona OF 92-0391

stratigraphy

Apache County Arizona B 1808-O

Gila County Arizona OP-398

structural geology

OP-679; OP-1886; OP-1957

Mohave County Arizona OP-19

Picacho Arizona OP-1220

sulfides, Coconino County Arizona OP-1993

uranium ores $\mathrm{OP}-1617$

volcanism I-2291-A

Arkansas see also Mississippi Embayment; Mississippi River; New Madrid region; Ouachita Mountains; Ozark Mountains; Reelfoot Rift. engineering geology OF 93-0349

foraminifera OP-1757

ground water

WRI 91-4149; WRI 91-4150; WRI 924102; WRI 92-4104; WRI 92-4120; OF 920492; OF 92-0496; OF 93-0096

Union County Arkansas WRI 92-4094 highways WRI 92-4147

hydrogeology

WRI 92-4044; OF 92-0108; OF 93-0048

Arkansas County Arkansas OF 93-0136

Ashley County Arkansas OF 93-0166; OF 93-0167

Carroll County Arkansas OF 93-0150

Clay County Arkansas OF 93-0424

Craighead County Arkansas OF 93-0425

Cross County Arkansas OF 93-0427

Desha County Arkansas OF 93-0428

Drew County Arkansas OF 93-0429

Greene County Arkansas OF 93-0430

Independence County Arkansas OF 93-0431

Jackson County Arkansas OF 93-0432

hydrology

W 2400; WRI 92-4060; WRI 93-4013; OF 91-0485; OF 93-0071

Benton County Arkansas OF 93-0171

Crawford County Arkansas OF 93-0171

Perry County Arkansas OF 93-0070

Pulaski County Arkansas OF 93-0122

Saline County Arkansas OF 93-0122

Scott County Arkansas OF 93-0171

Sebastian County Arkansas OF 93-0171
Washington County Arkansas OF 93-0171

Yell County Arkansas OF 93-0070

Invertebrata

Hempstead County Arkansas OP-525

Washington County Arkansas OP-360

maps SGM

metal ores MF-1835-H

mineral resources

Baxter County Arkansas MF-1994-D

Boone County Arkansas MF-1994-D

Carroll County Arkansas MF-1994-D

Madison County Arkansas MF-1994-D

Marion County Arkansas MF-1994-D

petrology OP-1837

phosphates, Garland County Arkansas OP-681

Quaternary

OF 93-0273; OP-1683

Crittenden County Arkansas OF 93-0273

Phillips County Arkansas OF 93-0273

sedimentary petrology, Mississippi County Ar-

kansas OF 93-0291

sedimentation OP-1529

seismology SM

stratigraphy

OF 93-0199

Clark County Arkansas OP-527

Hempstead County Arkansas OP-527

Howard County Arkansas OP-527

structural geology, Craighead County Arkansas OP-1970

waterways WRI $92-4126$

Arkansas River Basin Compact ArkansasOkJahoma

hydrology OF 93-0171

Arkansas River valley

environmental geology OF 92-0391

hydrogeology OP-408

hydrology OF 93-0171

Arkhangelsk Russian Federation see Novaya Zemlya

Arkoma Basin

sedimentary petrology OP-451

Arlis Fault

plate tectonics OP-1429

Armenia see also Spitak earthquake 1988.

earthquakes OF 93-0216

seismology OF 93-0216

Armenia earthquake 1988 see Spitak earthquake 1988

Arnold Air Force Base ground water OF 92-0135

aromatic hydrocarbons see also benzene; biomarkers; polycyclic aromatic hydrocarbons; toluene; xylene.

Missouri, environmental geology OF 93-0153

New Jersey, geochemistry OP-219

Arrow Canyon Quadrangle

maps OF 92-0681

Arroyo del Mimbral Formation stratigraphy OP-1179

Arroyo Penasco hydrogeology OP-1299

Arroyo Penasco Group stratigraphy $B$ 1787-EE

arroyos

Arizona OP-1060

New Mexico

hydrogeology OP-347

hydrology OF 92-0653

Utah OP-1060 arsenate ion

mineralogy OP-1985; OP-1986

arsenates

OP-336; OP-1058

geochemistry OP-1987

arsenic

Alaska, pollution OP-66

California, geochemistry OP-625

Georgia

oceanography OP-1502

pollution OP-1501

hydrology OP-1836

Missouri, pollution OF 93-0101

New Jersey, environmental geology OF 930243

Oklahoma, geochemistry OP-891

pollution OP-864; OP-948

Utah, mineral resources MF-2081-D; MF2081-E

Artemis Corona OP-1725

artesian waters

Utah, ground water OP-61

Arthropoda see also Mandibulata;

Trilobitomorpha.

Ophiomorpha, New Zealand OP-1391

arthropods see crustaceans; insects; trilobites

Articulata see Strophomenida

artifacts see also archaeological sites.

Quaternary OP-1524

artificial dikes

Nevada, ground water WRI 92-4051

artificial intelligence OF 93-0012

As see arsenic

As Sila United Arab Emirates stratigraphy OP-1453

asbestos

pollution OP-864

asbestos deposits OF 92-0020-B

Ascension Canyon

oceanography OP-1444

Ascraeus Mons OP-1163; OP-1722

ash

Colorado, sedimentary petrology OP-1382

Indiana, sedimentary petrology OF 92-0682

sedimentary petrology OP-1293

West Virginia, sedimentary petrology OP-778

ash falls

Alaska

geologic hazards B 1996

Quatemary OP-1250; OP-1342; OP-1699; OP-1739

Oregon, magmas OP-982

Philippine Islands, geologic hazards WRI 92 4039; OP-726

ash flows

Alaska, geochemistry OP-926

Nevada, geochemistry OP-313

Ash Meadows

geochemistry OP-774; OP-1775

ash-flow tuff

Alaska, geochemistry OP-1770

Colorado

geochemistry OP-1825

geophysical surveys OP-1813

Idaho

OP-1381

Quatemary OF 92-0408

Nevada

OF 93-0021

geochemistry OP-1609 
paleomagnetism OP-863

Quatemary OP-459

Wyoming, Quaternary OF 92-0408

ASHES Field

tectonophysics OP-897

Ashley Formation

Quaternary I-1935

Asia see also Arabian Peninsula; Central Asia; Far

East; Himalayas; Indian Peninsula; Kyrgyzstan;

Middle East; Tadzhikistan.

Cenozoic

Lake Baikal C 1086; OP-2003

Siberia C 1086

energy sources

Lena Basin OP-1967

Siberian Lowland OP-1284; OP-1967

Tunguska Basin OP-1967

geochemistry

Lake Baikal OP-130; OP-1605

Norilsk Russian Federation OP-1086

Sakhalin OP-1412

Siberia OP-1086

geochronology, Siberia OP-134

geologic hazards

Brahmaputra River OF 92-0391

Ganges River OF 92-0391

geomorphology

Brahmaputra River OP-1273

Lake Baikal OP-1291

Siberia OP-1291

geophysical surveys

Baikal rift zone OF 93-0007

Lake Baikal OF 92-0693; OF 93-0007; OP898

Selenga River valley OP-898

Siberian Platform OP-898

geophysics, Siberia OP-136

Invertebrata, Kuril Islands OP-109

Mesozoic, Siberia OP-1494

metal ores

Chukchi Peninsula OF 93-0339

Norilsk region OP-2014

Norilsk Russian Federation OP-1313

Russian Pacific region OF 93-0339

Yakutia Russian Federation OF 93-0339

mineralogy, Tien Shan OP-373

Miocene, Lake Baikal OP-198

oceanography, Kuban River OF 93-0274

Phanerozoic

Aldan Shield OP-1493

Siberia OP-1493

plate tectonics, Karatau Range OP-1295

Quaternary

Lake Baikal C 1086; OP-1208; OP-1334; OP-1492; OP-1532; OP-1604; OP-1763; OP-1764; OP-1874; OP-1904; OP-2004

Siberia C 1086; OP-1208; OP-1334; OP1492; OP-1532; OP-1604; OP-1763; OP1764; OP-1874; OP-1904; OP-2004

Yakutia Russian Federation B 2036

sedimentary petrology

Lena Basin OF 92-0391

Siberia OF 92-0391

Tunguska OF 92-0391

seismology OP-1160

structural geology

Lake Baikal OP-1597

Siberia OP-1597

tectonics, Main Central Thrust OP-1637

Vertebrata

Kolyma River basin B 2037

Siberia B 2037
Yakutia Russian Federation B 2037

Asia Minor see Turkey
asphalt
OP-1260
Alaska, environmental geology OP-564
associations
environmental geology OP-701
hydrology OF 93-0138
Nevada, industrial minerals B 2013
asteroids
OP-857; OP-1583; OP-1879; OP-1883
Iowa, geomorphology OP-1834
petrology OP-1199
Rocky Mountains, diagenesis OP-1792
Western Interior, diagenesis OP-1792
asthenosphere
Alaska, neotectonics OP-1852
Arizona, structural geology OP-1886
Idaho, structural geology OP-941
Japan, neotectonics OP-1852
Mexico, structural geology OP-1886
Minnesota, geochemistry OF 92-0525
Montana, structural geology OP-941
Asuka Meteorite
petrology OP-2025
asymmetric folds
Michigan B 1904-L
ATES
ground water P 1530-A
Athabasca District
metal ores OP-1431
Atitlan Caldera
geomorphology OP-277
Atlanta Georgia
ground water OP-172
The

Atlantic Coastal Plain see also Delaware; Florida; Georgia; Maryland; Massachusetts; Middendorf Formation; New Jersey; New York; New York Bight; North Carolina; Outer Banks; Rhode Island; Salisbury Embayment; South Carolina: Virginia.

ecology OF 93-0303

environmental geology OP-1185

geologic hazards YR; OF 92-0377-A; OF 920377-B

geophysical surveys OF 92-0723

ground water W 2340; WRI 91-4126; WRI 914191; WRI 92-4090; WRI 92-4111; WRI 93-4038; OF 92-0052; OF 92-0459; OF 92-0460; OF 92-0461; OF 92-0462; OF 92-0463; OF 92-0464; OP-671; OP-777; OP-1239; OP-1707

hydrogeology WRI 92-4061; OF 92-0052; OF 93-0069

hydrology WRI 91-4115; OF 92-0123; OF 920498

oceanography OP-1337

Paleogene OP-351; OP-757

palynomorphs OP-1659

Pliocene OF 92-0262

Quaternary OF 92-0263; I-1935

sedimentation OP-1211

seismicity OP-2032

stratigraphy OF 92-0399; OP-950; OP-979; OP-2009

Atlantic Ocean see also DSDP Site 548; DSDP

Site 612; North Atlantic.

continental margin

B 2002

Blake-Bahama Outer Ridge B 2002 continental shelf

MF-2221; OP-483; OP-546

Gulf Stream OP-346

continental slope B 2002

Cretaceous OP-1894

crust, Gulf of Maine OP-1920

ecology, Georges Bank OF 92-0566

engineering geology OP-96

environmental geology OP-1185

geophysical surveys, Mid-Atlantic Ridge

OF 93-0264

heavy mineral deposits OF 93-0341

marine geology OP-822

Mesozoic, Georges Bank OP-801

natural gas OF 93-0230

nodules, Puerto Rico Trench OP-886

ocean floors, Georges Bank I-2279-A

oceanography

DDS-0003; B 2002; OF 92-0717; OF 93-

0214; OP-1131; OP-1502

Blake Plateau OP-1073

Blake-Bahama Outer Ridge OP-1337

Great Bahama Bank OP-1073

Little Bahama Bank OP-1073

paleobotany, Rockall Bank OP-292

Pliocene

C 1086

Cape Verde Atlantic OF 92-0413

Great Bahama Bank OF 92-0508

North Atlantic Deep Water OP-1535

North Atlantic Ridge OF 92-0413

Quaternary

Gulf of Maine OP-749

Long Island Sound OP-1650

sands OF 92-0717

sedimentary petrology

OP-1677

Blake Plateau OP-1931

sedimentation

Georges Bank I-2279-B

Great Bahama Bank OP-928

Long Island Sound OF 92-0550

stratigraphy

Baltimore Canyon Trough P 1542

Georges Bank basin OP-1797

Mid-Atlantic Ridge OP-1484

structural geology, Blake Plateau OP-1132

tectonophysics OP-1080

Atlantic Ocean Islands seealso Bermuda; Canary Islands.

engineering geology, Tristan da Cunha $\mathrm{OP}-443$

Atlantic region

engineering geology OP-96

Atlantic-type margins see passive margins

Atlantis II Deep

brines OP-2029

Atlas Crater OP-1439

atmosphere see also atmospheric precipitation; degassing; paleoatmosphere; sulfur dioxide. OP-107; OP-141; OP-857; OP-1153; OP-1221; OP-1269; OP-1270; OP-1694; OP-1831

Alaska

ecology C 1086

environmental geology C 1086

Quaternary C 1086

Antarctica, environmental geology OF 91-0014

Canada, hydrology C 1086

Colorado, hydrology OF 92-0645; OP-133

ecology C 1086

environmental geology C 1086

hydrology OP-577 
Kansas, environmental geology OP-507; OP729; OP-946

Maryland, geochemistry OP-3

Minnesota, hydrology OF 93-0127

Nevada, hydrology OP-448

paleomagnetism C 1086

pollution C 1086

Quatemary OP-55

soils C 1086

United States, hydrology C 1086

Wyoming, Quaternary OP-711

atmospheric precipitation see also acid rain.

Alaska

geologic hazards OP-1708

hydrology W 2400

Quaternary OP-1507

Atlantic Coastal Plain, pollution OP-1458

California

ground water OP-995

hydrogeology OP-256

hydrology C 1086

Quatemary OP-1897

Colorado

hydrogeology OP-300

hydrology OP-559

Greenland, Quaternary OP-1507

ground water OP-1514

Hawaii, geomorphology OP-782

hydrogeology OP-772

hydrology C 1086; OF 93-0056; OP-1044

Illinois, hydrology OF 92-0485

Midwest, pollution OF 93-0418

Minnesota, hydrology OF 92-0475

Mississippi Valley, geologic hazards C 1120-B

Nevada

ground water OP-995

hydrogeology OF 90-0153

New England, pollution OF 93-0418

New York, geochemistry OP-776

North Carolina, hydrology OF 92-0498

North Dakota, hydrogeology WRI 92-4110

Oregon, hydrology WRI 92-4108

Philippine Islands, geologic hazards OP-781

Puerto Rico, hydrology W 2400

South Dakota, hydrology W 2340

Vermont, hydrology C 1086

Virginia, hydrology B 1981

West Virginia, hydrology B 1981

Wisconsin, hydrology WRI 90-4126

Wyoming, geochemistry OP-712

Atoka Formation

sedimentary petrology $\mathrm{OP}-451$

Texas OF 93-0522

atolls.

Canary Islands, engineering geology OP-443

Marshall Islands, ground water OP-26

Micronesia, ground water OP-26

atomic absorption

geochemistry B 1770; B 2046; OP-675

atomic force microscopy

geochemistry OP-1554; OP-1737

sedimentary petrology $\mathrm{OP}-1352$

atoms OF 91-0014

atrazine

lowa, ground water OF 92-0085

Kansas

environmental geology OP-4 geochemistry OP-5

Midwest, pollution OF 93-0418

Minnesota

ground water OF 92-0085 pollution OF 93-0042; OF 93-0043; OF 930079

pollution OP-816

attenuation

elastic waves OP-220

engineering geology $\mathrm{OP}-67$

Florida, marine installations OP-892

geophysical surveys OP-1054

Hawaii, engineering geology B 2006

Indonesia, engineering geology OP-993

Nevada, petroleum OP-614

seismology OP-1064

structural geology OP-401

Au see gold

augite OP-233

Augusta Maine

geochemistry OP-750

Augustine

geologic hazards YR

geophysical surveys B 1966

volcanology OP-349

Aurora Deposit

economic geology OP-834

Austin Quadrangle maps I-1420 (NH-14)

Australasia see also Australia; New Zealand; Papua New Guinea. stratigraphy B 2050

Australia see also New South Wales Australia; Northem Territory Australia; Queensland Australia; South Australia; Victoria Australia; Western Australia.

energy sources OP-1624

Invertebrata OP-1839

metal ores C 0930-M; C 0930-N

sedimentary petrology OP-1478

Austria

Quaternary P 1386-E; OP-386

automatic cartography see digital cartography

automatic data processing see data processing

avalanches see debris avalanches

Avalon Terrane

structural geology OP-1079

Averitt, Paul

energy sources $\mathrm{OP}-440$

AVIRIS

copper ores B 2039

geophysical surveys OF 91-0449-G; OP-227; OP-543; OP-1402

Avon Park Formation

hydrogeology W 2340

Avra Valley Aquifer

ground water OP-1467; OP-1468

A VS OF 92-0720

Axemann Limestone

ground water OP-111

Axial Seamount

tectonophysics OP-897

Ayrshire Scotland

geochemistry OF 93-0267

azurite

Arizona OP-1993

\section{B}

B see boron

B horizon

metal ores OF 92-0615

soils OF 92-0721
B-11/B-10

geochemistry OP-763; OP-1942

metal ores OP-942

Ba see barium

Babine Intrusion

copper ores OP-273

Bachelor Caldera

metal ores P 1537

stratigraphy OP-985

Bachelor Mountain Member stratigraphy OP-985

Bacillariophyta Quatemary OF 93-0289

back-arc basins

Antarctica, igneous rocks OP-1995

Arizona, geochemistry OP-203

Bering Sea, deformation OP-211

Costa Rica, structural geology OP-785

Mariana Islands, plate tectonics OP-14

Micronesia, plate tectonics OP-14

Nevada, structural geology OP-933

Oregon, magmas OP-1139

Pacific Ocean, plate tectonics OP-413

Panama, structural geology OP-785

Papua New Guinea, economic geology OP-639

Saudi Arabia, Proterozoic B 1976

bacteria

OP-409

Alaska, gold ores OP-1057

Arkansas, hydrology OF 93-0070

Atlantic Coastal Plain, ground water OP-1239

Colorado, pollution OP-1968

geochemistry OP-608; OP-1426

Greenland, Archean OP-848

ground water OP-154; OP-1473

Idaho, hydrogeology OF 93-0102

Nevada, pollution OP-1765

New Hampshire, geochemistry OP-1207

Ohio, environmental geology WRI 92-4130

Washington, hydrology WRI 91-4073

Wyoming, geochemistry OP -49

Baculites

Colorado, stratigraphy B 2024

Texas, stratigraphy OP-177; OP-526

baddeleyite

Minnesota, geochronology OP-758

Montana, petrology OP-604

Bagdad Quadrangle geophysical surveys OF 91-0640

Bahama Platform see Blake Platean

Bahamas

Quaternary OP-706

sedimentation OP-928

structural geology, Tongue of the Ocean OP1132

Baid al Jimalah Deposit metal ores OP-1559

Baikal (Lake) see Lake Baikal

Baikal rift zone geophysical surveys OF 93-0007

Baird Mountains Quadrangle metal ores B 2003

Baja California

energy sources OP-1657

metal ores B 2039

Quaternary OP-707

structural geology OP-1547

Baja California Mexico see also Cerro Prieto. Quaternary OP-707 
Baja California Sur Mexico Invertebrata OP-1800 Quaternary OP-707

Baker Terrane guidebook OP-87

Bakken Formation petroleum B 1909

Baksan River magmas OP-91

Balcones fault zone ground water OP-1675

Bald Knob Basin Quatemary OP-1309

Balder Formation stratigraphy OP-1359

balls, coal see coal balls

Baltic Shield ground water OP-1039

Baltimore Canyon Trough stratigraphy P 1542

Baltimore Maryland engineering geology OF $92-0541$ environmental geology OP-1089

Baluchistan Pakistan tectonophysics OP-1548

banded iron formations see iron formations

Bangladesh see Brahmaputra River, Ganges River

Banning Fault structural geology OP-649

Bannock Peak Limestone stratigraphy OP-1320

Bannock Range stratigraphy OP-1320

Bara Formation coal OF 92-0281; OF 93-0255; OF 93-0256 stratigraphy OF 92-0517

Baraga Group structural geology B 1904-Q

Barataria Bay hydrogeology OF 92-0492

Barbados Quatemary OP-706

Barcelona Spain ground water OP-1310; OP-1449

Bare Mountain sedimentary petrology OP-1795 structural geology OP-1400

Barents Sea structural geology OP-1890 tectonophysics OP-1891

barite

OP-1752

California, orogeny OP-797

Idaho, orogeny OP-797

Mexico, Paleozoic OP-56

barite deposits

B 2003; OP-170; OP-853; OP-960; OP-1257

Alaska OF 93-0215

Califomia OP-260

Mexico OP-796

Nevada OP-260; OP-531

barium

Utah,mineral resources MF-2081-C;MF-2081-

barometry, geologic see geologic barometry

Barre Granite fractures OP-1026

Barrel Springs Formation petrology OP-1611 barrier bars see longshore bars

barrier islands

engineering geology OF 92-0722

Gulf Coastal Plain

geomorphology OF 92-0530

Quaternary OF 92-0530

Gulf of Mexico, Quatemary OF 92-0530

Louisiana

conservation OF 92-0530

engineering geology OF 92-0530

environmental geology OF 92-0530

geologic hazards YR; OF 92-0530; I-2150-

A

geomorphology OF $92-0530$

sands OF $92-0530$

sedimentary petrology OP-262

sedimentation OF 92-0530

Massachusetts, Quaternary OP-749

North Carolina, geologic hazards P 1177-B

Barro Colorado Nature Monument weathering C 1086

Barrow Arch

energy sources B 2034-A

bars see also longshore bars; point bars.

Arizona, fluvial features OP-947

Arkansas, fluvial features OP-1700

Missouri, fluvial features OP-1700

Montana, sedimentary petrology B 1917-L

Wyoming, sedimentary petrology B 1917-L

Bartlett Mountain

molybdenum ores OP-1050

Bartletts Ferry fault zone structural geology OP-1918

basaltic domes see shield volcanoes

basalts see also alkali basalts; flood basalts; lava; mid-ocean ridge basalts; tholeiite; tholeiitic basalt.

OF 92-0020-G; OP-478; OP-783; OP-1806;

OP-1841; OP-2025

Alaska

geochronology OF 92-0701

stratigraphy OP-1169

California, stratigraphy OP-1281

Cameroon, geologic hazards OP-903

Chile, Quatemary OP-279

Greenland OP-636

Hawaii

OP-1001

geochemistry OP-1997

Iceland

geochemistry OP-511; OP-1997

stratigraphy OP-1303

Idaho

hydrogeology OF 91-0098; OP-1654

Quaternary OP-452

India, geochronology OP-1346

Michigan

copper ores OP-2019

geochemistry OP-1747

New Jersey

OP-1003

geochemistry OF 93-0010

Oregon

ground water WRI 90-4085

hydrogeology WRI 91-4087; OF 91-0098

sedimentary petrology OP-1134

Philippine Islands OP-1768

Russian Federation, metal ores OP-2014

tectonics OP-137

Virginia geochemistry B 1839-I,J

Washington, ground water WRI 90-4085

West Virginia, geochemistry B 1839-I,J basanite

Alaska, geochemistry OP-242

basculating faults see wrench faults

base flow

New York, hydrogeology WRI 90-4205

base metals see also copper ores; zinc ores.

OP-853

California, orogeny OP-797

Colorado P 1537; OF 93-0183; OP-582; OP944; OP-1633

Idaho, orogeny OP-797

Mexico B 2039

Nevada OP-79

Spain OP-31

Utah OP-394

Wyoming I-2232

baseline studies

Alaska, geochemistry OF 93-0014

South Carolina, ecology OF 93-0303

BASIC

OF 92-0369-A; OF 92-0369-B

geomorphology OF 93-0546

Basin and Range Province see also Arizona: Great Basin; Idaho; Nevada; New Mexico; Utah. earthquakes OP-905

environmental geology B 2013

industrial minerals B 2013

metal ores OP-965; OP-1464

natural gas OF 93-0248

Neogene OP-92

neotectonics OP-611

non-metal deposits B 2013

petroleum OF 93-0248

petrology OP-1381

plate tectonics OP-759; OP-1903

Quaternary OP-52; OP-618; OP-620; OP-908; OP-910; OP-911; OP-1021; OP-1022; OP 1897

structural geology B 2011; OP-19; OP-108 OP-619; OP-718; OP-769; OP-773; OP-909

\section{basin range structure}

Arizona, neotectonics OP-611

Basin and Range Province, structural geology OP-19

Colorado Plateau, structural geology OP-19

Nevada, structural geology OP-108

basin, structural see basins

Basin-Margin Anticline natural gas OP-449

basin-range structure see basin range structure

basins see also back-arc basins; basin range structure; fore-arc basins; foreland basins; intermontane basins; pull-apart basins.

OP-237; OP-366; OP-416; OP-906; OP-1485; OP-1647

Alaska

heat flow OP-253

natural gas B 2034-A

petroleum OP-492

Appalachians

ground water OP-1928

sedimentary petrology B $1839-\mathrm{I}, \mathrm{J}$

structural geology OP-1479

Arizona, Neogene OP-92

Atlantic Coastal Plain, Paleogene OP-757

Australia, metal ores OP-1431

California

continental margin I-2090-A; I-2090-B

earthquakes OP-329

energy sources B 2034-A; OF 89-0450-D; OF 92-0383 
geologic hazards OP-221 ground water OP-961 petroleum B 2034-A

Canada

Devonian OF 93-0184

metal ores OP-1431

palynomorphs B 1909

China, natural gas OF 93-0004

Colorado

energy sources OP-1753

natural gas OF 92-0524

petroleum OF 93-0337

sedimentary rocks B 1787-DD

Commonwealth of Independent States, energy sources OP-1261

energy sources B 1909

Europe, energy sources OP-1261

geochemistry OP-533

Great Plains, energy sources OF 93-0337

Gulf of Mexico, structural geology OP-1932

hydrology OP-1036

Idaho, Eocene OP-617

Kentucky, energy sources B 1909

Massachusetts, Mesozoic OP-801

metal ores OP-853

Michigan, sedimentary petrology OF 93-0236

Midwest, ground water OF 92-0489

Mississippian B 1909

Montana

I-2380-A

Eocene OP-617

sedimentary petrology B 1917-L

stratigraphy OP-1744; OP-1798

Triassic B 1917-P

natural gas B 1839-I,J; B 1909; OF 92-0524; OF 93-0337

Nevada

Neogene OP-92

sedimentary petrology B 1988-E

stratigraphy B 1988-C; B 1988-D; B 1988F; B 1988-G

New Jersey, Triassic MF-2208

New Mexico

energy sources OF 93-0522

petroleum OF 93-0337; OF 93-0522

New York

ground water WRI $91-4012$

stratigraphy B 1839-L

Triassic MF-2208

North Dakota, stratigraphy OF 93-0335

Pacific Coast, energy sources B 2034-A

Pacific Ocean, petroleum OP-1829

petroleum B 1909; B 2048

Poland, structural geology OP-967

Rocky Mountains

energy sources OF 93-0337

natural gas OP-1350

Russian Federation

energy sources OP-1967

geophysical surveys OP-898

Phanerozoic OP-1493

seismology OP-959

South Dakota, stratigraphy OF 93-0335

stratigraphy B 1808-O; B 1909; B 1917-M

tectonics OP-137

Texas

energy sources OF 93-0522

petroleum OF $93-0522$

United Kingdom, sedimentary petrology OF 93-0236

United States

Devonian OF 93-0184

palynomorphs B 1909
Phanerozoic OP-1493

Utah

sedimentary petrology B 2000-E

sedimentary rocks $\mathrm{B}$ 1787-DD

structural geology B 1787- $\mathrm{HH}$

West Virginia, energy sources B 1909

Western U.S., energy sources OF 92-0524

Wyoming

I-2380-A

geophysical surveys OF 93-0002

sedimentary petrology B 1917-L

stratigraphy OP-1744

Triassic B 1917-P

Basins and Arches region

ground water OF 92-0489; OF 93-0119; OP1648

basins, drainage see drainage basins

BASIX

geophysical surveys OF 93-0276; OF 93-0301

bastnaesite see rare earth deposits

bastnasite see bastnaesite

batholiths

OP-596; OP-1246

Alaska OP-1195

British Columbia, copper ores OP-273

California

OP-1146; OP-1691

geochemistry OP-182; OP-678

geochronology OP-333

Colorado, Proterozoic OP-10

Ecuador, gold ores B 2039

Idaho

OP-630

gold ores B 2039

Montana, copper ores OP-273

Nevada, economic geology B 2039

Pacific Ocean OP-105

Vermont OP-37

Washington I-1963

Bathonian

Califomia OP-385; OP-1413

bathymetric maps

Atlantic Ocean, ocean floors I-2279-A

California, continental margin I-2089-C; I2090-B; I-2090-C

Hawaii, oceanography MF-2231; MF-2233

New Jersey, continental shelf MF-2221

North Carolina

continental margin MF-2209

geomorphology WRI 93-4031

Baton Rouge Louisiana

environmental geology C 1120-C

Battle Mountain

geochemistry OF 92-0525

gold ores OP-921; OP-994

molybdenum ores B 2039

Battle Mountain-Eureka mineral belt

metal ores OP-627

Bavaria Germany see Ries Crater

Baxter Shale sedimentary petrology B 2051

Bay Area Seismic Imaging Experiment geophysical surveys OF 93-0276; OF 93-0301

Bayan Obo Deposit

metal ores OF 92-0525; OP-153; OP-1238

metasomatism OP-1343

Bayfield Group

stratigraphy B 1989-E

Bayhorse District

geochemistry OP-912

tungsten ores OP-1296
Baynunah Formation

stratigraphy OP-1453

Bayou d'Inde

geochemistry OP-935

Bayou Grand Caillou

shore features OF 92-0530

bayous

Gulf Coastal Plain, environmental geology OF 92-0530

Bayport Limestone

ground water WRI 91-4133

bays

engineering geology OF 92-0722

Be see beryllium

Be-7

North Carolina, geochemistry OP-1684

$\mathrm{Be}-9 / \mathrm{Be}-10$ see $\mathrm{Be}-10 / \mathrm{Be}-9$

Be-10

Appalachians, stratigraphy OP-1380

Arkansas, Quaternary OP-1683

geomorphology OP-1750

Mississippi Valley, Quaternary OF 93-0273

Tennessee, Quatemary OP-1683

Be-10/Al-26

meteor craters OP-550

Be-10/Be-9

California, geochemistry OP-1018 pedogenesis $\mathrm{OP}-48$

beaches see also shorelines.

Alaska, environmental geology OP-564

Arizona, hydrology OF 93-0071

Louisiana, sedimentary petrology OP-262

Mexico, hydrogeology OP-38

Pacific Coast, Quaternary C 1086

Puerto Rico OF 92-0717

Bear Canyon-Toponce Subplate structural geology OP-523

Bear Island Granodiorite metamorphism OP-1152

Bear River

hydrogeology $\mathrm{OP}-425$

Bearpaw Mountain maps OF 93-0220

Beartooth Mountains

areal geology OF 93-0207

bibliography OF 93-0285-A; OF 93-0285-B

coal OF 93-0207

crust OP-2017

economic geology OF 93-0207

metal ores OF 93-0207

mineral resources OF 93-0207; OF 93-0505

petroleum OF 93-0207

petrology OP-604; OP-1456; OP-1716

Beatty Nevada

waste disposal WRI 92-4032; OF 92-0484

Beaufort Gyre oceanography OF 93-0019; OP-835

Beaufort Sea

continental slope B 2002

engineering geology OP-516

oceanography OF 93-0019

Quatemary C 1086; OF 92-0439; OP-515; OP1225

Beaverhead Formation stratigraphy OF 92-0391

Beaverhead Mountains structural geology OP-941

bed forms see bedforms

bed-load see bedload

bedded volcano see stratovolcanoes 
bedding

California, manganese ores OP-458

Ohio OF 92-0558

bedding faults

California, seismology OP-1794

bedding plane irregularities see dune structures;

flute casts; ripple marks

bedding structures, planar see planar bedding structures

Bedford Shale

B 1909

hydrogeology OP-1228

bedforms

sedimentary petrology OP-1717

South Carolina, continental shelf OP-346

bedload

Alaska, hydrology OF 93-0162

Colorado, hydrogeology OP-300

hydrogeology OP-24

hydrology OF 92-0651

Mississippi, hydrology OF 92-0469

Mississippi Valley, hydrology OF 91-0485

sedimentary petrology OP-1717

Wisconsin, hydrology WRI 90-4124

Wyoming, hydrology OF 93-0142

Beekmantown Group

environmental geology OP-901

ground water OP-111

Behrendt Mountains petrology OP-1027

beidellite

Wyoming, diagenesis OP-1950

Belau geochemistry OP-59; OP-1150

Belgian Congo see Zaire

Bell Canyon Formation OP-354

Bell Pass Melange

stratigraphy OP-1480

Bellamy River basin ground water WRI 90-4161 hydrogeology OF 89-0583

Belle Fourche River environmental geology OP-641

Belle Fourche Shale stratigraphy OP-1798

Bellefonte Dolomite ground water OP-111

Bellerophontacea

Invertebrata OP-86 stratigraphy OP-85

Bells Canyon Quatemary OP-910

Beloc Formation geochronology B 2065

Beloc Haiti

petrology OP-1873 stratigraphy OP-1414

Belt Basin geochemistry OP-1094

Belt Supergroup structural geology P 1524; B 1993

belts, fold see fold belts

belts, greenstone see greenstone belts

Beluga Formation

energy sources B 2034-A

Bemidji Minnesota

pollution OP-430; OP-629; OP-1526

bench marks

geophysical surveys B 1966
Bend Arch

petroleum OF 93-0522

Bend Oregon Quaternary OP-1404

Bendeleben Quadrangle metal ores MF-1838-D

Benioff zone

Alaska, seismology OP-1384

tectonophysics OP-1585

bentonite

OP-89; OP-1352; OP-2000

environmental geology OP-1898

Haiti, geochronology B 2065

Mississippi, Oligocene OP-746

Montana, geochronology B 2065 stratigraphy OP-1702

benzene

environmental geology OP-1898 pollution OP-1128

Beowawe Geysers thermal waters B 1998

Berea Sandstone

B 1909

energy sources OP-1751

frost action OP-389

Berenguela Bolivia metal ores B 2039; OF 93-0016; OP-1306

Bergen Norway petrology OP-1173

Bering Glacier geologic hazards YR hydrology C 1086

Quatemary C 1086; OF 93-0266; OP-1719

Bering land bridge see Beringia

Bering Sea

deformation OP-211

engineering geology, Navarin Basin OP-140

geochemistry, Navarin Basin OP-242

oceanography

B 2002

Norton Sound OP-129

plate tectonics OP-1859

Quaternary OP-515

seismology OP-1

Bering Sea earthquake 1991 seismology OP-1

Bering Strait Invertebrata OP-1681

Beringia

Alaska

engineering geology OP-140

oceanography B 2002

Quatemary OP-33; OP-299

Bermuda

Quatemary OP-706

Bernard Formation guidebook OP-87

Bernardsville Quadrangle geochemistry OF 93-0010

bernstein see amber

berthierine

Ontario

OP-1892

polymetallic ores OP-484

Berthoud Plutonic Suite

Proterozoic OP-10

Berwind Field

energy sources OP-1751

beryllium

Be-7, North Carolina OP-1684
$\mathrm{Be}-10$

Appalachians OP-1380

Arkansas OP-1683

geomorphology OP-1750

Mississippi Valley OF 93-0273

Tennessee OP-1683

$\mathrm{Be}-10 / \mathrm{Be}-9$

California OP-1018

pedogenesis OP-48

Utah, mineral resources MF-2081-C; MF-2081E

beryllium ores B 2013

Bethel Quadrangle

geochemistry OF $92-0582$

intrusions OP-1401

maps MF-2226-A

mineral resources OF 92-0315; OF 92-0379-A; OF 92-0379-B; OF 92-0380-A; OF 92 0380-B

pollution $\mathrm{OP}-66$

sedimentation OP-1186

BHTV see borehole televiewers

Bi see bismuth

Bi'r Idamah Quadrangle maps OP-371; OP-372

bibliography see also biography.

CAT; OF 93-0516; OF 93-0575

Alaska

OF $92-0596$

economic geology C 1091; C 1094

hydrogeology C 1081

metal ores OF 93-0339

metamorphic rocks $P$ 1497-C

petroleum OF 93-0330

waste disposal OF 92-0502

Appalachians, economic geology B 1979

Arkansas, stratigraphy OF 93-0199

Atlantic Coastal Plain, stratigraphy P 1542

California, economic geology B 2019

Canada, metamorphic rocks P 1497-C

economic geology OF 92-0020-B

geochemistry OF 93-0001-B

geomorphology OF 93-0262-A; OF 93-0262B; OF 93-0262-C

geophysical surveys OF 92-0390-A; OF $92-$ 0390-B; OF 92-0579-A; OF 92-0579-B; OF 92-0579-C; OF 93-0323; OP-807

Georgia, hydrology OF 93-0055

Hawaii, environmental geology OF 93-0512-A

hydrogeology OF 93-0106

hydrology WRI 92-4095

Illinois, hydrology OF 92-0451; OF 92-0452

marine geology OF 92-0585

metal ores OF 93-0208-A; OF 93-0208-B

Michigan

ground water OF 92-0114

hydrogeology OF 92-0157

mineral resources OF 92-0557

Missouri, hydrogeology OF 92-0626

Montana

OF 93-0285-A; OF 93-0285-B

mineral resources $\mathrm{C} 1088$

Triassic B 1917-P

Nevada, economic geology B 2019

New Mexico, hydrogeology OF 93-0144

New York, hydrogeology OF 92-0473

Nicaragua, mineral resources OF 92-0547

Oklahoma, stratigraphy OF 93-0199

petroleum OF 93-0012

pollution OF 92-0494; OF 92-0527

Puerto Rico, hydrogeology C 1081

Russian Federation, metal ores OF 93-0339 
South Carolina, hydrogeology OF 93-0035 stratigraphy B 1917-M

Utah, geologic hazards P 1519

Virginia, Phanerozoic OF 93-0222

Washington hydrology OF 91-0453

Quaternary OF 93-0289

Wisconsin, hydrogeology OF 93-0129

Wyoming, Triassic B 1917-P

Bidahochi Formation

petrology OP-1341

Biederman Argillite

sedimentary petrology OP-1553

Big Basin Redwoods State Park seismology P 1550-C

Big Bear earthquake 1992 earthquakes EV; OP-90; OP-406

Big Belt Mountains earthquakes YR

Big Blue River basin pollution OF 93-0087

Big Branch Wilderness economic geology B 1955

Big Horn Basin see Bighom Basin

Big Horn Mountains see Bighom Mountains

Big Spring basin pollution OP-588

Big Springs Quadrangle maps I-2290

Big Ten Peak Caldera volcanism OF 93-0021

Big Thompson Canyon Cretaceous OP-11

Big Timber Stock maps MF-2253

Bighorn Basin natural gas OF 93-0337; OP-449 neotectonics OP-780 sediments OP-556 stratigraphy OP-98

Bighorn Dolomite hydrogeology WRI 91-4044 Invertebrata OP-860

Bighorn Mountains crust OP-2017 petrology OP-1456

Bighorn Uplift diagenesis OP-395

Billefjorden fault zone structural geology OP-1890

Binnewater Sandstone stratigraphy B 1839-L

bioclastic sedimentation Antarctic Ocean OP-263 Arctic Ocean, Quaternary OF 92-0426

biodegradation see also biomarkers. OP-154; OP-1128; OP-1383; OP-1426; OP1477; OP-1478

biogenic structures see bioherms; bioturbation; lebensspuren; stromatolites

biogeochemical methods mineral resources OF 90-0506

biogeography

Alaska

Invertebrata OP-1681

stratigraphy OP-85

Trilobita OP-1123

Antarctic Ocean, stratigraphy OP-470

Arctic Ocean, Pliocene OP-223

Midwest, Quaternary OP-1896
Nevada

Brachiopoda OP-491

Invertebrata OP-86

stratigraphy B 1988-F

Permian OP-1982

Peru, stratigraphy OP-1330

Quaternary C 1086

Russian Federation, Brachiopoda OP-491 stratigraphy OP-8

biography

OP-444

energy sources OP-374; OP-440

Invertebrata OP-283

Mexico, geologic hazards OF 93-0197-A

Missouri, geologic hazards C 1083

paleontology OP-422

Russian Federation, Vertebrata B 2037

structural geology OP-117

bioherms

Nevada, stratigraphy OP-1846

biologic evolution see also cladistics; life origin; radiation.

Alaska, Invertebrata OP-1681

Arctic region, Invertebrata OP-1839

Atlantic Coastal Plain paleontology OP-1205 stratigraphy OP-2009

Far East, Invertebrata OP-1839

Gulf Coastal Plain paleontology OP-1205 stratigraphy OP-2009

stratigraphy GN

Texas, Conodonta OP-1622

biological degradation see biodegradation

biological zones see biozones

biomarkers

Alaska, energy sources OP-626

California, energy sources OP-1255

Colorado, energy sources OP-674

Commonwealth of Independent States, petroleum OP-1265

Europe, petroleum OP-1265

geochemistry OP-183

New Mexico, energy sources OP-674

Wyoming, petroleum OP-1767

biomechanics

Vertebrata OP-1511

biomes

geophysical surveys OF 91-0014

biometry

Alaska, Vertebrata OP-163

Arkansas, Invertebrata OP-360

Oklahoma, Invertebrata OP-360

Vertebrata OP-1511

Washington, Quaternary OF 93-0289

Western Interior, Invertebrata P 1533

biopelite see black shale

bioremediation

Colorado, pollution OP-1968

pollution OP-1665

blestratigraphy see also algal flora; ammonoids; amphibians; biozones; bivalves; brachiopods; conodonts; corals; diatom flora; dinoflagellates; fish; foraminifers; fusulinids; gastropods; graptolites; mammals; miospores; mollusks; nannofossils; ostracods; paleoecology; palynomorphs; plants; radiolarians; reptiles; silicoflagellates; trilobites; vertebrates.

GN; OP-1756

Arkansas

$\mathrm{OP}-360$
Quaternary OF 93-0273

California OP-469

Celebes Sea, marine geology OP-823

Melanesia, marine geology OP-192

New Mexico OP-573

Oklahoma OP-360

Russian Federation B 2037

South America OP-97

Tennessee, Quaternary OF 93-0273

Texas OP-526; OP-1622

Vanuatu, sedimentation OP-188

biotite

Alabama, geochronology OP-968

Alaska

folds OP-1427

geochronology OF 92-0701

Bolivia, metal ores B 2039

California, stratigraphy B 2015

Ecuador, gold ores B 2039

England, geochemistry OP-158

Georgia, geochronology OP-968

Poland, Carboniferous OP-1917

Quebec, gold ores OP-1097

Russian Federation, Precambrian OP-1777

bioturbation

Arctic Ocean, Quatemary OF 92-0426; OP1796

Mississippian B 1909

Pacific Ocean, geochemistry OP-519

West Virginia, Pennsylvanian OP-1357

biozones

Arkansas

Invertebrata OP-525

stratigraphy OP-527

Atlantic Coastal Plain, stratigraphy OP-950

Atlantic Ocean, Pliocene OF 92-0508

Colorado

Paleogene B 1787-Q

palynomorphs OF 92-0391

stratigraphy B 2024

Indiana, stratigraphy OP-1845

Mississippi, Oligocene OP-746

Nevada

Brachiopoda OP-491

Invertebrata OP-86 petroleum OF 92-0391

New Jersey, stratigraphy OP-979

Ordovician OP-1819

Pacific Ocean, marine geology OP-819

Russian Federation, Brachiopoda OP-491

South Carolina, stratigraphy B 2030

stratigraphy OP-88; OP-528; OP-1245

Texas, stratigraphy OP-177

Utah, Paleogene B 1787-Q

Birch Creek Piuton petrology OP-1148

Birch Hill Field energy sources OP-626

birds

Utah, ecology WRI 92-4084

Biscayne Aquifer geologic hazards YR ground water OP-671

Biscayne Bay Quatemary OP-1930

Bishop Tuff

OP-1538

geochemistry OP-954

Quaternary OP-1843

Bismarck Archipelago see also Rabaul Caldera. gold ores B 2039 
bismuth

Utah, mineral resources MF-2081-D; MF2081-E

bitter spar see dolomite

bitumenite see torbanite

bitumens

Alaska OF 92-0391

asphalt

OP-1260

Alaska OP-564

Canada, palynomorphs B 1909

Colorado OP-1753

Gabon, geochemistry OP-713

United States, palynomorphs B 1909

bituminous coal

OP-1244; OP-1477; OP-1822; OP-1823

Australia OP-1478

Colorado OP-850; OP-1382

Indiana OF 92-0682

Indonesia OP-1478

Nova Scotia OP-1673

bituminous sands see oil sands

bituminous shale see black shale

bivalves

Atlantic Coastal Plain, stratigraphy OP-2009

California

environmental geology OF 92-0456

hydrogeology OF 93-0146

Quaternary OF 93-0286

stratigraphy $P 1521$

Gulf Coastal Plain, stratigraphy OP-2009

Oregon, stratigraphy P 1521

pollution OP-297

South Carolina, stratigraphy B 2030

Bivalvia see also Glycymeris; Ostreacea; Pteriina.

Arctic region OP-1839

Far East OP-1839

Black Canyon Arizona inclusions OP-1748

Black Creek Aquifer ground water WRI 92-4000; OP-1202

Black Creek Formation OP-950

Black Fork geomorphology B 1981

black lead see graphite

Black Mountain

geologic hazards OP-1793

phosphates OP-115 .

Black Pine Range stratigraphy OP-1320

Black Prince Mine metal ores OP-942

Black River hydrology WRI 90-4124

Black Sea

geochemistry OP-1331

oceanography OF 93-0274

Quaternary C 1086

black shale

Alaska, petroleum B 2034-A

Atlantic Ocean, Cretaceous OP-1894

Canada, palynomorphs B 1909

Carboniferous OP-1232

China

geochemistry OF 92-0525

metal ores OP-363; OP-1432

Colorado

OP-1961

natural gas OP-1262

petroleum OF 92-0391 energy sources B 1909

Kentucky

OF 92-0558

energy sources B 1909

Maine, geochemistry OP-750

metal ores OP-362; OP-714

Mississippian B 1909

natural gas B 1909

Nebraska, geochemistry OF 92-0592

Nevada, gold ores OP-624

New York, natural gas B 1909

Ontario, Devonian B 1909

Pacific Ocean, Cretaceous OP-1894

Pennsylvanian OP-1233

Peru, geochemistry OP-1331

petroleum B 1909

Rocky Mountains, Pennsylvanian OP-1103

South Dakota, geochemistry OF 92-0592

stratigraphy B 1909; OP-1345

Sweden, geochemistry OP-584; OP-1649

United States

geochemistry OP-584; OP-1649

palynomorphs B 1909

Utah

OP-1961

natural gas OP-1262

petroleum OF 92-0391

West Virginia

energy sources B 1909

natural gas B 1909

Yukon Territory geochemistry OF $92-0525$ metal ores OP-363; OP-1432

Black Warrior River Aquifer ground water P 1410-G

Blackbird mining district metal ores OP-715

Blackbird Mountain Quadrangle maps MF-2234

Blackbird State Forest ground water OP-777

Blackleaf Formation OP-1351

Blair Formation sedimentary petrology B 2051

Blair River Complex geochemistry OP-1122

Blake Escarpment continental margin B 2002

Blake Outer Ridge see Blake-Bahama Outer Ridge

Blake Plateau

oceanography OP-1073

sedimentary petrology OP-1931

structural geology OP-1132

Blake-Bahama Outer Ridge continental margin B 2002 oceanography OP-1337

Blancan

Idaho OP-1850

Blanco-Mesaverde Field energy sources OP-518

blind deposits

Colorado, molybdenum ores OP-375

Idaho, metal ores OF 93-0235

Nevada

base metals OP-79 gold ores B 2039; OP-779

Saudi Arabia, tin ores OP-499

bloating shale see shale

block clay see melange

block structures

Antarctic Ocean, tectonophysics OP-1446
Arizona

igneous rocks OP-1112

neotectonics OP-611

Atlantic Ocean, continental margin B 2002

Basin and Range Province, structural geology OP-19

Bering Sea, deformation OP-211

California

deformation OP-972

igneous rocks OP-1112

Colorado Plateau, structural geology OP-19

Commonwealth of Independent States energy sources OP-1261 petroleum OP-1265

Europe

energy sources OP-1261

petroleum OP-1265

plate tectonics OP-206

Idaho, structural geology OP-523

Michigan, structural geology B 1904-L

Missouri, deformation OP-1861

Nevada

gold ores B 2039

structural geology B 2011

stratigraphy B 1839-K

Texas, ground water OP-1675

Utah, structural geology B 2011

Bloom SE Quadrangle

maps OF 92-0697

Bloom SW Quadrangle

maps OF 92-0698

Bloomsburg Formation B 1839-L

Blue Gulch Mudstone Member stratigraphy $\mathrm{P} 1521$

Btue Hill Mine

gold ores MF-2214

Blue Holes Quadrangle

Quaternary OF 92-0391

structural geology OP-1539

Blue Lake Quadrangle

maps OF 93-0297

blue lead see galena

Blue Mound Quadrangle maps I-2377

Blue Mountains guidebook OP-87

Blue Ridge Province

economic geology B 1979; B 2005

ground water OP-239; OP-400; OP-983; OP1707; OP-1928

hydrology OP-1610

intrusions OP-1106

orogeny OP-1612

petrology OP-1002

Proterozoic B 2029

structural geology OP-1955

blueschist

California, structural analysis OP-1546

tectonophysics OP-1366

blueschist facies

Alaska, metamorphic rocks P 1497-C

California

metamorphism OP-1165 structural geology OP-1971

Canada, metamorphic rocks P 1497-C

Italy, petrology OP-851

structural geology OP-401

Bluestone Formation

stratigraphy OP-1368

blufifs

Alaska, Quatemary OP-390 


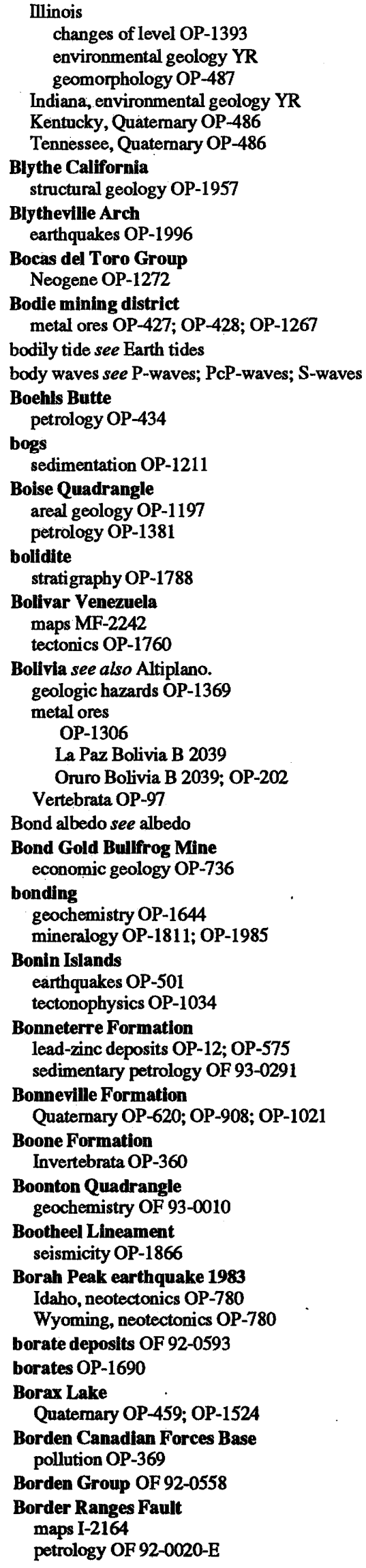

Border Ranges Formation metamorphic rocks P 1497-C

Border Sea OP-1439; OP-1485; OP-1830

Borealis Basin OP-1933; OP-1934

borehole breakouts

Indian Ocean, deformation OP-146

Washington, structural geology OF 92-0715

borehole packers

geophysical surveys OF 93-0071

borehole televiewers

Connecticut, hydrogeology WRI 92-4074

Florida, ground water WRI 91-4168

Indian Ocean, deformation OP-146

Boriana Deposit

metal ores B 1737-E

Bomeo see Brunei; East Malaysia; Kalimantan Indonesia

boron

borates OP-1690

geochemistry OP-763

New South Wales Australia, metal ores OP-942

Queensland Australia, metal ores OP-942

Tadzhikistan, mineralogy OP-373

Virginia, mineralogy OP-1755

boron deposits see borate deposits

borosilicates OP-1690

Borrego Formation

Quaternary OP-1843

Boston Massachusetts

continental shelf OP-546

estuaries OP-932

neotectonics OP-555

oceanography DDS-0003

sedimentation OP-1598

Botryococcus geochemistry OP-1923

bottom currents

Atlantic Ocean, continental shelf OP-483

Spain, oceanography OP-722

bottom features

Alaska, oceanography B 2002

Atlantic Ocean continental margin B 2002

ocean floors I-2279-A

California, continental margin B 2002; I-2089C; I-2090-C; I-2091-C

Hawaii, oceanography OF 92-0206

Massachusetts continental shelf OP-546 oceanography DDS-0003

ocean floors OF 91-0014

Russian Federation, geomorphology OP-1291

bottom load see bedload

Bougainville

marine geology OP-192

Bougainville Seamount

marine geology OP-187

plate tectonics OP-185; OP-197

tectonophysics OP-1908

Bouguer anomalies

Antarctic Ocean, plate tectonics OP-65

Arizona

geophysical surveys OF 91-0640 Neogene OP-92

Colorado

economic geology B 2035

geophysical surveys MF-2236

geophysical surveys DDS-0009

Kenya, structural geology OP-2

Mediterranean region, tectonophysics OP-1606
Middle East, tectonophysics OP-1606

Montana, economic geology OF 93-0207

Nevada

economic geology B 2039

Neogene OP-92

New Mexico, geophysical surveys WRI 914065; OF 92-0503

Boulder Batholith

copper ores OP-273

boulders

Nevada, Quaternary OP-1070

West Virginia, geomorphology B 1981

Bouma sequence

California, stratigraphy OP-1281

boundaries, stratigraphic see stratigraphic boundary

Bowers Basin

deformation OP-211

bowieite

sulfides OP-64

Box Elder Laccolith magmas OP-1294

Braae Wyoming maps I-2232

Brachiopoda

Nevada OP-491

Russian Federation OP-491

Strophomenida Arkansas OP-360

Oklahoma OP-360

brachiopods

Arkansas, sedimentary petrology OF 93-0291

Colorado, stratigraphy OF 92-0689

Missouri, sedimentary petrology OF 93-0291

Nevada, stratigraphy B 1988-D; OP-1846 stratigraphy OP-354

Bradley River hydrology OF 93-0095

Brahmaputra River geologic hazards OF 92-0391 geomorphology OP-1273

BRANCH hydrogeology OF 92-0138

Branch of Atlantic Marine Geology marine geology OF 92-0585

Branch of Geochemistry geochemistry OF 92-0392; OF 93-0001-B; OF 93-0533

Branch of Petroleum Geology petroleum OF 93-0330

Bransfield Strait Quatemary OP-1307

Bras d'Or Terrane geochemistry OP-1122

Brassfield Formation hydrogeology OP-1228

braunite California, manganese ores OP-458

Brazil see also Amazon Basin; Amazon River. geophysical surveys, Sergipe Brazil OP-1329 ground water, Pocos de Caldas Brazil OP-737 metal ores C 0930-M; C 0930-N

Brazos River waterways OP-150

breakouts see borehole breakouts

Breathitt Formation

OF 92-0558; OF 93-0312; OP-1821 sedimentary petrology OF $92-0558$ sedimentation OF 92-0558 
breccia see also volcanic breccia.

OP-1674

Bolivia, metal ores OP-1306

California, structural geology OP-1474; OP1971

Chile, lava OP-957

Ecuador, gold ores B 2039

Iowa

crystalline rocks OP-1114

geochronology OP-475; OP-1613

paleomagnetism OP-1915 petrology OP-1113; OP-1540

Mexico, geochronology OP-920

Nevada

metal ores OF 93-0249

stratigraphy OP- 1847

volcanism OF 93-0021

petrology OP-1199

Poland, metal ores OF 92-0704

South Dakota, geochronology OP-475

Utah

OF 92-0391

mineral resources B 2039

Washington, lava OP-957

breccia pipes

Arizona

I -2290

economic geology OF 93-0329

sulfides OP-1993

uranium ores OP-613; OP-1617

Missouri, metal ores B 2039; OP-1327

Brenna Formation

clays OF 92-0514

Bridge Lake Field

petroleum OP-1635

Bridger Formation P 1506-D; P 1506-F

bridges

Alaska, hydrology OF 93-0162

Arkansas, waterways WRI 92-4126

engineering geology OP-384

Texas, engineering geology OP-280

Brigham Group

structural geology OP-941

Brightseat-Potomac Aquifer

ground water WRI $92-4175$

brines see also salt water, salt-water intrusion. OP-225; OP-1035

California, geophysical surveys OP-227

geochemistry OP-58; OP-326; OP-605

Great Plains, geochemistry OP-879

ground water OP-1706

Illinois

OP-1419

hydrogeology OP-1782

Kentucky

OP-1419

hydrogeology OP-1782

Mexico OP-1657

Michigan, sedimentary petrology OF 93-0236

Mississippi, geochemistry OP-1577

New Mexico, geomorphology OF 92-0391

Ohio, pollution OP-155

Pacific Ocean, tectonophysics OP-897

Red Sea OP-2029

Russian Federation, Phanerozoic OP-1493

Texas, ground water OP-1849

United Kingdom, sedimentary petrology OF 93-0236

United States, Phanerozoic OP-1493

Utah

hydrogeology OP-1736

hydrology WRI 91-4117
Bristle Cone Nature Preserve

economic geology OP-260

bristlecone pines

Colorado, Quaternary OF 93-0250

Bristol Basin

natural gas B 2034-A

Bristol Dry Lake Deposit

evaporite deposits OP-226

British Columbia

copper ores, Guichon Creek Batholith OP-273

Devonian OF 93-0184

hydrology C 1086

metal ores OP-9

ocean circulation OP-320

paleobotany OP-1082

petrology OP-1463

stratigraphy OP-708; OP-1776

structural geology OP-1159

brittle deformation

OF 93-0245; OP-1026

California OP-23

crust OP-884

rock mechanics OP-600

brochantite

Arizona OP-1993

Broken Hill

lead-zinc deposits OP-787

metal ores OP-942

sheet silicates OP-1489

bromide ion

Colorado, hydrogeology OP-408

Kentucky, hydrology WRI 92-4057

Utah, hydrogeology OP-1736

Bronson Hill Anticlinorium

metamorphic rocks OP-1188

Brookian Orogeny

sedimentary petrology OP-1553

Brooks Range

barite deposits OF 93-0215

energy sources B 2034-A

folds OP-1427; OP-1789

geochemistry OP-721

heat flow OP-253

natural gas OP-74

petroleum OP-492

sedimentary petrology OP-1553

brown mica see phlogopite

Browning, Iben

geologic hazards C 1083

brucite OP-1878

Brune method

hydrology W 2340

Bruneau Idaho

hydrogeology WRI 93-4001

stratigraphy OF 92-0713

Brunel

petroleum OP-1829

Brunhes Epoch

Arctic Ocean OP-799

Idaho OF 93-0327; OP-561

Indonesia OP-1538

Ivory Coast OF 92-0699

New Mexico OF 92-0699; OP-1538

Brush Creek Coal

palynomorphs OP-1603

Brushy Basin Shale Member OP-1963

non-metal deposits B 2061-A

Vertebrata OP-1252
Brushy Canyon Formation

stratigraphy OP-354

bryophytes

Musci, Alaska OF 93-0014

bryozoans

Nevada, stratigraphy OP-1846

bubble gauges

California, hydrology W 2340

Buckeye Mine

manganese ores OP-458

Buckhorn Mine metal ores OP-1715

Buckingham Deposit

geochemistry OF 92-0525

molybdenum ores B 2039

Buckskin Basin

Quaternary OP-452

buddingtonite

California

mineralogy OP-1038

sulfides OP-557

Nevada, sulfides OP-557

building stone

OF 92-0514

Appalachians MF-2215-A

Idaho B 2013

Illinois OF 92-0514

Maryland, engineering geology OF 92-0541

Michigan OF 92-0514

Pennsylvania, engineering geology OF 920391

Wisconsin OF 92-0514

Bull Lake Glaciation

Wyoming OP-1455; OP-1884

burial diagenesis

OP-1135; OP-1353

Alabama OP-1858

California OP-1791

Colorado, natural gas OF 92-0524

Mississippi OP-1858

burial metamorphism

Gulf of Mexico

OP-287

sedimentary petrology OP-288

Pennsylvania, diagenesis OF 92-0568

petroleum OP-793

sedimentary petrology OP-1135

Victoria Australia OP-1136

buried channels

engineering geology OP-506

Maryland, geochemistry OP-439

burrows

New Zealand, sedimentation OP-1391

Bursum Caldera

geophysical surveys OF 92-0503

Bush City Quadrangle maps I-2377

Bush Dome economic geology OP-834

Butte Quadrangle

metal ores I-2050-F

mineral resources $\mathrm{C} 1088$

\section{C}

C see carbon

C-12

Rocky Mountains, Pennsylvanian OP-1103

Sweden, geochemistry OP-1649

United States, geochemistry OP-1649 


\section{C-12/C-13 see C-13/C-12}

C.13

Australia, sedimentary petrology OP-1478

diagenesis OP-1477

Florida, geochemistry OP-1906

Illinois, hydrogeology OP-1782

Indonesia, sedimentary petrology OP-1478

Kentucky, hydrogeology OP-1782

C-13/C-12

Alaska

energy sources OP-626

environmental geology OP-564

Quaternary OP-1616

Antarctic Ocean, Pliocene OP-1535

Antarctica, hydrology OP-949

California, hydrogeology OF 93-0146

Canada, stratigraphy OP-1776

Colombia, geochemistry OP-755

Colorado

hydrogeology W 2340

pollution WRI 93-4007

Commonwealth of Independent States

energy sources OP-1261 petroleum OP-1265

East Pacific Ocean Islands, geochemistry OP925

energy sources OF 92-0391; OP-1822; OP1823

England, geochemistry OP-755

Europe

energy sources OP-1261

petroleum OP-1265

Florida

geochemistry OP-1906

Quaternary OP-1930

Galapagos Islands, geochemistry OP-925

geochemistry OP-1292

Indiana, ground water OP-1648

Maryland, hydrology OP-524; OP-1572; OP1573

Minnesota, geochemistry OP-25

Montana, geochemistry OP-978

Nevada

geochemistry OP-643

Quaternary C 1086

New Mexico

geochemistry OP-1072

pollution WRI 93-4007

Ohio, ground water OP-1648

Pacific Ocean, geochemistry OP-628; OP-1127

Poland, geochemistry OP-755

Russian Federation, Quatemary OP-2004

Texas, geochemistry OP-755; OP-1072

United States, stratigraphy OP-1776

Utah, hydrogeology W 2340

Virginia, hydrology OP-524; OP-1573

Wyoming, geochemistry OP-978

C-14

Alaska

Quaternary OP-390

Vertebrata OP-163

Arkansas, Quaternary OF 93-0273; OP-1683

California

geochronology OP-68

ground water OP-474

Quaternary OF 93-0311; OP-338

sedimentary petrology OP-77

Colorado

geomorphology OP-885

Quaternary OP-1324; OP-1676

Dominican Republic, plate tectonics OP-808

Great Lakes, Quaternary OP-200; OP-1290
Hawaii, Quaternary OP-632; OP-633

Indiana, ground water OP-1648

Indonesia, Quaternary OP-1743

Italy, Quaternary OP-764

Louisiana, Quaternary OF 92-0530

Massachusetts, Quaternary OP-749

Minnesota, Quaternary C 1086; OP-20

Nevada, geochronology OP-68

New England, Quatemary OP-748

Ohio, ground water OP-1648

Oregon

earthquakes OP-720

magmas OP-982

Quatemary B 2038

Pacific Ocean, geochemistry OP-519; OP-628

pedogenesis OP-48

Russian Federation, Quaternary C 1086

Tennessee

hydrology WRI 92-4082

Quatemary OF 93-0273; OP-1683

Washington

earthquakes OP-720

maps OF 93-0233

Quaternary OP-120; OP-904

Ca see calcium

Ca-Mg carbonate

sedimentary petrology OF 92-0707

Cabo de Gata volcanic field

gold ores OP-231

Caborca-Hermosillo Block

deformation OP-972

Cache Valley

hydrogeology OF 92-0173; OP-425

cadmium

East Pacific Ocean Islands, geochemistry OP925

Galapagos Islands, geochemistry OP-925

geochemistry OP-974

Georgia

oceanography $\mathrm{OP}-1502$

pollution OP-1501

hydrology OP-1836

New Jersey, environmental geology OF 92 0153

sediments OP-1887

Utah, mineral resources MF-2081-D; MF2081-E

cadmium ores

Bolivia B 2039

Cady, Wallace $M$.

structural geology OP-117

Cagayan Ridge

marine geology OP-819

oceanography OP-820

Cainhoy Quadrangle

Quaternary I-1935

Cainozoic see Cenozoic

Cairo earthquake 199

earthquakes OP-992; OP-1092

Cairo Egypt

earthquakes OP-992; OP-1092

engineering geology OF 93-0181

Cajon Basin

neotectonics OP-1063

Cajon Valley Fault neotectonics OP-1063

Calabasas Quadrangle maps OF 93-0205

Calaveras Fault

geophysical surveys OF 93-0276

neotectonics OP-23 seismology OP-1280

calc-sinter see travertine

calc-tufa see tufa

calcareous algae

California

Miocene OF 93-0182

stratigraphy OF 93-0177

South Carolina, stratigraphy B 2030

calcareous clay see marl

calcareous nannofossils see nannofossils

calcareous sinter see travertine

calcareous tufa see tufa

Calcasieu River

geochemistry OP-935

pollution OF 92-0492

calcite see also calcium carbonate; travertine.

OP-1452; OP-1752

geochemistry OP-165; OP-1319

Georgia, ground water W 2392

Kansas, natural gas OP-725

Maryland, hydrology OP-524; OP-1573

Michigan

energy sources OF 92-0391

geochemistry OP-1204

Minnesota, geochemistry OP-251

Missouri, deformation OP-1861

Nevada

geochemistry OP-643

Pleistocene OP-1670

Quaternary C 1086; OP-294; OP-916

New Mexico, geochemistry OP-1072

South Carolina, ground water W 2392

Texas, geochemistry OP-1072

Utah, diagenesis OP-1465

Virginia, hydrology OP-524; OP-1573

calcium

Alaska, Quaternary OP-1507

California

geochemistry B 1995-C

sedimentary petrology OF 92-0707

Colorado, sedimentary petrology OP-1382

East Pacific Ocean Islands, geochemistry OP925

Galapagos Islands, geochemistry OP-925

Greenland, Quaternary OP-1507

Minnesota, sedimentary petrology OP-250

Nevada, geochemistry OP-76

petrology OP-393

Tennessee, ground water WRI 92-4092

Virginia, ground water WRI 92-4090

Wyoming geochemistry OP-712 petrology OP-1456

calcium carbonate

California, sedimentary petrology OF 92-0707; OP-77

geochemistry OP-1787

Minnesota

Quaternary OP-668

sedimentary petrology OP-250

Nevada, geochemistry OP-76

Wyoming, Quatemary OP-1884

calcium chloride

Great Plains, geochemistry OP-879

calcium-aluminum inclusions OP-1704; OP1705

calderas

OP-1831

Alaska GQ-1688

Arizona, geochemistry B 2021-C

Bolivia, economic geology YR 
California

geochemistry OP-955

geophysical surveys OF 92-0544; OP-1555; OP-2024

structural geology OP-569; OP-1536

Colorado

base metals OF $93-0183$

metal ores $\mathrm{P} 1537$

stratigraphy OP-985

Guatemala OP-277

Hawaii

magmas OP-1001

paleomagnetism OP-436

Idaho

metal ores OP-876

neotectonics OP-780

petrology OP-560; OP-561

Italy, geologic hazards OP-213

Montana, deformation OP-883

Nevada, volcanism OF 93-0021

New Mexico, geophysical surveys OF 92-0503

Oregon

magmas OP-982

metal ores OP-876

petrology OP-498

Papua New Guinea, economic geology OP-639

petrology OP-596

Russian Federation, magmas OP-91

Spain

gold ores OP-231

metal ores OP-875

Utah

metal ores OP-965; OP-1464

mineral resources B 2039

Wyoming

geochemistry OP-536

neotectonics OP-780

Caldwell Quadrangle

geochemistry OF 93-0010

Caledonides

Phanerozoic OP-1493

structural geology OP-1279

Caliente Basin

neotectonics OP-1063

Califon Quadrangle

geochemistry OF 93-0010

California see also Borax Lake; California Current; Catalina Schist; Coast Ranges; Colorado

River; Diablo Range; Franciscan Complex;

Great Basin; Great Valley Sequence; Klamath

Mountains; Lake Lahontan; Loma Prieta earthquake 1989; Mono Lake; Monterey Formation;

Peninsular Ranges; Peninsular Ranges Batholith; Sacramento Basin; San Francisco Peninsula; San Jacinto Fault; San Joaquin Basin; Santa

Barbara Basin; Santa Cruz Mountains; Sespe

Formation; Sierra Nevada; Sisquoc Formation;

White Mountains.

continental margin

B 2002

Cape Mendocino I-2090-A; I-2090-B; I2090-C; I-2091-C

Point Conception I-2089-C; I-2090-A; I2090-B; I-2090-C

Point Loma I-2089-C

continental shelf

OP-128

Del Norte County California B 2002

Humboldt County California B 2002

Monterey California OP-1443

core OP-1032

crust OF 92-0441 dams, Inyo County California OP-454

deformation

OP-1442

Garlock Fault OP-972

San Andreas Fault P 1550-C; OP-802; OP972

San Benito County California P 1550-C

San Gabriel Mountains OP-972

San Juan Bautista California P 1550-C

diagenesis

OP-1386

Santa Barbara California OP-174

earthquakes

EV; OF 92-0441; OF 93-0290; OF 93-

0509; OP-504; OP-700; OP-880; OP-958;

OP-1762

Cape Mendocino OF 92-0575

Coalinga California OP-1992

Fresno County California OP-1025

Garlock Fault OP-406

Humboldt County California OF 93-0219

Imperial Fault OF 91-0032

Mojave Desert YR; OP-699

Orange County California OP-698

Parkfield California OP-881; OP-1025; OP1498

Riverside County California OP-698; OP931

San Andreas Fault OF 91-0032; OP-126; OP-329; OP-406; OP-1025; OP-1102; OP-1587

San Bernardino County California YR; OF 93-0191; OP-90; OP-329; OP-406; OP-699; OP-931

San Diego County California OP-698

economic geology

Inyo County California OP-260

Inyo Mountains OP-204; OP-662

Kern County California OF 92-0595

Lassen County California B 2019

Los Angeles County California OF 92-0595

Mojave Desert OF 92-0595

Mono County California OP-260

San Bernardino County California OF $92-$ 0595

Sierra County California B 2019

elastic waves, Monterey County California OP913

energy sources

B 2034-A; OF 92-0524; OP-1946

Alameda County California B 2034-A

Contra Costa County California B 2034-A

Cuyama Basin B 2034-A; OF 89-0450-D

Fresno County California OF 89-0450-D

Kern County California OF 89-0450-D

Kings County California OF 89-0450-D

Los Angeles Basin B 2034-A

Los Angeles County California B 2034-A

Monterey County California B 2034-A; OF 89-0450-D

San Andreas Fault OP-267

San Francisco Bay region B 2034-A

San Luis Obispo County California B 2034A; OF 89-0450-C; OF 89-0450-D

San Mateo County California OF 89-0450D

Santa Barbara Channel OF 92-0571

Santa Barbara County California B 2034-A; OF 89-0450-C; OF 92-0571

Santa Cruz County California OF 89-0450-

Santa Maria Basin OF 89-0450-C

Sonoma County California B 2034-A
The Geysers OP-267

Ventura County California B 2034-A

engineering geology

EV

Alameda County California OP-882

Contra Costa County Califomia OP-882

Marin County California OP-882

Monterey Bay OP-1347

Napa County California OP-882

San Andreas Fault OF 91-0032; OP-125; OP-688; OP-1948

San Bernardino County California OF 93 . 0348

San Francisco Bay region OP-882; OP-1948

San Francisco California OP-1154

San Mateo County California OP-882

Santa Clara County California OP-882

Santa Cruz County California OP-882

Solano County Califomia OP-882

Sonoma County California OP-882

environmental geology

C 1086; OF 93-0292-I

Imperial County California OF 92-0447; OF 93-0083

Inyo County California OF 92-0447

Kern County California OF 92-0447

Merced County California OF 93-0294

Mojave Desert OF 92-0447; OP-2006

Palo Alto California OF 92-0456

Placer County California OP-1227

Riverside County California OF 92-0447; OF 93-0083

Salton Sea OF 93-0083

San Bernardino County California OF 92 0447

San Francisco Bay OF 92-0456

Shasta County California OP-1110

Stanislaus County California OF 93-0294

Tehachapi Mountains OP-2006

Eocene

San Francisco Bay region OF 93-0180

San Mateo County California OF 93-0180

Santa Clara County California OF 93-0180 geochemistry

OP-615; OP-730; OP-1578

Fresno County California OP-182

Inyo County California OP-182

Lompoc California B 1995-C; OF 92-0539C

Long Valley Caldera OP-954; OP-955

Mojave Desert OP-512; OP-678

Mono Craters OP-954

Salton Sea geothermal field OP-1018

Salton Trough OP-1018

San Andreas Fault OP-265

San Bernardino County California OP-512

San Luis Obispo County California OF 92 0539-A

Santa Barbara County California OF 920539-A

Santa Maria Basin B 1995-C; OF 92-0539A; OF 92-0539-C

Sierra Nevada Batholith OP-182

The Geysers OP-265

Tulare County California OP-182

geochronology OP-342

geologic hazards

YR; C 1086

Alameda County California P 1553-B

Hayward California OF 90-0677

Kern County California WRI 92-4035

Los Angeles Califomia OP-969 
Los Angeles County California WRI 924035

Mariposa County California OF 92-0387

Mojave Desert WRI 92-4035

San Andreas Fault OP-1793

San Bernardino County California WRI 924035

San Francisco California OF 90-0677

San Francisco County Califormia P 1553-B

San Jose California OF 90-0677

San Mateo County California P 1553-B; I1257-M

Santa Clara County California P 1553-B

Tuolumne County California OF 92-0387

Yosemite National Park OF 92-0387

geomorphology

OP-1528

Death Valley OF 93-0272

Inyo County California OF 93-0272

Modoc County California OP-266

Mojave Desert OP-1339

Mount Shasta OP-266

geophysical surveys

YR

Alameda County California OF 92-0531; OF 93-0276; OF 93-0277; OF 93-0301

Calaveras Fault OF 93-0276

Contra Costa County California OF 930276; OF 93-0301

Death Valley OP-227

Imperial County California OF 93-0217-A; OF 93-0217-B

Lassen Peak B 1966

Long Valley Caldera OF 92-0544; OP-1555; OP-2024

Los Angeles County California OF 930217-A; OF 93-0217-B

Marin County California OF 92-0570; OF 93-0276; OF 93-0301

Merced County California OF 93-0277

Mount Shasta B 1966

Napa County California OF 93-0276; OF 93-0301

Orange County California OF 93-0217-A; OF 93-0217-B

Riverside County California OF 92-0549; OF 93-0217-A; OF 93-0217-B

Sacramento County Califomia OF 93-0276; OF 93-0301

San Andreas Fault OF 93-0276

San Bernardino County California OP-543

San Diego County California OF 92-0548; OF 93-0217-A; OF 93-0217-B

San Francisco Bay region OF 92-0531; OF 93-0276; OF 93-0277; OF 93-0301

San Francisco County California OF 92 0570; OF 93-0276; OF 93-0301

San Joaquin County California OF 93-0301

San Mateo County California OF 92-0570; OF 93-0276; OF 93-0277; OF 93-0301

Santa Clara County California OF 93-0276; OF 93-0277; OF 93-0301

Santa Cruz County California OF 93-0277

Siskiyou County Califomia B 1966

Solano County California OF 93-0276; OF 93-0301

Sonoma County Califomia OF 93-0276; OF 93-0301

Stanislaus County California OF 93-0277

Yolo County California OF 93-0301 geothermal energy

Imperial County Califomia OP-298

Salton Sea OP-298; OP-324 ground water

OP-72; OP-73; OP-303; OP-995

Fresno County California W 2396; OF 91 0535

Imperial County California WRI 91-4142

Inyo County California OP-234

Kern County California OF 92-0655; OF 93-0148

Los Angeles County California OF 93-0148

Merced County California WRI 92-4153

Mojave Desert OF 93-0148

Oxnard California OF 93-0524

Riverside County California WRI 91-4142

San Bernardino California W 2340

San Bernardino County California WRI 914142; OF 93-0148; OF 93-0279

San Diego County California WRI 91-4142

San Joaquin Valley W 2396; WRI 92-4153; OF 91-0535; OF 92-0655

Santa Barbara County California W 2340

Santa Cruz County California WRI 91-4148

Tulare County California OF 92-0655

Ventura County California OP-255; OP474; OP-961

highways WRI 92-4147

hydrogeology

OP-659

Alameda County California OF 93-0146

American River OP-276

Contra Costa County California OF 93-0146

Imperial County California OF 92-0083; OF 93-0405

Marin County California OF 93-0146

Napa County California OF 93-0146

Riverside County California OF 92-0083; OF 93-0405

Sacramento County California OF 93-0146

San Bernardino County California OF 92 0083; OF 93-0405

San Francisco Bay OF 93-0146

San Francisco County Califomia OF 930146

San Mateo County California OF 93-0146

Santa Clara County California OF 93-0146

Solano County California OF 93-0146

Sonoma County California OF 93-0146

hydrology

W 2400; C 1086; OP-1044

Alameda County California OF 93-0057

American River C 1086

Contra Costa County Califomia OF 93-0057

El Dorado County California C 1086; OF 92-0627

Marin County California OF 93-0057

Mono County California C 1086; WRI 934030

Napa County Califomia OF 93-0057

Nevada County California C 1086

Placer County California C 1086; OF 92 0627

Sacramento County California C 1086; OF 92-0627; OF 93-0057

San Francisco Bay OF 93-0057

San Francisco County California OF 930057

San Mateo County California OF 93-0057

Santa Clara County Califomia WRI 924172; OF 93-0057

Solano County California OF 93-0057

Sonoma County California OF 93-005.?

Tulare County California WRI 93-4030

Tuolumne County California W 2340 igneous rocks
Cargo Muchacho Mountains OP-1112

Mojave Desert OP-1112

Old Woman Mountains OP-1112

San Gabriel Mountains OP-1112

Whipple Mountains OP-1112 intrusions OP-1126

Invertebrata, Monterey Bay OP-1800 lava

Lassen Volcanic National Park OP-1447

Shasta County California OP-1447 magmas, Old Woman Mountains OP-1711 mantle OP-71

maps

OF 93-0525; I-1943; I-1420 (NJ-10)

Alameda County California OF 93-0225

Contra Costa County California OF 93-0225

Death Valley OF 93-0506

Inyo County Califomia OF 93-0506

Los Angeles County California OF 93-0205; OF 93-0206

Mojave Desert OF 91-0435

Mono County California I-1995

Riverside County California OF 92-0446

San Bemardino County Califomia OF 91. 0435; OF 92-0446; OF 93-0198; OF 930506

San Francisco Bay region OF 93-0271

San Joaquin County California OF 93-0223; OF 93-0224; OF 93-0225

San Mateo County Califomia OF 93-0271

Santa Clara County California OF 93-0271

Santa Cruz County Califomia OF 93-0271

Santa Maria Basin OP-1945

Stanislaus County California OF 93-0223

mercury ores OP-162

metal ores

OP-428

Mono County California OP-427; OP-1267

San Bernardino County California OF 930228

Trinity County Califomia OP-554

metamorphic rocks

Salinian Block OP-1166

San Andreas Fault OP-1166

San Joaquin Valley OP-1166

Yolla Bolly Terrane OP-1166

metamorphism, Contra Costa County California OP-1165

mineral resources

Humboldt County California OF 92-0210A; OF 92-0210-B; OF 92-0316-A; OF 92-0316-B

Mendocino County California OF 92-0316A; OF 92-0316-B

Shasta County California OF 92-0316-A; OF 92-0316-B

Tehama County California OF 92-0316-A; OF 92-0316-B

Trinity County California OF 92-0210-A; OF 92-0210-B; OF 92-0316-A; OF 920316-B

mineralogy

Inyo County California OP-500

Lake County Califomia OP-1038

Miocene

Santa Barbara County California OF 93 0182

Santa Maria Basin OF 93-0182; OP-1570

natural gas, Humboldt County California B 2034-A

neotectonics

Alameda County Califormia OP-23

Calaveras Fault OP-23 
Elsinore Fault OP-1063

Kettleman Hills OP-83

Kings County California OP-83

San Andreas Fault OP-23; OP-83; OP-1063

San Francisco Bay region OP-23

San Gabriel Fault OP-1063

Santa Clara County California OP-23

Transverse Ranges OP-1063 oceanog raphy

B 2002; OF 93-0298; OP-751; OP-1444

San Francisco Bay OF 92-0382

San Francisco Bay region OF 92-0555; OF 93-0011

orogeny, Mojave Desert OP-1566

oxides, San Benito County California OP-849

paleomagnetism

Marin County California OP-385

Salinian Block OP-1504

Santa Clara County California OP-385

Sonoma County California OP-385

The Geysers OP-385

petroleum

B 2034-A

Point Sal OP-1910

San Luis Obispo County California OF 920539-F

Santa Barbara California OP-1910

Santa Barbara Channel OP-1910

Santa Barbara County California OF 920539-F

Santa Maria Basin OF 92-0539-F; OP-793; OP-1910

Ventura County California OF 92-0539-F petrology

OP-1146; OP-1167; OP-1584

Lassen County California OP-1271

Modoc Plateau OP-638

Mojave Desert OP-1376; OP-1691

Old Woman Mountains OP-1691

Sierra Nevada Batholith OP-1282

plate tectonics

OP-1628

Cape Mendocino OP-145; OP-1749

Humboldt County California OP-752

Mendocino County California OP-145

Salinian Block OP-759

San Andreas Fault OP-145; OP-1749

San Joaquin Valley OP-1749

Santa Clara County California OP-759

Santa Cruz County Califomia OP-759

platinum ores, Del Norte County Califomia B 2014

Pleistocene OP-1619

pollution

Fresno County California WRI 91-4119

Oxnard California OP-473

San Joaquin Valley WRI 91-4119; OP-264; OP-599

Quaternary

C 1086; OF 93-0340; MF-2212; OP-707; OP-878; OP-1844

Alpine County California OP-1253

Contra Costa County California OF 93-0286

Death Valley OP-1897

Imperial County Califormia OP-1843

Inyo County Califomia OF 93-0232

Kern County California OF 93-0263

Lassen Peak OP-201

Los Angeles County California OF 93-0263; OP-338

Mojave Desert OP-1897

Mono County Califomia OF 93-0232; OP831
Obsidian Dome OP-1524

Riverside County California OP-1843

Salton Trough OP-1843

San Andreas Fault OP-338; OP-1843

San Bernardino County California OF 930263; OF 93-0311; OP-338; OP-1833

San Francisco Bay C 1086

San Francisco Bay region OF 93-0286

Siskiyou County California C 1086

Solano County Califomia OF 93-0286

sedimentary petrology

Colusa County California OF 92-0707

Kern County California OP-445

Mojave Desert OP-445

Shasta County California OP-1344

sedimentation OP-1098

seismicity

OP-1914

Fresno County California OP-286

Monterey County California OP-286

Pajaro Valley P 1550-C

San Andreas Fault P 1550-C; OP-286

San Benito County California OP-286

San Francisco County California OP-121

Santa Clara County California P 1550-C seismology

EV; OF 92-0441; OF 93-0227; OF 93-

0295; OP-328; OP-438; OP-466; OP-541;

OP-1046; OP-1746

Alameda County California P 1550-C

Butte County California P 1550-C

Calaveras Fault OP-1280

Calistoga California P 1550-C

Cape Mendocino OP-673

Inyo County California OF 92-0340

Long Valley Caldera OP-964; OP-1503

Monterey County California P 1550-C; OP302

Parkfield California OP-868; OP-1872

Riverside County California OP-966

San Andreas Fault P 1550-C; OP-302; OP868; OP-966; OP-1280; OP-1360; OP1581

San Benito County California P 1550-C

San Bermardino County California OF 92 0340; OP-411; OP-593; OP-966

San Francisco California OP-1047

Santa Clara County California P 1550-C soils

Merced County California OP-1065

Mojave Desert C 1086

Sacramento County California OP-1713

San Francisco Bay region OP-1713

San Joaquin County California OP-1713

San Joaquin Valley OP-1170

Solano County California OP-1713

stratigraphy

OP-708

Amador County California OF 92-0588

Lompoc California OF 92-0539-B; OF 92 0539-D; OF 93-0177

Mojave Desert B 2015

Salton Sea OP-257

San Bernardino County California B 2015

San Luis Obispo County California OF 92 0539-E

Santa Barbara California OP-469

Santa Barbara County California OF 920539-E

Santa Maria Basin OF 92-0539-B; OF $92-$ 0539-D; OF 92-0539-E; OF 93-0177

Siskiyou County California P 1521

Stanislaus County California OF 92-0588
Transverse Ranges OP-1281

Ventura County California OF 92-0539-E

structural geology

OP-78; OP-159; OP-1957

Alameda County California OP-405

Banning Fault OP-649

Cape Mendocino OP-144

Channel Islands OP-1172

Contra Costa County California OP-405

Death Valley OP-442

Funeral Mountains OP-442

Gabilan Range OP-803

Long Valley Caldera OP-569; OP-1536

Marin County California OP -405

Mendocino County California OP-648

Mojave Desert OP-649; OP-803; OP-936

Monterey Bay OP-340

Napa County California OP-405

Parkfield California OP-936

Plumas County California OP-1474

Salinian Block OP-936

San Andreas Fault OP-113; OP-332; OP649; OP-702; OP-703; OP-803; OP-804; OP-936

San Emigdio Mountains OP-803; OP-936

San Francisco Bay region OP-405

San Francisco County California OP-405

San Gabriel Fault OP-649

San Gabriel Mountains OP-703; OP-803

San Gorgonio Pass OP-703

San Juan Bautista Califomia OP-936

San Luis Obispo County California OP-1701

San Mateo County California OP-405

Solano County California OP-405

Tehachapi Mountains OP-803

Transverse Ranges OP-703; OP-803

sulfides

Lake County California OP-557

Napa County California OP-557

tectonics, Inyo County California OP-977

tectonophysics

OP-1157

Channel Islands OP-2010

Los Angeles Basin OP-2010

San Andreas Fault P 1550-C; OP-2010

San Francisco Bay OP-1733

San Juan Bautista California P 1550-C

Santa Barbara Channel OP-2010

thermal waters, Lake County California OP-997

waterways OP-567

California Current

Quaternary C 1086

caliper logging

California, geophysical surveys OF 92-0544

Connecticut, hydrogeology WRI 92-4074

Florida, ground water WRI 91-4168

Idaho, ground water WRI 92-4184

Nevada, ground water WRI 91-4167

New Hampshire, environmental geology OF 92-0647

Tennessee, ground water OF 92-0135

Calistoga California

seismology P 1550-C

Callisto Satellite OP-1348

Callovian

California OP-1413

Caltech-USGS Seismic Processing

earthquakes OF 92-0577

Calumet Trough

structural geology B 1904-L

Cambrian

B 1839-I,J; B 1839-K; B 1917-M 
Alaska OP-1123

Arctic region OP-1839

Bonneterre Formation

lead-zinc deposits OP-12; OP-575

sedimentary petrology OF 93-0291

Brigham Group, structural geology OP-941

California OP-797

Carrara Formation, mineralogy OP-1452

Cheshire Formation, economic geology B 1955

Chilhowee Group OP-1642

Conococheague Formation, environmental geology OP-901

Far East OP-1839

Flathead Sandstone, hydrogeology WRI 914044

Great Lakes P 1405-C

Idaho OP-797

Kazakhstan OP-1295

Lamotte Sandstone

lead-zinc deposits OP-12

metal ores OP-1418

Midwest P 1405-B; OP-1799

Missouri OP-644

Mount Simon Sandstone, sedimentary petrology OP-1385

Nevada OF 93-0249; OP-623; OP-994

Pennsylvania OP-915

Sweden OP-584; OP-1649

United States OP-584; OP-1649

camcorders

marine geology OF 92-0537

Cameroon

geochemistry, Lake Nyos OP-306; OP-1011 geologic hazards, Lake Nyos OP-903

Camflo Deposit gold ores OP-1097

Camp Rock Fault

earthquakes OP-699

seismology OP-411

Campania Italy see Naples Italy; Pozzuoli Italy

Campania-Lucania earthquake 1980 see Irpinia earthquake 1980

Campanian

OP-528

Arkansas OP-525; OP-527; OP-1757

Colorado B 2024; OF 92-0391

Iowa OP-475

New Jersey OF 92-0399; OP-529

South Dakota OP-475

Texas OP-177; OP-178

Western Interior OF 92-0391

Wyoming B 2051

Campi Flegrei see Phlegraean Fields

\section{Camptosaurus}

Vertebrata OP-1252

Canada see also Eastern Canada; Western Canada.

core OP-1032

ecology YR

geochemistry, Canadian Cordillera OP-721

geophysical surveys OP-1440

metal ores C 0930-M; C 0930-N

metamorphic rocks, Stikinia Terrane P 1497-C

orogeny, Grenville Front OP-138

stratigraphy, Canadian Cordillera OP-402

structural geology, Gander Zone OP-1525

tectonics, Grenville Front OP-1215

Canada Basin

Quatemary C 1086

Canadian Cordillera

geochemistry OP-721 stratigraphy $\mathrm{OP}-402$

Canadian Series

Michigan OP-1116

Canadian Shield

crust, Grenville Province OP-1316

economic geology, Superior Province B 2039

gold ores, Abitibi Belt OP-1097

intrusions, Wabigoon Belt OP-247

orogeny OP-138

petrology

Central Metasedimentary Belt OP-214

Superior Province OP-1560

structural geology, Grenville Province OP-460

Canal Zone see Panama Canal Zone

canals

Florida, ground water OP-671

Louisiana, ground water OP-742

Montana, hydrogeology WRI 92-4066

North Carolina, hydrology OF 92-0498

Wyoming, hydrology OF 93-0142

Canary Islands

engineering geology, Hierro OP-443

Candor Chasma OP-1162; OP-1235

Canning Formation

petroleum OP-1285

Cannonball Sea

diagenesis OP-395

sedimentary petrology B 1917-L

Canon City Colorado

environmental geology OF 92-0391

geophysical surveys B 2039; OF 91-0449-D; OF 91-0449-E; OF 91-0449-F

stratigraphy OP-1963

canonical analysis

Quatemary OP-549

canyons OP-142; OP-987; OP-1408

Cape Breton Island geochemistry OF 92-0525; OP-1122

Cape Cod

ground water OF 92-0143; OP-431; OP-1815 guidebook OF 92-0551

Cape Fear landslide

continental margin MF-2209

continental slope B 2002

Cape Flattery Quadrangle maps I-1946

Cape Hatteras geophysical surveys OF 93-0264

Cape Lookout Bight geochemistry OP-1684

Cape Mendocino continental margin I-2090-A; I-2090-B; I2090-C; I-2091-C

earthquakes $\mathrm{OF}$ 92-0575

plate tectonics OP-145; OP-1749

seismology OP-673

structural geology OP-144

Cape Mendocino earthquake 1992 earthquakes OF 92-0575; OF 93-0219

engineering geology $\mathrm{EV}$

plate tectonics OP-752

seismology OP-673

structural geology OP-144

Cape Romain National Wildlife Refuge ecology OF 93-0303

Cape Verde Atlantic

Pliocene OF 92-0413

Capitanian

stratigraphy OP-354
Carangas Deposit

metal ores OP-1306

carbargilite see coal

carbohydrates see cellulose

carbon see also organic carbon.

Antarctica, geochemistry OP-664

C-12

Rocky Mountains OP-1 103

Sweden OP-1649

United States OP-1649

C-13

Australia OP-1478

diagenesis OP-1477

Florida OP-1906

Illinois OP-1782

Indonesia OP-1478

Kentucky OP-1782

C-13/C-12

Alaska OP-564; OP-626; OP-1616

Antarctic Ocean OP-1535

Antarctica OP-949

California OF 93-0146

Canada OP-1776

Colombia OP-755

Colorado W 2340; WRI 93-4007

Commonwealth of Independent States OP1261; OP-1265

East Pacific Ocean Islands OP-925

energy sources OF 92-0391; OP-1822; OP1823

England OP-755

Europe OP-1261; OP-1265

Florida OP-1906; OP-1930

Galapagos Islands OP-925

geochemistry OP-1292

Indiana OP-1648

Maryland OP-524; OP-1572; OP-1573

Minnesota OP-251

Montana OP-978

Nevada C 1086; OP-643

New Mexico WRI 93-4007; OP-1072

Ohio OP-1648

Pacific Ocean OP-628; OP-1127

Poland OP-755

Russian Federation OP-2004

Texas OP-755; OP-1072

United States OP-1776

Utah W 2340

Virginia OP-524; OP-1573

C-14

Alaska OP-163; OP-390

Arkansas OF 93-0273; OP-1683

California OF 93-0311; OP-68; OP-77; OP338; OP-474

Colorado OP-885; OP-1324; OP-1676

Dominican Republic OP-808

Great Lakes OP-200; OP-1290

Hawaii OP-632; OP-633

Indiana OP-1648

Indonesia OP-1743

Italy OP-764

Louisiana OF 92-0530

Massachusetts OP-749

Minnesota C 1086; OP-20

Nevada OP-68

New England OP-748

Ohio OP-1648

Oregon B 2038; OP-720; OP-982

Pacific Ocean OP-519; OP-628

pedogenesis OP-48

Russian Federation C 1086 
Tennessee WRI 92-4082; OF 93-0273; OP1683

Washington OF 93-0233; OP-120; OP-720; OP-904

California, environmental geology OF 93-0294

Canada, hydrology W 2400

Colorado, geochemistry OP-1965

ecology C 1086

fluid inclusions $\mathrm{OP}-1773$

geochemistry B 1770; OP-477

Kentucky, geochemistry B 2046

Maryland, geochemistry OP-439

Nevada, gold ores B 2039

Ohio, ground water OP-1454

phase equilibria OP-1726

pollution $\mathrm{C} 1086$

soils C 1086; OF 91-0513

United States, hydrology W 2400

Utah, geochemistry OP-1965

Wyoming, petrology OP-1456

carbon dioxide see also greenhouse effect.

OP-1153; OP-1270

Arizona, geochemistry OF 92-0599

California

hydrogeology OP-256

soils OP-1713

thermal waters OP-997

Cameroon

geochemistry OP-306; OP-1011

geologic hazards OP-903

Colorado, sedimentary petrology OP-1382

ecology C 1086

economic geology OP-57

energy sources OP-1822; OP-1823

geochemistry B 1966; OP-58; OP-533

Greenland, Quaternary C 1086

hydrology OF 92-0480

Illinois

hydrogeology OP-1782

non-metal deposits OP-1419

Kentucky

hydrogeology OP-1782

non-metal deposits OP-1419

mineral resources OP-574

New Jersey, pollution OP-1383

Oregon, geochemistry OP-43

petrology OP-696; OP-1061; OP-1355

phase equilibria OP-1176

pollution C 1086; OP-1128

Quaternary OP-980; OP-2011

Quebec, gold ores OP-1097

Rocky Mountains, natural gas OP-1350

sediments OP-1887

carbon-12 see $\mathrm{C}-12$

carbon-13 see $\mathrm{C}-13$

carbon-14 see $\mathrm{C}-14$

carbonaceous chondrites see Allende Meteorite

carbonaceous shale see black shale

carbonate platforms

Atlantic Ocean, oceanography OP-1073

Florida, sedimentary petrology OP-1931

Gulf of Mexico, structural geology OP-1932

Nevada

sedimentary petrology OP-1795

stratigraphy OP-1847

Texas, stratigraphy OP-1387

carbonate ramps

Alaska, sedimentary petrology OP-1268

Canada, Devonian OF 93-0184

United States, Devonian OF 93-0184 carbonate rocks see also carbonate platforms; chalk; dolostone; grainstone; limestone; packstone; travertine.

Alabama, energy sources OP-1602

Basin and Range Province, natural gas OP-208

Colorado

energy sources OF 93-0248

geochemistry OP-1965

natural gas OP-1262

petroleum OF 92-0391

stratigraphy B 1787-EE; B 1787-GG; OP1399

Commonwealth of Independent States

energy sources OP-1261

petroleum OP-1265

Europe

energy sources OP-1261

petroleum OP-1265

Florida

ground water WRI 91-4168

hydrogeology OP-2001

Georgia, hydrogeology W 2391

Great Basin, natural gas OP-208

Great Lakes, ground water OP-1354

Illinois, hydrogeology OP-1782

Kazakhstan, plate tectonics OP-1295

Kentucky, hydrogeology OP-1782

Massachusetts, Mesozoic OP-801

metal ores OF 92-0557

Mexico, hydrogeology OP-2001

Midwest, ground water P 1405-B; OF 92-0489

Minnesota, non-metal deposits OF 92-0514

natural gas B 1839-I,J; OF 92-0524

Nevada

B 1988-E

gold ores B 2039

ground water WRI 91-4167

metal ores OF 93-0249

natural gas $O F$ 93-0248

petroleum OF 92-0391

stratigraphy B 1988-F

New Jersey, hydrogeology OP-652

New Mexico, stratigraphy B 1787-EE

New York, stratigraphy B 1839-L

Ohio, ground water WRI 91-4024

Pacific Ocean, Pennsylvanian OP-1356

Pennsylvania, ground water OP-111

Pennsylvanian OP-1233

Poland, metal ores OF 92-0704

Quatemary OF 92-0525

Rocky Mountains, Pennsylvanian OP-1103

stratigraphy B 1917-M

Tennessee, hydrogeology OP-1283

Turkey, ground water OP-39

Utah

energy sources OF 93-0248

geochemistry OP-1965

gold ores OP-1096

metal ores OP-1464

natural gas OP-1262

petroleum OF 92-0391

stratigraphy B 1787-BB

Vanuatu, plate tectonics OP-197

West Virginia, environmental geology OP-901

Western Interior OP-1332

carbonate sediments see also carbonates; oolite. OP-1662

Florida B 2002

Georgia, pollution OP-1501

Mississippi Valley, Ordovician OP-1818 carbonates see also aragonite; azurite; bastnaesite; calcite; calcium carbonate; cerussite; dolomite; gaylussite; magnesian calcite; malachite; thodochrosite; siderite; strontianite; trona.

California, geochronology OP-68

Colorado, sedimentary petrology OP-1382.

geochemistry OP-974; OP-1415

Minnesota, geochemistry OP-248

Nevada, geochronology OP-68

Pacific Ocean, geochemistry OP-519

carbonatites

California OP-1584

Colorado OP-1584

economic geology OF 92-0557

carbonic acid

phase equilibria OP-1176

Carboniferous see also Hercynian Orogeny; Mississippian; Pennsylvanian.

OF 93-0513; OP-1232

Alabama OP-1918

Chile OP-1107

Dinantian

Canada OF 93-0184

Poland OP-967

United States OF 93-0184

Georgia OP-1918

Kansas OF 93-0549

Manning Canyon Shale OP-1320

Nova Scotia OP-1673; OP-2034

Stellarton Group, sedimentary petrology OP1672

Tournaisian

Virginia OP-1367

West Virginia OP-1367

Venezuela OP-1107

Western Interior OP-1231

Westphalian

Canada OP-1905

Nova Scotia OP-1672

Ohio OP-1513

United States OP-1905

West Virginia OP-778

carbonization see coalification

Cargo Muchacho Mountains

igneous rocks OP-1112

Caribbean Plate

Dominican Republic, plate tectonics OP-808

plate tectonics OP-1133

Caribbean region see West Indies

Caribbean Sea

geochemistry OP-755

geophysical surveys, Cayman Trough MF2083-B

oceanography DDS-0015; OF 92-0513

structural geology OP-785

Caribou volcanic field

lava OP-1447

Carlile Shale OF 93-0335

Carlin Trend

gold ores OP-27

Carlsbad Caverns

geomorphology OF 92-0391

solution features OP-1629

Carmel Canyon

continental shelf OP-1443

oceanography OP-1444

Carnian

Virginia OP-1660

Carnivora see Fissipeda

Carolina slate belt

economic geology B 2039 


\author{
geochemistry OP-1607 \\ Carolina Terrane \\ geochemistry OP-1607 \\ Caroline Islands see Belan \\ Carpenter Ridge Tuff \\ stratigraphy OP-985 \\ Carrara Formation
}

mineralogy OP-1452

Carson River basin

ground water W 2340; OP-995

hydrogeology OP-276

hydrology C 1086; OF 92-0627

Carson Spring

hydrogeology WRI 91-4190

carst see karst

Cartesian coordinates

geophysical surveys OP-951

Cartographic Technical Standards maps OF 93-0188-A; OF 93-0188-B

cartography see also digital cartography. YR; OF 92-0391; OF 93-0506; OF 93-0516; OP-839; OP-866; OP-1149; OP-1242; OP-1543; OP-1595; OP-1596; OP-1935

copper ores B 2039

core OP-1031

economic geology C 1094

engineering geology $P$ 1519; OF 92-0391; OF 92-0530; OP-96; OP-1184

environmental geology YR; C 1086; OF 92 0717; OP-1608

geologic hazards YR; P 1519; C 1111; OF $92-$ 0717

geomorphology OF 91-0014; OF 92-0530; OP1623

geophysical surveys C 1086; OP-227; OP-543

ground water OF 92-0492; OP-952; OP-961; OP-1009

hydrogeology OF 92-0492; OP-562

hydrology OP-337

mineral resources $\mathrm{OP}-1853$

natural gas OF 92-0524

non-metal deposits OF 92-0514

pollution OP-155; OP-1448

Quaternary P 1386-E

sediments OP-1403

soils C 1086

Carver Lake

geologic hazards W 2340

caryopllite

California, manganese ores OP-458

Casa Diablo

Quaternary OP-459

Casamero Lake Quadrangle maps GQ-1716

Cascade Range see also Mount Hood; Mount

Rainier, Mount Saint Helens; Mount Shasta;

Newberry Volcano.

geochemistry OF 93-0314; OP-1121

geologic hazards W 2340

geophysical surveys B 1966; OF 93-0319; OP1374

hydrogeology OP-468

lava OP-957; OP-1447

magmas OP-982

maps OF 93-0297; I-2005

petrology OP-638; OP-1271; OP-1463

stratigraphy OP-1480

Cascade subduction zone neotectonics OP-1852

Cascades see Cascade Range
Cascades Volcano Observatory

geophysical surveys B 1966

seismology B 1966

Cascadia subduction zone

earthquakes OP-1259

geomorphology OP-840

seismology OP-673

structural geology OP-144

Casco Bay Group OP-1530

Casper Wyoming

pollution OP-1871

Caspian Basin

energy sources OP-1967

cassiterite see tin ores

Castaneda Hills

neotectonics OP-611

Caster, Kenneth Edward OP-444

Castile Spain see New Castile Spain

Castle Pines Colorado

ground water OF 93-0071; OP-854

casts, flute see flute casts

casts, load see load casts

Cat Cay

sedimentation OP-928

Cat Island Pass

geomorphology OF 92-0530

sedimentation OF 92-0530

cataclasis

Missouri, deformation OP-1861

Catalina Schist

petrology OP-1900

structural geology OP-1172; OP-1971

catalogs see also libraries.

CAT; OF 93-0575; I-2392

Alaska

earthquakes OF 93-0309

hydrology W 2400; OF 93-0029

seismology P 1527

Arizona, geochemistry B 2021-C

Armenia, earthquakes OF 93-0216

California

OF 93-0506

earthquakes EV

engineering geology EV

seismology EV

Central America

earthquakes DDS-0007

seismology OP-1066

earthquakes PDE; OF 91-0600-D; OF 92-0583;

OF 92-0584; OF 92-0600-A; OF 92-0600-

B; OF 92-0600-D; OF 92-0601-A; OF 920601-B; OF 92-0602-A; OF 92-0602-B; OF 92-0603-A; OF 92-0603-B; OF 920604-A; OF 92-0604-B; OF 92-0605-A; OF 92-0605-B; OF 92-0606-A; OF 920606-B; OF 92-0607-A; OF 92-0607-B OF 92-0608-A; OF 92-0608-B; OF 920609-A; OF 92-0609-B; OF 92-0610-A; OF 92-0610-B; OF 92-0611-A; OF 92 0611-B; OF 92-0612-A; OF 92-0612-B; OF 93-0204; OP-940

Europe, Quaternary P 1386-E

Georgia, hydrology OF 92-0113

Hawaii

earthquakes EV

petrology OF 92-0586

hydrology WRI 93-4076; OF 93-0138

Kansas, paleontology OF 93-0549

Mississippi Valley

engineering geology OF 93-0349

Paleozoic OF 92-0685
Montana, metal ores OF 93-0207

Nevada OF 93-0506

New York, hydrology WRI 92-4042

paleontology OF 93-0513

Philippine Islands, earthquakes EV

pollution OF 92-0527.

Puerto Rico, hydrology W 2400; OF 93-0029

stratigraphy DDS-0006

Tennessee, hydrogeology WRI 91-4195

Turkey, seismology EV

uranium ores DDS-0001

Washington

earthquakes EV

Quatemary OF 93-0289

Catalonia Spain see Barcelona Spain

Cataract Formation

hydrogeology OP-1228

catchments see drainage basins

catechol

Australia, sedimentary petrology OP-1478

diagenesis OP-1477

Indonesia, sedimentary petrology OP-1478

Catheart Mountain

metal ores B 2039

Catheys Formation

hydrogeology OP-1283

cathodoluminescence OP-1305; OP-1466

cation exchange capacity B 2061-A; OF 930321; OP-1458

cation-ratio dating

Nevada, Quatemary OP-1070

Catoctin Formation

geochemistry OP-3

structural geology OP-1955

Catoctin Mountain

environmental geology OF 92-0168

geochemistry OP-3; OP-1824

hydrogeology OF 92-0649

hydrology OP-524; OP-1572; OP-1573

Catskill Mountains

environmental geology OP-1130; OP-1735

hydrology OP-1734

pollution OP-975

Caucasus

earthquakes OP-1025

geochronology OP-1407

magmas OP-91

Cave Springs

hydrogeology WRI 92-4018

caverns

New Mexico, geomorphology OF 92-0391

caves see also speleothems.

New Mexico, solution features OP-1629

Cayce Valley Branch

hydrology OF 92-0648

Cayman Trough

geophysical surveys MF-2083-B

Cd see cadmium

CD-ROM

OF 91-0014; OP-1095; OP-1111; OP-1516 Quaternary OP-1719

Cedar Breaks National Monument sedimentary petrology OF 92-0391

Cedar Grove Tennessee ground water OF 92-0166

Cedar Mountalns

geochemistry OP-1609

Cedar Peak

gold ores B 2039 
Cedar River basin

ground water OF 92-0085

Celebes

engineering geology OP-993

sedimentary petrology OP-870

Celebes Sea see also Leg 124; ODP Site 770. geophysical surveys OP-587

Cellte Mine geochemistry B 1995-C

cellulose

Nova Scotia, sedimentary petrology OP-1673

cement

barite deposits OP-960

California, sedimentary petrology OF 92-0707

Illinois, sedimentary petrology OP-1385

Indiana

diagenesis OP-1466

sedimentary petrology OP-1385

Mississippi, diagenesis OP-1856

Nevada, geochemistry OP-643

New Mexico, geochemistry OP-1072

Texas

geochemistry OP-1072

geomorphology OP-1703

Wyoming, natural gas OP-1569

Cement Field

energy sources OP-268

cement materials

Michigan OF 92-0514

South Dakota OF 92-0514

Cenomanian

California OP-385

Colombia OP-755

Colorado OF 92-0391

England OP-755

Montana OP-395

Poland OP-755

Texas OP-755

Wyoming OP-395

Cenozoic see also Quatemary; Tertiary.

C 1086; OF 92-0593; OP-88

Alaska C 1086; OP-74

Antarctic Ocean OP-65

Antarctica OP-1317

Appalachians OP-1484

Atlantic Coastal Plain P 1404-G; P 1542

Bering Sea OP-211

Blancan, Idaho OP-1850

California B 2019; I-1943; OP-83; OP-332; OP-1166

Colorado WRI 93-4007

Glenns Ferry Formation OF 92-0542; OF 920713; OP-1850

Guatemala OP-277

Gulf of Mexico OP-288

Idaho OP-1067

Illinois OP-1742

Koobi Fora Formation OP-656

Matuyama Epoch

Idaho OP-1850

Indonesia OP-1538

Ivory Coast OF 92-0699

New Mexico OF 92-0699; OP-1538

Mexico MF-2238

Missouri OP-1742,

Nevada B 2019; I-2342; OP-999

New Mexico WRI 93-4007

Oregon OF 93-0189; OP-1166

Pacific Ocean OP-105; OP-419

Russian Federation C 1086; OP-2003

Santa Fe Group, ground water WRI 91-4155

Shungura Formation OP-656
South Carolina OF 92-0723

Vanuatu OP-197

Venezuela OP-1760

Washington OF 93-0332; GQ-1679; OP-1067

Yukon Territory C 1086

census

Atlantic Coastal Plain

Pliocene OF 92-0262

Quatemary OF 92-0263

Atlantic Ocean, Pliocene OF 92-0413

Pliocene OF 92-0414; OF 92-0418

centers, spreading see spreading centers

Centerville Quadrangle

maps I-2377

Central Africa see Gabon; Rwanda; Zaire

Central America see also Costa Rica; El Salva-

dor, Guatemala; Honduras; Nicaragua; Panama. earthquakes DDS-000?

geologic hazards, Panama Canal Zone OP-1862 tectonophysics OP-1034

Central American Geothermal Resources Program

geothermal energy OP-1496

Central Asia see Kazakhstan

Central Basin hydrogeology OP-1283

Central Basin Aquifer ground water WRI 92-4092

Central City District

base metals OP-944

geophysical surveys OF 91-0449-E; OF 910449-F

metal ores OP-582; OP-937

Central Coastal Basins

energy sources OF 89-0450-D

Central Europe see Austria; Czechoslovakia; Germany; Hungary; Poland; Silesia; Sudeten Mountains

central granite see batholiths

Central Greece see Sterea Ellas

Central Metasedimentary Belt petrology OP-214

Central Oklahoma Aquifer geochemistry OP-891

ground water OF 92-0641 pollution OP-1251

Central Siberian Plateau see Siberian Platform

Cephalopoda see Tetrabranchiata

cephalopods see ammonoids

CERCLA see Superfund

Ceres Asteroid OP-1583

Ceresco Deposit

molybdenum ores OP-1050

Cerranius Fossae OP-1984

Cerro Prieto

energy sources OP-1137; OP-1657

geothermal energy OP-984 sedimentary petrology OF 92-0391; OP-50

Cerro Rico de Potosi Deposit metal ores OP-1306

cerussite

Arizona, metal ores OP-290

California OP-500

cesium

Cs-137, Great Lakes OP-1290

CFCs

ground water YR

Chaco River

hydrogeology OF 93-0084
Chad Basin

fluvial features OP-314

Chadwell Gap Member

stratigraphy OP-1368

Chagrin Shale

energy sources B 1909

Chain O'Lakes State Park

hydrology WRI 92-4033

chain silicates see amphibole group; jade; pyroxene group; rhodonite

Chainman Shale B 1988-G

chalcedony

Wyoming, geochemistry OP-520

chalcocite see copper ores

chalcopyrite

Colorado, molybdenum ores OF 92-0525

chalk

Atlantic Coastal Plain, environmental geology OP-378

Gulf Coastal Plain, environmental geology OP378

Chalk Hills

paleomagnetism OF $92-0542$

Challis Volcanics OP-479; OP-617

chalybite see siderite

chambers, magma see magma chambers

Chandalar River

folds OP-1427

Chandeleur Islands

geomorphology OF 92-0530

Chandina Formation

geomorphology OP-1273

Chandler Bridge Formation Quaternary I-1935

Chandler Lake Quadrangle

mineral resources MF-2144-B; MF-2144-C; MF-2144-D

Changcheng System OP-1361

changes of level see also isostasy; shorelines; terraces.

Alabama oceanography OF 92-0530 Quaternary OF 92-0530

Alaska

Invertebrata OP-1800

neotectonics OP-1852

Quaternary OP-515

Atlantic Coastal Plain, hydrology C 1086

Atlantic Ocean, Quatemary OP-1650

Basin and Range Province, Quaternary C 1086

Black Sea, oceanography OF 93-0274

California

Invertebrata OP-1800

Quaternary OF 93-0232; OP-707

Chile, Quaternary OP-35; OP-719

Delaware

ground water OF 92-0052

hydrogeology C 1086; OF 92-0052

Florida, Pliocene OP-1075

Great Basin, Quaternary C 1086

Gulf Coastal Plain, Quaternary OF 92-0530

Gulf of Mexico, Quaternary OF 92-0530

hydrogeology OF $92-0052$

Illinois OP-1393

Indonesia, Quaternary OP-1743

Japan, neotectonics OP-1852

Louisiana

OF 92-0530

Quaternary OF 92-0530

Marshall Islands, Neogene OP-1457 
Massachusetts neotectonics OP-555 Quaternary OP-749

Mexico Invertebrata OP-1800 Quatemary OP-707

Micronesia, Neogene OP-1457

Middle East, oceanography OF 93-0274

Mississippi oceanography OF $92-0530$ Quaternary OF 92-0530

Nevada, Quatemary OP-69

New England, Quaternary C 1086

New Jersey ground water OF 92-0052 hydrogeology C 1086; OF 92-0052

New York, ground water WRI 88-4127

North Dakota, hydrology W 2340

Oregon, Quaternary OP-707

Pacific Coast, Quaternary C 1086

Polynesia, geochronology OP-1436

Quaternary OF 92-0525; OP-756

South Dakota, hydrology W 2340

Utah, Quaternary OP-52; OP-620; OP-622; OP908; OP-1021; OP-1022

Washington, Quaternary OF 93-0284

Wisconsin, hydrogeology OF 92-0026

channel geometry

Alaska

geologic hazards OF 93-0094 hydrology OF 93-0162

Arkansas, fluvial features OP-1700

hydrology W 2339; OF 92-0651

Mississippi, hydrogeology OP-1010

Mississippi Valley, hydrology OF 91-0485; OP-1720

Missouri, fluvial features OP-1700

Oregon, geomorphology OP-840

Tennessee, waterways OP-1084

waterways OP-157

Channel Islands

structural geology OP-1172

tectonophysics OP-2010

channels see also channel geometry; fluvial features; streamflow; tidal channels; waterways.

OP-1221; OP-1224; OP-1266; OP-1338; OP1667; OP-1838; OP-1937; OP-1940

Arizona, geomorphology OP-426; OP-1060

Gulf of Mexico, ocean floors OP-743

Minnesota, non-metal deposits OF 92-0514

Montana, sedimentary petrology B 1917-L

Nevada, sedimentary petrology B 1988-E

New Mexico, hydrogeology OP-347

Utah, geomorphology OP-1060

Virginia, geomorphology B 1981

West Virginia, geomorphology B 1981

Wyoming, sedimentary petrology B 1917-L; B 2051

chaos

Italy, geologic hazards OP-213

Charana Bolivia

metal ores OF 93-0016

Charco Azul Group

Neogene OP-1272

charcoal

Dominican Republic, plate tectonics OP-808

Oregon, Quaternary B 2038

Washington, Quatemary OP-904.

Charleston Canal hydrogeology OP-424

Charleston earthquake 1886

South Carolina, Quatemary I-1935
Charleston Quadrangle

Quaternary I-1935

Charleston South Carolina

seismicity OP-2032

Charlie Fault

plate tectonics OP-1429

Charlotte Harbor

hydrogeology WRI 92-4062

chartology see cartography

Chatham Group

stratigraphy OP-597

Chatham Quadrangle geochemistry OF 93-0010.

Chattahoochee River Aquifer ground water P 1410-G

Chattanooga Quadrangle economic geology B 2005

Chattanooga Shale

B 1909

geochemistry OP-584; OP-1649

Cheat River basin geomorphology B 1981

Cheeneetnuk Limestone

Brachiopoda OP-491

Invertebrata OP-84

Chegem Caldera

geochronology OP-1407

magmas OP-91

chemical analysis see also atomic absorption; emission spectroscopy; inductively coupled plasma methods; infrared spectroscopy; mass spectroscopy; minor-element analyses; neutron activation analysis; optical spectroscopy; titration; ultraviolet spectroscopy; X-ray analysis; $\mathrm{X}$-ray fluorescence.

geochemistry YR; B 1770; B 2046; OF 920009; OF 92-0345; OF 92-0392; OF 92 0445; OF 93-0001-A; OF 93-0001-B; OF 93-0001-C; OP-935; OP-1923

hydrogeology WRI 92-4075; OF 92-0146; OF 92-0163

soils OF 93-0281

chemical remanent magnetization

Alaska, structural geology OP-94

chemical weathering

Alaska OP-1553

Colorado OP-1051

geochemistry OP-1292

Maryland, hydrology OP-1573; OP-1610

Pennsylvanian OP-1233

Puerto Rico, hydrogeology C 1086

Virginia

geochemistry OP-1774

ground water WRI 92-4090

hydrology OP-1573; OP-1610

Washington, geochemistry OP-1121

Western Australia, geochemistry OP-1774

chemically precipitated rocks see chert; evaporites; iron formations; phosphate rocks; siliceous sinter; taconite; tufa

chemostratigraphy

New Jersey OP-979

cheniers

Louisiana, Quaternary OF 92-0530

Chepultepec Dolomite hydrogeology WRI 91-4190

Cherokee Group

energy sources OP-1476

metal ores MF-1835-H
Cherry Canyon Formation OP-354; OP-1387

chert

Alaska, stratigraphy OP-1169

California

manganese ores $\mathrm{OP}-458$

paleomagnetism OP-385

Canada, stratigraphy OP-708

Kentucky, stratigraphy OF 92-0558

Kenya OP-1490

Nevada, metal ores OF 93-0249

Oregon OP-1490

stratigraphy OP-88

United States, stratigraphy OP-708

Chesapeake and Delaware Canal

stratigraphy OP-528

Chesapeake Bay geochemistry OP-439

Chesapeakella nodatum stratigraphy OP-528

Cheshire Formation economic geology B 1955

Cheshire Quadrangle maps I-2369

Chester Series see Chesterian

Chesterfield Group guidebook OP-359

Chesterfield Range stratigraphy OP-1320

Chesterian see also Golconda Formation. Arkansas OP-360

Oklahoma OP-360

Cheyenne Belt

Cretaceous OP-11

structural geology OP-149

Chiapas Mexico see El Chichon

Chicago Illinois

changes of level OP-1393

environmental geology YR

hydrology YR

non-metal deposits OF 92-0514

Chicago River hydrology YR

Chichagof Island petrology OP-1396

Chickahominy Creek reservoir hydrology WRI 92-4034

Chickahominy-Piney Point Aquifer ground water WRI 92-4175 hydrogeology OP-1196

Chickaloon Formation geochemistry OP-1410

Chickies Quartzite ground water OP-915

Chiclayo Canyon plate tectonics OP-1901

Chicot Aquifer ground water OF 92-0492; OF 93-0081; OF 930086; OP-742

Chicxulub geochronology OP-920 stratigraphy B 2050

Chilhuahua Mexico geochemistry OP-132 maps YR; I-2287

Chile see also Chile earthquake 1960; Cordillera de la Costa; Patagonia. copper ores OP-2027 geochemistry OP-2005 geologic hazards OP-1369 lava OP-957 
magmas OP-971

plate tectonics OP-586

Quaternary OP-35; OP-279; OP-719

Chile earthquake 1960

Chile OP-53

Chile Ridge

plate tectonics OP-586; OP-1651

Chile Trench see Peru-Chile Trench

Chilhowee Group OP-1642

CHILLER OP-1785

CHIM method

metal ores OP-582

China see also Fujian China; Guizhou China;

Hebei China; Hunan China; Inner Mongolia

China; Xinjiang China; Yunnan China.

economic geology OF 92-0525

energy sources OP-1624

Invertebrata OP-1839

metal ores C 0930-M; C 0930-N; OP-317; OP363; OP-1432.

natural gas OF 93-0004

petroleum OP-1829

plate tectonics OP-1519

Chinle Formation

OP-1659

sedimentary petrology B 2000-E

uranium ores $\mathrm{OP}-1848$

Chippewa River

hydrology WRI 90-4124

Chiricahua Peak Quadrangle

geochemistry B 2021-C

Chirikof Island

Invertebrata OP-1800

Chiwaukum Schist

maps I-1963

Chkalov Russian Federation see Orenburg Russian

Federation

chloride ion

Antarctica, hydrology OP-949

California, pollution OP-473

Colorado

hydrogeology OP-408

hydrology WRI 92-4081

Florida, ground water W 2340; OP-1568

geochemistry OP-1312

Iowa, ground water OP-612

Nevada, ground water W 2340

New York, geochemistry OP-776

South Carolina, ecology OF 93-0303

Texas, ground water OP-2013

Utah, hydrogeology OP-1736

Wyoming, geochemistry OP-712

chlorides see halite

chlorinated hydrocarbons see also DDT; PCBs;

trichloroethylene.

ground water YR

Idaho, ground water WRI 93-4054

Kansas, pollution OF 93-0087

Nebraska, pollution OF 93-0087

chlorine

Canada, hydrology W 2400

Cl-36

Idaho OP-147

Nevada OP-1070

Cl-37/Cl-35, geochemistry OP-605

geochemistry B 1770

Idaho, metal ores OP-715

Kentucky, hydrology WRI 92-4057

New Hampshire, environmental geology OF 92-0647

New York, pollution OP-412
Oregon, geochemistry $\mathrm{OP}-43$

Pacific Ocean, geochemistry OP-419

Philippine Islands, geochemistry OP-1994

United States, hydrology W 2400

Vermont, pollution $\mathrm{OP}-412$

Wyoming, ground water OF 91-0533

chlorite

Colorado, diagenesis OP-1961

Ecuador, gold ores B 2039

Greenland, phase equilibria OP-636

Utah, diagenesis OP-1961

Wyoming, diagenesis OP-1950

chlorite group see also cookeite.

California, manganese ores OP-458

Ontario, polymetallic ores OP-484

chlorofluorocarbons

ground water YR

Idaho, ground water WRI 93-4054

chlorophenothane see DDT

chlorophyll

California, hydrogeology OF 93-0146

Colorado, hydrology WRI 92-4053

Florida, oceanography OP-893

Virginia, hydrology WRI 92-4034

Chlorophyta see Botryococcus

Chocolate Mountains

structural geology OP-649; OP-803

cholestane

Alaska, energy sources OP-626

Cholla Fault

metal ores B 2042-C

chondrites see also carbonaceous chondrites; LL chondrites.

OP-1561

petrology OF 92-0525; OP-1727; OP-1977

chondrules

petrology OP-1666

Chordata see Vertebrata

chorology see biogeography

chromite ores

geochemistry OP-1621

Montana OF 93-0207

Puerto Rico OP-1656

Texas OP-1229

chromium

Colombia, geochemistry OP-755

Costa Rica, pollution OP-335

England, geochemistry OP-755

geochemistry C 1086; OP-16; OP-104; OP675; OP-1426

Louisiana, geochemistry OP-935

Poland, geochemistry OP-755

sediments OP-1887

Texas, geochemistry OP-755

chromium ores see chromite ores

Chryse Planitia OP-142; OP-987; OP-1838; OP1937

chrysocolla

Arizona OP-1993

Chrysophyta

Washington, Quaternary OF 93-0289

Chrysothamnus

thermal waters OF 93-0017-A; OF 93-0017-B

Chuar Group

natural gas OF 92-0524

sedimentary petrology OF 92-0391

Chuckwalla Mountains

igneous rocks OP-1112

petrology OP-1376
Chugach Mountains

economic geology C 1094

gold ores OF 93-0325

maps I-2164

metamorphic rocks $P$ 1497-C

petrology OF 92-0020-E

Quaternary OP-1719

stratigraphy OP-1169

structural geology OP-94

Chugach Terrane

geochemistry OP-1410

maps I-2164

metamorphic rocks OP-1194

Chugwater Formation

Triassic B 1917-P

Chuitna Alaska

maps OF 92-0346

Chukchi Borderland

plate tectonics OP-1429

Chukchi Peninsula

metal ores OF 93-0339

Chukchi Sea

Quaternary OP-299

Chukotskiy Peninsula see Chukchi Peninsula

Churchill method

hydrology W 2340

Churchill Valley

ground water OP-995

Churchtown Pennsylvania ground water OP-387

Cibao Valley

plate tectonics OP-808

Cid Formation

geochemistry OP-1607

Cimmerian Orogeny

plate tectonics OP-1628

Cincinnatian

Midwest OF 92-0489

Cinder Butte

geomorphology OP-266

Circleville Quadrangle

engineering geology OP-1542

maps OP-1543

Circum-Pacific region

energy sources OP-1614

petrology OP-105

seismology OP-1488

cirques

California, Quaternary OP-1253

Colorado, Quaternary OP-1324

cistern rock see laccoliths

citation indexes OP-1164

Ciudad Real Spain

pollution OP-599

Cl see chlorine

Cl-36

Idaho, ground water OP-147

Nevada, Quatemary OP-1070

Cl-37/Cl-35

geochemistry OP-605

cladistics

South America, Vertebrata OP-97

Claiborne Aquifer

ground water WRI 91-4150; WRI 92-4102; WRI 92-4104

Claiborne Group see also Cockfield Formation; Sparta Sand.

structural geology OP-1970 


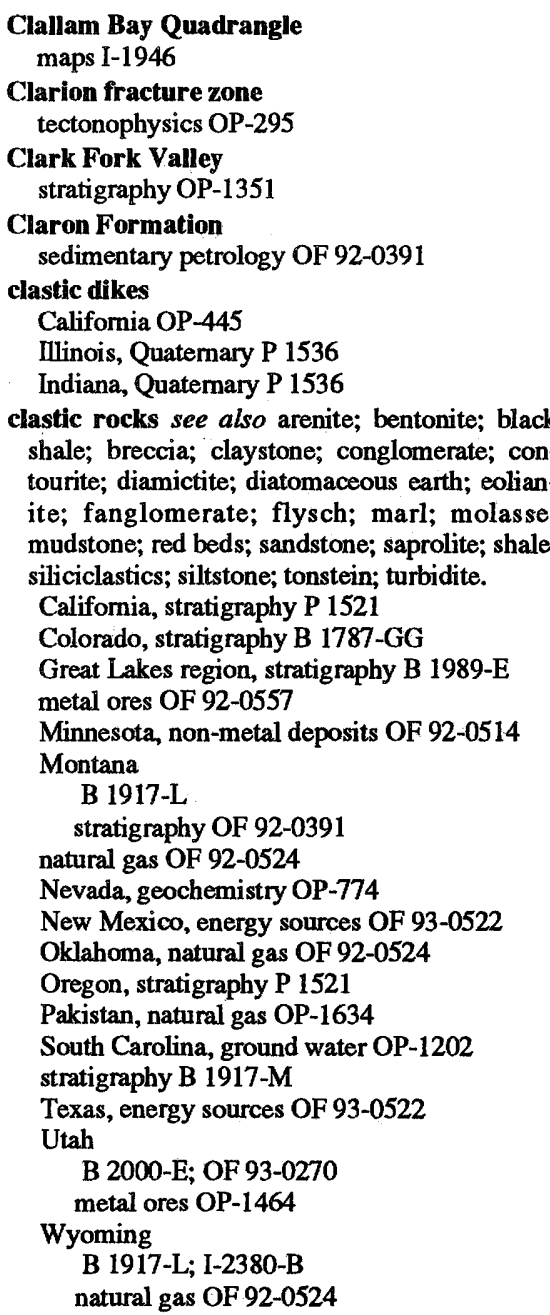

clastic sediments see also alluvium; boulders; clay; cobbles; colluvium; diamicton; dust; flint clay; gravel; loess; mud; ooze; outwash; pebbles; sand; silt; till; turbidite.

Appalachians, stratigraphy OP-1484

Connecticut, ground water WRI 87-4144

Minnesota, Quaternary OP-668

New Hampshire ground water WRI 90-4161; WRI 91-4025; OF $92-0095$

hydrogeology OF 89-0583

New York, ground water WRI 88-4127; WRI $91-4030$

Ohio, ground water WRI 93-4047

South Carolina, stratigraphy B 2030

Washington OF 93-0233

West Virginia, environmental geology OP-901 clathrates

geochemistry OP-58

natural gas OF 92-0381; OP-1615

Russian Federation, Quatemary OP-1532

clay see also bentonite.

Atlantic Ocean OP-1650

California, structural geology OP-702

Colorado, environmental geology OP-902

Great Lakes, Quaternary OP-1288

Hawaii, soil mechanics OP-1814

hydrology OF 92-0651

Oregon, Quaternary OF 93-0212

Washington, Quatemary OF 93-0212

Wyoming, Quatemary OP-1884 clay liners see disposal barriers

clay mineralogy see also crystal growth; crystal structure; weathering.

OP-93; OP-1068

Black Sea, oceanography OF 93-0274

engineering geology OP-760

Gulf of Mexico OP-288

Middle East, oceanography OF 93-0274

Missouri OP-522

New Mexico, petroleum B 2039

Ontario, polymetallic ores OP-484

Pennsylvania OF 92-0568

Peru, stratigraphy OP-1330

petroleum B 1909; OP-793

Western Interior OP-794

Wyoming, petroleum B 2039

clay minerals see also beidellite; dickite; halloys-

ite; illite; kaolinite; montmorillonite; sepiolite; smectite.

geochemistry OP-165

soils OP-1761

Utah, oil sands OP-1855

Wyoming

natural gas OP-1569

thermal waters OF 93-0293

clay stone see claystone

clays see also kaolin deposits.

OF 92-0514

Minnesota OF 92-0514

Ohio OF 92-0514

South Dakota OF 92-0514

\section{claystone}

Colorado, stratigraphy OP-1880

Iowa, stratigraphy OP-1537

New Mexico, stratigraphy OP-1880

Western Interior

OP-794

stratigraphy OP-1182

Clean Water Act

hydrology W 2400

Clear Creek Mine

oxides OP-849

Clear Lake Volcanics

energy sources OP-267

geochemistry OP-265

Clearwater Mountains gold ores OP-1099

Clearwater National Forest mineral resources OF 90-0672; OF 92-0384

cleavage

Idaho

metal ores OF 93-0235

structural geology OP-523

Pennsylvania, geochronology OF 92-0525

Virginia

orogeny OP-1612

structural geology OF 93-0025

Clementine Program OP-1693; OP-1881; OP1974

Cleveland Member

energy sources B 1909

cliff of displacement see fault scarps

Cliffside Field

economic geology OP-834

climatology, paleo-see paleoclimatology

Climax Mine

molybdenum ores OP-1050

climax-type

Colorado, molybdenum ores OF 92-0525; OP1913 clinker

Montana C-0142

clinoamphibole see actinolite; amosite; crocido-

lite; glaucophane; hornblende; pargasite; tremolite

clinoptilolite

Colorado

geochemistry OF 93-0321

non-metal deposits B 2061-A

New Mexico, non-metal deposits B 2061-A

clinopyroxene see also augite; jadeite.

Montana, petrology OP-604

Clipperton fracture zone

tectonophysics OP-295

Cloudburst Fault

metal ores B 2042-C

CMOGS

stratigraphy OF 93-0177

Co see cobalt

$\mathrm{CO} 2$ see carbon dioxide

Coachella Valley

ground water WRI $91-4142$

Quaternary OP-1843; OP-1844

seismology OP-959; OP-966

structural geology OP-703

coal see also coal assessment; coal balls; coa

fields; coal seams; coalbed methane; coalification; lignite; macerals.

OP-6; OP-93; OP-152; OP-1226; OP-1476

Alaska

OF 92-0391

geochemistry OF 92-0391

anthracite, Pennsylvania OF 92-0568

bituminous coal

OP-1244; OP-1477; OP-1822; OP-1823

Australia OP-1478

Colorado OP-850; OP-1382

Indiana OF 92-0682

Indonesia OP-1478

Nova Scotia OP-1673

Canada, geochemistry OP-1905

coke coal, Colorado OP-1382

Colorado

OP-674

ground water WRI 92-4067; OF 92-0122

hydrogeology WRI 92-4050

Far East OP-1624

geochemistry OP-1769

Indiana OP-1466

Kentucky, stratigraphy OF 92-0558

Mexico OP-50

Montana B 1917-L; C-0142

New Mexico

OP-17; OP-674

hydrogeology WRI 92-4004

Ohio

OF 92-0558

ground water OP-1454

palynomorphs OP- 1603

stratigraphy OP-1513

Pennsylvania

OF 92-0568; OP-1234

geochemistry OP-762

hydrogeology OF 93-0115

Puerto Rico OF 92-0567

Rocky Mountains OP-1792

stratigraphy OP-1345

subbituminous coal

OP-228

Pakistan OF 92-0576

United States, geochemistry OP $\div 1905$ 
Utah OF 93-0270; C-0144

Virginia, ground water W 2388

West Virginia, hydrogeology WRI 92-4073

Westem Interior OF 92-0391; OP-1792

Wyoming

B 1917-L

stratigraphy $P 1532$

coal assessment

Pakistan OF 92-0281; OF 93-0255; OF 93-0256; OP-996 lignite OF 92-0576

coal balls

Nova Scotia

OP-2034

sedimentary petrology OP-1672

coal beds see coal seams

coal fields

Pakistan OP-996

Puerto Rico, sedimentary petrology OF 92 0391

coal mines

engineering geology OP-506

Ohio, hydrology OF 92-0120

coal seams see also coal balls.

Colorado, sedimentary petrology OP-1382

Montana, geochemistry OP-1305

Pakistan

OP-996

lignite $O F$ 92-0576

Pennsylvania, waste disposal OP-1301

Utah, sedimentary petrology OP-1779

coal tar

Minnesota, pollution WRI 90-4150

coalbed methane

OP-1244; OP-1822; OP-1823

Colorado OP-1911

Montana OF 93-0207

Pacific Coast OP-1946

coalfields see coal fields

coalification

Australia, sedimentary petrology OP-1478

diagenesis OP-1477

energy sources OP-1822

geochemistry OP-1923

Indonesia, sedimentary petrology OP-1478

Nova Scotia, sedimentary petrology OP-1673

Pennsylvania, diagenesis OF 92-0568

Coalinga California

earthquakes OP-1992

coalitions

Idaho, industrial minerals B 2013

industrial minerals B 2013

Utah, industrial minerals B 2013

COALREAP

coal OF 92-0281

Coast Mountains

metamorphic rocks OP-1194

petrology OF 92-0724

Coast plutonic complex

metamorphic rocks OP-1194

Coast Range Fault

structural geology OP-401

Coast Range Ophiolite

maps OP-1945

metamorphic rocks OP-1166

structural geology OP-401

Coast Ranges

areal geology OF 93-0189

geochemistry OP-890

geomorphology OP-840 geophysical surveys OF 93-0319

manganese ores $\mathrm{OP}-458$

metal ores OP-554

metamorphism OP-1165

plate tectonics OP-145; OP-1749

Quatemary B 2038

sedimentary petrology OF 92-0707

structural geology $\mathrm{OP}-1547$

coastal dunes

Indiana, ground water OP-923

Louisiana OF 92-0530

coastal features see shore features

coastal plains

Alabama, ground water P 1410-G

Atlantic Coastal Plain

ground water $P$ 1404-G

heavy mineral deposits B 2039 stratigraphy P 1542

Delaware, ground water OP-777

Florida, hydrogeology OF 91-0483

Georgia, heavy mineral deposits B 2039

Gulf Coastal Plain, ground water WRI 91-4150;

WRI 91-4151; WRI 91-4152; WRI 92-

4102; WRI 92-4103; WRI 92-4104; WRI 92-4105; OF 92-0492

Mississippi, ground water P 1410-G

Mississippi Valley, ground water WRI 914150; WRI 92-4102; WRI 92-4104

South Carolina

geophysical surveys OF 92-0723

ground water WRI 92-4000

heavy mineral deposits B 2039

hydrogeology OF 91-0483

Texas, ground water OF 93-0062

Virginia, ground water WRI 92-4175; WRI 934015

coastal sedimentation

California OP-751

Louisiana

OF $92-0530$

engineering geology OF $92-0530$

environmental geology OF 92-0530

geomorphology OF 92-0530

Quaternary OF 92-0530

Tonga, geomorphology OP-989

Utah OP-1779

Wyoming B 2051

coastlines see also barrier islands; beaches; bluffs; spits.

Antarctica, Quaternary C 1086

Atlantic Coastal Plain, geologic hazards OF 920377-A; OF 92-0377-B

geologic hazards OF 91-0014

Great Lakes OP-1143

Gulf Coastal Plain OF $92-0530$

Gulf of Mexico OF 92-0530

Louisiana, Quatemary OF 92-0530

Massachusetts

OF 93-0185

neotectonics OP-555

Puerto Rico

environmental geology OF 92-0717

oceanography OF 92-0717

Utah, Quaternary OP-52

Wisconsin MF-2252

cobalt

Colombia, geochemistry OP-755

England, geochemistry OP-755

gold ores OP-168

Hawaii, oceanography OP-418

Poland, geochemistry OP-755

Texas, geochemistry OP-755 cobalt ores

Idaho OP-715

cobbles

Pakistan, tectonophysics OP-1548

Coccolithophoraceae see Emiliania huxleyi

coccoliths

Minnesota, Quaternary C 1086

Cocheco River basin

ground water WRI 90-4161

hydrogeology OF 89-0583

Cochiti Dam

hydrogeology WRI 92-4193

Cochrane District Ontario see Timmins Ontario

Cockfield Aquifer hydrogeology OP-32

Cockfield Formation hydrogeology OP-32

Coconino Sandstone mineral resources OF 92-0509-A; OF 92-0509B

COCORP

Arkansas, structural geology OP-1970

Michigan, structural geology B 1904-S

Minnesota, structural geology B 1904-S

Cocos Plate

plate tectonics OP-670

cod

Atlantic Ocean, ecology OF 92-0566

coda waves

OF 92-0441; OP-959; OP-1064

California OP-1498

Cody Shale

B $1917-0$

energy sources OF 93-0337

coefficient of permeability see hydraulic conductivity

Coelenterata

Montastrea, Florida OP-1930

Porites, Pacific Ocean C 1086

Rugosa, New York B 2024

coelenterates see corals

Coelophysidae

Vertebrata OP-1511

Coeur d'Alene mining district metal ores OF 93-0235

Coffee Creek Limestone guidebook OP-87

coke coal

Colorado OP-1382

Coldwater Shale

ground water WRI 91-4133 palynomorphs B 1909

COLLAGE oceanography DDS-0015

collapse structures

Arizona, economic geology OF 93-0329

Oregon, magmas OP-982

West Virginia, hydrogeology W 2384

collecting

Arizona, metal ores OP-290

mineral inventory OP-682

college-level education

YR

Alaska, sea ice OF 93-0237

colleges see academic institutions

colloquia see symposia

colluvium

Hawaii, geomorphology OP-782

Italy, Quaternary OP-764 
Nevada

geomorphology OP-1276

Quaternary OP-1070

Utah, Quaternary OP-970

Virginia, fluvial features B 1981

West Virginia, fluvial features B 1981

Colombia

geochemistry OP-755

geophysical surveys B 1966

Quaternary, Nevado del Ruiz OP-677

Vertebrata OP-97

Colon Archipelago see Galapagos Islands

Colony Quadrangle

maps I-2379

color alteration index

Alaska, petroleum OP-492

Nevada, petroleum OF 92-0391

Colorado see also Cutler Formation; Dakota Formation; Denver Basin; Front Range; Fruitland Formation; Green River Formation; Hermosa Formation; Lake Uinta; Leadville Formation; Mesaverde Group; Niobrara Formation; Paradox Basin; Paradox Member; Pierre Shale; Point Lookout Sandstone; Raton Basin; Red Mountain; San Juan Basin; San Luis Valley. base metals

Gilpin County Colorado OP-944

Silverton Caldera OF 93-0183

coal, Piceance Creek basin OP-1911

Cretaceous

Colorado mineral belt OP-11

Rangely Colorado I-1797-D

crystalline rocks OP-827

earthquakes, Hinsdale County Colorado OP1423

ecology OP-1328

economic geology

Eagle County Colorado B 2035; B 2039

Garfield County Colorado B 2035; B 2039

Gunnison County Colorado B 2035

Lake County Colorado B 2035

Mesa County Colorado B 2039

Pitkin County Colorado B 2035; B 2039

Rio Blanco County Colorado B 2035; B 2039

Summit County Colorado B 2035; B 2039 energy sources

OF 92-0524; OF 93-0248; OF 93-0337

Archuleta County Colorado OP-518

Dolores County Colorado OF 93-0248

La Plata County Colorado OP-518

Montezuma County Colorado OF 93-0248

Montrose County Colorado OF 93-0248

Piceance Creek basin OP-1264; OP-1753

San Miguel County Colorado OF 93-0248

environmental geology

C 1086; OF 92-0614; OF 93-0292-H

Canon City Colorado OF 92-0391

Denver Colorado OP-902

Otero County Colorado OF 92-0391

Pikes Peak Batholith OP-1394

geochemistry

OF 92-0525; OP-538

Idaho Springs Colorado OF 93-0321

San Juan volcanic field OP-490

San Miguel County Colorado OP-1218

geologic hazards

Colorado Springs Colorado OP-1545

Teller County Colorado OP-1545

geomorphology

OP-1051
Gunnison County Colorado OP-859; OP885

Hinsdale County Colorado OP-859; OP885; OP-1171

geophysical surveys

MF-2236

Alamosa County Colorado OF 93-0018

Canon City Colorado B 2039; OF 91-0449D; OF 91-0449-E; OF 91-0449-F

Cripple Creek Colorado OF 91-0449-G

Custer County Colorado OF 93-0018

Gilpin County Colorado OF 91-0449-E; OF 91-0449-F

Pikes Peak Batholith OP-1813

Saguache County Colorado OF 93-0018

ground water

B 1989-D; OF 93-0071

Denver Colorado OP-854

Routt County Colorado WRI 92-4067; OF 92-0122; OP-167

hydrogeology

C 1086; OP-300

Adams County Colorado OF 93-0106

Arapahoe County Colorado OF 93-0106

Denver Colorado WRI 92-4030; OF 930039

Denver County Colorado OF 93-0106

Douglas County Colorado OF 93-0106

Jefferson County Colorado OF 93-0106

Lake County Colorado OP-408

Logan County Colorado OF 93-0106

Moffat County Colorado WRI 92-4050

Montezuma County Colorado W 2340

Morgan County Colorado OF 93-0106

Saguache County Colorado OF 93-0282

Sedgwick County Colorado OF 93-0106

Weld County Colorado OF 93-0106

hydrology

W 2400; C 1086; WRI 92-4060; OF 920645; OP-559; OP-1044

Colorado Springs Colorado WRI 91-4176

Delta County Colorado C 1086; OF 92-0627

Garfield County Colorado OP-133

Grand County Colorado C 1086

Gunnison County Colorado C 1086; OF 920627

Jefferson County Colorado WRI 92-4053

Lake County Colorado WRI 92-4081

Larimer County Colorado C 1086; OF 92 0628

Las Animas County Colorado WRI 91-4095

Mesa County Colorado C 1086

Montrose County Colorado C 1086; OF 92 0627

Pueblo County Colorado WRI 91-4176

Rio Blanco County Colorado OP-133

Rocky Mountain National Park OF 92-0628 maps

Conejos County Colorado OF 92-0711

Garfield County Colorado OF 93-0310; OF 93-0320; MF-2220

Las Animas County Colorado I-2266

Moffat County Colorado MF-2232

Rio Blanco County Colorado MF-2216; MF2220; MF-2232

metal ores

C 0930-M; OP-465; OP-1633

Boulder County Colorado OP-582

Creede Colorado OF 92-0557

Creede mining district $P 1537$

Gilpin County Colorado OP-582

Idaho Springs Colorado OP-937

Leadville mining district OF 93-0343
Mineral County Colorado OF 92-0525

San Juan volcanic field P 1537

mineral resources

OP-95

Colorado mineral belt OP-828

Dolores County Colorado OF 92-0709

Eagle County Colorado B 2039

Garfield County Colorado B 2039

Hinsdale County Colorado OF 92-0709

La Plata County Colorado OF 92-0709

Mesa County Colorado B 2039

Mineral County Colorado OF 92-0709

Montezuma County Colorado OF 92-0709

Pitkin County Colorado B 2039

Rio Blanco County Colorado B 2039

Rio Grande County Colorado OF 92-0709

San Juan County Colorado OF 92-0709

San Miguel County Colorado OF 92-0709

Sawatch Range OP-828

Summit County Colorado B 2039

molybdenum ores

OF 92-0525; OP-1913

Crested Butte Colorado OP-375

Lake County Colorado OP-1050

natural gas

OF 92-0524

Archuleta County Colorado OF 93-0248

Conejos County Colorado OF 93-0248

Gilpin County Colorado OF 93-0248

Grand County Colorado OF 93-0248

Jackson County Colorado OF 93-0248

La Plata County Colorado OF 93-0248

Montezuma County Colorado OF 93-0248

Park County Colorado OF 93-0248

Piceance Creek basin OF 93-0248

Rio Grande County Colorado OF 93-0248

Summit County Colorado OF 93-0248

non-metal deposits

La Plata County Colorado B 2061-A

Montezuma County Colorado B 2061-A

oil and gas fields, Piceance Creek basin OP1857

paleobotany, Creede Colorado OP-1082

Paleogene

Delta County Colorado B 1787-Q

Garfield County Colorado B 1787-Q

Mesa County Colorado B 1787-Q

Piceance Creek basin B 1787-Q

Rio Blanco County Colorado B 1787-Q

palynomorphs

OP-1388

Delta County Colorado OF 92-0391

petroleum

OF 93-0337

Bent County Colorado OF 93-0337

Cheyenne County Colorado OF 93-0337

Custer County Colorado OF 93-0337

Huerfano County Colorado OF 93-0337

Kiowa County Colorado OF 93-0337

Las Animas County Colorado OF 93-0337

Montezuma County Colorado OF 92-0391

Otero County Colorado OF 93-0337

petrology OP-1584

pollution

Colorado mineral belt OP-315

Idaho Springs Colorado OP-1968

La Plata County Colorado WRI 93-4007

Leadville Colorado.OP-1579

San Juan volcanic field OP-315

Proterozoic

Clear Creek County Colorado OP-10

Gilpin County Colorado OP-10

Jefferson County Colorado OP-10 
Quaternary

C 1086

Clear Creek County Colorado OF 93-0250

Logan County Colorado OP-1676

Park County Colorado OF 93-0250

rock mechanics OF 93-0071

sedimentary petrology

OP-1332

La Plata County Colorado OF 93-0306

Pitkin County Colorado OP-1382

sedimentary rocks, Piceance Creek basin

B 1787-DD

soils C 1086

stratigraphy

Archuleta County Colorado B 1808-O; B 2025

Canon City Colorado OP-1963

Chaffee County Colorado B 1787-EE

Eagle County Colorado B 1787-EE; B 1787GG

Fremont County Colorado B 1787-EE

Garfield County Colorado B 1787-EE

Grand County Colorado B 2024

Hinsdale County Colorado B 1808-O

La Plata County Colorado B 1808-O; B 2025; OF 92-0689

Mineral County Colorado OP-985

Moffat County Colorado P 1506-F

Montezuma County Colorado B 1808-O; B 2025

Pitkin County Colorado B 1787-EE

Pueblo County Colorado B 1787-EE

Saguache County Colorado OP-985

San Juan County Colorado B 1808-O

Sawatch Range B 1787-EE

structural geology OP-679

thermal waters, Saguache County Colorado

OF 93-0017-A; OF 93-0017-B

uranium ores OP-568

Colorado mineral belt

Cretaceous OP-11

mineral resources OP-828

pollution OP-315

Colorado Plateau see also Colorado; New Mex-

ico; Utah.

energy sources OP-518

environmental geology OF 93-0292-I

palynomorphs OP-1659

petroleum OF 93-0248

plate tectonics OP-1903

pollution $\mathrm{OP}-1023$

structural geology OP-19; OP-769

uranium ores OP-1848

Colorado Province

Cretaceous OP-11

Colorado River

environmental geology OF 93-0083; OP-990

fluvial features OP-947

hydrogeology OF 93-0405; OP-2007

hydrology OP-1434

impact statements YR

inclusions OP-1748

maps I-2290

Colorado River basin

hydrogeology OF 92-0083

hydrology C 1086

Colorado River delta stratigraphy OP-257

Colorado Springs Colorado geologic hazards OP-1545 hydrology WRI 91-4176
Colton Formation

oil sands OP-1855

sedimentary rocks B 1787-DD

Columbia Aquifer

ground water WRI 92-4111

hydrogeology OP-1196

Columbia Glacier Quatemary C 1086

Columbia Plateau

environmental geology OF 93-0292-H

ground water WRI 90-4085; OP-184; OP-1016

natural gas B 2034-A

neotectonics OP-634

tectonics OP-877

Columbia River

hydrology W 2400; C 1086

Columbia River Basalt Group see also Grande

Ronde Basalt; Saddle Mountains Basalt;

Wanapum Basalt.

ground water OP-184

hydrogeology WRI 91-4087

petrology B 2054

tectonics OP-877

Columbia River plateau see Columbia Plateau

Columbia South Carolina engineering geology WRI 90-4056

Columbia Tennessee

hydrology OF 92-0648

columbium see niobium

Columbus Limestone

hydrogeology OP-1228

Columbus Ohio

environmental geology WRI 92-4130

Colville Basin

natural gas OP-74

structural geology OP-1428

Colville Batholith

structural geology OP-1159

Colville River

petroleum OP-492

Colville River valley

Quatemary OP-143

Comanche Springs

hydrogeology WRI 92-4190

comets

OF 91-0014; OP-857; OP-1879

Colorado, stratigraphy OP-1880

Iowa, geomorphology OP-1834

New Mexico, stratigraphy OP-1880

Committee on Earth and Environmental Sciences

environmental geology C 1086

common mica see muscovite

common salt see halite

Commonwealth of Independent States see also

Armenia; Kazakhstan; Kyrgyzstan; Pripet Basin;

Russian Federation; Tadzhikistan; Timan Ridge;

Urals; West Siberia.

earthquakes OP-1025

tectonophysics OP-1646

composite volcano see stratovolcanoes

Comprehensive Environmental Response, Compensation and Liability Act see Superfund

compression tectonics

OP-1422; OP-1938; OP-1939

Alaska

OP-1789

petroleum OP-492

Appalachians OP-1479

California OP-1063; OP-1566 crust OP-2030

Illinois OP-1742

Michigan, geochemistry OP-1204

Missouri OP-1742

Nevada, stratigraphy B 1988-C

Pakistan, natural gas OP-1634

compressional waves see $\mathrm{P}$-waves

computer animation

geomorphology OF 93-0278-A; OF 93-0278-B

computer languages see also BASIC.

Arkansas, hydrology WRI 93-4013

earthquakes OP-1053

engineering geology $\mathrm{OP}-455$

geophysical surveys OF 93-0287; OP-212

hydrogeology WRI 92-4123; OF 91-0366-A; OF 91-0366-BC

New Mexico, ground water OF 91-0455

Texas, ground water OF 91-0455

computer methods see data processing

computer programs see also BASIC; expert sys-

tems; PHREEQE.

OF 92-0565; OF 92-0691; OF 92-0720; OF 93-

0013; OF 93-0123; OF 93-0188-A; OF 93-

0188-B; OF 93-0241-A; OF 93-0241-B;

OF 93-0305; OF 93-0511; OF 93-0536; OF 930575; OP-1785

Alaska

petroleum DDS-0005

seismology OF 92-0560-A; OF 92-0560-B

Arkansas

hydrogeology OF 92-0108

hydrology WRI 93-4013

California

earthquakes OF 92-0441

seismology OF 92-0441

Caribbean Sea, oceanography DDS-0015

Central America, earthquakes DDS-0007

Colorado geophysical surveys OF 91-0449-D; OF 910449-E; OF 91-0449-F; OF 91-0449-G hydrogeology C 1086

earthquakes OF 92-0441; OF 92-0577; OF 930022

elastic waves OF 92-0441

engineering geology $\mathrm{OP}-455$

environmental geology OP-701

Florida, hydrogeology WRI 92-4061

geochemistry OF 92-0543; OF 93-0001-A; OF 93-0001-B; OF 93-0001-C; OP-790; OP-869

geologic hazards DDS-0008

geomorphology OF 93-0278-A; OF 93-0278B; OP-1623

geophysical surveys DDS-0009; OF 91-0449A; OF 91-0449-B; OF 91-0449-C; OF 920569; OF 92-0590; OF 93-0005; OF 93-0226; OF 93-0234-A; OF 93-0234B; OF 93-0287; OP-212; OP-565

Georgia, ground water OP-867

ground water TWI 03-B4; TWI 06-A5; OF 900194; OF 91-0471; OF 92-0477; OF 920659; OP-684; OP-1640

Gulf Coastal Plain, ground water OF 92-0661

Gulf of Mexico, oceanography DDS-0015

hydrogeology WRI 92-4123; WRI 93-4011; OF 91-0366-A; OF 91-0366-BC; OF 920138; OF 93-0039

hydrology OF 92-0105; OF 92-0144

Idaho, gold ores OF 93-0527

marine geology OF 92-0536

Massachusetts, oceanography DDS-0003

Mississippi Valley OP-754 
natural gas OF 92-0679

Nevada, ground water WRI 92-4051

North Dakota, geochemistry OF 93-01 17

petroleum OF 92-0391

pollution OP-948

sea water DDS-0010

seismic sources OF 93-0221

seismology OF 92-0441; OF 92-0597; OF 920598; OP-1784

Texas, ground water WRI 92-4155

uranium ores DDS- 0001

Virginia OF 93-0231

Washington, hydrology W 2340

Wisconsin, ground water OP-1090

computers see workstations

Comstock Lode mining district

geochemistry OP-1302

comstock-type

Colorado, metal ores OF 92-0557

metal ores OF 92-0389

Comus Formation

gold ores OP-365

Conant Creek Tuff

paleomagnetism OP-697

Cóncord Fault

structural geology OP-405

Concord Syenite

geochemistry OP-1607

\section{concretions}

California, geochemistry B 1995-C

geochemistry OP-183

Kenya OP-1490

Oregon OP-1490

condensation OP-1153

cone penetration tests

California, engineering geology OP-1154

oceanography OF 92-0719

Conemaugh Group OF 93-0312; OP-1603

Conestoga River

hydrogeology WRI 90-4131

conferences see symposia

confined aquifers

Atlantic Coastal Plain, ground water OP-1239

Florida, ground water OP-1568

Gulf Coastal Plain, ground water P 1416-C

Michigan, ground water WRI 91-4133

Midwest, ground water OF 92-0489

New Jersey, ground water WRI 90-4151

New York, ground water WRI 90-4151

Oklahoma, geochemistry OP-891

Virginia, ground water OP-1902

Congaree River

engineering geology WRI 90-4056

congeliturbation see cryoturbation

conglomerate

OP-709

California

OF 92-0707

Idaho

stratigraphy OF 92-0588; OP-469

geochronology OP-479

stratigraphy OP-1351

Michigan OP-1495

Montana, stratigraphy OP-1351

Nevada B 1988-E

New York, stratigraphy B 1839-L

Ohio, stratigraphy OF 92-0558

Pakistan, tectonophysics OP-1548

Pennsylvania, stratigraphy OF 92-0568

Saudi Arabia, Proterozoic B 1976

United Arab Emirates, stratigraphy OP-1453
Coniacian

Colorado OF 92-0391

Utah OP-1779

Coniferales see Picea; Pinaceae

connate waters

California, geochemistry OP-265

China, copper ores OP-456

Connecticut

engineering geology OP-384

geochronology OF 92-0525

ground water, Fairfield County Connecticut WRI 87-4144

hydrogeology

Litchfield County Connecticut WRI 854267

Windham County Connecticut WRI 924074

hydrology W 2400

maps I-1420 (NK-18)

metamorphic rocks OP-1188

oceanography OF 93-0214

Conococheague Formation

environmental geology OP-901

Conodonta

Gnathodus, stratigraphy OP-1245

Neogondolella, Permian OP-1982

Polygnathus, stratigraphy OP-1245

Texas OP-1622

conodonts

Alaska, petroleum OP-492

Appalachians, stratigraphy OP-1988

Arkansas, sedimentary petrology OF 93-0291

Califormia, stratigraphy B 2015

Canada

Devonian OF 93-0184

palynomorphs B 1909

Colorado, stratigraphy B 1787-EE

Idaho, stratigraphy OP-1320

Indiana, stratigraphy OP-1845

Kazakhstan, plate tectonics OP-1295

Kentucky, stratigraphy OF 93-0312

Mississippi Valley, Ordovician OP-1818

Missouri, sedimentary petrology OF 93-0291

Nevada

Invertebrata OP-86

petroleum OF 92-0391

sedimentary petrology OP-1795

stratigraphy B 1988-D; OP-1846; OP-1847

New Mexico, stratigraphy B 1787-EE

Ohio, stratigraphy OF 93-0312

Oklahoma, Ordovician OP-1712

Ordovician OP-1819

Permian OP-1982

stratigraphy B 1839-K; OP-354; OP-1245; OP1983

Texas, geomorphology OP-1703

United States

Devonian OF 93-0184

palynomorphs B 1909

coniservation see also impact statements; wetlands.

OF 92-0514

Africa C 1086

Arkansas, hydrogeology OF 93-0166; OF 930167

Basin and Range Province B 2013

Illinois OF 92-0514

Louisiana

engineering geology OF 92-0530

geomorphology OF 92-0530

ground water OP-742

mineral resources OP-1679; OP-1730
Consortium for Continental Reflection Profiling see COCORP

construction materials see also aggregate; gravel deposits; limestone deposits; sands; sandstone deposits; shale.

B 2013; OF 92-0514

Appalachians B 1979

building stone

OF 92-0514

Appalachians MF-2215-A

Idaho B 2013

Illinois OF 92-0514

Maryland OF 92-0541

Michigan OF 92-0514

Pennsylvania OF 92-0391

Wisconsin OF 92-0514

cement materials

Michigan OF 92-0514

South Dakota OF 92-0514

conservation OF 92-0514

dimension stone

Michigan OF 92-0514

Minnesota OF 92-0514

South Dakota OF 92-0514

Wisconsin OF 92-0514

earthquakes OP-540

Illinois OF 92-0514

Indiana OF 92-0514

Michigan OF 92-0514

Minnesota

OF 92-0514

environmental geology OF 92-0514

Ohio OF 92-0514

Samoa OP-844

South Dakota OF 92-0514

Utah B 2013

Vermont B 1955

Wisconsin OF 92-0514

contact metamorphism

Greenland OP-636

sedimentary petrology OP-1135

Victoria Australia OP-1136

containment liners see disposal barriers

Conterminous United States Mineral Assessment

Program see CUSMAP

continental crust see also COCORP.

Alaska OP-253

Arctic Ocean OP-1429; OP-1891

Arctic region OP-1891

Arizona, geophysical surveys YR

Basin and Range Province geochemistry OP-2015

structural geology OP-19

Califormia

OP-126; OP-286; OP-438

geochemistry OP-955

geophysical surveys YR; OP-1555

petrology OP-1691

structural geology OP-1413; OP-1536

Canada

geophysical surveys OP-1440

orogeny OP-138

Colorado Plateau, structural geology OP-19

geochemistry OF 92-0525; OP-1377; OP-1621

geophysical surveys YR

Great Basin, geochemistry OP-2015

Idaho

geochronology OP-1067

structural geology OP-18

Iowa, stratigraphy OP-1537

Italy, metal ores OF 93-0504

Kenya, structural geology OP-2 
Malaysia, geochemistry OF 92-0525

Mexico, geochemistry OP-132

Michigan, structural geology B 1904-L; B 1904-Q

Minnesota, geochemistry OF 92-0525

Mississippi Valley OP-1661

Montana

Archean OP-705

deformation OP-883

natural gas OF 92-0524

Nevada stratigraphy B 1988-C structural geology OP-108 thermal waters B 1998

New Mexico, geophysical surveys WRI 914065; OF 92-0503

New York, structural geology OP-460; OP-461

Northern Territory Australia, Quaternary B 2032-A

Nova Scotia, geochemistry OF 92-0525

Ontario, structural geology OP-460

Poland, structural geology OP-967

Rocky Mountains, petrology OP-1716

Russian Federation geochemistry OP-1086 geophysical surveys OF 93-0007

Saudi Arabia, orogeny OP-1921

South Australia, Quatemary B 2032-B

tectonics OP-137

United States, geophysical surveys OP-1440

Vermont, structural geology OP-461

Virginia, geochemistry B 1839-I,J

Washington geochronology OP-1067 structural geology OP-18

West Virginia, geochemistry B 1839-I,J

Wyoming geochemistry OP-2016 structural geology OP-149

Yemen, orogeny OP-1921

continental drift see also Gondwana.

OP-1366

Arctic Ocean OP-1626

continental dunes

Arkansas, Quatemary OF 93-0273

continental margin see also active margins; backarc basins; continental slope; passive margins; submarine canyons.

Alaska

B 2002

geochemistry OP-242

geophysical surveys OF 93-0238

metamorphic rocks P 1497-C

Appalachians, stratigraphy OP-1484

Arctic Ocean, tectonophysics OP-1891

Arctic region, tectonophysics OP-1891

Atlantic Coastal Plain

OP-1337

environmental geology OP-1185

Quaternary OF 92-0263

stratigraphy $P 1542$

Atlantic Ocean B 2002

Atlantic region, engineering geology OP-96

Basin and Range Province, faults OP-1158

California

B 2002; I-2089-C; I-2090-A; I-2090-B; I2090-C; I-2091-C

deformation OP-972; OP-1442

geophysical surveys OF 93-0276

orogeny OP-797

paleomagnetism OP-385; OP-1504

plate tectonics OP-759 stratigraphy B 2015

structural geology OP-649

tectonics OP-977

tectonophysics OP-1733

Canada, metamorphic rocks P 1497-C

Caribbean Sea DDS-0015

geochemistry OF 92-0525

Great Basin, faults OP-1158

Gulf of Mexico DDS-0015

Idaho, orogeny OP-797

Michigan, structural geology B 1904-L

Montana, petrology OP-1731

Nevada, sedimentary petrology OP-1795

North Carolina MF-2209

Oregon, geophysical surveys OF 93-0318

Pacific Ocean, energy sources OP-1614

Peru, geochemistry OP-1331

plate tectonics OP-680

stratigraphy B 1917-M

structural geology OP-159

continental margin sedimentation

Arizona, geochemistry OP-203

continental migration see continental drift

Continental Offshore Stratigraphic Test

Massachusetts, Mesozoic OP-801

continental platform see continental shelf

Continental Scientific Drilling Program

New Mexico, molybdenum ores OP-1243

Westem Interior, sedimentary petrology OP1332

continental shelf see also changes of level; conti-

nental margin; ocean currents; submarine canyons.

Alaska

OP-837

engineering geology B 2002

seismology OP-1

Atlantic Coastal Plain, non-metal deposits OP1104

Atlantic Ocean

OP-483

stratigraphy OP-1797

California

B 2002; OF 93-0011; OP-128

energy sources OF $92-0383$

Connecticut OF 93-0214

Georgia, sedimentary petrology OP-1677

Gulf Coastal Plain

ground water P 1416-C

Quaternary OF 92-0530

Gulf of Mexico

B 2002

Quaternary OF $92-0530$

Louisiana B 2002; OF 92-0530

Massachusetts DDS-0003; OP-546

New Jersey MF-2221

Rhode Island OF 93-0214

South Carolina OP-346

continental slope see also submarine canyons.

Alaska B 2002

Arctic Ocean, engineering geology OP-516

Atlantic Ocean B 2002

California

OF 92-0382; OF 92-0555; OF 93-0011; OF 93-0298

Quatemary OF 93-0340

Florida B 2002; OP-1510

Gulf of Mexico B 2002

Massachusetts, Mesozoic OP-801

Oregon, energy sources OP-731

Pacific Ocean, plate tectonics OP-1901

Peru, stratigraphy OP-1330
Russian Federation, geochemistry OP-1412

continental terrace see continental shelf

continental type see continental crust

contour maps

California, continental margin I-2089-C; I2090-C

Colorado, stratigraphy B 2025

Guatemala, geomorphology OP-277

New Mexico, stratigraphy B 2025

Oregon, Quaternary B 2038

stratigraphy B 1909

contourite

Spain, oceanography OP-722

Cook Inlet

energy sources B 2034-A; OP-268; OP-626

geologic hazards YR; B 1996; OP-1708

petroleum OP-492

Quaternary OP-826

seismology OF 92-0560-A; OF 92-0560-B

Cook Islands

geochronology OP-1436

Cook Mountain Special Management Area mineral resources OF 90-0672

cookeite

Michigan, petrology OP-1116

Cooperative Monterey Organic Geochemistry Study

geochemistry OF 92-0539-A; OF 92-0539-C

Miocene OF 93-0182

petroleum OF 92-0539-F

stratigraphy OF 92-0539-B; OF 92-0539-D; OF 92-0539-E; OF 93-0177

Copernican OP-657; OP-1697

copper see also heavy metals.

hydrology OP-1836

Idaho, gold ores B 2039

sediments OP-1887

Utah,mineral resources MF-2081-C; MF-2081$\mathrm{E}$

copper ores see also porphyry copper.

B 2003; OF 92-0557; OP-465

Alaska OP-570

Arizona

B 1737-E; B 2042-C; OF 93-0228; OF 93-

0329

sulfides OP-1993

Bolivia OP-202

California OF 93-0228; OP-260

Canada OP-728

China OP-456

geochemistry OF $92-0559$

Great Lakes region OP-1216

Idaho OP-715

Michigan

OF 92-0391; OP-1688; OP-2019

geochemistry OP-1204

Missouri OP-1326

Montana OF 93-0207

Nevada B 2039; OP-260; OP-627

New Mexico OP-1715

Ontario OP-1978; OP-1979

Russian Federation OP-2014

United States OP-728

Utah OP-965; OP-1464

Vermont B 2039

copper pyrites see chalcopyrite

Copper River

hydrology OF 93-0162

Copper River basin

maps I-2164

natural gas B 2034-A 
Coprates Chasma OP-142; OP-1408

Coprates Rise OP-1939; OP-1940

coral bleaching

Florida, ecology C 1086

coral reefs see reefs

corals

East Pacific Ocean Islands, geochemistry OP925

Florida

ecology C 1086

Quaternary C 1086; OP-1930

Galapagos Islands, geochemistry OP-925

Nevada, stratigraphy B 1988-F; OP-1846

Pacific Ocean, Quaternary C 1086

Polynesia, geochronology OP-1436

Puerto Rico, environmental geology OF 920717

Quaternary OF 92-0525

Cordillera de la Costa metal ores OP-1107

Cordillera Oriental see Eastern Cordillera

Cordilleran Geosyncline

Appalachians, structural geology OP-1147

Cordilleran Orogeny

Califomia

orogeny OP-797

tectonics OP-977

Colorado Plateau, structural geology OP-679

Idaho, orogeny OP-797

metal ores OP-465

petrology OP-596

plate tectonics OP-124

Rocky Mountains, structural geology OP-679

structural geology OP-159

tectonics OP-1520

Cordova Quadrangle maps I-1984

Cordylodus proavus

Ordovician OP-1712

core see core-mantle boundary

core complexes see metamorphic core complexes

Core Research Center

geophysical surveys OF 92-0391

core-mantle boundary

Alaska OP-1032

California OP-1032

Canada OP-1032

China OP-1031

tectonophysics OP-1441

Cornubian Batholith

geochemistry OP-158

petrology OP-1246

Cornubian Deposit metal ores OP-1541

Cornwall England economic geology OF 92-0525

Cornwallis Cave Aquifer ground water WRI 92-4111

coronae OP-1984

Corsicana Formation stratigraphy OP-526

Corso-Sardinian Block plate tectonics OP-1682

coseismic processes

Mexico, plate tectonics OP-670

cosmochronology

geochronology OF 92-0525

cosmolites see meteorites

Costa Rica

geochemistry OP-812
Neogene, Nicoya Peninsula OP-1272

pollution OP-335

seismology OP-1066

structural geology OP-785

Costa Rica earthquake 1991

structural geology OP-785

coulometry

Kentucky, geochemistry B 2046

Nova Scotia, sedimentary petrology OP-1672

Cowbell Member

stratigraphy OF 92-0558

Cox and Singer models metal ores OF 92-0389

Coyote Butte Limestone guidebook OP-87

Coyote Canyon Cretaceous OP-919

Coyote Lake earthquake 1979 California OP-1047

Coyote Spring Valley ground water WRI 91-4167

Cr see chromium

Cracow Poland metal ores OF 92-0704

Craig Quadrangle economic geology MF-2217-A mineral resources OF 92-0552; MF-2217-B

Crassatellidae stratigraphy OP-2009

Crater Flat Basin structural geology OP-1400

Crater Lake geochemistry OF 93-0314; OP-42; OP-43 magmas OP-982 petrology OP-498 volcanology OP-1124

\section{crater lakes}

Indonesia, geophysical surveys B 1966

Oregon, magmas OP-982

Washington, geophysical surveys B 1966

\section{Crater Peak}

geochemistry OP-1754

Quatemary OP-1699; OP-1714; OP-1772

seismology OP-1556

cratering OP-28

craters see also impact features; lunar craters; volcanic features.

OP-366; OP-609; OP-783; OP-1697; OP-1781;

OP-1790; OP-1840; OP-1879

Iowa

geochronology OP-475

petrology OP-1540

South Dakota, geochronology OP-475

Washington, geophysical surveys B 1966

Crazy Mountains maps MF-2253

Creede Colorado metal ores OF 92-0557 paleobotany OP-1082

Creede mining district metal ores P 1537

\section{creede-type}

metal ores OF 92-0389

crenulation cleavage see slip cleavage

creosote

Massachusetts, environmental geology OF 92 0646

Crested Butte Colorado molybdenum ores OP-375
Cretaceous see also Laramide Orogeny.

OC-0140; OP-753; OP-1115; OP-1511

Alabama P 1410-G

Alaska B 2034-A; OF 92-0391; I-2164; OP589; OP-1169; OP-1195; OP-1203; OP1461

Albian, Arctic Ocean C 1086

Almond Formation petroleum OP-1635

sedimentary petrology OF 92-0391

Antarctica OP-1027

Appalachians OP-1484

Arctic Ocean OP-1428

Arizona OP-1957

Atlantic Coastal Plain P 1404-G; P 1542

Atlantic Ocean OP-1797; OP-1894

Black Creek Formation OP-950

Blackleaf Formation OP-1351

Blair Formation, sedimentary petrology B 2051

California B 2034-A; OF 89-0450-D; OP-333; OP-678; OP-1282; OP-1461; OP-1957

Campanian

OP-528

Arkansas OP-525; OP-527; OP-1757

Colorado B 2024; OF 92-0391

Iowa OP-475

New Jersey OF 92-0399; OP-529

South Dakota OP-475

Texas OP-177; OP-178

Western Interior OF 92-0391

Wyoming B 2051

Carlile Shale OF 93-0335

Cenomanian

California OP-385

Colombia OP-755

Colorado OF 92-0391

England OP-755

Montana OP-395

Poland OP-755

Texas OP-755

Wyoming OP-395

Cody Shale

B 1917-O

energy sources OF 93-0337

Colorado OF 93-0248; I-1797-D; I-2266; OP11; OP-1911

Coniacian

Colorado OF 92-0391

Utah OP-1779

Dakota Formation

B 2025; OP-1182

energy sources OF 93-0337

hydrogeology WRI $92-4004$

natural gas OF 93-0248

petroleum OF 93-0337; OP-1635

sedimentary rocks $B$ 1787-DD

Eagle Sandstone, coal OF 93-0207

Europe OP-1193

Eutaw Formation OP-1817

Florida OP-1931

Fox Hills Formation

P 1532

impact statements WRI 90-4154

Frontier Formation

B 1917-O; OF 92-0391

energy sources OF 93-0337

sedimentary petrology OF 92-0391

sedimentary rocks $B$ 1787-DD

Fruitland Formation

OP-1182

energy sources OP-674

natural gas OF 93-0248

pollution WRI 93-4007 
sedimentary petrology OF 92-0391; OP-850 Gallup Sandstone

B 2025

coal OP-17

natural gas $\mathrm{OF} 93-0248$

Greenhòn Limestone OF 93-0335

Gulf Coastal Plain OP-838

Hell Creek Formation OP-1550; OP-1744

Hornbrook Formation P 1521

Idaho OP-523; OP-630

$\mathrm{K}-\mathrm{T}$ boundary

OP-1177; OP-1180; OP-1702

Atlantic Coastal Plain OP-2009

Colorado OP-1388; OP-1804; OP-1880

Germany B 2050

Gulf Coastal Plain OP-2009

Haiti B 2065; OP-1179; OP-1181; OP-1414; OP-1873

India OP-1346

Iowa B 2050; OP-1114; OP-1537; OP-1613; OP-1882; OP-1915

Ivory Coast OP-1181

Mexico B 2050; OP-920; OP-1179; OP1414

Montana B 2065; OP-1744; OP-1745

New Mexico OP-1388; OP-1880

North Dakota OP-1550

North Sea OP-1359

Rocky Mountains OP-1792

Western Interior OP-794; OP-1182; OP1792

Wyoming OP-1181; OP-1744; OP-1745

Kirtland Shale, natural gas OF 93-0248

Kootenay Formation OP-1798

Kuskokwim Group

metal ores OP-123

sedimentation OP-1186

Lance Formation

P 1532; OP-1744; OP-1745

sedimentary petrology OF 92-0391

Lewis Shale

P 1532; B 1917-O

energy sources OF 93-0337

Maestrichtian

Arkansas OP-527

Montana OP-395

New Jersey OF 92-0399

Texas OP-526

Western Interior OF 92-0391

Wyoming OP-395

Mancos Shale OF 92-0391

Mesaverde Group

B 1917-O

energy sources OF 93-0337

hydrogeology WRI 92-4004

natural gas OF 92-0524

oil and gas fields OP-1857

sedimentary rocks B 1787-DD

Middendorf Formation B 2030

Mississippi P 1410-G; OP-1577

Montana P 1524; OF 93-0337; OC-0135; OC0138; OP-1462

Moreno Formation, hydrogeology WRI $92-$ 4004

Mowry Shale

OP-1798

sedimentary rocks B 1787-DD

Muddy Sandstone, energy sources OF 93-0337

Navarro Group OP-527

Navesink Formation, environmental geology OP-378

Nevada B 2039; OP-27; OP-45

New Mexico I-2266; OP-11
New York WRI 88-4127

Niobrara Formation

OF 93-0335

natural gas OF 93-0337

sedimentary petrology OP-1791

North Carolina OF 92-0396; OP-356

Oklahoma OP-1741

Oman OP-296

Oregon OP-1140

Pacific Ocean OP-295; OP-813; OP-1230; OP1894

Parkman Sandstone B 1917-O

Peedee Formation OP-950

Pictured Cliffs Sandstone B 2025

natural gas OF 93-0248

Pierre Shale

B 2024; OP-475

environmental geology OF 92-0391

geochemistry OF 92-0592

Invertebrata $P 1533$

maps I-2343-A; I-2343-B; I-2380-A; I2380-B

natural gas OF 93-0337

structural geology OP-118

Point Lookout Sandstone

B 2025

energy sources OP-518

sedimentary petrology OF 93-0306; OP1567

Ripley Formation, ground water WRI 92-4080

Rock Springs Formation OP-1182

sedimentary petrology B 2051

Santonian

South Carolina B 2030

Utah OP-1779

Wyoming B'2051

Saratoga Chalk OP-527

Shannon Sandstone Member B 1917-O

energy sources OF 93-0337

petroleum B 2039

South Carolina OP-356

Sussex Sandstone Member, energy sources OF 92-0391; OF 93-0337

Taylor Marl OP-527

Turonian

Colombia OP-755

Colorado OF 92-0391

England OP-755

Montana OP-395

Poland OP-755

Texas OP-755

Wyoming OP-395

Tuscaloosa Formation OP-1817

Utah OF 93-0248; OF 93-0270; I-1797-D; OP919

Valdez Group, geochemistry OP-1410

Victoria Australia OP-1136

Washington OP-1480

Western Interior OP-1332

Williams Fork Formation, sedimentary petrology OF 92-0391

Wyoming OF 92-0388; OC-0135; OC-0136; OC-0137; OC-0138

Cretaceous-Tertiary boundary see K-T boundary

Cricetidae

Russian Federation B 2037

crinoids

Nevada, stratigraphy OP-1846
Cripple Creek Colorado

geophysical surveys OF 91-0449-G

CRM see chemical remanent magnetization

Croatia OP-558

crocidolite

pollution OP-864

cross faults

California, earthquakes OP-698

Cross Mine

metal ores OP-582

cross-bedding

California, stratigraphy OP-1281

Colorado OP-1567

Gulf Coastal Plain, stratigraphy OP-1817

Kentucky OF 92-0558

United Arab Emirates, stratigraphy OP-1453

Wyoming B 2051

cross-stratification

OP- 1717

Ohio OF 92-0558

Pakistan, tectonophysics OP-1548

crossbedding see cross-bedding

Crow Creek Member

geochronology OP-475

Crowder Basin

neotectonics OP-1063

Crowley's Ridge Arkansas

Quaternary OP-1683

structural geology OP-1970

Crows Landing Quadrangle maps OF 93-0223

crude oil

Alaska

energy sources OP-626

environmental geology OP-564

geochemistry OP-533

Kentucky, pollution WRI 92-4138

crust see also crustal shortening; crustal thinning; geothermal gradient; heat flow; sea-floor spreading.

OF 92-0441; OP-884; OP-987; OP-1037; OP1408; OP-1460; OP-1561; OP-1674; OP-2030; OP-2031

Alaska

geochemistry OP-721

geophysical surveys OF 93-0238

Arizona, petrology OP-1341

California

OF 92-0441; OP-1157; OP-2010

deformation $\mathrm{P}$ 1550-C

geochemistry OP-182

geophysical surveys OF 92-0570; OF 930276

geothermal energy OP-298

neotectonics OP-23

structural geology OP-113

Canadian Shield OP-1316

Central America OP-1066

Chile, Quaternary OP-279

Colorado

geochemistry OP-490; OP-1825

geomorphology OP-1171

Commonwealth of Independent States OP-1646

continental crust

Alaska OP-253

Arctic Ocean OP-1429; OP-1891

Arctic region OP-1891

Arizona YR

Basin and Range Province OP-19; OP-2015 
California YR; OP-126; OP-286; OP-438; OP-955; OP-1413; OP-1536; OP-1555; OP-1691

Canada OP-138; OP-1440

Colorado Plateau OP-19

geochemistry OF 92-0525; OP-1377; OP1621

geophysical surveys YR

Great Basin OP-2015

Idaho OP-18; OP-1067

Iowa OP-1537

Italy OF 93-0504

Kenya OP-2

Malaysia OF 92-0525

Mexico OP-132

Michigan B 1904-L; B 1904-Q

Minnesota OF 92-0525

Mississippi Valley OP-1661

Montana OP-705; OP-883

natural gas OF 92-0524

Nevada B 1988-C; B 1998; OP-108

New Mexico WRI 91-4065; OF 92-0503

New York OP-460; OP-461

Northem Territory Australia B 2032-A

Nova Scotia OF 92-0525

Ontario OP-460

Poland OP-967

Rocky Mountains OP-1716

Russian Federation OF 93-0007; OP-1086

Saudi Arabia OP-1921

South Australia B 2032-B

tectonics OP-137

United States OP-1440

Vermont OP-461

Virginia B 1839-I, J

Washington OP-18; OP-1067

West Virginia B 1839-I,J

Wyoming OP-149; OP-2016

Yemen OP-1921

faults OP-685

geochemistry OF 92-0525; OP-30

geochronology OF 92-0525

geophysical surveys OP-325; OP-364

Hawaii, engineering geology B 2006

Idaho, petrology OP-630

lower crust

California OP-1503; OP-1711

Chile OP-971

geochemistry OP-1377

Italy OF 93-0504

magmas OP-1138

Mexico OP-132

Mississippi Valley OP-1661

natural gas OF 92-0524

Nevada OP-795

New York OP-461

Vermont OP-461

Maine OP-1920

Mediterranean region OP-1606

Middle East OP-1606

Montana

OP-2017

petrology OP-1462

Nevada, gold ores OP-27

New Mexico, geochemistry OP-490

Newfoundland, structural geology OP-1525

Northwest Territories, geochemistry OP-721 oceanic crust

OP-392

Arctic Ocean OP-1429; OP-1891

Arctic region OP-1891

Atlantic Ocean B 2002; OP-1080

Bering Sea OP-211
California OP-759; OP-890; OP-972; OP1413; OP-1733

Indian Ocean OP-146

Iowa OP-1537

Pacific Ocean OP-1080

Tonga OP-1969

Vanuatu OP-197

Oklahoma OP-301

Ontario, metal ores OP-1978

Oregon, geophysical surveys OF 93-0318

Quebec OP-1920

Syria OP-1322

Washington, tectonics OP-877

Wyoming OP-2017

Crustacea see Malacostraca; Ostracoda

crustaceans see ostracods

crustal shortening

Alaska, petroleum OP-492

Appalachians, structural geology OP-1147

Basin and Range Province, tectonics OP-2021

California

neotectonics $\mathrm{OP}-83$

structural geology OP-1474

tectonics OP-977

Great Basin, tectonics OP-2021

Idaho, structural geology OP-523

tectomics OP-1520

crustal thickening

Colorado, geochemistry OP-490

New Mexico, geochemistry OP-490

crustal thinning

Great Lakes, structural geology OP-1533

Kenya, tectonophysics OP-521

cryostratigraphy

Wyoming, geochemistry OP-712

\section{cryoturbation}

Alaska, Quatemary OP-390

crystal chemistry see also bonding.

Arkansas, phosphates OP-681

California

mineralogy OP-1038

oxides OP-849

mineralogy OP-112; OP-414; OP-493; OP1922

Virginia, mineralogy OP-1755

crystal form

clay mineralogy OP-1069

Montana, geochemistry OP-1305

Greenland, phase equilibria OP-636

Mesozoic OP-1494

Nevada, geochemistry OP-76

Russian Federation, Phanerozoic OP-1493

United States, Phanerozoic OP-1493

crystal structure see also bonding; crystal chemistry.

California, mineralogy OP-500

mineral inventory OP-1508

mineralogy OP-770; OP-1452; OP-1878

New Jersey, sheet silicates OP-1489

New South Wales Australia, sheet silicates OP1489

crystalline limestone see marbles

crystalline rocks

California, structural geology OP-649

Colorado OP-827

geologic hazards OP-1052

ground water $\mathrm{OF}$ 93-0071

Iowa OP-1114

Montana, Archean OP-705

New England, ground water OP-1472

New Jersey, hydrogeology OP-652
North Carolina, ground water OP-239

Pennsylvania, ground water WRI 91-4182.

crystalline structure see crystal structure

crystallization remanent magnetization see chemical remanent magnetization

Cs-137

Great Lakes, Quatemary OP-1290

CSDP see Continental Scientific Drilling Program CTS

maps OF 93-0188-A; OF 93-0188-B

Cu see copper

cube spar see anhydrite

Cucaracha Formation

geologic hazards OP-1862

Culebra Puerto Rico

environmental geology OF 92-0717

marine installations OP-1863

Culman Basin

Mesozoic OP-1494

Culpeper Basin

stratigraphy OP-1660

Cultus Bay

Quatemary OP-36

Cumberland Gap

stratigraphy OP-1368

Cumberland Plateau

economic geology B 2005

Cumnock Formation

stratigraphy OP-597

current meters

Alaska, hydrology OF 92-0493

currents see bottom currents; fluvial currents; ocean currents; turbidity currents

Cushing Formation

stratigraphy OP-1530

CUSMAP

California

economic geology B 2019

mineral resources OF 92-0210-A; OF 92 0210-B; OF 92-0316-A; OF 92-0316-B

Idaho, gold ores B 2039

Minnesota, economic geology B 2039

Montana, mineral resources C 1088

Nevada, economic geology B 2019

non-metal deposits OF 92-0514

Utah, mineral resources B 2039

CUSP

earthquakes OF 92-0577

Cusseta Formation

stratigraphy OP-1817

Custer National Forest

areal geology OF 93-0207

bibliography OF 93-0285-A; OF 93-0285-B

coal OF 93-0207

economic geology OF 93-0207

metal ores OF 93-0207

mineral resources OF 93-0207; OF 93-0505

petroleum OF 93-0207

Cutler Formation

OP-1399

diagenesis OP-1465

sedimentary petrology B 2000-E

Cutoff Formation

Conodonta OP-1622

stratigraphy OP-354

Cuyama Basin

energy sources B 2034-A; OF 89-0450-D

cyclones

Vanuatu, geologic hazards OP-1521 
cyclothems

Pacific Ocean, Pennsylvanian OP-1356

Western Interior, Carboniferous OP-1231

Cyrtinoides

Brachiopoda OP-491

Cytheracea see Leptocythere

Cytherocopina see Cytheracea

Cytheromorpha

Invertebrata OP-109

Czechoslovakia

Slovakia OP-558

\section{D}

\section{Sandstone}

natural gas $\mathrm{OF} 93-0337$

D\#DP layer

core OP-1031

d'Entrecasteaux Ridge

Vanuatu

marine geology OP-190; OP-195

ocean floors OP-368

plate tectonics OP-185

tectonophysics OP-1908

d'Entrecasteaux Zone

Vanuatu

marine geology OP-186; OP-189; OP-190; OP-195; OP-196

plate tectonics OP-185; OP-197

D-J Basin see Denver Basin

D/H

OP-1221; OP-1389

Alaska, hydrology OP-330

Brazil, ground water OP-737

California

energy sources OP-267

geochemistry OP-890

ground water OF 92-0655

pollution OP-473

Colorado

economic geology OP-872

geochemistry OP-490

hydrogeology W 2340

metal ores OP-1151

pollution WRI 93-4007

energy sources OP-1822; OP-1823

geochemistry OF 92-0009; OP-953

Idaho, geochemistry OP-912

Indiana, ground water OP-1648

Maryland, geochemistry OP-1824

metal ores OP-1117

Mexico, economic geology OP-872

mineralogy OP-1922

Montana, geochemistry OP-637

Nevada, ground water W 2340

New Mexico

geochemistry OP-490

pollution WRI 93-4007

Ohio, ground water OP-1648

Ontario, geochemistry OP-1942

Peru, economic geology OP-872

Russian Federation, Quaternary OP-1874

Utah

economic geology OP-872

hydrogeology W 2340

Washington, geochemistry OP-998

Wyoming, geochemistry OP-637; OP-874

dacites

Alaska

geochemistry OP-1771
Quaternary OP-826

Bolivia, metal ores B 2039

California, metal ores OP-427

geochemistry OF 92-0525

Nevada B 2052

Oregon, geochemistry OF 93-0314

Philippine Islands OP-1768

Spain, gold ores OP-231

Washington OP-1362

Dahlgren Laboratory

hydrogeology OP-1196

Dahlonega gold belt gold ores MF-2213

Dahshur earthquake 1992 engineering geology OF 93-0181

Dakota Formation

B 2025; OP-1182

energy sources OF 93-0337

hydrogeology WRI $92-4004$

natural gas OF 93-0248

petroleum OF 93-0337; OP-1635

sedimentary rocks B 1787-DD

Dalton Formation

economic geology B 1955

damage, radiation see radiation damage

damping see attenuation

dams

Alaska, hydrology OF 93-0095

Arizona, impact statements YR

California OP-454

Cameroon, geologic hazards OP-903

Louisiana, hydrogeology OF 92-0492

Mississippi Valley OF 93-0349

Missouri WRI 92-4118

North Carolina, hydrology WRI 92-4097

Danian

Alaska OP-1680

Northwest Térritories OP-1680

Dara-i-Pioz Massif

mineralogy OP-373; OP-1445

Dark Ridge Member

stratigraphy OP-1368

Darwin Plateau

tectonics OP-977

data bases see also geographic information sys-

tems; information systems; NAWDEX.

DDS-0006; YR; OF 93-0575; OP-887; OP1854

Alaska

ecology C 1086

engineering geology OF 93-0338

hydrology OF 93-0029

petroleum DDS-0005

Appalachians, stratigraphy OP-1484

Arkansas, hydrology OF 93-0122

Central America, earthquakes DDS-0007

Colorado, petroleum OP-435

earthquakes OP-1053

energy sources OP-1244

geochronology OF 93-0336

geologic hazards P 1519

geophysical surveys OP-364

gold ores OF 92-0573-A; OF 92-0573-B

ground water OF 92-0652

heavy mineral deposits OF 93-0240-A; OF 930240-B

hydrology C 1086; OF 92-0627

Kansas, paleontology OF 93-0549

mineral resources OF 93-0280; OP-1730

New Mexico, petroleum OP-435

North Dakota, geochemistry OF 93-0117 paleontology OF 93-0513

Puerto Rico, hydrology OF 93-0029

soils C 1086

South America, metal ores OF 93-0328

stratigraphy DDS-0006

uranium ores DDS-0001

Virginia OF 93-0231

data processing $\mathrm{C} 1086$; OF 91-0014

databases see data bases

dating, fission-track see fission-track dating

Davidson Stock

geochemistry OP-1302

Davis Formation

metal ores MF-1835-H

Davis Mountain Quadrangle maps I-2342

Davis Mountains petrology OP-1611

Dawson Canyon Formation Mesozoic OP-801

Dayton Limestone

hydrogeology OP-1228

DDT

Oregon, pollution WRI 92-4136

Washington environmental geology C 1090 pollution OP-1827

Dead Sea Rift

tectonophysics OP-1606

Death Valley

geomorphology OF 93-0272

geophysical surveys OP-227

maps OF 93-0506

Quaternary OP-1897

structural geology OP-442

debris avalanches

Alaska, geologic hazards B 1996; OP-1708

Hawaii, oceanography B 2002

debris flows

W 2340; OF 93-0278-A; OF 93-0278-B; OP142; OP-1242

Alaska, geologic hazards B 1996; OF 93-0094

California

geologic hazards I-1257-M

oceanography OP-1444

Quaternary OP-338

Colorado OP-859

engineering geology OP-1655

Gulf of Mexico, oceanography OP-1864

Haiti, stratigraphy OP-1179

Hawaii

geologic hazards OF 92-0521; OF 93-0213

hydrogeology OF $92-0486$

soil mechanics OP-1814

Iowa OP-1882

Mexico, stratigraphy OP-1179

Mississippi, oceanography OP-1740

Nevada

OP-1276

sedimentary petrology B 1988-E

Oregon, geologic hazards OF 92-0483

Utah, geologic hazards P 1519

Virginia B 1981

Washington, engineering geology OP-907; OP956

West Virginia B 1981

debris slopes see talus slopes

decarbonatization

Nevada, gold ores OP-27

decarboxylation

Pacific Ocean, geochemistry OP-1127 


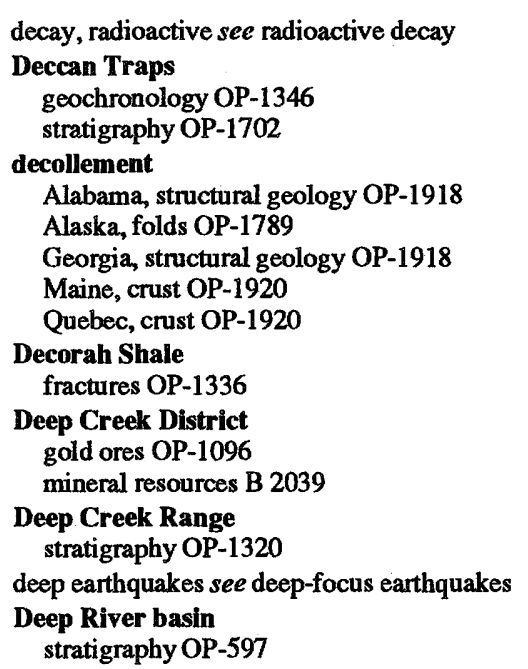

Deep Sea Drilling Project see also IPOD; Leg 5; Leg 41.

Cretaceous OP-1193

Pliocene OP-1535

deep seismic sounding

Alaska, geophysical surveys OF 93-0238

Commonwealth of Independent States, tectonophysics OP-1646

seismology OP-70

Washington geophysical surveys OF 92-0714 tectonics OP-877

deep-focus earthquakes Fiji OP-1758

tectonophysics OP-1585

Tonga OP-1758

deep-sea fans see submarine fans

deep-sea sedimentation

OP-738

Atlantic Coastal Plain, environmental geology OP-1185

Pacific Ocean, geochemistry OP-519

Deer Lake Peridotite

Archean B 1904-P

deethylatrazine

Kansas, geochemistry OP-5

Defiance Uplift petroleum OF 93-0248

Defiance-Zuni Platform stratigraphy OP-1523

defoliation

Hawaii, pollution WRI 92-4168

deformation see also cataclasis; compression tectonics; decollement; extension tectonics; folds; foliation; fractures; geodesy; lineation; melange. OP-602; OP-740

Alaska, metal ores OP-224

Arizona OP-1957

Bangladesh, geomorphology OP-1273

brittle deformation

OF 93-0245; OP-1026

California OP-23

crust OP-884

rock mechanics OP-600

California

P 1550-C; OP-802; OP-1442; OP-1957

economic geology OP-260

engineering geology OP-125; OP-688

petrology OP-1691

seismology OP-1872

tectonophysics P 1550-C; OP-2010
Colorado

earthquakes OP-1423

geomorphology OP-885

Costa Rica OP-785

ductile deformation

OP-1026

Alaska OP-1349

California OP-512

Colorado OP-827

Idaho OF 93-0235

magmas OP-814

Manitoba OP-1560

New England OF 92-0525

Oman OP-815

Ontario OP-1560

engineering geology OP-579; OP-744

Hawaii, Quaternary OP-1759

Idaho, petrology OP-630; OP-1671

Illinois OP-1471

Indian Ocean OP-146

mineralogy OP-1452

Mississippi Valley OP-358

Missouri OP-1471

Nevada, economic geology OP-260

New South Wales Australia, metal ores OP-942

Oregon, petrology OP-498

Pakistan OP-1125

Panama OP-785

Pennsylvania, diagenesis OF 92-0568

plate tectonics OP-680

Poland, Carboniferous OP-1917

Quaternary OP-1256

Queensland Australia, metal ores OP-942

Tonga, plate tectonics OP-345

Vanuatu, plate tectonics OP-345

degassing

California, geochemistry OP-955

Cretaceous OP-1115

geologic hazards C 1086

Oregon, geochemistry OP-43

Philippine Islands, geochemistry OP-1994

\section{deglaciation}

Atlantic Ocean, Quaternary OP-1650

Austria, Quaternary OP-386

Colorado, Quaternary OP-1324

Great Lakes, Quatemary OP-1288

Iceland, Quaternary OP-386

Massachusetts, Quaternary OP-749

Minnesota, Quaternary OP-21

New England, Quaternary C 1086

Quaternary OP-396; OP-980

Washington, Quaternary OP-143; OP-1999

Del Puerto Ophiolite

structural geology OP-401

Delamar Lake Quadrangle maps GQ-1730

Delaware see also Delaware Bay; Delaware River

basin; Delmarva Peninsula.

ground water

P 1404-G; OP-400

New Castle County Delaware OF 92-0052; OP-777

hydrogeology

Kent County Delaware OF 93-0040

New Castle County Delaware OF 92-0052; OF 93-0040

Sussex County Delaware OF 93-0040

hydrology W 2400

stratigraphy, New Castle County Delaware OP528

Delaware Basin

energy sources OF 93-0522 stratigraphy OP-1387

Delaware Bay

hydrogeology C 1086; OF 92-0052

Delaware Limestone

hydrogeology OP-1228

Delaware Mountain Group see Cherry Canyon

Formation

Delaware River basin

hydrogeology C 1086; OF 92-0052

hydrology C 1086; OF 92-0052; OP-1964

Quatemary OP-2011

Delle phosphatic event

stratigraphy B 1988-G

Delmarva Peninsula

ground water OP-777; OP-1174

hydrogeology OF 93-0040

pollution C 1080; OP-922; OP-1458; OP-1876

Delorme method

geochemistry OP-943

delta fans see fan deltas

delta plains

Lonisiana

conservation OF $92-0530$

engineering geology OF 92-0530

environmental geology OF 92-0530

geomorphology OF 92-0530

Quaternary OF 92-0530

shore features OF 92-0530

Delta Quadrangle

gold ores OP-1096

mineral resources B 2039; MF-2081-C; MF2081-D; MF-2081-E

deltaic sedimentation

Georgia, heavy mineral deposits B 2039

Louisiana

B 2002; OP-653

Quaternary OF 92-0530

shore features OF $92-0530$

South Carolina, heavy mineral deposits B 2039

deltas see also fan deltas.

Bangladesh, geologic hazards OF 92-0391

Gulf Coastal Plain, Quatemary OF 92-0530

Gulf of Mexico, Quaternary OF 92-0530

Louisiana

conservation $\mathrm{OF} 92-0530$

engineering geology OF $92-0530$

environmental geology OF 92-0530

geomorphology OF 92-0530

land subsidence OF 92-0530

Quaternary OF 92-0530

shore features OF 92-0530

New England, Quatemary C 1086

Samoa OP-844

demethylation

Australia, sedimentary petrology OP-1478

diagenesis OP-1477

Indonesia, sedimentary petrology OP-1478

Denali Fault

metamorphic rocks $P$ 1497-C

Denay Limestone

Brachiopoda OP-491

dendrochronology see tree rings

density logging

engineering geology OP-760

denudation

California, structural geology OP-1172; OP1971

Denver Basin

natural gas OF 92-0524; OF 93-0337

oil and gas fields OP-1857 
petroleum OP-793

sedimentary petrology OP-1791

Denver Colorado

environmental geology OP-902

ground water OP-854

hydrogeology WRI 92-4030; OF 93-0039

Denver Julesberg Basin see Denver Basin

depressions

OP-1668

Arizona, Neogene OP-92

Great Lakes, hydrology OP-199

Nevada, Neogene OP-92

Des Moines River

ground water OP-612

Des Moines Series see Desmoinesian

Desert Mountain

gold ores OP-1096

mineral resources B 2039

desertification

geomorphology C 1086

Great Plains, Quatemary C 1086 OP-847

Basin and Range Province, hydrogeology OP1551

California

economic geology OF 92-0595

environmental geology OF 92-0447

Great Basin, hydrogeology OP-1551

Desmoceratida

Arkansas OP-525

Texas

OP-178

stratigraphy OP-177

Desmoinesian see also Cherokee Group;

Marmaton Group.

Texas OF 93-0522

detachment see decollement

detachment faults

Arizona

OP-611

metal ores B 2042-C; OF 93-0228

British Columbia OP-1159

California

OP-442

energy sources OP-267

metal ores OF 93-0228

Idaho, Eocene OP-617

Montana, Eocene OP-617

Nevada B 2011; OP-1400

Pennsylvania B 1994

Utah B 2011

Washington OP-1159; OP-1187

detrital fan see alluvial fans

detrital sedimentation

Black Sea OF 93-0274

Middle East OF 93-0274

Detroit mining district gold ores OP-741; OP-1096

Detroit River Group

hydrogeology OP-1228

deuterium see also $\mathrm{D} / \mathrm{H}$.

California, thermal waters OP-997

Devils Hole

hydrogeology OF 90-0381

Quaternary C 1086; OP-294; OP-916

Devils Icebox

Pleistocene OP-1670

Devils Lake

hydrology W 2340; OF 93-0066; OP-1071 devolatilization

energy sources OP-1822

petrology OP-1355

Devonian see also Antler Orogeny; Chattanooga

Shale.

B 1909

Acadian Phase

Pennsylvania OF 92-0525

Vermont OF 92-0282-A

Alaska OP-570; OP-1268

Barre Granite, fractures OP-1026

California OP-797

Canada OF 93-0184

China OF 92-0525

Cleveland Member, energy sources B 1909

Columbus Limestone, hydrogeology OP-1228

Commonwealth of Independent States OP-1261

Delaware Limestone, hydrogeology OP-1228

Detroit River Group, hydrogeology OP-1228

Eifelian

OP-84

Alaska OP-85

Nevada OP-86; OP-491

Russian Federation OP-491

Europe OP-1261

Frasnian

Appalachians OP-1988

Nevada OP-1847

Genesee Group

B 1909

natural gas B 1909

Givetian

Nevada OP-491

Russian Federation OP-491

Great Lakes OP-1354

Great Plains OF 93-0337

Guilmette Formation B 1988-G; OP-1847

Huron Member, natural gas B 1909

Idaho OP-797

Kentucky B 1909

Ludlowville Formation B 1909

Marcellus Shale

B 1909

natural gas B 1909

Mexico OP-796

Montana OF 93-0337

Moscow Formation B 1909

Nevada B 1988-E; B 2039

New Albany Shale

B 1909; OP-1845

energy sources B 1909

hydrogeology OP-1228

Ohio Shale

B 1909

geochemistry B 2046

hydrogeology OP-1228

Olentangy Shale, hydrogeology OP-1228

Onondaga Limestone, Invertebrata B 2024

Ontario B 1909

Oriskany Sandstone, natural gas B 1839-I,J

Russian Federation OP-1258

Sonyea Group B 1909

Traverse Group

B 1909

hydrogeology OP-1228

Tully Limestone B 1909

United States OF 93-0184

Vermont OP-37

West Falls Formation B 1909

West Virginia B 1909

Yukon Territory OF 92-0525

dextral faults see right-lateral faults diabase

Alaska, structural geology OP-94

Arizona, stratigraphy OP-398

geochronology OF 92-0525

Pacific Ocean, Cretaceous OP-1230

Sweden, geochemistry OP-552

Wyoming OP-1456

Diablo Mountain Wilderness Study Area mineral resources OF 90-0506

Diablo Range

manganese ores OP-458

metamorphic rocks OP-1166

metamorphism OP-1165

neotectonics $\mathrm{OP}-83$

structural geology $\mathrm{OP}-401$

diagenesis see also coalification; dolomitization;

phosphatization; weathering.

OP-433; OP-1627

Alaska

energy sources OP-268

Quaternary OP-515

Arizona, ground water OP-1639

barite deposits OP-960; OP-1257

burial diagenesis

OP-1135; OP-1353

Alabama OP-1858

California OP-1791

Colorado OF 92-0524

Mississippi OP-1858

California

OP-174; OP-1386

geochemistry OP-615

stratigraphy OP-469

China, metal ores OP-1432

Colorado

OP-1961

energy sources OP-518; OP-1753

stratigraphy $B$ 1787-EE

Dominican Republic, metal ores OP-532

energy sources OF 92-0391

Florida, geochemistry OP-1906

geochemistry OP-841; OP-1005; OP-1769

geochronology OF $92-0525$

Georgia, ground water W 2392

ground water B 1989-D

Gulf of Mexico OP-288

Haiti, stratigraphy OP-1181

Hawaii, oceanography OP-418

Illinois, hydrogeology OP-1782

Indiana OF 92-0391; OP-1466

Iraq, geochemistry OP-615

Ivory Coast, stratigraphy OP-1181

Kentucky

hydrogeology OP-1782

stratigraphy OF 92-0558

Mississippi OP-1856

Missouri, metal ores OP-1418

Montana OP-395

natural gas OF 92-0524

New Hampshire, geochemistry OP-1207

New Mexico

energy sources OP-518

geochemistry OP-1072

stratigraphy B 1787-EE

non-metal deposits OF 92-0593

North Carolina, geochemistry OP-1684

Oklahoma

energy sources OP-268

petroleum OF 92-0391

Pacific Ocean, paleomagnetism OP-747

Pennsylvania, geochronology OF 92-0525

Peru, geochemistry OP-1331 
petroleum OP-793; OP-1206

Rocky Mountains OP-1792

Russian Federation, Quatemary OP-1208

South Carolina, ground water W 2392

stratigraphy OP-88

syngenesis

England OP-1541

metal ores B 2003

Texas, geochemistry OP-1072

United Arab Emirates, Quatemary OF 92-0391

Utah

OP-1465; OP-1961

oil sands OP-1855

Virginia, mineralogy OP-1755

Western Interior OP-1792

Wyoming

OP-395; OP-1950

energy sources OF 92-0391

natural gas OP-1569

stratigraphy OP-1181

Yukon Territory, metal ores OP-1432

dialogite see rhodochrosite

dialysis

hydrogeology OF 92-0146

diamictite

Antarctic Ocean, Quatemary OP-1630

California, orogeny OP-797

Idaho, orogeny OP-797

diamicton

Antarctic Ocean OP-263

diamond

non-metal deposits OF 92-0557

diaphthoresis see retrograde metamorphism

diapiric fold see diapirs

diapirism

Alaska, geochemistry OP-242

Atlantic Ocean, continental slope B 2002

diapirs

OP-1984

Atlantic Coastal Plain, oceanography OP-1337

Diapsida see Archosauria

Diascund Creek reservoir

hydrology WRI 92-4034

diatom flora

Antarctic Ocean, Tertiary OP-1145

Arctic Ocean, Quaternary OF 92-0426; OF 92 0439

Arctic region, Quatemary OF 92-0439

California

Miocene OF 93-0182; OP-1570

Quaternary C 1086; OF 93-0340

stratigraphy OF 92-0539-D; OF 92-0539-E; OF 93-0177

Minnesota

geochemistry OP-251

Quaternary C 1086; OP-668

New Jersey, stratigraphy OP-979

Oregon, Quaternary OF 93-0212

Pacific Ocean, Pliocene OP-54

Russian Federation, Quaternary OP-1874

Washington, Quatemary OF 93-0212; OF 930284; OF 93-0289

diatomaceous earth

California

energy sources B 2034-A

geochemistry B 1995-C

diatoms

Atlantic Ocean, marine geology OP-822

California, Quatemary OF 93-0340

Celebes Sea, oceanography OP-821

Minnesota OP-101
Pacific Ocean

marine geology OP-819; OP-822

oceanography OP-820

Pliocene OP-222

Washington, Quatemary OF 93-0289

diatremes

OP-596

Dominican Republic, metal ores OP-532

non-metal deposits OF 92-0557

Saudi Arabia OP-1952

Virginia, geochemistry B 1839-I,J

West Virginia, geochemistry B 1839-I,J

dibromoethane

Florida, pollution W 2402; OP-513

dicarboxylic acid

California, geochemistry OP-1578

dichloro-diphenyl-trichloro-ethane see DDT

dickite

Wyoming, diagenesis OP-1950

dicophane see DDT

Dicotyledoneae see Rosidae

Didymoceras

stratigraphy OP-529

Dietz coal seam

geochemistry OP-1305

sedimentary petrology OP-228

diffusion OP-16; OP-165; OP-324; OP-572; OP-

582; OP-888; OP-902; OP-949; OP-1239; OP-

1266; OP-1383; OP-1591; OP-1705; OP-1814;

OP-1849; OP-2013

digital cartography

DDS-0002; YR; OF 92-0691; OF 92-0710; OF 92-0711; OF 92-0716; OF 93-0013; OF 930188-A; OF 93-0188-B; OF 93-0206; OF 930268-A; OF 93-0268-B; OF 93-0299; OF 93-0352; OF 93-0525; OF 93-0526; OF 930536; OP-818; OP-981; OP-1015; OP-1907; OP-1945

continental margin I-2089-C; I-2090-C

ecology OF 92-0566

engineering geology OF 93-0338; OF 93-0349

environmental geology OP-60

geochemistry OF 92-0559

geomorphology YR; OP-693; OP-1398

geophysical surveys OF 91-0573; OF 93-0573-$$
\text { B }
$$

ground water OP-745

marine geology OF 92-0536

metamorphic rocks OP-1166

non-metal deposits OP-63

oceanography DDS-0003; DDS-0015

peat OP-131

Quatemary OF 93-0543

seismology OF 92-0441

stratigraphy B 2025

digital elevation models see digital terrain models

digital line graphs

YR; OP-156; OP-1907; OP-1954

geomorphology OP-1398

digital orthophotoquads YR

digital terrain models

YR; OP-1162; OP-1406; OP-1669

Alaska, geomorphology C 1086

geomorphology YR; C 1086

Iceland OP-1405

Italy, plate tectonics OP-1682

Nevada, geomorphology OP-1276

dike swarms

California, petrology OP-1148; OP-1376

Canada, orogeny OP-138

OP-1417; OP-1421
Alaska, structural geology OP-94

Arizona

OP-1748

structural geology OP-1886

British Columbia, structural geology OP-1159

California

OP-1691; OP-1711

geochemistry OP-678

Colorado

OP-827

base metals OF 93-0183

molybdenum ores OP-1050

geochronology OF 92-0525

gold ores OP-168

Idaho OP-560

Illinois, non-metal deposits OP-1419

Italy, structural geology OP-1808

Kentucky, non-metal deposits OP-1419

Kenya, tectonophysics OP-521

Maine, metal ores B 2039

Mexico, structural geology OP-1886

Missouri, iron ores OP-1297

Nevada

B 2052

metal ores OF 93-0249

Red Sea, brines OP-2029

Syria OP-1322

Utah, structural geology B 1787-HH

Victoria Australia OP-1136

Virginia, geochemistry B 1839-I,J

Washington, structural geology OP-1159

West Virginia, geochemistry B 1839-I,J

Wyoming OP-1456

dilatational wave see $\mathrm{P}$-waves

Diligencia Formation

structural geology OP-332

Dillon Quadrangle

maps I-1803-H

Dillon Ranger District

economic geology B 2035

mineral resources B 2039

dimension stone

Michigan OF 92-0514

Minnesota OF 92-0514

South Dakota OF 92-0514

Wisconsin OF 92-0514

Dinantian see also Tournaisian.

Canada OF 93-0184

Poland OP-967

United States OF 93-0184

dinoflagellates

OP-293

Atlantic Ocean OP-292

California OF 92-0539-E

Georgia, Invertebrata OP-291

Pacific Ocean OF 92-0712

South Carolina, Invertebrata OP-291

Dinosaur National Monument

stratigraphy OP-1963

Vertebrata OP-1252

dinosaurs see also Ornithischia; Saurischia. Colorado, stratigraphy OP-1963

diorites see also monzodiorite; quartz diorites; tonalite; trondhjemite.

Arizona, structural geology OP-1886

California

geochemistry OP-182

Phanerozoic OP-1340

Mexico, structural geology OP-1886

dip-slip faults

Arizona, geologic hazards P 0497-H 
California OP-23

Chile, seismology OP-53

Diplomoceratidae

stratigraphy OP-526

dipyrite see pyrthotite

disconformities see erosional unconformities

Disenchantment Bay

marine geology OF 92-0706

dispersion patterns

California, metal ores OP-428

China, gold ores OP-945

displacement theory see continental drift

disposal barriers

environmental geology OP-1898

disposal, waste see waste disposal

disseminated organic materials

Mexico

energy sources OP-1137

sedimentary petrology OF 92-0391

District of Columbia

environmental geology OP-60

geologic hazards C 1111

hydrology W 2400

District of Sudbury see Sudbury District Ontario

Ditch Creek Siltstone Member

stratigraphy P 1521

divergence, plate see plate divergence

divergent folds

Virginia, structural geology OF 93-0025

Divide Creek Quadrangle

maps MF-2232

Dixie Valley

natural gas OF 93-0248

Dixon Entrance Quadrangle

economic geology MF-2217-A

mineral resources OF 92-0552; MF-2217-B

Dizon Deposit

metal ores OP-9

DLGOCOD OF 93-0305

DLGOGSM OF 93-0305

DLGSCOD OF 93-0305

DLGSGSM OF 93-0305

Dockum Group see Chinle Formation

Dodge Spring Quadrangle maps GQ-1721

dolerite see diabase

Dolly Creek Sequence

stratigraphy B 1988-D

dolomite

California

orogeny OP-797

sedimentary petrology OF 92-0707

Florida, ground water OP-494

Idaho, orogeny OP-797

Minnesota, sedimentary petrology OP-250

Missouri, lead-zinc deposits OP-575

Oklahoma, geochemistry OP-891

dolomitite see dolostone

Alabama, energy sources OP-1602

Florida OP-1931

Midwest, hydrogeology OP-1228

Ordovician OP-1819

Tennessee, hydrogeology WRI 91-4190

dolostone deposits

OF $92-0514$

Michigan OF 92-0514

Minnesota OF 92-0514

Ohio OF 92-0514 domes

Appalachians OP-1479

Bolivia, metal ores OP-1306

California OP-83

geophysical surveys OP-2024

Nevada, metal ores OP-205

Spain, gold ores OP-231

Vermont, copper ores B 2039

Dominican Republic

metal ores OP-532; OP-1576

petrology OP-1900

plate tectonics OP-808

stratigraphy OP-1625

Don Pedro Reservoir hydrology W 2340

Dongchuan Deposit copper ores OP-456

Doppler methods hydrology W 2395

Dorsa Argentea OP-508; OP-1563

Dos Pobres Deposit metal ores OP-9

Doswell Formation

guidebook OP-359 stratigraphy OP-1660

Double Glacier Volcano Quaternary OP-826

Double Lakes Texas

ground water OP-1849; OP-2013

hydrogeology OP-1200

sedimentary petrology OP-1991

doublet wells

Minnesota, ground water P 1530-A

drag folds

Illinois OP-1471

Missouri OP-1471

drainage basins

Alaska

geologic hazards OF 93-0094 pollution OP-66

Arizona

geomorphology OP-426

pollution OP-1023

Arkansas, hydrology OF 93-0171

Atlantic Coastal Plain, hydrology C 1086

California, hydrology C 1086; WRI 92-4172

Canada, hydrology W 2400; C 1086

Colorado

hydrogeology C 1086; OP-408 hydrology C 1086

Delaware

ground water OF 92-0052; OP-777

hydrogeology OF 92-0052

geochemistry OP-353

Georgia, heavy mineral deposits B 2039

Great Lakes, plate tectonics OP-13

Great Lakes region, plate tectonics OP-13

Hawaii, hydrology WRI 92-4049

hydrogeology C 1086; OF 92-0052; OF 920083; OF 93-0106; OP-161

hydrology C 1086; OF 92-0052; OF 92-0627

Idaho, hydrology P 0870-A

Indiana, hydrology WRI 92-4113

Iowa, hydrology OF 92-0094

Midwest, pollution OF 93-0418

Minnesota, geomorphology OP-1664

Mississippi Valley, hydrology OF 91-0485

Montana, hydrology WRI 91-4199

Nevada, hydrology C 1086

New Hampshire ground water WRI 90-4161; WRI 91-4025

hydrogeology OF 89-0583

New Jersey

ground water WRI 90-4151; OF 92-0052

hydrogeology WRI 91-4169; OF 92-0052

New Mexico

ground water P 1407-C

pollution OP-1023

New York, ground water WRI 90-4151

North Carolina, hydrology WRI 92-4129

North Dakota, hydrology W 2340

Oklahoma, hydrology OF 93-0171

Oregon, hydrology WRI 92-4108

Pennsylvania, hydrogeology OF 92-0165

Sahara, fluvial features OP-314

South Carolina, heavy mineral deposits B 2039

South Dakota, hydrology W 2340

Tennessee, hydrogeology WRI 91-4190

Texas

ground water P 1407-C

hydrogeology OF 92-0160

United States, hydrology W 2400; C 1086

Virginia, geomorphology B 1981

Washington

environmental geology C 1090

hydrogeology OF 92-0520; OF 92-0644

hydrology WRI 91-4073; OF 91-0453; OF 91-0454

Quaternary OP-323

West Virginia

geomorphology B 1981

hydrogeology W 2384

Wisconsin, hydrology WRI 90-4126

Wyoming, hydrology WRI 91-4199

drainage patterns

Appalachians, stratigraphy OP-1484

Pennsylvania, geomorphology OF 92-0568

Draper Formation

Quaternary OP-1021; OP-1022

dravite

Saudi Arabia, sedimentary petrology OP-1378

Drift River basin

geologic hazards OF 93-0094

Drum Mine

gold ores OP-741

Drum Mountains

gold ores OP-741

dry ashing

geochemistry OF 92-0345

Dry Creek

earthquakes OP-905

Quaternary OP-620

dry delta see alluvial fans

Dry Fork Anticline

energy sources OP-1751

dry lakes

California, Quaternary OF 93-0232; OF 93 0311

DSDP see Deep Sea Drilling Project

DSDP Site 32

Pliocene OF $92-0712$

DSDP Site 367

geochemistry OP-755

DSDP Site 396

Pliocene OF 92-0414

DSDP Site 541

Pliocene OF 92-0418

DSDP Site 546

Pliocene OF 92-0418

DSDP Site 548

Pliocene OP-271 


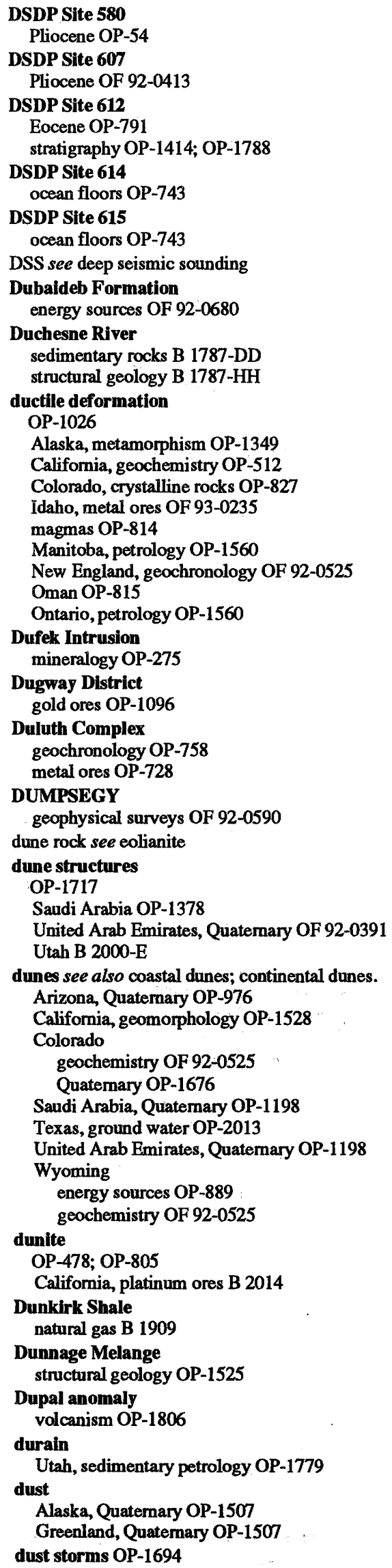

Dutch Creek Coal sedimentary petrology OP-1382

Dutch East Indies see Indonesia

Dutrochus alaskensis Invertebrata OP-84 dykes see dikes

\section{$\mathbf{E}$}

Eagle Basin

mineral resources OP-828 natural gas OF 93-0248 stratigraphy B 1787-GG

Eagle Mills Formation palynomorphs OP-1659

Eagle Mountains petrology OP-1376

Eagle Sandstone coal OF 93-0207

Eagle Valley Evaporite Pennsylvanian OP-1103 stratigraphy B 1787-GG

earth flows see earthflows

Earth tides

California, tectonophysics P 1550-C

Earth waves see elastic waves

earth, diatomaceous see diatomaceous earth

Earth-Moon coupleOP-657;OP-1217;OP-1439; OP-1841

earthflows

Colorado

OP-885; OP-1171

earthquakes OP-1423

earthquake prediction see also seismic gaps.

Armenia, seismology OF 93-0216

California

deformation P 1550-C

earthquakes OP-126; OP-698; OP-881

engineering geology OP-882

Quaternary OP-338; OP-1833

seismicity P 1550-C; OP-121

seismology P 1550-C; EV; OP-302; OP868; OP-1488; OP-1581 tectonophysics $\mathrm{P}$ 1550-C

Dominican Republic, plate tectonics OP-808 earthquakes OP-539; OP-766; OP-768; OP1024

faults OP-640

Kentucky, Quaternary OP-486

Missouri, geologic hazards C 1083

South Australia, Quaternary B 2032-B

Tennessee, Quaternary OP-486

Turkey, seismology EV

earthquake sea wave see tsunamis

earthquakes see also aftershocks; elastic waves; epicenters; focal mechanism; foreshocks; geologichazards; GEOS; ground motion; isoseismic maps; main shocks; modified Mercalli scale; New Madrid region; paleoseismicity; Q; Richter Scale; rock mechanics; seismic gaps; seismic intensity; seismic moment; seismic response; seismic sources; seismic zoning; slope stability; tsunamis.

OF 92-0441; OF 92-0577; OF 93-0022; OF $92-$ 0533; OP-540; OP-1019; OP-1053; OP-1161

Alaska

OP-1325; OP-1556 core OP-1032

Alaska earthquake 1964
Alaska OP-564; OP-1142; OP-1384; OP1852

Japan OP-1852

Armenia OF 93-0216

Borah Peak earthquake 1983

Idaho OP-780

Wyoming OP-780

California

OP-90; OP-357; OP-411; OP-466; OP-699; OP-880; OP-1025; OP-1280; OP-1360; OP1587; OP-1746

continental shelf B 2002; OP-1443

core OP-1032

structural geology OP-144

Canada, core OP-1032

Charleston earthquake 1886, South Carolina I1935

Chile, Quaternary OP-35

Chile earthquake 1960, Chile OP-53

Coyote Lake earthquake 1979, California OP1047

deep-focus earthquakes

Fiji OP-1758

tectonophysics OP-1585

Tonga OP-1758

Europe, plate tectonics OP-206

Hebgen Lake earthquake 1959

Idaho OP-780

Montana OP-883

Wyoming OP-780

Irpinia earthquake 1980 , Italy OP-764

Kenya, tectonophysics OP-521

Loma Prieta earthquake 1989, California P 1550-C; P 1553-B; OF 90-0677; OF 920441; OF 92-0570; OP-121; OP-221; OP407; OP-969; OP-1047; OP-1154; OP-1347; OP-1488; OP-1581; OP-1582; OP-1658; OP-1793; OP-1794; OP-1865

microearthquakes, Califormia P 1550-C

Morgan Hill earthquake 1984, California P 1550-C; OP-1047

Nevada OP-357

New Madrid earthquakes 1811-1812 OP-1866

Kentucky OP-486

Mississippi Valley OP-358

Tennessee OP-486; OP-856

North Palm Springs earthquake 1986 OP-959

Oklahoma OP-301

Oregon OP-720; OP-1120

Oroville earthquake 1975, Califomia P 1550-C

Pacific Coast OP-1259

Pacific Ocean OP-734

Pacific region, mantle OP-1020

Parkfield earthquake 1966, Califomia OP-913; OP-1872

Parkfield earthquakes California EV; OP-286; OP-302 Turkey EV

Philippine Islands EV; OP-1998

San Francisco earthquake 1906, California OP121; OP-648; OP-1047; OP-1347; OP-1865

San Salvador earthquake 1986, El Salvador OP399

shallow-focus earthquakes

OP-497

Alaska OP-1

El Salvador OP-399

Washington OP-36; OP-647

Spitak earthquake 1988, Armenia OF 93-0216

Superstition Hills earthquake 1987, California OP-328; OP-1046

Tonga, tectonophysics OP-1969 
volcanic earthquakes OP-1557

Alaska OF 92-0560-A; OF 92-0560-B; OP1802

California OP-569; OP-955; OP-1503; OP1555

Hawaii OP-116; OP-252; OP-1001; OP1420; OP-1759

Iceland OP-322

Philippine Islands OP-502

Washington B 1966; OP-647

Washington OP-720; OP-1119; OP-1120

East Africa see Kenya; Mozambique; Turkana Basin

East African Lakes see Lake Magadi

East African Rift tectonophysics OP-521

East Antelope Basin Quatemary OF 93-0263

East European Platform see Russian Platform

East Evaluation Creek Quadrangle maps MF-2220

East Malaysia see Sarawak Malaysia

East Mariana Basin geochronology OP-813

East Mediterranean see Adriatic Sea; Black Sea

East Mojave National Scenic Area maps OF 91-0435

East Pacific Ocean Islands see Galapagos Islands; Hawaii

East Pakistan see Bangladesh

East Poplar Field energy sources OP-1947

East Summit Dome metal ores OP-627

East Weitas Special Management Area mineral resources OF 90-0672

East-Central Alaska see Fairbanks Alaska

\section{Easter Microplate}

plate tectonics OP-900

Eastern Canada see Gander Zone; Maritime Provinces; Newfoundland; Ontario; Quebec

Eastern Cordillera Quatemary OP-855

Eastern Gas Shales Project petroleum B 1909

Eastern Interior

Carboniferous OP-1231

Eastern Sea OP-416; OP-1437; OP-1482; OP1486; OP-1487

Easton Schist maps I-1963 stratigraphy OP-1480

Eburnean Orogeny see Pan-African Orogeny

echinoderms crinoids, Nevada OP-1846

echo sounding

Antarctica OP-842

Puerto Rico, oceanography OF 92-0513

Echus Chasma OP-987

eclogite

OP-635

Norway OP-1173

eclogite facies

Poland, structural geology OP-967; OP-1916 ecology see also deltas; deserts; estuaries; fires; greenhouse effect; impact statements; reefs; tundra; wetlands.

C 1086; OP-476; OP-576; OP-583

Alaska YR; C 1086; OF 92-0596

Arctic region C 1086

Atlantic Coastal Plain

ground water OP-1239

Quaternary OF 92-0263

Atlantic Ocean OF 92-0566

California

OF 92-0456; OF 93-0083

ground water OF 92-0655

hydrology WRI 93-4030

Canada YR

Colorado

OP-1328

hydrology OF 92-0628

Costa Rica, geochemistry OP-812

geophysical surveys OF 91-0014

ground water OP-154

Gulf Coastal Plain C 1120-C; OF 92-0530

Gulf of Mexico C 1120-C; OF 92-0530

hydrogeology OF $92-0083$

hydrology OF 93-0104

Nevada, hydrogeology OF 90-0381

New Jersey, hydrogeology WRI 91-4169

New York OP-1130; OP-1735

North Carolina

economic geology B 2039

hydrology WRI 92-4129

North Dakota, hydrology OF 93-0066

Puerto Rico OF 92-0150

Washington

C 1090; OF 91-0453

hydrogeology OF 92-0644

hydrology OF 91-0453

Quatemary OF 93-0284

Wisconsin, hydrology WRI 90-4126

economic geology see aggregate; anhydrite deposits; antimony ores; asbestos deposits; asphalt; barite deposits; base metals; beryllium ores; bitumens; borate deposits; boron deposits; brines; building stone; cadmium ores; cement materials; chromite ores; clays; coal; cobalt ores; construction materials; copper ores; dimension stone; dolostone deposits; energy sources; evaporite deposits; fluorspar; gems; geothermal energy; granite deposits; graphite deposits; gravel deposits; gypsum deposits; heavy mineral deposits; hematite; industrial minerals; iron ores; kaolin deposits; lead ores; lead-zinc deposits; lignite; limestone deposits; manganese ores; mercury ores; metal ores; mineral resources; molybdenum ores; monazite deposits; natural gas; nickel ores; niobium ores; nonmetal deposits; oil and gas fields; oil sands; oil shale; palladium ores; peat; pegmatite; petroleum; phosphate deposits; platinum ores; polymetallic ores; pumice deposits; rare earth deposits; rhodium ores; salt; sands; sandstone deposits; shale; silver ores; soapstone; strategic minerals; sulfur deposits; talc deposits; tantalum ores; thorium ores; tin ores; titanium ores; trona; tungsten ores; uranium ores; vanadium ores; water resources; zeolite deposits; zinc ores

economic geology maps see also industrial minerals maps; metallogenic maps; petroleum maps. OF 92-0020-B

Alaska .

metal ores MF-1996-E; MF-2228; OP-123 mineral resources OF 92-0690
Appalachians, building stone MF-2215-A

Arizona, metal ores B 1737-E

Arkansas, mineral resources MF-1994-D

California B 2019

Colorado B 2035

Kansas, metal ores MF-2125-E

metal ores MF-1838-D

Mexico, metal ores B 2039

Missouri

metal ores MF-2125-E

mineral resources MF-1994-D

Montana

OF 93-0207

metal ores I-2050-F

Nevada

B 2019

non-metal deposits OP-765

North Carolina B 2005

Puerto Rico, copper ores OF 92-0578

Tennessee B 2005

West Virginia, peat I-2364-B

ecoulement see gravity sliding

Eestall Pluton

petrology OP-1463

Ecuador

gold ores B 2039

EDAX data

geochemistry OP-1305

EDB

pollution W 2402

edenite

petrology OP-393

EDGE

geophysical surveys OF 93-0238

edge waves

California, oceanography OP-751

education see also academic institutions; collegelevel education; elementary school; high school; junior high school.

YR; OF 91-0014; OF 93-0123; OP-616; OP-

1111

earthquakes OF 92-0441

engineering geology $\mathrm{OP}-1483$

Europe OP-558

geomorphology OF 93-0278-A; OF 93-0278-B

hydrogeology YR; OF 92-0637

Virginia OF 93-0231

Edwards Air Force Base

geologic hazards WRI 92-4035

ground water $\mathrm{OF}$ 93-0148

Quatemary OF 93-0263

Edwards Aquifer

environmental geology WRI 92-4117

ground water WRI 92-4155; OP-1675

hydrogeology OF $92-0160$

Edwards-Trinity Aquifer hydrogeology WRI $92-4190$

EDXRF

geochemistry B 1770

Eel River

natural gas B 2034-A

Eel River basin

plate tectonics OP-1749

Efate

geologic hazards OP-1521

eggstone see oolite

EGSP see Eastern Gas Shales Project

Egypt

earthquakes, Cairo Egypt OP-992; OP-1092

engineering geology, Cairo Egypt OF 93-0181 
Eifelian

OP-84

Alaska OP-85

Nevada OP-86; OP-491

Russian Federation OP-491

Eights Coast

tectonophysics OP-1446

eklogite facies see eclogite facies

Eklutna Lake basin

hydrology WRI 92-4132

El Cajon Quadrangle

geophysical surveys OF 92-0548

El Chichon

geochemistry OP-1778

El Nino

Alaska, Quaternary C 1086

California, Quatemary C 1086

Nevada, Quatemary C 1086

Pacific Ocean, geologic hazards C 1086

Quaternary OP-1989

El Paso Mountains

deformation OP-972

El Salvador

seismology

OP-1066

San Salvador El Salvador OP-399

El Salvador earthquake 1986 see San Salvador earthquake 1986

elastic waves see also attenuation; body waves; seismic sources; surface waves.

OF 91-0014; OF 92-0441

California

P 1550-C; OF 92-0441; OP-438; OP-913; OP-1728

engineering geology OP-1582

Nevada, geophysical surveys OF 93-0187

South Africa, engineering geology OP-660

Washington B 1966

Elbrook Formation

environmental geology OP-901

Eldjurta Granite geochronology OP-1407

Eleana Formation geochemistry OP-774

electrical field

Kazakhstan, geophysics OP-367

Kyrgyzstan, geophysics OP-367

electrical logging

California, geophysical surveys OF 92-0544

Montana, Cretaceous OC-0135; OC-0138

New Hampshire, environmental geology OF 92-0647

South Carolina, stratigraphy B 2030

Tennessee, ground water OF 92-0135; OF 92 0166

Wyoming, Cretaceous OC-0135; OC-0136; OC-0137; OC-0138

electrical methods

OF 93-0071; OP-1580

base metals OP-944

earthquakes OP-540

environmental geology WRI 92-4012; WRI 92 4056

ground water OF.93-0071

hydrology OF 92-0490; OF 93-0071

rock mechanics OF 93-0071

electrical properties

tectonophysics OP-135

electrical sounding

Califormia, ground water OF 93-0279; OF 930524
Colorado, hydrogeology OF 93-0282

electrical surveys see also electrical methods.

Colorado, metal ores OP-582

Minnesota, kaolin deposits OF 92-0514

Ohio, pollution OP-155

Saudi Arabia, tin ores OP-499

Texas, hydrogeology OP-1200

electromagnetic field

California, seismology P 1550-C earthquakes OP-766; OP-768

electromagnetic methods OF 92-0553-A; OF 92-0553-B; OF 93-0234-A; OF 93-0234-B

electromagnetic seismographs seismology OP-858

electromagnetic survey maps

Nevada, gold ores GP-1003-A

California, seismology P 1550-C

engineering geology OP-384

Montana, energy sources OP-1947

Nevada, gold ores B 2039; OP-779

New Jersey, environmental geology OF 920153

Ontario, pollution OP-369

Texas, hydrogeology OP-1200

electron paramagnetic resonance

geochronology OP-1436

electronic data processing see data processing

elementary school

OP-1049; OP-1219

ground water $Y R$

Elk Lake

geochemistry OP-248; OP-251; OP-943

paleobotany OP-101

Quatemary C 1086; OP-20; OP-21; OP-99; OP100; OP-668

sedimentary petrology OP-250; OP-739

Elkhorn Spring paleomagnetism OP-697

Elko Canyon Formation stratigraphy B 1988-C

Elko Orogeny structural geology OP-999

Ellenville Tongue stratigraphy B 1839-L

Ellesmerian energy sources B 2034-A

Ellsworth Land petrology OP-1027

Ellsworth Mountains tectonophysics OP-1446

Ellsworth Shale

hydrogeology OP-1228

palynomorphs B 1909

Elsinore Fault neotectonics OP-1063

Elvins Group sedimentary petrology OF 93-0291

Ely Quadrangle petrology OP-795

Elysium see also Elysium Mons. OP-906; OP-1222

Elysium Fossae OP-1240

Elysium Mons OP-142; OP-1240

embankments

South Carolina, engineering geology WRI 904056

embryos

Utah, Vertebrata OP-1252

emerald

Afghanistan, gems OP-1869
Pakistan, gems OP-1869

Emerson Fault

earthquakes OP-699

seismology OP-411; OP-593

Emigrant Fault

neotectonics OP-780

Emigrant Gap Pluton

structural geology OP-1413

Emiliania huxleyi

Minnesota, Quaternary C 1086

emission spectroscopy see also inductively cou-

pled plasma methods. geochemistry B 1770

en echelon faults

California, engineering geology OF 93-0348

Nevada OF 91-0623

Texas, ground water OP-1675

Utah, Quatemary OP-970

en echelon folds

California, seismicity OP-1914

Enallophrentis

Invertebrata B 2024

encroachment (ground water) see salt-water intrusion

encrustations

Hawaii, oceanography OP-418

endellite see halloysite

Endicott Group

energy sources B 2034-A

endogene processes

Saudi Arabia, metal ores OP-1559

energy sources see also coal; natural gas; petro-

leum.

OP-450

Alaska C 1094

Colorado

B 2035

Paleogene B 1787-Q

ecology C 1086

Hungary YR

North Carolinà B 2005

Tennessee B 2005

Utah, Paleogene B 1787-Q

energy-dispersive $X$-ray fluorescence geochemistry B 1770

Enewetak Atoll

Neogene OP-1457

engineering geology see dams; earthquakes; explosions; geologic hazards; highways; land subsidence; marine installations; nuclear facilities; permafrost; reservoirs; rock mechanics; soil mechanics; tunnels; underground installations; waste disposal; waterways

engineering geology maps

OP-67; OP-1184

California, geologic hazards I-1257-M

Hawaii OF 92-0501

New York I-2003

Washington OF 91-0441-T

engineering, petroleum see petroleum engineering

England

economic geology, Cornwall England OF 920525

geochemistry OP-158; OP-755

metal ores OP-1541

English Coast petrology OP-1027

Eniwetok Atoll see Enewetak Atoll

Ennis Lake Quadrangle maps GQ-1729 


\author{
ENSO see El Nino \\ enstatite \\ petrology OP-1727 \\ Enterprise Quadrangle \\ maps OF 93-0203 \\ entrainment
}

Colorado, hydrogeology OP-300

environmental geology see conservation; ecology; geologic hazards; impact statements; pollution; reclamation; waste disposal

Eocene see also Challis Volcanics.

OP-159; OP-753

Absaroka Supergroup, natural gas OF 93-0337

Alaska P 1497-C

Atlantic Coastal Plain OP-1205

Atlantic Ocean OP-791

Bridger Formation P 1506-D; P 1506-F

California OF 92-0588; OF 93-0180; OP-936

Canada P 1497-C

Claiborne Group, structural geology OP-1970

Cockfield Formation, hydrogeology OP-32

Colton Formation

oil sands OP-1855

sedimentary rocks B 1787-DD

Georgia OP-291

Green River Formation

P 1506-D; B 1787-BB

natural gas OF 93-0248

oil sands OP-1855

sedimentary rocks B 1787-DD

structural geology B 1787-HH

Gulf Coastal Plain OP-1205

Idaho OP-18; OP-912; OP-1081

Indonesia OP-870

Jackson Group, Quaternary OP-486

Lake Gosiute, energy sources OF 92-0391

Lake Uinta

B 1787-BB

energy sources OF 92-0391

Lisbon Formation, hydrogeology W 2391

Montana P 1524

Nevada B 1988-C

New Mexico OP-573

New Zealand OP-1391

Ocala Group, hydrogeology W 2340

Pakistan OF 92-0281; OP-1548

South Carolina OP-291

Sparta Sand, hydrogeology OP-32

Uinta Formation

sedimentary rocks B 1787-DD

structural geology B 1787-HH

Vanuatu OP-1908

Virginia B 1839-I,J

Washington OP-18; OP-1083; OP-1187; OP1397

West Virginia B 1839-I,J

Wilkins Peak Member P 1506-F

Willwood Formation

OP-98

hydrogeology WRI 91-4044

sediments OP-556

Wyoming OP-464

Yazoo Clay OP-746

Eogene see Paleogene

eolian features see also coastal dunes; continental

dunes; deserts.

Alaska, Quaternary OP-33

eolianite

Pacific Coast, Quaternary C 1086

epeirophoresis theory see continental drift
Ephrata Pennsylvania

pollution OP-388

epicenters

Alaska

earthquakes OF 93-0309

seismology P 1527; OP-1

Atlantic Ocean, tectonophysics OP-1080

California

earthquakes OF 92-0575; OF 93-0191; OP406; OP-931

plate tectonics OP-752

seismicity P 1550-C; OP-286

seismology P 1550-C; OP-328; OP-541; OP-1046

structural geology OP-340

Central America, earthquakes DDS-0007

earthquakes PDE; OF 91-0600-D; OF 92-0441; OF 92-0583; OF 92-0584; OF 92-0600-A; OF 92-0600-B; OF 92-0600-C; OF 920600-D; OF 92-0601-A; OF 92-0601-B; OF 92-0602-A; OF 92-0602-B; OF 920603-A; OF 92-0603-B; OF 92-0604-A; OF 92-0604-B; OF 92-0605-A; OF 920605-B; OF 92-0606-A; OF 92-0606-B; OF 92-0607-A; OF 92-0607-B; OF 920608-A; OF 92-0608-B; OF 92-0609-A; OF 92-0609-B; OF 92-0610-B; OF 920611-A; OF 92-0611-B; OF 92-0612-A; OF 92-0612-B; OF 93-0204; OP-1364

Egypt, engineering geology OF 93-0181

Hawaii

engineering geology B 2006

geophysical surveys OP-252

magmas OP-1001

seismology OP-116

Kentucky, Quaternary OP-486

mantle OP-1363

Mississippi Valley, seismology SM

Missouri, earthquakes OP-1996

Montana, deformation OP-883

Nevada, engineering geology OF 93-0073

Northern Territory Australia, Quaternary B 2032-A

Pacific Ocean, tectonophysics OP-1080

Tennessee, Quaternary OP -486

epldote

Canada, petrology OP-1463

United States, petrology OP-1463

epigene processes

Alaska, metal ores OP-224

China, metal ores OP-153; OP-1238

Colorado, metal ores OF 92-0557

ground water B 1989-D

Mesozoic OP-1494

metal ores OF 92-0389

Missouri, lead-zinc deposits OP-575

Epiguruk Alaska

Quaternary OP-33; OP-390; OP-391

Epirus Greece

plate tectonics OP-542

epithermal processes

Alaska, metal ores OP-123

Bolivia, metal ores B 2039; OF 93-0016

California

energy sources OP-267

metal ores OP-428

Colorado, economic geology OP-872

economic geology OP-57

metal ores OP-853

Mexico '

economic geology OP-872

metal ores B 2039
Missouri, metal ores OP-1326

Nevada, metal ores OP-205

New Mexico, molybdenum ores OP-1243

Peru

economic geology OP-872

silver ores OP-1212

Utah, economic geology OP-872

Epoch 2002

hydrology OF 92-0534

Equatorial Pacific see Clipperton fracture zone

equilibrium line altitudes

California, Quaternary OP-1253

Equity Fault

metal ores $\mathbf{P} 1537$

Eratosthenian OP-1697

Erickson District

gold ores OP-1096

erosion see also erosion features; erosion rates; geologic hazards; glacial erosion; landslides; shorelines; valleys; waterways; weathering.

OP-1323; OP-1668

Alaska, petroleum OP-492

Antarctic Ocean, Quaternary OP-1358

engineering geology OP-384

geomorphology C 1086

Great Lakes, geomorphology OP-1143

Gulf of Mexico, ocean floors OP-743

Illinois

changes of level OP-1393

geomorphology OP-487

Japan, tectonophysics OP-1620

Louisiana

Quaternary OF 92-0530

sedimentary petrology OP-262

Massachusetts

geomorphology OF 93-0185

sedimentation OP-1598

Nevada, geomorphology OP-1276

Pacific Ocean, plate tectonics OP-1651

sedimentary petrology OP-1717

structural geology OP-159

Texas, engineering geology OP-280

Washington, environmental geology C 1090

Wisconsin, soils OP-22

Wyoming, Quaternary OP-1884

erosion features see also arroyos; gullies; talus

slopes.

OP-1933; OP-1934

California

continental shelf OP-1443

oceanography OP-1444

sedimentary petrology OP-709

Syria OP-1322

erosion rates

California, geomorphology OP-1339

geomorphology OP-1750

Nevada, geomorphology OP-1339

erosional features see erosion features

erosional unconformities

Califomia, stratigraphy OF 92-0588

Florida, oceanography OP-1510

Nevada, stratigraphy B 1988-G

New Jersey, stratigraphy OP-979

Utah, sedimentary petrology B 2000-E

Virginia, Proterozoic B 2029

eruptions see also explosive eruptions; pliniantype eruptions; pyroclastics; volcanic earthquakes; volcanic risk; volcanoes.

Alaska

geochemistry OP-926

Quatemary OP-1342; OP-1699; OP-1772 
California, seismology P 1550-C

Chile, Quaternary OP-279

engineering geology $\mathrm{OP}-1483$

hydrogeology OP-467

Idaho

petrology OP-560

Quaternary OF 92-0408

Nevada, volcanism OF 93-0021

Oregon, petrology OP-498

Philippine Islands, magmas OP-1768

sedimentary petrology OP-1293

Spain, metal ores OP-875

Wyoming, Quaternary OF 92-0408

eruptive rocks see volcanic rocks

Erzincan earthquake 1992

seismology EV

Escanaba Quadrangle maps 1-2356

escarpments see scarps

Escherichia coli

environmental geology WRI 92-4130 hydrology WRI 91-4073

eskers

OP-1563

Quaternary OP-1256

Espiritu Santo Island

sedimentation OP-188

tectonophysics OP-1908

Estherville Meteorite

petrology OP-1199

estuaries see also waterways.

California

hydrogeology OF 93-0146

hydrology OF 93-0057

Quaternary C 1086

Delaware

ground water OF 92-0052

hydrogeology OF 92-0052

Florida

hydrogeology WRI 92-4062

hydrology WRI 91-4115

hydrology W 2395

Louisiana, Quaternary OF 92-0530

Maryland, hydrology W 2340

Massachusetts OP-932

New Jersey

ground water OF 92-0052

hydrogeology OF 92-0052

North Carolina

OP-1131

hydrogeology OF 93-0069

hydrology OF 92-0123

Virginia, hydrology W 2340

estuarine sedimentation

Atlantic Ocean OP-483

Florida OP-893

Kentucky OF 92-0558

Massachusetts OP-546

Ethnic Minority Advisory Committee YR

ethylene dibromide

Florida, pollution W 2402

eugeosynclines

Mexico, Paleozoic OP-56

Eurasia

tectonophysics OP-1548

Eurasian lce sheet

Quatemary OP-1256

Eurasian Plate

Iceland, tectonophysics OP-420

Pakistan, natural gas OP-1634
Eureka Nevada

gold ores OP-921

Europe see also Alps; Armenia; Central Europe; Georgian Republic; Southern Europe; Western

Europe.

Brachiopoda, Timan Ridge OP-491

Carboniferous

Snieznik OP-1917

Sudeten Mountains OP-1917

Cretaceous OP-1193

earthquakes, Caucasus OP-1025

energy sources

Orenburg Russian Federation OP-1258

Pannonian Basin OP-1263; OP-1687

Pripet Basin OP-1261

Timan-Pechora region OP-1967

engineering geology, Novaya Zemlya OF 930501

geochronology, Caucasus OP-1407

ground water, Baltic Shield OP-1039.

lead-zinc deposits OP-787

magmas, Caucasus OP-91

metal ores, Silesia OF 92-0704

oceanography, Gibraltar OP-722

petroleum, Pripet Basin OP-1265.

plate tectonics

OP-1519

Adriatic region OP-206

Precambrian, Kola Peninsula OP-1777

Quaternary P 1386-E

stratigraphy OP-527

structural geology

Polish Sudeten Mountains OP-967

Snieznik OP-967

Sudeten Mountains OP-1916

European Atlantic see North Sea

European Plate see Eurasian Plate

eustacy

Atlantic Coastal Plain, Paleogene OP-351

Carboniferous OP-1232

Colombia, geochemistry OP-755

England, geochemistry OP-755

Gulf Coastal Plain, Paleogene OP-351

Poland, geochemistry OP-755

Rocky Mountains, Pennsylvanian OP-1103

Texas, geochemistry OP-755

Westem Interior, Carboniferous OP-1231

Eutaw Formation OP-1817

Eutaw-MeShan Aquifer

ground water P 1410-G

Eutheria see Camivora; Rodentia

Evangeline Aquifer ground water OF 93-0081; OF 93-0086

Evanston Quadrangle maps I-2168

evaporite deposits

California OP-226

Nevada OP-226

New Mexico OP-2012

Texas OP-2012

evaporites see also halite; salt.

California, geophysical surveys OP-227

Colorado

geochemistry OP-1965

natural gas OP-1262

petroleum OF 92-0391

stratigraphy B 1787-GG; OP-1523

Commonwealth of Independent States, energy sources OP-1261

Europe, energy sources OP-1261

Kenya OP-1490
Massachusetts, Mesozoic OP-801

New Mexico, evaporite deposits OP-2012

non-metal deposits OP-225

Oregon

OP-1490

mineral resources OF 90-0506

Pennsylvanian OP-1233

Red Sea, brines OP-2029

Rocky Mountains, Pennsylvanian OP-1103

Texas, evaporite deposits OP-2012

Utah

geochemistry OP-1965

natural gas OP-1262

petroleum OF 92-0391

stratigraphy OP-1523.

EXAFS

orthosilicates OP-1810

Exeter Mines

hydrogeology WRI 92-4073

Exeter River basin

ground water OF 92-0095

exhalative processes

California, manganese ores OP-319; OP-458

Idaho, metal ores OP-715

metal ores OP-1506

Vermont, copper ores B 2039

exhumation

Poland, structural geology OP-967

exinite see sporinite

Exmouth Plateau

marine geology OP-361

exogenous inclusions see xenoliths

expert systems see also artificial intelligence. petroleum B 2048; OP-1710

waste disposal OF 92-0526-A; OF 92-0526-B

explosions

Nevada OP-2026

nuclear explosions

Alaska OF 92-0502

China OP-1031

Russian Federation OF 93-0501

Washington, Quatemary OP-647

explosive eruptions

OP-1831

Alaska

magmas OP-1469

Quaternary OP-1250; OP-1714; OP-1739

Hawaii, Quaternary OP-284

Mariana Islands, geologic hazards OP-1962

Micronesia, geologic hazards OP-1962

Oregon, geochemistry OP-43

exposure age

OP-806

Basin and Range Province, Quatemary OP-618

extension faults

OP-401

Alaska OP-1427

Arctic Ocean OP-1428

Arizona, metal ores B 2042-C

Idaho OP-523; OP-780

Nevada

OF 92-0391

gold ores OP-1048

seismology OP-1275

Utah

metal ores OP-1464

mineral resources B 2039

Wyoming OP-780

extension fractures

Wyoming OF 92-0388 
extension tectonics

OP-159; OP-401; OP-1235; OP-1790; OP-

1936; OP-1938

Alaska OP-1427

Antarctica, tectonophysics OP-1317

Arizona OP-1886

Basin and Range Province OP-1158

Bering Sea OP-211

California

OP-703; OP-972; OP-1172; OP-1971

geologic hazards OP-1793

petrology OP-1376

plate tectonics OP-759

stratigraphy OP-1281

crust OP-2030

Great Basin OP-1158

Idaho OP-523; OP-941

Illinois, non-metal deposits OP-1419

Italy OP-1808

Kentucky, non-metal deposits OP-1419

metal ores OP-853

Mexico OP-1886

Midwest OP-1799

Montana OP-941

Nevada

OP-108; OP-999; OP-1400

geochemistry OP-1609

metal ores OP-397

petroleum OP-614

New Mexico, petrology OF 92-0528

Norway OP-1279

Poland OP-1916

Red Sea, brines OP-2029

Washington, petrology OP-1397

Exxon Valdez

environmental geology OP-564

Eye-Dashwa Lakes Pluton

petrology OP-1560

\section{$\mathbf{F}$}

F see fluorine

facies see amphibolite facies; blueschist facies; eclogite facies; granulite facies; greenschist facies; prehnite-pumpellyite facies; zeolite facies

facilities, nuclear see nuclear facilities

Fairbanks Alaska

hydrology OP-330

Fairweather Mountains

Quaternary OP-1719

Falconbridge Mine metal ores OP-1979

Fall Zone heavy mineral deposits B 2039

Falling Creek Member stratigraphy OP-1660

Falls Quadrangle gold ores OP-168

Falls River Fault structural geology B 1904-Q

Falmouth Massachusetts

geochemistry OP-215 pollution OP-1574

fan deltas Utah, structural geology OP-619

fanglomerate Arizona, inclusions OP-1748
Far East see also Bomeo; China; Indochina; Indonesia; Japan; Korea; Malaysia; Philippine Islands; Thailand; Vietnam.

metal ores, Sino-Korean Platform OP-1238

metasomatism, Sino-Korean Platform OP-1343

petroleum, Sarawak Malaysia OP-1829

Plantae, Kalimantan Indonesia OP-695

sedimentary petrology, Kalimantan Indonesia OP-870

sedimentation, Sarawak Malaysia OP-1211

Farallon Plate

Alaska, structural geology OP-94

California

structural geology OP-1172; OP-1547

tectonophysics OP-1733

Mexico, structural geology OP-1547

Oregon, structural geology OP-1547

Pacific Ocean, tectonophysics OP-1926

plate tectonics OP-1903

Farallones Guif

oceanography OF 93-0298

Farm Gneiss

geochemistry OP-344

Farmville Metagranite

petrology OP-1237

Fars Group

stratigraphy OP-1453

Farther India see Indochina

fatty acids see lipids

fault blocks see block structures

fault scarps

Atlantic Ocean, continental margin B 2002

Basin and Range Province, Quatemary OP-618

California, Quatemary OP-338

Northern Territory Australia, Quaternary B 2032-A

South Australia, Quaternary B 2032-B

Utah

geologic hazards P 1519

Quatemary OP-52

structural geology OP-718; OP-909

\section{fault zones}

Alaska, gold ores OP-589

California

deformation OP-1442

earthquakes OP-126; OP-1762

seismology OP-1581

Colorado

base metals OP-944

metal ores OP-937

faults OP-127; OP-601; OP-640

hydrogeology OP-659

Idaho, metal ores OP-876

Nevada

gold ores OP-716

metal ores OP-489

Oklahoma, seismology OP-301

Oregon, metal ores OP-876

seismicity OP-1866

Utah

geomorphology I-2199

Quaternary OP-970

structural geology OP-621

Washington, geomorphology OP-1552

faults see also block structures; breccia; decollement; deformation; earthquakes; fault scarps; folds; foliation; fractures; geologic hazards; gouge; grabens; lineaments; scarps; seismic moment; shear zones.

OP-259; OP-437; OP-1235; OP-1668

active faults

OP-119

Alaska OF 93-0338; OP-1

California YR; P 1550-C; OF 91-0032; OF 93-0276; OF 93-0348; OP-23; OP90; OP-125; OP-126; OP-145; OP-286; OP-302; OP-338; OP-357; OP-512; OP593; OP-648; OP-688; OP-698; OP-868; OP-882; OP-931; OP-958; OP-966; OP1581; OP-1833

Colorado OP-1171; OP-1423

Dominican Republic OP-808

earthquakes OP-539

Greece OP-542

Hawaii OP-252

Italy OP-764

Mississippi Valley OF 92-0391; OP-358

Nevada OP-357

Northem Territory Australia B 2032-A

seismicity OP-1866

South Australia B 2032-B

Utah P 1519; OP-621; OP-970

Washington OP-120

Wyoming OP-1780

Arizona, petrology OP-1341

Arkansas OP-1970

Atlantic Coastal Plain, oceanography OP-1337

Basin and Range Province OP-1158

bedding faults, Califomia OP-1794

California

elastic waves OP-913

geochemistry OP-265

Quatemary OF 93-0263; OP-1843

Colorado

OF 92-0711; OP-118

hydrogeology OF 93-0282

detachment faults

Arizona B 2042-C; OF 93-0228; OP-611

British Columbia OP-1159

California OF 93-0228; OP-267; OP-442

Idaho OP-617

Montana OP-617

Nevada B 2011; OP-1400

Pennsylvania B 1994

Utah B 2011

Washington OP-1159; OP-1187

dip-slip faults

Arizona P 0497-H

California OP-23

Chile OP-53

en echelon faults

California OF 93-0348

Nevada OF 91-0623

Texas OP-1675

Utah OP-970

extension faults

OP-401

Alaska OP-1427

Arctic Ocean OP-1428

Arizona B 2042-C

Idaho OP-523; OP-780

Nevada OF 92-0391; OP-1048

seismology OP-1275

Utah B 2039; OP-1464

Wyoming OP-780

Fiji, seismology OP-1758

Great Basin OP-1158

Gulf Coastal Plain, Cretaceous OP-838

Hawaii, seismology OP-116

high-angle faults 
Argentina OP-1129

Arizona I-2290

Bolivia B 2039

California OP-267

Illinois OP-1471

Missouri OP-1471; OP-1861

Montana P 1524

Idaho OP-1 197

lowa, geomorphology OP-1834

left-lateral faults

California OP-703; OP-802; OP-803; OP1063; OP-1793

Missouri OP-1861

plate tectonics OP-1133

stratigraphy OP-1368

listric faults

California OP-338

Colorado OP-1171

Commonwealth of Independent States OP1265

Europe OP-1265

Idaho OP-18; OP-523

Maine OP-1920

Montana P 1524

Nevada OP-108

Quebec OP-1920

Washington OP-18

low-angle faults

Basin and Range Province OP-769

California OP-267

Colorado Plateau OP-769

Hawaii OP-252

Nevada B 1988-C; B 1988-D; OF 92-0391; OP-614

Minnesota, economic geology B 2039

Nevada

I-2342; OP-933

Quaternary OP-916

New Mexico

OF 92-0711

petroleum OF 93-0522

stratigraphy OP-573

normal faults

OP-401; OP-1890

Appalachians B 2039

Arizona B 2042-C; I-2290

Atlantic Ocean OP-1080

Basin and Range Province OP-19; OP-769

California OP-438; OP-662; OP-803; OP1281; OP-1451

Colorado Plateau OP-19; OP-769

Commonwealth of Independent States OP1265

Europe OP-1265

Idaho OF 93-0235; OP-18; OP-523; OP617; OP-634

Inlinois OP-1471

Italy OP-764

metal ores OF 92-0557

Midwest OP-1799

Missouri OP-1318; OP-1471; OP-1861

Montana P 1524; OP-617

Nevada OF 92-0343; OF 92-0391; OP-108; OP-1400

Oregon OP-634

Pacific Ocean OP-1080; OP-1651

Poland OP-967; OP-1916

Utah P 1519; B 1787-HH; OP-621

Venezuela OP-1760

Washington OP-18

oblique-slip faults

California OP-1172

Idaho OP-634
Missouri OP-1336; OP-1861

Nevada OP-1400

Oregon OP-634

overthrust faults

OP-753

Alaska OP-224

Califomia OP-759

Papua New Guinea, petroleum OP-307

parallel faults, California OP-405

Pennsylvania, energy sources OP-1842

reverse faults

OP-1890

Atlantic Ocean OP-1080

California OP-83; OP-340; OP-803; OP1945

Idaho OF 93-0235

Missouri OP-1861

Northem Territory Australia B 2032-A

Pacific Ocean OP-1080; OP-1901

South Australia B 2032-B

Wyoming OP-149

right-lateral faults

Alaska OP-1186

California OP-405; OP-411; OP-593; OP649; OP-699; OP-700; OP-802; OP-803; OP-931; OP-972; OP-1063; OP-1442; OP-1701

Illinois OP-1471

Michigan I-2355

Missouri OP-1471

Nevada OP-1400

Poland OP-1916

Venezuela OP-1760

Russian Federation, Quaternary OP-1532

strike-slip faults

OP-1652; OP-1721; OP-1790

Basin and Range Province OP-19

Bering Sea OP-211

California OP-23; OP-113; OP-286; OP405; OP-406; OP-411; OP-438; OP-649; OP-688; OP-703; OP-802; OP-803; OP931; OP-972; OP-1166; OP-1547; OP1749

Colorado OP-1171; OP-1423

Colorado Platean OP-19

Greece OP-542

Illinois OP-1471; OP-1742

Mexico OP-1547

Michigan B 1904-S

Minnesota B 1904-S

Missouri OP-1471; OP-1742

Nevada B 201 1; OF 91-0623

Oregon OP-1166; OP-1547

seismicity OP-1866

seismology OP-1867

South Carolina OP-2032

stratigraphy OP-1368

Utah B 2011

thrust faults

OP-159; OP-1790

Alaska B 2034-A; OP-1427

Appalachians B 2039

Argentina OP-1129

Arizona OP-1957

Bahamas OP-1132

Basin and Range Province OF 93-0248

California OP-144; OP-512; OP-752; OP1762; OP-1914; OP-1957

Canada OP-1215

Colorado OF 92-0391; OP-1171; OP-1523; OP-1813

Colorado Plateau OF 93-0248; OP-679

Costa Rica OP-785
Hungary OP-1687

Idaho OP-617

Michigan I-2355; OP-1214

Montana OF 93-0337; OP-617

natural gas OF 93-0248

Nevada B 2011

Pacific Ocean OP-1651

Panama OP-785

Pennsylvania B 1994

Poland OP-967; OP-1916

Rocky Mountains OP-679; OP-1350

South Carolina OP-2032

United States OP-1215

Utah B 201 1; OP-1464; OP-1523

Vermont B 2039

Washington B 1966

Wisconsin OP-1214

Wyoming OF 93-0337

Tonga, seismology OP-1758

transcurrent faults

California OP-340

China OP-1519

Manitoba OP-1560

Ontario OP-1560

United States OP-1519

transform faults

OP-1890

Alaska OP-1430

Atlantic Ocean OP-1080

California OP-145; OP-267; OP-759; OP1281

Mexico B 2039

Pacific Ocean OP-1080

tectonophysics OP-463

underthrust faults

Alaska P 1497-C

Appalachians OP-1079

Canada P 1497-C

tectonophysics OP-1037

Utah OP-619; OP-773

Washington I-1963

wrench faults

California OP-1442

Greece OP-542

Montana OF 93-0337

Fauquier Formation orogeny OP-1612

Fayetteville Formation Invertebrata OP-360

Fayetteville North Carolina hydrology WRI 92-4097

Fe see iron

features, bottom see bottom features

features, eolian see eolian features

features, erosion see erosion features

features, fluvial see fluvial features

features, glacial see glacial features

features, impact see impact features

features, lacustrine see lacustrine features

features, periglacial see periglacial features

features, shore see shore features

features, solution see solution features

features, volcanic see volcanic features

Federal-State Cooperative Water-Resources Program hydrogeology OF 93-0120

Federated States of Micronesia see Micronesia

feeding ground see drainage basins

Felch Trough

structural geology B 1904-L 
feldspar group see also alkali feldspar, plagioclase.

Atlantic Coastal Plain, pollution OP-1458

California OP-1038

Colorado

geochemistry OP-490

metal ores $\mathrm{OF} 92-0525$

India, geochronology OP-1346

New Mexico, geochemistry OP-490

phase equilibria OP-1475

Fena Valley Reservoir

hydrology WRI 92-4114

Fennoscandian Shield see Baltic Shield

Fenstermaker Wash Formation

sedimentary petrology OP-1795

ferns

geochemistry OP-1769

Nova Scotia, sedimentary petrology OP-1673

ferrihydrite

OP-336; OP-1058; OP-1810; OP-1811; OP-

1985; OP-1986

geochemistry OP-1319; OP-1987

Greenland, Archean OP-848

Ferris Formation

natural gas OF 92-0524

ferrisurite

California, mineralogy OP-500

ferroan anorthosite OP-661

Fidalgo Mine

metal ores OP-224

field trips see also guidebook.

YR

Oreg on OF 93-0189

Utah, Quaternary OP-622

field, electrical see electrical field

field, electromagnetic see electromagnetic field

field, gravity see gravity field

field, magnetic see magnetic field

fields, coal see coal fields

fields, geothermal see geothermal fields

fields, lava see lava fields

fields, oil and gas see oil and gas fields

FIFE

environmental geology OP-507; OP-729; OP946

Fiji

seismology OP-1758

fiord see fjords

fireclay

Missouri, clay mineralogy OP-522

fires

California, hydrology WRI 92-4172

Pacific Ocean, geologic hazards C 1086

Wyoming, pollution OP-930

fish

Alaska, hydrology OF 93-0095

Atlantic Ocean, ecology OF 92-0566

Canada, palynomorphs B 1909

hydrology OF 93-0104

Nevada, hydrogeology OF 90-0381

New York, environmental geology OP-1130; OP-1735

North Carolina, hydrology WRI 92-4129

Ohio

hydrology OF 92-0120

stratigraphy OP-1513

pollution OP-580

United States, palynomorphs B 1909

Virginia, Phanerozoic OF 93-0222

Washington ecology OF 91-0453

environmental geology C 1090

hydrology OF 91-0453

pollution OP-1827

Fish Canyon Tuff

OP-1538

geochemistry OP-1825

Fish Lake valley

Quaternary OP-831

Fish Springs District gold ores OP-1096

Fishers Island Sound oceanography OF 93-0214

fission-track dating

Alaska, Quaternary C 1086; OP-1059

Namibia, meteor craters OP-550

Nevada, gold ores OP-27

New Mexico, stratigraphy OP-573

Utah, stratigraphy B 1787-BB

Wyoming, Miocene B 1917-O

Fissipeda

Alaska OP-163

fjords

Antarctic Ocean, oceanography OP-263

flame ionization mass spectroscopy geochemistry OP-991

flame structures

California, stratigraphy OP-1281

Flathead Indian Reservation hydrogeology WRI 92-4066

Flathead Sandstone hydrogeology WRI 91-4044

Flattops Wilderness Area hydrology OP-133

Flaxman Member

Quatemary OP-1225

flexure

OP-1936

Appalachians, zinc ores B 2039

Flinn-Engdahl regionalization scheme seismology OP-1091

flint clay

Kentucky, stratigraphy OF 92-0558

Flint Creek Range

stratigraphy OP-1351

flood basalts

geochemistry OP-30

geochronology OP-134

Great Lakes region, copper ores OP-1216

Russian Federation, geochemistry OP-1086

Flood Member

stratigraphy OP-1351

flood tuff see ignimbrite

floodplains

Alaska

pollution OP-66

Quatemary OP-33

Arizona OP-426

California, dams OP-454

hydrogeology OF 92-0083

hydrology W 2339

lowa, hydrology OF 92-0094

New Mexico, hydrogeology WRI 92-4193

South Carolina, engineering geology WRI 904056

South Dakota, environmental geology OP-641

Tennessee, hydrology WRI 92-4082

Virginia B 1981

West Virginia B 1981 floods see also waterways.

OP-142; OP-987; OP-1221; OP-1242; OP-

1323; OP-1838

Alaska

geologic hazards OF 93-0094 hydrology W 2400

Arizona, hydrology OF 93-0054

Bangladesh

geologic hazards OF 92-0391 geomorphology OP-1273

California, hydrology WRI 92-4172

Canada, hydrology C 1086

Colorado, geologic hazards OP-1545

engineering geology OP-1483

geologic hazards P 1240-B; OF 91-0014; OP1043; OP-1976

Georgia, hydrology WRI 93-4016

Gulf Coastal Plain, environmental geology C 1120-C

Gulf of Mexico, environmental geology C 1120-C

hydrology OF 92-0105

Illinois

hydrogeology WRI 92-4149

hydrology YR

Mississippi, hydrogeology OP-1010

Mississippi Valley

geologic hazards C 1120-B; OP-669

hydrology C 1120-A

Montana, hydrogeology WRI 92-4185

New Jersey, geologic hazards OP-899

Oregon geologic hazards W 2340 hydrology WRI 91-4063

Pacific Ocean, geologic hazards C 1086

Pennsylvania, geologic hazards YR

Puerto Rico, hydrology W 2400

Quaternary OP-1989

South Dakota, hydrology W 2340

Tennessee, hydrology WRI 92-4165

United States, hydrology C 1086

Utah, geologic hazards P 1519

Vermont, engineering geology B 2043

Virginia

fluvial features B 1981 geomorphology B 1981

West Virginia

fluvial features B 1981

geomorphology B 1981

Florida see also Saint Johns River basin. continental slope B 2002

ecology, Florida Keys C 1086

energy sources OF 92-0524

engineering geology, Tampa Bay OP-895 environmental geology

Alachua County Florida WRI 92-4058

Bradford County Florida WRI 92-4058

Lafayette County Florida WRI 92-4058

Pinellas County Florida WRI 91-4181

Polk County Florida WRI 92-4086

Suwannee County Florida WRI 92-4058

geochemistry OP-151; OP-1905; OP-1906

geologic hazards

YR

Biscayne Aquifer YR

Dade County Florida YR

ground water

YR; P 1416-C; WRI 92-4103; OF 92-0492;

OP-494; OP-514

Biscayne Aquifer OP-671

Brevard County Florida W 2340; WRI 914168 
Charlotte County Florida OF 92-0471: OF 92-0472; OF 93-0053

Citrus County Florida OF 92-0472; OF 930049

Dade County Florida OP-671

De Soto County Florida OF 92-0471; OF 92-0472; OF 93-0053

Hardee County Florida OF 92-0471; OF $92-$ 0472; OF 93-0049

Hernando County Florida OF 92-0472; OF 93-0049

Highlands County Florida OF 92-0471; OF 92-0472; OF 93-0053

Hillsborough County Florida OF 92-0471; OF 92-0472; OF 93-0049; OF 93-0053

Lake County Florida W 2340

Lee County Florida OF 93-0053

Manatee County Florida OF 92-0471; OF 92-0472; OF 93-0049; OF 93-0053

Marion County Florida W 2340

Orange County Florida W 2340

Osceola County Florida WRI 92-4076

Palm Beach County Florida WRI 91-4168

Pasco County Florida OF 92-0472; OF 930049

Pinellas County Florida OF 92-0472; OF 93-0049; OF 93-0053

Polk County Florida W 2340; OF 92-0471; OF 92-0472; OF 93-0049; OF 93-0053

Saint Lucie County Florida WRI 91-4168

Sarasota County Florida OF 92-0471; OF 92-0472; OF 93-0049; OF 93-0053; OP-1568

Southwest Florida Water Management District OF 92-0471; OF 92-0472

Sumter County Florida OF 92-0472; OF 930049

hydrogeology

WRI 91-4123; WRI 91-4186; WRI 92

4140; OF 91-0483; OF 92-0629; OF 93-

0067; OP-672; OP-2001

Broward County Florida WRI 92-4061

Charlotte County Florida WRI 92-4062

Citrus County Florida WRI 92-4069

De Soto County Florida WRI 93-4002

Hardee County Florida WRI 93-4002

Hernando County Florida WRI 92-4069

Hillsborough County Florida WRI 93-4002

Lee County Florida WRI 92-4062

Manatee County Florida WRI 93-4002

Polk County Florida WRI 93-4002

Putnam County Florida WRI 91-4180

Sarasota County Florida W 2340

Southwest Florida Water Management District W 2340

hydrology

W 2400

Duval County Florida WRI 91-4115

Nassau County Florida WRI 91-4115

marine installations, Tampa Bay OP-892

oceanography

OP-1510

Hillsborough County Florida OP-893

Pinellas County Florida OP-893

Tampa Bay OP-893

palynomorphs OP-2002

Pliocene

De Soto County Florida OP-1075

Manatee County Florida OP-1075

pollution

Highlands County Florida W 2402; OP-513

Polk County Florida W 2402
Quaternary

OP-706

Biscayne Bay OP-1930

Florida Keys C 1086; OP-1930

sedimentary petrology OP-1931

waste disposal

Charlotte County Florida OP-1531

Sarasota County Florida OP-1531

Florida Current

reefs OP-1662

Florida Keys

ecology C 1086

Quaternary C 1086; OP-1930

Florida Platform

oceanography OP-1073

structural geology OP-1932

Floridan Aquifer see also Ocala Group.

environmental geology WRI 91-4181; WRI 92 4086

ground water W 2340; W 2392; WRI 91-4168; WRI 92-4076; WRI 93-4038; OF 92-0472; OF 93-0049; OF 93-0050; OP-494; OP-867; OP-1568

hydrogeology W 2391; WRI 91-4196; OF 910483; OF 92-0466; OF 92-0629; OP-672; OP-2001

pollution WRI 91-4178

flowstone see speleothems

fluid inclusions see also carbon dioxide; geologic barometry; geologic thermometry; paleosalinity. OP-1773

Alaska, metal ores OP-1433

geochemistry OP-914

gold ores OP-1175

Idaho, Eocene OP-1081

Illinois, sedimentary petrology OP-1385

Indiana, sedimentary petrology OP-1385

Indonesia, sedimentary petrology OP-870

Kansas, natural gas OP-725

Maine, metal ores B 2039

metal ores OP-1509

Michigan

energy sources OF 92-0391

geochemistry OP-1204

Missouri, metal ores OP-1327

Montana, geochemistry OP-1305

natural gas OF 92-0524

Nevada

geochemistry OF 92-0525

gold ores OP-441; OP-994

metal ores OP-45; OP-489

molybdenum ores B 2039

New Mexico, geochemistry OP-1072

Philippine Islands, geochemistry OP-1994

Texas, geochemistry OP-1072

Victoria Australia OP-1136

Wyoming, geochemistry OP-49

fluids, ore-forming see ore-forming fluids

fluorides see bastnaesite; fluorite; pyrochlore; topaz

fluorimetry

hydrology W 2340

fluorine

Brazil, ground water OP-737

Colorado

geomorphology OP-1051

sedimentary petrology OP-1382

geochemistry B 1770

Oregon, geochemistry OP-43

Pacific Ocean, geochemistry OP-419

petrology OP-1061
Virginia, mineralogy OP-1755

fluorite

OP-1752

Idaho

Eocene OP-1081

geochemistry OP-912

Illinois, hydrogeology OP-1782

Kentucky, hydrogeology OP-1782

fluorometry see fluorimetry

fluorspar

Far East OF 92-0525

Great Britain OF 92-0525

Illinois OP-1419

Kentucky OP-1419

Nevada OP-736

flute casts

California, stratigraphy OP-1281

fluvial currents

hydrology W 2395

fluvial features see also alluvial fans; arroyos; bars; bluffs; buried channels; canyons; channel geometry; drainage patterns; eskers; floodplains; meanders; point bars; rivers; streams; waterfalls. OP-1934

Atlantic Coastal Plain, hydrology C 1086

Bangladesh OP-1273

California, hydrology C 1086

Canada, hydrology C 1086

Colorado

hydrogeology C 1086; OP-408

hydrology C 1086

Georgia, heavy mineral deposits B 2039

Great Lakes, plate tectonics OP-13

Great Lakes region, plate tectonics OP-13

hydrogeology C 1086; OF 92-0052

hydrology C 1086

Nevada, hydrology C 1086

New Hampshire ground water WRI 91-4025 hydrogeology OF 89-0583

New Jersey, ground water WRI 90-4151

New York, ground water WRI 90-4151

North Carolina, hydrology WRI 92-4129

Oregon, Quaternary B 2038

Sahara OP-314

South Carolina, heavy mineral deposits B 2039

Tennessee

OP-767

hydrogeology WRI $91-4190$

Quatemary MF-2218

United States, hydrology C 1086

Virginia B 1981

Washington

environmental geology C 1090

hydrogeology OF 92-0644

hydrology OF 91-0453

Quaternary OP-323

West Virginia B 1981

fluvial sedimentation see also fluviolacustrine sedimentation; glaciofluvial sedimentation.

Alabama, hydrology W 2340

Alaska, hydrology OF 93-0162

Arizona, impact statements YR

Black Sea OF 93-0274

Georgia, heavy mineral deposits B 2039

hydrogeology OP-24

hydrology OF 92-0651

Idaho, hydrology P 0870-A

Middle East OF 93-0274

Mississippi Valley, hydrology OF 91-0485

Missouri, geomorphology OP-1544

Montana B 1917-L 
North Carolina, hydrology W 2364 Samoa OP-844

South Carolina, heavy mineral deposits B 2039

South Dakota, environmental geology OP-641

Tennessee, hydrology W 2340; WRI 92-4082

West Virginia, geomorphology B 1981

Wisconsin, hydrology WRI 90-4124

Wyoming B 1917-L; OP-556

fluvial transport see stream transport

fluviolacustrine sedimentation

Alaska, hydrology WRI 92-4132

Mariana Islands, hydrology WRI 92-4114

Micronesia, hydrology WRI 92-4114

fly ash see ash

flysch

Alaska, metamorphic rocks P 1497-C

Canada, metamorphic rocks P 1497-C

Nevada

OP-1795

stratigraphy OP-1846

Foaming Sea OP-1439

focal mechanism

Alaska

earthquakes OP-1618

seismology OP-1

Atlantic Ocean, tectonophysics OP-1080

California

earthquakes OF 92-0441; OP-504; OP-698; OP-931; OP-958; OP-1762; OP-1992

elastic waves OP-913

engineering geology OP-125; OP-688

plate tectonics OP-145; OP-752

seismicity OP-286

seismology OF 92-0340; OP-1047; OP1728; OP-1872

Central America, seismology OP-1066

earthquakes OF 92-0441; OP-179; OP-258; OP-939; OP-1274; OP-1678; OP-1893

El Salvador, seismology OP-399

Fiji, seismology OP-1758

Hawaii, seismology OP-116

Iceland, seismicity OP-322

Mexico, plate tectonics OP-670

Mississippi Valley, structural geology OP-358

Nevada, seismology OF 92-0340

Pacific Ocean, tectonophysics OP-1080

seismology OP-676; OP-1033; OP-1275; OP2033

South Carolina, seismicity OP-2032

tectonophysics OP-1585

Tonga, seismology OP-1758

Foerstia

Devonian B 1909

natural gas B 1909

palynomorphs B 1909

fold and thrust belts

Alaska, energy sources B 2034-A

Appalachians, structural geology OP-1147

Michigan, structural geology B 1904-L; B 1904-Q

Montana, structural geology P 1524

Wyoming, structural geology OP-149

fold belts

Alaska, energy sources B 2034-A

Antarctic Ocean, orogeny OP-1395

Appalachians, economic geology B 1979

Texas, natural gas OF 93-0522 folds see also arches; basins; cleavage; decolle-

ment; foliation; fractures; nappes.

OP-159; OP-1940

Alaska

OP-1427

petroleum B 2034-A

anticlines

Alaska B 2034-A

California B 2034-A; OP-83; OP-1945

Idaho OP-617

Montana B 1993; OF 93-0337; OP-617

Pakistan OF 93-0255; OF 93-0256

Pennsylvania OP-1842

Wyoming OF 93-0337

anticlinoria

New York OP-461

Vermont OP-461

Virginia OP-1612

asymmetric folds, Michigan B 1904-L

Bahamas OP-1132

Basin and Range Province OP-19

Bolivia, metal ores B 2039

Califormia OP-340

Colorado Plateau OP-19; OP-679

domes

Appalachians OP-1479

Bolivia OP-1306

California OP-83; OP-2024

Nevada OP-205

Spain OP-231

Vermont B 2039

drag folds

Illinois OP-1471

Missouri OP-1471

en echelon folds, California OP-1914

isoclinal folds

Montana B 1993

Vermont B 1955; B 2039

monoclines

Arizona I-2290

Missouri OP-1861

Nevada B 2011

overturned folds, Michigan B 1904-L

Pakistan, natural gas OP-1634

Pennsylvania OF 92-0568

plunging folds

Alaska OP-224

Montana B 1993

recumbent folds, California OP-1474

Rocky Mountains OP-679

synclines

OP-1652

Appalachians OP-1147

Colorado B 1787-GG

Idaho OP-523; OP-617

Kentucky B 1909

Montana B 1993; OP-617

West Virginia B 1909

synclinoria, Saudi Arabia B 1976

Texas, natural gas OF 93-0522

Utah

B 2011

metal ores OP-1464

Vermont OF 92-0282-A

foliation see also cleavage.

California, economic geology OP-662

Colorado

OF 92-0391

geophysical surveys OP-1813

Proterozoic OP-10

Italy OP-1808

Michigan B 1904-L; OP-1889
Oman OP-815

slip cleavage, Califomia OP-1413

Vermont, copper ores B 2039

Foord coal seam

OP-2034

sedimentary petrology OP-1672

Foot of the Hills Field

energy sources OP-1255

foraminifera

Antarctic Ocean, stratigraphy $\mathrm{OP}-470$

Arkansas OP-1757

Miliolidae, United Arab Emirates OF 92-0391

foraminifers

Antarctic Ocean

Pliocene OP-1535

Quaternary OP-1307

stratigraphy OP-470

Tertiary OP-1145

Arctic Ocean, Quaternary C 1086; OF 92-0426; OF 93-0218; OF 93-0515; OP-799; OP1796

Atlantic Coastal Plain, Paleogene OP-351

Atlantic Ocean

Cretaceous OP-1894

marine geology OP-822

Pliocene C 1086; OF 92-0413; OF 92-0508; OP-271

barite deposits OP-960

California

Eocene OF 93-0180

stratigraphy P 1521; OF 92-0539-D; OF 92 0539-E; OF 93-0177

Celebes Sea, oceanography OP-821

Colombia, geochemistry OP-755

Costa Rica, Neogene OP-1272

England, geochemistry OP-755

Europe, Cretaceous OP-1193

Florida, Pliocene OP-1075

fusulinids

Mexico OP-56

Nevada B 1988-D

Oregon OP-87

Gulf Coastal Plain, Paleogene OP-351

Mississippi, Oligocene OP-746

Nevada, stratigraphy B $1988-F$

New Jersey, stratigraphy OP-979

Oregon, stratigraphy $P 1521$

Pacific Ocean

Cretaceous OP-1894

marine geology OP-819; OP-822

oceanography OP-820

Panama, Neogene OP-1272

Pliocene OF 92-0414; OF 92-0418; OP-222

Poland, geochemistry OP-755

Saudi Arabia, Quaternary OP-1198

South Carolina, stratigraphy B 2030

stratigraphy OP-270

Texas

geochemistry OP-755

geomorphology OP-1703

United Arab Emirates

Quaternary OF 92-0391; OP-1198

stratigraphy OP-1453

Vanuatu, plate tectonics OP-197

Fordilla troyensis

Invertebrata OP-1839

fore-arc basins

Alaska, geochemistry OP-1410

California

metamorphic rocks OP-1166

plate tectonics OP-1749 .

structural geology OP-1547 
Chile, plate tectonics OP-586

Melanesia, marine geology OP-192

Mexico, structural geology OP-1547

Oregon

metamorphic rocks OP-1166 structural geology OP-1547

Pacific Ocean, plate tectonics OP-1651

structural geology OP-401

Vanuatu, ocean floors OP-368

foreland basins

Alaska, natural gas OP-74

China, plate tectonics OP-1519

Colorado, Paleogene B 1787-Q

Pakistan, tectonophysics OP-1548

tectonics OP-753

United States, plate tectonics OP-1519

Utah, Paleogene B 1787-Q

foreshocks see also main shocks.

California

earthquakes OF 91-0032; OP-931; OP-1102 engineering geology OF 91-0032 seismology OP-302

earthquakes OP-1024

engineering geology OP-67

Forked Deer River

hydrology WRI 92-4082

sedimentation OP-1529

form, crystal see crystal form

formation waters see connate waters

formations, iron see iron formations

Fort Belknap Indian Reservation ground water WRI 92-4162; WRI 92-4163

Fort Hall Indian Reservation

ground water WRI 92-4014

structural geology OP-523

Fort McHenry Maryland engineering geology OF 92-0541

Fort Moultrie Quadrangle Quaternary I-1935

Fort Payne Aquifer hydrogeology OP-1283

Fort Peck Indian Reservation energy sources OP-1947 hydrogeology WRI 92-4185

Fort Ranikot Pakistan coal OF 93-0256

Fort Union Formation see also Ludlow Member,

Tongue River Member, Tullock Member. coal OF 93-0207

diagenesis OP- 1950

hydrogeology WRI 91-4044

impact statements WRI 90-4154

maps C-0142

natural gas OP-1569

palynomorphs OP-1745

petroleum OP-1767

sedimentary rocks B 1787-DD

Fort Worth Basin petroleum OF 93-0522

Fortress Mountain Formation sedimentary petrology OP-1553

Fortymile Wash geophysical surveys OF 92-0343

fossill localities

Idaho, paleomagnetism OF 92-0542

Kansas, paleontology OF 93-0549

paleontology OF 93-0513

fossil soils see Paleosols

fossil wood

Australia, sedimentary petrology OP-1478
Indonesia, sedimentary petrology OP-1478

foundations see bridges; dams; marine installa-

tions; seismic response

Four Corners

energy sources OF 93-0248

Fourier analysis

geophysical surveys OP-1054

seismology OP-1275; OP-1557

Fowler SE Quadrangle

maps OF $92-0698$

Fox Hills Formation

P 1532

impact statements WRI 90-4154

FPF1T

earthquakes OF 92-0441

fractional crystallization

OP-1698

Antarctica, petrology OP-1027

California

orogeny OP-1566 petrology OP-1282

Canada, metal ores OP-728

magmas OP-1138

Missouri, metal ores OP-1326

Nevada, petrology B 2052

United States, metal ores OP-728

Vermont, magmas OP-37

fractionation OP-605; OP-790; OP-953; OP1973

fracture zones

Bering Sea, deformation OP-211

plate tectonics OP-1133

Virginia, geochemistry B 1839-I,J

West Virginia, geochemistry B 1839-I,J

Wyoming, geochemistry OP-464

fractures see also brittle deformation; foliation; naturally fractured reservoirs.

OP-142; OP-1201; OP-1321; OP-1721; OP1984

Arkansas, ground water OP-1191

Bolivia, metal ores OP-1306

California

energy sources OP-1255

geologic hazards OP-1793

seismology OP-1865

Connecticut, hydrogeology WRI 92-4074

elastic waves OP-220

engineering geology OP-506

extension fractures, Wyoming OF 92-0388

geophysical surveys OP-1580

ground water OP-571

Hawaii, lava OF 93-0015

Hungary, energy sources OP-1687

joints

Missouri OP-1861

Pennsylvania OF 92-0568

petroleum OP-1972

Utah B 1787-HH

West Virginia W 2384

Wyoming OF 92-0388

Kentucky, energy sources B 1909

Manitoba, petrology OP-1560

Missouri

OP-1336

ground water OP-1191

Nevada, geochemistry OP-643

New England, ground water OP-1472

New Hampshire, environmental geology WRI 92-4012; WRI 92-4056; OF 92-0647

Ohio, ground water OP-1454

Ontario, petrology OP-1560
Oregon, geochemistry OP-42

rock mechanics OP-603; OP-689

South Carolina, seismicity OP-2032

Virginia, energy sources OP-1751

Washington, geophysical surveys B 1966

West Virginia

energy sources B 1909

natural gas B 1909

framework silicates see feldspar group; nepheline group; reedmergnerite; scapolite group; silica minerals; zeolite group

France

Quaternary

French Alps P 1386-E

French Pyrenees P 1386-E

Nice France OP-310

Franciscan Complex

OP-385

energy sources OP-267

manganese ores $\mathrm{OP}-458$

maps OP-1945

metal ores OP-554

metamorphic rocks OP-1166

petrology OP-1900

structural analysis OP-1546

structural geology OP-401; OP-1547; OP-1701

francolite

California, geochemistry B 1995-C

Franconia-Ironton-Galesville Aquifer ground water P 1530-A

Franklin Crater OP-1439

Franklin District Northwest Territories see Arctic Archipelago

Franklin Lake Playa ground water OP-234

Franklin New Jersey sheet silicates OP-1489

Franklin Quadrangle maps MF-2223

Fraser Glaciation maps OF 93-0233

Frasnian Appalachians OP-1988 Nevada OP-1847

Freeport Formation geochemistry OP-762

sedimentary petrology OP-1234

freeze-thaw action see frost action

Fremont Glacier

Quaternary OP-711

Fremont Lake

Quaternary OP-1455; OP-1884

French Alps

Quaternary P 1386-E

French Indochina see Indochina

French Pyrenees

Quatemary P 1386-E

Frenchman Flat

geochemistry OP-1775

Friendly Islands see Tonga

Fries, Carl, Jr. geologic hazards OF 93-0197-A

Frolikha Bay geochemistry OP-130

Front Range

base metals OP-944

diagenesis OP-395

foliation OF 92-0391

geophysical surveys OP-1813

mineral resources OP-828 
Proterozoic OP-10

Quaternary OP-1324

stratigraphy B 1787-EE; OP-1523

structural geology OP-118

Frontenac Terrane crust OP-1316

Frontier Formation

B 1917-O; OF 92-0391

energy sources OF 93-0337

sedimentary petrology OF 92-0391

sedimentary rocks B 1787-DD

frost action

OP-389; OP-1593

hydrogeology OP-1085

North Dakota, hydrogeology WRI 92-4110

frost stirring see cryoturbation

Fruitland Formation

OP-1182

energy sources OP-674

natural gas OF 93-0248

pollution WRI 93-4007

sedimentary petrology OF 92-0391; OP-850

fuel resources maps see petroleum maps

Fujian China

geochemistry OP-457

Fuller Field

diagenesis OP-1950

fulvic acids

Antarctica, geochemistry OP-664

geochemistry OP-1644

Pacific Ocean, geochemistry OP-628

fumaroles see also solfataras.

Alaska OP-926; OP-1770; OP-1771

Quaternary OP-549

volcanology OP-349

California, geochemistry OP-955

Wyoming, geochemistry OP-520

functional morphology

Vertebrata OP-1511

Funeral Mountains

structural geology OP-442

fusulinids

Mexico, Paleozoic OP-56

Nevada, stratigraphy B 1988-D

Oregon OP-87

fyord see fjords

\section{$\mathbf{G}$}

G.K. Gilbert see Gilbert, Grove Karl

gabbros see also alkali gabbros; anorthosite; nor-

ite; troctolite.

OF 92-0020-G; OP-814

California

geochemistry OP-182; OP-1141

platinum ores B 2014

Oman, structural geology OP-815

Oregon

OP-1139

geochemistry OP-1141

Vermont OP-37

Gabllan Range

structural geology OP-803

Gabon

geochemistry, Oklo OP-713

gageite

Califomia, manganese ores $\mathrm{OP}-458$

Galapagos Islands

geochemistry OP-925
Galapages Rift

plate tectonics OP-900

tectonophysics $\mathrm{OP}-432$

galena

Colorado, metal ores OF 92-0525

Malaysia, geochemistry OF 92-0525

Galeras

geophysical surveys B 1966

Galilean satellites see Io Satellite

Galileo Program OP-366; OP-416; OP-657; OP-

783; OP-1217; OP-1437; OP-1438; OP-1439;

OP-1485; OP-1486; OP-1487; OP-1497; OP-

1696; OP-1697; OP-1781

Gallatin National Forest

areal geology OF 93-0207

bibliography OF 93-0285-A; OF 93-0285-B

coal OF 93-0207

economic geology OF 93-0207

metal ores OF 93-0207

mineral resources OF 93-0207; OF 93-0505

petroleum OF 93-0207

Gallatin Range

petrology OP-1716

Gallinas Mountains metal ores OP-1715

Gallup Sandstone

B 2025

coal OP-17

natural gas OF 93-0248

Galveston Texas ground water OF 93-0086

gamma-ray methods

DDS-0009

engineering geology OP-760

Minnesota, kaolin deposits OF 92-0514

Mississippi, stratigraphy OF 92-0394

New Mexico, geochemistry OP-1072

North Carolina, heavy mineral deposits OF 92 0396

Texas, geochemistry OP-1072

gammacerane

Commonwealth of Independent States energy sources OP-1261 petroleum OP-1265

Europe energy sources OP-1261 petroleum OP-1265

Gander Zone

structural geology OP-1525

Ganges River geologic hazards OF 92-0391

Ganjo Takkar Inlier stratigraphy OF 92-0517

Gannett Glacier

Quaternary OP-711

Ganymede Satellite OP-1348

Garberville Quadrangle mineral resources OF 92-0316-A; OF 92-0316B

Garlock Fault

deformation OP-972

earthquakes OP-406

garnet group see also almandine.

OP-233; OP-682

California, structural geology OP -442

China, geochemistry OP-457

Colorado, energy sources OP-518

Manitoba, geochronology OP-1709

New Mexico, energy sources OP-518

New York, geochronology OP-1709
Garni Armenia

earthquakes OF 93-0216

seismology OF 93-0216

gas chromatography

diagenesis OP-1477

geochemistry OF 92-0445

sedimentary petrology OP-1478

gas fields, oil and see oil and gas fields

gas hydrates

Alaska

continental slope B 2002

energy sources OP-1284

environmental geology C 1086

petroleum OP-1285

Quaternary C 1086

Arctic Ocean, engineering geology OP-516

Atlantic Coastal Plain, oceanography OP-1337

Atlantic Ocean, continental slope B 2002

California, continental shelf B 2002

geochemistry OP-563

natural gas OF 92-0381; OP-1615

Pacific Coast, energy sources OP-1946

Pacific Ocean, energy sources OP-1614

Russian Federation

energy sources OP-1284

geochemistry OP-1412

Quaternary OP-1532

gas shale

Kentucky, geochemistry B 2046

Gasconade Formation

Ordovician OP-1819

gasoline see hydrocarbons

Gasquet Quadrangle

platinum ores B 2014

gastaldite see glaucophane

Gastropoda see also Archaeogastropoda.

Wyoming OP-860

gastropods

California

stratigraphy $P 1521$

structural geology OP-1701

Idaho, paleomagnetism OP-1850

Oregon, stratigraphy $P 1521$

pollution OP-297

Gates, George 0.

energy sources OP-374

Gatesburg Formation

lead-zinc deposits OP-12

Gauss Crater OP-1439; OP-1830

gaylussite

California, sedimentary petrology OP-77

geliturbation see cryoturbation

gems see emerald; jade

gemstones see gems

general circulation models

environmental geology C 1086

General Earthquake Observation System see GEOS

Genesee Group

B 1909

natural gas B 1909

Geneseo Shale

natural gas B 1909

Geneva Quadrangle

maps I-2378

geoarchaeology see archaeology

geobarometry see geologic barometry

geobotanical methods see also biogeochemical methods.

economic geology B 2039 
thermal waters OF 93-0017-A; OF 93-0017-B geochemical anomalies

Alaska, metal ores B 1968

Colombia, geochemistry OP-755

Colorado, base metals OP-944

England, geochemistry OP-755

geochemistry OP-30

Minnesota, metal ores OP-169

Nevada, metal ores OP-169

Poland, geochemistry OP-755

Texas, geochemistry OP-755

geochemical controls

Alaska, gold ores OP-1057

Bolivia, metal ores B 2039

California, metal ores OP-1267

Colorado, metal ores OF 92-0525

Dominican Republic, metal ores OP-532

England, metal ores OP-1541

mineral resources OP-642

Minnesota, non-metal deposits OF 92-0514

Missouri, metal ores OP-1418

non-metal deposits OP-225

Russian Federation, metal ores OP-2014

geochemical cycle

Alaska

ecology C 1086

Quaternary C 1086

Antarctica, hydrology OP-949

California

environmental geology OF 93-0294 soils OP-1713

ecology C 1086

geochemistry OF 92-0525; OP-244; OP-608

Mariana Islands, plate tectonics OP-14

Maryland, hydrology OP-1573

Micronesia, plate tectonics OP-14

New York, geochemistry OP-776

pollution C 1086

Puerto Rico

ecology OF 92-0150

hydrogeology C 1086

Quatemary OP-396; OP-980

soils C 1086; OF 91-0513

South Carolina, ecology OF 93-0303

Virginia, hydrology OP-1573

Wisconsin, ground water C 1086

geochemical exploration see geochemical methods

geochemical maps

Alabama, gold ores MF-2214

Alaska

economic geology MF-2217-A

gold ores MF-2227

metal ores B 1968

mineral resources MF-2144-B; MF-2144-C; MF-2144-D

geochemistry OF 92-0559

Georgia, gold ores MF-2213

Gulf Coastal Plain, ground water WRI 91-4149

hydrogeology WRI 91-4196

metal ores B 2003

mineral resources MF-2217-B

Mississippi Valley, ground water WRI 91-4149

Montana, economic geology OF 93-0207

North Carolina

MF-2223

mineral resources MF-2203

Utah, mineral resources MF-2081-C; MF-2081D; MF-2081-E

Virginia

ground water WRI 92-4175

mineral resources MF-2203 geochemical methods see also biogeochemical methods; dispersion patterns; geobotanical methods.

base metals OP-944

copper ores OF 93-0178; OF 93-0179

economic geology B 1955; B 2019; C 1094;

OF 93-0207; MF-2217-A; OP-204; OP-662

energy sources OP-1137

evaporite deposits OP-226

geochemistry OF 92-0582; OF 92-0599

gold ores B 2039; OF 92-0573-A; OF 92-0573-

B; OF 92-0591-A; OF 92-0591-B; OF 93-

0527; MF-2213; MF-2214; OP-168;

OP-589; OP-624; OP-716; OP-741; OP-784

heavy mineral deposits B 2039; OF 93-0240-A; OF 93-0240-B; OF 93-0341

metal ores B 1968; B 2003; B 2042-C; OF $92-$ 0615; OP-9; OP-169; OP-427; OP-582; OP1006; OP-1107

mineral resources B 2039; OF 90-0672; OF 92 0008-A; OF 92-0008-B; OF 92-0210-A; OF 92-0210-B; OF 92-0315; OF 92-0316A; OF 92-0316-B; OF 92-0379-A; OF 920379-B; OF 92-0380-B; OF 92-0384; OF 92-0509-A; OF 92-0509-B; OF 920552; OF 92-0708-A; OF 92-0708-B; OF 92-0709; OF 93-0259-A; OF 93-0259B; OF 93-0505; MF-2081-C; MF-2081-D; MF-2081-E; MF-2144-B; MF-2144-C; MF2144-D; MF-2203; MF-2217-B

molybdenum ores OP-375

tin ores OF 92-0268

geachemistry

lithogeochemistry

Alaska OP-242

Antarctica OP-1027

California B 2014; OF 92-0210-A; OF 920210-B; OF 92-0316-A; OF 92-0316-B; OF 93-0177

Haiti B 2065

Kentucky B 2046

Micronesia OP-59

Montana B 2065

Nevada OF 93-0249

New Jersey OP-1379

New Mexico OP-278

New York B 1909

Ohio B 1909

Oregon OF 93-0314

Sweden OP-584

United States OP-584

Virginia B 1839-I,J; OP-1002

West Virginia B 1839-I,J

geochronology see also absolute age; Archean; Cambrian; Carboniferous; Cenozoic; Cretaceous; Devonian; Eocene; Holocene; Jurassic; Mesozoic; Miocene; Mississippian; Neogene; Oligocene; Ordovician; Paleocene; Paleogene; paleomagnetism; Paleozoic; Pennsylvanian; Permian; Phanerozoic; Pleistocene; Pliocene; Precambrian; Proterozoic; Quatemary; Silurian; tephrochronology; Tertiary; Triassic.

OP-988

seismicity OP-1866

geodes

Alaska, geochemistry OP-1373

geodesy see also geodetic networks; Global Positioning System.

Alaska, seismology OP-1142

Antarctica OP-1912

Arizona, geologic hazards P 0497-H

California deformation P 1550-C

earthquakes OP-700

elastic waves OP-913

geologic hazards WRI $92-4035$

geophysical surveys B 1966; OP-1555

seismicity OP-1914

structural geology OP-648

Colorado, ecology OP-1328

geophysical surveys B 1966

Hawaii, geophysical surveys OF 92-0686; OP252

Indonesia, geophysical surveys B 1966

Nevada, geophysical surveys OF 92-0450

New Zealand, geophysical surveys B 1966

Oregon, geophysical surveys B 1966

Washington, geophysical surveys B 1966

Wyoming

geophysical surveys B 1966

tectonophysics OP-1780

geodetic coordinates OF 93-0536

geodetic networks

California, structural geology OP-569

geophysical surveys B 1966

Mariana Islands, geologic hazards OP-1962

Micronesia, geologic hazards OP-1962

Mississippi Valley, heat flow OP-1661

Montana, deformation OP-883

Washington, geophysical surveys B 1966

geographic information systems

OP-156; OP-352; OP-380; OP-381; OP-382; OP-383; OP-717; OP-865; OP-866; OP-963;

OP-1015; OP-1333; OP-1692; OP-1907

Appalachians, ground water OP-400; OP-983; OP-1707

Arizona, hydrology WRI 92-4133

Arkansas, hydrogeology OF 92-0108

Atlantic Coastal Plain, ground water OP-1707

Basin and Range Province, mineral resources OP-1853

California, environmental geology OP-1227

Colorado, stratigraphy B 2025

District of Columbia, environmental geology OP-60

engineering geology $\mathrm{OF} 92-0530$

environmental geology OP-173; OP-701

Florida, hydrogeology WRI 92-4061

Great Basin, mineral resources OP-1853

hydrology OP-337

Kansas, ground water OF 93-0092

Louisiana, geologic hazards OF 93-0210

Massachusetts hydrology OP-1826 oceanography DDS-0003

Midwest, pollution OF 93-0418

Minnesota, geomorphology OP-1664

Mississippi, hydrogeology OP-1010

Mississippi Valley, engineering geology OF 93-0349

Nevada

DDS-0002

environmental geology OP-1227

geophysical surveys OP-1041 ground water OP-1009

New Mexico, stratigraphy B 2025

New York, ground water WRI 92-4100

peat OP-131

Texas, ground water WRI 92-4155

Virginia, ground water WRI 93-4015

West Virginia

OP-1543

engineering geology OP-1542

Wyoming, pollution OP-1871 


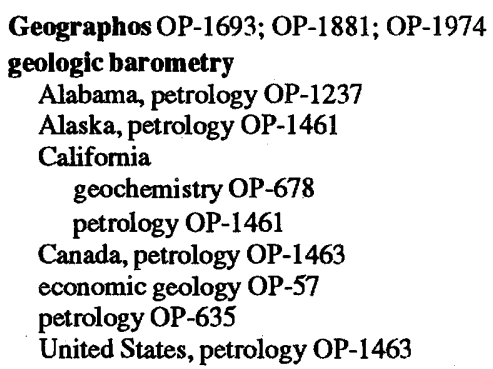

geologic chronology see geochronology

geologic hazards see also avalanches; fires: floods; geologic hazards maps; ground motion; hurricanes; impact statements; land subsidence; landslides; liquefaction; liquefaction potential; paleoseismicity; reservoirs; seismic risk; slope stability; tsunamis; tunnels; volcanic earthquakes; volcanic risk; volcanoes.

YR; P 1240-B; C 1086; C 1111; OF 93-0195; OF 93-0292-G; OF 93-0292-H; OF 93-0292-I; OF 93-0292-J; OP-173; OP-1052

Alaska

YR; OF 93-0292-J

hydrology C 1086

seismology P 1527; C 1031

Arizona P 0497-H; OF 93-0292-I

Arkansas, sedimentary petrology OF 93-0291

Armenia, seismology OF 93-0216

Atlantic Coastal Plain OF 92-0377-A; OF 920377-B; OP-378

Bering Sea, oceanography OP-129

California

YR; P 1553-B; OF 90-0677; OF 93-0292-I; OF 93-0348; OP-882

earthquakes YR; EV; OF 91-0032; OF 930191; OF 93-0290; OP-698; OP-931

geophysical surveys OF 93-0276; OF 930301

seismicity P 1550-C; OP-121

seismology EV; OF 92-0340; OP-302; OP868; OP-966; OP-1581

Cameroon OP-903

Colorado OF 92-0391; OF 93-0292-H; OP-902

earthquakes OF 92-0601-A; OF 92-0601-B; OF 92-0602-A; OF 92-0602-B; OF 920603-A; OF 92-0603-B; OF 92-0604-A; OF 92-0604-B; OF 92-0605-A; OF 920605-B; OF 92-0606-A; OF 92-0606-B; OF 92-0607-A; OF 92-0607-B; OF 920608-A; OF 92-0608-B; OF 92-0609-A; OF 92-0609-B; OF 92-0610-A; OF 920610-B; OF 92-0611-A; OF 92-0611-B; OF 92-0612-A; OF 92-0612-B; OF 93-0204

East Pacific Ocean Islands OF 93-0292-I

Egypt OF 93-0181

geochemistry OF 92-0391; OP-343; OP-379; OP-563

geophysical surveys OP-1374

Gulf Coastal Plain

OF 92-0530; OP-378

Quaternary OF 92-0530

Gulf of Mexico

OF 92-0530

Quaternary OF 92-0530

Hawaii B 2006; OF 93-0292-I

Idaho

OF 93-0292-J

neotectonics OP-634

Iowa OF 93-0292-G

Kansas OF 93-0292-G

Louisiana OF 92-0530; OF 93-0210; I-2150-A
Mississippi Valley, seismology SM

Missouri

C 1083; OF 93-0292-G

sedimentary petrology OF 93-0291

Montana OF 93-0292-H

natural gas OP-1615

Nebraska OF 93-0292-G

Nevada

OF 92-0516; OF 93-0073

geophysical surveys OF 92-0028; OF 920343; OF 92-0450

seismology OF $92-0340$

structural geology OF 91-0623

North Carolina P 1177-B

North Dakota OF 93-0292-H

Oregon

OF 93-0292-J

neotectonics OP-634

Pennsylvania OP-1895

Polynesia OF 93-0292-I

Puerto Rico

OF $92-0717$

seismology C 1031

Quaternary C 1086; OP-81

seismology OF 91-0014; OP-735

South Carolina

geophysical surveys OF 92-0723

Quatemary I-1935

South Dakota OF 93-0292-H

Texas OF 92-0391

Turkey, seismology EV

Utah P 1519; OF 93-0292-H

Virginia

geochemistry OP-344

hydrology B 1981

Washington B 1966; OF 93-0292-J

West Virginia

OP-901

hydrology B 1981

Wyoming OF 93-0292-H

geologic hazards maps

Alaska B 1996

Atlantic Ocean, continental slope B 2002

California I-1257-M

Hawaii OF 93-0213

Philippine Islands WRI 92-4039

geologic maps

OF 92-0562; I-2208; I-2209; I-1420 (NJ-14);

I-1420 (NJ-15); OP-981; OP-1015

Alaska

OF 92-0346; OF 92-0594; GQ-1688; MF2226-A; I-1984; I-2032; I-2164

geologic hazards B 1996

hydrology WRI 92-4132

metal ores B 1968; OP-123

Appalachians, economic geology B 1979

Arizona

OF 92-0198; MF-2230; I-2198; I-2290; I2420

ground water WRI 90-4105

metal ores B 2042-C

Arkansas SGM

California

OF 91-0435; OF 92-0446; OF 93-0198; OF 93-0205; OF 93-0206; OF 93-0223; OF 93-0224; OF 93-0225; OF 93-0271; OF 93-0525; I-1943; I-1995; I-1420 (NJ10); OP-1945

platinum ores B 2014

stratigraphy P 1521; B 2015

structural geology OP-649; OP-803; OP-804

Canada I-1420 (NK-18); I-1420 (NL-18)
Caribbean Sea, oceanography DDS-0015

Colorado

OF 92-0711; OF 93-0310; OF 93-0320; MF-2216; MF-2220; MF-2232; I-2266

sedimentary rocks B 1787-DD

Georgia GQ-1705

Gulf of Mexico, oceanography DDS-0015

Hawaii

I-2274

hydrogeology WRI 91-4197

Idaho

MF-2234; I-1803-H; I-2299

hydrogeology $P 1408-F$

Indiana OF 93-0268-B

Kansas OF 92-0697; OF 92-0698; I-2377; I2378; I-2379

Kentucky SGM

Mariana Islands I-2408

Massachusetts

I-2369

oceanography DDS-0003

metal ores B 2003

Mexico I-2287; I-1420 (NG-14)

Michigan I-2356; I-1420 (NL-17)

Micronesia I-2408

Midwest, ground water P 1405-B

Montana

GQ-1724; GQ-1729; MF-2253; I-1803-H; I-2267; I-2343-A; I-2380-A; C-0142 economic geology OF 93-0207

ground water WRI 92-4162 structural geology P 1524; B 1993

Nevada

DDS-0002; OF 92-0554; OF 92-0580; OF 92-0613; OF 92-0681; OF 93-0198; OF 93-0220; OF 93-0299; OF 93-0519; GQ-1714; GQ-1721; GQ-1730; MF-1877. A; I-2173; I-2342; I-2394

petrology OP-973

structural geology B 2011

New Jersey GQ-1707

New Mexico

OF 92-0710; OF 92-0711; GQ-1716; I2266

coal OP-17

North Carolina

OF 93-0244; MF-2223

economic geology B 2005

Ontario I-1420 (NL-17)

Oregon

OF 92-0695; OF 93-0302

hydrogeology WRI 91-4087

stratigraphy $P 1521$

Pennsylvania B 1994

Saudi Arabia

OP-308; OP-309; OP-370; OP-371; OP-372 Proterozoic B 1976

South Australia, Quatemary B 2032-B

Tennessee, economic geology B 2005

Texas I-1420 (NG-14); I-1420 (NH-14)

United States I-1420 (NK-18); I-1420 (NL-18)

Utah

OF 92-0385; OF 92-0589; OF 93-0003; OF 93-0190; OF 93-0203; GQ-1712; GQ1713; GQ-1721; MF-2250; C-0144 ground water WRI 90-4105; WRI 92-4070 sedimentary rocks B 1787-DD structural geology B 1787-HH; B 2011

Vanuatu, plate tectonics OP-197

Venezuela MF-2242

Vermont

OF 92-0282-A; MF-2224; I-2369

economic geology B 1955 
Virginia

OF 92-0716; OF 92-0725; OF 93-0024; OF 93-0244

fluvial features B 1981

Washington OF 93-0233; OF 93-0297; GQ1679; I-1946; I-1963; I-2005

West Virginia, fluvial features B 1981

Wisconsin I-2356

Wyoming

I-2168; I-2232; I-2343-A; I-2343-B; I2380-A; I-2380-B

hydrogeology WRI 91-4044; WRI 91-4108

impact statements WRI 90-4154

stratigraphy $P 1520$

Geologic Names of the United States DDS-0006

Geologic Names Unit Lexicon

DDS-0006

stratigraphy DDS-0006

geologic surveys see survey organizations

geologic thermometry see also geologic barome-

try; S-34/S-32.

California

diagenesis OP-1386

geochemistry OP-955

petrology OP-638

sedimentary petrology OP-1791

thermal waters OP-997

Canada, metal ores OP-728

Colorado, petroleum OF 92-0391

Ecuador, gold ores B 2039

Florida, Quatemary C 1086

geochemistry OP-1870

Greenland, phase equilibria OP-636

Idaho

geochemistry OP-912

tungsten ores OP-1296

Missouri

lead-zinc deposits OP-575

metal ores B 2039

Ontario, petrology OP-214

Oregon

geochemistry OP-42

petrology B 2054

petroleum OP-793

petrology OP-393; OP-1246

Russian Federation, Phanerozoic OP-1493

Saudi Arabia, tin ores OP-1558

sedimentary petrology OP-1135

United States

metal ores OP-728

Phanerozoic OP-1493

Utah, petroleum OF 92-0391

geological barometry see geologic barometry

Geological Hazards Data Base

engineering geology OF 93-0349

Geological Long-Range Inclined ASDIC see GLORIA

geological oceanography see marine geology

Geological Survey of Canada

Alaska, Cenozoic C 1086

Yukon Territory, Cenozoic C 1086

GeoMedia YR

geomorphic'geology see geomorphology

geomorphologic effects

Virginia

fluvial features B 1981

geomorphology B 1981

West Virginia

fluvial features B 1981

geomorphology B 1981 geomorphologic maps

I-2276

geomorphology I-2206

Oregon, Quaternary B 2038

West Virginia, geomorphology B 1981

geomorphology see also changes of level; eolian features; fluvial features; frost action; glacial geology; impact features; lacustrine features; mass movements; meteor craters; shore features; solution features; volcanic features; weathering. hydrogeology OP-1004

GEONAMES DDS-0006

geophysical anomalies

Alaska, mineral resources OF 92-0690

geophysical logging see well-logging

geophysical methods

OF 93-0013; OP-1055; OP-1056

acoustical methods

OF 93-0242

hydrology W 2395; OP-1335; OP-1888

marine geology OF 92-0536

sedimentary petrology OP-738

structural geology OP-602

economic geology OF 92-0557

electrical methods

OF 93-0071; OP-1580

base metals OP-944

earthquakes OP-540

environmental geology WRI 92-4012; WRI 92-4056

ground water OF 93-0071

hydrology OF 92-0490; OF 93-0071

rock mechanics OF 93-0071

electromagnetic methods OF 92-0553-A; OF 92-0553-B; OF 93-0234-A; OF 930234-B

gold ores OF 92-0557

gravity methods OF 93-0287; OP-212; OP-565

heat flow OP-176

infrared methods, petrology OP-1584

magnetic methods OP-212

magnetotelluric methods OF 92-0569

metal ores OF 92-0389; OF 92-0557

mineral resources OF 92-0557

non-metal deposits OF 92-0557

seismic methods

OF 92-0561; OF 92-0590; OF 93-0005;

OF 93-0226; OP-318; OP-1374; OP-1807

environmental geology WRI 92-4012; WRI 92-4056

seismic sources OF 93-0221

seismology OP-15

tin ores OF 92-0557

waste disposal OF 92-0526-A; OF 92-0526-B

geophysical survey maps

OP-1149

Colorado, economic geology B 2035

oceanography MF-2211

geophysical surveys see also acoustical surveys; electrical surveys; electromagnetic surveys; geodesy; Global Positioning System; gravity surveys; magnetic surveys; radioactivity surveys; remote sensing; seismic surveys; well-logging.

Alaska

economic geology C 1094

mineral resources OF 92-0690

Brazil OP-1329

California, economic geology B 2019

Canada OP-1440

Colorado, mineral resources B 2039

Idaho, ground water WRI 92-4184

Nevada, economic geology B 2019
Ohio, ground water OP-1454

United States OP-1440

GEOPROBE

oceanography OP-129

Georges Bank

ecology OF 92-0566

Mesozoic OP-801

ocean floors I-2279-A

sedimentation I-2279-B

Georges Bank basin stratigraphy OP-1797

Georgetown District mineral resources OP-95

Georgia see also Eutaw Formation; Piedmont; Savannah River; Tuscaloosa Formation. building stone

Banks County Georgia MF-2215-A

Elbert County Georgia MF-2215-A

Franklin County Georgia MF-2215-A

Habersham County Georgia MF-2215-A

Hall County Georgia MF-2215-A

Hart County Georgia MF-2215-A

Jackson County Georgia MF-2215-A

Lumpkin County Georgia MF-2215-A

Madison County Georgia MF-2215-A

Rabun County Georgia MF-2215-A

Stephens County Georgia MF-2215-A

Towns County Georgia MF-2215-A

Union County Georgia MF-2215-A

White County Georgia MF-2215-A

engineering geology OF 93-0349

geochemistry, Rockdale County Georgia OP917

geochronology

Harris County Georgia OP-968

Muscogee County Georgia OP-968

gold ores

Bartow County Georgia MF-2213

Carroll County Georgia MF-2213

Cherokee County Georgia MF-2213

Douglas County Georgia MF-2213

Fayette County Georgia MF-2213

Forsyth County Georgia MF-2213

Fulton County Georgia MF-2213

Haralson County Georgia MF-2213

Paulding County Georgia MF-2213

ground water

YR; OP-867

Atlanta Georgia OP-172

Bryan County Georgia W 2392

Bulloch County Georgia W 2392

Candler County Georgia W 2392

Chatham County Georgia W 2392

Coweta County Georgia OP-172

Dougherty County Georgia WRI 93-4038

Effingham County Georgia W 2392

Emanuel County Georgia W 2392

Evans County Georgia W 2392

Fayette County Georgia OP-172

Henry County Georgia OP-172

Lamar County Georgia OP-172

Meriwether County Georgia OP-172

Pike County Georgia OP-172

Screven County Georgia W 2392

Spalding County Georgia OP-172

Talbot County Georgia OP-172

Treutlen County Georgia W 2392

Upson County Georgia OP-172

heavy mineral deposits B 2039; OF 93-0240-A; OF 93-0240-B

hydrogeology

OP-311; OP-312 
Baker County Georgia W 2391

Bryan County Georgia OF 92-0629

Chatham County Georgia OF 92-0629

Colquitt County Georgia W 2391

Dougherty County Georgia W 2391

Effingham County Georgia OF 92-0629

Jasper County Georgia OF 92-0629

Lee County Georgia W 2391

Liberty County Georgia OF 92-0629

Rockdale County Georgia OP-918

Terrell County Georgia W 2391

Walton County Georgia OP-171

Worth County Georgia W 2391

hydrology

W 2400; WRI 93-4016; OF 92-0113; OP-

1515

Clayton County Georgia C 1086

De Kalb County Georgia C 1086; OF 930055

Henry County Georgia C 1086

Rockdale County Georgia OF 93-0055 maps

Lumpkin County Georgia GQ-1705

White County Georgia GQ-1705 oceanography OP-1502

pollution

OP-1501

Dougherty County Georgia WRI 91-4178

sedimentary petrology OP-1677

structural geology OP-1918

Georgian Republic see Kuban River

GEOS

Armenia, earthquakes OF 93-0216

geotectonics see tectonics

\section{GEOTHERM}

tectonophysics OP-897

geothermal energy see also brines; geothermal

fields; hot springs; thermal waters.

California OP-298; OP-324

Guatemala OP-1496

Hawaii, environmental geology OF 93-0512-A

Honduras OP-1496

Mexico OP-984

Oregon, petrology B 2054

geothermal fields see also Cerro Prieto; The Geysers.

Colorado, thermal waters OF 93-0017-A; OF 93-0017-B

geothermal gradient

OP-1266

Alabama, sedimentary petrology OP-1636

California, geothermal energy OP-324

Chile, plate tectonics OP-586

China, copper ores OP-456

Colorado

petroleum OF 92-0391

sedimentary rocks B 1787-DD

Great Lakes region, copper ores OP-1216

Guatemala, geothermal energy OP-1496

heat flow OP-176

Honduras, geothermal energy OP-1496

Idaho, petrology OP-560

Kansas, natural gas OP-725

metal ores OP-852

Michigan, structural geology OP-1214

Mississippi, sedimentary petrology OP-1636

Nevada, geochemistry OP-643

Pennsylvania, diagenesis OF 92-0568

Tonga, petroleum OP-896

Utah

petroleum OF 92-0391; OP-1635

sedimentary rocks $B$ 1787-DD
Wisconsin, structural geology OP-1214

Wyoming, petroleum OP-1635

geothermal surveys see heat flow

geothermometry see geologic thermometry

German Continental Deep Drilling Program see KTB

German Southwest Africa see Namibia

Germany

rock mechanics OP-1029

stratigraphy, Ries Crater B 2050

Getchell Mine

gold ores B 2039; GP-1003-A; OP-365; OP-

447; OP-624; OP-779; OP-784

metal ores OP-45

stratigraphy $\mathrm{OP}-623$

geysers

OP-1590; OP-1592

California, seismology P 1550-C

hydrogeology OP-467

Nevada, thermal waters B 1998

Wyoming

geochemistry OP-874

thermal waters OF 93-0293

Geysers, The see The Geysers

Ghazij Formation

tectonophysics OP-1548

gibbsite

OP-1752

geochemistry OP-1737; OP-1738

Gibraltar oceanography OP-722

Gilbert, Grove Karl

Basin and Range Province, Quaternary OP-910

Rocky Mountains, Quaternary OP-910

Utah

earthquakes OP-905

Quaternary OP-52; OP-620; OP-622; OP908; OP-911

structural geology OP-619; OP-718; OP773; OP-909

\section{Givetian}

Nevada OP-491

Russian Federation OP-491

GKS-PC OF 93-0241-A; OF 93-0241-B

glacial erosion

Alaska

GQ-1688

glacial extent

Alaska, Quaternary OP-1718

Europe, Quaternary P 1386-E

Washington OF 93-0233

glacial features see also cirques; eskers; fjords; glacial lakes; glaciers; kettles; moraines; valleys. OP-508; OP-1564

Antarctica, geophysical surveys OP-610

glacial geology see also changes of level; cirques; eskers; glacial extent; glacial lakes; glaciation; glaciers; ice movement; ice sheets; ice shelves; ice-marginal features; moraines; periglacial features; permafrost; rock glaciers; till.

Minnesota, Quaternary OP-100

Quatemary OP-686

Russian Federation, Miocene OP-198

glacial lakes see also glaciolacustrine sedimentation; varves.

OP-1241

Alaska, Quatemary OF 93-0266

Antarctica OP-842

Minnesota, clays OF 92-0514

glacial land forms see glacial features glacial outwash see outwash

Glacial Peak Ash

Quaternary OP-143

glacial recession see deglaciation

glacial sedimentation see also glaciofluvial sedi-

mentation; glaciolacustrine sedimentation;

glaciomarine sedimentation.

Great Lakes, Quaternary OP-1290

ground water OP-952

Washington OF 93-0233

glaciated terrains

Connecticut, ground water WRI 87-4144

Indiana OF 93-0268-A; OF 93-0268-B

lowa, hydrogeology OF $92-0500$

Massachusetts, continental shelf OP-546

Michigan, ground water WRI 91-4133

Minnesota

economic geology B 2039

heavy mineral deposits OF 93-0345

New York

ground water WRI 88-4127; WRI 91-4030; WRI 92-4100

Obio bydrogeology W 2387; WRI 90-4205

ground water WRI 93-4047

hydrogeology WRI 92-4072

Wisconsin, ground water WRI 92-4077

glaciation see also changes of level; deglaciation; erosion; glacial erosion; glacial extent; glacial features; ice movement; ice sheets; Milankovitch theory.

OP-1240

Alaska

Invertebrata OP-1681

Quaternary OP-391; OP-1225

Greenland, Quaternary B 2036

New England, Quaternary OP-748

Northwest Territories, Quaternary B 2036

Russian Federation, Quaternary B 2036

Washington I-1963

Wisconsin, Quaternary OP-391

Wyoming, Quaternary OP-1455

Glacier Bay

bibliography OF 92-0596

Quaternary OP-1801

Glacier Bay National Park

bibliography OF 92-0596

glaciers see also deglaciation; ice; ice movement; ice shelves; ice-marginal features; icebergs; moraines; rock glaciers.

Alaska

OF $92-0596$

hydrology C 1086; WRI 92-4132

Quaternary C 1086; OP-651; OP-1719

Arctic region, Quaternary $P$ 1386-E

Austria, Quaternary P 1386-E

Basin and Range Province, Quaternary OP-910

British Columbia, hydrology C 1086

Europe, Quaternary P 1386-E

France, Quatemary P 1386-E

hydrology C 1086

Italy, Quaternary P 1386-E

Jan Mayen, Quaternary P 1386-E

Norway, Quaternary P 1386-E

Peru, Quaternary OP-855

Quaternary C 1086

Rocky Mountains, Quatemary OP-910

Spain, Quaternary P 1386-E

Sweden, Quaternary P 1386-E

Switzerland, Quaternary P 1386-E

Washington

hydrology W 2340 
Quaternary OP-323

glaciofluvial sedimentation

Minnesota, heavy mineral deposits OF 93-0345

glaciolacustrine sedimentation see also varves.

Great Lakes, Quaternary OP-1288

glaciology see glacial geology

glaciomarine sedimentation

Alaska

engineering geology B 2002

Quaternary OP-1225

Arctic Ocean, Quaternary C 1086; OF 92-0426

Gulf of Mexico, Quaternary OF 92-0530

glass see glasses

Glass Mountain

maps I-1995

glass, volcanic see volcanic glass

glasses see also obsidian; palagonite; tektites; volcanic glass.

OP-843

Alaska OP-1469; OP-1929

geochemistry OP-1653

Haiti, stratigraphy OP-1179

Hawaii, geochemistry OP-446

Mexico, stratigraphy OP-1179

mineralogy OP-233

Oregon, geochemistry OP-42

Philippine Islands, geochemistry OP-1994

glassy feldspar see sanidine

glaucophane

Italy, petrology OP-851

Glen Canyon Dam

impact statements YR

Glenns Ferry Formation OF 92-0542; OF 920713; OP-1850

Glick Field

energy sources OP-1751

gliding (tectonics) see gravity sliding

GLIMPCE

Great Lakes, structural geology OP-1533

Great Lakes region, geophysical surveys OP1213

Global Change Hydrology Program hydrology OF 93-0036

Global Change Research Program

Cenozoic C 1086

ecology C 1086

environmental geology C 1086

Global Geoscience Transects

geophysical surveys $O P-1440$

tectonics OP-1215

Global Positioning System

California

earthquakes OP-90; OP-699

seismology P 1550-C; OP-1658

tectonophysics OP-2010

geophysical surveys OF 93-0196; OP-951

Hawaii, earthquakes EV

Iceland, tectonophysics OP-420

Mississippi Valley, heat flow OP-1661

Global Resources Information Data Base YR

global warming see also greenhouse effect.

Florida, ecology C 1086

hydrology OP-1044

natural gas OP-1615

Globe Arizona

hydrogeology OF 92-0468

Globe Hill Deposit geophysical surveys OF 91-0449-G

Globe Mine

metal ores OP-942
Globotruncanita calcarata

foraminifera OP-1757

GLORIA

Alaska

engineering geology $\mathrm{OP}-140$

oceanography B 2002

Atlantic Ocean, nodules OP-886

California, oceanography B 2002

Canary Islands, engineering geology OP-443

Caribbean Sea, oceanography DDS-0015

engineering geology OP-744

Florida, continental slope B 2002

Gulf of Mexico

oceanography DDS-0015

sedimentation OP-1012

Hawaii, oceanography B 2002; OF 92-0206

ocean floors OF 91-0014

oceanography MF-2211

Glorieta Sandstone

ground water WRI 91-4033

glossaries

OF 93-0516

Basin and Range Province, petroleum of 93 0248

Colorado Plateau, petroleum OF 93-0248 environmental geology OF 93-0292-G; OF 930292-H; OF 93-0292-I; OF 93-0292-J

Great Plains, energy sources OF 93-0337

hydrology W 2400

New Mexico, petroleum OF 93-0522

New York, hydrology OF 92-0476

Pacific Coast, energy sources B 2034-A

Rocky Mountains, energy sources OF 93-0337

sedimentary petrology OP-738

Texas, petroleum OF 93-0522

Virginia, ground water WRI 93-4015

West Virginia, hydrogeology W 2384

Wisconsin, hydrology WRI 90-4126.

glowing avalanche see ash flows

Glusford Formation

hydrogeology W 2386

Glycymeris

Alaska OP-1800

California OP-1800

Mexico OP-1800

Gnathodus

stratigraphy OP-1245

gneisses see also orthogneiss; paragneiss.

Alabama OP-1237

Appalachians, structural geology OP-1479

Arizona, gold ores OF 92-0591-A; OF 920591-B

California OP-1691

Colorado OP-827

Connecticut, hydrogeology WRI 92-4074

faults OP-685

Germany, rock mechanics OP-1029

Maryland OP-1106

Mexico, geochemistry OP-132

Michigan, structural geology B 1904-Q; B 1904-S; I-2355; OP-1889

Minnesota, structural geology B 1904-S

Montana, Archean OP-705

New England, geochronology OF 92-0525

Rocky Mountains OP-1716

Russian Federation, Precambrian OP-1777

Virginia OP-1106

Washington OP-1397

Wyoming, stratigraphy P 1520

GNULEX

DDS-0006

stratigraphy DDS-0006
Goat Rock fault zone

structural geology OP-1918

Golconda Allochthon

geophysical surveys OP-1041

stratigraphy B 1988-D

structural geology OP-933

Golconda Formation B 1988-F

gold

Alaska MF-2227

Colombia, geochemistry OP-755

England, geochemistry OP-755

Idaho OF 93-0527

Kentucky, geochemistry B 2046

Minnesota, metal ores OF 92-0615

Nevada B 2039

Poland, geochemistry OP-755

Texas, geochemistry OP-755

Utah, mineral resources MF-2081-D

Gold Beach Terrane

structural geology OP-1547

Gold Hill District

gold ores OP-1096

gold ores

B 2003; OF 92-0389; OF 92-0557; OF 920573-A; OF 92-0573-B; OF 93-0194; OP-168;

OP-1175

Alabama MF-2214

Alaska B 1968; OF 93-0325; MF-2227; OP123; OP-570; OP-589; OP-1006; OP-1057; OP-1099; OP-1416

Arizona B 1737-E; B 2042-C; OF 92-0591-A; OF 92-0591-B; OF 93-0228; OP-9

Australia OP-1431

Bolivia B 2039; OF 93-0016; OP-202

British Columbia OP-9

California

OF 93-0228; OP-204; OP-260; OP-267;

OP-427; OP-662; OP-934; OP-1267

geochemistry OP-265

sulfides OP-557

Canada OP-1431

China OP-363; OP-945; OP-1432

Colorado

P 1537; OF 92-0525; OP-582; OP-937; OP1151

geophysical surveys OF 91-0449-F; OF 91 0449-G

Dominican Republic OP-532

Ecuador B 2039

Far East OF 92-0525

Georgia MF-2213

Great Britain OF 92-0525

Idaho B 2039; OF 93-0527

Mexico B 2039

Montana I-2050-F

Nevada

B 2039; OF 93-0249; GP-1003-A; OP-27;

OP-205; OP-260; OP-365; OP-441; OP-

447; OP-489; OP-624; OP-627; OP-716;

OP-779; OP-784; OP-921; OP-994; OP-

1048

geochemistry OP-1609

stratigraphy OP-623

sulfides OP-557

Papua New Guinea B 2039; OP-639

Peru OP-82

Philippine Islands OP-9

Puerto Rico OF 92-0567

Quebec OP-1097

Saudi Arabia YR

South Africa, engineering geology OP-660

South Dakota, environmental geology OP-641 
Spain OP-231; OP-875

Utah B 2013; OP-741; OP-965; OP-1096; OP1464

Yukon Territory OP-363; OP-1432

Golden Horn Deposit

metal ores OP-123

golden-brown algae see Chrysophyta

goldfield-type

Colorado, metal ores OF 92-0557

Goldstrike Stock

gold ores OP-27

Goleta California

geochemistry OF 92-0539-C

Miocene OF 93-0182

stratigraphy OF 92-0539-B; OF 92-0539-D; OF 93-0177; OP-469

Gomez Tuff

petrology OP-1611

Gondwana

Antarctic Ocean

orogeny OP-1395

tectonophysics OP-1446

Antarctica, tectonophysics OP-1317

gonnardite

Arkansas, petrology OP-1837

Goodnews Bay Quadrangle

metal ores MF-2228

mineral resources OF 92-0008-A; OF 92-0008B

Goose Creek Limestone

Quaternary I-1935

Goose Egg Formation

hydrogeology WRI 91-4044

Triassic B 1917-P

Gorda Plate

plate tectonics OP-752

Gordon, Mackenzie, Jr.

Invertebrata OP-283

paleontology OP-422

Gorontalo Basin

engineering geology OP-993

gossan

Nevada, metal ores OF 93-0249

Gotlandian see Silurian

gouge

California

engineering geology OP-688

structural geology OP-702

earthquakes OP-1893

faults OP-127; OP-601; OP-640

government agencies see also survey organiza-

tions.

OP-352; OP-382

economic geology B 2013

environmental geology C 1086; OP-173

mineral resources OF $92-0514$

NASA, Colorado OF 91-0449-G

Oak Ridge National Laboratory, Tennessee WRI 92-4131

petroleum B 1909

U. S. Bureau of Mines

economic geology OF 92-0514

industrial minerals B 2013

Utah, industrial minerals B 2013

goyazite

Haiti, stratigraphy OP-1181

Ivory Coast, stratigraphy OP-1181

Wyoming, stratigraphy OP-1181

GPS tracking see Global Positioning System grabens see also horsts.

OP-1321; OP-1323; OP-1421; OP-1422; OP-

1936; OP-1938; OP-1984

Arctic Ocean, plate tectonics OP-1429

Bahamas, structural geology OP-1132

Illinois, structural geology OP-1742

Maine, crust OP-1920

Minnesota, geochronology OP-758

Mississippi Valley, engineering geology OF 92-0391

Missouri, structural geology OP-1742

Nevada, structural geology OF 91-0623

Quebec, crust OP-1920

Red Sea, brines OP-2029

stratigraphy B $1839-\mathrm{K}$

Syria OP-1322

Utah, geologic hazards P 1519

Graber Pond

hydrology WRI 92-4029

graded bedding

Gulf of Mexico, oceanography OP-1864

Pakistan, tectonophysics OP-1548

graduate-level education

hydrogeology OP-421

grainstone

Idaho, stratigraphy OP-1320

Gramineae see Spartina alterniflora

Grand Canyon

environmental geology OP-990

fluvial features OP-947

gold ores OF 92-0591-A; OF 92-0591-B

hydrology OF 93-0071; OP-1434

impact statements YR

natural gas OP-1350

Quatemary OP-1375

sedimentary petrology OF 92-0391

uranium ores OP-613; OP-655

Grand Plateau Glacier

Quaternary OP-1719

Grand Teton National Park

guidebook OF 92-0504

Quaternary OF 92-0504

Grand Wash Clifis

ground water WRI 91-4185

Grande River see Rio Grande

Grande Ronde Basalt

Oregon, ground water WRI 90-4085

Washington, ground water WRI 90-4085

Granicus Valles OP-1240

Granisle Deposit

metal ores OP-9

granite see granites

granite deposits

Minnesota OF 92-0514

Wisconsin OF 92-0514

Granite Mountains

igneous rocks OP-1112

petrology OP-1376; OP-1456

granites see also A-type granites; aplite; granodi-

orites; I-type granites; leucogranite; metagranite;

microgranite; monzogranite; pegmatite; quartz

monzonite; S-type granites; two-mica granite.

OP-1061

Alaska OF 92-0724; OP-1194

Appalachians, stratigraphy OP-1380

Arizona, gold ores OF 92-0591-A; OF 920591-B

California

OP-1126; OP-1711

geochemistry OP-678; OP-1141

Colorado geomorphology OP-1051

molybdenum ores OF 92-0525; OP-1913

England, geochemistry OP-158

fractures OF 93-0245; OP-1026; OP-1721

heavy minerals OF 92-0386

Idaho OP-1671

Manitoba OP-1560

Michigan, structural geology B 1904-S; OP1889

Minnesota, structural geology B 1904-S

Nevada, molybdenum ores B 2039

New South Wales Australia OP-7

Ontario OP-1560

Oregon, geochemistry OP-1141

rock mechanics OP-600; OP-603; OP-689

Saudi Arabia

metal ores OP-1559

tin ores OP-499; OP-1558

structural geology OP-602

Sweden, geochemistry OP-1042

Washington GQ-1679; OP-1397

granodiorites

OP-1138

California

OP-1691

geochemistry OP-182

Canada OP-1463

Maine, metal ores B 2039

Montana, structural geology B 1993

Nevada

geochemistry OP-1302

gold ores OP-779

metal ores OP-45

Nova Scotia, geochemistry OP-1122

Oregon

OP-1124

geochemistry OP-42

Puerto Rico, ground water OP-1960

Rocky Mountains OP-1716

United States OP-1463

Vermont OP-37

granophyre

Oregon, geochemistry OP-42

Grant Range

economic geology B 2039

petroleum OP-614

granulite see granulites

granulite facies

Mexico, geochemistry OP-132

Montana, petrology OP-1731

Norway, petrology OP-1173

Quebec, gold ores OP-1097

granulites

Colorado, molybdenum ores OP-1913

faults OP-685

geochronology OF 92-0525

Manitoba, geochronology OP-1709

New York, geochronology OP-1709

Norway OP-1173

Quebec, gold ores OP-1097

graphite

Gabon, geochemistry OP-713

graphite deposits

Michigan OF 92-0514

graptolites

Arkansas, stratigraphy OF 93-0199

Mexico, Paleozoic OP-56

Nevada, stratigraphy OP-623

Oklahoma, stratigraphy OF 93-0199

Pennsylvania B 1994 
Grassy Mountain Deposit metal ores OP-876

gravel

Arkansas

fluvial features OP-1700

Quaternary OP-1683

geochemistry OP-16

hydrogeology OP-24

Illinois, Quatemary P 1536

Indiana, Quaternary P 1536

Massachusetts, geochemistry OP-215

Missouri

fluvial features OP-1700

geomorphology OP-1544

pollution OP-1155

Tennessee, Quaternary OP-1683

Utah

Quaternary OP-908; OP-911; OP-1021

structural geology OP-909

gravel deposits see also aggregate.

OF 93-0200; OP-229

environmental geology OF 92-0514

Minnesota, reclamation OF 92-0514

Ohio OF 92-0514

South Dakota OF 92-0514

gravitational sliding see gravity sliding

gravity anomalies see Bouguer anomalies

gravity faults see normal faults

gravity field

crust OP-884

gravity gliding see gravity sliding

gravity logging

Brazil, geophysical surveys OP-1329

Washington, tectonics OP-877

gravity methods OF 93-0287; OP-212; OP-565

gravity sliding

Poland, structural geology OP-1916

gravity survey maps

Arizona, geophysical surveys OF 91-0640

Colorado, geophysical surveys MF-2236

Montana, economic geology OF 93-0207

New Mexico, geophysical surveys WRI 914065; OF 92-0503

Alaska OF 93-0508-A; OF 93-0508-B seismology OP-1142

Arctic Ocean

plate tectonics OP-1429

tectonophysics OP-1891

Arctic region, tectonophysics OP-1891

Bering Sea, deformation OP-211

California

economic geology OP-204

geophysical surveys OF 93-0217-A; OF 930217-B

petrology OP-1167

Celebes Sea, geophysical surveys OP-585

Colorado

economic geology B 2039

geophysical surveys OF 93-0018

geophysical surveys DDS-0009

Gulf of Mexico, structural geology OP-1932

Hawaii, oceanography OF 92-0206

Mediterranean region, tectonophysics OP-1606

Middle East, tectonophysics OP-1606

Minnesota, kaolin deposits OF 92-0514

Missouri, earthquakes OP-1996

Nevada

base metals OP-79

geophysical surveys OF 92-0343; OP-1041

gold ores OP-921

petrology OP-795 structural geology OF 92-0391

Utah, Quatemary OP-970

Wyoming, geophysical surveys OF 93-0002

Grayback Pluton

magmas OP-1139

Grays Point Quarry

fractures OP-1336

Great Appalachian Valley

areal geology B 1994

environmental geology OP-901

ground water OP-1707

Great Bahama Bank

oceanography OP-1073

Pliocene OF 92-0508

sedimentation OP-928

Great Basin see also Chainman Shale.

evaporite deposits OP-226

faults OP-1158

geochemistry OP-2015

gold ores B 2013

ground water W 2340; OP-727

hydrogeology OP-1551

mineral resources B 2039; OP-218; OP-817; OP-1853

natural gas OP-208

petrology OP-545

Quatemary C 1086; OP-1156

sedimentary petrology B 1988-E

seismology OF 92-0340; OP-357

soils $\mathrm{C} 1086$

stratigraphy B 1988-C; B 1988-D; B 1988-F

tectonics OP-2021

Great Bay

geochemistry OP-1207

Great Britain see England; Scotland

Great Egg Harbor River basin ground water WRI 91-4126

Great Falls of the Potomac River metamorphism OP-1152

Great Lakes

changes of level, Lake Michigan OP-1393

environmental geology

Lake Erie OP-1608

Lake Michigan YR

geomorphology, Lake Michigan MF-2252; OP487; OP-836; OP-1143

ground water

Lake Erie OP-1354; OP-1648

Lake Michigan P 1405-C; OP-923

hydrology

W 2400; OP-1278

Lake Michigan WRI 92-4019; OP-199

plate tectonics, Lake Superior OP-13

Quaternary, Lake Michigan C 1086; OP-200;

OP-1288; OP-1289; OP-1290

structural geology

OP-1889

Lake Superior OP-1533

tectonics OP-1215

Great Lakes International Multidisciplinary Program on Crustal Evolution see GLIMPCE

Great Lakes region see also Illinois; Indiana; Lake Superior region; Michigan; Minnesota; New York; Ohio; Ontario; Wisconsin. energy sources B 1909 geophysical surveys OP-1213

ground water WRI 91-4133

hydrology WRI 92-4019; OF 92-0485

maps I-2356

non-metal deposits OF 92-0514

plate tectonics OP-13 structural geology I-2355

Great Lakes tectonic zone

structural geology I-2355; OP-1889

Great Plains see also Colorado; Kansas; Montana; Nebraska; New Mexico; North Dakota; Saskatchewan; South Dakota; Wyoming. geochemistry OF 92-0592; OP-879

hydrology W 2340

petroleum OF 93-0337

plate tectonics OP-1903

Quaternary C 1086

sedimentary petrology OP-1991

stratigraphy OF 93-0335

Great Plains Aquifer

ground water HA-0722-G

Great Salt Lake

engineering geology P 1519

geologic hazards P 1519

hydrology WRI 91-4117

Quaternary OP-908

seismology OP-1076

Great Swamp National Wildlife Refuge environmental geology OF 92-0153

Great Tonalite Sil metamorphic rocks OP-1194

Great Valley Sequence

energy sources OP-267?

geochemistry OP-265

maps OP-1945

metamorphic rocks OP-1166

structural geology OP-1547; OP-1701

Greater Aneth oil field ground water OF 92-0124

Greater Antilles see Hispaniola; Puerto Rico

Greater Antilles outer ridge nodules OP-886

Greece

plate tectonics

Epirus Greece OP-542

Sterea Ellas OP-542

Green Bay

geomorphology MF-2252

Green Mountains

structural geology OP-461

Green River basin

ecology WRI 92-4084

palynomorphs P 1506-D

petroleum OP-1635

sedimentary petrology OP-1791

stratigraphy P 1506-F

Green River Formation see also Lake Gosiute;

Wilkins Peak Member.

P 1506-D; B 1787-BB

natural gas OF 93-0248

oil sands OP-1855

sedimentary rocks B 1787-DD

structural geology B 1787-HH

Green Valley Fault

geophysical surveys OF 93-0276

structural geology OP-405

Greenbrier Limestone

fluvial features B 1981

Greenhorn Limestone OF 93-0335

greenhouse effect

Cretaceous OP-1115

ecology C 1086

environmental geology C 1086; C 1105

geochemistry OP-563

hydrogeology OF 92-0052

hydrology OP-704 


\section{Greenland}

Archean, Isua Belt OP-848

Invertebrata OP-1839

phase equilibria, Skaergaard Intrusion OP-636

Pliocene, Peary Land OP-110

Quaternary B 2036; C 1086; OP-1507

greenschist facies

Alaska

I-2164

metal ores OP-570

metamorphic rocks P 1497-C

petroleum OP-492

Canada, metamorphic rocks P 1497-C

gold ores OF 92-0557

Greenland, phase equilibria OP-636

Idaho, petrology OP-1671

Oregon, petrology B 2054

Saudi Arabia, metal ores OP-1559

Virginia, Proterozoic B 2029

\section{greenstone}

Alaska, stratigraphy OP-1169

Michigan, structural geology B 1904-S; OP1889

Minnesota, structural geology B 1904-S

greenstone belts

Alaska, gold ores OP-1416

gold ores OF 92-0557

Michigan, Archean B 1904-P

Wyoming, stratigraphy P 1520

Greenville Quadrangle

building stone MF-2215-A

Gregory Hill Mine

gold ores MF-2214

greigite

geochemistry OP-841

greisen

Saudi Arabia

metal ores OP-1559

tin ores OP-499

tin ores OF 92-0557

greisenization

Saudi Arabia, tin ores OP-1558

Grenville Front

orogeny OP-138

tectonics OP-1215

Grenville Orogeny see Grenvillian Orogeny

Grenville Province see also Central

Metasedimentary Belt.

crust OP-1316

structural geology OP-460

Grenvillian Orogeny

OF 92-0525

Canada, orogeny OP-138

New York, structural geology OP-461

North Carolina, geochemistry OP-1607

Ontario, petrology OP-214

Vermont, structural geology OP-461

Virginia, orogeny OP-1612

GRID YR

Grindstone Terrane

guidebook OP-87

Grotte du Lazaret

Quaternary OP-310

ground ice OP-1323

ground motion see also strong motion.

Armenia, earthquakes OF 93-0216

California

earthquakes OF 92-0575; OP-329; OP-958; OP-1183

engineering geology OP-1582; OP-1948

geologic hazards OP-221; OP-1793 seismicity P 1550-C

seismology P 1550-C; OF 93-0295

earthquakes OP-179; OP-1274

Egypt, earthquakes OP-1092

El Salvador, seismology OP-399

engineering geology P 1240-B; OP-67; OP1108; OP-1184

geologic hazards OP-1109

Italy, geologic hazards OP-213

Mississippi Valley, engineering geology OF 92-0391

seismology OP-959; OP-1275; OP-1370

South Africa, engineering geology OP-660

Spain, geologic hazards OP-1372

Utah

engineering geology P 1519

geologic hazards P 1519

ground probing radar see ground-penetrating radar

ground water see also alluvium aquifers; aqui-

fers; artesian waters; confined aquifers; hot springs; hydraulics; hydrologic cycle; hydrology; hydrothermal alteration; infiltration; leaky aquifers; liquid waste; perched aquifers; recharge; salt water, salt-water intrusion; shallow aquifers; springs; thermal waters; tracers; waste disposal; water resources.

YR; TWI 03-B4; TWI 06-A3; TWI 06-A5; OF 90-0194; OF 91-0471; OF 92-0652; OF 920659; HA-0730-J; OP-103; OP-154; OP-207; OP-553; OP-571; OP-733; OP-987; OP-1514; OP-1933

Alaska, heat flow OP-253

Appalachians OP-240; OP-417

Arizona WRI 90-4105; WRI 91-4185

Atlantic Coastal Plain, pollution OP-1876

Basin and Range Province OP-727

Brazil OP-737

California

WRI 92-4153; OF 93-0148; OF 93-0279; OP-995

earthquakes OP-126; OP-1025

geologic hazards WRI 92-4035

pollution WRI 91-4119

seismology OP-868

Colorado, environmental geology OF 92-0391

Colorado Plateau, uranium ores OP-1848

Columbia Plateau OP-184

Delaware

OP-777

pollution $\mathrm{C} 1080$

energy sources OP-1822; OP-1823

engineering geology $\mathrm{OP}-472$

environmental geology OP-1277

Florida

W 2340

pollution OP-513

geochemistry OP-343; OP-829

geophysical surveys OF 93-0071

Georgia, geochemistry OP-917

Great Basin OP-727

Great Plains OF 93-0114

Hawaii

OP-1527

engineering geology OF 92-0501

Idaho WRI 92-4014

Illinois, Quaternary P 1536

Indiana

OF 92-0055

Quaternary P 1536

Iowa OF 92-0167; OP-612

Kansas

environmental geology $\mathrm{OP}-4$ geochemistry OP-5

Kentucky, pollution WRI 92-4138

Louisiana OF 92-0492; OP-742

Maryland, pollution C 1080

Massachusetts OP-800

metal ores OP-1035

mineralogy OP-1752

Minnesota

geochemistry OP-943

pollution OF 93-0043; OP-430; OP-1526

Missouri, pollution OF 93-0101; OP-2028

Montana, pollution OF 93-0064

Nevada

W 2340; WRI 91-4185; OP-995; OP-1009; OP-1899

geochemistry OP-643; OP-775

New Jersey

OP-986

environmental geology OP-832

pollution OP-1383

New Mexico

OF 91-0455; OP-230

evaporite deposits OP-2012

geomorphology OF 92-0391

geophysical surveys WRI 91-4065

New York OP-2023

North Carolina

OP-239

pollution OP-403

Ohio, pollution OP-155

Oklahoma, pollution OP-1251

Ontario

geophysical surveys OF 93-0071

pollution OP-369

Oregon, soils OP-1028

Pennsylvania WRI 91-4182; WRI 92-4183; OF 93-0027; OF 93-0028; OP-915

Puerto Rico

YR; OP-1960

economic geology OF 92-0567

South Carolina, pollution OP-1040

Tennessee OF 92-0166

Texas

OF 91-0455; OF 93-0062; OP-1675; OP-

1849

environmental geology OF 92-0391

evaporite deposits OP-2012

Turkey OP-39

United Arab Emirates, stratigraphy OP-1453

uranium ores DDS-0001

Utah

WRI 90-4105

geologic hazards P 1519

Washington

WRI 93-4060

Quatemary OP-323

Wyoming

OF $91-0533$

pollution OP-930

Ground Water Site Inventory

ground water OP-745

ground-penetrating radar

engineering geology OP-384

Massachusetts, environmental geology OF 920646

New Hampshire, environmental geology WRI 92-4012; WRI 92-4056

Ontario, pollution OP-369

ground-water replenishment see recharge

groundwater see ground water

Grove Karl Gilbert see Gilbert, Grove Karl

GSMAP OF 93-0305; OF 93-0511; OF 93-0536 


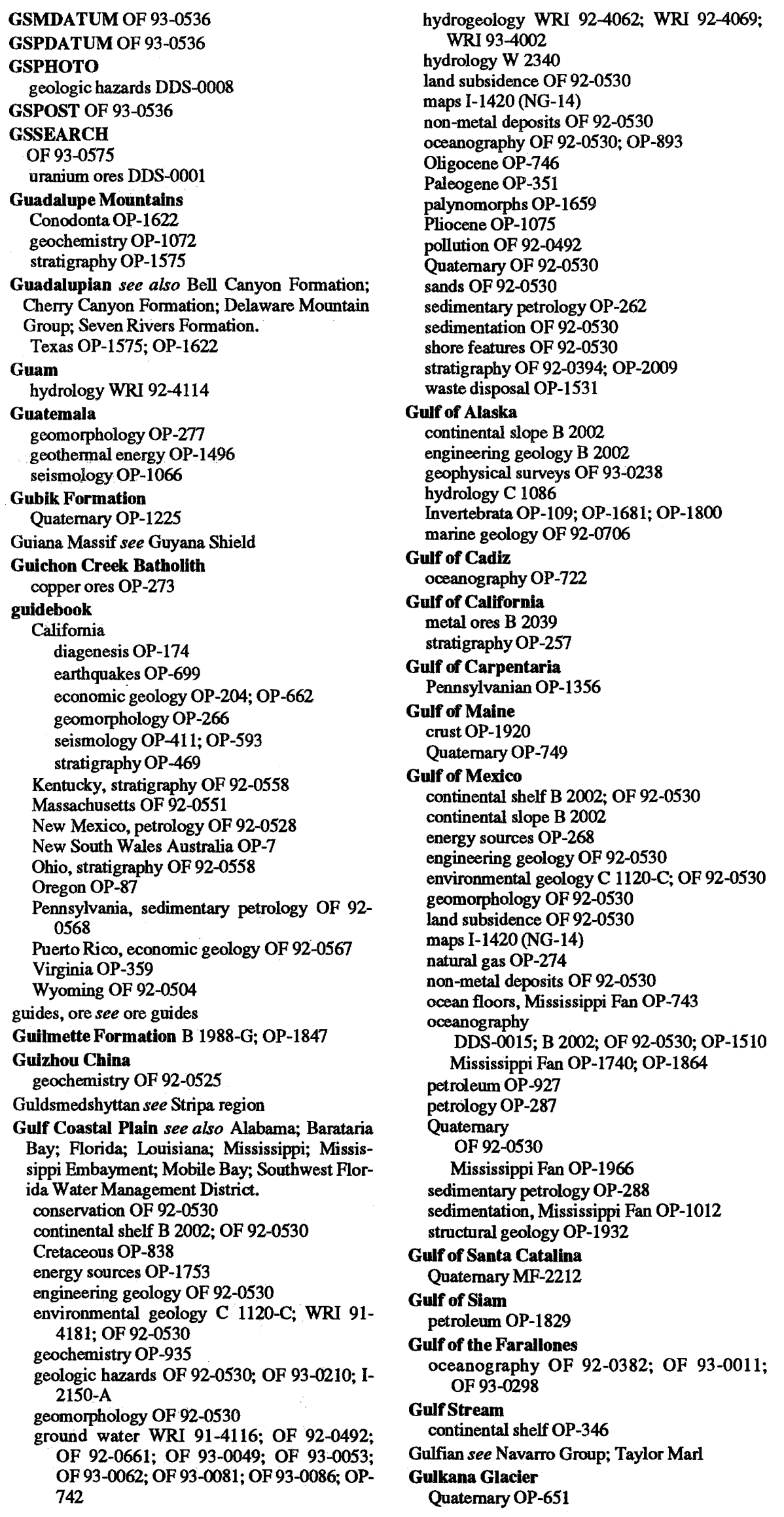

gullies

engineering geology $\mathrm{OP}-1512$

Gunnison River basin hydrogeology OP-300 hydrology C 1086; OF 92-0627; OP-559

Quaternary C 1086

Guri Quadrangle maps MF-2242

gusher see geysers

Guyana Shield

tectonics OP-1760

guyots see seamounts

gymnosperm flora

Colorado, Quaternary OF 93-0250

South Carolina, ecology OF 93-0303

gymnosperms

diagenesis OP-1477

Neuropteris, Nova Scotia OP-1673

Picea glauca, Alaska OF 93-0014

Pinus

Colorado OF 93-0250

South Carolina OF 93-0303

gypsum

Florida, ground water OP-1568

geochemistry OP-165

New Mexico, geomorphology OF 92-0391

Texas, ground water OP-1849

gypsum deposits

OF 92-0593

Arizona OF 93-0329

Ohio OF 92-0514

gyttja

Oregon, Quatemary OF 93-0212

Washington, Quaternary OF 93-0212

\section{H}

H see hydrogen

$\mathrm{H}-2$ see deuterium

H-3 see tritium

H. J. Andrews Experimental Forest geologic hazards OF 92-0483

Haag Nunataks

tectonophysics OP-1446

Hadriaca Basin OP-1647

hafnium

Atlantic Coastal Plain, heavy mineral deposits B 2039

Hagemeister Island Quadrangle metal ores MF-2228

Hahn Crater OP-1439

Haiku Valley

hydrology WRI 92-4049 pollution WRI 92-4168

Hailey Quadrangle gold ores B 2039

Haiti

geochronology B 2065

petrology OP-1873

Quaternary OP-706

stratigraphy OP-1179; OP-1181; OP-1414

Halawa Valley

hydrogeology WRI 91-4197

hydrology WRI 92-4049

half grabens

Russian Federation, geophysical surveys OP898

halides see also chlorides; fluorides. gold ores OP-1175 
New Mexico, metal ores OP-1715

halite see also sodium chloride.

Michigan, sedimentary petrology OF 93-0236

Mississippi, diagenesis OP-1856

Missouri, metal ores OP-1885

sedimentary petrology $\mathrm{OP}-433$

United Kingdom, sedimentary petrology OF 93-0236

Wyoming, geochemistry OP-520

halloysite

Rocky Mountains, diagenesis OP-1792

Western Interior

clay mineralogy OP-794

diagenesis OP-1792

halogenide see halides

halogens see also chlorine; fluorine. pollution OP-580

halokinesis see salt tectonics

Hamilton Group see Ludlowville Formation; Marcellus Shale; Moscow Formation; Onondaga Limestone

hamlinite see goyazite

Hampton University YR

handbooks see manuals

Hanna Formation

natural gas OF 92-0524

Hanson Creek Formation gold ores OP-441

harmonic analysis see Fourier analysis

Harmony Formation gold ores OP-365; OP-994

Harney Basin petrology OP-1549

Harrat Hutaymah petrology OP-1952

Harrell Shale stratigraphy OP-1988

Harrisburg Pennsylvania geologic hazards YR

Harrison Quadrangle mineral resources MF-1994-D

Hart Syncline hydrogeology WRI 92-4050

Hatchie River valley fluvial features OP-767

Hatter's Pond Field energy sources OP-1753

Hatteras Basin stratigraphy P 1542

Hatu Deposit gold ores OP-945

hausmannite

California, manganese ores OP-319; OP-458

Havallah Sequence stratigraphy B 1988-D

Hawail

earthquakes, Kilauea EV

engineering geology

B 2006

Oahu OF 92-0501

environmental geology

OF 93-0292-I

Kilauea OF 93-0512-A

Mauna Kea OF 93-0512-A

Mauna Loa OF 93-0512-A

geochemistry, Kilanea OP-348; OP-446; OP1997

geologic hazards

YR

Honolulu Hawaii OF 92-0521; OF 93-0213
Kauai YR

Kauai County Hawaii YR

geomorphology

OP-693; OP-782

Mauna Loa OP-694

geophysical surveys

Kilauea OF 92-0686; OP-252

Mauna Kea OF 92-0686

Mauna Loa OF 92-0686

Puu Oo OP-252

ground water, Oahu OP-1527

hydrogeology

WRI 92-4099

Honolulu Hawaii OF 92-0486

Oahu WRI 91-4197

hydrology

W 2400

Koolau Range WRI 92-4049

lava, Kilauea OF 93-0015

magmas, Kilauea OP-1001

maps, Hilo Hawaii I-2274

oceanography

B 2002; OF 92-0206; OP-418

Hawaii County Hawaii MF-2233

Kilauea MF-2231

Mauna Loa MF-2233

Oahu B 2002

paleomagnetism, Hawaii County Hawaii OP436

petrology

Hualalai OP-164

Kilauea OF 92-0586; OF 93-0342-A; OF 93-0342-B; OP-631; OP-667; OP1499

Puu Oo OP-164; OP-631

pollution, Oahu WRI $92-4168$

Quaternary

Hawaii County Hawaii OP-1759

Hawaii Island OP-632; OP-633

Kilauea OP-284

Mauna Loa OP-1759

seismicity, Hawaii County Hawaii OP-1812

seismology

Hawaii County Hawaii OP-1088

Kilauea OP-116; OP-1420

Puu Oo OP-1420

soil mechanics, Honolulu Hawaii OP-1814

Hawail Geothermal Project environmental geology OF 93-0512-A

Hawaii Island see also Hilo Hawaii; Hualalai; Kilauea; Mauna Kea; Puu Oo.

Quaternary OP-632; OP-633

Hawaii Ridge see Hawaiian Ridge

Hawaii Volcano Observatory geophysical surveys OF 92-0686

Hawaiian Islands see Hawaii

Hawaiian Ridge oceanography B 2002

Hayfork Quadrangle mineral resources OF 92-0210-A; OF 92-0210-

Hayward California geologic hazards OF 90-0677

Hayward Fault

earthquakes OF 91-0032

engineering geology OP-688; OP-882; OP1948

geophysical surveys OF 93-0276

neotectonics OP-23

structural geology OP-405
Hazaran Orogeny

structural geology OP-1125

Hazard Creek Complex petrology OP-630

hazardous waste pollution OF 92-0527

waste disposal OF 92-0526-A; OF 92-0526-B

hazards, geologic see geologic hazards

HCDN

hydrology C 1086; WRI 93-4076; OF 92-0129; OF $92-0632$

He see helium

$\mathrm{He}-\mathbf{4} / \mathbf{H e}-3$

California, geochemistry OP-955

Hawaii, geochemistry OP-446

Wyoming, geochemistry OP-327; OP-536

Healdsburg Terrane structural geology OP-1547

Heard Plateau see Kerguelen Plateau

heat flow see also geothermal energy; geothermal gradient; hot springs; sea-floor spreading; thermal waters.

OP-28; OP-29

Alaska OP-253

Arctic Ocean OP-1626

California, structural geology OP-702

Celebes Sea, geophysical surveys OP-585

Commonwealth of Independent States, energy sources OP-1261

Europe, energy sources OP-1261

ground water B 1989-D

Mississippi Valley OP-1661

Quatemary OP-81

stratigraphy OP-270

Vanuatu, sedimentation OP-188

West Pacific Ocean Islands OP-1034

heavy metals

Alaska, pollution OP-66

Arizona, pollution OP-592

Colorado

environmental geology OF 92-0614

geochemistry OF 93-0321

pollution OP-1968

Costa Rica, pollution OP-335

environmental geology C 1105; OP-180

pollution OP-181

heavy mineral deposits see also monazite deposits.

OF 93-0240-A; OF 93-0240-B

Atlantic Coastal Plain B 2039; OP-1104

Georgia B 2039

Minnesota OF 93-0345

North Carolina OF 92-0396

Puerto Rico OF 92-0703; OF 93-0341

South Carolina B 2039

heavy minerals

OF 92-0386

Alaska

metal ores B 1968; MF-1996-E

mineral resources OF 92-0708-A; OF 92 0708-B; MF-2144-B

Arizona, metal ores B 2042-C

Arkansas OF 93-0291

China, gold ores OP-945

Colorado, mineral resources OF 92-0709

gold ores OF 92-0573-A; OF 92-0573-B

Great Lakes region, stratigraphy B 1989-E

Idaho, mineral resources OF 90-0672; OF 92 0384

metal ores B 2003 
mineral resources OF 92-0380-A; OF 92-0380B; OF 92-0552; MF-2207; MF-2217-B

Minnesota, heavy mineral deposits OF 93-0345

Missouri OF 93-0291

Montana, economic geology OF 93-0207

Oregon, mineral resources OF 90-0506; OF 93 0259-A; OF 93-0259-B

Puerto Rico, heavy mineral deposits OF 92 0703; OF 93-0341

Samoa OP-844

South Carolina, tin ores OF 92-0268

Utah, mineral resources MF-2081-E

Wyoming, palynomorphs $P$ 1506-D

heavy oil

Alaska, energy sources OF 92-0391

Pacific Coast, energy sources OP-1946

Utah, oil sands OP-1855

Hebei China

stratigraphy, Jixian China OP-1361

Hebgen Lake earthquake 1959

Idaho, neotectonics OP-780

Montana, deformation OP-883

Wyoming, neotectonics OP-780

Hebo Quadrangle

maps OF 93-0302

Heise volcanic field paleomagnetism OP-697

helium

Alaska, geochemistry OP-926

economic geology OP-834

$\mathrm{He}-4 / \mathrm{He}-3$

California OP-955

Hawaii OP-446

Wyoming OP-327; OP-536

Hell Creek Formation OP-1550; OP-1744

Hellas Planitia I-2332; I-2333; I-2334; I-2335; I-2336; OP-1647

hematite

OP-112

Greenland, Archean OP-848

Missouri B 2039; OP-1418

Hemlock Conglomerate

energy sources B 2034-A; OP-626

Henderson Field

geochemistry OP-1072

Hengill-Grensdalur volcanic complex seismicity OP-322

Hensley Member stratigraphy OP-1368

herbicides see also atrazine.

Atlantic Coastal Plain, pollution OP-1876

California, pollution OP-264

Great Plains, ground water OF 93-0114

Gulf Coastal Plain, environmental geology C 1120-C

Gulf of Mexico, environmental geology C 1120-C

Iowa, pollution OP-1981

Kansas, pollution OF 93-0087; OP-1909

Kentucky, hydrology WRI 92-4078

Midwest

environmental geology OP-1000

pollution OF 93-0418

Missouri, pollution OP-2028

Nebraska, pollution OF 93-0087; OP-1909

New England, pollution OF 93-0418

North Carolina, hydrogeology OF 93-0163

pollution OF 93-0418; OP-1425; OP-1600

Hercynian Orogeny

China, metal ores OP-1238

England, geochemistry OP-158
Italy, structural geology OP-1808

Poland

Carboniferous OP-1917

structural geology OP-967; OP-1916

Hermosa Formation see also Paradox Member. OP-1399

natural gas OP-1262

Hesketh Island

stratigraphy OP-1169

Hesperian

OP-987; OP-1240; OP-1242; OP-1338; OP1934; OP-1935; OP-1936; OP-1938; OP-1939;

OP-1984

Syria OP-1322

Heterophrentis

Invertebrata B 2024

Hevelius Formation OP-416

Hf see hafnium

$\mathrm{Hg}$ see mercury

Hicks Dome

hydrogeology OP-1782

non-metal deposits OP-1419

structural geology OP-1799

Hidalgo Volcanics

stratigraphy OP-573

Hierro

engineering geology $\mathrm{OP}-443$

High Falls Shale

stratigraphy B 1839-L

High Plains see Great Plains

High Point Lake watershed hydrogeology OF 93-0163

high school see also elementary school; junior high school.

YR; OF 91-0014

Antarctica, environmental geology OF 91-0014 geomorphology OF 91-0014

ocean floors OF 91-0014

Pacific Ocean, geochemistry OF 91-0014 seismology OF 91-0014

High View Tongue stratigraphy B 1839-L

high-angle faults

Argentina OP-1129

Arizona I-2290

Bolivia, metal ores B 2039

California, energy sources OP-267

Illinois OP-1471

Missouri OP-1471; OP-1861

Montana P 1524

high-grade metamorphism

Appalachians, structural geology OP-1079

Greenland OP-636

New South Wales Australia, metal ores OP-942

Queensland Australia, metal ores OP-942

Wyoming, structural geology OP-149

Highland Rim

economic geology B 2005

ground water WRI 92-4092

hydrogeology OP-1283

highways see also bridges; embankments.

WRI 92-4147

Hawaii

hydrogeology WRI 91-4197

hydrology WRI 92-4049

Vermont B 2043

Hiko Quadrangle maps OF 92-0613

Hiko Spring

geochemistry OP-1775
Hillsboro Sandstone

hydrogeology OP-1228

Hilo Hawaii

maps I-2274

Hilo Quadrangle maps I-2274

Hilt Bed

stratigraphy $\mathrm{P} 1521$

Hilton Head Island

hydrogeology OF 91-0483

Himalayas

natural gas OP-1634

structural geology OP-1125

Hindeodus

Permian OP-1982

stratigraphy OP-1245; OP-1983

Hindsville Limestone

Invertebrata OP-360

Hinton Formation stratigraphy OP-1368

Hispaniola see Dominican Republic; Haiti

Histosols

Alaska, Quaternary OP-33

HISWA

engineering geology OF 92-0722

Hocomonco Pond environmental geology OF 92-0646

Hogback fault zone stratigraphy OP-1523

Holbrook Lineament petrology OP-1341

Holitna Lowland Quaternary OP-1059

Holocene see also Lake Bonneville. C 1086; OP-55; OP-293; OP-396; OP-1662; OP-1769; OP-1989; OP-2011

Alabama OF 92-0530

Alaska C 1086; OP-845; OP-1507; OP-1800

Antarctic Ocean OP-263; OP-1307

Arctic Ocean OF 93-0515

Arizona OP-426; OP-976; OP-1060; OP-1375

Atlantic Coastal Plain OF 92-0263

Australia OP-1478

Bangladesh OF 92-0391; OP-1273

Black Sea OF 93-0274

California OP-878; OP-1253; OP-1800; OP1833

Canada OP-1905

Chile OP-35; OP-719

Colorado OF 92-0525; OF 93-0250

Delaware C 1086

Dominican Republic OP-808

East Pacific Ocean Islands OP-925

Florida C 1086; OP-1930

Galapagos Islands OP-925

Georgia OP-1501

Great Lakes OP-200; OP-1288; OP-1290

Great Plains C 1086

Greenland OP-1507

Gulf Coastal Plain OF 92-0530

Gulf of Mexico OF 92-0530

Hawaii OP-632; OP-633; OP-1997

Iceland OP-1997

Idaho WRI 93-4054; OP-561; OP-1654

Illinois P 1536

Indiana P 1536

Indonesia OP-695; OP-1478

Italy OP-764

Kentucky OP-486

Louisiana OF 92-0530; OP-262

Massachusetts OP-546; OP-749 
Mexico OP-1800

Middle East OF 93-0274

Minnesota C 1086; OP-20; OP-21; OP-99; OP100; OP-101; OP-248; OP-251; OP-668; OP-739; OP-943

Mississippi OF 92-0530

Missouri OP-1544

Neoglacial

Alaska OP-1718

Califomia OP-1254

New Jersey C 1086

Oregon B 2038; OF 93-0212; OP-43; OP-982

Pacific Ocean C 1086

Peru OP-1331

Polynesia OP-1436

Rhode Island OP-1424

Sweden OP-1039

Tennessee WRI 92-4082; OP-486; OP-856

United States OP-1905

Utah OP-1060

Washington OF 91-0441-T; OF 91-0453; OF 93-0212; OF 93-0284; OF 93-0289; OP1118; OP-1119

Wyoming OF 92-0504; OF 92-0525; OP-711

Holton Circle New Hampshire

environmental geology OF 92-0647

homestake-type

gold ores OF 92-0557

Homestead Florida geologic hazards YR

Homestead Valley earthquake 1979 seismology OP-411

Homestead Valley Fault earthquakes OP-699

Hondo Field energy sources OF 92-0383

Honduras geothermal energy OP-1496

Honeydew earthquake 1991 earthquakes OP-1762

Honolulu Hawail geologic hazards OF 92-0521; OF 93-0213 hydrogeology OF $92-0486$ soil mechanics OP-1814

Honshu

neotectonics OP-1852

tectonophysics OP-1620

Hood River petrology B 2054

Hook Mountain Basalt geochemistry OF 93-0010 magmas OP-1003

hopanes Alaska, energy sources OP-626

Hope Basin petroleum B 2034-A

Hopi Buttes Field petrology OP-1341

Hoplitaceae stratigraphy OP-177

Hoploscaphites stratigraphy B 2024

Horgl Formation stratigraphy OP-1303

Horn Mountains mineral resources OF 92-0708-A; OF 92-0708B

hornblende OP-233

Alabama, geochronology OP-968
Alaska, petrology OP-1461

Argentina, structural geology OP-1129

Bolivia, metal ores B 2039

California

geochronology OP-333

petrology OP-1461

stratigraphy B 2015

Colorado, metal ores OP-1633

Connecticut, metamorphic rocks OP-1188

Georgia, geochronology OP-968

Greenland, phase equilibria OP-636

Idaho, petrology OP-1671

Maryland, metamorphism OP-1152

Massachusetts, metamorphic rocks OP-1188

Norway, structural geology OP-1279

petrology OP-393

Poland, Carboniferous OP-1917

Virginia

metamorphism OP-1152

orogeny OP-1612

hornblendite

California, geochemistry OP-730

Hornbrook Formation P 1521

hornfels

Greenland OP-636

Montana, geochemistry OP-1087

hornstone see chert

Horse Flat Quadrangle maps C-0144

Horse Prairie Basin

Eocene OP-617

Horse Spring Formation

Neogene OP-92

horsts

OP-1940

Midwest, structural geology OP-1799

Hosselkus Limestone sedimentary petrology OP-1344

Hot Creek Range sedimentary petrology OP-1795

hot spots

Idaho, neotectonics OP-780

tectonophysics OP-1366; OP-1534

Wyoming

neotectonics OP-780

Quaternary OF 92-0391

tectonophysics OP-1780

hot springs

California, geochemistry OP-955

Colorado OF 93-0017-A; OF 93-0017-B; OF 93-0282

Idaho

OF $92-0175$

metal ores OP-876

metal ores OF 92-0557

Nevada, geochemistry OP-1609

Oregon

OP-468

metal ores OP-876

Papua New Guinea, gold ores B 2039

Utah, geochemistry OF 93-0260

Wyoming

OF 93-0293

geochemistry OP-464; OP-520

Hot Springs Arkansas petrology OP-1837

Hot Springs Basin Group geochemistry OP-464

House Creek Field energy sources OF 92-0391
Houston Texas

ground water OF 93-0086

Howard Pass Quadrangle

barite deposits OF 93-0215

Hualalai

petrology OP-164

Hualapai Indian Reservation gold ores OF 92-0591-A; OF 92-0591-B

Huanghai Sea see Yellow Sea

Huanzo Cordillera

silver ores OP-1212

Huasna Syncline structural geology OP-1701

Hubbard Glacier marine geology OF 92-0706 Quatemary C 1086; OP-1718; OP-1719

Hudson River hydrology OP-1335

Hudson River Quadrangle maps I-1420 (NK-18)

Huincan Intrusive Suite structural geology OP-1129

Humacao Puerto Rico hydrogeology C 1086 weathering C 1086

humates geochemistry OP-1990 soils OP-1951

Humboldt Basim continental shelf B 2002 natural gas B 2034-A

Humboldt Range stratigraphy OP-1776 structural geology OP-999

Humboldtianum Basin OP-1485

Humboldts Sea OP-1439; OP-1830

HUMEX geochemistry OP-353

humic acids geochemistry OP-353 Pacific Ocean, geochemistry OP-628

humus

soils OF 91-0513

Washington, Quaternary OP-120

Hunan China geochemistry OF 92-0525

Hungary see also Pannonian Basin. OP-558 economic geology YR

Hungry Valley Formation structural geology OP-649

Huron Member natural gas B 1909

Huron River Unit structural geology B 1904-Q

Huronian see Onaping Formation

Hurricane Andrew geologic hazards YR sedimentation OP-928

Hurricane Hugo environmental geology OF 92-0717 geologic hazards OF 92-0717; OP-1409; OP1631; OP-1835 geomorphology OF 92-0717 marine installations OP-1863 oceanography OF 92-0717 sands OF 92-0717

Hurricane Iniki geologic hazards YR 
Hurricane Iwa

oceanography B 2002

hurricanes see also Agnes.

Bahamas, sedimentation OP-928

East Pacific Ocean Islands, geologic hazards YR

Florida, geologic hazards YR

Gulf Coastal Plain, geomorphology OF 920530

Gulf of Mexico, geomorphology OF 92-0530

Hawaii

geologic hazards YR oceanography B 2002

Louisiana geologic hazards YR geomorphology OF 92-0530

Polynesia, geologic hazards YR

Puerto Rico environmental geology OF 92-0717 geologic hazards OP-1409; OP-1631; OP1835

marine installations OP-1863

Vanuatu, geologic hazards OP-1521

Hwang Hai see Yellow Sea

hyalotektite

Sweden, mineralogy OP-1445

Tadzhikistan, mineralogy OP-1445

hydrargillite see gibbsite

hydrates see also gas hydrates.

geophysics OP-282

Nevada, geochemistry OP-76

hydrates, gas see gas hydrates

hydraulic conductivity

Arizona, ground water OP-1639

Atlantic Coastal Plain, ground water OP-1239

Colorado ground water WRI 92-4067 hydrogeology WRI 92-4050; OP-408

Columbia Plateau, ground water OP-1016

Connecticut, hydrogeology WRI 92-4074

environmental geology OP-173; OP-1898

Florida

ground water WRI 92-4076; OP-671 hydrogeology W 2340

Georgia, hydrogeology W 2391

ground water B 1989-D; W 2412; TWI 06-A3; TWI 06-A5; WRI 92-4124; OP-684; OP733; OP-1640

Hawaii engineering geology OF 92-0501 ground water OP-1527

Idaho, hydrogeology P 1408-F; OF 91-0098; OP-1654

Illinois, hydrogeology W 2386

Iowa, hydrogeology OF 92-0500

Maryland, environmental geology OP-658

Massachusetts, ground water OF 92-0143; OP431

Mexico, ground water WRI 91-4155

Michigan, ground water WRI 91-4133

Midwest, ground water OF 92-0489

Minnesota, ground water P 1530-A

Montana, ground water WRI 92-4162

Nevada, waste disposal WRI 92-4032

New England, ground water OP-1472

New Hampshire, ground water WRI 91-4177

New Jersey

environmental geology OP-832 ground water WRI 90-4151

New Mexico, ground water P 1407-C; WRI 914155

New York ground water WRI 90-4151; WRI 91-4012

hydrogeology W 2387

North Dakota, ground water OP-1924

Ohio, ground water WRI 93-4047; OP-1925

Oregon, hydrogeology OF 91-0098

Pennsylvania, ground water OP-111

soil mechanics B 1842-D

Tennessee, hydrogeology WRI 92-4131

Texas, ground water P 1407-C; WRI 91-4155

Virginia

ground water W 2388

hydrogeology OP-1196

West Virginia, hydrogeology W 2384

Wisconsin, ground water WRI 92-4077

hydraulic fracturing

geophysical surveys OP-325

ground water OF 93-0071

Oklahoma, seismology OP-301

hydraulics see also waterways.

California, ground water W 2340

Colorado, hydrogeology OP-300

ground water W 1536-G

hydrogeology OP-482

hydrology W 2339

Idaho, hydrogeology WRI 93-4001

Hydro-Climatic Data Network

hydrology C 1086; WRI 93-4076; OF 92-0129; OF 92-0632

hydrocarbons see also aliphatic hydrocarbons; aromatic hydrocarbons; crude oil; hopanes;

Rock-Eval; steranes; terpanes.

environmental geology OP-180

geochemistry OP-810

Georgia, ground water WRI 93-4038

ground water OP-154

Michigan, energy sources OF 92-0391

Minnesota, pollution WRI 90-4150; OP-629

natural gas OF 92-0524

New Jersey

ground water OP-350

pollution OP-1383

New Mexico, geomorphology OF 92-0391

pollution OP-181

South Carolina, pollution OP-1040

hydrofluoric acid stratigraphy OP-88

hydrogen see also deuterium; tritium.

Atlantic Coastal Plain, ground water OP-1239

$\mathrm{D} / \mathrm{H}$

OP-1221; OP-1389

Alaska OP-330

Brazil OP-737

California OF 92-0655; OP-267; OP-473; OP-890

Colorado W 2340; WRI 93-4007; OP-490; OP-872; OP-1151

energy sources OP-1822; OP-1823

geochemistry OF 92-0009; OP-953

Idaho OP-912

Indiana OP-1648

Maryland OP-1824

metal ores OP-1117

Mexico OP-872

mineralogy OP-1922

Montana OP-637

Nevada W 2340

New Mexico WRI 93-4007; OP-490

Ohio OP-1648

Ontario OP-1942

Peru OP-872

Russian Federation OP-1874

Utah W 2340; OP-872
Washington OP-998

Wyoming OP-637; OP-874

earthquakes OP-540

fluid inclusions OP-1773

geophysical surveys OP-1580

Kentucky, geochemistry B 2046

petrology OP-696

phase equilibria OP-1726

Puerto Rico, ground water OP-1960

Russian Federation, geochemistry OP-130

Wyoming, geochemistry OP-536

hydrogen fluoride see hydrofluoric acid

hydrogeologic maps

Arizona, ground water WRI 90-4105; WRI 914185

Arkansas, ground water WRI 92-4120

Atlantic Coastal Plain

ground water P. 1404-G

hydrogeology OF 92-0629

Connecticut, ground water WRI 87-4144

Florida, ground water OF 92-0471; OF 92 0472; OF 93-0049; OF 93-0050; OF 93 0053

Georgia, hydrogeology W 2391

ground water HA-0730-J

Gulf Coastal Plain, ground water P 1416-C. WRI 91-4149; WRI 91-4150; WRI 914151; WRI 91-4152; WRI 92-4102; WRI 92-4103; WRI 92-4104; WRI 92-4105

hydrogeology WRI 91-4196; OF 92-0466

Idaho, hydrogeology P 1408-F; OF 91-0098

Kansas, ground water HA-0722-G; HA-0722H; HA-0722-I

Louisiana, hydrogeology WRI 91-4109

Maryland, ground water OF 92-0459; OF 920460; OF 92-0461; OF 92-0462; OF 920463; OF 92-0464

Midwest, ground water OF 92-0489

Mississippi, ground water WRI 92-4080

Mississippi Valley, ground water -WRI 91 4149; WRI 91-4150; WRI 92-4102; WRI 92-4104

Nevada, ground water WRI 91-4185

New Hampshire ground water WRI 90-4161; WRI 91-4025; OF 92-0095

hydrogeology OF 89-0583

New Jersey

ground water WRI 90-4151; WRI 91-4126 hydrogeology WRI 91-4169

New Mexico, ground water P 1407-C; OP-230

New York

ground water WRI 88-4127; WRI 90-4151; WRI 91-4030

hydrogeology W 2387

Ohio

ground water WRI 91-4024

hydrogeology WRI 92-4072

Oklahoma, ground water WRI 88-4208

Oregon

ground water WRI 90-4085

hydrogeology OF 91-0098

Pennsylvania, ground water WRI 91-4182. WRI 92-4183; WRI 92-4194; OF 93-0027 OF 93-0028

South Carolina, ground water WRI 92-4000

Texas

ground water P 1407-C; WRI 88-4208;

OF 93-0062; OF 93-0081; OF 93-0086

hydrogeology WRI $92-4190$

Utah, ground water WRI 90-4105; WRI 92 4070; WRI 92-4160 
Washington, ground water WRI 90-4085 Wyoming, hydrogeology WRI 91-4108

hydrogeology see also ground water, hydrology; springs; thermal waters.

OP-1004

hydrohalite

geochemistry OP-58

hydrologic cycle

Alaska, hydrology C 1086

Colorado

hydrogeology $\mathrm{OP}-408$

hydrology OP-133; OP-559

ground water B 1989-D

hydrogeology WRI 93-4011; OF 92-0138

hydrology C 1086; OP-40; OP-577; OP-704

Indiana, ground water OP-923

Kansas, hydrogeology WRI 92-4137

New Mexico, ground water P 1407-C

Oregon, hydrogeology OP-62

Puerto Rico, ecology OF 92-0150

Texas, ground water P 1407-C

Washington, hydrogeology OP-62

Wisconsin, ground water C 1086

Hydrologic Instrumentation Facility hydrology OF 93-0058

hydrologic maps

Colorado, hydrogeology WRI 92-4050

Hawaii, hydrogeology WRI 91-4197

Illinois, hydrogeology WRI 92-4149

Michigan, hydrogeology WRI 91-4120

Minnesota, hydrology HA-0551

Montana

hydrogeology WRI 92-4185

hydrology WRI 92-4048

New Jersey, ground water WRI 90-4151

New York

ground water WRI 90-4151

hydrology WRI 92-4042

North Carolina, hydrology W 2403

South Carolina, engineering geology WRI 904056

Virginia fluvial features B 1981

geomorphology B 1981

Washington, hydrology OF 91-0453

West Virginia

fluvial features B 1981

geomorphology B 1981

hydrologic provinces

Michigan, hydrogeology WRI 91-4120

hydrological methods

heavy mineral deposits OF 92-0703

uranium ores DDS-0001

hydrology see also atmosphere; atmospheric precipitation; channel geometry; floods; fluvial currents; glacial geology; glaciers; hydrologic cycle; hydrologic maps; ice; infiltration; karst hydrology; lakes; limnology; NAWDEX; reservoirs; rivers; springs; tracers; water resources; waterways.

YR; W 1619-U; W 2220; W 2340; W 2400; C 1086; WRI 91-4110; WRI 92-4060; WRI 924075; WRI 93-4076; OF 92-0052; OF 92-0129; OF 92-0134; OF 92-0144; OF 92-0146; OF 920480; OF 92-0490; OF 92-0495; OF 92-0632; OF 92-0634; OF 92-0637; OF 93-0032; OF 930036; OF 93-0040; OF 93-0058; OF 93-0071; OF 93-0104; OF 93-0106; OF 93-0125; OF 930405; OP-337; OP-481; OP-495; OP-871; OP-
929; OP-1036; OP-1077; OP-1078; OP-1085; OP-1266; OP-1638; OP-1674; OP-1809; OP1820; OP-1836; OP-1888; OP-1964

Alabama W 2400

Alaska

W 2400; OF 92-0493; OF 93-0029; OF 930095; OP-330

pollution C 1007

Arizona

W 2400; WRI 92-4133; OF 92-0468; OF 93-0071; OP-1434

pollution OP-592

Arkansas W 2400; WRI 93-4013; OF 93-0071; OF 93-0166; OF 93-0167; OF 93-0171; OF 93-0424; OF 93-0425; OF 93-0427; OF 93-0428; OF 93-0429; OF 93-0430; OF 93-0431; OF 93-0432

Atlantic Coastal Plain OF 92-0629

Brazil OP-666

California

W 2400; OF 93-0057

environmental geology OF 93-0083

seismology P 1550-C

Canada W 2400

Colorado

W 2400; C 1086; WRI 91-4095; WRI 914176; OF 92-0628; OP-962

environmental geology C 1086; OF 92-0614 geochemistry OF 93-0321

Connecticut W 2400

Costa Rica, pollution OP-335

Delaware W 2400; C 1086

District of Columbia W 2400

ecology C 1086

environmental geology OP-1411

Florida

W 2400; WRI 91-4115; WRI 92-4061; WRI 92-4140; WRI 93-4002 environmental geology WRI 92-4058 geologic hazards YR pollution W 2402

geochemistry OP-160; OP-953

Georgia W 2400; C 1086; OF 93-0055; OP918; OP-1515

Hawaii

W 2400; WRI 92-4049

pollution WRI $92-4168$

Idaho P 0870-A; P 1408-F; W 2400; WRI $92-$ 4196; OP-166

Illinois W 2400

Indiana

W 2400; WRI $92-4019$

environmental geology W 2393

lowa W 2400; OF 92-0500

Kansas

W 2400

pollution OP-1909

Kentucky W 2400; WRI 92-4057; WRI $92-$ 4150

Louisiana

W 2340; W 2400

pollution OF $92-0492$

Maine W 2400

Maryland

W 2340; W 2400; WRI 91-4179; OP-261; OP-1572; OP-1573; OP-1610 geochemistry OP-1824

Massachusetts W 2400; OP-1828

Mexico OP-200

Michigan W 2400; WRI 91-4194

Micronesia W 2400

Midwest environmental geology OF 93-0418; OP1000

pollution OF 93-0418

Minnesota W 2400; OP-423

Mississippi W 2400; OF 92-0469

Mississippi Valley OP-1643

Missouri

W 2400; WRI 93-4012

geomorphology OP-1544

Montana W 2400; WRI 91-4199; WRI 92 4066; OP-166

Nebraska

W 2400

pollution OP-1909

Nevada W 2400; OF 93-0097

New Hampshire W 2400; OF 89-0583

New Jersey

W 2400; C 1086; WRI 91-4169

environmental geology OF 92-0153

New Mexico W 2400; OF 92-0653; OF 93 0084; OP-598; OP-1435

New York

W 2387; W 2400; WRI 90-4205; OF 920476; OP-1093; OP-1335; OP-1734 environmental geology OP-1130; OP-1735

North Carolina W 2364; W 2400; WRI $92-$ 4129; OF 92-0123; OF 92-0639

North Dakota W 2400; OP-1071

Ohio

W 2400; OF 92-0120

environmental geology WRI 92-4130

Oklahoma W 2400; OF 93-0171

Oregon

W 2400

geologic hazards OF 92-0483

pollution WRI 92-4136

Panama, weathering C 1086

Pennsylvania W 2400; WRI 90-4011; WRI 90 4131; OF 93-0115

Philippine Islands, geologic hazards WRI 924039

pollution YR; OF 92-0494; OP-181; OP-321; OP-691; OP-692; OP-816; OP-1425; OP1645

Puerto Rico

W 2400; C 1086; WRI 90-4125; OF 930029

pollution OP-663

weathering $C 1086$

Rhode Island W 2400

South Carolina W 2400

South Dakota W 2400

Tennessee W 2400; WRI 92-4131; OF 92-0482

Texas W 2400

United States W 2400; OP-2007

Utah W 2400; OP-424

Vermont W 2400

Virginia W 2340; W 2400; OP-1573; OP-1610

Washington

W 2340; W 2400; WRI 91-4073; OF 910453; OF 91-0454

environmental geology C 1090

geochemistry OP-1121

pollution OP-1827

West Pacific Ocean Islands W 2400

West Virginia W 2400; WRI 92-4073; OF $92-$ 0065; OP-1543

Wisconsin W 2400; WRI 92-4029

Wyoming

W 2400; WRI $91-4199$

impact statements WRI 90-4154 
hydrothermal alteration see also ore-forming

fluids; thermal waters.

OP-1246; OP-1248; OP-1785

Bolivia, metal ores OF 93-0016

California, geochemistry OP-890

China, metal ores OP-153

Colorado, stratigraphy OP-985

deformation OP-740

economic geology OP-873

Ecuador, gold ores B 2039

engineering geology $\mathrm{OP}-760$

Gabon, geochemistry OP-713

geochemistry OP-537

Hawaii, paleomagnetism OP-436

Iceland, geochemistry OP-511

Michigan

OP-1116

geochemistry OP-1747

Nevada, metal ores OP-627

New Mexico, molybdenum ores OP-1243; OP1927

New South Wales Australia, metal ores OP-942

North Carolina, economic geology B 2039

Oregon B 2054

Queensland Australia, metal ores OP-942

sedimentary petrology OP-1135

Washington GQ-1679

hydrothermal chimneys see hydrothermal vents

hydrothermal processes see also epithermal pro-

cesses; hot springs; igneous processes; ore-forming fluids.

Arizona, metal ores B 2042-C

British Columbia, copper ores OP-273

California

geothermal energy OP-324

metal ores OP-554

Canada, metal ores OP-728

China

metal ores OP-1238

metasomatism OP-1343

Colorado

base metals OF 93-0183

metal ores OF 92-0525; OP-937; OP-1633

molybdenum ores OP-1050

sedimentary petrology OP-1382

Dominican Republic, metal ores OP-532

England, geochemistry OP-158

Hawaii, oceanography OP-418

metal ores OP-852; OP-1117

Michigan, energy sources OF 92-0391

Missouri, metal ores OP-1418; OP-1885

Montana, copper ores OP-273

Nevada

economic geology OP-736

geochemistry OP-1302

gold ores OP-27; OP-994

metal ore OP-489

New Mexico, petroleum B 2039

Ontario, polymetallic ores OP-484

Pacific Ocean, sedimentation OP-243

Papua New Guinea, economic geology OP-639

Russian Federation, geochemistry OP-130

Spain, metal ores OP-875

United States, metal ores OP-728

Utah, gold ores OP-1096

Wyoming, petroleum B 2039

hydrothermal vents

California, geochemistry OP-955

Pacific Ocean

plate tectonics OP-1901

tectonophysics OP-897
Hylas Zone

geochemistry OP-344

HYPERMAG

geophysical surveys OF 93-0287

hypermedia

Arctic region, ecology C 1086

Hypertext OP-2008

HYPO71

earthquakes OF 92-0441

HYPOELLIPSE

earthquakes OF 92-0441

hypogene processes see endogene processes

HYPOSHOT

seismic sources OF 93-0221

hysteresis

hydrogeology OP-732

\section{I}

\section{I-type granites}

Canada OP-1463

Sweden, geochemistry OP-552

United States OP-1463

lasp91 model

earthquakes OP-1364

Iberian Peninsula see Gibraltar, Portugal; Spain

Ibexian

Ordovician OP-1818

ice

OP-281; OP-1224; OP-1348; OP-1667

Alaska, Quaternary C 1086; OP-1507

California, Quaternary OP-1254

frost action OP-389

geophysics OP-282; OP-1586

Greenland, Quaternary OP-1507

hydrology OF 92-0534

Nevada, hydrology OP -448

Quatemary OP-686

Wyoming

geochemistry OP-712

Quaternary OP-711

ice mantle see ice sheets

ice movement see also ice streams.

OP-508

Alaska

geologic hazards YR

hydrology C 1086

Quatemary C 1086

Antarctica, Quatemary C 1086

Massachusetts, neotectonics OP-555

ice rafting

Alaska

continental shelf OP-837

oceanography OF 93-0019

sea ice OF 93-0237

Antarctic Ocean, oceanography OP-263

Arctic Ocean

oceanography OP-835

Quaternary OF 92-0439

Arctic region, Quatemary OF 92-0439

GreatLakes, geomorphology OP-836; OP-1143

ice ridges

Illinois, environmental geology YR

Indiana, environmental geology YR

ice sheets

OP-1241; OP-1564; OP-1565

Antarctic Ocean

Quaternary OP-1358; OP-1630

Tertiary OP-1145

Antarctica OP-842 ground water OP-952

Massachusetts, neotectonics OP-555

Quatemary OP-81; OP-201

Washington, Quaternary OP-1999

ice shelves

Antarctica, Quaternary C 1086

ice streams

Quatemary OP-81

ice-marginal features

Alaska, Quaternary OF 93-0266

New England, Quatemary C 1086

ice-rafting see ice rafting

icebergs

Alaska, geologic hazards YR

Iceland

OP-1405

geochemistry

OP-1997

Surtsey OP-511

Quaternary, Vatnajokull OP-386

seismicity OP-322

stratigraphy OP-1303

tectonophysics OP-420

icy satellites see also Ariel Satellite; Triton Satellite.

OP-281

geophysics OP-282

Idaho see also Beaverhead Mountains; Brigham Group; Cache Valley; Challis Volcanics; Columbia Plateau; Columbia River Basalt Group;

Glenns Ferry Formation; Idaho Batholith;

Salmon River, Westem Overthrust Belt.

areal geology OP-594

Ada County Idaho OP-1197

building stone $\mathrm{B} 2013$

Devonian

Bonner County Idaho OF 93-0184

Boundary County Idaho OF 93-0184

economic geology OF $92-0525$

energy sources OF 93-0248

environmental geology

OF 93-0292-J

Butte County Idaho OF 92-0156

Snake River plain OF 92-0156

Eocene OP-1081

faults OP-685

geochemistry

Custer County Idaho OP-912

Lemhi County Idaho OP-912

geochronology

Benewah County Idaho OP-1067

Bonner County Idaho OP-1067.

Butte County Idaho OP-479.

Custer County Idaho OP-479

Kootenai County Idaho OP-1067

Lemhi County Idaho OP-479

Lemhi Range OP-479

Lost River Range OP -479

gold ores

Adams County Idaho OF 93-0527

Blaine County Idaho B 2039

Boise County Idaho B 2039; OF 93-0527

Camas County Idaho B 2039

Custer County Idaho B 2039

Elmore County Idaho B 2039

Gem County Idaho OF 93-0527

Lemhi County Idaho B 2039

Valley County Idaho OF 93-0527

Washington County Idaho OF 93-0527

ground water

YR; WRI 92-4116 
Bannock County Idaho WRI 92-4014

Bingham County Idaho WRI 92-4014; WRI 93-4054; OF 92-0643

Butte County Idaho WRI 92-4184; WRI 934054; OF 92-0643; OF 93-0034

Elmore County Idaho WRI 92-4027

Jefferson County Idaho WRI 93-4054; OF 92-0643

Snake River plain WRI 92-4014; WRI 92 4184; WRI 93-4054; OF 92-0643; OF 93-0034; OP-147

heavy mineral deposits OF 93-0240-A; OF 930240-B

hydrogeology

OF 93-0149; OP-166

Bannock County Idaho OF 92-0173

Bingham County Idaho P 1408-F; OF 92 0174; OF 93-0102

Blaine County Idaho P 1408-F; OF 93-0102

Bonneville County Idaho P 1408-F

Butte County Idaho P 1408-F; OF 92-0174; OF 93-0102

Cassia County Idaho OF 93-0102

Clark County Idaho P 1408-F

Franklin County Idaho OF 92-0173

Fremont County Idaho P 1408-F

Gooding County Idaho OF 93-0102

Jefferson County Idaho P 1408-F; OF $92-$ 0174

Jerome County Idaho P 1408-F; OF 93-0102

Lincoln County Idaho P 1408-F; OF 930102

Madison County Idaho P 1408-F

Minidoka County Idaho P 1408-F; OF 930102

Owyhee County Idaho WRI 93-4001

Power County Idaho P 1408-F; OF 93-0102

Snake River plain P 1408-F; WRI 93-4001; OF 91-0098; OF 92-0174; OF 93-0102; OP-1654

Twin Falls County Idaho OF 93-0102 hydrology

W 2400; WRI 92-4060; OP-1044

Bingham County Idaho WRI 92-4196

Butte County Idaho WRI 92-4196

Clark County Idaho WRI 92-4196

Custer County Idaho P 0870-A; WRI 92 4196

Jefferson County Idaho WRI 92-4196

Snake River plain WRI 92-4196

industrial minerals B 2013

maps

YR

Idaho County Idaho I-2299

Lemhi County Idaho MF-2234; I-1803-H

metal ores

C 0930-M; OP-876

Blackbird mining district OP-715

Shoshone County Idaho OF 93-0235

mineral resources

Clearwater County Idaho OF 90-0672; OF 92-0384

Idaho County Idaho OF 90-0672

Shoshone County Idaho OF 92-0384

natural gas

OF 92-0524; OF 93-0248

Snake River plain OF 93-0248

neotectonics

Adams County Idaho OP-634

Snake River plain OP-780

Washington County Idaho OP-634 orogeny OP-797

paleobotany, Salmon Idaho OP-1082 paleomagnetism

Canyon County Idaho OF 92-0542

Snake River plain OF 92-0542; OP-697

petrology

OP-434

Ada County Idaho OP-1381

Adams County Idaho OP-630

Idaho County Idaho OP-630

Snake River plain OP-560; OP-561

Valley County Idaho OP-630

Quaternary

OP-201; OP-459; OP-1524

Butte County Idaho OF 93-0327

Fremont County Idaho OF 92-0408

Snake River plain OF 93-0327; OP-452

stratigraphy

Bannock Range OP-1320

Owyhee County Idaho OF 92-0713

Pioneer Mountains OP-1351

Snake River plain OF 92-0713

structural geology

OP-523

Boundary County Idaho OP-18

tectonics OP-753

thermal waters OF 92-0175

tungsten ores, Custer County Idaho OP-1296

uranium ores $\mathrm{OP}-655$

Idaho Batholith

gold ores B 2039

petrology OP-630; OP-1463; OP-1671

Idaho National Engineering Laboratory environmental geology OF 92-0156

ground water WRI 92-4184; WRI 93-4054;

OF 92-0643; OF 93-0034; OP-147

hydrogeology OF 93-0102

hydrology WRI 92-4196

Quaternary OF 93-0327

Idaho Springs Colorado

geochemistry OF 93-0321

metal ores OP-937

pollution OP-1968

Idarado Mine

base metals OF 93-0183

Iditarod mining district

metal ores OP-123; OP-1203

Ignacio Blanco Field

energy sources OP-518

igneous processes

Colorado, economic geology OP-872

Illinois

hydrogeology OP-1782

non-metal deposits OP-1419

Italy, metal ores OF 93-0504

Kentucky

hydrogeology OP-1782

non-metal deposits OP-1419

Mexico, economic geology OP-872

Michigan, copper ores OP-1688

Missouri

iron ores OP-1297

metal ores OP-1326; OP-1327

Peru, economic geology OP-872

Utah

base metals OP-394

economic geology OP-872 .

metal ores OP-1464

Igneous rocks see also intrusions; plutonic rocks;

plutons.

A-type granites, Virginia OP-1002

Alaska, metal ores OP-224; OP-1203

alkali basalts

Arizona OP-1748 geochemistry OP-537

andesites

Alaska OP-316; OP-826

Argentina OP-1129

California OP-342; OP-427; OP-1474; OP1701

Chile OP-957

Colorado OP-490

geochemistry OF 92-0525

Idaho OP-434

Mexico OP-1778

Nevada OP-342; OP-1302

New Mexico OP-490; OP-573

Oregon OP-982; OP-1134

Russian Federation OP-1407

Spain OP-875

Washington OP-957

anorthosite

OP-661; OP-1392; OP-1482; OP-1698; OP-

1803; OP-1805

Idaho OP-434

Minnesota OP-758

Montana OP-604; OP-1663

Nova Scotia OP-1122

aplite, Oregon OP-42

Arizona OP-1112

ash-flow tuff

Alaska OP-1770

Colorado OP-1813; OP-1825

Idaho OF 92-0408; OP-1381

Nevada OF 93-0021; OP-863; OP-1609

Quatemary OP-459

Wyoming OF 92-0408

basalts

OF 92-0020-G; OP-478; OP-783; OP-

1806; OP-1841; OP-2025

Alaska OF 92-0701; OP-1169

California OP-128

Cameroon OP-903

Chile OP-279

Greenland OP-636

Hawaii OP-1001; OP-1997

Iceland OP-511; OP-1303; OP-1997

Idaho OF 91-0098; OP-452; OP-1654

India OP-1346

Michigan OP-1747; OP-2019

New Jersey OF 93-0010; OP-1003

Oregon WRI 90-4085; WRI 91-4087; OF 91-0098; OP-1134

Philippine Islands OP-1768

Russian Federation OP-2014

tectonics OP-137

Virginia B 1839-I,J

Washington WRI 90-4085

West Virginia B 1839-I,J

basanite, Alaska OP-242

California

OP-1112

economic geology B 2019

carbonatites

California OP-1584

Colorado OP-1584

economic geology OF 92-0557

Colorado

metal ores OF 92-0557; OF 93-0343

mineral resources OP-95

Colorado Platean, structural geology OP-679

dacites

Alaska OP-826; OP-1771

Bolivia B 2039

California OP-427

geochemistry OF 92-0525

Nevada B 2052 
Oregon OF 93-0314

Philippine Islands OP-1768

Spain OP-231

Washington OP-1362

diabase

Alaska OP-94

Arizona OP-398

geochronology OF $92-0525$

Pacific Ocean OP-1230

Sweden OP-552

Wyoming OP-1456

diorites

Arizona OP-1886

California OP-182; OP-1340

Mexico OP-1886

dunite

OP-478; OP-805

Califormia B 2014

economic geology OF 92-0020-B

flood basalts

geochemistry OP-30

geochronology OP-134

Great Lakes region OP-1216

Russian Federation OP-1086

gabbros

OF 92-0020-G; OP-814

Califomia B 2014; OP-182; OP-1141

Oman OP-815

Oregon OP-1139; OP-1141

Vermont OP-37

geochronology OF 92-0525

glasses

OP-843

Alaska OP-1469; OP-1929

geochemistry OP-1653

Haiti OP-1179

Hawaii OP-446

Mexico OP-1179

mineralogy OP-233

Oregon OP-42

Philippine Islands OP-1994

granites

OP-1061

Alaska OF 92-0724; OP-1194

Appalachians OP-1380

Arizona OF 92-0591-A; OF 92-0591-B

California OP-678; OP-1126; OP-1141; OP1711

Colorado OF 92-0525; OP-1051; OP-1913

England OP-158

fractures OF 93-0245; OP-1026; OP-1721

heavy minerals OF 92-0386

Idaho OP-1671

Manitoba OP-1560

Michigan B 1904-S; OP-1889

Minnesota B 1904-S

Nevada B 2039

New South Wales Australia OP-7

Ontario OP-1560

Oregon OP-1141

rock mechanics OP-600; OP-603; OP-689

Saudi Arabia OP-499; OP-1558; OP-1559

structural geology OP-602

Sweden OP-1042

Washington GQ-1679; OP-1397

granodiorites

OP-1138

California OP-182; OP-1691

Canada OP-1463

Maine B 2039

Montana B 1993

Nevada OP-45; OP-779; OP-1302

Nova Scotia OP-1122
Oregon OP-42; OP-1124

Puerto Rico OP-1960

Rocky Mountains OP-1716

United States OP-1463

Vermont OP-37

granophyre, Oregon OP-42

hornblendite, California OP-730

I-type granites

Canada OP-1463

Sweden OP-552

United States OP-1463

ignimbrite

Alaska OP-316

Idaho OP-697; OP-780

Nevada OF 93-0248

Oregon OP-1404

Wyoming OP-697; OP-780

ijolite, Arkansas OP-1837

kimberlite

Montana OP-1491

non-metal deposits OF 92-0557

lamprophyres

OP-1417

Arizona OP-1886

Mexico OP-1886

latite, Colorado OP-1633

leucogranite

Nevada OF 92-0525

Vermont OP-37

lherzolite, China OP-457

metal ores OF 92-0557

Michigan, structural geology OP-1214

microgranite, Scotland OF 93-0267

mid-ocean ridge basalts, Pacific Ocean OP-413; OP-813

mineral resources OF 92-0557

mineralogy OP-414

monzodiorite, Vermont OP-37

monzogranite, Montana B 1993

monzonites

Colorado OP-1633

Quebec OP-1097

Nevada

base metals OP-79

economic geology B 2019

gold ores OP-921

norite OP-478; OP-805

obsidian

Indonesia OP-1538

Ivory Coast OF 92-0699

New Mexico OF 92-0699; OP-1538

Oregon OP-982

Quaternary OP-459; OP-1524

palagonite, Iceland OP-511

peridotites

California OP-730

Fiji OP-1758

Saudi Arabia OP-1952

Tonga OP-1758

plutonic rocks

Alaska OF 92-0020-E

Antarctica OP-1027

California OP-260; OP-333

Colorado OP-11; OP-828; OP-1825

geochemistry OF 92-0525

Idaho OP-630; OP-1067

Italy OF 93-0504

Montana OP-1462

Nevada OP-260

New Mexico OP-11

Nova Scotia OF 92-0525

Pacific Ocean OP-105

Washington I-1963; OP-1067 porphyry, Arizona B 2021-C

pumice

Alaska OP-1469

Nevada OP-1899

Oregon OP-43

Wyoming OF 92-0391

pyroclastics

OP-1323; OP-1830

Alaska OF 92-0701; OP-845; OP-1754

Arizona B 2021-C

Califomia OP-428

Guatemala OP-277

Iceland OP-511

Oregon OP-1549

Philippine Islands OP-1994

Washington OP-956

pyroxenite

California B 2014

Saudi Arabia OP-1952

quartz diorites

Canada OP-1463

Oregon OP-1139

United States OP-1463

quartz monzonite, Montana OP-1087

rhyodacites, Oregon OF 93-0314; OP-982

rhyolite tuff

Idaho OP-479

Utah B 2039

rhyolites

OP-1061

Alaska OP-316; OP-1770

Arizona B 2021-C

Califomia OP-266; OP-1474

Idaho OF 92-0408; OP-617; OP-1381

Indonesia OP-1538

Ivory Coast OF 92-0699

Missouri B 2039; OP-1327

Montana OP-617

Nevada OF 93-0249; OP-809

New Mexico OF 92-0699; OP-278; OP1538

Virginia B 1839-I,J

West Virginia B 1839-I,J

Wyoming OF 92-0408; OP-49

Rocky Mountains, structural geology OP-679

S-type granites, Malaysia OF 92-0525

scoria, Philippine Islands OP-1768

stratigraphy OP-1756

syenites

Arkansas OP-1837

Montana OP-1294

Nova Scotia OP-1122

tholeiite

Oregon OP-1139

Red Sea OP-2029

tholeiitic basalt, Minnesota OF 92-0525

tonalite

Alaska OP-1194

Canada OP-1463

Nova Scotia OP-1122

Oregon OP-1139

Rocky Mountains OP-1716

United States OP-1463

trachyandesites, Mexico OP-1778

trachytes

Hawaii OP-164

Virginia B 1839-I,J

West Virginia B 1839-I,J

troctolite

OP-805; OP-806

Minnesota OP-758

trondhjemite

California OP-1141 


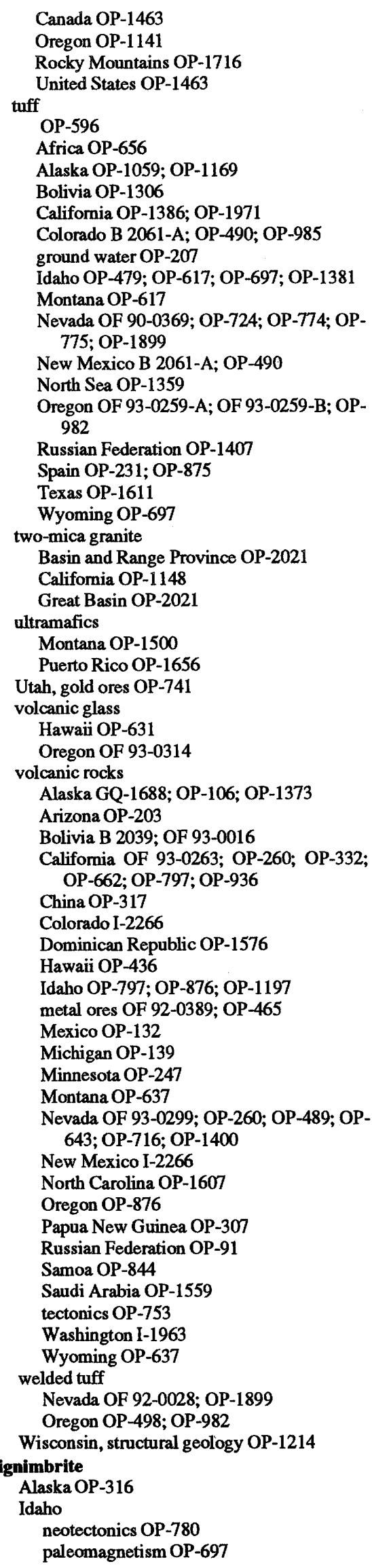

Nevada, natural gas OF 93-0248

Oregon, Quaternary OP-1404

Wyoming

neotectonics OP-780

paleomagnetism OP-697

ignition

Kentucky, geochemistry B 2046

ijolite

Arkansas OP-1837

ikaite

Califomia, sedimentary petrology OP-77

Nevada, geochemistry OP-76

\section{Illinoian}

OP-201

Illinois OP-1309

New England OP-748

Illinois see also Brassfield Formation; Illinois

Basin; Lake Michigan; Maquoketa Formation;

Michigan Basin; Mississippi Embayment; Mis-

sissippi River, Mount Simon Sandstone; New

Madrid region; Saint Peter Sandstone; Upper

Mississippi Valley.

changes of level, Chicago Illinois OP-1393

engineering geology OF 93-0349

environmental geology

Alexander County Illinois C 1120-C

Burean County Illinois W 2390

Chicago Illinois YR

Kane County Illinois OF 92-0514

Lake County Illinois YR

Pike County Illinois C 1120-C

Pulaski County Illinois C 1120-C

ground water P 1405-B; OF 92-0694; OF 930114

highways WRI 92-4147

hydrogeology

WRI 92-4149

Bureau County Illinois W 2386

hydrology

W 2400; C 1120-A; OF 91-0485; OF 92-

0451; OF 92-0452

Chicago Illinois YR

Du Page County Illinois OF 92-0485

industrial minerals OF 92-0514 maps

$\mathrm{I}-1420$ (NJ-15)

Lake County Illinois YR

metal ores MF-1835-H

non-metal deposits

OF 92-0514; OP-1419

Alexander County Illinois OF 92-0514

Chicago Illinois OF 92-0514

Kankakee County Illinois OF 92-0514

Massac County Illinois OF 92-0514

Pope County Illinois OF 92-0514

Pulaski County Illinois OF 92-0514

Will County Illinois OF 92-0514

Quaternary

OP-1309

Clark County Illinois P 1536

Crawford County Illinois P 1536

Lawrence County Illinois P 1536

Wabash County Illinois P 1536

White County Illinois P 1536

seismology SM

\section{Illinois Basin}

diagenesis OP-1466

energy sources B 1909

ground water $P$ 1405-C

hydrogeology OP-1782

Mississippian B 1909

petroleum B 1909 sedimentary petrology OF 92-0391

structural geology OP-1799

Illinois River

environmental geology C 1120-C

Illinoisan see Illinoian

illite

California

diagenesis OP-1386

sedimentary petrology OP-1791

structural geology OP-702

clay mineralogy OP-1069

Colorado, diagenesis OP-1961

diagenesis OP-1627

geochemistry OP-289

Gulf of Mexico

petrology OP-287

sedimentary petrology OP-288

Indiana, diagenesis OP-1466

New Mexico, petroleum B 2039

petroleum B 1909; OP-793

Rocky Mountains, diagenesis OP-1792

sedimentary petrology OP-1352; OP-1353

Utah, diagenesis OP-1961

Western Interior clay mineralogy OP-794

diagenesis OP-1792

Wyoming

diagenesis OP-1950

petroleum B 2039

ilmenite

OP-112

Montana, petrology OP-604

imbricate tectonics

Appalachians OP-1147

Montana

B 1993

petroleum OF 93-0337

Vanuatu, tectonophysics OP-1908

imbrication

Pakistan, tectonophysics OP-1548

Imbrium Basin see Sea of Rains

impact craters see also meteor craters.

OP-29; OP-142; OP-148; OP-237; OP-246; OP-

416; OP-657; OP-690; OP-887; OP-1062; OP-

1236; OP-1485; OP-1724; OP-1790; OP-1854;

OP-1938

Germany, stratigraphy B 2050

Iowa

OP-1882

geochronology OP-475; OP-1613

petrology OP-1113

stratigraphy B 2050

Mexico, stratigraphy B 2050

petrology OP-1177

South Dakota, geochronology OP-475 OP-786; OP-1459; OP-1841

Colorado, stratigraphy OP-1880

Iowa, stratigraphy $\mathrm{OP}-1537$

New Mexico, stratigraphy OP-1880

Sweden, geochemistry OP-552

impact statements

Alaska geochemistry OF 93-0014

hydrology OF 93-0095

Arizona

YR

ground water WRI 90-4105

California OF 92-0447

Colorado

ground water OF 92-0122

hydrogeology WRI 92-4050

hydrology WRI 91-4095 
Florida WRI 91-4181

Hawaii

OF 93-0512-A

hydrology WRI 92-4049

Illinois, non-metal deposits OF 92-0514

Massachusetts, oceanography DDS-0003

New Mexico, hydrogeology WRI 92-4004

Ohio, hydrology OF 92-0120

Puerto Rico

OF $92-0717$

sands OF 92-0717

South Carolina, engineering geology. WRI 904056

Utah, ground water WRI 90-4105

Wisconsin

hydrology WRI $92-4029$

non-metal deposits OF 92-0514

Wyoming

WRI 90-4154

hydrology WRI 92-4091

impactite

OP-1314; OP-1315

Sweden, geochemistry OP-552

Imperial Fault

earthquakes OF 91-0032

Imperial Valley

environmental geology OF 93-0083

stratigraphy OP-257

incarbonization see coalification

inclination, magnetic see magnetic inclination

inclusions see also fluid inclusions.

Arizona OP-1748

calcium-aluminum inclusions OP-1704; OP1705

Califormia OP-1376

mineral inclusions, Montana OP-604

Oregon, geochemistry OF 93-0314

sedimentary petrology OP-1293

xenoliths

OP-1704; OP-1943

Califomia OP-678; OP-730; OP-1711

Chile OP-279

China OP-457

Colorado OP-490

Ecuador B 2039

geochemistry OF 92-0525

Hawaii OP-164

Mexico OP-132

New Mexico OP-490

Saudi Arabia OP-1952

incoalation see coalification

Incorporated Research Institutions for Seismology network see IRIS network

increment see recharge

incrustations see encrustations

Independence Mountains gold ores OP-441

index maps

Alaska, environmental geology SM

India see also Deccan Traps.

geophysics OP-136

metal ores C 0930-N

Indian Bathtub Spring

hydrogeology WRI 93-4001

Indian Ocean see also Arabian Sea; Red Sea.

deformation, Argo abyssal plain OP-146

geochemistry OP-755

mantle OP-71

marine geology

Argo abyssal plain OP-361

Exmouth Plateau OP-361
Tertiary, Kerguelen Plateau OP-1145

Indian Peninsula see Afghanistan; Bangladesh; India; Pakistan

Indian Plate

Indian Ocean, deformation OP-146

Pakistan

natural gas OP-1634

structural geology OP-1125

tectonophysics OP-1548

Vanuatu, tectonophysics OP-1908

Indian reservations see also Nåvajo Indian Reservation; Yakima Indian Reservation.

Arizona, gold ores OF 92-0591-A; OF 920591-B

Colorado

non-metal deposits B 2061-A

sedimentary petrology OF 93-0306

Idaho, ground water WRI 92-4014

mineral resources OF 92-0514

Montana

ground water WRI 92-4162; WRI 92-4163 hydrogeology WRI 92-4066; WRI 92-4185

New Mexico

ground water WRI 91-4033

non-metal deposits B 2061-A

Oregon, hydrogeology WRI 91-4087

South Dakota, non-metal deposits OF 92-0514

Wisconsin, hydrogeology OF 92-0026

Wyoming

hydrogeology WRI 91-4108 hydrology OF 93-0142

Indian Well Formation stratigraphy B 1988-C

Indiana see also Brassfield Formation; Illinois

Basin; Lake Michigan; Michigan Basin; Mount

Simon Sandstone; New Albany Shale.

engineering geology OF 93-0349

environmental geology

Johnson County Indiana W 2393

Lake County Indiana YR

Marion County Indiana W 2393

Morgan County Indiana W 2393

Porter County Indiana YR

geochemistry, Marion County Indiana OP-1685

ground water

P 1405-B; OF 92-0489; OF 92-0694; OF 93-0114; OF 93-0119; OP-1648 Elkhart County Indiana OF 92-0055 Porter County Indiana OP-923

hydrogeology, Henry County Indiana WRI 924025

hydrology

W 2400; OF 92-0651

Laporte County Indiana WRI 92-4019

Noble County Indiana WRI 92-4033

Union County Indiana WRI 92-4113

Wayne County Indiana WRI 92-4113

industrial minerals OF 92-0514

maps OF 93-0268-A; OF 93-0268-B

non-metal deposits OF 92-0514

Quaternary

OP-1308

Gibson County Indiana P 1536

Knox County Indiana P 1536

Pike County Indiana P 1536

Posey County Indiana P 1536

Sullivan County Indiana P 1536

Vigo County Indiana P 1536

sedimentary petrology

Clay County Indiana OF 92-0682

Daviess County Indiana OF 92-0682

Dubois County Indiana OF 92-0682
Gibson County Indiana OF 92-0682

Greene County Indiana OF 92-0682

Knox County Indiana OF 92-0682

Martin County Indiana OF 92-0682

Owen County Indiana OF 92-0682

Parke County Indiana OF 92-0682

Perry County Indiana OF 92-0682

Pike County Indiana OF 92-0682

Spencer County Indiana OF 92-0682

Sullivan County Indiana OF 92-0682

Vermillion County Indiana OF 92-0682

Vigo County Indiana OF 92-0682

Warrick County Indiana OF 92-0682 seismology SM

tectonics OP-1652

Indiana Dunes National Lakeshore

environmental geology YR

Indianapolis Indiana

environmental geology W 2393

geochemistry OP-1685

Indio Hills

Quaternary OP-1844

Indochina

petroleum OP-1829

Indonesia

engineering geology, Celebes OP-993

geochronology, Sumatra OP-1538

geophysical surveys, Java B 1966

Plantae, Kalimantan Indonesia OP-695

Quatemary OP-1743

sedimentary petrology

OP-1478

Celebes OP-870

Kalimantan Indonesia OP-870

sedimentation, Sumatra OP-1211

Indonesian Seas see Celebes Sea

induced polarization

California, geophysical surveys OF 92-0544

inductive terrain conductivity

New Hampshire, environmental geology WRI 92-4012; WRI 92-4056

inductively coupled plasma methods geochemistry B 1770; OP-505; OP-1653 hydrology OF 92-0634

Kentucky, geochemistry B 2046

Indus Plain

lignite OF 92-0576

industrial ash see ash

industrial minerals see also graphite deposits;

industrial minerals maps; zeolite deposits.

B 2013; OF 92-0514

Alaska C 1091

Appalachians B 1979

Arizona OF 93-0329

Basin and Range Province B 2013

environmental geology B 2013

environmental geology B 2013

Far East C 0930-N

Idaho B 2013

Thinois OF 92-0514

Indiana OF 92-0514

Michigan OF 92-0514

Midwest OF 92-0514

Minnesota OF 92-0514

Nevada

B 2013; OP-765

environmental geology B 2013

North Carolina B 2005

North Dakota OF 92-0514

Ohio OF 92-0514 
South Dakota OF 92-0514

Tennessee B 2005

Utah

B 2013

environmental geology B 2013

waste disposal B 2013

waste disposal B 2013

Wisconsin OF 92-0514

industrial minerals maps

Arizona OF 92-0687

industrial waste

New York, ground water WRI 90-4182

Vermont, environmental geology OP-1481

inert gases see noble gases

infiltration

Georgia, hydrology OP-1875

Hawaii

hydrogeology WRI 91-4197

soil mechanics OP-1814

highways WRI 92-4147

hydrology WRI $92-4095$

Idaho

ground water OP-147

hydrogeology OP-1654

New York, ground water WRI 91-4012

West Virginia, hydrogeology W 2384

Wyoming, geochemistry OP-327

Inflatia

Invertebrata OP-360

inflation

California, structural geology OP-569

Hawaii, petrology OF 93-0342-A; OF 930342-B

information systems see also geographic information systems.

YR; C 1086; OP-830; OP-2008

Arctic region, ecology C 1086

environmental geology C 1086

geochemistry OF $92-0392$

geologic hazards OP-114

hydrology OF 92-0632

Mississippi, ground water OP-745

Utah, geologic hazards P 1519

infrared methods

petrology OP-1584

infrared spectroseopy

hydrology OF 92-0480

Iniskin Peninsula

energy sources OP-626

Inner Mongolia China

metal ores OF 92-0525; OP-153; OP-1238

metasomatism OP-1343

inner transition elements see rare earths

Inoceramidae

Texas, stratigraphy OP-177

insecticides

New Jersey, environmental geology OF $92-$ 0153

pollution OP-816

insects

Alaska, Quaternary OP-299

Washington, ecology OF 91-0453

installations, marine see marine installations

installations, underground see underground instal-

lations

insular slope

Puerto Rico, oceanography B 2002

Interior Coal Province

energy sources OP-1476 intermontane basins

Basin and Range Province, petroleum OF 930248

China, plate tectonics OP-1519

Colorado, Paleogene B 1787-Q

Colorado Platean, petroleum OF 93-0248

Idaho

ground water WRI $92-4116$

hydrogeology OP-166

Montana

ground water WRI 92-4116

hydrogeology OP-166

natural gas OF 93-0337

stratigraphy $P$ 1506-F

United States, plate tectonics OP-1519

Utah, Paleogene B 1787-Q

Wyoming

energy sources OF 93-0337 natural gas $\mathrm{OF}$ 93-0337

International Falls Quadrangle soils OF 92-0721

International Lithosphere Program engineering geology OF 93-0338

International Seismological Centre earthquakes OP-1019

International Seismological Observing Period earthquakes OP-1161

seismology OP-1160; OP-1365; OP-1783

interplanetary dust $\mathrm{OP}-1389$

Interstate Mining Compact Commission economic geology B 2013

intertidal sedimentation Kentucky OF 92-0558

intrusion (ground water) see salt-water intrusion

intrusions see also domes.

OP-1408

Alaska

OP-1401

geochemistry OP-721

Antarctic Ocean, tectonophysics OP-1446

Arizona, stratigraphy OP-398

Basin and Range Province, structural geology OP-769

batholiths

OP-596; OP-1246

Alaska OP-1 195

British Columbia OP-273

California OP-182; OP-333; OP-678; OP1146; OP-1691

Colorado OP-10

Ecuador B 2039

Idaho B 2039; OP-630

Montana OP-273

Nevada B 2039

Pacific Ocean OP-105

Vermont OP-37

Washington I-1963

breccia pipes

Arizona OF 93-0329; I-2290; OP-613; OP1617; OP-1993

Missouri B 2039; OP-1327

Califomia OP-1126; OP-1282

Canada, metal ores OP-728

Colorado, metal ores OP-1633

Colorado Plateau, structural geology OP-769

diatremes

OP-596

Dominican Republic OP-532

non-metal deposits OF 92-0557

Saudi Arabia OP-1952

Virginia B 1839-I,J

West Virginia B 1839-I,J dikes

OP-1417; OP-1421

Alaska OP-94

Arizona OP-1748; OP-1886

British Columbia OP-1159

California OP-678; OP-1691; OP-1711

Colorado OF 93-0183; OP-827; OP-1050

geochronology OF 92-0525

gold ores OP-168

Idaho OP-560

Illinois OP-1419

Italy OP-1808

Kentucky OP-1419

Kenya OP-521

Maine B 2039

Mexico OP-1886

Missouri OP-1297

Nevada B 2052; OF 93-0249

Red Sea OP-2029

Syria OP-1322

Utah B 1787-HH

Victoria Australia OP-1136

Virginia B 1839-I,J

Washington OP-1159

West Virginia B 1839-I,J

Wyoming OP-1456

economic geology OF 92-0557

geochemistry OP-2018

Italy, metal ores OF 93-0504

laccoliths, Montana OP-1294

layered intrusions

OP-814

California B 2014

geochemistry OP-1621

Greenland OP-636

Montana OF 93-0207; OP-604; OP-1663

Oman OP-815

Maryland OP-1106

Minnesota OP-247

Northwest Territories, geochemistry OP-721

plugs

Argentina OP-1129

Illinois OP-1419

Kentucky OP-1419

Nevada B 2052; OP-809

Virginia B 1839-I,J

West Virginia B 1839-I,J

plutons

OP-1246

Alaska P 1497-C; OF 92-0724; I-2164; OP589; OP-1396; OP-1461

Antarctica OP-1995

Appalachians OP-1380; OP-1479

Basin and Range Province OP-545; OP2015; OP-2021

California B 2014; B 2015; OP-333; OP512; OP-1141; OP-1376; OP-1461; OP1566; OP-1691; OP-1971

Canada P 1497-C; OP-1215; OP-1463

Colorado OF 92-0391; OP-10; OP-490; OP1813

England OP-158

geophysical surveys OP-1374

Great Basin OP-545; OP-2015; OP-2021

Idaho OP-630; OP-1067; OP-1671

Manitoba OP-1560

metal ores OP-465

Minnesota OP-758

Mississippi Valley OF 92-0391

Missouri OP-1297; OP-1326; OP-1996

Nevada OP-218; OP-795

New Mexico OP-490

Nova Scotia OP-1122 
Ontario OP-1560

Oregon OP-1139; OP-1140; OP-1141

Pakistan OP-1125

Quebec OP-1097

Russian Federation OP-91; OP-1407

United States OP-1215; OP-1463

Washington GQ-1679; I-1963; OP-1067

ring complexes, Missouri OP-1297.

Russian Federation, metal ores OP-2014

Saudi Arabia, metal ores OP-1559

sills

Califormia B 2014

China OP-1361

Montana OP-1500

Nevada OP-27

Pacific Ocean OP-1230

Red Sea OP-2029

Sweden OP-552

Utah B 1787-HH

Virginia B 1839-I,J

West Virginia B 1839-I,J stocks

Bolivia B 2039

Maine B 2039

Michigan OP-1688

Montana B 1993; MF-2253

Nevada OP-1302

tin ores OF 92-0557

United States, metal ores OP-728

Utah, metal ores OP-965

Virginia OP-1106

intrusive mountain see batholiths

Invertebrata see Arthropoda; Brachiopoda;

Coelenterata; Mollusca; Protista

invertebrates see also arthropods; brachiopods; bryozoans; corals; echinoderms; foraminifers; graptolites; mollusks; radiolarians.

North Carolina, hydrology WRI 92-4129

Ohio, hydrology OF 92-0120

silicoflagellates

California OF 92-0539-E

New Jersey OP-979

Peru OP-1330

Inyo Mountains

economic geology OP-204; OP-662

Inyo National Forest

economic geology OP-260

Io Satellite I-2209; OP-1561

Ione Formation

stratigraphy OF 92-0588

ionium see Th-230

Iowa see also Cherokee Group; Marmaton Group; Mississippi River, Missouri River, Upper Mississippi Valley.

crystalline rocks OP-1114

engineering geology OF 93-0349

environmental geology

OF 93-0292-G

Clinton County Iowa C 1120-C

geochronology

OP-1613

Calhoun County Iowa OP-475

geomorphology OP-1834; OP-1882

ground water

P 1405-B; OF 92-0027; OF 93-0114; HA0730-J

Black Hawk County Iowa OF 92-0085

Boone County lowa OF 92-0167

Bremer County lowa OF 92-0085

Butler County Iowa OF 92-0085

Floyd County Iowa OF 92-0085

Jasper County Iowa OP-612
Linn County Iowa OF 92-0085

Marion County lowa OP-612

Polk County Iowa OP-612

Story County Iowa OF 92-0167

Warren County Iowa OP-612

Worth County Iowa OF 92-0085

hydrogeology

OF 92-0154

Linn County Iowa OF 92-0500

hydrology

W 2400; C 1120-A

Buena Vista County Iowa OF 92-0094

Calhoun County Iowa OF 92-0094

Carroll County lowa OF 92-0094

Dallas County lowa OF 92-0094

Greene County Iowa OF 92-0094

Guthrie County Iowa OF 92-0094

Pocahontas County Iowa OF 92-0094

Sac County Iowa OF 92-0094

Webster County Iowa OF 92-0094

natural gas OF 92-0524

Ordovician OP-1819

paleomagnetism OP-1915

petrology OP-1113; OP-1540

pollution YR; OP-588; OP-1981

sedimentary petrology OF 92-0391

stratigraphy

B 1989-E; OP-1537

Calhoun County Iowa B 2050

IPOD see Leg 45; Leg 46; Leg 78A; Leg 79; Leg

80; Leg 86; Leg 94; Leg 95; Leg 96

Ir see iridium

Iraq

geochemistry OP-615

iridium

Colombia, geochemistry OP-755

Colorado, palynomorphs OP-1388

England, geochemistry OP-755

Haiti

geochronology B 2065

stratigraphy OP-1414

Mexico

geochronology OP-920

stratigraphy OP-1414

Montana

geochronology B 2065

stratigraphy OP-1744

New Mexico, palynomorphs OP-1388

North Dakota, stratigraphy OP-1550

North Sea, stratigraphy OP-1359

Poland, geochemistry OP-755

Rocky Mountains, diagenesis OP-1792

Texas, geochemistry OP-755

Westem Interior, diagenesis OP-1792

Wyoming, stratigraphy OP-1744

IRIS network

earthquakes OP-1053

iron

Brazil, ground water OP-737

California, geochemistry B 1995-C; OP-625

Cameroon, geochemistry OP-1011

Colorado, sedimentary petrology OP-1382

geochemistry OP-104; OP-183; OP-608; OP1554; OP-1987

Greenland, Archean OP-848

Haiti, petrology OP-1873

hydrology OP-1836

Idaho, metal ores OP-715

Louisiana, geochemistry OP-935

Missouri, pollution OF 93-0101

Nevada, gold ores OP-441

New Hampshire, geochemistry OP-1207
New Jersey OF 92-0153

Oklahoma, geophysical surveys OP-1741

orthosilicates OP-1810

pollution OP-1155

Virginia, ground water WRI 92-4090

Wyoming, petrology OP-1456

\section{iron formations}

Australia, metal ores OP-1431

Canada, metal ores OP-1431

Greenland, Archean OP-848

Michigan OP-1495

Montana

geochemistry OP-1087

petrology OP-1731

iron meteorites petrology OF 92-0525; OP-1977

Iron Mountain Quadrangle maps I-2356

iron ores see also hematite.

Canada OP-728

China

OF 92-0525; OP-153; OP-1238

metasomatism OP-1343

Missouri OP-1297; OP-1326; OP-1327; OP1885

United States OP-728

iron oxides

Arizona, geochemistry OP-590

Colorado, molybdenum ores OP-375

geochemistry B 1770

Greenland, Archean OP-848

Nevada, paleomagnetism OP-863

iron-formations see iron formations

Ironton-Galesville Aquifer

ground water $P$ 1405-B

Iroquois Formation

Mesozoic OP-801

Irpinia earthquake 1980

Italy, Quaternary OP-764

Irpinia Fault

Quatemary OP-764

irrotational wave see $P$-waves

irruption (intrusion) see intrusions

Irvingtonian

Califomia OP-1844

Isabel National Forest geophysical surveys OF 93-0018

Ishpeming greenstone belt Archean B 1904-P

island ares see also back-arc basins; fore-arc basins.

Alaska

geophysical surveys OF 93-0238

intrusions OP-1401

petrology OP-1195

Quaternary OP-826

seismology OP-1

tectonophysics OP-1430

Basin and Range Province, faults OP-1158

California

geochemistry OP-890

paleomagnetism OP-1504

sedimentary petrology OP-1344

structural geology OP-1451

Central America, seismology OP-1066

Great Basin, faults OP-1158

Louisiana, geomorphology OF 92-0530

Oregon OP-87

Pacific Ocean, earthquakes OP-734

Pacific region, mantle OP-1020

plate tectonics OP-392 
Tonga

plate tectonics OP-345

tectonophysics OP-1969

Vanuatu

marine geology OP-191

plate tectonics OP-185; OP-197; OP-345; OP-1286; OP-1287

Wyoming, structural geology OP-149

Isles Dernieres

conservation OF 92-0530

geomorphology OF 92-0530

oceanography OF 92-0530

sands OF 92-0530

sedimentary petrology OP-262

sedimentation OF 92-0530

ISLSCP

environmental geology OP-507; OP-729; OP946

isoclinal folds

Montana B 1993

Vermont

copper ores B 2039

economic geology B 1955

isoleucine

California, Pleistocene OP-1619

Isom Formation

sedimentary petrology OF 92-0391

ISOP

earthquakes OP-1161

seismology OP-1160; OP-1365; OP-1783

isopach maps

California

continental margin I-2090-A

Quaternary MF-2212

South Carolina, Quatemary I-1935

stratigraphy B 1808-O; B 1917-M

isoseismic maps

Alaska, seismology P 1527

Hawaii, engineering geology B 2006

isostasy see also isostatic compensation.

Alaska, petroleum OP-492

geophysical surveys DDS-0009

Great Lakes, Quaternary OP-1289

New Mexico, geophysical surveys WRI 914065

isostatic compensation OP-29

isothermal remanent magnetization

California, paleomagnetism OP-385

Colorado, stratigraphy OP-985

Nevada, paleomagnetism OP-863

isotopes see also fractionation; lead; neodymium; potassium; radioactive isotopes; stable isotopes; strontium; sulfur; tracers; uranium.

Al-26, geomorphology OP-1750

Ar-40/Ar-39

California OP-1340

England OP-158

Far East OF 92-0525

geochronology OF 92-0525

Great Britain OF 92-0525

Idaho OP-617

Mesozoic OP-1494

Mississippi OP-746

Montana OP-617

Namibia OP-550

Nevada OF 92-0525

Ontario OP-214

Pacific Ocean OP-813

Peru OP-1601

Poland OP-1917

Russian Federation OP-1493 stratigraphy OP-1756

United States OP-1493

Arkansas, ground water OP-1191

Be-7, North Carolina OP-1684

$\mathrm{Be}-10$

Appalachians OP-1380

Arkansas OP-1683

geomorphology OP-1750

Mississippi Valley OF 93-0273

Tennessee OP-1683

$\mathrm{Be}-10 / \mathrm{Be}-9$

California OP-1018

pedogenesis OP-48

C-12

Rocky Mountains OP-1 103

Sweden OP-1649

United States OP-1649

C-13

Australia OP-1478

diagenesis OP-1477

Florida OP-1906

Illinois OP-1782

Indonesia OP-1478

Kentucky OP-1782

C-13/C-12

Alaska OP-564; OP-626; OP-1616

Antarctic Ocean OP-1535

Antarctica OP-949

California OF 93-0146

Canada OP-1776

Colombia OP-755

Colorado W 2340; WRI 93-4007

Commonwealth of Independent States OP1261; OP-1265

East Pacific Ocean Islands OP-925

energy sources OF 92-0391; OP-1822; OP1823

England OP-755

Europe OP-1261; OP-1265

Florida OP-1906; OP-1930

Galapagos Islands OP-925

geochemistry OP-1292

Indiana OP-1648

Maryland OP-524; OP-1572; OP-1573

Minnesota OP-251

Montana OP-978

Nevada C 1086; OP-643

New Mexico WRI 93-4007; OP-1072

Ohio OP-1648

Pacific Ocean OP-628; OP-1127

Poland OP-755

Russian Federation OP-2004

Texas OP-755; OP-1072

United States OP-1776

Utah W 2340

Virginia OP-524; OP-1573

C-14

Wyoming OP-978

Alaska OP-163; OP-390

Arkansas OF 93-0273; OP-1683

California OF 93-0311; OP-68; OP-77; OP338; OP-474

Colorado OP-885; OP-1324; OP-1676

Dominican Republic OP-808

Great Lakes OP-200; OP-1290

Hawaii OP-632; OP-633

Indiana OP-1648

Indonesia OP-1743

Italy OP-764

Louisiana OF 92-0530

Massachusetts OP-749

Minnesota C 1086; OP-20

Nevada OP-68
New England OP-748

Ohio OP-1648

Oregon B 2038; OP-720; OP-982

Pacific Ocean OP-519; OP-628

pedogenesis OP-48

Russian Federation C 1086

Tennessee WRI 92-4082; OF 93-0273; OP1683

Washington OF 93-0233; OP-120; OP-720; OP-904

Cl-36

Idaho OP-147

Nevada OP-1070

Cl-37/Cl-35, geochemistry OP-605

Cs-137, Great Lakes OP-1290

$\mathrm{D} / \mathrm{H}$

OP-1221; OP-1389

Alaska OP-330

Brazil OP-737

California OF 92-0655; OP-267; OP-473; OP-890

Colorado W 2340; WRI 93-4007; OP-490; OP-872; OP-1151

energy sources OP-1822; OP-1823

geochemistry OF 92-0009; OP-953

Idaho OP-912

Indiana OP-1648

Maryland OP-1824

metal ores OP-1117

Mexico OP-872

mineralogy OP-1922

Montana OP-637

Nevada W 2340

New Mexico WRI 93-4007; OP-490

Ohio OP-1648

Ontario OP-1942

Peru OP-872

Russian Federation OP-1874

Utah W 2340; OP-872

Washington OP-998

Wyoming OP-637; OP-874

economic geology OP-873

geochemistry OF 92-0525; OP-763; OP-1980

ground water OP-1706

$\mathrm{He}-4 / \mathrm{He}-3$

California OP-955

Hawaii OP-446

Wyoming OP-327; OP-536

Idaho

Eocene OP-1081

K-40

California OP-995

Nevada OP-995

Louisiana, pollution OF 92-0492

Missouri, ground water OP-1191

N-15

geochemistry OP-1990

soils OP-1951

$\mathrm{N}-15 / \mathrm{N}-14$

California OP-557

energy sources OF 92-0391

Maryland OP-1174

Minnesota OP-551

Nevada OP-557

Nd-144/Nd-143

Alaska OP-242; OP-721

Califomia OP-182; OP-730; OP-1141; OP1282

Canadian Shield OP-1316

China OP-457

Colorado OP-490; OP-1825

geochemistry OF 92-0525; OP-30 
geochronology OF 92-0525

Idaho OP-1067

Minnesota OF 92-0525

Montana OP-122; OP-2017

Nevada OP-313

New Mexico OP-490

North Carolina OP-1607

Northwest Territories OP-721

Oregon OP-1141

petrology OP-1 199

Russian Federation OP-1086

Washington OP-1067

Wyoming OP-122; OP-2017

$\mathrm{Ne}-22 / \mathrm{Ne}-20$, Hawaii OP-446

Nevada, gold ores OP-784

New South Wales Australia, metal ores OP-942

O-18

California OP-890; OP-997

Florida C 1086

Illinois OP-1782

Kentucky OP-1782

0-18/O-16

Alaska OP-330; OP-1225

Antarctic Ocean OP-1145; OP-1535

Bahamas OP-706

Barbados OP-706

Bermuda OP-706

Brazil OP-737

California OF 92-0655; OP-267; OP-332; OP-473; OP-1141; OP-1148

Colorado OP-490; OP-872; OP-1151

East Pacific Ocean Islands OP-925

energy sources OF 92-0391

Florida OP-706; OP-1930

Galapagos Islands OP-925

geochemistry OF 92-0009; OP-953

Greenland C 1086

Haiti OP-706

Iceland OP-511

Idaho OP-697

Indiana OP-1648

Maryland OP-1824

metal ores OP-1117

Mexico OP-706; OP-872

Michigan OP-1747; OP-2019

mineralogy OP-1922

Minnesota C 1086; OP-251

Missouri OP-1327

Montana OP-637; OP-978

Nevada C 1086; OP-313; OP-441; OP-643 OP-916; OP-1302

New Mexico OP-490; OP-1072

Nova Scotia OF 92-0525

Ohio OP-1648

Ontario OP-1942

Oregon OP-1141

Pacific Ocean OP-419; OP-1127

Peru OP-872

Russian Federation OP-1874

Saudi Arabia OP-1559

Sweden OP-552

Texas OP-1072

Utah OP-872

Washington OP-998

Wyoming OP-637; OP-697; OP-711; OP978

Oklahoma, ground water OF 92-0641

Ontario, metal ores OP-1978; OP-1979

Oregon, petrology OP-1140

Os-187/Os-186

China OF 92-0525

Colorado OP-1913

geochemistry OP-1621 petrology OP-1727; OP-1977

Yukon Territory OF 92-0525

$\mathrm{Pb}-206 / \mathrm{Pb}-204$

OP-806; OP-1805

Alaska OP-570

California OP-678

China OP-457

Colorado OF 92-0525; OP-11; OP-375; OP490; OP-1825

England OP-1541

geochemistry OF 92-0525; OP-2018

geochronology OF $92-0525$

Malaysia OF 92-0525

Montana OP-1087

New Mexico OP-11; OP-490

Nova Scotia OF 92-0525; OP-1122

Proterozoic OF 92-0525

Spain OP-31

$\mathrm{Pb}-207 / \mathrm{Pb}-204$

OP-806; OP-1805

Alaska OP-242; OP-570

Argentina OP-2027

Chile OP-2027

Colorado OF 92-0525; OP-11; OP-375; OP. 490

England OP-1541

geochemistry OF 92-0525

Malaysia OF 92-0525

Montana OP-1087; OP-1094

New Mexico OP-11; OP-490

Nova Scotia OF 92-0525; OP-1122

Proterozoic OF 92-0525

Spain OP-31

$\mathrm{Pb}-207 / \mathrm{Pb}-206$

Colorado OP-11

New Mexico OP-11

$\mathrm{Pb}-208 / \mathrm{Pb}-204$

Argentina OP-2027

Chile OP-2027

Colorado OF 92-0525; OP-11; OP-375; OP490

England OP-1541

geochemistry OP-2018

geochronology OF 92-0525

Malaysia OF 92-0525

Montana OP-1087

New Mexico OP-11; OP-490

Nova Scotia OP-1122

Proterozoic OF 92-0525

Spain OP-31

$\mathrm{Pb}-210$, Great Lakes OP-1290

Queensland Australia, metal ores OP-942

Ra-226

California OP-995

Nevada OP-995

New Jersey OP-986

Pennsylvania OP-915

Tennessee WRI 92-4092

Ra-228

California OP-995

Nevada OP-995

Pennsylvania OP-915

Tennessee WRI 92-4092

Rb-87/Sr-86

Colorado OP-490

New Mexico OP-490

$\mathrm{Rn}-222$

Alaska OF 93-0292-J

Arizona OF 93-0292-1

California OF 93-0292-I; OP-995

Colorado OF 93-0292-H; OP-902; OP-1394

earthquakes OP-539

East Pacific Ocean Islands OF 93-0292-I environmental geology OF 93-0292-G; OF 93-0292-H; OF 93-0292-I; OF 930292-J

geochemistry OP-379

geologic hazards OP-1052

Hawaii OF 93-0292-I

Idaho OF 93-0292-J

Iowa OF 93-0292-G

Kansas OF 93-0292-G

Missouri OF 93-0292-G

Montana OF 93-0292-H

Nebraska OF 93-0292-G

Nevada OP-995

North Dakota OF 93-0292-H

Oregon OF 93-0292-J

Pennsylvania OP-915

Polynesia OF 93-0292-I

South Dakota OF 93-0292-H

Tennessee WRI 92-4092

Utah OF 93-0292-H

Washington OF 93-0292-J

Wyoming OF 93-0292-H

S-34, Florida OP-1906

S-34/S-32

Alaska OP-570; OP-1304

Canada OP-1905

China OP-1432

Colorado W 2340; OP-872; OP-1151; OP1965

Dominican Republic OP-532

energy sources OF 92-0391

England OP-1541

Florida OP-151; OP-1906

geochemistry OF 92-0009

Indiana OP-1648

Maine OP-750

metal ores OP-1117

Mexico OP-872

Michigan OP-1688; OP-2019

Micronesia OP-59; OP-1150

Missouri OP-1327; OP-1885

Nevada OP-441; OP-774

Ohio OP-1648

Peru OP-872

Poland OF 92-0704

Russian Federation C 1086

South Carolina OF 93-0303

United States OP-1905

Utah W 2340; OP-872; OP-1965

Yukon Territory OP-1432

Sm-147/Nd-144

Colorado OP-490

geochemistry OF 92-0525

New Mexico OP-490

Russian Federation OP-1086

Sr-87/Sr-86

Alaska OP-242; OP-515; OP-721; OP-826

Argentina OP-2027

Arizona OP-1886

Basin and Range Province OP-2015

Brazil OP-737

California OP-182; OP-332; OP-333; OP678; OP-730; OP-1065; OP-1141; OP1282

Chile OP-2027

China OP-457

Colorado OP-490; OP-1825

geochemistry OF 92-0525; OP-30

geochronology OF $92-0525$

Great Basin OP-2015

Indiana OP-1648

Maine B 2039

Maryland OP-1572 
Mexico OP-1886

Michigan OP-1747

Montana OP-122; OP-978

Nevada OP-313; OP-643; OP-1041; OP1775

New Jersey OP-979

New Mexico OP-278; OP-490

North Carolina OP-1607

Northwest Territories OP-721

Ohio OP-1648

Oregon OP-42; OP-1141

Pacific Ocean OP-419; OP-1230

petrology OP-1199

Russian Federation OP-1086

South Carolina OP-1202

Wyoming OP-122; OP-978

stratigraphy OP-1144

Th-230

Nevada OP-916

Pacific Ocean OP-519

Th-232, Gabon OP-713

Th-232/Th-230, Mexico OP-1778

U-234/Th-230

California OP-707

Mexico OP-707

Oregon OP-707

U-235, Gabon OP-713

U-238

California OP-995

Colorado OP-1394

Gabon OP-713

Mexico OP-1778

Nevada OP-995

U-238/Th-230, Quaternary OF 92-0525

$\mathrm{U}-238 / \mathrm{U}-234$

Montana OP-978

Polynesia OP-1436

Quaternary OF 92-0525

Wyoming OP-978

volcanism OP-1806

Wyoming, ground water OF 91-0533

Israel see also Dead Sea Rift; Sinai. Quatemary OP-75

Isua Belt

Archean OP-848

Italy see also Apennines. geologic hazards

Naples Italy OP-213

Pozzuoli Italy OP-213

metal ores, Ivrea-Verbano Zone OF 93-0504

petrology, Sesia-Lanzo Zone OP-851

plate tectonics, Sicily Italy OP-1682

Quaternary P 1386-E

structural geology

Ivrea-Verbano Zone OP-1808

Piemonte Italy OP-1808

Itasca State Park

Quaternary OP-668

sedimentary petrology OP-739

Ivory Coast

Quaternary OF 92-0699

stratigraphy OP-118

Ivrea-Verbano Zone

metal ores OF 93-0504

structural geology OP-1808

Izee Terrane

guidebook OP-87
$\mathbf{J}$

J Sandstone

natural gas OF 92-0524; OF 93-0337

oil and gas fields OP-1857

J-M Reef

metal ores OF 93-0207

Jack Ranch Fault

structural geology OP-936

Jackpile Sandstone Member uranium ores $\mathrm{OP}-1848$

Jackson Group see also Yazoo Clay. Quaternary OP-486

Jackson Hole

guidebook OF 92-0504

neotectonics OP-780

Jacobsville Sandstone

sedimentary petrology OP-1495

Jacque Mountain Limestone Member stratigraphy B 1787-GG

jacupirangite

Arkansas, petrology OP-1837

jade

economic geology OF 92-0020-B

jadeite

Italy, petrology OP-851

petrology OP-1450

Jake Ridge

geomorphology OP-1276

James W. Ellsworth Land see Ellsworth Land

Jamuna River

geomorphology OP-1273

Jan Mayen

Quatemary P 1386-E

Japan

energy sources OP-1624

neotectonics, Honshu OP-1852

tectonophysics, Honshu OP-1620

Japan Trench

tectonophysics OP-1620

Jaramillo Event

Indonesia OP-1538

Ivory Coast OF 92-0699

New Mexico OF 92-0699; OP-1538

jarosite

California, environmental geology OP-1110

jasper

geochemistry OP-505

Java

geophysical surveys B 1966

Java Formation

stratigraphy B 1909

JEdI OF 91-0014

Jeletzkytes

stratigraphy B 2024; OP-526

Jellyfish Lake geochemistry OP-59; OP-1150

Jemez Mountains see Valle Grande Mountains

Jibal Al Quahr Saudi Arabia maps OP-370

Jixian China

stratigraphy OP-1361

Jixian Group stratigraphy OP-1361

Joana Limestone B 1988-G; OP-1846

John Henry Member sedimentary petrology OP-1779
Johnson Creek

pollution WRI 92-4136

Johnson Valley Fault earthquakes OP-699

Joint Education Initiative OF 91-0014

Joint Eurasian Seismic Studies Program seismology OF 93-0216

joints

Missouri OP-1861

Pennsylvania OF 92-0568

petroleum OP-1972

Utah B 1787-HH

West Virginia, hydrogeology W 2384

Wyoming OF 92-0388

Joplin Quadrangle

metal ores MF-2125-E

Jordan see also Dead Sea Rift. energy sources OF 92-0680

Joshua Tree earthquake 1992 earthquakes OP-503 seismology OP-411

Joulters Cays sedimentation OP-928

Juan de Fuca Plate earthquakes OP-720 geophysical surveys OF 93-0318 tectonophysics OP-1926

Juan de Fuca Ridge geochemistry OP-1127 sedimentation OP-243 tectonophysics OP-897

Juan de Fuca Strait continental margin 1-2091-C

Julcani District economic geology OP-872

Jumbo Mine metal ores OP-205

Jumpup Canyon Quadrangle maps I-2290

Juneau Alaska petrology OF 92-0724

Juneau gold belt gold ores OP-1416

junior high school

YR; OF 91-0014; OP-1049; OP-1219; OP-2020 Antarctica, geophysical surveys OF 91-0014 stratigraphy GN

Jupiter see Callisto Satellite; Galilean satellites; Ganymede Satellite; Io Satellite

Jurassic see also Navajo Sandstone; Nevadan Orogeny; Passaic Formation. OP-680

Alabama OP-1636

Alaska I-2164; OP-1169; OP-1195; OP-1349

Antarctic Ocean OP-1395

Antarctica OP-1995

Arizona OP-613

Atlantic Coastal Plain P 1404-G

Atlantic Ocean OP-1797

Bathonian, California OP-385; OP-1413

Brushy Basin Shale Member OP-1963

non-metal deposits B 2061-A

Vertebrata OP-1252

California OP-333; OP-1451; OP-1733

Callovian, California OP-1413

Coast Range Ophiolite

maps OP-1945

metamorphic rocks OP-1166

structural geology OP-401 
Ecuador B 2039

Mississippi OP-1577; OP-1636

Montana OF 93-0337

Naknek Formation, energy sources OP-626

Nevada OP-27

New Jersey OF 93-0010; OP-1003; OP-1379

Norphlet Formation

diagenesis OP-1856

energy sources OP-1753

sedimentary petrology OP-1858

Nugget Sandstone, petroleum OP-1767

Oregon OP-1139

Oxfordian, California OP-385

Pacific Ocean OP-813

Peru OP-1601

Pliensbachian, California OP-385

Salt Wash Sandstone Member, uranium ores OP-1848

Smackover Formation, energy sources OP1602

Tadzhikistan OP-373

Talkeetna Formation, energy sources OP-626

Tithonian, Utah OP-1252

Virginia B 1839-I,J

West Virginia B 1839-I,J

Westwater Canyon Sandstone Member, uranium ores $\mathrm{OP}-1848$

Juventae Chasma OP-1408; OP-1868

\section{K}

\section{K see potassium}

$\mathrm{K}-40$

Califomia, ground water OP-995

Nevada, ground water OP-995

K-41/K-39

geochemistry OP-991

\section{K-feldspar}

Alaska, geochemistry OP-1373

Colorado

Cretaceous OP-11

geochemistry OF 92-0525

geochemistry OP-1312

Illinois, sedimentary petrology OP-1385

Indiana, sedimentary petrology OP-1385

lead-zinc deposits OP-12

Mesozoic OP-1494

New Mexico, Cretaceous OP-11

Quebec, gold ores OP-1097

Russian Federation, Phanerozoic OP-1493

United States, Phanerozoic OP-1493

Virginia, orogeny OP-1612

Wyoming, geochemistry OF $92-0525$

K-T boundary

OP-1177; OP-1180; OP-1702

Atlantic Coastal Plain OP-2009

Colorado OP-1388; OP-1804; OP-1880

Germany B 2050

Gulf Coastal Plain OP-2009

Haiti B 2065; OP-1179; OP-1181; OP-1414; OP-1873

India OP-1346

Iowa B 2050; OP-1114; OP-1537; OP-1613; OP-1882; OP-1915

Ivory Coast OP-1181

Mexico B 2050; OP-920; OP-1179; OP-1414

Montana B 2065; OP-1744; OP-1745

New Mexico OP-1388; OP-1880

North Dakota OP-1550

North Sea OP-1359

Rocky Mountains OP-1792
Westem Interior OP-794; OP-1182; OP-1792 Wyoming OP-1181; OP-1744; OP-1745

$\mathrm{K} / \mathbf{A}$

OP-805

Africa, stratigraphy OP-656

Alaska

geochemistry OP-242

Quaternary OP-826

Bolivia, metal ores B 2039

California geochronology OP-342 metamorphism OP-1165

Phanerozoic OP-1340

stratigraphy B 2015

structural geology OP-332; OP-442;OP-936

China, metal ores OF 92-0525

geochronology OF 92-0525

Gulf of Mexico

petrology OP-287

sedimentary petrology OP-288

Idaho, Quaternary OF 92-0408; OF 93-0327

Indonesia, geochronology OP-1538

Iowa, stratigraphy OP-1537

Namibia, meteor craters OP-550

Nevada

economic geology OP-736

geochronology OP-342

gold ores OP-27

metal ores OP-205; OP-627

New Mexico

geochronology OP-1538

stratigraphy OP-573

Pacific Ocean, geochronology OP-813

Papua New Guinea, gold ores B 2039

Peru, geochronology OP-1601

Texas

petrology OP-1611

stratigraphy OP-177

Utah, stratigraphy B 1787-BB

Virginia, geochemistry B 1839-I,J

West Virginia, geochemistry B 1839-I,

Wyoming

Quaternary OF 92-0408

structural geology OP-1539

$\mathrm{K} / \mathrm{T}$ boundary see $\mathrm{K}-\mathrm{T}$ boundary

Kachemak Terrane

stratigraphy OP-1169

Kahe Point

oceanography B 2002

Kaibab Formation

mineral resources OF 92-0509-A; OF 92-0509B

Kaibab National Forest

economic geology OF 93-0329

mineral resources OF 92-0509-A; OF 92-0509B

Kaiparowits Plateau

Cretaceous OP-919

sedimentary petrology OP-1779

sedimentary structures OF 93-0270

Kalimantan Indonesia

Plantae OP-695

sedimentary petrology OP-870

Kalispell Quadrangle

maps I-2267

kalium see potassium

Kallarichuk Hills

metal ores B 2003

Kanab Creek

geomorphology OP-1060

maps I-2290
Kandik Basin

natural gas B 2034-A

petroleum B 2034-A; OP-492

sedimentary petrology OP-1553

Kansas see also Anadarko Basin; Cheroke

Group; Marmaton Group; Niobrara Formation. environmental geology

OF 93-0292-G

Manhattan Kansas OP-507; OP-729; OP946

Topeka Kansas OP-4

geochemistry, Kansas River valley OP-5

geologic hazards C 1120-B; OP-669

ground water

OF 93-0114; HA-0722-G; HA-0722-H; HA-0722-I

Harvey County Kansas WRI 93-4036

Reno County Kansas WRI 92-4169

Sumner County Kansas WRI 92-4177

Wyandotte County Kansas OF 93-0092

hydrogeology

Douglas County Kansas WRI 92-4137

Geary County Kansas WRI 92-4137

Jackson County Kansas WRI 92-4137

Jefferson County Kansas WRI 92-4137

Johnson County Kansas WRI 92-4137

Kansas River WRI 92-4137

Leavenworth County Kansas WRI 92-4137

Pottawatomie County Kansas WRI 92-4137

Riley County Kansas WRI 92-4137

Shawnee County Kansas WRI 92-4137

Wabaunsee County Kansas WRI 92-4137

Wyandotte County Kansas WRI 92-4137

hydrology W 2400; C 1120-A

maps

I-1420 (NJ-14); I-1420 (NJ-15)

Anderson County Kansas I-2377; I-2378; I-2379

Clark County Kansas OF 92-0697; OF 920698

metal ores

Allen County Kansas MF-2125-E

Bourbon County Kansas MF-2125-E

Cherokee County Kansas MF-2125-E

Crawford County Kansas MF-2125-E

Labette County Kansas MF-2125-E

Montgomery County Kansas MF-2125-E

Neosho County Kansas MF-2125-E

Wilson County Kansas MF-2125-E

Woodson County Kansas MF-2125-E

natural gas OF 92-0524; OP-725

paleontology OF 93-0549

pollution

Kansas River valley OP-1909

Marshall County Kansas OF 93-0087

Pottawatomie County Kansas OF 93-0087

Tuttle Creek Dam OF 93-0087

Washington County Kansas OF 93-0087

sedimentary petrology OP-1332

soils C 1086

stratigraphy B 1989-E

Kansas River

hydrogeology WRI 92-4137

Kansas River valley

geochemistry OP-5

pollution OP-1909

kansite see mackinawite

Kaoiki earthquake 1983

seismicity OP-1812

kaolin deposits

Minnesota OF 92-0514 


\section{kaolinite}

Colorado, stratigraphy OP-1880 geochemistry OP-829; OP-1738

Indonesia, sedimentary petrology OP-870

New Mexico

petroleum B 2039 stratigraphy OP-1880

Rocky Mountains, diagenesis OP-1792

Western Interior

clay mineralogy OP-794

diagenesis OP-1792

Wyoming

diagenesis OP-1950

petroleum B 2039

Kap Kobenhavn Formation

Pliocene OP-110

Kapuni Group

sedimentation OP-1391

Karafuto see Sakhalin

Karatau Range

plate tectonics OP-1295

karst see also karst hydrology; sinkholes.

Poland, metal ores OF 92-0704

karst hydrology

OP-40

Arkansas, hydrogeology OF 93-0150

Florida

environmental geology WRI 91-4181

hydrogeology WRI 91-4180

hydrogeology OP-376

Kentucky

WRI 92-4078

environmental geology WRI 92-4195

Mexico, hydrogeology OP-38

Puerto Rico

economic geology OF 92-0567

geomorphology OP-1007

Turkey, ground water OP-39

karst topography see karst

karstification

Mexico, hydrogeology OP-38

Texas, stratigraphy OP-1575

Kasel Vallis I-2208; OP-987; OP-1338; OP-1674

KATALASE OF 93-0123

Kathul Gray wacke

sedimentary petrology OP-1553

Katmai

petrology OP-316

Katmai National Monument

geochemistry OP-926

Kauai

geologic hazards YR

Kazakhstan

geophysics OP-367

plate tectonics, Karatau Range OP-1295

Keddie Ridge Block

structural geology OP-1474

Keenan Quartzite

sedimentary petrology OP-1553

Keg Mountain gold ores OP-1096 structural geology OP-619

Keller Butte Suite structural geology OP-1159

Kelly Limestone stratigraphy B 1787-EE

Kelly-Cayuse Wilderness Area mineral resources OF 90-0672

Kelso dune field geomorphology OP-1528
Kelut crater lake

geophysical surveys B 1966

Kemik Sandstone sedimentary petrology OP-1553

Kenai Group see Hemlock Conglomerate

Kenai Peninsula

geophysical surveys OF 93-0238 stratigraphy OP-1169

Kendrick Reclamation Project ground water OF 91-0533

Kendrick Shale Member stratigraphy OP-1821

Kentucky see also Appalachian Basin; Chattanooga Shale; Illinois Basin; Mississippi Embayment; Mississippi River; New Albany Shale;

New Madrid region; Ohio Shale; Rome Trough; Saint Peter Sandstone.

coal OP-1226

engineering geology OF 93-0349

environmental geology

OP-1608

Logan County Kentucky WRI 92-4195

geochemistry

OP-1905

Rowan County Kentucky B 2046

ground water WRI 91-4150; WRI 92-4102; WRI 92-4104

hydrogeology, Louisville Kentucky OF $92-$ 0638

hydrology

W 2400; WRI 92-4057; OF 91-0485

Hardin County Kentucky WRI 92-4078

Louisville Kentucky WRI 92-4150

maps SGM

non-metal deposits

OP-1419

Ballard County Kentucky OF 92-0514

McCracken County Kentucky OF 92-0514

pollution, Morgan County Kentucky WRI 924138

Quaternary

Ballard County Kentucky OP -486

Carlisle County Kentucky OP-486

Fulton County Kentucky OP-486

Hickman County Kentucky OP-486

sedimentary petrology, Carter County Kentucky OF 92-0558

sedimentation, Greenup County Kentucky OF 92-0558

seismology SM

stratigraphy

OF 92-0558; OP-1368

Boyd County Kentucky OF 92-0558; OF 93-0312

Carter County Kentucky OF 92-0558

Greenup County Kentucky OF 92-0558; OF 93-0312

Kenya see also East African Rift sedimentary petrology, Lake Magadi OP-1490 structural geology, Kenya Rift valley

OP-2

Kenya Rift valley

structural geology OP-2

Keokukls

Invertebrata OP-360

kerabitumen see kerogen

Kerguelen Plateau

Tertiary OP-1145

Kermadec Islands

tectonophysics OP-1969 kerogen

Alaska, energy sources OP-626

California, petroleum OP-1910

Canada, palynomorphs B 1909

Colorado energy sources OP-1753 natural gas OP-1262

Commonwealth of Independent States, petroleum OP-1265

energy sources OP-1260

Europe, petroleum OP-1265

geochemistry OP-533

natural gas OF 92-0524

Rocky Mountains, Pennsylvanian OP-1103

sedimentary petrology OP-451; OP-1944

United States, palynomorphs B 1909

Utah, natural gas OP-1262

Ketchikan Quadrangle

economic geology MF-2217-A

mineral resources OF 92-0552; OF 92-0690; MF-2217-B

Kettle Highlands

structural geology OP-1159

Kettle Point Formation

Devonian B 1909

Kettle River Fault

structural geology OP-1159

Kettle Rock Formation

structural geology OP-1474

Kettleman Hills

neotectonics OP-83

Kettleman Hills South Dome neotectonics OP-83

kettles

Wisconsin, ground water C 1086

Keweenaw Peninsula

areal geology $\mathrm{OP}-139$

copper ores OP-1688; OP-2019

Keweenawan see also Portage Lake Lava Series. OF 92-0524

Great Lakes OP-13

Great Lakes region B 1989-E; OP-13

Michigan OP-139

Minnesota OP-758

Keweenawan Rift

areal geology OP-139

copper ores OP-1216; OP-2019

energy sources OF 92-0391

geochemistry OF 92-0525; OP-1204; OP-1747

geochronology OP-758

metal ores OP-728

natural gas OP-725; OP-1350

orogeny OP-138

plate tectonics OP-13

stratigraphy B 1989-E

structural geology OP-1214; OP-1533

tectonics OP-137; OP-1215

tectonophysics OP-1534

KGRA, Roosevelt Hot Springs see Roosevelt Hot Springs KGRA

Kickapoo Fault earthquakes OP-699

Kidd Creek Deposit

geochemistry OP-1942

polymetallic ores OP-484 sulfides OP-1892

Kilauea

earthquakes EV

environmental geology OF 93-0512-A geochemistry OP-348; OP-446; OP-1997 geophysical surveys OF 92-0686; OP-252 
lava OF 93-0015

magmas OP-1001

oceanography MF-2231

petrology OF 92-0586; OF 93-0342-A; OF 93-

0342-B; OP-631; OP-667; OP-1499

Quatemary OP-284

seismology OP-116; OP-1420

Kilgore Fint Member stratigraphy OF 92-0558

Kilgore Tuff paleomagnetism OP-697

Killingworth Dome metamorphic rocks OP-1188

kimberlite

Montana OP-1491

non-metal deposits OF 92-0557

Kimmerian Orogeny see Cimmerian Orogeny

Kimmswick Limestone

fractures OP-1336

Kincaid Quadrangle maps I-2377

Kinderhookian

Nevada OP-1846

Kings Bowl lava field petrology OP-560

Kings River Ophiolite orogeny OP-797

Kirgizia see Kyrgyzstan

Kirkuk Field

geochemistry OP-615

Kirkwood Formation OP-979

Kirkwood-Cohansey Aquifer ground water WRI 91-4126

Kirtland Shale natural gas OF 93-0248

Kitchi Formation Archean B 1904-P

Kittanning Formation ground waterOP-1454

Kjeldahl method

hydrogeology OF 92-0146

Klamath Basin

geophysical surveys OF 93-0020

sedimentation OP-1098

Klamath Falls Oregon geophysical surveys OF 93-0020

Klamath Mountains geochemistry OP-1141

gold ores OP-934

magmas OP-1139

orogeny OP-797

petrology OP-1140

Phanerozoic OP-1340

structural geology OP-1451; OP-1547

tectonophysics OP-1733

Klamath Plate

tectonophysics OP-1733

Klamath River Conglomerate Member stratigraphy P 1521

Klamath Terrane

sedimentary petrology OP-1344

Klerksdorp Fleld engineering geology OP-660

Klondike Mountain Formation structural geology OP-1159

Klondike Ranch Quadrangle Invertebrata OP-860

Knife Point Glacier geochemistry OP-712
Quaternary OP-711

knowledge-based systems see expert systems

Knox Group

natural gas B 1839-I, J

Knoxville Quadrangle economic geology B 1979

Kobuk River valley Quaternary OP-33; OP-390

Kodiak Island

continental slope B 2002

petroleum B 2034-A

Kokomo Mine

base metals OP-944

metal ores OP-582

Kola Peninsula

Precambrian OP-1777

Kola Well

Precambrian OP-1777

Kolima River basin see Kolyma River basin

Kolor-map maps OF 93-0013

Kolyma River basin Vertebrata B 2037

Komandorski Basin deformation OP-211

Komiella Brachiopoda OP-491

Konnarock Formation Proterozoic B 2029

Konocti Bay Fault thermal waters OP-997

Kontinentales Tiefbohrprogramm der Bundesrepublik Deutschland see KTB

Konza Prairie Research Area environmental geology OP-507; OP-729; OP946

Koobi Fora Formation OP-656

Koolau Range hydrology WRI 92-4049

Kootenay Formation OP-1798

Korea

energy sources

North Korea OP-1624

South Korea OP-1624

Kori Kollo Deposit metal ores OP-202

kosnarite Maine, phosphates OP-115

Kosovo-Metohija OP-558

Kossen Marl energy sources OP-1263

Koyukuk Basin see Yukon-Koyukuk Basin

Krakow see Cracow Poland

Krasnoyarsk Russian Federation see Taymyr Dolgan-Nenets Russian Federation

KREEP OP-478; OP-806; OP-1803; OP-1841

kriging

ground water $\mathrm{OP}-867$

non-metal deposits OP-63

krokidolite see crocidolite

Krumbo Reservoir Quadrangle petrology OP-1549

Kruzof Island magmas OP-845

KTB

Germany, rock mechanics OP-1029

Kuban River oceanography OF 93-0274
Kula Plate

structural geology OP-94; OP-1547

Kupaianaha geophysical surveys OP-252

Kuparuk River energy sources OP-1284 petroleum OP-1285

Kuril Islands Invertebrata OP-109

Kuskokwim Group metal ores OP-123 sedimentation OP-1186

Kuskokwim Mountains metal ores OP-123; OP-1203

Kuskokwim River pollution OP-66

Kweichow China see Guizhou China

kyanite petrology OP-635

Kyrgyzstan geophysics OP-367

$\mathbf{L}$

L waves see surface waves

La Barca Deposit metal ores OP-202

La Espanola Deposit metal ores B 2039

La Honda Basin energy sources B 2034-A; OF 89-0450-D

La Joya Deposit metal ores OP-202; OP-1306

La Olivina Mexico geochemistry OP-132

La Paz Bolivia metal ores B 2039

Lac du Bonnet Batholith petrology OP-1560

laccoliths

Montana OP-1294

Lacus Autumni OP-1437

Lacus Veris OP-1437

lacustrine features see also lakes; playas. Antarctica, hydrology OP-949

Basin and Range Province, Quaternary OP-910

Rocky Mountains, Quaternary OP-910

Utah, Quaternary OP-620; OP-908; OP-911

lacustrine sedimentation see also fluviolacustrine sedimentation; glaciolacustrine sedimentation.

Arkansas, hydrology OF 93-0122

California geochronology OP-68 Quatemary OP-831

Great Lakes, Quaternary OP-1290

Indiana, hydrology WRI 92-4033; WRI 924113

Nevada geochronology OP-68 Quaternary OP-831

North Carolina, geomorphology WRI 93-4031

Ohio, ground water OP-1925

Russian Federation

Cenozoic OP-2003

Quaternary OP-1208; OP-1492

structural geology OP-1597

West Virginia, Pennsylvanian OP-1357 
Ladolam Deposit

gold ores B 2039

Lafourche Delta

Quatemary OF 92-0530

lahars

OP-1323

Alaska, geologic hazards OP-1708

Philippine Islands, geologic hazards WRI 924039; OP-781

Washington, engineering geology OP-907; OP956

Lake Agassiz

clays OF 92-0514

gold ores OP-168

Quaternary OP-1289

\section{Lake Baikal}

Cenozoic C 1086; OP-2003

geochemistry OP-130; OP-1605

geomorphology OP-1291

geophysical surveys OF 92-0693; OF 93-0007; OP-898

Miocene OP-198

Quaternary C 1086; OP-1208; OP-1334; OP1492; OP-1532; OP-1604; OP-1763; OP1764; OP-1874; OP-1904; OP-2004

structural geology OP-1597

Lake Barco

hydrogeology WRI 91-4180

Lake Bonneville

earthquakes OP-905

engineering geology $\mathrm{P} 1519$

Quaternary C 1086; OP-52; OP-620; OP-622; OP-908; OP-910; OP-1021; OP-1022; OP1156

structural geology OP-619; OP-718; OP-773; OP-909

Lake Bonneville Group

Quaternary OP-1022

Lake Champlain

environmental geology OP-1481

pollution OP-412

Lake Charles Louisiana

ground water OF 92-0492; OP-742

Lake Connecticut

Quaternary OP-1650

Lake Erie

environmental geology OP-1608

ground water OP-1354; OP-1648

Lake Fryxell

hydrology OP-949

Lake George Subterrane metamorphism OP-1349

Lake Gogebic sedimentary petrology OP-1495

Lake Gosiute energy sources OF 92-0391

Lake Lahontan

OP-68

geochemistry OP-76

Quaternary C 1086; OP-69; OP-1156

Lake Magadi

sedimentary petrology OP-1490

Lake Mead

ground water WRI 91-4185

Lake Michie

geomorphology WRI 93-4031

Lake Michigan

changes of level OP-1393

environmental geology YR geomorphology MF-2252; OP-487; OP-836; OP-1143

ground water P 1405-C; OP-923

hydrology WRI 92-4019; OP-199

Quaternary C 1086; OP-200; OP-1288; OP1289; OP-1290

Lake Michigan Basin see Michigan Basin

Lake Nyos

geochemistry OP-306; OP-1011

geologic hazards OP-903

Lake Owyhee

metal ores OP-876

Lake Pleasant Quadrangle maps I-1946

Lake Powell

hydrogeology OP-645

impact statements YR

Lake Provo

Quaternary OP-910; OP-911

Lake Rennie

Quaternary OP-831

lake sediments

Alaska, metal ores OP-1006

Dominican Republic, metal ores OP-532

gold ores OP-168

Oregon, mineral resources OF 90-0506

Russian Federation, Quaternary OP-1764

Texas OP-1991

Lake Shasta

sedimentary petrology OP-1344

Lake Superior

plate tectonics OP-13

structural geology OP-1533

Lake Superior region

Archean B 1904-P

copper ores OP-1216

metal ores OP-728

natural gas OF 92-0524

stratigraphy B 1989-E

structural geology B 1904-L; B 1904-Q; B 1904-S

tectonics OP-137

Lake Tahoe

environmental geology OP-1227

Lake Taupo

geophysical surveys B 1966

Lake Tecopa

diagenesis OP-1386

Lake Thompson

hydrology W 2340

Lake Uinta

B 1787-BB

energy sources OF 92-0391

Lake Waramaug hydrogeology WRI 85-4267

lakes see also crater lakes; glacial lakes; limnology.

OP-906; OP-1669

Basin and Range Province, Quaternary C 1086

California, Quatemary OF 93-0232; OP-831; OP-1897

Cameroon, geologic hazards OP-903

energy sources OF 92-0391

geochemistry OP-353

Great Basin, Quaternary C 1086

Illinois, environmental geology YR

Indiana, environmental geology YR

Minnesota, Quatemary OP-21

Nevada

geochemistry OP-76

Quaternary OP-831
Utah, Quaternary OP-622

Lakeview Mountains Pluton intrusions OP-1126

Lakhra Formation

coal OF 92-0281

stratigraphy OF 92-0517

Lakhra Pakistan coal OF 93-0255

Laki Formation

coal OF 92-0281

stratigraphy OF 92-0517

Lamarck Granodiorite

geochemistry OP-182

petrology OP-1282

laminations

Arctic Ocean, Quaternary OP-1796

Bahamas, sedimentation OP-928

barite deposits OP-960

Califomia, stratigraphy OP-1281

Minnesota

OP-739

Quaternary OP-20; OP-668

Oregon, Quaternary OF 93-0212

Washington, Quaternary OF 93-0212

Lamotte Sandstone

lead-zinc deposits OP-12

metal ores OP-1418

Lamprey River basin ground water OF 92-0095

lamprophyres

OP-1417

Arizona, structural geology OP-1886

Mexico, structural geology OP-1886

Lance Formation

P 1532; OP-1744; OP-1745

sedimentary petrology OF 92-0391

land canyons see canyons

land cover

Alaska, environmental geology SM

Colorado, environmental geology C 1086

environmental geology C 1086

land reclamation see reclamation

land subsidence see also collapse structures.

P 1240-B; OP-1512

Arizona

ground water OP-1468

structural geology OP-1220

California

geologic hazards WRI 92-4035

ground water OF 93-0148; OP-72; OP-73

ground water OP-1640

Gulf Coastal Plain, Quaternary OF 92-0530

Gulf of Mexico, Quaternary OF 92-0530

Louisiana OF 92-0530

Texas, ground water OF 93-0062; OF 93-0081; OF 93-0086

Utah, geologic hazards P 1519

Washington, neotectonics OF 93-0332

land use see also conservation; geologic hazards;

impact statements; reclamation; waste disposal.

Alaska OF 92-0596

Basin and Range Province, industrial minerals B 2013

California

economic geology OF 92-0595

environmental geology OF 93-0294

ground water WRI 92-4153

Colorado, environmental geology C 1086

District of Columbia, environmental geology OP-60

ecology C 1086 
environmental geology YR; B 2013; C 1086; C 1105; OF 92-0514; OP-548; OP-701

Florida ground water W 2340

hydrogeology WRI 92-4061

Great Plains, ground water OF 93-0114

ground water OP-952

Gulf Coastal Plain, environmental geology OF $92-0530$

hydrogeology OF 93-0040

Iowa

ground water OF 92-0167

pollution OP-588

Kentucky, hydrology WRI 92-4150

Midwest, environmental geology OF 93-0418

mineral resources OF 92-0514

Minnesota

environmental geology OF 92-0514

non-metal deposits OF 92-0514

Missouri, geomorphology OP-1544

Nevada

environmental geology B 2013

industrial minerals B 2013

New York

ground water WRI 92-4100

hydrogeology WRI 90-4205

non-metal deposits OF 92-0514

Oregon

hydrogeology OP-62

hydrology WRI 91-4063; WRI 92-4108

Pennsylvania

energy sources OF $92-0568$

environmental geology OF 92-0568

hydrogeology WRI 90-4131

hydrology WRI 90-4011

pollution YR; C 1086; OP-1600

Puerto Rico, pollution OP-663

Texas, environmental geology WRI 92-4117

Utah, environmental geology B 2013

Washington

environmental geology C 1090

hydrogeology OP-62

West Virginia OP-1543

land use maps

Washington, hydrology WRI 91-4073

Lander Sandstone Member

Invertebrata OP-860

Landers earthquake 1992

earthquakes YR; EV; OF 93-0191; OP-90; OP406; OP-503; OP-504; OP-699; OP-700; OP-931

engineering geology OF 93-0348

Quaternary OP-1833

seismology OP-411; OP-438; OP-593; OP-966

landfills see also disposal barriers.

geologic hazards C 1111

Kansas, ground water WRI 92-4169; WRI $92-$ 4177; WRI 93-4036

Maryland, environmental geology OP-1089

New Jersey, environmental geology OF 920153

Tennessee, ground water WRI 91-4173

landslldes see also mudflows; rockslides.

OF 93-0278-A; OF 93-0278-B

Alaska

continental slope B 2002

engineering geology B 2002; OP-140

geologic hazards B 2002

oceanography B 2002

Andes, geologic hazards OP-1369

Arctic Ocean, engineering geology OP-516

Atlantic Coastal Plain, oceanography OP-1337
Atlantic Ocean

continental margin B 2002

continental slope B 2002

California

continental margin B 2002

continental shelf B 2002

economic geology OP-662

oceanography B 2002

Canary Islands, engineering geology OP -443

Central America, geologic hazards OP-1862

Colorado

OP-885; OP-1171

earthquakes OP-1423

engineering geology OP-579; OP-744

Florida, continental slope B 2002

geologic hazards OP-114; OP-1190

Gulf of Mexico, oceanography B 2002

Hawaii

OP-693; OP-694; OP-782

engineering geology OF 92-0501

oceanography B 2002

soil mechanics OP-1814

Iowa OP-1882

Kentucky, Quaternary OP-486

Louisiana, continental shelf B 2002

Mississippi Valley, engineering geology OF 93-0349

oceanography B 2002

Pacific Ocean, engineering geology OP-1641

Puerto Rico

geologic hazards OP-1631; OP-1632

hydrogeology C 1086

oceanography B 2002

soil mechanics OP-485

soil mechanics B 1842-D

Tennessee, Quatemary OP-486

Utah

geologic hazards P 1519

rock mechanics OP-404

Vermont, engineering geology B 2043

Virginia B 1981

Washington

earthquakes EV

engineering geology OP-907; OP-956

West Virginia

B 1981

engineering geology $\mathrm{OP}-1542$

Langban Sweden

mineralogy OP-1445

lanthanoans see rare earths

Laplace transformations

ground water OP-683

Laramide Orogeny

Arizona, metal ores B 2042-C

Basin and Range Province, energy sources OF 93-0248

Colorado

geophysical surveys OP-1813

metal ores OP-937

mineral resources OP-828

Proterozoic OP-10

sedimentary rocks B 1787-DD

structural geology OP-118

Colorado Platean, energy sources OF 93-0248

Great Plains, energy sources OF 93-0337

Montana, diagenesis OP-395

New Mexico, stratigraphy OP-573

plate tectonics OP-1903

Rocky Mountains, energy sources OF 93-,0337

stratigraphy B 1917-M

structural geology OP-159

Utah, sedimentary rocks B 1787-DD
Wyoming, diagenesis OP-395

Laramie Mountains

petrology OP-1456

structural geology OP-149

Las Animas Arch petroleum OF 93-0337

Las Vegas Nevada geophysical surveys OF 92-0450

Las Vegas Valley ground water WRI 92-4051

Lassen Peak

geophysical surveys B 1966

Quatemary OP-201

Lassen Volcanic National Park lava OP-1447

Last Chance Fault tectonics OP-977

lateral faults see left-lateral faults; right-lateral faults

laterites

Puerto Rico economic geology OF 92-0567 metal ores OP-1656

Latir volcanic field geochemistry OP -490

latite

Colorado, metal ores OP-1633

latitude, paleo-see paleolatitude

Lau Basin plate tectonics OP-413

Laura Majoro Atoll ground water OP-26

Laurani Deposit metal ores OP-1306

Laurentia

North Carolina, structural geology OP-1955

Virginia, structural geology OP-1955

Laurentian Plateau see Canadian Shield

Laurentide ice sheet

Great Lakes, Quaternary OP-1289

ground water OP-952

New England, Quaternary C 1086

Quatemary OP-396; OP-1256

lava see also plugs.

OP-366; OP-1438; OP-1831

Alaska

geochemistry OP-242; OP-1754

Quaternary OP-826

structural geology OP-94

Arizona

OF 92-0198

geochemistry B 2021-C

California

OP-1271; OP-1447

geomorphology OP-266

structural geology OP-1701

Canada, orogeny OP-138

Chile OP-957

Colorado, geochemistry OP-490; OP-1825

Hawaii

OF 93-0015; OP-631; OP-1499

geochemistry OP-348; OP-446

Quatemary OP-284; OP-632; OP-633

Iceland OP-1405

Idaho

OP-561; OP-1381

geochronology OP-479

Quaternary OF 93-0327

New Mexico

OF 92-0528 
geochemistry OP-490

Oregon

$$
\text { B } 2054
$$

geochemistry OF 93-0314; OP-42

pahoehoe, Hawaii OF 93-0342-A; OF 930342-B

Texas OP-1611

Vanuatu, sedimentation OP-188

Washington GQ-1679; OP-957

Lava Beds National Monument geomorphology OP-266

Lava Creek B Tephra

Quaternary OF 92-0391

structural geology OP-1539

lava domes see shield volcanoes

lava fields OP-142

lava lakes

Cameroon, geologic hazards OP-903

Hawaii

OF 93-0015

petrology OP-1499

lava tubes

California OP-266

layered intrusions

OP-814

California, platinum ores B 2014

geochemistry OP-1621

Greenland OP-636

Montana

OP-604

geochemistry OP-1663

metal ores OF 93-0207

Oman, structural geology OP-815

LCGISN

geologic hazards OF 93-0210

lead see also heavy metals; $\mathrm{Pb} / \mathrm{Pb} ; \mathrm{U} / \mathrm{Pb}$.

Basin and Range Province geochemistry OP-2015 tectonics OP-2021

Chile, geochemistry OP-2005

Colorado, metal ores OP-115.

Great Basin geochemistry OP-2015 tectonics OP-2021

hydrology OP-1836

Massachusetts, geochemistry OP-215

Minnesota, geochemistry OF 92-0525

New Jersey, environmental geology OF 92 0153

Pacific Ocean, Cretaceous OP-1230

$\mathrm{Pb}-206 / \mathrm{Pb}-204$

OP-806; OP-1805

Alaska OP-570

California OP-678

China OP-457

Colorado OF 92-0525; OP-11; OP-375; OP490; OP-1825

England OP-1541

geochemistry OF 92-0525; OP-2018

geochronology OF 92-0525

Malaysia OF 92-0525

Montana OP-1087

New Mexico OP-11; OP-490

Nova Scotia OF 92-0525; OP-1122

Proterozoic OF 92-0525

Spain OP-31

$\mathrm{Pb}-207 / \mathrm{Pb}-204$

OP-806; OP-1805

Alaska OP-242; OP-570

Argentina OP-2027

Chile OP-2027
Colorado OF 92-0525; OP-11; OP-375; OP490

England OP-1541

geochemistry OF $92-0525$

Malaysia OF 92-0525

Montana OP-1087; OP-1094

New Mexico OP-11; OP-490

Nova Scotia OF 92-0525; OP-1 122

Proterozoic OF 92-0525

Spain OP-31

$\mathrm{Pb}-207 / \mathrm{Pb}-206$

Colorado OP-11

New Mexico OP-11

$\mathrm{Pb}-208 / \mathrm{Pb}-204$

Argentina OP-2027

Chile OP-2027

Colorado OF 92-0525; OP-11; OP-375; OP490

England OP-1541

geochemistry OP-2018

geochronology OF 92-0525

Malaysia OF 92-0525

Montana OP-1087

New Mexico OP-11; OP-490

Nova Scotia OP-1122

Proterozoic OF 92-0525

Spain OP-31

Pb-210, Great Lakes OP-1290

Russian Federation, metal ores OP-2014

sediments OP-1887

Utah

metal ores OP-965

mineral resources MF-2081-C; MF-2081-E

lead glance see galena

lead ores see also mississippi valley-type.

Arizona OP-290

Bolivia OP-202

California OP-204; OP-260; OP-662

Missouri, hydrology WRI 93-4012

Nevada OP-260

Spain OP-875

Utah OP-965

lead-lead see $\mathrm{Pb} / \mathrm{Pb}$

lead-zinc deposits see also mississippi valleytype.

B 2003; OP-12

Alaska OP-570

Arizona B 2042-C

Bolivia B 2039

Colorado OF 93-0343; OP-937; OP-1151

Missouri OP-575; OP-644

Nevada OP-531

New Brunswick OP-787

New South Wales Australia OP-787; OP-942

Queensland Australia OP-942

Utah OP-1464

Vermont B 1955

Leadville Colorado

pollution OP-1579

Leadville Formation

B 1787-EE

metal ores OP-1151

Leadville mining district metal ores OF 93-0343

leaky aquifers

Florida, hydrogeology W 2340

hydrogeology WRI 93-4011

LEAP

earthquakes OF 92-0577

Lebanon

tectonophysics OP-1606 lebensspuren

Kentucky OF 92-0558

Lechuguilla Cave

geomorphology OF 92-0391

solution features OP-1629

Lee Flat Fault

tectonics OP-977

Lefkas Island

barite deposits OP-960

left-lateral faults

California

OP-703; OP-802; OP-803; OP-1063

geologic hazards OP-1793

Missouri OP-1861

plate tectonics OP-1133

stratigraphy OP-1368

Leg 5 see DSDP Site 32

Leg 41 see DSDP Site 367

Leg 46 see DSDP Site 396

Leg 78A see DSDP Site 541

Leg 79 see DSDP Site 546

Leg 80 see DSDP Site 548

Leg 86 see DSDP Site 580

Leg 94 see DSDP Site 607

Leg 95 see DSDP Site 612

Leg 96 see DSDP Site 614; DSDP Site 615

Leg 108 see ODP Site 661

Leg 110 see ODP Site 672

Leg 119 see ODP Site 737; ODP Site 741; ODP Site 744

Leg 123 see ODP Site 765; ODP Site 766

Leg 124 see also ODP Site 768; ODP Site 769; ODP Site 770.

geophysical surveys OP-585

marine geology OP-819; OP-823; OP-824; OP825

Leg 129 see also ODP Site 800; ODP Site 801; ODP Site 802. geochemistry OP-510

Leg 134

geophysical surveys OP-318

marine geology OP-186; OP-187; OP-189; OP-

190; OP-191; OP-192; OP-193; OP-194; OP-195; OP-196

ocean floors OP-368

plate tectonics OP-185; OP-1287

sedimentation OP-188

tectonophysics OP-1908

Leg 135

plate tectonics OP-413

Leg 139

geochemistry OP-1127

sedimentation OP-243

Leg 141 plate tectonics OP-586; OP-1651

Lehigh Gap Pennsylvania geochronology OF 92-0525

lehm see loess

Leipers Formation hydrogeology OP-1283

Lemhi Group structural geology OP-941

Lemhi Range geochronology OP-479

Lena Basin energy sources OP-1967 sedimentary petrology OF 92-0391

Leo Formation energy sources OF 93-0337 
Pennsylvanian OP-1103

Leonardian

Texas OP-1387; OP-1575

Lepanto Deposit

metal ores OP-9

Leppy Hills stratigraphy B 1988-G

Leptocythere Russian Federation OP-109

Lesser Antilles see also Barbados. hydrogeology

OP-1959

U. S. Virgin Islands C 1081

hydrology, U. S. Virgin Islands W 2400

leucogranite

Nevada, geochemistry OF 92-0525

Vermont OP-37

Levach West Mine

metal ores OP-1979

level, changes of see changes of level

Lewis Shale

$P$ 1532; B 1917-O

energy sources OF 93-0337

lexicons

DDS-0006 stratigraphy DDS-0006

Lexington Reservoir hydrology WRI 92-4172

Therzolite

China, geochemistry OP-457

$\mathrm{Li}$ see lithium

Li-7/Li-6

geochemistry OP-122; OP-1973

ground water OP-1202

Libby thrust belt structural geology P 1524

libraries

OP-830; OP-1516

geologic hazards DDS-0008

lichens

Alaska, geochemistry OF 93-0014

Liebre Mountain

neotectonics OP-1063

structural geology OP-649; OP-803

life origin

Greenland, Archean OP-848

ligands

geochemistry OP-530

lightning

Alaska, Quatemary OP-1772

lightweight aggregate see aggregate

lignin

Australia, sedimentary petrology OP-1478

diagenesis OP-1477

Indonesia, sedimentary petrology OP-1478

Nova Scotia, sedimentary petrology OP-1673

Russian Federation, Quatemary OP-1763; OP1764

lignite

OP-410

Indonesia, Plantae OP-695

Pakistan OF 92-0576

Lihir Islands

gold ores B 2039

Lima Peaks

stratigraphy OF 92-0391

lime mud

Bahamas, sedimentation OP-928 limestone see also micrite.

Alaska, stratigraphy OP-1169

California

stratigraphy OP-1281

structural geology OP-1474

Canada, stratigraphy OP-1776

Carboniferous OP-1232

Florida

OP-1931

ground water W 2340; OP-494

hydrogeology W 2340

geochemistry OP-165

Georgia, ground water W 2392

Haiti, stratigraphy OP-1179

Indiana, stratigraphy OP-1845

Mexico, stratigraphy OP-1179

Midwest, hydrogeology OP-1228

Montana, Triassic B 1917-P

Nevada

geochemistry OP-1775

gold ores OP-441 stratigraphy OP-623

New Mexico, ground water WRI 91-4033

Pakistan, tectonophysics OP-1548

Saudi Arabia, Proterozoic B 1976

South Carolina, ground water W 2392

stratigraphy OP-1345

United Arab Emirates, stratigraphy OP-1453

United States, stratigraphy OP-1776

West Virginia, Pennsylvanian OP-1357

Wyoming, Triassic B 1917-P

limestone deposits

OF 92-0514

Arizona OF 93-0329

Michigan OF 92-0514

Minnesota OF 92-0514

Ohio OF 92-0514

Puerto Rico OF 92-0567

limnology see also paleolimnology.

Alaska, hydrology WRI 92-4132

Antarctica

geochemistry OP-664

hydrology OP-949.

Arkansas, hydrology OF 93-0070; OF 93-0122

California, hydrology C 1086; WRI 92-4172; WRI 93-4030; OF 93-0059

Cameroon, geochemistry OP-1011

Colorado, hydrology WRI 92-4053; OP-133

Connecticut, hydrogeology WRI 85-4267

Delaware, ground water OP-777

Florida, hydrogeology WRI 91-4180

Great Lakes, hydrology OP-199; OP-1278

Indiana, hydrology WRI 92-4033

Indonesia, geophysical surveys B 1966

Kansas, pollution OF 93-0087

Minnesota

hydrology OF 92-0475; OF 93-0127

Quaternary OP-668

Missouri, hydrogeology WRI 92-4167

Nebraska, pollution OF 93-0087

Nevada, hydrology OP-448

New Mexico, hydrogeology WRI 92-4004

New Zealand, geophysical surveys B 1966

North Carolina geomorphology WRI 93-4031 hydrogeology OF 93-0163

North Dakota, hydrology W 2340; OF 93-0066

Oregon, Quaternary OF 93-0212

Russian Federation geomorphology OP-1291 geophysical surveys OF 93-0007

South Dakota, hydrology W 2340
Texas, hydrogeology OP-1200

Utah

ecology WRI 92-4084

hydrology WRI 91-4117

Virginia, hydrology WRI 92-4034

Washington

geophysical surveys B 1966

Quaternary OF 93-0212

Wisconsin

ground water $\mathrm{C} 1086$

hydrogeology OF 92-0026

hydrology WRI 90-4126

Wyoming, geophysical surveys B 1966

Limon Basin

Neogene OP-1272

lineaments

Arctic Ocean, tectonophysics OP-1891

Arctic region, tectonophysics OP-1891

Idaho, neotectonics OP-634

Italy, plate tectonics OP-1682

Nevada, structural geology OF 91-0623

New Mexico OF 92-0710

Oregon, neotectonics OP-634

seismology OP-1867

structural geology OP-1890

Washington, tectonics OP-877

lineation see also folds; foliation.

Michigan I-2355

stratigraphy OP-1756

liners see disposal barriers

Lions Head California

geochemistry OF 92-0539-C

Miocene OF 93-0182

stratigraphy OF 92-0539-B; OF 92-0539-D; OF 93-0177

lipids

geochemistry OP-183

North Carolina, geochemistry OP-1684

liquefaction see also liquefaction potential.

California

continental shelf B 2002

engineering geology OP-1154; OP-1347

earthquakes OP-102

Egypt, earthquakes OP-1092

engineering geology P 1240-B; OP-415; OP1184

Illinois, Quatemary P 1536

Indiana, Quaternary P 1536

Mississippi Valley, engineering geology OF 92-0391; OF 93-0349

Missouri, earthquakes OP-1996

seismicity OP-1866

South Carolina, seismicity OP-2032

Tennessee, Quaternary MF-2218; OP-856

liquefaction potential

soil mechanics OP-254

Utah, geologic hazards P 1519

Washington, engineering geology OF 91-0441$T$

liquid inclusions see fluid inclusions

liquid waste see also waste water.

Pennsylvania, waste disposal OP-1301

Lisbon Formation

hydrogeology W 2391

Lisburne Group

energy sources B 2034-A

listric faults

Califomia, Quaternary OP-338

Colorado, geomorphology OP-1171

Commonwealth of Independent States, petroleum OP-1265 
Europe, petroleum OP-1265

Idaho OP-18; OP-523

Maine, crust OP-1920

Montana P 1524

Nevada OP-108

Quebec, crust OP-1920

Washington OP-18

\section{lithium}

California, thermal waters OP-997

Colorado, hydrogeology OP-408

geochemistry OP-1973

mineralogy OP-414

Montana, geochemistry OP-122

Scotland, geochemistry OF 93-0267

Wyoming, geochemistry OP-122

lithofacies maps see lithologic maps

lithogeochemistry see also fluid inclusions.

Alaska OP-242

Antarctica, petrology OP-1027

California

mineral resources $O F$ 92-0210-A; OF 92 0210-B; OF 92-0316-A; OF 92-0316-B

platinum ores B 2014

stratigraphy OF 93-0177

Haiti, geochronology B 2065

Kentucky B 2046

Micronesia OP-59

Montana, geochronology B 2065

Nevada, metal ores OF 93-0249

New Jersey, sedimentary petrology OP-1379

New Mexico, magmas OP-278

New York, natural gas B 1909

Ohio, energy sources B 1909

Oregon OF 93-0314

Sweden OP-584

United States OP-584

Virginia

B 1839-I,J

petrology OP-1002

West Virginia B 1839-I,J

lithologic maps

Alaska, metamorphic rocks P 1497-C

California, metamorphic rocks OP-1166

Canada, metamorphic rocks P 1497-C

Oregon, metamorphic rocks OP-1166

lithologic traps see stratigraphic traps

lithostratigraphy see also seismic stratigraphy.

P 1506-F; B 1808-O; B 1839-K; B 1909; B 1917-M; OP-1232

Alabama, Quaternary OF 92-0530

Alaska, Quaternary OP-390; OP-1059

Arctic Ocean, Quaternary OF 92-0426

Arkansas

Quaternary OF 93-0273

sedimentary petrology OF 93-0291

Atlantic Coastal Plain P 1542

Atlantic Ocean OP-1894

California

P 1521; B 2015; OF 92-0539-B; OF 92 0539-E; OF 92-0588; OF 93-0177; OP-469 neotectonics OP-83

Canada B 1909; OF 93-0184

Celebes Sea

marine geology OP-823

oceanography OP-821

Colorado

B 1787-EE; B 1787-GG; OF 92-0689; I1797-D

geochemistry OP-490

metal ores OF 93-0343

geochronology OP-134

Great Lakes region B 1989-E
Idaho, metal ores OP-715

Kentucky OF 92-0558

Louisiana

Quaternary OF 92-0530

shore features OF $92-0530$

Massachusetts OP-801

Melanesia, marine geology OP-192

Mexico OP-56

Michigan B 1904-P

Mississippi

OF 92-0394

Quaternary OF 92-0530

Missouri, sedimentary petrology OF 93-0291

Montana

B 1917-P; I-2380-A; OC-0135

geochemistry OP-1305

sedimentary petrology B 1917-L

structural geology P 1524

Nevada

B 1988-C; B 1988-D; B 1988-G; OP-623

gold ores B 2039

metal ores OP-531

New Jersey MF-2208

New Mexico

B 1787-EE; OP-573

coal OP-17

geochemistry OP-490

New South Wales Australia OP-7

metal ores OP-942

New York B 1839-L; MF-2208

North Carolina OP-356; OP-597

North Dakota OF 93-0335

Northern Territory Australia, Quaternary B 2032-A

Ohio OF 92-0558

Ontario B 1909

Oregon P 1521

Pacific Coast, Quaternary C 1086

Pacific Ocean

OP-1894

marine geology OP-819

Pakistan, coal OF 92-0281; OF 93-0256; OP996

Papua New Guinea, petroleum OP-307

Pennsylvania B 1994

Queensland Australia, metal ores OP-942

Saudi Arabia B 1976

South Australia, Quatemary B 2032-B

South Carolina B 2030; OP-356

South Dakota OF 93-0335

United States B 1909; OF 93-0184

Utah I-1797-D

Virginia B 2029; OP-359

Washington OF 92-0581; OF 93-0233

Western Interior OP-1231

Wyoming

P 1506-D; P 1520; P 1532; B 1917-P; I2380-A; I-2380-B; OC-0135; OC-0137 sedimentary petrology B 1917-L

Little Bahama Bank oceanography OP-1073

Little Colorado River hydrology OP-1435

Little Cottonwood Canyon earthquakes OP-905 Quaternary OP-910

Little Creek Reservoir hydrology WRI 92-4034

Little Egg Inlet continental shelf MF-2221
Little Fork River hydrology HA-0551

Little Glass Mountain geomorphology OP-266

Little Hatchet Mountains stratigraphy OP-573

Little Ice Age see Neoglacial

Little Rocky Mountains ground water WRI 92-4162; WRI 92-4163

Little Sespe Field energy sources OP-1255

Little Skull Mountain earthquake 1992 earthquakes OP-1300

Little Stone Gap Member stratigraphy OP-1368

Little Valley Alloformation Quaternary OP-911

Livengood Quadrangle gold ores OP-589 maps OF 92-0562 stratigraphy $\mathrm{OP}-85$

Livermore Basin energy sources B 2034-A plate tectonics OP-1749

Livermore California geophysical surveys OF 92-0531

Liverpool Cyclothem stratigraphy OP-1345

LL chondrites see Semarkona Meteorite

Llallagua Deposit metal ores OP-202

Llewellyn Formation stratigraphy OF 92-0568

Llobregat Delta ground water OP-1449

Llobregat River basin ground water OP-1310

Lloyd Aquifer ground water WRI 88-4127

load casts California, stratigraphy OP-1281

Local Earthquake Analysis Program earthquakes OF 92-0577

Loch Vale watershed hydrology C 1086; OF 92-0628

Lockatong Formation energy sources OP-1842 ground water OP-986

Lockport Formation ground water OP-2023 hydrogeology OP-1228

locks Missouri, engineering geology WRI 92-4118 loess

Alaska, Quatemary OP-390

Arkansas, Quatemary OF 93-0273; OP-1683

Great Lakes, geomorphology OP-836

Mississippi Valley, Quatemary OF 93-0273

Missouri, ground water OP-1571

Quaternary OF 93-0273

Tennessee, Quaternary OF 93-0273; OP-1683

Logan Canyon Formation

Mesozoic OP-801

logging, acoustical see acoustical logging

logging, caliper see caliper logging

logging, electrical see electrical logging

LOGRAF

natural gas OF 92-0679

petroleum OF 92-0391 
Loihi Seamount

geochemistry OP-446

Loma Prieta earthquake 1989

California

P 1550-C; OF 90-0677; OF 92-0441; OP121; OP-221; OP-407; OP-1047; OP-1154;

OP-1347; OP-1488; OP-1581; OP-1582; OP-1658; OP-1793; OP-1794; OP-1865 deformation P 1550-C geologic hazards P 1553-B; OP-969 geophysical surveys OF 92-0570 tectonophysics P 1550-C

Lomonosov-Fleming Sea OP-1485

Lompoc California geochemistry B 1995-C; OF 92-0539-C stratigraphy OF 92-0539-B; OF 92-0539-D; OF 93-0177

Londonderry New Hampshire environmental geology OF 92-0647

Lone Pine Subplate structural geology OP-523

Lone Tree Creek Quadrangle maps OF 93-0224

Long Island ground water P 1404-G; WRI 88-4127; WRI 90-4182; WRI 91-4012; WRI 924100; OF 91-0180 hydrogeology WRI 90-4205 Quaternary OP-748

Long Island Sound Quaternary OP-1650 sedimentation OF 92-0550

Long Valley geophysical surveys OP-2024 hydrogeology OP-652

Long Valley Caldera geochemistry OP-954; OP-955 geophysical surveys OF 92-0544; OP-1555; OP-2024

seismology OP-964; OP-1503

structural geology OP-569; OP-1536

long-wall mining see longwall mining

longitudinal wave see $\mathrm{P}$-waves

longshore bars

South Carolina, ecology OF 93-0303

longwall mining Ohio, hydrology OF 92-0120

loop-loop methods OF 92-0553-A; OF 92-0553B

Loosahatchie River Quaternary OF 93-0273

Los Alamos National Laboratory geothermal energy OP-1496

Los Alamos Syncline maps OP-1945

Los Angeles Basin energy sources B 2034-A tectonophysics OP-2010

Los Angeles California geologic hazards OP-969

Los Frailes Caldera gold ores OP-231

Los Pinos Quadrangle maps OF 92-0711

Los Ranchos Formation metal ores OP-1576

Lospe Formation petroleum OP-1910

loss on ignition Kentucky, geochemistry B 2046
Lost River Range geochronology OP-479

Louisiana see also Mississippi River, Mississippi Valley.

conservation

Isles Dernieres OF 92-0530

Lafourche Parish Louisiana OF 92-0530

Mississippi Delta OF 92-0530

Plaquemines Parish Louisiana OF 92-0530

Saint Bemard Parish Louisiana OF 92-0530

Terrebonne Parish Louisiana OF 92-0530

continental shelf

Mississippi Delta B 2002

Saint Bernard Parish Louisiana OF 92-0530 ecology OF 92-0530

energy sources OF 92-0524

engineering geology

Lafourche Parish Louisiana OF 92-0530

Mississippi Delta OF 92-0530

New Orleans Louisiana OF 92-0530

Plaquemines Parish Louisiana OF 92-0530

Saint Bernard Parish Louisiana OF 92-0530

Terrebonne Parish Louisiana OF 92-0530

environmental geology

Baton Rouge Louisiana C 1120-C

Jefferson Parish Louisiana OF 92-0530

Lafourche Parish Louisiana OF 92-0530

Mississippi Delta OF 92-0530

Plaquemines Parish Louisiana OF 92-0530

Saint Bemard Parish Louisiana OF 92-0530

Terrebonne Parish Louisiana OF 92-0530

geochemistry

Calcasieu Parish Louisiana OP-935

Calcasieu River OP-935

Cameron Parish Louisiana OP-935

Jefferson Davis Parish Louisiana OP-935

geologic hazards

YR

Cameron Parish Louisiana OF 93-0210

Iberia Parish Louisiana OF 93-0210

Jefferson Parish Louisiana OF 93-0210; I2150-A

Lafourche Parish Louisiana OF 92-0530; OF 93-0210; 1-2150-A

Orleans Parish Louisiana OF 93-0210

Plaquemines Parish Louisiana OF 92-0530; OF 93-0210

Saint Bernard Parish Louisiana OF 93-0210; I-2150-A

Saint Mary Parish Louisiana OF 93-0210

Terrebonne Parish Louisiana OF 92-0530; OF 93-0210; I-2150-A

Vermilion Parish Louisiana OF 93-0210

geomorphology

Isles Dernieres OF 92-0530

Lafourche Parish Louisiana OF 92-0530

Mississippi Delta OF 92-0530

Plaquemines Parish Louisiana OF 92-0530

Saint Bernard Parish Louisiana OF 92-0530

Terrebonne Parish Louisiana OF 92-0530 ground water

P 1416-C; WRI 91-4149; WRI 91-4151; WRI 91-4152; WRI 92-4103; WRI 924105; OF 92-0492

Allen Parish Louisiana OF 92-0492

Beauregard Parish Louisiana OF 92-0492

Calcasieu Parish Louisiana OF 92-0492; OP-742

Evangeline Parish Louisiana OF 92-0492

Ouachita Parish Louisiana OF 92-0492

Rapides Parish Louisiana OF 92-0492

Vernon Parish Lowisiana OF $92-0492$ hydrogeology

OF 92-0492

Avoyelles Parish Louisiana WRI 91-4109; OF $92-0492$

Barataria Bay OF 92-0492

Jefferson Davis Parish Louisiana OP-216

Jefferson Parish Louisiana OF 92-0492

Lafourche Parish Louisiana OF 92-0492

Plaquemines Parish Louisiana OF 92-0492

hydrology

W 2400; WRI 92-4060

East Baton Rouge Parish Louisiana W 2340

East Feliciana Parish Louisiana W 2340

Livingston Parish Louisiana W 2340

New Orleans Louisiana W 2400

Saint Helena Parish Louisiana W 2340

Saint Tammany Parish Louisiana W 2340

Tangipahoa Parish Louisiana W 2340

West Feliciana Parish Louisiana W 2340

land subsidence

Lafourche Parish Louisiana OF 92-0530

Mississippi Delta OF 92-0530

Plaquemines Parish Louisiana OF 92-0530

Saint Bernard Parish Louisiana OF 92-0530

Terrebonne Parish Louisiana OF 92-0530

maps YR

oceanography, Isles Dernieres OF 92-0530

pollution

Calcasieu Parish Louisiana OF 92-0492

Calcasieu River OF 92-0492

Cameron Parish Louisiana OF 92-0492

Quaternary

Lafourche Parish Louisiana OF 92-0530

Mississippi Delta OF 92-0530

Plaquemines Parish Louisiana OF 92-0530

Saint Bernard Parish Louisiana OF 92-0530

Terrebonne Parish Louisiana OF 92-0530

sands

Isles Dernieres OF 92-0530

Lafourche Parish Louisiana OF 92-0530

Plaquemines Parish Louisiana OF 92-0530

Saint Bemard Parish Louisiana OF 92-0530

Terrebonne Parish Louisiana OF 92-0530

sedimentary petrology

Isles Dernieres OP-262

Mississippi Delta OP-653

sedimentation, Isles Dernieres OF 92-0530

shore features

Mississippi Delta OF 92-0530

Plaquemines Parish Louisiana OF 92-0530

Saint Bernard Parish Louisiana OF 92-0530

Terrebonne Parish Louisiana OF 92-0530

Louisiana Coastal Geographic Information System Network geologic hazards OF 93-0210

Louisiana Geological Survey ecology OF 92-0530 environmental geology OF 92-0530

Louisville Kentucky hydrogeology OF 92-0638 hydrology WRI 92-4150

Loveland Loess Quatemary OP-1683

Lovell Wash Member Neogene OP-92

low-angle faults

Basin and Range Province OP-769

Califomia, energy sources OP-267

Colorado Plateau OP-769

Hawaii, geophysical surveys OP-252

Nevada

OF 92-0391 


\author{
petroleum OP-614 \\ stratigraphy B 1988-C; B 1988-D \\ low-grade metamorphism \\ Greenland OP-636 \\ Montana \\ OP-1731 \\ structural geology P 1524 \\ petroleum B 1909 \\ structural geology OP-401 \\ Virginia, mineralogy OP-1755 \\ Lower Cambrian see Cheshire Formation; \\ Chilhowee Group \\ Lower Carboniferous see Dinantian \\ Lower Coon Mountain Pluton \\ platinum ores B 2014 \\ Lower Cretaceous see Albian; Blackleaf Forma- \\ tion; Kootenay Formation; Muddy Sandstone \\ lower crust \\ Califomia \\ OP-1503 \\ magmas OP-1711 \\ Chile, magmas OP-971 \\ geochemistry OP-1377 \\ Italy, metal ores OF 93-0504 \\ magmas OP-1138 \\ Mexico, geochemistry OP-132 \\ Mississippi Valley OP-1661 \\ natural gas OF 92-0524 \\ Nevada, petrology OP-795 \\ New York, structural geology OP-461 \\ Vermont, structural geology OP-461 \\ Lower Devonian see Oriskany Sandstone \\ lower Eocene see Willwood Formation \\ Lower Jurassic see middle Liassic; Nugget Sand- \\ stone; Talkeetna Formation \\ lower mantle see also core-mantle boundary. \\ OP-135 \\ volcanism OP-1806 \\ Lower Mississippi Valley \\ ground water WRI 91-4149 \\ hydrology OP-1643 \\ Lower Mississippian see Joana Limestone; \\ Kinderhookian; Osagian \\ lower Neogene see Miocene \\ Lower Ordovician see Beekmantown Group; Ca- \\ nadian Series \\ lower Paleocene see Danian; K-T boundary \\ Lower Peninsula, Michigan see Michigan Lower \\ Peninsula \\ Lower Pennsylvanian see Morrowan; Pocahontas \\ Formation \\ Lower Permian see Cherry Canyon Formation; \\ Leonardian \\ lower Pleistocene see Jaramillo Event \\ lower Precambrian see Archean \\ lower Proterozoic see Willyama Complex \\ Lower Silurian see Brassfield Formation; \\ Tuscarora Formation \\ Lu see lutetium \\ Lucero Peak Pluton \\ geochemistry OP-490 \\ Lucky Ditch Field \\ petroleum OP-1635 \\ Ludlow Member OP-1550 \\ Ludlow Quadrangle \\ maps OF 92-0282-A \\ Ludlowville Formation B 1909 \\ luminescence analysis see fluorimetry
}

Lunae Planum

OP-987; OP-1163; OP-1868; OP-1984

Syria OP-1322

lunar breccia OP-478

lunar craters OP-237; OP-416; OP-657; OP-1943

lunar crust OP-416; OP-478; OP-783; OP-805; OP-1482; OP-1781; OP-1943

lunar highlands OP-478; OP-657; OP-1487

Lunar Scout OP-1486

lunar soils OP-609; OP-657; OP-1697; OP-1781

Luquillo Mountains

ecology OF 92-0150

hydrogeology C 1086

weathering C 1086

Luquillo Puerto Rico

marine installations OP-1863

oceanography OF 92-0717

lutecite

Kenya, sedimentary petrology OP- 1490

Oregon, sedimentary petrology OP-1490

lutetium

Kentucky, geochemistry B 2046

Luzon

geologic hazards WRI 92-4039; OP-781

Lycopsida

Ohio, palynomorphs OP-1603

$\mathbf{M}$

M-discontinuity see Mohorovicic discontinuity

Maar-Diatreme Member metal ores OP-1576

maars

Dominican Republic, metal ores OP-532

Maastrichtian see Maestrichtian

macerals see also alginite; durain; exinite; vitrain; vitrinite.

Colorado, energy sources OP-1264

West Virginia, sedimentary petrology OP-778

MacH'O

hydrogeology OF 91-0366-A; OF 91-0366-BC

mackinawite geochemistry OP-841

Maclurina manitobensis Invertebrata OP-860

Macoma balthica environmental geology OF 92-0456

Macroneuropteris scheuchzeri sedimentary petrology OP-1673

Madera Formation

hydrogeology OP-1299

Madison Group

energy sources OF 93-0337; OP-1947

hydrogeology WRI 91-4044

Madison Range

Archean OP-705

petrology OP-1716

Madre de Dios Peru

gold ores OP-82

Maestrichtian

Arkansas OP-527

Montana OP-395

New Jersey OF 92-0399

Texas OP-526

Western Interior OF 92-0391

Wyoming OP-395

mafic magmas

Antarctic Ocean, orogeny OP-1395 magadiite

Kenya, sedimentary petrology OP-1490

Oregon, sedimentary petrology OP-1490

magma see magmas

magma chambers

OP-1943

Alaska, magmas OP-845

Bolivia, metal ores OP-1306

California

geophysical surveys OP-1555

petrology OP-1167

structural geology OP-1536

Colorado, geochemistry OP-490

energy sources OP-1822; OP-1823

geophysical surveys OP-1374

Hawaii

geochemistry OP-348

magmas OP-1001

petrology OP-1499

magmas OP-814

Nevada, petrology B 2052

New Mexico

geochemistry OP-490

magmas OP-278

Oman, structural geology OP-815

Oregon

geochemistry $\mathrm{OP}-42$

magmas OP-982

Philippine Islands, magmas OP-1768

Washington, geophysical surveys B 1966

magmas see also fractional crystallization; magmatic differentiation; volcanology.

OP-596; OP-661; OP-806; OP-1392; OP-1408;

OP-1417; OP-1732; OP-1805

Alaska

OP-1469

geochemistry OP-721

Antarctica, tectonophysics OP-1317

Arizona OP-1341

California

OP-1271; OP-1376; OP-1711

geochemistry OP-512; OP-678; OP-954; OP-955

geophysical surveys OP-2024

structural geology OP-1451

Cameroon, geochemistry OP-1011

Chile OP-971

Colorado

economic geology OP-872

geochemistry OP-1825 molybdenum ores OP-1913

Colorado Plateau, structural geology OP-679

Commonwealth of Independent States, energy sources OP-1261

economic geology OP-873

Europe, energy sources OP-1261

geochemistry OF 92-0525; OP-30; OP-1377; OP-1621

Hawaii

geophysical surveys OP-252

Quaternary OP-284; OP-1759

Idaho

OP-560; OP-561

geochronology OP-479

Kenya, structural geology OP-2

mafic magmas, Antarctic Ocean OP-1395

metal ores OP-465

Mexico

economic geology OP-872

geochemistry OP-1778

Minnesota, geochronology OP-758

Missouri, iron ores OP-1297 
Montana

OP-1500

geochemistry OP-1663

Nevada, geochemistry OP-313

New Jersey OP-1003

New Mexico, molybdenum ores OP-1927

Northwest Territories, geochemistry OP-721

Nova Scotia, geochemistry OP-1122

Ontario, metal ores OP-1978

Oregon OP-1139

Pacific Ocean, plate tectonics OP-413

Papua New Guinea OP-1729

Peru

economic geology OP-872 geochronology OP-1601

Philippine Islands OP-1729

earthquakes OP-1998

geochemistry OP-1994

plate tectonics OP-680; OP-1903

Quaternary OP-459

Quebec, gold ores OP-1097

Rocky Mountains, structural geology OP-679

Russian Federation OP-91

Saudi Arabia OP-1952

structural geology OP-159

tectonophysics OP-1460

Utah, economic geology OP-872

Virginia, geochemistry B 1839-I,J

Washington OP-1362

West Pacific Ocean Islands, earthquakes OP501

West Virginia, geochemistry B 1839-I,J

Wyoming, geochemistry OP-536

magmatic differentiation

Montana, magmas OP-1294

magnesian calcite

Minnesota, sedimentary petrology OP-250

magnesian spar see dolomite

magnesium

Califormia

sedimentary petrology OF 92-0707

thermal waters OP-997

Cameroon, geochemistry OP-1011

Colorado, sedimentary petrology OP-1382

Minnesota, sedimentary petrology OP-250

Tennessee, ground water WRI 92-4092

Wyoming, petrology OP-1456

magnesium calcite see magnesian calcite

magnesium carbonate

California, sedimentary petrology OF 92-0707

Magnet Cove Arkansas

petrology OP-1837

magnetic anomalies

Alaska, energy sources OP-268

Arizona

Neogene OP-92

petrology OP-1341

California, economic geology OP-662

Caribbean Sea, geophysical surveys MF-2083B

Celebes Sea, geophysical surveys OP-585

Colorado, economic geology B 2035

geophysical surveys OF 93-0287; OP-364

Idaho

gold ores B 2039

petrology OP-560

Minnesota, economic geology B 2039

Missouri, geophysical surveys OF 91-0573

Montana, economic geology OF 93-0207

Nevada

economic geology B 2039 geophysical surveys OF 92-0343

Neogene OP-92

Oklahoma, energy sources OP-268

Pacific Ocean, tectonophysics OP-295

magnetic declination

Arizona, stratigraphy OP-398

tectonophysics GP-1004-D

magnetic field see also magnetic inclination; magnetic intensity.

California, seismology P 1550-C

earthquakes OP-766

India, geophysics OP-136

Kazakhstan, geophysics OP-367

Kyrgyzstan, geophysics OP-367

Maine, geophysical surveys OF 93-0573-B

paleomagnetism C 1086

tectonophysics OP-1441

magnetic inclination

Arizona, stratigraphy OP-398

Idaho, Quaternary OF 93-0327

tectonophysics GP-1004-I

magnetic intensity

Hawaii, Quaternary OP-632; OP-633

Missouri, geophysical surveys OF 91-0573

tectonophysics GP-1004-F; GP-1004-H; GP1004-Z

magnetic iron ore see magnetite

magnetic jerks

tectonophysics OP-1441

magnetic logging

California, geophysical surveys OF 92-0544

magnetic methods see also magnetic anomalies. OP-212

\section{magnetic minerals}

Nevada, paleomagnetism OP-863

Oklahoma, geophysical surveys OP-1741

magmetic properties see also magnetic susceptibility.

Hawaii, paleomagnetism OP-436

Mexico, geochronology OP-920

mineralogy OP-112; OP-770

magnetic survey maps see also aeromagnetic maps.

Caribbean Sea, geophysical surveys MF-2083B

Montana, economic geology OF 93-0207

magnetic surveys see also aeromagnetic maps; magnetic anomalies.

Antarctic Ocean, plate tectonics OP-65

Arctic Ocean, tectonophysics OP-1891

Arctic region, tectonophysics OP-1891

Bering Sea, deformation OP-211

California

economic geology OP-204

geophysical surveys OP-1555

paleomagnetism OP-1504

seismology P 1550-C

Celebes Sea, geophysical surveys OP-587

Colorado

economic geology B 2039

foliation OF 92-0391

geophysical surveys OP-1813

geophysical surveys DDS-0009

Hawaii

oceanography OF 92-0206

paleomagnetism OP-436

Minnesota, kaolin deposits OF 92-0514

Missouri, iron ores OP-1297

Nevada

base metals OP-79

geophysical surveys OP-1041 gold ores OP-365

petrology OP-795

New Jersey, geophysical surveys OF 92-0700-

A

Quatemary OP-81

structural geology OP-1890

magnetic susceptibility

Alaska, petrology OF 92-0724

Arkansas, Quatemary OF 93-0273

Colorado, stratigraphy OP-985

Haiti, petrology OP-1873

Hawaii, Quatemary OP-632

Iowa, petrology OP-1540

Nevada, paleomagnetism OP-863

Oklahoma, geophysical surveys OP-1741

Tennessee, Quaternary OF 93-0273

magnetism, paleo- see paleomagnetism

magnetite see also iron ores.

Colorado, molybdenum ores OF 92-0525

phase equilibria OP-1311

magnetization see remanent magnetization

magnetosphere

Kazakhstan, geophysics OP-367

Kyrgyzstan, geophysics OP-367

magnetostratigraphy

OP-1756

Antarctic Ocean, Pliocene OP-1535

Atlantic Ocean, Cretaceous OP-1894

California, Quaternary OP-1844

Idaho, paleomagnetism OP-1850

North Dakota OP-1550

Pacific Ocean, Cretaceous OP-1894

magnetotelluric methods OF 92-0569

Magoffin Member

stratigraphy OP-1821

Magothy Aquifer

ground water WRI 88-4127; WRI 90-4182; OF 92-0460; OF 92-0464

mahlmoodite

Arkansas, phosphates OP-681

Mahoning Coal

palynomorphs OP-1603

Maiden Gneiss

geochemistry OP-344

Main Central Thrust

tectonics OP-1637

main shocks

Alaska, seismology OP-1

Califormia

earthquakes OP-700

plate tectonics OP-752

seismology OP-673; OP-1658

Hawaii, seismology OP-1088

Maine

crust OP-1920

geochemistry

OF 92-0525

Augusta Maine OP-750

geophysical surveys

Aroostook County Maine OF 93-0573-B

Penobscot County Maine OF 93-0573-B

Piscataquis County Maine OF 93-0573-B

Somerset County Maine OF 93-0573-B

hydrology W 2400

maps I-1420 (NK-18)

metal ores, Somerset County Maine B 2039

phosphates, Oxford County Maine OP-115

Quaternary OP-748

stratigraphy, Norumbega fault zone OP-1530

Majoro Atoll

ground water OP-26 
Makarov Basin

tectonophysics OP-1626

malachite see copper ores

Malacostraca see Ophiomorpha

Malartic Quebec gold ores OP-1097

Malaspina Glacier hydrology C 1086

Quaternary C 1086; OP-1718; OP-1719

Malay Archipelago see also Borneo; New Guinea.

petroleum, Sarawak Malaysia OP-1829

Plantae, Kalimantan Indonesia OP-695

sedimentary petrology, Kalimantan Indonesia OP-870

sedimentation, Sarawak Malaysia OP-1211

Malaysia

energy sources OP-1624

geochemistry OF $92-0525$

metal ores C 0930-M

petroleum, Sarawak Malaysia OP-1829

sedimentation, Sarawak Malaysia OP-1211

Mallard-Larkin Wilderness

mineral resources OF 92-0384

Mameyes landslide 1985

soil mechanics OP-485

Mammalia

Cricetidae, Russian Federation B 2037

Fissipeda, Alaska OP-163

Marsupialia, South America OP-97

mammals

Idaho, paleomagnetism OP-1850

Wyoming, stratigraphy OP-98

Mammoth District

metal ores B 2042-C

Mammoth Hot Springs geochemistry OP-536; OP-637

Mammoth Mountain geochemistry OP-954; OP-955 geophysical surveys B 1966 seismology OP-1503

Mana Formation stratigraphy OP-1303

Management Systems Evaluation Areas ground water $\mathrm{OF}$ 92-0167

pollution YR; OF 93-0042; OF 93-0043; OF 93-0079

Manassas Sandstone stratigraphy OP-1660

Mancos Shale see also Frontier Formation. OF 92-0391

Mandibulata see Crustacea

Mangala Valles OP-1242

manganese

Colombia, geochemistry OP-755

Colorado, sedimentary petrology OP-1382

East Pacific Ocean Islands, geochemistry OP925

England, geochemistry OP-755

Galapagos Islands, geochemistry OP-925

Louisiana, geochemistry OP-935

New Hampshire, geochemistry OP-1207

Poland, geochemistry OP-755

Quaternary OP-459

Sweden, mineralogy OP-1445

Tadzhikistan, mineralogy OP-1445

Texas, geochemistry OP-755

manganese ores

California OP-319; OP-458

geochemistry OF 92-0559
Nevada OF 93-0249

manganese oxides

Arizona

geochemistry OP-590 pollution OP-591

Colorado, molybdenum ores OP-375

Manglaur Formation

structural geology OP-1125

Manhasset Formation

Quaternary OP-748

Manhasset Neck

ground water WRI 88-4127

Manhattan Kansas

environmental geology OP-507; OP-729; OP946

Manitoba see also Red River. geochronology OP-1709 petrology, Lac du Bonnet Batholith OP-1560

Manning Canyon Shale OP-1320

Manoa Valley

engineering geology OF 92-0501

manometers

Califomia, hydrology W 2340

Manson impact structure

crystalline rocks OP-1114

geochronology OP-475; OP-1613

geomorphology OP-1834; OP-1882

paleomagnetism OP-1915

petrology OP-1113; OP-1540

stratigraphy B 2050; OP-1537

mantle see also asthenosphere; heat flow; hot spots; isostasy.

OP-141; OP-1037; OP-1363; OP-1593; OP-

1941

Alaska, geochemistry OP-242

Antarctica OP-1317

California

OP-71

geochemistry OP-730

Chile, Quatemary OP-279

Colorado, geochemistry OP-490; OP-1825

Commonwealth of Independent States OP-1646

geochemistry OP-30

Kenya

OP-521

structural geology OP-2

lower mantle

OP-135

volcanism OP-1806

Mediterranean region OP-1606

Middle East OP-1606

Minnesota, intrusions OP-247

Montana, petrology OP-1491

Nevada, petrology OP-795

New Mexico, geochemistry OP-490

Pacific region OP-1020

Philippine Islands OP-502

Russian Federation, geochemistry OP-1086

Virginia, geochemistry B 1839-I,J

West Virginia, geochemistry B 1839-I,J

Wyoming, geochemistry OP-2016

mantle-core boundary see core-mantle boundary

mantos

Illinois, non-metal deposits OP-1419

Kentucky, non-metal deposits OP-1419

manuals YR

manufactured gas

Georgia, pollution WRI 91-4178

MAPPER

oceanography DDS-0003; DDS-0015

petroleum DDS-0005 maps see also digital cartography.

I-2311; I-2312; I-2313; I-2314; I-2315; I-2316;

I-2317; I-2318; I-2319; I-2320; I-2321; I-2322;

I-2323; I-2324; I-2325; I-2332; I-2333; I-2334;

I-2335; I-2336; I-2337; I-2338; I-2339; I-2340;

OP-1594; OP-1723; OP-1954

aeromagnetic maps

California OF 92-0531; OF 92-0548; OF 92-0549; OF 93-0277

Maine OF 93-0573-B

Missouri OF 91-0573

Oregon OF 93-0211

Washington OF 93-0211

Alaska, gold ores OF 93-0325

Appalachians, structural geology OP-1479

Atlantic Coastal Plain, geologic hazards OF 92 0377-A

bathymetric maps

Atlantic Ocean I-2279-A

Califomia I-2089-C; I-2090-B; I-2090-C

Hawaii MF-2231; MF-2233

New Jersey MF-2221

North Carolina WRI 93-4031; MF-2209

contour maps

California I-2089-C; I-2090-C

Colorado B 2025

Guatemala OP-277

New Mexico B 2025

Oregon B 2038

stratigraphy B 1909

economic geology maps

OF 92-0020-B

Alaska OF 92-0690; MF-1996-E; MF-2228; OP-123

Appalachians MF-2215-A

Arizona B 1737-E

Arkansas MF-1994-D

Califormia B 2019

Colorado B 2035

Kansas MF-2125-E

metal ores MF-1838-D

Mexico B 2039

Missouri MF-1994-D; MF-2125-E

Montana OF 93-0207; I-2050-F

Nevada B 2019; OP-765

North Carolina B 2005

Puerto Rico OF 92-0578

Tennessee B 2005

West Virginia I-2364-B

electromagnetic survey maps, Nevada GP1003-A

engineering geology maps

OP-67; OP-1184

California I-1257-M

Hawaii OF 92-0501

New York I-2003

Washington OF 91-0441-T

geochemical maps

Alabama MF-2214

Alaska B 1968; MF-2144-B; MF-2144-C; MF-2144-D; MF-2217-A; MF-2227

geochemistry OF 92-0559

Georgia MF-2213

Gulf Coastal Plain WRI 91-4149

hydrogeology WRI 91-4196

metal ores B 2003

mineral resources MF-2217-B

Mississippi Valley WRI 91-4149

Montana OF 93-0207

North Carolina MF-2203; MF-2223

Utah MF-2081-C; MF-2081-D; MF-2081-E

Virginia WRI 92-4175; MF-2203

geologic hazards maps 
Alaska B 1996

Atlantic Ocean B 2002

California I-1257-M

Hawaii OF 93-0213

Philippine Islands WRI 92-4039

geologic maps

OF 92-0562; I-2208; I-2209; I-1420 (NJ-

14); I-1420 (NJ-15); OP-981; OP-1015

Alaska B 1968; B 1996; WRI 92-4132; OF 92-0346; OF 92-0594; GQ-1688; MF-2226-A;I-1984; I-2032; I-2164; OP123

Appalachians B 1979

Arizona B 2042-C; WRI 90-4105; OF $92-$ 0198; MF-2230; I-2198; I-2290; I-2420

Arkansas SGM

California P 1521; B 2014; B 2015; OF 910435; OF 92-0446; OF 93-0198; OF 930205; OF 93-0206; OF 93-0223; OF 93-0224; OF 93-0225; OF 93-0271 OF 93-0525; I-1943; I-1995; I-1420 (NJ10); OP-649; OP-803; OP-804; OP-1945

Canada I-1420 (NK-18); I-1420 (NL-18)

Caribbean Sea DDS-0015

Colorado B 1787-DD; OF 92-0711; OF 93 0310; OF 93-0320; MF-2216; MF-2220; MF-2232; I-2266

Georgia GQ-1705

Gulf of Mexico DDS-0015

Hawaii WRI 91-4197; I-2274

Idaho P 1408-F; MF-2234; I-1803-H; I2299

Indiana OF 93-0268-B

Kansas OF 92-0697; OF 92-0698; I-2377; I-2378; I-2379

Kentucky SGM

Mariana Islands I-2408

Massachusetts DDS-0003; I-2369

metal ores B 2003

Mexico I-2287; I-1420 (NG-14)

Michigan I-2356; I-1420 (NL-17)

Micronesia 1-2408

Midwest P 1405-B

Montana P 1524; B 1993; WRI 92-4162; OF 93-0207; GQ-1724; GQ-1729; MF2253; I-1803-H; I-2267; I-2343-A; I2380-A; C-0142

Nevada DDS-0002; B 2011; OF 92-0554; OF 92-0580; OF 92-0613; OF 92-0681; OF 93-0198; OF 93-0220; OF 93-0299; OF 93-0519; GQ-1714; GQ-1721; GQ1730; MF-1877-A; I-2173; I-2342; I2394; OP-973

New Jersey GQ-1707

New Mexico OF 92-0710; OF 92-0711; GQ-1716; I-2266; OP-17

North Carolina B 2005; OF 93-0244; MF2223

Ontario I-1420 (NL-17)

Oregon P 1521; WRI 91-4087; OF 92-0695; OF 93-0302

Pennsylvania B 1994

Saudi Arabia B 1976; OP-308; OP-309; OP370; OP-371; OP-372

South Australia B 2032-B

Tennessee B 2005

Texas I-1420 (NG-14); I-1420 (NH-14)

United States I-1420 (NK-18); I-1420 (NL18)

Utah B 1787-DD; B 1787-HH; B 2011; WRI 90-4105; WRI 92-4070; OF 92-
0385; OF 92-0589; OF 93-0003; OF 93 0190; OF 93-0203; GQ-1712; GQ-1713; GQ-1721; MF-2250; C-0144

Vanuatu OP-197

Venezuela MF-2242

Vermont B 1955; OF 92-0282-A; MF-2224; I-2369

Virginia B 1981; OF 92-0716; OF 92-0725. OF 93-0024; OF 93-0244

Washington OF 93-0233; OF 93-0297; GQ1679; I-1946; I-1963; I-2005

West Virginia B 1981

Wisconsin I-2356

Wyoming P 1520; WRI 90-4154; WRI 914044; WRI 91-4108; I-2168; I-2232; I2343-A; I-2343-B; I-2380-A; I-2380-B

geomorphologic maps

I-2276

geomorphology I-2206

Oregon B 2038

West Virginia B 1981

geophysical survey maps

OP-1149

Colorado B 2035

oceanography MF-2211

gravity survey maps

Arizona OF 91-0640

Colorado MF-2236

Montana OF 93-0207

New Mexico WRI 91-4065; OF 92-0503

Great Lakes region, ground water OF 92-0694

hydrogeologic maps

Arizona WRI 90-4105; WRI 91-4185

Arkansas WRI 92-4120

Atlantic Coastal Plain P 1404-G; OF 92 0629

Connecticut WRI 87-4144

Florida OF 92-0471; OF 92-0472; OF 930049; OF 93-0050; OF 93-0053

Georgia W 2391

ground water HA-0730-J

Gulf Coastal Plain P 1416-C; WRI 91-4149. WRI 91-4150; WRI 91-4151; WRI 914152; WRI 92-4102; WRI 92-4103; WRI 92-4104; WRI 92-4105

hydrogeology WRI 91-4196; OF 92-0466

Idaho P 1408-F; OF 91-0098

Kansas HA-0722-G; HA-0722-H; HA0722-I

Louisiana WRI $91-4109$

Maryland OF 92-0459; OF 92-0460; OF 920461; OF 92-0462; OF 92-0463; OF 920464

Midwest OF 92-0489

Mississippi WRI 92-4080

Mississippi Valley WRI 91-4149; WRI 914150; WRI 92-4102; WRI 92-4104

Nevada WRI 91-4185

New Hampshire WRI 90-4161; WRI 914025; OF 89-0583; OF 92-0095

New Jersey WRI 90-4151; WRI 91-4126; WRI 91-4169

New Mexico P 1407-C; OP-230

New York W 2387; WRI 88-4127; WRI 904151; WRI 91-4030

Ohio WRI 91-4024; WRI 92-4072

Oklahoma WRI 88-4208

Oregon WRI 90-4085; OF 91-0098

Pennsylvania WRI 91-4182; WRI 92-4183; WRI 92-4194; OF 93-0027; OF 93-0028

South Carolina WRI 92-4000
Texas P 1407-C; WRI 88-4208; WRI $92-$ 4190; OF 93-0062; OF 93-0081; OF 930086

Utah WRI 90-4105; WRI 92-4070; WRI 924160

Washington WRI 90-4085

Wyoming WRI 91-4108

hydrologic maps

Colorado WRI 92-4050

Hawaii WRI 91-4197

Illinois WRI 92-4149

Michigan WRI 91-4120

Minnesota HA-0551

Montana WRI 92-4048; WRI 92-4185

New Jersey WRI 90-4151

New York WRI 90-4151; WRI 92-4042

North Carolina W 2403

South Carolina WRI 90-4056

Virginia B 1981

Washington OF 91-0453

West Virginia B 1981

index maps, Alaska SM

industrial minerals maps, Arizona OF 92-0687

isopach maps

California MF-2212; I-2090-A

South Carolina I-1935

stratigraphy B 1808-O; B 1917-M

isoseismic maps

Alaska P 1527

Hawaii B 2006

land use maps, Washington WRI 91-4073

lithologic maps

Alaska P 1497-C

Califomia OP-1166

Canada P 1497-C

Oregon OP-1166

Louisiana, geologic hazards I-2150-A

magnetic survey maps

Caribbean Sea MF-2083-B

Montana OF 93-0207

marine geology maps

Atlantic Ocean I-2279-A; I-2279-B

California OF 93-0298; I-2089-C; I-2090A; I-2090-C; I-2091-C

Caribbean Sea DDS-0015

Gulf of Mexico DDS-0015

Massachusetts DDS-0003

New Jersey MF-2221

metal ores MF-1835-H

metallogenic maps

Alaska OF 93-0339

metal ores OF 93-0208-A; OF 93-0208-B

Russian Federation OF 93-0339

mineral resources MF-2207

Nevada, geochronology. OF 93-0538

paleogeographic maps, Wyoming P 1532

petroleum maps

natural gas OF 92-0696

Oregon OP-731

photogeologic maps, Nevada OF 91-0623

seismicity maps

earthquakes OF 92-0533

Hawaii B 2006

Mississippi Valley SM

seismotectonic maps, Missouri OP-1996

shaded relief maps

I-2276; OP-1149; OP-1589; OP-1595; OP1596

geomorphology I-2206

site location maps

Alaska P 1497-C; WRI 92-4132; OF 920008-A; OF 92-0008-B; OF 92-0315; OF 92-0708-A; OF 93-0215 
Arizona B 2021-C; OF 92-0509-A

Arkansas WRI 93-4013

Atlantic Ocean B 2002

Califomia OF 92-0210-A; OF 92-0316-A

Canada P 1497-C

Colorado B 1787-DD; WRI 91-4095; WRI 92-4050; WRI 93-4007; OF 920709; OF 93-0017-A

economic geology OF 92-0020-B

Idaho OF 90-0672; OF 92-0173; OF 920384

Kansas OF 93-0092

Kentucky WRI 92-4195

Michigan WRI 91-4133

mineral resources OF 92-0552

Montana WRI 92-4162; OF 93-0207

natural gas $O F$ 92-0524

New Hampshire OF 92-0095

New Mexico WRI 93-4007

New York W 2387; WRI 88-4127; WRI 91 4030

North Carolina WRI 92-4097

North Dakota OP-1071

Oregon OF 90-0506; OF 93-0259-A

Puerto Rico OF 93-0178; OF 93-0179

South Australia B 2032-B

stratigraphy B 1808-O; B 1909

Texas OF 93-0112

Utah B 1787-DD; WRI 92-4160; OF $92-$ 0173; OF 92-0640

Vermont B 1955

Washington WRI 91-4073; OF 91-0453

Wyoming P 1532; WRI 90-4154; WRI 914044; OF 93-0192

stratigraphic maps

New Jersey MF-2208

New York MF-2208

structural maps

Mexico B 2039; MF-2238

Michigan I-2355

Montana I-2267; I-2343-A

Northern Territory Australia B 2032-A

Utah B 1787-HH

Vermont OF 92-0282-A

Virginia W 2388

Wyoming I-2343-A; I-2343-B

structure contour maps

Colorado I-2266

Montana I-2343-A

New Mexico I-2266

South Carolina I-1935

stratigraphy B 1808-O; B 1909

Wyoming I-2343-A; I-2343-B

surficial geology maps

Indiana OF 93-0268-B

Midwest OF 93-0543

New Jersey MF-2221

New Mexico WRI 91-4033

New York WRI 91-4012

Utah I-2199

Virginia B 1981

Washington OF 93-0233

West Virginia B 1981; OP-1543

tectonic maps

Idaho OP-594; OP-780

Nevada B 2011

Utah B 2011

Wyoming OP-594; OP-780

tectonophysics GP-1004-D; GP-1004-F; GP1004-H; GP-1004-I; GP-1004-Z

topographic maps

I-2392; OP-1149; OP-1162; OP-1907

Atlantic Ocean I-2279-A
California I-2089-C; I-2091-C geomorphology OP-1398

volcanism I-2291-A

Wisconsin, geomorphology MF-2252

Maquoketa Formation

fractures OP-1336

ground water OF $92-0489$

hydrogeology OP-1228

Marathon Basin

natural gas OF 93-0522

Marble Mountain Terrane

Phanerozoic OP-1340

Marble Mountains

structural geology OP-1451

marbles

Alaska, stratigraphy OP-1169

Canada, stratigraphy OP-1776

Pennsylvania, engineering geology OF 920391

United States, stratigraphy OP-1776

Marcellus Shale

B 1909

natural gas B 1909

Mare Crisium see Sea of Crises

Mare Fecunditatis see Sea of Fertility

Mare Imbrium see Sea of Rains

Mare Orientale see Eastern Sea

mare ridges see wrinkle ridges

Mare Serenitatis see Sea of Serenity

Mare Spumans see Foaming Sea

Mare Undarum see Sea of Waves

margin, continental see continental margin

marginal trench see trenches

maria

OP-366; OP-416; OP-657; OP-783; OP-1437; OP-1438; OP-1439; OP-1697; OP-1781; OP1830 petrology OP-2025

Mariana Basin see Mariana Trough

Mariana Islands

geologic hazards OP-1962

hydrology, Guam WRI 92-4114

maps I-2408

plate tectonics OP-14

Mariana Trough

geochronology OP-813

Marianas Islands see Mariana Islands

Maricopa Agricultural Center hydrology WRI 92-4133

Marie Byrd Land tectonophysics OP-1446

Marina District engineering geology OP-1154

marine geology see also bottom features; continental shelf; marine geology maps; ocean circulation.

OF 92-0536; OF 92-0537; OF 92-0585

Alaska OF 92-0706

Atlantic Ocean OP-822

Celebes Sea

OP-821; OP-823; OP-824; OP-825 geophysical surveys OP-585

Indian Ocean OP-361

Melanesia OP-192

Pacific Ocean OP-819; OP-820; OP-822 plate tectonics $\mathrm{OP}-413$

Vanuatu

OP-186; OP-187; OP-189; OP-190; OP191; OP-193; OP-194; OP-195; OP-196 geophysical surveys OP-318

plate tectonics OP-185

marine geology maps

Atlantic Ocean

ocean floors I-2279-A

sedimentation I-2279-B

California

continental margin I-2089-C; I-2090-A; I2090-C; I-2091-C

oceanography OF 93-0298

Caribbean Sea, oceanography DDS-0015

Gulf of Mexico, oceanography DDS-0015

Massachusetts, oceanography DDS-0003

New Jersey, continental shelf MF-2221

marine installations

Florida OP-892

Puerto Rico OP-1863

marine placers

Puerto Rico, heavy mineral deposits OF 930341

marine sedimentation see also glaciomarine sedimentation.

Atlantic Ocean

ecology OF 92-0566

Quaternary OP-1650

Caribbean Sea DDS-0015

Gulf Coastal Plain, Cretaceous OP-838

Gulf of Mexico DDS-0015

Louisiana B 2002; OF $92-0530$ geomorphology OF 92-0530

Nevada, stratigraphy OP-1847

Pacific Ocean, plate tectonics OP-1901

Puerto Rico OF 92-0717

Samoa OP-844

marine sediments

OF $92-0719$

Adriatic Sea, pollution OP-47

Alabama

OF $92-0530$

Quaternary OF 92-0530

Alaska

B 2002; OF 93-0019

engineering geology B 2002

Quatemary OP-515

Antarctic Ocean OP-263

Appalachians, stratigraphy OP-1484

Arctic Ocean engineering geology OP-516

Quaternary C 1086; OF 92-0426; OF 920439; OF 93-0218; OP-1796

Arctic region, Quatemary OF 92-0439

Atlantic Coastal Plain OP-1337

paleontology OP-1205

Quatemary OF 92-0263

stratigraphy $P 1542$

Atlantic Ocean

B 2002; OF 92-0550; OP-822

Eocene OP-791

Pliocene OF 92-0508

Bahamas OP-928

Bering Sea OP-129

Black Sea OF 93-0274

California

B 2002; I-2090-A; OP-128; OP-1443; OP-

1444

engineering geology B 2002

Quatemary OF 93-0340; MF-2212

Celebes Sea OP-821

Connecticut OF 93-0214 
Florida

B 2002; OP-893

geochemistry OP-151

geochemistry OF 92-0525; OP-608

Georgia

OP-1502

pollution OP-1501

Gulf Coastal Plain

paleontology OP-1205

Quatemary OF 92-0530

Gulf of Mexico, Quaternary OF 92-0530

Hawaii B 2002

Louisiana

OF $92-0530$

engineering geology OF $92-0530$

Quaternary OF 92-0530

sands OF 92-0530

Maryland, geochemistry OP-439

Massachusetts

DDS-0003

Quaternary OP-749

Middle East OF 93-0274

Mississippi

OF $92-0530$

Quatemary OF 92-0530

New Hampshire, geochemistry OP-1207

Pacific Ocean

OP-819; OP-820; OP-822

geochemistry OP-419; OP-510; OP-519

Pliocene OF 92-0712

Peru, geochemistry OP-1331

Puerto Rico

OF 92-0717

heavy mineral deposits OF 93-0341 sands OF 92-0717

Rhode Island OF 93-0214

Vanuatu

OP-187; OP-368

plate tectonics OP-197

marine terraces

Califomia, Quatemary OF 93-0286; OP-707

Mexico, Quaternary OP-707

Oregon, Quaternary OP-707

Pacific Coast, Quatemary C 1086

marine transport

OF 92-0720

Antarctic Ocean, oceanography OP-263

Atlantic Ocean

oceanography OP-1073

sedimentation OF $92-0550$

Califomia, oceanography OF 93-0011

Louisiana

engineering geology OF 92-0530

geomorphology OF 92-0530

sedimentation OF $92-0530$

Mariner 6 OP-1209

Mariner 7 OP-1209; OP-1210

Mariner 10 OP-1830

Mariner Program see Mariner 6; Mariner 7

Maritime Provinces see New Brunswick; Nova

Scotia

MARK3

economic geology B 2035

Markagunt Plateau

sedimentary petrology OF 92-0391

Marks Head Formation

Quatemary I-1935

marl

California, Quatemary OF 93-0232

Hungary, energy sources OP-1687

United Arab Emirates, stratigraphy OP-1453
Marmaton Group

energy sources OP-1476

Marquesas Keys

reefs OP-1662

Marquette Michigan

structural geology OP-1889

Marryat Creek earthquake 1986 Quaternary B 2032-B

Mars see also Amazonian; Hesperian; marsquakes; Noachian; Phobos Satellite.

I-2311; I-2312; I-2313; I-2314; I-2315; I-2316;

I-2317; I-2318; I-2319; I-2320; I-2321; I-2322;

I-2323; I-2324; I-2325; I-2332; I-2333; I-2334;

I-2335; I-2336; I-2337; I-2338; I-2339; I-2340;

I-2392; OP-141; OP-508; OP-509; OP-1153; OP-1209; OP-1210; OP-1221; OP-1224; OP-

1241; OP-1266; OP-1269; OP-1270; OP-1406;

OP-1421; OP-1563; OP-1564; OP-1565; OP-

1647; OP-1667; OP-1723; OP-1785; OP-1831;

OP-1832; OP-2022

Alba Patera

OP-1984

Syria OP-1322

Antarctica OP-842

Ascraeus Mons OP-1163; OP-1722

Chryse Planitia OP-142; OP-987; OP-1838; OP-1937

Elysium OP-906; OP-1222

Elysium Mons OP-142; OP-1240

Greenland, Archean OP-848

Kasei Vallis I-2208; OP-987; OP-1338; OP1674

Lunae Planum

OP-987; OP-1163; OP-1868; OP-1984

Syria OP-1322

Mangala Valles OP-1242

Tharsis

OP-107; OP-142; OP-987; OP-1222; OP1235; OP-1323; OP-1936; OP-1938; OP1984

Syria OP-1322

Valles Marineris OP-142; OP-1162; OP-1235; OP-1408; OP-1668; OP-1669; OP-1868; OP-1937

Mars Observer OP-1223

Marshall Islands

ground water OP-26

Neogene, Enewetak Atoll OP-1457

Marshall Metagranite

intrusions OP-1106

Marshall Sandstone

ground water WRI 91-4133; OP-1706

marshes see salt marshes

marsquakes OP-1422; OP-1937

Marsupialia

South America OP-97

Martinsburg Formation

OF 92-0525

areal geology B 1994

environmental geology OP-901

structural geology OF 93-0025

Maryland see also Blue Ridge Province; Catoctin

Formation; Chesapeake Bay, Delmarva Peninsula; Piedmont; Valley and Ridge Province. engineering geology, Baltimore Maryland OF $92-0541$

environmental geology

Baltimore Maryland OP-1089

Frederick County Maryland OF 92-0168

Harford County Maryland OP-1089

geochemistry OF 92-0525; OP-1824 ground water

YR; P 1404-G

Anne Arundel County Maryland OF 92 0459; OF 92-0460; OF 92-0461; OF 92 0462; OF 92-0463; OF 92-0464

Calvert County Maryland OF 92-0459, OF 92-0460; OF 92-0461; OF 92-0463; OF $92-0464$

Charles County Maryland OF 92-0459; OF 92-0460; OF 92-0461; OF 92-0462; OF 92-0463; OF 92-0464

Howard County Maryland OP-1100

Prince Georges County Maryland OF 920459; OF 92-0460; OF 92-0461; OF 92 0462; OF 92-0463; OF 92-0464

Saint Marys County Maryland OF 92-0459, OF 92-0460; OF 92-0461; OF 92-0463; OF 92-0464

hydrogeology

WRI 91-4179

Caroline County Maryland OF 93-0040

Cecil County Maryland OF 93-0040

Dorchester County Maryland OF 93-0040

Frederick County Maryland OF 92-0649

Howard County Maryland OP-261

Kent County Maryland OF 93-0040

Queen Annes County Maryland OF 93-0040

Somerset County Maryland OF 93-0040

Talbot County Maryland OF 93-0040

Wicomico County Maryland OF 93-0040

Worcester County Maryland OF 93-0040

hydrology

W 2400; WRI 92-4060; OP-524; OP-1573

Charles County Maryland W 2340

Frederick County Maryland OP-1572

Prince Georges County Maryland W 2340

metamorphism, Montgomery County Maryland OP-1152

paleontology OP-1205

pollution, Frederick County Maryland OP-833 stratigraphy

OP-1788

Cecil County Maryland OP-528

Marysvale Utah economic geology OP-872

Maslum Synclinorium

Proterozoic B 1976

Mason Coal

palynomorphs OP-1603

Masonic Park Tuff

geochemistry OP-1825

mass extinctions

geochronology OP-134

Germany, stratigraphy B 2050

Iowa, stratigraphy B 2050

Mexico, stratigraphy B 2050

mass movements see also avalanches; debris avalanches; debris flows; earthflows; erosion; lahars; landslides; mudflows; rockfalls; rockslides; talus slopes.

OP-1832

Atlantic region, engineering geology OP-96

California, engineering geology OP-882

earthquakes OP-1893

Great Lakes, hydrology OP-199

rock mechanics OP-600

Vanuatu, plate tectonics OP-185

mass spectroscopy

diagenesis OP-1477

geochemistry B 1770; OF 92-0543; OF 930267; OP-991

Quaternary OF 92-0525 
sedimentary petrology OP-1478

mass wasting see mass movements

Massabesic gneiss complex

structural geology OP-1079

Massachusetts see also Bronson Hill Anticlinorium.

continental shelf, Boston Massachusetts OP546

environmental geology, Worcester County

Massachusetts OF 92-0646

estuaries, Boston Massachusetts OP-932

geochemistry OP-215

geochronology OF 92-0525

geomorphology

Nantucket County Massachusetts OF 930185

Nantucket Island OF 93-0185

ground water

Cape Cod OF 92-0143; OP-431; OP-1815

Norfolk County Massachusetts OP-800

guidebook, Cape Cod OF 92-0551

hydrology W 2400; OP-1826; OP-1828

maps

I-1420 (NK-18)

Berkshire County Massachusetts I-2369

Mesozoic OP-801

neotectonics, Boston Massachusetts OP-555

non-metal deposits OP-1104

oceanography

Boston Massachusetts DDS-0003

Norfolk County Massachusetts DDS-0003

Plymouth County Massachusetts DDS-0003 pollution OP-1574

Quaternary

OP-749

Nantucket Island OP-748

sedimentation, Boston Massachusetts OP-1598

Massachusetts Bay

continental shelf OP-546

oceanography DDS-0003

pollution OP-47

Massachusetts Military Reservation ground water OF 92-0143

Massanutten Mountain hydrology OP-524; OP-1573

Massanutten Synclinorium environmental geology OP-901

massive deposits

OP-1565

Alaska, metal ores OP-224; OP-570

California, metal ores OP-554

geochemistry OP-763

metal ores $\mathrm{OP}-465$

Ontario

polymetallic ores $\mathrm{OP}-484$

sulfides OP-1892

Red Sea, brines OP-2029

massive sulfide deposits

geochemistry OP-763

Pacific Ocean, sedimentation OP-243

Matador Arch

energy sources OF 93-0522

Matanuska Formation

energy sources OP-626

geochemistry OP-1410

Matanuska Valley economic geology C 1094

Matochkin Shar Russian Federation engineering geology OF 93-0501

Matuyama Epoch

Idaho OP-1850
Indonesia OP-1538

Ivory Coast OF 92-0699

New Mexico OF 92-0699; OP-1538

Mauch Chunk Formation

OF 92-0568

fluvial features B 1981

Maumelle Reservoir hydrology OF 93-0122

Mauna Kea

environmental geology OF 93-0512-A geophysical surveys OF 92-0686

Mauna Loa

environmental geology OF 93-0512-A

geomorphology OP-694

geophysical surveys OF 92-0686

oceanography MF-2233

Quaternary OP-1759

Maunder Formation OP-416; OP-1482

Mauri Formation metal ores B 2039

Maurice River environmental geology OF 93-0243

Maxwell Montes OP-1724

Maynardville Limestone lead-zinc deposits OP-12

McArthur Deposit metal ores OP-942

McCoy Creek Group OP-1776

McDermitt Caldera economic geology OP-834

McGrath Quadrangle Brachiopoda OP-491

Invertebrata OP-84

McHugh Complex OP-1169 geochemistry OP-1410

McKinley Fault metamorphic rocks P 1497-C

McNairy-Nacatoch Aquifer ground water OP-1191

Meadow Valley Mountains maps I-2173

meanders

Illinois, Quaternary P 1536

Indiana, Quaternary P 1536

Mississippi, hydrogeology OP-1010

mechanical weathering

OP-389

Pennsylvanian OP-1233

Medfra Quadrangle mineral resources MF-2207

Medicine Bow Mountains stratigraphy $\mathrm{P} 1520$

Medicine Lake geomorphology OP-266 geophysical surveys B 1966

Medicine Lodge Basin Eocene OP-617

Medicine Lodge Peak Quadrangle maps GQ-1724

Medicine Peak Quartzite Cretaceous OP-11

Mediterranean region see Israel; Lebanon

Mediterranean Sea see also East Mediterranean; West Mediterranean. oceanography OP-722

meerschaum see sepiolite

meetings see symposia megabreccia

Nevada, volcanism OF 93-0021

Utah, mineral resources B 2039

Mekong Delta

petroleum OP-1829

Melanesia see Fiji; Vanuatu

melange

Alaska

I-2164

metamorphic rocks P 1497-C stratigraphy OP-1169

Califomia

metal ores OP-554

structural analysis OP-1546

Canada, metamorphic rocks P 1497-C

Oregon OP-87

Pakistan, tectonics OP-1637

petrology OF 92-0020-G

Melas Chasma OP-1162; OP-1235

Mele Bay

geologic hazards OP-1521

melnikovite see greigite

Melton Valley

hydrogeology WRI 92-4131

Memphis Tennessee

ground water WRI 91-4173

menaccanite see ilmenite

Mendeleyev abyssal plain

tectonophysics OP-1626

Mendeleyev Ridge

tectonophysics OP-1626

Mendenhall Glacier

Quatemary C 1086

Mendez Formation stratigraphy OP-1179

Mendocino (Cape) see Cape Mendocino

Mendocino fault zone earthquakes OP-1762

Mendocino fracture zone

earthquakes OP-1762

metamorphic rocks OP-1166

plate tectonics OP-145; OP-752; OP-759; OP1749

tectonophysics OP-1926

Mendoza Argentina

structural geology OP-1129

Menuites

Invertebrata P 1533

Meramecian see also Saint Louis Limestone; Warsaw Formation.

Arkansas OP-360

Oklahoma OP-360

Mercalli scale, modified see modified Mercalli scale

Merced California soils OP-1065

Merced River environmental geology OF 93-0294 soils OP-1170

Merchants Exchange Building engineering geology OF 92-0391

Merchantville Formation stratigraphy OP-528

Mercur Mine gold ores B 2013

Mercurius OP-1439

mercury

Alaska, pollution OP-66

Colorado, sedimentary petrology OP-1382

hydrology OF 93-0032; OP-1836 
Idaho, gold ores B 2039

sediments OP-1887

mercury ores

Alaska OP-1433

California

OP-162; OP-267

geochemistry OP-265

Nevada OP-489

Meriamella

Invertebrata OP-86

Merrillina

Permian OP-1982

Merrimack Group OP-1530

Merrimack River valley

ground water WRI 91-4025

Mesaverde Group see also Gallup Sandstone;

Point Lookout Sandstone.

B 1917-O

energy sources OF 93-0337

hydrogeology WRI 92-4004

natural gas OF 92-0524

oil and gas fields OP-1857

sedimentary rocks $B$ 1787-DD

Mesilla Basin

ground water P 1407-C; WRI 91-4155; OF 910455

Mesogondolella

Conodonta OP-1622

mesosiderite

petrology OP-1 199

mesothermal processes

Alaska

gold ores OP-1099

metal ores OP-123

metal ores OF 93-0194

Mesozoic see also Cretaceous; Jurassic; Triassic. OP-88; OP-596; OP-853; OP-1494; OP-2018

Alabama OP-968

Alaska P 1497-C; B 2034-A; OP-1427; OP1680

Antarctic Ocean OP-1446

Antarctica OP-1317

Appalachians OP-1479

Arctic Ocean OP-1429; OP-1626

Basin and Range Province OP-2015

California B 2019; OP-342; OP-1146; OP1474; OP-1691

Canada P 1497-C

Cimmerian Orogeny, plate tectonics OP-1628

Colorado OF 93-0248

Franciscan Complex

OP-385

energy sources OP-267

manganese ores $\mathrm{OP}-458$

maps OP-1945

metal ores OP-554

metamorphic rocks OP-1166

petrology OP-1900

structural analysis OP-1546

structural geology OP-401; OP-1547; OP1701

Georgia OP-968

Great Basin OP-2015

Great Valley Sequence

energy sources OP-267

geochemistry OP-265

maps OP-1945

metamorphic rocks OP-1166

structural geology OP-1547; OP-1701

Gulf of Mexico OP-1932

Hungary OP-1687
Idaho OP-1067

Massachusetts OP-801

McHugh Complex

OP-1169

geochemistry OP-1410

Navajo Sandstone

ground water WRI 90-4105

hydrogeology W 2340; OP-1736

uranium ores $\mathrm{OP}-1848$

Nevada B 1988-C; B 2019; OP-342; OP-999

Nevadan Orogeny

California OP-1141; OP-1413

Oregon OP-1140; OP-1141

Newark Supergroup

OP-1659; OP-1660

guidebook OP-359

magmas OP-1003

Northwest Territories OP-1680

Oregon OP-87

Pacific Ocean OP-105; OP-510

Passaic Formation energy sources OP-1842 ground water OP-986

Pictou Group, geochemistry OP-1905

South Carolina OF 92-0723

Washington OP-1067

Messala Crater OP-1439

Messoyakha Field

energy sources OP-1284

meta-andesite

Alaska I-2164

meta-ophiolite see ophiolite

metabasalt

Greenland OP-636

metachert

California, manganese ores OP-458

metaconglomerate

Montana OP-1731

metadiamictite

Virginia, Proterozoic B 2029

metagabbro

Russian Federation, Precambrian OP-1777

metagranite

Alaska, geochemistry OP-721

California, geochemistry OP-512

Colorado, Proterozoic OP-10

geochemistry OP-1377

Montana, Archean OP-705

Northwest Territories, geochemistry OP-721

metagraywacke

California, manganese ores OP-458

metaigneous rocks see also meta-andesite;

metabasalt; metagabbro; metagranite; metaperidotite; metarhyolite; metatuff; serpentinite.

Italy, structural geology OP-1808

metal ores see also antimony ores; base metals; beryllium ores; cadmium ores; chromite ores; cobalt ores; copper ores; gold ores; iron ores; lead ores; lead-zinc deposits; manganese ores; mercury ores; metallogenic maps; metallogenic provinces; metallogeny; molybdenum ores; nickel ores; niobium ores; palladium ores; platinum ores; polymetallic ores; precious metals; rare earth deposits; rhodium ores; silver ores; tantalum ores; thorium ores; tin ores; titanium ores; tungsten ores; uranium ores; vanadium ores; zinc ores.

B 2039; MF-1838-D; OP-362; OP-714; OP852; OP-1035; OP-1117; OP-1509

Alaska MF-1996-E; MF-2228; OP-224
Appalachians B 1979

Bolivia YR

California B 2019; OF 92-0595; OP-554

Chile OP-1107

Colorado B 2035

Dominican Republic OP-1576

England, geochemistry OP-158

Hawaii, oceanography OP-418

Idaho OF 93-0235

Minnesota OF 92-0615; OP-169

Montana

OF 93-0207; OF 93-0285-A

geochemistry OP-1094

Nevada B 2019; OP-169; OP-397; OP-736

North Carolina B 2005

Puerto Rico OP-217

Russian Federation OP-1313

Tennessee B 2005

Venezuela OP-217; OP-1107

metallic meteorites see iron meteorites

metallogenesis see metallogeny

metallogenic maps

Alaska, metal ores OF 93-0339

metal ores OF 93-0208-A; OF 93-0208-B

Russian Federation, metal ores OF 93-0339

economic geology OF 92-0020-B

New Brunswick, lead-zinc deposits OP-787

New South Wales Australia, lead-zinc deposits OP-787

metallogeny see also metallogenic maps.

Alaska, metal ores OP-1203

Canada, metal ores OP-728

Italy, metal ores OF 93-0504

metal ores OP-339; OP-465

Nevada, metal ores OP-627

New South Wales Australia OP-7

Peru, geochronology OP-1601

South America, metal ores OF 93-0328

United States, metal ores OP-728

metals see also actinides; alkali metals; alkaline earth metals; aluminum; antimony; arsenic; bismuth; cadmium; chromium; cobalt; copper; gold; hafnium; iron; lead; manganese; mercury; molybdenum; nickel; niobium; platinum group; rare earths; thenium; silver, tantalum; tin; titanium; trace metals; tungsten; vanadium; zinc; zirconium.

Adriatic Sea, pollution OP-47

Arizona

metal ores OP-9

pollution OP-591

British Columbia, metal ores OP-9

Colorado

geochemistry OP-1965

pollution OP-315; OP-1579; OP-1968

geochemistry OP-1319

Hungary, energy sources OP-1263

Kentucky, geochemistry B 2046

Massachusetts, ground water OP-800

metal ores OP-1506

Mississippi, geochemistry OP-1577

Missouri, hydrology WRI 93-4012

Montana

OF 93-0285-B

geochemistry OP-1305

Nevada, gold ores OP-716

Philippine Islands, metal ores OP-9

platinum group

Australia OP-1431

Califomia B 2014

Canada OP-1431

Chile OP-1107 
China OP-363

metal ores OF 92-0557

Russian Federation OP-2014

Venezuela OP-1107

Yukon Territory OP-363

pollution OP-297; OP-788

precious metals

Bolivia OP-1306

Colorado OF 92-0557; OP-937; OP-944; OP-1633

Idaho OP-876

Nevada OP-79; OP-627

Oregon OP-876

Spain OP-31; OP-231

Utah OP-394

Wyoming I-2232

Russian Federation

geochemistry OP-130

Quaternary OP-1208

South Dakota, environmental geology OP-641

Sweden, geochemistry OP-584; OP-1649

United States, geochemistry OP-584; OP-1649

Utah, geochemistry OP-1965

metaluminous composition

Arizona, igneous rocks OP-1112

California

igneous rocks OP-1112

petrology OP-1691

Canada, petrology OP-1463

United States, petrology OP-1463

metamorphic core complexes

Arizona, structural geology OP-1886

Basin and Range Province, structural geology OP-769

British Columbia, structural geology OP-1159

Colorado Plateau, structural geology OP-769

Mexico, structural geology OP-1886

Pacific Ocean, tectonophysics OP-1926

Washington

petrology OP-1397

structural geology OP-1159

metamorphic processes

California, manganese ores OP-319

gold ores OF 92-0557

metamorphic rocks see also amphibolite facies; blueschist facies; greenschist facies; metasomatic rocks; prehnite-pumpellyite facies.

Alabama, geochronology OP-968

Alaska OP-1194

amphibolites

California OP-1340

Colorado OP-827

faults OP-685

Germany OP-1029

New England OF 92-0525

Saudi Arabia OP-1952

Appalachians, economic geology B 1979

blueschist

California OP-1546

tectonophysics OP-1366

California

OP-1166

economic geology B 2019; OP-260

Colorado, mineral resources OP-95

Connecticut OP-1188

eclogite

OP-635

Norway OP-1173

Georgia, geochronology OP-968

gneisses

Alabama OP-1237

Appalachians OP-1479
Arizona OF 92-0591-A; OF 92-0591-B

California OP-1691

Colorado OP-827

Connecticut WRI 92-4074

faults OP-685

Germany OP-1029

Maryland OP-1106

Mexico OP-132

Michigan B 1904-Q; B 1904-S; I-2355; OP1889

Minnesota B 1904-S

Montana OP-705

New England OF 92-0525

Rocky Mountains OP-1716

Russian Federation OP-1777

Virginia OP-1106

Washington OP-1397

Wyoming P 1520

granulites

Colorado OP-1913

faults OP-685

geochronology OF 92-0525

Manitoba OP-1709

New York OP-1709

Norway OP-1173

Quebec OP-1097

greenstone

Alaska OP-1169

Michigan B 1904-S; OP-1889

Minnesota B 1904-S

hornfels

Greenland OP-636

Montana OP-1087

marbles

Alaska OP-1169

Canada OP-1776

Pennsylvania OF 92-0391

United States OP-1776

Massachusetts OP-1188

meta-andesite, Alaska I-2164

metabasalt, Greenland OP-636

metachert, California OP-458

metaconglomerate, Montana OP-1731

metagabbro, Russian Federation OP-1777

metagranite

Alaska OP-721

California OP-512

Colorado OP-10

geochemistry OP-1377

Montana OP-705

Northwest Territories OP-721

metagraywacke, California OP-458

metaigneous rocks, Italy OP-1808

metaperidotite, Michigan B 1904-P

metaplutonic rocks

Alaska I-2164

California B 2014

Colorado OP-10

Idaho OP-630

New York OP-460

Ontario OP-460

metarhyolite, Virginia B 2029

metasedimentary rocks

Alaska I-2164; OP-721

California B 2015

Canada OP-1776

Canadian Shield OP-1316

China OF 92-0525

Colorado OP-944

Gabon OP-713

geochemistry OF 92-0525

gold ores OF 92-0557

Michigan B 1904-Q
Montana P 1524; OP-705

New York OP-460

Northwest Territories OP-721

Ontario OP-460

Pennsylvania WRI 91-4182

United States OP-1776

Virginia B 2029

Wyoming P 1520; OP-149

metatuff, Michigan B 1904-P

metavolcanic rocks

Ecuador B 2039

gold ores OF 92-0557

Michigan B 1904-P

Montana OP-1731

Oregon B 2054

Virginia B 2029

Wyoming P 1520

Michigan, structural geology B 1904-L

migmatites, Colorado OP-827

mineral resources OF 92-0557

mineralogy OP-25

mylonites

British Columbia OP-1159

geochronology OF 92-0525

Michigan B 1904-S; I-2355; OP-1889

Minnesota B 1904-S

New York OP-460; OP-461

Ontario OP-460

Poland OP-967

Vermont OP-461

Washington OP-1159

Wyoming OP-149

natural gas OF 92-0524

Nevada, economic geology B 2019; OP-260

Oman, Cretaceous OP-296

Ontario OP-214

Oregon OP-1166

orthogneiss

Alaska OP-721; OP-1427

Canadian Shield OP-1316

Idaho OP-630

Northwest Territories OP-721

paragneiss

New York OP-461

Vermont OP-461

Washington I-1963

phyllites, Washington I-1963

quartzites

Idaho B 2013

Nevada OF 93-0249

New South Wales Australia OP-942

Queensland Australia OP-942

schists

Alabama OP-1237

Alaska OP-570; OP-1427

Arizona OF 92-0591-A; OF 92-0591-B

California OP-442; OP-1971

heavy minerals OF 92-0386

Idaho OP-434

Maryland OP-658

Montana OP-705; OP-1731

Nevada OF 93-0249

New York OP-461

Vermont B 2039; OP-461

Washington I-1963

serpentinite

OF 92-0020-G

economic geology OF 92-0020-B

slates, Pennsylvania OF 92-0525

tourmalinite

geochemistry OP-763

New South Wales Australia OP-942

Queensland Australia OP-942 
Virginia, orogeny OP-1612

metamorphism see also greenschist facies.

OP-635; OP-1591

Alabama, geochronology OP-968

Alaska OP-1349

Appalachians, structural geology OP-1479

burial metamorphism

Gulf of Mexico OP-287; OP-288

Pennsylvania OF 92-0568

petroleum OP-793

sedimentary petrology OP-1135

Victoria Australia OP-1136

Califomia

OP-1165; OP-1900

structural geology OP-442

contact metamorphism

Greenland OP-636

sedimentary petrology OP-1135

Victoria Australia OP-1136

Dominican Republic OP-1900

geochronology OF 92-0525

Georgia, geochronology OP-968

high-grade metamorphism Appalachians OP-1079

Greenland OP-636

New South Wales Australia OP-942

Queensland Australia OP-942

Wyoming OP-149

Idaho OP-434

low-grade metamorphism

Greenland OP-636

Montana P 1524; OP-1731

petroleum B 1909

structural geology OP-401

Virginia OP-1755

Maryland OP-1152

Michigan, structural geology B 1904-L; B 1904-Q

natural gas OF $92-0524$

New Mexico, molybdenum ores OP-1927

Norway, structural geology OP-1279

Oman, Cretaceous OP-296

Ontario OP-214

Pakistan, structural geology OP-1125

Poland, structural geology OP-967; OP-1916

polymetamorphism

Alaska P 1497-C; I-2164

Canada P 1497-C

Connecticut OP-1188

Maine OP-750

Manitoba OP-1709

Massachusetts OP-1188

New York OP-1709

Vermont B 1955

Virginia OP-1612

prograde metamorphism

Manitoba OP-1709

New South Wales Australia OP-942

New York OP-1709

Queensland Australia OP-942

Quebec, gold ores OP-1097

regional metamorphism

OP-1355

Alaska P 1497-C; I-2164; OP-570; OP-1304

California B 2015

Canada P 1497-C

gold ores OF 92-0557

Idaho OP-1671

Maine OP-750

Nevada OP-999

New England OF 92-0525

North Carolina B 2039
Vermont B 2039

retrograde metamorphism

Ecuador B 2039

New South Wales Australia OP-942

New York OP-461

Queensland Australia OP-942

Vermont B 1955; OP-461

shock metamorphism

Colorado OP-1388; OP-1804

Iowa OP-475; OP-1537; OP-1613

Mexico OP-920

Montana OP-1744

New Mexico OP-1388

Ontario OF 92-0391; OP-1178

Rocky Mountains OP-1792

South Dakota OP-475

stratigraphy OP-1788

Western Interior OP-1792

Wyoming OP-1744

thermal metamorphism, sedimentary petrology OP-1135

Virginia OP-1152

Washington OP-1900

metaperidotite

Michigan, Archean B 1904-P

metaplutonic rocks

Alaska I-2164

California, platinum ores B 2014

Colorado, Proterozoic OP-10

Idaho OP-630

New York, structural geology OP-460

Ontario, structural geology OP-460

metarhyolite

Virginia, Proterozoic B 2029

metasedimentary rocks see also metachert; metaconglomerate; metagraywacke; paragneiss.

Alaska

I-2164

geochemistry OP-721

California, stratigraphy B 2015

Canada, stratigraphy OP-1776

Canadian Shield, crust OP-1316

China, metal ores OF 92-0525

Colorado, base metals OP-944

Gabon, geochemistry OP-713

geochemistry OF 92-0525

gold ores OF 92-0557

Michigan, structural geology B 1904-Q

Montana

Archean OP-705

structural geology P 1524

New York, structural geology OP-460

Northwest Territories, geochemistry OP-721

Ontario, structural geology OP-460

Pennsylvania, ground water WRI 91-4182

United States, stratigraphy OP-1776

Virginia, Proterozoic B 2029

Wyoming

stratigraphy $P 1520$

structural geology OP-149

metasomatic rocks

China, metal ores OP-317

greisen

Saudi Arabia OP-499; OP-1559

tin ores OF 92-0557

Maine, metal ores B 2039

serpentinite

OF 92-0020-G

economic geology OF 92-0020-B

skam

California OP-662

Colorado OF 93-0183
Ecuador B 2039

Idaho OP-1296

Nevada OF 93-0249; OP-994

Sweden OP-1445

Tadzhikistan OP-1445

tin ores OF 92-0557

metasomatism

OP-1417

Alabama OP-1237

albitization, Saudi Arabia OP-1558

alunitization, economic geology OP-873

argillization, Nevada OP-27

California

OP-1900

geochemistry OP-730

China OP-1343

Dominican Republic OP-1900

greisenization, Saudi Arabia OP-1558

hydrothermal alteration

OP-1246; OP-1248; OP-1785

Bolivia OF 93-0016

California OP-890

China OP-153

Colorado OP-985

deformation OP-740

economic geology OP-873

Ecuador B 2039

engineering geology OP-760

Gabon OP-713

geochemistry OP-537

Hawaii OP-436

Iceland OP-511

Michigan OP-1116; OP-1747

Nevada OP-627

New Mexico OP-1243; OP-1927

New South Wales Australia OP-942

North Carolina B 2039

Oregon B 2054

Queensland Australia OP-942

sedimentary petrology OP-1135

Washington GQ-1679

Idaho OP-434

Mesozoic OP-1494

Nevada, geochemistry OP-1609

propylitization, Colorado OP-1633

wall-rock alteration

Alaska OP-349

Colorado OF 92-0525; OP-315

Washington OP-1900

metasomatites see metasomatic rocks

metastability

phase equilibria OP-1726

Metatheria see Marsupialia

metatuff

Michigan, Archean B 1904-P

metavolcanic rocks

Ecuador, gold ores B 2039

gold ores OF 92-0557

Michigan, Archean B 1904-P

Montana OP-1731

Oregon B 2054

Virginia, Proterozoic B 2029

Wyoming, stratigraphy P 1520

meteor craters

Mexico, geochronology OP-920

Namibia OP-550

meteoric iron see iron meteorites

meteorites

Allende Meteorite, petrology OP-1704

chondrites

OP-1561

petrology OF 92-0525; OP-1727; OP-1977 
geochronology OF 92-0525

iron meteorites, petrology OF 92-0525; OP1977

mesosiderite, petrology OP-1199

petrology OP-1177; OP-1 180; OP-1705

Semarkona Meteorite, petrology OP-1666

Yamato Meteorites, petrology OP-1956; OP2025

methane see also coalbed methane.

OP-1591

Alaska

ecology C 1086

environmental geology C 1086

Quatemary C 1086; OP-1616

Antarctica, hydrology OP-949

Atlantic Coastal Plain, oceanography OP-1337

California

hydrology C 1086

soils OP-1713

Cameroon, geochemistry OP-306

Colorado, pollution WRI 93-4007

geochemistry OF 92-0445; OP-563; OP-914; OP-1766

Kentucky, hydrology WRI 92-4057

Maryland, geochemistry OP-439

Minnesota, pollution OP-1526

natural gas OP-1615

New Mexico, pollution WRI 93-4007

Pacific Ocean

energy sources OP-1614

geochemistry OP-1127

Puerto Rico, hydrogeology C 1086

Rocky Mountains, natural gas OP-1350

soils C 1086

methoxychlor see DDT

Mexican Pass Quadrangle

Quatemary OF 92-0391

structural geology OP-1539

Mexico

barite deposits, Sonora Mexico OP-796

economic geology OP-872

energy sources

Baja California OP-1657

Cerro Prieto OP-1137; OP-1657

geochemistry

Chihuahua Mexico OP-132

El Chichon OP-1778

geochronology, Yucatan Peninsula OP-920

geologic hazards, Paricutin OF 93-0197-A; OF 93-0197-B

geothermal energy, Cerro Prieto OP-984

ground water WRI 91-4155

hydrogeology

OP-2007

Yucatan Mexico OP-38

Yucatan Peninsula OP-2001

Invertebrata, Baja California Sur Mexico OP1800

maps

I-1420 (NG-14)

Chihuahua Mexico YR; 1-2287

metal ores, Baja California B 2039

neotectonics, Sonora Mexico MF-2238

Paleozoic, Sonora Mexico OP-56

plate tectonics, Michoacan Mexico OP-670

Quaternary

Baja California OP-707

Baja California Mexico OP-707

Baja California Sur Mexico OP-707

Yucatan Peninsula OP-706

sedimentary petrology, Cerro Prieto OF 92 0391; OP-50 stratigraphy

OP-1179; OP-1414

Colorado River delta OP-257

Yucatan Peninsula B 2050

structural geology

Baja California OP-1547

Sonora Mexico OP-1886

$\mathrm{Mg}$ see magnesium

Miami Wash

hydrogeology OF 92-0468

Mic Mac Formation

Mesozoic OP-801

mica group see also biotite; muscovite; phlogopite; sericite.

California, structural geology OP-442

phase equilibria OP-1311

Virginia, orogeny OP-1612

Michigan see also Antrim Shale; Detroit River

Group; Lake Michigan; Lake Superior region;

Lockport Formation; Michigan Basin; Nonesuch

Shale; Oronto Group; Salina Group; Traverse

Group.

Archean, Marquette County Michigan B 1904$P$

areal geology

Gogebic County Michigan OP-139

Keweenaw Peninsula OP-139

Ontonagon County Michigan OP-139

Porcupine Mountains OP-139

copper ores

Keweenaw Peninsula OP-1688; OP-2019

White Pine Mine OP-1688

energy sources, White Pine Mine OF 92-0391

geochemistry

Porcupine Mountains OP-1747

White Pine Mine OP-1204

ground water

OF 92-0114; OF 92-0489; OF 92-0694;

OF 93-0071; OF 93-0114; HA-0730-J

Huron County Michigan WRI 91-4133

Michigan Lower Peninsula WRI 91-4133

hydrogeology WRI 91-4120; OF 92-0157

hydrology W 2400; WRI 91-4194

industrial minerals OF 92-0514

maps

I-1420 (NL-17)

Dickinson County Michigan I-2356

non-metal deposits OF 92-0514

palynomorphs, Michigan Lower Peninsula B 1909

petrology OP-1116

sedimentary petrology

Gogebic County Michigan OP-1495

Michigan Lower Peninsula OF 93-0236

Missaukee County Michigan OF 93-0236

structural geology

OP-1214

Baraga County Michigan B 1904-Q

Dickinson County Michigan B 1904-L

Iron County Michigan B 1904-L; B 1904-Q

Marquette County Michigan B 1904-Q; I2355

Marquette Michigan OP-1889

Michigan Upper Peninsula B 1904-S

Michigan Basin

ground water P 1405-C; OP-1706

palynomorphs B 1909

petroleum B 1909

Quaternary OP-1289

sedimentary petrology OF 93-0236

Michigan Formation

ground water WRI 91-4133
Michigan Lower Peninsula

ground water WRI 91-4133

palynomorphs B 1909

sedimentary petrology OF 93-0236

Michigan Upper Peninsula see also Keweenaw

Peninsula; Porcupine Mountains.

structural geology B 1904-S

Michoacan Mexico see also Paricutin. plate tectonics OP-670

micrite

Nevada OP-1795

microcline

Alabama, geochronology OP-968

Georgia, geochronology OP-968

Russian Federation, Precambrian OP-1777

Microdomatacea

Invertebrata OP-84

microearthquakes

Califomia P 1550-C

microfossils see algae; algal flora; Conodonta; conodonts; foraminifers; Ostracoda; ostracods; palynomorphs; Protista; radiolarians

microgranite

Scotland, geochemistry OF 93-0267

Micronesia see also Mariana Islands; Marshall Islands.

geochemistry, Belau OP-59; OP-1150

hydrology W 2400

micropetrological unit see macerals

micropyrolysis geochemistry OP-1923

microrelief

California, geomorphology OF 93-0272

microseismicity see seismicity

Mid-Arctic Ocean Ridge

plate tectonics OP-1429

Mid-Atlantic Ridge see also North Atlantic

Ridge.

geophysical surveys OF 93-0264

stratigraphy OP-1484

Mid-Continent see Midcontinent

Mid-continent Rift see Keweenawan Rift

mid-ocean ridge basalts

Pacific Ocean

geochronology OP-813

plate tectonics $\mathrm{OP}-413$

mid-ocean ridges see also Chile Ridge.

Alaska, structural geology OP-94

Arctic Ocean, Quaternary OF 92-0426

Atlantic Ocean, tectonophysics OP-1080

Hawaii, oceanography B 2002

Pacific Ocean, tectonophysics OP-1080

Midas Mountains gold ores OP-1048

Midcontinent see also Arkansas; Colorado;

Illinois; Indiana; Iowa; Kansas; Kentucky;

Michigan; Minnesota; Missouri; Nebraska; New

Mexico; North Dakota; Ohio; Oklahoma; South

Dakota; Texas; Wisconsin; Wyoming.

Ordovician OP-1818

Pennsylvanian OP-1518

petrology OP-1417

pollution OF 93-0418; OP-816; OP-1425; OP1600

stratigraphy OP-1345

Midcontinent Rift System see Keweenawan Rift

Midcontinent Stategic and Critical Minerals

Project

metal ores MF-1835-H 
Middendorf Aquifer ground water WRI $92-4000$

Middendorf Formation B 2030

Middle Cambrian see Flathead Sandstone

Middle Devonian see Columbus Limestone; Delaware Limestone; Detroit River Group; Eifelian; Givetian; Hamilton Group; Ludlowville Formation; Marcellus Shale; Moscow Formation; Onondaga Limestone; Tully Limestone

Middle East see also Iraq; Israel; Jordan; Lebanon; Syria; Turkey. tectonophysics, Dead Sea Rift OP-1606

middle Eocene see Claiborne Group; Cockfield Formation; Lisbon Formation; Sparta Sand

Middle Jurassic see Bathonian; Callovian middle Liassic see Pliensbachian

middle Miocene see Kirkwood Formation

Middle Ordovician see Ammonoosuc Volcanics; Decorah Shale; Saint Peter Sandstone

Middle Park Colorado

natural gas OF 93-0248

stratigraphy B 2024

Middle Pennsylvanian see Allegheny Group; Atokan; Breathitt Formation; Desmoinesian; Hermosa Formation; Paradox Member; Tradewater Formation

middle Proterozoic see Belt Supergroup

Middle Silurian see Niagaran; Roberts Mountains Formation; Rochester Formation

Middle West (United States) see Midwest

Middlesboro Member

stratigraphy OP-1368

Middlesex Shale

natural gas B 1909

Middleton Island Quadrangle maps I-1984

Middletown Quadrangle

maps OF 93-0024

structural geology OF 93-0025

Midland Basin

energy sources OF 93-0522

midoceanic ridges see mid-ocean ridges

Midway Field

geochemistry OP-615

Midway Quadrangle

maps OF 93-0225

Midwest see also Mississippi Valley. environmental geology OF 93-0292-G; OF 93 0418; OP-1000

ground water P 1405-B; P 1405-C; OF 92 0489; OF 92-0694; OF 93-0114; OF 93 0119; OP-1354; OP-1648

hydrogeology OP-1228

hydrology OP-1720

industrial minerals OF 92-0514

intrusions OP-247

pollution OF 93-0418

Quaternary OF 93-0543; OP-1896

structural geology OP-1799; OP-1889

Midwestern Basins and Arches Study Area ground water OF 93-0119

migmatites

Colorado OP-827

Miguelito Member

Miocene OP-1570

Milankovitch theory

OP-1879

Bahamas, Quatemary OP-706

Barbados, Quaternary OP-706

Bermuda, Quaternary OP-706
Florida, Quatemary OP-706

Haiti, Quaternary OP-706

Mexico, Quatemary OP-706

Nevada, Quaternary OP-916

Quaternary OP-55

Russian Federation, Quaternary OP-2004

stratigraphy OP-1756

Milford New Hampshire

environmental geology WRI 92-4056

ground water WRI 91-4177

Milford-Souhegan Aquifer

ground water WRI 91-4177

Miliolidae

United Arab Emirates, Quaternary OF 92-0391

Miliolina see Miliolacea

military geology

Australia, metal ores C 0930-M

Brazil, metal ores C 0930-M

California, ground water OF 93-0148

Canada, metal ores C 0930-M

China, metal ores C 0930-M

Colorado

hydrology WRI 91-4095

metal ores C 0930-M

Far East, metal ores C 0930-N

geomorphology OP-847

Idaho, metal ores $\mathrm{C}$ 0930-M

Malaysia, metal ores C 0930-M

Missouri, environmental geology OF 93-0153

Mozambique, metal ores C $0930-\mathrm{M}$

Nigeria, metal ores C 0930-M

Rwanda, metal ores C 0930-M

Thailand, metal ores C 0930-M

Zaire, metal ores C 0930-M

Milwaukee Wisconsin

non-metal deposits OF 92-0514

Mimbres Basin

ground water OP-230

Minas Gerais Brazil see Pocos de Caldas Brazil

mineral assessment see also biogeochemical methods; blind deposits; CUSMAP; dispersion patterns; geobotanical methods; geochemical anomalies; geochemical methods; geophysical methods; geophysical surveys; glaciated terrains; hydrological methods; lake sediments; ore guides; remote sensing; stream sediments; welllogging.

Alaska, metal ores OF 93-0339

Appalachians

economic geology B 1979

zinc ores B 2039

Arizona

economic geology OF 93-0329

industrial minerals OF 92-0687

metal ores B 1737-E

Arkansas, mineral resources MF-1994-D

Atlantic Coastal Plain, non-metal deposits OP1104

Basin and Range Province, mineral resources OP-1853

Bolivia, economic geology YR

California

economic geology OF $92-0595$

mercury ores OP-162

platinum ores B 2014

Colorado

economic geology B 2035; B 2039

metal ores $P 1537$

non-metal deposits B 2061-A

economic geology OP-834

Ecuador, gold ores B 2039

geochemistry OP-581
Great Basin mineral resources OP-1853

Gulf Coastal Plain, non-metal deposits OF 920530

Gulf of Mexico, non-metal deposits OF 920530

Louisiana, sands OF $92-0530$

metal ores OF 93-0194; MF-1835-H

Michigan, non-metal deposits OF 92-0514

mineral resources B 2039; OF 92-0514; OF 930023; OF 93-0258-A; OF 93-0258-B; OP574; OP-642; OP-938

Minnesota, kaolin deposits OF 92-0514

Missouri, mineral resources MF-1994-D

Montana

economic geology OF 93-0207

metal ores OF 93-0207; I-2050-F

mineral resources OF 93-0207

natural gas OF 92-0679

Nevada

economic geology B 2039

gold ores GP-1003-A; OP-365

structural geology OP-999

New Mexico, non-metal deposits B 2061-A

North Carolina

economic geology B 2005

heavy mineral deposits OF 92-0396

Puerto Rico

YR

economic geology OF 92-056?

metal ores OP-217

Russian Federation, metal ores OF 93-0339

Samoa OP-844

Saudi Arabia, gold ores YR

South Dakota, non-metal deposits OF 92-0514

sulfur deposits OF 92-0705

Tennessee, economic geology B 2005 uranium ores OP-655

Utah, sedimentary petrology B 2000-E

Venezuela, metal ores OP-217

Wyoming, impact statements WRI 90-4154

mineral chemistry see crystal chemistry

mineral deposits, genesis see also endogene processes; epigene processes; epithermal processes; exhalative processes; geochemical controls; hydrothermal processes; igneous processes; massive deposits; mesothermal processes; metallogenic maps; metallogenic provinces; metallogeny; metamorphic processes; metasomatism; mississippi valley-type; ore-forming fluids; paragenesis; placers; porphyry copper, porphyry molybdenum; quartz veins; stockwork deposits; syngenesis; wall-rock alteration; weathering.

Arizona

metal ores $\mathrm{OF} 93-0228$

sulfides OP-1993

barite deposits OP-170; OP-960

Bolivia, metal ores B 2039

California, metal ores OF 93-0228

Colorado

metal ores OF 93-0343

mineral resources OP-828

molybdenum ores OF 92-0525

Far East, economic geology OF 92-0525

Georgia, heavy mineral deposits B 2039

Great Britain, economic geology OF 92-0525

Idaho

gold ores B 2039

metal ores OF 93-0235

tungsten ores OP-1296

lead-zinc deposits OP-12

metal ores B 2039; OP-362; OP-714 
Minnesota, clays OF 92-0514

Nevada

gold ores OP-921; OP-1048

metal ores OP-397; OP-531

mineral resources OP-218

stratigraphy OP-623

New Mexico, metal ores OP-1715

non-metal deposits OF 92-0593

Ontario, metal ores OP-1979

Papua New Guinea, gold ores B 2039

Saudi Arabia, tin ores OP-1558

South Carolina, heavy mineral deposits B 2039

Spain, base metals OP-31

sulfur deposits OF 92-0705

Utah

metal ores OP-965

mineral resources B 2039

mineral economics

Basin and Range Province, non-metal deposits B 2013

Colorado, economic geology B 2035

industrial minerals B 2013; OF 92-0514

Utah, industrial minerals B 2013

waste disposal B 2013

Mineral Hot Springs KGRA

hydrogeology OF 93-0282

thermal waters OF 93-0017-A; OF 93-0017-B

mineral inclusions

Montana OP-604

mineral inventory

OP-682; OP-1508

Australia, metal ores C 0930-M

Brazil, metal ores C 0930-M

Canada, metal ores C $0930-\mathrm{M}$

China, metal ores $\mathrm{C}$ 0930-M

Colorado, metal ores C 0930-M

Far East, metal ores C $0930-\mathrm{N}$

Idaho, metal ores $\mathrm{C}$ 0930-M

Malaysia, metal ores C 0930-M

Mozambique, metal ores C 0930-M

New Mexico, metal ores OP-1715

Nigeria, metal ores C 0930-M

Rwanda, metal ores C 0930-M

Thailand, metal ores C 0930-M

Zaire, metal ores C 0930-M

mineral resources see also mineral deposits, genesis; mineral economics.

B 2039; OF 92-0380-A; OF 92-0380-B; OF 92 0514; OF 92-0552; OF 92-0557; OF 93-0023; OF 93-0258-A; OF 93-0258-B; OF 93-0280; MF-2207; MF-2217-B; OP-6; OP-63; OP-225; OP-574; OP-654; OP-938; OP-1679; OP-1730

Alaska C 1091; C 1094; OF 92-0008-A; OF 92-0008-B; OF 92-0315; OF 92-0379A; OF 92-0379-B; OF 92-0690; OF 920708-A; OF 92-0708-B; MF-2144-B; MF-2144-C; MF-2144-D; MF-2228; OP106

Appalachians B 1979

Arizona B 1737-E; OF 92-0509-A; OF 920509-B; OF 93-0329

Arkansas MF-1994-D

Basin and Range Province OP-817; OP-1853

Bolivia YR

California B 2019; OF 92-0210-A; OF 920210-B; OF 92-0316-A; OF 92-0316-B; OF 92-0595; OP-204; OP-260; OP-662

Colorado

B 2039; OF 92-0709; OP-95

Paleogene B 1787-Q

Great Basin OP-817; OP-1853

Hungary YR
Idaho OF 90-0672; OF 92-0384

Kansas MF-2125-E

Missouri MF-1994-D; MF-2125-E

Montana C 1088; OF 93-0207; OF 93-0505

Nevada

B 2019; OP-260; OP-765

structural geology OP-999

Nicaragua OF 92-0547

North Carolina B 2005; MF-2203

Oregon OF 90-0506; OF 93-0259-A; OF 930259-B

Puerto Rico OF 92-0567

Tennessee B 2005

Utah

MF-2081-C; MF-2081-D; MF-2081-E

Paleogene B 1787-Q

Vermont B 1955

Virginia MF-2203

Mineral Resources Data System

mineral resources OP-1730

mineral sequence see paragenesis

mineral soap see bentonite

mineral-water interface

geochemistry OP-244; OP-245; OP-289

mineralogy OP-789

mineralogy see aluminosilicates; arsenates; borates; carbonates; halides; hydrates; mineral inventory; nitrates; organic compounds; orthosilicates; oxides; phosphates; sheet silicates; silicates; sulfates; sulfides

Minerals Information Office

mineral resources OP-1730

mines see coal mines

Mini-Sosie

geologic hazards OP-969

mining see solution mining; surface mining; underground mining

mining geology see also coal mines; underground mining.

Alaska, pollution OP-66

economic geology YR

gravel deposits OP-229

Hungary, economic geology YR

Pennsylvania, coal OF 92-0568

South Africa, engineering geology OP-660

mining, open-pit see open-pit mining

MINITAB

hydrogeology OF 93-0039

Minneapolis Minnesota

non-metal deposits OF 92-0514

Minnelusa Formation

energy sources OF 93-0337; OP-889; OP-1260

natural gas OP-449

sedimentary petrology OP-1791

Minneola Quadrangle

maps OF 92-0698

Minnesota see also Elk Lake; Lake Superior region; Mississippi River; Oronto Group; Rainy Lake; Red River; Upper Mississippi Valley.

clays, Kittson County Minnesota OF 92-0514 economic geology

Beltrami County Minnesota B 2039

Clearwater County Minnesota B 2039

Itasca County Minnesota B 2039

Koochiching County Minnesota B 2039

Lake of the Woods County Minnesota B 2039

Roseau County Minnesota B 2039

environmental geology, Hennepin County Minnesota OF 92-0514 geochemistry

OF 92-0525; OP-249

Clearwater County Minnesota OP-248; OP251; OP-943

geochronology

Cook County Minnesota OP-758

Duluth Complex OP-758

Lake County Minnesota OP-758

Saint Louis County Minnesota OP-758

geomorphology, Minnesota River valley OP1664

ground water

P 1405-B; OF 92-0085; OF 93-0114; HA-

0730-J

Hubbard County Minnesota OP-551

Saint Paul Minnesota P 1530-A

heavy mineral deposits

Crow Wing County Minnesota OF 93-0345

Lake County Minnesota OF 93-0345

Mille Lacs County Minnesota OF 93-0345

Saint Louis County Minnesota OF 93-0345

highways WRI 92-4147

hydrogeology OF 93-0065

hydrology

W 2400; C 1120-A; OP-423

Hubbard County Minnesota OF 92-0475; OF 93-0127

Itasca County Minnesota HA-0551

Saint Louis County Minnesota HA-0551

kaolin deposits

OF 92-0514

Redwood County Minnesota OF 92-0514

metal ores

MF-1835-H; OP-169

Duluth Complex OP-728

Saint Louis County Minnesota OF 92-0615

Vermilion Range OF 92-0615

non-metal deposits

OF 92-0514

Anoka County Minnesota OF 92-0514

Dakota County Minnesota OF 92-0514

Hennepin County Minnesota OF 92-0514

Minneapolis Minnesota OF 92-0514

Minnesota River valley OF 92-0514

Saint Paul Minnesota OF 92-0514

Ordovician OP-1819

paleobotany, Clearwater County Minnesota OP-10

pollution

YR; OP-1526

Beltrami County Minnesota OP-430; OP629

Hennepin County Minnesota WRI 90-4150

Mille Lacs County Minnesota OF 93-0042; OF 93-0043; OF 93-0079

Quatemary

OP-1896

Clearwater County Minnesota OP-20; OP21; OP-99; OP-100; OP-668

reclamation OF 92-0514

sedimentary petrology, Clearwater County Minnesota OP-250; OP-739

soils

Koochiching County Minnesota OF 920721

Roseau County Minnesota OF 92-0721

Minnesota Academy of Science OP-341

Minnesota River valley

geomorphology OP-1664

non-metal deposits OF 92-0514

minor planets see asteroids 


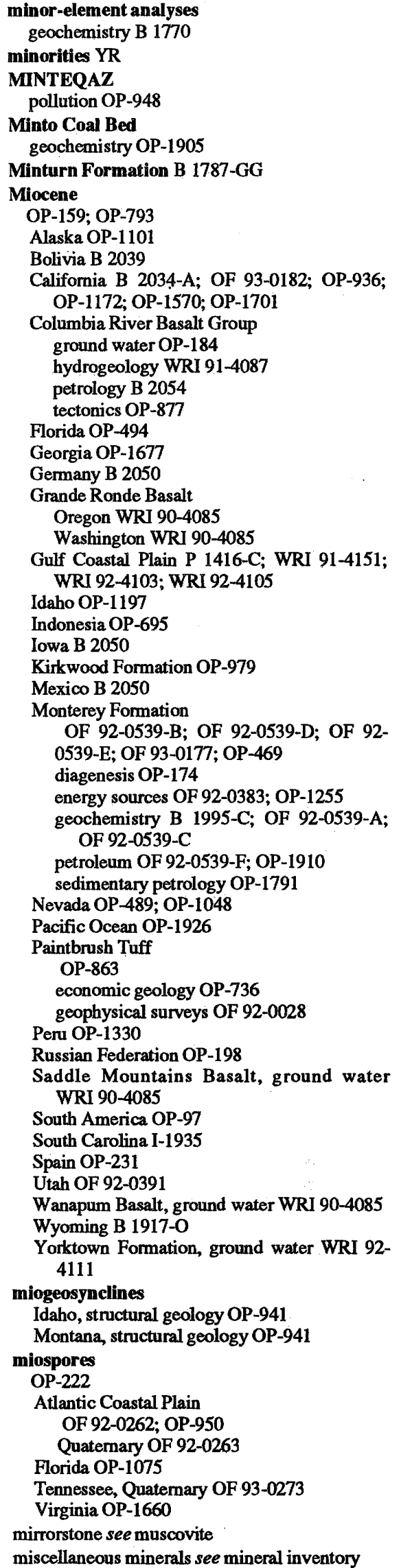

Mission Fault

neotectonics OP-23

Missisauga Formation

Mesozoic OP-801

Mississippi see also Eutaw Formation; Mississippi Embayment; Mississippi River; Pearl River, Reelfoot Rift; Selma Group; Tuscaloosa Formation.

diagenesis, Wayne County Mississippi OP1856

energy sources OF $92-0524$

engineering geology OF 93-0349

geochemistry OP-1577

ground water

P 1410-G; P 1416-C; WRI 91-4149; WRI 91-4150; WRI 91-4151; WRI 914152; WRI 92-4102; WRI 92-4103; WRI 92-4104; WRI 92-4105; OF 92-0492; OP-745

Benton County Mississippi WRI 92-4080

Chickasaw County Mississippi WRI 92 4080

Marshall County Mississippi WRI 92-4080

Pontotoc County Mississippi WRI 92-4080

Prentiss County Mississippi WRI 92-4080

Tippah County Mississippi WRI 92-4080

Tishomingo County Mississippi WRI $92-$ 4080

Union County Mississippi WRI 92-4080

hydrogeology

Hinds County Mississippi OP-32

Madison County Mississippi OP-32

Rankin County Mississippi OP-32

hydrology

W 2400; OF 91-0485

Calhoun County Mississippi OF 92-0469

Grenada County Mississippi OF 92-0469

Holmes County Mississippi OF 92-0469

Lafayette County Mississippi OF 92-0469

Panola County Mississippi OF 92-0469

Tate County Mississippi OF 92-0469

Yalobusha County Mississippi OF 92-0469

oceanography OF 92-0530; OP-1740

Oligocene

Hinds County Mississippi OP-746

Madison County Mississippi OP-746

Quatemary OF 92-0530

sedimentary petrology

OP-1636

Clarke County Mississippi OP-1858

seismology SM

stratigraphy, Jackson County Mississippi OF $92-0394$

waterways, Prentiss County Mississippi OF 900110

Mississippi Arch

hydrogeology OP-1782

Mississippi Delta

conservation OF 92-0530

continental shelf B 2002

engineering geology OF $92-0530$

environmental geology OF 92-0530

geomorphology OF 92-0530

land subsidence OF 92-0530

Quatemary OF 92-0530

sedimentary petrology $\mathrm{OP}-653$

shore features OF 92-0530

Mississippi Embayment

geologic hazards OP-969

ground water OP-1191

hydrogeology OP-32

Paleozoic OF 92-0685 structural geology OP-1471; OP-1742

tectonics OP-1652

Mississippi Fan

ocean floors OP-743

oceanography OP-1740; OP-1864

Quaternary OP-1966

sedimentation OP-1012

Mississippi River

OP-754

engineering geology WRI 92-4118; OF $92-$ 0530

geologic hazards OP-669

ground water $P$ 1405-C

hydrogeology OP-607

hydrology W 2400; OF 92-0651; OP-1643; OP-1720

pollution OP-580; OP-1645

Mississippi River basin

environmental geology $C 1120-C$

geologic hazards C 1120-B; OP-669

hydrology C 1120-A; OF 91-0485

pollution OF 93-0418

Mississippi River delta see Mississippi Delta

Mississippi River valley see Mississippi Valley

Mississippi salt basin

diagenesis OP-1856

Mississippi Valley see also Arkansas; llinois; lowa; Kentucky; Minnesota; Mississippi; Mississippi River, Missouri; Reelfoot Rift; Tennessee; Wisconsin.

geologic hazards

C 1083

Upper Mississippi Valley C 1120-B; OP669

ground water, Lower Mississippi Valley WRI 91-4149

heat flow OP-1661

hydrology

WRI 93-4012

Lower Mississippi Valley OP-1643

Upper Mississippi Valley OP-1720

metal ores B 2039

Paleozoic, Upper Mississippi Valley OF $92-$ 0685

Phanerozoic OP-1493

Quaternary OF 93-0273; MF-2218

mississippi valley-type

Appalachians, zinc ores B 2039

Illinois, non-metal deposits OP-1419

Kansas, metal ores MF-2125-E

Kentucky, non-metal deposits OP-1419

metal ores MF-1835-H; OP-1035; OP-1117

mineral resources OP-574

Missouri, metal ores MF-2125-E; OP-1418

Poland, metal ores OF 92-0704

Russian Federation, Phanerozoic OP-1493

United States, Phanerozoic OP-1493

Mississippian see also Antler Orogeny.

B 1909; OP-793; OP-1368; OP-1706; OP-1983

Boone Formation, Invertebrata OP-360

Borden Group OF 92-0558

Chainman Shale B 1988-G

Chesterian

Arkansas OP-360

Oklahoma OP-360

Colorado OF 93-0337

Fayetteville Formation, Invertebrata OP-360

Golconda Formation B 1988-F

Greenbrier Limestone, fluvial features B 1981

Joana Limestone B 1988-G; OP-1846

Kinderhookian, Nevada OP-1846 
Leadville Formation B 1787-EE metal ores OP-1151

Madison Group energy sources OF 93-0337; OP-1947 hydrogeology WRI 91-4044

Mauch Chunk Formation OF 92-0568

fluvial features B 1981

Meramecian

Arkansas OP-360

Oklahoma OP-360

Mexico OP-796

Montana OF 93-0337

Osagian OP-1245

Price Formation OP-1367

Redwall Limestone maps I-2290 sulfides OP-1993

Saint Louis Limestone, ground water OP-612

Sunbury Shale B 1909

Texas OF 93-0522

Warsaw Formation, ground water OP-612

Windsor Group, sedimentary petrology $O P$ 1672

Missouri see also Bonneterre Formation; Cherokee Group; Decorah Shale; Lamotte Sandstone; Maquoketa Formation; Marmaton Group; Mississippi Embayment; Mississippi River, Missouri River; Missouri River valley; New Madrid region; Ozark Mountains; Reelfoot Rift; Upper Mississippi Valley.

clay mineralogy OP-522

engineering geology

OF 93-0349

Lincoln County Missouri WRI 92-4118

environmental geology

OF 93-0292-G

Gasconade County Missouri C 1120-C

Saint Charles County Missouri OF 93-0153 geologic hazards, New Madrid Missouri C 1083 geophysical surveys OF 91-0573

ground water

P 1405-B; WRI 91-4149; WRI 92-4102; OF 93-0114

Boone County Missouri OP-1571

Saint Charles County Missouri OF 93-0109

hydrogeology

OF 92-0626

Henry County Missouri WRI 92-4167

hydrology

W 2400; C 1120-A; OF 91-0485

Saint Francois County Missouri WRI 934012

iron ores, Saint Francois Mountains OP-1297

lead-zinc deposits

Maries County Missouri OP-12

Saint Francois County Missouri OP-12

Springfield Missouri OP-644

metal ores

OP-1326; OP-1327; OP-1885

Barton County Missouri MF-2125-E

Jasper County Missouri MF-2125-E

Vernon County Missouri MF-2125-E

Washington County Missouri B 2039 mineral resources

Barry County Missouri MF-1994-D

Christian County Missouri MF-1994-D

Douglas County Missouri MF-1994-D

Ozark County Missouri MF-1994-D

Stone County Missouri MF-1994-D

Taney County Missouri MF-1994-D non-metal deposits OF $92-0514$

Ordovician OP-1819

pollution

YR

Andrew County Missouri OF 93-0101

Atchison County Missouri OF 93-0101

Bates County Missouri OP-2028

Buchanan County Missouri OF 93-0101

Carroll County Missouri OF 93-0101

Cass County Missouri OP-2028

Chariton County Missouri OF 93-0101

Clay County Missouri OF 93-0101

Holt County Missouri OF 93-0101

Jackson County Missouri OF 93-0101

Lafayette County Missouri OF 93-0101

Ray County Missouri OF 93-0101

Saint Clair County Missouri OP-2028

Saline County Missouri OF 93-0101

Vernon County Missouri OP-2028

Quaternary OP-1308

sedimentary petrology

Mississippi County Missouri OF 93-0291

Pemiscot County Missouri OF 93-0291

seismology SM

structural geology, New Madrid Missouri OP1318

\section{Missouri River}

environmental geology C 1120-C

ground water P 1405-C

Missouri River valley

geochemistry OF $92-0592$

ground water OF 93-0109; OF 93-0140

pollution OF 93-0101

mitridatite

California, geochemistry B 1995-C

Miyaoka Deposit

metal ores OP-570

MM scale see modified Mercalli scale

Mn see manganese

Mo see molybdenum

Mobile Bay

sedimentary petrology OP-1858

Mocha Island

Quaternary OP-719

MODBRANCH

hydrogeology WRI 93-4011; OF 92-0138

MODFE

ground water TWI 06-A3; TWI 06-A5; OF 900194; OF 91-0471; OP-867

\section{MODFLOW}

ground water OF 92-0477; OP-1639; OP-1640

hydrogeology WRI 93-401 1; OF 92-0138

modified Mercalli scale

Califormia, earthquakes OF 93-0191

Egypt, earthquakes OP-992

Indonesia, engineering geology OP-993

Utah, engineering geology P 1519

Modoc Plateau petrology OP-638

Modular Hydrologic Modeling System hydrology OP-1820

Moenkopi Formation maps I-2290

Moenkopi Plateau

Quatemary OP-976

moganite

Kenya, sedimentary petrology OP-1490

Oregon, sedimentary petrology OP-1490

Mohave Desert see Mojave Desert
Mohawk Formation

Mesozoic OP-801

Mohican Formation

Mesozoic OP-801

Moho see Mohorovicic discontinuity

Mohon Mountains

maps OF 92-0198

Mohorovicic discontinuity

New York, structural geology OP-460

Ontario, structural geology OP-460

structural geology OP-1890

Mojave Block

igneous rocks OP-1112

Mojave Desert

earthquakes YR; OP-699

economic geology OF 92-0595

environmental geology OF 92-0447; OP-2006

geochemistry OP-512; OP-678

geologic hazards WRI 92-4035

geomorphology OP-1339

ground water $\mathrm{OF}$ 93-0148

igneous rocks OP-1112

maps OF 91-0435

orogeny OP-1566

petrology OP-1376; OP-1691

Quaternary OP-1897

sedimentary petrology OP-445

soils C 1086

stratigraphy B 2015

structural geology OP-649; OP-803; OP-936

Molas Formation

stratigraphy B 1787-EE; OP-1399

molasse

Pakistan, tectonophysics OP-1548

molecular fossils see biomarkers

Mollusca

Ammonites, Arkansas OP-527; OP-1757

Ammonoidea

New Jersey OP-529

stratigraphy OP-528

Western Interior P 1533

Archaeogastropoda

OP-84

Alaska OP-85

Nevada OP-86

Baculites

Colorado B 2024

Texas OP-177; OP-526

Bivalvia

Arctic region OP-1839

Far East OP-1839

Desmoceratida

Arkansas OP-525

Texas OP-177; OP-178

Gastropoda, Wyoming OP-860

Glycymeris

Alaska OP-1800

California OP-1800

Mexico OP-1800

Inoceramidae, Texas OP-177

Ostrea, California OF 93-0286

mollusks

Alaska

Invertebrata OP-1681

Mesozoic OP-1680

Quaternary OP-515; OP-1225

ammonoids

Colombia OP-755

Colorado B 2024

England OP-755

Iowa OP-475 
New Jersey OP-529

Poland OP-755

South Dakota OP-475

stratigraphy OP-354; OP-528

Texas OP-755

bivalves

Atlantic Coastal Plain OP-2009

California P 1521; OF 92-0456; OF 930146; OF 93-0286

Gulf Coastal Plain OP-2009

Oregon P 1521

pollution OP-297

South Carolina B 2030

Colorado OF 92-0391

Paleogene B 1787-Q

gastropods

California P 1521; OP-1701

Idaho OP-1850

Oregon P 1521

pollution OP-297

Minnesota, Quatemary OP-668

Nevada, stratigraphy B 1988-D

Northwest Territories, Mesozoic OP-1680

Pacific Coast, Quatemary C 1086

stratigraphy P 1506-F

Utah, Paleogene B 1787-Q

West Virginia, Pennsylvanian OP-1357

molybdates see wulfenite

molybdenite

Colorado, molybdenum ores OF 92-0525; OP1050

molybdenite porphyry see porphyry molybdenum

molybdenum

Utah

metal ores OP-1464

mineral resources MF-2081-C; MF-2081-E

molybdenum ores see also porphyry molybdenum.

OP-465

Arizona B 2042-C

China

OP-363; OP-1432

geochemistry OF $92-0525$

Colorado OF 92-0525; OP-1913

Nevada

B 2039; OP-627

geochemistry OF 92-0525

New Mexico OP-1243; OP-1927

Yukon Territory

OP-363; OP-1432

geochemistry OF 92-0525

Mona Formation

Archean B 1904-P

monazite

California

geochemistry OP-678

magmas OP-1711

Far East, metal ores C 0930-N

Maryland, intrusions OP-1106

Nevada, gold ores OP-27

Norway, structural geology OP-1279

Virginia, intrusions OP-1106

monarite deposits

Far East C 0930-N

Mongolo-Okhotsk fold belt

Mesozoic OP-1494

Monitor Range

sedimentary petrology OP-1795

Mono Craters

geochemistry OP-954
Mono Lake

geochemistry OP-625

hydrology C 1086

sedimentary petrology OP-77

monoclines

Arizona I-2290

Missouri OP-1861

Monocotyledoneae see Gramineae

Montana see also Absaroka Supergroup; Beartooth Mountains; Beaverhead Mountains; Bighorn Basin; Bighom Mountains; Blackleaf Formation; Dakota Formation; Flint Creek Range; Fort Union Formation; Frontier Formation; Hell Creek Formation; Kootenay Formation; Lance Formation; Madison Group; Mesaverde Group; Mowry Shale; Muddy Sandstone; Phosphoria Formation; Powder River basin; Red River Formation; Shannon Sandstone Member, Stillwater Complex; Sweetgrass Arch; Tongue River Member, Tullock Member, Westem Interior Seaway; Western Overthrust Belt; Williston Basin; Wyoming Province; Yellowstone National Park.

Archean

Gallatin County Montana OP-705

Madison County Montana OP-705 areal geology

Carbon County Montana OF 93-0207

Park County Montana OF 93-0207

Stillwater County Montana OF 93-0207

Sweet Grass County Montana OF 93-0207 bibliography

Carbon County Montana OF 93-0285-A; OF 93-0285-B

Park County Montana OF 93-0285-A; OF 93-0285-B

Stillwater County Montana OF 93-0285-A; OF 93-0285-B

Sweet Grass County Montana OF 93-0285A; OF 93-0285-B

coal

Carbon County Montana OF 93-0207

Park County Montana OF 93-0207

Stillwater County Montana OF 93-0207

Sweet Grass County Montana OF 93-0207

copper ores, Boulder Batholith OP-273

Cretaceous

Big Horn County Montana OC-0135; OC0138

Carter County Montana OC-0135; OC-0138

Powder River County Montana OC-0135; OC-0138

deformation

Gallatin County Montana OP-883

Madison County Montana OP-883

Park County Montana OP-883

Devonian

Flathead County Montana OF 93-0184

Lincoln County Montana OF 93-0184

economic geology

Carbon County Montana OF 93-0207

Park County Montana OF 93-0207

Stillwater County Montana OF 93-0207

Sweet Grass County Montana OF 93-0207

energy sources OF 93-0337

environmental geology OF 93-0292-H

Eocene, Beaverhead County Montana OP-617

faults OP-685

geochemistry

OP-978

Gallatin County Montana OP-1094

Jefferson County Montana OP-1094
Meagher County Montana OP-1094

Silver Bow County Montana OP-1094

geochronology B 2065

ground wate

WRI 92-4116

Blaine County Montana WRI 92-4162; WRI 92-4163

Phillips County Montana WRI 92-4162

heavy mineral deposits OF 93-0240-A; OF 930240-B

hydrogeology

OP-166

Flathead County Montana WRI 92-4066

Lake County Montana WRI 92-4066

Missoula County Montana WRI 92-4066

Sanders County Montana WRI 92-4066

Valley County Montana WRI 92-4185

hydrology

W 2400; WRI 92-4048; WRI 92-4060; OP-

1044

Carter County Montana WRI 91-4199

Custer County Montana WRI 91-4199

Powder River County Montana WRI 914199

magmas, Shonkin Sag Laccolith OP-1294 maps

Beaverhead County Montana GQ-1724; I1803-H

Big Horn County Montana I-2343-A; I2380-A; C-0142

Carter County Montana I-2343-A; I-2380-A

Custer County Montana C-0142

Deer Lodge County Montana I-1803-H

Flathead County Montana I-2267

Granite County Montana I-1803-H

Jefferson County Montana I-1803-H

Lincoln County Montana I-2267

Madison County Montana GQ-1729; I1803-H

Park County Montana MF-2253

Powder River County Montana I-2343-A; I-2380-A; C-0142

Ravalli County Montana I-1803-H

Roosevelt County Montana C-0142

Rosebud County Montana I-2343-A; I2380-A

Silver Bow County Montana I-1803-H

Sweet Grass County Montana MF-2253

Treasure County Montana C-0142

metal ores

Carbon County Montana OF 93-0207

Deer Lodge County Montana I-2050-F

Granite County Montana I-2050-F

Jefferson County Montana I-2050-F

Lewis and Clark County Montana I-2050-F

Missoula County Montana I-2050-F

Park County Montana OF 93-0207

Powell County Montana I-2050-F

Ravalli County Montana I-2050-F

Silver Bow County Montana I-2050-F

Stillwater County Montana OF 93-0207

Sweet Grass County Montana OF 93-0207 mineral resources

Carbon County Montana OF 93-0207; OF 93-0505

Deer Lodge County Montana C 1088

Granite County Montana C 1088

Jefferson County Montana C 1088

Lewis and Clark County Montana C 1088

Missoula County Montana C 1088

Park County Montana OF 93-0207; OF 930505

Powell County Montana C 1088 
Ravalli County Montana C 1088

Silver Bow County Montana C 1088

Stillwater County Montana OF 93-0207; OF 93-0505

Sweet Grass County Montana OF 93-0207; OF 93-0505

natural gas OF 92-0524

paleobotany OP-1082

petroleum

OF 93-0337

Carbon County Montana OF 93-0207

Golden Valley County Montana OF 930337

Musselshell County Montana OF 93-0337

Park County Montana OF 93-0207

Rosebud County Montana OF 93-0337

Stillwater County Montana OF 93-0207

Sweet Grass County Montana OF 93-0207

Treasure County Montana OF 93-0337

Wheatland County Montana OF 93-0337

Yellowstone County Montana OF 93-0337

petrology OP-1462; OP-1491

pollution OF 93-0064

Quatemary OP-201

sedimentary petrology

Big Horn County Montana B 1917-L

Powder River County Montana B 1917-L

Treasure County Montana B 1917-L

stratigraphy, Beaverhead County Montana OF $92-0391$

structural geology

OP-679

Deer Lodge County Montana B 1993

Granite County Montana B 1993

Lincoln County Montana P 1524

tectonics OP-753

Triassic

Big Horn County Montana B 1917-P

Custer County Montana B 1917-P

Powder River County Montana B 1917-P

Rosebud County Montana B 1917-P

Montana de Oro State Park

Miocene OP-1570

Montastrea

Florida, Quatemary OP-1930

Montauk Till

Quaternary OP-748

Montebello earthquake 1989 earthquakes OP-503

Monterey Bay

engineering geology OP-1347

Invertebrata OP-1800

structural geology OP-340

Monterey California

continental shelf OP-1443

Monterey Canyon

continental shelf OP-1443

oceanography OP-1444

Monterey Formation

OF 92-0539-B; OF 92-0539-D; OF 92-0539-E;

OF 93-0177; OP-469

diagenesis OP-174

energy sources OF 92-0383; OP-1255

geochemistry B 1995-C; OF 92-0539-A; OF 92-0539-C

petroleum OF 92-0539-F; OP-1910

sedimentary petrology OP-1791

Monterey Gorge see Monterey Canyon

Monterey Quadrangle

maps I-1420 (NG-14)

Monterey Trough see Monterey Canyon
Montes Rook Formation OP-416

Montezuma Canyon

hydrogeology W 2340

Montezuma Formation

Neogene OP-1272

Montezuma shear zone

mineral resources OP-95

montmorillonite

California, structural geology OP-702

Wyoming, diagenesis OP-1950

Monument Creek

hydrology WRI 91-4176

Monument Peak

neotectonics OP-23

monzodiorite

Vermont OP-37

monzogranite

Montana, structural geology B 1993

monzonites

Colorado, metal ores OP-1633

Quebec, gold ores OP-1097

Moon see also Earth-Moon couple; Eratosthenian;

KREEP; lunar breccia; lunar craters; lunar crust;

lunar highlands; lunar soils; maria.

I-2276; OP-661; OP-1315; OP-1392; OP-1497;

OP-1693; OP-1696; OP-1698; OP-1805; OP-

1881; OP-1974

Aristarchus OP-1437

Eastern Sea OP-416; OP-1437; OP-1482; OP1486; OP-1487

Foaming Sea OP-1439

petrology OP-1956

Sea of Crises OP-1439; OP-1485

Sea of Fertility OP-1439

Sea of Rains OP-237; OP-1314; OP-1485; OP 1487; OP-1841

Sea of Serenity OP-237; OP-609; OP-1781

Sea of Waves OP-1439

Taurus-Littrow OP-609; OP-805; OP-1074

Wyoming, petrology OP-1456

Moore Deposit

metal ores OP-1576

Moore House Member ground water WRI 92-4111

Moorefield Formation Invertebrata OP-360

moraines

Alaska

marine geology OF 92-0706

Quaternary OP-1801

Atlantic Ocean, Quatemary OP-1650

California, Quaternary OP-1254

Indiana, ground water OP-923

Ohio, ground water OP-1925

Oregon, geologic hazards W 2340

Quatemary OP-201

MORB see mid-ocean ridge basalts

Moreno Formation hydrogeology WRI 92-4004

Morgan Hill earthquake 1984 California P 1550-C; OP-1047

Mormon Mountains structural geology B 2011

morphodynamics

Gulf Coastal Plain, geomorphology OF 920530

Gulf of Mexico, geomorphology OF 92-0530

Louisiana, geomorphology OF 92-0530

morphology see functional morphology
Morris Fault

structural geology B 1904-S

Morrison Formation see Brushy Basin Shale Member; Salt Wash Sandstone Member, Westwater Canyon Sandstone Member

Morro do Ferro Mine ground water OP-737

Morrowan

California OP-1791

Colorado OF 93-0337

Texas OF 93-0522

moscovite see muscovite

Moscow Formation B 1909

Mosquito Range

mineral resources OP-828 stratigraphy B 1787-EE

Moss Back Member sedimentary petrology B 2000-E

motion, ground see ground motion

motion, strong see strong motion

Mounds Gravel structural geology OP-1471

Mount Angayukaqsraq geochemistry OP-721

Mount Ararat Formation stratigraphy OP-1530

Mount Baker geophysical surveys B 1966

Mount Borah earthquake, 1983 see Borah Peak earthquake 1983

Mount Edgecumbe volcanic field magmas OP-845

Mount Emmons Deposit molybdenum ores OF 92-0525; OP-375; OP1913

Mount Evans Batholith Proterozoic OP-10

Mount Hayes Quadrangle maps OF 92-0594 metal ores MF-1996-E

Mount Hoffiman geomorphology OP-266

Mount Holly Quadrangle economic geology B 1955 maps OF 92-0282-A

Mount Hood geophysical surveys B 1966 petrology B 2054

Mount Ichabod maps OF 92-0580 stratigraphy B 1988-D

Mount Isa Australia metal ores OP-942

Mount Jura structural geology OP-1474

Mount Katmai Quadrangle maps I-2032

Mount Lassen see Lassen Peak

Mount Lewis earthquake 1986 seismology P 1550-C

Mount Mazama geochemistry OP-42; OP-43 magmas OP-982

Mount Mica phosphates OP-115

Mount Morrison Block deformation OP-972

Mount Rainier engineering geology OP-907 
geophysical surveys B 1966

Mount Rock Spring basin hydrogeology OF 92-0165

Mount Rogers Formation

Proterozoic B 2029 structural geology OP-1955

Mount Saint Helens

earthquakes EV

elastic waves B 1966

engineering geology OP-956

geologic hazards B 1966

geophysical surveys B 1966

magmas OP-1362

maps GQ-1679

Quaternary OP-647

seismology B 1966

volcanic features B 1966

Mount Saint Helens J Ash

Quatemary OP-143

Mount Shasta

geomorphology OP-266

geophysical surveys B 1966

Mount Simon Aquifer ground water $P$ 1405-B

Mount Simon Sandstone sedimentary petrology OP-1385

Mount Spurr

geochemistry OP-1754

geologic hazards YR

magmas OP-1469

petrology OP-1929

Quatemary OP-1342; OP-1699; OP-1714; OP1739; OP-1772

seismicity OP-1802

seismology OP-1556

Mount St. Helens see Mount Saint Helens

Mountain Home Air Force Base ground water WRI 92-4027

Mountain Pass California geophysical surveys OP-543 petrology OP-1584

movements, mass see mass movements movies

Mexico, geologic hazards OF 93-0197-A; OF 93-0197-B

Mowry Shale

OP-1798

sedimentary rocks B 1787-DD

Moxa Arch

natural gas OF 93-0248

petroleum OP-1635

Mozambique

metal ores C 0930-M

MRPP OP-754

MSEA

ground water OF 92-0167

pollution YR; OF 93-0042; OF 93-0043; OF 93-0079

Mt. Hood see Mount Hood

Mt. Rainier see Mount Rainier

Mt. St. Helens see Mount Saint Helens

MTM 20032 Quadrangle I-2311

MTM 20037 Quadrangle I-2314

MTM 25032 Quadrangle I-2312

MTM 25037 Quadrangle I-2313

MTM 25042 Quadrangle I-2315

MTM 25052 Quadrangle I-2208

MTM 25057 Quadrangle I-2208

MTM 35132 Quadrangle I-2324
MTM 35137 Quadrangle I-2323

MTM 35142 Quadrangle I-2322

MTM 35307 Quadrangle I-2332

MTM 35312 Quadrangle I-2333

MTM 40132 Quadrangle I-2325

MTM 40137 Quadrangle I-2320

MTM 40142 Quadrangle I-2321

MTM 40302 Quadrangle I-2334

MTM 40307 Quadrangle I-2335

MTM 40312 Quadrangle I-2336; I-2337

MTM 40317 Quadrangle I-2338

MTM 45162 Quadrangle I-2316

MTM 45167 Quadrangle I-2317

MTM 45172 Quadrangle I-2318

MTM 45177 Quadrangle I-2319

MTM 45312 Quadrangle I-2339

MTM 45317 Quadrangle I-2340

Muan, Arnulf

phase equilibria OP-1013

mud

OP-723

Atlantic Ocean, Quaternary OP-1650

Bahamas OP-928

geochemistry OP-183

Gulf of Mexico, Quatemary OP-1966

mud flats

California, environmental geology OF 92-0456

Tonga, geomorphology OP-989

mud flows see mudflows

Mud Lake Florida

geochemistry OP-1905; OP-1906

Muddy Creek Formation OP-92

Muddy Sandstone

energy sources OF 93-0337

mudflats see mud flats

mudflows

California, engineering geology B 2002

mudrocks see mudstone

MudScan

geophysical surveys OF 93-0242

mudstone

Colorado Plateau, uranium ores OP-1848

Idaho, stratigraphy OP-1351

Mexico OP-50

Montana, stratigraphy OP-1351

Pennsylvania, geochronology OF 92-0525

United Arab Emirates, stratigraphy OP-1453

Utah

Cretaceous OP-919

Vertebrata OP-1252

Munson-Nygren landslide complex continental margin B 2002

Murdama Group

Proterozoic B 1976

Murfreesboro Tennessee

hydrology OF 92-0482

Musci

Alaska, geochemistry OF 93-0014

muscovite

OP-493

Alabama, geochronology OP-968

Alaska, folds OP-1427

England, geochemistry OP-158

geochemistry OP-1312; OP-1554

Georgia, geochronology OP-968

Maryland, metamorphism OP-1152

Norway, structural geology OP-1279

Ontario, petrology OP-214

Poland, Carboniferous OP-1917
Quebec, gold ores OP-1097

Russian Federation, Precambrian OP-1777

Virginia, metamorphism OP-1152

MVT see mississippi valley-type

mylonites

British Columbia, structural geology OP-1159

geochronology OF 92-0525

Michigan, structural geology B 1904-S; I-2355; OP-1889

Minnesota, structural geology B 1904-S

New York, structural geology OP-460; OP-461

Ontario, structural geology OP-460

Poland, structural geology OP-967

Vermont, structural geology $\mathrm{OP}-461$

Washington, structural geology OP-1159

Wyoming, structural geology OP-149

Mymensingh Terrace

geomorphology OP-1273

Myomorpha see Cricetidae

Myrtle Beach South Carolina

stratigraphy B 2030

\section{$\mathbf{N}$}

N see nitrogen

N-15

geochemistry OP-1990

soils OP-1951

N-15/N-14

California, sulfides OP-557

energy sources OF 92-0391

Maryland, ground water OP-1174

Minnesota, ground water OP-551

Nevada, sulfides OP-557

Na see sodium

Na-montmorillonite see montmorillonite

Nabesna Quadrangle maps GQ-1688

Nacimiento Block structural geology OP-1547

NACSN stratigraphy OP-285

Nagylengyel Field energy sources OP-1263

Naknek Formation energy sources OP-626

Naknek Quadrangle maps I-2032

Nambija Ecuador gold ores B 2039

Namibia

metal ores C 0930-N

meteor craters OP-550

Nanafalia-Clayton Aquifer ground water WRI $91-4116$

nannofossils

Antarctic Ocean, Tertiary OP-1145

Atlantic Coastal Plain, paleontology OP-1205

Atlantic Ocean, marine geology OP-822

California

Miocene OF 93-0182

stratigraphy OF 92-0539-D; OF 92-0539-E: OF 93-0177

Celebes Sea, oceanography OP-821

Costa Rica, Neogene OP-1272.

Europe, Cretaceous OP-1193

Gulf Coastal Plain, paleontology OP-1205

Pacific Ocean

marine geology OP-819; OP-822

oceanography OP-820 
paleomagnetism OP-747

Panama, Neogene OP-1272

South Carolina, stratigraphy B 2030

Vanuatu

plate tectonics OP-197

tectonophysics OP-1908

Nantucket Island

geomorphology OF 93-0185

Quaternary OP-748

Naples Beach California

geochemistry OF 92-0539-C

Miocene OF 93-0182

stratigraphy OF 92-0539-B; OF 92-0539-D; OF 93-0177

Naples Italy geologic hazards OP-213

Napoleon Sandstone Member ground water WRI 91-4133

Napoli Italy see Naples Italy

nappes

Alaska, tectonophysics OP-1430

Hungary, energy sources OP-1687

Michigan, structural geology B 1904-L; B 1904-Q; B 1904S

Minnesota, structural geology B 1904-S

Norway, structural geology OP-1279

Narrows Subplate

structural geology OP-523

Narvik-Nordmannvik Nappe structural geology OP-1279

NASA

Colorado, geophysical surveys OF 91-0449-G

Nasca Plate see Nazca Plate

Nashville Basin economic geology B 2005

Nassau River basin hydrology WRI 91-4115

National Aeronautics and Space Administration see NASA

National Atmospheric Deposition Program hydrology OF 93-0056

National Capital Planning Commission environmental geology OP-60

National Earthquake Hazards Reduction Program

earthquakes OF 93-0290

engineering geology $\mathrm{OP}-415$

geologic hazards P 1519; OF 93-0195

National Field Quality Assurance Program hydrogeology OF 92-0163

national forests

Arizona

economic geology OF 93-0329

industrial minerals OF 92-0687

mineral resources OF 92-0509-A; OF 920509-B

Colorado

economic geology B 2035; B 2039

geophysical surveys OF 93-0018

mineral resources B 2039; OF 92-0709

Idaho

gold ores OF 93-0527

mineral resources OF 92-0384

Montana

OF 93-0285-A; OF 93-0285-B

economic geology OF 93-0207

mineral resources OF 93-0505

Oregon, geologic hazards OF 92-0483

National Geochemical Data Base

uranium ores DDS-0001
National Geochronological Data Base geochronology OF 93-0336

National Geologic Mapping Act maps YR

National Geologic Mapping Program geologic hazards C 1111

National Mapping Division OP-963; OP-1954

National Mapping Program maps YR; OP-818

National Mineral Resource Assessment Program

mineral resources OP-1679

National Paleontological Data Base paleontology OF 93-0549

National Park Service OP-771 ecology OP-476

National Petroleum Reserve Alaska hydrogeology OF 91-0458 natural gas OP-74 petroleum DDS-0005; OP-1285

National Seismic System seismology C 1031

National Trends Network hydrology OF 93-0056

National Uranium Resource Evaluation Program see NURE

National Urban Runoff Program hydrogeology OF 93-0039

National Water Data Exchange see NAWDEX

National Water Information System ground water OP-745

National Water Quality Laboratory hydrogeology OF 92-0146 hydrology OF 92-0480; OF 92-0495; OF 920634; OF 93-0125

National Water Summary on Stream Water Quality hydrology OF 93-0029

National Water-Data Storage and Retrieval System hydrology OF 92-0105

National Water-Quality Assessment Program environmental geology OP-576; OP-1411 ground water OF 92-0641 hydrogeology YR; OF 93-0106 hydrology OF 93-0104; OP-598 pollution OF 92-0494

National Water-Quality Laboratory . hydrogeology WRI 92-4075

National Weather Service geologic hazards YR

native elements see diamond; graphite

natrium see sodium

natrolite

Arkansas, petrology OP-1837

natural coke see coke coal

natural dams

Oregon, geologic hazards W 2340

natural gas see also gas hydrates; methane; petroleum maps; stratigraphic traps; structural traps.

B 1839-IJ; B 1909; OF 92-0524; OF 92-0679;

OP-34; OP-272; OP-646; OP-834; OP-861; OP862; OP-1860

Alaska YR; C 1091; OF 93-0230; OP-74

Arizona OF 93-0248

Basin and Range Province OF 93-0248

California B 2034-A; OF 89-0450-C; OF 890450-D; OP-1255

China OF 93-0004 coalbed methane

OP-1244; OP-1822; OP-1823

Colorado OP-1911

Montana OF 93-0207

Pacific Coast OP-1946

Colorado OF 92-0524; OF 93-0248; OP-518 OP-1262; OP-1264

Colorado Plateau OF 93-0248

Gulf of Mexico OP-274

Hungary OP-1687

Idaho OF 93-0248

Jordan OF 92-0680

Kansas OP-725

Kentucky, geochemistry B 2046

Montana OF 93-0337; OP-449

Nevada OF 93-0248

New Mexico

OF 93-0248; OF 93-0522; OP-518 geomorphology OF 92-0391

New York B 1909

New Zealand, sedimentation OP-1391

North Dakota, stratigraphy OF 93-0335

Ohio B 1909

Oklahoma OF 92-0524; OF 93-0230

Oregon B 2034-A

Pacific Coast B 2034-A

Pakistan OP-1634

Pennsylvania OP-1842

Pennsylvanian OP-1233

South Dakota

OF 93-0337

stratigraphy OF 93-0335

stratigraphy B 1909

Texas OF 93-0522

Utah OF 93-0248; OP-1262

Virginia OP-1751

Washington B 2034-A

Western U.S. OF 92-0524

Wyoming OF 92-0524; OF 93-0192; OP-449; OP-1569

natural reactors

Gabon, geochemistry OP-713

natural remanent magnetization

Colorado, stratigraphy OP-985

Hawaii, Quaternary OP-632; OP-633

naturally fractured reservoirs

Nevada, petroleum OP-614

Rocky Mountains, natural gas OP-1350

Naturita Formation

palynomorphs OF 92-0391

Navajo Aquifer

ground water WRI 92-4070; WRI 92-4160; OF 92-0124

hydrogeology OP-1736

Navajo Indian Reservation ground water OF 92-0124 petrology OP-1341

Navajo Lake Quadrangle maps OF 93-0190

Navajo Sandstone ground water WRI 90-4105 hydrogeology W 2340; OP-1736 uranium ores OP-1848

Naval Reactors Facility ground water OF 93-0034

Naval Surface Warfare Center hydrogeology OP-1196

Navarin Basin engineering geology OP-140 geochemistry OP-242

Navarro Group OP-527 
Navesink Formation

environmental geology OP-378

navigation $O F$ 92-0565

NAVSTAR GPS see Global Positioning System

NAWDEX

Alaska, hydrology OF 93-0076

hydrology OF 93-0138

NAWQA

ground water OF 92-0641

hydrogeology YR; OF 93-0106

hydrology OF 93-0104

pollution OF 92-0494

Nazea Plate

plate tectonics OP-586; OP-900; OP-1651

tectonophysics OP-432

$\mathrm{Nb}$ see niobium

$\mathrm{Nd}$ see neodymium

Nd-144/Nd-143

Alaska, geochemistry OP-242; OP-721

California

geochemistry OP-182; OP-730; OP-1141 petrology OP-1282

Canadian Shield, crust OP-1316

China, geochemistry OP-457

Colorado, geochemistry OP-490; OP-1825

geochemistry OF $92-0525$; OP-30

geochronology OF 92-0525

Idaho, geochronology OP-1067

Minnesota, geochemistry OF 92-0525

Montana

crust OP-2017

geochemistry OP-122

Nevada, geochemistry OP-313

New Mexico, geochemistry OP-490

North Carolina, geochemistry OP-1607

Northwest Territories, geochemistry OP-721

Oregon, geochemistry OP-1141

petrology OP-1199

Russian Federation, geochemistry OP-1086

Washington, geochronology OP-1067

Wyoming

crust OP-2017

geochemistry OP-122

$\mathbf{N d} / \mathbf{N d}$

igneous rocks OP-1995

petrology OP-545

$\mathrm{Nd} / \mathrm{Sm}$ see $\mathrm{Sm} / \mathrm{Nd}$

$\mathrm{Ne}-22 / \mathrm{Ne}-20$

Hawaii, geochemistry OP-446

nearside I-2276

Nebraska see also Cherokee Group; Denver

Basin; Niobrara Formation; Pierre Shale.

environmental geology OF 93-0292-G

geochemistry, Knox County Nebraska OF 92 0592

geologic hazards C 1120-B; OP-669

ground water B 1989-D; OF 93-0114

hydrogeology

OF $92-0633$

Keith County Nebraska OF 93-0106

Lincoln County Nebraska OF 93-0106

hydrology W 2400; C 1120-A

pollution

YR; OP-1909

Gage County Nebraska OF 93-0087

stratigraphy B 1917-M; B 1989-E

Ned Wilson Lake

hydrology OP-133

Needle Siltstone Member

stratigraphy B 1988-G
Neenach Volcanies

structural geology OP-936

NEHRP

earthquakes OF 93-0290

NeHT tomography

geophysical surveys OP-1374

Nehumkeag Pond Formation

stratigraphy OP-1530

Nei Mongol see Inner Mongolia China

neodymium see also $\mathrm{Sm} / \mathrm{Nd}$.

Basin and Range Province, tectonics OP-2021

Great Basin, tectonics OP-2021

Montana, petrology OP-1462

Nd-144/Nd-143

Alaska OP-242; OP-721

California OP-182; OP-730; OP-1141; OP1282

Canadian Shield OP-1316

China OP-457

Colorado OP-490; OP-1825

geochemistry OF 92-0525; OP-30

geochronology OF 92-0525

Idaho OP-1067

Minnesota OF 92-0525

Montana OP-122; OP-2017

Nevada OP-313

New Mexico OP-490

North Carolina OP-1607

Northwest Territories OP-721

Oregon OP-1141

petrology OP-1199

Russian Federation OP-1086

Washington OP-1067

Wyoming OP-122; OP-2017

Nova Scotia, geochemistry OF 92-0525

Sm-147/Nd-144

Colorado OP-490

geochemistry OF 92-0525

New Mexico OP-490

Russian Federation OP-1086

Wyoming, geochemistry OP-2016

Neogene see also Miocene; Pliocene.

Alaska OF 92-0701; OP-1681

Arizona OP-92

Atlantic Ocean OP-822

Basin and Range Province OP-19

Bolivia OF 93-0016

California B 2034-A; OP-340; OP-1749

Celebes Sea OP-821; OP-823

Colorado Plateau OP-19

Costa Rica OP-1272

Georgia OP-1502

Idaho OP-523

Marshall Islands OP-1457

Micronesia OP-1457

Mississippi OF 92-0394

Nevada B 2011; OF 92-0391; OP-92; OP-973

New Mexico OP-1072

Pacific Ocean OP-819; OP-820; OP-822

Panama OP-1272

Purisima Formation, ground water WRI 914148

Ridge Route Formation, structural geology OP649

Sisquoc Formation

energy sources OF 92-0383

sedimentary petrology OP-1791

Tamiami Formation OP-1075

Texas OP-1072

Utah B 2011

Neoglacial

Alaska OP-1718
Califomia OP-1254

Neogondolella

Permian OP-1982

neon

$\mathrm{Ne}-22 / \mathrm{Ne}-20$, Hawaii OP-446

Neosho Falls Quadrangle

maps I-2378

neotectonics see also changes of level; faults;

folds; uplifts.

Arizona

OP-611

geologic hazards $\mathrm{P}$ 0497-H

Neogene OP-92

Bangladesh, geologic hazards OF 92-0391

California

OP-23; OP-83

engineering geology OF 93-0348

geologic hazards OP-969

seismicity P 1550-C; OP-286

tectonophysics OP-2010

Greece, plate tectonics OP-542

Hawaii, geophysical surveys OP-252

Idaho OP-634

Mexico MF-2238

Nevada, Neogene OP-92

Northern Territory Australia, Quaternary B 2032-A

Oregon OP-634

Utah

geologic hazards P 1519

Quaternary OP-970

Washington

OF 93-0332

Quaternary OP-36

Nepa-Botuoba Arch

energy sources OP-1967

nepheline

Arkansas, petrology OP-1837

Neslen Formation

sedimentary petrology OF 92-0391

nesosilicates see andalusite; braunite; garnet group; kyanite; olivine group; titanite; topaz; zircon

Netherland India see Indonesia

NETPATH

geochemistry OP-790

network deposits see stockwork deposits

Neuquen Basin

structural geology OP-1129

Neuropteris

Nova Scotia, sedimentary petrology OP-1673

Neuse River

oceanography OP-1131

neutron activation analysis geochemistry B 1770; B 2046

Nevada see also Amargosa Desert; Battle Mountain; Colorado River, Grant Range; Great Basin; Joana Limestone; Lake Lahontan; McCoy Creek Group; Paintbrush Tuff; Pilot Shale; Roberts Mountains Formation.

base metals OP-79

Brachiopoda, Eureka County Nevada OP-491

copper ores, Esmeralda County Nevada B 2039 earthquakes, Nevada Test Site OP-1300

economic geology

OP-834

Churchill County Nevada B 2019

Douglas County Nevada B 2019

Esmeralda County Nevada OP-260

Lyon County Nevada B 2019

Mineral County Nevada B 2019; OP-260 
Nye County Nevada B 2039

Storey County Nevada B 2019

Washoe County Nevada B 2019

energy sources OF 93-0248

engineering geology

Nevada Test Site OF 93-0073

Yucca Mountain OF 93-0073

environmental geology

OF 93-0292-I

Douglas County Nevada OP-1227

Nevada Test Site OF 92-0516

Washoe County Nevada B 2013; OP-1227

Yucca Mountain OF 92-0516

geochemistry

OP-313; OP-774; OP-775; OP-1302

Esmeralda County Nevada OP-1609

Lander County Nevada OF 92-0525

Nevada Test Site OP-1775

Tonopah Nevada OP-1609

Yucca Flat OP-1775

Yucca Mountain OP-643

geochronology

OP-342

Nevada Test Site OF 93-0538

Yucca Mountain OF 93-0538

geomorphology

OP-1339

Yucca Mountain OP-1276

geophysical surveys

OP-1041

Esmeralda County Nevada OF 92-0450

Las Vegas Nevada OF 92-0450

Nevada Test Site OF 92-0028; OF 92-0343; OF 92-0572; OF 93-0187

Nye County Nevada OF 92-0450; OF 930187

Yucca Mountain OF 92-0028; OF 92-0343; OF 92-0572

gold ores

Elko County Nevada B 2039; OP-441

Eureka Nevada OP-921

Getchell Mine B 2039; GP-1003-A; OP365 ; OP-447; OP-624; OP-779; OP-784

Humboldt County Nevada OP-716

Osgood Mountains B 2039; GP-1003-A; OP-365; OP-447; OP-624; OP-779; OP784; OP-1048

ground water

OP-995

Clark County Nevada WRI 91-4167; WRI 91-4185; WRI 92-4051

Lander County Nevada W 2340

Lincoln County Nevada WRI 91-4167

Lyon County Nevada W 2340

Nevada Test Site OF 90-0369; OF 91-0478; OF 93-0071

Yucca Mountain OF 90-0369; OF 91-0478; OF 93-0071; OP-234; OP-235; OP-269; OP-1009; OP-1899

hydrogeology

OF 93-0097; OP-276; OP-659

Clark County Nevada OF 92-0083; OF 93 . 0405

Elko County Nevada OF 90-0153

Eureka County Nevada OF 90-0153

Lincoln County Nevada OF 90-0153

Nye County Nevada OF 90-0153; OF 900381

White Pine County Nevada OF 90-0153

hydrology

W 2400; OP-1044

Churchill County Nevada OF 92-0627

Douglas County Nevada C 1086
Lyon County Nevada C 1086; OF 92-0627

Storey County Nevada C 1086; OF 92-0627

Washoe County Nevada C 1086; OF 92$0627 ; \mathrm{OP}-448$

industrial minerals B 2013

Invertebrata

Elko County Nevada OP-86

Eureka County Nevada OP-86

Lander County Nevada OP-86

White Pine County Nevada OP-86

lava, Elko County Nevada OP-809

maps

DDS-0002

Clark County Nevada OF 92-0554; OF $92-$ 0681; OF 93-0198; GQ-1714; I-2173

Elko County Nevada OF 92-0580; OF 930220; I-2394

Esmeralda County Nevada OF 93-0506; I2342

Eureka County Nevada OF 93-0519

Humboldt County Nevada I-2394

Lincoln County Nevada OF 92-0613; GQ1721; GQ-1730; I-2173

Nevada Test Site OF 93-0299

Nye County Nevada OF 93-0506; MF-1877A

Pahute Mesa OF 93-0299

metal ores

OP-169; OP-397; OP-465; OP-627

Esmeralda County Nevada OP-531

Getchell Mine OP-45

Humboldt County Nevada OF 93-0249; OP205

Nye County Nevada OP-489

Osgood Mountains OP-45

molybdenum ores, Lander County Nevada B 2039

natural gas

OF 93-0248

Churchill County Nevada OF 93-0248

Neogene

Clark County Nevada OP-92

Lincoln County Nevada OP-92

non-metal deposits OP-765

paleomagnetism

Nevada Test Site OP-863

Nye County Nevada OP-863 petroleum

Clark County Nevada OF 93-0186

Elko County Nevada OF 93-0186

Lincoln County Nevada OF 93-0186

Nevada Test Site OF 92-0391

White Pine County Nevada OF 93-0186

Yucca Mountain OF 92-0391

petrology

OP-795; OP-973

Lincoln County Nevada B 2052

plate tectonics OP-1628

pollution, Churchill County Nevada OP-1765

Quatemary

C 1086; OP-459; OP-1524

Esmeralda County Nevada OP-831

Mineral County Nevada OP-69

Nevada Test Site OP-1070

Nye County Nevada C 1086; OP-294; OP916

Yucca Mountain OP-1070

sedimentary petrology

Elko County Nevada B 1988-E

Toquima Range OP-1795

seismology '

Clark County Nevada OF 92-0340

Esmeralda County Nevada OF 92-0340
Lincoln County Nevada OF 92-0340

Lyon County Nevada OF 92-0340

Mineral County Nevada OF 92-0340

Nevada Test Site OP-2026

Nye County Nevada OF 92-0340; OP-2026

Yucca Flat OP-2026

stratigraphy

OP-1847

Elko County Nevada B 1988-C; B 1988-D; B 1988-F; B 1988-G

Esmeralda County Nevada B 1988-F

Eureka County Nevada B 1988-C; B 1988D

Getchell Mine OP-623

Humboldt County Nevada B 1988-F

Nye County Nevada B 1988-F

Pershing County Nevada B 1988-F

Roberts Mountains Allochthon B 1988-D; B 1988-F

structural geology

OP-679; OP-933; OP-999

Clark County Nevada OP-19

Lincoln County Nevada B 2011

Mormon Mountains B 2011

Nevada Test Site OF 91-0623; OP-108

Nye County Nevada OF 92-0391; OP-108

Yucca Mountain OF 91-0623; OP-1400

sulfides

Elko County Nevada OP-557

Eureka County Nevada OP-557

Humboldt County Nevada OP-557

Lander County Nevada OP-557

thermal waters, Eureka County Nevada B 1998 volcanism, Nye County Nevada OF 93-0021

waste disposal

Beatty Nevada WRI 92-4032; OF 92-0484

Nevada Test Site OF 91-0493

Yucca Mountain OF 91-0493; OP-724; OP1522

Nevada Mining Association

industrial minerals B 2013

Nevada Test Site

earthquakes OP- 1300

engineering geology $\mathrm{OF}$ 93-0073

environmental geology OF 92-0516

geochemistry OP-1775

geochronology OF 93-0538

geophysical surveys OF 92-0028; OF 92-0343; OF 92-0572; OF 93-0187

ground water OF 90-0369; OF 91-0478; OF 930071

maps OF 93-0299

paleomagnetism OP-863

petroleum OF 92-0391

Quaternary OP-1070

seismology OP-2026

structural geology OF 91-0623; OP-108

waste disposal OF 91-0493

Nevadan Orogeny

California

geochemistry OP-1141

structural geology OP-1413

Oregon

geochemistry OP-1141

petrology OP-1140

Nevado del Ruiz

Quaternary OP-677

New Albany Shale

B 1909; OP-1845

energy sources B 1909

hydrogeology OP-1228 
New Brunswick see also Pictou Group. lead-zinc deposits OP-787

New Castile Spain see Ciudad Real Spain

New Castle Quadrangle

maps OF 93-0310

New England

geochronology OF 92-0525

ground water OP-1472

magmas OP-37

metamorphic rocks OP-1188

neotectonics OP-555

pollution OF 93-0418

Quatemary C. 1086; OP-748

structural geology OP-461; OP-1079

New England Orogeny

California, structural geology OP-78

New South Wales Australia

guidebook OP-7

structural geology OP-78

New Guimea

Quaternary OP-706

New Hampshire

environmental geology

Hillsborough County New Hampshire WRI 92-4056

Rockingham County New Hampshire OF 92-0647

Strafford County New Hampshire WRI 92 4012

geochemistry

Rockingham County New Hampshire OP1207

Strafford County New Hampshire OP-1207

geochronology

OF 92-0525

Coos County New Hampshire OP-1105

Grafton County New Hampshire OP-1105

ground water

YR

Belknap County New Hampshire WRI 904161

Hillsborough County New Hampshire WRI 91-4177

Rockingham County New Hampshire WRI 91-4025; OF 92-0095

Strafford County New Hampshire WRI 904161

hydrogeology

Rockingham County New Hampshire OF 89-0583

Strafford County New Hampshire OF 890583

hydrology W 2400

maps I-1420 (NK-18); I-1420 (NL-18)

New Hebrides see Vanuatu

New Ireland Basin

economic geology OP-639

petroleum OP-307

New Jersey see also Delaware Bay; Delaware

River basin; Lockatong Formation; Navesink

Formation; Newark Basin; Newark Supergroup;

Passaic Formation; Piedmont; Stockton Formation.

continental shelf MF-2221

environmental geology

OP-377

Atlantic County New Jersey OP-832

Cumberland County New Jersey OF 930243

Morris County New Jersey OF 92-0153

geochemistry

OP-219
Essex County New Jersey OF 93-0010

Hunterdon County New Jersey OF 93-0010

Morris County New Jersey OF 93-0010

Passaic County New Jersey OF 93-0010

Somerset County New Jersey OF 93-0010

Watchung Mountains OF 93-0010

geologic hazards

Passaic River OP-899

Somerset County New Jersey OP-899

geophysical surveys OF 92-0700-A

ground water

YR; P 1404-G

Atlantic County New Jersey WRI 91-4126; OP-350

Bergen County New Jersey WRI 90-4151

Camden County New Jersey WRI 91-4126; OF 92-0052

Cape May County New Jersey WRI 91-4191

Gloucester County New Jersey WRI 914126

Passaic River basin WRI 90-4151

hydrogeology

Cumberland County New Jersey OF 92 0052

Hunterdon County New Jersey OP-652

Morris County New Jersey WRI 91-4169; OP-652

New Jersey Highlands OP-652

Raritan River OP-652

Sussex County New Jersey WRI 91-4169

hydrology W 2400

maps

I-1420 (NK-18)

Sussex County New Jersey GQ-1707

paleontology OP-1205

pollution OP-1383

sheet silicates OP-1489

stratigraphy

OP-1788

Atlantic County New Jersey OP-979

Burlington County New Jersey OP-528; OP979

Camden County New Jersey OF 92-0399

Cape May County New Jersey OP-979

Cumberland County New Jersey OP-979

Gloucester County New Jersey OF 92-0399

Monmouth County New Jersey OF 92-0399; OP-528; OP-529

Ocean County New Jersey OF 92-0399; OP979

Salem County New Jersey OF 92-0399; OP979

Triassic

Bergen County New Jersey MF-2208

Essex County New Jersey MF-2208

Hudson County New Jersey MF-2208

Hunterdon County New Jersey MF-2208

Middlesex County New Jersey MF-2208

Monmouth County New Jersey MF-2208

Morris County New Jersey MF-2208

Passaic County New Jersey MF-2208

Somerset County New Jersey MF-2208

Sussex County New Jersey MF-2208

Union County New Jersey MF-2208

New Jersey Highlands

hydrogeology OP-652

New Madrid earthquakes 1811-1812

OP-1866

Kentucky, Quatemary OP-486

Mississippi Valley, structural geology OP-358

Tennessee, Quatemary OP-486; OP-856
New Madrid Missouri

geologic hazards $\mathrm{C} 1083$

structural geology OP-1318

New Madrid region see also New Madrid earthquakes 1811-1812.

deformation OP-1861

earthquakes OP-1996

engineering geology OF 92-0391

heat flow OP-1661

sedimentary petrology OF 93-0291

seismology OP-1867

structural geology OP-1471; OP-1799

New Mexico see also Dakota Formation; Delaware Basin; Fruitland Formation; Madera Formation; Palo Duro Basin; Permian Basin; Raton Basin; Rio Puerco; San Juan Basin.

coal, Cibola County New Mexico OP-17

Cretaceous

Picuris Range OP-11

Taos Plateau OP-11

Tusas Mountains OP-11

energy sources

OF 93-0248; OF 93-0337

San Juan County New Mexico OP-518

evaporite deposits OP-2012

geochemistry

Eddy County New Mexico OP-1072

Otero County New Mexico OP-1072

Questa Caldera OP-490

Rio Arriba County New Mexico OP-490

Taos Plateau OP-490

geochronology, Valle Grande Mountains OP1538

geologic hazards C 1086

geomorphology, Carlsbad Caverns OF 92-0391

geophysical surveys

WRI 91-4065

Catron County New Mexico OF 92-0503

Grant County New Mexico OF 92-0503

ground water

B 1989-D; OP-230

Bemalillo County New Mexico WRI 914033

Cibola County New Mexico WRI 91-4033

Dona Ana County New Mexico P 1407-C WRI 91-4155; OF 91-0455; OF 92-0465

Lincoln County New Mexico OF 92-0465

McKinley County New Mexico WRI 914033

Otero County New Mexico OF 92-0465

Sandoval County New Mexico WRI 914033

Sierra County New Mexico OF 92-0465

Socorro County New Mexico OF 92-0465

Valencia County New Mexico WRI 91 4033

Zuni Mountains WRI 91-4033

hydrogeology

OP-347

Catron County New Mexico WRI 92-4004

Chaves County New Mexico OF 93-0144

Cibola County New Mexico WRI 92-4004

De Baca County New Mexico OF 93-0144

Eddy County New Mexico OF 93-0144

Guadalupe County New Mexico OF 930144

Lincoln County New Mexico OF 93-0144

Otero County New Mexico OF 93-0144

San Juan County New Mexico OF 93-0084

Sandoval County New Mexico WRI 924193 
hydrology

W 2400; OP-598; OP-1044

Albuquerque New Mexico OF 92-0653 magmas, Catron County New Mexico OP-278 maps

Colfax County New Mexico I-2266

McKinley County New Mexico GQ-1716

Rio Arriba County New Mexico OF 920710; OF 92-0711

Taos County New Mexico OF 92-0710; OF 92-0711

Union County New Mexico I-2266

metal ores, Lincoln County New Mexico OP1715

molybdenum ores

OP-1927

Valles Caldera OP-1243

natural gas

Bernalillo County New Mexico OF 93-0248

Dona Ana County New Mexico OF 93-0248

Grant County New Mexico OF 93-0248

Hidalgo County New Mexico OF 93-0248

Lincoln County New Mexico OF 93-0248

Luna County New Mexico OF 93-0248

McKinley County New Mexico OF 93-0248

Otero County New Mexico OF 93-0248

Rio Arriba County New Mexico OF 930248

San Juan County New Mexico OF 93-0248

Sandoval County New Mexico OF 93-0248

Santa Fe County New Mexico OF 93-0248

Sierra County New Mexico OF 93-0248

Socorro County New Mexico OF 93-0248

Valencia County New Mexico OF 93-0248

non-metal deposits, San Juan County New

Mexico B 2061-A

palynomorphs OP-1388

petroleum

OF 93-0337; OF 93-0522

Colfax County New Mexico OF 93-0337

Grant County New Mexico B 2039

Harding County New Mexico OF 93-0337

Mora County New Mexico OF 93-0337

Union County New Mexico OF 93-0337 petrology

Taos County New Mexico OF 92-0528

Taos Plateau OF 92-0528

pollution

McKinley County New Mexico OP-1023

San Juan County New Mexico WRI 93-4007

Quatemary, Valles Caldera OF 92-0699

solution features, Carlsbad Caverns OP-1629

stratigraphy

Grant County New Mexico OP-573

McKinley County New Mexico B 1808-O

Rio Arriba County New Mexico B 1808-O; B 2025

San Juan County New Mexico B 1808-O; B 2025

San Miguel County New Mexico B 1787-EE

Sandoval County New Mexico B 1808-O

Socorro County New Mexico B 1787-EE

Taos County New Mexico B 1787-EE

structural geology OP-679

volcanism I-2291-A

New Orleans Louisiana

engineering geology OF 92-0530

hydrology W 2400

New River

hydrology OF 92-0065

New River Gorge National River

hydrology OF 92-0065
New South Wales Australia see also Broken Hill;

Willyama Complex.

guidebook OP-7

structural geology OP-78

New Tripoli Quadrangle

areal geology B 1994

New York see also Appalachian Basin; Delaware River basin; Genesee Group; Grenville Province; Hamilton Group; Hudson River, Lake Champlain; Long Island; Ludlowville Formation; Marcellus Shale; Moscow Formation; Onondaga Limestone; Oriskany Sandstone;

Tully Limestone; West Falls Formation. engineering geology

Bronx County New York I-2003

New York County New York I-2003

Queens County New York I-2003

environmental geology, Catskill Mountains OP-1130; OP-1735

geochemistry, Adirondack Mountains OP-776 geochronology, Adirondack Mountains OP1709

ground water

Nassau County New York WRI 88-4127; WRI 90-4182; WRI 91-4012; OF 910180

Niagara County New York OP-2023

Rockland County New York WRI 90-4151

Suffolk County New York WRI 92-4100; OF $91-0180$

Westchester County New York WRI 914030

highways WRI 92-4147

hydrogeology

OF $92-0473$

Broome County New York W 2387

Nassau County New York WRI 90-4205

Suffolk County New York WRI 90-4205

hydrology

W 2400; WRI 92-4042; WRI 92-4060;

OF $92-0476$

Catskill Mountains OP-1734

Monroe County New York OP-1093

Ogdensburg New York W 2400

maps I-1420 (NK-18); I-1420 (NL-18)

natural gas

Allegany County New York B 1909

Cattaraugus County New York B 1909

Livingston County New York B 1909

Steuben County New York B 1909

non-metal deposits, New York Bight OP-1104

pollution, Catskill Mountains OP-975

stratigraphy

Orange County New York B 1839-L

Shawangunk Mountains B 1839-L

Sullivan County New York B 1839-L

structural geology

Adirondack Mountains OP-46

Essex County New York OP-461

Triassic

Kings County New York MF-2208

Richmond County New York MF-2208

New York Bight

non-metal deposits OP-1104

New York Butte Quadrangle

economic geology OP-662

New York Mountains maps OF 93-0198

New Zealand see also Taranaki Basin. energy sources OP-1624 geophysical surveys, Lake Taupo B 1966

\section{Newark Basin}

energy sources OP-1842

geochemistry OF 93-0010

ground water OP-986

magmas OP-1003

sedimentary petrology OP-1379

Triassic MF-2208

Newark Canyon Formation

stratigraphy B 1988-C

Newark Supergroup see also Lockatong Forma-

tion; Passaic Formation; Stockton Formation.

OP-1659; OP-1660

guidebook OP-359

magmas OP-1003

Newberry Volcano

geophysical surveys B 1966

Newcastle Quadrangle geophysical surveys OF 93-0002

Newfound Member

stratigraphy OP-1660

Newfoundland

structural geology OP-1525

Newport Fault

structural geology OP-18

Newton East Quadrangle maps GQ-1707

NGDB

geochronology OF 93-0336

Ni see nickel

Niagaran see Lockport Formation

Nicaragua

mineral resources OF 92-0547

seismology OP-1066

Nice France

Quaternary OP-310

Nicholson Deposit metal ores OP-1431

Nick Mine geochemistry OF 92-0525

nickel

Colombia, geochemistry OP-755

England, geochemistry OP-755

geochemistry OP-530

hydrology OP-1836

Maryland, environmental geology OP-1089

Poland, geochemistry OP-755

Puerto Rico, metal ores OP-1656

Texas, geochemistry OP-755

nickel ores

Australia OP-1431

Canada OP-728; OP-1431

China

OP-363; OP-1432

geochemistry OF 92-0525

geochemistry OF 92-0559

Italy OF 93-0504

Montana OF 93-0207

Ontario OP-1978; OP-1979

Puerto Rico OF 92-0567

Russian Federation OP-2014

United States OP-728

Yukon Territory

OP-363; OP-1432

geochemistry OF 92-0525

Nicolas Terrane

structural geology OP-1172; OP-1971

Nicoya Peninsula

Neogene OP-1272

Nigeria

metal ores C 0930-M 
Nile River

fluvial features OP-314

Nile Valley

earthquakes OP-992

Nilinger-Tromso Nappe

structural geology OP-1279

Nimrod Lake

hydrology OF 93-0070

niobates see niobotantalates

niobium

Australia, metal ores C $0930-\mathrm{M}$

Brazil, metal ores C 0930-M

Canada, metal ores C 0930-M

China

metal ores C $0930-\mathrm{M}$

metasomatism OP-1343

Colorado, metal ores C 0930-M

geochemistry OP-30

Idaho, metal ores $\mathrm{C}$ 0930-M

Malaysia, metal ores C 0930-M

Mozambique, metal ores C 0930-M

Nigeria, metal ores C 0930-M

Rwanda, metal ores C 0930-M

Thailand, metal ores C 0930-M

Zaire, metal ores C 0930-M

niobium ores

Australia C 0930-M

Brazil C 0930-M

Canada C 0930-M

China C 0930-M; OF 92-0525; OP-153; OP1238

Colorado C 0930-M

Idaho C 0930-M

Malaysia C 0930-M

Mozambique C 0930-M

Nigeria C 0930-M

Rwanda C 0930-M

Thailand C 0930-M

Zaire C 0930-M

niobotantalates see pyrochlore

Niobrara Formation

OF 93-0335

natural gas OF 93-0337

sedimentary petrology OP-1791

nitrates

Great Plains, ground water OF 93-0114

Gulf Coastal Plain, environmental geology C 1120-C

Gulf of Mexico, environmental geology C 1120-C

hydrogeology OF 93-0040

Idaho, ground water WRI 92-4014

Massachusetts, ground water OP-800

Midwest

environmental geology OF 93-0418

pollution OF 93-0418

Washington, ground water WRI 93-4060

nitrite lon

Missouri, pollution OF 93-0101

soils OP-1951.

nitrogen

OP-1590; OP-1591

Antarctica, geochemistry OP-664

Arizona, geochemistry OF 92-0599

California, ground water OF 92-0655.

Canada, hydrology W 2400

Colorado, hydrology WRI 92-4053

environmental geology OP-548

Florida, environmental geology WRI 91-4181

geochemistry OP-914; OP-1247; OP-1766

hydrology OF 93-0032
Idaho, ground water WRI 92-4014

Kansas, pollution OP-1909

Maryland

environmental geology OP-658

geochemistry OP-439

Missouri, pollution OF 93-0101

N-15

geochemistry OP-1990

soils OP-1951

$\mathrm{N}-15 / \mathrm{N}-14$

California OP-557

energy sources OF 92-0391

Maryland OP-1174

Minnesota OP-551

Nevada OP-557

Nebraska, pollution OP-1909

Pennsylvania

clay mineralogy OF 92-0568

hydrogeology WRI 90-4131; OF 92-0165 soils OF 90-0130

United States, hydrology W 2400

Washington, ground water WRI 93-4060

Nittany Dolomite

ground water OP-111

Nixon Fork Terrane

Paleozoic OP-1168

Noachian

OP-906; OP-987; OP-1338; OP-1933; OP-

1934; OP-1935; OP-1938; OP-1939; OP-1940;

OP-1984

Syria OP-1322

noble gases see also helium; radon. gold ores OP-1175

nodules

Atlantic Ocean OP-886

geochemistry OF 92-0559

Nonesuch Shale

copper ores OP-1688

energy sources OF 92-0391

geochemistry OP-1204

natural gas OF 92-0524; OP-725

sedimentary petrology OF 92-0391

nonmagnetic minerals

Alaska

metal ores MF-1996-E

mineral resources $\mathrm{MF}-2144-\mathrm{B}$

mineral resources OF 92-0380-A; OF 92-0380-

B; MF-2207; MF-2217-B

nonmare basalt see KREEP

nonmetal deposits

California OF 92-0595

Montana OF 93-0207

Wisconsin OF 92-0514

nonmetals

Peru, geochemistry OP-1331

Nora Trend

energy sources OP-1751

Nordland Norway see Ofoten

Nordlinger Ries Crater see Ries Crater

Norian

Virginia OP-1660

Noril'sk Russian Federation see Norilsk Russian

Federation

Norilsk region

metal ores OP-2014

Norilsk Russian Federation

geochemistry OP-1086

metal ores OP-1313

norite OP-478; OP-805

normal earthquake see shallow-focus earthquakes normal faults

OP-401; OP-1890

Appalachians, zinc ores B 2039

Arizona

I-2290

metal ores B 2042-C

Atlantic Ocean, tectonophysics OP-1080

Basin and Range Province OP-19; OP-769

California

OP-803; OP-1451

economic geology OP-662

seismology OP-438

stratigraphy OP-1281

Colorado Plateau OP-19; OP-769

Commonwealth of Independent States, petroleum OP-1265

Europe, petroleum OP-1265

Idaho

OP-18; OP-523; OP-634

Eocene OP-617

metal ores OF 93-0235

Illinois OP-1471

Italy, Quaternary OP-764

metal ores OF 92-0557

Midwest OP-1799

Missouri OP-1318; OP-1471; OP-1861

Montana

P 1524

Eocene OP-617

Nevada

OF 92-0391; OP-108; OP-1400

geophysical surveys OF 92-0343

Oregon OP-634

Pacific Ocean

plate tectonics OP-1651

tectonophysics OP-1080

Poland OP-967; OP-1916

Utah

B 1787-HH; OP-621

geologic hazards P 1519

Venezuela OP-1760

Washington OP-18

Norphlet Formation

diagenesis OP-1856

energy sources OP-1753

sedimentary petrology OP-1858

Norris Geyser basin

geochemistry OP-122; OP-327; OP-520; OP536; OP-637

North Adams Quadrangle

maps I-2369

North Africa see Algeria; Egypt; Tunisia

North America see also Appalachians; Basin and Range Province; Canada; Canadian Shield; Great Lakes; Great Lakes region; Great Plains; Gulf Coastal Plain; Rocky Mountains; Westem Interior.

Archean, Lake Superior region B 1904-P areal geology, Keweenawan Rift OP-139 barite deposits OP-1257

Carboniferous, Appalachian Basin OP-1232 continental margin, Juan de Fuca Strait I-2091 C

copper ores

Keweenawan Rift OP-1216; OP-2019

Lake Superior region OP-1216

deformation OP-972

diagenesis, Appalachian Basin OF 92-0568

earthquakes DDS-0007; OF 93-0509

energy sources

Appalachian Basin B 1909

Keweenawan Rift OF 92-0391 
Rocky Mountains foreland OF 93-0337

Sweetgrass Arch OF 93-0337

Williston Basin OF 92-0524; OF 93-0337; OP-1753

environmental geology

SM

Lake Champlain OP-1481

Mississippi River basin C 1120-C

Eocene OP-1081

geochemistry

OP-1377

Belt Basin OP-1094

Keweenawan Rift OF 92-0525; OP-1204; OP-1747

Rio Grande Rift OP-490

Yukon-Tanana Terrane OP-721

geochronology, Keweenawan Rift OP-758

geologic hazards, Mississippi River basin

C 1120-B; OP-669

geomorphology C 1086; OF 91-0014

ground water, Michigan Basin P 1405-C; OP1706

hydrogeology

OP-1085

Appalachian Basin OP-1228

hydrology

Mississippi River basin C 1120-A; OF 91 0485

Saint Lawrence River W 2400

Invertebrata B 2024

maps

OF 92-0391

Straight Creek Fault I-1963

metal ores

OF 92-0704; OF 93-0328; OP-853

Keweenawan Rift OP-728

Lake Superior region OP-728

Yukon-Tanana Terrane OP-570

metamorphic rocks

Coast plutonic complex OP-1194

Denali Fault P 1497-C

natural gas

Appalachian Basin B 1839-I,J; B 1909

Keweenawan Rift OP-725; OP-1350

Lake Superior region OF 92-0524

Rio Grande Rift OF 93-0248

Rocky Mountains foreland OF 92-0524; OF 93-0337

Western Overthrust Belt OF 93-0248

oceanography, Yukon River OP-129

orogeny, Keweenawan Rift OP-138

paleobotany OP-1082

paleomagnetism OP-1504

palynomorphs, Michigan Basin B 1909

Pennsylvanian, Appalachian Basin OP-1357

petroleum

B 1909; B 2034-A

Appalachian Basin B 1909

Michigan Basin B 1909

Western Overthrust Belt OF 93-0337

Williston Basin B 1909

petrology

OP-1463

Rio Grande Rift OF 92-0528

plate tectonics

OP-680; OP-1628

Keweenawan Rift OP-13

Rio Grande Rift OP-1903

pollution

Lake Champlain OP-412

Mississippi River basin OF 93-0418

Quatemary

C 1086; OP-396; OP-706
Michigan Basin OP-1289

sedimentary petrology

Appalachian Basin B 1839-I,J; OP-1234; OP-1293

Michigan Basin OF 93-0236

Tintina Fault OP-1553

stratigraphy

OP-1702

Appalachian Basin B 1839-K; B 1839-L; B 1909; OF 92-0558; OP-1345; OP-1821

Keweenawan Rift B 1989-E

Lake Superior region B 1989-E

Saint Lawrence River OP-1484

Williston Basin OF 93-0335

structural geology

Avalon Terrane OP-1079

Keweenawan Rift OP-1214; OP-1533

Lake Superior region B 1904-L; B 1904-Q; B 1904-S

tectonics

Keweenawan Rift OP-137; OP-1215

Lake Superior region OP-137

tectonophysics

OP-1430

Keweenawan Rift OP-1534

North American Atlantic see Baltimore Canyon Trough; Caribbean Sea; Georges Bank basin; Gulf of Mexico

North American Commission on Stratigraphic Nomenclature

stratigraphy OP-285

North American Cordillera see Canadian Cordillera

North American Pacific see Axial Seamount; Gulf of Alaska; Gulf of Califomia; Rivera fracture zone

North American Plate

California

energy sources OP-267

neotectonics OP-1063

plate tectonics OP-752

structural geology OP-1172; OP-1547

tectonophysics OP-1733

Dominican Republic, plate tectonics OP-808

Iceland, tectonophysics OP-420

Mexico

plate tectonics OP-670

structural geology OP-1547

Oregon, structural geology OP-1547

Pacific Ocean, tectonophysics OP-1926

plate tectonics OP-1133; OP-1903

structural geology OP-401

North Amethyst Vein

metal ores P 1537; OF 92-0525

North Aoba Basin

marine geology OP-193

sedimentation OP-188

North Atlantic see Cape Verde Atlantic; European Atlantic, Little Bahama Bank; North American Atlantic; North Atlantic Ridge

North Atlantic Deep Water Pliocene OP-1535

North Atlantic Ridge Pliocene OF 92-0413

North Australian Seas Pennsylvanian OP-1356

North Carolina see also Blue Ridge Province; Carolina slate belt; Outer Banks; Piedmont. building storie Clay County North Carolina MF-2215-A Macon County North Carolina MF-2215-A continental margin MF-2209

Cretaceous OP-356

economic geology

Alamance County North Carolina B 2039

Chatham County North Carolina B 2039

engineering geology B 2017

geochemistry OP-1684

geomorphology, Durham County North Carolina WRI 93-4031

geophysical surveys, Cape Hatteras OF 93 0264

ground water P 1404-G

heavy mineral deposits

B 2039; OF 93-0240-A; OF 93-0240-B

Halifax County North Carolina OF 92-0396

Harnett County North Carolina OF 92-0396

Johnston County North Carolina OF 920396

Moore County North Carolina OF 92-0396

highways WRI 92-4147

hydrogeology

OF 93-0113

Bertie County North Carolina OF 93-0069

Camden County North Carolina OF 93-0069

Chowan County North Carolina OF 93-0069

Currituck County North Carolina OF 930069

Dare County North Carolina OF 93-0069

Guilford County North Carolina OF 930163

Pasquotank County North Carolina OF 930069

Perquimans County North Carolina OF 930069

Tyrrell County North Carolina OF 93-0069

Washington County North Carolina OF 93 0069

hydrology

W 2364; W 2400; WRI 92-4129

Beaufort County North Carolina OF 920498; OP-1958

Bertie County North Carolina OF 92-0123; OF 92-0639

Camden County North Carolina OF 92-0123

Chowan County North Carolina OF 92-0123

Cumberland County North Carolina WRI 92-4097

Currituck County North Carolina OF 920123

Dare County North Carolina OF 92-0123

Hyde County North Carolina OF 92-0498; OP-1958

Martin County North Carolina OF 92-0123; OF 92-0639

Pasquotank County North Carolina OF 92 0123

Perquimans County North Carolina OF 92 0123

Tyrrell County North Carolina OF 92-0123

Washington County North Carolina OF 92 0123

maps

Granville County North Carolina OF 930244

Macon County North Carolina MF-2223

Person County North Carolina OF 93-0244

Vance County North Carolina OF 93-0244

Warren County North Carolina OF 93-0244 mineral resources

Granville County North Carolina MF-2203

Person County North Carolina MF-2203

oceanography, Pamlico River OP-1131 
pollution, Guilford County North Carolina OP403

stratigraphy OP-597; OP-1788

North Central (United States) see Midwest

North Central Oil Corporation energy sources OP-1842

North Charleston Quadrangle Quatemary I-1935

North Coles Levee Field geochemistry OP-1578

North Dakota see also Bakken Formation; Fort Union Formation; Hell Creek Formation; Ludlow Member, Madison Group; Red River, Red River Formation; Williston Basin.

energy sources OF 93-0337

environmental geology OF 93-0292-H

geochemistry OF 93-0117

geologic hazards OP-669

geophysical surveys OC-0140

ground water OF 93-0114

hydrogeology

OF 93-0052

Dickey County North Dakota WRI 92-4110 hydrology

W 2400; C 1120-A; WRI 92-4020; OP-

1071

Benson County North Dakota W 2340 OF 93-0066

Cavalier County North Dakota W 2340

Ramsey County North Dakota W 2340; OF 93-0066

Towner County North Dakota W 2340

industrial minerals OF 92-0514

petroleum OF 93-0337

Quaternary OP-1896

stratigraphy

B 1917-M

Burleigh County North Dakota OF 93-0335

Emmons County North Dakota OF 93-0335

Kidder County North Dakota OF 93-0335

Logan County North Dakota OF 93-0335

McIntosh County North Dakota OF 93-0335

Sioux County North Dakota OF 93-0335

Stutsman County North Dakota OF 93-0335

North Fiji Basin

seismology OP-1758

North Fork Forked Deer River hydrology WRI 92-4082

North Horn Formation sedimentary rocks B 1787-DD

North Island geophysical surveys B 1966

North Korea energy sources OP-1624

North Pacific see Clarion fracture zone; Loihi Seamount

North Palm Springs earthquake 1986 OP-959

North Park Colorado natural gas OF 93-0248

North Platte River ground water $O F$ 91-0533

North Polar Sea see Arctic Ocean

North Sea

stratigraphy OP-1359

North Slope

ecology C 1086

energy sources B 2034-A

geochemistry OF 92-0391

heat flow OP-253

natural gas OP-74

petroleum OP-1285
Quaternary B 2036; C 1086

sedimentary petrology OF 92-0391; OP-1553

Vertebrata OP-163

North Sulawesi earthquake 1990

engineering geology OP-993

North Victoria Land see Victoria Land

North Vietnam see Vietnam

North-Central (United States) see Midwest

North-West Frontier Pakistan see Swat Pakistan

Northeast Pacific see Califormia Current

Northern Alaska see Arctic National Wildlife Refuge; Brooks Range; National Petroleum Reserve Alaska: Prudhoe Bay; Prudhoe Bay Field

Northern Arapaho Tribe hydrogeology WRI 91-4108

Northern California earthquake 1980 continental shelf B 2002

Northern Hemisphere

natural gas OF $93-0230$

Pliocene OP-1949

Northern Peninsula, Michigan see Michigan Upper Peninsula

Northern Territory Australia

metal ores, Pine Creek Geosyncline OP-1431

Quaternary, Tennant Creek Australia B 2032-A

Northwest Atlantic see Blake Plateau

Northwest Territories

geochemistry, Arctic Archipelago OP-721

Mesozoic, Arctic Archipelago OP-1680

Quaternary, Arctic Archipelago B 2036

Northwind Ridge

Quaternary OF 92-0426; OF 93-0218; OF 930515; OP-799; OP-1796 structural geology OP-1428

Norton Sound oceanography OP-129

Norumbega fault zone stratigraphy OP-1530

Norway

petrology, Bergen Norway OP-1173

Quatemary P 1386-E

structural geology

Ofoten OP-1279

Troms Norway OP-1279

Nostoceras

Invertebrata OP-525

stratigraphy OP-526; OP-527; OP-529

Nova Scotia see also Stellarton Group; Sydney coal field; Windsor Group. coal OP-2034

geochemistry, Cape Breton Island

OF 92-0525; OP-1122

Novarupta

geochemistry OP-926 petrology OP-316

Novaya Zemlya engineering geology $\mathrm{OF}$ 93-0501

NPBAS OF 92-0369-A; OF 92-0369-B

NPDB

paleontology OF 93-0549

NPRA see National Petroleum Reserve Alaska

NRM see natural remanent magnetization

nuclear explosions

Alaska OF 92-0502

China, core OP-1031

Russian Federation OF 93-0501

nuclear facilities B 2017 nuclear logging

Nevada, ground water WRI 91-4167

nuclear waste see radioactive waste

Nugget Sandstone

petroleum OP-1767

NURE

Alaska, metal ores OP-1006

Atlantic Coastal Plain, heavy mineral deposits B 2039

heavy mineral deposits OF 93-0240-A; OF 930240-B

uranium ores DDS-0001; OP-655

Nushagak Bay Quadrangle

metal ores MF-2228

Nutters Hole Quadrangle

maps MF-2250

Nyos see Lake Nyos

$\mathbf{0}$

O see oxygen

O-16/O-18 see O-18/0-16

0-18

Califomia

geochemistry OP-890

thermal waters OP-997

Florida, Quatemary C 1086

Illinois, hydrogeology OP-1782

Kentucky, hydrogeology OP-1782

0-18/0-16 see also geologic thermometry.

Alaska

hydrology OP-330

Quatemary OP-1225

Antarctic Ocean

Pliocene OP-1535

Tertiary OP-1145

Bahamas, Quatemary OP-706

Barbados, Quatemary OP-706

Bermuda, Quatemary OP-706

Brazil, ground water OP-737

California

energy sources OP-267

geochemistry OP-1141

ground water OF 92-0655

petrology OP-1148

pollution OP-473

structural geology OP-332

Colorado

economic geology OP-872

geochemistry OP-490

metal ores OP-1151

East Pacific Ocean Islands, geochemistry OP925

energy sources OF 92-0391

Florida, Quatemary OP-706; OP-1930

Galapagos Islands, geochemistry OP-925

geochemistry OF 92-0009; OP-953

Greenland, Quatemary C 1086

Haiti, Quaternary OP-706

Iceland, geochemistry OP-511

Idaho, paleomagnetism OP-697

Indiana, ground water OP-1648

Maryland, geochemistry OP-1824

metal ores OP-1117

Mexico

economic geology OP-872

Quaternary OP-706

Michigan

copper ores OP-2019

geochemistry OP-1747

mineralogy OP-1922 
Minnesota

geochemistry OP-251

Quaternary C 1086

Missouri, metal ores OP-1327

Montana, geochemistry OP-637; OP-978

Nevada

geochemistry OP-313; OP-643; OP-1302

gold ores $\mathrm{OP}-441$

Quatemary C 1086; OP-916

New Mexico, geochemistry OP-490; OP-1072

Nova Scotia, geochemistry OF 92-0525

Ohio, ground water OP-1648

Ontario, geochemistry OP-1942

Oregon, geochemistry OP-1141

Pacific Ocean, geochemistry OP-419; OP-1127

Peru, economic geology OP-872

Russian Federation, Quaternary OP-1874

Saudi Arabia, metal ores OP-1559

Sweden, geochemistry OP-552

Texas, geochemistry OP-1072

Utah, economic geology OP-872

Washington, geochemistry OP-998

Wyoming

geochemistry OP-637; OP-978

paleomagnetism OP-697

Quaternary OP-711

Oahu see also Honolulu Hawaii; Koolau Range. engineering geology OF 92-0501

ground water OP-1527

hydrogeology WRI $91-4197$

oceanography B 2002

pollution WRI 92-4168

Oak Ridge National Laboratory

Tennessee, hydrogeology WRI 92-4131

Oasis Valley Caldera

geochemistry OP-313

Oat Mountain Quadrangle maps OF 93-0525

obduction

Appalachians, structural geology OP-1479

Obion River

Quaternary MF-2218

waterways OP-1084

Obispo Formation

structural geology OP-1701

oblique-slip faults

California OP-1172

Idaho OP-634

Missouri OP-1336; OP-1861

Nevada OP-1400

Oregon OP-634

obsidian

Indonesia, geochronology OP-1538

Ivory Coast, Quatemary OF 92-0699

New Mexico geochronology OP-1538

Quaternary OF 92-0699

Oregon OP-982

Quatemary OP-459; OP-1524

Obsidian Clifis

Quatemary OP-459

Obsidian Dome

Quaternary OP-1524

Ocala Group

hydrogeology W 2340

Ocala National Forest

ground water W 2340

ocean basins OP-1667

ccean bottom seismographs

Russian Federation, geophysical surveys OF 92-0693; OF 93-0007 ocean circulation see also continental slope; ocean currents.

OF 92-0720

Alaska OF 93-0019

Antarctic Ocean, Pliocene OP-1535

North Carolina OP-1131

ocean crust see oceanic crust

ocean currents

Atlantic Ocean, oceanography OP-1073

British Columbia, ocean circulation OP-320

California

oceanography OF 92-0382; OF 92-0555; OP-75

Quaternary C 1086; OP-878

Massachusetts, estuaries OP-932

Nevada, Quaternary C 1086

Ocean Drilling Program see also Leg 108; Leg

110; Leg 119; Leg 123; Leg 124; Leg 129; Leg

134; Leg 135 .

Cretaceous OP-1193

geochemistry OP-755; OP-1127

geophysical surveys OP-587

plate tectonics OP-586; OP-1651

sedimentation OP-243

ocean floors see also abyssal plains; bathymetric maps; bottom features; continental margin; continental slope; mid-ocean ridges; paleo-oceanography; seamounts; submarine canyons; submarine fans.

Arctic Ocean, structural geology OP-1428 natural gas OP-1615

Pacific Ocean, engineering geology OP-1641

Russian Federation, geophysical surveys OP898

Vanuatu OP-368

Ocean Margin Drilling Program

stratigraphy OP-1484

ocean ridges see mid-ocean ridges

ocean waves

California OP-751

engineering geology OF $92-0722$

ocean-bottom seismometers see ocean bottom seismographs

ocean-floor spreading see sea-floor spreading

Oceania see Melanesia; Micronesia; Polynesia

oceanic crust see also ophiolite complexes.

OP-392

Arctic Ocean OP-1429; OP-1891

Arctic region OP-1891

Atlantic Ocean

OP-1080

continental margin B 2002

Bering Sea, deformation OP-211

California

OP-759; OP-1733

deformation OP-972

geochemistry OP-890

structural geology OP-1413

Indian Ocean, deformation OP-146

Iowa, stratigraphy OP-1537

Pacific Ocean OP-1080

Tonga OP-1969

Vanuatu OP-197

oceanic trench see trenches

oceanography see continental margin; continental shelf; continental slope; estuaries; marine geology; nodules; ocean basins; ocean circulation; ocean floors; ocean waves; reefs; sea ice; sea water, sedimentation; sediments

Oceanus Borealis OP-1838
Ocotillo Formation

Quaternary OP-1843; OP-1844

octahedral iron ore see magnetite

octahedrite (mineral) see anatase

ODP see Ocean Drilling Program

ODP Site 661

Pliocene OF 92-0413

ODP Site 672

Pliocene OF 92-0414

ODP Site 737

Tertiary OP-1145

ODP Site 741

Quaternary OP-1630

ODP Site 744

Tertiary OP-1145

ODP Site 765

deformation OP-146

marine geology OP-361

ODP Site 766

marine geology OP-361

ODP Site 768

marine geology OP-822

ODP Site 769

oceanography OP-820

ODP Site 770

oceanography OP-821

ODP Site 800

Cretaceous OP-1230

geochronology OP-813

paleomagnetism OP-747

ODP Site 801

geochronology OP-813

paleomagnetism OP-747

ODP Site 802

Cretaceous OP-1230

geochronology OP-813

ODP Site 825

tectonophysics OP-1908

ODP Site 827

marine geology OP-189; OP-196

ODP Site 828

marine geology OP-195; OP-196

ODP Site 829

marine geology OP-190; OP-196

ODP Site 830

marine geology OP-187; OP-196

ODP Site 831

marine geology OP-192; OP-196

ODP Site 832

marine geology OP-196

sedimentation OP-188

ODP Site 833

marine geology OP-193; OP-196

ODP Site 855

sedimentation OP-243

ODP Site 856

sedimentation OP-243

ODP Site 857

geochemistry OP-1127

sedimentation OP-243

ODP Site 858

sedimentation OP-243

ODP Site 859

plate tectonics OP-586; OP-1651

ODP Site 860

plate tectonics OP-586; OP-1651

ODP Site 861

plate tectonics OP-586 
ODP Site 862

plate tectonics OP-586

ODP Site 863

plate tectonics OP-586; OP-1651

OEMG OF 92-0691

Office of Energy and Marine Geology OF 920691

Office of Mineral Resources

mineral resources B 2039

Ofoten

structural geology OP-1279

Ofoten-Lyngen Nappe

structural geology OP-1279

Ogallala Aquifer

pollution OP-599

Ogasawara Islands see Bonin Islands

Ogden Utah

structural geology OP-718

Ogdensburg New York hydrology W 2400

Ohio see also Allegheny Group; Appalachian Basin; Bedford Shale; Berea Sandstone; Brassfield Formation; Columbus Limestone; Conemaugh Group; Delaware Limestone; Detroit River Group; Kittanning Formation; Lake Erie; Lockport Formation; Marcellus Shale; Michigan Basin; Ohio Shale; Olentangy Shale; Salina Group; Sunbury Shale. energy sources

Ashtabula County Ohio B 1909

Cuyahoga County Ohio B 1909

Erie County Ohio B 1909

Huron County Ohio B 1909

Lake County Ohio B 1909

Lorain County Ohio B 1909

Summit County Ohio B 1909

Trumbull County Ohio B 1909

engineering geology OF 93-0349

environmental geology, Columbus Ohio WRI 92-4130

ground water

OF 92-0489; OF 92-0694; OF 93-0114;

OF 93-0119; OP-1925

Clark County Ohio WRI 93-4047

Greene County Ohio WRI 93-4047

Lucas County Ohio WRI 91-4024

Montgomery County Ohio WRI 93-4047

Wood County Ohio WRI 91-4024

hydrogeology

Greene County Ohio WRI 92-4072

Montgomery County Ohio WRI 92-4072

hydrology

W 2400

Gallia County Ohio OF 92-0120

Meigs County Ohio OF 92-0120

Vinton County Ohio OF 92-0120

industrial minerals OF 92-0514

non-metal deposits OF 92-0514

pollution YR; OP-155

sedimentary petrology, Jackson County Ohio OF 92-0558

stratigraphy

OF 92-0558

Athens County Ohio OF 93-0312

Columbiana County Ohio B 1839-K

Coshocton County Ohio OF 93-0312

Jackson County Ohio OF 92-0558; OF 930312

Jefferson County Ohio OF 93-0312

Lawrence County Ohio OF 92-0558; OF 930312
Mahoning County Ohio OF 93-0312; OP1513

Medina County Ohio B 1839-K

Muskingum County Ohio OF 93-0312

Stark County Ohio B 1839-K

Tuscarawas County Ohio OF 93-0312

Ohio River

environmental geology C 1120-C

geochemistry OP-628

hydrology OP-1720

structural geology OP-1799

Ohio Shale see also Cleveland Member, Huron Member.

B 1909

geochemistry B 2046

hydrogeology OP-1228

oil and gas see petroleum

oil and gas fields see also natural gas; petroleum; stratigraphic traps.

California, geochemistry OP-1578

Colorado OP-1857

Montana OP-1947

New Mexico, geochemistry OP-1072

Texas, geochemistry OP-1072

Utah OP-1857

Wyoming, diagenesis OP-1950

oll sands

Alaska OF 92-0391

Utah OP-1465; OP-1855

oll seeps

Alaska, energy sources OP-268

California, energy sources OP- 1255

Oklahoma, energy sources OP-268

Tonga, petroleum OP-896

oll shale

OP-1599

Colorado, rock mechanics OF 93-0071

Ontario, Devonian B 1909

stratigraphy $P$ 1506-F

Wyoming, palynomorphs $P$ 1506-D

oll spills

Alaska

environmental geology OP-564

hydrology W 2400

environmental geology C 1105

Kentucky, pollution WRI 92-4138

Minnesota, pollution OP-430

Puerto Rico, hydrology W 2400

\section{Okhotsk Sea}

geochemistry OP-1412

Oklahoma see also Anadarko Basin; Marmaton

Group; Ouachita Mountains; Ozark Mountains.

energy sources OF 92-0524; OP-268

geochemistry OP-891

geophysical surveys OP-1741

ground water

Atoka County Oklahoma WRI 88-4208

Bryan County Oklahoma WRI 88-4208

Choctaw County Oklahoma WRI 88-4208

Cleveland County Oklahoma OF 92-0641

Johnston County Oklahoma WRI 88-4208

Lincoln County Oklahoma OF 92-0641; OF 93-0071

Logan County Oklahoma OF 92-0641

Love County Oklahoma WRI 88-4208

Marshall County Oklahoma WRI 88-4208

McCurtain County Oklahoma WRI 88-4208

Oklahoma County Oklahoma OF 92-0641

Pottawatomie County Oklahoma OF 920641 hydrology

W 2400

Adair County Oklahoma OF 93-0171

Cherokee County Oklahoma OF 93-0171

Delaware County Oklahoma OF 93-0171

Haskell County Oklahoma OF 93-0171

Latimer County Oklahoma OF 93-0171

Le Flore County Oklahoma OF 93-0171

Muskogee County Oklahoma OF 93-0171

Invertebrata

Adair County Oklahoma OP-360

Cherokee County Oklahoma OP-360

Delaware County Oklahoma OP-360

Mayes County Oklahoma OP-360

Muskogee County Oklahoma OP-360

Ottawa County Oklahoma OP-360

maps I-1420 (NJ-14)

metal ores MF-1835-H

natural gas

Caddo County Oklahoma OF 92-0524

Canadian County Oklahoma OF 92-0524

Grady County Oklahoma OF 92-0524

Woodward County Oklahoma OF 92-0524

Ordovician, Arbuckle Mountains OP-1712

pollution

Canadian County Oklahoma OP-1251

Cleveland County Oklahoma OP-1251

Oklahoma County Oklahoma OP-1251

sedimentary petrology OF 92-0391

seismology OP-301

stratigraphy OF 93-0199

Oklahoma City Oklahoma pollution OP-1251

Oklo

geochemistry OP-713

Okpikruak Formation sedimentary petrology OP-1553

Oktyabr'sky Mine metal ores OP-1313

Old Crow Tephra

Quaternary C 1086; OP-1059

Old Faithful Geyser seismology P 1550-C

Old Lead Belt hydrology WRI 93-4012

Old Woman Mountains

igneous rocks OP-1112

magmas OP-1711

petrology OP-1691

Old Woman-Piute Batholith

geochemistry OP-678

petrology OP-1691

Olentangy River environmental geology WRI 92-4130

Olentangy Shale hydrogeology OP-1228

Oligocene see also Challis Volcanics. Arizona B 2021-C

Bolivia B 2039

California OF 92-0588

Colorado OP-985

Fish Canyon Tuff OP-1538 geochemistry OP-1825

Georgia OP-291; OP-1677

Gulf Coastal Plain P 1416-C

Hemlock Conglomerate, energy sources B 2034-A; OP-626

Mississippi OP-746

Nevada B 1988-C; OF 93-0021; OP-489; OP973 
New Mexico OP-278

South America OP-97

South Carolina I-1935; OP-291

Suwannee Limestone, hydrogeology W 2340

Texas OP-1611

Utah OP-394

olistoliths

engineering geology OP-744

olistostromes

California OP-1344

Vanuatu, tectonophysics OP-1908

olivine

petrology OP-696

olivine group see tephroite

olympic dam-type

metal ores OF 92-0557

Missouri, metal ores OP-1327

Olympic Mountains

Quaternary OP-201; OP-904

Olympic Peninsula maps I-1946

Olympic-Wallowa Lineament neotectonics OP-634 tectonics OP-877

Olyor Suite

Vertebrata B 2037

\section{Oman}

Cretaceous OP-296

structural geology, Oman Mountains OP-815

Oman Mountains

structural geology OP-815

Onaping Formation

mineralogy OP-1178

petrology OF 92-0391

Oneota Formation

Ordovician OP-1819

Onondaga Limestone

Invertebrata B 2024

Ontario see also Central Metasedimentary Belt; Grenville Province; Lake Superior region; Michigan Basin; Saint Lawrence River.

Devonian B 1909

geochemistry OP-1942

geophysical surveys OF 93-0071

maps I-1420 (NK-18); I-1420 (NL-17); I-1420 (NL-18)

metal ores

Strathcona Mine OP-1979

Sudbury Irruptive OP-1978; OP-1979

mineralogy, Sudbury District Ontario OP-1178 petrology

Eye-Dashwa Lakes Pluton OP-1560

Sudbury Basin OF 92-0391

pollution OP-369

polymetallic ores $\mathrm{OP}-484$

sulfides, Timmins Ontario OP-1892

oolite

Saudi Arabia, Quaternary OP-1198

United Arab Emirates, Quaternary OF 92-0391; OP-1198

ooze

Vanuatu, plate tectonics OP-197

opal

Wyoming, geochemistry OP-520

\section{open-pit mining}

Far East, metal ores C 0930-N

Nova Scotia, sedimentary petrology OP-1672

Wyoming, impact statements WRI 90-4154 ophiolite

Alaska

geochemistry OP-1304

petrology OF 92-0020-E

structural geology OP-94

California, geochemistry OP-890

Chile, metal ores OP-1107

geochronology OF 92-0525

magmas OP-814

New South Wales Australia OP-7

Venezuela, metal ores OP-1107

ophiolite complexes

economic geology OF 92-0020-B

Oman, structural geology OP-815

petrology OF 92-0020-G

Ophiomorpha

New Zealand, sedimentation OP-1391

Ophir Chasma OP-1162; OP-1408

Ophir District

geochemistry OP-1218

optical spectroscopy

geochemistry B 1770

Oquirrh Fault

Quaternary OP-52

Oquirrh Formation OP-1320

Oquirrh Mountains

Quatemary OP-52

Oranda Formation

structural geology OF 93-0025

Orange Mountain Basalt

geochemistry OF 93-0010

magmas OP-1003

Triassic MF-2208

Orca Group

geochemistry OP-1410

\section{Ordovician}

B 1839-I,J; B 1839-K; B 1917-M; OP-1819

Ammonoosuc Volcanics OP-1105

Arctic region OP-1839

Arkansas OF 93-0199

Beekmantown Group

environmental geology OP-901

ground water OP-111

California OP-797

Canadian Series, Michigan OP-1116

Cincinnatian, Midwest OF 92-0489

Decorah Shale, fractures OP-1336

Far East OP-1839

Great Lakes P 1405-C

Idaho OP-797

Jordan OF 92-0680

Kazakhstan OP-1295

Maine B 2039

Maquoketa Formation

fractures OP-1336

ground water OF $92-0489$

hydrogeology OP-1228

Martinsburg Formation

OF 92-0525

areal geology B 1994

environmental geology OP-901

structural geology OF 93-0025

Midwest P 1405-B

Mississippi Valley OP-1818

Nevada OF 92-0391; OF 93-0249; OP-623; OP-624

Oklahoma OF 93-0199; OP-1712

Red River Formation, energy sources OF 930337

Reedsville Formation engineering geology $\mathrm{OP}-1542$ fluvial features B 1981

Saint Peter Sandstone, hydrogeology OP-1782

Vinini Formation, metal ores OP-531

Virginia OP-1755

ore exploration see mineral assessment ore guides

Colorado, molybdenum ores OP-375

Idaho, gold ores B 2039

mineral resources OF 92-0557

Nevada, gold ores B 2039

New Mexico, petroleum B 2039

Wyoming, petroleum B 2039

ore of sedimentation see placers

ore-forming fluids

Alaska

gold ores OP-1416

metal ores OP-1433

Bolivia, metal ores B 2039

China

copper ores OP-456

metal ores OP-1432

Colorado

economic geology OP-872

metal ores P 1537; OP-1151

geochemistry OP-1312

gold ores OP-1175

Great Lakes region, copper ores OP-1216

Maine, metal ores B 2039

metal ores OP-1035; OP-1509

Mexico, economic geology OP-872

Michigan, copper ores OP-2019

Missouri

lead-zinc deposits OP-575

metal ores B 2039; OP-1327

Nevada

gold ores OP-441

metal ores OP-45

Peru, economic geology OP-872

petrology OP-1061

Poland, metal ores OF 92-0704

Red Sea, brines OP-2029

Russian Federation, Phanerozoic OP-1493

Saudi Arabia, metal ores OP-1559

United States, Phanerozoic OP-1493

Utah, economic geology OP-872

Yukon Territory, metal ores OP-1432

Orebro Sweden see Stripa region

Oregon see also Borax Lake; Cascade Range;

Coast Ranges; Columbia Plateau; Columbia

River; Columbia River Basalt Group; Great

Basin; Klamath Mountains.

areal geology, Tillamook County Oregon OF 93-0189

earthquakes OP-720; OP-1120

economic geology OP-834

energy sources B 2034-A; OP-731; OP-1946

engineering geology $\mathrm{OP}-384$

environmental geology OF 93-0292-J geochemistry

Klamath County Oregon OF 93-0314

Mount Mazama OP-42; OP-43

geologic hazards

Deschutes County Oregon W 2340

Lane County Oregon OF 92-0483

geophysical surveys

Columbia County Oregon OF 93-0347

Deschutes County Oregon B 1966

Klamath Falls Oregon OF 93-0020

Lane County Oregon B 1966; OF 93-0347

Lincoln County Oregon OF 93-0318; OF 93-0319

Linn County Oregon OF 93-0347 
Marion County Oregon OF 93-0319; OF 93 0347

Mount Hood B 1966

Newberty Volcano B 1966

Polk County Oregon OF 93-0318; OF 930319; OF 93-0347

Portland Oregon OF 93-0211

Washington County Oregon OF 93-0347

Willamette Valley OF 93-0319; OF 930347

Yamhill County Oregon OF 93-0347 ground water

YR

Gilliam County Oregon WRI 90-4085

Morrow County Oregon WRI 90-4085

Sherman County Oregon WRI 90-4085

Umatilla County Oregon WRI 90-4085

Wasco County Oregon WRI 90-4085 guidebook

Crook County Oregon OP-87

Harney County Oregon OP-87

heavy mineral deposits OF 93-0240-A; OF 930240-B

highways WRI 92-4147

hydrogeology

OF 91-0098; OP-62; OP-659

Umatilla County Oregon WRI 91-4087

hydrology

W 2400; OP-1044

Douglas County Oregon WRI 91-4063

Lincoln County Oregon WRI 92-4108

Wasco County Oregon W 2400

Willamette Valley WRI 91-4063

magmas, Mount Mazama OP-982

maps

Jackson County Oregon OF 92-0695

Josephine County Oregon OF 92-0695

Tillamook County Oregon OF 93-0302

Yamhill County Oregon OF 93-0302 metal ores OP-876

metamorphic rocks OP-1166

mineral resources

Lake County Oregon OF 90-0506

Malheur County Oregon OF 93-0259-A; OF 93-0259-B

natural gas B 2034-A

neotectonics

Baker County Oregon OP-634

Wallowa County Oregon OP-634

petroleum B 2034-A

petrology

OP-1549

Clackamas County Oregon B 2054

Klamath County Oregon OP-498

Mount Hood B 2054

plate tectonics OP-1628

pollution

Clackamas County Oregon WRI 92-4136

Malheur County Oregon OP-471

Portland Oregon WRI 92-4136

Quatemary

C 1086; OP-707

Coos County Oregon B 2038

Deschutes County Oregon OF 93-0212; OP1404

Douglas County Oregon B 2038; OF 930212

Grant County Oregon OF 93-0212

Jefferson County Oregon OF 93-0212

Klamath County Oregon OF 93-0212

Lane County Oregon B 2038; OF 93-0212

Lincoln County Oregon B 2038

sedimentary petrology OP-1134; OP-1490 sedimentation OP-1098

sediments, Willamette Valley OP-1403

soils, Umatilla County Oregon OP-1028

stratigraphy

OP-708

Jackson County Oregon P 1521

structural geology OP-159

volcanology, Klamath County Oregon OP-1 124

Orenburg Russian Federation

energy sources OP-1258

ores, polymetallic see polymetallic ores

organic carbon

Adriatic Sea, pollution OP-47

Alaska, energy sources OP-626

Atlantic Ocean, Cretaceous OP-1894

California

energy sources OP-1255

petroleum OP-1910

Colorado, natural gas OP-1262

energy sources OP-1476

Florida, geochemistry OP-1906

geochemistry OP-810

Hungary, energy sources OP-1263

hydrology OF 92-0480

Kansas, natural gas OP-725

Kentucky

geochemistry B 2046

hydrology WRI 92-4057

Louisiana, geochemistry OP-935

Minnesota, geochemistry OP-251

New York

environmental geology OP-1735

natural gas B 1909

pollution OP-412

Ontario, Devonian B 1909

Pacific Ocean, Cretaceous OP-1894

Papua New Guinea, petroleum OP-307

petroleum B 1909

pollution OP-1155

Quatemary OP-396

Rocky Mountains, Pennsylvanian OP-1103

Russian Federation, Miocene OP-198

Sweden, geochemistry OP-584

United States, geochemistry OP-584

Utah, natural gas OP-1262

Vermont, pollution $\mathrm{OP}-412$

Virginia, hydrology WRI 92-4034

organic compounds see also amber.

Indiana, geochemistry OP-1685

pollution OP-580

sedimentary petrology $\mathrm{OP}-410$

organic materials see also bitumens; carbon.

Alaska, pollution C 1007

aliphatic hydrocarbons, geochemistry OP-1923

alkanes, Michigan OP-1204

amino acids

Antarctica OP-664

Pacific Ocean OP-628

Arizona, sedimentary petrology OF 92-0391

Arkansas, hydrology OF 93-0122

aromatic hydrocarbons

Missouri OF 93-0153

New Jersey OP-219

Atlantic Coastal Plain, ground water OP-1239

barite deposits OP-960

benzene

environmental geology OP-1898

pollution OP-1128

California

geochemistry OF 92-0539-A; OF 92-0539-

C

hydrology OF 93-0057 petroleum OF 92-0539-F

stratigraphy OF 92-0539-B; OF 92-0539-D;

OF 92-0539-E; OF 93-0177; OP-469

Canada, stratigraphy OP-1776

Carboniferous OP-1232

cellulose, Nova Scotia OP-1673

chlorophyll

California OF 93-0146

Colorado WRI 92-4053

Florida OP-893

Virginia WRI 92-4034

Colorado

Quaternary OP-1676

sedimentary petrology OP-1382

Colorado Plateau, uranium ores OP-1848

energy sources B 1909; OF 92-0391

Florida, pollution OP-513

fulvic acids

Antarctica OP-664

geochemistry OP-1644

Pacific Ocean OP-628

geochemistry OP-44; OP-104; OP-305; OP1005

hopanes, Alaska OP-626

humates

geochemistry OP-1990

soils OP-1951

humic acids

geochemistry OP-353

Pacific Ocean OP-628

humus

soils OF 91-0513

Washington OP-120

hydrocarbons

environmental geology OP-180

geochemistry OP-810

Georgia WRI 93-4038

ground water $\mathrm{OP}-154$

Michigan OF 92-0391

Minnesota WRI 90-4150; OP-629

natural gas OF 92-0524

New Jersey OP-350; OP-1383

New Mexico OF 92-0391

pollution OP-181

South Carolina OP-1040

hydrology OF 93-0125

Idaho, hydrogeology OF 92-0174; OF 93-0102

Iowa, sedimentary petrology OF 92-0391

isoleucine, Califomia OP-1619

Kansas, ground water WRI 92-4169; WRI 934036

Kentucky

geochemistry B 2046

hydrology WRI 92-4078

kerogen

Alaska OP-626

California OP-1910

Canada B 1909

Colorado OP-1262; OP-1753

Commonwealth of Independent States OP1265

energy sources OP-1260

Europe OP-1265

geochemistry OP-533

natural gas OF 92-0524

Rocky Mountains OP-1103

sedimentary petrology OP-451; OP-1944

United States B 1909

Utah OP-1262

lignin

Australia OP-1478

diagenesis OP-1477

Indonesia OP-1478 
Nova Scotia OP-1673

Russian Federation OP-1763; OP-1764

lipids

geochemistry OP-183

North Carolina OP-1684

Louisiana

ground water OF $92-0492$

pollution OF 92-0492

methane

OP-1591

Alaska C 1086; OP-1616

Antarctica OP-949

Atlantic Coastal Plain OP-1337

Califomia C 1086; OP-1713

Cameroon OP-306

Colorado WRI 93-4007

geochemistry OF 92-0445; OP-563; OP914; OP-1766

Kentucky WRI 92-4057

Maryland OP-439

Minnesota OP-1526

natural gas OP-1615

New Mexico WRI 93-4007

Pacific Ocean OP-1127; OP-1614

Puerto Rico C 1086

Rocky Mountains OP-1350

soils C 1086

Mexico

energy sources OP-1137

geothermal energy OP-984

sedimentary petrology OF 92-0391; OP-50

Minnesota, Quaternary OP-668

New Hampshire, geochemistry OP-1207

New Jersey, sedimentary petrology OP-1379

North Carolina, hydrogeology OF 93-0163

Oklahoma, ground water OF 92-0641

organic carbon

Adriatic Sea OP-47

Alaska OP-626

Atlantic Ocean OP-1894

California OP-1255; OP-1910

Colorado OP-1262

energy sources OP-1476

Florida OP-1906

geochemistry OP-810

Hungary OP-1263

hydrology OF 92-0480

Kansas OP-725

Kentucky B 2046; WRI 92-4057

Louisiana OP-935

Minnesota OP-251

New York B 1909; OP-412; OP-1735

Ontario B 1909

Pacific Ocean OP-1894

Papua New Guinea OP-307

petroleum B 1909

pollution OP-1155

Quaternary OP-396

Rocky Mountains OP-1103

Russian Federation OP-198

Sweden OP-584

United States OP-584

Utah OP-1262

Vermont OP-412

Virginia WRI 92-4034

phenols

Australia OP-1478

diagenesis OP-1477

Indonesia OP-1478

phytane

Colorado OP-674

Commonwealth of Independent States OP1261; OP-1265
Europe OP-1261; OP-1265

Hungary OP-1263

New Mexico OP-674

pigments, Minnesota OP-251

pollution OF 92-0494

polycyclic aromatic hydrocarbons

Gabon OP-713

New Jersey OF 92-0153

pristane

Colorado OP-674

Commonwealth of Independent States OP1261

Europe OP-1261

Hungary OP-1263

New Mexico OP-674

proteins, geochemistry OP-608

Russian Federation

geochemistry OP-1605

Quaternary OP-1532; OP-1604; OP-2004

sedimentary petrology OF 92-0391

sapropel, Florida OP-1906

sedimentation OP-1211

sediments OP-1887

steranes

Colorado OP-674

Commonwealth of Independent States OP1265

Europe OP-1265

New Mexico OP-674

Wyoming OP-1767

steroids, Wyoming OP-1767

Sweden, geochemistry OP-1649

Tennessee, ground water OF 92-0135

terpanes

Alaska OP-626

Colorado OP-674

Commonwealth of Independent States OP1265

Europe OP-1265

New Mexico OP-674

Wyoming OP-1767

toluene, pollution OP-1128

United States

geochemistry OP-1649

stratigraphy OP-1776

Virginia, ground water OP-1902

volatile organic compounds

geochemistry OP-331

Georgia WRI 93-4038

Iowa OP-1981

Kentucky WRI 92-4138

New Hampshire WRI 90-4161; OF 92 0095; OF 92-0647

New York WRI 90-4182; WRI 92-4100; OF 91-0180

Washington, hydrogeology OF 92-0644

Wyoming, ground water OF 91-0533

xylene, pollution OP-1128

organic mound see bioherms

organic residues see coal; gyttja; oil sands; oil shale; peat; torbanite

organo-metallics

Greenland, Archean OP-848

Orinda Basin

energy sources B 2034-A

Orinoco River

tectonics OP-1760

Oriskany Sandstone

natural gas B 1839-I,J

Ornithischia

Utah OP-1252
Ornithopoda

Vertebrata OP-1252

ORNL see Oak Ridge National Laboratory oroclines

California, deformation OP-972

Nevada, structural geology OF 91-0623

Orocopia Mountains

structural geology OP-803

orogenesis see orogeny

orogenic beits see also oroclines.

Arizona, structural geology OP-1957

Basin and Range Province, structural geology OP-19

Califomia, structural geology OP-1957

Colorado Plateau, structural geology OP-19

Nevada, structural geology B 2011

tectonics OP-1520

Utah, structural geology B 2011

orogeny see also Acadian Phase; Alleghany Orogeny; Antler Orogeny; Appalachian Phase; Cordilleran Orogeny; Grenvillian Orogeny; Hercynian Orogeny; Laramide Orogeny; New England Orogeny; Pan-African Orogeny; Penokean Orogeny; Taconic Orogeny; transpression.

Alaska

petroleum OP-492

sedimentary petrology OP-1553

Antarctic Ocean OP-1395

California

OP-1566

geochemistry OP-512

Canada, stratigraphy OP-402

Canadian Shield, crust OP-1316

Mesozoic OP-1494

Pennsylvanian OP-1233

Washington, stratigraphy OP-1480

Orogrande Basin

natural gas OF 93-0248

Oronto Group B 1989-E

Oroville earthquake 1975

California P 1550-C

Ortega Group OP-11

orthogneiss

Alaska

folds OP-1427

geochemistry OP-721

Canadian Shield, crust OP-1316

Idaho OP-630

Northwest Territories, geochemistry OP-721

orthopyroxene see also enstatite. OP-770

orthosilicates see also nesosilicates; sorosilicates. OP-1810

Oruro Bolivia

metal ores B 2039; OP-202

Oruro Deposit

metal ores OP-1306

os see eskers

Os see osmium

Os-187/Os-186

China, geochemistry OF 92-0525

Colorado, molybdenum ores OP-1913

geochemistry OP-1621

petrology OP-1727; OP-1977

Yukon Territory, geochemistry OF 92-0525

Os/Re see $\operatorname{Re} / O s$

Osagian OP-1245

Osamu Utsumi Mine

ground water OP-737 


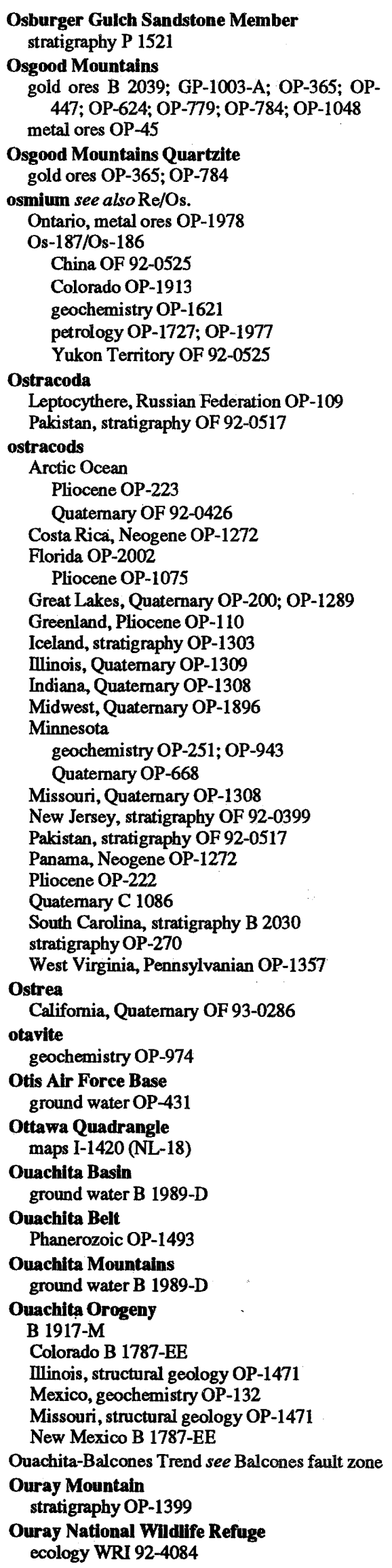

Outer Banks

geologic hazards P 1177-B

outgassing see degassing

outwash

Massachusetts, ground water OP-431

Quaternary OP-201

Oval Peak Pluton

petrology OP-1463

Ovda Reglo OP-1724; OP-1725

overthrust faults

OP-753

Alaska, metal ores OP-224

Califomia, plate tectonics OP-759

overturned folds

Michigan B 1904-L

Owens Valley

economic geology OP-204

geomorphology OP-1339

Quaternary OF 93-0232

Owl Creek basin

hydrogeology WRI 91-4108

\section{Oxfordian}

California OP-385

oxides see also anatase; baddeleyite; brucite; cassiterite; ferrihydrite; gibbsite; hausmannite; hematite; ilmenite; iron oxides; magnetite; manganese oxides; niobates; perovskite; rutile; spinel; tantalates; uraninite.

Appalachians, stratigraphy OP-1380

California

OP-849

geochemistry B 1995-C

Colorado, molybdenum ores OP-1913

metal ores OP-1117

Oxnard Aquifer

ground water OP-961

Oxnard California

ground water OF 93-0524

pollution $\mathrm{OP}-473$

Oxnard Plain

ground water OF 93-0524

pollution OP-473

oxygen

Arizona, geochemistry OF 92-0599

California, hydrology WRI 92-4172

energy sources OP-1822

fluid inclusions OP-1773

Hawaii, geochemistry OP-348

Indiana, environmental geology W 2393

New Jersey, pollution OP-1383

North Carolina, hydrogeology OF 93-0069

O-18

California OP-890; OP-997

Florida C 1086

Illinois OP-1782

Kentucky OP-1782

O-18/0-16

Alaska OP-330; OP-1225

Antarctic Ocean OP-1145; OP-1535

Bahamas OP-706

Barbados OP-706

Bermuda OP-706

Brazil OP-737

Califomia OF 92-0655; OP-267; OP-332; OP-473; OP-1141; OP-1148

Colorado OP-490; OP-872; OP-1151

East Pacific Ocean Islands OP-925

energy sources OF 92-0391

Florida OP-706; OP-1930

Galapagos Islands OP-925

geochemistry OF 92-0009; OP-953
Greenland C 1086

Haiti OP-706

Iceland OP-511

Idaho OP-697

Indiana OP-1648

Maryland OP-1824

metal ores OP-1117

Mexico OP-706; OP-872

Michigan OP-1747; OP-2019

mineralogy OP-1922

Minnesota C 1086; OP-251

Missouri OP-1327

Montana OP-637; OP-978

Nevada C 1086; OP-313; OP-441; OP-643. OP-916; OP-1302

New Mexico OP-490; OP-1072

Nova Scotia OF 92-0525

Ohio OP-1648

Ontario OP-1942

Oregon OP-1141

Pacific Ocean OP-419; OP-1127

Peru OP-872

Russian Federation OP-1874

Saudi Arabia OP-1559

Sweden OP-552

Texas OP-1072

Utah OP-872

Washington OP-998

Wyoming OP-637; OP-697; OP-711; OP978

phase equilibria OP-1726

Polynesia, geochronology OP-1436

Oxyspira

Invertebrata OP-86

Oyster River basin

ground water OF 92-0095

Ozan Formation

Invertebrata OP-178

Ozark Aquifer

ground water OP-1191

Pennsylvanian OP-1192

Ozark Mountains

Carboniferous OP-1231

deformation OP-1861

fluvial features OP-1700

geomorphology OP-1544

ground water B 1989-D

Invertebrata OP-360

maps I-1420 (NJ-15)

metal ores OP-1035; OP-1117

Pennsylvanian OP-1192; OP-1518

petrology OP-1116

Ozark Plateau Quadrangle

maps I-1420 (NJ-15)

Ozarks see Ozark Mountains

Ozette Lake Quadrangle

maps I-1946

$\mathbf{P}$

P see phosphorus

P-waves see also PcP-waves.

OP-1019; OP-1033; OP-1364

Alaska OP-1

Armenia OF 93-0216

Atlantic Ocean, tectonophysics OP-1080

Califomia OP-71; OP-698; OP-964; OP-1183; OP1280 structural geology OP-569

tectonophysics OP-1157 
Celebes Sea, geophysical surveys OP-585

China, core OP-1031

geophysical surveys OF 92-0561

Hawaii OP-116

hydrology OF 92-0534

Maine, crust OP-1920

Mexico, plate tectonics OP-670

Pacific Ocean, tectonophysics OP-1080

Pacific region, mantle OP-1020

Papua New Guinea, magmas OP-1729

Philippine Islands

OP-1998

magmas OP-1729

Quebec, crust OP-1920

South Australia, Quaternary B 2032-B

Tonga, tectonophysics OP-1969

West Pacific Ocean Islands OP-501

\section{PACE}

geophysical surveys YR

Pachydiscidae

Invertebrata P 1533

Pacific Basin

energy sources OP-1624

petroleum OP-1829

Pacific Coast

earthquakes OP-1259

energy sources B 2034-A; OF 92-0524; OP1946

geophysical surveys OF 92-0714

hydrology C 1086

metamorphism OP-1165

petroleum B 2034-A

petrology OP-1271

plate tectonics OP-1519

Quaternary C 1086; OP-647; OP-1999

sedimentation OP-1098

seismology OP-541

soils OP-1065; OP-1713

Pacific Ocean see also DSDP Site 32; DSDP Site

580; El Nino; Fiji; Hawaii; Leg 129; Leg 134;

Mariana Islands; North American Pacific; ODP

Site 800; ODP Site 801; ODP Site 802; Pacific

Plate; Tonga; Vanuatu; West Pacific.

bibliography OF 92-0596

continental margin B 2002; I-2090-A; I-2090B; I-2090-C

continental shelf

B 2002

Monterey Canyon OP-1443

continental slope, Gulf of Alaska B 2002

core OP-1032

Cretaceous OP-1894

deformation, Aleutian Ridge OP-211

earthquakes

OF 93-0219; OP-734

Juan de Fuca Plate OP-720

Mendocino fracture zone OP-1762

energy sources

OF 92-0383; OP-731

Circum-Pacific region OP-1614

Pacific Basin OP-1624

engineering geology

OP-1641

Gulf of Alaska B 2002

Santa Barbara Basin B 2002

geochemistry

OF 91-0014; OP-419; OP-519; OP-628;

OP-755; OP-925; OP-1331

Juan de Fuca Ridge OP-1127

Loihi Seamount OP-446

Santa Barbara Basin OF 92-0539-A; OF $92-$ 0539-C geochronology

Mariana Trough OP-813

South Polynesian Pacific OP-1436

geophysical surveys

Aleutian Trench OF 93-0238

Gulf of Alaska OF 93-0238

Juan de Fuca Plate OF 93-0318

Sulu Sea OP-585; OP-587

hydrology

C 1086

Gulf of Alaska C 1086

Invertebrata, Gulf of Alaska OP-109; OP-1681; OP-1800

mantle OP-1020

marine geology

Gulf of Alaska OF 92-0706

Sulu Sea OP-819; OP-822; OP-823; OP824 ; OP-825

metamorphic rocks, Mendocino fracture zone OP-1166

Miocene, Santa Barbara Basin OF 93-0182; OP-1570

ocean circulation OP-320

oceanography

B 2002; OF 93-0011; OF 93-0298; MF-

2231; MF-2233; OP-751

Hawaiian Ridge B 2002

Monterey Canyon OP-1444

Sulu Sea OP-820

Pennsylvanian, North Australian Seas OP-1356 petroleum

Pacific Basin OP-1829

Santa Barbara Basin OF 92-0539-F

petrology, Circum-Pacific region OP-105

plate tectonics

Chile Ridge OP-586; OP-1651

Cocos Plate OP-670

Galapagos Rift OP-900

Lau Basin OP-413

Mendocino fracture zone OP-145; OP-752; OP-759; OP-1749

Nazca Plate OP-586; OP-900; OP-1651

Peru-Chile Trench OP-586; OP-1651; OP1901

Tonga Trench OP-413

Quaternary

C 1086; OF 93-0340; MF-2212

California Current C 1086

sedimentation

Juan de Fuca Ridge OP-243

Taranaki Basin OP-1391

seismology

OP-1 160

Circum-Pacific region OP-1488

stratigraphy

OP-1330

Santa Barbara Basin OF 92-0539-B; OF 920539-D; OF 92-0539-E; OF 93-0177

structural geology

OP-340

Kula Plate OP-94; OP-1547

tectonophysics

OP-1080

Axial Seamount OP-897

Clarion fracture zone OP-295

Clipperton fracture zone OP-295

Galapagos Rift OP-432

Japan Trench OP-1620

Juan de Fuca Plate OP-1926

Juan de Fuca Ridge OP-897

Mendocino fracture zone OP-1926

Nazca Plate OP-432

Rivera fracture zone OP-1926
Pacific Plate

Alaska

earthquakes OP-1618

geophysical surveys OF 93-0238

California

neotectonics OP-1063

plate tectonics OP-752; OP-759

structural geology OP-1172

tectonophysics OP-2010

Fiii, seismology OP-1758

Pacific Ocean, tectonophysics OP-1926

Tonga, seismology OP-1758

Vanuatu, tectonophysics OP-1908

Pacific region see also Pacific Ocean. metal ores OF 93-0339

stratigraphy OP-402

Pacific to Arizona Crustal Experiment geophysical surveys YR

packers

Arizona, hydrology OF 93-0071

Colorado

ground water OF 93-0071

rock mechanics OF 93-0071

geophysical surveys OF 93-0071

ground water OF 93-0071

Michigan, ground water OF 93-0071

Ontario, geophysical surveys OF 93-0071

packstone

Idaho, stratigraphy OP-1320

Paducah Quadrangle

non-metal deposits OF 92-0514

pahoehoe

Hawaii OF 93-0342-A; OF 93-0342-B

Pahranagat Valley geochemistry OP-774; OP-1775

Pahroc Summit Pass Quadrangle maps OF 92-0613

PAHs environmental geology OF 92-0153

Pahute Mesa maps OF 93-0299

Paintbrush Fault geophysical surveys OF 92-0343

Paintbrush Tuff

OP-863

economic geology OP-736 geophysical surveys OF 92-0028

Paiute Mesa see Pahute Mesa

Pajarito Fault hydrogeology OP-1299

Pajaro Valley seismicity P 1550-C

Pakistan see also Indian Plate. coal, Sind Pakistan OF 92-0281; OF 93-0255; OF 93-0256; OP-996 gems OP-1869

lignite, Sind Pakistan OF 92-0576

stratigraphy, Sind Pakistan OF 92-0517

tectonics, Swat Pakistan OP-1637

tectonophysics, Baluchistan Pakistan OP-1548

Palaeothentes

Vertebrata OP-97

palagonite

Iceland, geochemistry OP-511

Palau see Belau

paleo-oceanography see also sea-floor spreading. OF 92-0414; OF 92-0418; OP-270; OP-798; OP-1233; OP-1949

Alaska, Quaternary C 1086; OP-515; OP-1225 
Antarctic Ocean OP-1535

Quatemary OP-1307

Arctic Ocean

OP-223

Quaternary C 1086; OP-799; OP-1796

Atlantic Coastal Plain, paleontology OP-1205

Atlantic Ocean C 1086; OF 92-0413; OP-271

California

OP-385

Quaternary C 1086

Canada OF 93-0184

East Pacific Ocean Islands, geochemistry OP925

Europe OP-1193

Florida, Quaternary OP-1930

Galapagos Islands, geochemistry OP-925

geochemistry C 1086

Gulf Coastal Plain, paleontology OP-1205

Nevada, Quatemary C 1086

Pacific Coast, Quaternary C 1086

Pacific Ocean

geochemistry OP-419

Quaternary C 1086

United States OF 93-0184

paleoatmosphere

Dominican Republic OP-1625

geochronology OP-134

Greenland, Quaternary C 1086

Quatemary OP-980

paleobiogeography see biogeography

paleobotany see algae; angiosperms; bacteria; gymnosperms; lichens; palynomorphs; Plantae; Protista

Paleocene see also Fort Union Formation; Hanna Formation; Laramide Orogeny.

OP-753

Alaska OP-1396; OP-1401

Atlantic Coastal Plain OP-1205

Chile OP-2005

Colorado OP-1633

Danian

Alaska OP-1680

Northwest Territories OP-1680

Florida OP-494

Georgia OP-291

Gulf Coastal Plain OP-1205

K-T boundary

OP-1177; OP-1180; OP-1702

Atlantic Coastal Plain OP-2009

Colorado OP-1388; OP-1804; OP-1880

Germany B 2050

Gulf Coastal Plain OP-2009

Haiti B 2065; OP-1179; OP-1181; OP-1414; OP-1873

India OP-1346

Iowa B 2050; OP-1114; OP-1537; OP-1613; OP-1882; OP-1915

Ivory Coast OP-1181

Mexico B 2050; OP-920; OP-1179; OP1414

Montana B 2065; OP-1744; OP-1745

New Mexico OP-1388; OP-1880

North Dakota OP-1550

North Sea OP-1359

Rocky Mountains OP-1792

Western Interior OP-794; OP-1182; OP1792

Wyoming OP-1181; OP-1744; OP-1745

Ludlow Member OP-1550

Pakistan OF 92-0281; OF 93-0255; OF 930256
South Carolina OP-291

Tongue River Member

geochemistry OP-1305

sedimentary petrology OP-228

Tullock Member

OP-1744

diagenesis OP-395

sedimentary petrology B 1917-L

paleoclimatology see also $\mathrm{C}-13 / \mathrm{C}-12$; glaciation;

isotopes; Milankovitch theory; O-18/0-16.

P 1506-F; B 1808-O; C 1086; OP-222; OP-270;

OP-509; OP-798; OP-1115; OP-1232; OP-1233;

OP-1345; OP-1934; OP-1949; OP-1982

Alaska

C 1086

palynomorphs OP-1101

Quatemary C 1086

Appalachians OP-1380

Arctic Ocean

OP-223

Quaternary C 1086; OP-799; OP-1796

Arkansas, Quaternary OF 93-0273; OP-1683

Atlantic Coastal Plain, paleontology OP-1205

Atlantic Ocean C 1086

Basin and Range Province, Quaternary C 1086; OP-910; OP-1156

California

OF $92-0588$

Quaternary C 1086; OF 93-0232; OF 93 0311; OF 93-0340

ecology C 1086

Florida

OP-1075; OP-2002

oceanography OP-1510

Quatemary C 1086

geochronology OP-134

geomorphology C 1086

Great Basin, Quaternary C 1086; OP-1156

Great Lakes, Quaternary OP-1288

Great Plains, Quaternary C 1086

Greenland OP-110

ground water B 1989-D

Gulf Coastal Plain, paleontology OP-1205

heat flow OP-176

Iceland OP-1303

Idaho OF 92-0713

Illinois, Quaternary OP-1309

Indiana, Quaternary OP-1308

Indonesia, Quaternary OP-1743

Minnesota

geochemistry OP-248

paleobotany OP-101

Quaternary C 1086; OP-21; OP-99; OP-100; OP-668

sedimentary petrology OP-739

Missouri, Quaternary OP-1308

Montana OP-1744

Nevada

geochemistry OP-76

Quaternary C 1086; OP-1070

New Jersey, sedimentary petrology OP-1379

non-metal deposits OF 92-0593

Ohio OP-1603

Oregon, Quatemary B 2038; OF 93-0212

Pacific Coast, Quaternary C 1086

Pacific Ocean

OF 92-0712; OP-54; OP-1356

Quaternary C 1086

Quaternary C 1086; OP-980; OP-1989; OP2011

Rocky Mountains

OP-1103
Quaternary OP-910

Russian Federation

C 1086; OP-198; OP-2003

Quaternary C 1086; OP-1334; OP-1492; OP-1604; OP-1763; OP-1764

Tennessee, Quaternary OF 93-0273; OP-1683

Virginia

B 2029

geochemistry OP-1774

Washington

Plantae OP-1083

Quaternary OF 93-0212

Western Australia, geochemistry OP-1774

Western Interior OP-1231

Wyoming

P 1506-D; OP-1744

Quatemary OF 92-0504

Yukon Territory C 1086

paleoearthquakes see paleoseismicity

paleoecology see also biogeography; changes of

level; reefs.

OP-1144; OP-1983

Alaska

C 1086

Quatemary OP-299; OP-391

Atlantic Coastal Plain OF 92-0262

California

OF 93-0180

Quaternary C 1086; OF 93-0340

geochronology OP-134

Greenland

OP-110

Quaternary B 2036

Idaho OF 92-0713

Minnesota, Quaternary C 1086

Montana

OP-1744

sedimentary petrology B 1917-L

Northwest Territories, Quaternary B 2036

Quaternary C 1086

Russian Federation, Quatemary B 2036

South Carolina B 2030

Tennessee, Quaternary OF 93-0273

Washington, Quaternary OF 93-0289

Wisconsin, Quaternary OP-391

Wyoming

OP-98; OP-1744

Quaternary OF 92-0504

sedimentary petrology B 1917-L

Yukon Territory C 1086

Paleogene see also Eocene; Oligocene; Paleocene.

OF 92-0525

Alaska I-2164; OP-94; OP-1800

Atlantic Coastal Plain OP-351; OP-757

Califomia B 2034-A; OP-1800

Canada OP-1082

Celebes Sea OP-823

Colorado B 1787-Q

Gulf Coastal Plain OP-351

Hanna Formation, natural gas OF 92-0524

Mexico OP-1800

Montana B 1993

Nevada B 2039

Orca Group, geochemistry OP-1410

Sespe Formation, energy sources OP-1255

Tyonek Formation, energy sources OP-626

United States OP-1082

Utah B 1787-Q

Wasatch Formation

P 1506-D; P 1506-F

impact statements WRI 90-4154 
maps C-0142

natural gas OF 93-0248

sedimentary rocks B 1787-DD

structural geology B 1787-HH

Washington OP-1552

paleogeographic maps

Wyoming P 1532

paleogeography see also basins; biogeography;

changes of level; transgression.

P 1506-F; OP-1345

Alaska

OP-1168; OP-1680

natural gas OP-74

Quaternary OP-33

sedimentary petrology OP-1553

tectonophysics OP-1430

Appalachians OP-1484

California

OF 92-0539-B; OP-385; OP-469

deformation OP-972

Quaternary OF 93-0311; OP-831; OP-1843

structural geology OP-649; OP-936

Canada OP-708

Colorado B 1787-Q; OP-1523

ground water B 1989-D

Gulf Coastal Plain OP-838

Iceland OP-1303

Indiana, Quaternary OP-1308

Kentucky

OF 92-0558

sedimentary petrology OF 92-0558

Missouri, Quaternary OP-1308

Nevada, Quaternary OP-831

Northwest Territories OP-1680

Peru, Quaternary OP-855

plate tectonics OP-124

United States OP-708

Utah

B 1787-Q; OP-1523

sedimentary structures OF 93-0270

Virginia B 2029

Washington

OF 92-0581

geomorphology OP-1552

paleokarst

Arizona, sulfides OP-1993

Arkansas, ground water OP-1191

Hungary, energy sources OP-1687

Missouri, ground water OP-1191

Texas OP-1703

paleolatitude

Alaska

OP-1169

structural geology OP-94

California OP-385

Pacific Ocean OP-747

paleolimnology

OP-1934

Basin and Range Province, Quatemary C 1086

California, Quaternary C 1086

Colorado B 1787-Q

Great Basin, Quatemary C 1086

Great Lakes, Quaternary OP-200

Minnesota

paleobotany OP-101

Quaternary C 1086; OP-100

sedimentary petrology OP-739

Nevada

geochemistry OP-76

Quaternary OP-69

Quatemary C 1086
Russian Federation

C 1086

geochemistry OP-1605

Quaternary C. 1086; OP-1208; OP-1334; OP-1492; OP-1532; OP-1604; OP-1763; OP-1764; OP-1874; OP-1904; OP-2004 structural geology OP-1597

Utah B 1787-Q

paleomagnetism see also Brunhes Epoch; chemical remanent magnetization; Jaramillo Event; magnetic anomalies; magnetic declination; magneticfield; magnetic inclination; magnetic intensity; magnetic susceptibility; magnetostratigraphy; Matuyama Epoch; natural remanent magnetization; paleolatitude; pole positions; remanent magnetization; sea-floor spreading; thermoremanent magnetization.

Arctic Ocean, Quatemary OP-1796

Arkansas, Quaternary OF 93-0273

Atlantic Ocean, marine geology OP-822

California

geophysical surveys OP-1555

structural geology OP-1547

Celebes Sea

marine geology OP-823

oceanography OP-821

Chile, Quaternary OP-279

China OP-1361

Great Lakes, Quatemary OP-1288

Hawaii OP-436

Idaho OF 92-0542

Iowa OP-1915

Mexico

geochronology OP-920

structural geology OP-1547

Minnesota, geochronology OP-758

Oregon

Quaternary OP-1404

structural geology OP-1547

Pacific Ocean

geochemistry OP-510

marine geology OP-819; OP-822

oceanography OP-820

Tennessee, Quaternary OF 93-0273

Vanuatu, sedimentation OP-188

paleontology see also Brachiopoda; Conodonta;

foraminifera; Ostracoda; Protista; Trilobita.

B 2024

paleosalinity

Canada, metal ores OP-728

Colorado, economic geology OP-872

economic geology OP-57

Idaho, geochemistry OP-912

Mexico, economic geology OP-872

Missouri

lead-zinc deposits OP-575

metal ores OP-1885

Oregon, petrology B 2054

Peru, economic geology OP-872

Poland, metal ores OF 92-0704

Saudi Arabia, tin ores OP-1558

United States, metal ores OP-728

Utah, economic geology OP-872

paleoseismicity

Califomia

geologic hazards OP-969

Quaternary OP-338; OP-1833

Dominican Republic, plate tectonics OP-808

Illinois, Quaternary P 1536

Indiana, Quaternary P 1536

Italy, Quaternary OP-764

Kentucky, Quaternary OP-486
Mississippi Valley, structural geology OP-358

Northern Territory Australia, Quaternary B 2032-A

South Australia, Quaternary B 2032-B

Tennessee, Quaternary MF-2218; OP-486

Utah

earthquakes OP-905

Quaternary OP-52

structural geology OP-773; OP-909

Washington

engineering geology OF 91-0441-T

Quatemary OP-36; OP-120; OP-904

\section{Paleosols}

Alaska, Quaternary C 1086; OP-390

Appalachians, stratigraphy OP-1380

Arkansas, Quatemary OF 93-0273; OP-1683

Carboniferous OP-1232

Colorado, Quatemary OP-1676

Gulf Coastal Plain, stratigraphy OP-1817

Italy, Quaternary OP-764

Pennsylvanian OP-1233

Quatemary OP-396

stratigraphy OP-1345

Tennessee, Quaternary OF 93-0273; OP-1683

West Virginia, Pennsylvanian OP-1357

Wyoming

sediments OP-556

stratigraphy OP-98

Palenzoic see also Cambrian; Carboniferous;

Devonian; New England Orogeny; Ordovician;

Permian; Silurian.

OP-1628

Alabama OP-968

Alaska OP-721; OP-1168

Antarctic Ocean OP-1395; OP-1446

Antler Orogeny

B 1917-M

Nevada B 1988-F; B 1988-G; OP-999; OP1846

Antrim Shale

B 1909

hydrogeology OP-1228

Bakken Formation, petroleum B 1909

Basin and Range Province OF 93-0248; OP208

Bedford Shale

B 1909

hydrogeology OP-1228

Berea Sandstone

B 1909

energy sources OP-1751

frost action OP-389

California OP-972

Casco Bay Group OP-1530

Chattanooga Shale

B 1909

geochemistry OP-584; OP-1649

China OP-1238

Colorado OF 93-0183

Commonwealth of Independent States OP-1265

Connecticut OP-1188

Endicott Group, energy sources B 2034-A

England OP-158

Europe OP-1265

Georgia OP-968

Great Basin OP-208

Hanson Creek Formation, gold ores OP-441

Hungary OP-1687

Knox Group, natural gas B 1839-I,J

Lisburne Group, energy sources B 2034-A

Maryland OP-1152

Massachusetts OP-1188 
Merrimack Group OP-1530

Mexico OP-56

Minnelusa Formation

energy sources OF 93-0337; OP-889; OP1260

natural gas OP-449

sedimentary petrology OP-1791

Minnesota OF 92-0514

Mississippi WRI 92-4080

Mississippi Valley OF 92-0685

Montana B 1993

Nevada B 1988-D; OF 92-0681; OP-627; OP779

Northwest Territories OP-721

Nova Scotia OP-1122

Oquirrh Formation OP-1320

Oregon OP-87

Ouachita Orogeny

B 1917-M

Colorado B 1787-EE

IIlinois OP-1471

Mexico OP-132

Missouri OP-1471

New Mexico B 1787-EE

Pacific Ocean OP-1901

Pilot Shale

B 1988-G; OP-1846

sedimentary petrology OP-1795

Poland OP-1916

Shawangunk Formation B 1839-L

Taconic Orogeny

Appalachians B 2039

Pennsylvania B 1994

Vermont OF 92-0282-A

Tensleep Sandstone, hydrogeology WRI 914044

Virginia OP-1152; OP-1612

Washington OP-1480

Wells Formation OP-1320

Woodford Shale, energy sources OP-1753

palladium

Idaho, gold ores B 2039

palladium ores

Montana OF 93-0207

Palm Springs Formation

Quaternary OP-1843; OP-1844

Palm Springs Quadrangle geophysical surveys OF 92-0549

Palmer Peninsula see Antarctic Peninsula

Palmer Quadrangle structural geology I-2355

Palo Alto California environmental geology OF 92-0456

Palo Alto Quadrangle Eocene OF 93-0180 maps OF 93-0271

Palo Duro Basin energy sources OF 93-0522

Palo Duro Canyon chromite ores OP-1229

Paloma Field geochemistry OP-1578

paludal sedimentation

Colorado OP-850

Montana B 1917-L

Tennessee, hydrogeology OP-462

Wyoming B 1917-L

palynology

paleobotany OF 92-0564 palynomorphs see also pollen.

Alaska

OP-1101

Quaternary OP-299

Califomia, Quaternary OP-878

Canada B 1909

Colorado OF 92-0391; OP-1388

dinoflagellates

OP-293

Atlantic Ocean OP-292

California OF 92-0539-E

Georgia OP-291

Pacific Ocean OF 92-0712

South Carolina OP-291

Idaho OF 92-0713

Illinois, Quaternary OP-1309

miospores

OP-222

Atlantic Coastal Plain OF 92-0262; OF 92 0263; OP-950

Florida OP-1075

Tennessee OF 93-0273

Virginia OP-1660

Montana

OP-1745

sedimentary petrology B 1917-L

New Mexico OP-1388

North Carolina OP-597

North Dakota OP-1550

Ohio OP-1603

Quaternary C 1086

Rocky Mountains, natural gas OF 92-0524

United States B 1909

West Virginia, sedimentary petrology OP-778

Wyoming

OP-1745

Quaternary OF 92-0504

sedimentary petrology B 1917-L

Pamlico River

oceanography OP-1131

Pan-African Orogeny

Saudi Arabia, orogeny OP-1921

Yemen, orogeny OP-1921

\section{Panama}

Neogene OP-1272

structural geology OP-785

weathering C 1086

Panama Canal Zone

geologic hazards OP-1862

Panamint Valley

Quaternary OF 93-0232

Pancake Range

stratigraphy OP-1846

Pangaea

Canada, stratigraphy OP-708

Poland, structural geology OP-967; OP-1916 stratigraphy B 1808-O

United States, stratigraphy OP-708

Panizos Caldera

economic geology YR

Pannonian Basin energy sources OP-1263; OP-1687

Panola Mountain geochemistry OP-917

hydrogeology OP-918

hydrology C 1086; OF 93-0055; OP-1515; OP1875

Papua New Guinea

economic geology OP-639

gold ores, Bismarck Archipelago B 2039

magmas, Rabaul Caldera OP-1729 marine geology, Bougainville OP-192

petroleum OP-307

Paradise Peak Deposit

metal ores OP-489

Paradox Basin

diagenesis OP-1465

energy sources OF 93-0248

geochemistry OP-1965

natural gas OP-1262

petroleum OF 92-0391

sedimentary petrology B 2000-E

stratigraphy OF 92-0689; OP-1399; OP-1523

Paradox Member

OF 92-0689; OP-1523

diagenesis OP-1961

geochemistry OP-1965

hydrogeology W 2340; OP-1736

paragenesis

Antarctica, mineralogy OP-275

Arizona, metal ores OP-290

China, metal ores OP-1238

Colorado, metal ores P 1537; OF 92-0525

Missouri, metal ores B 2039; OP-1885

Poland, metal ores OF 92-0704

paragneiss

New York, structural geology OP-461

Vermont, structural geology OP-461

Washington I-1963

Paragonah Quadrangle

maps GQ-1713

paralic environment

Utah, sedimentary petrology OP-1779

Wyoming, sedimentary petrology B 2051

parallel faults

California OP-405

pargasite

petrology OP-393

Paricutin

geologic hazards OF 93-0197-A; OF 93-0197B

Parkfield California

earthquakes OP-881; OP-1025; OP-1498

seismology OP-868; OP-1872

structural geology OP-936

Parkfield earthquake 1934

elastic waves OP-913

seismology OP-1872

Parkfield earthquake 1966

California OP-913; OP-1872

Parkfield earthquakes

Califomia EV; OP-286; OP-302

Turkey EV

Parkman Sandstone B 1917-O

Parowan Gap Quadrangle maps GQ-1712

Parowan Quadrangle maps OF 93-0003

Parterze Glacier Quaternary OP-386

Pasadena earthquake 1989 earthquakes OP-503

Pasco Basin ground water WRI 93-4060

Pascola Arch

ground water OP-1191 structural geology OP:1471

Pashiy Formation energy sources OP-1258

Passaic Formation energy sources OP-1842 
ground water OP-986

Passaic River geologic hazards OP-899

Passaic River basin ground water WRI 90-4151

passive margins

Alaska, tectonophysics OP-1430

Appalachians, zinc ores B 2039

Atlantic Ocean, continental margin B 2002

Basin and Range Province, natural gas OP-208

China, metal ores OP-1432

Costa Rica, Neogene OP-1272

Great Basin, natural gas OP-208

metal ores $\mathrm{OP}-465$

Panama, Neogene OP-1272

tectonophysics OP-463

Yukon Territory, metal ores OP-1432

Patagonia

Vertebrata OP-97

Patapsco Aquifer

ground water OF 92-0461; OF 92-0462

Paterson Quadrangle geochemistry OF 93-0010

Patrick Draw Field petroleum OP-1635

Patterson Quadrangle maps OF 93-0223

Patton Escarpment structural geology OP-1172

Pavillon Quadrangle Quaternary OF 92-0391 structural geology OP-1539

Payette National Forest gold ores OF 93-0527

$\mathrm{Pb}$ see lead

$\mathrm{Pb}-204 / \mathrm{Pb}-208$ see $\mathrm{Pb}-208 / \mathrm{Pb}-204$

$\mathrm{Pb}-206 \mathrm{~Pb}-207$ see $\mathrm{Pb}-207 / \mathrm{Pb}-206$

\section{Pb-206/Pb-204}

OP-806; OP-1805

Alaska, metal ores OP-570

California, geochemistry OP-678

China, geochemistry OP -457

Colorado

Cretaceous OP-11

geochemistry OP-490; OP-1825

metal ores OF 92-0525

molybdenum ores OP-375

England, metal ores OP-1541

geochemistry OF 92-0525; OP-2018

geochronology OF 92-0525

Malaysia, geochemistry OF 92-0525

Montana, geochemistry OP-1087

New Mexico

Cretaceous OP-11

geochemistry OP-490

Nova Scotia, geochemistry OF 92-0525; OP 1122

Proterozoic OF 92-0525

Spain, base metals OP-31

$\mathrm{Pb}-206 / \mathrm{Pb}-207$ see $\mathrm{Pb}-207 / \mathrm{Pb}-206$

$\mathrm{Pb}-207 / \mathrm{Pb}-204$

OP-806; OP-1805

Alaska

geochemistry OP-242

metal ores OP-570

Argentina, copper ores OP-2027

Chile, copper ores OP-2027

Colorado

Cretaceous OP-11

geochemistry OP -490

metal ores OF 92-0525 molybdenum ores OP-375

England, metal ores OP-1541

geochemistry OF 92-0525

Malaysia, geochemistry OF 92-0525

Montana, geochemistry OP-1087; OP-1094

New Mexico

Cretaceous OP-11

geochemistry OP -490

Nova Scotia, geochemistry OF 92-0525; OP1122

Proterozoic OF 92-0525

Spain, base metals OP-31

Pb-207/Pb-206

Colorado, Cretaceous OP-11

New Mexico, Cretaceous OP-11

\section{Pb-208/Pb-204}

Argentina, copper ores OP-2027

Chile, copper ores OP-2027

Colorado

Cretaceous OP-11

geochemistry OP -490

metal ores OF 92-0525

molybdenum ores OP-375

England, metal ores OP-1541

geochemistry OP-2018

geochronology OF 92-0525

Malaysia, geochemistry OF 92-0525

Montana, geochemistry OP-1087

New Mexico

Cretaceous OP-11 geochemistry OP-490

Nova Scotia, geochemistry OP-1122

Proterozoic OF 92-0525

Spain, base metals OP-31

$\mathbf{P b}-210$

Great Lakes, Quaternary OP-1290

$\mathbf{P b} / \mathbf{P b}$

OP-805; OP-806

Arizona, igneous rocks OP-1112

California, igneous rocks OP-1112

Colorado

geochemistry OF 92-0525

Proterozoic OP-10

Idaho, geochronology OP-1067

lead-zinc deposits OP-12

Montana, Archean OP-705

Quebec, gold ores OP-1097

Washington, geochronology OP-1067

Wyoming, geochemistry OF 92-0525

PC-FILES

paleontology OF 93-0513; OF 93-0549

PC.PLOT

earthquakes OF 93-0022

PC-QMAP

seismology OF 92-0597

PC-WATSTORE

hydrology OF 92-0105

PCBs

Hawaii, pollution WRI 92-4168

New Jersey, environmental geology OF 92 0153

Oregon, pollution WRI 92-4136

pollution OP-321; OP-580

PCEQ

earthquakes OF 92-0441

PeP-waves

Alaska, core OP-1032

California, core OP-1032

Canada, core OP-1032

$\mathrm{Pd}$ see palladium
Pea Ridge Deposit

iron ores OP-1297

metal ores B 2039; OP-1327; OP-1885

Peace Valley Formation

structural geology OP-649

Pearl River

hydrogeology OP-1010

Pearl River Aquifer

ground water P 1410-G

Peary Land

Pliocene OP-110

peat

OP-131; OP-228; OP-410; OP-1211; OP-1476;

OP-1477

Alaska, Quatemary OP-299; OP-390

Australia OP-1478

Califormia

Quatemary OP-338

soils OP-1713

Canada, geochemistry OP-1905

Colorado OP-850

Florida, geochemistry OP-1906

geochemistry OP-1292

Indonesia

OP-1478

Plantae OP-695

Quatemary OP-1743

Louisiana OP-653

Montana, geochemistry OP-1305

Ohio OF 92-0514

Puerto Rico OF 92-0391

Rocky Mountains OP-1792

United States, geochemistry OP-1905

Utah OP-1779

Vermont B 1955

West Virginia I-2364-B; OP-778

Western Interior OP-1792

pebbles

Pakistan, tectonophysics OP-1548

Pedernal Uplift

petroleum OF 93-0522

pedogenesis

OP-48; OP-1470

Israel, Quaternary OP-75

Nevada, geochemistry OP-643

United States, Quaternary OP-75

Wyoming, Quaternary OP-1455; OP-1884

Peedee Formation OP-950

Peel Fault

structural geology OP-78

pegmatite

China OP-317

Maine, phosphates OP-115

New South Wales Australia OP-942

Queensland Australia OP-942

Russian Federation, Precambrian OP-1777

South Dakota OF 92-0514

Sweden, mineralogy OP-1445

Tadzhikistan, mineralogy OP-373; OP-1445

Pekin Formation

stratigraphy OP-597

Pelecypoda see Bivalvia

pelecypods see bivalves

Pelew see Belau

Pelham Dome

metamorphic rocks OP-1188

structural geology OP-1079

pelite see shale

pelitic schist see slates 
Pellejas River pollution OP-663

Pena Blanca New Mexico hydrogeology WRI 92-4193

penetration tests see cone penetration tests

Peneus Patera OP-1647

Peninsular Ranges structural geology OP-803; OP-1971

Peninsular Ranges Batholith petrology OP-1461

Peninsular Terrane geochemistry OP-1410 maps I-2164 metamorphic rocks $P$ 1497-C

Penn Yan Shale natural gas B 1909

Pennsylvania see also Appalachian Basin; Delaware River basin; Freeport Formation; Genesee Group; Hamilton Group; Marcellus Shale; Moscow Formation; Oriskany Sandstone; Piedmont; Tully Limestone; Valley and Ridge Province. areal geology

Berks County Pennsylvania B 1994

Carbon County Pennsylvania B 1994

Lehigh County Pennsylvania B 1994

Schuylkill County Pennsylvania B 1994 clay mineralogy

Carbon County Pennsylvania OF 92-0568

Dauphin County Pennsylvania OF 92-0568

Lackawanna County Pennsylvania OF 920568

Lebanon County Pennsylvania OF 92-0568

Luzerne County Pennsylvania OF 92-0568

Monroe County Pennsylvania OF 92-0568

Schuylkill County Pennsylvania OF 920568

Snyder County Pennsylvania OF 92-0568

Sullivan County Pennsylvania OF 92-0568

Wyoming County Pennsylvania OF 920568

coal

Carbon County Pennsylvania OF 92-0568

Dauphin County Pennsylvania OF 92-0568

Lackawanna County Pennsylvania OF 920568

Lebanon County Pennsylvania OF 92-0568

Luzerne County Pennsylvania OF 92-0568

Monroe County Pennsylvania OF 92-0568

Schuylkill County Pennsylvania OF 920568

Snyder County Pennsylvania OF 92-0568

Sullivan County Pennsylvania OF 92-0568

Wyoming County Pennsylvania OF 920568

diagenesis

Carbon County Pennsylvania OF 92-0568

Dauphin County Pennsylvania OF 92-0568

Lackawanna County Pennsylvania OF 920568

Lebanon County Pennsylvania OF 92-0568

Luzeme County Pennsylvania OF 92-0568

Monroe County Pennsylvania OF 92-0568

Schuylkill County Pennsylvania OF 920568

Snyder County Pennsylvania OF 92-0568

Sullivan County Pennsylvania OF 92-0568

Wyoming County Pennsylvania OF 920568

energy sources

Bucks County Pennsylvania OP-1842

Carbon County Pennsylvania OF 92-0568

Dauphin County Pennsylvania OF 92-0568
Lackawanna County Pennsylvania OF 92 0568

Lebanon County Pennsylvania OF 92-0568

Luzerne County Pennsylvania OF 92-0568

Monroe County Pennsylvania OF 92-0568

Schuylkill County Pennsylvania OF 92 0568

Snyder County Pennsylvania OF 92-0568

Sullivan County Pennsylvania OF 92-0568

Wyoming County Pennsylvania OF 92 0568

engineering geology, Philadelphia Pennsylvania OF 92-0391

environmental geology

Carbon County Pennsylvania OF 92-0568

Dauphin County Pennsylvania OF 92-0568

Lackawanna County Pennsylvania OF 92 0568

Lebanon County Pennsylvania OF 92-0568

Luzerne County Pennsylvania OF 92-0568

Monroe County Pennsylvania OF 92-0568

Schuylkill County Pennsylvania OF 92 0568

Snyder County Pennsylvania OF 92-0568

Sullivan County Pennsylvania OF 92-0568

Wyoming County Pennsylvania OF 92 0568

geochemistry, Indiana County Pennsylvania OP-762

geochronology, Carbon County Pennsylvania OF 92-0525

geologic hazards

Chester County Pennsylvania OP-1895

Harrisburg Pennsylvania YR

geomorphology

Carbon County Pennsylvania OF 92-0568

Dauphin County Pennsylvania OF 92-0568

Lackawanna County Pennsylvania OF 92 0568

Lebanon County Pennsylvania OF 92-0568

Luzerne County Pennsylvania OF 92-0568

Monroe County Pennsylvania OF 92-0568

Schuylkill County Pennsylvania OF 920568

Snyder County Pennsylvania OF 92-0568

Sullivan County Pennsylvania OF 92-0568

Wyoming County Pennsylvania OF 920568

ground water

OP-547

Bucks County Pennsylvania WRI 92-4183; WRI 92-4194; OF 93-0027; OF 93-0028

Centre County Pennsylvania OP-111

Chester County Pennsylvania WRI 91-4182

Lancaster County Pennsylvania OP-387

hydrogeology

Clarion County Pennsylvania OF 93-0115

Cumberland County Pennsylvania OF 920165

Lancaster County Pennsylvania WRI 904131

hydrology

W 2400

Centre County Pennsylvania WRI 90-4011

Clearfield County Pennsylvania WRI 904011

Clinton County Pennsylvania WRI 90-4011 Pittsburgh Pennsylvania W 2400

lead-zinc deposits, Blair County Pennsylvania OP-12

maps I-1420 (NK-18)

pollution, Lancaster County Pennsylvania OP388 sedimentary petrology

Carbon County Pennsylvania OF 92-0568

Dauphin County Pennsylvania OF 92-0568

Lackawanna County Pennsylvania OF 92 0568

Lebanon County Pennsylvania OF 92-0568

Luzerne County Pennsylvania OF 92-0568

Monroe County Pennsylvania OF 92-0568

Schuylkill County Pennsylvania OF 92 0568

Snyder County Pennsylvania OF 92-0568

Sullivan County Pennsylvania OF 92-0568

Wyoming County Pennsylvania OF 92 0568

stratigraphy

Bedford County Pennsylvania B 1839-K

Carbon County Pennsylvania OF 92-0568

Dauphin County Pennsylvania OF 92-0568

Lackawanna County Pennsylvania OF 92 0568

Lebanon County Pennsylvania OF 92-0568

Luzeme County Pennsylvania OF 92-0568

Monroe County Pennsylvania OF 92-0568

Schuylkill County Pennsylvania OF 92 0568

Snyder County Pennsylvania OF 92-0568

Somerset County Pennsylvania B 1839-K

Sullivan County Pennsylvania OF 92-0568

Wyoming County Pennsylvania OF 92 0568

structural geology

Carbon County Pennsylvania OF 92-0568

Dauphin County Pennsylvania OF 92-0568

Lackawanna County Pennsylvania OF 920568

Lebanon County Pennsylvania OF 92-0568

Luzerne County Pennsylvania OF 92-0568

Monroe County Pennsylvania OF 92-0568

Schuylkill County Pennsylvania OF 92 0568

Snyder County Pennsylvania OF 92-0568

Sullivan County Pennsylvania OF 92-0568

Wyoming County Pennsylvania OF 92 0568

waste disposal OP-1301

Pennsylvanian see also Tyler Formation.

B 1808-0; OP-1117; OP-1233; OP-1293; OP-

1368; OP-1518; OP-1983

Alaska I-2164

Allegheny Group

OF 92-0558; OF 93-0312; OP-1513

structural geology OP-1147

Arkansas OP-1192

Atoka Formation, sedimentary petrology OP451

Atokan, Texas OF 93-0522

Breathitt Formation OF 92-0558; OF 93-0312; OP-182 sedimentary petrology OF $92-0558$ sedimentation OF 92-0558

Cherokee Group energy sources OP-1476

metal ores MF-1835-H

Colorado OF 93-0248

Conemaugh Group OF 93-0312; OP-1603

Desmoinesian, Texas OF 93-0522

Freeport Formation geochemistry OP-762 sedimentary petrology OP-1234

Hermosa Formation

OP-1399

natural gas OP-1262 
Indiana OP-1466

Kittanning Formation, ground water OP-1454

Madera Formation, hydrogeology OP-1299

Marmaton Group, energy sources OP-1476

Mexico OP-796

Michigan OP-1116

Minturn Formation B 1787-GG

Missouri OP-644; OP-1192

Morrowan

California OP-1791

Colorado OF 93-0337

Texas OF 93-0522

New Mexico OF 93-0522

Ohio OF 92-0558

Pacific Ocean OP-1356

Paradox Member

OF 92-0689; OP-1523

diagenesis OP-1961

geochemistry OP-1965

hydrogeology W 2340; OP-1736

Pittsburgh Coal, geochemistry OP-1769

Pocahontas Formation, hydrogeology WRI 92 4073

Pottsville Group OF 92-0558; OF 92-0568

Rocky Mountains OP-1103

Saginaw Formation, ground water WRI 914133

Texas OF 93-0522

Tradewater Formation, sedimentary petrology OF 92-0391

Utah OF 93-0248

West Virginia OP-778; OP-1357

Westerly Granite, fractures OF 93-0245; OP1721

Penokean Orogeny

Canada, tectonics OP-1215

Michigan, structural geology B 1904-L; B 1904-Q

United States, tectonics OP-1215

Pensacola Mountains

mineralogy OP-275

Peoples Democratic Republic of Yemen see Yemen

Peoria Loess

Quaternary OF 93-0273; OP-1683

perched aquifers

Arizona, ground water OP-1467

Hawaii, hydrogeology WRI 91-4197

Idaho, ground water WRI 92-4027

perennial streams

Hawaii, hydrogeology WRI 92-4099

Peri-Caspian Depression see Caspian Basin

peridotites see also dunite; lherzolite.

California, geochemistry OP-730

Fiji, seismology OP-1758

Saudi Arabia OP-1952

Tonga, seismology OP-1758

periglacial features see also permafrost. OP-509

permafrost see also frost action.

Alaska, Quatemary C 1086; OP-1616

permeability coefficient see hydraulic conductivity

Permian see also Alleghany Orogeny; Minnelusa

Formation.

B 1808-O; OF 93-0513; OP-134; OP-1982; OP1983

Appalachian Phase

Appalachians OP-1479

geochemistry OF 92-0525

Gulf Coastal Plain OP-1817
Maine OP-1920

New York OP-461

Quebec OP-1920

tectonics OP-1517

Vermont OP-461

Bell Canyon Formation OP-354

California OP-977

Cherry Canyon Formation OP-354; OP-1387

Chile OP-2005

Coconino Sandstone, mineral resources OF 920509-A: OF 92-0509-B

Colorado OF 93-0248

Cutler Formation

OP-1399

diagenesis OP-1465

sedimentary petrology B 2000-E

Glorieta Sandstone, ground water WRI 914033

Guadalupian, Texas OP-1575; OP-1622

Italy OF 93-0504

Kaibab Formation, mineral resources OF 920509-A; OF 92-0509-B

Kansas OF 93-0549

Leonardian, Texas OP-1387; OP-1575

New Mexico OF 93-0522

Phosphoria Formation

OP-708

natural gas OF 92-0524; OF 93-0337

petroleum OP-1767

San Andres Formation

geochemistry OP-1072

ground water WRI 91-4033

Seven Rivers Formation, geochemistry OP1072

Texas OF 93-0522; OP-1703

Utah OF 93-0248

Wellington Formation, ground water WRI 92 4177

Yates Formation, geochemistry OP-1072

Permian Basin

energy sources OF 92-0524; OF 93-0522

geochemistry OP-1072

natural gas OP-274

stratigraphy OP-1575

perovskite

geophysics OP-480

Perrysburg Formation

stratigraphy B 1909

Persian Gulf

plate tectonics OP-1519

Quatemary OP-1198

stratigraphy OP-1453

Peru see also Eastern Cordillera.

economic geology OP-872

geochemistry OP-1331

geochronology OP-1601

geologic hazards OP-1369

gold ores OP-82

silver ores OP-1212

stratigraphy OP-1330

Peru Peak Wilderness

economic geology B 1955

Peru-Chile Trench

plate tectonics OP-586; OP-1651; OP-1901

pesticides see also DDT; herbicides.

California, environmental geology OF 93-0083

Delaware, pollution C 1080

environmental geology OP-1411

Florida, pollution W 2402

Idaho, environmental geology OF 92-0156

Maryland, pollution C 1080

Missouri, pollution OF 93-0101
New Jersey, environmental geology OF 92 0153

New York, ground water OF 91-0180

Oklahoma, pollution OP-1251

Oregon, pollution $\mathrm{OP}-471$

pollution OP-321; OP-580

Washington, hydrogeology OF 92-0644

Pete Hanson Creek Quadrangle

maps OF 93-0519

petrified moss see tufa

petrified wood see fossil wood

petrofabrics

California, geochemistry OP-512

petrogeometry see structural analysis

petroleum see also bitumens; crude oil; heavy oil;

kerogen; natural gas; naturally fractured reser-

voirs; oil seeps; petroleum accumulation; petro-

leum assessment; stratigraphic traps; structural traps.

B 1909; OF 92-0391; OP-6; OP-710; OP-1014

OP-1206; OP-1476; OP-1686; OP-1972

Alaska

OF 93-0330; OP-1285

hydrogeology OF 91-0458

California

OF 92-0539-F; OF 92-0571

geochemistry OF 92-0539-A; OP-615

orogeny OP-797

stratigraphy $\mathrm{OP}-469$

Colorado

OF 92-0391; OP-674

geochemistry OP-1965

stratigraphy B 2025

ground water B 1989-D

Gulf of Mexico OP-927

Idaho, orogeny OP-797

Illinois

hydrogeology OP-1782

sedimentary petrology OP-1385

Indiana, sedimentary petrology OP-1385

Iraq, geochemistry OP-615

Kentucky, hydrogeology OP-1782

Michigan

OF 92-0391

geochemistry OP-1204

Montana OF 93-0207

Nevada

OF 92-0391

structural geology OF 92-0391

New Mexico

OP-674

stratigraphy B 2025

Pacific Ocean OP-1829

Papua New Guinea OP-639

pollution OP-1155

stratigraphy B 1839-K; B 1917-M

Utah

OF 92-0391; OP-1635

geochemistry OP-1965

ground water OF 92-0124

hydrogeology OP-1736

Wyoming

OF 92-0391; OP-889; OP-1635

Miocene B 1917-O

petroleum accumulation see also stratigraphic traps; structural traps.

Alaska

OP-492

energy sources OP-626

Arizona

OF 93-0248

natural gas OF 93-0248 
Basin and Range Province energy sources OF 93-0248 natural gas OF 93-0248

Colorado energy sources OF 93-0248 natural gas OF 93-0248

Colorado Plateau, energy sources OF 93-0248 Great Plains, energy sources OF 93-0337

Idaho, natural gas OF 93-0248

natural gas OF. 92-0524

Nevada, natural gas OF 93-0248

New Mexico, natural gas OF 93-0248

Oklahoma OF 92-0391

Pacific Coast, energy sources B 2034-A

Rocky Mountains, energy sources OF 93-0337

Utah

energy sources OF 93-0248

natural gas OF 93-0248

petroleum assessment see also stratigraphic traps; structural traps.

B 2048; OF 93-0012; OP-793; OP-1710

Alaska

DDS-0005; B 2034-A

natural gas YR

Arizona

OF 93-0248

natural gas OF 93-0248

Basin and Range Province

OF 93-0248

energy sources OF 93-0248

natural gas OF 93-0248

California

B 2034-A

energy sources B 2034-A; OF 92-0383

China, plate tectonics OP-1519

Colorado

OF 93-0337; OP-435

coal OP-1911

energy sources OF 93-0248

natural gas OF 93-0248; OP-1262

Colorado Plateau

OF 93-0248

energy sources OF 93-0248

Commonwealth of Independent States OP-1265

energy sources OP-453

Europe OP-1265

Far East, energy sources OP-1624

Great Plains

OF 93-0337

energy sources OF 93-0337

Hungary, energy sources OP-1263; OP-1687

Idaho, natural gas OF 93-0248

Kansas, natural gas OP-725

Montana

OF 93-0337

energy sources $\mathrm{OF}$ 93-0337

natural gas B 1839-I,J; OF 92-0524; OP-1860

Nevada

OF 93-0186

natural gas OF 93-0248

New Mexico

B 2039; OF 93-0337; OF 93-0522; OP-435

energy sources OF $93-0522$

natural gas OF 93-0248

Oregon, natural gas B 2034-A

Pacific Coast

B 2034-A

energy sources B 2034-A

Papua New Guinea OP-307

Rocky Mountains

OF 93-0337

energy sources OF 93-0337
South Dakota, natural gas OF 93-0337

Texas

OF 93-0522

energy sources OF 93-0522

United States, plate tectonics OP-1519

Utah

energy sources OF 93-0248

natural gas OF 93-0248; OP-1262

Washington, natural gas B 2034-A

Wyoming

B 2039

energy sources OF 93-0337

natural gas OF 93-0192

petroleum engineering see natural gas

petroleum maps

natural gas OF 92-0696

Oregon, energy sources OP-731

petroleum products see hydrocarbons

petroleum provinces

Great Plains, energy sources OF 93-0337

New Mexico OF 93-0522

Pacific Coast, energy sources B 2034-A

Rocky Mountains, energy sources OF 93-0337

Texas OF 93-0522

petroleum seepage see oil seeps

petrologen see kerogen

petrology see crystalline rocks; fluid inclusions; igneous rocks; inclusions; intrusions; lava; magmas; metamorphic rocks; metamorphism; metasomatism; meteor craters; phase equilibria; volcanism; volcanology

petromorphology see structural analysis

petrostratigraphy see lithostratigraphy

PGE see platinum group

Phanerozoic see also Paleozoic.

B 1989-D; C 1086; OP-714; OP-1366

Alaska OP-1430

California OP-1340

Colorado OF 93-0343

Russian Federation OP-1493

United States OP-1493

Virginia OF 93-0222

Phantom Lake Suite

stratigraphy $P 1520$

phase equilibria see also carbon dioxide; crystal chemistry; crystal growth; magmas; metamorphism; metasomatism.

OP-595; OP-1013; OP-1248; OP-1311; OP-

1475; OP-1561; OP-1726; OP-1919

California, environmental geology OP-1110

Dominican Republic, metal ores OP-532

geochemistry OP-175; OP-1319; OP-1415

geophysics OP-282; OP-924

Italy OP-851

Maine, metal ores B 2039

mineralogy OP-25; OP-770; OP-789

Mississippi, geochemistry OP-1577

New Mexico, molybdenum ores OP-1243

Pacific Ocean, tectonophysics OP-897

Russian Federation, metal ores OP-1313

sedimentary petrology OP-1689

Victoria Australia OP-1136

phenols

Australia, sedimentary petrology OP-1478

diagenesis OP-1477

Indonesia, sedimentary petrology OP-1478

Philadelphia Creek Quadrangle maps MF-2216

Philadelphia Pennsylvania engineering geology OF 92-0391

\section{Philippine Islands}

earthquakes EV; OP-1998

energy sources OP-1624

geochemistry OP-1994

geologic hazards

OP-726

Luzon WRI 92-4039; OP-781

magmas OP-1729; OP-1768

mantle OP-502

metal ores OP-9

Phlegraean Fields

geologic hazards OP-213

phlogopite

Ontario, petrology OP-214

Phobos see Phobos Satellite

Phobos 2 spacecraft OP-1163

Phobos Satellite OP-1223

phosphate deposits

OP-63; OP-429

Florida, hydrogeology WRI 93-4002

Georgia, oceanography

OP-1502

phosphate rocks

Georgia

OP-1677

oceanography OP-1502

phosphates see also apatite; francolite; goyazite;

monazite; vivianite; xenotime.

Arkansas OP-681

Maine OP-115

Missouri, clay mineralogy OP-522

Montana, geochemistry OP-1305

phosphatization

Pacific Ocean, geochemistry OP-419

Phosphoria Formation

OP-708

natural gas OF 92-0524; OF 93-0337

petroleum OP-1767

phosphorite see phosphate rocks

phosphorus

California, ground water OF 92-0655

Colorado, hydrology WRI 92-4053

geochemistry C 1086

hydrogeology OF $92-0146$

hydrology OF 93-0032

Pacific Ocean, geochemistry OP-419

Pennsylvania, hydrogeology WRI 90-4131; OF 92-0165

soils OF $90-0130$

Wisconsin, hydrology WRI 90-4126

photogeologic maps

Nevada, structural geology OF 91-0623

phreatophytic taxa

hydrogeology OF 92-0083

Nevada, ground water W 2340

PHREEQE

geochemistry OP-355

PHRQPITZ

evaporite deposits OP-2012

geochemistry OP-355

PHRQXL

geochemistry OP-355

phyllites

Washington I-1963

phyllosilicates see sheet silicates

phylogeny see cladistics

phytane

Colorado, energy sources OP-674

Commonwealth of Independent States energy sources OP-1261 


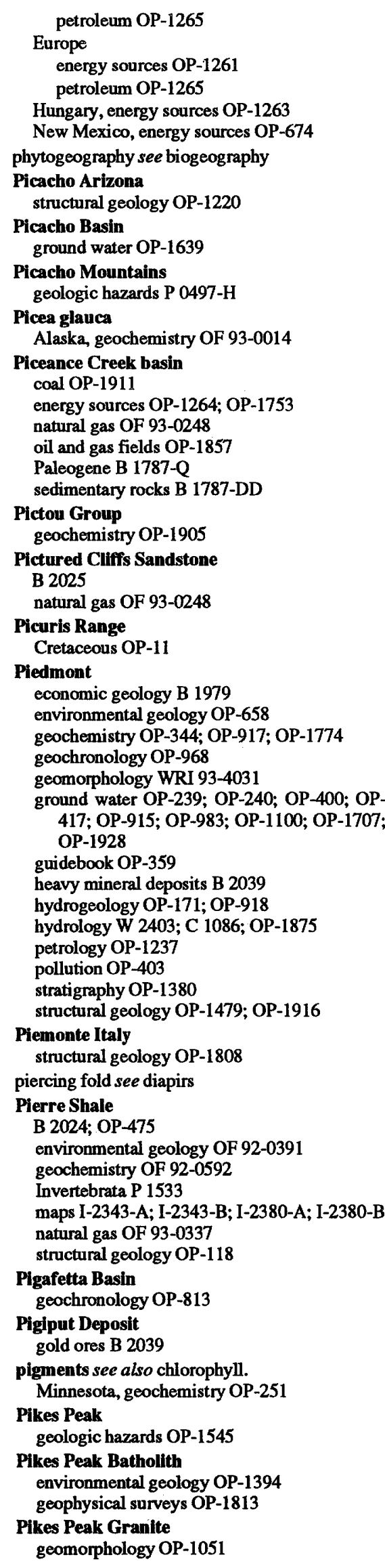

Pikwitonei Granulite

geochronology OP-1709

Pilot Knob Valley

stratigraphy B 2015

Pilot Shale

B 1988-G; OP-1846

sedimentary petrology OP-1795

Pinaceae see Pinus

Pinal Creek

geochemistry OP-590

hydrogeology OF 92-0468

pollution OP-591; OP-592

Pinatubo

earthquakes EV; OP-1998

geochemistry OP-1994

geologic hazards WRI 92-4039; OP-726; OP781

magmas OP-1729; OP-1768

mantle OP-502

Pine Barrens Long İsland ground water WRI 92-4100

Pine Creek Geosyncline metal ores OP-1431

Pine Mountain Window geochronology OP-968 structural geology OP-1918

Pine Ridge Indian Reservation non-metal deposits OF 92-0514

Pinedale Glaciation

Colorado OP-1676

Wyoming OP-1455; OP-1884

Pinkerton Trail Formation stratigraphy OF 92-0689

Pinnacle Overlook Member stratigraphy OP-1368

Pinnacles Volcanics

structural geology OP-936

Pinon Canyon Maneuver Site hydrology WRI 91-4095

Pinson Mine gold ores OP-784

Pinturas Formation Vertebrata OP-97

Pinus

Colorado, Quaternary OF 93-0250

South Carolina, ecology OF 93-0303

Pinware Terrane crust OP-1316

Pioneer Batholith petrology OP-1462

Pioneer Mountains stratigraphy OP-1351

Pipe Creek Shale natural gas B 1909

pipes see breccia pipes

Pismo Formation

Miocene OP-1570

pistacite see epidote

Pit Formation sedimentary petrology OP-1344

pitching folds see plunging folds

Pittshurgh Coal geochemistry OP-1769

Pittsburgh Pennsylvania hydrology W 2400

Piute Mountains geochemistry OP-512 orogeny OP-1566

\author{
Piute Platform \\ stratigraphy OP-1523 \\ PIX \\ petroleum DDS-0005 \\ PKPPKP-waves \\ mantle OP-71 \\ Placenticeratidae \\ stratigraphy OP-177; OP-529
}

placers see also heavy mineral deposits; monazite deposits.

Alaska

gold ores OP-1057

metal ores OF 93-0339; OP-123; OP-1006

gold ores OF 92-0573-A; OF 92-0573-B

metal ores OF 92-0557

Peru, gold ores OP-82

Russian Federation, metal ores OF 93-0339

plagioclase see also albite; anorthite.

OP-661; OP-1392

Alaska, geochronology OF 92-0701

California, soils OP-1170

Montana, geochemistry OP-1087; OP-1663

Oregon, geochemistry OP-43

petrology OP-393

stratigraphy OP-1702

plagioclasite see anorthosite

planar bedding structures see also bedding; cross-bedding; cross-stratification; cyclothems; imbrication; laminations; thythmite; sand bodies; varves.

California, stratigraphy OP-469

New Hampshire

ground water WRI 90-4161; WRI 91-4025; OF 92-0095

hydrogeology OF 89-0583

New York, ground water WRI 91-4030

planetary interiors OP-28; OP-29

planetology see also icy satellites. OF 91-0014

Plantae see also bryophytes; pteridophytes; Spermatophyta; thallophytes.

Indonesia OP-695

Washington OP-1083

plants see also algal flora; angiosperm flora; ferns; gymnosperm flora.

Alaska, geochemistry OF 93-0014

Florida, geochemistry OP-1906

geochemistry OF 92-0345; OP-1292

Montana, sedimentary petrology B 1917-L

North Carolina, economic geology B 2039

Pennsylvania, stratigraphy OF 92-0568

Quaternary C 1086

South Carolina, ecology OF 93-0303

Tennessee, Quaternary OF 93-0273

Washington, Quaternary OP-1999

Wyoming

Quaternary OF 92-0504

sedimentary petrology B 1917-L

plaster stone see gypsum

plate boundaries see also active margins; passive margins; plate convergence; plate divergence.

Alaska, neotectonics OP-1852

Bering Sea, plate tectonics OP-1859

California

plate tectonics OP-752

structural geology OP-1172

tectonophysics OP-1733

Dominican Republic, plate tectonics OP-808

Japan, neotectonics OP-1852

Mexico, plate tectonics OP-670

Oregon, earthquakes OP-1120 
Pacific Ocean

earthquakes OP-734

plate tectonics OP-900

tectonophysics OP-1926

Papua New Guinea, petroleum OP-307

Rocky Mountains, natural gas OP-1350

Spain, geologic hazards OP-1372

tectonophysics OP-2031

Vanuatu

plate tectonics OP-197

tectonophysics OP-1908

Washington, earthquakes OP-1120

plate collision

Appalachians, structural geology OP-1479

Bangladesh, geologic hazards OF 92-0391

California, structural geology OP-1413

Mexico, geochemistry OP-132

Michigan, structural geology B 1904-Q; B 1904-S; I-2355

Minnesota, structural geology B 1904-S

Pakistan

natural gas OP-1634

tectonophysics OP-1548

Vanuatu

marine geology OP-191

ocean floors OP-368

plate tectonics OP-185; OP-197; OP-1286; OP-1287

tectonophysics OP-1908

Wyoming, structural geology OP-149

plate convergence

Alaska, petroleum OP-492

Appalachians, zinc ores B 2039

California, structural geology OP-78; OP-340; OP-1547

Central America, seismology OP-1066

Chile, plate tectonics OP-586

China, plate tectonics OP-1519

Japan, tectonophysics OP- 1620

Mexico, structural geology OP-1547

New South Wales Australia, structural geology OP-78

Oregon, structural geology OP-1547.

Pacific Coast, earthquakes OP-1259

Pacific Ocean, plate tectonics OP-1901

plate tectonics OP-392

tectonophysics OP-463; OP-1037; OP-1460

United States, plate tectonics OP-1519

plate divergence

California, structural geology OP-703

Iceland, tectonophysics $\mathrm{OP}-420$

tectonophysics OP-463

plate margins see plate boundaries

plate rotation

Califomia, structural geology OP-340

Idaho, structural geology OP-523

Pacific Ocean

plate tectonics OP-900

tectonophysics OP-1926

tectonophysics OP-2031

plate tectonics see also accretionary wedges; active margins; Antarctic Plate; back-arc basins; Benioff zone; Caribbean Plate; Cascadia subduction zone; Cocos Plate; continental crust; continental drift; continental margin; crustal shortening; earthquakes; Eurasian Plate; extension tectonics; Farallon Plate; fore-arc basins; fracture zones; Galapagos Rift; hot spots; island arcs; Kula Plate; melange; Nazca Plate; North American Plate; ophiolite complexes; Pacific Plate; passive margins; plate boundaries; plate collision; plate convergence; plate divergence; plumes; rift zones; sea-floor spreading, seismotectonics; South American Plate; spreading centers; subduction; subduction zones; suture zones; terranes; transform faults; transpression; triple junctions.

YR; OP-124; OP-1628

Alaska, Invertebrata OP-1681

Antarctic Ocean OP-65

Colorado Plateau, structural geology OP-679

energy sources OP-453

Italy OP-1682

Kazakhstan OP-1295

metal ores OP-339

Minnesota, geochronology OP-758

Nevada, geophysical surveys OP-1041

Rocky Mountains, structural geology OP-679

Washington, structural geology OF 92-0715

West Pacific Ocean Islands OP-1034

plateau basalts see flood basalts

\section{platinum}

China, geochemistry OF 92-0525

Colombia, geochemistry OP-755

England, geochemistry OP-755

Poland, geochemistry OP-755

Texas, geochemistry OP-755

Yukon Territory, geochemistry OF 92-0525

platinum group see also iridium; osmium; palladium.

Australia, metal ores OP-1431

California, platinum ores B 2014

Canada, metal ores OP-1431

Chile, metal ores OP-1107

China, metal ores OP-363

metal ores OF 92-0557

Russian Federation, metal ores OP-2014

Venezuela, metal ores OP-1107

Yukon Territory, metal ores OP-363

platinum ores

OF $92-0557$

Alaska OP-1006

California B 2014

Canada OP-728

China

OP-1432

geochemistry OF $92-0525$

geochemistry OP-1621

Italy OF 93-0504

Montana OF 93-0207

Puerto Rico OP-1656

United States OP-728

Yukon Territory

OP-1432

geochemistry OF 92-0525

Plattin Group

fractures OP-1336

Playa Axul earthquake 1981

plate tectonics OP-670

playas

California

diagenesis OP-1386

evaporite deposits OP-226

geophysical surveys OP-227

ground water OP-234

Nevada

evaporite deposits OP-226

ground water OP-234

Texas, sedimentary petrology OP-1991

Pieistocene see also Glenns Ferry Formation; Koobi Fora Formation; Shungura Formation. OP-55; OP-1756

Alaska OP-163; OP-299; OP-391; OP-515; OP$1507 ;$ OP-1800
Arctic Ocean OP-516

Basin and Range Province OP-910

Bishop Tuff

OP-1538

geochemistry OP-954

Quaternary OP-1843

California OP-831; OP-878; OP-1386; OP1619; OP-1800

Celebes Sea OP-823

Colorado OP-1324

Georgia OP-1502; OP-1677

Germany B 2050

Great Lakes OP-1354

Greenland OP-150

Gubik Formation, Quaternary OP-1225

Gulf Coastal Plain WRI 91-4152

Gulf of Mexico OP-1864; OP-1966

Hawaii OP-633

Iceland OP-1303

Idaho OP-561

Illinoian

OP-201

Illinois OP-1309

New England OP-748

Indiana OP-1308

Iowa B 2050; OF 92-0500

Irvingtonian, California OP-1844

Jaramillo Event

Indonesia OP-1538

Ivory Coast OF 92-0699

New Mexico OF 92-0699; OP-1538

Lake Agassiz

clays OF 92-0514

gold ores OP-168

Quaternary OP-1289

Lake Lahontan

OP-68

geochemistry OP-76

Quaternary C 1086; OP-69; OP-1156

Louisiana OP-742

Mexico B 2050; OP-1800

Missouri OP-1308

Nevada OP-294; OP-831; OP-1070; OP-1670

New Mexico OF 92-0528

New York WRI 88-4127

Old Crow Tephra, Quatemary C 1086; OP1059

Oregon B 2038; OP-1404

Pacific Ocean OP-820

Peoria Loess, Quaternary OF 93-0273; OP1683

Peru OP-855

Polynesia OP-1436

Riss/Wurm Interglacial, France OP-310

Rocky Mountains OP-910

Russian Federation B 2037; OP-91; OP-1407, OP-1764

Samoa OP-844

Sangamonian, Illinois OP-1309

Spain OP-722

Tennessee OF 93-0273

United Arab Emirates OF 92-0391

Utah OP-908; OP-1022

Vanuatu OP-188; OP-1908

Washington OP-143

Wisconsin OP-391

Wisconsinan

OP-201

Illinois OP-1309

Maryland OP-439

Massachusetts OP-555; OP-749

New England OP-748

Wyoming OP-1455 
Wyoming OF 92-0391; OP-1884

Younger Dryas, Great Lakes OP-1289

Pliensbachian

California OP-385

plinian-type eruptions

Alaska, petrology OP-316

Oregon, magmas OP-982

Philippine Islands, earthquakes OP-1998

Pliocene see also Glenns Ferry Formation; Koobi

Fora Formation; Shungura Formation; Tamiami

Formation.

C 1086; OF 92-0414; OF 92-0418; OP-222; OP-798; OP-1756; OP-1949

Alaska C 1086; OP-515

Antarctic Ocean OP-1535

Arctic Ocean OP-223

Arkansas OF 93-0273

Atlantic Coastal Plain OF 92-0262

Atlantic Ocean C 1086; OF 92-0413; OF 920508; OP-271; OP-292

Bidahochi Formation, petrology OP-1341

Califomia C 1086; OP-759; OP-831; OP-1065; OP-1098

Georgia OP-1677

Greenland OP-110

Gulf Coastal Plain P 1416-C; WRI 91-4151; WRI 91-4152

Iceland OP-1303

Nevada OP-831

New Mexico OF 92-0528

Oregon OP-1098

Pacific Coast C 1086

Pacific Ocean OF 92-0712; OP-54

Papua New Guinea B 2039

Peru OP-1330

Russian Federation B 2037; OP-91; OP-1407

South Carolina I-1935

Spain OP-722

Tennessee OF 93-0273

Vanuatu OP-188

Pliocene Research, Interpretation, and Synop-

tic Mapping C 1086; OP-798

pliomagmatic zone see eugeosynclines

plugs

Argentina, structural geology OP-1129

Illinois, non-metal deposits OP-1419

Kentucky, non-metal deposits OP-1419

Nevada B 2052; OP-809

Virginia, geochemistry B 1839-I,J

West Virginia, geochemistry B 1839-I,J

plumes see also hot spots.

Alaska, Quatemary OP-1714

Arctic Ocean, tectonophysics OP-1626

Canada, orogeny OP-138

Cretaceous OP-1115

geochemistry B 1966

Great Lakes, plate tectonics OP-13

Great Lakes region, plate tectonics OP-13

Hawaii geochemistry OP-446 petrology OP-667

Minnesota, geochemistry OF 92-0525

pollution OP-1155

Russian Federation, geochemistry OP-1086

plunging folds

Alaska, metal ores OP-224

Montana B 1993

Plush Ranch Formation

stratigraphy OP-1281

structural geology OP-332 plutonic rocks see also carbonatites; diabase; diorites; gabbros; granites: lamprophyres; syenites; ultramafics.

Alaska OF 92-0020-E

Antarctica OP-1027

California

economic geology OP-260

geochronology OP-333

Colorado

Cretaceous OP-11

geochemistry OP-1825

mineral resources OP-828

geochemistry OF 92-0525

Idaho

OP-630

geochronology OP-1067

Italy, metal ores OF 93-0504

Montana OP-1462

Nevada, economic geology OP-260

New Mexico, Cretaceous OP-11

Nova Scotia, geochemistry OF 92-0525

Pacific Ocean OP-105

Washington

I-1963

geochronology OP-1067

plutonium

geochemistry OP-175

plutons

OP-1246

Alaska

P 1497-C; OF 92-0724; I-2164; OP-1396; OP-1461

gold ores OP-589

Antarctica OP-1995

Appalachians

stratigraphy OP-1380

structural geology OP-1479

Basin and Range Province

OP-545

geochemistry OP-2015

tectonics OP-2021

California

OP-1376; OP-1461; OP-1691

geochemistry OP-512; OP-1141

geochronology OP-333

orogeny OP-1566

platinum ores B 2014

stratigraphy B 2015

structural geology OP-1971

Canada

P 1497-C; OP-1463

tectonics OP-1215

Colorado

foliation OF 92-0391

geochemistry OP-490

geophysical surveys OP-1813

Proterozoic OP-10

England, geochemistry OP-158

geophysical surveys OP-1374

Great Basin

OP-545

geochemistry OP-2015

tectonics OP-2021

Idaho

OP-630; OP-1671

geochronology OP-1067

Manitoba OP-1560

metal ores OP-465

Minnesota, geochronology OP-758

Mississippi Valley, engineering geology OF 92-0391

Missouri earthquakes OP-1996

iron ores OP-1297

metal ores OP-1326

Nevada

OP-795

mineral resources OP-218

New Mexico, geochemistry OP -490

Nova Scotia, geochemistry OP-1122

Ontario OP-1560

Oregon

OP-1139; OP-1140

geochemistry OP-1141

Pakistan, structural geology OP-1125

Quebec, gold ores OP-1097

Russian Federation

OP-91

geochronology OP-1407

United States

OP-1463

tectonics OP-1215

Washington

GQ-1679; I-1963

geochronology OP-1067

pluvial environment

Nevada, Quatemary OP-1070

Poachie Range

maps I-2198

Pocahontas Formation

hydrogeology WRI 92-4073

Pocos de Caldas Brazil

ground water OP-737

Podocopida see Cytherocopina

Point Arena

plate tectonics OP-145

structural geology OP-648

point bars

Texas, waterways OP-150

Point Conception

continental margin I-2089-C; I-2090-A; I2090-B; I-2090-C

Point Loma

continental margin I-2089-C

Point Lookout Sandstone

B 2025

energy sources OP-518

sedimentary petrology OF 93-0306; OP-1567

Point Sal

petroleum OP-1910

Pojetaia

Invertebrata OP-1839

Poland see also Snieznik; Sudeten Mountains. OP-558

geochemistry OP-755

metal ores, Cracow Poland OF 92-0704

soils OF 93-0281

structural geology, Polish Sudeten Mountains OP-967

polar caps OP-508; OP-1210; OP-1593

pole positions

Africa, stratigraphy OP-656

Antarctic Ocean, tectonophysics OP-1446

Arizona, stratigraphy OP-398

California, paleomagnetism OP-1504

Poleta Canyon

economic geology OP-260

policy OP-687

Polish Sudeten Mountains

structural geology OP-967

polished surface see slickensides 
pollen

Atlantic Coastal Plain

Pliocene OF 92-0262

Quaternary OF 92-0263

Florida

palynomorphs OP-2002

Pliocene OP-1075

Great Lakes, Quaternary OP-1290

Greenland, Quaternary B 2036

Minnesota, Quatemary C 1086

Northwest Territories, Quaternary B 2036

Pacific Ocean, Pliocene OF 92-0712

palynomorphs OP-1659

Pliocene OP-222

Russian Federation, Quaternary B 2036

Tennessee, Quatemary OF 93-0273

Utah, sedimentary petrology OP-1779

Wyoming, palynomorphs P 1506-D

pollution see also acid mine drainage; acid rain; creosote; hazardous waste; heavy metals; hydrocarbons: impact statements; industrial waste; land use; oil spills; PCBs; radioactive waste; radioactivity; trace metals; waste disposal; waste disposal sites.

OF 92-0494; OF 93-0292-G; OF 93-0292-H; OF 93-0292-I; OF 93-0292-J; OF 93-0418; OP-

297; OP-576; OP-691; OP-692; OP-816; OP-

864; OP-1030; OP-1128; OP-1155; OP-1425;

OP-1448; OP-1645; OP-1665; OP-1975

Adriatic Sea OP-47

Alaska C 1007; OF 93-0292-J

Algeria OP-599

Arizona OF 93-0292-

Arkansas, hydrology OF 93-0070

Atlantic Coastal Plain OP-378; OP-1458; OP1876

Basin and Range Province B 2013

Bering Sea, oceanography OP-129

California

WRI 91-4119; OF 93-0083; OF 93-0292-I; OP-264; OP-473; OP-599

ground water OF 91-0535; OF 92-0655; OP303

Colorado

WRI 93-4007; OF 92-0391; OF 93-0292-

H; OP-902

ground water OP-854

hydrology OF 92-0645

Connecticut, hydrogeology WRI 92-4074

Delaware C 1080; OP-922

East Pacific Ocean Islands OF 93-0292-I

Florida W 2402; OP-513

geochemistry OF 92-0391; OP-343; OP-379; OP-1426; OP-1816

Georgia WRI 91-4178; OP-1501

Great Lakes region, ground water OF 92-0694

ground water YR; OP-761; OP-1473

Gulf Coastal Plain C 1120-C; OF 92-0530; OP378

Gulf of Mexico C 1120-C; OF 92-0530

Hawaii

OF 93-0292-I

hydrogeology WRI 91-4197

hydrogeology OF 93-0106

hydrology W 2400; OF 92-0651; OP-40

Idaho

OF 93-0292-J

ground water WRI 92-4014

hydrogeology OF 93-0102

Iowa

OF 93-0292-G; OP-1981

ground water $\mathrm{OF}$ 92-0085
Kansas

OF 93-0087; OF 93-0292-G; OP-4; OP-

1909

geochemistry OP-5

Kentucky

hydrogeology OF 92-0638

hydrology WRI 92-4057; WRI 92-4078

Louisiana

OF $92-0492$

ground water OF 92-0492

hydrogeology OF 92-0492

Maryland

C 1080; OP-833; OP-922

ground water OP-1174

Massachusetts

OP-1574

ground water $O F$ 92-0143

Midwest OF 93-0418

Minnesota

OF 93-0042; OF 93-0043; OF 93-0079;

OP-1526

ground water OF 92-0085; OP-551

Missouri

OF 93-0101; OF 93-0292-G; OP-2028

hydrology WRI 93-4012

Montana

OF 93-0064; OF 93-0292-H

energy sources OP-1947

Nebraska

OF 93-0087; OF 93-0292-G; OP-1909

geochemistry OF 92-0592

Nevada OP-1765

New England OF 93-0418

New Hampshire, ground water WRI 91-4177

New Mexico WRI 93-4007

New York

OP-412; OP-1735

hydrology OF 92-0476

North Carolina

OP-403

hydrogeology OF 93-0163

North Dakota OF 93-0292-H

Ohio OP-155

Oklahoma OP-1251

Ontario OP-369

Oregon OF 93-0292-J; OP-471

Pennsylvania

OP-388

engineering geology OF 92-0391

Polynesia OF 93-0292-I

Puerto Rico, hydrology W 2400

Rocky Mountains OP-1008

South Carolina, hydrogeology OF 93-0035

South Dakota

OF 93-0292-H

geochemistry OF 92-0592

Spain

OP-599

ground water OP-1449

Texas OF 92-0391

Tunisia OP-599

United States, hydrology W 2400

Utah

OF 93-0292-H

ground water WRI 92-4070

Vermont OP-412

Virginia, geochemistry OP-344

Washington

OF 93-0292-J; OP-1827

ground water WRI 93-4060

hydrogeology OF 92-0644

hydrology WRI 91-4073; OF 91-0453
West Virginia

OP-901

hydrology OF 92-0065

Wyoming OF 93-0292-H; OP-930; OP-1871

polychlorobiphenyls see $\mathrm{PCB}$

polycyclic aromatic hydrocarbons

Gabon, geochemistry OP-713

New Jersey, environmental geology OF 92 0153

polyethylene

pollution OP-1645

Polygnathus

stratigraphy OP-1245

polymetallic ores

OF 92-0389; OF 92-0557; OF 93-0194

Alaska OP-123

Arizona B 1737-E; OF 93-0228

Bolivia B 2039; OP-202; OP-1306

California OF 93-0228

Colorado OP-1151

England OP-1541

Maine B 2039

Ontario OP-484

Utah OP-1464

polymetamorphism

Alaska P 1497-C; I-2164

Canada P 1497-C

Connecticut OP-1188

Maine, geochemistry OP-750

Manitoba, geochronology OP-1709

Massachusetts OP-1.188

New York, geochronology OP-1709

Vermont, economic geology B 1955

Virginia, orogeny OP-1612

polymorphism

Kenya, sedimentary petrology OP-1490

mineralogy OP-1986

Ontario, polymetallic ores $\mathrm{OP}-484$

Oregon, sedimentary petrology OP-1490

Western Interior, Invertebrata P 1533

Polynesia see also Hawaii; Samoa; Tonga. geochronology, Cook Islands OP-1436

polynyas

Alaska, continental shelf OP-837

Arctic Ocean, sea ice C 1086

Pompton Plains Quadrangle geochemistry OF 93-0010

Ponce Puerto Rico

copper ores OF 93-0178; OF 93-0179

soil mechanics OP-485

popular geology see also collecting; education. YR; OF 93-0251

Alaska, non-metal deposits $\mathrm{C} 1110$

Arkansas, hydrogeology OF 93-0048; OF 930136; OF 93-0166; OF 93-0167; OF 930424: OF 93-0425; OF 93-0427; OF 93-0428; OF 93-0429; OF 93-0430; OF 93-0431; OF 93-0432

California

earthquakes EV

environmental geology OF 93-0294

geomorphology OP-266

Colorado, Quatemary OF 93-0250

energy sources $\mathrm{OP}-453$

engineering geology $P$ 1240-B

environmental geology YR; C.1105

geologic hazards $P$ 1240-B

Hawaii, earthquakes EV

hydrogeology YR; W 2220

Mexico, geologic hazards OF 93-0197-A; OF 93-0197-B 
Missouri, geologic hazards C 1083

Montana, pollution OF 93-0064

Nevada, thermal waters B 1998

North Carolina, geologic hazards P 1177-B

Puerto Rico, ground water OF 85-0642

tectonophysics OP-463

Washington, environmental geology C 1090

Porcupine Creek

hydrogeology WRI 92-4185

Porcupine Mountains

areal geology OP-139

geochemistry OP-1747

Porcupine River geochronology OF 92-0701

Porcupine Volcanics

copper ores OP-1688

geochemistry OP-1747

Porites

Pacific Ocean, Quatemary C 1086

Porkchop Geyser

geochemistry OP-520

porosity traps see stratigraphic traps

porphyry

Arizona, geochemistry B 2021-C

porphyry copper

Alaska, metal ores B 1968

Argentina, copper ores OP-2027

Arizona, metal ores OP-9

British Columbia

copper ores OP-273

metal ores OP-9

Chile, copper ores OP-2027

Maine, metal ores B 2039

Montana

copper ores OP-273

metal ores I-2050-F

Philippine Islands, metal ores OP-9

Puerto Rico

copper ores OF 92-0578; OF 93-0178; OF 93-0179

economic geology OF 92-0567

Washington GQ-1679

porphyry molybdenum

Alaska, metal ores B 1968

Colorado

metal ores OP-1633

molybdenum ores OP-375; OP-1050

Maine, metal ores B 2039

Montana, metal ores I-2050-F

porphyry tungsten

Montana, metal ores I-2050-F

Port Fidalgo Deposit

metal ores OP-224

Port Moller Quadrangle metal ores B 1968

Port Royal Sound hydrogeology OF 91-0483

Port Valdez see Valdez Alaska

Port Washington Aquifer ground water WRI 88-4127

Portage Lake Lava Series copper ores OP-2019 geochemistry OP-1747

Portal Ridge structural geology OP-803

Portland Oregon geophysical surveys OF 93-0211 pollution WRI 92-4136

Portlandian see Tithonian
Portneuf Range

structural geology OP-523

Portugal

economic geology OF 92-0525

Portuguese East Africa see Mozambique

positions, pole see pole positions

Post-Betze Deposit

gold ores OP-27

Postglacial see Holocene

potash feldspar see $\mathrm{K}$-feldspar

potash mica see muscovite

potassium

Alaska, Quaternary OP-1507

Brazil, ground water OP-737

Colorado

geophysical surveys OP-1813

stratigraphy OP-985

geochemistry OP-289; OP-991

Georgia, pollution OP-1501

Greenland, Quaternary OP-1507

K-40

California OP-995

Nevada OP-995

mineralogy OP-789; OP-1068

phase equilibria OP-1475

sedimentary petrology OP-1353

potassium bromide

mineralogy OP-789

potassium chloride

geochemistry OP-326

mineralogy OP-789

potassium feldspar see $\mathrm{K}$-feldspar

potassium-argon see $\mathrm{K} / \mathrm{Ar}$

Potomac Aquifer ground water WRI 92-4175

Potomac River hydrology W 2340

Potomac River basin geomorphology B 1981 waterways OP-888

Potomac Terrane

metamorphism OP-1152

pottery see artifacts

Pottsville Group see also Breathitt Formation. OF 92-0558; OF 92-0568

Potwar Plateau

natural gas OP-1634

Powder River basin

Cretaceous OC-0135; OC-0136; OC-0137; OC0138

diagenesis OP-395

energy sources OF 92-0391; OF 93-0337; OP889

geochemistry OP-1305

geophysical surveys OF 93-0002; OC-0140

hydrology WRI 91-4199

impact statements WRI 90-4154

maps I-2343-A; I-2343-B; I-2380-A; I-2380-B; C-0142

Miocene B 1917-O

natural gas OP-449

palynomorphs OP-1745

Pennsylvanian OP-1103

petroleum B 2039; OP-793

sedimentary petrology B 1917-L; OP-228

stratigraphy B 1917-M; OP-1182; OP-1744

Triassic B 1917-P

Powers Lake

hydrology WRI 90-4126
Poxono Island Formation

stratigraphy B 1839-L

Pozzuoli Italy

geologic hazards OP-213

Pre-Cambrian see Precambrian

Preakness Basalt

geochemistry OF 93-0010

magmas OP-1003

Preble Formation

gold ores OP-365; OP-784

metal ores OF 93-0249

stratigraphy OP-623

Precambrian see also Archean; Duluth Complex: upper Precambrian.

B 1989-D; OF 92-0525; OP-339; OP-714; OP-

1377; OP-1803

Catoctin Formation geochemistry OP-3 structural geology OP-1955

Changcheng System OP-1361

Chuar Group natural gas OF 92-0524 sedimentary petrology OF 92-0391

Colorado OP-95; OP-118; OP-827; OP-828; OP-944

Grenvillian Orogeny

OF $92-0525$

Canada OP-138

New York OP-461

North Carolina OP-1607

Ontario OP-214

Vermont OP-461

Virginia OP-1612

Michigan I-2356

Nonesuch Shale

copper ores OP-1688

energy sources OF 92-0391

geochemistry OP-1204

natural gas OF 92-0524; OP-725

sedimentary petrology OF 92-0391

Nova Scotia OP-1122

Penokean Orogeny

Canada OP-1215

Michigan B 1904-L; B 1904-Q

United States OP-1215

Russian Federation OP-1777

Stillwater Complex

bibliography OF 93-0285-A; OF 93-0285-B

economic geology OF 93-0207

geochemistry OP-1087; OP-1621; OP-1663

magmas OP- 1500

petrology OP-604

Virginia OP-1774

Westem Australia OP-1774

Wisconsin I-2356

Yellowjacket Formation, metal ores OP-715

Precambrian Shield see Canadian Shield

precious metals

Bolivia, metal ores OP-1306

Colorado

base metals OP-944 metal ores OF 92-0557; OP-937; OP-1633

Idaho, metal ores OP-876

Nevada

base metals OP-79

metal ores OP-627

Oregon, metal ores OP-876

Spain

base metals OP-31

gold ores OP-231

Utah, base metals OP-394

Wyoming I-2232 
precipitation-runoff modeling system Oregon, hydrology WRI 92-4108

predation

ground water OP-1473

prehnite-pumpellyite facies

Alaska, metamorphic rocks P 1497-C

Canada, metamorphic rocks $P$ 1497-C

Michigan, copper ores OP-2019

pressure transducers

Arizona, hydrology OF 93-0071

Arkansas, hydrology OF 93-0071

Colorado, ground water OF 93-0071

geophysical surveys OF 93-0071

hydrology OF 93-0071

Michigan, ground water OF 93-0071

Nevada

ground water OF 93-0071

waste disposal OF 91-0493

Oklahoma, ground water OF 93-0071

pressure wave see $\mathrm{P}$-waves

pressuremeter tests

California, ground water OF 93-0148

Preuss Range

stratigraphy OP-1320

Prewitt Reservoir

Quatemary OP-1676

Price Formation OP-1367

Pride's Creek Mine

Quaternary OP-1308

primary wave see $\mathrm{P}$-waves

Prince Creek Formation

Mesozoic OP-1680

Prince Rupert Quadrangle

economic geology MF-2217-A

mineral resources OF 92-0552; OF 92-0690; MF-2217-B

Prince William Sound

economic geology C 1094

environmental geology OP-564

geochemistry OP-1304

metal ores OP-224

seismology OP-1384

Prince William Terrane

geochemistry OP-1410

gold ores OF 93-0325

structural geology OP-94

Princeton Minnesota MSEA

pollution OF 93-0042; OF 93-0043; OF 930079

Pripet Basin

energy sources OP-1261

petroleum OP-1265

PRISM

Pliocene C 1086; OP-222; OP-798; OP-1949

pristane

Colorado, energy sources OP-674

Commonwealth of Independent States, energy sources OP-1261

Europe, energy sources OP-1261

Hungary, energy sources OP-1263

New Mexico, energy sources OP-674

PRMS

hydrology WRI 92-4108

progradation

Alaska, petroleum OP-1285

Antarctic Ocean, Quaternary OP-1358

Georgia, sedimentary petrology OP-1677

Mississippi, oceanography OP-1740

reefs OP-1662

Texas, stratigraphy OP-1387; OP-1575
Utah, Cretaceous OP-919

prograde metamorphism

Manitoba, geochronology OP-1709

New South Wales Australia, metal ores OP-942

New York, geochronology OP-1709

Queensland Australia, metal ores OP-942

programming languages see computer languages

Project Voyager see Voyager Program

propylitization

Colorado, metal ores OP-1633

proteins

geochemistry OP-608

Proterozoic

OF 92-0525; OP-12; OP-465

Alaska OP-721

Antarctic Ocean OP-1395

Arizona OF 92-0591-A; OF 92-0591-B; OP203; OP-398; OP-1341

Australia OP-1431

Baraga Group, structural geology B 1904-Q

Belt Supergroup, structural geology P 1524; B 1993

California OP-797; OP-1691

Canada OP-1431

Canadian Shield OP-1316

China OP-1238; OP-1343; OP-1361

Colorado OF 92-0525; OF 93-0343; OP-10; OP-1051

Gabon OP-713

Idaho OP-434; OP-715; OP-797

Kansas OP-725

Keweenawan

OF 92-0524

Great Lakes OP-13

Great Lakes region B 1989-E; OP-13

Michigan OP-139

Minnesota OP-758

Manitoba OP-1709

Maryland OP-1106

McCoy Creek Group OP-1776

Mexico OP-132

Michigan OF 92-0391; OP-1204; OP-1214

Minnesota OF 92-0525

Missouri OP-1326; OP-1327

New York OP-1709

Northwest Territories OP-721

Onaping Formation

mineralogy OP-1178

petrology OF 92-0391

Ontario OP-214

Oronto Group B 1989-E

Ortega Group OP-11

Pacific Ocean OP-105

Pan-African Orogeny

Saudi Arabia OP-1921

Yemen OP-1921

Portage Lake Lava Series

copper ores OP-2019

geochemistry OP-1747

Riphean

Arizona OF 92-0391

Iowa OF 92-0391

Russian Federation OF 92-0391

Saudi Arabia B 1976; OP-499; OP-1558; OP 1559

Vendian

Arizona OF 92-0391

Iowa OF 92-0391

Russian Federation OF 92-0391

Virginia B 2029; OP-1002; OP-1106

Willyama Complex, metal ores OP-942

Wisconsin OP-1214
Wyoming P 1520; OF 92-0525; OP-149

Protista see also foraminifera.

ground water OP-1473

silicoflagellates

California OF 92-0539-E

New Jersey OP-979

Peru OP-1330

proton probe data

Russian Federation, metal ores OP-1313

Providence Formation stratigraphy OP-1817

Providence-Ripley Aquifer ground water WRI 91-4116

Providencia District economic geology OP-872

provinces, metallogenic see metallogenic prov-

inces

Provo Utah

Quatemary OP-908

Prudhoe Bay

energy sources OP-1284

petroleum OP-1285

Prudhoe Bay Field petroleum OP-1285

Prydz Bay

Quatemary OP-1358; OP-1630

Tertiary OP-1145

Pryor Mountains diagenesis OP-395

psammite see sandstone

pseudogalena see sphalerite

pseudomorphism

Alaska, gold ores OP-1057

Haiti, stratigraphy OP-1181

Ivory Coast, stratigraphy OP-1181

Wyoming, stratigraphy OP-1181

Pseudomphalotrochus stratigraphy OP-85

Pseudomyona Invertebrata OP-1839

Pseudopolygnathus stratigraphy OP-1245

psychrometers hydrology OF 92-0490

Pt see platinum

pteridophytes

Lycopsida, Ohio OP-1603

Pteridospermae see Neuropteris

Pteriina see Inocerami

Pu see plutonium

Pu'u O'o see Puu Oo

Puale Bay energy sources OP-626

public lands mineral resources OP-1679

public response California, geologic hazards P 1553-B

Public Seismic Network geologic hazards OP-221

Pueblo Viejo District metal ores OP-532; OP-1576

Puerco River see Rio Puerco

Puerco River basin pollution OP-1023

Puerto Limon Group Neogene OP-1272

Puerto Rico areal geology YR 
copper ores

OF 92-0578

Arecibo Puerto Rico OF 93-0178; OF 930179

Ponce Puerto Rico OF 93-0178; OF 93-0179

ecology OF 92-0150

economic geology OF 92-0567

environmental geology OF 92-0717

geologic hazards

OF 92-0717; OP-1631; OP-1632; OP-1835

San Juan Puerto Rico OP-1409

geomorphology OF 92-0717; OP-1007

ground water OF 85-0642; OP-1960

heavy mineral deposits OF 92-0703; OF 930341

hydrogeology C 1081; C 1086; WRI 90-4125

hydrology W 2400; OF 93-0029

marine installations, San Juan Puerto Rico OP1863

metal ores OP-217; OP-1656

oceanography B 2002; OF 92-0513; OF 920717

pollution OP-663

sands OF 92-0717

sedimentary petrology OF 92-0391

seismology C 1031

soil mechanics, Ponce Puerto Rico OP-485

weathering C 1086

Puerto Rico Trench

nodules OP-886

Puget Lowland

geomorphology OP-1552

geophysical surveys OF 93-0347

neotectonics OF 93-0332

Quatemary OP-36; OP-120; OP-201

stratigraphy OF 92-0581

Puget Sound

Quaternary OP-36; OP-120

Puget Sound earthquake 892 earthquakes OP-1118

pull-apart basins

Illinois, structural geology OP-1471

Missouri, structural geology OP-1471

pulsating spring see geysers

pumice

Alaska OP-1469

Nevada, ground water OP-1899

Oregon, geochemistry OP-43

Wyoming, Quaternary OF 92-0391

pumice deposits

Arizona OF 93-0329

Punchbowl Fault

neotectonics OP-1063

pure coal see vitrain

Purgatoire Formation petroleum OF 93-0337

purgeable organic compounds Idaho, hydrogeology OF 92-0174

Purisima Formation ground water WRI 91-4148

push-pull wave see $P$-waves

Putnam Fault structural geology OP-523

Putnam-Nashoba Zone structural geology OP-1079

Puu Oo geophysical surveys OP-252 petrology OP-164; OP-631 seismology OP-1420

Puu Waawaa petrology OP-164
Pyramid Hills

neotectonics OP-83

Pyramid Lake

hydrology OP -448

Quatemary

OP-1156

Pyrenees

Quaternary

French Pyrenees P 1386-E

Spanish Pyrenees P 1386-E

pyrite see also iron ores.

Bolivia, metal ores B 2039

Canada, geochemistry OP-1905

Colorado, molybdenum ores OF 92-0525

Dominican Republic, metal ores OP-532; OP1576

geochemistry OP-829; OP-841

United States, geochemistry OP-1905

pyrochlore

Australia, metal ores C 0930-M

Brazil, metal ores C 0930-M

Canada, metal ores C 0930-M

China, metal ores C 0930-M

Colorado, metal ores C 0930-M

Idaho, metal ores C 0930-M

Malaysia, metal ores C 0930-M

Mozambique, metal ores C 0930-M

Nigeria, metal ores C 0930-M

Rwanda, metal ores C 0930-M

Thailand, metal ores C 0930-M

Zaire, metal ores C $0930-\mathrm{M}$

pyroclastic flows

Alaska, geologic hazards B 1996

Nevada, petrology B 2052

Oregon, magmas OP-982

Philippine Islands, geologic hazards WRI 924039

pyroclastics see also ash-flow tuff; ignimbrite; pumice; thyolite tuff; scoria; tuff; volcaniclastics; welded tuff.

OP-1323; OP-1830

Alaska

OP-845

geochemistry OP-1754 geochronology OF 92-0701

Arizona, geochemistry B 2021-C

California, metal ores OP-428

Guatemala, geomorphology OP-277

Iceland, geochemistry OP-511

Oregon OP-1549

Philippine Islands, geochemistry OP-1994

Washington, engineering geology OP-956

pyrolysis see also Rock-Eval.

OP-251; OP-533; OP-1382; OP-1477; OP-

1478; OP-1923

pyroxene group see also clinopyroxene; orthopyroxene.

OP-661; OP-1392

Ecuador, gold ores B 2039

Greenland, phase equilibria OP-636

Wyoming, petrology OP-1456

pyroxenite

California, platinum ores B 2014

Saudi Arabia OP-1952

pyrrhotite

geochemistry OP-841

\section{$\mathbf{Q}$}

$\mathbf{Q}$

California, earthquakes OP-1498 earthquakes OF 92-0441

seismology OP-1064

Utah, rock mechanics OP-404

QCODA

earthquakes OF 92-0441

Qingbaikou Group

stratigraphy OP-1361

Qiqu Deposit

gold ores OP-945

QMAP

seismology OF 92-0441

QPLOT

earthquakes OF 93-0022

Quadricarina

Invertebrata OP-86

quality assurance

hydrogeology WRI 92-4075; OF 92-0163

hydrology W 2400; OF 92-0495

Oklahoma, ground water OF 92-0641

Pennsylvania, hydrogeology OF 92-0165

quartz

Bolivia, metal ores B 2039

California

OP-557

manganese ores OP-458

metal ores OP-428

Colorado, geochemistry OP-490

geochemistry OP-326; OP-1312; OP-1870

geophysics OP-924; OP-1877

Georgia, oceanography OP-1502

Illinois, sedimentary petrology OP-1385

Indiana, sedimentary petrology OP-1385

Indonesia, sedimentary petrology OP-870

Iowa, geochronology OP-475

Missouri, metal ores B 2039; OP-1885

Nevada

OP-557

lava OP-809

New Mexico, geochemistry OP-490

petrology OP-696; OP-1450

Saudi Arabia, tin ores OP-1558

South Dakota, geochronology OP -475

Spain, metal ores OP-875

Utah, diagenesis OP-1465

Victoria Australia, petrology OP-1136

Wyoming, geochemistry OP-49

quartz diorites

Canada OP-1463

Oregon OP-1139

United States OP-1463

quartz monzonite

Montana, geochemistry OP-1087

quartz veins

Arizona, gold ores OF 92-0591-A; OF 920591-B

California

gold ores OP-934

metal ores $\mathrm{OP}-427$

Colorado

base metals OP-944

metal ores OP-937

gold ores OF 92-0557

Nevada

geochemistry OF 92-0525

metal ores $\mathrm{OP}-45$

molybdenum ores B 2039

New South Wales Australia, metal ores OP-942

pedogenesis OP-48

Quebec, gold ores OP-1097

Queensland Australia, metal ores OP-942

Saudi Arabia, metal ores OP-1559 
quartzites

Idaho, building stone B 2013

Nevada, metal ores OF 93-0249

New South Wales Australia, metal ores OP-942

Queensland Australia, metal ores OP-942

Quaternary see also Holocene; Pleistocene.

C. 1086; OF 93-0273; I-1420 (NJ-14); I-1420 (NJ-15); OP-756; OP-952; OP-959; OP-980; OP-1470

Alaska C 1086; OF 92-0701; GQ-1688; I-2032; OP-33; OP-242; OP-390; OP-826

Arctic Ocean C 1086; OF 92-0426; OF 920439; OF 93-0218; OP-1796

Arctic region OF 92-0439

Arkansas OF 93-0096; OF 93-0273

Basin and Range Province C 1086; OP-618

Brunhes Epoch

Arctic Ocean OP-799

Idaho OF 93-0327; OP-561

Indonesia OP-1538

Ivory Coast OF 92-0699

New Mexico OF 92-0699; OP-1538

Bull Lake Glaciation, Wyoming OP-1455; OP1884

California C 1086; OF 93-0223; OF 93-0224; OF 93-0225; OF 93-0232; OF 93-0263; OF 93-0286; OF 93-0311; OF 93-0340; MF-2212; I-1420(NJ-10); OP-707; OP-759; OP-1065; OP-1098; OP-1271; OP-1339; OP-1897

Canada I-1420 (NK-18); I-1420 (NL-18)

Celebes Sea OP-821

Chile OP-279

Colorado I-2266

Florida OP-1510

Great Basin C 1086

Greenland C 1086

Gulf Coastal Plain P 1416-C; WRI 91-4149

Idaho OF 91-0098; OF 92-0408; OP-452; OP634

Indiana OF 93-0268-A; OF 93-0268-B

Israel OP-75

Louisiana OF 92-0530

Mexico I-1420 (NG-14); OP-707

Michigan I-1420 (NL-17)

Midwest OF 93-0543; OP-1896

Mississippi OF 92-0394

Mississippi Valley WRI 91-4149; OF 93-0273

Montana OP-978

Nevada C 1086; OP-916; OP-973; OP-1339

New England C 1086

New Mexico I-2266

Northern Territory Australia B 2032-A

Ontario I-1420 (NL-17)

Oregon B 2054; OF 91-0098; OP-634; OP-707; OP-1098

Pacific Coast C 1086

Papua New Guinea B 2039

Pennsylvania B 1994

Peru OP-1330

Pinedale Glaciation

Colorado OP-1676

Wyoming OP-1455; OP-1884

Russian Federation C 1086; OP-1334; OP1492; OP-1604; OP-1763; OP-1874; OP2004

Saudi Arabia OP-1198

South Australia B 2032-B

South Carolina I-1935

Tennessee OF 93-0273

Texas I-1420 (NG-14); I-1420 (NH-14); OP1991
United Arab Emirates OP-1198

United States I-1420 (NK-18); I-1420 (NL-18); OP-75

Utah OP-970

Virginia OF 92-0395

Washington OF 93-0233; OP-1999

West Virginia OF 92-0395

Wyoming OF 92-0408; OF 92-0504; OP-978; OP-1539

Quebec see also Abitibi Belt. crust OP-1920 maps I-1420 (NL-18)

Queensiand Australia

metal ores, Mount Isa Australia OP-942

Questa Caldera

geochemistry OP-490

Quezaltenango Basin

geomorphology OP-277

Quick Quadrangle

sedimentary petrology OP-778

quicksilver see mercury

Quincy Bay

ground water OP-800

quoins

Maryland, engineering geology OF 92-0541

$\mathbf{R}$

$R$ waves see Rayleigh waves

Ra see radium

Ra-226

California, ground water OP-995

Nevada, ground water OP-995

New Jersey, ground water OP-986

Pennsylvania, ground water OP-915

Tennessee, ground water WRI 92-4092

Ra-228

Califormia, ground water OP-995

Nevada, ground water OP-995

Pennsylvania, ground water OP-915

Tennessee, ground water WRI 92-4092

Rabaul Caldera magmas OP-1729

Rabbit Creek Deposit gold ores OP-447; OP-624 metal ores OP-169

rabbitbrush

Colorado, thermal waters OF 93-0017-A; OF 93-0017-B

Raccoon River basin

hydrology OF 92-0094

racemization OP-1619

radar methods see ground-penetrating radar

RADB

geochronology OF 93-0336

radial fractures

Washington, geophysical surveys B 1966

radiation

Colorado, palynomorphs OP-1388

New Mexico, palynomorphs OP-1388

radiation damage

Nevada, lava OP-809

radlo programs OP-616

radioactive decay see also absolute age.

Gabon, geochemistry OP-713

geochemistry OF 92-0525

radioactive isotopes see $\mathrm{Al}-26$; $\mathrm{Ar}-40 / \mathrm{Ar}-39$; $\mathrm{Be}-$

7; Be-10; Be-10/Be-9; C-14; Cl-36; Cs-137; K-

40; Os-187/Os-186; Pb-206/Pb-204;
Pb-207/Pb-204; Pb-208/Pb-204; Pb-210; Ra226; Ra-228;Rb-87/Sr-86;Rn-222; Sm-147/Nd144; Th-230; Th-232; Th-232/Th-230; tritium; U-234/Th-230; U-235; U-238; U-238/Th-230; U-238/U-234

radioactive waste

Alaska, waste disposal OF 92-0502

California, seismology OF 92-0340

engineering geology OP-544

Gabon, geochemistry OP-713

Idaho

environmental geology OF 92-0156 ground water OP-147

Illinois

environmental geology W 2390 hydrogeology W 2386

Missouri, ground water OF 93-0109

Nevada

engineering geology OF 93-0073

environmental geology OF 92-0516

geophysical surveys OF 92-0028; OF 92 0343; OF 92-0572

ground water OF 90-0369; OF 91-0478; OF 93-0071; OP-235

petroleum OF 92-0391

seismology OF 92-0340

structural geology OF 91-0623; OP-108; OP-1400

waste disposal WRI 92-4032; OF 91-0493; OF 92-0484; OP-724; OP-1522

pollution OP-181

Sweden, ground water OP-1039

Tennessee, hydrogeology WRI 92-4131

radioactivity

Arizona, pollution OP-1023

California, geophysical surveys OF 92-0544

Idaho, ground water WRI 92-4184; OF 93 0034

Nevada

ground water WRI 91-4167 lava OP-809

New Mexico, pollution OP-1023

Tennessee, ground water WRI 92-4092; OF $92-$ 0135; OF 92-0166

radioactivity surveys

Colorado

foliation OF 92-0391

geophysical surveys OP-1813

geophysical surveys DDS-0009

Minnesota, kaolin deposits OF 92-0514

Nevada, geophysical surveys OP-1041

North Carolina, heavy mineral deposits OF 92 0396

West Virginia, environmental geology OP-901

radiocarbon dating see $\mathrm{C}-14$

radiolarians

Alaska, stratigraphy OP-1169

Arctic Ocean, Quaternary OF 92-0426

Atlantic Ocean, marine geology OP-822

barite deposits OP-960

Califormia

paleomagnetism OP-385 stratigraphy OF 92-0539-E

Canada, stratigraphy OP-402; OP-708

Celebes Sea, oceanography OP-821

Mexico, Paleozoic OP-56

Nevada, stratigraphy B 1988-D

New South Wales Australia OP-7

Oregon OP-87

Pacific Ocean

geochemistry OP-510

marine geology OP-819; OP-822 
oceanography OP-820

paleomagnetism OP-747

Peru, stratigraphy OP-1330

stratigraphy OP-8; OP-88

United States, stratigraphy OP-708

radiometers

Hawaii, petrology OF 93-0342-A; OF 930342-B

Radiometric Age Data Bank

geochronology OF 93-0336

radium

Colorado, uranium ores OP-568

Ra-226

California OP-995

Nevada OP-995

New Jersey OP-986

Pennsylvania OP-915

Tennessee WRI 92-4092

Ra-228

California OP-995

Nevada OP-995

Pennsylvania OP-915

Tennessee WRI 92-4092

radon

Atlantic Coastal Plain, environmental geology OP-378

earthquakes OP-540

environmental geology C 1105; OP-377

geochemistry OF 92-0391; OP-343; OP-1816

geophysical surveys OP-1580

Gulf Coastal Plain, environmental geology OP378

Maryland, pollution OP-833

Montana, pollution OF 93-0064

Nebraska, geochemistry OF 92-0592

New Mexico, solution features OP-1629

pollution OP-1448

Rn-222

Alaska OF 93-0292-J

Arizona OF 93-0292-I

Califomia OF 93-0292-I; OP-995

Colorado OF 93-0292-H; OP-902; OP-1394

earthquakes OP-539

East Pacific Ocean Islands OF 93-0292-I

environmental geology OF 93-0292-G; OF 93-0292-H; OF 93-0292-I; OF 930292-J

geochemistry OP-379

geologic hazards OP-1052

Hawaii OF 93-0292-I

Idaho OF 93-0292-J

Iowa OF 93-0292-G

Kansas OF 93-0292-G

Missouri OF 93-0292-G

Montana OF 93-0292-H

Nebraska OF 93-0292-G

Nevada OP-995

North Dakota OF 93-0292-H

Oregon OF 93-0292-J

Pennsylvania OP-915

Polynesia OF 93-0292-I

South Dakota OF 93-0292-H

Tennessee WRI 92-4092

Utah OF 93-0292-H

Washington OF 93-0292-J

Wyoming OF 93-0292-H

South Dakota, geochemistry OF 92-0592

Virginia, geochemistry OP-344

West Virginia, environmental geology OP-901

radon-222 see $\mathrm{Rn}-222$

Raft Formation

Quaternary OP-452 rafting, ice see ice rafting

Raging River Formation stratigraphy OF $92-0581$

Railroad Valley

economic geology B 2039

petroleum OF 92-0391; OP-614

structural geology OF 92-0391

Rainbow Gardens Member Neogene OP-92

Rainy Lake intrusions OP-247

Ram Sandstone sedimentary petrology OP-1378

Ramapo River basin ground water WRI 90-4151

Rampart District gold ores OP-589

Rancheria Gulch Sandstone Beds stratigraphy P 1521

range, basin see basin range structure

Rangely Colorado

Cretaceous I-1797-D

rare earth deposits

Alaska OP-1006

China OF 92-0525; OP-153

Far East C 0930-N

Missouri B 2039; OP-1326; OP-1327; OP-1885

rare earths see also lutetium; neodymium; scandium.

OP-478; OP-806; OP-1392

Alaska, geochemistry OP-1373; OP-1410; OP1770; OP-1771

Antarctica, mineralogy OP-275

Arizona, geochemistry OP-203

Atlantic Coastal Plain, heavy mineral deposits B 2039

California geochemistry B 1995-C; OP-512 manganese ores OP-319; OP-458 structural geology OP-332

Chile, magmas OP-971

China

metal ores OP-1238

metasomatism OP-1343

Colorado

geochemistry OP-1218

metal ores OF 92-0525

sedimentary petrology OP- 1382

heavy mineral deposits OF 93-0240-A; OF 930240-B

Indonesia, sedimentary petrology $\mathrm{OP}-870$

Kentucky, geochemistry B 2046

Mexico, geochemistry OP-132

Montana

Archean OP-705

geochemistry OP-1663

petrology OP-1731

Nevada

lava OP-809

petrology B 2052

volcanism OF 93-0021

New Mexico, petrology OF 92-0528

New South Wales Australia, metal ores OP-942

Pacific Ocean, geochemistry OP-419

petrology OF 92-0020-G

Queensland Australia, metal ores OP-942

Rocky Mountains, petrology OP-1716

Vermont, magmas OP-37

Western Interior, stratigraphy OP-1182

rare gases see noble gases
Raritan River

hydrogeology OP-652

RASA

Alabama, ground water P 1410-G

Atlantic Coastal Plain, ground water P 1404-G

California

ground water W 2396; OF 91-0535; OP-72

pollution WRI 91-4119; OP-473

Columbia Plateau, ground water OP-184; OP1016

Great Lakes, ground water P 1405-C

Gulf Coastal Plain, ground water P 1416-C WRI 91-4149; WRI 91-4150; WRI 914151; WRI 91-4152; WRI 92-4102; WRI 92-4103; WRI 92-4104; WRI 924105; OF 92-0661

hydrogeology OP-659

Idaho

ground water WRI 92-4116

hydrogeology P 1408-F; OF 91-0098; OP166

Indiana, ground water OF 93-0119

Michigan, ground water OF 93-0071

Midwest, ground water P 1405-B; OF 92-0489

Mississippi, ground water P 1410-G

Mississippi Valley, ground water WRI 914149; WRI 91-4150; WRI 92-4102; WRI 92-4104

Montana ground water WRI 92-4116 hydrogeology OP-166

New Mexico, ground water $P$ 1407-C

Ohio, ground water OF 93-0119

Oregon ground water WRI 90-4085 hydrogeology OF 91-0098; OP-62

Texas, ground water P 1407-C; WRI 92-4155

Washington

ground water WRI 90-4085

hydrogeology OP-62

rate of sedimentation see sedimentation rates

Raton Basin

geochronology OP-1804

maps I-2266

petroleum OF 93-0337

stratigraphy OP-1182; OP-1880

Raton Formation

maps I-2266

Raton Quadrangle maps I-2266

Rattlesnake Tuff petrology OP-1549

Rawlins Uplift structural geology OF 92-0388

Rayleigh waves

Philippine Islands OP-502

West Pacific Ocean Islands OP-501

Raymond Basin Quaternary OP-1309

$\mathrm{Rb}$ see rubidium

Rb-87/Sr-86

Colorado, geochemistry OP-490 New Mexico, geochemistry OP-490

$\mathbf{R b} / \mathbf{S r}$

OP-805; OP-806

Alabama, structural geology OP-1918

Basin and Range Province, petrology OP-545 geochronology OF 92-0525

Georgia, structural geology OP-1918

Great Basin, petrology OP-545

Maine, metal ores B 2039 
Michigan, structural geology OP-1214

Montana, Archean OP-705

Namibia, meteor craters OP-550

New England, geochronology OF 92-0525 petrology OP-1199

Saudi Arabia, Proterozoic B 1976

Wisconsin, structural geology OP-1214

Wyoming, stratigraphy P 1520

Re see thenium

Re/Os

China, geochemistry OF $92-0525$

Colorado, molybdenum ores OF 92-0525; OP1913

geochemistry OP-1980

geochronology OF 92-0525

Ontario, metal ores OP-1979

petrology OF 92-0525; OP-1977

Yukon Territory, geochemistry OF 92-0525

real-time seismic-amplitude measurement

Washington, elastic waves B 1966

Recapture Shale Member

uranium ores OP-1848

Recent see Holocene

recharge see also hydrologic cycle; infiltration. OP-1838

Alabama, ground water WRI 91-4116

Appalachians, ground water OP-983

Arizona, ground water OP-1468

Basin and Range Province, Quaternary OP1156

California, ground water W 2340; W 2396; WRI 91-4142; OF 91-0535; OP-234; OP255; OP-303; OP-474

Cameroon, geochemistry OP-306

Colorado

ground water OP-167

hydrogeology WRI 92-4050

Columbia Plateau, ground water OP-1016

Florida, ground water WRI 92-4076; OP-671

Georgia, hydrogeology OP-171

Great Basin, Quaternary OP-1156

Great Lakes, ground water P 1405-C

ground water W 2412

Idaho

ground water WRI 93-4054

hydrogeology $\mathrm{P}$ 1408-F

Illinois

hydrogeology W 2386

Quatemary OP-1309

Indiana, ground water OP-1648

Kentucky, hydrology WRI 92-4078

Louisiana, ground water OF 92-0492

Maryland, environmental geology OP-658

Mexico, hydrogeology OP-2007

Michigan, ground water WRI 91-4133

Minnesota, pollution OF 93-0042; OF 93-0079

Mississippi, hydrogeology OP-32

Nevada

geochemistry OP-774; OP-1775

ground water W 2340; OP-234

New England, ground water OP-1472

New Hampshire, ground water WRI 91-4177

New Mexico, ground water WRI 91-4033

North Dakota, hydrogeology WRI 92-41 10

Ohio, ground water OP-1648; OP-1925

Oklahoma, ground water WRI 88-4208

Pennsylvania, ground water OP-387

South Carolina, ground water OP-1202

Spain, ground water OP-1449

Tennessee, hydrogeology WRI 91-4190; ground water WRI 88-4208; OP-2013

hydrogeology WRI 92-4190

United States, hydrogeology OP-2007

Utah, ground water WRI 92-4070; WRI 92 4160

Virginia, ground water WRI 92-4090; OP-1902

Washington, ground water OP-1017

West Virginia, hydrogeology WRI 92-4073

Wyoming, geochemistry OP-874

reclamation see also conservation.

OP-1953

Alaska, non-metal deposits C 1110

Basin and Range Province, non-metal deposits B 2013

Colorado

OF 92-0614

ground water WRI 92-4067; OP-167

Florida, hydrogeology WRI 93-4002

Kansas OP-4

Louisiana, sands OF $92-0530$

Minnesota OF 92-0514

Missouri, hydrogeology WRI 92-4167

Pennsylvania, hydrogeology OF 93-0115

Wyoming, ground water OF 91-0533

recumbent folds

California

OP-1474

red beds

California, energy sources OP-1255

geochemistry OP-104

Missouri, metal ores OP-1418

Montana, Triassic B 1917-P

New York, stratigraphy B 1839-L

Wyoming, Triassic B 1917-P

Red Cloud mining district metal ores OP-290; OP-1715

Red Mountain

economic geology OP-872

Red River

ground water OP-1924

hydrogeology WRI 91-4109; OF 92-0492

hydrology C 1086

petroleum OP-1829

Red River Formation

energy sources OF 93-0337

Red River of the North

hydrology C 1086

red rock see red beds

Red Rock Dam

ground water OP-612

Red Sea

brines, Atlantis II Deep OP-2029

Red Sea region

petrology OP-1952

redbeds see red beds

Redding Quadrangle

gold ores OP-934

mineral resources OF 92-0210-A; OF 92-0210B; OF 92-0316-A; OF 92-0316-B

Redoubt

earthquakes OP-1325

elastic waves B 1966

geologic hazards YR; B 1996; OF 93-0094

Quaternary OP-1250

Redstone Limestone

Pennsylvanian OP-1357

Redwall Limestone

maps I-2290

sulfides OP-1993

reedmergnerite

Sweden OP-1445
Tadzhikistan OP-373; OP-1445

Reedsville Formation

engineering geology OP-1542

fluvial features B 1981

reefs

OP-1662

Alaska OP-1268

atolls

Canary Islands OP -443

Marshall Islands OP-26

Micronesia OP-26

East Pacific Ocean Islands, geochemistry OP925

Florida, ecology C 1086

Galapagos Islands, geochemistry OP-925

geochemistry OP-1005

Hawaii OF 92-0206

Pacific Ocean, Quaternary C 1086

Polynesia, geochronology OP-1436

Puerto Rico

environmental geology OF 92-0717

marine installations OP-1863

Russian Federation, energy sources OP-1967

Samoa OP-844

stratigraphy B 1917-M

Tonga, petroleum OP-896

Reelfoot Rift

deformation OP-1861

earthquakes OP-1996

non-metal deposits OP-1419

Ordovician OP-1818

petrology OP-1417

sedimentary petrology OF 93-0291

structural geology OP-1318; OP-1799; OP1970

tectonics OP-1652

refractory clay see fireclay

Regional Aquifer-System Analysis Program see RASA

regional metamorphism

OP-1355

Alaska

P 1497-C; I-2164

geochemistry OP-1304

metal ores OP-570

Califomia, stratigraphy B 2015

Canada P 1497-C

gold ores OF 92-0557

Idaho OP-1671

Maine, geochemistry OP-750

Nevada, structural geology OP-999

New England, geochronology OF 92-0525

North Carolina, economic geology B 2039

Vermont, copper ores B 2039

regolith

OP-366; OP-609; OP-657; OP-783; OP-1785

Appalachians, ground water OP-400; OP-417; OP-983

North Carolina

ground water OP-239

pollution $\mathrm{OP}-403$

Virginia, Quaternary OF 92-0395

West Virginia, Quaternary OF 92-0395

Reimer technique

environmental geology OP-377

relief

OP-1724; OP-2022

Califomia, geomorphology OF 93-0272

Colorado, hydrogeology OP-408

geomorphology I-2206 
remanent magnetization see also chemical remanent magnetization; isothermal remanent magnetization; natural remanent magnetization; thermoremanent magnetization.

Idaho, paleomagnetism OP-697

Wyoming, paleomagnetism OP-697

REMAPP

geophysical surveys OF 91-0449-A; OF 910449-B; OF 91-0449-C; OF 91-0449-D; OF 91-0449-E; OF 91-0449-F; OF 910449-G

remediation see bioremediation

remote sensing see also albedo; Global Positioning System; infrared methods; SLAR; telemetry. OP-366; OP-416; OP-783; OP-818; OP-906;

OP-987; OP-1323; OP-1438

Africa, conservation C 1086

Alaska

continental shelf OP-837

ecology YR; C 1086

environmental geology SM

Antarctica

geophysical surveys C 1086; OF 91-0014; OP-610

Quaternary C 1086

Arctic Ocean, sea ice C 1086

Arctic region, Quatemary P 1386-E

Arizona, hydrology WRI 92-4133

Austria, Quatemary P 1386-E; OP-386

Bolivia, metal ores OF 93-0016

California

geomorphology OF 93-0272

geophysical surveys OP-227; OP-543 sulfides OP-557

Canada, ecology YR

Colorado

geophysical surveys B 2039; OF 91-0449 D; OF 91-0449-E; OF 91-0449-F; OF 91-0449-G

thermal waters OF 93-0017-A; OF 93-0017.

engineering geology OF 92-0530

environmental geology C 1086

Europe, Quatemary P 1386-E

France, Quaternary P 1386-E

geomorphology OP-847

geophysical surveys YR; OF 91-0014; OF 910449-A; OF 91-0449-B; OF 91-0449-C. OP-1054; OP-1055; OP-1056; OP-1402

Great Lakes, environmental geology OP-1608

Guatemala, geomorphology OP-277

Gulf Coastal Plain, geomorphology OF 920530

Hawaii, geomorphology OP-693

hydrogeology OP-562

hydrology C 1086

Iceland, Quaternary OP-386

Italy, Quatemary P 1386-E

Jan Mayen, Quaternary P 1386-E

Kansas, environmental geology OP-507; OP729; OP-946

metal ores OF 92-0389

Nevada

copper ores B 2039

geochemistry OP-1609

gold ores OP-447; OP-779

sulfides OP-557

non-metal deposits OP-225

North Carolina, economic geology B 2039

Norway, Quatemary P 1386-E

Quatemary C 1086; OP-81

sea water DDS-0010
South Dakota, hydrology W 2340

Spain, Quaternary P 1386-E

Sweden, Quaternary P 1386-E

Switzerland, Quatemary P 1386-E

Texas, environmental geology WRI $92-4117$

Rennie Lake

Quaternary OP-831

Reno Quadrangle

economic geology B 2019

Renpet Mons OP-1725

Repetto Formation

energy sources OF 92-0383

report see annual report

reptiles

Idaho, paleomagnetism OP-1850

Virginia, Phanerozoic OF 93-0222

\section{Reptilia}

Ornithischia, Utah OP-1252

Theropoda OP-1511

Republic Graben

structural geology OP-1187

reservoirs see also floods.

Alabama, hydrology W 2340

Arizona, hydrogeology OP-645

Arkansas, hydrology OF 93-0122

Califomia, hydrology W 2340

Colorado, hydrology WRI 92-4053

hydrogeology C 1086

Idaho, hydrogeology OP-425

Indiana

hydrogeology WRI 92-4025 hydrology WRI 92-4113

Mariana Islands, hydrology WRI 92-4114

Micronesia, hydrology WRI 92-4114

Midwest, pollution OF 93-0418

New Mexico, hydrogeology WRI 92-4193; OP347

North Carolina, geomorphology WRI 93-4031

Puerto Rico, geologic hazards OP-1409

Tennessee, hydrology W 2340

Texas, hydrogeology OF 92-0160

Utah, hydrogeology OP-425; OP-645

Virginia, hydrology WRI 92-4034

Wyoming, ground water OF 91-0533

resurfacing I-2209; OP-28; OP-246; OP-1790

resurgent calderas

California, structural geology OP-569

Resurrection Peninsula

structural geology OP-94

retrograde metamorphism

Ecuador, gold ores B 2039

New South Wales Australia, metal ores OP-942

New York, structural geology OP-461

Queensland Australia, metal ores OP-942

Vermont

economic geology B 1955

structural geology OP-461

Revere Anticline

energy sources OP-1842

reverse faults

OP-1890

Atlantic Ocean, tectonophysics OP-1080

California OP-83; OP-340; OP-803; OP-1945

Idaho, metal ores OF 93-0235

Missouri OP-1861

Northern Territory Australia, Quaternary B 2032-A

Pacific Ocean

plate tectonics OP-1901

tectonophysics OP-1080

South Australia, Quatemary B 2032-B
Wyoming OP-149

reverse slip faults see thrust faults

rhenium see also $\mathrm{Re} / \mathrm{Os}$.

Ontario, metal ores OP-1978

petrology OP-1727

Rhinestreet Shale

natural gas B 1909

Rhode Island

geologic hazards, Providence County Rhode Island OP-1424

hydrology W 2400

maps I-1420 (NK-18)

non-metal deposits OP-1104

oceanography OF 93-0214

Rhode Marsh Deposit

evaporite deposits OP-226

rhodium ores

Montana OF 93-0207

rhodochrosite

California, manganese ores OP-319; OP-458

Minnesota, sedimentary petrology OP-250

Rhododendron Formation petrology B 2054

rhodonite

California, manganese ores OP-319

rhyacolite see sanidine

rhyodacites

Oregon

OP-982

geochemistry OF 93-0314

rhyolite see rhyolites

rhyolite tuff

Idaho, geochronology OP-479

Utah, mineral resources B 2039

rhyolites

OP-1061

Alaska

OP-316

geochemistry OP-1770

Arizona, geochemistry B 2021-C

California

geomorphology OP-266

structural geology OP-1474

Idaho

OP-1381

Eocene OP-617

Quatemary OF 92-0408

Indonesia, geochronology OP-1538

Ivory Coast, Quatemary OF 92-0699

Missouri, metal ores B 2039; OP-1327

Montana, Eocene OP-617

Nevada

OP-809

metal ores OF 93-0249

New Mexico

OP-278

geochronology OP-1538

Quaternary OF 92-0699

Virginia, geochemistry. B 1839-I,J

West Virginia, geochemistry B 1839-I,J

Wyoming geochemistry OP-49

Quatemary OF 92-0408

rhythmite

Kentucky OF 92-0558

Rice Formation

natural gas OP-725

Richmond Basin

guidebook OP-359

Richmond Comer Formation

stratigraphy OP-1530 
Richter Scale

California, seismology OF 92-0441

Rico paleothermal anomaly metal ores OP-1633

Ridge Route Formation structural geology OP-649

Ries Crater stratigraphy B 2050

rift zones

OP-1940

Arctic Ocean

plate tectonics OP-1429

tectonophysics OP-1891

Arctic region, tectonophysics OP-1891

Basin and Range Province, natural gas OP-208

China, metal ores OP-1432

Florida, sedimentary petrology OP-1931

Great Basin, natural gas OP-208

Great Lakes

plate tectonics OP-13

structural geology OP-1533

Great Lakes region, plate tectonics OP-13

Hawaii

geochemistry OP-348

geophysical surveys OP-252

magmas OP-1001

paleomagnetism OP-436

Quaternary OP-284

Idaho, petrology OP-560; OP-561

Illinois, non-metal deposits OP-1419

Kentucky, non-metal deposits OP-1419

Kenya

structural geology OP-2

tectonophysics OP-521

Mediterranean region, tectonophysics OP-1606 metal ores OP-853

Middle East, tectonophysics OP-1606

Minnesota, geochemistry OF 92-0525

New Mexico, petrology OF 92-0528

North Carolina, structural geology OP-1955

Pacific Ocean, tectonophysics OP-432

petrology OP-1417

Quaternary OP-81

Red Sea, brines OP-2029

Russian Federation

geophysical surveys OF 93-0007

Miocene OP-198

structural geology OP-1597

Saudi Arabia, petrology OP-1952

tectonics OP-137

Virginia, structural geology OP-1955

Yukon Territory, metal ores OP-1432

right-lateral faults

Alaska, sedimentation OP-1186

California

OP-405; OP-649; OP-802; OP-803; OP-

972; OP-1063; OP-1442; OP-1701

earthquakes OP-699; OP-700; OP-931

seismology OP-411; OP-593

Illinois OP-1471

Michigan I-2355

Missouri OP-1471

Nevada OP-1400

Poland OP-1916

Venezuela OP-1760

Riley Formation

lead-zinc deposits OP-12

Rincon Formation

energy sources OF 92-0571

petroleum OP-1910

ring complexes

Missouri, iron ores OP-1297 ring silicates see dravite; emerald; tourmaline

ring structures

Papua New Guinea, magmas OP-1729

Philippine Islands, magmas OP-1729

Sweden, geochemistry OP-552

Ringbone Formation

stratigraphy OP-573

rings, tree see tree rings

Rio Amazonas see Amazon River

Rio Bravo del Norte see Rio Grande

Rio Cibuco

heavy mineral deposits OF 92-0703

Rio Grande

hydrogeology WRI 92-4193

Rio Grande de Arecibo Basin pollution OP-663

Rio Grande de Tarcoles pollution OP-335

Rio Grande National Forest geophysical surveys OF 93-0018

Rio Grande Rift

geochemistry OP-490

natural gas OF 93-0248

petrology OF 92-0528

plate tectonics OP-1903

Rio Grande River see Rio Grande

Rio Hondo Pluton

geochemistry OP-490

Rio Lapa

hydrogeology WRI 90-4125

Rio Majada

hydrogeology WRI 90-4125

Rio Puerco

hydrology OP-1435

pollution OP-1023

Rio Vivi District

copper ores OF 93-0178; OF 93-0179

Riphean

Arizona OF 92-0391

Iowa OF 92-0391

Russian Federation OF 92-0391

Ripley Aquifer

ground water P 1410-G; WRI 92-4080

Ripley Formation

ground water WRI 92-4080

ripple marks

Idaho, stratigraphy OP-1351

Montana, stratigraphy OP-1351

Risha Field

energy sources OF $92-0680$

risk, seismic see seismic risk

Riss/Wurm Interglacial France OP-310

Rivera fracture zone tectonophysics OP-1926

rivers see also channel geometry; channels; drainage basins; floodplains; stream transport.

Idaho, hydrogeology OP-425

Louisiana, Quaternary OF 92-0530

Utah, hydrogeology OP-425

RIverside Quadrangle

maps OF 92-0554

Rn see radon

Rn-222

Alaska, environmental geology OF 93-0292-J

Arizona, environmental geology OF 93-0292-I

California

environmental geology OF 93-0292-I

ground water OP-995
Colorado, environmental geology OF 93-0292H; OP-902; OP-1394

earthquakes OP-539

East Pacific Ocean Islands, environmental geology OF 93-0292-I

environmental geology OF 93-0292-G; OF 930292-H; OF 93-0292-I; OF 93-0292-J

geochemistry OP-379

geologic hazards OP-1052

Hawaii, environmental geology OF 93-0292-1

Idaho, environmental geology OF 93-0292-J

Iowa, environmental geology OF 93-0292-G

Kansas, environmental geology OF 93-0292-G

Missouri, environmental geology OF 93-0292-

Montana, environmental geology OF 93-0292-

Nebraska, environmental geology OF 93-0292G

Nevada, ground water OP-995

North Dakota, environmental geology OF 93 0292-H

Oregon, environmental geology OF 93-0292-J

Pennsylvania, ground water OP-915

Polynesia, environmental geology OF 93-0292I

South Dakota, environmental geology OF 93 0292-H

Tennessee, ground water WRI 92-4092

Utah, environmental geology OF 93-0292-H

Washington, environmental geology OF 93 0292-J

Wyoming, environmental geology OF 93 0292-H

Road Canyon Formation geomorphology OP-1703

Roadian stratigraphy OP-354

Roanoke River hydrology OF 92-0123; OF 92-0639

Roaring Fork Trend energy sources $\mathrm{OP}-1751$

Roberts Creek Mountain metal ores OP-627

Roberts Mountain Allochthon see Roberts Mountains Allochthon

Roberts Mountains

Brachiopoda OP-491

geophysical surveys OP-1041

metal ores OP-627

orogeny OP-797

sedimentary petrology OP-1795

Roberts Mountains Allochthon stratigraphy B 1988-D; B 1988-F

Roberts Mountains Formation gold ores OP-27; OP-441 sedimentary petrology B 1988-E

Robertson River igneous suite orogeny OP-1612 structural geology OP-1955

Robinson Limestone Member stratigraphy B 1787-GG

robots geochemistry YR

Rochester Formation hydrogeology OP-1228

Rock Eval see Rock-Eval

rock glaciers

California, Quatemary OP-1254 
rock mechanics see also deformation; highways; hydraulic fracturing.

OP-51; OP-544; OP-600; OP-603; OP-1249

California, earthquakes OP-126

Colorado

OF 93-0071

sedimentary petrology OF 93-0306

earthquakes OP-258

faults OP-601

fractures OF 93-0245

geochemistry OP-572

Germany OP-1029

New Hampshire, environmental geology WRI 92-4012; WRI 92-4056

Ontario, geophysical surveys OF 93-0071

petroleum OP-1206

Utah OP-404

Rock River Formation

Invertebrata P 1533

rock salt see halite

rock slip see rockslides

Rock Springs Formation

OP-1182

sedimentary petrology B 2051

Rock Springs Uplift

petroleum OP-1635

sedimentary petrology B 2051

stratigraphy P 1532

structural geology OF 92-0388

rock varnish

Nevada, Quatemary OP-1070

Rock-Eval

California

energy sources OF 92-0571

petroleum OP-1910

Colorado

coal OP-1911

diagenesis OP-1961

energy sources OP-674; OP-1753

energy sources OP-1476

Mexico, geothermal energy OP-984

Nevada, petroleum OF 93-0186

New Mexico, energy sources OP-674

Sweden, geochemistry OP-584

United States, geochemistry OP-584

Utah, diagenesis OP-1961

rock-stratigraphy see lithostratigraphy

rock-water interface

geochemistry OP-1786

Rockall Bank

paleobotany OP-292

Rockaway River basin

hydrogeology WRI 91-4169

rockfalls

OF 93-0278-A; OF 93-0278-B

California, geologic hazards OF 92-0387

Utah, geologic hazards P 1519

Vermont, engineering geology B 2043

rockslides

Colorado OP-859

earthquakes OP-517

Washington, Quatemary OP-904

Rocky Face Fault

stratigraphy OP-1368

Rocky Gulch Sandstone Member stratigraphy P 1521

Rocky Hills Quadrangle maps OF 93-0519

Rocky Mountain foreland see Rocky Mountains foreland
Rocky Mountain National Park

hydrology OF 92-0628

Rocky Mountains see also Madison Range; Rocky Mountains foreland.

areal geology, Beartooth Mountains OF 930207

base metals, San Juan Mountains OF 93-0183

bibliography, Beartooth Mountains OF 930285-A; OF 93-0285-B

coal, Beartooth Mountains OF 93-0207

crust

Beartooth Mountains OP-2017

Bighorn Mountains OP-2017

deformation OP-883

Devonian OF 93-0184

diagenesis OP-1792

economic geology, Beartooth Mountains OF 93-0207

energy sources OF 92-0524; OF 93-0337

environmental geology OF 93-0292-H

foliation OF 92-0391

geochemistry

San Juan Mountains OP-490; OP-1218

Sangre de Cristo Mountains OP -490

Wind River Range OP-712

geomorphology, San Juan Mountains OP-859

geophysical surveys, Sangre de Cristo Mountains OF 93-0018

ground water WRI 92-4116; WRI 92-4162; WRI 92-4163

hydrogeology WRI 92-4050; OP-166; OP-408

hydrology C 1086; OF 92-0628

maps GQ-1724; GQ-1729; MF-2253; I-1803H; I-2267

metal ores

I-2050-F

Beartooth Mountains OF 93-0207

San Juan Mountains P 1537

mineral resources

C 1088; OF 92-0709

Beartooth Mountains OF 93-0207; OF 930505

Sawatch Range OP-828

natural gas OF 92-0524; OP-1350

Pennsylvanian OP-1103

petroleum

OF 93-0337

Beartooth Mountains OF 93-0207

Uinta Mountains OP-1635

petrology

Beartooth Mountains OP-604; OP-1456; OP-1716

Bighorn Mountains OP-1456

Laramie Mountains OP-1456

plate tectonics OP-1519; OP-1903

pollution OF 93-0064; OP-1008

Quaternary

OF 93-0250

Wasatch Range OP-910

Wind River Range OP-711; OP-1455; OP1884

soils C 1086

stratigraphy

Medicine Bow Mountains P 1520

San Juan Mountains OP-985

Sangre de Cristo Mountains B 1787-EE

Sawatch Range B 1787-EE

structural geology

P 1524; B 1993; OP-118; OP-679

Laramie Mountains OP-149

Rocky Mountains foreland

energy sources OF 93-0337 natural gas OF 92-0524; OF 93-0337

Rodentia see Myomorpha

Rodgers Creek Fault

engineering geology OP-1948

structural geology OP-405

roestone see oolite

Rogers Lake

Quaternary OF 93-0263

roller gates

Missouri, engineering geology WRI 92-4118

Rolling Knoll Landfill

environmental geology OF 92-0153

Romania

oceanography OF 93-0274

Romashkino Field

energy sources OP-1258

Rome Trough

natural gas B 1839-I,J

stratigraphy B 1839-K

roof pendants

Ecuador, gold ores B 2039

Roosevelt Hot Springs KGRA geochemistry OF 93-0260; OP-1505

Roseau Quadrangle soils OF 92-0721

Rosidae

Canada OP-1082

United States OP-1082

Ross Orogeny orogeny OP-1395

Ross Sea

geophysical surveys OF 92-0556

plate tectonics OP-65

stratigraphy OP-470

Roswell Basin

hydrogeology OF 93-0144

rotational wave see $\mathbf{S}$-waves

Roter Kamm Crater meteor craters OP-550

Rough Creek Graben structural geology OP-1799

Roumania see Romania

Routt Plutonic Suite

Proterozoic OP-10

Rowland Quadrangle maps OF 93-0220

Roxana Loess

Quatemary OP-1683

RSAM

elastic waves B 1966

Rua Cove Deposit geochemistry OP-1304

Ruanda see Rwanda

Rub al Khali

Quatemary OP-1198

rubblerock see breccia

rubidium see also $\mathrm{Rb} / \mathrm{Sr}$. $\mathbf{R b}-87 / \mathrm{Sr}-86$

Colorado OP -490

New Mexico OP-490

Scotland, geochemistry OF 93-0267

rubidium-strontium see $\mathrm{Rb} / \mathrm{Sr}$

Ruby River basin paleobotany OP-1082

Rugosa

New York B 2024

Rumania see Romania

rural environment

Georgia, hydrology WRI 93-4016 
Tennessee, hydrology WRI $92-4165$

Russian Federation see also Caucasus; Kuban

River, Siberian Lowland.

Brachiopoda, Timan Ridge OP-491

Cenozoic, Lake Baikal C 1086; OP-2003

energy sources

Lena Basin OP-1967

Orenburg Russian Federation OP-1258

Timan-Pechora region OP-1967

Tunguska Basin OP-1967

engineering geology, Novaya Zemlya OF 930501

geochemistry

Lake Baikal OP-130; OP-1605

Norilsk Russian Federation OP-1086

Sakhalin OP-1412

geomorphology, Lake Baikal OP-1291

geophysical surveys

Baikal rift zone OF 93-0007

Lake Baikal OF 92-0693; OF 93-0007; OP898

Siberian Platform OP-898

Invertebrata, Kuril Islands OP-109

metal ores

Chukchi Peninsula OF 93-0339

Norilsk region OP-2014

Norilsk Russian Federation OP-1313

Russian Pacific region OF 93-0339

Yakutia Russian Federation OF 93-0339

Miocene, Lake Baikal OP-198

Phanerozoic, Aldan Shield OP-1493

Precambrian, Kola Peninsula OP-1777

Quaternary

Lake Baikal C 1086; OP-1208; OP-1334; OP-1492; OP-1532; OP-1604; OP-1763; OP-1764; OP-1874; OP-1904; OP-2004

Yakutia Russian Federation B 2036

sedimentary petrology

Lena Basin OF 92-0391

Tunguska OF 92-0391

structural geology, Lake Baikal OP-1597

Vertebrata

Kolyma River basin B 2037

Yakutia Russian Federation B 2037

Russian Mission Quadrangle

geochemistry OF 92-0582

maps MF-2226-A

mineral resources OF 92-0315; OF 92-0379-A

OF 92-0379-B; OF 92-0380-A; OF 920380-B

Russian Pacific region see also Kuril Islands. metal ores OF 93-0339

Russian Platform see also Timan Ridge. earthquakes OP-1025

Russian Republic see Russian Federation

Russian River

continental shelf $\mathrm{OP}-128$

rutile

petrology OP-635

Rwanda

metal ores C 0930-M

S see sulfur

S-32/S-34 see $\mathrm{S}-34 / \mathrm{S}-32$

S-34

Florida, geochemistry OP-1906

S-34/S-32

Alaska geochemistry OP-1304

metal ores OP-570

Canada, geochemistry OP-1905

China, metal ores OP-1432

Colorado

economic geology OP-872

geochemistry OP-1965

hydrogeology W 2340

metal ores OP-1151

Dominican Republic, metal ores OP-532

energy sources OF 92-0391

England, metal ores OP-1541

Florida, geochemistry OP-151; OP-1906

geochemistry OF 92-0009

Indiana, ground water OP-1648

Maine, geochemistry OP-750

metal ores OP-1117

Mexico, economic geology OP-872

Michigan, copper ores OP-1688; OP-2019

Micronesia, geochemistry OP-59; OP-1150

Missouri, metal ores OP-1327; OP-1885

Nevada

geochemistry OP-774

gold ores OP-441

Ohio, ground water OP-1648

Peru, economic geology OP-872

Poland, metal ores OF 92-0704

Russian Federation, Cenozoic C 1086

South Carolina, ecology OF 93-0303

United States, geochemistry OP-1905

Utah

economic geology OP-872

geochemistry OP-1965

hydrogeology W 2340

Yukon Territory, metal ores OP-1432

S-type granites

Malaysia, geochemistry OF 92-0525

S-waves see also SH-waves.

OP-959; OP-1033; OP-1364

Alaska

OP-1

core OP-1032

Armenia OF 93-0216

California

OP-407; OP-1183; OP-1280

core OP-1032

Canada, core OP-1032

engineering geology OP-497

geophysical surveys OF 92-0561

Hawaii OP-116

hydrology OF 92-0534

Rhode Island, geologic hazards OP-1424

Sabine River

ground water OP-742

Sacra Fossae OP-987

Sacramento Basin

energy sources B 2034-A

plate tectonics OP-1749

Sacramento River

soils OP-1713

Saddle Mountains Basalt ground water WRI 90-4085

sado-type

Colorado, metal ores OF 92-0557

metal ores OF 92-0389

Sagavanirktok Formation

petroleum OP-1285

Saghalin see Sakhalin

Saginaw Formation

ground water WRI 91-4133
Sahara see also Algeria; Tunisia fluvial features OP-314

Sahe

conservation C 1086

Sailor Canyon Formation structural geology OP-1413

Saint Croix Indian Reservation hydrogeology OF 92-0026

Saint Francois Aquifer Pennsylvanian OP-1 192

Saint Francois Mountains iron ores OP-1297

Saint Joe National Forest mineral resources OF 92-0384

Saint Johns River basin ground water OF 93-0050 hydrogeology OF 92-0466

Saint Johns River Water Management District ground water OF 93-0050 hydrogeology OF 92-0466

Saint Kevin Gulch hydrogeology OP-408 hydrology WRI 92-4081 pollution OP-1579

Saint Lawrence River hydrology W 2400 stratigraphy OP-1484

Saint Louks Limestone ground water OP-612

Saint Paul Minnesota ground water $P$ 1530-A non-metal deposits OF 92-0514

Saint Peter Aquifer pollution WRI 90-4150

Saint Peter Sandstone hydrogeology OP-1782

Saint Peter-Prairie du Chien-Jordan Aquifer ground water $P$ 1405-B

Sainte Genevieve Fault deformation OP-1861

Sakhalin geochemistry OP-1412

Sakhalin Basin energy sources OP-1967

Sakhalin Island see Sakhalin

Sakhalin Russian Federation see Kuril Islands; Sakhalin

Salamonie Dolomite hydrogeology OP-1228

Salina Group hydrogeology OP-1228 sedimentary petrology OF 93-0236

Salinas Valley energy sources B 2034-A; OF 89-0450-D

Saline Valley Deposit economic geology OP-662 evaporite deposits OP-226

saline water see salt water

Salinian Block metamorphic rocks OP-1166 paleomagnetism OP-1504 plate tectonics OP-759 structural geology OP-936

Salisbury Embayment stratigraphy P 1542

Salmon Falls River basin ground water WRI 90-4161 hydrogeology OF 89-0583 
Salmon Idaho paleobotany OP-1082

Salmon River hydrology P 0870-A petrology OP-1671

salt see also sodium chloride. OF 92-0593

Colorado OF 93-0248

New York, hydrology OP-1335

Ohio OF 92-0514

phase equilibria OP-1475

Utah

OF 93-0248

hydrology WRI 91-4117

salt domes

Gulf of Mexico, oceanography B 2002

Mississippi, geochemistry OP-1577

Salt Lake City Utah

environmental geology B 2013

geologic hazards $\mathrm{C} 1111$

Quatemary OP-1021

Salt Lake Valley

ground water OF 92-0640

Quatemary OP-911

seismology OP-1076

salt lakes

California, diagenesis OP-1386

Micronesia, geochemistry OP-59

New Mexico, hydrogeology WRI 92-4004

Utah, hydrology WRI 91-4117

salt marshes

geochemistry OP-183

South Carolina, ecology OF 93-0303

salt tectonics see diapirism; faults; salt domes

Salt Wash Sandstone Member

uranium ores OP-1848

salt water see also salt-water intrusion.

Montana, energy sources OP-1947

New Mexico, hydrogeology OP-1299

North Dakota, ground water OP-1924

Utah, ground water OF 92-0124

salt-water intrusion

Atlantic Coastal Plain, hydrogeology OF 920629

California

ground water WRI 91-4148; OF 93-0524; OP-303; OP-961

pollution $\mathrm{OP}-473$

Colorado, hydrogeology W 2340

Delaware, hydrogeology C 1086

Florida

environmental geology WRI 91-4181

ground water W 2340; OP-1568

hydrogeology WRI 92-4062; WRI 92-4069; OF 91-0483; OP-2001

Georgia, ground water W 2392

Massachusetts, ground water OP-1815

Mexico, hydrogeology OP-2001

Nevada, ground water WRI 92-4051

New Jersey ground water WRI 91-4191 hydrogeology C 1086

New Mexico, hydrogeology WRI 92-4004

South Carolina

ground water W 2392

hydrogeology OF 91-0483

Spain, ground water OP-1310; OP-1449

Utah, hydrogeology W 2340

saltation OP-894

Salton Sea

environmental geology OF 93-0083 geothermal energy OP-298; OP-324

stratigraphy OP-257

Salton Sea geothermal field

geochemistry OP-1018

Salton Trough

geochemistry OP-1018

Quaternary OP-1843

Samana Peninsula petrology OP-1900

Samaria Range stratigraphy OP-1320

samarium

$\mathrm{Sm}-147 / \mathrm{Nd}-144$

Colorado OP-490

geochemistry OF 92-0525

New Mexico OP-490

Russian Federation OP-1086

Samoa

areal geology OP-844

sample location maps see site location maps

San Andreas Fault

deformation $\mathrm{P} 1550-\mathrm{C} ;$ OP-802; OP-972

earthquakes OF 91-0032; OP-126; OP-329; OP-406; OP-1025; OP-1102; OP-1587

energy sources $\mathrm{OP}-267$

engineering geology OF 91-0032; OP-125; OP688; OP-1948

geochemistry OP-265

geologic hazards OP-1793

geophysical surveys OF 93-0276

metamorphic rocks OP-1166

neotectonics OP-23; OP-83; OP-1063

plate tectonics OP-145; OP-1749

Quaternary OP-338; OP-1843

seismicity P 1550-C; OP-286

seismology P 1550-C; OP-302; OP-868; OP966; OP-1280; OP-1360; OP-1581 structural geology OP-113; OP-332; OP-649; OP-702; OP-703; OP-803; OP-804; OP-936 tectonophysics P 1550-C; OP-2010

San Andres Formation see also Leonardian. geochemistry OP-1072 ground water WRI 91-4033

San Andres-Glorieta Aquifer ground water WRI 91-4033

San Antonio Mountain Quadrangle maps OF $92-0710$

San Antonio Texas ground water OP-1675

San Augustine Coal Area hydrogeology WRI 92-4004

San Bernardino California ground water W 2340

San Bernardino Mountains deformation OP-972 structural geology OP-649; OP-803

San Bernardino Valley earthquakes OP-329 structural geology OP-703

San Cristobal Island geochemistry OP-925

San Emigdio Mountains structural geology OP-803; OP-936

San Francisco Bay

environmental geology OF 92-0456

hydrogeology OF 93-0146

hydrology OF 93-0057

oceanogräphy OF 92-0382

Quaternary C 1086

tectonophysics OP-1733
San Francisco Bay Quadrangle maps $\mathrm{I}-1420(\mathrm{NJ}-10)$

San Francisco Bay region see also Loma Prieta earthquake 1989.

energy sources B 2034-A

engineering geology OP-882; OP-1948

Eocene OF 93-0180

geophysical surveys OF 92-0531; OF 93-0276; OF 93-0277; OF 93-0301

maps OF 93-0271

neotectonics OP-23

oceanography OF 92-0555; OF 93-0011

Quaternary OF 93-0286

soils OP-1713

structural geology OP-405

San Francisco California

engineering geology OP-1154

geologic hazards OF 90-0677

seismology OP-1047

San Francisco earthquake 1906 Califormia

OP-121; OP-1047; OP-1347; OP-1865

structural geology OP-648

San Francisco Peninsula seismology OP-407

San Gaban igneous complex geochronology OP-1601

San Gabriel Fault neotectonics OP-1063 structural geology OP-649

San Gabriel Mountains deformation OP-972 igneous rocks OP-1112 structural geology OP-703; OP-803

San Gabriel River basin hydrogeology OF 92-0160

San Gorgonio Pass

structural geology OP-703

San Jacinto Fault

earthquakes OF 91-0032; OP-406; OP-503; OP-698; OP-1102

seismology OP-966; OP-1728

structural geology OP-649; OP-703

San Joaquin Basin

energy sources B 2034-A

San Joaquin River soils OP-1713

San Joaquin Valley ground water W 2396; WRI 92-4153; OF 91 0535; OF 92-0655

metamorphic rocks OP-1166

plate tectonics OP-1749

pollution WRI 91-4119; OP-264; OP-599 soils OP-1170

San Jose California geologic hazards OF 90-0677

San Jose Quadrangle geophysical surveys OF 93-0277

San Juan Basin coal OP-1911 energy sources OP-518; OP-674; OP-1264 hydrogeology OP-1299 natural gas OF 93-0248 petroleum OP-435 pollution WRI 93-4007 sedimentary petrology OF 93-0306; OP-850 stratigraphy B 1808-O; B 2025

San Juan Bautista California deformation P 1550-C structural geology OP-936 tectonophysics P 1550-C 
San Juan Mountains base metals OF 93-0183 geochemistry OP-490; OP-1218 geomorphology OP-859 metal ores P 1537 stratigraphy OP-985

San Juan National Forest mineral resources OF 92-0709

San Juan Puerto Rico geologic hazards OP-1409 marine installations OP-1863

San Juan River hydrogeology OF 93-0084

San Juan Trough stratigraphy OP-1523

San Juan volcanic field see also Fish Canyon Tuff.

geochemistry OP-490

metal ores P 1537 pollution OP-315

San Luis Caldera metal ores P 1537

San Luis Hills geochemistry OP-490

San Luis Valley hydrogeology OF 93-0282

hydrology OP-962 natural gas OF 93-0248 thermal waters OF 93-0017-A; OF 93-0017-B

San Manuel District metal ores B 2042-C

San Pablo Bay Quaternary OF 93-0286

San Pedro River geomorphology OP-426

San Salvador earthquake 1986 El Salvador OP-399

San Salvador EI Salvador seismology OP-399

sand

OP-723

Adriatic Sea, pollution OP-47 Alaska, Quaternary OP-1059

Arizona, Quatemary OP-976

Arkansas, Quaternary OP-1683

Califormia, engineering geology OP-1154

Colorado geochemistry OF 92-0525

Quaternary OP-1676

geochemistry OP-16

geomorphology OP-1750

Georgia OP-1502

Great Plains, Quaternary C 1086

ground water OP-207

Gulf of Mexico OP-1864

Illinois

changes of level OP-1393

Quaternary P 1536

Indiana, Quaternary P 1536

Louisiana, geomorphology OF 92-0530

Massachusetts OP-1598

geochemistry OP-215

Minnesota, pollution OF 93-0043

Ohio, ground water WRI 91-4024

Pacific Coast, Quatemary C 1086

pollution OP-1155

Puerto Rico

OF 92-0717

geologic hazards OP-1835 heavy mineral deposits OF 92-0703; OF 93 0341

marine installations $\mathrm{OP}-1863$

Saudi Arabia, Quaternary OP-1198

Spain OP-722

Tennessee, Quaternary OP-1683

United Arab Emirates, Quaternary OP-1198

Washington, Quaternary OP-36

Wyoming, geochemistry OF 92-0525

sand bars see bars

sand bodies

Louisiana, geomorphology OF 92-0530

Montana B 1917-L

Wyoming B 1917-L

sand boils

Califomia, sedimentary petrology OP-445

sand dunes see dunes

sands

Gulf Coastal Plain

OF $92-0530$

Quaternary OF 92-0530

Gulf of Mexico OF 92-0530

Quaternary OF 92-0530

Louisiana OF 92-0530

Michigan OF 92-0514

Puerto Rico OF 92-0717

Sands Quadrangle

structural geology I-2355

sandstone

OF 92-0386; OP-709

Alabama OP-1858

Alaska

OP-1553

energy sources OP-626

natural gas B 2034-A; OF 93-0230

petroleum B 2034-A

stratigraphy OP-1169

Arizona, geochemistry B 2021-C

Arkansas OF 93-0291

Atlantic Coastal Plain, environmental geology OP-378

California

energy sources B 2034-A

stratigraphy OF 92-0588; OP-1281

structural geology OP-1701

China, metal ores OP-317

Colorado

OF 93-0306; OP-1567

hydrogeology W 2340

natural gas OF 92-0524

oil and gas fields OP-1857

petroleum OF 93-0337

stratigraphy B 2025; OP-1399

Colorado Plateau, uranium ores OP-1848

engineering geology OP-760

Gulf Coastal Plain, environmental geology OP378

Idaho

stratigraphy OP-1351

structural geology OP-941

Indiana OF 92-0391; OP-1466

Kentucky

OF 92-0558

stratigraphy OF 92-0558

Maryland, engineering geology OF 92-0541

Mexico OP-50

Michigan OP-139

Midwest, ground water P 1405-B

Minnesota, ground water P 1530-A

Mississippi

OP-1856; OP-1858 geochemistry OP-1577

Missouri OF 93-0291

Montana

energy sources OF 93-0337

stratigraphy OP-1351

structural geology OP-941

natural gas B 1839-I,J; OF 92-0524; OF 930337

New Jersey OP-1379

New Mexico ground water WRI 91-4033

stratigraphy B 2025

New York, stratigraphy B 1839-L

New Zealand OP-1391

Ohio

OF 92-0558

stratigraphy OF 92-0558

Oklahoma

geophysical surveys OP-1741

ground water WRI 88-4208; OF 93-0071

natural gas OF 92-0524; OF 93-0230

petroleum OF 92-0391

Oregon, natural gas B 2034-A

Pennsylvania

energy sources OP-1842

stratigraphy OF 92-0568.

Pennsylvanian OP-1518

petroleum OP-1206

Saudi Arabia

metal ores OP-1559

Proterozoic B 1976

stratigraphy OP-1368

structural geology OP-602

Texas

ground water WRI 88-4208

petroleum OF 93-0522

United Arab Emirates, stratigraphy OP-1453

Utah

Cretaceous OP-919

ground water OF 92-0124

hydrogeology W 2340

oil and gas fields OP-1857

oil sands OP-1855

stratigraphy $B$ 1787-BB

Victoria Australia, petrology OP-1136

Virginia

energy sources OP-1751

stratigraphy OP-1367

Washington

I-1963

natural gas B 2034-A

stratigraphy OF 92-0581

West Virginia, stratigraphy OP-1367

Wisconsin, ground water OP-1090

Wyoming

B 2051; OP-1950

energy sources OF 92-0391; OF 93-0337

Miocene B 1917-O

natural gas OP-1569

stratigraphy $P 1532$

structural geology OF 92-0388

sandstone deposits

Ohio OF 92-0514

Sandusky River

ground water OP-1354

Sanford Formation

stratigraphy OP-597

Sanford Volcano

maps GQ-1688

Sangamonian

Illinois OP-1309 
Sangerville Formation geochemistry OP-750

Sangre de Cristo Mountains geochemistry OP-490 geophysical surveys OF 93-0018 stratigraphy $B$ 1787-EE

Sangsang Mine sedimentary petrology OP-870 sanidine

Haiti, geochronology B 2065 Indonesia, geochronology OP-1538

Iowa, geochronology OP-475 Ivory Coast, Quaternary OF 92-0699

Montana, geochronology B 2065

New Mexico geochronology OP-1538 Quatemary OF 92-0699

phase equilibria OP-1311 South Dakota, geochronology OP-475 Wyoming, Quaternary OF 92-0391

Santa Ana Quadrangle geophysical surveys OF 93-0217-A; OF 930217-B

Santa Ana Terrane

structural geology OP-1172; OP-1971

Santa Barbara Basin

engineering geology B 2002

geochemistry OF 92-0539-A; OF 92-0539-C

Miocene OF 93-0182; OP-1570

petroleum OF 92-0539-F

stratigraphy OF 92-0539-B; OF 92-0539-D; OF 92-0539-E; OF 93-0177

Santa Barbara California diagenesis OP-174 petroleum OP-1910 stratigraphy $\mathrm{OP}-469$

Santa Barbara Channel energy sources OF 92-0571 petroleum OP-1910 tectonophysics OP-2010

Santa Barbara Islands see Channel Islands

Santa Catalina Island structural geology OP-1971

Santa Clara River ground water OP-255; OP-474

Santa Cruz California engineering geology OP-1582 geologic hazards $\mathrm{P}$ 1553-B

Santa Cruz Formation

Vertebrata OP-97

Santa Cruz Mountains earthquakes OP-1183 geologic hazards OP-1793 seismicity P 1550-C seismology OP-1794

Santa Fe Basin natural gas OF 93-0248

Santa Fe Group ground water WRI 91-4155

Santa Maria Basin energy sources OF 89-0450-C geochemistry B 1995-C; OF 92-0539-A; OF 92-0539-C

maps OP-1945

Miocene OF 93-0182; OP-1570

petroleum OF 92-0539-F; OP-793; OP-1910

stratigraphy OF 92-0539-B; OF 92-0539-D; OF 92-0539-E; OF 93-0177

Santa Maria Islands

sedimentation OP-188
Santa Maria Quadrangle maps OP-1945

Santa Rosa II Dome geochronology OP-1538

Santonian

South Carolina B 2030

Utah OP-1779

Wyoming B 2051

saprolite

Appalachians, ground water OP-400

Maryland, environmental geology OP-658

Minnesota, kaolin deposits OF 92-0514

North Carolina

MF-2223

pollution OP-403

Virginia, geochemistry OP-1774

Western Australia, geochemistry OP-1774

sapropel

Florida, geochemistry OP-1906

SAR OP-786; OP-1062; OP-1596

Sarasota Arch

sedimentary petrology OP-1931

Saratoga Chalk OP-527

Sarawak Malaysia

petroleum OP-1829

sedimentation OP-1211

Saskatchewan

hydrology C 1086

metal ores, Athabasca District OP-1431

satellites see Callisto Satellite; Galilean satellites;

Ganymede Satellite; icy satellites; Io Satellite;

Triton Satellite

Saturn OP-1348

Saudi Arabia see also Arabian Shield. gold ores YR maps OP-308; OP-309; OP-370; OP-371; OP372

metal ores OP-1559

Proterozoic B 1976

Quaternary OP-1198

sedimentary petrology $\mathrm{OP}-1378$

Saurischia see Theropoda

Savannah Georgia

hydrogeology OF $92-0629$

Savannah River

Invertebrata OP-291

Savannah River Plant engineering geology B 2017

Sawatch Range mineral resources OP-828 stratigraphy B 1787-EE

Sawyers Bar Terrane structural geology OP-1451

Saxidomus giganteus Pleistocene OP-1619

Sb see antimony

Sc see scandium

Scaliognathus stratigraphy OP-1245

Scandinavia see Norway; Sweden scandium

Colombia, geochemistry OP-755

England, geochemistry OP-755

Poland, geochemistry OP-755

Texas, geochemistry OP-755

Scanlon Nappe petrology OP-1691

scanning electron microscopy sedimentary petrology OP-89
Scaphitaceae

stratigraphy OP-177; OP-526

scapolite group see magadiite

scarps see also erosion features.

OP-609; OP-1240; OP-1647; OP-1938; OP-

$1939 ;$ OP-1940

Florida

geochemistry OP-151

sedimentary petrology OP-1931

Italy, plate tectonics OP-1682

Pacific Ocean, plate tectonics OP-1901

Puerto Rico, oceanography B 2002

scheelite

New South Wales Australia, metal ores OP-942

Queensland Australia, metal ores OP-942

schists see also blueschist; greenstone; tourmalinite.

Alabama OP-1237

Alaska

folds OP-1427

metal ores OP-570

Arizona, gold ores OF 92-0591-A; OF 920591-B

California, structural geology OP-442; .OP1971

heavy minerals OF $92-0386$

Idaho OP-434

Maryland, environmental geology OP-658

Montana

OP-1731

Archean OP-705

Nevada, metal ores OF 93-0249

New York, structural geology OP-461

Vermont

copper ores B 2039

structural geology OP-461

Washington I-1963

schizomycetes see bacteria

Schlumberger methods

California, ground water OF 93-0279; OF 930524

Colorado, hydrogeology OF 93-0282

schuppen texture see imbricate tectonics

Scioto River

environmental geology WRI 92-4130

Scleractinia see Montastrea; Porites

scoria

Philippine Islands OP-1768

Scotia Sea Islands see South Shetland Islands

Scotland

geochemistry, Ayrshire Scotland OF 93-0267

ScP-waves

core OP-1032

SDO-1 shale sample

geochemistry B 2046

SDTS

maps YR

Se see selenium

Sea Beam see Seabeam

sea fan see submarine fans

sea floor spreading see sea-floor spreading

sea floors see ocean floors

sea ice

Alaska OF 93-0019; OF 93-0237

Arctic Ocean C 1086

Sea Mapping and Remote Characterization see SeaMarc

sea mounts see seamounts

Sea of Cold OP-1439; OP-1485; OP-1830

Sea of Crises OP-1439; OP-1485 
Sea of Fertility OP-1439

Sea of Okhotsk see Okhotsk Sea

Sea of Rains OP-237; OP-1314; OP-1485; OP1487; OP-1841

Sea of Serenity OP-237; OP-609; OP-1781

Sea of Serpents OP-1439

Sea of Waves OP-1439

sea water see also brines; salt-water intrusion. DDS-0010

Alaska OF 93-0019

California

hydrogeology OF 93-0146

hydrology OF 93-0057

Florida, ecology C 1086

geochemistry OF 92-0525; OP-537; OP-1973

Hawaii OF 92-0206

Pacific Ocean, geochemistry OF 91-0014; OP628

sea-floor spreading see also fracture zones; magnetic anomalies; plate divergence; spreading centers.

Alaska OP-1430

Antarctic Ocean OP-1446

California, metal ores OP-554

Colombia, geochemistry OP-755

England, geochemistry OP-755

Pacific Ocean OP-432

Poland, geochemistry OP-755

Red Sea, brines OP-2029

stratigraphy OP-1756

Texas, geochemistry OP-755

sea-floor trench see trenches

sea-level changes see changes of level

sea-surface temperature

sea water DDS-0010

sea-water intrusion see salt-water intrusion

Seabeam

Vanuatu, plate tectonics OP-197

Seaman volcanic center

petrology B 2052

SeaMarc

Gulf of Mexico ocean floors OP-743 oceanography OP-1864 Quaternary OP-1966

Hawaii, oceanography B 2002

seamounts

Canary Islands, engineering geology OP-443

Italy, plate tectonics OP-1682

Kazakhstan, plate tectonics OP-1295

Pacific Ocean

geochemistry OP-419

tectonophysics OP-897

Vanuatu, plate tectonics OP-185; OP-197; OP1286

seams, coal see coal seams

SEAPCONE

oceanography OF 92-0719

Searles Lake

Quaternary OF 93-0232; OF 93-0311

Seattle Basin

neotectonics OF 93-0332

Seattle Quadrangle maps OF 93-0233

Seattle Washington earthquakes OP-1118

engineering geology OF 91-0441-T

neotectonics OF 93-0332

seawater see sea water
Sebascodegan Formation

stratigraphy OP-1530

secondary structures see concretions; geodes

secondary wave see $\mathrm{S}$-waves

sediment load see bedload

sediment supply

Arizona, Quaternary OP-976

Mississippi, oceanography OP-1740

sediment transport see also ice rafting; marine

transport; saltation; stream transport.

Alaska

engineering geology $\mathrm{OP}-140$

geologic hazards OF 93-0094

hydrology WRI 92-4132

Bering Sea, oceanography OP-129

California

continental shelf OP-128

oceanography OP-751

Great Plains, Quaternary C 1086

Gulf of Mexico

oceanography OP-1864

Quaternary OP-1966

Idaho, stratigraphy OP-1351

Louisiana OP-262

Minnesota, paleobotany OP-101

Montana, stratigraphy OP-1351

Pennsylvanian OP-1233

Puerto Rico, marine installations OP-1863

Samoa OP-844

Saudi Arabia, Quaternary OP-1198

South Carolina, continental shelf OP-346

United Arab Emirates, Quaternary OP-1198

sedimentary petrology see clay mineralogy; diagenesis; heavy minerals; reefs; sedimentary structures; sedimentation; sediments; weathering

sedimentary rocks see also cement; chemically precipitated rocks; clay mineralogy; coal; diagenesis; lithostratigraphy; oil sands; oil shale; organic materials; volcaniclastics.

Alaska, heat flow OP-253

Appalachians, zinc ores B 2039

Arctic Ocean, structural geology OP-1428

arenite

Michigan OP-1495

Saudi Arabia B 1976

Virginia OP-1755

Arizona

geochemistry OP-203

mineral resources OF 92-0509-A; OF 92 0509-B

Neogene OP-92

Atlantic Ocean, stratigraphy OP-1797

bentonite

OP-89; OP-1352; OP-2000

environmental geology OP-1898

Haiti B 2065

Mississippi OP-746

Montana B 2065

stratigraphy OP-1702

black shale

Alaska B 2034-A

Atlantic Ocean OP-1894

Canada B 1909

Carboniferous OP-1232

China OF 92-0525; OP-363; OP-1432

Colorado OF 92-0391; OP-1262; OP-1961

energy sources B 1909

Kentucky B 1909; OF 92-0558

Maine OP-750

metal ores OP-362; OP-714

Mississippian B 1909 natural gas B 1909

Nebraska OF 92-0592

Nevada OP-624

New York B 1909

Ontario B 1909

Pacific Ocean OP-1894

Pennsylvanian OP-1233

Peru OP-1331

petroleum B 1909

Rocky Mountains OP-1103

South Dakota OF 92-0592

stratigraphy B 1909; OP-1345

Sweden OP-584; OP-1649

United States B 1909; OP-584; OP-1649

Utah OF 92-0391; OP-1262; OP-1961

West Virginia B 1909

Yukon Territory OF 92-0525; OP-363; OP1432

breccia

OP-1674

Bolivia OP-1306

California OP-1474; OP-1971

Chile OP-957

Ecuador B 2039

Iowa OP-475; OP-1113; OP-1114; OP1540; OP-1613; OP-1915

Mexico OP-920

Nevada OF 93-0021; OF 93-0249; OP-1847

petrology OP-1199

Poland OF 92-0704

South Dakota OP-475

Utah B 2039; OF 92-0391

Washington OP-957

California

OP-1945

economic geology B 2019; OP-260; OP-662

energy sources OF 92-0383

Miocene OF 93-0182

carbonate rocks

Alabama OP-1602

Basin and Range Province OP-208

Colorado B 1787-EE; B 1787-GG; OF 920391; OF-93-0248; OP-1262; OP-1399; OP-1965

Commonwealth of Independent States OP1261 ; OP-1265

Europe OP-1261; OP-1265

Florida WRI 91-4168; OP-2001

Georgia W 2391

Great Basin OP-208

Great Lakes OP-1354

Illinois OP-1782

Kazakhstan OP-1295

Kentucky OP-1782

Massachusetts OP-801

metal ores OF 92-0557

Mexico OP-2001

Midwest P 1405-B; OF 92-0489

Minnesota OF 92-0514

natural gas B 1839-I,J; OF 92-0524

Nevada B 1988-E; B 1988-F; B 2039; WRI 91-4167; OF 92-0391; OF 930248; OF 93-0249

New Jersey OP-652

New Mexico B 1787-EE

New York B 1839-L

Ohio WRI 91-4024

Pacific Ocean OP-1356

Pennsylvania OP-111

Pennsylvanian OP-1233

Poland OF 92-0704

Quaternary OF 92-0525

Rocky Mountains OP-1103 
stratigraphy B 1917-M

Tennessee OP-1283

Turkey OP-39

Utah B 1787-BB; OF 92-0391; OF 93-0248; OP-1096; OP-1262; OP-1464; OP-1965

Vanuatu OP-197

West Virginia OP-901

Western Interior OP-1332

chalk

Atlantic Coastal Plain OP-378

chert

Gulf Coastal Plain OP-378

Alaska OP-1169

Califomia OP-385; OP-458

Canada OP-708

Kentucky OF 92-0558

Kenya OP-1490

Nevada OF 93-0249

Oregon OP-1490

stratigraphy OP-88

United States OP-708

clastic rocks

Califomia P 1521

Colorado B 1787-GG

Great Lakes region B 1989-E

metal ores OF 92-0557

Minnesota OF 92-0514

Montana B 1917-Li OF 92-0391

natural gas OF 92-0524

Nevada OP-774

New Mexico OF 93-0522

Oklahoma OF 92-0524

Oregon P 1521

Pakistan OP-1634

South Carolina OP-1202

stratigraphy B 1917-M

Texas OF 93-0522

Utah B 2000-E; OF 93-0270; OP-1464

Wyoming B 1917-L; OF 92-0524; I-2380-B

claystone

Colorado OP-1880

Iowa OP-1537

New Mexico OP-1880

Western Interior OP-794; OP-1182

Colorado

B 1787-DD; I-2266

pollution WRI $93-4007$

conglomerate

OP-709

Califomia OF 92-0588; OF 92-0707; OP469

Idaho OP-479; OP-1351

Michigan OP-1495

Montana OP-1351

Nevada B 1988-E

New York B 1839-L

Ohio OF 92-0558

Pakistan OP-1548

Pennsylvania OF 92-0568

Saudi Arabia B 1976

United Arab Emirates OP-1453

contourite, Spain OP-722

diamictite

Antarctic Ocean OP-1630

California OP-797

Idaho OP-797

diatomaceous earth, California B 1995-C; B 2034-A

dolostone

Florida OP-1931

Midwest OP-1228

Ordovician OP-1819

Tennessee WRI 91-4190
Dominican Republic, metal ores OP-1576

eolianite, Pacific Coast C 1086

evaporites

California OP-227

Colorado B 1787-GG; OF 92-0391; OP1262; OP-1523; OP-1965

Commonwealth of Independent States OP1261

Europe OP-1261

Kenya OP-1490

Massachusetts OP-801

New Mexico OP-2012

non-metal deposits OP-225

Oregon OF 90-0506; OP-1490

Pennsylvanian OP-1233

Red Sea OP-2029

Rocky Mountains OP-1103

Texas OP-2012

Utah OF 92-0391; OP-1262; OP-1523; OP1965

fanglomerate, Arizona OP-1748

flysch

Alaska P 1497-C

Canada P 1497-C

Nevada OP-1795; OP-1846

geochemistry OF 92-0525

grainstone, Idaho OP-1320

Great Lakes region, copper ores OP-1216

Iceland, stratigraphy OP-1303

Idaho

natural gas OF 93-0248

Quaternary OP -452

iron formations

Australia OP-1431

Canada OP-1431

Greenland OP-848

Michigan OP-1495

Montana OP-1087; OP-1731

Kentucky, stratigraphy OF 92-0558

limestone

Alaska OP-1169

California OP-1281; OP-1474

Canada OP-1776

Carboniferous OP-1232

Florida W 2340; OP-494; OP-1931

geochemistry OP-165

Georgia W 2392

Haiti OP-1179

Indiana OP-1845

Mexico OP-1179

Midwest OP-1228

Montana B 1917-P

Nevada OP-441; OP-623; OP-1775

New Mexico WRI 91-4033

Pakistan OP-1548

Saudi Arabia B 1976

South Carolina W 2392

stratigraphy OP-1345

United Arab Emirates OP-1453

United States OP-1776

West Virginia OP-1357

Wyoming B 1917-P

marl

California OF 93-0232

Hungary OP-1687

United Arab Emirates OP-1453

Mexico, barite deposits OP-796

Michigan, copper ores OP-1688

micrite, Nevada OP-1795

mineral resources OF 92-0557

Mississippi Valley, Paleozoic OF 92-0685

Missouri, lead-zinc deposits OP-644

molasse, Pakistan OP-1548
Montana

Cretaceous OC-0138

structural geology B 1993

mudstone

Colorado Plateau OP-1848

Idaho OP-1351

Mexico OP-50

Montana OP-1351

Pennsylvania OF 92-0525

United Arab Emirates OP-1453

Utah OP-919; OP-1252

natural gas $\mathrm{OF}$ 92-0524

Nevada

economic geology B 2019; OP-260

gold ores OP-27; OP-779; OP-1048

metal ores $\mathrm{OP}-627$

mineral resources OP-218

Neogene OP-92

petrology OP-973

New Mexico

I-2266

pollution WRI 93-4007

Ohio, stratigraphy OF 92-0558

packstone, Idaho OP-1320

phosphate rocks, Georgia OP-1502; OP-1677 red beds

California OP-1255

geochemistry OP-104

Missouri OP-1418

Montana B 1917-P

New York B 1839-L

Wyoming B 1917-P

sandstone

OF 92-0386; OP-709

Alabama OP-1858

Alaska B 2034-A; OF 93-0230; OP-626; OP-1169; OP-1553

Arizona B 2021-C

Arkansas OF 93-0291

Atlantic Coastal Plain OP-378

California B 2034-A; OF 92-0588; OP1281; OP-1701

China OP-317

Colorado B 2025; W 2340; OF 92-0524; OF 93-0306; OF 93-0337; OP-1399; OP1567; OP-1857

Colorado Plateau OP-1848

engineering geology OP-760

Gulf Coastal Plain OP-378

Idaho OP-941; OP-1351

Indiana OF 92-0391; OP-1466

Kentucky OF 92-0558

Maryland OF 92-0541

Mexico OP-50

Michigan OP-139

Midwest P 1405-B

Minnesota P 1530-A

Mississippi OP-1577; OP-1856; OP-1858

Missouri OF 93-0291

Montana OF 93-0337; OP-941; OP-1351

natural gas B 1839-I,J; OF 92-0524; OF 930337

New Jersey OP-1379

New Mexico B 2025; WRI 91-4033

New York B 1839-L

New Zealand OP-1391

Ohio OF 92-0558

Oklahoma WRI 88-4208; OF 92-0391; OF 92-0524; OF 93-0071; OF 93-0230; OP-1741

Oregon B 2034-A

Pennsylvania OF 92-0568; OP-1842

Pennsylvanian OP-1518 
petroleum OP-1206

Saudi Arabia.B 1976; OP-1559

stratigraphy OP-1368

structural geology OP-602

Texas WRI 88-4208; OF 93-0522

United Arab Emirates OP-1453

Utah B 1787-BB; W 2340; OF 92-0124; OP-919; OP-1855; OP-1857

Victoria Australia OP-1136

Virginia OP-1367; OP-1751

Washington B 2034-A; OF 92-0581; I-1963

West Virginia OP-1367

Wisconsin OP-1090

Wyoming P 1532; B 1917-O; B 2051; OF 92-0388; OF 92-0391; OF 93-0337;

saprolite OP-1569; OP-1950

Appalachians OP-400

Maryland OP-658

Minnesota OF 92-0514

North Carolina MF-2223; OP-403

Virginia OP-1774

Western Australia OP-1774

shale

B 1909; OF 92-0391; MF-1835-H

Alaska OP-626

Atlantic Coastal Plain OP-378

California OF 92-0571; OP-797; OP-1281

Canada B 1909

Central America OP-1862

Colorado OF 92-0391; OP-1965

Commonwealth of Independent States OP1261

Europe OP-1261

geochemistry OP-1923

Great Plains OP-879

Gulf Coastal Plain OP-378

Gulf of Mexico OP-287; OP-288

Hungary OP-1687

Idaho OP-797; OP-1351

Kentucky B 1909; B 2046

Michigan OP-139

Mississippian B 1909

Montana I-2380-A; OP-1351

New Jersey OP-1379

New York B 1839-L

Ohio B 1909; OF 92-0558

Oklahoma OP-1741

Pacific Ocean OP-1356

Pennsylvania OF 92-0568; OP-1842

Poland OF 92-0704

stratigraphy OP-1368

Texas OF 92-0391

United States B 1909

Utah OP-919; OP-1965

Virginia OP-1367; OP-1751

West Virginia B 1909; OP-1367; OP-1542

Wyoming I-2380-A

siliceous sinter, Wyoming OF 93-0293

siltstone

Colorado OP-1262

Idaho OP-1351

Kansas OP-725

Montana OP-1351

Nevada OP-441; OP-1795

New Jersey OP-1379

Texas OP-1387

Utah OP-919; OP-1262

Virginia OP-1751

stratigraphy OP-1756

taconite, Minnesota OF 92-0514

tonstein

OP-93; OP-228; OP-1293
Indonesia OP-870

stratigraphy OP-1821

Western Interior OP-1182

torbanite, geochemistry OP-1923

travertine

California OF 92-0707

Montana OP-978

Wyoming OP-464; OP-978

tufa

California OF 93-0232; OF 93-0311; OP-77 Nevada OP-76

Utah

B 1787-DD

gold ores OP-74

volcanic breccia, Oregon OP-982

Wyoming, Cretaceous OC-0136; OC-0138

sedimentary structures

bedding

California OP-458

Ohio OF 92-0558

bioherms, Nevada OP-1846

bioturbation

Arctic Ocean OF 92-0426; OP-1796

Mississippian B 1909

Pacific Ocean OP-519

West Virginia OP-1357

Bouma sequence, California OP-1281

clastic dikes

California OP-445

Illinois $\mathrm{P} 1536$

Indiana $P 1536$

concretions

California B 1995-C

geochemistry OP-183

Kenya OP-1490

Oregon OP-1490

cross-bedding

California OP-1281

Colorado OP-1567

Gulf Coastal Plain OP-1817

Kentucky OF 92-0558

United Arab Emirates OP-1453

Wyoming B 2051

cross-stratification

OP-1717

Ohio OF 92-0558

Pakistan OP-1548

cyclothems

Pacific Ocean OP-1356

Western Interior OP-1231

dune structures

OP-1717

Saudi Arabia OP-1378

United Arab Emirates OF 92-0391

Utah B 2000-E

flame structures, California OP-128

flute casts, California OP-1281

geodes, Alaska OP-1373

graded bedding

Gulf of Mexico OP-1864

Pakistan OP-1548

Idaho, structural geology OP-941

imbrication, Pakistan OP-1548

laminations

Arctic Ocean OP-1796

Bahamas OP-928

barite deposits OP-960

California OP-1281

Minnesota OP-20; OP-668; OP-739

Oregon OF 93-0212

Washington OF 93-0212

lebensspuren, Kentucky OF 92-0558 load casts, California OP-1281

Montana, structural geology OP-941

Nevada B 1988-E

olistoliths, engineering geology OP-744

olistostromes

California OP-1344

Vanuatu OP-1908

planar bedding structures

California OP-469

New Hampshire WRI 90-4161; WRI 914025; OF 89-0583; OF 92-0095

New York WRI 91-4030

hythmite, Kentucky OF 92-0558

ripple marks

Idaho OP-1351

Montana OP-1351

sand bodies

Louisiana OF 92-0530

Montana B 1917-L

Wyoming B 1917-L

stromatolites

Colorado OF 92-0525

Wyoming OF 92-0525

Utah OF 93-0270

varves

Atlantic Ocean OP-1650

Minnesota C 1086; OP-20; OP-21; OP-100; OP-101; OP-248; OP-251; OP-739

stratigraphy $P$ 1506-F

sedimentation see also basins; bedload; bioturbation; changes of level; channels; continental margin sedimentation; continental shelf; continental slope; cyclothems; diagenesis; heavy minerals; ice rafting; lakes; marine transport; reefs; saltation; sediment supply; sediment transport; sedimentary rocks; sedimentation rates; sediments; stream transport; tidal flats.

OP-509; OP-1211

Alaska

OP-1186

Quaternary OP-1059; OP-1507

Arizona, neotectonics OP-611

Atlantic Coastal Plain, geologie hazards OF 92 0377-A; OF 92-0377-B

Atlantic Ocean

I-2279-B

Pliocene OF 92-0508

bioclastic sedimentation

Antarctic Ocean OP-263

Arctic Ocean OF 92-0426

California

OP-1098

paleomagnetism OP-385 stratigraphy B 2015

Canada, stratigraphy OP-708

coastal sedimentation

California OP-751

Louisiana OF 92-0530

Tonga OP-989

Utah OP-1779

Wyoming B 2051

Colorado

geochemistry OF 92-0525

stratigraphy OP-1523

structural geology OP-118

deep-sea sedimentation

OP-738

Atlantic Coastal Plain OP-1185

Pacific Ocean OP-519

deltaic sedimentation

Georgia B 2039

Louisiana B 2002; OF 92-0530; OP-653 
South Carolina B 2039

detrital sedimentation

Black Sea OF 93-0274

Middle East OF 93-0274

estuarine sedimentation

Atlantic Ocean OP-483

Florida OP-893

Kentucky OF 92-0558

Massachusetts OP-546

fluvial sedimentation

Alabama W 2340

Alaska OF 93-0162

Arizona YR

Black Sea OF 93-0274

Georgia B 2039

hydrogeology OP-24

hydrology OF 92-0651

Idaho $P$ 0870-A

Middle East OF 93-0274

Mississippi Valley OF 91-0485

Missouri OP-1544

Montana B 1917-I

North Carolina W 2364

Samoa OP-844

South Carolina B 2039

South Dakota OP-641

Tennessee W 2340; WRI 92-4082

West Virginia B 1981

Wisconsin WRI 90-4124

Wyoming B 1917-L; OP-556

fluviolacustrine sedimentation

Alaska WRI 92-4132

Mariana Islands WRI 92-4114

Micronesia WRI 92-4114

glacial sedimentation

Great Lakes OP-1290

ground water OP-952

Washington OF 93-0233

glaciofluvial sedimentation, Minnesota OF 930345

glaciolacustrine sedimentation, Great Lakes OP-1288

glaciomarine sedimentation

Alaska B 2002; OP-1225

Arctic Ocean C 1086; OF 92-0426

Gulf of Mexico OF 92-0530

Greenland, Quaternary OP-1507

Gulf of Mexico OP-1012

Idaho, geochronology OP-479

intertidal sedimentation, Kentucky OF 92-0558

Kazakhstan, plate tectonics OP-1295

Kentucky

OF 92-0558

stratigraphy OF $92-0558$

lacustrine sedimentation

Arkansas OF 93-0122

California OP-68; OP-831

Great Lakes OP-1290

Indiana WRI 92-4033; WRI 92-4113

Nevada OP-68; OP-831

North Carolina WRI 93-4031

Ohio OP-1925

Russian Federation OP-1208; OP-1492; OP1597; OP-2003

West Virginia OP-1357

marine sedimentation

Atlantic Ocean OF 92-0566; OP-1650

Caribbean Sea DDS-0015

Gulf Coastal Plain OP-838

Gulf of Mexico DDS-0015

Louisiana B 2002; OF 92-0530

Nevada OP-1847

Pacific Ocean OP-1901
Puerto Rico OF 92-0717

Samoa OP-844

Massachusetts OP-1598

Montana

geochemistry OP-1094

stratigraphy OF 92-0391

New Zealand OP-1391

Ontario, Devonian B 1909

Oregon OP-1098

Pacific Ocean OP-243

paludal sedimentation

Colorado OP-850

Montana B 1917-L

Tennessee OP-462

Wyoming B 1917-L

Pennsylvanian OP-1518

petroleum OP-710

Puerto Rico, geomorphology OP-1007

Russian Federation, Miocene OP-198

Saudi Arabia, Proterozoic B 1976

stratigraphy $P$ 1506-F

structural geology OP-159

United States, stratigraphy OP-708

Utah, stratigraphy B 1787-BB; OP-1523

Vanuatu OP-188

Washington

engineering geology OP-956

stratigraphy OF 92-0581

Wyoming

energy sources OP-889

geochemistry OF $92-0525$

stratigraphy $P 1532$

sedimentation rates

Arkansas OP-1529

Atlantic Coastal Plain, oceanography OP-1337

Califomia

Quaternary OP-338; OP-878

stratigraphy OP-469

Celebes Sea

marine geology OP-823

oceanography OP-821

Colorado, geochemistry OP-1965

Great Lakes, Quatemary OP-1288; OP-1290

Gulf of Mexico, oceanography OP-1864

Louisiana, continental shelf B 2002

Minnesota OP-739

Mississippian B 1909

New Jersey, stratigraphy OP-979

North Carolina, geochemistry OP-1684

Pacific Ocean

geochemistry OP-510

oceanography OP-820

Pakistan, natural gas OP-1634

Philippine Islands, geologic hazards WRI 92 4039

Russian Federation, Quaternary OP-1208

Sweden, geochemistry OP-584

Tennessee

OP-1529

hydrogeology OP-462

hydrology WRI $92-4082$

United States, geochemistry OP-584

Utah, geochemistry OP-1965

Vermont, environmental geology OP-1481

Wyoming

OP-556

stratigraphy OP-98 sediments see also bedload; clay mineralogy; diagenesis; halite; heavy minerals; lithostratigraphy; peat; volcaniclastics; weathering.

OP-241; OP-894; OP-1887

Alaska

GQ-1688

engineering geology OP-140

mineral resources MF-2144-C; MF-2144-D

Quatemary OF 93-0266

alluvium

Alaska OP-33

Arizona P 0497-H; OP-426

Arkansas OF 93-0273

California OP-1065

Colorado OP-1676; OP-1813

Dominican Republic OP-808

Georgia B 2039

hydrogeology OP-659

Illinois P 1536

Indiana P 1536

Kentucky WRI 92-4138

Missouri OF 93-0101; OF 93-0109; OF 930140; OP-1544

Montana WRI 92-4163

Nevada WRI 92-4032; OP-624

Puerto Rico OP-1960

Quaternary OP-459

seismology OP-959

South Carolina B 2039

Tennessee OF 93-0273

Washington OF 91-0441-T

West Virginia OP-1542

Arctic Ocean, oceanography OP-835

Arkansas

ground water OF 93-0096 hydrology OF 93-0122

Atlantic Coastal Plain environmental geology OP-378; OP-1185

ground water P 1404-G; OP-1239

non-metal deposits OP-1104

Basin and Range Province, Quaternary C 1086

boulders

Nevada OP-1070

West Virginia B 1981

California

environmental geology OF $92-0456$

Quatemary C 1086; OF 93-0232; OP-878

carbonate sediments

OP-1662

Florida B 2002

Georgia OP-1501

Mississippi Valley OP-1818

clastic sediments

Appalachians OP-1484

Connecticut WRI 87-4144

Minnesota OP-668

New Hampshire WRI 90-4161; WRI 914025; OF 89-0583; OF 92-0095

New York WRI 88-4127; WRI 91-4030

Ohio WRI 93-4047

South Carolina B 2030

Washington OF 93-0233

West Virginia OP-901

clay

Atlantic Ocean OP-1650

California OP-702

Colorado OP-902

Great Lakes OP-1288

Hawaii OP-1814

hydrology OF 92-0651

Oregon OF 93-0212

Washington OF 93-0212

Wyoming OP-1884 
cobbles, Pakistan OP-1548

colluvium

Hawaii OP-782

Italy OP-764

Nevada OP-1070; OP-1276

Utah OP-970

Virginia B 1981

West Virginia B 1981

Colorado

hydrology WRI 91-4095

pollution WRI 93-4007

Quaternary OP-1324

diamicton, Antarctic Ocean OP-263

dust

Alaska OP-1507

Greenland OP-1507

engineering geology OP-579

flint clay, Kentucky OF 92-0558

Florida

marine installations OP-892

oceanography OP-1510

geochemistry OP-44; OP-1766; OP-1990

gravel

Arkansas OP-1683; OP-1700

geochemistry OP-16

hydrogeology OP-24

Illinois P 1536

Indiana P 1536

Massachusetts OP-215

Missouri OP-1544; OP-1700

pollution OP-1155

Tennessee OP-1683

Utah OP-908; OP-909; OP-911; OP-1021

Great Basin, Quaternary C 1086

Great Lakes

hydrology OP-199

Quatemary OP-200; OP-1290

ground water OP-1473

Gulf Coastal Plain

environmental geology OP-378

ground water P 1416-C; WRI 91-4150;

WRI 91-4151; WRI 91-4152; WRI 92

4102; WRI 92-4103; WRI 92-4104; WRI 92-4105

gyttja

Oregon OF 93-0212

Washington OF 93-0212

hydrology OF 93-0125

Idaho

ground water WRI 92-4116

paleomagnetism OF 92-0542

stratigraphy OF 92-0713

Illinois

environmental geology W 2390

Quatemary OP-1309

Indiana

geochemistry OP-1685

hydrology WRI 92-4019

loess

Alaska OP-390

Arkansas OF 93-0273; OP-1683

Great Lakes OP-836

Mississippi Valley OF 93-0273

Missouri OP-1571

Quaternary OF 93-0273

Tennessee OF 93-0273; OP-1683

Louisiana

engineering geology OF 92-0530

geochemistry OP-935

pollution OF 92-0492

Quatemary OF 92-0530

marine sediments

OF 92-0719
Adriatic Sea OP-47

Alabama OF 92-0530

Alaska B 2002; OF 93-0019; OP-515

Antarctic Ocean OP-263

Appalachians OP-1484

Arctic Ocean C 1086; OF 92-0426; OF 92 0439; OF 93-0218; OP-516; OP-1796

Arctic region OF 92-0439

Atlantic Coastal Plain P 1542; OF 92-0263; OP-1205; OP-1337

Atlantic Ocean B 2002; OF 92-0508; OF 92-0550; OP-791; OP-822

Bahamas OP-928

Bering Sea OP-129

Black Sea OF 93-0274

California B 2002; OF 93-0340; MF-2212; I-2090-A; OP-128; OP-1443; OP-1444

Celebes Sea OP-821

Connecticut OF 93-0214

Florida B 2002; OP-151; OP-893

geochemistry OF 92-0525; OP-608

Georgia OP-1501; OP-1502

Gulf Coastal Plain OF 92-0530; OP-1205

Gulf of Mexico OF 92-0530

Hawaii B 2002

Louisiana OF 92-0530

Maryland OP-439

Massachusetts DDS-0003; OP-749

Middle East OF 93-0274

Mississippi OF 92-0530

New Hampshire OP-1207

Pacific Ocean OF 92-0712; OP-419; OP510; OP-519; OP-819; OP-820; OP-822

Peru OP-1331

Puerto Rico OF 92-0717; OF 93-0341

Rhode Island OF 93-0214

Vanuatu OP-187; OP-197; OP-368

Micronesia, geochemistry OP-59

Midwest, Quaternary OF 93-0543

Minnesota

OP-739

geochemistry OP-249; OP-251

paleobotany OP-101

Quatemary C 1086; OP-20; OP-21; OP-100

Mississippi, geochemistry OP-1577

Mississippi Valley, ground water WRI 914150; WRI 92-4102; WRI 92-4104

Missouri, hydrology WRI 93-4012

Montana, ground water WRI 92-4116 mud

OP-723

Atlantic Ocean OP-1650

Bahamas OP-928

geochemistry OP-183

Gulf of Mexico OP-1966

Nevada, Quatemary C 1086

New Jersey

environmental geology OF 93-0243

hydrogeology WRI 91-4169

stratigraphy OP-979

New Mexico

hydrogeology OP-347

pollution WRI 93-4007

New York

hydrology OF 92-0476

pollution OP-412

North Carolina

heavy mineral deposits OF 92-0396 hydrogeology OF 93-0163

North Dakota, hydrology OF 93-0066

ooze, Vanuatu OP-197

Oregon

OP-1403
Quaternary B 2038

outwash

Massachusetts OP-431

Quaternary OP-201

Pacific Ocean, geochemistry OP-1127

paleobotany OP-293

pebbles, Pakistan OP-1548

pollution OP-948

Puerto Rico, geologic hazards OP-1409

Quaternary C 1086

Rhode Island, geologic hazards OP-1424

Russian Federation

Cenozoic C 1086; OP-2003

geochemistry OP-1412

geophysical surveys OF 93-0007

Quatemary C 1086; OP-1334; OP-1532; OP-1604; OP-1763; OP-1874; OP-1904;

sand OP-2004

OP-723

Adriatic Sea OP-47

Alaska OP-1059

Arizona OP-976

Arkansas OP-1683

California OP-1154

Colorado OF 92-0525; OP-1676

geochemistry OP-16

geomorphology OP-1750

Georgia OP-1502

Great Plains C 1086

ground water OP-207

Gulf of Mexico OP-1864

Illinois P 1536; OP-1393

Indiana $P 1536$

Louisiana OF 92-0530

Massachusetts OP-215; OP-1598

Minnesota OF 93-0043

Ohio WRI 91-4024

Pacific Coast C 1086

pollution OP-1155

Puerto Rico OF 92-0703; OF 92-0717; OF 93-0341; OP-1835; OP-1863

Saidi Arabia OP-1198

Spain OP-722

Tennessee OP-1683

United Arab Emirates OP-1198

Washington OP-36 Wyoming OF 92-0525

Adriatic Sea OP-47

Georgia OP-1502

Great Lakes OP-1288

Gulf of Mexico OP-1864; OP-1966

hydrology OF 92-0651

Indiana OP-1308

Massachusetts OP-1598

Missouri OP-1308

soils OF 91-0513

South Carolina

ecology OF 93-0303

Quatemary I-1935

stratigraphy OP-1788

Tennessee, fluvial features OP-767

till

Great Lakes OP-1288

Iceland OP-1303

Iowa OF 92-0500

Minnesota OP-169

Missouri OP-1571

Nevada OP-169

New England OP-748

North Dakota OP-1924

Quaternary OP-1256 
Tonga, geomorphology OP-989

Utah ecology WRI 92-4084 mineral resources MF-2081-C Quaternary OP-620

Vermont environmental geology OP-1481 pollution OP-412

Virginia

ground water WRI 92-4090; WRI 92-4111 Quaternary OF 92-0395

Washington

hydrogeology OF 92-0520; OF 92-0644 hydrology OF 91-0453 pollution OP-1827

West Virginia, Quaternary OF 92-0395

Wisconsin

ground water C 1086; WRI 92-4077

hydrogeology OF 92-0026

Wyoming OP-556

seeps, oil see oil seeps

SEG-Y

geophysical surveys OF 93-0226

SEGDB

petroleum DDS-0005

Segerstrom, Kenneth

geologic hazards OF 93-0197-A

SEGMENT

petroleum DDS-0005

seiches

Utah, geologic hazards P 1519

Seigler Spring

thermal waters OP-997

SEISGRAM

elastic waves OF 92-0441

seismic energy

Alaska, Quaternary OP-1714

seismicity OP-1866

seismic gaps

Alaska, neotectonics OP-1852

California, neotectonics OP-23

Hawaii, seismology OP-1088

Japan, neotectonics OP-1852

seismology OP-735

SEISMIC II

earthquakes OP-1678

seismic intensity see also modified Mercalli scale.

Alaska, seismology P 1527

Califomia

earthquakes OF 92-0575

engineering geology EV

Egypt, engineering geology OF 93-0181

Hawaii, engineering geology B 2006

seismic methods see also elastic waves; seismic profiles.

OF 92-0561; OF 92-0590; OF 93-0005; OF 93 0226; OP-318; OP-1374; OP-1807

environmental geology WRI 92-4012; WRI 92 4056

seismic sources OF 93-0221

seismology OP-15

seismic moment

OP-1422

Alaska, earthquakes OP-1189

Atlantic Ocean, tectonophysics OP-1080

California

earthquakes OP-503; OP-504; OP-1992

neotectonics OP-23

seismology OP-1872

earthquakes OP-940; OP-1024

Pacific Ocean, tectonophysics OP-1080 seismology OP-1033; OP-1370; OP-1371

South Africa, engineering geology OP-660

West Pacific Ocean Islands, earthquakes OP501

seismic networks

Alaska

earthquakes OF 93-0309

seismology C 1031

Armenia, earthquakes OF 93-0216

California

earthquakes YR; OP-1183; OP-1498

geologic hazards OP-221

seismology OF 92-0340; OF 92-0441; OF 93-0227; OF 93-0295

Colorado, earthquakes OP-1423

earthquakes OF 92-0441; OF 92-0577

Mariana Islands, geologic hazards OP-1962

Micronesia, geologic hazards OP-1962

Nevada

earthquakes OP- 1300 seismology OF 92-0340

Pacific Ocean, seismology OP-1160

Puerto Rico, seismology C 1031

seismology OF 92-0441; OP-70; OP-1365

Washington, seismology B 1966

seismic profiles see also vertical seismic profiles.

Alabama, Quaternary OF 92-0530

Alaska

continental slope B 2002

engineering geology B 2002

geophysical surveys OF 93-0238

natural gas OP-74

oceanography B 2002

Quaternary OF 93-0266

seismology OP-1384

Arkansas, structural geology OP-1970

Atlantic Coastal Plain, oceanography OP-1337

Atlantic Ocean

continental margin B 2002

continental slope B 2002

Bering Sea, deformation OP-211

California

continental margin B 2002

continental shelf B 2002

engineering geology B 2002

geophysical surveys OF 92-0570; OF 930276

neotectonics OP-83

oceanography B 2002

structural geology OP-340

Canada, metal ores OP-728

Caribbean Sea, oceanography DDS-0015

Chile, plate tectonics OP-586

Florida, sedimentary petrology OP-1931

Great Lakes

hydrology OP-199

Quaternary OP-1289

Gulf of Mexico

ocean floors OP-743

oceanography DDS-0015

sedimentation OP-1012

Hawaii, oceanography OF 92-0206

Illinois, non-metal deposits OP-1419

Jordan, energy sources OF 92-0680

Kentucky, non-metal deposits OP-1419

Kenya, structural geology OP-2

Louisiana

geomorphology OF 92-0530

Quatemary OF 92-0530

Michigan, structural geology B 1904-S

Midwest, structural geology OP-1799

Minnesota, structural geology B 1904-S
Mississippi, Quaternary OF 92-0530

Nevada, structural geology OP-108

New York, structural geology OP-461

North Carolina, geophysical surveys OF 93 0264

Oregon, geophysical surveys OF 93-0318

Pacific Ocean, Pennsylvanian OP-1356

Papua New Guinea, petroleum OP-307

Puerto Rico, marine installations OP-1863

reefs OP-1662

Russian Federation

geomorphology OP-1291

structural geology OP-1597

sedimentary petrology OP-723; OP-738

South Carolina

geophysical surveys OF 92-0723

seismicity OP-2032

stratigraphy OP-1788

structural geology OP-1890

United States, metal ores OP-728

Utah, mineral resources B 2039

Vanuatu

marine geology OP-191

plate tectonics OP-185

Vermont, structural geology OP-461

seismic response

Califormia

earthquakes OF 93-0509; OP-329

engineering geology $\mathrm{OP}-1582$

geologic hazards OF $90-0677$

seismology OF 93-0295; OP-407

engineering geology OP-497

Rhode Island, geologic hazards OP-1424

seismology OP-1390

Utah, seismology OP-1076

seismic risk see also nuclear facilities; seismic zoning.

Alaska, engineering geology OF 93-0338

California, engineering geology OF 91-0032

earthquakes OP-1024

engineering geology $\mathrm{OP}-1108$

geologic hazards P 1519 OP-1109

Indonesia, engineering geology OP-993

Nevada, structural geology OP-1400

Pacific Ocean, earthquakes OP-734

Rhode Island, geologic hazards OP-1424

Utah

engineering geology $P 1519$

geologic hazards P 1519

seismic sea waves see tsunamis

seismic sounding see deep seismic sounding

seismic sources

OF 93-0221; OP-676; OP-1033; OP-1275; OP-

1370; OP-1371

Atlantic Ocean, tectonophysics OP-1080

engineering geology B 2017; OP-1108

geophysical surveys OF $92-0561$

Indonesia, engineering geology OP-993

mantle OP-1363

Mexico, plate tectonics OP-670

Pacific Ocean, tectonophysics OP-1080

selsmic stratigraphy

OP-1144

Antarctic Ocean, Quaternary OP-1358

Arizona, Neogene OP-92

Atlantic Ocean, Quaternary OP-1650

Great Lakes, Quaternary OP-1288; OP-1290

Nevada, Neogene OP-92

Papua New Guinea, economic geology OP-639

Russian Federation, Cenozoic OP-2003

sedimentary petrology $\mathrm{QP}-723$

Vanuatu, sedimentation OP-188 
seismic surge see tsunamis

seismic surveys see also crust; seismic profiles; vertical seismic profiles.

Alaska

earthquakes OP-1325

marine geology OF 92-0706

oceanography B 2002

petroleum DDS-0005; OP-1285

Quaternary OP-1342

Antarctic Ocean, geophysical surveys OF 920556

Arctic Ocean, plate tectonics OP-1429

Arizona, geophysical surveys YR

Atlantic Coastal Plain, stratigraphy P 1542

California

geologic hazards OP-969

geophysical surveys YR; OF 93-0301

plate tectonics OP-759

Celebes Sea, geophysical surveys OP-585; OP587

Great Lakes region, geophysical surveys OP-

Gulf Coastal Plain

non-metal deposits OF 92-0530

Quaternary OF 92-0530

Gulf of Mexico

non-metal deposits OF 92-0530

Quaternary OF 92-0530

structural geology OP-1932

Louisiana, sands OF 92-0530

Massachusetts, environmental geology OF 92 0646

Nevada

geophysical surveys OF 93-0187

petroleum OP-614

structural geology OF 92-0391

New Hampshire, environmental geology WRI 92-4012; WRI 92-4056

New York, structural geology OP-460

Ontario, structural geology OP -460

Oregon, geophysical surveys OF 93-0347

Pennsylvania, energy sources OP-1842

Puerto Rico, oceanography OF 92-0513

Russian Federation geophysical surveys OF 92-0693; OF 930007; OP-898

Utah Quaternary OP-1532

Quaternary OP-970 seismology OP-1076

Vanuatu, geophysical surveys OP-318

Washington, geophysical surveys OF 92-0714; OF 93-0347

Wisconsin, ground water WRI 92-4077

seismic waves see elastic waves

seismic zoning

engineering geology B 2017; OP-1184

Mississippi Valley, structural geology OP-358

South Carolina, Quaternary I-1935

seismicity see also seismic gaps; seismicity maps;

seismotectonics.

OP-1866; OP-1937

Alaska P 1527; OP-1556; OP-1802

Califormia

OF 92-0340; OP-121; OP-357; OP-438;

OP-466; OP-673; OP-1280; OP-1360; OP-

1746; OP-1914

geochemistry OP-955

geophysical surveys OP-1555

structural geology OP-569

earthquakes OP-517

Egypt, earthquakes OP-1092 engineering geology B 2017; OP-67

Great Lakes, structural geology OP-1533

Hawaii OP-1812

hydrogeology OP-467

Iceland OP-322

Idaho, neotectonics OP-780

Illinois, structural geology OP-1471

Indonesia, engineering geology OP-993

Kenya, tectonophysics OP-521

Midwest, structural geology OP-1799

Mississippi Valley, heat flow OP-1661

Missouri, structural geology OP-1471

Nevada OF 92-0340; OP-357; OP-2026

Oklahoma OP-301

Pacific region, mantle OP-1020

Papua New Guinea, magmas OP-1729

Philippine Islands, magmas OP-1729

South Carolina

OP-2032

geophysical surveys OF 92-0723

Spain, geologic hazards OP-1372

tectonics OP-1652

Tennessee, Quaternary OP-856

Utah, rock mechanics OP-404

Washington, magmas OP-1362

Wyoming, neotectonics OP-780

seismicity maps

earthquakes OF 92-0533

Hawaii, engineering geology B 2006

Mississippi Valley, seismology SM

seismographs see electromagnetic seismographs; ocean bottom seismographs; short-period seismographs; three-component seismographs

seismology see also core; crust; earthquakes; elastic waves; explosions; mantle; microearthquakes; Mohorovicic discontinuity; seismic sources; seismicity.

OF 92-0441

seismostratigraphy see seismic stratigraphy

seismotectonic maps

Missouri, earthquakes OP-1996

seismotectonics see also seismic gaps.

OP-1422

Alaska, seismology OP-1

Atlantic Ocean, tectonophysics OP-1080

California

OP-113

earthquakes OP-406; OP-699; OP-1025

plate tectonics OP-145; OP-752

seismicity P 1550-C; OP-286

seismology OP-411; OP-541; OP-593; OP1581

Chile, seismology OP-53

earthquakes OP-1893

Europe, plate tectonics OP-206

Idaho OP-634

Italy, Quaternary OP-764

Mexico, plate tectonics OP-670

Mississippi Valley, engineering geology OF $92-0391$

Missouri OP-1318

Oregon OP-634

Pacific Ocean, tectonophysics OP-1080

seismology OP-1275; OP-1867; OP-2033

Utah

OP-621; OP-909

earthquakes OP-905

Seldovia Arch

petroleum OP-492

selenate ion

Nevada, pollution OP-1765
Selenga River valley

geophysical surveys OP-898

selenium

Alaska, pollution OP-66

California

ground water W 2396; OF 91-0535; OF 92 0655

pollution WRI 91-4119

Colorado, sedimentary petrology OP-1382

Nevada, pollution OP-1765

pollution OP-181

Utah, ecology WRI 92-4084

Wyoming

ground water OF 91-0533

pollution OP-1871

Selma Group see Eutaw Formation

Selwyn Basin metal ores OP-1432

Semail Ophiolite

Oman, structural geology OP-815

Semarkona Meteorite petrology OP-1666

Senakin Coal sedimentary petrology $\mathrm{OP}-870$

Seneca Mine ground water OF 92-0122; OP-167

Senonian see Campanian; Coniacian; Maestrichtian; Santonian

sensing, remote see remote sensing

sensitive clays

Utah, geologic hazards P 1519

sepiolite

Texas, sedimentary petrology OP-1991

Septentrional Fault

plate tectonics OP-808

sequence stratigraphy

Atlantic Coastal Plain P 1542

Louisiana, Quaternary OF 92-0530

New Jersey OP-979

reefs OP-1662

Utah, Cretaceous OP-919

Sequoia 2000 OP-383

Serbia see Kosovo-Metohija

Sergipe Brazil

geophysical surveys OP-1329

sericite

Bolivia, metal ores B 2039

California, economic geology OP-260

Nevada

economic geology OP-260

gold ores OP-27.

serpentine group

Ontario OP-1892

serpentinite

OF 92-0020-G

economic geology OF 92-0020-B

Sesia-Lanzo Zone petrology OP-851

Sespe Formation energy sources OP-1255

Seven Rivers Formation geochemistry OP-1072

Sevier orogenic belt

Paleogene B 1787-Q

tectonics OP-2021

Seward Alaska geologic hazards B 2002

Seward Peninsula petroleum B 2034-A 
Sexton Creek Limestone

hydrogeology OP-1228

SH-waves

Atlantic Ocean, tectonophysics OP-1080

Pacific Ocean, tectonophysics OP-1080

shaded relief maps

I-2276; OP-1149; OP-1589; OP-1595; OP-1596

geomorphology I-2206

shake wave see $\mathrm{S}$-waves

shale see also clays; oil shale.

B 1909; OF 92-0391; MF-1835-H

Alaska OP-626

Atlantic Coastal Plain, environmental geology OP-378

Califormia

OF 92-0571

orogeny OP-797

stratigraphy OP-1281

Canada, palynomorphs B 1909

Central America, geologic hazards OP-1862

Colorado

environmental geology OF 92-0391

geochemistry OP-1965

Commonwealth of Independent States OP-1261

Europe OP-1261

geochemistry OP-1923

Great Plains, geochemistry OP-879

Gulf Coastal Plain, environmental geology OP378

Gulf of Mexico

OP-288

petrology OP-287

Hungary OP-1687

Idaho

orogeny OP-797

stratigraphy OP-1351

Kentucky

B 1909

geochemistry B 2046

Michigan OP-139

Mississippian B 1909

Montana

I-2380-A

stratigraphy OP-1351

New Jersey OP-1379

New York, stratigraphy B 1839-L

Ohio B 1909; OF 92-0558

Oklahoma, geophysical surveys OP-1741

Pacific Ocean, Pennsylvanian OP-1356

Pennsylvania OF 92-0568; OP-1842

Poland OF 92-0704

stratigraphy OP-1368

Texas, environmental geology OF 92-0391

United States, palynomorphs B 1909

Utah

Cretaceous OP-919

geochemistry OP-1965

Virginia

OP-1751

stratigraphy OP-1367

West Virginia

B 1909

engineering geology OP-1542

stratigraphy OP-1367

Wyoming I-2380-A

shale oil see oil shale

shallow aquifers

Alabama, ground water P 1410-G

Atlantic Coastal Plain, pollution OP-1458

California, ground water W 2396; OF 92-0655

Colorado, pollution WRI 93-4007

Florida, hydrogeology WRI 91-4186 ground water YR; W 2412

hydrogeology OF 93-0040

Kansas, ground water WRI 92-4169; WRI 924177; WRI 93-4036

Mississippi, ground water P 1410-G

Montana, ground water WRI 92-4163

Nevada, ground water WRI 92-4051

New Jersey

environmental geology OF 92-0153

ground water WRI 91-4191

New Mexico, pollution WRI 93-4007

New York, ground water WRI 91-4030; WRI 92-4100

pollution OF 93-0418

Utah, ground water OF 92-0640

Virginia

ground water WRI 92-4090; WRI 92-4111 hydrogeology OP-1196

shallow-focus earthquakes

OP-497

Alaska OP-1

El Salvador OP-399

Washington, Quatemary OP-36; OP-647

Shannon Sandstone Member

B 1917-O

energy sources OF 93-0337

petroleum B 2039

Sharon Springs Member

geochemistry OF 92-0592

Shawangunk Formation B 1839-L

Shawangunk Mountains

stratigraphy B $1839-\mathrm{L}$

shear cleavage see slip cleavage

shear wave see S-waves

shear zones see also mylonites.

Arctic Ocean, tectonophysics OP-1891

Arctic region, tectonophysics OP-1891

Arizona, metal ores OP-290

California

engineering geology OF 93-0348; OP-125; OP-688

orogeny OP-1566

petrology OP-1691

Colorado, geophysical surveys OP-1813

faults OP-127; OP-601; OP-640; OP-685

geochemistry OP-379

Idaho, gold ores B 2039

plate tectonics OP-1133

Quebec, gold ores OP-1097

tectonophysics OP-463

Venezuela, tectonics OP- 1760

Virginia, geochemistry OP-344

Sheep Range

geochemistry OP-1775

sheet silicates see also berthierine; chlorite group;

chrysocolla; clay minerals; mica group; serpen-

tine group; talc.

New Jersey OP-1489

New South Wales Australia OP-1489

Sheffield Illinois

environmental geology W 2390

hydrogeology W 2386

shelf, continental see continental shelf

shelves, ice see ice shelves

shield volcanoes

OP-142; OP-1222; OP-1406

Alaska GQ-1688

geophysical surveys OP-1374

Hawaii, paleomag̀netism OP-436

Iceland OP-1405

Washington geologic hazards B 1966

geophysical surveys B 1966

Shingobee Lake

hydrology OF 93-0127

Shirley Ann Deposit

mineralogy OP-500

shoals

Gulf Coastal Plain, Quatemary OF 92-0530

Gulf of Mexico, Quaternary OF 92-0530

Shochary Ridge Sequence

areal geology B 1994

shock metamorphism

Colorado

geochronology OP-1804

palynomorphs OP-1388

Iowa

geochronology OP-475; OP-1613

stratigraphy OP-1537

Mexico, geochronology OP-920

Montana, stratigraphy OP-1744

New Mexico, palynomorphs OP-1388

Ontario

OF 92-0391

mineralogy OP-1178

Rocky Mountains, diagenesis OP-1792

South Dakota, geochronology OP-475

stratigraphy OP-1788

Western Interior, diagenesis OP-1792

Wyoming, stratigraphy OP-1744

shock waves OP-857

Shoemaker Canyon Quadrangle coal OP-17

Shonkin Sag Laccolith

magmas OP-1294

shore features see also barrier islands; beaches;

cheniers; coastal dunes; coastlines; deltas;

fjords; marine terraces; shoals; spits; tidal chan-

nels; tidal flats; tidal inlets.

Chile, Quaternary OP-35; OP-719

Quaternary OP-756

shorelines see also barrier isłands; bays; coastal

sedimentation; coastlines.

Alaska

engineering geology B 2002

oceanography B 2002

Basin and Range Province, Quaternary OP-910

engineering geology OF 92-0530

Florida, engineering geology OP-895

geophysical-surveys OF $93-0257$

Gulf Coastal Plain, Quatemary OF 92-0530

Gulf of Mexico, Quaternary OF 92-0530

Hawaii, geologic hazards YR

Louisiana

ecology OF 92-0530

engineering geology OF 92-0530

geologic hazards OF $93-0210$

land subsidence OF $92-0530$

sands OF 92-0530

Puerto Rico

environmental geology OF 92-0717

geologic hazards OF 92-0717

marine installations OP-1863

Rocky Mountains, Quatemary OP-910

Samoa OP-844

Vanuatu, geologic hazards OP-1521

short-period seismographs

Califomia, seismology OF 93-0295

shortening, crustal see crustal shortening

Shoshone geyser basin

thermal waters OF 93-0293 
Shuksan Suite petrology OP-1900

Shumagin Islands neotectonics OP-1852

Shungura Formation OP-656

Siam see Thailand

Siberia

Cenozoic C 1086

geochemistry OP-1086

geochronology OP-134

geomorphology OP-1291

geophysics OP-136

Mesozoic OP-1494

Phanerozoic OP-1493

Quaternary C 1086; OP-1208; OP-1334; OP-

1492; OP-1532; OP-1604; OP-1763; OP-

1764; OP-1874; OP-1904; OP-2004

sedimentary petrology OF 92-0391

structural geology OP-1597

Vertebrata B 2037

Siberian Lowland

energy sources OP-1284; OP-1967

Siberian Platform see also Aldan Shield;

Tunguska.

geophysical surveys OP-898

Siberian Traps

geochronology OP-134

Sicily Italy

plate tectonics OP-1682

side-looking airborne radar see SLAR

siderite

Dominican Republic, metal ores OP-532

geochemistry OP-183

siderite (meteorite) see iron meteorites

sideromelane

Iceland, geochemistry OP-511

Sierra de Luquillo

hydrogeology C 1086

weathering C 1086

Sierra Grande

petroleum OF 93-0337

Sierra Juarez

maps I-2287

Sierra Madre earthquake 1991 earthquakes OP-503

Sierra Madre Range hydrology WRI 92-4091 stratigraphy P 1520

Sierra Nevada

geochronology OP-333

geomorphology OP-1339

hydrogeology OP-256; OP-276

hydrology WRI 93-4030; OF 93-0059

manganese ores OP-319

metamorphic rocks OP-1166

orogeny OP-797

Quaternary C 1086; OP-1253; OP-1254 structural geology OP-803; OP-1413; OP-1474

Sierra Nevada Batholith

geochemistry OP-182

petrology OP-1282

Signal Mountain Limestone

Ordovician OP-1712

Silesia

metal ores OF 92-0704

silica

Alaska, geochemistry OP-1373

Kenya, sedimentary petrology OP-1490

Oregon, sedimentary petrology OP-1490

Pacific Ocean, paleomagnetism OP-747
Wyoming, geochemistry OP-520

silica minerals see chalcedony; jasper, opal; quartz

silicates see also aluminosilicates; asbestos; boro-

silicates; chain silicates; framework silicates; or-

thosilicates; ring silicates; sheet silicates.

petrology OP-843

siliceous sinter

Wyoming, thermal waters OF 93-0293

siliciclastics

Alaska, geochemistry OP-1410

Arkansas, sedimentary petrology OF 93-0291

Georgia

oceanography OP-1502

pollution OP-1501

Illinois, sedimentary petrology OP-1385

Indiana, sedimentary petrology OP-1385

Missouri, sedimentary petrology OF 93-0291

New York, stratigraphy B 1839-L

Pennsylvanian OP-1233

sedimentary petrology OP-723

Texas, stratigraphy OP-1387

Western Interior, sedimentary petrology OP1332

silicified wood see fossil wood

silicoflagellates

California, stratigraphy OF 92-0539-E

New Jersey, stratigraphy OP-979

Peru, stratigraphy OP-1330

Siljan Ring

geochemistry OP-552

sills

California, platinum ores B 2014

China, stratigraphy OP-1361

Montana OP-1500

Nevada, gold ores OP-27

Pacific Ocean, Cretaceous OP-1230

Red Sea, brines OP-2029

Sweden, geochemistry OP-552

Utah, structural geology B 1787-HH

Virginia, geochemistry B 1839-I,J

West Virginia, geochemistry B 1839-I,J

Silsilah Deposit

tin ores OP-499; OP-1558

silt

Adriatic Sea, pollution $\mathrm{OP}-47$

Georgia OP-1502

Great Lakes, Quaternary OP-1288

Gulf of Mexico OP-1864

Quatemary OP-1966

hydrology OF 92-0651

Indiana, Quatemary OP-1308

Massachusetts OP-1598

Missouri, Quaternary OP-1308

siltstone

Colorado, natural gas OP-1262

Idaho, stratigraphy OP-1351

Kansas, natural gas OP-725

Montana, stratigraphy OP-1351

Nevada

OP-1795

gold ores OP-441

New Jersey OP-1379

Texas, stratigraphy OP-1387

Utah

Cretaceous OP-919

natural gas OP-1262

Virginia, energy sources OP-1751

Silurian

B 1839-I,J; B 1917-M

Alaska OP-1268
Arkansas OF 93-0199

Bloomsburg Formation B 1839-L

Brassfield Formation, hydrogeology OP-1228

California OP-797

Great Lakes OP-1354

Idaho OP-797

Lockport Formation

ground water OP-2023

hydrogeology OP-1228

North Carolina OP-1607

Oklahoma OF 93-0199

Roberts Mountains Formation gold ores OP-27; OP-441 sedimentary petrology B 1988-E

Rochester Formation, hydrogeology OP-1228

Salina Group

hydrogeology OP-1228

sedimentary petrology OF 93-0236

Sangerville Formation, geochemistry OP-750

Tuscarora Formation, mineralogy OP-1755

Waterville Formation, geochemistry OP-750

silver

gold ores OP-168

hydrology OP-1836

Idaho, gold ores B 2039

New Jersey, environmental geology OF 92 0153

Utah, mineral resources MF-2081-C;MF-2081$\mathbf{E}$

Sllver Bell Deposit

geochemistry OP-1505

Silver Creek Deposit

metal ores OP-1633

silver ores

B 2003; OF 92-0389; OF 92-0557

Alaska OP-570

Arizona B 2042-C; OF 93-0228; OP-290

Bolivia B 2039; OF 93-0016; OP-202

California OF 93-0228; OP-204; OP-260; OP427; OP-662; OP-1267

Colorado P 1537; OF 92-0525; OF 93-0343; OP-937; OP-1151

Dominican Republic OP-532

Idaho OP-715

Mexico B 2039

Montana I-2050-F

Nevada OP-205; OP-260; OP-489; OP-627

New Mexico OP-1715

New South Wales Australia OP-942

Peru OP-1212

Puerto Rico OF 92-0567

Queensland Australia OP-942

Utah OP-965; OP-1464

Silver Plume District

mineral resources OP-95

Silverton Caldera

base metals OF 93-0183

Simeonof Island Quadrangle metal ores B 1968

Simmons Creek Quadrangle maps OF 92-0697

Simons Ranch Anticline energy sources OP-889

Simpson Park Mountains maps OF 93-0519

Sinal

OP-1322

tectonophysics OP-1606

Sind Pakistan

coal OF 92-0281; OF 93-0255; OF 93-0256; OP-996 
lignite OF $92-0576$ stratigraphy OF 92-0517

sinkholes

Arizona I-2290

metal ores OP-1117

Sinkiang Weiwu'er Zizhiqu see Xinjiang China

Sino-Korean Platform

metal ores OP-1238

metasomatism OP-1343

Sioux Arch

natural gas OF 93-0337

Siphonophrentidae

Invertebrata B 2024

Sisquoc Formation

energy sources OF 92-0383

sedimentary petrology OP-1791

Sisters Oregon

geologic hazards W 2340

site location maps

Alaska

barite deposits OF 93-0215

hydrology WRI $92-4132$

metamorphic rocks $P$ 1497-C

mineral resources OF 92-0008-A; OF 920008-B; OF 92-0315; OF 92-0708-A

Arizona

geochemistry B 2021-C

mineral resources OF 92-0509-A

Arkansas, hydrology WRI 93-4013

Atlantic Ocean, continental slope B 2002

California, mineral resources OF 92-0210-A; OF 92-0316-A

Canada, metamorphic rocks P 1497-C

Colorado

hydrogeology WRI 92-4050

hydrology WRI 91-4095

mineral resources OF 92-0709

pollution WRI 93-4007

sedimentary rocks $B$ 1787-DD

thermal waters OF 93-0017-A

economic geology OF 92-0020-B

Idaho

hydrogeology OF $92-0173$

mineral resources OF 90-0672; OF 92-0384

Kansas, ground water OF 93-0092

Kentucky, environmental geology WRI 92 4195

Michigan, ground water WRI 91-4133

mineral resources OF 92-0552

Montana

economic geology OF 93-0207

ground water WRI 92-4162

natural gas OF 92-0524

New Hampshire, ground water OF 92-0095

New Mexico, pollution WRI 93-4007

New York

ground water WRI 88-4127; WRI 91-4030 hydrogeology W 2387

North Carolina, hydrology WRI 92-4097

North Dakota, hydrology OP-1071

Oregon, mineral resources OF 90-0506; OF 930259-A

Puerto Rico, copper ores OF 93-0178; OF 930179

South Australia, Quaternary B 2032-B

stratigraphy B 1808-O; B 1909

Texas, hydrogeology OF 93-0112

Utah

ground water WRI 92-4160; OF 92-0640

hydrogeology OF 92-0173

sedimentary rocks $B$ 1787-DD

Vermont, economic geology B 1955
Washington, hydrology WRI 91-4073; OF 910453

Wyoming

hydrogeology WRI 91-4044

impact statements WRI 90-4154

natural gas OF 93-0192

stratigraphy $P 1532$

sites, archaeological see archaeological sites

Sitkoh Bay

petrology OP-1396

Skaergaard Intrusion

phase equilibria OP-636

Skajit Allochthon

folds OP-1427

Skaneateles Shale

stratigraphy B 1909

skarn

California, economic geology OP-662

Colorado, base metals OF 93-0183

Ecuador, gold ores B 2039

Idaho, tungsten ores OP-1296

Nevada

gold ores OP-994

metal ores OF 93-0249

Sweden, mineralogy OP-1445

Tadzhikistan, mineralogy OP-1445

tin ores OF 92-0557

Skunk Ranch Formation stratigraphy OP-573

Skykomish River Quadrangle maps I-1963

skystones see meteorites

SLAR

Alaska, Quaternary OP-1718

natural gas OP-1860

Slate Creek

maps I-2299

slates

Pennsylvania, geochronology OF 92-0525

Slaven Chert

sedimentary petrology OP-1795

Sleeper Deposit

gold ores OP-716

metal ores OP-169; OP-205

Sleepers River hydrology C 1086

Sleeping Lion Formation petrology OP-1611

Sleetmute Quadrangle mineral resources OF 92-0708-A; OF 92-0708B

Trilobita OP-1123

slickenlines

Nevada, structural geology OF 91-0623

slickensides

engineering geology OP-506

Slide Mountain Terrane

stratigraphy OP-402

sliding, gravity see gravity sliding

slip cleavage

California OP-1413

Slocum Creek Wilderness Area mineral resources OF 93-0259-A; OF 93-0259B

slope stability see also debris avalanches; debris flows; earthflows; highways; landslides; liquefaction; liquefaction potential; mass movements; mudflows; rockfalls.

engineering geology OP-472; OP-578

geologic hazards P 1240-B
Mississippi, waterways OF 90-0110

North Carolina, continental margin MF-2209

Washington, Quaternary OP-904

slope, continental see continental slope

Slovakia OP-558

Slovenia OP-558

Slovensko see Slovakia

Slumgullion landslide

earthquakes OP-1423

geomorphology OP-1171

Sm-147/Nd-144

Colorado, geochemistry OP-490

geochemistry OF $92-0525$

New Mexico, geochemistry OP-490

Russian Federation, geochemistry OP-1086

$\mathbf{S m} / \mathbf{N d}$

OP-805; OP-806

Basin and Range Province, petrology OP-545

geochemistry OF 92-0525; OP-1377; OP-1621

geochronology OF 92-0525

Great Basin, petrology OP-545

Idaho, geochronology OP-1067

Manitoba, geochronology OP-1709

Montana, Archean OP-705

New England, geochronology OF 92-0525

New York, geochronology OP-1709

petrology OP-1199; OP-1246; OP-1956

Poland, structural geology OP-967

Washington, geochronology OP-1067

Smackover Formation

energy sources OP-1602

smaragd see emerald

smectite

OP-1068

Black Sea, oceanography OF 93-0274

California

OP-500

diagenesis OP-1386

sedimentary petrology OP-1791

clay mineralogy OP-1069

Colorado, diagenesis OP-1961

diagenesis OP-1627

geochemistry OP-289

Gulf of Mexico, sedimentary petrology OP-288

Iceland, geochemistry OP-511

Indiana, diagenesis OP-1466

Middle East, oceanography OF 93-0274

New Mexico, petroleum B 2039

petroleum OP-793

Rocky Mountains, diagenesis OP-1792

sedimentary petrology OP-1352; OP-1353; OP1689; OP-2000

Texas, sedimentary petrology OP-1991

Utah

diagenesis OP-1961

Vertebrata OP-1252

Western Interior

clay mineralogy OP-794

diagenesis OP-1792

Wyoming

diagenesis OP-1950

petroleum B 2039

Smith Creek valley

ground water W 2340

Smithsonian Butte Quadrangle

maps OF 92-0589

Smyths Sea OP-1439; OP-1485; OP-1830

Sn see tin

Snake Mountains

gold ores B 2039

sedimentary petrology B $1988-\mathrm{E}$ 
Snake River Group

hydrogeology OF 91-0098

Snake River plain

environmental geology OF 92-0156

ground water WRI 92-4014; WRI 92-4184;

WRI 93-4054; OF 92-0643; OF 93-0034; OP-147

hydrogeology P 1408-F; WRI 93-4001; OF 910098; OF 92-0174; OF 93-0102; OP-1654

hydrology WRI 92-4196

natural gas OF 93-0248

neotectonics OP-780

paleomagnetism OF 92-0542; OP-697

petrology OP-560; OP-561

Quaternary OF 93-0327; OP-452

stratigraphy OF 92-0713

Snake River Plain Aquifer

environmental geology OF 92-0156

ground water WRI 92-4184; WRI 93-4054; OF 92-0643; OF 93-0034

hydrogeology OF 91-0098; OF 92-0174; OF 93-0102

Sniezik Complex

structural geology OP-1916

Snieznik

Carboniferous OP-1917

structural geology OP-967

Snowshoe Formation guidebook OP-87

Snowstorm Mountains maps I-2394

Snowy Pass Supergroup stratigraphy $\mathbf{P} 1520$

$\mathrm{SO} 2$ see sulfur dioxide

soap clay see bentonite

soapstone see talc deposits

sodium

California, ground water OF 92-0655

mineralogy OP-1068

New Hampshire, environmental geology OF 92-0647

phase equilibria OP-1475

sodium chloride

geochemistry OP-58; OP-326

sodium polytungstate

heavy minerals OF 92-0386

soft coal see bituminous coal

soft sediment deformation see clastic dikes; flame structures; olistoliths; olistostromes

software see computer programs

Sohnari Formation

stratigraphy OF 92-0517

soil liners see disposal barriers

soil mechanies see also alluvium; clay; cone penetration tests; geologic hazards; highways; land subsidence; liquefaction; rock mechanics; slope stability.

California, continental shelf B 2002

Indonesia OP-993

soil ulmin see humus

soil-structure interface

Maryland, pollution OP-833

soils see also alluvium; highways; humus; infiltration; land use; landslides; pedogenesis; reclamation; regolith; weathering.

C 1086; OF 90-0130; OP-1723; OP-1761; OP1951

Alaska

environmental geology OF 93-0292-J

geochemistry OF 93-0014 hydrogeology OF 91-0458

Arizona

environmental geology OF 93-0292-I

geochemistry OF 92-0599

hydrology WRI 92-4133

Atlantic Coastal Plain, environmental geology OP-378

California

OP-1713

environmental geology OF 93-0083; OF 93 0292-I

ground water $\mathrm{OF}$ 91-0535

hydrology WRI 93-4030; OF 93-0059

platinum ores B 2014

Colorado

environmental geology OF 93-0292-H; OP902

ground water $\mathrm{OF} 92-0122$

environmental geology OF 93-0292-I; OP-377

Florida, pollution W 2402

geochemistry OP-343; OP-379; OP-505; OP1766; OP-1990

Georgia

geochemistry OP-917

hydrogeology OP-918

hydrology OP-1515

ground water OP-207; OP-1514

Gulf Coastal Plain, environmental geology OP378

Hawaii, environmental geology OF 93-0292-I

Histosols, Alaska OP-33

hydrogeology OP-161; OP-732

hydrology W 1619-U; OF 92-0052

Idaho, environmental geology OF 93-0292-J

Illinois, hydrogeology W 2386

Iowa, environmental geology OF 93-0292-G

Kansas

environmental geology OF 93-0292-G geochemistry OP-5

laterites, Puerto Rico OF 92-0567; OP-1656

Maryland, pollution OP-833

Minnesota

OF 92-0721

metal ores OF 92-0615

pollution OF 93-0042; OF 93-0043; OF 930079; OP-430

Mississippi Valley, Quaternary OF 93-0273

Missouri

environmental geology OF 93-0153; OF 930292-G

ground water OP-1571

Montana

environmental geology OF 93-0292-H

hydrogeology WRI 92-4066

Nebraska

environmental geology OF 93-0292-G geochemistry OF 92-0592

North Carolina, economic geology B 2039

North Dakota

environmental geology OF 93-0292-H

hydrogeology WRI 92-4110

Ontario, pollution OP-369

Oregon

OP-1028

earthquakes OP-720

environmental geology OF 93-0292-J

Pacific Ocean, geochemistry OP-628

Paleosols

Alaska C 1086; OP-390

Appalachians OP-1380

Arkansas OF 93-0273; OP-1683

Carboniferous OP-1232

Colorado OP-1676
Gulf Coastal Plain OP-1817

Italy OP-764

Pennsylvanian OP-1233

Quatemary OP-396

stratigraphy OP-1345

Tennessee OF 93-0273; OP-1683

West Virginia OP-1357

Wyoming OP-98; OP-556

Poland OF 93-0281

pollution OP-1665

South Carolina, ecology OF 93-0303

South Dakota

environmental geology OF 93-0292-H

geochemistry OF 92-0592

Ultisols, Pennsylvanian OP-1233

Utah

environmental geology OF 93-0292-H

geochemistry OF 93-0260

Virginia, geochemistry OP-344

Washington

earthquakes OP-720

environmental geology OF 93-0292-J

hydrogeology OF 92-0644

West Virginia, environmental geology OP-901

Wisconsin OP-22

Wyoming

environmental geology OF 93-0292-H

hydrology OF 93-0142

pollution OP-1871

solar activity

geomorphology C 1086

hydrogeology OP-772

paleomagnetism C 1086

sole faults see detachment faults

Solenoceras

stratigraphy B 2024

solfataras

Papua New Guinea, gold ores B 2039

Solomon Islands

marine geology, Bougainville OP-192

Solomon Quadrangle

metal ores MF-1838-D

Solor Church Formation

natural gas OF 92-0524

solution features see caves; karst; paleokarst; sink-

holes; speleothems

solution mining

Arizona, ground water WRI 90-4105

Utah, ground water WRI 90-4105

solution phenomena see solution features

solution transport

Colorado

hydrogeology OP-408

hydrology WRI 92-4081

Costa Rica, geochemistry OP-812

engineering geology OP-544

Florida

hydrogeology OP-672

pollution W 2402

ground water OP-236

Gulf Coastal Plain, environmental geology C 1120-C

Gulf of Mexico, environmental geology C 1120-C

hydrogeology OP-232

Kansas

geochemistry OP-5

pollution OF 93-0087

Massachusetts, ground water OP-431

Midwest, pollution OF 93-0418 
Minnesota, pollution OF 93-0042; OF 930079; OP-430

Nebraska, pollution OF 93-0087

Nevada, ground water WRI 92-4051

Ontario, geophysical surveys OF 93-0071

waste disposal OF 92-0457

Solvents-in-Groundwater Project pollution OP-369

SOLVEQ OP-1785

Solyo Quadrangle maps OF 93-0224

Sonda coal field OP-996

Song Hong Basin

petroleum OP-1829

sonic waves see acoustical waves

Sonoma Basin

energy sources B 2034-A

Sonoma Orogeny

structural geology OP-999

Sonoma Range

metal ores OF 93-0249

Sonora Mexico

barite deposits OP-796

neotectonics MF-2238

Paleozoic OP-56

structural geology OP-1886

Sonyea Group B 1909

Soquel Canyon

continental shelf OP-1443

oceanography OP-1444

Soquel-Aptos Basin ground water WRI 91-4148

Sor Range

tectonophysics OP-1548

sorosilicates see epidote group

Sosneado Fault

structural geology OP-1129

sound waves see acoustical waves

sources, energy see energy sources

sources, seismic see seismic sources

South Africa

engineering geology, Klerksdorp Field OP-660 metal ores $\mathrm{C} 0930-\mathrm{N}$

South America see also Andes; Argentina; Bolivia; Brazil; Chile; Colombia; Ecuador; Peru; Venezuela.

continental shelf, Amazon River OP-483

hydrology

Amazon Basin OP-666

Amazon River OP-666

mantle OP-71

metal ores OF 93-0328

tectonics

Guyana Shield OP-1760

Orinoco River OP-1760

Vertebrata, Patagonia OP-97

South American Pacific see Chile Ridge

South American Plate

Pacific Ocean, plate tectonics OP-1651

plate tectonics OP-1133

South Arabia see Yemen

South Australia

Quaternary B 2032-B

South Boston Quadrangle maps OF 93-0244

South Carolina see also Blue Ridge Province; Piedmont; Savannah River.

building stone

Abbeville County South Carolina MF-2215A
Anderson County South Carolina MF-2215A

Greenville County South Carolina MF2215-A

Greenwood County South Carolina MF2215-A

Laurens County South Carolina MF-2215-A

Oconee County South Carolina MF-2215-A

Pickens County South Carolina MF-2215-A

Spartanburg County South Carolina MF2215-A

continental shelf OP-346

Cretaceous OP-356

ecology, Charleston County South Carolina

OF 93-0303

engineering geology

OF 93-0349

Aiken County South Carolina B 2017

Barnwell County South Carolina B 2017

Columbia South Carolina WRI 90-4056

Lexington County South Carolina WRI 904056

Savannah River Plant B 2017

geophysical surveys

Aiken County South Carolina OF 92-0723

Bamberg County South Carolina OF 920723

Barnwell County South Carolina OF 920723

Colleton County South Carolina OF 920723

ground water

WRI 92-4000; OP-1202

Beaufort County South Carolina W 2392

Jasper County South Carolina W 2392

heavy mineral deposits B 2039; OF 93-0240-A; OF 93-0240-B

hydrogeology

OF 93-0035

Beaufort County South Carolina OF 910483; OF 92-0629

hydrology W 2400; WRI 92-4040

pollution, Berkeley County South Carolina OP-

1040

Quaternary

Berkeley County South Carolina I-1935

Charleston County South Carolina I-1935

seismicity, Charleston South Carolina OP-2032

stratigraphy, Horry County South Carolina B 2030

tin ores

Greenville County South Carolina OF $92-$ 0268

Laurens County South Carolina OF 92-0268

South Cascade Glacier

geochemistry OP-1121

hydrology W 2340

Quatemary OP-323

South China Sea

petroleum, Gulf of Siam OP-1829

South Dakota see also Madison Group; Pierre Shale; Red River; Red River Formation;

Williston Basin.

energy sources OF 93-0337

environmental geology

OF 93-0292-H

Lawrence County South Dakota OP-641 geochemistry

Brule County South Dakota OF 92-0592

Charles Mix County South Dakota OF 920592

Lyman County South Dakota OF 92-0592 geochronology

Lyman County South Dakota OP-475

Yankton County South Dakota OP-475

geologic hazards C 1120-B

geophysical surveys OC-0140

ground water OF 93-0114

hydrology

W 2400; C 1120-A

Clark County South Dakota W 2340

Hamlin County South Dakota W 2340

Kingsbury County South Dakota W 2340

Lake County South Dakota W 2340

Miner County South Dakota W 2340

industrial minerals $\mathrm{OF}$ 92-0514

natural gas OF 92-0524; OF 93-0337

non-metal deposits

OF 92-0514

Bennett County South Dakota OF 92-0514

Jackson County South Dakota OF 92-0514

Shannon County South Dakota OF 92-0514 petroleum OF 93-0337

Quaternary OP-1896

stratigraphy

B 1917-M

Campbell County South Dakota OF 93-0335

Corson County South Dakota OF 93-0335

Dewey County South Dakota OF 93-0335

Potter County South Dakota OF 93-0335

Walworth County South Dakota OF 930335

South Korea

energy sources OP-1624

South Park Colorado

natural gas OF 93-0248

Quaternary OF 93-0250

South Pole-Aitken Basin OP-416

South Polynesian Pacific

geochronology OP-1436

South Shetland Islands oceanography OP-263

South Sister geophysical surveys B 1966

South Victoria Land see Victoria Land

Southeastern Alaska see Alexander Archipelago;

Glacier Bay National Park; Juneau Alaska

Southem Africa see Namibia; South Africa

Southern Alaska see Anchorage Alaska; Chugach

Mountains; Kenai Peninsula; Matanuska Valley;

Prince William Sound; Talkeetna Mountains;

Turnagain Arm; Valdez Alaska; Wrangell

Mountains; Yakutat Bay

Southern California Seismographic Network earthquakes OP-700

Southern Cook Islands see Cook Islands

Southern Europe see Greece; Iberian Peninsula; Italy; Romania; Yugoslavia

Southern Hemisphere volcanism OP-1806

southern Italy earthquake 1980 see Irpinia earthquake 1980

Southem Ocean see Antarctic Ocean

Southern Oscillation Quaternary C 1086

Southern Peninsula, Michigan see Michigan Lower Peninsula

Southern Powder River Uranium District impact statements WRI 90-4154

Southern Ute Indian Reservation energy sources OP-518 sedimentary petrology OF 93-0306 
Southern Yemen see Yemen

Southwest Florida Water Management District ground water OF 92-0471; OF 92-0472 hydrogeology W 2340

Southwestem Alaska see Alaska Peninsula; Aleutian Islands; Katmai; Katmai National Monument; Kodiak Island; Valley of Ten Thousand Smokes

Soviet Pacific region see Russian Pacific region

Spacelab Program

environmental geology C 1086

Spain

base metals OP-31

geologic hazards OP-1372

gold ores, Almeria Spain OP-231

ground water, Barcelona Spain OP-1310; OP1449

metal ores, Almeria Spain OP-875

oceanography OP-722

pollution, Ciudad Real Spain OP-599

Quaternary, Spanish Pyrenees

P 1386-E

Spanish Pyrenees

Quaternary P 1386-E

Sparta Aquifer

ground water OF 92-0492

hydrogeology OP-32

Sparta Sand

hydrogeology OP-32

Spartina alterniflora

South Carolina, ecology OF 93-0303

spatial data handling

YR; OP-156; OP-383; OP-717; OP-1692

hydrology OP-337

specific yield

ground water W 1536-C

spectroscopy

electron paramagnetic resonance, geochronology OP-1436

emission spectroscopy, geochemistry B 1770

inductively coupled plasma methods

geochemistry B 1770; OP-505; OP-1653

hydrology OF 92-0634

Kentucky B 2046

infrared spectroscopy, hydrology OF 92-0480

mass spectroscopy

diagenesis OP-1477

geochemistry B 1770; OF 92-0543; OF 93 0267; OP-991

Quaternary OF 92-0525

sedimentary petrology OP-1478

optical spectroscopy, geochemistry B 1770

ultraviolet spectroscopy, hydrology OF 92 0480

speleothems see also stalagmites.

New Mexico OF 92-0391

Spermatophyta see angiosperms; gymnosperms

\section{sphalerite}

Colorado, molybdenum ores OF 92-0525

geochemistry OP-1312

metal ores OP-1035

sphene see titanite

Sphenodiscus

stratigraphy OP-526

spills, oil see oil spills

spinel

Hawaii, petrology OP-667

Saudi Arabia, petrology OP-1952

Spirit Lake East Quadrangle

maps GQ-1679
Spitak earthquake 1988

Armenia OF 93-0216

spits

Utah, Quaternary OP-911

Spitsbergen

structural geology OP-1890

spontaneous fission-track dating see fission-track dating

sporinite

Colorado, coal OP-1911

spreading centers

Hawaii, geochemistry OP-446

Oman, structural geology OP-815

Pacific Ocean, sedimentation OP-243

spreading-floor hypothesis see sea-floor spreading

Spring Mountains geochemistry OP-1775

Springeran sedimentary petrology OP-1791

Springfield Missouri

lead-zinc deposits OP-644

Springfield Plateau Aquifer

Pennsylvanian OP-1192

Springfield Quadrangle

lead-zinc deposits OP-644

springs

Arkansas OF 93-0150

California

energy sources OP-267

sedimentary petrology OP-77

Colorado WRI 92-4050

Florida WRI 92-4069

Georgia OP-171

hot springs

California OP-955

Colorado OF 93-0017-A; OF 93-0017-B OF 93-0282

Idaho OF 92-0175; OP-876

metal ores OF 92-0557

Nevada OP-1609

Oregon OP-468; OP-876

Papua New Guinea B 2039

Utah OF 93-0260

Wyoming OF 93-0293; OP-464; OP-520

Idaho WRI 93-4001; OF 92-0173; OF 92-0174, OF 93-0102; OP-1654

Indonesia, geophysical surveys B 1966

Iowa, pollution OP-588

Kentucky, environmental geology WRI 92 4195

Nevada

OF 90-0153; OF 90-0381

Quaternary OP-294

New Mexico WRI 92-4004; OF 93-0144; OP1299

Pennsylvania OF 92-0165

Tennessee WRI 91-4190; WRI 92-4018; OP1283

Texas WRI 92-4190

Utah OF 92-0173

Washington geochemistry OP-998 geophysical surveys B 1966

Wyoming

WRI 91-4108

geochemistry OP-327; OP-536; OP-874

Sq currents

geophysics OP-136

Sr see strontium

Sr-86/Rb-87 see $\mathrm{Rb}-87 / \mathrm{Sr}-86$
Sr-87/Sr-86

Alaska

geochemistry OP-242; OP-72

Quatemary OP-515; OP-826

Argentina, copper ores OP-2027

Arizona, structural geology OP-1886

Basin and Range Province, geochemistry OP2015

Brazil, ground water OP-737

California

geochemistry OP-182; OP-678; OP-730; OP-1141

geochronology OP-333

petrology OP-1282

soils OP-1065

structural geology OP-332

Chile, copper ores OP-2027

China, geochemistry OP-457

Colorado, geochemistry OP-490; OP-1825

geochemistry OF 92-0525; OP-30

geochronology OF 92-0525

Great Basin, geochemistry OP-2015

Indiana, ground water OP-1648

Maine, metal ores B 2039

Maryland, hydrology OP-1572

Mexico, structural geology OP-1886

Michigan, geochemistry OP-1747

Montana, geochemistry OP-122; OP-978

Nevada

geochemistry OP-313; OP-643; OP-1775

geophysical surveys OP-1041

New Jersey, stratigraphy OP-979

New Mexico

geochemistry OP-490

magmas OP-278

North Carolina, geochemistry OP-1607

Northwest Territories, geochemistry OP-721

Ohio, ground water OP-1648

Oregon, geochemistry OP-42; OP-1141

Pacific Ocean

Cretaceous OP-1230

geochemistry OP-419

petrology OP-1199

Russian Federation, geochemistry OP-1086

South Carolina, ground water OP-1202

Wyoming, geochemistry OP-122; OP-978

$\mathrm{Sr} / \mathrm{Rb}$ see $\mathrm{Rb} / \mathrm{Sr}$

Sr/Sr

Antarctica, igneous rocks OP-1995

Basin and Range Province, petrology OP-545

Great Basin, petrology OP-545

Pacific Ocean, geochemistry OP-419

St. Francois Mountains see Saint Francois Moumtains

St. Johns River basin see Saint Johns River basin

St. Lawrence River see Saint Lawrence River

St. Louis Limestone see Saint Louis Limestone

St. Paul see Saint Paul Minnesota

St. Peter Sandstone see Saint Peter Sandstone

stable isotopes see $\mathrm{Ar}-40 / \mathrm{Ar}-39$; $\mathrm{Be}-10 / \mathrm{Be}-9$; $\mathrm{C}$ 12; C-13; C-13/C-12; Cl-37/Cl-35; D/H; deuterium; $\mathrm{He}-4 / \mathrm{He}-3 ; \mathrm{N}-15 ; \mathrm{N}-15 / \mathrm{N}-14$; Nd-144/Nd-143; Ne-22/Ne-20; O-18; 0-18/O16; Os-187/Os-186; Pb-206/Pb-204; Pb-207/Pb-

204; $\mathrm{Pb}-207 / \mathrm{Pb}-206 ; \quad \mathrm{Pb}-208 / \mathrm{Pb}-204$

Rb-87/Sr-86; S-34; S-34/S-32; Sm-147/Nd-144; $\mathrm{Sr} r-87 / \mathrm{Sr}-86$

Stagecoach Valley

ground water W 2340

stalagmites

France, Quaternary OP-310 
Standley Lake Colorado hydrology WRI 92-4053

\section{Stanovoy fold belt}

Mesozoic OP-1494

statistical analysis see canonical analysis; kriging; trend-surface analysis

Steele Member

Miocene B 1917-O

Stellarton Group

sedimentary petrology OP-1672

Stepovak Bay Quadrangle

metal ores B 1968

steranes

Colorado, energy sources OP-674

Commonwealth of Independent States, petroleum OP-1265

Europe, petroleum OP-1265

New Mexico, energy sources OP-674

Wyoming, petroleum OP-1767

Sterea Ellas

plate tectonics OP- 542

stereochemistry see crystal chemistry

stereographic projection

OP-690

Pennsylvania, engineering geology OF 920391

Sterling Formation

energy sources B 2034-A

steroids

Wyoming, petroleum OP-1767

Stewart Lake Waterfowl Management Area ecology WRI 92-4084

stibium see antimony

Stikinia Terrane

metamorphic rocks $P$ 1497-C

Stillwater Complex see also J-M Reef. bibliography OF 93-0285-A; OF 93-0285-B economic geology OF 93-0207

geochemistry OP-1087; OP-1621; OP-1663

magmas OP-1500

petrology OP-604

stocks

Bolivia, metal ores B 2039

Maine, metal ores B 2039

Michigan, copper ores OP-1688

Montana

MF-2253

structural geology B 1993

Nevada, geochemistry OP-1302

Stockton Formation

energy sources OP-1842

ground water OP-986

sedimentary petrology OP-778

Stockton Quadrangle

maps OF 92-0385

stockwork deposits

barite deposits OP- 1257

Bolivia, metal ores B 2039

Montana, metal ores I-2050-F

Nevada

geochemistry OF 92-0525

molybdenum ores B 2039

Puerto Rico, copper ores OF 92-0578

Saudi A rabia, metal ores OP-1559

Utah, metal ores OP-1464

stone, building see building stone

stone, dimension see dimension stone

Stonehenge Limestone

ground water OP-111
Stony Gap Sandstone Member

stratigraphy OP-1368

stony irons see mesosiderite

stony meteorites see chondrites

Storm King Mountain Quadrangle maps OF $93-0320$

storm water

Kentucky

hydrogeology OF $92-0638$

hydrology WRI 92-4078

Straight Clifis Aquifer ground water WRI 92-4070

Straight Clifis Formation

sedimentary petrology OP-1779

sedimentary structures OF 93-0270

Straight Creek Fault

maps I-1963

strain-slip cleavage see slip cleavage

Strait of Juan de Fuca see Juan de Fuca Strait

strategic minerals

Australia C 0930-M

Brazil C 0930-M

Canada C 0930-M

China C 0930-M

Colorado C 0930-M

Far East C 0930-N

Great Lakes region, stratigraphy B 1989-E

Idaho C 0930-M

Malaysia C 0930-M

Mozambique C 0930-M

Nigeria C 0930-M

Rwanda C 0930-M

Thailand C 0930-M

Zaire C 0930-M

Strathclyde region Scotland see Ayrshire Scotland

Strathcona Mine

metal ores OP-1979.

stratified volcano see stratovolcanoes

stratigraphic boundary see also K-T boundary.

California, stratigraphy OF 92-0588

Colombia, geochemistry OP-755

Colorado

I-2266

stratigraphy OP-1399

England, geochemistry OP-755

Indonesia, geochronology OP-1538

Ivory Coast, Quaternary OF 92-0699

Mississippi, Oligocene OP-746

Montana, stratigraphy OP-1798

New Mexico

I-2266

geochronology OP-1538

Quaternary OF 92-0699

Poland, geochemistry OP-755

Texas, geochemistry OP-755

stratigraphic codes

stratigraphy OP-285

stratigraphic geology see stratigraphy

stratigraphic maps

New Jersey, Triassic MF-2208

New York, Triassic MF-2208

stratigraphic tongues

New York, stratigraphy B 1839-L

stratigraphic traps

Alaska, energy sources B 2034-A

Colorado

natural gas OF 93-0248

petroleum OF 93-0337

natural gas OF 93-0337

New Mexico, natural gas OF 93-0248
Russian Federation, energy sources OP-1258; OP-1967

Utah, diagenesis OP-1465

West Virginia, natural gas B 1909

Wyoming, petroleum OP-1767

stratigraphy see also Archean; Cambrian; Carboniferous; Cenozoic; Cretaceous; Devonian; Eocene; Holocene; Jurassic; Mesozoic; Miocene; Mississippian; Neogene; Oligocene; Ordovician; Paleocene; Paleogene; paleomagnetism; paleontology; Paleozoic; palynomorphs; Pennsylvanian; Permian; Phanerozoic; Pleistocene; Pliocene; Precambrian; Proterozoic; Quaternary; Silurian; Tertiary; Triassic.

B 2024

stratovolcanoes

Alaska, geochemistry OP-926

Chile, Quaternary OP-279

Nevada, petrology B 2052

Oregon, petrology B 2054

stream flow see streamflow

stream gradient

Georgia, heavy mineral deposits B 2039

Oregon, geomorphology OP-840

South Carolina, heavy mineral deposits B 2039

stream placers see heavy mineral deposits

stream sediments

Alaska

economic geology MF-2217-A

metal ores B 1968; MF-1996-E; OP-1006

mineral resources OF 92-0379-A; OF 920379-B; OF 92-0708-A; OF 92-0708-B

Arizona

gold ores OF 92-0591-A; OF 92-0591-B

metal ores B 2042-C

mineral resources OF 92-0509-A; OF 920509-B

Atlantic Coastal Plain, heavy mineral deposits B 2039

California, economic geology OP-260

Colorado, mineral resources OF 92-0709

heavy mineral deposits OF 93-0240-A; OF 930240-B

Idaho

gold ores B 2039; OF 93-0527

mineral resources OF 90-0672; OF 92-0384

metal ores B 2003

mineral resources OF 92-0380-A; OF 92-0380B; OF 92-0552; MF-2207; MF-2217-B

Montana, economic geology OF 93-0207

Nevada, economic geology OP-260

Oregon, mineral resources OF 90-0506; OF 93 0259-A; OF 93-0259-B

Puerto Rico, heavy mineral deposits OF 920703

South Carolina, tin ores OF 92-0268

uranium ores DDS-0001

Utah, mineral resources MF-2081-D

Vermont, economic geology B 1955

stream transport see also bedload; fluvial sedimentation.

Arizona, hydrology OP-1434

Arkansas, fluvial features OP-1700

Colorado, pollution OP-1579

Costa Rica, pollution OP-335

Gulf Coastal Plain, environmental geology C 1120-C

Gulf of Mexico, environmental geology C 1120-C

Hawaii, pollution WRI 92-4168

hydrogeology OP-488 
hydrology OP-1836

Indiana, hydrology WRI 92-4019

Kansas, pollution OF 93-0087

Midwest, pollution OF 93-0418

Mississippi Valley, hydrology OP-1643

Missouri, fluvial features OP-1700

Nebraska, pollution OF 93-0087

New York, hydrology OP-1335

Philippine Islands, geologic hazards WRI 924039

Puerto Rico, pollution OP-663

sedimentary petrology OP-894

West Virginia, hydrology OF 92-0065

Wyoming, hydrology WRI 92-4091

streamflow

Alaska, hydrology W 2400; WRI 92-4132; OF 93-0095

Arizona, hydrology OF 93-0054

Arkansas, hydrology WRI 93-4013; OF 930171

California

hydrogeology OP-276

hydrology C 1086

seismology P 1550-C

Colorado

hydrogeology OP-300

hydrology WRI 91-4095

hydrogeology OP-1045

hydrology W 2339; C 1086; WRI 93-4076; OF 92-0129; OF 92-0144; OF 92-0632; OP871; OP-1036

Idaho, hydrology P 0870-A; WRI 92-4196

Illinois, hydrogeology WRI 92-4149

Indiana, hydrology WRI 92-4019

Louisiana, hydrology W 2340

Maryland, hydrogeology OP-261

Massachusetts, hydrology OP-1826; OP-1828

Michigan, hydrology WRI 91-4194

Mississippi Valley geologic hazards OP-669 hydrology C 1120-A; OF 91-0485

Montana, hydrology WRI 92-4048

Nevada, hydrogeology OP-276

New Hampshire, hydrogeology OF 89-0583

New Jersey, hydrogeology WRI 91-4169

New Mexico, hydrology OF 92-0653

New York, hydrogeology WRI 90-4205

North Carolina, hydrology W 2403; OF $92-$ 0123; OF 92-0639

North Dakota, hydrology WRI 92-4020

Ohio, hydrology OF 92-0120

Oklahoma, hydrology OF 93-0171

Puerto Rico, hydrology W 2400

Tennessee, hydrology WRI 92-4082; OF 920482

Washington, hydrology W 2340

West Virginia

hydrogeology W 2384

hydrology OF 92-0065

Wyoming

hydrogeology WRI $91-4044$

impact statements WRI 90-4154

STREAMLINK

hydrogeology WRI 93-4011

streams see also channel geometry; channels. Arizona, pollution OP-591

geomorphology OP-1623

Puerto Rico, geologic hazards OP-1409

Tennessee, hydrology WRI 92-4165

Washington, hydrology W 2340

strewn fields

Germany, stratigraphy B 2050
Iowa, stratigraphy B 2050

Mexico, stratigraphy B 2050

strike-slip faults see also oblique-slip faults; transform faults.

OP-1652; OP-1721; OP-1790

Basin and Range Province OP-19

Bering Sea OP-211

California

OP-23; OP-113; OP-405; OP-649; OP-703;

OP-802; OP-803; OP-972; OP-1547

earthquakes OP-406; OP-931

engineering geology $\mathrm{OP}-688$

metamorphic rocks OP-1166

plate tectonics OP-1749

seismicity OP-286

seismology OP-411; OP-438

Colorado

earthquakes OP-1423

geomorphology OP-1171

Colorado Plateau OP-19

Greece, plate tectonics OP-542

Illinois OP-1471; OP-1742

Mexico OP-1547

Michigan B 1904-S

Minnesota B 1904-S

Missouri OP-1471; OP-1742

Nevada B 2011; OF $91-0623$

Oregon

OP-1547

metamorphic rocks OP-1166

seismicity OP-1866

seismology OP-1867

South Carolina, seismicity OP-2032

stratigraphy OP-1368

Utah B 2011

Stripa region

geochemistry OP-1042

stromatolites

Colorado, geochemistry OF 92-0525

Wyoming, geochemistry OF 92-0525

strong motion

Armenia, earthquakes OF 93-0216

California

earthquakes OF 93-0509; OP-504

engineering geology EV

plate tectonics OP-752

seismology OP-1046

Central America, earthquakes DDS-0007

earthquakes OP-102; OP-496

engineering geology $\mathrm{OP}-497$

Indonesia, engineering geology OP-993

Kentucky, Quaternary OP-486

seismology OP-1371

Tennessee, Quatemary OP-486

strontianite

geochemistry OP-1787

strontium

Basin and Range Province, tectonics OP-2021

Colorado, sedimentary petrology OP-1382

geochemistry OP-1377

Great Basin, tectonics OP-2021

Marshall Islands, Neogene OP-1457

Micronesia, Neogene OP-1457

Quaternary OP-459

$\mathrm{Rb}-87 / \mathrm{Sr}-86$

Colorado OP-490

New Mexico OP-490

Scotland, geochemistry OF 93-0267

Sr-87/Sr-86

Alaska OP-242; OP-515; OP-721; OP-826

Argentina OP-2027

Arizona OP-1886
Basin and Range Province OP-2015

Brazil OP-737

California OP-182; OP-332; OP-333; OP678; OP-730; OP-1065; OP-1141; OP1282

Chile OP-2027

China OP-457

Colorado OP-490; OP-1825

geochemistry OF 92-0525; OP-30

geochronology OF 92-0525

Great Basin OP-2015

Indiana OP-1648

Maine B 2039

Maryland OP-1572

Mexico OP-1886

Michigan OP-1747

Montana OP-122; OP-978

Nevada OP-313; OP-643; OP-1041; OP1775

New Jersey OP-979

New Mexico OP-278; OP-490

North Carolina OP-1607

Northwest Territories OP-721

Ohio OP-1648

Oregon OP-42; OP-1141

Pacific Ocean OP-419; OP-1230

petrology OP-1199

Russian Federation OP-1086

South Carolina OP-1202

Wyoming OP-122; OP-978

strontium carbonate

geochemistry OP-1787

Strophomenida

Arkansas OP-360

Oklahoma OP-360

structural analysis see also cleavage; deformation; faults; folds; foliation; fractures; lineation; melange.

Colorado, metal ores OF 93-0343

Montana P 1524

Pennsylvania B 1994

plate tectonics OP-1628

structural basins see basins

structural geology see deformation; faults; folds;

foliation; fractures; isostasy; lineation;

neotectonics; orogeny; salt tectonics; tectonics

structural maps

Mexico

metal ores B 2039

neotectonics MF-2238

Michigan, structural geology I-2355

Montana I-2267; I-2343-A

Northern Territory Australia, Quaternary B 2032-A

Utah, structural geology B 1787-HH

Vermont OF 92-0282-A

Virginia, ground water W 2388

Wyoming I-2343-A; I-2343-B

structural traps

Alaska energy sources B 2034-A natural gas B 2034-A

Basin and Range Province natural gas OP-208 petroleum OF 93-0248

California energy sources B 2034-A natural gas B 2034-A

Colorado, natural gas OF 93-0248

Colorado Plateau, petroleum OF 93-0248

Commonwealth of Independent States, energy sources OP-1261 
Europe, energy sources OP-1261

Great Basin, natural gas OP-208

Great Plains, energy sources OF 93-0337

Kentucky, energy sources B 1909

Montana

natural gas OF 93-0337

petroleum OF 93-0337

natural gas $O F$ 93-0248

Oregon, natural gas B 2034-A

Rocky Mountains, natural gas OF 92-0524

Russian Federation, energy sources OP-1258; OP-1967

Texas, natural gas OF 93-0522

Washington, natural gas B 2034-A

West Virginia

energy sources B 1909

natural gas B 1909

Wyoming

energy sources OF 93-0337

natural gas OF 93-0337

petroleum OP-1767

structure contour maps

Colorado I-2266

Montana I-2343-A

New Mexico I-2266

South Carolina, Quaternary I-1935

stratigraphy B 1808-O; B 1909

Wyoming I-2343-A; I-2343-B

structure maps see structural maps

structure-soil interface see soil-structure interface

Strzelecki Group

petrology OP-1136

study and teaching see education

sub-bituminous coal see subbituminous coal

subarctic regions

hydrogeology OP-1085

subbituminous coal

OP-228

Pakistan OF 92-0576

subduction see also Benioff zone.

Alaska

intrusions OP-1401

metamorphism OP-1349

Bering Sea, plate tectonics OP-1859

California

plate tectonics OP-752

stratigraphy OP-1281

Chile

tectonophysics OP-1157; OP-1733

plate tectonics OP-586

Quaternary OP-279

Fiji, seismology OP-1758

Melanesia, marine geology OP-192

metal ores OP-465

New South Wales Australia OP-7

Oregon, geomorphology OP-840

Pacific Coast, earthquakes OP-1259

Pacific Ocean

plate tectonics OP-413; OP-1651

tectonophysics OP-1926

plate tectonics OP-680; OP-1903

structural geology OP-159; OP-401

tectonophysics OP-1037

Tonga

plate tectonics OP-345

seismology OP-1758

Vanuatu, plate tectonics OP-345; OP-1286

Washington, earthquakes OP-1119

subduction zones see also back-arc basins; forearc basins.

Alaska neotectonics OP-1852

stratigraphy OP-1169

Arizona, structural geology OP-1886

California

deformation OP-802

petrology OP-1900

Dominican Republic, petrology OP-1900

Japan, neotectonics OP-1852

Mexico, structural geology OP-1886

Michigan, structural geology B 1904-S

Minnesota, structural geology B 1904-S

Oregon, earthquakes OP-720; OP-1120

Pacific Ocean, earthquakes OP-734

Pacific region, mantle OP-1020

Tonga, tectonophysics OP-1969

Vanuatu, plate tectonics OP-1287

Washington

earthquakes OP-720; OP-1120

petrology OP-1900

submarine canyons see also Monterey Canyon.

Alaska

engineering geology $\mathrm{OP}-140$

oceanography B 2002

Mississippi, oceanography OP-1740

Nevada, sedimentary petrology B 1988-E

Gulf of Mexico, ocean floors OP-743

Kazakhstan, plate tectonics OP-1295

sedimentary petrology OP-238; OP-723

submarine features see bottom features

submarine geology see marine geology

submarine landslides

Alaska

continental slope B 2002

engineering geology B 2002

geologic hazards B 2002

oceanography B 2002

Atlantic Ocean

continental margin B 2002

continental slope B 2002

California

continental margin B 2002

continental shelf B 2002

engineering geology B 2002

oceanography B 2002

Florida, continental slope B 2002

Gulf of Mexico, oceanography B 2002

Hawaii, oceanography B 2002

Louisiana, continental shelf B 2002

oceanography B 2002

Puerto Rico, oceanography B 2002

submarine valleys see submarine canyons

submarine volcanoes

Pacific Ocean, tectonophysics OP-897

subsurface mining see underground mining

Sudbury Basin

petrology OF 92-0391

Sudbury District Ontario

mineralogy OP-1178

Sudbury Irruptive

metal ores OP-1978; OP-1979

Sudbury Quadrangle

maps I-1420 (NL-17)

Sudeten Mountains see also Polish Sudeten

Mountains.

Carboniferous OP-1917

structural geology OP-1916

SUDS

earthquakes OP-1053

SUDSMAN

seismology OF 92-0597
SUDSPICK

seismology OF 92-0441; OF 92-0597

SUDSPLOT

seismology OF 92-0441; OF 92-0597

SUDSPROC

seismology OF 92-0597

SUDSSQZ

seismology OF 92-0597

suevite OP-1236

Sulawesi see Celebes

sulfates see also alunite; anhydrite; barite; brochantite; gypsum; jarosite.

Brazil, ground water OP-737

sulfidation

Dominican Republic, metal ores OP-532

Nevada, gold ores OP-441

sulfides see also chalcocite; chalcopyrite; galena; greigite; mackinawite; molybdenite; pyrite; pyrrhotite; sphalerite.

OP-64

Alaska

geochemistry OP-1304

metal ores OP-570

Arizona

OP-1993

metal ores OP-290

California

OP-557

metal ores OP-554

orogeny OP-797

China

copper ores OP-456

geochemistry OF 92-0525

Colorado

metal ores OP-937

molybdenum ores OP-1913

sedimentary petrology OP-1382

England, metal ores OP-1541

geochemistry OP-763

Idaho, orogeny OP-797

Italy, metal ores OF 93-0504

Maryland, geochemistry OP-439

metal ores B 2039; MF-1835-H; OP-465; OP1117

Nevada

OP-557

metal ores OP-531

Ontario

OP-1892

metal ores OP-1978; OP-1979

polymetallic ores OP-484

Red Sea, brines OP-2029

Yukon Territory, geochemistry OF 92-0525 sulfur

Alaska, geochemistry OF 92-0391

Canada, hydrology W 2400

Colorado, pollution OP-1968

geochemistry B 1770; OP-841

Hungary, energy sources OP-1263

Kentucky, geochemistry B 2046

Mariana Islands, plate tectonics OP-14

Micronesia, plate tectonics OP-14

New Mexico, geomorphology OF 92-0391

New York, pollution OP-412

Nova Scotia, sedimentary petrology OP-1672

Ohio, ground water OP-1454

Pacific Ocean, geochemistry OP-419; OP-1127

Philippine Islands, geochemistry OP-1994

Russian Federation, Quatemary OP-1904

S-34, Florida OP-1906

S-34/S-32

Alaska OP-570; OP-1304 
Canada OP-1905

China OP-1432

Colorado W 2340; OP-872; OP-1151; OP1965

Dominican Republic OP-532

energy sources OF 92-0391

England OP-1541

Florida OP-151; OP-1906

geochemistry OF 92-0009

Indiana OP-1648

Maine OP-750

metal ores OP-1117

Mexico OP-872

Michigan OP-1688; OP-2019

Micronesia OP-59; OP-1150

Missouri OP-1327; OP-1885

Nevada OP-441; OP-774

Ohio OP-1648

Peru OP-872

Poland OF 92-0704

Russian Federation C 1086

South Carolina OF 93-0303

United States OP-1905

Utah W 2340; OP-872; OP-1965

Yukon Territory OP-1432

Sweden, geochemistry OP-584

United States

geochemistry OP-584

hydrology W 2400

Vermont, pollution OP-412

Wyoming, petroleum OP-1767

sulfur deposits OF 92-0705

sulfur dioxide

geochemistry B 1966

geochronology OP-134

Sulfur Springs New Mexico

molybdenum ores OP-1243

sulphates see sulfates

sulphides see sulfides

sulphur see sulfur

Sulphur Bank Deposit

mineralogy OP-1038

sulrhodite

sulfides OP-64

Sulu Sea

geophysical surveys OP-585; OP-587

marine geology OP-819; OP-822; OP-823; OP824; OP-825

oceanography OP-820

Sumatra

geochronology OP-1538

sedimentation OP-1211

Summit Lake Reservioir

hydrogeology WRI 92-4025

Summit Mine

gold ores OP-934

Summitville District

economic geology OP-872

Sumbury Shale B 1909 .

Sunderland Quadrangle

maps MF-2224

sundry minerals see mineral inventory

Superfund

Kentucky, environmental geology WRI 924195

Massachusetts, environmental geology OF 92 0646

New Hampshire, environmental geology OF 92-0647

New Jersey, environmental geology OF 930243 superimposed metamorphism see polymetamorphism

Superior Province see also Abitibi Belt; Wabigoon Belt.

economic geology B 2039

petrology OP-1560

superplumes

Cretaceous OP-1115

Superstition Hills earthquake 1987

California OP-328; OP-1046

Sur Canyon

continental shelf OP-1443

oceanography B 2002; OP-1444

surface mining see also open-pit mining.

Colorado, ground water WRI 92-4067; OF 920122; OP-167

New Mexico, hydrogeology WRI 92-4004

Pennsylvania, hydrogeology OF 93-0115

surface waves see also coda waves; Rayleigh waves.

OP-15

California OP-1047

lowa, ground water OF 92-0085

mantle OP-1941

Minnesota, ground water OF 92-0085

surfactants

pollution OP-1645

surficial aquifers

Florida, environmental geology WRI 91-4181; WRI 92-4086

Great Plains, ground water OF 93-0114

surficial geology see also soils; surficial geology maps.

Arkansas, Quaternary OF 93-0273

California, earthquakes OP-1183

Virginia, Quaternary OF 92-0395

West Virginia, Quaternary OF 92-0395

surficial geology maps

Indiana OF 93-0268-B

Midwest, Quatemary OF 93-0543

New Jersey, continental shelf MF-2221

New Mexico, ground water WRI 91-4033

New York, ground water WRI 91-4012

Utah, geomorphology I-2199

Virginia, fluvial features B 1981

Washington OF 93-0233

West Virginia

OP-1543

fluvial features B 1981

surite

California, mineralogy OP-500

Surtsey

geochemistry OP-511

survey organizations

geologic hazards OP-114

Geological Survey of Canada

Alaska C 1086

Yukon Territory C 1086

industrial minerals B 2013

U.S, Geological Survey

YR; CAT; OF 92-0391; OF 92-0691;

OF 93-0123; OF 93-0575; I-2392; OP-771;

OP-830; OP-963; OP-1049; OP-1095; OP-

1219; OP-1516; OP-1954

Alaska C 1086; OF 92-0391; OF 92-0479; OF 92-0493; OF 92-0502; OF 93-0330

Antarctic Ocean OF 92-0556

Antarctica OP-1912

Basin and Range Province OP-1853

California OF 93-0290; OF 93-0294; OF 93-0295 earthquakes OP-102

East Pacific Ocean Islands YR

ecology C 1086; OP-476

energy sources OP-450

environmental geology C 1086; OF 93 0292-G; OF 93-0292-H; OF 93-0292-I; OF 93-0292-J; OP-180; OP-1277; OP1411

geochemistry OF 92-0392; OF 93-0001-B OF 93-0533; OP-505

geochronology OF 93-0336

geologic hazards DDS-0008; C 1111; OP1976

geomorphology OP-1398

geophysical surveys B 1966; OF 92-0391

Great Basin OP-1853

ground water YR; OF 92-0659

Guatemala OP-1496

Gulf of Mexico OP-274

Honduras OP-1496

hydrogeology YR; WRI 92-4075; OF 920146; OF 92-0161; OF 92-0163; OF 92 0497; OF 93-0120; OF 93-0154; OP-488; OP-606

hydrology C 1086; WRI 92-4060; OF 920105; OF 92-0134; OF 92-0480; OF 920634; OF 93-0032; OF 93-0036. OF 93-0058; OF 93-0104; OF 93-0125; OP-337; OP-1809

Idaho OF 93-0149

Illinois OF 92-0451; OF 92-0452

industrial minerals B 2013

lowa OF 92-0154

Kansas OF 93-0549

Kentucky B 2046

Louisiana OF 92-0492; OF 92-0530

maps OP-818; OP-839

marine geology OF 92-0585

Michigan OF 92-0157

mineral resources B 2039; OF 93-0258-A OF 93-0258-B; OP-1679; OP-1730

Minnesota OF 93-0065; OP-423

Mississippi OP-745

Missouri OF 92-0626; OF 93-0140

Montana OP-449

natural gas OP-646; OP-1860

Nebraska OF 92-0633

Nevada OF 93-0097

New Mexico OP-598

New York OF 92-0473

North Carolina OF 93-0113

North Dakota OF 93-0052

Pacific Coast OP-1946

paleontology OF 93-0513; OP-792

petroleum OP-1710

Pliocene OP-798

pollution OP-181; OP-1448

Polynesia YR

Texas OF 93-0112; OP-280

Utah P 1519

waterways OP-334

Wisconsin OF 93-0129

Wyoming OP-449

Yukon Territory C 1086

surveys see geophysical surveys

suspect terranes see terranes

suspension current see turbidity currents

Susquehanna River

geologic hazards YR

hydrogeology W 2387

hydrology WRI 90-4011 
Sussex Sandstone Member energy sources OF 92-0391; OF 93-0337

SUTRA

hydrogeology OF 91-0483

suture zones

Alaska, seismology OP-1384

Idaho, petrology OP-1671

Michigan, structural geology B 1904-S; I-2355

Minnesota, structural geology B 1904-S

Pakistan, tectonics OP-1637

Suwannee Limestone

hydrogeology W 2340

Suwannee River geochemistry OP-1644

Svalbard see also Spitsbergen. Quatemary P 1386-E tectonophysics OP-1891

Swanson River Field energy sources OP-626

Swat Pakistan tectonics OP-1637

Sweden see also Baltic Shield. geochemistry

OP-584; OP-1649

Siljan Ring OP-552

Stripa region OP-1042

mineralogy OP-1445

Quaternary P 1386-E

Sweetgrass Arch

energy sources OF 93-0337

Sweetina

Permian OP-1982

Swiss Alps

Quaternary P 1386-E

Switzerland

Quaternary, Swiss Alps P 1386-E

Sydney coal field

sedimentary petrology OP-1673

Sydney Mines Formation sedimentary petrology OP-1673

syenites see also monzonites.

Arkansas OP-1837

Montana OP-1294

Nova Scotia, geochemistry OP-1122

Sylvester Allochthon

stratigraphy OP-402

symmicton see diamicton

symposia

YR; OP-341; OP-509

Appalachians, ground water OP-240

Basin and Range Province

industrial minerals B 2013

mineral resources OP-817

California, Quaternary C 1086

earthquakes OP-768

ecology C 1086

economic geology YR

environmental geology C 1086

geochemistry OF 92-0525; OP-245; OP-353; OP-534; OP-535

geophysical surveys OF 93-0071

Great Basin, mineral resources OP-817

ground water OP-811

hydrogeology OP-376; OP-482; OP-495; OP665; OP-1077

hydrology OP-481; OP-1078

magmas OP-1732

metal ores OP-339; OP-362; OP-714

Midwest, industrial minerals OF 92-0514

Nevada, Quaternary C 1086 pollution OP-691; OP-692

seismology OP-676

structural geology OP-119

Utah, geologic hazards P 1519

synclines

OP-1652

Appalachians OP-1147

Colorado, stratigraphy B 1787-GG

Idaho

OP-523

Eocene OP-617

Kentucky, energy sources B 1909

Montana

B 1993

Eocene OP-617

West Virginia, energy sources B 1909 synclinoria

Saudi Arabia, Proterozoic B 1976

syngenesis

England, metal ores OP-1541

metal ores B 2003

synthetic aperture radar see SAR

Syria OP-1322

szymanskiite

California, oxides OP-849

$\mathbf{T}$

Ta see tantalum

Tabar Island

gold ores B 2039

Tabb fault system

structural geology OP-1799

Tabuk Formation sedimentary petrology OP-1378

Taconic Orogeny

Appalachians, zinc ores B 2039

Pennsylvania, areal geology B 1994

Vermont, maps OF 92-0282-A

taconite

Minnesota, non-metal deposits OF 92-0514

Tactical Air Command Sites

sedimentary petrology OP-1677

TACTS

sedimentary petrology OP-1677

Tadzhikistan

mineralogy OP-373; OP-1445

Taft Hill Member stratigraphy OP-1351

Tahoe Environmental Geographic Information System

environmental geology OP-1227

tainter gates

Missouri, engineering geology WRI 92-4118

Tajiguas Landfill

energy sources OF 92-0571

Tajikistan see Tadzhikistan

talc

Italy, petrology OP-851

Talc City Fault tectonics OP-977

talc deposits

OF 92-0020-B

California OP-204; OP-662

Talkeetna Formation energy sources OP-626

Talkeetna Mountains economic geology C 1094
Talnakh Russian Federation geochemistry OP-1086 metal ores OP-1313; OP-2014

talus fan see alluvial fans

talus slopes

Nevada, Quaternary OP-1070

Tamiami Formation OP-1075

Tamiami Trail ground water OP-671

Tampa Bay engineering geology OP-895 marine installations OP-892 oceanography OP-893

Tanada Volcano maps GQ-1688

Tanama Deposit copper ores OF 92-0578

Tanamo-Helecho District copper ores OF 93-0179

Tanawal Formation structural geology OP-1125

taneyamalite

California, manganese ores OP-458

tangential wave see $\mathrm{S}$-waves

Tanjung Formation sedimentary petrology $\mathrm{OP}-870$

tantalates see niobotantalates

tantalum

Australia, metal ores C 0930-M

Brazil, metal ores C 0930-M

Canada, metal ores C 0930-M

China, metal ores C 0930-M

Colorado, metal ores C 0930-M

geochemistry OP-30

Idaho, metal ores C 0930-M

Malaysia, metal ores C 0930-M

Mozambique, metal ores C 0930-M

Nigeria, metal ores C $0930-\mathrm{M}$

Rwanda, metal ores C 0930-M

Thailand, metal ores C 0930-M

Zaire, metal ores C 0930-M

tantalum ores

Australia C 0930-M

Brazil C 0930-M

Canada C 0930-M

China C 0930-M

Colorado C 0930-M

Idaho C 0930-M

Malaysia C 0930-M

Mozambique C 0930-M

Nigeria C 0930-M

Rwanda C 0930-M

Thailand C 0930-M

Zaire C 0930-M

Tantalus Fossa OP-1984

Taos Plateau

Cretaceous OP-11

geochemistry OP-490

petrology OF 92-0528

Tar Creek Field energy sources OP-1255

Tar Sand Triangle diagenesis OP-1465

tar sands see oil sands

Tarakan Basin petroleum OP-1829

Taranaki Basin sedimentation OP-1391

Tartara-San Pedro Volcano Quatemary OP-279 
Tatau Island gold ores B 2039

Taurus Littrow see Taurus-Littrow

Taurus Mountains ground water $\mathrm{OP}-39$

Taurus-Littrow OP-609; OP-805; OP-1074

Taylor Creek Rhyolite geochronology OP-1538 magmas OP-278

Taylor Group Invertebrata OP-525

Taylor Marl OP-527

Taylor Mountain Terrane metamorphism OP-1349

Taylorsville Basin guidebook OP-359 stratigraphy OP-1660

Taymyr Dolgan-Nenets Russian Federation see Norilsk region; Norilsk Russian Federation

\section{TDETECT}

seismology OF 92-0441

Teapot Dome

sedimentary petrology B 1917-L

Teche Delta

Quaternary OF 92-0530

technical cooperation

YR

Califomia, earthquakes YR

Poland, soils OF 93-0281

Utah, geologic hazards P 1519

Tecovas Formation

chromite ores OP-1229

tectites see tektites

tectogenesis see orogeny

tectonic imbrication see imbricate tectonics

tectonic lines see lineaments

tectonic maps

Idaho

OP-594

neotectonics OP-780

Nevada, structural geology B 2011

Utah, structural geology B 2011

Wyoming

OP-594

neotectonics.OP-780

tectonic sutures see suture zones

tectonics see also accretionary wedges; Alleghany Orogeny; Antler Orogeny; Appalachian Phase: back-arc basins; basin range structure; basins; continental margin; Cordilleran Orogeny; crust crustal shortening; deformation; faults; fold and thrust belts; folds; foliation; foreland basins; Hercynian Orogeny; lineaments; lineation; nappes; neotectonics; orogenic belts; orogeny; plate tectonics; pull-apart basins; rift zones; salt tectonics; shearzones; structural analysis; suture zones; terranes; transpression; uplifts.

OP-28; OP-1323; OP-1421; OP-1652

California

geochronology OP-333

stratigraphy OP-257

Canada OP-1215

compression tectonics

OP-1422; OP-1938; OP-1939

Alaska OP-492; OP-1789

Appalachians OP-1479

Califomia OP-1063; OP-1566

crust OP-2030

Illinois OP-1742

Michigan OP-1204
Missouri OP-1742

Nevada B 1988-C

Pakistan OP-1634

extension tectonics

OP-159; OP-401; OP-1235; OP-1790; OP-

1936; OP-1938

Alaska OP-1427

Antarctica OP-1317

Arizona OP-1886

Basin and Range Province OP-1158

Bering Sea OP-211

California OP-703; OP-759; OP-972; OP1172; OP-1281; OP-1376; OP-1793; OP1971

crust OP-2030

Great Basin OP-1158

Idaho OP-523; OP-941

Illinois OP-1419

Italy OP-1808

Kentucky OP-1419

metal ores OP-853

Mexico OP-1886

Midwest OP-1799

Montana OP-941

Nevada OP-108; OP-397; OP-614; OP-999; OP-1400; OP-1609

New Mexico OF 92-0528

Norway OP-1279

Poland OP-1916

Red Sea OP-2029

Washington OP-1397

imbricate tectonics

Appalachians OP-1147

Montana B 1993; OF 93-0337

Vanuatu OP-1908

Japan, tectonophysics OP-1620

Mexico, stratigraphy OP-257

Minnesota, intrusions OP-247

Montana, stratigraphy OF 92-0391

Norway, petrology OP-1173

Proterozoic OF 92-0525

Quaternary OP-756

seismotectonic

OP-1422

Alaska OP-1

Atlantic Ocean OP-1080

California P 1550-C; OP-113; OP-145; OP286; OP-406; OP-411; OP-541; OP-593. OP-699; OP-752; OP-1025; OP-1581

Chile OP-53

earthquakes OP-1893

Europe OP-206

Idaho OP-634

Italy OP-764

Mexico OP-670

Mississippi Valley OF 92-0391

Missouri OP-1318

Oregon OP-634

Pacific Ocean OP-1080

seismology OP-1275; OP-1867; OP-2033

Utah OP-621; OP-905; OP-909

stratigraphy OP-1345

Tonga, petroleum OP-896

United States OP-1215

Virginia, geochemistry B 1839-I,J

West Virginia, geochemistry B $1839-1, J$

Western Interior, sedimentary petrology OF 92 0391

tectonophysics see continental drift; core; crust; heat flow; isostasy; mantle; Mohorovicic discontinuity; ocean basins; paleomagnetism; plate tectonics; sea-floor spreading tectonostratigraphic terranes see terranes

Teels Marsh Deposit

evaporite deposits OP-226

Tehachapi Mountains

environmental geology OP-2006

structural geology OP-803

tektites

Atlantic Ocean, Eocene OP-791

Germany, stratigraphy B 2050

Haiti

geochronology B 2065

petrology OP-1873

stratigraphy OP-1181; OP-1414

lowa

geochronology OP-1613

stratigraphy B 2050

Ivory Coast

Quaternary OF 92-0699

stratigraphy OP-118

Mexico, stratigraphy B 2050; OP-1414

Montana, geochronology B 2065

New Mexico, Quaternary OF 92-0699

stratigraphy OP-1702

Wyoming, stratigraphy OP-1181

Tele-Prospector OP-1943

telecommunications

California, geologic hazards YR

telemetry

geophysical surveys B 1966

hydrology WRI 92-4060; OP-929

seismology OF 92-0441

Teluk Keramat Deposit Plantae OP-695

Tempe Terra OP-987; OP-1321; OP-1937; OP1984

temperature logging

Alaska, Quaternary C 1086

Florida, ground water WRI 91-4168

Hawaii, petrology OF 92-0586

Idaho, ground water WRI 92-4184

New Hampshire, environmental geology OF 92-0647

Tennessee, ground water OF 92-0135

temperature surveys see heat flow

Tengiz Field

energy sources OP-1967

Tenmile Canyon Colorado crystalline rocks OP-827

Tennant Creek Australia Quatemary B 2032-A

Tennant Creek earthquake 1988 Quatemary B 2032-A

Tennessee see also Appalachian Basin; Chattanooga Shale; Cumberland Plateau; Eutaw Formation; Knox Group; Mississippi Embayment; Mississippi River, New Madrid region; Reelfoot Rift; Rome Trough; Selma Group; Tennessee River, Tuscaloosa Formation; Valley and Ridge Province.

engineering geology B 2017; OF 93-0349

fluvial features, Hardeman County Tennessee OP-767

ground water

WRI 91-4150; WRI 92-4102; WRI 924104

Carroll County Tennessee OF 92-0166

Coffee County Tennessee OF 92-0135

Franklin County Tennessee OF 92-0135

Hickman County Tennessee WRI 92-4092

Maury County Tennessee WRI 92-4092

Memphis Tennessee WRI 91-4173 
hydrogeology

WRI 91-4195

Anderson County Tennessee WRI 92-4131

Benton County Tennessee OP-462

Carroll County Tennessee OP-462

Hamilton County Tennessee WRI 91-4190; WRI 92-4018

Jackson County Tennessee OP-1283

Knox County Tennessee OF 93-0039

Lauderdale County Tennessee OP-462

Putnam County Tennessee OP-1283

Tipton County Tennessee OP-462

hydrology

W 2400; WRI 92-4165; OF 91-0485

Columbia Tennessee OF 92-0648

Dyer County Tennessee WRI 92-4082

Rutherford County Tennessee OF 92-0482

lead-zinc deposits, Jefferson County Tennessee OP-12

Quatemary

OF 93-0273; OP-856; OP-1683

Dyer County Tennessee MF-2218; OP-486

Fayette County Tennessee OF 93-0273

Lake County Tennessee OP-486

Lauderdale County Tennessee OP-486

Obion County Tennessee MF-2218; OP-486

Shelby County Tennessee OP-486

Tipton County Tennessee OP-486

sedimentation OP-1529

seismology SM

stratigraphy OP-1368

waterways, Dyer County Tennessee OP-1084

Tennessee River

hydrology W 2340

Tenpeak Pluton

petrology OP-1463

Tensleep Sandstone

hydrogeology WRI 91-4044

tephra see pyroclastics

tephrochronology

Alaska, Quatemary C 1086

California, Quaternary OP-831; OP-1844

Idaho

neotectonics OP-634

paleomagnetism OF $92-0542$

Nevada, Quaternary OP-831

Oregon, neotectonics OP-634

Pacific Coast, Quaternary C 1086

Washington, Quatemary OP-143

Wyoming, Quaternary OF 92-0391

tephroite

California, manganese ores OP-319

terpanes

Alaska, energy sources OP-626

Colorado, energy sources OP-674

Commonwealth of Independent States, petroleum OP-1265

Europe, petroleum OP-1265

New Mexico, energy sources OP-674

Wyoming, petroleum OP-1767

Terra Cimmeria OP-1694

terraces see also fluvial features.

Bahamas, Quaternary OP-706

Barbados, Quatemary OP-706

Bermuda, Quatemary OP-706

Colorado, Quaternary OP-1676

Florida, Quaternary OP-706

Haiti, Quaternary OP-706

Mexico, Quaternary OP-706

reefs OP-1662

South Carolina, Quaternary I-1935

Tennessee, Quaternary OP-856
Wyoming, Quatemary OF 92-0391.

terranes see also accretionary wedges. Alaska

I-2164

geochemistry OP-721

metamorphic rocks $P$ 1497-C

petrology OF 92-0020-E

structural geology OP-94

tectonophysics OP-1430

Appalachians, ground water OP-1707

Arctic Ocean, tectonophysics OP-1891

Arctic region, tectonophysics OP-1891

Atlantic Coastal Plain, ground water OP-1707

Basin and Range Province, structural geology OP-19

Califomia

deformation OP-972

economic geology B 2019

metamorphic rocks OP-1166

structural geology OP-78; OP-649; OP-1172

Canada

metal ores OP-728

metamorphic rocks $P$ 1497-C

stratigraphy $\mathrm{OP}-402 ; \mathrm{OP}-708$

Canadian Shield, crust OP-1316

Colorado

Cretaceous OP-11

foliation OF 92-0391

Colorado Plateau, structural geology OP-19

Connecticut, metamorphic rocks OP-1188

geochemistry OF 92-0525

Idaho, petrology OP-630

Iowa, geomorphology OP-1882

Maine, crust OP-1920

Massachusetts, metamorphic rocks OP-1188

Michigan, structural geology B 1904-Q; B 1904-S; I-2355

Minnesota

economic geology B 2039

structural geology B 1904-S

Nevada

economic geology B 2019

stratigraphy B 1988-C

structural geology OP-933

New Mexico, Cretaceous OP-11

New South Wales Australia, structural geology OP-78

New York, structural geology OP-460

Northwest Territories, geochemistry OP-721

Nova Scotia, geochemistry OF 92-0525; OP1122

Ontario, structural geology OP-460

Oregon, metamorphic rocks OP-1166

Peru, stratigraphy OP-1330

petrology OF 92-0020-G

Quebec, crust OP-1920

Saudi Arabia, orogeny OP-1921

stratigraphy OP-8

structural geology $\mathrm{OP}-401$

tectonics OP-1517

United States

metal ores OP-728

stratigraphy OP-708

Utah, metal ores OP-1464

Washington

I-1963

stratigraphy OP-1480

Yemen, orogeny OP-1921

TERRAscope

earthquakes OP-503; OP-504
Tertiary see also Neogene; Paleogene.

OC-0140; OP-960

Alabama OP-1636

Alaska B 2034-A; OF 92-0391; OP-492; OP589; OP-1203

Antarctic Ocean OP-1145

Antarctica OP-1027

Arctic Ocean OP-1428: OP-1429; OP-1626

Arizona OF 92-0198

Atlantic Coastal Plain OP-378

Australia OP-1478

Basin and Range Province OP-1 158; OP-2015

Bolivia B 2039

California B 2034-A; OF 89-0450-D; OP-342: $\mathrm{OP}-442$

Central America OP-1862

Challis Volcanics OP-479; OP-617

Colorado I-2266

Great Basin OP-1158; OP-2015

Gulf Coastal Plain OP-378

Idaho OF 93-0248; OP-166

Indonesia OP-1478

Mississippi OP-1636

Montana OP-166; OP-1462

Muddy Creek Formation OP-92

Nevada B 2052; OF 92-0525; OF 93-0248; OF 93-0299; OP-108; OP-342; OP-397; OP643

New Mexico I-2266

Oregon B 2034-A; OF 93-0314

Pacific Ocean OP-295; OP-1829

Papua New Guinea OP-307

Puerto Rico OF 92-0391

Tonga OP-896

Utah B 2039

Vanuatu OP-185; OP-191

Vaqueros Formation, structural geology OP1701

Victoria Australia OP-1136

Washington B 2034-A

Wyoming OP-1569

Tethys

energy sources OP-1686

tectonics OP-1520

Tetrabranchiata see Ammonoidea

Tetracorallia see Rugosa

Tetrapoda see also Mammalia.

dinosaurs, Colorado OP-1963

Omithischia, Utah OP-1252

Theropoda OP-1511

tetrapods see amphibians; birds; mammals; reptiles

Texas see also Anadarko Basin; Cherry Canyon Formation; Delaware Basin; Guadalupe Mountains; Gulf Coastal Plain; Permian Basin; Trans-

Pecos.

chromite ores OP-1229

economic geology, Texas Panhandle OP-834

energy sources

Texas Panhandle OF 93-0522

Val Verde Basin OF 93-0522

engineering geology OP-280

environmental geology

OP-377

Edwards Aquifer WRI 92-4117

Texas Panhandle OF 92-0391

Uvalde County Texas WRI 92-4117

evaporite deposits OP-2012

geochemistry

OP-755

Winkler County Texas OP-1072

geomorphology OP-1703 
ground water

OP-2013

Balcones fault zone OP-1675

Bowie County Texas WRI 88-4208

Brazoria County Texas OF 93-0062; OF 930086

Cooke County Texas WRI 88-4208

Edwards Aquifer WRI 92-4155; OP-1675

El Paso County Texas P 1407-C; WRI 91 4155; OF 91-0455

Fannin County Texas WRI 88-4208

Fort Bend County Texas OF 93-0062; OF 93-0081

Galveston Texas OF 93-0086

Grayson County Texas WRI 88-4208

Harris County Texas OF 93-0062

Houston Texas OF 93-0086

Lamar County Texas WRI 88-4208

Lynn County Texas OP-1849

Red River County Texas WRI 88-4208

San Antonio Texas OP-1675

hydrogeology

OF 93-0112; OP-1200

Edwards Aquifer OF 92-0160

Pecos County Texas WRI 92-4190

Williamson County Texas OF 92-0160

hydrology W 2400

Invertebrata, Fannin County Texas OP-178

lead-zinc deposits OP-12

maps

YR; I-1420 (NH-14); I-1420 (NJ-14)

Brooks County Texas I-1420 (NG-14)

Cameron County Texas I-1420 (NG-14)

Duval County Texas I-1420 (NG-14)

El Paso County Texas YR

Hidalgo County Texas I-1420 (NG-14)

Jim Hogg County Texas I-1420 (NG-14)

Jim Wells County Texas I-1420 (NG-14)

Kenedy County Texas I-1420 (NG-14)

Kleberg County Texas I-1420 (NG-14)

Nueces County Texas I-1420 (NG-14)

Starr County Texas I-1420 (NG-14)

Webb County Texas I-1420 (NG-14)

Willacy County Texas I-1420 (NG-14)

Zapata County Texas I-1420 (NG-14)

natural gas

Brewster County Texas OF 93-0522

Pecos County Texas OF 93-0522

Terrell County Texas OF 93-0522

Val Verde County Texas OF 93-0522

petroleum

OF 93-0522

Fort Worth Basin OF 93-0522

sedimentary petrology, Lynn County Texas OP1991

stratigraphy

OP-526

Hunt County Texas OP-177

volcanism I-2291-A

waterways, Brazos River OP-150

Texas Department of Transportation engineering geology OP-280

Texas Panhandle

economic geology OP-834

energy sources OF 93-0522

environmental geology OF 92-0391

texthooks

hydrogeology OP-421

Th see thorium

Th-230

Nevada, Quatemary OP-916

Pacific Ocean, geochemistry OP-519
Th-230/Th-232 see Th-232/Th-230

Th-230/U-234 see U-234/Th-230

Th-230/U-238 see U-238/Th-230

Th-232

Gabon, geochemistry OP-713

Th-232/Th-230

Mexico, geochemistry OP-1778

Th/Th

California, Quaternary OF 93-0286

Nevada, Quatemary OP-294

Th/U

Bahamas, Quatemary OP-706

Barbados, Quatemary OP-706

Bermuda, Quatemary OP-706

California

geochemistry OP-678

Quatemary OF 93-0286

Colorado, Cretaceous OP-11

Florida, Quatemary OP-706

Haiti, Quatemary OP-706

Mexico, Quatemary OP-706

Nevada

Pleistocene OP-1670

Quatemary OP-294; OP-916

New England, Quatemary OP-748

New Mexico, Cretaceous OP-11

Pacific Coast, Quaternary C 1086

Quaternary OF 92-0525

Thackaringa Group

metal ores OP-942

Thai Chao-Phraya Rift petroleum OP-1829

Thailand

metal ores C 0930-M

thallophytes see algae; bacteria; lichens

Thar Desert

lignite OF 92-0576

Tharsis

OP-107; OP-142; OP-987; OP-1222; OP-1235;

OP-1323; OP-1936; OP-1938; OP-1984

Syria OP-1322

Tharsis Montes Formation OP-1338

Thaumasia OP-142; OP-1938; OP-1939.

The Banks see Outer Banks

The Geysers

energy sources OP-267

geochemistry OP-265

paleomagnetism OP-385

The Himalaya see Himalayas

Theria see Eutheria; Metatheria

thermal inertia OP-107

thermal ionization mass spectroscopy

geochemistry OF 92-0543

Quatemary OF 92-0525

thermal metamorphism

sedimentary petrology OP-1135

thermal remanent magnetization see themoremanent magnetization

thermal springs see hot springs

thermal surveys see heat flow

thermal waters see also fumaroles; geothermal

fields; geysers; hot springs; springs.

California

OP-997

geochemistry OP-265; OP-954

petrology OP-638

Idaho OF 91-0098

Montana, geochemistry OP-122; OP-637

Oregon OF 91-0098

Wyoming, geochemistry OP-122; OP-637 thermocouples

Hawaii, petrology OF 93-0342-A; OF 930342-B

hydrology OF 92-0490

thermoluminescence

Alaska, Quaternary OP-1059

Arkansas, Quaternary OP-1683

Oregon, Quaternary B 2038

Quatemary OF 93-0273

Tennessee, Quaternary OP-1683

thermometamorphism see thermal metamorphism

Thermopolis Shale

stratigraphy OP-1798

thermoremanent magnetization Alaska, structural geology OP-94

Arizona, stratigraphy OP-398

Hawaii, Quaternary OP-632; OP-633

Theropoda OP-1511

thick-skinned tectonics

Wyoming, structural geology OP-149

thinolite

Nevada, geochemistry OP-76

tholeiite

Oregon OP-1139

Red Sea, brines OP-2029

tholeitic basalt

Minnesota, geochemistry OF 92-0525

Thompson Mine

economic geology OP-736

thomsonite

Arkansas, petrology OP-1837

thorium

Atlantic Coastal Plain, heavy mineral deposits B 2039

Colorado, geophysical surveys OP-1813

geochemistry $\mathrm{B} 1770$

geochronology OF 92-0525

heavy mineral deposits OF 93-0240-A; OF 930240-B

Th-230

Nevada OP-916

Pacific Ocean OP-519

Th-232, Gabon OP-713

Th-232/Th-230, Mexico OP-1778

$\mathrm{U}-234 / \mathrm{Th}-230$

California OP-707

Mexico OP-707

Oregon OP-707

U-238/Th-230, Quaternary OF 92-0525

thorium ores

Vermont B 1955

thorium-uranium see $\mathrm{Th} / \mathrm{U}$

thoron see $\mathbf{R n}-222$

three-component seismographs

Armenia

earthquakes OF 93-0216

seismology OF 93-02,16

Central America, earthquakes DDS-0007

geophysical surveys OF 92-0561

Oregon, geophysical surveys OF 93-0318

Threeman Deposit

metal ores OP-224

Threnginger Formation stratigraphy OP-1303

thrust faults see also compression tectonics; crustal shortening; fold and thrust belts; foreland 
basins; imbricate tectonics; overthrust faults; reverse faults.

OP-159; OP-1790

Alaska

OP-1427

energy sources B 2034-A

petroleum B 2034-A

Appalachians, zinc ores B 2039

Argentina OP-1129

Arizona OP-1957

Bahamas OP-1132

Basin and Range Province, petroleum OF 930248

California

OP-144; OP-1957

earthquakes OP-1762

geochemistry OP-512

plate tectonics OP-752

seismicity OP-1914

Canada OP-1215

Colorado

OF 92-0391

geomorphology OP-1171

geophysical surveys OP-1813

stratigraphy OP-1523

Colorado Plateau

OP-679

petroleum OF 93-0248

Costa Rica OP-785

Hungary, energy sources OP-1687

Idaho, Eocene OP-617

Michigan I-2355; OP-1214

Montana

Eocene OP-617

natural gas OF 93-0337

petroleum OF 93-0337

natural gas OF 93-0248

Nevada B 2011

Pacific Ocean, plate tectonics OP-1651

Panama OP-785

Pennsylvania B 1994

Poland OP-967; OP-1916

Rocky Mountains OP-679

natural gas OP-1350

South Carolina, seismicity OP-2032

United States OP-1215

Utah

B 2011

metal ores OP-1464

stratigraphy OP-1523

Vermont, copper ores B 2039

Washington, geologic hazards B 1966

Wisconsin OP-1214

Wyoming, natural gas OF 93-0337

thrust sheets

Appalachians, economic geology B 1979

thrusts and thrusting see thrust faults

Thumb Member

Neogene OP-92

thunder eggs see geodes

Thurston Island

tectonophysics OP-1446

Ti see titanium

Tian-Shan see Tien Shan

Tibbet Canyon

Cretaceous OP-919

tidal channels

Bahamas, sedimentation OP-928

tidal flats

Washington, Quaternary OP-36; OP-120 tidal inlets

Louisiana

OF $92-0530$

sedimentation OF 92-0530

tidal marshes

Washington, Quaternary OP-36; OP-120

tidal outlets see tidal inlets

tidal wave see tsunamis

tide gates

North Carolina, hydrology OP-1958

Tidwell Member

stratigraphy OP-1963

Tien Shan see also Karatau Range. mineralogy OP-373

Tieton Andesite lava OP-957

Tiger Mountain Formation stratigraphy $\mathrm{OF}$ 92-058

till

Great Lakes, Quaternary OP-1288

Iceland, stratigraphy OP-1303

Iowa, hydrogeology OF $92-0500$

Minnesota, metal ores OP-169

Missouri, ground water OP-1571

Nevada, metal ores OP-169

New England, Quaternary OP-748

North Dakota, ground water OP-1924

Quatemary OP-1256

THlandsia usneoides

ecology OF 93-0303

Timan Ridge

Brachiopoda OP-491

Timan-Pechora region energy sources OP-1967

Timber Mountain Caldera geochemistry OP-313

Timber Mountains

economic geology OP-736

Timmins Ontario

sulfides OP-1892

TIMS

Quaternary OF 92-0525

tin

Utah, mineral resources MF-2081-C; MF-2081-

tin ores

OF 92-0557

Bolivia OP-1306

England OP-1541

Far East OF 92-0525

Great Britain OF 92-0525

New South Wales Australia OP-7

Peru, geochronology OP-1601

Saudi Arabia OP-499; OP-1558

South Carolina OF 92-0268

Tintic mining district

base metals OP-394

gold ores OP-1096

metal ores OP-965; OP-1464

mineral resources B 2039

Tintina Fault

sedimentary petrology OP-1553

tissue-contaminant studies

pollution OF 92-0494

titanite

California, ground water OP-995

Colorado, Proterozoic OP-10

Nevada, ground water OP-995

petrology OP-635

Quebec, gold ores OP-1097 titanium

Atlantic Coastal Plain, heavy mineral deposits B 2039

Colombia, geochemistry OP-755

England, geochemistry OP-755

gold ores OP-168

heavy mineral deposits OF 93-0240-A; OF 930240-B

petrology OP-1705

Poland, geochemistry OP-755

Quaternary OP-459

Texas, geochemistry OP-755

titanium ores

Canada OP-728

United States OP-728

Tithonian

Utah OP-1252

Titicus River valley

ground water WRI 87-4144

titration OF 93-0125; OP-477

Tiva Canyon Member geophysical surveys OF 92-0028 paleomagnetism OP-863

Toano Range lava OP- 809

Toba Tuff geochronology OP-1538

Todos Santos Deposit metal ores OP-1306

toluene pollution OP-1128

Tombigbee River Aquifer ground water P 1410-G

Tombstone Arizona maps I-2420

Tombstone volcanic center maps I-2420

tonalite

Alaska OP-1194

Canada OP-1463

Nova Scotia, geochemistry OP-1122

Oregon OP-1139

Rocky Mountains OP-1716

United States OP-1463

Tonga

geomorphology OP-989

petroleum OP-896

plate tectonics OP-345

seismology OP-1758

tectonophysics OP-1969

Tonga Trench

plate tectonics OP-413

Tongass National Forest mineral resources OP-106

Tongatapu geomorphology OP-989

Tongue of the Ocean structural geology OP-1132

Tongue River Member geochemistry OP-1305 sedimentary petrology OP-228

tongues

New York, stratigraphy B 1839-L

Tonkin Spring Mine metal ores OP-627

tonnage

Arizona, metal ores OF 93-0228

Califomia, metal ores OF 93-0228

metal ores OF 93-0194

mineral resources OF 93-0280 
Montana, metal ores OF 93-0207

Tonopah Junction Nevada

geophysical surveys OF 92-0450

Tonopah Nevada

geochemistry OP-1609

Tonopah Quadrangle

maps MF-1877-A

tonstein

OP-93; OP-228; OP-1293

Indonesia OP-870

stratigraphy OP-1821

Western Interior, stratigraphy OP-1182

Tonto Basin Supergroup

geochemistry OP-203

Topatopa Field

energy sources OP-1255

topaz

Nevada, lava OP-809

petrology OP-1061

topaz rhyolite

Nevada, lava OP-809

Topeka Kansas

environmental geology OP-4

tophus see tufa

topographic maps

I-2392; OP-1149; OP-1162; OP-1907

Atlantic Ocean, ocean floors I-2279-A

California, continental margin I-2089-C; I2091-C

geomorphology OP-1398

Toquima Range

sedimentary petrology OP-1795

torbanite

geochemistry OP-1923

Tori Shima

earthquakes OP-501

Torrey Hill Formation

stratigraphy OP-1530

torsion faults see wrench faults

tourmaline

Colorado, energy sources OP-518

geochemistry OP-763

New Mexico, energy sources OP-518

New South Wales Australia, metal ores OP-942

Ontario, geochemistry OP-1942

Queensland Australia, metal ores OP-942

Virginia OP-1755

tourmalínite

geochemistry OP-763

New South Wales Australia, metal ores OP-942

Queensland Australia, metal ores OP-942

Tournaisian

Virginia OP-1367

West Virginia OP-1367

Trace Creek Member stratigraphy OP-1821

trace metals

Arizona, geochemistry OP-590

Arkansas, hydrology OF 93-0122

Australia, metal ores C 0930-M

Brazil, metal ores C 0930-M

California, environmental geology OF $92-0456$

Canada, metal ores C 0930-M

China, metal ores $\mathrm{C}$ 0930-M

Colorado, metal ores C 0930-M

geochemistry C 1086

hydrology OF 92-0634

Idaho

environmental geology OF 92-0156

metal ores C 0930-M
Louisiana

geochemistry OP-935

pollution OF 92-0492

Malaysia, metal ores C 0930-M

metal ores OP-1035

Mozambique, metal ores C 0930-M

New Jersey, environmental geology OF 920153

Nigeria, metal ores $\mathrm{C}$ 0930-M

Rwanda, metal ores C 0930-M

Tennessee, ground water OF 92-0135

Thailand, metal ores C 0930-M

Utah, ground water OF 92-0640

Wyoming, ground water OF 91-0533

Zaire, metal ores C 0930-M

TracePlot

geophysical surveys OF 93-0005; OF 93-0226

tracers see also $\mathrm{D} / \mathrm{H}$.

OP-409

California, ground water OP-474

Colorado

geochemistry OF 92-0525

hydrogeology OP -408

hydrology WRI $92-4081$

pollution OP-1579

East Pacific Ocean Islands, geochemistry OP925

Galapagos Islands, geochemistry OP-925

geochemistry OF 92-0525; OP-530; OP-605

ground water YR; OP-683; OP-1473

Idaho, ground water OP-147

Maryland, hydrology OP-524

Massachusetts, ground water OP -431

Minnesota, pollution OF 93-0042; OF 93-0079

Missouri, ground water OP-1571

Virginia, hydrology OP-524

waste disposal OF 92-0457

Wyoming, geochemistry OF 92-0525

trachyandesites see also latite.

Mexico OP-1778

Trachyscaphites

Invertebrata OP-178

trachytes

Hawaii OP-164

Virginia, geochemistry B 1839-I,J

West Virginia, geochemistry B 1839-I,J

Tracy Quadrangle

maps OF 93-0225

Tradewater Formation

sedimentary petrology OF 92-0391

Tradewater Group

diagenesis OP-1466

Trail Formation

structural geology OP-1474

Tranquillity Base see Taurus-Littrow

Trans-Alaska Pipeline

natural gas OP-74

Trans-Jordan see Jordan

Trans-Koolau Tumnel hydrology WRI 92-4049

Trans-Pecos

ground water OF 91-0455

hydrogeology WRI 92-4190

maps YR

petrology OP-1611

transcurrent faults

California OP-340

China, plate tectonics OP-1519

Manitoba, petrology OP-1560

Ontario, petrology OP-1560

United States, plate tectonics OP-1519 transducers

Arizona, hydrology OF 93-0071

Arkansas, hydrology OF 93-0071 '

Colorado

ground water OF 93-0071

rock mechanics OF 93-0071

geophysical surveys OF 93-0071

ground water $O F$ 93-0071

hydrology OF 93-0071

Michigan, ground water OF 93-0071

Nevada

ground water OF 93-0071

waste disposal OF 91-0493

Oklahoma, ground water OF 93-0071

transform faults

OP-1890

Alaska, tectonophysics OP-1430

Atlantic Ocean, tectonophysics OP-1080

California

energy sources OP-267

plate tectonics OP-145; OP-759

stratigraphy OP-1281

Mexico, metal ores B 2039

Pacific Ocean, tectonophysics OP-1080

tectonophysics OP-463

transformations, Laplace see Laplace transformations

transgression see also changes of level.

Atlantic Coastal Plain, stratigraphy OP-950

Colorado

sedimentary petrology OP-1567

stratigraphy B 1787-EE

Gulf Coastal Plain, stratigraphy OP-1817

Louisiana, Quaternary OF 92-0530

Montana

stratigraphy OP-1798.

Triassic B 1917-P

natural gas B 1909

New Mexico, stratigraphy B 1787-EE

stratigraphy B 1808-O

Texas, stratigraphy OP-1575

Utah

Cretaceous OP-919

stratigraphy B 1787-BB

Wyoming

energy sources OP-889

Triassic B 1917-P

transpression

Alaska, metamorphic rocks OP-1194

Bering Sea, plate tectonics OP-1859

Missouri, deformation OP-1861

Poland, structural geology OP-1916

Rocky Mountains, natural gas OP-1350

Wyoming, structural geology OP-149

Transverse Ranges

neotectonics OP-1063

stratigraphy OP-1281

structural geology OP-703; OP-803

transverse wave see $S$-waves

traps see stratigraphic traps; structural traps

Traverse Group

B 1909

hydrogeology OP-1228

Traverse Mountains

Quatemary OP-911

travertine

California OF 92-0707

Montana, geochemistry OP-978

Wyoming, geochemistry OP-464; OP-978

tree rings

Colorado 
geomorphology OP-885

Quaternary OF 93-0250

Maryland, environmental geology OP-1089

Tennessee

hydrogeology OP-462

tremolite hydrology WRI 92-4082

petrology OP-393

trenches

Alaska, geophysical surveys OF 93-0238

trenching

Northern Territory Australia, Quaternary B 2032-A

Tennessee, Quaternary MF-2218

trend-surface analysis

hydrogeology WRI 92-4044

hydrology OF 93-0056

Triassic see also Chugwater Formation.

OP-134; OP-1983

Alaska OP-626; OP-1349

Antarctic Ocean OP-1395

Arizona OP-613

Camian, Virginia OP-1660

Chinle Formation

OP-1659

sedimentary petrology B 2000-E

uranium ores $\mathrm{OP}-1848$

Hungary OP-1263

Lockatong Formation

energy sources OP-1842

ground water OP-986

Moenkopi Formation, maps I-2290

Nevada B 1988-D; OF 93-0248

New Jersey MF-2208

New York MF-2208

Norian, Virginia OP-1660

North Carolina OP-597

Peru OP-1601

Utah OP-1736

triazine

pollution OP-816

trichloroethylene

Ontario, pollution OP-369

trihalomethane

Kentucky, hydrology WRI 92-4057

Trilobita

Alaska OP-1123

trilobites

Arkansas, sedimentary petrology OF 93-0291

Kazakhstan, plate tectonics OP-1295

Missouri, sedimentary petrology OF 93-0291

Nevada, stratigraphy OP-623

Trilobitomorpha see Trilobita

Trinity Aquifer ground water WRI 92-4155

Trinity Shoal

Quaternary OF 92-0530

triple junctions

California, plate tectonics OP-145; OP-752; OP-759; OP-1749

Chile, plate tectonics OP-586

Greece, plate tectonics OP-542

Iceland, seismicity OP-322

Pacific Ocean, plate tectonics OP-1651

tripoli deposits

non-metal deposits OF 92-0514

tripolite see diatomaceous earth

Tripon Pass Limestone stratigraphy OP-1846

Tristan da Cunha engineering geology $\mathrm{OP}-443$ tritium

California

geochemistry OP-955

ground water OF 92-0655; OP-474

Idaho, ground water OP-147

Illinois

environmental geology W 2390

hydrogeology W 2386

Missouri, ground water OP-1571

Triton Satellite OP-1348; OP-1562; OP-1590; OP-1591; OP-1592; OP-1593; OP-1695

TRM see thermoremanent magnetization troctolite

OP-805; OP-806

Minnesota, geochronology OP-758

Troms Norway

structural geology OP-1279

trona

stratigraphy $\mathrm{P}$ 1506-F

trondhjemite

California, geochemistry OP-1141

Canada OP-1463

Oregon, geochemistry OP-1141

Rocky Mountains OP-1716

United States OP-1463

Truckee River hydrology C 1086; OF 92-0627

Tsankawi Pumice Bed geochronology OP-1538

tsunamis

Alaska, environmental geology OP-564

Califormia, engineering geology EV

Costa Rica, structural geology OP-785

engineering geology OP-415; OP-1483 geologic hazards P 1240-B

Panama, structural geology OP-785

Washington

earthquakes OP-1118

Quaternary OP-36

West Pacific Ocean Islands, earthquakes OP501

Tuarangia

Invertebrata OP-1839

tubes, lava see lava tubes

Tuckahoe Group guidebook OP-359

Tucson Arizona geochemistry OF 92-0599; OP-1505

Tucson Basin ground water OP-1468

Tucupita Quadrangle maps MF-2242

tufa

California

OP-77

Quaternary OF 93-0232; OF 93-0311

Nevada, geochemistry OP-76

tuff see also ash flows; volcaniclastics.

OP-596

Africa, stratigraphy OP-656

Alaska

Quaternary OP-1059

stratigraphy OP-1169

Bolivia, metal ores OP-1306

California

diagenesis OP-1386

structural geology OP-1971

Colorado

geochemistry OP-490

non-metal deposits B 2061-A

stratigraphy OP-985 ground water OP-207

Idaho

OP-1381

Eocene OP-617

geochronology OP-479

paleomagnetism OP-697

Montana, Eocene OP-617

Nevada

geochemistry OP-774; OP-775

ground water OF 90-0369; OP-1899

waste disposal OP-724

New Mexico

geochemistry OP-490

non-metal deposits B 2061-A

North Sea, stratigraphy OP-1359

Oregon

OP-982

mineral resources OF 93-0259-A; OF 93 0259-B

Russian Federation, geochronology OP-1407

Spain

gold ores OP-231

metal ores OP-875

Texas OP-1611

Wyoming, paleomagnetism OP-697

tuff lava see welded tuff

tuft see tufa

Tug Fork

hydrogeology WRI 92-4073

Tujunga Terrane

igneous rocks OP-1112

stratigraphy OP-128

Tulare Basin

ground water OF 92-0655

Tulelake California

geomorphology OP-266

Quaternary C 1086

Tullock Member

OP-1744

diagenesis OP-395

sedimentary petrology B 1917-L

Tully Limestone B 1909

tundra

Alaska, ecology C 1086

tungstates see scheelite; wolframite

tungsten

Utah, mineral resources MF-2081-E

Tungsten Jim Mine

tungsten ores OP-1296

tungsten ores

Califomia OP-260; OP-662

Far East OF 92-0525

Great Britain OF 92-0525

Idaho OP-1296

Montana I-2050-F

Nevada OP-260

Peru, geochronology OP-1601

Tunguska

sedimentary petrology OF 92-0391

Tunguska Basin

energy sources OP-1967

Tunisia

pollution OP-599

tunnels

Alaska, Quaternary OP-1616

Illinois, hydrology YR

Nevada, geophysical surveys OF 93-0187

turbidite see also Bouma sequence; turbidity currents.

Alaska, energy sources B 2034-A

Arctic Ocean, Quaternary OF 92-0426 
Black Sea, oceanography. OF 93-0274

Haiti, stratigraphy OP-1179

Kenya, sedimentary petrology OP-1490

Mexico, stratigraphy OP-1179

Middle East, oceanography OF 93-0274

Nevada sedimentary petrology B 1988-E; OP-1795 stratigraphy OP-1846

Oregon, sedimentary petrology OP-1490 petroleum OP-710

sedimentary petrology OP-238; OP-709; OP723; OP-738

Texas, stratigraphy OP-1387

turbidity current structures see Bouma sequence; graded bedding; load casts

turbidity currents see also submarine canyons. Alaska, oceanography OP-1298

Vanuatu, ocean floors OP-368

Turkana Basin stratigraphy OP-656

Turkey ground water, Taurus Mountains OP-39 oceanography OF 93-0274 seismology EV

Turkey Creek Caldera geochemistry B 2021-C

Turkey Mountain Quadrangle maps MF-2230

Turnagain Arm stratigraphy OP-1169

Turonian

Colombia OP-755

Colorado OF 92-0391

England OP-755

Montana OP-395

Poland OP-755

Texas OP-755

Wyoming OP-395

Turrilitaceae

Invertebrata OP-525

stratigraphy OP-526; OP-527

Turtle Fault metal ores B 2042-C

Turtie Lake Formation structural geology OP-1413

Tusas Mountains Cretaceous OP-11

Tusayan Dunes Quaternary OP-976

Tuscaloosa Aquifer ground water P 1410-G

Tuscaloosa Formation OP-1817

Tuscarora Formation mineralogy OP-1755

tutorials OF 93-0526

Tuttle Creek Dam pollution OF 93-0087

Tuxedni Group energy sources OP-626

Twentynine Palms California ground water OF 93-0279

two-mica granite Basin and Range Province, tectonics OP-2021 California OP-1148 Great Basin, tectonics OP-2021

Tyler Formation petroleum OF 93-0337

Tyonek Formation energy sources OP-626
Tyonek Quadrangle maps OF 92-0346

Tyrrhena Patera OP-1647

Tyrrhenian Sea

plate tectonics OP-1682

$\mathbf{U}$

U see uranium

U-234/Th-230

California, Quaternary OP-707

Mexico, Quaternary OP-707

Oregon, Quatemary OP-707

$\mathrm{U}-234 / \mathrm{U}-238$ see $\mathrm{U}-238 / \mathrm{U}-234$

U-235

Gabon, geochemistry OP-713

U-238

California, ground water OP-995

Colorado, environmental geology OP-1394

Gabon, geochemistry OP-713

Mexico, geochemistry OP-1778

Nevada, ground water OP-995

U-238/Th-230

Quaternary OF 92-0525

U-238/U-234

Montana, geochemistry OP-978

Polynesia, geochronology OP-1436

Quatemary OF 92-0525

Wyoming, geochemistry OP-978

U. S. Agency for International Development geothermal energy OP-1496

U.S. Bureau of Indian Affairs mineral resources OF 92-0514

U.S. Bureau of Mines economic geology OF 92-0514 industrial minerals B 2013

U.S. Department of the Interior YR

environmental geology C 1086

U.S. Exclusive Economic Zone see United States Exclusive Economic Zone

U.S. Geological Survey

YR; CAT; OF 92-0391; OF 92-0691; OF 930123; OF 93-0575; I-2392; OP-771; OP-830; OP-963; OP-1049; OP-1095; OP-1219; OP1516; OP-1954

Alaska

OF 92-0391

Cenozoic C 1086

hydrogeology OF 92-0479

hydrology OF 92-0493

petroleum OF 93-0330

waste disposal OF 92-0502

Antarctic Ocean, geophysical surveys OF 920556

Antarctica OP-1912

Basin and Range Province, mineral resources OP-1853

California

earthquakes OF 93-0290

environmental geology OF 93-0294

seismology OF 93-0295

earthquakes OP-102

East Pacific Ocean Islands, geologic hazards YR

ecology C 1086; OP-476

energy sources $\mathrm{OP}-450$

environmental geology C 1086; OF 93-0292G; OF 93-0292-H; OF 93-0292-I; OF 930292-J; OP-180; OP-1277; OP-1411 geochemistry OF 92-0392; OF 93-0001-B; OF 93-0533; OP-505

geochronology OF 93-0336

geologic hazards DDS-0008; C 1111; OP-1976

geomorphology OP-1398

geophysical surveys B 1966; OF 92-0391

Great Basin, mineral resources OP-1853

ground water YR; OF 92-0659

Guatemala, geothermal energy OP-1496

Gulf of Mexico, natural gas OP-274

Honduras, geothermal energy OP-1496

hydrogeology YR; WRI 92-4075; OF 92-0146; OF 92-0161; OF 92-0163; OF 92-0497; OF 93-0120; OF 93-0154; OP-488; OP-606

hydrology C 1086; WRI 92-4060; OF 92-0105; OF 92-0134; OF 92-0480; OF 92-0634; OF 93-0032; OF 93-0036; OF 93-0058; OF 93-0104; OF 93-0125; OP-337; OP1809

Idaho, hydrogeology OF 93-0149

IIlinois, hydrology OF 92-0451; OF 92-0452

industrial minerals B 2013

Iowa, hydrogeology OF 92-0154

Kansas, paleontology OF 93-0549

Kentucky, geochemistry B 2046

Louisiana

ecology OF 92-0530

environmental geology OF 92-0530

hydrogeology OF $92-0492$

maps OP-818; OP-839

marine geology OF 92-0585

Michigan, hydrogeology OF 92-0157

mineral resources B 2039; OF 93-0258-A; OF 93-0258-B; OP-1679; OP-1730

Minnesota

hydrogeology OF 93-0065

hydrology OP-423

Mississippi, ground water OP-745

Missouri

ground water OF 93-0140

hydrogeology OF $92-0626$

Montana, natural gas OP-449

natural gas OP-646; OP-1860

Nebraska, hydrogeology OF 92-0633

Nevada, hydrogeology OF 93-0097

New Mexico, hydrology OP-598

New York, hydrogeology OF 92-0473

North Carolina, hydrogeology OF 93-0113

North Dakota, hydrogeology OF 93-0052

Pacific Coast, energy sources OP-1946

paleontology OF 93-0513; OP-792

petroleum OP-1710

Pliocene OP-798

pollution OP-181; OP-1448

Polynesia, geologic hazards YR

Texas

engineering geology OP-280

hydrogeology OF 93-0112

Utah, geologic hazards P 1519

waterways OP-334

Wisconsin, hydrogeology OF 93-0129

Wyoming, natural gas OP-449

Yukon Territory, Cenozoic C 1086

U.S. Minerals Management Service energy sources OP-1946

U. S. National Bureau of Standards OP-866

U.S. Rocky Mountains see Absaroka Range; Bighom Mountains; Laramie Mountains; Medicine Bow Mountains; San Juan Mountains; Sangre de Cristo Mountains; Sawatch Range; Uinta Mountains; Wasatch Range; Wind River Range 
U. S. Virgin Islands

hydrogeology C 1081

hydrology W 2400

$\mathrm{U} / \mathrm{Pb}$ see also $\mathrm{Pb} / \mathrm{Pb}$.

OP-1803; OP-1805

Appalachians, structural geology OP-1079

Arizona, uranium ores OP-613

California

petrology OP-1376

Phanerozoic OP-1340

structural geology OP-1413

Colorado

Cretaceous OP-11 geochronology OP-1804

England, geochemistry OP-158

geochemistry OP-1377

geochronology OF 92-0525; OP-134

Idaho, petrology OP-630

Manitoba, geochronology OP-1709

Maryland, intrusions OP-1106

Minnesota, geochronology OP-758

Montana

crust OP-2017

petrology OP-1731

New England, geochronology OF 92-0525

New Hampshire, geochronology OP-1105

New Mexico, Cretaceous OP-11

New York, geochronology OP-1709

North Carolina

geochemistry OP-1607

structural geology OP-1955

Norway, structural geology OP-1279

Peru, geochronology OP-1601

petrology OP-1199; OP-1246; OP-2025

Saudi Arabia, Proterozoic B 1976

Virginia

intrusions OP-1106

structural geology OP-1955

Wyoming

crust OP-2017

geochemistry OP-2016

$\mathrm{U} / \mathrm{Th} \operatorname{see} \mathrm{Th} / \mathrm{U}$

$\mathbf{U} / \mathbf{T h} / \mathbf{P b}$

OP-806

geochronology OF 92-0525

petrology OP-1956

Proterozoic OF 92-0525

Ubehebe District

mineralogy OP-500

Ubehebe Peak Quadrangle

economic geology OP-662

Uchee Belt

geochronology OP-968

structural geology OP-1918

Uinta Basin

Cretaceous I-1797-D

energy sources OP-1753

natural gas OF 93-0248

oil and gas fields OP-1857

oil sands OP-1855

Paleogene B 1787-Q

sedimentary rocks B 1787-DD

stratigraphy B 1787-BB

structural geology B 1787-HH

Uinta Fault

petroleum OP-1635

Uinta Formation

sedimentary rocks B 1787-DD

structural geology B 1787-HH

Uinta Mountains

petroleum OP-1635
Uinta-Piceance Basin Study Area Paleogene B 1787-Q

Uintah Basin see Uinta Basin

UK-US West Antarctic Tectonics Project tectonophysics OP-1446

ULF waves

earthquakes OP-766

geophysics OP-367

ulminite

geochemistry OP-1923

Ultisols

Pennsylvanian OP-1233

ultramafics see also homblendite; kimberlite; op-

hiolite; peridotites; pyroxenite.

Montana OP-1500

Puerto Rico, metal ores OP-1656

ultraviolet spectroscopy

hydrology OF 92-0480

Um Sahm Sandstone

sedimentary petrology OP-1378

Umatilla Indian Reservation

hydrogeology WRI 91-4087

Umnak Plateau

engineering geology $\mathrm{OP}-140$

Uncompahgre Fault

stratigraphy OP-1523

Uncompahgre Formation

Cretaceous OP-11

unconformities see erosional unconformities

underground installations

Nevada, waste disposal OP-724

underground mining see also longwall mining. engineering geology OP-506

West Virginia, hydrogeology W 2384

underground water see ground water

underthrust faults

Alaska, metamorphic rocks P 1497-C

Appalachians OP-1079

Canada, metamorphic rocks P 1497-C

tectonophysics OP-1037

Union Carbide V Deposit phosphates OP-681

United Arab Emirates Quaternary, Abu Dhabi OF 92-0391; OP-1198 stratigraphy, Abu Dhabi OP-1453

United Kingdom see also Great Britain. sedimentary petrology OF 93-0236

United States see also Alabama; Alaska; Appalachians; Arizona; Arkansas; Atlantic Coastal Plain; California; Colorado; Colorado Plateau; Columbia Plateau; Connecticut; Delaware; District of Columbia; Florida; Georgia; Great Basin; Great Lakes; Great Plains; Hawaii; Idaho; Illinois; Illinois Basin; Indiana; lowa; Kansas; Kentucky; Louisiana; Maine; Maryland; Massachusetts; Michigan; Midwest; Minnesota; Mississippi; Mississippi Valley; Missouri; Montana; Nebraska; Nevada; New England; New Hampshire; New Jersey; New Mexico; New York; North Carolina; North Dakota; Ohio; Oklahoma; Oregon; Pennsylvania; Rhode Island; Rocky Mountains; South Carolina; South Dakota; Tennessee; Texas; U. S. Virgin Islands; United States Exclusive Economic Zone; Utah; Vermont; Virginia; Washington; West Virginia; Westem U.S.; Wisconsin; Wyoming. DDS-0006; YR; OP-352; OP-382; OP-963 Archean, Wyoming Province OP-705 areal geology, Beartooth Mountains OF 930207 base metals, San Juan Mountains OF 93-0183 bibliography, Beartooth Mountains OF 930285-A; OF 93-0285-B

Carboniferous, Ozark Mountains OP-1231

coal, Beartooth Mountains OF 93-0207

Cretaceous

Powder River basin OC-0135; OC-0136; OC-0137; OC-0138

Uinta Basin I-1797-D

Wyoming Province OP-11

crust

Beartooth Mountains OP-2017

Bighorn Mountains OP-2017

Wyoming Province OP-2017

deformation

New Madrid region OP-1861

Ozark Mountains OP-1861

Reelfoot Rift OP-1861

diagenesis, Powder River basin OP-395

earthquakes

OP-102

Mount Saint Helens EV

New Madrid region OP-1996

Reelfoot Rift OP-1996

Wasatch fault zone OP-905

economic geology, Beartooth Mountains OF 93-0207

elastic waves, Mount Saint Helens B 1966

energy sources

OP-453; OP-861; OP-862

Anadarko Basin OP-1753

Delaware Basin OF 93-0522

Newark Basin OP-1842

Palo Duro Basin OF 93-0522

Permian Basin OF 92-0524; OF 93-0522

Powder River basin OF 92-0391; OF 930337; OP-889

Uinta Basin OP-1753

engineering geology

OF 92-0514; OP-415; OP-506; OP-1108

Mississippi River WRI 92-4118; OF 920530

Mount Rainier OP-907

Mount Saint Helens OP-956

New Madrid region OF 92-0391

Wasatch Front P 1519

environmental geology

YR; C 1086; C 1105; OP-180; OP-548; OP1277; OP-1411

Arkansas River valley OF 92-0391

Floridan Aquifer WRI 91-4181; WRI 924086

Lake Tahoe OP-1227

Missouri River C 1120-C

Ohio River C 1120-C

fluvial features, Ozark Mountains OP-1700 geochemistry

OF 92-0525; OP-379; OP-584; OP-1644;

OP-1649; OP-2018

Amargosa Desert OP-1775

Cascade Range OF 93-0314; OP-1121

Chesapeake Bay OP-439

Klamath Mountains OP-1141

Missouri River valley OF 92-0592

Newark Basin OF 93-0010

Ohio River OP-628

Permian Basin OP-1072

Powder River basin OP-1305

San Juan Mountains OP-490; OP-1218

Sangre de Cristo Mountains OP -490

Wind River Range OP-712

Wyoming Province OP-2016 
Yellowstone National Park OP-49; OP-122; OP-327; OP-464; OP-536; OP-637; OP874; OP-998

geochronology

OF 93-0336

Pine Mountain Window OP-968

geologic hazards

OP-114; OP-846; OP-1052

Cascade Range W 2340

Mississippi Embayment OP-969

Mississippi River OP-669

Mount Saint Helens B 1966

Susquehanna River YR

Wasatch fault zone P 1519

Wasatch Front P 1519

geomorphology

I-2206

Mount Shasta OP-266

Ozark Mountains OP-1544

Potomac River basin B 1981

San Juan Mountains OP-859

Wasatch fault zone I-2199

geophysical surveys

DDS-0009; OP-364; OP-951; OP-1440

Cascade Range B 1966; OF 93-0319; OP1374

Mount Hood B 1966

Mount Rainier B 1966

Mount Saint Helens B 1966

Mount Shasta B 1966

Newberry Volcano B 1966

Powder River basin OF 93-0002; OC-0140

Sangre de Cristo Mountains OF 93-0018 gold ores.

Idaho Batholith B 2039

Klamath Mountains OP-934

ground water

OF 92-0652; OP-240; OP-417; OP-811;

OP-983; OP-1928

Anadarko Basin B 1989-D

Chicot Aquifer OF 92-0492; OF 93-0081; OF 93-0086; OP-742

Delmarva Peninsula OP-777; OP-1174

Floridan Aquifer W 2340; W 2392; WRI 91-4168; WRI 92-4076; WRI 934038; OF 92-0472; OF 93-0049; OF 930050; OP-494; OP-867; OP-1568

Magothy Aquifer WRI 88-4127; WRI 904182; OF 92-0460; OF 92-0464

Merrimack River valley WRI 91-4025

Mississippi Embayment OP-1191

Mississippi River P 1405-C

Missouri River P 1405-C

Missouri River valley OF 93-0109; OF 930140

Navajo Indian Reservation OF 92-0124

Newark Basin OP-986

Ouachita Mountains B 1989-D

Ozark Mountains B 1989-D

Trans-Pecos OF 91-0455

heat flow, New Madrid region OP-1661

hydrogeology

OF 93-0120; OF 93-0154; OP-488; OP-

772; OP-1045; OP-1638

Arkansas River valley OP-408

Cascade Range OP-468

Delaware Bay C 1086; OF 92-0052

Delaware River basin C 1086; OF 92-0052

Delmarva Peninsula OF 93-0040

Floridan Aquifer W 2391; WRI 91-4196; OF 91-0483; OF 92-0466; OF 92-0629; OP-672; OP-2001

Lake Powell OP-645
Mississippi Embayment OP-32

Mississippi River OP-607

Susquehanna River W 2387

Trans-Pecos WRI 92-4190

hydrology

W 2400; C 1086; WRI 93-4076; OF 92-

0129; OF 92-0632; OF 93-0056; OP-704;

OP-1036; OP-1836

Arkansas River valley OF 93-0171

Delaware River basin C 1086; OF 92-0052; OP-1964

Mississippi River W 2400; OF 92-0651; OP-1643; OP-1720

Ohio River OP-1720

Potomac River W 2340

Powder River basin WRI 91-4199

Susquehanna River WRI 90-4011

Tennessee River W 2340

Truckee River C 1086; OF 92-0627

impact statements

Lake Powell YR

Powder River basin WRI 90-4154

Invertebrata

Ozark Mountains OP-360

Savannah River OP-291

lava, Cascade Range OP-957; OP-1447

magmas

Cascade Range OP-982

Klamath Mountains OP-1139

Mount Saint Helens OP-1362

Newark Basin OP-1003

maps

OF 92-0391

Cascade Range OF 93-0297; I-2005

Mount Saint Helens GQ-1679

Ozark Mountains I-1420 (NJ-15)

Powder River basin I-2343-Á; I-2343-B; I2380-A; I-2380-B; C-0142

Trans-Pecos YR

metal ores

C 0930-N

Beartooth Mountains OF 93-0207

Ozark Mountains OP-1035; OP-1117

San Juan Mountains P 1537

metamorphic rocks, Bronson Hill Anticlinorium OP-1188

mineral resources

B 2039; OP-654; OP-1679; OP-1730

Beartooth Mountains OF 93-0207; OF 930505

Sawatch Range OP-828

Miocene, Powder River basin B 1917-O

Mississippi River OP-754

natural gas

OF 92-0524; OF 92-0696; OP-272; OP-

646; OP- 1860

Albuquerque Basin OF 93-0248

Anadarko Basin OF 92-0524; OF 93-0230

Denver Basin OF 92-0524; OF 93-0337

Moxa Arch OF 93-0248

Orogrande Basin OF 93-0248

Permian Basin OP-274

Powder River basin OP -449

Uinta Basin OF 93-0248

Neogene, Virgin River valley OP-92

neotectonics, Wasatch Front OP-780

non-metal deposits

B 2013; OF 92-0514

Reelfoot Rift OP-1419

oil and gas fields

Denver Basin OP-1857

Uinta Basin OP-1857

oil sands, Uinta Basin OP-1855
Ordovician

Midcontinent OP-1818

Reelfoot Rift OP-1818

orogeny, Klamath Mountains OP-797

Paleogene

Sevier orogenic belt B 1787-Q

Uinta Basin B 1787-Q

Paleozoic, Mississippi Embayment OF 92 0685

palynomorphs

Powder River basin OP-1745

Washakie Basin P 1506-D

Pennsylvanian

OP-1233

Midcontinent OP-1518

Ozark Mountains OP-1192; OP-1518

Powder River basin OP-1103

petroleum

B 1909

Anadarko Basin OF 92-0391; OP-793

Beartooth Mountains OF 93-0207

Denver Basin OP-793

Moxa Arch OP-1635

Powder River basin B 2039; OP-793

Uinta Mountains OP-1635

petrology

Beartooth Mountains OP-604; OP-1456; OP-1716

Bighorn Mountains OP-1456

Cascade Range OP-638; OP-1271; OP-1463

Gallatin Range OP-1716

Idaho Batholith OP-630; OP-1463; OP-1671

Klamath Mountains OP-1140

Laramie Mountains OP-1456

Midcontinent OP-1417

Mount Hood B 2054

Navajo Indian Reservation OP-1341

Ozark Mountains OP-1116

Reelfoot Rift OP-1417

Trans-Pecos OP-1611

Wyoming Province OP-1716; OP-1731

Phanerozoic

Klamath Mountains OP-1340

Ouachita Belt OP-1493

Pleistocene, Amargosa Desert OP-1670

pollution

OP-47; OP-181; OP-864; OP-1448

Delmarva Peninsula C 1080; OP-922; OP1458; OP-1876

Floridan Aquifer WRI 91-4178

Midcontinent OF 93-0418; OP-816; OP1425; OP-1600

Mississippi River OP-580; OP-1645

Missouri River valley OF 93-0101

Ogallala Aquifer OP-599 .

Yellowstone National Park OP-930

Quaternary

C 1086; OP-75

Delaware River basin OP-2011

Mount Saint Helens OP-647

Wasatch fault zone OP-622; OP-970

Wasatch Range OP-910

Wind River Range OP-711; OP-1455; OP1884

Yellowstone National Park OF 92-0391; OF 92-0408

rock mechanics, Wasatch Front OP-404

sedimentary petrology

Anadarko Basin OP-1791

Arkoma Basin OP-451

Denver Basin OP-1791

New Madrid region OF 93-0291

Newark Basin OP-1379 
Powder River basin B 1917-L; OP-228

Reelfoot Rift OF 93-0291

sedimentary rocks, Uinta Basin B 1787-DD seismology

Mount Saint Helens B 1966

New Madrid region OP-1867

soils OF 90-0130

stratigraphy

DDS-0006

Cascade Range OP-1480

Culpeper Basin OP-1660

Delaware Basin OP-1387

Dinosaur National Monument OP-1963

Medicine Bow Mountains P 1520

Midcontinent OP-1345

Permian Basin OP-1575

Powder River basin B 1917-M; OP-1182; OP-1744

Salisbury Embayment P 1542

San Juan Mountains OP-985

Sangre de Cristo Mountains B 1787-EE

Sawatch Range B 1787-EE

Uinta Basin B 1787-BB

structural geology

OP-1479

Amargosa Desert OP-108

Klamath Mountains OP-1451; OP-1547

Laramie Mountains OP-149

Mississippi Embayment OP-1471; OP-1742

New Madrid region OP-1471; OP-1799

Ohio River OP-1799

Pine Mountain Window OP-1918

Reelfoot Rift OP-1318; OP-1799; OP-1970

Uinta Basin B 1787-HH

Virgin River valley OP-19

Wasatch fault zone OP-619; OP-621; OP718; OP-773

Washakie Basin OF 92-0388

Yellowstone National Park OP-1539

tectonics

OP-1517

Mississippi Embayment OP-1652

Reelfoot Rift OP-1652

Sevier orogenic belt OP-2021

tectonophysics

Klamath Mountains OP-1733

Yellowstone National Park OP-1780

thermal waters, Yellowstone National Park OF 93-0293

Triassic

Newark Basin MF-2208

Powder River basin B 1917-P

Vertebrata, Dinosaur National Monument OP1252

volcanic features, Mount Saint Helens B 1966 waterways, Potomac River basin OP-888

United States Exclusive Economic Zone

Alaska

continental slope B 2002

engineering geology B 2002

geologic hazards B 2002

oceanography B 2002

Atlantic Ocean

continental margin B 2002

continental slope B 2002

California

continental margin B 2002; I-2090-C

continental shelf B 2002

engineering geology B 2002

oceanography B 2002

Caribbean Sea, oceanography DDS-0015

Florida, continental slope B 2002
Gulf of Mexico, oceanography DDS-0015; B 2002

Hawaii, oceanography B 2002; OF 92-0206

Louisiana, continental shelf B 2002

oceanography B 2002

Puerto Rico, oceanography B 2002

United States Geological Survey see U.S. Geological Survey

universities see academic institutions

Upland earthquake 1990

earthquakes OP-503

uplifts see also domes.

OP-1940

Alaska

folds OP-1427

neotectonics OP-1852

petroleum OP-492

seismology OP-1142

Bangladesh, geomorphology OP-1273

California

economic geology OP-662

geochemistry B 1995-C

geologic hazards OP-1793

neotectonics OP-1063

Quatemary OP-707

structural geology OP-144; OP-340; OP569; OP-649; OP-703; OP-1172; OP1536 ; OP-1971

Chile

Quatemary OP-35; OP-719

seismology OP-53

Colorado

Paleogene B 1787-Q

petroleum OF 93-0337

sedimentary rocks $B$ 1787-DD

Costa Rica, structural geology OP-785

Gulf Coastal Plain, stratigraphy OP-1817

Hawaii, petrology OF 93-0342-A; OF 930342-B

Idaho

neotectonics OP-780

petrology OP-1671

structural geology OP-941

Illinois, structural geology OP-1471

Japan, neotectonics OP-1852

Massachusetts, neotectonics OP-555

Mexico, Quaternary OP-707

Mississippi Valley, structural geology OP-358

Missouri

deformation OP-1861

structural geology OP-1471

Montana

diagenesis OP-395

sedimentary petrology B 1917-L

stratigraphy OP-1744

structural geology OP-941

Nevada

petroleum OP-614

structural geology B 2011; OP-1400

New England, Quaternary C 1086

New Mexico

petroleum OF 93-0337

stratigraphy OP-573

Oregon

geomorphology OP-840

Quaternary OP-707

Pakistan, tectonophysics OP-1548

Panama, structural geology OP-785

Pennsylvanian OP-1518

plate tectonics OP-1903

Poland, structural geology OP-1916

Quebec, gold ores OP-1097
Utah

diagenesis OP-1465

Paleogene B 1787-Q

sedimentary petrology OF 92-0391

sedimentary rocks B 1787-DD

structural geology B 2011

Venezuela, tectonics OP-1760

Washington

earthquakes OP-1118

Quaternary OP-120

Wyoming

diagenesis OP-395

neotectonics OP-780

Quatemary OF 92-0391

sedimentary petrology B 1917-L

stratigraphy OP-1744

structural geology OP-149; OP-1539

tectonophysics OP-1780

Upolu Basin areal geology OP-844

Upper Cambrian see Bonneterre Formation; Conococheague Formation; Lamotte Sandstone; Mount Simon Sandstone

Upper Carboniferous see Westphalian

Upper Cretaceous see Almond Formation; Black Creek Formation; Blair Formation; Carlile Shale; Cenomanian; Cody Shale; Eagle Sandstone; Eutaw Formation; Fox Hills Formation; Frontier Formation; Fruitland Formation; Gallup Sandstone; Greenhorn Limestone; Gulfian; Hell Creek Formation; Hornbrook Formation; K-T boundary; Kirtland Shale; Lance Formation; Lewis Shale; Mesaverde Group; Middendorf Formation; Moreno Formation; Mowry Shale; Navesink Formation; Niobrara Formation; Parkman Sandstone; Peedee Formation; Pictured Cliffs Sandstone; Pierre Shale; Point Lookout Sandstone; Ripley Formation; Rock Springs Formation; Saratoga Chalk; Selma Group; Senonian; Shannon Sandstone Member, Sussex Sandstone Member, Turonian; Tuscaloosa Formation; Williams Fork Formation

Upper Devonian see Cleveland Member, Frasnian; Huron Member, New Albany Shale; Ohio Shale; Olentangy Shale; Sonyea Group; West Falls Formation

upper Eocene see Jackson Group; Ocala Group; Uinta Formation; Yazoo Clay

Upper Jurassic see Brushy Basin Shale Member, Morrison Formation; Naknek Formation; Oxfordian; Portlandian; Salt Wash Sandstone Member, Smackover Formation; Westwater Canyon Sandstone Member

Upper Leslie Gulch Wilderness Area mineral resources OF 93-0259-A; OF 93-0259-

upper Miocene see Yorktown Formation

Upper Mississippi Valley geologic hazards C 1120-B; OP-669 hydrology OP-1720 Paleozoic OF 92-0685

Upper Mississippian see Chesterian; Fayetteville Formation; Greenbrier Limestone; Mauch Chunk Formation; Meramecian

upper Oligocene see Suwannee Limestone

Upper Ordovician see Cincinnatian; Maquoketa Formation; Red River Formation; Reedsville Formation

upper Paleozoic see Antrim Shale; Bakken Formation 
Upper Peninsula, Michigan see Michigan Upper Peninsula

upper Pleistocene see Illinoian; Old Crow Tephra; Sangamonian; Weichselian; Wisconsinan upper Precambrian see Proterozoic upper Proterozoic see McCoy Creek Group; Riphean; Vendian

upper Quaternary see Bull Lake Glaciation; Pinedale Glaciation

Upper Silurian see Bloomsburg Formation; Salina Group

Upper Triassic see Carnian; Chinle Formation; Dockum Group; Lockatong Formation; Norian

Urals see also Novaya Zemlya.

Brachiopoda OP-491

energy sources OP-1258

uraninite

Gabon, geochemistry OP-713

uranium see also $\mathrm{U} / \mathrm{Pb}$.

Arizona, pollution OP-1023

Atlantic Coastal Plain environmental geology OP-378 heavy mineral deposits B 2039 .

Colorado environmental geology OF 92-0391 geophysical surveys OP-1813

environmental geology C 1105 geochemistry B 1770; OP-608

geologic hazards OP-1052

Gulf Coastal Plain, environmental geology OP378

heavy mineral deposits OF 93-0240-A; OF 930240-B

Kentucký, geochemistry B 2046

New Jersey, ground water OP-986

New Mexico hydrology OP-1435

pollution OP-1023

Oklahoma, geochemistry OP-891

pollution OP-1665

Texas, environmental geology OF 92-0391

U-234/Th-230

California OP-707

Mexico OP-707

Oregon OP-707

U-235, Gabon OP-713

U-238

California OP-995

Colorado OP-1394

Gabon OP-713

Mexico OP-1778

Nevada OP-995

U-238/Th-230, Quaternary OF 92-0525

U-238/U-234

Montana OP-978

Polynesia OP-1436

Quaternary OF 92-0525

Wyoming OP-978

Virginia, geochemistry OP-344

uranium disequilibrium

Bahamas, Quaternary OP-706

Barbados, Quatemary OP-706

Bermuda, Quaternary OP-706

California, Quaternary OF 93-0232; OF 930286; OF 93-0311

Florida, Quatemary OP-706

France, Quatemary OP-310

Haiti, Quaternary OP-706

Mexico, Quatemary OP-706

Nevada, Quatemary OP-294

Polynesia, geochronology OP-1436
Quaternary OF 92-0525

uranium ores

DDS-0001; OF 92-0557; OP-465; OP-655; OP834

Alaska C 1091

Arizona OF 93-0329; OP-613; OP-1617

Australia OP-1431

California OP-260

Canada OP-1431

China OP-317

Colorado OP-568; OP-937

environmental geology OF 92-0391

Colorado Plateau OP-1848

Nevada OP-260

Texas, environmental geology OF 92-0391

Utah, sedimentary petrology B 2000-E

Vermont B 1955

Wyoming, impact statements WRI 90-4154

uranium-lead see $\mathrm{U} / \mathrm{Pb}$

uranium-series method see uranium disequilibrium

uranium-thorium see $\mathrm{Th} / \mathrm{U}$

Urban and Regional Information Systems Association

environmental geology OP-701

URISA

environmental geology OP-701

USBM see U. S. Bureau of Mines

Utah see also Cache Valley; Colton Formation; Cutler Formation; Drum Mountains; Frontier Formation; Green River basin; Green River Formation; Hermosa Formation; Lake Bonneville; Lake Powell; Lake Uinta; Mancos Shale; McCoy Creek Group; Mesaverde Group; Moxa Arch; Navajo Sandstone; North Horn Formation; Paradox Basin; Paradox Member, Uinta Basin; Uinta Formation; Uinta Mountains; Wasatch fault zone; Wasatch Formation; Wasatch Front; Western Interior Seaway; Western Overthrust Belt; Williams Fork Formation.

base metals, Tintic mining district OP-394

Cretaceous

Kaiparowits Plateau OP-919

Uintah County Utah I-1797-D

earthquakes, Salt Lake County Utah OP-905

ecology, Uintah County Utah WRI 92-4084

economic geology, Marysvale Utah OP-872

energy sources

OF 92-0524; OF 93-0248

San Juan County Utah OF 93-0248

engineering geology

Great Salt Lake P 1519

Salt Lake County Utah P 1519

environmental geology

OF 93-0292-H

Salt Lake City Utah B 2013

geochemistry, Roosevelt Hot Springs KGRA OF 93-0260; OP-1505

geologic hazards

Cache County Utah P 1519

Davis County Utah P 1519

Great Salt Lake P 1519

Juab County Utah P 1519

Salt Lake City Utah C 1111

Salt Lake County Utah P 1519

Tooele County Utah P 1519

Utah County Utah P 1519

Weber County Utah P 1519

geomorphology

Davis County Utah I-2199

Kane County Utah OP-1060
Weber County Utah I-2199

gold ores

Tintic mining district OP-1096

Tooele County Utah B 2013

Utah County Utah B 2013

ground water

OP-61

Kane County Utah WRI 90-4105; WRI 92407.0

Salt Lake County Utah OF 92-0640

San Juan County Utah OF 92-0124

Washington County Utah WRI 92-4160

hydrogeology

Cache County Utah OF 92-0173

San Juan County Utah W 2340

Wasatch County Utah OP-424

hydrology

W 2400; OP-1044

Box Elder County Utah WRI 91-4117

Great Salt Lake WRI 91-4117

Tooele County Utah WRI 91-4117

industrial minerals

B 2013

Salt Lake County Utah B 2013

maps

Carbon County Utah MF-2250

Iron County Utah OF 93-0003; OF 93-0190; OF 93-0203; GQ-1712; GQ-1713

Kane County Utah OF 93-0190; C-0144

Tooele County Utah OF 92-0385

Uintah County Utah MF-2250

Washington County Utah OF 92-0589; OF 93-0203; GQ-1721

metal ores

OP-465

Tintic mining district OP-965; OP-1464

mineral resources

Juab County Utah B 2039; MF-208.1-C; MF2081-D; MF-2081-E

Millard County Utah B 2039; MF-2081-C; MF-2081-D; MF-2081-E

Sanpete County Utah MF-2081-C; MF2081-D; MF-2081-E

Tintic mining district B 2039

Tooele County Utah MF-2081-C; MF-2081D; MF-2081-E

Utah County Utah MF-2081-C; MF-2081D; MF-2081-E

natural gas OF 92-0524; OF 93-0248

non-metal deposits B 2013

Paleogene

Duchesne County Utah B 1787-Q

Uintah County Utah B 1787-Q

Wasatch County Utah B 1787-Q

petroleum, San Juan County Utah OF 92-0391

Quatemary

OP-1524

Davis County Utah OP-970

Great Salt Lake OP-908

Millard County Utah OP-1022

Oquirrh Mountains OP-52

Provo Utah OP-908

Salt Lake City Utah OP-1021

Tooele County Utah OP-911

Utah County Utah OP-620

sedimentary petrology

Iron County Utah OF 92-0391

Kaiparowits Platean OP-1779

San Juan County Utah B 2000-E

sedimentary structures

Kaiparowits Platean OF 93-0270

Kane County Utah OF 93-0270

seismology, Great Salt Lake OP-1076 
stratigraphy

Daggett County Utah P 1506-F

Duchesne County Utah B 1787-BB

San Juan County Utah B 1808-O

Summit County Utah P 1506-F

structural geology

Box Elder County Utah OP-773

Davis County Utah OP-718

Duchesne County Utah B 1787-HH

Ogden Utah OP-718

Salt Lake County Utah OP-909

Uintah County Utah B 1787-HH

Utah County Utah OP-619

Washington County Utah B 2011 ; OP-19

uranium ores $\mathrm{OP}-655$

Vertebrata, Uintah County Utah OP-1252

waste disposal B 2013

\section{Utah Valley}

Quatemary OP-620; OP-911

structural geology OP-619

utahite see jarosite

Ute Mountain Ute Indian Reservation non-metal deposits B 2061-A

Utopia Planitia OP-906; OP-1241; OP-1565

Uwharrie Formation

geochemistry OP-1607

\section{V}

V see vanadium

Val Verde Basin energy sources OF 93-0522

Valdez A-4 Quadrangle maps I-2164

Valdez Alaska

environmental geology OP-564

geologic hazards B 2002 stratigraphy OP-1169

Valdez B-3 Quadrangle maps I-2164

Valdez B-4 Quadrangle maps I-2164

Valdez C-3 Quadrangle maps I-2164

Valdez C-4 Quadrangle maps I-2164

Valdez Creek District gold ores OP-1099

Valdez D-4 Quadrangle maps I-2164

Valdez Group geochemistry OP-1410

Valle de Yabucoa Aquifer ground water OP-1960

Valle Grande Mountains geochronology OP-1538

Vallecitos Trough plate tectonics OP-1749

Valles Caldera molybdenum ores OP-1243 Quatemary OF 92-0699

Valles Marineris OP-142; OP-1162; OP-1235; OP-1408; OP-1668; OP-1669; OP-1868; OP1937

Valley and Ridge Province areal geology B 1994 economic geology B 1979; B 2005 engineering geology $\mathrm{OP}-1542$ environmental geology OF 92-0568 geochemistry B 1839-I, J

geomorphology OF 92-0568

ground water W 2388; OP-983; OP-1707; OP1928

hydrology OP-1610

sedimentary petrology OF 92-0568

stratigraphy OP-1988

Valley of Ten Thousand Smokes geochemistry OP-926; OP-1770; OP-1771 Quaternary OP-549

Valley Springs Formation stratigraphy OF 92-0588

Valley View Hot Springs KGRA thermal waters OF 93-0017-A; OF 93-0017-B

valleys see also canyons; erosion features. Chile, Quatemary OP-279

Montana, ground water WRI 92-4162

Rhode Island, geologic hazards OP-1424

West Virginia, geomorphology B 1981

Wisconsin, ground water WRI 92-4077

Valmy Formation

gold ores OP-365

stratigraphy B 1988-D

vanadium

Colombia, geochemistry OP-755

England, geochemistry OP-755

Georgia, oceanography OP- 1502

Poland, geochemistry OP-755

Texas, geochemistry OP-755

vanadium ores

Canada OP-728

United States OP-728

Vancouver Washington geophysical surveys OF 93-0211

Vanuatu

geologic hazards OP-1521

geophysical surveys OP-318

marine geology OP-186; OP-187; OP-189; OP-

190; OP-191; OP-192; OP-193; OP-194; OP. $195 ;$ OP-196

ocean floors OP-368

plate tectonics OP-185; OP-197; OP-345; OP1286; OP-1287

sedimentation $\mathrm{OP}-188$

tectonophysics OP-1908

Vaqueros Formation

structural geology OP-1701

Variscan Orogeny see Hercynian Orogeny

varves

Atlantic Ocean, Quatemary OP-1650

Minnesota

OP-739

geochemistry OP-248; OP-251

paleobotany OP-101

Quatemary C 1086; OP-20; OP-21; OP-100 stratigraphy $P$ 1506-F

Vasquez Formation

structural geology OP-332

Vatnajokull

Quaternary OP-386

Vaughn Member stratigraphy OP-1351; OP-1798

Vedder Complex stratigraphy OP-1480

veins see quartz veins

Velasco Formation

stratigraphy OP-1179

Vendian

Arizona OF 92-0391

Iowa OF 92-0391
Russian Federation OF 92-0391

Venezuela see also Cordillera de la Costa. maps, Bolivar Venezuela MF-2242 metal ores OP-217

tectonics, Bolivar Venezuela OP-1760

Ventura Basin

energy sources B 2034-A; OF 92-0571

geochemistry OF 92-0539-A; OF 92-0539-C

Miocene OF 93-0182; OP-1570

petroleum OF 92-0539-F; OP-1910

stratigraphy OF 92-0539-B; OF 92-0539-D; OF 92-0539-E; OF 93-0177

tectonophysics OP-2010

Venus

OF 93-0516; OP-28; OP-29; OP-148; OP-246; OP-690; OP-786; OP-857; OP-887; OP-988; OP-1062; OP-1149; OP-1236; OP-1459; OP1588; OP-1589; OP-1594; OP-1595; OP-1596; OP-1725; OP-1790; OP-1840; OP-1851; OP1854

Iceland OP-1405

Maxwell Montes OP-1724

Venus Geologic Mapping Program OF 93-0516

Vermejo Formation

maps I-2266

Vermilion District

metal ores OF 92-0615

Vermilion Range

metal ores OF 92-0615

.Vermillion East Fork Aquifer hydrology W 2340

Vermillion River basin hydrology W 2340

Vermont see also Lake Champlain. copper ores, Orange County Vermont B 2039 economic geology

Bennington County Vermont B 1955

Rutland County Vermont B 1955 engineering geology B 2043 geochronology OF 92-0525 hydrology

W 2400

Caledonia County Vermont C 1086 magmas OP-37

maps

I-1420 (NK-18); I-1420 (NL-18)

Bennington County Vermont MF-2224; I2369

Rutland County Vermont OF 92-0282-A

Windham County Vermont MF-2224

Windsor County Vermont OF 92-0282-A structural geology

Addison County Vermont OP-461

Caledonia County Vermont OP-461

Washington County Vermont OP-461

Vertebrata see Tetrapoda

vertebrates see also fish; tetrapods.

Alaska, Quaternary OP-391

California, Quatemary OP-1844

Idaho, paleomagnetism OF 92-0542

Illinois, Quaternary OP-1309

United Arab Emirates, stratigraphy OP-1453

Wisconsin, Quaternary OP-391

vertical seismic profiles

Oregon, geophysical surveys OF 93-0319

very long baseline interferometry

tectonophysics OP-2010

Vester Formation

guidebook OP-87

Victoria Australia

petrology OP-1136 
Victoria Land

geophysical surveys OP-610

Victoria Peak Formation

stratigraphy OP-1387

videotapes

Alaska, Quaternary OP-1699

Great Lakes, geomorphology OP-1143

Vieques Puerto Rico

geologic hazards OP-1835

marine installations OP-1863

Vietnam

energy sources OP-1624

petroleum, Mekong Delta OP-1829

Vinini Formation

metal ores OP-531

Virgillina District

geochemistry OP-1607

mineral resources MF-2203

Virgin Islands see U.S. Virgin Islands

Virgin River

ground water WRI 91-4185

Quaternary OP-1989

Virgin River valley

Neogene OP-92

structural geology OP-19

Virginia see also Appalachian Basin; Blue Ridge Province; Catoctin Formation; Delmarva Peninsula; Genesee Group; Knox Group; Marcellus Shale; Newark Supergroup; Oriskany Sandstone; Piedmont; Potomac River basin; Price Formation; Richmond Basin; Tuscarora Formation; Valley and Ridge Province.

OF 93-0231

coal OP-1226

energy sources OP-1751

fluvial features, Highland County Virginia B 1981

geochemistry

OF 92-0525

Highland County Virginia B 1839-I,J

geologic hazards, Loudoun County Virginia C 1111

geomorphology

Augusta County Virginia B 1981

Highland County Virginia B 1981

Rockingham County Virginia B 1981

Shenandoah County Virginia B 1981

ground water

P 1404-G; WRI 92-4175; WRI 93-4015; OP-1902

Buchanan County Virginia W 2388

Dickenson County Virginia W 2388

Lee County Virginia W 2388

Russell County Virginia W 2388

Scott County Virginia W 2388

Tazewell County Virginia W 2388

Wise County Virginia W 2388

York County Virginia WRI 92-4090 WRI 92-4111

heavy mineral deposits OF 93-0240-A; OF 930240-B

hydrogeology

OP-1196

Accomack County Virginia OF 93-0040

Northampton County Virginia OF 93-0040

hydrology

B 1981; W 2400; WRI 92-4034; WRI 92

4060; OP-524; OP-1573

Fairfax County Virginia W 2340

Prince William County Virginia W 2340 maps
Campbell County Virginia OF 92-0725

Charlotte County Virginia OF 92-0725; OF 93-0244

Frederick County Virginia OF 93-0024

Halifax County Virginia OF 92-0725; OF 93-0244

Loudoun County Virginia OF 92-0716

Lunenburg County Virginia OF 93-0244

Mecklenburg County Virginia OF 93-0244

Shenandoah County Virginia OF 93-0024

metamorphism, Fairfax County Virginia OP1152

mineral resources, Halifax County Virginia MF-2203

paleontology OP-1205

petrology

Culpeper County Virginia OP-1002

Fauquier County Virginia OP-1002

Rappahannock County Virginia OP-1002

Phanerozoic OF 93-0222

Proterozoic

Grayson County Virginia B 2029

Washington County Virginia B 2029

Quaternary

Clarke County Virginia OF 92-0395

Frederick County Virginia OF 92-0395

Shenandoah County Virginia OF 92-0395

stratigraphy

OP-1368; OP-1788

Hanover County Virginia OP-1660

structural geology

Frederick County Virginia OF 93-0025

Shenandoah County Virginia OF 93-0025 vitrain

Utah, sedimentary petrology OP-1779

vitrinite

Alabama, sedimentary petrology OP-1636

Alaska

natural gas OP-74

petroleum B 2034-A; OP-492

Arizona, sedimentary petrology OF 92-0391

California

energy sources OF 92-0571

petroleum OP-1910

Colorado

coal OP-1911

energy sources OP-674; OP-1753

sedimentary petrology OP-1382

sedimentary rocks B 1787-DD

energy sources OP-1244

geochemistry OP-810; OP-1923

lowa, sedimentary petrology OF 92-0391

Mexico

energy sources OP-1137

geothermal energy OP-984

sedimentary petrology OF 92-0391; OP-50

Mississippi, sedimentary petrology OP-1636

New Mexico, energy sources OP-674

Oklahoma, natural gas OF 92-0524

Pennsylvania, sedimentary petrology OF 92 0568

Russian Federation, sedimentary petrology OF 92-0391

sedimentary petrology OP-451; OP-1135

Utah

petroleum OP-1635

sedimentary rocks B 1787-DD

Victoria Australia, petrology OP-1136

Wyoming, petroleum OP-1635

Vitus Arch

deformation OP-211
Vitus Lake

Quaternary OF 93-0266

Vivi River

pollution OP-663

vivianite

California, geochemistry B 1995-C

VLBI see very long baseline interferometry

VMAP OF 93-0516

volatile matter see volatiles

volatile organic compounds

geochemistry OP-331

Georgia, ground water WRI 93-4038

Iowa, pollution OP-1981

Kentucky, pollution WRI 92-4138

New Hampshire

environmental geology OF 92-0647

ground water WRI 90-4161; OF 92-0095

New York, ground water WRI 90-4182; WRI 92-4100; OF 91-0180 OP-1591; OP-1785

Arizona, geochemistry OP-1505

Bolivia, metal ores OP-1306

Colorado, sedimentary petrology OP-1382

energy sources OP-1244; OP-1476; OP-1823

Illinois, non-metal deposits OP-1419

Kentucky

geochemistry B 2046

non-metal deposits OP-1419

New Jersey, pollution OP-1383

New Mexico, petroleum B 2039

New York, pollution OP-412

Oregon, geochemistry OP-42

petrology OP-1355

Philippine Islands, geochemistry OP-1994

Utah, geochemistry OP-1505

Vermont, pollution OP-412

Wyoming, petroleum B 2039

volcanic arcs see island arcs

volcanic ash see also ash falls; ignimbrite; volcaniclastics.

Alaska, geologic hazards YR

Califormia, Quaternary OP-1843

clay mineralogy OP-93

Indonesia, sedimentary petrology OP-870

Montana, geochemistry OP-1305

sedimentary petrology OP-228

Vanuatu, sedimentation OP-188

Washington, Quaternary OP-143

volcanic breccia

Oregon, magmas OP-982

volcanic clay see bentonite

volcanic earthquakes

OP-1557

Alaska OF 92-0560-A; OF 92-0560-B; OP1802

California

OP-1503

geochemistry OP-955

geophysical surveys OP-1555

structural geology OP-569

Hawaii

OP-116; OP-1420

geophysical surveys OP-252

magmas OP-1001

Quatemary OP-1759

Iceland OP-322

Philippine Islands OP-502

Washington

B 1966

Quaternary OP-647 
volcanic features see also calderas; lava fields; lava tubes; volcanoes.

OP-148; OP-690; OP-987; OP-1222; OP-1438; OP-1725

Arizona I-2420

Chile, Quaternary OP-279

Colorado, geochemistry OP-490

Iceland OP-1405

Nevada, petrology B 2052

New Mexico, geochemistry OP-490

Virginia, Proterozoic B 2029

volcanism I-2291-A

volcanic fields

Arizona OF 92-0198

California, petrology OP-1167

Colorado, metal ores P 1537

Idaho, geochronology OP-479

New Mexico, petrology OF 92-0528

volcanic glass

Hawaii OP-631

Oregon, geochemistry OF 93-0314

\section{volcanic risk}

Colombia, Quatemary OP-677

geologic hazards OP-846

geophysical surveys B 1966

Idaho, Quaternary OF 93-0327

Mariana Islands, geologic hazards OP-1962

Micronesia, geologic hazards OP-1962

volcanic rocks see also andesites; basalts; dacites; glasses; granophyre; lava; pyroclastics; rhyodacites; rhyolites; trachyandesites; trachytes; volcanic fields; volcanism; volcanoes.

Alaska

GQ-1688

geochemistry OP-1373

mineral resources OP-106

Arizona, geochemistry OP-203

Bolivia, metal ores B 2039; OF 93-0016

California

economic geology OP-260; OP-662

orogeny OP-797

Quaternary OF 93-0263

structural geology OP-332; OP-936

China, metal ores OP-317

Colorado I-2266

Dominican Republic, metal ores OP-1576

Hawaii, paleomagnetism OP-436

Idaho

OP-1197

metal ores OP-876

orogeny OP-797

metal ores OF 92-0389; OP-465

Mexico, geochemistry OP-132

Michigan OP-139

Minnesota OP-247

Montana, geochemistry OP-637

Nevada

OF 93-0299

economic geology OP-260

geochemistry OP-643

gold ores OP-716

metal ores OP-489

structural geology OP-1400

New Mexico I-2266

North Carolina, geochemistry OP-1607

Oregon, metal ores OP-876

Papua New Guinea, petroleum OP-307

Russian Federation OP-91

Samoa OP-844

Saudi A rabia, metal ores OP-1559

tectonics OP-753

Washington I-1963
Wyoming, geochemistry OP-637

volcanic tremors see volcanic earthquakes

volcanicity see volcanism

volcaniclastics

Alaska

petrology OP-1929

Quaternary OP-1714; OP-1739; OP-1772

California

Quaternary OP-831

structural geology OP-1474

Idaho, stratigraphy OP-1351

Minnesota, intrusions OP-247

Montana, stratigraphy OP-1351

Nevada, Quaternary OP-831

Oregon

petrology B 2054

Quaternary OF 93-0212

Pacific Coast, Quaternary C 1086

Papua New Guinea, petroleum OP-307

Philippine Islands, magmas OP-1768

Saudi Arabia, Proterozoic B 1976

Utah, sedimentary petrology OF 92-0391

Vanuatu

plate tectonics OP-185

tectonophysics OP-1908

Washington

GQ-1679

Quaternary OF 93-0212

Wyoming, geochemistry OP-464

volcanics see volcanic rocks

volcanism see also calderas; eruptions; lahars;

lava; pyroclastic flows; shield volcanoes; volca-

nic features; volcanic fields; volcanic risk; vol-

canoes.

I-2209; OP-28; OP-1221; OP-1242; OP-1408;

OP-1459; OP-1561; OP-1593; OP-1669; OP-

1806; OP-1830; OP-1934; OP-1935; OP-1940

Arizona OP-1341

California

energy sources OP-267

sedimentary petrology OP-1344

seismology OP-438

Cretaceous OP-1115

geochemistry OF 92-0525; OP-30

Great Lakes region, copper ores OP-1216

India, geochronology OP-1346

Michigan, Archean B 1904-P

Nevada

OP-973

economic geology OP-736

metal ores OP-205

North Sea, stratigraphy OP-1359

Oregon OP-87

Pacific Ocean, Cretaceous OP-1230

Pakistan, structural geology OP-1125

Quaternary OP-81

Saudi Arabia, Proterozoic B 1976

stratigraphy OP-1702

tectonics OP-137

tectonophysics $\mathrm{OP}-463$

Vanuatu, plate tectonics OP-197

volcanoes see also ash falls; shield volcanoes; stratovolcanoes; submarine volcanoes; volcanic earthquakes.

YR; OP-1321; OP-1831; OP-1832

Alaska

geologic hazards YR; OF 93-0094; OP-1708

Quaternary OP-1714

volcanology OP-349

Bolivia, economic geology YR

California

geophysical surveys B 1966 structural geology OP-1536

Canary Islands, engineering geology OP-443

Colombia

geophysical surveys B 1966

Quaternary OP-677

Costa Rica, geochemistry OP-812

environmental geology OP-1953

geochemistry B 1966

geologic hazards DDS-0008; P 1240-B;

C 1086; OP-846

geophysical surveys B 1966

Hawaii

earthquakes EV

environmental geology OF 93-0512-A

geomorphology OP-693

geophysical surveys OF 92-0686

lava OF 93-0015

oceanography B 2002; MF-2231; MF-2233

petrology OF 92-0586; OF 93-0342-A; OF 93-0342-B; OP-631

Indonesia, geophysical surveys B 1966

Italy, geologic hazards OP-213

Mariana Islands

I-2408

geologic hazards OP-1962

-Mexico, geologic hazards OF 93-0197-A; OF 93-0197-B

Micronesia

I-2408

geologic hazards OP-1962

New Zealand, geophysical surveys B 1966

Oregon, geophysical surveys B 1966

Papua New Guinea, gold ores B 2039

Philippine Islands

earthquakes EV; OP-1998

geochemistry OP-1994

geologic hazards OP-781

Washington

engineering geology OP-907

geophysical surveys B 1966

magmas OP-1362

volcanic features B 1966

Wyoming, geophysical surveys B 1966

volcanology see also calderas; craters; eruptions;

fumaroles; lava; volcanic earthquakes; volcanic

features; volcanic rocks; volcanism.

geophysical surveys B 1966

Oregon OP-1124

Washington, geologic hazards B 1966

volcanos see volcanoes

VOLPLOT

seismology OF 92-0560-A; OF 92-0560-B

volume susceptibility (magnetic) see magnetic susceptibility

volumetric analysis see titration

volunteerism

YR

Alaska, geologic hazards YR

Arizona, geophysical surveys YR

Califomia, geophysical surveys YR

Voyager 2 OP-1592

Voyager Program see also Ariel Satellite. OF 91-0014; OP-1590

vulcanism see volcanism

vulcanology see volcanology

Vung Tau Basin

petroleum OP-1829 


\author{
$\mathbf{W}$ \\ W see tungsten \\ Wabash River valley \\ ground water OP-1354 \\ Quaternary P 1536 \\ Wabayuma Peak Wilderness Study Area \\ metal ores B 1737-E \\ Wabigoon Belt \\ intrusions OP-247 \\ Wadati-Benioff Zone see Benioff zone \\ Wadi Baysh Quadrangle \\ maps OP-308; OP-309. \\ WAIS YR \\ Walker Lake \\ Quaternary OP-69 \\ Walker Lane \\ geochemistry OP-1609 \\ metal ores OP-397 \\ wall-rock alteration \\ Alaska OP-349 \\ Colorado \\ metal ores OF 92-0525 \\ pollution OP-315 \\ Walnut Creek basin \\ ground water OF 92-0167 \\ Walnut Gulch Experimental Watershed \\ geophysics OP-80 \\ Wamsutter Arch \\ petroleum OP-1635 \\ Wanapum Basalt \\ ground water WRI 90-4085 \\ Wapi lava field \\ petrology OP-560 \\ Ward Terrace \\ Quatemary OP-976 \\ Warm Springs Fault \\ structural geology OP-909 \\ Warnick Canyon \\ sedimentary petrology OF 92-0707 \\ Warsaw Formation \\ ground water OP-612 \\ Wasatch fault zone \\ earthquakes OP-905 \\ geologic hazards P 1519 \\ geomorphology I-2199 \\ Quaternary OP-622; OP-970 \\ structural geology OP-619; OP-621; OP-718; \\ OP-773 \\ Wasatch Formation \\ P 1506-D; P 1506-F \\ impact statements WRI 90-4154 \\ maps $\mathrm{C}-0142$ \\ natural gas OF 93-0248 \\ sedimentary rocks B 1787-DD \\ structural geology B 1787- $\mathrm{HH}$ \\ Wasatch Front \\ engineering geology $P 1519$ \\ geologic hazards $\mathrm{P} 1519$ \\ neotectonics OP-780 \\ rock mechanics OP-404 \\ Wasatch Range \\ Quatemary OP-910 \\ Washakie Basin \\ palynomorphs $P$ 1506-D \\ structural geology OF 92-0388 \\ Washakie Formation \\ palynomorphs P 1506-D \\ stratigraphy P 1506-F
}

Washington see also Cascade Range; Columbia

Plateau; Columbia River; Columbia RiverBasalt

Group; Yellow Aster Complex.

earthquakes

OP-720; OP-1119; OP-1120

Mount Saint Helens EV

Seattle Washington OP-1118

ecology

Benton County Washington OF 91-0453

Kittitas County Washington OF 91-0453

Yakima County Washington OF 91-0453

Yakima Indian Reservation OF 91-0453

elastic waves, Mount Saint Helens B 1966

energy sources B 2034-A; OP-1946

engineering geology

Mount Rainier OP-907

Mount Saint Helens OP-956

Seattle Washington OF 91-0441-T

environmental geology

OF 93-0292-J

Benton County Washington C 1090

Kittitas County Washington C 1090

Yakima County Washington C 1090

Yakima Indian Reservation C 1090

geochemistry

OP-998

South Cascade Glacier OP-1121

geochronology

Pend Oreille County Washington OP-1067

Spokane County Washington OP-1067 geologic hazards, Mount Saint Helens B 1966 geomorphology, Puget Lowland OP-1552 geophysical surveys

OF 92-0714

Cowlitz County Washington OF 93-0347

King County Washington OF 93-0347

Lewis County Washington OF 93-0347

Mount Rainier B 1966

Mount Saint Helens B 1966

Pierce County Washington OF 93-0347

Puget Lowland OF 93-0347

Skagit County Washington OF 93-0347

Snohomish County Washington OF 930347

Vancouver Washington OF 93-0211

Whatcom County Washington OF 93-0347 ground water

YR; OP-1017

Adams County Washington WRI 90-4085

Asotin County Washington WRI 90-4085

Benton County Washington WRI 90-4085

Columbia County Washington WRI 904085

Douglas County Washington WRI 90-4085

Franklin County Washington WRI 90-4085; WRI 93-4060

Garfield County Washington WRI 90-4085

Grant County Washington WRI 90-4085

Kittitas County Washington WRI 90-4085

Klickitat County Washington WRI 90-4085

Lincoln County Washington WRI 90-4085

Spokane County Washington WRI 90-4085

Walla Walla County Washington. WRI 904085

Whitman County Washington WRI 90-4085

Yakima County Washington WRI 90-4085

heavy mineral deposits OF 93-0240-A; OF 930240-B

hydrogeology

OP-62

Benton County Washington OF 91-0453; OF 92-0520; OF 92-0644

King County Washington OF 93-0039
Kittitas County Washington OF 91-0453; OF 92-0520; OF 92-0644

Yakima County Washington OF 91-0453; OF 92-0520; OF 92-0644

Yakima Indian Reservation OF 91-0453 hydrology

W 2340; W 2400; OP-1044

Benton County Washington WRI 91-4073; OF 91-0453; OF 91-0454

Kittitas County Washington WRI 91-4073; OF 91-0453; OF 91-0454

South Cascade Glacier W 2340

Yakima County Washington WRI 91-4073; OF 91-0453; OF 91-0454

Yakima Indian Reservation OF 91-0453

magmas, Mount Saint Helens OP-1362

maps

Chelan County Washington I-2005

Clallam County Washington OF 93-0233; I-1946

Clark County Washington I-2005

Cowlitz County Washington I-2005

Jefferson County Washington OF 93-0233

King County Washington OF 93-0233; I1963; I-2005

Kitsap County Washington OF 93-0233

Kittitas County Washington I-1963; I-2005

Lewis County Washington OF 93-0297; I2005

Mount Saint Helens GQ-1679

Okanogan County Washington I-2005

Olympic Peninsula I-1946

Pierce County Washington I-1963; I-2005

Skagit County Washington I-2005

Skamania County Washington OF 93-0297; I-2005

Snohomish County Washington OF 930233; I-1963; I-2005

Whatcom County Washington I-2005

Yakima County Washington I-2005

natural gas B 2034-A

neotectonics

Puget Lowland OF 93-0332

Seattle Washington OF 93-0332

petroleum B 2034-A

petrology OP-1397; OP-1900

Plantae, Ferry County Washington OP-1083

pollution OP-1827

Quaternary

C 1086; OP-1999

Clallam County Washington OP-904

Ferry County Washington OF 93-0212

Island County Washington OP-36

Jefferson County Washington OP-120; OP904

King County Washington OP-120

Kitsap County Washington OP-120

Mason County Washington OP-120; OP904

Mount Saint Helens OP-647

Okanogan County Washington OF 93-0212

Olympic Mountains OP-201; OP-904

Pierce County Washington OP-120

Puget Lowland OP-36; OP-120; OP-201

Puget Sound OP-36; OP-120

Snohomish County Washington OP-120

South Cascade Glacier OP-323

Stevens County Washington OF 93-0212; OP-143

Thurston County Washington OP-120

Willapa Bay OF 93-0284; OF 93-0289

seismology, Mount Saint Helens B 1966 
stratigraphy

OP-708

King County Washington OF 92-0581

Puget Lowland OF 92-0581

structural geology

OF 92-0715; OP-159; OP-679; OP-1159;

OP-1187

Pend Oreille County Washington OP-18 tectonics

Benton County Washington OP-877

Chelan County Washington OP-877

Douglas County Washington OP-877

Franklin County Washington OP-877

Grant County Washington OP-877

Kittitas County Washington OP-877

Yakima County Washington OP-877

uranium ores OP-655

volcanic features, Mount Saint Helens B 1966

waste disposal see also agricultural waste; creosote; disposal barriers; geologic hazards; hazardous waste; impact statements; industrial waste; landfills; liquid waste; pesticides; radioactive waste; reclamation; underground installations; waste disposal sites; waste water.

B 2013; OF 92-0457; OP-51

Arkansas, ground water WRI 92-4094

Atlantic Coastal Plain OP-1185

California, oceanography OF 93-0011

Florida WRI 92-4086

geochemistry OP-305; OP-572; OP-869

Georgia, ground water WRI 93-4038

Idaho, hydrogeology OF 92-0174

Missouri

OF 93-0153

ground water OF 93-0140

Nevada, geochronology OF 93-0538

New Hampshire

WRI 92-4012; WRI 92-4056; OF 92-0647 ground water WRI 91-4025

New Jersey OF 93-0243

Ohio WRI 92-4130

Utah B 2013

waste disposal sites see also radioactive waste.

California, oceanography OF 92-0382

Kentucky, environmental geology WRI 92 4195

waste water

Florida, waste disposal OP-1531

Indiana, environmental geology W 2393

waste, agricultural see agricultural waste

waste, industrial see industrial waste

waste, liquid see liquid waste

waste, radioactive see radioactive waste

Watchung Mountains

geochemistry OF 93-0010

water cycle see hydrologic cycle

water falls see waterfalls

water resources see also artesian waters; reservoirs; springs.

YR

Alabama, ground water OP-46

Alaska, hydrogeology C 1081

Algeria, pollution OP-599

Appalachians, ground water OP-1707

Arkansas

ground water OF 92-0496

hydrogeology OF 92-0108; OF 93-0048

Atlantic Coastal Plain

ground water OP-1707

hydrology C 1086

California ground water OP-73; OP-255; OP-303

hydrology C 1086

pollution OP-599

Colorado, ground water OP-854

Delaware, pollution OP-922

environmental geology OP-576

Florida, hydrogeology WRI 91-4123; OF 93 0067

geochemistry OP-41

Georgia

ground water OP-172

hydrogeology W 2391; OP-311; OP-312

ground water OP-952

hydrogeology YR; WRI 92-4123; OF 92-0052;

OF 92-0161; OF 92-0497; OF 93-0120;

OF 93-0154; OP-421; OP-606; OP-659

hydrology W 2400; C 1086; OF 92-0105; OF 92-0627

Idaho, hydrogeology OF 93-0149

Illinois, hydrology OF 92-0451; OF 92-0452

Iowa, hydrogeology OF 92-0154

Kansas, ground water OF 93-0092

Louisiana, hydrogeology OF 92-0492; OP-216; OP-607

Marshall Islands, ground water OP-26

Maryland, pollution OP-922

Massachusetts, hydrology OP-1826

Michigan

ground water WRI 91-4133

hydrogeology WRI 91-4120; OF 92-0157

Micronesia, ground water OP-26

Midwest, pollution OF 93-0418

Minnesota

hydrogeology OF 93-0065

hydrology HA-0551

pollution OP-629

Mississippi, ground water OP-745

Missouri, hydrogeology OF 92-0626

Nebraska, hydrogeology OF 92-0633

Nevada, hydrology C 1086

New Jersey

ground water WRI 91-4126

hydrogeology OP-652

New Mexico, ground water OF 92-0465

North Carolina, hydrogeology OF 93-0113

North Dakota, hydrogeology OF 93-0052

Oregon, hydrogeology WRI 91-4087

Pennsylvania, geologic hazards OP-1895

Puerto Rico, hydrogeology C 1081

South Carolina, hydrogeology OF 93-0035

Spain, pollution OP-599

Tennessee, hydrogeology WRI 91-4195

Texas, hydrogeology OF 93-0112

Tunisia, pollution OP-599

Utah, hydrogeology OP-1736

Washington

ground water OP-1017

hydrogeology OF 91-0453

Wisconsin, hydrogeology OF 93-0129

Wyoming, hydrogeology WRI 91-4044

Water Resources Division

OF 93-0123

hydrogeology WRI 92-4075; OF 92-0157; OF 92-0161; OF 92-0163; OF 92-0479; OF 92-0492; OF 93-0052; OF 93-0065; OF 93-0097; OF 93-0112; OF 93-0129; OF 93-0154

hydrology OF $92-0451$; OF $92-0452$; OF $92-$ 0493; OF 93-0036; OP-423

waterways OP-334

Water Resources Research Grant Program hydrogeology OF 93-0154 water use

Alaska, hydrogeology C 1081

Arkansas

ground water OF 92-0496

hydrogeology OF 93-0048; OF 93-0166; OF 93-0167; OF 93-0424; OF 93-0425; OF 93-0427; OF 93-0428; OF 93-0429; OF 93-0430; OF 93-0431; OF 93-0432

Colorado, bydrogeology WRI 92-4030

Florida, hydrogeology WRI $91-4123$

hydrogeology OF 92-0083

hydrology WRI 91-4110

Michigan, ground water OF 92-0114

New Jersey, ground water WRI 91-4126

Puerto Rico, hydrogeology C 1081

Tennessee, hydrogeology WRI 91-4195

water, energy, and biogeochemical budget

Colorado, hydrology C 1086

Georgia, hydrology OF 93-0055

Panama, weathering C 1086

Puerto Rico

ecology OF 92-0150

hydrogeology C 1086

weathering C 1086

Vermont, hydrology C 1086

Wisconsin, ground water C 1086

water, waste see waste water

water-rock interface see rock-water interface

waterfalls

California, seismology P 1550-C

Waterville Formation

geochemistry OP-750

waterways see also canals.

OP-157; OP-334; OP-566; OP-888

Alaska, hydrology OF 93-0162

Arkansas WRI 92-4126

Califormia OP-567

Georgia, hydrology OF 92-0113

Iowa, hydrology OF 92-0094

Louisiana

OF $92-0530$

hydrogeology WRI 91-4109; OF 92-0492

Mississippi OF 90-0110

Missouri WRI 92-4118

Montana, hydrology WRI 92-4048

New York, hydrology WRI 92-4042

North Carolina, hydrology WRI 92-4097; OP1958

North Dakota, hydrology WRI 92-4020

South Carolina

WRI 90-4056

hydrology WRI 92-4040

Tennessee

OP-1084

hydrology WRI 92-4082; OF 92-0648

Texas OP-150

West Virginia, geomorphology B 1981

Wisconsin, hydrology WRI 90-4124

Wyoming, hydrology WRI 92-4091

WATSTORE

hydrology C 1086; OF 92-0105; OF 92-0632

Waucoba Wash Quadrangle

economic geology OP-662

Wawarsing Limestone

stratigraphy B $1839-\mathrm{L}$

weathering

OP-1689; OP-1832

Alaska

pollution OP-66

Quaternary OP-549

Appalachians, stratigraphy OP-1380 
Atlantic Coastal Plain, pollution OP-1458

Australia, metal ores OP-1431

Bangladesh OP-1273

California

soils OP-1065; OP-1170

stratigraphy OF 92-0588

Canada, metal ores OP-1431

chemical weathering

Alaska OP-1553

Colorado OP-1051

geochemistry OP-1292

Maryland OP-1573; OP-1610

Pennsylvanian OP-1233

Puerto Rico C 1086

Virginia WRI 92-4090; OP-1573; OP-1610; OP-1774

Washington OP-1121

Western Australia OP-1774

Colorado

environmental geology OF 92-0391

hydrology OF 92-0628

earthquakes OP-517

Georgia, hydrology OF 93-0055

Hawaii, geochemistry OP-1997

Iceland, geochemistry OP-1997

Maryland

engineering geology OF 92-0541

hydrology OP-524

mechanical weathering OP-389

Pennsylvanian OP-1233

Minnesota

geochemistry OP-248

kaolin deposits OF 92-0514

non-metal deposits OF 92-0514

Oregon OP-1134

Panama C 1086

pollution OP-788

Puerto Rico

C 1086

copper ores OF 92-0578

ecology OF 92-0150

ground water OP-1960

Rocky Mountains, pollution OP-1008

Texas, environmental geology OF 92-0391

Virginia, hydrology OP-524

Wyoming, pollution OP-930

weathering rinds

Quaternary OP-201

\section{WEBB}

ecology OF 92-0150

ground water C 1086

hydrogeology C 1086

hydrology C 1086; OF 92-0628; OF 93-0055 weathering C 1086

Weber Segment

geomorphology I-2199

Weddell Sea

orogeny OP-1395

Quatemary OP-1307

stratigraphy $\mathrm{OP}-470$

tectonophysics OP-1446

Weddellia

tectonophysics OP-1446

Wegener hypothesis see continental drift

Weichselian see Younger Dryas

Weiser Ridge Quadrangle

maps GQ-1714

Welda Quadrangle

maps I-2379 welded tuff

Nevada

geophysical surveys OF 92-0028

ground water OP-1899

Oregon OP-498; OP-982

Weldon Spring Missouri

environmental geology OF 93-0153

ground water OF 93-0109; OF 93-0140

well logging see well-logging

well stimulation

ground water OF 93-0071

well-logging see also gamma-ray methods.

acoustical logging

engineering geology OP-760

Nevada WRI 91-4167

Tennessee OF 92-0135

California

energy sources OF $92-0383$

ground water OF 93-0148

caliper logging

California OF 92-0544

Connecticut WRI 92-4074

Florida WRI 91-4168

Idaho WRI 92-4184

Nevada WRI 91-4167

New Hampshire OF 92-0647

Tennessee OF 92-0135

Canada, palynomorphs B 1909

Colorado

base metals OF 93-0183

ground water WRI 92-4067; OF 93-0071

rock mechanics OF 93-0071

electrical logging

Califomia OF 92-0544

Montana OC-0135; OC-0138

New Hampshire OF $92-0647$

South Carolina B 2030

Tennessee OF 92-0135; OF 92-0166

Wyoming OC-0135; OC-0136; OC-0137; OC-0138

geophysical surveys YR; OF 92-0390-A; OF 92-0390-B; OF 92-0391; OF 92-0579A; OF 92-0579-B; OF 92-0579-C; OF 930071; OF 93-0323; OF 93-0324; OC-0140; OP-807

gravity logging

Brazil OP-1329

Washington OP-877

ground water OF 93-0071; OP-761

Hawaii, lava OF 93-0015

Idaho, ground water WRI 92-4027

magnetic logging, California OF 92-0544

Mississippi Valley, Paleozoic OF 92-0685

Montana, sedimentary petrology B 1917-L

natural gas OF 92-0381; OF 92-0524

Nevada

geophysical surveys OF 92-0028; OF 920572

petroleum OF 92-0391; OF 93-0186

waste disposal OP-724

Oklahoma

geophysical surveys OP-1741

ground water OF 93-0071

natural gas OF 92-0524

Ontario, geophysical surveys OF 93-0071

Oregon

geophysical surveys OF 93-0020 petrology B 2054

Pacific Coast, energy sources B 2034-A

Pakistan, lignite OF 92-0576

pollution OP-1030

Puerto Rico, copper ores OF 92-0578 stratigraphy OP-1144

temperature logging

Alaska C 1086

Florida WRI 91-4168

Hawaii OF 92-0586

Idaho WRI 92-4184

New Hampshire OF 92-0647

Tennessee OF 92-0135

United States, palynomorphs B 1909

Utah, sedimentary structures OF 93-0270

Virginia, Quaternary OF 92-0395

Washington

engineering geology OF 91-0441-T

neotectonics OF 93-0332

West Virginia, Quatemary OF 92-0395

Westem Interior, geophysical surveys OF 92 0397

Wyoming, sedimentary petrology B 1917-L

wellbore breakouts see borehole breakouts

Wellington Formation

ground water WRI 92-4177

Wells Formation OP-1320

Wenonah Formation

stratigraphy OP-529

West Africa see Cameroon; Ivory Coast; Nigeria

West Antarctic Rift

plate tectonics OP-65

West Coast see Pacific Coast

West Falls Formation B 1909

West Foreland Formation energy sources OP-626

West Greenland see Isua Belt

West Huasna Fault

structural geology OP-1701

West Indies see Antilles; Bahamas

West Mediterranean see Tyrrhenian Sea

West Mellott Field

energy sources OP-889

West Mojave Management Area economic geology OF 92-0595

West Pacific see Bering Sea; Indonesian Seas; Japan Trench; North Australian Seas; Okhotsk Sea; South China Sea; Sulu Sea; Taranaki Basin; Yellow Sea

West Pacific Ocean Islands

earthquakes, Bonin Islands OP-501

hydrology W 2400

tectonophysics

Bonin Islands OP-1034

Kermadec Islands OP-1969

West Pakistan see Pakistan

West Siberian Plain see Siberian Lowland

West Siberian Platform see Siberian Platform

West Virginia see also Appalachian Basin; Genesee Group; Hamilton Group; Marcellus Shale; Ohio Shale; Oriskany Sandstone; Potomac River basin; Rome Trough; Valley and Ridge Province.

coal OP-1226

engineering geology, Pendleton County West Virginia OP-1542

environmental geology

OP-1608

Berkeley County West Virginia OP-901

Jefferson County West Virginia OP-901

fluvial features, Pendleton County West Virginia B 1981

geochemistry, Pendleton County West Virginia B 1839-IJ

geomorphology 
Barbour County West Virginia B 1981 Grant County West Virginia B 1981

Hampshire County West Virginia B 1981

Hardy County West Virginia B 1981

Mineral County West Virginia B 1981

Monongalia County West Virginia B 1981

Pendleton County West Virginia B 1981

Preston County West Virginia B 1981

Randolph County West Virginia B 1981

Tucker County West Virginia B 1981

highways WRI 92-4147

hydrogeology

W 2384

McDowell County West Virginia WRI 92 4073

hydrology

B 1981; W 2400

Fayette County West Virginia OF 92-0065

Summers County West Virginia OF 920065

maps OP-1543

peat

Grant County West Virginia I-2364-B

Tucker County West Virginia I-2364-B

Quaternary

Berkeley County West Virginia OF 92-0395

Hampshire County West Virginia OF 92 0395

Hardy County West Virginia OF 92-0395

Jefferson County West Virginia OF 92-0395

Mineral County West Virginia OF 92-0395

Morgan County West Virginia OF 92-0395

sedimentary petrology, Kanawha County West Virginia OP-778

stratigraphy

OP-1367

Hampshire County West Virginia B 1839-K

Hancock County West Virginia B 1839-K

West-Central Alaska see Nixon Fork Terrane;

Seward Peninsula

Westeriy Granite

fractures OF 93-0245; OP-1721

Western Australia

geochemistry OP-1774

metal ores, Yilgam Block OP-1431

Western Canada see Alberta; British Columbia; Canadian Cordillera; Manitoba; Northwest Territories; Saskatchewan; Yukon Territory

Western Europe see France; Iceland; Scandinavia; United Kingdom

Western Hemisphere

ecology C 1086

engineering geology OF 93-0338

metal ores $\mathrm{OF} 93-0328$

Western Interior see also Montana; Utah; Wyoming.

Carboniferous OP-1231

clay mineralogy OP-794

diagenesis OP-1792

foraminifera OP-1757

geochemistry OP-755

geophysical surveys, Western Interior Seaway OF 92-0397

ground water HA-0722-H; HA-0722-I

Invertebrata OP-525

sedimentary petrology, Western Interior Seaway B 2051; OP-1332

stratigraphy

OF 93-0335; OP-1414

Western Interior Seaway P 1532; OP-1351

Western Interior Plains Aquifer ground water HA-0722-H; HA-0722-I
Western Interior Seaway

geophysical surveys OF 92-0397

sedimentary petrology B 2051; OP-1332

stratigraphy P 1532; OP-1351

Western Interior Seaway Scientific Drilling Project geophysical surveys OF 92-0397

Western Overthrust Belt natural gas OF 93-0248 petroleum OF 93-0337

Western Samoa see Samoa

Western U.S. see Pacific Coast

Westphalia Quadrangle maps I-2378

Westphalian

Canada OP-1905

Nova Scotia OP-1672

Ohio OP-1513

United States OP-1905

West Virginia OP-778

Westray Mine

sedimentary petrology OP-1672

Westwater Canyon Sandstone Member uranium ores OP-1848

wetlands

Algeria, pollution OP-599

Arkansas, sedimentation OP-1529

California, pollution OP-599

Colorado, pollution OP-1968

ecology C 1086

environmental geology OF 92-0514

Florida, ground water OP-671

geochemistry OF 92-0445

Gulf Coastal Plain

environmental geology OF 92-0530

Quaternary OF 92-0530

Gulf of Mexico, Quaternary OF 92-0530

Hawaii, pollution WRI 92-4168

hydrogeology YR; OP-1077; OP-1085

hydrology OP-1078

Indiana, ground water OP-923

Louisiana

conservation OF 92-0530

ecology OF 92-0530

engineering geology OF $92-0530$

environmental geology OF 92-0530

geologic hazards YR; OF 93-0210

Quaternary OF 92-0530

peat OP-131

South Carolina, ecology OF 93-0303

Spain, pollution OP-599

Tennessee

hydrogeology OP-462

sedimentation OP-1529

Tunisia, pollution OP-599

Utah, ecology WRI 92-4084

Wisconsin, geomorphology MF-2252

Wyoming, ground water OF 91-0533

Whidbey Island

Quaternary OP-36

Whipple Mountains

igneous rocks OP-1112

white mica see muscovite

White Mountains

economic geology OP-260

petrology OP-1148

White Pine Mine

copper ores OP-1688

energy sources OF 92-0391

geochemistry OP-1204
White Rim Sandstone Member

diagenesis OP-1465

White River National Forest economic geology B 2035; B 2039

mineral resources B 2039

White Sands

ground water OF 92-0465

White-Inyo Range see Inyo Mountains

Whitewater Lake

hydrology WRI 92-4113

Whitmore Mountains

tectonophysics OP-1446

Wichita Quadrangle maps I-1420 (NJ-14)

Wilbert Formation structural geology OP-941

Wilcox Aquifer ground water WRI 92-4102

Wild River Pluton folds OP-1427

Wilder Mountain Roadless Area economic geology B 1955

Wilkes Land

Quaternary OP-1358

Wilkins Peak Member P 1506-F

Willamette National Forest geologic hazards OF 92-0483

Willamette Valley

geophysical surveys OF 93-0319; OF 93-0347 hydrology WRI 91-4063

sediments OP-1403

Willapa Bay

Quaternary OF 93-0284; OF 93-0289

Williams Fork Formation

sedimentary petrology OF 92-0391

Williams Kimberlite petrology OP-1491

Williams Lake hydrology OF 92-0475; OF 93-0127

Williamstown Quadrangle maps I-2369

Willimantic Window structural geology OP-1079

Williston Basin energy sources OF 92-0524; OF 93-0337; OP1753

petroleum B 1909

stratigraphy OF 93-0335

Wills Mountain Anticline fluvial features B 1981

Willwood Formation

OP-98

hydrogeology WRI 91-4044

sediments OP-556

Willyama Complex metal ores OP-942

Wilson cycle

Appalachians, structural geology OP-1479

Winchester Quadrangle

Quaternary OF 92-0395

Wind River

structural geology OP-1539

Wind River basin

diagenesis OP-1950

energy sources OF 93-0337; OP-1753

natural gas OF 92-0524; OP-1569

petroleum OP-1767

Quaternary OF 92-0391 
Wind River Federal Irrigation Project hydrology OF 93-0142

Wind River Range

geochemistry OP-712

Quaternary OP-711; OP-1455; OP-1884

Windsor Group

sedimentary petrology OP-1672

Wineglass Welded Tuff

petrology OP-498

Winona Reservoir

hydrology OF 93-0122

wireline logging see well-logging

Wisconsin seealso Keweenawan; Lake Michigan; Lake Superior region; Michigan Basin; Mississippi River, Oronto Group; Upper Mississippi Valley.

geomorphology

Marinette County Wisconsin MF-2252

Oconto County Wisconsin MF-2252

ground water

P 1405-B; C 1086; OF 92-0694; OF 93-

0114; HA-0730-J; OP-1090

Waukesha County Wisconsin WRI 92-4077

hydrogeology

OF 93-0129

Barron County Wisconsin OF 92-0026

Burnett County Wisconsin OF 92-0026

Polk County Wisconsin OF 92-0026

hydrology

W 2400; C 1120-A

Dane County Wisconsin WRI 92-4029

Dunn County Wisconsin WRI 90-4124

Grant County Wisconsin WRI 90-4124

Kenosha County Wisconsin WRI 90-4126

Pepin County Wisconsin WRI 90-4124

Richland County Wisconsin WRI 90-4124

Trempealeau County Wisconsin WRI 904124

Walworth County Wisconsin WRI 90-4126

Wisconsin River WRI 90-4124

maps

Florence County Wisconsin I-2356

Marinette County Wisconsin I-2356

metal ores MF-1835-H

non-metal deposits

OF $92-0514$

Milwaukee Wisconsin OF 92-0514

Racine County Wisconsin OF 92-0514

Waukesha County Wisconsin OF 92-0514

Quaternary OP-391; OP-1896

soils, Grant County Wisconsin OP-22

structural geology OP-1214

Wisconsin River

hydrology WRI 90-4124

Wisconsinan

OP-201

Illinois OP-1309

Maryland OP-439

Massachusetts OP-555; OP-749

New England OP-748

Wyoming OP-1455

WISRD

geomorphology OP-1623

Wolcott Syncline

stratigraphy B 1787-GG

Wolfe City Sand

stratigraphy $\mathrm{OP}-177$

wolframite

Saudi Arabia

metal ores OP-1559

tin ores OP-1558
Wolftever Creek basin

hydrogeology WRI $91-4190$

Wolverine Glacier

hydrology C 1086

Quaternary C 1086; OP-651

women YR

Woodford Shale

energy sources OP-1753

Woodruff Formation

sedimentary petrology OP-1795

Wordian

stratigraphy OP-354

workstations

hydrology OF $92-0534$

World Stress Map Project

crust OP-2030

Worldwide Earthquake Risk Management

Program

geologic hazards OP-1109

Wrangell Mountains maps GQ-1688

Wrangell-Saint Elias National Park and Preserve

geochemistry OF 93-0014

Wrangellia

Alaska

maps I-2164

metamorphic rocks P 1497-C; OP-1194

Califomia, paleomagnetism OP-1504

Canada, metamorphic rocks P 1497-C

wrench faults

California OP-1442

Greece, plate tectonics OP-542

Montana, petroleum OF 93-0337

Wright-Patterson Air Force Base ground water WRI 93-4047

hydrogeology WRI 92-4072

wrinkle ridges $\mathrm{OP}-1421$; OP-1422

Wroe Wolfe, Caleb OP-616

WTAQ1

ground water OP-684

wulfenite

Arizona, metal ores OP-290

Wurtsboro Tongue

stratigraphy B 1839-L

Wyoming see also Absaroka Supergroup; Almond Formation; Beartooth Mountains; Bighom Basin; Bighorn Mountains; Cody Shale; Dakota Formation; Denver Basin; Fort Union Formation; Frontier Formation; Granite Mountains; Green River Formation; Lake Uinta; Lance Formation; Laramie Mountains; Lewis Shale; Mesaverde Group; Minnelusa Formation; Moxa Arch; Muddy Sandstone; Niobrara Formation; Nugget Sandstone; Phosphoria Formation; Pierre Shale; Powder River basin; Rock Springs Formation; Shannon Sandstone Member; Sussex Sandstone Member, Tullock Member, Western Overthrust Belt; Willwood Formation; Wyoming Province; Yellowstone National Park. areal geology OP-594

Cretaceous

Campbell County Wyoming OC-0135; OC0136; OC-0137; OC-0138

Converse County Wyoming OC-0135; OC0136; OC-0137; OC-0138

Crook County Wyoming OC-0135; OC0136; OC-0137; OC-0138

Johnson County Wyoming OC-0135; OC0136; OC-0137; OC-0138
Natrona County Wyoming OC-0135; OC0136; OC-0137; OC-0138

Niobrara County Wyoming OC-0135; OC0136; OC-0137; OC-0138

Sheridan County Wyoming OC-0135; OC0136; OC-0137; OC-0138

Weston County Wyoming OC-0135; OC0136; OC-0137; OC-0138

diagenesis, Fremont County Wyoming OP1950

energy sources

OF 92-0524; OF 93-0337

Campbell County Wyoming OF 92-0391

Crook County Wyoming OP-889

environmental geology OF 93-0292-H

faults OP-685

geochemistry

OF 92-0525; OP-520; OP-978

Wind River Range OP-712

geophysical surveys

Campbell County Wyoming OF 93-0002

Converse County Wyoming OF 93-0002

Niobrara County Wyoming OF 93-0002

Teton County Wyoming B 1966

Weston County Wyoming OF 93-0002

ground water

B 1989-D

Natrona County Wyoming OF 91-0533

guidebook

Grand Teton National Park OF 92-0504

Jackson Hole OF 92-0504

heavy mineral deposits OF 93-0240-A; OF 930240-B

highways WRI 92-4147

hydrogeology

Fremont County Wyoming WRI 91-4108

Hot Springs County Wyoming WRI 914108

Laramie County Wyoming OF 93-0106

Washakie County Wyoming WRI 91-4044 hydrology

W 2400; OP-1044

Campbell County Wyoming WRI 91-4199

Carbon County Wyoming WRI 92-4091

Fremont County Wyoming OF 93-0142

Johnson County Wyoming WRI 91-4199

Natrona County Wyoming WRI 91-4199

Sheridan County Wyoming WRI 91-4199

Sierra Madre Range WRI 92-4091

impact statements, Converse County Wyoming WRI 90-4154

Invertebrata, Johnson County Wyoming OP860

maps

Albany County Wyoming I-2232

Big Hom County Wyoming I-2343-A

Campbell County Wyoming I-2343-A; I2343-B; I-2380-A; I-2380-B

Converse County Wyoming I-2343-B; I2380-B

Crook County Wyoming I-2343-A; I-2380-

Goshen County Wyoming I-2343-B

Johnson County Wyoming I-2343-A; I2343-B; I-2380-A; I-2380-B

Natrona County Wyoming I-2343-B; I2380-B

Niobrara County Wyoming I-2343-B; I2380-B

Platte County Wyoming I-2232; I-2343-B

Sheridan County Wyoming I-2343-A; I2380-A

Sweetwater County Wyoming I-2168 
Uinta County Wyoming I-2168

Washakie County Wyoming I-2343-A

Weston County Wyoming I-2343-A; IMiocene 2343-B; I-2380-A; I-2380-B

Campbell County Wyoming B 1917-O

Converse County Wyoming B 1917-O

Johnson County Wyoming B 1917-O

natural gas

OF 93-0192

Carbon County Wyoming OF 92-0524

Fremont County Wyoming OF 92-0524

neotectonics, Jackson Hole OP-780

paleomagnetism OP-697

palynomorphs, Sweetwater County Wyoming P 1506-D

petroleum

OF 93-0337

Rock Springs Uplift OP-1635

pollution, Casper Wyoming OP-1871

Quaternary

Fremont County Wyoming OF 92-0391

Grand Teton National Park OF 92-0504

Park County Wyoming OF 92-0391; OF $92-$ 0408

Teton County Wyoming OF 92-0391; OF 92-0408

Wind River Range OP-711; OP-1455; OP1884

sedimentary petrology

Campbell County Wyoming B 1917-L

Natrona County Wyoming B 1917-L

Niobrara County Wyoming B 1917-L

Rock Springs Uplift B 2051

Sweetwater County Wyoming B 2051

Teapot Dome B 1917-L

sediments, Washakie County Wyoming OP556

stratigraphy

OP-1181

Albany County Wyoming P 1520

Carbon County Wyoming P 1520

Lincoln County Wyoming P 1506-F

Rock Springs Uplift P 1532

Sierra Madre Range P 1520

Sublette County Wyoming P 1506-F

Sweetwater County Wyoming P 1506-F; P 1532

Uinta County Wyoming P 1506-F

structural geology

OP-679

Albany County Wyoming OP-149

Carbon County Wyoming OF 92-0388

Converse County Wyoming OP-149

Laramie County Wyoming OP-149

Natrona County Wyoming OP-149

Platte County Wyoming OP-149

Rock Springs Uplift OF 92-0388

Sweetwater County Wyoming OF 92-0388 tectonics OP-753

thermal waters, Teton County Wyoming OF 93-0293

Triassic

Campbell County Wyoming B 1917-P

Converse County Wyoming B 1917-P

Crook County Wyoming B 1917-P

Johnson County Wyoming B 1917-P

Niobrara County Wyoming B 1917-P

Sheridan County Wyoming B 1917-P

Weston County Wyoming B 1917-P

Wyoming Province

Archean OP-705
Cretaceous OP-11

crust OP-2017

geochemistry OP-2016

petrology OP-1716; OP-1731

Wytheville Quadrangle

Proterozoic B 2029

\section{$\mathbf{X}$}

$\mathrm{X}$-ray analysis see $\mathrm{X}$-ray fluorescence

$\mathrm{X}$-ray diffraction analysis

intrusions OP-1126

$\mathrm{X}$-ray fluorescence

geochemistry B 1770; B 2046; OP-505

\section{XDETECT}

seismology OF 92-0441; OF 92-0597

Xela Caldera

geomorphology OP-277

xenoliths

OP-1704; OP-1943

California

OP-1711

geochemistry OP-678; OP-730

Chile, Quaternary OP-279

China, geochemistry OP-457

Colorado, geochemistry OP -490

Ecuador, gold ores B 2039

geochemistry OF 92-0525

Hawaii OP-164

Mexico, geochemistry OP-132

New Mexico, geochemistry OP-490

Saudi Arabia OP-1952

xenotime

California, geochemistry OP-678

Far East, metal ores C 0930-N

\section{Xinjiang China}

core OP-1031

gold ores OP-945

Xray diffraction analysis see $\mathrm{X}$-ray diffraction analysis

xylene

pollution OP-1128

\section{$\mathbf{Y}$}

Yakataga Gap

neotectonics OP-1852

Yakima Indian Reservation

ecology OF 91-0453

environmental geology C 1090

hydrogeology OF 91-0453

hydrology OF 91-0453

Yakima River basin

ecology OF 91-0453

environmental geology C 1090

hydrogeology OF 91-0453; OF 92-0520; OF 92-0644

hydrology WRI 91-4073; OF 91-0453; OF 910454

pollution OP-1827

Quatemary OP-201

Yakut A.S.S.R. see Yakutia Russian Federation

Yakutat Bay marine geology OF 92-0706

Yakutia Russian Federation

metal ores OF 93-0339

Quaternary B 2036

Vertebrata B 2037
Yamato Meteorites

petrology OP-1956; OP-2025

Yates Formation

geochemistry OP-1072

Yazoo Clay OP-746

Yazoo River basin

hydrology OF 92-0469

Yellow Aster Complex

Washington, stratigraphy OP-1480

Yellow Sea

petroleum OP-1829

Yellowjacket Formation metal ores OP-715

Yellowstone hot spot

neotectonics OP-780

Quaternary OF 92-0391

structural geology OP-1539

Yellowstone Lake geophysical surveys B 1966 '

Yellowstone National Park geochemistry OP-49; OP-122; OP-327; OP464; OP-536; OP-637; OP-874; OP-998 pollution OP-930

Quaternary OF 92-0391; OF 92-0408

structural geology OP-1539

tectonophysics OP-1780

thermal waters OF 93-0293

Yemen see Arabian Shield

Yilgarn Block

metal ores OP-1431

Yolla Bolly Terrane

metamorphic rocks OP-1166

YoNav OF 92-0565

Yorktown Formation ground water WRI 92-4111

Yorktown-Eastover Aquifer ground water WRI 92-4111; WRI 92-4175

Yosemite National Park

geologic hazards OF 92-0387

Younger Dryas

Great Lakes OP-1289

Yucaipa Quadrangle maps OF 92-0446

Yucatan Mexico hydrogeology OP-38

Yucatan Peninsula geochronology OP-920

hydrogeology OP-2001

Quaternary OP-706

stratigraphy B 2050

Yucca Flat

geochemistry OP-1775

seismology OP-2026

Yucca Mountain

engineering geology OF 93-0073

environmental geology OF 92-0516

geochemistry OP-643

geochronology OF 93-0538

geomorphology OP-1276

geophysical surveys OF 92-0028; OF 92-0343; OF 92-0572

ground water OF 90-0369; OF 91-0478; OF 93 0071; OP-234; OP-235; OP-269; OP-1009; OP-1899

petroleum OF 92-0391

Quatemary OP-1070

structural geology OF 91-0623; OP-1400

waste disposal OF 91-0493; OP-724; OP-1522

Yugoslavia

Croatia OP-558 


\author{
Kosovo-Metohija OP-558 \\ Slovenia OP-558 \\ Yukhtinskiy Formation \\ Mesozoic OP-1494 \\ Yukon see Yukon Territory \\ Yukon Island \\ stratigraphy OP-1169 \\ Yukon River \\ oceanography OP-129 \\ Yukon Territory \\ Cenozoic C 1086 \\ geochemistry OF 92-0525 \\ metal ores \\ OP-363 \\ Selwyn Basin OP-1432 \\ Yukon-Koyukuk Basin \\ folds OP-1427 \\ Yukon-Tanana Terrane \\ geochemistry OP-721 \\ metal ores OP-570 \\ Yunnan China \\ copper ores OP-456
}

\section{$\mathbf{Z}$}

Zaire

metal ores C 0930-M

Zala Basin

energy sources OP-1263; OP-1687

Zamora Ecuador

gold ores B 2039

Zarembo Island

geochemistry OP-1373

Zayante seismic experiment geophysical surveys OF 92-0561

zeolite deposits

Colorado B 2061-A

New Mexico B 2061-A

South Dakota OF 92-0514

zeolite facies

Oregon, petrology B 2054 zeolite group see also clinoptilolite; natrolite; thomsonite.

Califomia, diagenesis OP-1386

Nevada, waste disposal OP-724

Zhemchug submarine canyon

engineering geology OP-140

Zihuatanejo earthquake 1985

plate tectonics OP-670

zinc see also heavy metals. geochemistry OP-530; OP-1312

Georgia, oceanography OP-1502

hydrology OP-1836

Massachusetts, geochemistry OP-215

New Jersey, environmental geology OF 920153

sediments OP-1887

Utah, mineral resources MF-2081-D; MF2081-E

zinc blende see sphalerite

zinc ores see also mississippi valley-type. Arizona B 1737-E

Bolivia OP-202

California OP-204; OP-260; OP-662

Nevada OP-260; OP-627

Spain OP-875

zircon

California

geochemistry OP-678

magmas OP-1711

petrology OP-1376

Phanerozoic OP-1340

structural geology OP-1413

Colorado

Cretaceous OP-11

energy sources OP-518

geochronology OP-1804

geochronology OF 92-0525; OP-134

Idaho, petrology OP-630

Maryland, intrusions OP-1106

Minnesota, geochronology OP-758

Montana

Archean OP-705 crust OP-2017

petrology OP-1731

Nevada, gold ores OP-27

New Hampshire, geochronology OP-1 105

New Mexico

Cretaceous OP-11

energy sources OP-518

North Carolina, geochemistry OP-1607

Ontario

OP-1178

petrology OF 92-0391

Quebec, gold ores OP-1097

Saudi Arabia

Proterozoic B 1976

sedimentary petrology OP-1378

Utah, stratigraphy B 1787-BB

Virginia, intrusions OP-1106

Wyoming

crust OP-2017

geochemistry OP-2016

zirconium

heavy mineral deposits OF 93-0240-A; OF 930240-B

Quaternary OP-459

$\mathrm{Zn}$ see zinc

Zoantharia see Rugosa; Scleractinia

zone of mobility see asthenosphere

zone, Benioff see Benioff zone

zones, fault see fault zones

zones, fracture see fracture zones

zones, rift see rift zones

zones, shear see shear zones

zones, subduction see subduction zones

zones, suture see suture zones

zoogeography see biogeography

Zuni Basin

coal OP-17

Zuni Mountains

ground water WRI 91-4033

\section{AUTHORS}

\section{A}

Aaronson, D. B. WRI 91-4012

Abers, G. A. OP-1

Able, K. W. MF-2221

Ablin, K. K. OP-1832, 2022

Abrahamsen, Niels OP-413

Abrams, G. A. OF 92-0503, 930018; MF-2236

Abston, C. C. DDS-0006, 0008

Acevedo, William C 1086

Achauer, Ulrich OP-2, 521

Acker, J. G. OP-3

Acosta, A. V. OF 93-0526

Acosta, Juan MF-2242

Adam, D. P. C 1086; OF 930020; OP-1098

Adams, C. D. OP-4, 5

Adams, D. D. OP-1099

Adams, G. S. OF $92-0482$

Adams, P. M. OP-500

Adamski, J. C. OP-261, 1100
Adamson, A. C. OP-361

Adel-Hadadi, M. A. OP-1873

Adham, Samy OP-1092

Adrian, B. M. OF 90-0506, 900672, 92-0008-A, 92-0008-B 92-0268

Aelion, C. M. OP-1040

Affolter, R. H. OF 92-0391

Aga, D. S. OF 93-0418

Agar, R. A. OP-1921

Agena, W. F. OF 92-0680, 930264

Ager, T. A. C 1086; OP-1101

Agnew, D. C. OF 91-0032; OP90,1102

Aharonian, V. OF 93-0216

Ahlbrandt, T. S. OP-6, 1103, 1233

Ahmad, L. OP-1637

Ahmad, Mujeeb OF 92-0576

Ahrens, Kimberly OP-1587

Aichele, H. OP-1091

Aiken, G. R. OP-664
Aitchison, J. OP-8

Aitchison, J. C. OP-7

Akentiev, Lyosha OF 92-0693

Aki, Keiiti OP-676

Akimoto, Kazumi OP-186, 187 , $188,189,190,191,192,193$, $194,195,196$

Akstin, K. C. OP-733

Alam, A. K. OF 92-0391; OP1273

Albanese, J. R. OP-1104

Albers, J. P. OP-465

Albino, G. V. OP-9

Aleinikoff, J. N. OF 92-0525, 92-0594; OP-10, 11, 12, 570 1079, 1105, 1106, 1316, 1530,1955

Alexander, A. G. WRI 92-4138

Alexander, J. OP-1063

Alexander, R. B. W 2400; OF $90-0130$

Alexander, R. H. C 1086

Alexander, T. W. WRI 92-4118
Alfaro, Guillermo OP-1107

Alfaro, L. D. OP-1862

Alger, C. S. OF 92-0387

Algermissen, S. T. OP-993, $1108,1109,1948$

Alicea-Ortiz, José OF 85-0642

Allen, C. R. OF 91-0032

Allen, D. J. OP-13

Allen, James OP-413

Allen, R. L. WRI 92-4108

Allison, M. L. B 2013

Alminas, H. V. OF 92-0615

Alonso, Belén OP-723

Alpers, C. N. OP-1110

Alpha, A. G. B 1988-C

Alpha, T. R. OF 93-0278-A, 930278-B

Alt , J. C. OP-14

Alvarez C., Orlando OP-2027

Alvarez G., Salvador OP-399

Amadei, Bernard OP-884

Ambats, Gil OP-533, 637, 1578 
Ambroziak, R. A. DDS-0002, 0003, 0005, 0009, 0015; OF 92-0691, 93-0231; OP1111

Amirbekian, R. OF 93-0216

Ammon, C. J. OP-15

Amos, G. L. OF 93-0065

Anderholm, S. K. P 1407-C; WRI 91-4033

Anders, D. E. OP-626, 674, 1767

Anders, F. J. OF 92-0530

Andersen, Anett OF 92-0391

Anderson, Barclay OF 91-0014

Anderson, D. L. C 1031

Anderson, H. W., Jr. OP-551

Anderson, J. L. OP-1112

Anderson, L. C. OP-1574

Anderson, L. D. OP-16, 530 . 590

Anderson, L. R. P 1519

Anderson, O. J. OP-17

Anderson, R. E. B 2011; GQ1721; OP-18, 19

Anderson, R. G. OP-680

Anderson, R. R. OP-1113, $1114,1834,1882$

Anderson, R. Y. OP-20, 21, 100,739

Anderson, W. OF 92-0514

Anderson, W. L. OF 92-0553A, 92-0553-B, 93-0234-A, 93-0234-B

Anderson, William OP-415

Andersson, Johan OP-1039

Andraski, B. J. OF 92-0484; OP-22

Andreasen, D. C. OF 92-0459, 92-0460, 92-0461, 92-0462, 92-0463, 92-0464

Andreasen, G. E. OP-1606

Andresen, A. OP-1279

Andrews, D. J. OP-23, 1201

Andrews, E. D. OP-24, 488, 947

Andrews, W. J. WRI 92-4058

Andrle, V. A. OF 92-0262, 92 0263; OP-293

Annan, A. P. OP-369

Anovitz, L. M. OP-25, 1690

Anthony, S. S. OP-26

Antonenko, I. OP-1485

Antweiler, J. C. OF 92-0573-A, 92-0573-B, 92-0591-A, 920591-B; I-2050-F

Apoian, G. OF 93-0216

Appel, C. A. WRI 92-4124

Arabasz, W. J. C 1031; OP-438

Arav, Sara OP-1002

Arbogast, B. F. MF-2217-A, 2217-B; OP-505

Arcement, G. J., Jr. W 2339

Arculus, R. J. OP-604, 1663

Arehart, G. B. OP-27

Arend, Meijer OP-51

Arends, R. G. OF 92-0539-C, 92-0539-D

Arespón, Jesús MF-2242

Arkani-Hamed, Jafar OP-28, 29

Armstrong, A. K. B 1787-EE

Amadottir, Thora OP-252

Amdt, N. T. OP-30, 1086
Arndt, R. E. OP-1730

Amett, T. L. OF 92-0480

Amold, J. R. OP- 1750

Amold, Jay OF 93-0210

Aronson, J. L. OP-1359

Arora, B. R. OP-136

Arribas, Antonio, Jr. OF 92 0009; OP-31, 231, 875

Arth, J. G. OP-37

Arthur, J. K. OP-32

Arthur, M. A. OF 92-0397; OP$1115,1331,1332$

Aruscavage, P. J. B 1770

Arvidson, R. E. OP-786, 1851

Ash, S. R. OP-597, 1659

Asher-Bolinder, Sigrid OF 920391; OP-902, 1116, 1117

Ashley, G. M. OP-33, 390, 391

Ashley, P. M. OP-7

Ashley, R. P. GQ-1679

Ask, M. V. OP-186, 187, 188, $189,190,191,192,193,194$, 195, 196

Asudeh, Isa OF 93-0319, 930347

Atkins, J. B. WRI 92-4147

Attanasi, E. D. OP-34, 861

Attrep, Moses, Jr. OP-755

Atwater, B. F. OP-35, 36, 1118 , 1119,1120

Atwater, T. M. OP-432

Atwood, Genevieve P 1519

Atwood, J. W. OF 93-0117

Audet, D. J. OF 93-0083

August, M. H. OF 92-0627

Ault, C. H. OF 92-0514

Austin, G. T. B 2013

Avé Lallemant, H. G. OP-1427

Averett, R. C. OP-990

Axtmann, E. V. OP-1121

Ayers, M. A. C 1086; OF 920052; OP-2011

Ayuso, R. A. B 2039; OF 920525; OP-37, 1122

Azevedo, Glenn P 1553-B

Azevedo, Steve OF 93-0319

\section{B}

Babcock, L. E. OP-1123

Back, J. M. OP-153, 1238, 2019

Back, William OP-38, 39, 40, $41,376,599,1959$

Backman, J. D. WRI 92-4105

Bacon, C. R. OF 93-0314; OP $42,43,498,846,982,1124$

Badardinov, Alik OF 93-0007

Badri, A. OP-1026

Baebenroth, R. W. OF 92-0094

Baedecker, M. J. OP-44, 219, 629,1155

Baedecker, P. A. B 1770

Baedke, S. J. OF 92-0514

Baehr, A. L. OP-1128, 1383

Bagby, W. C. OP-45

Bahls, L. L. W 2400

Baier, W. G. OF 93-0056, 930123

Baig, M. S. OP-1125, 1637

Bailey, A. OP-653
Bailey, E. A. OF 92-0379-A, 92-0379-B, 92-0380-A, 92 0380-B

Bailey, R. A. I-1995

Baines, K. H. OP-1217

Bair, E. S. OP-155

Baird, A. K. OP-1126

Baird, D. OP-1513

Baird, J. K. OF 92-0524, 92 0696, 93-0335; OP-1350

Baker, C. L. I-1420 (NL-17)

Baker, G. S. OP-1861

Baker, J. L. OF 92-0167

Baker, L. M. OP-1390

Baker, M. OP-52

Baker, P. A. OP-243, 1127

Baker, P.E. OP-186, 187, 188, $189,190,191,192,193,194$, 195,196

Baker, R. G. OP-1309

Baker, R. J. OP-1128

Baker, R. M. OP-46

Baksi, A. K. OP-1702

Bakun, W. H. P 1550-C; OF 930290

Balay, R. H. OF 92-0391, $92-$ 0679, 93-0241-A, 93-0241-B

Baldauf, J. G. OP-1145

Baldauf, P. E. OP-1129

Baldigo, B. P. OP-1130, 1735

Balding, G. O. W 2400 ; WRI 92-4149; OF 92-0451, 92-0452

Baldwin, J. A. WRI 91-4033

Bales, J. D. OF 92-0123, $92-$ 0498, 92-0639; OP-1131, 1958

Bales, J. T. WRI 91-4185

Balistrieri, L. S. C 1086; OF 930243

Ball, F. D. OP-1599

Ball, J. W. OP-1110, 1752

Ball, M. M. OF 93-0522; OP$1132,1133,1265$

Ballantyne, V. A. OP-320

Balsom, J. R. OP-1375

Baltzer, R. A. OP-888

Banach, F. S. W 2400

Banerdt, W. B. OP-1421, 1422

Banerjee, S. K. OP-112

Banfield, J. F. OP-1134

Banfill, Robert OF 92-0441, 93 0216; OP-221, 1300

Bangs, N. L. OP-586

Bankey, Viki B 2035, 2039; OF 92-0389, 92-0557; OP365

Banks, Harold OF 91-0014

Banks, W. S. OP-1876

Banta, E. R. WRI 91-4044; OP854

Baransky, L. N. OP-367

Baraza, Jesús OP-722

Barbanti, A. OP-47

Barber, J. H., Jr. B 2002; OP723

Barbero, R. S. P 1386-E

Barbie, D. L. OF 93-0081

Barczuk, Andrzej B 1989-E

Bardardinov, A. OP-1291

Bardocz, Bela OP-1687
Barg, E. OP-48

Bargar, K. E. B 2054; OP-49

Barkatt, A. OP-1873

Barker, C. E. OF 92-0391, 93 0186; OP-50, 984, 1135, 1136, 1137

Barker, Fred OP-1138, 1377, 2017

Barker, J. L. WRI 90-4011

Barker, J. S. OP-501

Barks, C. S. OF 93-0171

Barlow, P. M. OF 92-0143

Barnes, C. G. OP-1139, 1140 , 1141

Bames, C. R. W 2400; OP-580

Barnes, D. F. OP-1142

Bames, H. L. OP-51

Barnes, J. H. P 1519

Barnes, M. A. OP-1139

Barnes, P. W. OF 93-0019, 930237; OP-835, 836, 1143

Barnes, R. G. OP-942

Barnhard, T. P. B 2011; OP-19,

Barnum, B. E. MF-2232

Barr, G. L. WRI 92-4086

Barr, S. M. OF 92-0525; OP1122

Barrash, Warren WRI 92-4184

Barrera, Luis B 2039

Barrientos, S. E. OP-53

Barringer, J. L. OP-652

Barringer, T. H. WRI 91-4191

Barron, J. A. OF 92-0439, 92 0539-C, 93-0177, 93-0182; OP-54, 1144, 1145, 1330 , 1570,1901

Barsotti, A. F. B 2013

Bartel, A. J. B 1770

Barth, A. P. OP-1112, 1146

Bartholomay, R. C. WRI 934054; OF 92-0156, 92-0643, 93-0034, 93-0102

Bartholomew, M. J. OP-1147

Bartlein, P. J. C 1086; OP-55, 1999

Bartolini, Claudio OP-56

Barton, C. C. OP-213, 1014

Barton, H. N. OF 90-0672, 920384, 92-0709, 93-0527; MF2144-C

Barton, M. D. OP-1148, 1900

Barton, P. B. OP-57, 58

Bartow, A. J. OF 92-0588

Bartsch-Winkler, S. B. OP-1679

Basabilvazo, G. T. OP-573

Basilevsky, A. T. OP-1062, 1149,1851

Baskerville, C. A. B 2043; I2003

Bassett, W. A. OP-924, 1877

Basu, A. R. OP-457

Bates, A. L. C 1086; OP-59, $1150,1904,1905,1906$

Bates, G. T. OP-448

Batson, R. M. OP-1149

Battaglin, W. A. C 1086, 1120 C; OF 93-0418

Batten, L. G. OP-60

Batten, W. G. WRI 92-4077

Batty, D. M. OP-61

Bawer, A. M. OF 92-0514 
Bauer, C. I. OP- 1342

Bauer, H.H. OP-62, 1017

Bauer, P. N. OP-1706

Baum, R. L. B 1842-D; OF 920501; OP-1814

Baumgartner, P. O. OP-361

Bawiec, W. J. DDS-0002; YR; OP-63

Baxter, J. W. OF 92-0514

Bayless, E. R. W 2400

Bayliss, Peter OP-64

Bayr, K. J. OP-386

Bazemore, D.E. OP-462

Beard, L. S. OP-614

Beary, E. A. OF 93-0119

Beary, E. S. OP-1973

Beasley, T. M. OP-147

Beaty, D. W. OP-1151

Beausillon, Roland OP-361

Beck, J. N. OP-742

Beck, K. A. OF 93-0014

Beck, R. E。 YR

Becker, J. L. OP-1152

Becker, K. J. OP-1217

Becker, Keir OP-243

Becker, T. L. OP-1439, 1485, 1487, 1696

Beckman, J. D. WRI 91-4149

Bednarz, Ultich OP-413

Beeman, W. R. OP-1945

Been, J. M. OF 92-0391

Beeson, M. H. B 2054

Beggs, J. M. OP-1391

Behl, R. J. OP-747

Behrendt, J. C. OP-65, 81, 1533

Behrmann, J. H. OP-586, 1651

Bektemirov, A. A. OP-367

Belakovskiy, D. I. OP-373, 1445

Belfield, W. C. OP-174

Belitz, K. R. W 2396; OF 910535

Belkin, H. E. OF 93-0010; OP$66,228,1305,1493,1821$

Bell, J. F. OP-1482

Bell, J. F., III OP-1153

Bell, R. E. OP-81

Bell, R. W. W 2400

Belton, M. J. OP-366, 416, $783,1437,1438,1439,1485$, $1486,1487,1497,1781$

Belval, D. L. W 2400

Bencala, K. E. WRI 92-4081; OP-408, 538, 1579

Bender, B. K. OP-67

Bender, E. E. OP-1112

Bender, J. F. W 2400

Benedict, S. T. WRI 90-4056

Benjamin, S. P. C 1086

Bennett, E. H. B 2013

Bennett, G. D. W 1536-G

Bennett, M. J. OP-1154

Bennett, P. C. OP-1155

Bennett, V. C. OP-678, 1711

Benninger, L. M. OP-419

Bennington, J. B. OF 92-0558

Bensley, D. F. OP-451

Benson, Carl OP-330

Benson, L. V. C 1086; OP-68, 69, 1156
Benz, H. M. OF 92-0723; OP$70,71,1031,1032,1157$, 1646,2026

Berenbrock, C. E. WRI $93-$ 4001; OP-454

Berendsen, Pieter B 1989-E; MF-2125-E

Berg, R. B. OF 92-0514

Berg, R. C. OF 92-0694

Berger, B. R. B 2039; OP-218, 1158, 1159

Berger, D. L. WRI 91-4167

Berger, V. I. OF 93-0194

Bergman, E. A. OP-1080, $1160,1161,1783,1784$

Bergquist, J. R. OF 93-0538

Berkas, W. R. W 2400

Berlin, G. L. OF 93-0272

Bemardi, Arman P 1550-C

Berndt, M. P. WRI 91-4186

Berner, Ulrich OP-587, 819, $820,821,822,823,824,825$

Bernick, R. W., Sr. B 2013

Bernknopf, R. L. C 1111

Beroza, G. C. OP-438, 752 , 1280

Berry, C. W. B 2013

Berry, Kevin W 2400

Berryman, K. R. OP-756

Bertoldi, G. L. OP-72, 73

Bertolini, L. M. C 1086; OP1162,1668

Bertrand, Philippe OP-587, $819,820,821,822,823,824$, 825

Betancourt, J. L. C 1086

Bethke, P. M. OF 92-0009; OP873

Betterton, W. J. OF 92-0391; OP-1178, 1179, 1180, 1181, 1414

Bettis, E. A., III OP-588

Betzler, C. G. OP-587, 819, $820,821,822,823,824,825$

Bevans, H. E. OF 93-0087

Beyer, L. A. B 2034-A; OF 930217-A, 93-0217-B; OP-565

Bhowmik, N. G. OP-482

Bibring, J. P. OP-1163

Bice, T. OP-1423

Bicknell, J. D. OP-660

Bie, S. W. OP-589

Biehler, Shawn OF 93-0217-A, 93-0217-B

Biek, R.F. OF 92-0514

Biewick, L. R. OC-0140

Bilham, Roger OF 91-0032

Billingsley, G. H. OF 92-0591A, 92-0591-B; I-2290

Bilodeau, W. L. OP-679

Bingham, J. W. WRI 87-4144

Bird, D. K. OP-636

Bird, K. J. B 2034-A; OP-34, $74,453,492,1285,1553$

Birkeland, P. W. OP-75, 1324

Bischoff, J. L. OF 93-0232, 930286, 93-0311; OP-76, 77 , $310,533,537$

Bisdorf, R. J. OF 93-0279, 930282, 93-0524

Bish, D. L. OP-572

Black, R. F. I-1420 (NK-18)

Black, Thomas OF 93-0294
Blackwell, C. D. OF 93-0076, 93-0138

Blackwood, D. S. OF 93-0185

Blair, N. L. OP-1164

Blake, D. F. OP-1389

Blake, M. C., Jr. OP-7, 78, 401, $1165,1166,1366,1547,1733$

Blakely, R. J. OF 93-0211, 930287; OP-79, 1167

Blakemore, R. P. OP-1207

Blanc, Gerard OP-413

Blanchard, P. J. WRI 92-4193

Blanchard, S. F. YR

Blanford, J. H. OP-80, 562

Blank, H. R., Jr. B 2039; OF 92 0391, 93-0203; OP-92

Blankenship, D. D. OP-81

Blanpied, M. L。 OP-1893

Blaser, R. A. OP-1668

Blazs, R. L. OF 93-0171

Bleuer, N. K. OP-1308

Blevins, D. W. WRI 92-4167; OF 93-0101; OP-1571, 2028

Bliss, J. D. OF 93-0200, 93 0329; OP-82

Bliss, N. B. C 1086

Bloch, R. B. OP-83

Blodgett, J. C. WRI 92-4035

Blodgett, R. B. OF 92-0562; OP-84, 85, 86, 491, 860, $1123,1168,1268$

Blome, C. D. OP-87, 88, 1169, 1480

Blomquist, J. D. W 2400

Bloomer, S. H. OP-413

Blum, A. E. OP-89, 493, 1065 , $1170,1352,1508,1554$, $1737,1738,1787$

Blum, J.S. OP-1765

Blumer, S. P. W 2400

Blyskun, G. J. OP-652

Boatwright, John OP-179

Bock, Yehuda OP-90

Boden, Per ' OP-586

Bodin, Paul OP-1171, 1423

Boe, Reidulv OP-413

Bogatikov, O. A. OP-91

Bogdanov, Y. OP-2004

Bogino, V. OP-1265

Bohannon, R. G. OF 92-0554 GQ-1714; OP-92, 1172, 1971

Bohlen, S. R. OP-25, 132, 480, $635,770,1173,1355,1450$, 1709

Bohlke, J. K. OP-1174, 1175

Böhlke, J. S. OP-1176

Bohm, R. A. OF 93-0291

Bohman, L. R. WRI 92-4040

Bohn, Diedra C 1091

Bohor, B. F. OF 92-0391; OP$93,794,1177,1178,1179$. $1180,1181,1182,1414$, 1702,1792

Bohr, J. R. W 2400

Bohrson, W. A. OP-164

Bol, A. J. · OP-94

Bolef, L. OP-1437, 1438

Bolin, R. C. P 1553-B

Bolke, E. L. WRI 91-4087

Bollinger, G. A. B 2017

Bolmer, S. T. OP-361
Bolton, Harvey, Jr. OP-1426

Bolton, P. A. P 1553-B; OP-677

Bonamassa, Ornella OP-1183

Bond, G. C. OF 92-0594

Bond, K. R. OF 93-0508-A, 930508-B, 93-0573-B

Bond, W. D. OF 93-0235

Bone, Yvonne OP-1136

Bonet, Andreu B 2039

Bonham, H. F., Jr. OP-342

Boni, Maria OP-243

Bonilla, M. G. P 1240-B; OP1154

Boning, C. W. YR

Bonito, M. V. YR

Bookstrom, A. A. OP-95, 1050

Boore, D. M. OF 93-0509; OP496, 497

Booth, D. B. I-1963

Booth, J. S. B 2002; OF $92-$ 0719; OP-96

Borcherdt, R. D. OF 93-0216; OP-1184

Borden, J. C. OF 92-0708-A, 92-0708-B

Bornhorst, T. J. B 1904-P

Bortoluzzi, Giovanni OP-1682

Bossiroy, D. OP-1950

Bossong, C. R. WRI 91-4121

Bostick, N. H. OP-984, 1382

Botbol, J. M. OF 92-0559

Bothner, M. H. DDS-0003; OP$47,1185,1598$

Botinelly, Theodore OP-115, 624

Bottazzi, Piero OP-414

Boulègue, J. J. OP-243

Boulin, Jean OP-197

Bourgois, Jacques OP-1330, 1901

Bourque, L. B. P 1553-B

Bouse, R. M. OP-554, 1086, 2005, 2014

Bow, C. S. I-2232

Bowell, J. A. OP-610

Bowers, T. S. OP-869

Bowers, W. E. C-0144

Bowes, D. R. OP-685, 705

Bowman, J. R. B 2032-A, 2032B; OP-521

Bowman, P. R. OF 92-0500

Bown, P. R. OP-361

Bown, T. M. OF 92-0391; OP$97,98,556,1198,1453$

Box, S. E. OF 92-0020-G; MF2226-A, 2228; OP-1186, 1187

Boyce, A. J. OP-1541

Boyce, J. M. OP-887

Boyd, D. W. OP-354

Boyd, J. OP-1188

Boyd, Ron OF 92-0530

Boyd, T. M. : OP-1189

Boyer, L. L. OF 93-0418

Boyle, M. E. OF 93-0242

Boyle, R. E. OF 93-0071

Brabb, E. E. OF 93-0271; OP1190

Brabets, T. P. WRI 92-4132; OF 93-0162

Bracchi, K. A. OP-1413 
Bracken, R. E. B 2039

Bradbury, J.P. C. 1086; OF 93 0212; OP-20, 21, 99, 100, $101,668,739,878$

Bradfield, A. D. WRI $92-4018$

Bradley, D. C. B 2039; OF 930325; OP-1410

Bradley, L. A. OF 92-0315, 92 0379-A, 92-0379-B, 92-0380A, 92-0380-B

Bradley, Lee-Ann MF-2218

Bradner, L. A. OF 92-0466, 930050

Bradt, R. C. B 2013

Brady, A. G. DDS-0007; OP102

Bragg, L. J. OF 92-0682

Brahana, J. V. OF 93-0150; OP1191,1192

Braile, L. W. OP-2, 521

Bralower, T. J. OP-1193

Branson, M. D. OP-577

Brass, G. W. OP-587, 819, 820, $821,822,823,824,825$

Braud, DeWitt, Jr. OF 93-0210

Bredehoeft, J. D. OP-103, 553 , 1025

Breed, C. S. C 1086; OP-314, 847,976

Breen, K. J. WRI 91-4024

Breger, I. A. OP-410

Breit, G. N. OP-104, 891

Brenton, R. W. OF 92-0480

Brereton, N. R. OP-361

Brew, D. A. OF 92-0596, 92 0724; OP-105, 106, 845, 1194, 1195, 1396

Brew, D. C. OP-1399

Brewer, L. R. OF 92-0575, 930191

Brewster, Michael OP-369

Breyer, J. A. OP-653

Briar, D. W. WRI 92-4162,924163; OF 93-0064

Bricker, O. P. OF 92-0168, 92 0649; OP-3, 1610, 1824

Bridges, N. T. OP-107, 1485

Briggs, P. H. OF 92-0384, 930281, 93-0303; OP-788, 1011, 1051

Briggs, W. M., Jr. OP-223

Briqueu, Louis OP-186, 187, $188,189,190,191,192,193$ $194,195,196$

Briskey, J. A., Jr. OP-654, 1679

Broadhead, R. F. B 1909

Brocher, T. M. OF 93-0238, 930276, 93-0318; OP-108, 759 , 1384

Brockman, A. R. WRI 924090, 92-4111; OP-1196

Bromley, Allan C 1086

Brooks, G. R. OF 92-0530; OP1510

Brooks, H. C. OP-1197, 1381

Brooks, J. OP-1300

Brooks, M. G. OP-331

Brooks, S. J. $\quad$ B 2013

Brooks, W. E. B 2039; MF2242; OP-999

Brookshire, D. S. C 1111

Broshears, R. E. WRI 92-4081; OP-538, 1579
Brouwers, E. M. B 2036 OF 92-0391, 92-0517; OP $109,110,223,837,1198$, 1453

Brouxel, Marc OP-1199

Brower, S. D. OP-901

Brown, Anton OP-1560

Brown, B. A. OF 92-0514

Brown, C. E. OP-111, 1200

Brown, C. L. OF 92-0456, $92-$ 0566, 93-0185; I-2279-A, 2279-B; MF-2209

Brown, F. H. OP-656

Brown, F. M. OF 93-0215

Brown, F. W. B 1770

Brown, G. A. WRI 90-4151; OP-350

Brown, J. L. B 1917-L, 2000E; OP-395, 1744, 1745

Brown, K. M. OP-586

Brown, Laurie OP-279

Brown, M. J. WRI 90-4131

Brown, N.E. OP-112

Brown, Nicholas DDS-0007

Brown, P. A. OP-1645

Brown, P. E. OP-224

Brown, R. D. OP-113

Brown, R. H. OP-1583, 1593

Brown, S. R. OP-1201

Brown, W. M. OP-114

Brown, W. O. W 2400

Browne, Q. J. OP-627

Brownfield, I. K. OF 92-0386

Brownfield, M. E. OF 92-0391; OP-115

Broxton, D.E. OP-313

Brozena, J. M. OP-81

Bruce, Scott OP-791

Bruggman, P. E. OF 93-0314

Brumbaugh, D. S. OP-438

Brune, J. N. OP-438

Brunett, J. O. OF 91-0458

Brunner, C. A. OP-243

Bruns, T. R. B 2034-A; OP413,1384

Brunstein, F. C. OF 93-0250

Bryan, B. A. OP-1084

Bryan, C. J. OP-116

Bryan, J. G. OP-268

Bryan, K. A. OP-1413

Bryan, W. B. OP-413

Bryant, B. H. I-2198; OP-117, 118,828

Bryant, Karen OF 93-0208-A, 93-0208-B

Bryant, W. A. DDS-0006; OP1757

Buchanan, Robert B 2013

Buchanan-Banks, J. M. I-2274

Buchmiller, R. C. OF 91-0458

Buck, B. W. B 2013

Bucknam, R. C. OP-119, 120

Budahn, J. R. OP-730

Budd, D. A. OP-515

Buden, R. V. OP-1238

Buell, G. R. W 2400

Bufe, C. G. OP-121, 415

Buffler, R. T. OP-361

Bukry, D. J. C 1086
Bukry, David OF 93-0177, 930182

Buland, R.P. C 1031

Bull, K. F. OP-123

Bullen, T. D. OF 93-0055; OP$122,1065,1202,1572$

Bullock, J. H., Jr. OF 92-0708A, 92-0708-B

Bultman, M. W. OF 93-0023

Bundtzen, T. K. OF 93-0339; OP-123, 1203

Burba, G. A. OP-1149

Burbey, T. J. WRI 92-4051

Burchfiel, B. C. OP-124

Burden, C. B. W 2400; WRI 91 4117; OP-424

Burger, P. A. OP-775

Burkart, M. R. OF 93-0114; OP-816, 1600

Burkhardt, D. J. OF 91-0493

Burneth, W. C. OP-59

Burnham, A. K. OP-984

Burns, L. E. OF 92-0020-E

Burns, M. G. OP-267

Burns, R. B. WRI 92-4138

Burns, R. J. WRI 92-4150; OP899

Burns, S. J. OP-1127

Burr, G. OP-808

Burruss, R. C. OF 92-0391, 920524; OP-725, 1072, 1204 , 1350,1782

Burt, R. A. W 2392

Burton, D. L. YR

Burton, W. C. OF 92-0716, 930244; MF-2224; OP-1106, 1612

Bus, P. S. OF 92-0514

Busby, J. F. WRI 91-4149, 914150, 91-4151, 91-4152, 92 4102, 92-4103, 92-4104, 92-4105

Busenberg, Eurybiades YR: WRI 93-4054; OP-572 $1174,1415,1787$

Bush, D. M. OF 92-0717; OP1835, 1863

Bush, W. V. I-1420 (NJ-15); MF-1994-D; SGM

Butler, W. C. OF 93-0012, 930248

Butman, Bradford OP-932

Butner, D. E. OF 92-0482

Buttleman, Cindy OF 92-0514

Buxton, H. T. OF 92-0637

Buzan, David W 2400

Byalobzhesky, S. G. OF 930339

Bybell, L. M. OP-1205, 1272

Byerlee, J. D. OP-125, 126, $127,601,602,688,689,702$

Byington, C. B. P 1537

Byrnes, A.P. OP-1206

Byrnes, M. R. OF 92-0530

\section{C}

Cabri, L. J. OP-1313

Caccavo, F., Jr. OP-120

Cacchione, D. A. I-2090-A, 2090-B; OP-128, 129

Caddey, S. W. P 1537
Caffee, M. W. OP-48, 1750

Cahoon, D. R. OF 92-0530

Cai, Jinkui OP-1801

Cain, D. J. OF 92-0456; OP-335

Caine, Nel OP-1324

Calder, J. H. OP-1672

Caldwell, W. S. WRI 92-4097, 92-4129

California Institute of Technology, Jet

Propulsion Laboratory OF 910014

Calk, L. C. OP-1313

Callender, E. C. OP-130, 1208, 1334

Calvin, W. M. OP-1153, 1209 , 1210,1583

Cameron, C. C. I-2364-B; OP131,1211

Cameron, K. L. OP-132

Campbell, B. G. WRI 92-4000

Campbell, D. B. OF 93-0516; OP-786

Campbell, D.H. C 1086; OF 92-0628, 92-0645; OP133

Campbell, D. L. OF 92-0557

Campbell, I. H. OP-134

Campbell, J. F. B 2002

Campbell, J. L. OP-233

Campbell, K. W. OP-1184

Campbell, L. J. OF 93-0102

Campbell, R. H. C 1111; OF 930206, 93-0525

Campbell, W.H. OP-135, 136

Campbell, W. J. C 1086

Campodonico, Al OF 93-0086

Campos, C. OP-1628

Canada Centre for Remote Sensing SM

Candela, L. OP-1449

Candiotti de Los Rios, H. OP1212

Cannon, S. H. OF 93-0213

Cannon, W. F. OP-13, 137. $138,139,728,1213,1214$, $1215,1216,1440,1533$, $1534,1747,2019$

Cantiller, R. R. W 2340

Canuel, E. A. OF 93-0146; OP1684

Capuano, R. M. OP-869

Carey, W. P. W 2340

Carlo, Milton OF 92-0717; OP1863

Carison, J. E. OP-973

Carlson, P. R. B 2002; OF 920706, 93-0266; OP-140, 564, 1298,1801

Carlson, R. R. OF 92-0509-A 92-0509-B, 93-0207

Carlson, R. W. OP-1217, 1621

Carlson-Foscz, V. L. OP-1218

Carmichael, J. K. WRI 914190; OF 92-0166

Carneggie, D. M. C 1086

Carothers, W. W. OF 92-0707

Carpenter, Catherine DDS-0007

Carpenter, J.R. OP-1219

Carpenter, M. C. P 0497-H; OF 93-0071, 93-0210; OP1220

Carr, C. E. B 1981 
Carr, M. D. B 2015; OF 920391; OP-108

Carr, M. H. OP-141, 142, 1221, $1222,1223,1224,1266$, $1437,1438,1487$

Carr, M. R. OF 91-0458

Carrara, P. E. OP-143

Carroll, R.D. OF 93-0187

Carson, S. E. OF 92-0446

Carter, Claire OF 93-0199; OP56

Carter, J. L. OP-1229

Carter, L. D. C 1086; OP-163 515,1225

Carter, L. M. B 1904-L, 1904 P, 1904-Q, 1904-S

Carter, M.D. OP-1226

Cartier, K. D. OP-1227

Carver, D. L. OF 93-0219; OP1300,1582

Carver, G. A. OP-144, 752, 1259

Casadevall, T. J. B 1966

Case, J. E. B 2035

Casey, G. D. OF 92-0489; OP1228

Casey, J. F, OP-1410

Cashion, W. B. MF-2250

Cashman, K. V. OP-631

Casson, R. N. WRI 88-4127

Cast, M.E. OP-104, 1229

Castillo, D. A. OP-145, 146 361

Castillo, P. R. OP-1230

Castor, S. B. B 2013; OP-809

Castro, R. OP-438

Catchings, R. D. OF 92-0570

Cathcart, J. D. OF 93-0153, 930303

Cathrall, J. B. OF 92-0552, 920573-A, 92-0573-B; MF2217-A, 2217-B; OP-1006

Caulet, J. P. OP-1330

Cauller, S. J. OF 91-0180

Cayan, D. R. C 1086; OP-256

Cecil, C. B. OP-1231, 1232, $1233,1234,1345,1356$, 1603,1743

Cecil, L. D. OP-147

Celebi, Mehmet OF 90-0677, 93-0181; OP-1092

Celia, M. A. OP-431

Cepak, Michael OF 92-0514

Cerling, T. E. OP-656

Cervantes, M. A. WRI 914151, 92-4102, 92-4104

Chabernaud, Thierry OP-186, $187,188,189,190,191,192$, $193,194,195,196$

Chadima, Sarah OF 92-0514

Chadwick, D. J. OP-148, 887, $1235,1236,1854,1936$

Chadwick, W. W., Jr MF-2231, 2233

Chaffee, M. A. OF 92-0509-A, 92-0509-B

Chafin, D. T. WRI 93-4007

Chalokwu, C. I. OP-1237

Chamberlain, K. R. OP-149

Chamley, Hervé OP-1330

Champion, D. E. OF 93-0327; OP-632, 633, 845, 1302
Chandio, A. H. OF 92-0281, 920576, 93-0256

Chandler, V. W. OF 92-0514

Chang, A.T. C 1086

Chang, H. H. OP-150

Chanton, J. P. OP-151

Chao, E. C. B 2050; OP-152, 153,1238

Chapelle, F. H. OP-154, 1239

Chapman, C. R. OP-1437, 1438,1487

Chapman, M. G. OF 93-0516; OP-906, 987, 1240, 1241 1242

Chapman, M. J. WRI 91-4178, 93-4038; OP-155

Chapman, R. H. OF 93-0217A, 93-0217-B

Chapman, R. M. OF 92-0562

Chapman, W. F. I-1420 (NK18), 1420 (NL-18)

Chappell, G. B. OP-156

Chaproniere, G. C. OP-413

Charles, R. W. OP-51, 1243

Charpentier, R. R. B 1909; OP$1014,1244,1245$

Charvet, Jacques OP-1628

Chase, E. B. W 2400

Chase, T. E. B 2002; I-2089-C, 2090-C, 2091-C

Chatman, M. L. B 1737-E

Chauvel, Catherine OP-1086

Chavez, P. S., Jr. OP-1617

Chen Jianyu OP-1262

Chen Keqiao OP-64

Chen Nansheng OP-363

Chen Zuyi OP-317

Chen, A. H. W 2400

Chen, Cheng-lung W 2340; OP157,1655

Chesley, J. T. OF 92-0525; OP158, 1246

Chesnut, D. R., Jr. OF 92-0558

Chezar, Henry OF 92-0537, 930257

Chiarabba, C. - OP-1374

Childs, J. R. OF 92-0556

Chin, J. L. I-1943

Chmura, G. L. OP-653

Choquette, A.F. OP-514

Chou, I-Ming OP-57, 58, 696, $914,924,1247,1248,1311$, $1726,1773,1877,1919$

Chouet, B. A. OP-1249, 1250 $1325,1420,1802,1998$

Christensen, J. E. B 2013

Christensen, N. I. OP-461

Christensen, P. K. WRI 92 $4162,92-4163$

Christenson, G. E. P 1519

Christenson, S. C. OF 92-0641; OP-1251

Christian, E. J. C 1086; YR: OF 93-0251

Christiansen, A. C. I-1420 (NH14), $1420(\mathrm{NJ}-14)$

Christiansen, Grey. C 0930-N

Christiansen, R. L. OP-159

Christie, D. M. OP-432

Christie, J. H. OF 92-0392

Christophersen, Nils OP-160, 161,1515

Chung, C. F. OP-162
Chung, R. M. OP-415

Church, S. E. OP-375, 570, 1418

Churcher, C. S. OP-163

Chure, D. J. OP-1252

Cichon, H. A. OF 92-0530

Cieutat, B. A. B 2003

Circé, R. C. OF 92-0530

Cisternas, M. E. OP-1107

Clague, D. A. MF-2231; OP164,446

Clardy, B. F。 SGM

Clark, A.E. OP-165

Clark, A. H. OP-1601

Clark, B. E. OP-1830

Clark, C. W. OP.489

Clark, D. E. W 2400

Clark, D. H. OP-1253, 1254

Clark, D. W. WRI 92-4116; OF 93-0064; OP-166

Clark, David OP-1550

Clark, Douglas $B 2013$

Clark, G. M. WRI 92-4067; OF 92-0122; OP-167

Clark, J. R. OF 92-0721; OP168,169

Clark, M. L. W 2400

Clark, M. M. OP-445, 1253, 1254

Clark, M. S. OP-1255

Clark, P. U. OP-1256

Clark, R. G. OP-1608

Clark, R. N. B 2039; OP-1583

Clark, S. H. B 1979, 2005; OP170, 1257

Clarke, J. S. OP-171, 172, 173

Clarke, J. W. MF-2215-A; OP1258

Clarke, R. T. OP-174

Clarke, S. H., Jr. OP-1259, 1442, 1749

Claypool, G. E. B 1909

Clayton, J. L. OF 92-0391; OP$1103,1233,1260,1261$, $1262,1263,1264,1265,1911$

Clayton, R. N. OP-1666

Clendenin, C. W. OP-1336

Cleveland, J. M. OP-175

Clifford, S. M. OP-1266, 1937

Clift, Peter OP-413

Clifton, H.E. I-1943

Cline, D. R. WRI 90-4085; OP184

Cline, J. S. OP-45

Cloem, J. E. OF 93-0146

Closs, L. G. OP-427, 428, 1267

Clough, J. G. OP-1268

Clow, D. A. OF 92-0645

Clow, G. D. C 1086; OP-176, 1269,1270

Cluff, R. M. B 1909

Clutson, F. G. OP-1329

Clynne, M. A. OP-1271, 1447

Coates, A. G. OP-1272

Coates, D. A. OF 92-0391; C0142; OP-1273

Cobb, J. C. OP-1226

Cobb, R. H. WRI 91-4116

Cobban, W. A. P 1533; B 1787Q; OP-177, 178, 475, 525, $526,527,528,529,1757$
Cocco, Massimo OP-179, 1274,1275

Cochrane, G. R. OF 92-0556

Coe, J. A. OF 92-0391, 930299; OP-1276

Coe, R. S. OP-94

Coen, A. W., III OF 92-0120

Coffin, J. E. WRI 91-4115

Coffman, J. L. P 1527

Cohen, D. A. OP-923

Cohen, Philip OP-180, 181. 1277

Cohn, T. A. OF 93-0056, 930123; OP-1278

Coker, J. E. OP-1279

Colberg, M. R. OP-1237

Colburn, Helen OF 93-0330

Cole, A. T. OP- 1280

Cole, J. C. OF 93-0299

Cole, J. E. OP-925

Cole, R. B. OP-1281

Coleman, D. F. OF 93-0007

Coleman, D.S. OP-182, 1282

Coleman, J. M. B 2002

Coleman, M. L. OP-183

Coles, D. G. OP-51

Collar, P.D. C 1086; OF 92 0150; OP-1283, 1960

Collerson, K. D. OP-132

Collett, T. S. C 1086; OF 920381; OP-1284, 1285.

Collins, C. A. WRI 90-4085; OP-184

Collins, D. S. OF 93-0291

Collins, George OP-173

Collins, J. J. OP-297

Collins, L. C. OP-1272

Collins, M. G. OP-186, 187, $188,189,190,191,192,193$, $194,195,196$

Collister, James OF 92-0391

Collombat, Hélène OP-586

Collot, Jean-Yves OP-185, 186, $187,188,189,190,191,192$, $193,194,195,196,197,368$, 1286, 1287, 1908

Colman, S. M. C 1086; OP198, 199, 200, 201, 439, 748, $749,1288,1289,1290,1291$, $1492,2003,2004$

Colton, G. W. MF-1994-D

Coltorti, Massimo OP-186, $187,188,189,190,191,192$, $193,194,195,196$

Colucci, S. J. B 1981

Columba C., Marwin OP-202

Combes, M. OP-1163

Combs, L. J. HA-0722-I

Comer, V. J. OP-1292

Compton, J. S. OP-361

Concha, J. F. OP-1369

Condie, K. C. OP-203

Condit, C. D. OF 93-0526

Condon, S. M. B 1808-O

Congdon, R. D. OP-1293, 1294,1672

Conklin, N. M. B 1770

Conkwright, R. OP-439

Conlan, L. M. OP-1619

Conlon, T. D. WRI 92-4077

Connery, N. R. OF 92-0514 
Connor, B. F. OP-1685

Connor, J. J. MF-2234; OP-715

Conrad, G. E. B 2013

Conrad, J. E. B 2039; OF $92-$ 0525, 93-0519; OP-204, 205, 662, 1238

Console, Rodolfo OP-206

Constantz, J. E. OP-207

Conway, C. M. B 1737-E; OP203

Cook, C. A. DDS-0015; OF 920691, 93-0231

Cook, H. E. B 2034-A; OF 930248; OP-208, 1295

Cookro, T. M. B 2035, 2039; OF 93-0249; OP-1296

Cooley, R. L. TWI 03-B4; OP209, 210

Cooper, A. K. OF 92-0556; OP$65,211,1358,1630$

Cope, C. M. OF 92-0028

Coplen, T. B. C 1086

Coplin, L. S. OF 93-0086

Coradini, A. OP-1163

Cordell, L. E. OF 92-0557; OP212, 1297

Corell, Robert C 1086

Corey, R. M. OF 92-0157

Corl, P. A. OP-847

Corro, P. F. OF 91-0014

Cortesini, Henry, Jr. OF $92-$ 0701

Cortini, Massimo OP-213

Cosca, M. A. OP-214

Costa, J. E. W 2340; OF 92 0483

Costard, F. M. OP-1565

Coston, J. A. OP-151, 215

Coté, T. OP-1525

Cotton, M. L. OF 92-0539-C, 92-0539-D

Coulon, Christian OP-1628

Coulter, H. W. B 2002

Councell, T. B. OP-879

Coupe, R. H. W 2340, 2400; OF 93-0418

Coury, A. B. OF 92-0391

Covay, K. J. OP-216

Coveney, R. M., Jr. OP-363, 1432

Covington, H. R. OP-561

Cowan, Brian OP-415

Cowan, E. A. OF 92-0706; OP1298, 1801

Cowan, W. D. I-1420 (NK-18)

Cowing, D. J. W 2400

Cox, B. F. OF $92-0446$

Cox, D. P. B 2039; OF 92 0567, 92-0578; MF-2242; OP-217, 218, 456

Cox, L. J. B 2042-C

Cox, S. E. WRI 93-4060

Cozzarelli, I. M. OP-44, 219

Craddock, R. A. I-2209

Craigg, S. D. OP-1299, 1947

Cranston, R. E. OP-1412

Cranswick, Edward OF 930216; OP-220, 221, 1300, 1423,1582

Cravotta, C. A., III OF 930115; OP-1301
Crawford, C. G. W 2393: WRI 92-4019; OP-1836

Crawford, J. K. OF 92-0494, 92-0644; OP-1827

Crawforth, J. E. YR

Cressman, E. R. P 1524; I-2267

Criddle, A. J. OP-64

Criley, E. E. OF 92-0723; OP521

Crisp, David OP-1153

Criss, R. E. OP-1302, 1559

Crock, J. G. B 1770; OF 930014, 93-0303

Crockett, R. N. C 0930-M

Crompton, E. J. OF 90-0153

Cromwell, R. E. WRI 92-4012

Cron, E. D. B 1981

Crone, A. J. B 2032-A, 2032-B

Cronin, T. M. C 1086; OP-110, $222,223,270,1075,1272$, $1303,1949,2002$

Cross, A. T. OP-1672

Cross, S. L. OP-1127

Crosson, W. L. OP-946

Crovelli, R. A. OF 92-0391, $92-$ 0524, 92-0679

Crowe, D. E. OP-224, 1304

Crowley, J. K. OP-225, 226, 227

Crowley, S. S. OP-228, 1305

Crown, D. A. 1-2209

Crozaz, Ghislaine OP-1392

Cruickshank, M. J. OP-229

Cruikshank, D. P. OP-1163

Cruikshank, K. M. OF 93-0348

Cruz, R. R. OP-230

Crysdale, B. L. OF 92-0391

Csallany, S. C. OP-692

Csaszar, Geza OP-1687

Csejtey, Bela, Jr. P 1497-C

Cuffney, T. F. OF 93-0104

Culbertson, C. W. OP-1713, 1766

Cummings, M. OP-1197

Cunningham, C. G. OP-202, $231,875,1306,1633$

Cunningham, K. I. OF 920391; OP-268, 1629

Curren, M. G. OP-1307

Curry, B. B. OP-1308, 1309

Curtin, G. C. MF-1996-E; OP-6

Curtin, S. E. OF 92-0459, 92 $0460,92-0461,92-0462,92$ 0463, 92-0464

Curtiss, D. A. WRI 92-4136

Curwick, P. B. OF 92-0492

Cushman, R. A., Jr. OF 92-0391

Custodio, Emilio OP-1310, 1449

Cvetkovic, V. D. OP-232, 236

Cygan, G. L. OP-1248, 1311, 1312

Cymerman, Zbignew OP-967, 1916, 1917

Czamanske, G. K. OP-30, 134, $233,275,414,490,1086$, $1087,1313,2014$

Czarnecki, J. B. OF 91-0478; OP-234, 235
D

D'Agostino, J. P. MF-2215-A

d'Angelo, W. L. OP-1312

d'Arcy, K. OP-2017

Da Conceicao, S. C. OP-666

Daag, A. S. WRI 92-4039

Daddow, P. B. WRI 90-4154

Dadisman, S. V. OF 92-0206; OP-639

Dagan, Gedeon OP-232, 236

Dahl, A. R. OP-441

Dahlem, D. H. OP-51

Daines, M. J. OP-1216

Dalrymple, G. B. B 2065; OP237, 617, 920, 1097, 1314, $1315,1841,1956$

Daly, J. S. OP-1316

Dalziel, W. D. OP-1317, 1446

Damaske, D. OP-65

Damuth, J.E. OP-238

Danforth, W. W. B 2002; OF 92-07 17; OP-1863

Daniel, C. C., III OP-239, 240, 403

Daniel, J. OP-197

Daniels, E. J. OF 92-0568

Danielson, G. E. OP-1217

Danielson, Joanne OP-934

Danskin, W. R. W 2340

Daroca, J. A. OP-2027

Dart, R. L. OF 92-0685, 930338; OP-1318, 1652

Dartnell, Peter OP-241

Dash, R. G. WRI 91-4095

Davenport, M. S. W 2400; OF 93-0035, 93-0163

David, N. L. OF 93-0190

Davidson, J. P. OP-279

Davies, J. N. OP-1802

Davies, M. E. OP-1437, 1438, 1487,1974

Davis, A. S. OP-242

Davis, D. W. OF 92-0530

Davis, E. E. OP-243

Davis, G. S. W 2391

Davis, J. A. OP-16, 215, 244, $245,335,336,530,1058$ $1319,1574,1810,1811$, $1985,1986,1987$

Davis, J. F. W 2400

Davis, J. V. W 2400

Davis, L. E. OP-1320

Davis, M. J. OP-1112, 1376

Davis, P. A. OF 93-0516; OP$1321,1322,1323,1722$

Davis, P. M. OP-2, 521

Davis, P. T. OP-1324

Davis, S. D. OP-438

Daws, T. A. OF 92-0391, 930186; OP-1265

Dawson, D. D. OP-246, 887

Dawson, P. B. OP-1325, 1536

Day, S. M. OP-405

Day, W. C. B 1904-S, 1989-D, 1989-E, 2039; OP-247, 1051, $1297,1326,1327,1394,1885$

De Cola, Lee C 1086; OP-1328

De Conto, R. OP-1484

De Jong, E. OP-857 de Lumley, Henry OP-310

de Moraes, Fernando OP-1329

de Roche, J. T. WRI 93-4047

De Wever, Patrick OP-1330, 1901

de Witt, Wallace, Jr. B 1839-I,J, 1909

Dean, W. E. C 1086; OF 920391, 92-0397, 93-0212; OP$20,21,99,100,248,249$. $250,251,668,739,1115$ 1331, 1332

DeAngelis, R. H. OP-1333

Dearmont, L. H. OP-196

Debusschere, Karolien OF 92 0530

Decker, J. L. OP-1568

Deike, R. G. OP-1208, 1334, 1960

Delaney, P. T. OF 92-0686, 930512-A; OP-252

Delin, G. N. P 1530-A; OF 930042, 93-0043, 93-0079

DeLong, L. L. WRI 92-4123

DeLorey, C. M. OF 92-0717; OP-1863

Delorme, L. D. OP-943

Demartin, M. OP-521

Demas, C. R. OF 92-0492; OP935

Dembroff, G. R. OF 93-0233

Demcheck, D. K. OF 92-0492

Deming, David OP-253

Dengler, L. A. OP-752

Denlinger, R. P. OP-254, 814, 815

Denne, J. E. I-1420 (NJ-14), 1420 (NJ-15)

Dennehy, K. F. OF 93-0106

Dennen, K. O. OP-1887

Denner, J. C. W 2400

Densmore, J. N. OF 93-0083; OP-255

Denson, N. M. I-2343-A, 2343B, 2380-A, 2380-B

Denver, J. M. OF 93-0040; OP$1174,1458,1876$

dePolo, D. M. OP-438

Dersch, J. S. B 2035, 2039

Desborough, G. A. B 2039. OF 92-0614, 93-0321; OP-64

Detra, D. E. OF 92-0552; OP624

Detra, P. S. B 2039

Detterman, R. L. I-2032

Dettinger, M. D. C 1086; OP256

Dever, G. R., Jr. OF 92-0514

Deverel, S. J. WRI 91-4119

deVries, M.P. OP-1335

Dewitt, David OP-1568

DeWitt, Ed OP-10

DeWolf, C. P. OF 92-0525

di Giovambattista, R. OP-206

Diáz, Leonardo OP-1107

Dibblee, T. W., Jr. OP-257

Dickinson, K. A. OF 92-0592, 93-0292-J; OP-379

Dickson, F. W. OP-572

Didenko, A. N. OP-586

Didyk, B. M. OP-586

Diehl, S. F. OP-1336, 1417, 1418 
Diehl, T. H. WRI 92-4082

Dietel, C. M. OF 93-0216

Dieterich, J. H. OP-258, 259

Dieterich-Rurup, K. V. OP-101

Diggles, M. F. OP-260

Digiacomo-Cohen, Mary OP1650

Dill, R. F. OP-928

Dilles, J. H. OP-1637

Dillon, W. P. B 2002; MF-2083B, 2211; OP-1337, 1931, 1932

Dindi, E. OP-521

Dine, J. R. OP-261

Diner, Richard OP-755

Dingler, J. R. OP-262

Dinicola, R.S. OP-1017

Dipietro, J. A. OP-1637

Dishart, J. E. OP-1899

Dixon, G. L. OF 93-0263

Dixon, M. OP-1820

Dockery, D. T., III OP-746

Dodd, K. A. YR; OF 93-0575

Dodge, D. A. OF 92-0441

Dodge, R. E. OP-1930

Doe, B. R. B 2039; OF $92-$ 0525; OP-2027

Doe, T. C. OP-441

Dohm, J. M. OP-906, 1338, 1938

Dohrenwend, J. C. OP-1339

Dolan, Robert P 1177-B OF 92-0377-A, 92-0377-B

Dolton, G. L. OF 92-0524, 92 0696, 93-0337; OP-449, 1265,1350

Domack, E. W. OP-263

Domagalski, J. L. OP-264

Dominic, D. F. OF 92-0558

Donato, M. M. OF 92-0695; OP-1340, 1451

Donnelly-Nolan, J. M. OP-265, 266, 267

Donovan, T. J. OP-268

Donovan-Ealy, P. F. OP-1341

Doonan, G. A. OP-311, 312

Doose, L. OP-1437, 1438

Dorais, M. J. OP-1079

Dorava, J. M. OF 93-0094; OP1699

Dorrzapf, A. F., Jr. B 1770

Doughten, M. W. OF 93-0001A, 93-0001-B, 93-0001-C; OP-1656

Douglass, Katrin OF 93-0227

Doukas, M. P. B 1966; OP1342, 1739

Doulgeris, Anthony OP-446

Dover, J. H. I-2168

Downey, J. S. OP-269, 774, 1009, 1775

Downie, E. A. B 1955

Dowsett, H. J. B 2030; C 1086; OF 92-0413, 92-0414, 92 0418; OP-222, 270, 271 , $1272,1535,1949$

Doyle, E. O. P 1497-C

Drake, A. A., Jr. GQ-1707; OP$1152,1479,1517$

Drake, D. E. I-2090-A, 2090-B; OP-128, 129

Drake, R. E. OP-279
Dreger, D. S. OP-504

Dresler, P. V. YR

Drew, L. J. OP-106, 272, 273, $274,1238,1343$

Drewes, H.D. I-2287

Drinkwater, J. L. OF 92-0724; OP-275

Driscoll, G. R. MF-2083-B

Drost, B. W. WRI 93-4060

du Bray, E. A. B 2021-C, 2052; OF 93-0207; MF-2253

Du, Xiaotao OP-587

Du, Yijun OP-913, 1872

Du, Yue OP-1344

Dubiel, R. F. B 2000-E; OF 930292-H, 93-0292-I; OP-379

Dubrovsky, N. M. OP-264

Duckworth, R. C. OP-243

Duddy, I. R. OP-1136

Dudley, Dan W 2400

Duell, L. F., Jr. OF 92-0655; OP-276

Duer, A. D. OP-1531

Duffield, W. A. OP-277, 278

Duffy, C. J. OP-305

Dugas, D. L. OF 93-0115

Duggar, J. B. OP-1300

Duke, S. K. OF 92-0527

Dulong, F. T. OP-1232, 1234, 1345,1382

Dumitrica, P. OP-1330

Dumouchelle, D. H. WRI 91 4024, 92-4072, 93-4047

Dumoulin, J. A. OP-361, 554

Dunbar, R. W. OP-518

Duncan, R. A. OP-1346

Duncker, J. J. OF 92-0485

Dungan, M. A. OP-279

Dunkle, S. A. OP-1174

Dunn, D. D. OP-280

Dunn, J. R. OF 92-0514

Dupre, W. R. OP-1347

Durbin, T. J. W 2340

Durham, W. B. OP-281, 282, 1348, 1586

Dusel-Bacon, Cynthia P 1497C; OP-1349

Dutro, J. T., Jr. OP-283, 422

Duval, D. M. OP-148

Duval, J. S. DDS-0009; OF 920391; OP-1041, 1813

Duval, T.S. P 1553-B

Duwelius, R. F. WRI 92-4025; OF 92-0055

Dvorak, J. J. OP-284, 1001

Dwyer, J. L. I-2050-F

Dyer, Russ I-2287

Dyman, T. S. OF 92-0391, $92-$ 0524, 93-0335, 93-0337; OP$1320,1350,1351,1798$

Dyni, J. R. OP-1599

Dziewonski, A. M. OP-501

Dzurisin, Daniel B 1966; OP1362,2024

\section{$\mathbf{E}$}

Earle, J. D. OF 92-0485

Early, C. OP-1300

Eastoe, C. J. OP-605
Easton, R. M. OP-285

Eaton, J. P. OF 92-0441, 930295; OP-752

Ebbert, J. C. WRI 93-4060

Eberhart-Phillips, Donna OF 92-0570; OP-286, 699 . 931, 1729

Eberl, D. D. OP-89, 287, 288, $289,1352,1353$

Eberts, S. M. OP-1354

Eble, C. F. OF 92-0558; OP-778

Eckert, J. O., Jr. OP-1173, 1355

Eddy, J. A. C 1086

Eddy-Miller, C. A. WRI 914199

Edelen, G. W., Jr. P 1240-B

Edgar, N. T. MF-2083-B; OP$1232,1233,1356$

Edson, G. M. OP-290

Edwards, B. D. B 2002; I-2090A, 2090-B; OP-140, 579

Edwards, C. A. OF 92-0391; OP-1238, 1516

Edwards, D. D. OF 92-0156, 92-0643, 93-0102

Edwards, K. B. OP-1594

Edwards, Kathleen OP-1217, 1830

Edwards, L. E. GN; OP-285, $291,292,293,791$

Edwards, R. L. OF 92-0525; OP-294

Edwards, T. K. WRI 92-4136

Effendi, Ismet OP-993

Eganhouse, R. P. OP-629

Eggleston, C. M. OP-1508

Eggleston, J. R. OF 92-0568; OP-1357

Eichelberger, J. C. OP-1714

Eidel, J. J. OF 92-0514

Eidenshink, J. C. YR

Eiken, O. OP-1890

Einarsson, Thorleifur OP-1303

Eissen, J. P. OP-197

Eiswerth, B. A. OF 93-0016

Eittreim, S. L. OP-295, 1358

Ekstrom, Goran OP-1, 501, 1914

El-Shazly, A. K. OP-296

Elachi, Charles OP-1062

Elder, J. F. C 1086; OP-297

Elder, W.P. OP-755

Elders, W. A. OP-298

Eldridge, C. S. OP-1688

Elias, S. A. OP-299

Ell, M. J. W 2400

Ellen, S. D. OF 92-0521, 930213; OP-782

Ellersieck, Inyo OP-1739

Elliott, J. E. C 1088; OF 930207; I-2050-F; MF-2253

Elliott, J. G. OP-300

Elliott, W. C. OP-1359

Ellis, M. A. OP-1866, 1867

Ellis, M. S. C-0142

Ellis, W.L. OP-301

Ellorda, R. L. OP-1962

Ellsworth, W. L. P 1550-C; C 1031; OP-145, 302, 438 , 1280,1360

Elston, D. P. OP-1361
Embrey, S. S. W 2400; WRI 914073; OF 91-0453

Emerson, D. G. WRI 92-4110

Emery, D. A. OP-131

Emmett, W. W. P 0870-A

Emmi, P. C. P 1519

Emsbo, Poul OP-1509

Endo, E. T. B 1966; OP-1362

Endrikat, Jeanne OF 91-0014

Engdahl, E. R. OP-1019, 1020 $1189,1363,1364,1365$, $1783,1784,1969$

Engebretson, D. C. OP-1366

English, D. OP-859

Englund, K. J. OP-1367, 1368

Epstein, J. B. B 1839-L, 1994; OF 92-0525, 93-0024, 930025

Erard, S. OP-1163

Ercit, T. S. OP-849

Erd, R. C. OP-849, 1038

Erdman, J. A. OF 93-0017-A, 93-0017-B

Erem in, R. A. OF 93-0339

Ericksen, G. E. OP-1306, 1369

Erickson, J. C. OF 92-0537

Erickson, M. S. OF 93 0259-A, 93-0259-B

Erickson, R. L. MF-1994-D, 2125-E; OP-1238

Ericson, D. W. HA-0551

Erlich, O. OF 92-0721

Ernst, W. G. OP-1451

Erslev, E. A. OP-705

Ervin, C. P. OP-279

Esparza, L. E. OF 92-0514

Espinosa, A.F. OP-1370, 1371, 1372

Essaid, H. I. . WRI 91-4148; OP$303,304,430,629,897$

Essene, E. J. OP-25, 214, 305, 1709

Esterle, J. S. OP-1211

Ethington, R. L. OP-1819

Eurick, G. M. B 2013

Evaldi, R. D. WRI 92-4057, 924150; OF 92-0638

Evans, B. J. OP-433

Evans, H. B. OP-1329

Evans, H. T., Jr. OP-681, 1489

Evans, J. G. OP-1197, 1381

Evans, J. R. OF 92-0441; OP$44,557,1373,1374,1777$

Evans, K. V. MF-2234

Evans, S. R. OF 92-0586

Evans, T. J. OF 92-0514

Evans, W. C. OP-306, 533, $536,638,955,997,101$

Evarts, Peter OP-890

Evarts, R. C. GQ-1679

Evenden, G. I. I-2089-C, 2090C, 2091-C

Evernden, J. F. OF 92-0516

Ewart, Anthony OP-413

Ewert, J. W. B 1966; OP-2024

Exon, N.F. OP-307, 639

F

Fagan, Pat OF 92-0514 
Fairbanks, R. G. OP-925

Fairer, G. M. OF 92-0697, 920698, 93-0310, 93-0320; OP 308,309

Faires, L. M. OF 92-0634

Fairgrieve, G. L. YR

Fairley, H. C. OP-1375

Faleide, J. I. OP-1891

Falguères, Christophe OP-310

Fallick, A. E. OP-1541

Fallon, J. D. OF 93-0418

Falls, W. F. W 2400

Fanale, F. P. OP-1163, 1217, $1437,1438,1487$

Fang, Peng OP-90

Fanning, J. L. OP-311, 312

Fantel, R. J. OP-429

Farah, F. S. OF 92-0517

Farber, D. F. OP- 1112

Farber, D. L. OP-1376

Fariduddin, Mohammad OF 920281, 92-0576, 93-0255

Farmer, G. L. OF 92-0525; OP$313,515,1138,1377$

Farrand, W. R. I-1420 (NL-17)

Farrar, C. D. OP-954, 955

Farrar, Edward OP-1601

Farrar, J. W. OF 93-0032

Fassett, J. D. OP-1980

Fatmi, S. F. OF 92-0281, 93 0255, 93-0256

Faulkender, D. J. OP-1378

Faure, H. OP-314

Favali, P. OP-206

Fedorenko, V. A. OP-30, 134,

Fedorko, Nick, III OP-1226

Fedorov, E. N. OP-367

Fedosh, M. S. OP-1379

Fehlhaber, K. L. $\quad$ OP-1337

Fehn, Udo OP-147

Feigenson, M. D. OP-979

Feldman, S. B. OP-1380

Feldman, S. M. WRI 90-4182

Felger, T. J. OF 93-0211

Ferm, J. C. OP-1513

Fernandez, G. OP-335

Fernandez, Gabriel OP-677

Fernandez, J. F. OP-812

Fernandez, Mario OP-1040

Ferns, M. L. · OP-1197, 1381

Ferree, D. M. OF 92-0641

Ferrell, G. M. WRI 92-4073

Ferrigno, C. F. YR

Ferrigno, J. G. P 1386-E; C 1086

Ferry, J. M. OP-51

Fey, D. L. OF 90-0506, 920509-A, 92-0509-B, 92 0709, 92-0721, 93-0014 93-0243, 93-0303

Ficklin, W. H. OF 93-0243; OP$315,788,948$

Field, M. E. B 2002; 1-2090-A 2090-B

Field, R. T. OP-507, 729, 946

Field, S. J. WRI 90-4126

Fierstein, J. E. OP-316

Filby, R. H. OP-762

Filewicz, M. V. OF 92-0539-C, 92-0539-D
Filson, J. R. OF 93-0216

Finch, W. I. OP-317, 655

Findley, E. L. YR

Findley, J. E. OF 93-0352

Finkel, R. C。OP-48, 1750

Finkelman, R. B. OP- 1382

Finley, J. B. OP-605

Finn, C. A. OP-81

Fiorito, D. F. OF 93-0010

Fischer, E. M. OP-783, 1439, $1485,1487,1697,1781$

Fischer, F. G. OF 93-0221

Fischer, J. M. WRI 92-4032; OP-1383

Fischer, K. M. OP-1424

Fishel, D. K. WRI 90-413I

Fisher, A. T. OP-243

Fisher, F. S. OF 93-0023, 930183

Fisher, M. A. B 2034-A; OP$185,186,187,188,189,190$, $191,192,193,194,195,196$, $197,318,345,1286,1384$

Fishman, M. J. OF 93-0125; OP-675

Fishman, N. S. OP-1385, 1386

Fishman, W. D. I-1420 (NJ-14), 1420 (NJ-15)

Fitchen, W. M. OP-1387, 1575

Fitzpatrick, D. J. OF 92-0492, 92-0633

Fitzpatrick, J. A. OF 93-0232, 93-0286; OP-76, 77

Fitzpatrick, J. J. C 1086; OF 920534

Flanagan, S. M. WRI 91-4025

Fleagle, J. G. OP-97

Fleck, R. J. B 2015; OF 930299

Fleet, M. E. OP-373, 1445

Fleming, R.F. OF 92-0712; OP1388

Fleming, R. H. OP-1389

Fleming, R. W. P 1240-B; OF 93-0348; OP-885

Fletcher, I. B. OP-1390

Fletcher, J. B. OP-1498

Flint, A. L. OP-471, 1028

Flohr, M. J. OP-319, 458, 1417,1837

Flood, P. G. OP-7

Flores, R. M. OP-1391, 1569, $1767,1911,1950$

Floss, Christine OP-1392

Flower, B. P. OF 92-0539-C

Flurkey, A. J. P 1520

Focazio, M. J. WRI 92-4175, 93-4015

Fogleman, K. A. OF 93-0309; OP-1618

Foglesong, M. T. OF 93-0097

Foland, K. A. OP-27

Foley, Duncan OP-277

Foley, J. Y. OF 92-0020-B

Foley, K. M. OF 93-0218, 930515

Foley, N. K. P 1537; B 1979, 2039; OF 92-0525

Folger, D. W. YR; OF 93-0185; OP-412, 791, 1393, 1481

Folger, P. F. B 2003; OP-1051, 1394

Fontaine, R. A. WRI 92-4099
Foord, E. E. OP-115, 500, 522

Foose, M. P. B 2013; OF 93 0208-A, 93-0208-B, 93-0328

Force, E. R. B 2042-C; OF 930023; MF-2223

Ford, A. B. OF 92-0724; OP$275,1195,1395,1396,1995$

Ford, P. G. OP-786

Foreman, M. G. OP-320

Foreman, W. T. OF 92-0644; OP-321

Forester, R. M. C 1086; OP$109,200,943,1289,1308$ 1309,1896

Formisano, V. OP-1163

Forni, O. OP-1163

Forsythe, J. OP-1217

Forsythe, R. D. OP-586

Fortier, J. D. OP-731

Foster, D. A. OP-678

Foster, D. S. OF 93-0185; OP$199,200,1288,1289$

Foster, G. D. OP-321

Foster, H. L. P 1497-C

Fouch, T. D. B 1787-Q; OF 92 0391

Foulger, G. R. OP-322, 420

Fountain, A. G. W 2340; C 1086; OP-323

Fournier, R. O. OP-324, 325, 326,327

Fourtanier, Elisabeth OP-1330, 1901

Fowler, M. G. OP-413

Fox, C. G. MF-2231, 2233; OP897

Fox, C. J. I-2091-C

Fox, J.E. OF 93-0337; OC$0135,0136,0137,0138$; OP889

Fox, K. F., Jr. OP-108, 1397

Fox, R. B. OP-1398

Franco, Luis MF-2242

Franczyk, K. J. B 1787-Q; OF 92-0689; OP-1399

Frank-Molnia D. G. OP-1719

Franke, O. L. OF 92-0637

Frankel, A. D. P 1536

Frankel, Arthur OP-328, 329

Franklin, J. M. OP-243

Franklin, Keith OF 91-0014

Fraser-Smith, A. C. P 1550-C

Freckleton, J. R. W 2340; OF 92-0477; OP-454

Fredrick, B. C. OP-1930

Freeman, C. J. OP-1099

Freeman, W. O. OP-1335

Freethey, G. W. WRI 90-4105, 92-4070, 92-4160

French, B. M. OP-1613

Frenzel, P. F. P 1407-C WRI 91-4155; OF 91-0455

Fretwell, J. D. W 2400

Frey, F. A. OP-279

Fridrich, C. J. OP-1400

Friedman, Irving OP-330, 953

Friedman, L. C. W 2400; OP331

Fries, Carl, Jr. OF 93-0197-A 93-0197-B

Fries, T. L. B 1770; OF 910453; OP-335, 557
Frishman, David OP-1051, 1394

Frisken, J. G. B 1968; MF2144-B

Fritschen, L. J. OP-507, 729, 946

Frizzell, V. A., Jr. OF 93-0299; I-1963; OP-332

Froelich, A. J. OF 92-0395, 92 0716; OP-359

Froelich, P. N. OP-586

Fromm, C. H。 OF 93-0087

Frost, B. R. OP-149

Frost, T. P. OF 92-0315, 92 0379-A, 92-0379-B, 92-0380A, 92-0380-B, 92-0525, 92-0582; MF-2226-A; OP$182,333,1282,1401$

Fuchs, Karl OP-2, 521

Fuhrer, G. J. OF 91-0453, 91$0454,92-0520,92-0644$; OP 1827

Fuis, G. S. OF 92-0570

Fulford, J. M. WRI 92-4123; OF 92-0493; OP-334

Fuller, C. C. OP-215, 335, 336, $1058,1319,1810,1811$, $1985,1986,1987$

Fullerton, D. S. I-1420 (NK18), 1420 (NL-17), 1420 (NL-18)

Fulton, J. L. OP-337

Fumal, T.E. OF 93-0509; OP338,1833

Funkhouser, R. A. OF 93-0071

Furman, F. C. B 2046

Furnish, W. M. OP-354, 860, 1819

Furukawa, B. T. B 1966

Furutani, T. T. OP-1619

Fusillo, T. V. C 1007

Futa, Kiyoto OP-643

\section{G}

Gaal, Gabor OP-339

Gaciri, S. J. OP-521

Gadd, N. R. I-1420 (NL-18)

Gaddis, L. R. OP-366, 657 $783,887,1217,1402,1437$. 1438

Gajewski, D. J. OP-2, 521

Galagian, H. OF 93-0216

Galbreath, K. C. OP-1770, 1771

Galileo Imaging Team OP-1485

Galileo SSI Team OP-1696, 1697,1781

Gallagher, A. J. $\quad$ B 2039; OF $91-$ 0449-A, 91-0449-B, 91-0449C, 91-0449-D, 91-0449-E, 91-0449-F, 91-0449-G

Gallagher, M. J. OP-170

Gallo, D. G. OP-900

Gallup, C. D. OP-294

Gamble, B. M. MF-1838-D

Gamble, C. R. WRI 92-4165

Gann, J. T. OF 92-0565, 93 0196, 93-0242

Gannett, M. W. OP-1403

Gao, Z. OP-1672

Garabedian, S. P. P 1408-F

Garbarino, J. R. OP-991 
Garcia, J. F. OF 93-0311

Garcia, M. O. MF-2231, 2233

Garcia, Rene W 2400; WRI 924078

Gardeweg, M. OP-957

Gardiner, W. W. OP-787

Gardner, B. OP-221

Gardner, C. A. OP-1404

Gardner, J. V. B 2002; C 1086; I-2090-A, 2090-B; OP-241

Gardner, M. H. OP-1387, 1575

Gardner, N. K. OP-1226

Gardner-Taggart, J. M. OP-340

Garklavs, George OP-341

Garrett, R. G. OF 92-0123, 930069

Garrett, S. W. OP-1317, 1446

Garrison, C. R. OF 92-0492

Garrison, J. A., Jr. OF 92-0394

Garrison, J. S. W 2400

Garrison, L.E. B 2002

Garside, L. J. OP-342

Garven, Grant OP-51

Garvin, J. B. OP-1405, 1406

Garza, Reggina OF 92-0629

Gates, A. E. OP-343, 344

Gates, J. S. OF 92-0497

Gates, P. M. OF 92-0644; OP321

Gathright, T. M., II OP-506

Gauslin, T. L. YR

Gauthier-Lafaye, François OP713

Gautier, D. L. YR; OF 920696, 93-0337; OP-453

Gaydos, L. J. C 1086

Gazis, Carey OP-1407

Gee, L. OP-752

Gein, L. M. OP-418

Geissier, P. E. OP-1408

Geist, E. L. OP-1, 345, 1172 , 1384

Gelfenbaum, G. R. OP-346

Gellis, A. C. OP-347, 1409

Gemmell, J. M. OF 93-0071

Genrich, J. F. OP-90

Gent, C. A. OP-1099, 1433

Gere, M. A., Jr. OF 92-0514

Gerlach, T. M. C 1086; OP348,1994

Getahun, Aberra OP-349

Gettings, M. E. OF 93-0023

Getty, S. R. OF 92-0525

Ghauri, A. A. OP-1637

Ghilarducci, Mark OF 91-0032

Gibbons, A. B. OC- 0140

Gibs, Jacob OP-350, 832

Gibson, M. L. I-2343-A, 2343B, 2380-A, 2380-B

Gibson, T. G. OP-351

Giese, G. L. W 2403

Gilbert, B. K. OF 93-0120

Gilbert, J. J. · W 2400

Gilbert, S. A. OP-1410

Gilbert, W. G. OP-1168

Giletti, B. J. OP-572

Gill, J. D. OP-1761

Gillespie, A. R. I-2342; OP1253, 1254

Gillespie, S. R. OP-352
Gillet, Philippe OP-851

Gilliom, R. J. OP-1411

Gillis, K. M. OP-1672

Gilmore, T. D. OF 92-0450

Ginsburg, G. D. OP-1412

Giorgi, F. OP-448, 1156

Giovannitti, R. M. OF 92-0165

Girty, G. H. OP-1413

Girty, M. S. OP-1413

Githui, A. OP-521

Gjessing, E. T. OP-353

Glaçon, Georgette OP-197

Gladwin, M. T. P 1550-C

Glahn, A. OP-521

Glancy, P. A. OP-1276

Glanzman, V. M. C 1110; OF 92-0502

Glass, B. P. OP-1181, 1414

Glass, R. L. OF 91-0458

Glassmoyer, G. N. OF 93-0216

Glazner, A. F. OP-182, 1282

Gleason, Jim OP-330

Glenister, B. F. OP-354

Glenn, M. E. OF 93-0067

Glick, D. C. OF 92-0568

Glick, E. E. SGM

Gloersen, Per C 1086

Gloyn, R. W. OP-741

Glynn, P. D. OP-355, 1415, 1787

Gnibidenko, H. S. OP-295

Goddard, K. E. OF 93-0054

Godson, R. H. OP-212

Goff, F.E. OP-267

Goff, S. J. OP-1496

Goff, W. F. OP-1243

Gohn, G. S. B 2030; OF 92 0394, 92-0399; OP-356

Gol'mshtok, A. Y. OP-898, 1532,1597

Gold, R. L. OF 92-0653

Goldberg, S. A. OP-1918

Goldfarb, R. J. B 2003; MF2228; OP-1099, 1416, 1433

Goldhaber, M. B. OP-1117, 1417, 1418, 1419, 1782, 1799

Goldsmith, G. D. WRI $92-4080$

Goldsmith, Richard OP-555

Goldstein, Peter OP-1420

Golightly, D. W. B 1770

Golombek, M. P. OP-1322, $1323,1421,1422$

Golovchenko, Xenia OP-586

Goltz, J. D. P 1553-B

Gomberg, J. S. OP-357, 358, $438,1171,1300,1423$

Goncalves, C. A. OP-1329

Gonthier, G. J. WRI 92-4120

Gonthier, J. B. WRI 91-4087

Gonzalez, E. OP-1424

Gonzalez, F. I. OP-752

Good, J. D. OF 92-0504

Goodbred, S. L. OF 93-0083

Goode, D. J. WRI 92-4124

Goodfellow, W.D. OP-243

Goodwin, B. K. OP-359

Goolsby, D. A. C 1120-C; OF 93-0418; OP-1000, 1425

Gorby, Y. A. OP-1426

Gordon, Mackenzie, Jr. OP-360
Gorham, Eville OP-249

Gori, P. L. P 1519

Gorodinsky, M. E. OF 93-0339

Goter, S. K. OF 92-0533

Gottfried, David OP-1003

Gottschalk, R. R. OP-1427

Gough, L. P. C 1105; OF 930303

Gove, H. E. OP-147

Gowen, M. H. OF 92-0717; OP1863

Gower, C. F. OP-1316

Grachev, M. A. OP-2003

Gradstein, F. M. OP-361

Grady, S. J. WRI 87-4144

Graf, J. B. OP-1434

Graff, P. J. P 1520

Graham, S. A. OP-159

Granahan, J. C. OP-1217

Granina, Liba OP-130

Grant, R. E. OP-354

Grant, W.P. OF 91-0441-T

Grantz, Arthur C 1086; OF 920426; OP-1428, 1429, 1430

Grason, David WRI 85-4267

Grassle, J. F. OP-1185

Grauch, R. I. OF 92-0525; OP$362,363,714,1431,1432$

Grauch, V. J. B 2039; GP-1003A; OP-364, 365, 447

Graves, Randall OF 92-0514

Gray, Floyd B 2014; MF-2242

Gray, J. E. OF 92-0008-A, 920008-B, 92-0708-A, 92-0708B; OP-1433

Gray, J.R. OP-1023, 1434, 1435

Gray, K. J. B 1839-I,J; OF 930505

Gray, LedaBeth OP-242

Gray, S.C. OP- 1436

Greb, S. F. OF $92-0558$

Greco, Steven B 1981

Greeley, Ronald I-2209; OP$366,416,783,786,1437$, $1438,1439,1485,1486$, $1487,1697,1781$

Green, A. G. OP-1213, 1215, 1440,1533

Green, A. W. OP-367, 1441

Green, Aaron WRI 92-4074

Green, G. A. WRI 92-4070

Green, M. W. OF 92-0697, 92 $0698,93-0310,93-0320$

Green, P. F. OP-1136

Green, R. W. OP-660

Green, W. R. W 2400; OF 930122

Green, W. V. OP-2, 521

Greenberg, Richard OP-1437, 1438,1487

Greene, H. G. OP-186, 187, $188,189,190,191,192,193$, $194,195,196,197,340,368$, $1287,1442,1443,1444$, 1521, 1908

Greene, R. C. B 1976

Greenhouse, J. P. OP-369

Greenwood, W. R. OP-370, 371,372

Gregg, W. J. B 1904-Q

Gregory, Glenn OP-1255
Gresham, A. OP-1518

Grew, E. S. OP-373, 1445

Grey, D. W. WRI 93-4007

Griffiths, C. M. OP-361

Griffiths, D. H. OP-521

Grim, M. S. I-2089-C, 2090-A, 2090-B, 2090-C, 2091-C; OP-1356

Griscom, Andrew B 2014; MF2228

Griswold, W. J. OP-1030

Groat, C. G. OF 92-0530

Gromet, L. P. OP-1279

Grommé, C. S. OP-94

Gronberg, J. M. W 2396; OF 91-0535

Gröschel-Becker, H. M. OP-243

Groschen, G. E. OP-1675

Grosse, C. OP-521

Grossman, J. N. OF 93-0001A, 93-0001-B, 93-0001-C; OP-458, 1148, 1666, 1727, 1900

Grossman, R. N. OP-1977

Grosz, A. E. B 2039; OF 92 0396, 93-0240-A, 93-0240 B; OP-1104

Grout, M. A. B 1787-HH; OF 92-0388; OP-1972

Grover, T. P. OF 92-0569, 930324

Grow, J. A. OF 92-0391; OP92,1842

Grubbs, G. H. W 2400

Gruber, J. R., Jr. OF 93-0207

Giundy, W. D. OP-63, 754

Grunow, A. M. OP-1317, 1446

Grybeck, D. J. OF 93-0339; MF-2217-B

Gryc, George OP-374

Gualtieri, Lynn OP-279

Guangwei, L. OP-1580

Gubbins, David OP-1969

Guest, J. E. OF 93-0516; OP1851

Guffanti, M. C. OP-1447

Gulson, B. L. OP-375

Gunay, Gultekin OP-39, 376

Gundersen, L. C. OF 93-0292G, 93-0292-H, 93-0292-I, 930292-J; OP-343, 344, 377, $378,379,1052,1448$

Gunderson, K. D. YR

Gunn, S. H. OP-242, 419

Gunnells, G. B. DDS-0001; OF 93-0575

Guo, L. OF 93-0043

Guptill, S. C. OP-380, 381, 382,383

Gurbanov, A. G. OP-91

Gurgui, A. OP-1449

Gurney, R. J. OP-507, 946

Gurrieri, Joseph WRI 92-4074

Gurtz, M. E. OF 93-0104

Gutentag, E. D. OP-269, 774, 1775

Gutmacher, C. E. B 2002; OP694

Gutscher, M. A. OP-1464

Guymon, G. L. OP-454

Guzzo, L. R. OF 92-0514

Gwim, C. J. OP-1174 
Gwynn, J. W. WRI 91-4117

Gwyther, R. L. P 1550-C

H

Haakensen, Nils P 1386-E

Haberle, R. M. OP-1269, 1270

Hacker, B. R. OP-1173, 1450, 1451,1452

Hadley, D. G. B 2005; OF $92-$ 0391; OP-1198, 1453

Haefner, R. J. OF 91-0180; OP1454

Haeni, F. P. WRI 92-4012, $92-$ 4056; OP-384

Haeussler, P. J. OF 93-0325

Hageman, P. L. OF 90-0506 92-0008-A, 92-0008-B, 92 0708-A, 92-0708-B, 930014, 93-0243, 93-0259-A, 93-0259-B

Hager, B. H. OF 91-0032; OP-

Hager, S. W. OF 93-0057

Hagstrum, J. T. OP-385

Haig, David OP-361

Hail, W. J., Jr。 MF-2232

Hainly, R. A. WRI 90-4011

Haitjema, H. M. OP-691

Hakhverdian, L. OF 93-0216

Haley, B. R. SGM

Haley, J. C. OF 92-0391

Halford, K. J. OF 92-0492

Halka, J. P. OP-439

Hall, A. J. OP-1541

Hall; D. K. OP-386

Hall, D. W. OP-387, 388

Hall, J. OP-1525

Hall, R. B 2002

Hall, R. B. OP-522

Hall, R. D. OP-1455, 1884

Hall, R. P. OP- 1456

Hallam, C. A. C 1086

Hallberg, G. R. OP-588

Haller, K. M. OF 93-0338; OP75

Hallet, Bernard OP-389

Halley, R. B. C 1086; OF 920717; OP-1073, 1457, 1863 1930

Halliday, A. N. OF 92-0525; OP-158, 1246, 1709

Hamilton, P. A. C 1080, 1090; YR; OF 93-0040; OP-1458

Hamilton, T. D. C 1086; OP$33,390,391$

Hamilton, W. B. OP-392, 1459, 1460

Hamlin, S. N. WRI 92-4153, 92-4172

Hammarstrom, J. M. B 2039; OF 93-0207, 93-0505; OP$393,994,1195,1461,1462$ 1463,1869

Hammermeister, D. P. OF 90 0369

Hammond, S. OP-221

Hampson, P. S. WRI 91-4115

Hampton, J. R. MF-1996-E

Hampton, M. A. B 2002; YR; OF 93-0298; I-2090-A, 2090B
Hanchar, J. M. OP-678, 1711

Hancock, P. L. OP-119

Hanesand, Trond OF 92-0391

Hankins, W. B. OP-1173, 1355

Hanna, W. F. C 1088; I-2050-F

Hannah, J. L. OP-394, 965, 1464

Hansen, B. P. OF 92-0646, 920647

Hansen, C. V. OF 93-0092; HA0722-H, 0722-I

Hansen, D. S. W 2340

Hansen, G. B. OP-1210

Hansen, G. K. W 2400

Hansen, M. E. OF 92-0722

Hansen, V. L. OP-1349

Hansley, P. L. B 2061-A; OF 92-0391; OP-395, 1296 1465,1466

Hanson, B. C. OP-1860

Hanson, K. M. OF 92-0173

Hanson, R. E. OP-1413

Hanson, R. T. OP-1467, 1468

Hanson, S. L. OP-993, 1948

Harbaugh, A. W. OF 92-0659

Harbin, M. L. OP-I469, 1754 , 1929

Harden, J. W. C 1086; OP-396, 1065,1470

Harder, S. OP-521

Hardie, J. K. OC-0140

Hardy, E. E. OF 92-0497

Hardy, M. A. OF 92-0153

Hardyman, R. F. B 2039; OP397

Hargadine, D. A. . WRI 92 4169, 92-4177, 93-4036

Harlan, S. S. OP-398, 1613

Harlow, D. H. OP-399, 1066, 1998

Harlow, G. E., Jr. W 2388; OP400,1196

Harlow, T. P. YR

Harmon, J. R. B 2013

Harmon, R. S. OP-132

Harms, T. A. OP-401, 402

Harms, T. F. OF 92-0599

Harmsen, S. C. OF 92-0340; OP- 438,1300

Harned, D. A. OP-403

Harned, William W 2400

Harp, E. L. OP-404

Harper, J. M. B 1981

Harper, Michael B 2013

Harrill, J. R. W 2340

Harrington, C. D. OP-1070

Harris, A. G. B 1839-K, 2015; OF 92-0391, 93-0184, 930215; OP-1988

Harris, D. P. OF 93-0258-A, 930258-B

Harris, G. C. OF 92-0514

Harris, L. D. B 1909

Harris, M. T. OP-354

Harris, Malcolm OF 92-0206

Harris, P. M. OP-1072

Harris, R. A. OF 92-0567; OP405,406

Harrison, D. W. OP-199

Harrison, J. E. P 1524; I-2267
Harrison, R. W. OP-1471, 1742,1861

Harrison, T. M. OP-678, 1711

Harrison, W. J. OF 92-0391

Hart, P. E. OF 92-0556, 930301; OP-83, 108

Hart, R. H. P 1550-C

Harte, P. T. WRI 91-4169, 91 4177 ; OP-1472

Hartshorn, J. H. I-1420 (NK-18)

Hartung, J. B. OP-550, 1113 , 1114

Hartzell, S. H. C 1031 ; OP407,1046

Harvey, J. W. OP-408

Harvey, R. W. OP-409, 1473

Harwood, D. S. OP-1413, 1474

Haselton, H. T. OP-1475

Hasenaka, Toshiaki OP-186, $187,188,189,190,191,192$ $193,194,195,196$

Hasenmueller, N. R. B 1909; OP-1845

Hassemer, J. R. B 1737-E; OF 92-0210-A, 92-0210-B 92-0316-A, 92-0316-B

Hassenmueller, W. A. OF 92 0682

Hassibe, W. R. YR

Hassig, P. OP-857

Hatch, J. R. OP-1476

Hatcher, P. G. OP-410, 1292, $1477,1478,1906$

Hatcher, R. D., Jr. OP-1479

Hatcher, S. A. OP-935

Hatfield, D. OP-857

Hatfield, D. B. B 1770

Hatfield, J. L. OF 92-0167

Hathon, L. A. OP-451

Hauck, S. A. OF 92-0514

Haugerud, R. A. OP-1480

Hauksson, Egill OF 91-0032. OP-411, 503, 504, 700, 931

Haupt, R. S. OP-412, 1481

Hausmann, R. OP-1436

Hawke, B. R. OP-1482, 1830

Hawkins, J. W. OP-413

Hawthorne, F. C. OP-414

Haxel, G. B. OP-1886

Hay, B. J. OF 93-0274

Hay, L. E. C 1086; OF 92 0052; OP-577, 2011

Hayden, E. C. OP-836, 1143

Hayden, T. J. OF 93-0235

Hayes, E. M. OP-1112

Hayes, K. F. OP-244, 245

Hayes, T. S. OF 92-0514; MF1994-D, 2125-E; OP-1419

Hays, W. W. P 1240-B; OP$415,1483,1484$

Head, J. W. OP-366, 416, 657, $783,1163,1437,1438,1439$ $1485,1486,1487,1497$, $1697,1781,1851$

Healy, J. H. OP-1488

Healy, R. W. W 2386, 2390

Heaney, P. J. OP-1489, 1490

Hearn, B. C., Jr. OP-1491

Hearn, P. P. C 1086; OP-12, 44 , $1492,1493,1494,1874$, 2003, 2004

Heath, R. C. W 2220; OP-417
Heatherington, A. L。 OP-1607, 1716,1731

Heaton, T. H. C 1031; OP-503, $504,931,1047,1941$

Hebson, C. S. WRI 90-4151

Heck, B. A. WRI 92-4169, 92 4177, 93-4036

Hedenquist, J. W. OP-1732

Hedge, C. E. OP-2027

Hedgman, C. A. OP-139, 1495

Hedrick, D. B. OP-183

Heffern, E. L. C-0142

Heffernan, C. OP-1696

Heggie, D. T. OP-361

Hegner, Ernst OF 92-0525

Heigold, P. C. OP-1799

Heiken, G. H. OP-277, 1496

Heilweil, V. M. WRI 90-4105

Heim, R. R., Jr. W 2400

Hein, J. R. OP-418, 419, 960, 1436

Heine, J. J. OF 92-0514

Hejl, H. R., Jr. OP-280

Heki, Kosuke OP-420

Helfenstein, Paul OP-1487, 1497

Helgesen, J. O. WRI 92-4137, 93-4036; HA-0551

Heliker, C. C. OP-846

Helle, Sonia OP-1107

Helley, E. J. OF 93-0286

Helliwell, R. A. P 1550-C

Hellweg, M. A. OP-1498

Helmberger, D. V. OP-1046, 1047

Helsel, D. R. W 2400; OP-421

Helsley, C. E. OP-295

Helz, R. T. OF 93-0015; OP1499,1500

Hem, J. D. W 2400; OP-591, 592

Hemingway, B. S. OP-25, 305 , $843,851,1690$

Hemley, J. J. OP-1312

Hemphill-Haley, Eileen OF 930284, 93-0289, 93-0340; OP120

Hendricks, J. D. OF 91-0640; OP-1341

Henry, C. D. OP-1611

Henry, M. E. OF 93-0522

Henry, R. F. OP-320

Henry, T. W. OF 93-0513, 930549; OP-360, 422, 1821

Heran, W. D. OF 92-0557

Herb, W. J. OP-423

Herbert, L. R. OP-61, 424, 425

Hereford, Richard OP-426, 1375

Hergt, J. M. OP-413

Herkelrath, W. N. OP-430

Herman, J. S. OP-40, 165, 1568,2001

Herndon, J. G. W 2391

Herraiz, M. OP-1370, 1371

Herrera, P. A. OP-427

Herrera, P. T. OP-428, 1267

Herring, J. R. OP-429, 1501 1502,1677

Herring, T. A. OP-90

Herrioth, Adrienne OF 91-0014

Herrmann, R. B. C 1083 
Herrmann, Raymond OP-846

Herzberg, M. OP-1833

Herzer, R. H. OP-896

Herzog, D. C. C 1086

Hess, A. E. OF 93-0071

Hess, G. W. WRI 93-4016; OF 92-0113

Hess, K. M. OP-304, 430, 431

Hester, T. C. OF 92-0391, 920524, 93-0230; OP-1350

Hettinger, R. D. OF 93-0270; OP-1779

Heusser, L. E。 OP-878

Hewitt, D. A. OF 92-0525

Hey, R. N. OP-432

Heyman, Barry OP-415

Heywood, C. E. WRI 91-4065

Hickey, J. J. WRI 9 I-4168

Hickman, S. H. OP-433

Hiebert, F. K. OP-1155

Hieshima, G. B. OP-1688

Hietanen, A. OP-434

Higgin, J. D. OP-775

Higley, D. K. OF 92-0391; OP435

Hiland, M. W. OF 92-0530, 930210

Hilbert, R.E. OP-695

Hildenbrand, T. G. OF 910573; OP-436

Hildreth, Wes OP-279, 316,971

Hileman, G. E. WRI 92-4092

Hill, B. E. OP-1404

Hill, B. R. WRI 92-4049, 924168

Hill, D. P. P 1550-C; OP-113, $437,438,569,1503$

Hill, G. T. OF 92-0615

Hill, J. M. OP-439

Hill, M. C. WRI 90-415I

Hill, P. L. OF 92-0527, 92-0557

Hill, R. I. OP-134

Hillhouse, J. W. OP-94, 656, 1504

Himmelberg, G. R. OP-1195

Hine, A. C. OP-1662

Hines, L. B. W 2340

Hinkle, M. E. OF 92-0599, 93 0260; OP-1505

Hinkley, T. K. C 1086; OP-667, 1506, 1507

Hintze, L. F. GQ-1721; OP-797

Hinze, W. J. OP-13, 138

Hippe, D. J. OF 92-0165

Hipps, L. E. OP-562

Hirn, Alfred OP-521

Hirsch, R. M. OP-421

Hite, R. J. OF 93-0236

Hobart, D. E. OP-305

Hobart, M. A. OP-186, 187, $188,189,190,191,192,193$, $194,195,196$

Hobba, W. A., Jr. W 2384

Hobbs, S. W: OP-440

Hoblit, R. P. OP-1768, 1772

Hochella, M. F., Jr. OP-493, $1170,1508,1554,1737,1997$

Hodge, S. A. OF 93-0150

Hodge, S. M. OP-81

Hodgson, S. A. OP-573

Hodkinson, R. A. OP-413
Hoering, T. C. OP-750

Hoffman, J. D. DDS-0001; OF 93-0305

Hoffman, M. F. OF 92-0395

Hoffmann, Harald OP-521, $657,783,1437,1438,1487$. 1497

Hofle, J. OP-1731

Hofstra, A. H. B 2005, 2039; OP-441, 1509

Hohn, M. E. B 1909

Hoisch, T. D. OP-442

Holbrook, D. F. I-1420 (NJ-15)

Holcomb, R. T. OP-443

Holdren, G. R. OP-572

Holland, F. D., Jr. OP-444

Holland, T. W. OF 92-0496, 93 0048, 93-0136, 93-0166, 930167, 93-0424, 93-0425, 93-0427, 93-0428, 93-0429, 93-0430, 93-0431, 93-0432

Holliger, Philippe OP-713

Hollyday, E. F. OP-547

Holmes, C. W. OP-1510

Holmes, M. L. I-2091-C

Holroyd, P. A. OF 93-0513, 930549

Holt, H. E. OP-1883

Holtschlag, D. J. WRI 91-4194

Holtz, T. R., Jr. OP-1511

Holzer, T. L. OP-445, 1154, 1512

Hon, Ken OF 93-0342-A, 930342-B

Honda, Masahiko OP-446

Hook, R. W. OP-1513

Hooper, R. P. C 1086; WRI 934030; OF 93-0055, 93-0059; OP-160, 161, 1514, 1515, 1875

Hoos, A. B. W 2400; OF 930039

Hoover, D. B. B 2039; OF 92 0557; GP-1003-A; OP-447, $582,779,944$

Hoover, D. L. OF 92-0554

Hopkins, I. L. OF 92-0391; OP1516

Hopkins, R. T. OF 90-0672, 920210-A, 92-0210-B, 92-

0268, 92-0316-A 92-0316-B, 92-0384, $92-$ 0615, 92-0709; OP-1035

Horan, D. M. OP-1974

Horan, M. F. OF 92-0525; OP1913, 1977

Horn, M. C. OF 91-0014

Hornberger, Michelle OF 920456

Horton, J. W., Jr. OF 93-0244; MF-2215-A; OP-1517

Horton, R. J. B 2039

Hosterman, J. W. B 1909

Hostetler, S. W. C 1086; OP$55,448,1156$

Hothem, L. D. OP-951

Hou Zhizhui OP-945

Hou Zonglin OP-1238

Hough, C. J. OF 92-0135

Hough, S. E. OP-931, 1424

Houghton, J. C. OP-449

House, L. OP-438

House, L. B. WRI 92-4029
Houseknecht, D. W. OP-450, 451,1518

Houser, B. B. OF 92-0687; OP452

Houston, Heidi OP-1033

Houston, R. S. P 1520

Howard, A. D. B 1981

Howard, K. A. OF 91-0435; OP-1691

Howd, P. A. OP-751

Howe, D. L. OF 92-0596

Howell, D. G. OP-453, 492, $1519,1520,1553,1628$

Howes, B. L. OP-949

Howington-Kraus, A. E. OP$1669,1832,2022$

Howland, J. R. W 2400

Howorth, Russell OP-1521

Howse, M. A. WRI 90-4131

Hoxie, D. T. OP-1522

Hoy, C. G. W 2400

Hromadka, T. V., II OP-454, 455

Hsieh, P. A. OF 92-0477, 930071

Hsu, A. Y. OP-946

Hsu, S. A. OP-262

Hsï, Vindell OP-587, 819, 820, $821,822,823,824,825$

Hua Renmin OP-456

Huang Wankang OP-457

Huang, Zehui OP-587, 819, $820,821,822,823,824,825$

Hubbard, E. F., Jr. WRI $92-$ 4060

Hubbard, L. E. WRI 91-4063

Huber, D. F. OP-1730

Huber, N. K. I-1420 (NJ-10)

Hubert, M. L. DDS-0006

Huddlestun, P. F. OP-1677

Hudnut, K. W. OF 91-0032; OP-90, 593, 699, 700, 931, 2010

Hudson, J. H. C 1086

Hudson, M. R. OF 91-0623, 930299; OP-1117

Huebner, J. S. OP-319, 458

Huffman, A. C., Jr. B 1808-O; OF 93-0248; OP-1523

Huffman, G. C. OF 92-0114

Huggett, Q. J. B 2002

Huggins, David OP-731

Hughes, D. J. OP-1456

Hughes, J. L. OP-995

Hughes, R. E. OF 92-0514; OP459,1524

Hughes, S. S. OP-1637

Hughes, Stephen OP-460, 461, 1525

Hui, J. OP-1217

Huka, Miroslav B 2046

Hulen, J. B. OP-1243

Hulsey, R. A. OP-4

Hult, M. F. OP-1526

Hunt, C. D., Jr. C 1086; OP1527

Hunter, L.E. OP-1801

Hunter, R. E. OP-1528

Huntington, T. G. C 1086; OF 93-0055

Hupp, C. R. OP-462, 1529

Hussain, A. OP-1637
Hussey, A. M., II OP-1530

Huston, D. L. MF-1996-E

Hutchinson, C. B. W 2340; OP1531

Hutchinson, D. R. OF 93-0264; OP-463, 898, 1532, 1533, 1534,1597

Hutchinson, R. A. OP-327, 464

Hutchinson, R. W. OP-465

Hutson, S. S. WRI 91-4195

Hutton, A. C. OP-1599

Hutton, L. K. OP-411, 466, $503,700,931$

Hyatt, Donald OF 91-0014

Hyde, G. R. B 2013

\section{I}

Iberall, A. S. OP-848

Ibrahim, A. B. OF 93-0181

Iida, Masahiro OP-959

Ikeya, Noriyuki OP-223

Ingebritsen, S. E. OP-467, 468, 636,897

Ingersoll, G. P. OF 92-0645

Irwin, G. A. W 2400

Irwin, J. J. OP-1175

Irwin, P. N. OF 92-0514

Isaacs, C. M. B 1995-C, 2034 A; OF 89-0450-C, 89-0450 D, 92-0383, 92-0539-A, 92-0539-B, 92-0539-C, $92-$ 0539-D, 92-0539-E, 92-0539F, 93-0177, 93-0182; OP-174, 469, 1946

Isaacson, K. A. OF 92-0387

Isbell, Brad OF 93-0319, 930347

Isbell, J. L. OP-1317, 1446

Isbell, N. K. OP-1669

Isherwood, D. J. OP-869

Ishii, A. L. WRI 92-4149

Ishiwatari, Akira OP-361

Ishman, S. E. OF 93-0515; OP$263,470,1075,1307,1535$

Istok, J. D. OP-471, 1028

Ivanov, B. A. OP-1062

Iven, M. E. B 1966

Iverson, J. L. OF 93-0418

Iverson, R. M. OF 92-0483; OP-254, 472, 782

Iwatsubo, E. Y. B 1966; OP2024

Iwatsubo, R. T. W 2400

Iyer, H. M. OF 92-0441; OP1536

Izawa, E. OP-1732

Izbicki, J. A. OP-255, 473, 474

Izett, G. A. B 2065; OF 92 0391, 92-0699; OP-475, $1537,1538,1539,1540$, $1702,1804,1873,1880$

Izuka, S. K. WRI 91-4197, 92 4168

\section{$\mathbf{J}$}

Jachens, R. C. B 1737-E OF $92-0548,92-0549,93-$ 0263, 93-0277; OP-79 
Jackson, D. D. OF 91-0032; OP-735

Jackson, J. B. OP-1272

Jackson, J. C. OF 92-0268

Jackson, L. L. B 1770; C 1086; OF 92-0383, 93-0303; OP$476,477,500$

Jackson, M. C. OP-14

Jackson, M. E. OP-1171

Jackson, N. J. OP-1541

Jackson, S. M. OP-438

Jackson, W. D. C 0930-N

Jacob, B. OP-2, 521

Jacoboni, J. M. OF 92-0627

Jacobs, C. L. MF-2083-B

Jacobs, J. M. OF 92-0583, 92 0584, 93-0204

Jacobson, M. L. OF 93-0195

Jacobson, R. B. B 1981; OP$1542,1543,1544,1700$

Jacques, D. V. WRI 92-4019

Jaeger, T. C. OP-156

Jaffe, B. E. OF 92-0530

Jaffé, P. R. OP-1898

Jahn, C. H. OP-420

Jakeman, A. J. OP-1572

Jakobsson, S. J. OP-511

James, O. B. OP-478, 1392

James, R. W., Jr. C 1120-A

Jan, Chyan-Deng OP-1655

Jan, M. Q. OP-1637

Janda, R. J. WRI 92-4039

Janecke, S. U. OP-479

Janecky, D. OP-1243

Janet, M. L. OF 92-0644

Janik, C. J. OP-926, 1243, 1496

Jansen, J. B. OP-1038

Jaques, R. OP-1518

Jarpe, S. P. OP-2026

Jarrard, R. D. OP-587, 819, $820,821,822,823,824,825$

Jarrett, R. D. OP-1545

Jaumann, R. OP-783, 1437, $1438,1487,1497$

Jaworowski, Cheryl OF 92 0391; OP-1539

Jayko, A. S. OP-144, 401, 752, 1546,1547

Jeanloz, Raymond OP-480, 770

Jeffcoat, H. H. WRI 92-4147

Jefferson, M. C. YR

Jelinski, J. C. OP-350

Jenkins, P. OP-2004

Jenkins-Bartle, K. L. OF 920626

Jenks, P. J. OF 92-0525

Jenne, E. A. OP-869

Jennings, David W 2400

Jennings, M. E. OP-150, 481, 482

Jensen, K. M. I-1420 (NJ-14), $1420(\mathrm{NJ}-15)$

Jenson, S. K. C 1086; YR

Jeton, A. E. OF 92-0627

Jewell, P. W. OP-483

Jiang, Wei-Teh OP-484, 1892

Jibson, R. W. OP-485, 486, 487

Jiménez Núñez, Héctor OP-35

Jimenez, Nestor B 2039

Jobson, H. E. OP-488
John, D. A. B 2019; MF-1877A; OP-489

Johnson, A. I. W 1619-U; OP376,811

Johnson, A. M. B 1842-D; OF 92-0514, 93-0348

Johnson, C. M. OP-490, 1825

Johnson, E. A. B 1917-P; OC0140; OP-1548

Johnson, H. P. OP-432

Johnson, J. A. OP-1549

Johnson, J. G. OP-86, 491

Johnson, K. OP-1140

Johnson, K. A. OP-1112, 1376

Johnson, K. R. OP-1550

Johnson, Kenneth OP-1139

Johnson, M. J. OP-1551

Johnson, M. L. WRI 91-4126

Johnson, R. C. B 1787-DD, 1787-Q, 1904-P; MF-2216

Johnson, R. G. B 1770

Johnson, S. E. OF 92-0166

Johnson, S. Y. OF 92-0581, $93-$ 0332; OP-1552

Johnson, T. V. OP-1217, 1437, $1438,1485,1487,1697,1781$

Johnson, T. W. OP-750

Johnson, W. D., Jr. I-2377, 2378, 2379

Johnsson, M. J. OP-492, 1553

Johnsson, P. A. OP-493, 1508, 1554

Johnston, A. C. C 1083

Johnston, M. J. P 1550-C; OP$438,766,768,1555$

Johnston, R. H. OP-494

Joines, A. E., Jr. YR

Jolly, A. D. OP-1556, 1802

Jones, B. F. OP-165, 1134, 1310, 1991

Jones, D. L. OP-708

Jones, F. W. OF 93-0210

Jones, G. A. OP-200, 749, 1289,1290

Jones, J. L. OF 93-0259-A, 930259-B

Jones, L. M. OF 91-0032, $92-$ 0577; OP-411, 438, 466, $503,699,700,931,1102$

Jones, M. E. OP-495

Jones, M. L. WRI 92-4027

Jones, M. R. OP-1356

Jordan, R. R. OP-285

Jorgensen, D. G. B 1989-D

Jorgensen, N. O. OP-110

Josberger, E. G. C 1086

Joseph, R. L. OF 93-0070

Joyner, L. OP-1456

Joyner, W. B. OF 93-0509; OP496,497

Judkins, T. W. DDS-0006

Judson, Sheldon I-1420 (NK18)

Judy, Clark OP-953

Juhasz, Erika OP-1687

Julian, B. R. OP-322, 420, 1557

Jull, A. J. OP-48
K

Kadel, S. D. OP-366, 1439, 1485

Kaehler, C. A. P 1407-C

Kagan, Y. Y. OP-735

Kaiser, W. P. B 1966

Kallemeyn, G. W. OP-2025

Kamata, Hiroki OP-498, 982

Kamilli, R. J. OP-499, 1558 , 1559

Kamineni, D. C. OP-1560

Kaminski, M. A. OP-361

Kaminski, W。OP-521

Kammerer, P. A., Jr. W 2400

Kamp, L. W. OP-1217

Kampf, A.R. OP-500

Kanamori, Hiroo OP-501, 502 $503,504,931,1047$

Kane, J. S. B 1770, 2046; OP505

Kane, W. F. OP-506

Kanemasu, E. T. OP-507, 729, 946

Kanivetsky, R. A. OP-692

Kanter, L. R. OP-1970

Kappel, W. M. OP-2023

Karabanov, E. B. C 1086; OP1291, 1492, 2003, 2004

Kargel, J. S. OP-508, 509 , $1561,1562,1563,1564,1565$

Karl, H. A. B 2002; I-2090-A, 2090-B; OP-140

Karl, S. M. OF 92-0690; OP$510,747,1169,1195$

Karlsson, H. R. OP-511, 1140

Karlstrom, K. E. P 1520; OP$512,1566,1691$

Karpoff, Anne-Marie OP-510

Karsten, R. A. OF 92-0154

Kashima, Kaoru OP-720

Kasmarek, M. C. OF 93-0086

Kastens, P. H. OP-451

Kattay, Vello OP-1599

Katz, B. G. W 2402; WRI 914186, 91-4196; OP-513, 514

Katzman, Danny OP-1567

Kauahikawa, J.P. OF 93-0342A, 93-0342-B, 93-0512-A; OP-436

Kauffman, E. G. OP-755

Kauffman, L. F. WRI 92-4030

Kauffman, S. J. OP-1568

Kaufman, D.S. OP-515

Kaufmann, R. S. OP-605

Kay, R. T. OP-761

Kayen, R. E. B 2002; OP-516, 579

Kazmi, A. H. OP-1637, 1869

Keck, B. D. OP-1666

Keefer, D. K. P 1240-B; OP486, 517

Keighin, C. W. OF 92-0524, 930306; OP-518, 1206, 1350, $1569,1767,1950$

Keigwin, L. D. OP-1289

Keir, R. S. OP-519

Keith, J. R. YR

Keith, T. E. B 2054; OP-520, $549,926,1770,1771$

Keith, W. E. W 2400
Keith, W. J. OF 93-0021

Keller, D. J. OP-522

Keller, G. R. OF 93-0347; OP2, 521

Keller, J. M. OP-1723

Keller, M. OP-1265

Keller, M. A. B 1995-C, 2034A; OP-1570

Keller, R. OP-438

Keller, W. D. OP-522

Kelley, B.P. OP-1571

Kelley, J. S. OF 93-0215

Kelley, K. D. MF-2144-B, 2144-C, 2144-D

Kellogg, K.S. GQ-1729; OP523

Kelly, W. C. OP-875, 1870

Kelly, W. M. OP-1104

Kelmelis, J. A. C 1086

Kemp, B. N. OF 93-0149

Kemp, R. L. OF 92-0482

Kempema, E. W. OF 93-0237

Kendall, Carol OF 93-0055; OP-524, 557, 1572, 1573

Kendy, Eloise WRI 92-4116; OP-166

Kennedy, B. M. OP-536, 955

Kennedy, D. J. OP-1819

Kennedy, G. L. C 1086; OP-707

Kennedy, M. M. OP-1610

Kennedy, M. P. OP-1442

Kennedy, W. J. P 1533; OP$177,178,525,526,527,528$, 529,1757

Kennett, D. M. OP-361

Kenny, J. F. W 2400; HA-0722-

Kent, D. B. OP-16, 530, 1574

Kent, D. V. OP-1317, 1446

Kenyon, N. H. B 2002; I-2090A, 2090-B; OP-1012, 1864, 1966

Kepferle, R. C. B 1909

Kerans, C. H. OP-1387, 1575

Kerrisk, J. F. OP-869

Kertapati, E. K. OP-993

Kesler, S. E. OP-27, 532, 1732

Kessler, S. E. OP-1576

Ketering, C. L., Jr. OF 92-0558

Ketner, K. B. B 1988-C, 1988D, 1988-E; OF 92-0580, 930220; OP-531, 999

Kettler, R. M. OP-362, 532, 1576

Khakhaev, B. N. OP-2003

Khan, I. H. OP-1548

Khan, M. A. OP-2,521

Khan, M. R. OP-996

Khan, R. A. OF 92-0576

Khan, S. A. OF 92-0281, 92 0576, 93-0255; OP-996

Kharaka, Y.K. OP-122, 533, $534,535,536,615,637,998$, 1577,1578

Kholodkevich, I. V. OP-537

Kibler, J. E. OF 92-0544

Kieffer, H. H. OP-1217, 1402

Kietzke, K. K. OP-573

Kilburn, J. E. B 2019; OF 92 0008-A, 92-0008-B; MP - 2228

Kilgore, B. D. OP-640 
Kilpatrick, F. A. WRI 92-4147; OF 92-0457

Kimball, B. A. W 2340; WRI 92-4081; OP-538, 1579

Kindel, B. OP-1423

Kindinger, J. L. OF 92-0530

King, B. S. B 1770

King, B. W. OP-1086

King, Chi-Yu OP-539, 540, 541,1580

King, G. C. OP-542, 966, 1581

King, H. D. OF 90-0506, 930259-A, 93-0259-B, 930527; MF-2207

King, K. W. OP-1076, 1582, 1970

King, P. R. OP-1391

King, R. B. WRI 92-4095

King, R. F. OP-521

King, R. W. OP-90

King, T. V. OP-1209, 1583

Kingsbury, J. A. OP-512, 1566

Kingston, M. J. OP-543, 1584

Kingston, Margo YR

Kinoshita, K. L. OF 92-0382, 92-0555, 93-0011

Kinoshita, Masataka OP-243

Kipfinger, R. P. OF 93-0324

Kirby, S. H. OP-281, 282, 544, $1173,1348,1450,1452$, $1585,1586,1758$

Kiremidjian, A.S. OP-1587

Kirk, R. L. OP-786, 887, 1588, $1589,1590,1591,1592$, $1593,1594,1595,1596$

Kirk, W. OP-521

Kirkham, R. M. OP-859

Kirkpatrick, K. A. OF 92-0661

Kirschbaum, M. A. OF 92-0391

Kistler, R. W. OP-545, 972, $1139,1140,1141,2015,2018$

Kisvarsanyi, E. B. B 2039; MF1994-D, 2125-E; OP-1326, 1327

Kite, J. S. B 1981

Kjelstrom, L. C. WRI 92-4196

Klaasen, K. P. OP-1437, 1438, $1485,1487,1497,1696,1781$

Klasner, J. S. B 1904-L

Kleckner, R. L. YR

Kleeschulte, M. J. OF 93-0109

Klein, D. P. OF 92-0389, $92-$ 0503, 92-0557

Klein, F. W. OF 93-0022

Klein, Jeffrey OP-550

Klein, T.L. OP-1607

Kleinkopf, M. D. B 2039

Kleinman, J. W. B 1966; OP2024

Kleinrock, M. C. OP-432

Klett, T. R. OP-1965

Kling, G. W. OP-306, 1011

Klitgord, K. D. OP-898, 900, 1597

Kluessendorf, Joame OF 920514

Knapton, J. R. W 2400

Knebel, H. J. DDS-0003; OP546,1598

Knepper, D. H., Jr. B 1737-E, 2039; OF 92-0557

Knifong, D. L. OF 93-0213
Knight, R. J. OP-1086

Knight, Richard OF 91-0014

Knobel, L. L. OF 92-0156, 930034

Knopman, D. S. OP-547

Knotis, A. L. P 1405-C

Knox, E. OP-548

Knox, J. L. C 1086

Knutson, C. F. OP-1599

Koch, R. D. OF 93-0339

Kockelman, W. J. P 1519

Koczot, K. OP-439

Kodama, Kazuto OP-361

Kodosky, L. G. OP-549

Koeberl, Christian OP-550, 2025

Koehnlein, S. A. OP-350

Koeppen, R. P. OP-1607

Kogerman, A. OP-1599

Kohl, C. P. OP-1750

Kohler, W. M. OF 92-0570

Kohrn, S. B, OF 92-0343

Koirtyohann, S. R. OP-991

Kojima, Hideyasu OP-2025

Kolbek, Olga P 1550-C

Kolm, K. E. OP-269, 1009

Koloord, R. OP-1437, 1438

Kolpin, D. W. OF 93-0114, 93 0418; OP-1000, 1600

Koltun, G. F. W 2400

Komor, S. C. OP-551, 552

Koncz, Istvan OP-1263, 1687

Konikow, L. F. OP-103, 553, 1449

Konopasek, Josef B 2046

Kontak, D. J. OP-1601

Konyukhov, B. A. OP-243

Kooker, L. D. OF 93-0242

Koozmin, E. D. DDS-0006

Kopaska-Merkel, David OP361,1602

Kopp, O. C. B 2046

Körner, Ulirike OP-243

Koronovskiy, N. I. OP-91

Kosanke, R. M. OP-1603

Koski, R. A. OP-554

Kostelnik, K. M. WRI 90-4131

Kosters, E. C. OP-653

Koteff, Carl C 1086; OP-555

Koterba, M. T. OP-1876

Kotra, R. K. OP-1379, 1604, 1605,1764

Kovach, R. L. OP-1606

Kovalenko, V. I. OP-91

Kovalsky, V. V. OP-583

Kover, A. N. OP-1860

Koyanagi, R. Y. B 2006; OP1088, 1962

Kozuch, M. J. OP-1607

Kozur, H. OP-354

Krabbenhoft, D.P. C 1086; OF $92-0026$

Kramer, P. OP-1930

Krammer, Anton OP-186, 187, $188,189,190,191,192,193$, $194,195,196$

Krasnov, S. G. OP-243

Kraus, M. J. OP-98, 556

Krause, R.E. OF 92-0629

KRISP Working Group OP-2
Krizman, T. L. WRI 92-4075

Krogh, E. J. OP-967, 1916

Krogh, T. E. OF 92-0525

Krogstad, E. J. OF 92-0525; OP-1462.

Krohelski, J. T. OF 92-0026

Krohn, K. K. OP-6

Krohn, M. D. OF 93-0293; OP$447,557,1608,1609$

Kroitoru, Levy OP-234

Kronenberg, A. K。 OP-51, 544

Krouse, H. R. OP-570

Krug, W. R. W 2400

Krushensky, R. D. OP-558

Ku, H. F. WRI 91-4012

Kubik, P. W. OP-147

Kucks, R. P. OF 91-0573

Kuebler, Anne OP-1610

Kuentz, D. C. OP-132

Kuhn, Gerhard OP-559

Kuksenko, V. OP-602

Kulik, D. M. OF 93-0207

Kulp, K. P. W 2400; WRI 854267

Kump, L. R. OP-1115

Kuniansky, E. L. WRI 92-4155

Kunk, M. J. OF 92-0525, 92$0701 ;$ OP-12, 214, 475, 550, $967,968,1079,1129,1152$. $1188,1279,1611,1612$, $1613,1777,1821,1916$, 1917,1918

Kuntz, M. A. OF 93-0327; OP$560,561,594,630$

Kurklin, J. K. W 2400

Kurneva, N. A. OP-367

Kurnosov, Victor OP-586

Kurtak, J. M. OF 93-0215

Kurtz, B. A. WRI 91-4169

Kurzmack, M. A. OF 92-0490

Kusky, T. M. OP-1410

Kustas, W.P. OP-507, 562 , 729,946

Kuzmin, M. OP-1532, 2003

Kuzmin, R. O. OP-142

Kvenvolden, K. A. C 1086; OP$563,564,1412,1614,1615$, 1616

Kwarteng, A.Y. OP-1617

Kwok, Yue-Kuen OP-565

\section{$\mathbf{L}$}

Lachenbruch, A. H. C 1086; OP-1626

Laenen, Antonius W 2340; WRI 92-4108; OP-495

Laenen, J. M. W 2400

LaFortune, J. R. OP-1637

Lagorio, H. J. OP-415

Lahr, J. C. OF 92-0441, 930221, 93-0309; OP-1250, $1325,1556,1618,1802$

LaHusen, R. G. OF 92-0483

Lai, Chintu OP-455, 566, 567

Laird, G. M. OP-123

Lajoie, K. R. OP-1619

Lal, D. OP-48

Lallemand, S. E. OP-197, 368, 1620

Lamb, J. A. OF 93-0043
Lamb, T. E. OF 93-0071

Lambert, D. D. OP-1621

Lambert, L. L. OP-354, 1622

Lambert, R. B. OF 92-0027

Lambert, S. C. W 2400; OF 930035

Lammers, Angie OP-1623

Lamons, R. C. OP-554

Lamothe, P. J. B 1770; OP-335

Land, L. F. OF 92-0160

Landa, E. R. OP-41, 568, 1665

Landis, E. R. OP-1624

Landis, G. P. B 2039; C 1086; OP-441, 1151, 1625

Landon, M. K. OF 93-0042, 930043, 93-0079

Landwehr, J. M. C 1086; WRI 93-4076; OF 92-0129, 92-0632; OP-916

Lane, D. E. B 1989-D, 1989-E

Lane, J. W., Jr. WRI 92-4056

Lanev, V. S. OP-1777

Laney, R. L. WRI 91-4185

Lanfear, K. J. W 2400; OF 92 0652, 93-0029

Lang, S. M. W 1536-C

Langbein, J. O. OP-569, 1555

Lange, L. M. OF 92-0594; OP570

Langenheim, V.E. OF 93-0217A, 93-0217-B

Langer, W. H. C 1110; OF 92 0514

Langevin, Y. OP-1163

Langseth, M. G. OP-243, 1626

Lanphere, M. A. OF 93-0299, 93-0327; OP-296, 826, 845, $1165,1340,1407$

Lanson, Bruno OP-1627

Lapcevic, P. A. OP-571

LaPierre, Henriette OP-1628

Large, D. E. OP-787

Largo, A. J. OF 92-0686

LaRock, E. J. OF 93-0207; OP1629

Larsen, Birger OP-I 145, 1630

Larsen, C. E. B 2039

Larsen, M. C. C 1086; OF 920150; OP-1631, 1632

Larsen, S. C. OP-90

Larson, K. S. YR

Larson, P. B. OP-1633

Larson, R. L. OP-1115

Lasaga, A.C. OP-572, 1737, 1738

Latkovich, V. J. OF 92-0134, 93-0058, 93-0071

Laudon, T. S. OP-1027

Lauer, D. T. C 1086

Laul, J. C. OP-1770, 1771

LaVoie, Dawn OP-413

Law, B.E. OF 93-0337; OP$674,1244,1634,1635,1636$

Lawlor, S. M. WRI 90-4161; OF 89-0583

Lawrence, E. P. OP-1052

Lawrence, R. D. OP-1125, 1637

Lawson, C. A. YR

Lawson, D. E. OF 92-0706; OP1298,1801

Lawton, T.F. OP-573

Lay, Thorne C 1031; OP-1034 
Layman, T. B. WRI 91-4150 91-4152, 92-4103

Le Compte, J. R. DDS-0006

Lea, D. W. OP-925

Lea, P. D. OP-1059

Leach, D. L. OF 92-0704; OP$574,575,1416$

Leahy, P. P. OP-576, 1638

Leake, S. A. OP-1639, 1640

LeaMond, C. E. OF 91-0180

Learned, R. E. YR; OF 930178, 93-0179

Leavesley, G. H. C 1086; OP577,1820

LeBlanc, D. R. OF 92-0143

LeCain, G. D. W 2388

Leckie, J. O. OP-974

Lecuyer, C. OP-1628

Ledbetter, Jacquelyn OP-413

Ledbetter, M. T. OP-340

Leder, J. J. OP-1930

Ledesert, B. OP-1026

Lee, F. N. W 2340

Lee, F. T. B 2043

Lee, G. K. B 2035, 2039; C 1088; OF 93-0207; I-2050 F; OP-589

Lee, H. J. B 2002; OP-516, $578,579,1641,1864,1966$

Lee, K. K. YR

Lee, K. Y. OP-1642

Lee, M. W. OF 92-0680, 930264; OP-1337, 1532, 1533, 1931, 1932

Lee, R. W. WRI 92-4092; OP1706

Lee, Susan P 1240-B

Lee, T. M. WRI 91-4180

Lee, W. H. OF 92-0441, 92 0561, 92-0597, 92-0598, 930216; OP-1183

Leenheer, J. A. OP-1643, 1644, 1645

Lehmann, E. K. OF 92-0514

Lehr, J. D. OF 92-0514

Leidy, V. A. WRI 92-4094; OF 93-0150

Leighton, D. A. WRI 91-4119

Leiker, T. J. OP-580

Leinz, R. W. OP-581, 582

Leith, W. S. OP-1646

LeMasurier, W.E. OP-65

Lemeshewsky, G. P. C 1086

Lemke, R. W. B 2002

Lemon, E. M., Jr. I-1935

Lennon, G. P. WRI 90-4151

Leo, G. W. OP-1106

Leonard, G. J. OP-1647

Leonard, J. N. OP-186, 187 $188,189,190,191,192,193$ $194,195,196$

Leopold, E. B. OP-120

Lepp, R. L. W 2400

Lerch, H. E. OP-1477, 1478, 1763,1764

Lerman, Abraham OP-869

Leslie, M. A. OP-1484

Lesney, L. L. OP-1648

Lesure, F. G. B 1979; MF$2203,2213,2214,2223$

Lettis, W. R. OF 93-0223, 93 $0224,93-0225$
Letunova, S. V. OP-583

Leventhal, J. S. C 1086; OF 92 0445 ; OP-441, 584, 713 714,1649

Levesque, V. A. OP-895

Levine, J. R. OF 92-0568

Lew, Melvin OF 92-0161, 930154

Lewan, M. D. OF 92-0539-D, 93-0177

Lewelling, B. R. WRI 93-4002

Lewis, A. J. OF 93-0210

Lewis, R. S. OF 92-0550, 93 0214; OP-1650

Lewis, S. D. OP-585, 586, 587, $819,820,821,822,823,824$ 825,1651

Lewis, S. E. OP-1147, 1351

Leyendecker, E. V. OP-1108

Li, C. OP-1978, 1979

$\mathrm{Li}$, Song-Lin OF 92-0723

Li, W. H. OP-144, 752

Li, Yong OP-1652

Libby, B. J. OP-1208

Libra, R. D. OP-588

Lichte, F. E. B 1770; OP-1653

Lico, M. S. OP-995

Lidke, D. J. B 1993; I-2050-F

Lidz, B. H. OF 92-0508; OP-

Lieblich, D. A. WRI 92-4012, 92-4056

Lief, C. J. I-2089-C, 2090-C, 2091-C

Lienkaemper, J. J. OP-23

Liestol, Olav P 1386-E

Light, T. D. OP-589

Likhachev, A. P. OP-1313, 2014

Lilje, Anne OP-931

Lillis, P. G. OP-1255, 1265

Lin, Jian OP-966

Lind, C. J. OP-590, 591, 592

Linde, A. T. P 1550-C

Lindh, A. G. OP-1581

Lindholm, G. F. OF 91-0098; HA-0551; OP-1654

Lindner-Lunsford, J. B. WRI 91-4199

Lindsay, J. R. B 1770

Lindsley-Griffin, Nancy OP586

Lindstrom, M. M. OP-2025

Lindt, John OF 93-0150

Lindvall, S. C. OP-593, 931,

Lineback, J. A. I-1420 (NJ-15)

Ling, Chi-Hai OP-1655

Lingineni, Srinivasa OF 930210

Link, P. K. OP-594, 941

Linker, M. F. OP-259

Linn, L. J. OP-925

Lins, H. F. P 1177-B; C 1086; OF 93-0036

Linsley, B. K. OP-587, 819, $820,821,822,823,824,825$

Linton, R. C. B 1981

Lipin, B. R. OP-595, 1013, 1656

Lipman, P. W. OF 92-0710, 92 0711; OP-91, 124, 490, 596, 1825
Lippman, M. J. OP-51

Lippmann, M. J. OP-1657

Lisle, R. E. OP-817

Lisowski, Michael P 1550-C OP-752, 882, 883, 1658

List, J. H. OF 92-0530, 92-0722

Liszewski, M. J. OF 92-0085, 92-0174

Litke, D. W. WRI 92-4030

Little, L. OP-1387

Litwin, R. J. OF 92-0262,92 0263; OP-597, 1075, 1659, 1660,2002

Liu, H. OP-1183

Liu, Jun OP-1173

Liu, Lanbo OP-1661

Livingston, G. P. C 1086

Livingston, R. K. OP-598

Livo, K. E. OF 91-0449-A, 91 0449-B, 91-0449-C, 91-0449D, 91-0449-E, 91-0449-F, 91-0449-G

Lizeca, J. L. B 2039

Llamas, M.R. OP-599, 1077 , 1078

Lobato, Jorge OP-279

Lobmeyer, D. H. OF 91-0493

Locke, G. L. OF 93-0062

Locker, S. D. OF 92-0530; OP1662

Lockhart, A. B. B 1966

Lockner, D. A. OP-600, 601, $602,603,1029,1721$

Lockwood, J. P. OP-903, 1011

Loferski, P. J. OP-604, 1663

Logan, R. L. OP-904

Lomax, A. OF 92-0441

Loney, R. A. OP-1195

Long, Austin OP-605

Long, D. T. OP-1706

Long, H. K. OF 93-0032

Long, K. F. OP-1227

Long, K. R. OF 92-0705, 930228

Longstaffe, F. J. OF 92-0525

Longsworth, S. A. OF 92-0468

Lopes-Gautier, R. OP-1217

Lopez, D. A. I-1803-H

Lopez, N. C. YR; OP-606

Lopez, Yolanda MF-2242

Lopez-Escobar, Leopoldo OP279

Lorca, Emilio OP-53

Lorenson, T. D. OP-1412, 1616

Lorenz, D. L. WRI 90-4150; OP-1664

Loskot, C. L. OF 90-0369, 92 0028

Loubere, Paul OP-271

Lough, R. G. OF 92-0566; I2279-B

Louthian, B. L. OF 93-0122

Lovelace, J. K. OF 92-0492; OP-607

Loveland, T. R. C 1086

Lovley, D. R. OP-183, 608, $1207,1426,1665$

Low, W. H. W 2400

Lowe, Mike P 1519

Lowery, Birl OP-22

Lowry, M. E. WRI 90-4154
Lowther, R. A. WRI 92-4155

Lu, J. OP-1666

Lucas, S. G. OP-573

Lucchitta, B. K. C 1086; OP$609,610,1235,1408,1667$ 1668,1669

Lucchitta, Ivo OP-611

Lucey, K. J。 OP-612

Lucey, P. G. OP-1482, 1830, 1974

Lucius, J. E. OF 92-0527; OP36

Luckey, R. R. OF 91-0493

Ludden, J. N. OP-361

Ludington, S. D. B 2039; YR; OP-106, 218

Ludtke, A. S. WRI 92-4075

Ludwig, A. H. WRI 93-4013

Ludwig, K. R. C 1086; OF $92-$ 0543; OP-294, 613, 916 , 1457,1670

Luedke, R. G. I-2291-A

Luepke, Gretchen OF 92-0703, 93-0341, 93-0345

Luetgert, J. H. OF 92-0723, 93 0319, 93-0347; OP-460, 461, $521,1525,1920$

Lugo, R. V. OF 93-0298

Lull, J. S. I-2164

Lum, M. G. W 2400

Lumb, A. M. WRI 93-4076

Lumia, Richard WRI 92-4042

Lund, Karen I-2299; OP-614, 1671

Lund, W. R. OP-905

Lundberg, N.S. OP-1908

Lundegard, P. D. OP-533, 615

Luo, Guangwei OP-540

Luoma, S. N. OF 92-0456, 920494

Luza, K. V. I-1420 (NJ-14), $1420(\mathrm{NJ}-15)$

Lyle, Mitchell OP-878

Lynch, D. D. WRI 92-4034

Lyons, P. C. OP-616, 1293, $1672,1673,1769,2034$

Lyttle, P. T. B 1994; OP-1106, 1612

\section{$\mathbf{M}$}

M'Gonigle, J. W. GQ-1724; OP-617

Ma, Zongjin OP-541

Maat, P. B. OF 93-0273

Macbeth, Alec OP-394

MacCarthy, Patrick OP-1644

MacDonald, C. G. OF 92-0391; OP-1516

MacDonald, D. I. OP-1317, 1446

Macdonald, J. K. WRI 91-4119

Macdonald, K. C. OP-432

MacDonald, R. A. YR

Macdougall, J. D. OF 92-0525

Machette, M. N. B 2032-A 2032-B; OF 93-0338; OP-75, $618,619,620,621,622$

Maciel, G. E. OP-410

Mack, F. K. OF 92-0459, 92 $0460,92-0461,92-0462,92$ 0463, 92-0464 
Mack, G. H. OP-573

Mack, T. J. WRI 90-4161, 914177; OF 89-0583

Mackay, Kevin OF 93-0342-A, 93-0342-B

Macke, D. L. B 1917-M

MacKinnon, D. J. OP-1674

MacLachlan, M. E. DDS-0006

MacLay, R. W. OP-1675

MacLeod, C. L. OP-350

MacLeod, N. S. I-1946; OP-731

MacNish, R. D. OF 93-0054

Madden, T.R. OP-766

Madden-McGuire, D. J. C 1094; MF-2227; OP-623. 624

Madole, R.F. C 1086; OP-1676

Madrid, R. J. OP-796, 797

Madsen, G. E. P. 1519

Maertz, D. E. OF 93-0129

Maest, A. S. : OP-534, 535, 625, 1574

Magaritz, Mordeckai OP-234

Magee, M. E. OF 92-0715; OP752,1762

Magner, J. E. OF 93-0187

Magoon, L. B. B 2034-A; OP626

Maguire, P. K. OP-2, 521

Mahan, S. A. OP-643, 774

Maher, B. J. OP-627

Mahon, G. L. W 2340

Mahoney, E. N. OF 92-0135

Major, R. P. OP-928

Malcolm, R. L. OP-628

Maldonado, Andrés OP-722, 723

Maldonado, Florian OF 930003; GQ-1712, 1713

Maley, R. D. OF 93-0101; OP2028

Malilay, Josephine OP-1092

Mallard, G. E. OF 93-0418; OP-

Mallory, M. J.' P 1410-G

Malone, S. D. OP-438

Maloney, T. J. WRI 92-4075

Mamet, B. L. B 1787-EE, 1988$F$

Mandle, R. J. P 1405-C

Manduca, C. A. OP-630

Mangan, M. T. OP-631

Manheim, F. T. OP-1502, 1677

Mankinen, E. A. OP-632, 633

Manley, W. F. OP-719

Mann, G. M. OP-634

Mann, L. J. WRI 92-4196; OF 92-0174

Mann, Paul OP-808

Mann, W. B., IV OF 93-0120

Manning, C. A. OF 92-0496, 93-0136, 93-0166, 93-0167. 93-0424, 93-0425, 93-0427, 93-0428, 93-0429, 93-0430, 93-0431, 93-0432

Manning, C. E. OP-635, 636

Mañón M., A. OP-1657

Manydeeds, Stephen OF 92 0514

Manzano, M. OP-1310

Mao, Shaozhi OP-243

Mapel, W. J. OP-17
Marbury, G. S. OP-1873

March, G. D. OF 92-0560-A, 92-0560-B; OP-1678, 1802

Marchig, Vesna OP-243

Marcino, Anthony OF 91-0014

Marcoux, J. P. OP-361

Marcus, S. M. OP-1679

Marella, R. L. WRI 91-4I23, 92-4140

Margat, Jean OP-599

Marin, L. E. OP-920

Marincovich, Louie, Jr. OP1680,1681

Mariner, R. H. OP-536, 637, $638,997,998$

Mark, R. K. C 1086; OF 930213; I-1257-M; OP-396, 693,1682

Markewich, H. W. OF 93-0273, OP-1683

Marlow, M. S. OF 92-0206 OP-1, 211, 242, 307, 639

Marlowe, J. I., II B 1979

Marone, C. J. OP-640

Marquez, Nicholas OP-373, 1445

Marr, J. D., Jr. OF 93-0244

Marron, D. C. OP-641

Marsaglia, K. M. OP-586

Marsh, B. D. OP-1294

Marsh, S. P. OP-642

Marshall, B. D. OF 93-0336; OP-643, 774

Marshall, G. A. OP-752

Marshall, M. P. OF 92-0473

Marshall, R. D. OF 90-0677

Marshallsea, S. J. OP-1136

Martens, C. S. OP-151, 1684

Martin, Angel, Jr. WRI 914109; OF 92-0492

Martin, C. R. OF 93-0052

Martin, J. A. OP-644

Martin, J. B. OP-186, 187, 188, $189,190,191,192,193,194$, 195,196

Martin, J. D. W 2400; OP-1685

Martin, J. G. OP-605

Martin, J. R. P 1536

Martin, P. M. W 2340; OF 93 0524; OP-474

Martin, T. Z. OP-1210

Martin, W. C. OF 92-0492

Martinez-Rodriguez, J. I. OP$186,187,188,189,190,191$, $192,193,194,195,196$

Martino, R. L. OF 92-0558

Marumo, Katsumi OP-243

Marvinney, R. G. OP-1530

Marz, John B 2013

Marzolf, G. R. OP-645

Maslanyj, M.P. OP-1317, 1446

Mason, R. R., Jr. W 2403; WRI 92-4097

Masson, D. G. I-2090-A, 2090B; OP-886

Masson, P. L. OP-142, 1163

Mast, M. A. OP-524, 1573

Mast, R. F. B 1909; OP-34, $435,449,862,1265$

Masters, C. D. OP-449, 646, 1686

Masters, J. M. OF 92-0514
Masterson, J. P. WRI 90-4182

Mastin, L. G. OP-647

Masuda, A. OP-2025

Matheson, S. M. B 2013

Matic, A. K. OF 91-0640

Matson, D. L. OP-1217

Matson, L. L. OF 93-007.1

Matsuda, Jun-ichi OP-550

Matsuoka, Iwao WRI 92-4099

Matsushima, Yoshiaki OP-720

Matthews, M. V. OP-648, 1812

Matthews, R. D. B 1909

Matti, J. C C 1111; OF 92 0446; OP-649, 703, 804

Mattick, R.E. OP-1687

Mattinson, J. M. OP-333

Matzko, J. R. OF 93-0501

Maughan, E. K. OF 93-0248, 93-0337

Mauk, J. L. OF 92-0391; OP1204,1688

Maurasse, F. J. OP-1873

May, B. A. OF 93-0094

May, H. M. OP-650, 1689

May, L. OP-1873

May, S. D. C 1086; OP-1429

Mayer, Adriano OF 93-0504

Mayio, A.E. W 2400

Mayo, L. R. C 1086; OP-651

Mayor, J. N. OF 93-0183

Mays, R. E. B 1770

Mazdab, F. K. OP-1690

Mazzella, A. T. OP-369

Mazzu, L. OP-990

Mazzullo, E. K. OP-361

McAda, D. P. OF 93-0144

McArdle, Jerome W 2400

McAuley, S. D. OP-652

McBride, R. A. OF 92-0530, 93-0210

McCabe, G. J., Jr. W 2400; C 1086; OF 92-0052; OP1964,2011

McCabe, P. J. OP-653, 850, 919

McCaffrey, K. J. OP-1691

McCammon, R. B. OP-317, 654,655

McCarthy, Jill YR; OF 93-0301

McCauley, J. F. OP-314, 847

McCollough, W. F. I-2299

McConnaughey, E. A. OP-925

McConnell, J. B. W 2400

McCord, T. B. OP-1163, 1217, 1486

McCord, V.A. OP-1060

McCormick, Michael OF 930019; OP-836, 837, 1143 1344

McCrory, P. A. MF-2212

McCulloch, D. S. I-2090-A, 2090-B

McDanal, S. K. MF-2217-A, 2217-B

McDermott, M. H. OP-1692

McDonnell, Rebecca OF 910014

McDougall, Ian OP-446, 656

McDougall,Kristin OF 930180; OP-837

McDowell, R. C. OF 93-0024; OP-1147
McEwen, A. S. OP-277, 366 $416,657,783,1162,1437$. $1438,1439,1485,1486$, $1487,1497,1693,1694$, 1695, 1696, 1697, 1781, 1974

McEwen, R. B. C 1086

McFaden, Dennis OF 91-0014

McFarland, E. R. OP-658

McFarland, J. D., III · MF-1994-

McFarland, M. C. OF 92-0514; MF-1994-D

McFarland, W. D. OP-659

McFarlane, R. D. OP-312

McFaul, E. J. OF 91-0014

McGarr, A. F. OP-660

McGee, E. S. OF 92-0541

McGee, J. J. OP-373, 661, 681, 1392, 1445, 1613, 1698

McGee, K. A. B 1966

McGeehin, J. P. B 1981; OF 930273

McGill, G. E. OF 93-0516; OP1851

McGill, P. R. P 1550-C

McGill, S. F. OP-931

McGimsey, R. G. OP-1699, 1739

McGonigle, J. W. I-2168

McGovern, H. E. HA-0722-G

McGregor, B. A. B 2002; OP$1012,1443,1444$

McGregor, J. K. DDS-0008; OF 92-0391; OP-1516

McGurk, J. M. OF 93-0575

McHugh, J. B. OF 92-0615, 930527; OP-315

McIntosh, W. C. OP-573

McKallip, T. E. W 2400

McKee, E. H. B 2039; OF 920525, 93-0519, 93-0538; OP$204,205,342,627,662,736$, $875,1212,1238$

McKee, M. J. C 1111

McKelvey, G. E. OF 92-0567

McKenney, R. A. OP-1544, 1700

McKenzie, S. W. C 1090; OF 91-0453, 91-0454, 92 0644; OP-1827

McKinley, P. W. OP-663

McKinney, J. E. OF 92-0633

McKnight, D. M. WRI $92-$ 4081; OP-538, 664, 1579, 1644

McKown, D. M. B 1770

McLaughlin, M. W. OF 920426

McLean, Hugh B 2034-A; OP1701, 1971

McLellan, M. W. OC-0140

McLelland, J. M. OP-1316

McLeod, Chris OP-413

McMahon, P. B. OP-1202, 1239

McMahon, T. A. OP-1036

McManus, B. C. WRI 91-4182, 92-4194

McMillan, N. J. OF $92-0528$

McMinn, Andrew OP-361

McNamee, James OP-1306

McNeal, J. M. DDS-0001

McNeil, D. H. OP-1796

McNulty, B. A. OP-1413 
McNutt, R. H. OP-737

McNutt, S. R. OP-1714, 1802

McPherson, R. OP-752

McRae, Mac OP-1918

McWilliams, M. O. OP-1702

McWreath, H. C. OF 92-0492 OP-665

Meade, R. H. OF 91-0485, 92 065 1; OP-666

Meador, M. R. OF 93-0104

Meadows, J. K. WRI 91-4142

Measures, E. A. OP-1703

Mechie, James OP-2, 521

Medrano, M. D. B 1995-C

Mee, J. S. OF 93-0281, 93-0314

Meeker, G.P. OP-667, 1389 , 1704,1705

Megard, R. O. OP-250, 668

Megeath, J. D. B 1909

Mehlman, R. OP-1217

Mehtab-ur-Rahman OF 92-0576

Meier, A. L。 OF 92-0721; OP$375,948,1182,1656$

Meisling, K. E. OP-1063

Meissner, B. D. OP-1706

Melcher, N. B. C 1120-A; OP669

Mello, K. A. OP-733

Mellor, G. L. OP-483

Melnikov, A. OP-1494

Mendes, R. V. OF 93-0533

Mendes, T. M. OP-1947

Mendoza, Carlos OP-670

Meng Qingren OP-1238, 1343

Menger, Stefan OP-186, 187, $188,189,190,191,192,193$ $194,195,196$

Menzie, W. D. OF 93-0280; OP-162, 273

Menzies, M. A. OF 92-0525

Mercier de Lepinay, Bernard OP-1901

Meremonte, M. E. OP-1300, 1423

Merewether, E. A. OF 93-0337

Merk, D. A. OF 92-0475, 930127

Merrill, D. L. OP-587, 819, $820,821,822,823,824,825$

Merritt, M. L. OP-671, 672

Mesander, B. A. OF 92-0641

Meschede, Martin OP-186, $187,188,189,190,191,192$. $193,194,195,196$

Mesko, T. O. OP-1707

Mesmer, R. E. OP-305

Messerich, J. A. OF 92-0391

Mestayer, J. T. OF 92-0530

Metz, G. W. OP-25

Metz, J. M. I-1995

Metzker, K. D. OF 92-0653

Meyer, C. E. C 1086; OP-634, 831

Meyer, D. F. OF 93-0094; OP1708

Meyer, H. J. OP-731

Meyer, M. T. OP-1000

Meyer, R. F. OF 92-0391

Meyer, R. P. OP-2, 521

Meyer, R. W. OF 92-0144

Meyers, M. T. OF 93-0418
Meyers, P. A. OP-532, 1576

Mezcua, J. OP-1372

Mezger, Klaus OF 92-0525; OP-158, 1246, 1709

Michael, A. J. OP-286, 438, 673

Michael, G. E. OP-674

Michaels, P. J. C 1086

Michaels, W. L. OF 92-0566

Michalski, T. C. OF 92-0391

Michaud, F. OP-1330, 1901

Michel, R. L. OF 93-0083; OP$147,474,519$

Middelburg, R. F. W 2400

Middleton, G. K. OP-255

Midgett, M. R. OP-675

Mielke, P. W., Jr. OP-754

Mikesell, J. L. OF 92-0544; OP1741

Mikita, M. A. OP-1951

Miklius, Asta OF 92-0686; OP252,1759

Mikulic, D. G. OF 92-0514

Mikumo, Takeshi OP-676

Milbert, D. G. OP-1780

Mileti, D. S. P 1553-B; OP-677

Milici, R. C. OP-506, 1751

Milkereit, Bernd OP-1533

Millar, I. C. OP-1317, 1446

Millard, H. T., Jr. B 1770; C 1086; OF 93-0273; OP1359,1683

Miller, A. J. B 1981

Miller, B. M. B 2025, 2048; OP-1035, 1710

Miller, C. F. OP-512, 678, $1566,1691,1711$

Miller, C. P. I-2089-C, 2090-C

Miller, D. M. OF 91-0435, 930198; OP-679, 680, 809, 1776

Miller, F. K. OP-1067

Miller, G. H. OP-515

Miller, G. K. OF 92-0693, 92 0719, 93-0007

Miller, J. B. WRI 92-4084

Miller, J. D., Jr. OP-758

Miller, J.F. OP-1712

Miller, J. J. OF 92-0391, 920680, 93-0005, 93-0226; OP92,1842

Miller, K. A. OF 93-0142; OP711

Miller, K. C. OF 93-0347

Miller, K. G. OP-979

Miller, L. G. OP-625, 949, 1713

Miller, M. L. OP-123, 1203

Miller, M. M. OP-797

Miller, R. G. OP-1014

Miller, R. J. OF 91-0435

Miller, R. T. P 1530-A

Miller, S. P. OP-432

Miller, T.P. YR; OP-826, 1469 $1714,1739,1754,1929$

Miller, T. R. OP-1513

Miller, W. A. W 2340

Miller, William OF 91-0014

Millgate, M. L. OF 92-0369-A, 92-0369-B

Milliman, J. D. OP-1073

Mills, P. C. W 2386, 2390

Milly, P. C. C 1086
Milton, Charles OP-681

Milton, Leanne OP-616

Minard, J. P. OF 93-0233

Minasian, D. L. OF 93-0189, 93-0302; I-1946

Minervini, William W 2400

Minkin, J. A. OP-153, 1238

Minor, S. A. OF 93-0299

Minster, J. B. OP-90

Mirecki, J. E. WRI 91-4173

Misawa, Keiji OP-1956, 2025

Mixon, R. B. OP-791, 1788

Miyaoka, R. T. OF 92-0594

Mizon, K. J. OP-375

Modreski, P. J. OP-682, 1715

Moench, A. F. OP-683, 684

Moench, R. H. OP-1105

Moffett, A. M. OF 92-0550, 930214; OP-800

Mogk, D. W. OP-685, 1716, 1731

Mogli, Sudish OF 93-021.0

Mohrig, D. C. OP-1717

Molenaar, C. M. B 1787-Q OF 93-0248; I-1797-D; OP74

Moll, S. H. I-2050-F; OP-589

Moll-Stalcup, E. J. OF $92-$ 0525; MF-2226-A; OP-1401

Molling, P. A. OP-1927

Molnia, B. F. C 1086; OF 930266; OP-686, 687, 1718, $1719,1789,2008$

Molnia, C. L. OC-0140

Moncrieff, J. B. OP-507

Monical, J.E. OF 92-0108

Mons-Wengler, M. C. OF 920585

Montgomery, L. T. OP-311

Monzier, Michel OP-197

Moody, D. W. W 2400; OP-548

Moody, J. A. OF 91-0485, 92 $0651 ;$ OP-1720

Moody, J. B. OP-51

Mooney, W. D. OF 93-0319, 93-0347; OP-2, 521

Moorbath, Stephen OP-971

Moore, A. L. OP-36

Moore, B. L. WRI 92-4150; OF $92-0638$

Moore, D. OP-1026

Moore, D. E. OF 93-0245; OP$603,688,689,1721$

Moore, D. G. C 1086

Moore, D. W. OF 92-0391, 92 $0589,93-0190 ; \mathrm{I}-1420$ (NG14), 1420 (NH-14)

Moore, H. J. OP-690, 887, $1062,1722,1723,1724$ 1725,1851

Moore, J. E. OP-691, 692

Moore, J. G. B 2002; MF-2231, 2233; OP-511, 693, 694

Moore, Jeffrey OP-509

Moore, R. B. OF 92-0095, 93 0512-A; I-2408, 2420; OP1962

Moore, R. C. OF 93-0003

Moore, T. A. OP-228, 695, 870, 1305,1513

Moore, T. C. OP-898, 1532, 1597
Moore, T. E. OP- 1430

Mooty, W. S. W 2400; OP-46

Moran, M. J. OP-361

Moran, M.S. OP-562

Morel-á-l'Hussier, Patrick OP1215

Morey, G. B. OF 92-0514

Morgan, A. V. OP-163

Morgan, F. D. OP-766

Morgan, G. B., VI OP-696, 1726, 1773

Morgan, H. F. OP-1594, 1595, 1596

Morgan, J. W. OF 92-0525; OP1621, 1727, 1913, 1977, 1978, 1979

Morgan, L. A. OP-697, 780

Morganwalp, D. W. YR

Mori, J. J. OF 93-0216, 930227; OP-502, 503, 698, $699,700,931,1728,1729$

Morin, R. H. WRI 92-4184

Morin, R. L. OF 93-0215

Moroz, V. I. OP-1163

Morris, A. J. WRI 9 I-4195

Morris, E. E. OF 93-0070

Morris, J. E. OF 92-0105

Morrison, H. F。 OP-766

Morrison, J. L。 OP-701

Morrison, M. S. OP-418

Morrison, T. D. OF 93-0144

Morrissey, L. A. C 1086

Morrow, C. A. OP-702

Morrow, J. R. I-1943

Mortensen, C.E. YR

Mortensen, J. K. OP-1097

Morton, D. M. OF 92-0446; OP-649, 703, 1126

Morton, R. B. WRI 88-4208

Mosenfelder, J. L. OP-1173

Moses, M. J. OF 93-0238, 93 0276, 93-0318

Mosier, D. L. OF 93-0280

Mosier, E. L. OF 92-0520, $92-$ 0573-A, 92-0573-B; OP-1418

Moss, M.E. C 1086; OP-704

Mossa, Joann OF 92-0530

Mossler, J. H. OF 92-0514

Mossman, D. J. OP-713

Mossotti, V. G. C 1086; OF $92-$ 0391

Motooka, J.M. OF 90-0672, 92-0315, 92-0379-A, 920380-A, 92-0380-B, 92 0552, 92-0709, 92-0721

Mottl, M. J. OP-243

Mouginis-Mark, P. J. OP-1831, 1832

Moy, Wai-See OF 93-0268-A, 93-0268-B

Moyer, L. A. OP-1730

Mueller, D. K. WRI 92-4053; OF 93-0418

Mueller, P. A. OP-685, 705, 1607, 1716, 1731, 2016, 2017

Mueller, R. J. P 1550-C; OP1555

Muffler, L. J. OP-1447, 1732

Muhs, D. R. C 1086; OP-706, 707

Mukinya, J. OP-521 
Mularoni, R. A. OF 92-0471, 92-0472, 93-0049, 93-0053

Mulilis, John-Paul P 1553-B

Mull, D. S. WRI 92-4195

Mullen, M. W. C 1086; OF 92 0426

Müller, Carla OP-587, 819, $820,821,822,823,824,825$

Muller, E. H. I-1420 (NK-18)

Mullineaux, D. R. P 1240-B

Mullins, J. L. YR

Mullins, K. F. OP-1402

Mulvany, JoAnn OF 91-0014

Munguia, L. OP-438

Munson, C. A. P 1536

Munson, P. J. P 1536

Murali, A. V. OP-1702

Murchey, B. L. B 1988-D; OF $92-0580 ;$ OP-8, 56, 78, $385,402,708,1733$

Murchie, S. L. OP-366, 416, $783,1437,1438,1487$

Murdoch, P. S. OP-975, 1130 , 1734, 1735

Murdock, C. R. DDS-0006

Murillo, Fernando B 2039

Murillo, M. M. OP-335

Murowchick, J. B. OP-363, 1432

Murphy, C. M. OF 93-0533

Murphy, J. L. YR

Murphy, J.M. OF 92-0570; MF-2226-A

Murray, H. E. OP-742

Murray, H. H. OF 92-0514

Murray, L. C. OF 92-0466, 930050

Murray, M. H. P 1550-C; OP752

Murray, P. D. OF 92-0161, 93 0154

Murray, P. M. WRI 92-4042

Murray, T. L. B 1966; OF $92-$ 0560-A, 92-0560-B, 930022; OP-1678, 1772

Murrell, M. T. OP-978, 1778

Musgrave, R. J. OP-586, 1651

Mussett, A. E. OP-521

Mustard, J. F. OP-416, 1497

Mutterlose, Jörg OP-361

Mutti, Emiliano OP-709, 710, 738

Mwango, F. OP-521

Myers, B. M. OP-647

Myers, D. N. WRI $92-4130$

Myers, L. V. OF 93-0094

Myers, N. C. WRI 92-4169, 92 4177

Myers, R. G. WRI 92-4004; OF 92-0465

Mysen, B. O. OP-595, 1013

\section{$\mathbf{N}$}

Nabelek, J. N. OF 93-0319, 930347

NacLeod, N.S. OF 93-0302

Naeser, C. W. OP-27

Naeser, N. D. B 1917-O; OF 92-0391; OP-1539

Naftz, D. L. OP-711, 712, 1736,1871
Nagao, Keisuke OP-550

Nagel, Engelbert OP-366, 416

Nagy, B. S. OP-713, 714

Nagy, K. L. OP-1737, 1738

Nakai, Shun' ichi OF 92-0525

Nakama, L. Y. WRI 92-4114

Nakata, J. K. OP-1748

Naldrett, A. J. OP-1978, 1979

Nalley, G. M. WRI 92-4117

Nash, J. T. OP-205, 489, 715, 716

Nassickhuk, W. W. OP-354

Natividade, J. R. OP-666

Nava, S. OP-438

Navrotsky, Alexandra OP-112, 1690

Nawyn, J. P. OP-986

Neal, C. A. OP-432, 1714, 1739,1772

Neal, Colin OP-161

Nealey, L. D. MF-2230

Nederbragt, Alexandra OP-587, $819,820,821,822,823,824$, 825

Needham, R. E. OP-940

Neff, K. C. OP-717

Negrini, Luisa OP-1808

Negrini, R. M. OP-1404

Neil, S. T. B 1770

Nelms, D. L. OP-400

Nelsen, C. OP-1424

Nelson, A. E. OF 92-0725; GQ1705; MF-2215-A; OP-1106

Nelson, A. R. I-2199; OP-621, $718,719,720,756$

Nelson, B. K. OP-721

Nelson, C. H. OP-722, 723, $1740,1864,1966$

Nelson, C. V. P 1519

Nelson, G. L. OF 91-0458

Nelson, J. D. OF 92-0492

Nelson, K. R. OP-1761

Nelson, P. H. OF 92-0544, 92 0572; OP-724, 1741

Nelson, S. W. OP-224, 721, 1169

Nelson, Steve OP-279

Nelson, W. J. OP-1742

Nestell, M. K. OP-87

Neukum, Gerhard OP-366, $416,657,783,1437,1438$, $1439,1485,1486,1487$, $1497,1697,1781$

Neuzil, S. G. OP-1743

Newell, K. D. OP-725

Newell, N. D. OP-354

Newhall, C. G. OP-726, 1768, 1953

Newkirk, S. R. OP-570

Newman, Sally OP-43, 631

Newton, T. W. OP-305

Ni Pei OP-456

Nichols, D. J. OF 92-0391; OP$1388,1550,1744,1745$

Nichols, D. R. P 1240-B; OF $92-0693$

Nichols, G. J. OP-587, 819 , $820,821,822,823,824,825$

Nichols, K. M. B 1988-G

Nichols, W. D. OP-727

Nicholson, Craig OP-1746
Nicholson, R. S. OP-652

Nicholson, S. W. OF 92-0525; OP-139, 728, 1747

$\mathrm{Nie}, \mathrm{D}$. OP-729, 946

Nielsen, D. T. OF 92-0524; OP1350

Nielson, D. R. B 2013

Nielson, J. E. OF 91-0435; OP730,1748

Niem, A. R. I-1946; OP-159, 731

Niem, W. A. OP-159, 731

Niemeyer, Sidney OP-132

Niles, H. B. OF 92-0514

Nilsen, T. H. P 1521; OP-679, 1749

Nilsson, Kristen OP-413

Nimmo, J. R. OP-732, 733

Nimz, G. J. OP-132

Nishenko, S.P. OP-734, 735

Nishi, Hiroshi OP-413

Nishi, J. M. B 2039; OP-1540

Nishiizumi, Kunihiko OP1750,2025

Noble, D. C. OP-736, 1212

Noble, M. A. OF 92-0382, $92-$ 0555, 93-0011; OP-346, 404

Noji, Eric OP-415

Nokleberg, W. J. P 1497-C; OF 92-0594, 93-0339; I2164; MF-1996-E; OP-570

Nolde, J. E. OP-1751

Noll, P. D., Jr. OP-203

Noller, J. S. OF 93-0223, 930224, 93-0225

Nord, G. L., Jr. OP-112

Nordstrom, D. K. OP-625, 737, $974,1042,1110,1218,1752$

Normark, W. R. B 2002; I2089-C, 2090-C, 2091-C; OP-238, 694, 709, 710, 738 743

Northrop, H. R. OP-289, 441

Norton, D. R. OF 93-0083; OP930

Novak, Elizabeth OF 92-0586

Novak, S. W. GQ-1730

Novakowski, K. S. OF 930071; OP-571

Noyes, T. I. OP-1645

Nozette, Stewart OP-1881, 1974

Nuccio, B.F. OF $92-0391$

Nuccio, V. F. B 1787-DD; OP1753

Nuelle, L. M. B 2039; OP-1327

Nuhfer, E. B. OP-739

Nullo, F.E. OP-1129

Nur, A.M. OP-740

Nutt, C. J. OP-741

Nyambok, 1. O. OP-2, 521

Nye, C. J. OP-1469, 1754, 1929

Nyman, D. J. OF 92-0492; OP742

\section{o}

O'Brien, D. P. OP-268, 1329

O'Brien, G. M. OF 93-0071, 93-0073

O'Brien, P. W. P 1553-B

O'Brien, T. F. OF 92-0717
O'Connell, S. B. OP-743

O'Connor, J. T. OP-1755

O'Leary, D. W. B 2002; MF2211; OP-96, 744

O'Leary, R. M. YR; OF $92-$ 0315, 92-0379-A, 92-0379. B, 92-0380-A, 92-0380-B; MF-2144C

O'Neill, Brennan OP-146, 361

O'Neill, Bridget OP-480

O'Neill, J. M. OF 91-0623; I1803-H

O'Neill, Katherine OF 93-0294

Oakley, W. T. OP-745

Oaks, A. T. OF 92-0482

Obando, J. A. OP-1272

Obel, J. OP-521

Oberhelman, M. W. OF 920514

Obermeier, S. F. P 1536

Oberst, Jürgen OP-1437, 1438, 1485

Oberti, Roberta OP-414

Oblinger Childress, C. J. W 2400

Obradovich, J. D. B 2065; OF 92-0408, 92-0699; OP$475,746,1538,1756,1757$

Obuch, R. C. OF 92-0524; OP1350

Ocampo, A.C. OP-1217

Oda, Hirokuni OP-243

Odum, J. K. OP-969, 1970

Oellermann, D. J. WRI 92-4162

Offield, T. W. B 2039; OP-1607

Ogden, A. E. OP-1283

Ogg, J. G. OP-361, 747

Ogle, K. M. WRI 91-4108

Ogrosky, Lesley OP-156

Ohnaka, Mitiyasu OP-676

Ohr, Matthias OF 92-0525

Ohta, Y. OP-1890

Okal, E. A. OP-1758

Okamura, A. T. OF 92-0686; OP-252, 1759

Okita, P. M. OP-1238, 1892

Okubo, P. G. OP-1759

Olcott, P. G. HA-0730-J

Oldale, R. N. OF 92-0551, $92-$ 0585, 93-0185; OP-748, 749

Oldow, J. S. OP-397, 1427

Olesen, Odleiv OP-1891.

Oleson, L. R. C 1086; YR

Olhoeft, G. R. OF 92-0526-A, 92-0526-B, 92-0527; OP-369

Oliva-Becerril, J. F. OP-796

Olive, W. W. OF 92-0514

Oliver, H. L. OF 93-0264

Oliver, N. H. OP-750

Oliver, W. A., Jr. B 2024

Olmore, S.D. OP-1760

Olona, Steve OP-150

Olsen, H. W. OP-1761

Olsen, K. H. OP-521

Olsen, S. N. OP-696

Olson, J. A. P 1550-C

Olson, J. R. W 2400

Olson, S. A. W 2400

Olson, S. S. OP-82

Oltman-Shay, Joan OP-751

Oltmann, R. N. W 2395 
Oman, C. L. OF 92-0682

Omang, R. J. WRI 92-4048, 924185

Ong, Kim W 2400

Oppenheimer, D. H. OF $92-$ 0441; OP-23, 673, 752, $1157,1581,1762$

Orem, W. H. OP-59, 1150 $1673,1763,1764$

Oremland, R. S. C 1086; OP$1713,1765,1766$

Oreskes, Naomi OP-1218

Oreskovich, J. A. OF 92-0514

Orheim, Olav P 1386-E

Oriel, S.S. OP-753

Orkild, P. P. OF 93-0299

Orlowski, L. A. OP-754

Orndorff, R. C. DDS-0006; OF 93-0024, 93-0575

Orris, G. J. OF 92-0593

Orth, C. J. OP-755

Ortiz-Zayas, J. R. OF 93-0106

Orzech, M. F. YR

Orzol, L. L. W 2340

Osberg, P. H. OP-1479

Oscarson, R. L. OF 92-0707; OP-849, 1313

Osozawa, Soichi OP-586

Osterkamp, W. R. OP-1004

Ostrem, Gunnar P 1386-E

Ota, Yoko OP-720,756

Ott, D. S. OF 92-0643

Otton, J. K. OF 93-0292-G, 930292-I, 93-0292-J; OP-379

Otway, P. M. B 1966

Outerbridge, W. F. OP-1293

Outlaw, G. S. OF 92-0482, 92 0648

Ovenshine, A. T. YR

Overturf, D. OP-1423

Owen, D. E. OF 93-0292-H, 93 0292-I, 93-0292-J; OP-285, 379,902

Owen-Joyce, S. J. WRI $92-$ 4133; OF 92-0083, 93-0405

Owens, J. P. OP-757, 979

Ozuna, G. B. WRI 92-4190

\section{$\mathbf{P}$}

Paces, J. B. OP-758

Padgett, Deems OP-1833

Page, B. M. OP-759

Page, N. J B 2014; OP-1107.

Page, R. A. OF 93-0309; OP$1250,1325,1384,1556$, 1618,1802

Page, W. R. OF 92-068

Paillet, F. L. WRI 92-4074, 924184; OF 93-0071; OP-571, $760,761,1030$

Pak, Connie W 2400

Palacas, J. G. OF 92-0391, 92 0524; OP-725, 1350, 1767

Pallister, J. S. B 2021-C; OP1768

Palmer, A. R. OP-797

Palmer, C. A. OP-762, 1211, 1769

Palmer, M. R. OP-763, 942 1942
Palmer-Rosenberg, P. S. OP1637

Paloc, Henri OP-40

Pampeyan, E. H. I-2173

Pandolfi, J. M. B 1988-E

Panin, G. OP-507

Pankhurst, R. J. OP-1317

Pantea, M. P. MF-2220; OP1095

Pantosti, Daniela OP-764

Papike, J. J. OP-1770, 1771

Papke, K. G. OP-765

Papp, C. S. OF 93-0014, 930243, 93-0303

Paque, J. M. OP-1705

Park, S. K. OP-766

Parker, R. A. MF-2208

Parker, R. S. C 1086; WRI 914095; OF 92-0627; OP-300, 559

Parker, T. J. OP-509, 690, 1724

Parker, T. N. OP-569

Parkhurst, D. L. OP-355, 790

Parkhurst, P. J. OP-1446

Parkhurst, R. S. OF 92-0475, 93-0127

Parkinson, D. J. B 1981

Parks, G. A. OP-51, 493, 974

Parks, J. E. OF 92-0525

Parks, W. S. WRI 91-4173; OP767

Parliman, D. J. WRI 92-4014, 92-4027; OF 92-0175

Parmenter, C. M. DDS-0003

Parrett, Charles C 1120-A; WRI 91-4199, 92-4060; OP669

Parrot, M. OP-768

Parson, L. M. B 2002; MF2083-B; OP-413, 1012

Parsonage, T. B. B 2013

Parsons, Tom OP-769

Pasilis, S. P. OP-625

Paskevich, V. F. OF 92-0536

Paskievitch, J. F. OP-1739, 1772

Pasteris, J. D. OP-696, 914, 1726,1773

Pasternak, M. P. OP-480, 770

Patchen, D. G. B 1909

Patel, J. P. OP-2, 521

Patel, S. C. OP-149

Patera, Edward OP-51

Patten, E. P., Jr. W 1536-G

Patterson, D. B. OP-446

Patterson, G. G. OF 93-0035

Patton, C. J. OF 92-0146

Patton, W. W., Jr. OF 92-0020-

Paulachok, G. N. W 2400

Paull, C. K. MF-2209; OP-151

Paulsen, P. J. OP-1980

Paulson, R. W. W 2400

Pavich, M. J. OF 93-0273; OP$48,1018,1380,1683,1774$

Pawlewicz, M. J. OF 92-0391, 92-0571; OP-50, 1137, 1910

Payás, Alba B 2039

Peacock, T. R. OF 92-0345, 93 0014, 93-0303

Peacor, D. R. OP-484, 1892
Peake, R. T. OP-378

Pearl, J. E. I-1946

Pearman, J. L. WRI 92-4147

Pearson, F. J., Jr. OP-869

Peatross, Judith OF 92-0377-A, 92-0377-B

Pechmann, J. C. OP-438

Peck, D. L. C 1086; OP-771

Peck, M. F. OP-172

Peddie, N. W. GP-1004-D, 1004-F, 1004-H, 1004-I, 1004-Z

Pedler, W. H. OP-761, 1030

Pelletier, Bernard OP-186, 187, $188,189,190,191,192,193$, $194,195,196,197,368$

Pelton, J. R. OP-970

Peltz, L. A. WRI 92-4084; OP1227

Penland, Shea OF 92-0530; I2150-A

Peper, J. D. B 1955; OF $93-$ 0244

Perala, O. J. OF 91-0453

Peralta, R. C. W 2340

Perembo, R. C. OP-186, 187, $188,189,190,191,192,193$, $194,195,196$

Perez, Ileana OF 93-0178, 93 0179

Perkins, D. M. OP-67

Perkins, W. J. OF 91-0441-T

Perlman, H. A. C 1081

Perry, C. A. OP-772, 816

Perry, D. L. OP-305

Perry, W. J., Jr. OF 92-0391, 92 $0524,93-0207,93-0337$; OP614, 1350

Person, W. J. OF 92-0583, 92 0584, 93-0204

Personius, S. F. B 2038; I2199; OP-621, 773

Pessel, G. H. I-2164

Peterman, Z. E. OP-643, 774, $1214,1560,1775$

Peters, C. A. W 2390; OP-775

Peters, E. K. OP-267

Peters, M. T. OP-1776

Peters, N.E. C 1086; WRI 934030; OF 93-0055, 93-0059; OP-776, 918, 1875

Petersen, J. C. W 2400

Petersen, R. C., Jr. OP-353

Petersen, S. W. OP-1141

Peterson, D. A. W 2400; OF 910533

Peterson, D. H. C 1086

Peterson, Fred OP-1252, 1963

Peterson, J. A. OF 93-0248, 93 0337; OP-1258

Peterson, J. C. WRI 92-4044

Peterson, M. L. OP-1065

Petrovich, Radomir OP-572

Pettengill, G. H. OP-786

Pettijohn, R. A. WRI 91-4149, $91-4150,91-4151,91-4152$, $92-4102,92-4103,92-4104$ 92-4105

Pezzopane, S. K. OP-338

Phan, L. T. OF 90-0677

Phelan, D. J. OF 92-0052, 920395
Phelps, G. G. OF 92-0466, $93-$ 0050

Philipov, G. V. OP-367

Phillips, E. J. OP-608, 1665

Phillips, J. D. DDS-0009; OP212, 1215

Phillips, P. J. OF 93-0040; OP777

Phillips, R. L. C 1086; OF 920426; OP-299, 799, 1796

Phillips, S. P. W 2396; OF $91-$ 0535

Philpotts, J. A. B 1770; OF 930267; OP-1373, 1777

Piatt, Jim W 2400

Pickens, Jim OP-279

Pickett, D. A. OP-1778

Pickthorn, W. J. OP-313, 890, 1416

Pierce, B. S. OP-778, 1779

Pierce, F. W. OC-0140

Pierce, H. A. OF 92-0547, 93$0178,93-0179$; OP-447, 779

Pierce, K. L. OF 92-0391, 920504; OP-201, 780, 978 , 1539,1780

Pierce, R. R. C 1081

Pierson, C. T. OF 93-0329

Pierson, T. C. WRI 92-4039; OP-781, 782

Pieters, C. M. OP-366, 416, $657,783,1437,1438,1439$, $1485,1486,1487,1497$, $1697,1781,1974$

Pike, R. J. OF 93-0262-A, 930262-B, 93-0262-C; I-2206; OP-1682

Pikul, J. L., Jr. OP-1028

Pilcher, C. B. OP-1437, 1438, 1485,1487

Pilipenko, V. A. OP-367

Pillmore, C. L. OF 92-0391; I2266

Pinter, P. J., Jr. OP-562

Pinto-Vasquez, José OP-1306

Piper, D. Z. B 1995-C; C 1086; OF 92-0539-C

Piper, E. M. OP-1599

Pitkin, J. A. B 1737-E; OP-447, 784

Pitman, J. K. OF 92-0391; OP1399,1782

Pitt , A. M. OP-883, 1503

Pittman, J.R. OP-147

Pitzer, K. S. OP-1919

Placzek, Gary OP-384

Plafker, George P 1497-C; I1984, 2164; OP-53, 785, 1384

Planert, Michael W 2340

Plank, Terry OP-361

Platt, L. B. OP-594

Plaut, J. J. OP-690, 786, 1724

Plescia, J. B. OF 91-0640; OP1323

Plesinger, A. OP-1783, 1784

Plimer, I. R. OP-787

Plumlee, G. S. OP- 315,788 , $829,948,1419,1785$

Plummer, L. N. YR; WRI 934054; OP-789, 790, 869, $1174,1415,1786,1787$

Plutchak, J. OP-1437, 1438, $1485,1487,1781$ 
Poag, C. W. P 1542; OP-791, $801,1788,1797,1932$

Podwysocki, M. H. OP-875

Poeter, E. P. OP-1051, 1394

Pogue, K. OP-1637

Pohn, H. A. OP-1789, 1790

Pojeta, John, Jr. GN; OP-444, 792,1839

Polanco, E. F. OF 92-0418

Polanco, José OP-532

Pollack, J. B. OP-1153

Pollastro, R. M. OF 92-0539-C; OP-793, 794, 1791, 1792, 1855

Pollock, D. W. W 2412

Polloni, C. F. DDS-0003, 0015

Pomes, M. L. OF 93-0418

Ponce, D. A. OF 92-0343; OP795

Pond, E. C. P 1536

Ponomarev, A. OP-602

Ponti, D. J. OP-1619, 1793, 1794

Pool, R. R. OF 92-0514

Poole, F. G. B 2015; OP-170, $796,797,1795,1846$

Poore, R.Z. C 1086; OF 930218; OP-270, 798, 799. 1796, 1949

Pope, D. L. OF 92-0530

Popenoe, Peter B 2002; MF2209, 2211; OP-1677

Poppe, L. J. OF 92-0550, 92$0703,92-0717,93-0214,93-$ 0274, 93-0341; OP-791, 800, 801, 1788, 1797, 1863

Porter, K. W. OP-1798

Posamentier, H. W. OP-738

Post, J.E. OP-1489, 1490

Potter, C. J. OF 92-0391; OP1419, 1799

Potter, D. B. I-2369

Powars, D. S. OP-791, 1788

Powell, C. L., II OP-1800

Powell, M. E. YR

Powell, R. D. OF 92-0706; OP1298,1801

Powell, R. E. OP-802, 803, 804

Power, J. A. OF 93-0022; OP$1250,1556,1802$

Powers, P. S. OF 93-0546; OP1423

Powers, R. B. B 2034-A: OF 93-0192, 93-0248, 930337, 93-0522

Poznaikovitch, Zinovy OP-1265

Pratt, Cristelle OP-413

Pratt, S. F. OP-1497

Pratt, T. L. OP-969, 1423

Pratt, W.P. MF-1835-H, 1994D, 2125-E; OP-644

Pray, L. C. OP-354

Predmore, S. K. OP-961

Preissler, A. M. W 2340

Premo, W. R. OP-805, 806, $1803,1804,1805$

Prensky, S. E. OF 92-0390-A, 92-0390-B, 92-0579-A, 92 0579-B, 92-0579-C, 930323; OP-807

Prentice, C. S. OP-808, 1865

Prescott, W. H. P 1550-C; OP883,1658
Presgrave, B. W. OP-206, 1091

Presser, T. S. OF 92-0707; OP638,997

Prestemon, E. C. OP-790

Prestvik, Tore OP-1139, 1141

Pribble, S. T. OF 93-0314

Price, C. V. OF 92-0052

Price, E. H. I-2299

Price, J. G. B 2013; OP-809

Price, Jason OP-1400

Price, L. C. OF 92-0524; OP. 810,1350

Prince, K. R. OP-811

Pringle, C. M. OP-812

Pringle, M. S. OP-813, 1230, 1346, 1806

Pringle, P. T. OP-904

Prinz, Martin OP-1666

Prior, D. B. B 2002

Prior, D. J. OP-586

Pritt, J. W. OF 92-0495

Prodehl, Claus OP-2, 521

Prosser, L. J., Jr. OF 92-0514

Prothero, W. A., Jr. OP-964

Pubellier, Manuel OP-587, 819, $820,821,822,823,824,825$

Pugh, A. L. OP-1544

Puigdomenech, Ignasi OP-737

Punongbayan, R. S. OP-726

Pupacko, Alex C 1086; OF 920627

Purdy, T. L. OP-1609

Purinton, Gary OF 91-0014

Pusey, L. C. OP-1807

Puura, V. A. OP-1599

Pye, Kenneth OP-183

\section{$\mathbf{Q}$}

Qian, J. L. OP-1599

Qualls, C. L. OP-1871

Quick, J. E. OF 93-0504; OP$814,815,1705,1808$

Quinn, T. M. OP-186, 187, 188 , $189,190,191,192,193,194$, 195,196

Quiñones-Marquez, Ferdinand OF 85-0642

Quintana, L. R. OP-755

Quinterno, P. J. OP-413

\section{$\mathbf{R}$}

Radicati di Brozolo, F. OP-1389

Radney, B. OP-702

Radtke, Ulrich OP-1436

Raese, J. W. OF 92-0495

Rafig, M. OP-1637

Ragone, S. E. C 1086; OP-816

Ragozin, Nikita OP-295

Rahimi, M. M. P 1553-B

Rai; Dhanpat OP-305

Raines, G. L. OP-817

Rait, Norma OF 93-0267

Ramey, B. S. OP-701, 818

Ramirez, C. F. OP-1369

Ramírez, P. C. OP-174

Ramirez, Pedro, Jr. OF 91-0533
Ramos-Gines, Orlando WRI 90 4125

Ramp, S. R. OF 92-0382, 930011

Ramsahoye, L. E. W 1536-C

Ramsey, K. E. OF 92-0530

Randtke, S. J. OP-4

Rangin, Claude OP-587, 819, $820,821,822,823,824,825$

Rankin, D. W. B 2029; OP-1517

Rankl, J. G. WRI 92-4091

Ranville, J. R. OP-712

Rao, G. N. OP-742

Rapp, D. H. OF 93-0071; OP1809

Ratcliffe, N. M. OF 92-0282A; I-2369; OP-1316, 1842

Rathbun, R. E. WRI 92-4057

Ratté, C. A. B 2043

Rau, W. W. I-1946

Raup, O. B. OF 93-0236

Raymond, L. H. WRI 92-4117

Raymond, W.H. B 2039

Rayol, J. M. OP-666

Rea, A.H. OF 92-0641; OP1251

Rea, B. A. OP-530, 1058, 1574, $1810,1811,1985,1986,1987$

Reagor, B. G. C 1083; OF 920575

Reasenberg, P. A. OF 92-0441; OP-438, 1812

Rebhan, H. OP-1497

Reches, Ze'ev OP-603

Redfield, B. J. OF 93-0083

Redman, J. D. OP-369

Redmond, K. T. OF 92-0627

Reeburgh, W.S. OP-1616

Reed, B. L. OP-826

Reed, J. C., Jr. OF 92-0391; OP$10,11,827,828,1813$

Reed, K. M. OF 93-0215; OP88,391

Reed, M. H. OP-349, 829

Reed, Randy W 2400

Reeves, W.E. OF 92-0160

Regan, C. L. OP-830

Regynski, Barb OF 92-0514

Reheis, M. C. I-2342; OP-831

Reichard, E. G. WRI 91-4142

Reichenbach, Paola OP-1682

Reichhoff, J. OF 92-0514

Reid, J. C. OF 92-0396

Reid, M. E. OF 92-0501; OP1814

Reid, R.P. OP-186, 187, 188, $189,190,191,192,193,194$. $195,196,1908$

Reid, R.R. OF 93-0235

Reilly, T. E. W 2412; OF 92 0637, 92-0659; OP-832, 1815

Reimer, G. M. OF 92-0391, 930292-I; OP-833, 834, 1816

Reimer, P. D. OF 92-0530

Reimnitz, Erk OF 93-0019, 93 0237; OP-835, 836, 837, 1143

Reimold, W. U. OP-550

Reinhardt, Juergen OF 92 0394; OP-838, 1817

Remy, R.R. B 1787-BB

Ren Tianxiang OP-945
Ren Yinchen OP-153

Ren Yingzhen OP-1238

Renard, K. G. OP-1004

Rendigs, R. R. OP-1598

Renn, D. E. WRI 92-4033, 92 4113

Repenning, C. A. B 2036, 2037

Repetski, J. E. B 1787-EE, 1839-K; OF 92-0391, 930220; OP-56, 1712, 1818, 1819

Resmini, R. G. OP-1294

Restrepo, P. J. OP-1820

Rettman, P. L. WRI 92-4117

Reuff, A. OF 92-0514

Rewis, D. L. OF 93-0148

Rexroad, C. B. OP-1845

Reynard, B. OP-851

Reynaud, Louis P 1386-E

Reynolds, J. S. OP-1968

Reynolds, M. W. YR; OP-839, 1015

Reynolds, R. L. OF 93-0273; OP-841, 985, 1540

Reynolds, Robin OP-413

Rhea, B. S. OF 92-0391; OP840,1996

Rheaume, S. J. WRI 90-4151, 91-4120

Rhodes, J. M. OP-279

Riaroh, D. OP-2, 521

Rice, C. A. OP-841

Rice, C. L. OF 92-0558, 930312; OP-1821

Rice, D.D. OP-1264, 1822 1823, 1911

Rice, J. A. OP-712

Rice, J. W., Jr. OP-842, 906

Rice, K. C. OF 92-0168, 920649; OP-524, 1573, 1610, 1824

Rich, F. J. OF 93-0273; OP1683

Richards, D. L. OF 92-0391

Richardson, D. L. WRI 92 4090, 92-4111

Richardson, Mark OP-1965

Richet, Pascal OP-843

Richmond, B. M. YR; OP-844

Richmond, B. R. OF 92-0717; OP-1863

Richmond, G. M. I-1420 (NG14), 1420 (NH-14), 1420 (NJ14), 1420 (NJ-15)

Richter, D. H. OF 92-0594; GQ-1688; OP-1739

Riciputi, L. R. OP-1825

Rickman, R. L. W 2400; OF 930095

Riddle, G. O. OF 92-0721

Ridley, W. I. OP-1653, 1785

Rieber, Michael OF 93-0258. A, 93-0258-B

Rieck, H. J. C 1086; OF 920426, 92-0542; OP-799, 1796

Riedel, W. R. OP-186, 187, $188,189,190,191,192,193$, $194,195,196$

Riehle, J. R. B 1996; I-2032; OP-845, 846

Ries, K. G., III OP-1826

Riess, T.E. OP-262

Rigali, M. J. OP-713 
Riggins, Michael OP-361

Riggs, A. C. C 1086; OP-294, 916,1670

Rigsby, C. A. OP-243

Riihiluoma, R. OF 92-0514

Rinehart, C. D. OF 92-0562

Rinella, J. F. C 1090; OF 910453, 91-0454, 92-0644; OP1827

Rinker, J. N. OP-847

Risch, J. S. B 2002

Risley, J. C. OP-1828

Ritchie, William OF 92-0530

Rivera, Mick OF 93-0083

Roach, S. L. YR

Roark, D. M. OF 92-0173

Robb, J. M. MF-2211

Robbins, E. I. OP-848

Robbins, S. L. OF 93-0002

Roberts, A. A. OP-834

Roberts, A. C. OP-849

Roberts, B. OP-1525

Roberts, C. W. OF 93-0277

Roberts, H. H. OF 92-0530

Roberts, L. N. OF 92-0391; OP-

Roberts, R. J. OF 92-0385

Roberts, S. B. OF 92-0391; OP1548

Robertson, E. C. OP-616

Robertson, J. F. GQ-1716; OP1040

Robie, R. A. OP-843, 851, 1690

Robinson, A. C. OP-2015, 2018

Robinson, G. R. B 1979; C. 1086; OP-555, 852, 853

Robinson, J. A. OF 92-0135

Robinson, J. V. OP-132

Robinson, K. W. W 2400

Robinson, Keith OF 93-0522; OP-1829

Robinson, M. S. OP-1437, $1438,1439,1485,1487$, $1696,1830,1831,1832$

Robinson, P. OP-1479

Robinson, P. D. OP-1960

Robison, R. M. P 1519

Robson, S. G. WRI 92-4050; OF 93-0071; OP-854

Rockwell, T. K. C 1086; OP707,1833

Rodbell, D. T. OF 93-0273; MF-2218; OP-855, 856, 1324,1683

Roddy, D. J. OP-857, 1113, 1114, 1834, 1882

Roden, E. E. OP-608

Rodgers, P. W. OP-858

Rodriguez, R. W. OF 92-0717; OP-1835, 1863

Roedder, E. W. OP-51

Roehler, H. W. P 1506-D, 1506F, 1532; B 2051

Roelandts, Iwan B 2046

Roeloffs, E. A. P 1550-C; OP868,1025

Roen, J. B. B 1909; OP-1368

Roeske, S. M. OP-1430

Rogers, P. G. OF 93-0516

Rogers, P. Z. OP-305

Rogers, R. J. W 2400

Rogers, W.P. OP-859
Rohmann, S. O. OP-1836

Rohr, D. M. OP-860

Rojstaczer, S. A. OP-467

Roldán-Quintana, Jaime MF2238

Roman-Mas, A. J. OP-1574

Romanowicz, Barbara OP-752

Ronen, Daniel OP-234

Roof, S. R. OP-477

Root, D. H. OP-449, 861, 862

Roperch, Pierrick OP-186, 187 $188,189,190,191,192,193$ $194,195,196$

Rose, W. J. WRI 90-4124

Rosenbauer, R. J. OF 91-0366 A, 91-0366-BC; OP-76, 77, 537,615

Rosenbaum, J. G. OF 93-0273; OP-436, 863, 985, 1540

Rosenberg, L. A. MF-2253

Rosenberg, Paul OP-673

Rosenberry, D. O. OF 92-0475, 93-0127

Rosenblatt M. OP-857

Rosenshein, J. S. OP-692

Ross, C. R. I-1943

Ross, D. R. OP-1837

Ross, Malcolm OP-864, 1837

Ross, R. J., Jr. OP-797

Rossi, R. E. C 1086

Rossmann, R. OP-1208

Rossmeissl, H. J. OP-865, 866

Rostad, C. E. OP-580

Rothwell, Guy OP-413

Rothwell, R. G. B 2002; OF 92 0206

Rott, Helmut P 1386-E

Rotto, S. L. OP-1838

Rouer, Olivier OP-1628

Rouhani, Shahrokh OP-867

Roure, François OP-1520

Roushey, B. H. OF 90-0672, 92-0384

Rowan, E. L. OP-575, 1419

Rowan, L. C. B 2019; C 1088; I-2050-F

Rowan, M. E. WRI 92-4175

Rowden, R. D. OP-588

Rowe, G. L. WRI 93-4047; OP812

Rowe, G. L., Jr. OP- 1454

Rowland, C. J. WRI 92-4194

Rowley, P. D. OP-1027, 1995

Rozenblum, I. S. OF 93-0339

Ruan Huichu OP-456

Rubeska, Ivan B 2046

Rubin, C. OP-1833

Rubin, C. M. OP-931

Rubin, D. M. OP-1528

Rubin, J. M. C 1090

Rubin, Meyer OF 93-0273

Rucker, S. J., IV WRI 90-4154

Ruddy, B. C. WRI 91-4176, 924053; OF 92-0627, 93-0418

Rudnicki, J. W. OP-868

Rueff, A. W. MF-1994-D

Ruff, L. J. OP-676

Rugg, R. D. OP-866

Ruiz, Joaquin OP-278

Rumble, Douglas, III OP-750
Rundle, J. B. OP-2024

Runnegar, B. N. OP-1839

Runnells, D. D. OP-930

Runnels, D. D. OP-869

Ruppel, E. T. I-1803-H

Ruppert, L. F. OP-228, 870, 1234, 1305

Rusanovs M. S。 OP-1777

Russ, D. P. YR

Russell, D. J. B 1909

Russell, J. F. OP-887, 1595, 1596,1840

Russell, L. A. P 1553-B

Russell, Norman OP-532

Rutledge, A. T. W 2340; OP871

Rutledge, E. M. OF 93-0273; OP-1683

Ryan, W. B. OP-743

Ryder, Graham OP-237, 920, $1314,1315,1841$

Ryder, J. L. OF 91-0453, 92 0520

Ryder, R. T. B 1839-K; OP1842

Rye, R. O. C 1086; OF 92 0009; OP-441, 532, 872 $873,874,912,1081,1327$ $1576,1870,1885,1922$

Rymer, M. J. OP-399, 1843, 1844

Rytuba, J. J. B 2039; OP-205, $231,875,876$

S

Saad, D. A. OF 93-0115

Sable, E. G. OF 92-0589

Sacks, L. A. WRI 91-4180; OP1568

Sacks, P. E. OF 93-0244

Sado, E. V. I-1420 (NL-17)

Sadowski, F. G. C 1086

Safarian, K. OF 93-0216

Safko, P. S. WRI 91-4168

Sager, W. W. OP-413

Sajona, F. G. OP-587, 819, 820, $821,822,823,824,825$

Sako, M. K. OF 92-0686; OP252, 1759, 1962

Sakss, Yula OF 93-0575

Salazar, Edixon MF-2242

Salehi, Habib WRI 91-4194

Sallenger, A. H., Jr. YR; OF 920530; I-2150-A; OP-989

Saltus, R. W. OF 93-0287; OP877,1780

Samora, B. A. OP-846

Samsel, T. B., III WRI 93-4015

San Juan, F. C., Jr. OF 92-0396

Sancetta, Constance OP-878

Sandberg, C. A. OP-797, 1245, $1795,1845,1846,1847$

Sander, K. A. OP-369

Sanders, G. L. OP-1531

Sanderson, D. D. OF 92-0558

Sando, S. K. OF 93-0066

Sando, W. J. B 1988-F, 2024

SanFilipo, J. R. OF 92-0281, 92-0576, 93-0255, 93-0256

Sanford, A. R. OP-438
Sanford, R. F, OP-1848

Sanford, W. E. OP-879, 1200 , $1849,2012,2013$

Sanjines, Orlando B 2039

Sankey, J. T. OP-1850

Santos, H. X. OF 93-0081

Sanzolone, R. F. OF 92-0520; OP-944

Sargent, K. A. YR

Sarna-Wojcicki, A. M. C 1086; OP-831, 1404

Sass, J. H. OP-298

Sasser, D. C. OP-216

Satake, K. OP-752

Sauer, V. B. OF 92-0144

Saunders, J. A. OF 92-0721. OP-716

Saunders, R. S. OF 93-0516, OP-690, 786, 1851

Savage, J. C. P 1550-C; OP$127,880,881,882,883$ $1423,1658,1852$

Savage, W.Z. OF 93-0546; OP$884,885,1171,1423$

Savard, C. S. OF 90-0153

Savoy, L. E. OF 93-0184

Sawatzky, D. L. OF 92-0391; OP-1853

Sawyer, D. A. OF 93-0299; OP985,1825

Sawyer, D. S. OP-586

Sawyer, T. L. I-2342

Saxton, J. L. OP-1619

Scanlon, K. M. B 2002; OF $92-$ 0513; MF-2083-B; OP-886

Scarascia, S. OP-521

Schaap, B. D. OF 92-0094, 920514

Schaber, G. G. OF 93-0272, 93 0516; I-2209; OP-28, 29 , $148,246,786,887,988$, $1062,1236,1790,1840$, 1851,1854

Schaefer, F. L. WRI 91-4169

Schafer, R. W. OP-817

Schaffranck, R. W. OP-888

Schalk, C. W. WRI 93-4047

Schellekens, J. H. OF 92-0567; OP-1656

Schenk, C. J. B 1787-GG; C 1086; OF 92-0391, 92 0514; OP-889, 1103, 1855 , 1856,1858

Schenk, P. M. OP-1725

Scherer, James B 2013

Scherer, R.P. OP-587, 819, $820,821,822,823,824,825$

Scherler, K. E. P 1386-E

Schiffmacher, R. OP-136

Schiffmann, Peter OP-890

Schilling, S. P. OF 93-0299, 930506

Schimschal, Ulrich OF 92-0572

Schindler, J. S. OF 92-0716; OP-1106, 1612

Schiner, G. R. WRI 92-4076

Schlee, J. S. MF-2211

Schlottmann, J. L. OP-891

Schmidt, A. R. YR

Schmidt, J. M. OF 93-0215

Schmidt, R. G. B 2039 
Schmoker, J. W. B 1909; OF 92-0391, 92-0524, 930230; OP-889, 1350, 1602 . $1753,1856,1857,1858$

Schmoll, H. R. OF 92-0346; GQ-1688

Schmuck, E. A. B 2002; MF2209

Schneider, George OP-369

Schneider, J. F. OP-1587

Schneider, J. L. C 1091

Schneider, V. R. W 2339

Schoellhamer, D. H. OP-892, $893,894,895$

Scholl, D. W. OP-211, 345, $586,896,1037,1859$

Scholl, M. A. OP-468, 897

Scholz, C. A. OP-898, 1532, 1597

Schoonmaker, J. W., Jr. OP1860

Schopp, R. D. OP-899

Schops, Dietmar OP-413

Schorr, L. J. OP-561

Schott, Michael OP-361

Schouten, Hans OP-900

Schreffler, C. L. WRI 92-4183; OF 93-0027, 93-0028

Schreiner, R. A. OP-1715

Schroder, L. J. OF 92-0163; OP-331

Schroeder, R. A. OF 93-0083

Schruben, P. G. OP-1730

Schuck-Kolben, R. E. WRI 904056

Schuenemeyer, J. H. OP-274

Schulte, A. OP-521

Schultz, A.P. OP-901, 1147 1471, 1861

Schultz, K. J. OF 92-0525

Schultz, R. A. OP-1939, 1940

Schulz, K. J. I-2356; OP-139, $339,728,1534$

Schulz, M. S. OP-1065

Schumacher, J. G. WRI 934012; OF 93-0153

Schumann, H. H. W 2400

Schumann, R. R. OF 93-0292G, 93-0292-H, 93-0292-I, 930292-J; OP-379, 902

Schumm, S. A. OP-754

Schuraytz, B. C. OP-920

Schuster, R. L. P 1240-B; OP$859,885,903,904,956,1862$

Schwab, C. E. OF 92-0594

Schwab, W. C. B 2002; OF 92 0717; OP-579, 1740, 1863. 1864, 1966

Schwartz, D. P. OP-338, 764, $905,1587,1833,1865$

Schweger, C. E. OP-391

Schweig, E. S., III OP-856, $1866,1867,1970$

Schweitzer, P. N. DDS-0010

Schytt, Valter P 1386-E

Scott, B. A. B 1770

Scott, D. H. I-2208; OP-906, $1338,1868,1984$

Scott, G. R. I-2266

Scott, J. C. WRI 91-4116

Scoth, K. M. W 2340; OP-907

Scott, R. B. OF 92-0613; GQ1730
Scott, R. W., Jr. B 2039

Scoth, W. B. YR

Scott, W. E. OP-622, 908, 909, $910,911,1768$

Scrivener, R. C. OP-158, 1246

Seal, R. R., II OP-912, 1869 , 1870,1874

Seanor, R. C. OF 92-0492

Searle, D. E. OP-1356

Searle, R. C. OP-432, 443

Sears, D. W. OP-1666

Seasor, R. W. OP-1688

See, R. B. OF 91-0533; OP711, 1871

Seeger, C. M. B 2039

Seehusen, Don B 2013

Seekins, B. A. I-2089-C, 2090C, 2091-C

Seekins, L. C. DDS-0007

Seeland, D. A. OC-0140

Seeling, Alan OP-731

Segall, Paul OP-648, 913, 1661,1872

Segerstrom, Kenneth OF 93 0197-A, 93-0197-B

Seiler, R. L。 W 2400

Seitz, J. C. OP-914

Seivard, L. D. W 2400

Self-Trail, J.M. OP-1205

Selkirk, T. L。 OF 92-0426

Selner, G. I. OF 93-0305, 930511, 93-0536

Sembera, E. D. OF 93-0216. OP-660

Sena, Joe OF 93-0216

Senftle, F. E. OP-1873

Senior, L. A. OP-915

Senterfit, R. M. OF 92-0503

Serrat, David P 1386-E

Sether, B. A. OF 93-0066

Setmire, J. G. OF 93-0083

Setterholm, D. R. OF 92-0514

Severson, M. OF 92-0514

Severson, R. C. OF 93-0303

Sevon, W. D. I-1420 (NK-18)

Seyfried, W. E. OP-51

Shackleton, N. J. OP-916

Shade, P. J. WRI 92-4168

Shaffer, K. R. OF 92-0514

Shaffranek, R. W. OP-567

Shamine, W. J. OF 92-0163

Shangreaux, Donavan OF $92-$ 0514

Shanks, W. C., III OP-14, 224 $750,1304,1874$

Shanley, J. B. C 1086; OP-917, 918,1875

Shanley, K. W. OP-919

Shapiro, A. M. OP-232, 236

Sharma, Pankaj OP-147

Sharp, R. V. OF 93-0181

Sharp, S. C. OF 92-0465

Sharpton, V. L. OP-920

Shasby, M. B. C 1086; YR

Shaw, C. A. OP-1484

Shaw, T. H. OP-1782

Shawe, D. R. OP-921

Shay, J. M. WRI 92-4172

Shearer, C. F. P 1240-B

Shearer, C. K. OP-1770, 1771
Shedlock, K. M. OP-969, 1970

Shedlock, R. J. C 1080; OF 93 0040; OP-777, 922, 923, 1876

Sheehan, P. M. B 1988-E

Sheehan, T. P. OF 92-0564

Shen Feng OP-317

Shen Shiquan OP-945

Shen, A. H. OP-924, 1877

Shen, G. T. OP-925

Shepherd, T. J. OP-158, 1246

Sheppard, D. S. OP-926

Sheppard, R. A. B 2061-A; OP1386,1490

Sherlock, M. G. OP-218

Sherman, D. M. OP-1311, 1583,1878

Sherrod, D. R. OP-468, 1549

Sherwood, S. I. OF 92-0391

Sheu, D. D. OP-587, 819, 820, $821,822,823,824,825$

Shew, N. B. B 2039

Shi, Haiyu OF 92-0514

Shibuya, Hidetoshi OP-587, $819,820,821,822,823,824$ 825

Shideler, G. L. MF-2252

Shimaraeva, M. C. OP-2004

Shinn, E. A. OF 92-0717; OP$927,928,1662,1863$

Shirey, S. B. OF 92-0525; OP1621

Shock, E. L. OP-1176

Shoemaker, C. S. OP-1750, 1883

Shoemaker, E. M. OP-1113, $1114,1750,1834,1879$ $1880,1881,1882,1883$, 1915,1974

Shope, W. G., Jr. OP-929

Short, S. K. OP-299

Showalter, D. H. C 1086

Showalter, P. K. OF 93-0205

Shpikerman, V. I. OF 93-0339

Shroba, R. R. OF 93-0310, 930320; OP-1455, 1884

Shumaker, R. C. B 1909

Shuster, R. D. OP-705

Shuttleworth, W. J. OP-946

Shvetzov, D. N. OP-367

Shyu, Jih-Ping OP-587, 819, $820,821,822,823,824,825$

Sidder, G. B. B 2039; OF 920514; OP-500, 1297, 1326 1327, 1885

Siders, M. A. OP-930

Sidorin, A. OP-602

Sidorov, A. A. OF 93-0339

Sieben, Ed OF 92-0514

Sieh, K. E. OF 91-0032; OP931,1833

Siems, D. F. OF 93-0281, 93 0314; OP-505, 1086

Signell, R. P. OP-932

Sigurdsson, Haraldur OP-1873

Sikora, R. F. OF 93-0217-A, 930217-B

Silberling, N. J. B 1988-G, 2019; OP-933

Silberman, M. L. OF 92-0210A, 92-0210-B, 92-0316-A, 92-0316-B; OP-427, 428, $624,934,1267$
Silva, R. J. OP-305

Silva, S. R. OF 92-0594

Silver, E. A. OP-587, 819, 820, $821,822,823,824,825$

Silver, L. T. OP-630

Silver, P. G. P 1550-C

Simmons, A. M. OF 92-0198; OP-1886

Simmons, C.E. W 2364

Simmons, D. L. WRI 90-4205; OF 92-0637

Simmons, G. R. OP-361

Simmons, K. R. OP-294, 613, 916,1670

Simon, Andrew OP-1632

Simon, N. S. OP-935, 1887

Simonds, F. W. OF 92-0554

Simoneit, B. R. OP-243

Simpson, Carol OP-442, 1691

Simpson, M. R. W 2395; OP1888

Simpson, R. W. OP-406, 438, 752

Sims, G. L. I-2343-A, 2343-B, 2380-A, 2380-B

Sims, J. D. OP-936

Sims, P. K. B 1904L, 1904-P, 1904-Q, 1904-S; OF $92-$ 0514; I-2355, 2356; OP-828, $937,1214,1889$

Singer, B. S. OP-279

Singer, D. A. OF 93-0280; OP$162,218,938$

Singer, R. B. OP-1408

Sinha, A. K. OF 92-0525

Sinigoi, Silvano OF 93-0504: OP-1808

Sinton, J. M. OP-432

Sipkin, S. A. OP-501, 939, 940

Sisolak, J. K. OF 93-0039

Sisson, T. W. OP-233

Sites, R. S. OP-1226

Siwiec, S. F. WRI 92-4100

Skeen, C. J. B 2046; OP-1769

Skilbrei, J. R. OP-1890, 1891

Skinner, J. E. OP-1413

Skipp, B. A. OP-941

Skipp, G. L. OF 92-0386

Slack, J. F. B 2039; OP-484 $763,787,942,1892,1942$

Slack, J. R. C 1086; WRI 934076; OF 92-0632

Slack, L. J. W 2400; OF 92 0469

Slack, $P$ OP-521

Slack, R. J. OF 92-0129

Slagle, S. E. WRI 92-4066

Slate, J. L. I-2342; OP-831

Sleep, N. H. OP-432, 1893

Sliter, W. V. OP-419, 1193, 1894

Sloto, R. A. OP-1895

Slucher, E. R. OF 92-0558

Small, T. A. WRI 92-4190

Smalley, M. L. WRI 91-4044, 92-4091

Smellie, J. A. OP-737

Smith, A. J. OP-943, 1896

Smith, B. J. WRI 93-4012; OF $93-0140$

Smith, B. S. OF 91-0483

Smith, C. F. OF 93-0054 
Smith, C. L. B 2013

Smith, D. B. OP-944, 945

Smith, E. A. OP-507, 729, 946

Smith, G. I. OF 93-0311; OP1897

Smith, G. M. B 1966

Smith, J. A. C 1007; WRI 914169; OP-1010, 1898

Smith, J. D. YR; OP-24, 947, 1434,1717

Smith, J. G. GQ-1688; I-2005; OP-875

Smith, J. L. OF 92-0627

Smith, J. R., Jr. MF-2231

Smith, K. S. C. 1086; OP-315, 788,948

Smith, L. R. OF 92-0514

Smith, M. C. MF-2216

Smith, N. P. OP-1383

Smith, R. A. W 2400; OF 900130

Smith, R. B. OP-438, 587, 819, $820,821,822,823,824,825$, 970

Smith, R. L. GQ-1688; OP$459,664,949,1524,1968$

Smith, S. M. OP-624

Smith, S. S. OP-1060

Smith, S. T. OF 93-0533

Smith, T. E. OF 92-0594

Smith, Terence OP-587, 819, $820,821,822,823,824,825$

Smith, Winchell W 2340

Smolensky, D. A. WRI 90-4182

Smoot, C. W. WRI 91-4109; OF 92-0492

Smoot, J. P. OP-359, 1379

Smothers, D. M. OF 92-0492

Smriglio, G. OP-206

Smyth, J. D. OP-471

Smythe, W. D. OP-1217

Snavely, P. D., Jr. OF 93-0189, 93-0302; I-1946; OP-159, 731

Snee, L. W. B 2065; OF $92-$ 0525; OP-158, 479, 999 . $1099,1125,1159,1246$, $1427,1433,1464,1613$, $1625,1637,1671,1869$

Snethen, D. H. W 2400

Snieder, Roel OP-1969

Snow, K. M. C 1086

Snow, R. F. WRI 91-4030

Snyder, E. F. OF 92-0479

Snyder, G. L. I-2232; OP-149, 1456

Snyder, J. B. OF 92-0387

Snyder, S. L. OF 92-0700-A, 93-0211

Soakai, Sione OP-413

Soderblom, L. A. OP-786, 857, $887,1163,1217,1402,1594$

Soeder, D. J. OP-1899

Soenksen, P. J. OF 92-0167

Sohl, N. F. B 2030; OP-950

Soler, Tomás OP-951

Solidum, R. U. $\quad$ OP-587, 819, $820,821,822,823,824,825$

Solin, G. L. OF 91-0458

Soller, D. R. C 1111; OF 92 0694, 93-0268-A, 93-0268B, 93-0543; OP-952

Solley, W. B. C 1081
Solomon, S. C. OP-1080, 1851

Soloviev, V. A. OP-1412

Solti, G. OP-1599

Somerville, P. G. OP-752

Sommerfeld, R. A. OP-953

Sonenshein, R. S. WRI 92-4061

Sonnenfeld, M. D. OP-1387, 1575

Sorensen, S. S. OP-1900

Sorenson, J. W. OP-173

Sorey, M. L. OP-954, 955, 978

Sorlien, Christopher OP-1172

Sosson, M. OP-1901

Sosunov, G. M. OF 93-0339

Sotin, C. J. OP-1163

Southard, R. E. WRI 92-4126

Southon, J. R. OP-48, 1750

Southworth, C. S. B 1839-I,J OF 92-07 16; OP-1106

Sowers, G. F. OP-956

Sowers, J. M. OF 93-0223, 930224, 93-0225

Spadea, Piera OP-587, 819, $820,821,822,823,824,825$

Spahr, N. E. C 1086; OF 920122, 92-0628; OP-133, 1008

Spakman, Wim OP-1020

Spangler, L. E. WRI 92-4070; OF 92-0124; OP-1736

Spanski, G. T. B 2005

Sparck, H. M. OP-66

Sparks, R. S. OP-957

Sparks, T. OF 92-0721

Speak, M. J. OP-1954

Spechler, R. M. OF 92-0466, 93-0050

Speiran, G. K. WRI 92-4175; OP-1902

Spence, W. J. C 1083; OP1189,1903

Spencer, C. W. OF 92-0524, 93 0248; OP-1350

Spidle, D. L. OP-1990

Spiegler, Dorothee OP-586

Spies, Otmar B 2046

Spiker, E. C. C 1086; OP-59. $1150,1292,1904,1905,1906$

Spilde, M. N. OP-1770, 1771

Spinello, A. G. WRI 90-4205

Spinosa, Claude OP-354

Spitz, F. J. WRI 91-4191

Spooner, J. D. OP-1907

Sposito, Garrison OP-493, 1811

Spotila, J. A. OP-931

Sproull, J. D. OF 91-0014

Spudich, Paul C 1031; OP-676, $958,959,1274,1275,1498$

Spudis, P. D. OP-1482, 1943

Squillace, P. J. OF 92-0085

Squyres, S. W. OP-1974

Srodon, Jan OP-289, 1353

Stacey, J. S. OP-1067, 1921, 2018

Stackelberg, P. E. WRI 924100; OF 91-0180

Stacy, N. J. OP-786

Staerker, T. S. OP-186, 187 , $188,189,190,191,192,193$, $194,195,196,1908$

Stafford, K. L. OF 93-0430, 930431, 93-0432

Stafford, T. W., Jr. OP-77, 720
Stakes, D. S. OP-243

Stallard, R. F. C 1086; OF 92 0150; OP-396, 483, 1121

Stallings, E. A. YR

Stamatakis, M. G. OP-960

Stamer, J. K. OP-1909

Stamey, T. C. WRI 93-4016; OF $92-0113$

Stamm, R. G. B 1988-D; OF 92-0580, 93-0220, 93 0312; OP-1983

Stamos, C. L. OP-961

Stanford, L. M. P 1553-B

Stang1, R. OP-521

Stanley, D. L。 OF 92-0163

Stanley, G. D., Jr. OP-1344

Stanley, R. G. B 2034-A; OF 92-0571; OP-1281, 1910

Stanley, R. S. I-2369

Stanley, W. D. OP-1167

Stannard, D. I. OP-80, 562, 962

Stannard, G. OP-1820

Stanton, M. R. OF 92-0391; OP-104

Stanton, R. W. OP-228, 778, $1234,1264,1779,1911$

Starbuck, M. J. OP-1912

Stark, J. R. WRI 90-4150

Stark, Keith OP-90

Stark, M. A. OP-438

Starr, L. E. OP-963

Starrat, S. W. DDS-0006

Stasiuk, M. V. OP-957

Staude, J. G. B 2039; OP-487

Steck, L. K. OP-964

Steele, C. W. OF 93-0298

Steele, G. V. OF 93-007 1

Steeves, P. A. OP-1826

Stein, H. J. OF 92-0525; OP$394,965,1464,1913$

Stein, R.S. OP-752, 966, 1914 2024

Steinberg, N. A. OP-1765

Steinen, R. P. OP-928

Steiner, M. B. OP-1915

Stekl, P. J. WRI 91-4025

Stellrecht, R. OP-521

Steltenpohl, M. G. OP-967 $968,1279,1916,1917,1918$

Stepanov, V. OP-134

Stephens, C. D. OF 93-0309; OP-1250, 1384, 1556, 1618, 1802

Stephens, D. W. W 2400; WRI 92-4084

Stephens, G. C. OP-1129

Stephenson, W. J. OP-969, 970

Stem, C. R. OP-971

Stern, L. A. OP-281, 282, 1586

Sterner, S. M. OP-1919

Stevens, A. R. YR

Stevens, B. P. OP-942

Stevens, C. H. OP-972, 977

Stevenson, A. J, OP-211, 1859

Steward, Joel WRI 91-4115

Stewart, D. B. OP-1920

Stewart, J. B. OP-507, 729, 946

Stewart, J. H. B 2019; MF2238,2242 ; OP-56, 797, 973

Stewart, K. C. B 1770; OF 92 0383
Stewart, S. K. OP-36I Steyaert, L. T. C 1086 Stickney, M. C. OP-438 Stiff, B. J. OF $92-0514$ Stibler, S. D. OP-1802 Stine, S. W. I-1420 (NJ-10)

Stine, Scott OP-77 Stipp, S. L. OP-974, 1508 Stith, D. A. OF 92-0514 Stock, J. M. OP-93I Stoddard, J. L. OP-975 Stoeser, D. B. B 2039 Stoesser, D. B. OP-1921 Stoewe, T. L. OP-1594

Stofan, E. R. OF 93-0516; OP786,1851

Stoffregen, R. E. OP-1922

Stoker, Y. E. WRI 92-4062

Stokes, J. B. B 1966

Stokes, Stephen OP-976

Stokking, L. B. OP-186, 187, $188,189,190,191,192,193$ $194,195,196,1287$

Stolper, E. M. OP-43

Stone, C. G. SGM

Stone, Denver OP-1560

Stone, J. R. OP-1650

Stone, M. A. WRI 92-4196

Stone, P. A. OP-240

Stone, Paul OF 91-0435; OP972, 977, 981

Stonebraker, Michael OP-383

Storey, B. C. OP-1317, 1446, 1995

Storzer, Dieter OP-550

Stout, J. H. OF 92-0594

Stout, S. A. OP-1906, 1923

Stover, C. W. P 1527

Stowe, A. M. OF 91-0014

Strain, G. A. W 2391

Strand, Kari OP-586

Strange, W.E. OP-951

Strause, J. L. W 2400

Streiffer, H. R. OF 93-0210

Streveler, G. P. OF 92-0596

Stribrny, Bernhard B 2046

Stricker, G. D. OF 92-0391

Strickland, A. G. OF 92-0123, 92-0639

Strickland, H. G. OP-173

Striegl, R. G. W 2390; C 1086

Stringfield, W. J. WRI 92-4000

Strobel, M. L. OP-1924, 1925

Strom, E. W. I-2279-A, 2279-B

Strom, R. G. OP-28, 29, 148, 246,887

Stuart, C. G. OF 92-0492

Stuart, W. D. OP-1926

Stuart, W. F. OP-1441

Stubblefield, W. L. OP-1443, 1444

Stubbs, C. W. OP-389

Stuckless, J. S. OP-643, 774, 1775

Stuiver, Minze OP-20, 251

Sturchio, N. C. OP-978

Sturdy, Derek OP-542

Sturrock, A. M., Jr. OP-216

Styzen, Michael OP-413

Subitzky, Seymour W 2340 
Suemnicht, G. A. OP-955

Sugarman, P. J. OP-979

Sullivan, R. J. OP-1439, 1485

Sullivan, Robert OP-1437, 1438,1487

Summers, R. OP-689

Sun Weijun OP-1238, 1343

Sundeen, S. P. OF 92-0514

Sundquist, E. T. C 1086; OP396,980

Sundvoll, B. OP-1141

Suneson, N. H. OP-611

Sunshine, J. M. OP-366, 783, $1437,1438,1439,1485$, $1487,1696,178$

Susong, D. D. WRI 91-4044

Suter, J. R. OF 92-0530

Sutley, S. J. OF 93-0153; MF2144-B, 2144-C, 2144-D; OP-115, 1417

Sutphin, D. M. C 0930-M

Sutter, J. F. B 1839-I,J; C 1111; OF 92-0525; OP-214, 839, 981, 1079, 1493, 1494

Sutton, A. J. B 1966

Sutton, A. L. OF 92-0392

Suzuki-Kamata, Keiko OP-498 982

Svarc, J. L. P 1550-C

Sverjensky, D. A. OP-1927

Swadley, W C OF 92-0613,930299; GQ-1730

Swain, E. D. WRI 93-4011; OF 92-0138

Swain, L. A. OP-983, 1928

Swain, W. C. OF 92-0655

Swaine, D. J. OP-249

Swanson, D. A. B 1966; OF 930297; OP-957, 1362

Swanson, D. M. WRI 93-4007

Swanson, Edwin W 2400

Swanson, S. E. OP-1469, 1754, 1929

Swart, P. K. OP-1930

Swayze, G. A. B 2039; OP1583

Sweat, M. J. WRI 91-4133

Sweeney, J. J. OP-984

Sweetkind, D. S. OP-985, 1289

Swiatek, E. OP-562

Swift, B. A. OP-1931, 1932

Swihart, T. M. W 2400

Swisher, C. C., III OP-746

Swolfs, H. S. OP-884, 1318

Sykes, L. R. OP-735

Sylvester, A. G. OF 91-0032

Symonds, R. B. OP-349

Szabo, B. J. C 1086; OP-294, 916,1670

Szabo, Z. G. OP-986

Szalay, Arpad OP-1687

Szarzi, S. L. OF 92-0391, 930292-G, 93-0292-H, 930292-I, 93-0292-J

Szent-Gyorgyi, Karoly OP-1687

Szeverenyi, N. M. OP-410

Szmajter, R. J. OF 93-0186

\section{$\mathbf{T}$}

Tabor, R. W. I-1963; OP-1480
Tagg, R. A. OF 93-0266

Taggart, J. E., Jr. B 1770

Tahirkheli, R. A. OP-1637

Tailleur, I. L. OF 93-0215

Takahashi, K. OP-2025

Takahashi, K. I. OF 92-0391; OP-435

Takahashi, Kozo OP-586

Takeda, Hiroshi OP-2025

Tanaka, K. L. OF 93-0516; OP$987,988,1242,1321,1322$ $1323,1421,1422,1647$, $1674,1838,1933,1934$, $1935,1936,1937,1938$, 1939,1940

Tanimoto, Toshiro OP-1941

Tannant, D. D. OP-587, 819 , $820,821,822,823,824,825$

Tanyileke, Greg OP-306

Tappan, G. G. C 1086

Tapper, R. J. OF 92-0153

Tappin, David OP-989

Tarr, A. C. P 1519; OF 92 0391, 93-0349

Tasker, G. D. C 1086; WRI 934013; OF 92-0052

Tatsumoto, Mitsunobu OP-457, $805,806,1199,1238,1805$ 1956,2025

Taunton, S. S. OF 92-0395

Tauxe, Lisa OP-1550

Taylor, A. M. OF 92-0468

Taylor, B. E. OP-1942

Taylor, C. D. OP-1373, 1419, 1799

Taylor, F. W. OP-186, 187 $188,189,190,191,192,193$, $194,195,196,808$

Taylor, G. J. OP-1943

Taylor, H.E. OP-990, 991

Taylor, M.E. OP-208, 1295

Taylor, M. J. WRI 92-4172

Taylor, R. B. OF 93-0511, 930536; OP-1015

Taylor, R. D. OP-480, 770

Taylor, R. E. WRI 92-4094

Taylor, T. A. WRI 92-4184; OP1394

Teerman, S. C. OP-1944

Teesdale, W. J. OP-233

Teleki, P. G. YR

Telnaes, Nils OF 92-0391

ten Brink, U. S. OF 93-0007; OP-898

Tennyson, M. E. B 2034A; OP-1945, 1946

Tepordei, V. V. B 2013

Tepper, D. H. OP-2023

Tera, Fouad OP-1018

Tessensohn, Franz OP-65, 610

Thamke, J. N. OP-1947

Thatcher, Wayne OP-1872

Thelin, G. P. I-2206

Thenhaus, P. C. OF 93-0181; OP-992, 993, 1109, 1948

Theobald, P. K. OP-945

Theodorakos, P. M. OF 92 0509-A, 92-0509-B, 92-0708A, 92-0708-B

Theodore, T. G. B 2039; OP994
Therberge, A. E., Jr. OP-1443, 1444

Thieler, E. R. OF 92-0717; OP1863

Thio, Hong-Kie OP-504, 931

Thiros, S. A. OF 92-0640

Thomas, B. K. OP-424, 425

Thomas, J. E. OF 93-0257

Thomas, J. M. OP-995

Thomas, P. C. OP-1974

Thomas, R. E. OP-996, 1368

Thomas, R. P. OF 92-0653

Thomas, W. A. OP-1479

Thomas, W. O., Jr. OP-1036

Thompson, D. B. . WRI 92-4123

Thompson, G. A. OP-2, 521, 769

Thompson, J. M. OP-267, 326 $327,464,997$

Thompson, M. R. OF 92-0514

Thompson, R. A. OF 92-0528, 92-0710, 92-0711, 93-0506 OP-279

Thompson, R. J. YR

Thompson, R. S. C 1086 OF 92-0713; OP-270, 1949, 1999

Thompson, T. A. OF 92-0514; OP-923

Thompson, T. B. OP-1151

Thompson, W. B. OP-555

Thomson, Elizabeth W 2400

Thordsen, J. J. OP-998, 1578

Thorez, J. OP-1950

Thorman, C. H. B 2039; OP741, 999

Thorn, C. R. OF 93-0084

Thorn, K. A. OP-1951, 1990

Thornber, C. R. OF 93-0504; OP-1952

Thorpe, A. N. OP-1873

Thrainsson, H. OP-1587

Threlkeld, C. N. OF 93-0186; OP-564

Throckmorton, C. K. OP-1336

Thruston, P. OP-1731

Thurman, E. M. C 1120-C; OF 92-0085, 93-0114, 930418 ; OP-4, 5, 816, 1000 , 1644

Thurow, Jürgen OP-361

Thybo, Hans : OP-2, 521

Tidy F., Enrique OP-2027

Tiffney, W. N., Jr. OF 93-0185

Tihansky, A. B. WRI 91-4180

Till , A. B. B 1996; MF-1838D; OP-721

Tilling, R. I. OF 93-0197-A, 930197-B; OP-1001, 1778, 1953

Timson, G. R. OP-1954

Tingle, T. N. OP-1508

Tingley, J. V. OP-218, 342

Tinker, S. W. OP-1387, 1575

Tinsley, J. C. OP-1076, 1347

Tollo, R.P. OP-1002, 1003, 1955

Tomascak, P. B. OP-1462

Tompkins, M. D. OP-261

Tomson, J. H. OF 92-0383, 92 0539-D, 93-0177
Tooker, E. W. B 2013; OF 92 0385

Topinka, L. J. B 1966

Toppin, K. W. W 2400

Torak, L. J. W 2391; TWI 06 A3, 06-A5; OF 90-0194, 91 0471; OP-867

Torigoye, Noriko OP-1956, 2025

Torikai, J. D. OF 92-0486, $92-$ 0521

Tornes, L. H. W 2400

Torres, Marta OP-586

Torresan, M. E. B 2002

Torson, J. M. OP-1217

Tosdal, R. M. B 2039; OP-31, $680,1112,1146,1376,1601$, $1957,2015,2018$

Toth, M. I. B 2035, 2039

Toth, T. A. OF 92-0514

Touschner, S. T. OF 93-0096, 93-0171

Toy, T. J. OP-1004

Trabant, D. C. C 1086; OP1708

Tracey, D. C. OF 93-0058

Tralli, D. M. OP-1422

Trapp, Henry, Jr. P 1404-G

Traudt, D. K. OF 91-0014

Trautwein, C. M. C 1088; I2050-F

Traverse, Alfred OP-1659

Travis, B. J. OP-869

Treece, M. W. OF 92-0498; OP1958

Tréhu, A. M. OF 93-0318, 930319, 93-0347; OP-65, 1533

Treiman, J. A. OP-931

Trent, R. E. OP-384

Trent, V.P. OP-312

Treworgy, J. D. OP-360

Trias, J. L. OF 92-0513, 920717; OP-1863

Tribble, G. W. C 1086; WRI 92 4168; OP-1005

Trim, H. E. OP-1148

Trimble, D. A. OF 93-0311; OP-143

Trimble, S. W. W 2340

Triplehorn, D. M. OP-93

Tripp, B. T. B 2013

Tripp, R. B. MF-1996-E, 2207, 2227; OP-1006

Triska, F J. OP-812

Troester, J. W. OP-1007, 1959, 1960

Trommer, J. T. W 2340; WRI 91-4181

Tromp, D.E. OP-1961

Truesdell, A. H. OP-874, 1657

Truitt, E. P. OF 92-0146

Trusdell, F. A. OF 92-0586; I2408; OP-1962

Tsukagoshi, Akira OP-223

Tsutsui, Bruce B 2002

Tsvetkov, A. A. OP-91

Tucci, Patrick WRI 92-4131

Tucker, B. J. OF 93-0034

Turk, J. T. C 1086; OF 92 0628, 92-0645; OP-133, 1008

Turner, A. K. OP-1009 
Turner, C. E. OP-1252, 1386, 1963

Turner, K. S. OF 92-0153; OP350

Tumer, R. M. DDS-0002

Tumipseed, I. P. OF 90-0110; OP-1010

Turrin, B. D. B 2039; OP-1238

Tusker, Gary OP-1964

Tuttle, M. L. OF 92-0391; OP$306,841,1011,1965$

Twichell, D. C: DIS-0003, 0015; B 2002; MF-2221; OP$1012,1740,1864,1966$

Tysdal, R. G. OP- 1351,1798

\section{$\mathbf{U}$}

U.S. Bureau of Mines OF 920514

U.S. Geological Survey DDS0006; W 2400; YR; EV; PDE; C.AT; WRI 91-4110 OF 92-0531, 92-0595; I$2276,2311,2312,2313$ $2314,2315,2316,2317$ $2318,2319,2320,2321$ $2322,2323,2324,2325$ $2332,2333,2334,2335$ $2336,2337,2338,2339$ 2340, 2392; SGM; SM

U.S. Geological Survey, National

Earthquake Information Center OF 91-0600-D, 92-0600-A 92-0600-B, 92-0600-C, 92 0600-D, 92-0601-A, 920601-B, 92-0602-A, 92-0602-B, 92-0603-A, 92 0603-B, 92-0604-A, 92-0604 B, 92-0605-A, 92-0605-B, 92-0606-A, 92-0606-B, 920607-A, 92-0607-B, 92-0608A, 92-0608-B, 92-0609-A, 92-0609-B, 92-0610-A, 920610-B, 92-0611-A, 92-0611B, 92-0612-A, 92-0612-B

Udias, Agustin OP-1372

Ulmer, G. C.. OP-595, 1013

Ulmishek, G. F. OF 93-0004; OP-1014, 1265, 1967

Ulrich, G. E. OP-1015 Umbal, J. V. WRI 92-4039

Umitsu, Masatomo OP-720

Underwood, J. R. OP-1378

Ungaretti, Luciano OP-414

Unger, J. D. OP-1646

Unruh, D. M. OP-730

Unthank, M. D. WRI 92-4138

Updegraff, D. M. OP-1968

Updike, R. G. OP-677

Urban, Hans B 2046

Urov, K. OP-1599

Urquida, F. OP-1369

Urrutia-Fucugauchi, Jaime OP920

Utterback, W. C. OP-205,716

Uzcategui, K. E. OF 93-0112

\section{V}

Vaccaro, J. J. OP-1016, 1017

Vachier, R. J. W 2400

Vail, T. J. OF 92-0485
Vakhrusheva, V. V. OP-1777

Valastro, S. OP-808

Valdes, C. M. OF 92-0441

Valensise, Gianluca OP-764

Valentine, D. W. OP-144, 752

Valentine, P. C. B 2002; OF $92-$ 0566; I-2279-A, 2279-B

Valette-Silver, N. J. P 1550-C; OP-1018

Valin, Z. C. OF 92-0571; OP1910

Valley, J. W. OP-224, 552

Valocchi, A. J. OP-869

Van Burgh, Dana OF 91-0014

Van de Pol, Hendrik OF 93 0181

van der Eerden, A. M. OP-1038

van der Hilst, R. D. OP-1019, 1020,1969

Van Domelen, D. J. OF 92 0542

Van Dreser, T. W. OP- 1300

Van Gosen, B. S. OF 92-0591A, 92-0591-B, 93-0207, 93 0285-A, 93-0285-B; MF-2253

Van Horn, Richard OP-1021, 1022

Van Liew, W. P. WRI 92-4050

Van Metre, P. C. OP-1023, 1435

Van Roermund, H. L. OP-1038

Van Tyne, A. M. B 1909

Van Valkenburg, S. G. OF 930273; OP-1683

VanArsdale, R. B. OP- 1970

Vandas, S. J. YR

Vander Meulen, D. B. OP-876

Vaniman, D. T. OP-572

VanSchaack, J. R. OF 92-0441

VanTrump, George OF 92 0573-A, 92-0573-B, 93-0017A, 93-0017-B; MF-2217-A, 2217-B

Vardiman, D. M. P 1537

Vargas, J. A. OP-335

Varnes, D. J. P 1240-B; OP$121,885,1022,1024$

Varnes, K. L. OF 92-0696, 930192

Vartanyan, G. S. OP-1025

Vassallo, A. M. OP-1478

Vaughan, D. K. OF 92-0524; OP-1350

Vaughn, B. H. OP-1121

Veblen, D. R. OP-1134

Vecchia, A. V. C. 1086

Vedder, J. G. OP-1971

Veenhuis, J. E. W 2400

Vees, R. OP-521

Vega-Faundez, Marta OP-586

Veillette, J. J. I-1420 (NL-18)

Velde, Bruce OP-1026, 1069 , 2000

Vennum, W. R. OP-1027 1317,1446

Ventura, Josep P 1386-E

Venugopal, D. V. OP-787

Verbeek, E. R. B 1787-HH; OF 92-0388; OP-1972

Vergara, Hernán OP-586

Verheyen, T. V. OP-1477
Verma, S. B. OP-507, 729, 946

Vermeul, V. R. OP-1028

Vernik, Lev OP-1029

Vernon, J. H. OP-1030

Veverka, Joseph OP-1437, $1438,1487,1497$

Vidal, A. OP-438

Vidale, J. E. OP-15, 70, 71 , $1031,1032,1033,1034$ 1183,1807

Viets, J. G. OF 92-0704; OP1035

Vigil, J. F. OF 93-0188-A, 930188-B

Villamil, Tomas $\mathrm{OP}-755$

Villard, O. G., Jr. P 1550-C

Villinger, H. W. OP-243

Vining, K. C. C: $1120-B$

Vita-Finzi, Claudio OP-35

Vivit, D. V. B 1770

Vocke, R. D., Jr. $\quad$ OF 92-0525; OP-1973

Vogel, K. L. OP-915

Vogel, R. M. OP-1036

Volkert, R. A. GQ-1707

von Breymann, M. T. OP-587, $819,820,821,822,823,824$ 825

von Guerard, Paul WRI 914095

von Huene, Roland OP-83, 1037,1620

Voncken, J. H. OP-1038

Vorder Bruegge, R. W. OP1974

Voss, C. I. OP- 1039

Vroblesky, D. A. OP-1040, 1089

Vulkan, Uzi OP-104

$\mathbf{W}$

Waber, N. OP-1042

Waddell, Bruce WRI 92-4084

Waddell, K. M. WRI 91-4117

Waddell, Sandra OF 92-0343

Wadsworth, W. B. OP-1126

Wagner, B. J. OP- 1975

Wagner, P. W. I-1420 (NK-18), 1420 (NL-18)

Wagner, Roland OP-366

Wahl, K. L. C 1120-B; OP$1043,1044,1045,1976$

Wahl, R. R. OF 93-0299

Wahrer, M. A. OP-1706

Wahrhaftig, Clyde I-1420 (NJ10)

Waite, T. D. OP-1574

Waitt, R. B. I-1963

Walbert, J. A. YR

Wald, D. J. OP-1046, 1047

Wald, L. A. YR; OF 92-0577, 93-0227; OP-1941

Walder, J.S. OP-389, 740, 1256

Waldron, M. C. W 2400

Walker, J. F. C 1086

Walker, R. J. OF 92-0525; OP1621, 1727, 1913, 1973, $1977,1978,1979,1980$

Wallace, A. R. B 2039; OF 930343; I-2394; OP-1048
Wallace, C A B 1993; C 1088 ; I-2050-F; OP-135

Wallace, L. G. B 1909; YR; OP-1049, 1219

Wallace, R. E. OP-113

Wallace, S. R. OP-1050

Wallace, W. C. OF 93-0101

Wallace, W. K. I-2164

Walter, J. V. OP-572

Walter, Marianne OP-12, 1106

Walter, R. C. $\quad$ OP-1059

Walter, S. R. OP-438

Walters, R. A. C. 1086; OF 92 $0052 ; \mathrm{OP}-320$

Walthall, F. G. OF 93-0267

Walton-Day, Katherine C 1086

Waltz, James OF 93-0071

Wan, Elmira C. 1086

Wandless, G. A. B 1770,2046 ; OP-5 10

Wandrey, C. J. OF 92-0524; OP-1350

Wang Junwen OP-457, 1238

Wang, Chung-Ho OP-419

Wang, Wuncheng OP-1981

Wangen, Lawrence OP-869

Wangsness, I. J. W 2393

Wannesson, Jacques OP-1358

Wanty, R. B. OP-1051, 1052 , 1394

Ward, A. W. OF 92-0198, 930263

Ward, L. OP- 1683

Ward, L. B. OF 93-0273

Ward, L. W. P 1542

Ward, P. L. OP- 1053

Ward, R. A. I-1420 (NJ-15)

Ward, S. N. OP-785

Warden, Augusta OP-564, 1265

Wardlaw, B. R. B 1988-D; OF 92-0580, 93-0220, 930312; OP-354, 1387, 1575, $1622,1703,1982,1983$

Wark, D. A. OP-678, 171

Warme, J. E. OP-1847

Warren, P. H. OP-2025

Warren, R. G. OF 93-0299; OP-

Warwick, P. D. OP- 1548

Waseda, Amane OP-586

Wasserman, M. D. OF 920009; OP-1922

Watkins, A. H. C 1086

Watkins, S. A. OF 93-0087

Watson, B. D. OF 91-0453

Watson, Kenneth OP-1054, 1055, 1056

Watson, L. R. OF 92-0055

Watt, M. K. WRI 91-4126

Watters, T. R. OP-1984

Watterson, J. R. OP-583, 1057

Watts, K. C., Jr. OF 93-0527

Watts, Kathy OF 93-0227

Watts, R. D. C 1086

Wavra, C. S. OF 93-0235

Waychunas, G. A. OP-336, $1058,1810,1811,1985$, 1986, 1987

Wayne, D. M. OF 92-0525

Wayne, L. D. OF 93-0210

Waythomas, C.F. OP-1059 
Wdowinski, Shimon OP-90

Weary, D. J. OP-1988

Weaver, H. L. OP-507, 729, 946

Weaver, J. C. . WRI 93-4031

Weaver, J. D. WRI 92-4165

Weaver, J. N. YR; OF 92-0391, 92-0567, 93-0207

Weaver, M. F. WRI 87-4144

Webb, R. H. YR; OP-1060, 1989

Webb, R. M. OF 92-0717; OP1835

Webb, Thompson, III OP-55

Weber, E. J. OP-1990

Weber, F. R. OF 92-0562

Weber, W. S. OP-835

Webster, D. A. WRI 91-4190

Webster, D. M. OP-1208, 1334, 1991

Webster, G. D. OP-1320

Webster, J. D. OP-1061

Weeks; E. P. WRI 93-4054

Weems, R. E. OF 93-0222; I1935; OP-359, 1660

Wegner, S. J. OF 92-0156

Wehde, M. E. C 1086

Wehr, W. C. OP-1082, 1083

Weide, D. L. I-1420 (NJ-15)

Weigand, P. W. OP-332

Weigel, J. F. OF 92-0476

Weiner, L. I. B 2013

Weintraub, V.C. OP-1906

Weir, G. W. MF-2230

Weisgerber, S. L. OF 92-0514

Weiss, J. S. P 1416-C.

Weiss, S. I. OP-736

Weissman, P. R. OP- 1217

Weitz, C. M. OP-1062

Welch, A. H. W 2340; OP-995

Weldon, R. J., II OP-338, 804, 1063

Wells, R.E. OF 93-0189, 930211; OP-1794

Wells, S. C. YR

Welsh, L. E. C. 1086

Wennerberg, L. G. OP-1064, 1992

Wenrich, K. J. OF 92-0591-A, 92-0591-B; OP-1993

Wentworth, C. M. OP-83, 1166

Werkheiser, W. H. OF 92-0052

Wermund, E. G., Jr. I-1420 (NG-14), 1420 (NH-14), 1420 (NJ-14)

Wernicke, B. P. OP-931

Wershaw, R. L. OF 91-0513; OP-1645

Wesely, M. L. OP-507, 946

Wessells, S. M. OF 93-0237

Wesson, R. L. OP-1746

West, John OP-812

West, S. M. OF 92-0413

West, W. J. OF 92-0514

Westcott, P. A. OP-1350

Westenberg, C. L. OF 90-0381

Westerfield, P. W. WRI 92 4120; OF 93-0096

Westgate, Matthew OF 93-0243

Westjohn, D. B. OF 93-0071

Westphal, K. A. OF 92-0530
Westrich, H. R. OP-1994

Westrum, E. F., Jr. OP-25

Wever, H. E. OP-1995

Wexler, E. J. OF 92-0138

Weyand, E. OP-1716

Whatley, R. C. OP-223, 270

Wheat, C. G. OP-243

Wheeler, J. C. WRI 91-4179; OF 92-0459, 92-0460, 92$0461,92-0462,92-0463,92-$ 0464

Wheeler, K. L. OF 92-0562

Wheeler, R. L. OF 92-0391; OP-1996

Whelan, J. F. C: 1086; OP-643, 1225

Whelan, J. K. OP-243

Whetten, J. T. I-1963

Whipple, J. W. I-2267

Whitcomb, James OP-415

White, A. F. OP-1065, 1170 , 1508, 1997

White, A. M. OP-572

White, D. C. OP- 183

White, D.E. B 1998; OF 93 0197-A, 93-0197-B

White, D. H., Jr. OF 92-0514

White, J. M. OP-1101

White, K. D. WRI 92-4057

White, L. D. OP-306, 637, 997, 998, 1389

White, R. A. P 1550-C; OP399, 1066, 1998

White, R. K. OP-240

White, R. S. OP-1534

White, S. W. OF 93-0292-G, 93-0292-H, 93-0292-I, 930292-J

Whitebread, D. H. MF-1877-A

Whited, C. R. OF 92-0114

Whitehead, J. A. OP-1073

Whitehouse, M. J. OP-1067, 1541, 1921, 2018

Whiteman, C. D., Jr. OF 920492

Whiteman, Jason C-0142

Whitfield, J. W. I-1420 (NJ-15)

Whitfield, M. S., Jr. OF 920028

Whitlock, Cathy OF 92-0504; OP-1999

Whitney, C. G. B 2039; OP$1068,1069,1961,2000$

Whitney, J. W. OF 91-0623, 920391; OP-542, 1070, 1276 1378

Whitney, Rita OP-995

Wiche, G. J. W 2340; C 1086, 1120-B; OP-1071

Wickham, S. M. OP-1776

Wicks, C. M. OP-200

Wicks, R. E. OF 93-0231; OP1111

Wieczorek, G. F. OF 92-0387

Wienke, S. M. OF 93-0146

Wieprecht, D. E. B 1966

Wiggins, W. D. OP-1072

Wiggs, C. R. OP-901

Wiggs, L. B. C. 1086; OF $92-$ 0414

Wilber, R. J. OP-1073

Wilber, W. G. OP-1411
Wilcox, D. A. OP-923

Wilcox, R. E. OF 93-0197-A, 93-0197-B

Wilde, G. L. OP-354

Wilde, Pat B 2002; I-2089-C, 2090-C, 2091-C

Wildeman, T. R. OP-1968

Wiley, J. B. OF 92-0065

Wilhelms, D.E. OP-1074

Wilkes, G. P. OP-359

Wilkinson, D. H. OP-2028

Wilkinson, S. K. OP-569

Wilkinson, W.H. OP-817

Willard, D. A. OP-1075, 2002

Williams, D. A. OP-366, 1439, 1485

Williams, D. F. C. 1086; OP1492, 2003, 2004

Williams, D. R. W 2400

Williams, J. M. YR

Williams, J. S. W 2400; WRI 92-4035

Williams, O. B. OF 93-0513

Williams, R. OP-1423

Williams, R. A. OP-969, 1076 , 1582,1970

Williams, R.C. YR; OP-890

Williams, R. S., Jr. P 1386-E; C. 1086; WRI 92-4067; OF 92-0122; OP-167, 386 , 1405,1406

Williams, S. J. YR; OF 92 0530, 93-0210; I-2150-A

Williams, V.S. GQ-1712, 1713

Williams, W. C. OP-2005

Williams-Sether, T. J. WRI 924020

Williamson, Courteney OF 930002

Wilshire, H. G. OF 91-0435, 92-0447; OP-730, 2006

Wilson, A. B. B 2035, 2039; MF-2253

Wilson, B. W. I-1797-D

Wilson, D. A. OP-573

Wilson, J. F., Jr. WRI 91-4199

Wilson, K. V., Jr. OF 90-0110

Wilson, M. A. OP-1478

Wilson, R. C. OF 92-0486, 920521

Wilson, R. P. OP-2007

Wilson, R. R. OF 93-0405

Wilson, Richard OF 92-0514

Wilson, S. A. B 1770; OF 930281, 93-0303

Wilson, Stephen YR

Wilson, T.P. OP-1706

Wilson, W. E. OP-235

Wiltshire, D. A. C 1086; YR; OP-2008

Wingard, G. L. OP-2009

Winkler, G. R. C. 1094; I-1984, 2164

Winn, W. M. W 2400

Winner, M. D., Jr. OF 93-0113

Winograd, I. J. C. 1086; OP294, 916, 1670

Winter, T. C. OF 92-0475, 93 0127; OP-1077, 1078, 1085, 1472

Winters, W. J. OF 92-0719

Winterstein, T. A. OF 93-0065
Wintsch, R. P. OF 92-0525; OP$1079,1152,1188$

Wirt, Laurie OP-605, 1435

Wise, S. W. OP-1908

Witkowski, P. J. C. 1007

Witt, E. C., III OF 92-0165

Wittinbrink, S. A. B 2039

Wittmann, J. H. YR

Witzke, B. J. OP-1114

Wnuk, Christopher OF $92-$ 0281, 92-0568, 92-0576, 930255, 93-0256

Wojniak, W. S. OF 92-0557; GP-1003-A

Wolcott, S. W. WRI 91-4030

Wold, S. R. WRI 91-4117

Wolery, T. J. OP-869

Wolf, M. OP-737

Wolf, R. J. WRI 92-4137; HA0722-G, 0722-H, 0722-I

Wolf, Rich OP-2010

Wolf, S. H. OP-43I

Wolfe, C. J. OP-1080

Wolfe, J. A. OP-1081, 1082 , 1083

Wolfe, R. F. OP-1883

Wolfe, W. J. WRI 92-4082; OP1084

Wolock, D. M. C 1086; OF 92 0052; OP-1964, 201

Wong, F. L. OF 93-0298; OP242

Wong, M. F. WRI 92-4049, 92 4099

Wong, V. OP-438

Woo, Ming-Ko OP-1085

Wood, A. M. OP-223, 270

Wood, C. W. OP-645

Wood, Gary OP-1518

Wood, J. L. OF 92-0484

Wood, M. I. OP-572

Wood, W. W. OP-879, 1200 , $1849,2012,2013$

Woodard, Richard W 2400

Wooden, J. L. OF 93-0198; OP$11,30,31,512,678,685$, $705,1086,1087,1112,1146$, $1376,1566,1711,1716$, $1731,2014,2015,2016$ 2017, 2018, 2021

Woodruff, L. G. OP-139, 1216, $1688,1747,2019$

Woodruff, M. E. OF 92-0541

Woodward, J. C. OP-608, 1665

Woodward, M. B. SGM

Woodwell, G. R. OF 93-0231; OP-1111

Woosley, L. H., Jr. W 2400

Woram, J. D. OP-1907

Worley, D. M. OP-1300, 1582

Worthington, E. W. OP-367

Wortman, Kathryn YR

Wracher, M. D. OP-1413

Wrege, B. M. OP-2020

Wright, B. E. C 1086

Wright, D. L. OF 93-0324

Wright; E. L. OF 92-0720

Wright, J. OP-1525

Wright, J. E. OP-1886, 2015, 2021

Wright, Richard OP-415 
Wright-Dunbar, Robyn OP1567

Wrucke, C. T. OP-797

Wu, S. S. OP-1831, 1832, 2022

Wulff, Andrew OP-279

Wulftange, W. H. OP-489

Wyatt, F. K. OP-90

Wyckoff, Mark OF 92-0514

Wylie, R. W. WRI 93-4002

Wysocki, D. A. OF 93-0273; OP-1683

Wyss, Max B 2006; OP-1088, 1812

\section{$\mathbf{Y}$}

Yager, D. B. B 2021-C

Yager, R. M. W 2387; OP-2023

Yamashita, K. M. B 1966; OP2024

Yanai, Keizo OP-2025

Yancey, T. E. OP-354

Yang Jianqiang OP-1265

Yang, I. C. OP-775

Yang, X. OP-1424

Yanosky, T. M. OP-1089

Yates, M. G. OP-373, 1445

Yearsley, E. N. OP-1761

Yeats, R. S. OP-159
Yee, J. J. W 2400

Yeh, Hsueh-Wen OP-419

Yehle, L. A. OF 92-0346

Yerkes, R. F. OF 93-0205, 930206, 93-0525

Yeskis, D. OP-761

Yetter, T. J. OF 92-0446

Yin, J. OP-868

Yobbi, D. K. WRI 92-4069

Yonover, R. N. OP-432

Yoshinobu, A. S. OP-1413

Youd, T. L. P 1240-B, 1536; OF 91-0441-T

Young, E. D. OP-1112, 1376

Young, H. L. P 1405-B; OP1090

Young, H. W. WRI 92-4014, 92-4027; OF 92-0175

Young, J. B. OP-1091

Young, J. I). I-2089-C, 2090-C

Yount, J. C. OF 93-0233; OP1552

Yount, M.E. B 1996

Yousef, Nabih OP-1092

$\mathbf{Z}$

Zablocki, C. J. OP-499

Zachariasen, Judith OP-931
Zachry, D. L. SGM

Zahn, Rainer OP-878

Zandt, George OP-1157, 2026

Zanon, Giorgio P 1386-E

Zapecza, O. S. OP-986

Zarriello, P. J. OP-1093

Zartman, R. E. OF 92-0525; I1963; OP-1094

Zaugg, S. D. OP-1685

Zech, R. S. OF 93-0306; OP518,1567

Zehner, R. E. OF 92-0594

Zelazny, L. W. OP-1380

Zelt, R. B. OP-1909

Zen'ko, T. E. OP-2014

Zen, E-an OP-393, 1463

Zenone, Chester OP-691, 692

Zentilli, Marcos OP-2027

Zettwoch, D. D. WRI 92-4138

Zhang Huimin OP-1361

Zhang Wenzhi OP-1361

Zhao, Xixi OP-186, 187, 188, $189,190,191,192,193,194$, 195, 196

Zhelinsky, V. M. OP-1494

Zhu, C. OP-1927

Zhu, Hong OP-1309

Ziegler, A.C. WRI 92-4167; OF 93-0101; OP-2028

Zielinski, R. A. OF 92-0391
Zientek, M. L. OF 93-0207; OP-1087, 1313

Zierenberg, R. A. OP-243 1127,2029

Zietz, Isidore OF 92-0391; OP1813

Zihlman, F. N. IDDS-0005; OF 92-0590, 92-0714; OP1095

Zimbelman, D. R. MF-2081-C, 2081-D, 2081-E; OP-741, 1096

Zimbelman, J. R. OF 93-0516; OP-1831, 1832, 1984

Zimmerman, B. S. OP-1633

Zimmermann, R. A. OP-999

Zoback, M. D. OP-1029, 1661, 2032, 2033

Zoback, M. L. OF 92-0715; OP$124,2030,2031,2032,2033$

Zodrow, E. L. OP-1672, 1673, 2034

Zohdy, A. A. OF 93-0013, 930282, 93-0524; OP-961

Zohn, H. L. YR

Zollweg, J. E. OP-438

Zonenshain, L. P. OP-898, 1597

Zucca, J. J. OP-1374

Zweng, P. L. OP-1097 
The Secretary of the Interior has determined that the publication of this periodical is necessary in the transaction of the public business required by law of this Department. Use of funds for printing this periodical has been approved by the Director of the Office of Management and Budget.

* U.S. G.P.0.:1994-301-077:80075 